


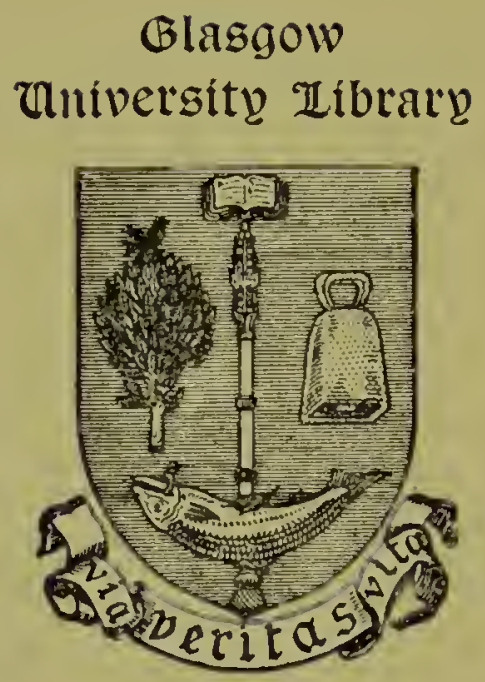




\section{Glasgow University Library}

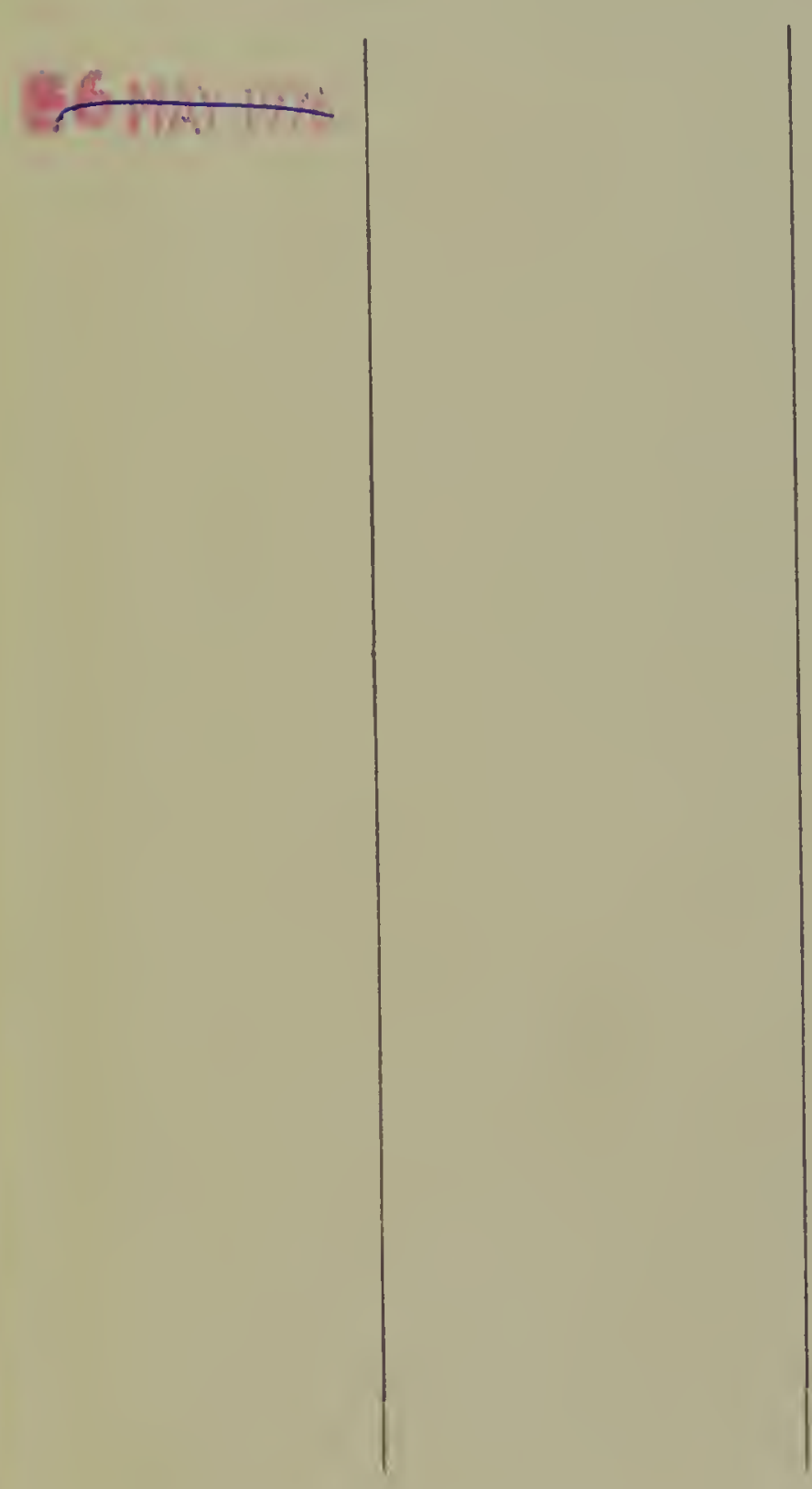

GUL 68.18 

PHARMACOGRAPHIA. 


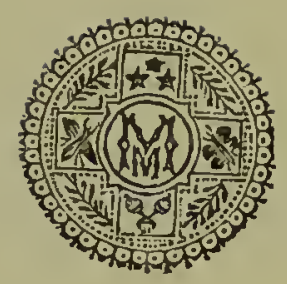




\section{PHARMACOGRAPHIA}

\section{HISTORY}

\section{OF THE PRINCIPAL DRUGS}

\section{OF VEGETABLE ORIGIN,}

GREAT BRITAIN AND BRITISH INDIA

FRIEDRICH A. FLÜCKIGER

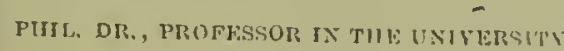

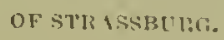

DANIEL HANBURY, F.R.S.

PELLOW OF THE LINNEAN AND OUMMCAL.

SOCIETTES OF LONUON.

\section{folfolom:}

$M \triangle C M I L L A N A N D$ ( ) ( . 
LONDON :

R. CLAY, SONS, AND TAYLOR, PRINTERS, RREAD STREET HILL. 


\section{PREFACE.}

Pharmacographia, the word which gives the title to this book, indicates the nature of the work to which it has been prefixed. The term means simply a writing about drugs; and it has been selected not without due consideration, as in itself distinctive, easily quoted, and intelligible in many languages.

Pharmacographia, in its widest sense, embodies and expresses the joint intention of the authors. It was their desire, not only to write upon the general subject, and to utilize the thoughts of others; but that the book which they had decided to produce together, should contain observations that no one else had written down. It is in fact a record of personal researches on the principal drugs derived from the vegetable kingdom, together with such results of an important character as have been obtained by the numerous workers on Materia Medica in Europe and America.

Unlike most of their predecessors in Great Britain during this century, the authors have not included in their programme either Pharmacy or Therapentics; nor have they attempted to give their work that diversity of scope which would render it independent of collateral publications on Botany and Chemistry.

While thus restricting the field of their inquiry, the authors have endeavoured to discuss with fuller detail many points of interest which are embraced in the special studies of the pharmacist; and at the same time have occasionally indicated the direction in which further investigations are desirable. A few remarks on the heads under which each particular article is treated, will explain more precisely their design.

The drugs included in the present work are chiefly those which are commonly kept in store by pharmacists, or are known in the drug and spice market of London. The work 
likewise contains a comparatively small number which belong to the Pharmacoperice of India: the ajpearince of this volume seemed to prescint a liavouralile opjortunity for giving some more copious notice of the latter than has litherto been attempted.

Supplementary to these two groups must be placed a very few substances which possess little more than historical interest, and have been introduced rather in obedience to custom and for the sake of completeness than on account of their intrinsic value.

Each drug is lieaded by the Latin name, followed by such ferw synonyms as may suffice for perfect identification, together' in most cases witl the English, French, and German designation.

In the next section, the Botanical Origin of the substance is discussed, and the area of its growth, or locality of its production is stated. Except in a few instances, no attempt has been made to furnish botanical descriptions of the plants to which reference is made. Such information may readily be obtained from original and special sources, where moleover, figures of the plants may not unfrequently be found.

Under the head of History, the authors have endeavoured to trace the introduction of each substance into medicine, and to bring forward other points in connexion therewith, which have not hitherto been much noticed in any recent work. This has involved researches which have been carried on for several years, and has necessitated the consultation of many works of general literature. The exact titles of these works have been scrupulously preserved, in order to enable the reader to verify the statements made, and to prosecute further historical inquirics. In this portion of their task, the authors have to acknowledge the assistance kindly given them by Professors Heyd of Stuttgart, Winkelmamn of Heidelberg, Monier Williams of Oxford, Dümichen of Strassburg; and on subjects connected with China, by Mr. A. Wylie and Dr. Bretschneider. The cooperation in various directions of many other friends has becn acknowledged in the text itself.

In some instances the Formation, Secretion or Method of Collection of a drug, has been next detailed: in others, the section History has been immediately followed hy the 
Description, succeeded by one in which the more salient features of Microscopic Structure have been set forth. The authors have not thought it desirable to amplify the lastnamed section, as the subject deserves to be treated in a specia] work, and to be illustrated by engravings. Written descriptions of microscopic structure are tedious and uninteresting, and however carefully drawn up, must often fail to convey the true meaning which would be easily made evident by the pencil. The reader who wishes for illustrations of the minute structure of drugs may consult the works named in the foot-note. ${ }^{1}$

The next division includes the important subject of Chemical Composition, in which the authors have striven to point out to the reader familiar with chemistry, what are the constituents of greatest interest in each particular drug,-what the characters of the less common of those constituents, - and by whom and at what date the chief investigations have been made. A knowledge of the name and date provides a clue to the original memoir, which may usually be found either in extenso or in abstract, in more than one periodical. It has been no part of the authors' plan to supersede reference to standard works on chemistry, or to describe the chemical characters of substances which may be easily ascertained from those sources of information which should be within the reach of every pharmaceutical inquirer.

In the section devoted to Production and Commerce, the authors have given such statistics and other trade information as they could obtain from reliable sources; but they regret that this section is of very unequal value. Duties have been abolished, and a general and continuous simplification of tariffs and trade regulations has ensued. The details therefore that used to be preserved regarding the commerce in drugs, exist no longer in anything like their former state of completeness: hence the fragmentary nature of much of the information recorded under this head.

1 Berg (Otto) Anatomischer A tlas zur pharmazentischen Waarenkunde, Berlin, 1865. 4to. with 50 plates.

Fliickiger (F. A.) Grnndlagen der pharmacentischen Waarenkunde, Einleitung in das Studium der Plarmacognosic, Berlin, 1873. Svo.

Planchon (Gustave) Traité pratique de la détermination des drogues simplés d'origine vééćcale, Paris, 1874. 8vo. (in progress). 
The medicinal uses of each particular drug are only slightly mentioned, it being felt that the science of therapeutics lies within the province of the physician, and may be wisely relinquished to his care. At the same time it may be remarked that the author's would have rejoiced had they locen able to give more definite information as to the technical or economic uses of some of the substances they have describer.

What has been written under the head of Adulteration is chicfly the result of actual observation, or might otherwise have been much extended. The author's would rather rely on the characters laid down in preceding sections than upon empirical methods for the determination of purity. The heading Substitutes has been adopted for certain drugs, more or less related to those described in special articles, yet not actually used by way of adulteration.

A work professing to bring together the latest researches in any subject will naturally be thought to contain needless innovations. Whilst deprecating the inconvenience of changes of nomenclature, the author's have had no alternative but to adopt the views sanctioned by the leaders of chemical and botanical science, and which the progress of knowledge has required. The common designations of drugs may indeed remain unchanged:-hellebore, aconite, colchicum, anise and caraway, need no modernizing touch. But when we attempt to combine with these simple names, words to indicate the organ of the plant of which they are constituted, questions arise as to the strict application of such terms as root, rhizome, tuber, corm, seed, and fruit, about some or all of which a diversity of opinion may be entertained.

It has been the authors' aim to investigate anew the field of Vegetable Materia Medica, in order as far as possible to clear up doubtful points, and to remove some at least of the uncertainties by which the subject is surrounded. In furtlerance of this plan they have availed themselves of the resources offered by Ancient and Modern History; nor have they hesitated to lay under contribution either the teaching of men eminent in science, or the labours of those who follow the paths of general literature. How far they have accomplished their desire, remains for the public to decide. 


\section{CONTENTS.}

PAGE

$\mathrm{V}$

Preface

Explanations

THERMOMETRTC TABLE

\section{I.-PHANOGAMOUS OR FLOWERING PLANTS.}

\section{四ínotulerons.}

\section{RanunCUlace雨}

Radix Hellebori nigri

Rhizoma Coptidis

Semen Staphisagriæe

Radix Aconiti

Folia Aconiti

Radix Aconiti Indica heterophylli

\section{___ Cimicifugæe}

\section{Magnoliace无}

Cortex Winteranus

Fructus Anisi stellati

MIENispermace.e

Radix Calumbæe

Pareira Brava

Cocculus Indicus ..

Gulancha ..

\section{BerberIDE $A$}

Cortex Berberidis Indicus

Rhizoma Podophylli

PAPAVERACE, $\mathbb{E}$

Petala Rhoeados

Caps tle Papaveris

Opium

\section{ÚRUCIFER}

Semen Sinapis nigree

Radix Armoracise

\section{(ANELLACEF}

Contex Canellax albie 
Dixinge

Semen Gynocindice

POLYGaLeAs

Rimlix Senege

Gu'prifera d:

Krameria ...

Cilmbogia

Olemm Garcinix

DIPTEROCARIEA:

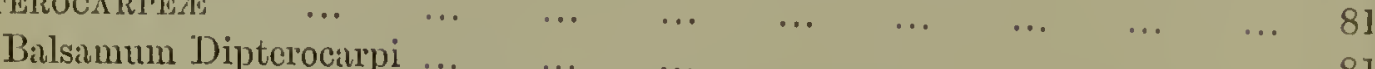

MaLvacét:

Radix Althaxe

Fructus Hibisci esculenti

Strerculiace

Oleum Cacno

LINEÆ ...

Semcn Lini

ZYGOPHYLLEA

Lignum Guaiaci

Resina Guaiaci

RutACEA

Cortex Angosturx

Folia Buchu

Radix Toddaliæe

Aurantiace.re

Fructus Limonis ...

Oleuun Limonis

- Bergamottæ

Cortex Aurantii ...

Oleum Neroli

Fructus Belæ

Simarubee

Lignum Quassiæ ..

Burserace

Olibanum ...

Myrrha

Elemi

MeLiaCe

Cortex Margosa ..

RhAM $A$ CEE Soymidx .

Fructus Rhamni ..

Ampelidew

Uvæ passæ

ANACARDIACEE

Mastiche

Terebintlina Chia

LEGUMINOS

Herba Scoparii

Semen Fœui-græci

Trugacantlia

Radix Glycyruhize 
Succus Glycyrrhiziv

Oleum Arachis ...

Ridix Abri

Sctr Mucumx

Semen Physostigmitis

Kino

Lignum Ptcrocarpi

Balsamum Tolutanum

Peruviauum

Semen Bonducellio

Lignum Hæmatoxyli

Folia Sennze

Fructus Cassix Fistula

Tamarindi Pulpa

Balsamum Copaiba

Gummi Acaciæ

Catechı

Rosace $\mathbb{E}$

Amygdalie dulces

Fructus Pruni

Cortex Pruni scrotinx

Folia Lauro-cerasi

Flores Koso

Petali Rosæe Gallicx

centifolio

Oleum Rosæ

Fructus Rosæ carinæ

Semcn Cydoniæe ...

HAMAMELIDEX

Styrax liquida

Myrtacew

Oleum Cajuputi ...

Caryophylli

Fructus Pimentre

Granate现

Cortex Granati fructus radicis

Cucurbitaces

Fructus Ecballii .

Colocynthidis

UMBELLIFERA

Herba Hydrocotyles

Fructus Conii

Folia Conii

Fructus Ajowan .

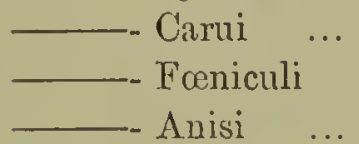

Radix Sumbul

Asaforticla

ralbanum

\begin{tabular}{|c|c|c|c|c|c|c|c|}
\hline .. & $\ldots$ & $\ldots$ & $\ldots$ & $\ldots$ & $\ldots$ & $\ldots$ & 163 \\
\hline$\ldots$ & $\ldots$ & $\ldots$ & $\cdots$ & $\ldots$ & $\ldots$ & $\ldots$ & 164 \\
\hline$\ldots$ & $\ldots$ & $\cdots$ & $\cdots$ & $\ldots$ & $\ldots$ & $\ldots$ & 165 \\
\hline$\ldots$ & $\cdots$ & $\cdots$ & $\cdots$ & $\ldots$ & $\ldots$ & $\ldots$ & 167 \\
\hline$\cdots$ & $\cdots$ & $\ldots$ & $\cdots$ & $\cdots$ & $\ldots$ & $\ldots$ & 170 \\
\hline ... & $\ldots$ & $\ldots$ & $\ldots$ & $\ldots$ & $\ldots$ & $\ldots$ & 175 \\
\hline ... & $\ldots$ & $\cdots$ & $\cdots$ & $\ldots$ & $\ldots$ & $\ldots$ & 177 \\
\hline ... & $\cdots$ & $\cdots$ & $\cdots$ & $\ldots$ & $\cdots$ & $\ldots$ & 179 \\
\hline$\ldots$ & $\ldots$ & $\cdots$ & $\ldots$ & $\ldots$ & $\ldots$ & $\ldots$ & 185 \\
\hline .. & $\ldots$ & $\ldots$ & $\cdots$ & $\ldots$ & $\ldots$ & $\ldots$ & 186 \\
\hline$\cdots$ & $\cdots$ & $\ldots$ & $\ldots$ & $\cdots$ & $\cdots$ & $\ldots$ & 189 \\
\hline$\cdots$ & $\ldots$ & $\cdots$ & $\cdots$ & $\ldots$ & $\ldots$ & $\ldots$ & 195 \\
\hline$\cdots$ & $\ldots$ & $\ldots$ & $\cdots$ & $\cdots$ & $\ldots$ & $\ldots$ & 197 \\
\hline$\cdots$ & $\ldots$ & $\ldots$ & $\ldots$ & $\ldots$ & $\ldots$ & $\ldots$ & 200 \\
\hline$\cdots$ & $\ldots$ & $\ldots$ & $\ldots$ & $\cdots$ & $\cdots$ & $\ldots$ & 206 \\
\hline$\cdots$ & $\cdots$ & $\cdots$ & $\ldots$ & $\cdots$ & $\ldots$ & $\ldots$ & 213 \\
\hline$\cdots$ & $\ldots$ & $\cdots$ & $\ldots$ & $\ldots$ & $\ldots$ & $\ldots$ & 216 \\
\hline$\ldots$ & $\ldots$ & $\ldots$ & $\ldots$ & $\ldots$ & $\ldots$ & $\ldots$ & 216 \\
\hline$\cdots$ & $\ldots$ & $\ldots$ & $\ldots$ & $\ldots$ & $\cdots$ & $\ldots$ & 219 \\
\hline ... & $\ldots$ & $\ldots$ & $\cdots$ & $\ldots$ & $\ldots$ & $\ldots$ & 223 \\
\hline$\cdots$ & $\ldots$ & $\ldots$ & $\cdots$ & $\ldots$ & $\ldots$ & $\ldots$ & 224 \\
\hline$\cdots$ & $\ldots$ & $\ldots$ & $\ldots$ & $\ldots$ & $\ldots$ & $\ldots$ & 226 \\
\hline$\ldots$ & $\ldots$ & $\ldots$ & $\ldots$ & $\ldots$ & $\ldots$ & $\ldots$ & 228 \\
\hline$\cdots$ & $\cdots$ & $\ldots$ & $\ldots$ & $\ldots$ & $\ldots$ & $\ldots$ & 230 \\
\hline$\ldots$ & $\ldots$ & $\ldots$ & $\ldots$ & $\ldots$ & $\ldots$ & $\ldots$ & 232 \\
\hline$\ldots$ & $\ldots$ & $\ldots$ & $\ldots$ & $\ldots$ & $\ldots$ & $\ldots$ & 233 \\
\hline$\ldots$ & $\cdots$ & $\ldots$ & $\ldots$ & $\ldots$ & $\ldots$ & $\ldots$ & 238 \\
\hline$\ldots$ & $\ldots$ & $\ldots$ & $\ldots$ & $\ldots$ & $\ldots$ & $\ldots$ & 239 \\
\hline$\ldots$ & $\cdots$ & $\ldots$ & $\ldots$ & $\ldots$ & $\ldots$ & $\ldots$ & 241 \\
\hline$\ldots$ & $\ldots$ & $\cdots$ & $\ldots$ & $\ldots$ & $\ldots$ & $\ldots$ & 211 \\
\hline$\ldots$ & $\ldots$ & $\ldots$ & $\ldots$ & $\ldots$ & $\ldots$ & $\ldots$ & 247 \\
\hline$\ldots$ & $\ldots$ & $\ldots$ & $\ldots$ & $\ldots$ & $\ldots$ & $\ldots$ & 247 \\
\hline$\ldots$ & $\ldots$ & $\ldots$ & $\ldots$ & $\ldots$ & $\ldots$ & $\ldots$ & 249 \\
\hline$\ldots$ & $\ldots$ & $\ldots$ & $\ldots$ & $\ldots$ & $\ldots$ & $\ldots$ & 255 \\
\hline$\ldots$ & $\ldots$ & $\ldots$ & $\ldots$ & $\ldots$ & $\ldots$ & $\ldots$ & 257 \\
\hline$\ldots$ & $\ldots$ & $\ldots$ & $\ldots$ & $\ldots$ & $\ldots$ & $\ldots$ & 257 \\
\hline$\ldots$ & $\ldots$ & $\ldots$ & $\ldots$ & $\ldots$ & $\ldots$ & $\ldots$ & 259 \\
\hline$\ldots$ & $\ldots$ & $\ldots$ & $\ldots$ & $\ldots$ & $\ldots$ & $\ldots$ & 260 \\
\hline$\ldots$ & $\ldots$ & $\ldots$ & $\ldots$ & $\ldots$ & $\ldots$ & $\ldots$ & 260 \\
\hline$\ldots$ & $\ldots$ & $\ldots$ & $\ldots$ & $\ldots$ & $\ldots$ & $\ldots$ & 263 \\
\hline$\ldots$ & $\ldots$ & $\ldots$ & $\ldots$ & $\ldots$ & $\ldots$ & $\ldots$ & 264 \\
\hline$\ldots$ & $\cdots$ & $\ldots$ & $\ldots$ & $\ldots$ & $\ldots$ & $\ldots$ & 264 \\
\hline$\ldots$ & $\ldots$ & $\ldots$ & $\ldots$ & $\ldots$ & $\ldots$ & $\ldots$ & 266 \\
\hline$\ldots$ & $\ldots$ & $\ldots$ & $\ldots$ & $\ldots$ & $\ldots$ & $\ldots$ & 268 \\
\hline$\ldots$ & $\ldots$ & $\ldots$ & $\ldots$ & $\ldots$ & $\ldots$ & $\ldots$ & 269 \\
\hline$\ldots$ & $\ldots$ & $\ldots$ & $\ldots$ & $\ldots$ & $\ldots$ & $\ldots$ & 271 \\
\hline$\ldots$ & $\ldots$ & $\ldots$ & $\ldots$ & $\ldots$ & $\ldots$ & $\ldots$ & 274 \\
\hline ... & $\ldots$ & $\ldots$ & $\ldots$ & $\ldots$ & $\ldots$ & $\ldots$ & 276 \\
\hline$\ldots$ & $\ldots$ & $\ldots$ & $\ldots$ & $\ldots$ & $\ldots$ & $\ldots$ & 278 \\
\hline$\ldots$ & $\ldots$ & $\ldots$ & $\ldots$ & $\ldots$ & $\ldots$ & $\ldots$ & 280 \\
\hline$\ldots$ & $\ldots$ & $\ldots$ & $\ldots$ & $\ldots$ & $\ldots$ & $\ldots$ & 285 \\
\hline
\end{tabular}


Ammoniacim

Fructus Ancthi

- Coriandri

Cumini

CAIRIFOLIACKA:

Flores Sambuci

RUBIACEA'

Gambiex

Cortex Cinchonse

Rialix Ipecicuanha

Valemianaces

Radix Valerianx

Composite

Radix Inula

--- Pyrethri

Flores Anthcmidis

Santonica

Radix Arnicæe

Herba Lactucæ virosæ

Lactucarium

LOBELIACEA

Herba Lobelix

ERICACEA

Folia Uvæ Ursi

EBENACE正

Fructus Diospyri

Styrace无

Oleacex

Resina Benzoë

Manna

Oleum Olivæ

APOCYNe

Cortex Alstoniæ

Asclepiadede ...

Radix Hemidesmi

Cortex Mudar

Folia Tylophoræ ..

LOGANIACEA

Nux Vomica

Semen Ignatii

Radix Spigeliæ

Gentianem

Radix Gentianx ...

Herba Chiratæ

Convolvulaceæ

Scammonium

Radix Jalapæ

Scmen Kaladanx

Solanace

Stipes Dulcamarce

Fructus Capsici 
Radix Belladomna?

Folia Belladonnæ

Herba.Stramonii

Semen Stramonii

et Folia Dature albie

Folia Hyoscyami ..

SCrophutariace.

Folia Digitalis

Acanthacez ...

Herba Andrographidis 424

SESAMEA

Oleum Sesami

LABIAT瓜

Flores Lavandula

Herba Menthæ viridis

Plantaginez ..

Semen Ispaghulæ

Polygonace

Radix Rhei

Mrristice店

Myristica ..

Macis

LAURACEA

Camphora

Cortex Cinnamomi

Cassie lignex

Bibiru

Radix Sassafras

THyMelex

Cortex Mezerei

ARTOCARPACEA

Caricæ

Moraces

Fructus Mori

Canvabinem

Herba Cannabis

Strobili Humuli

Glandulæ Humuli

ULMACEE

Cortex Ulmi

Euphorbiacede

$$
\text { fulvæ }
$$

Euphorbium

Cortcx Cascarillæ ..

Semen Tiglii

Kamala

$$
\text { Ricini }
$$


Piperaces

Fructus Piperis nigri

Cubcbre

Herba Matieo

ARISTOLOCIIACEN

Rardix Serpentirlie

CUPULIFLAL

Cortex Quereus

Gallie Hillepenses

SANTALACEI

Lignum Santali

Conifere

Terebinthina vulgaris

Cortex Laricis Veneta

Tcrebinthina Canadensis

Pix Burgundica

Argentoratensis

— liquida

— nigra ...

Fructus Juniperi

Herba Sabina

\section{fthonocotyleñons.}

Cannacees

Amylum Marantie

ZINGIBERACE

Rhizoma Zingiberis

—Curcumæ

Galanga

Fructus Cardamomi

ORCHIDACEA .

Salep

Vanilla

TRIDACEA

Rhizoma Iridis

Crocus

PALMLE ...

Semen Arecre

Sanguis Draconis ..

ArOIDEA

Rhizoma Calani aromatici

LILIACEA

Aloë

Bulbus Scillæ

MeLANTHACEג

Rhizoma Veratri allbi

Semen Sibarlillic.. viridis 


\section{CONTENTS.}

$\begin{array}{lllllllllll}\text { Semen Colchici } & \ldots & \ldots & \ldots & \ldots & \ldots & \ldots & \ldots & \ldots & \ldots & 638\end{array}$

SMLACEA:

Radix Sarsaparilla

Tuber China

CrRAMINTE

Saccharum

Hordeum decorticatum

Oleum Andropogonis

Rhizoma Graminis

\section{II.-CRYPTOGAMOUS OR FLOWERLESS PLANTS.}

\section{Acrogens.}

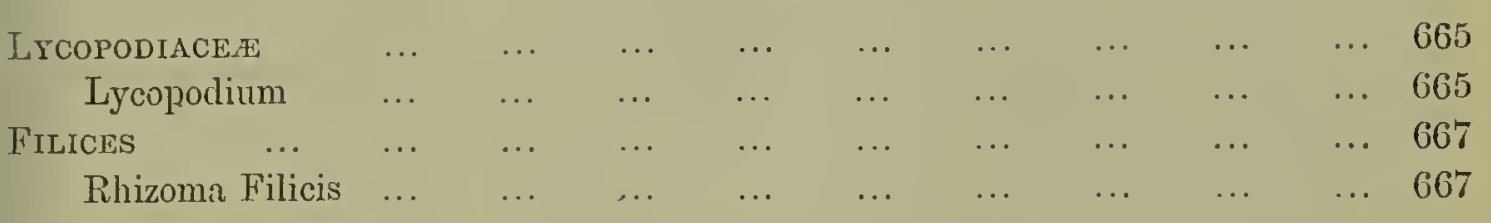

\section{Tyallonens.}

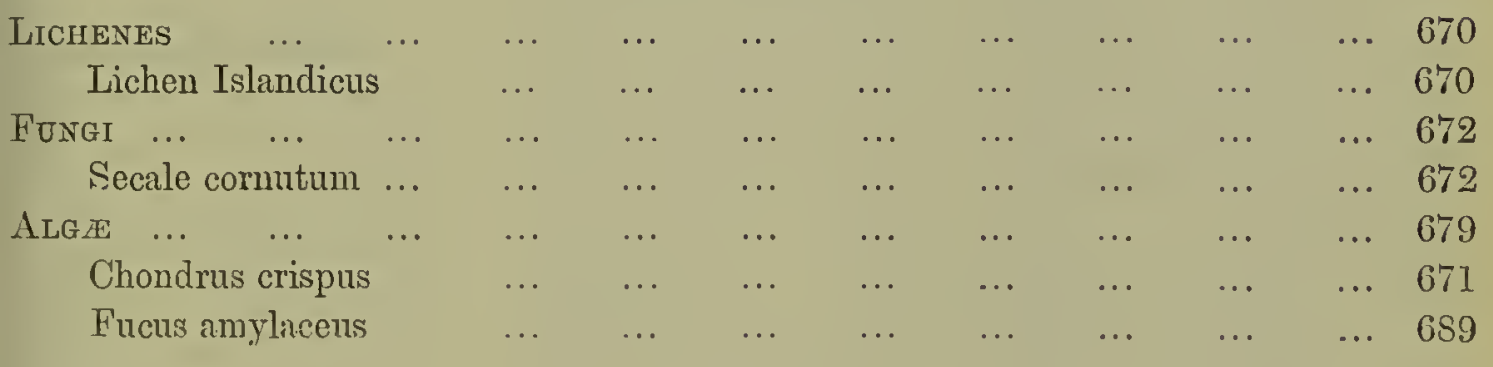




\section{EXPLANATIONS.}

Thermometer-The Centigrade Thermometer has been alone adopted. A table comparing its degrees with those of Fahrenheit's scale is given opposite.

Polarization-Most essential oils, and the solutions. of several substances described in this book are capable of effecting the deviation of a ray of polarized light. The amount of this rotatory power is greatly influcnced by various causcs, and can hardly be regarded as constant in many essential oils. As to alkaloids and other compounds of organic origin, the deviation much depends upon the nature and quantity of the solvent. The authors have thought it needful to record in numerous cases the results of such optical investigations, as detcrmined by the Polaristrobometer invented by Wild of St. Petcrsburg, and described in Poggendorff's Annalen der Physik und Chemie, vol. 122 (1864) p. 626 ; or more completely in the Bulletin de l'Académie impériale des Sciences de St. Pétersbourg, tome viii. (1869) p. 33.

Measurements -The authors regret to have been unable to adopt one standard system of stating measurements. They have mostly employed the English inch: the accompanying wood-cut will facilitate its comparison with the French decimal scalc. The word millimetre is indicated in the text by the contraction $\mathbf{m m}$.; micromillimetre, signifying the thousandth part of a millimetre, and only used in reference to the microscope, is abhreviated thus, $m \mathrm{~km}$.

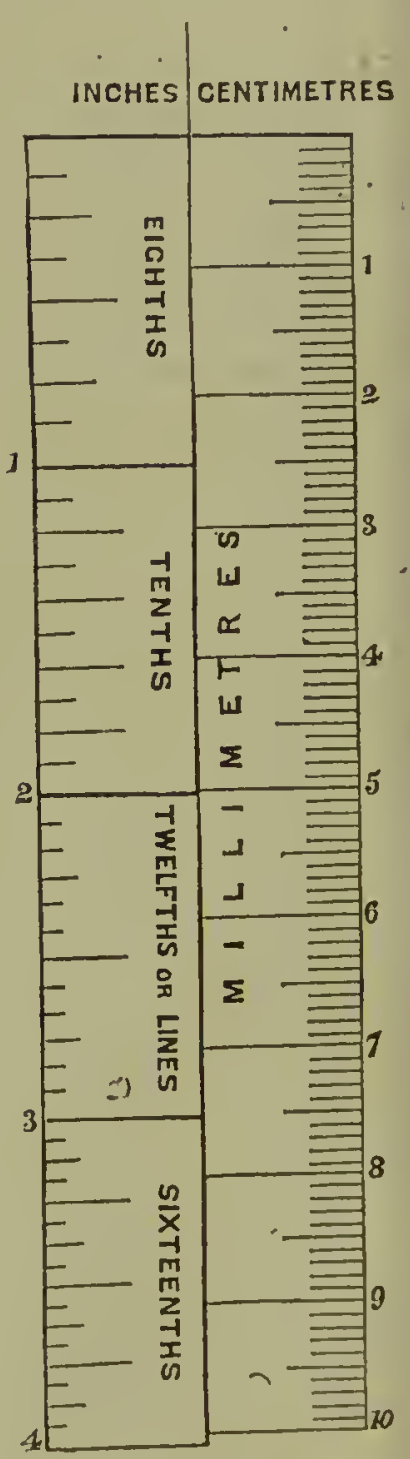


TABIE for comparing the digress (i) the Centigrade Ihermomal e' with those of Finn "nheit's scale.

\begin{tabular}{|c|c|c|c|c|c|c|c|}
\hline CENT. & F.IHIR & CENT. & FHHL: & 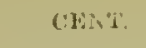 & HAIIIS. & CILNT. & $F$ \\
\hline $\begin{array}{c}-29^{\circ} \\
28 \\
27 \\
26 \\
25 \\
24 \\
23 \\
22 \\
21 \\
20\end{array}$ & $\begin{array}{r}-20.20 \\
18.4 \\
16.0 \\
14.8 \\
13.0 \\
11.2 \\
0.4 \\
.7 .6 \\
5.8 \\
4.0\end{array}$ & $\begin{array}{c}41^{\circ} \\
412 \\
43 \\
44 \\
45 \\
46 \\
47 \\
48 \\
49 \\
50\end{array}$ & $\begin{array}{c}105 \cdot 8^{\circ} \\
105 \cdot 6 \\
109 \cdot 4 \\
111 \cdot 2 \\
11 \% \cdot 0 \\
114 \cdot 8 \\
116 \cdot 6 \\
118 \cdot 4 \\
120 \cdot 2 \\
122 \cdot 0\end{array}$ & $\begin{array}{r}+111 \\
112 \\
113 \\
114 \\
115 \\
116 \\
117 \\
118 \\
119 \\
120\end{array}$ & $\begin{array}{r}+231 \cdot 8 \\
233 \cdot 6 \\
205 \cdot 4 \\
237 \cdot 2 \\
239 \cdot 0 \\
240 \cdot 8 \\
242 \cdot 6 \\
24.4 \cdot 4 \\
246 \cdot 2 \\
2480\end{array}$ & $\begin{array}{r}181 \\
182 \\
183 \\
184 \\
185 \\
186 \\
187 \\
188 \\
189 \\
190\end{array}$ & $\begin{array}{r}+357 \cdot 8 \\
35.6 \\
361 \cdot 4 \\
363 \cdot 2 \\
365 \cdot 0 \\
366 \cdot 8 \\
368 \cdot 6 \\
370 \cdot 4 \\
372 \cdot 2 \\
374 \cdot 0\end{array}$ \\
\hline $\begin{array}{l}19 \\
18 \\
17 \\
.16 \\
15 \\
11 \\
13 \\
12 \\
11 \\
10\end{array}$ & $\begin{array}{r}2.2 \\
0.4 \\
+1.4 \\
3 \cdot 2 \\
5 \cdot 0 \\
6.8 \\
8 \cdot 6 \\
10 \cdot 4 \\
12 \cdot 2 . \\
14 \cdot 0\end{array}$ & $\begin{array}{l}51 \\
52 \\
53 \\
51 \\
55 \\
56 \\
57 \\
5 S \\
59 \\
60\end{array}$ & $\begin{array}{l}123 \cdot 8 \\
125 \cdot 6 \\
127 \cdot 4 \\
129 \cdot 2 \\
131 \cdot 0 \\
132 \cdot 8 \\
131 \cdot 6 \\
136 \cdot 4 \\
138 \cdot 2 \\
140 \cdot 0\end{array}$ & $\begin{array}{l}121 \\
122 \\
123 \\
124 \\
125 \\
126 \\
127 \\
128 \\
129 \\
130\end{array}$ & $\begin{array}{l}219 \cdot 8 \\
251 \cdot 6 \\
253 \cdot 4 \\
255 \cdot 2 \\
257 \cdot 0 \\
25 \cdot 8 \\
260 \cdot 6 \\
262 \cdot 4 \\
261 \cdot 2 \\
266 \cdot 0\end{array}$ & $\begin{array}{l}191 \\
192 \\
193 \\
194 \\
195 \\
196 \\
197 \\
198 \\
199 \\
200\end{array}$ & $\begin{array}{l}375 \cdot 8 \\
377 \cdot 6 \\
379 \cdot 4 \\
381 \cdot 2 \\
383 \cdot 0 \\
384 \cdot 8 \\
386 \cdot 6 \\
388 \cdot 4 \\
390 \cdot 2 \\
392 \cdot 0\end{array}$ \\
\hline $\begin{array}{l}9 \\
8 \\
7 \\
6 \\
5 \\
4 \\
3 \\
8 \\
2 \\
1 \\
0\end{array}$ & $\begin{array}{r}15 \cdot 8 \\
17 \cdot 6 \\
19 \cdot 1 \\
21 \cdot 2 \\
23 \cdot 0 \\
24 \cdot 8 \\
26 \cdot 6 \\
28 \cdot 4 \\
30 \cdot 2 \\
32 \cdot 0\end{array}$ & $\begin{array}{l}61 \\
62 \\
63 \\
64 \\
65 \\
66 \\
67 \\
68 \\
69 \\
70\end{array}$ & $\begin{array}{l}141 \cdot 8 \\
143 \cdot 6 \\
145 \cdot 4 \\
147 \cdot 2 \\
119 \cdot 0 \\
150 \cdot 8 \\
152 \cdot 6 \\
154 \cdot 4 \\
156 \cdot 2 \\
158 \cdot 0\end{array}$ & $\begin{array}{l}131 \\
132 \\
133 \\
134 \\
135 \\
136 \\
137 \\
138 \\
139 \\
140\end{array}$ & $\begin{array}{l}267 \cdot 8 \\
269 \cdot 6 \\
271 \cdot 4 \\
273 \cdot 2 \\
275 \cdot 0 \\
27 \cdot 8 \\
27 \cdot 8 \\
280 \cdot 6 \\
282 \cdot 4 \\
284 \cdot 0\end{array}$ & $\begin{array}{l}201 \\
202 \\
203 \\
204 \\
205 \\
206 \\
207 \\
208 \\
209 \\
210\end{array}$ & $\begin{array}{l}393 \cdot 8 \\
385 \cdot 6 \\
397 \cdot 4 \\
399 \cdot 2 \\
401 \cdot 0 \\
402 \cdot 8 \\
404 \cdot 6 \\
406 \cdot 4 \\
408 \cdot 2 \\
410 \cdot 0\end{array}$ \\
\hline $\begin{array}{r}+1 \\
2 \\
3 \\
4 \\
5 \\
6 \\
6 \\
7 \\
8 \\
9 \\
10\end{array}$ & $\begin{array}{l}33 \cdot 8 \\
35 \cdot 6 \\
37 \cdot 4 \\
39 \cdot 2 \\
41 \cdot 0 \\
\cdot 42 \cdot 8 \\
44 \cdot 6 \\
46 \cdot 4 \\
48 \cdot 2 \\
50 \cdot 0\end{array}$ & $\begin{array}{l}71 \\
72 \\
73 \\
74 \\
75 \\
76 \\
77 \\
78 \\
79 \\
80\end{array}$ & $\begin{array}{l}150 \cdot 8 \\
161 \cdot 6 \\
163 \cdot 4 \\
165 \cdot 2 \\
167 \cdot 0 \\
168 \cdot 8 \\
170 \cdot 6 \\
172 \cdot 4 \\
174 \cdot 2 \\
176 \cdot 0\end{array}$ & $\begin{array}{l}141 \\
142 \\
143 \\
144 \\
145 \\
146 \\
147 \\
148 \\
149 \\
150\end{array}$ & $\begin{array}{l}285 \cdot 8 \\
287 \cdot 6 \\
289 \cdot 4 \\
291 \cdot 2 \\
293 \cdot 0 \\
294 \cdot 8 \\
296 \cdot 6 \\
298 \cdot 4 \\
300 \cdot 2 \\
3020\end{array}$ & $\begin{array}{l}211 \\
212 \\
213 \\
214 \\
215 \\
216 \\
217 \\
218 \\
219 \\
220\end{array}$ & $\begin{array}{l}411 \cdot 8 \\
413 \cdot 0 \\
415 \cdot 4 \\
417 \cdot 2 \\
419 \cdot 0 \\
420 \cdot 8 \\
422 \cdot 0 \\
424 \cdot 4 \\
426 \cdot 2 \\
428 \cdot 0\end{array}$ \\
\hline $\begin{array}{l}11 \\
12 \\
13 \\
14 \\
15 \\
16 \\
17 \\
18 \\
19 \\
20\end{array}$ & $\begin{array}{l}51 \cdot 8 \\
5 \cdot \cdot 6 \\
55 \cdot 1 \\
5 \cdot \cdot 2 \\
5 \cdot \cdot \cdot) \\
60 \cdot 8 \\
62 \cdot 0 \\
6.4 \cdot 4 \\
66 \cdot 2 \\
68 \cdot 0\end{array}$ & $\begin{array}{l}81 \\
82 \\
83 \\
84 \\
85 \\
86 \\
87 \\
88 \\
89 \\
9 !\end{array}$ & $\begin{array}{l}177 \cdot 8 \\
179 \cdot 6 \\
181 \cdot 4 \\
183 \cdot 2 \\
185 \cdot 0 \\
186 \cdot 5 \\
188 \cdot 6 \\
190 \cdot 4 \\
192 \cdot 2 \\
194 \cdot 0\end{array}$ & $\begin{array}{l}151 \\
152 \\
153 \\
154 \\
155 \\
156 \\
157 \\
159 \\
159 \\
160\end{array}$ & $\begin{array}{l}303 \cdot 8 \\
305 \cdot 6 \\
307 \cdot 4 \\
309 \cdot 2 \\
311 \cdot 0 \\
312 \cdot 8 \\
314 \cdot 6 \\
316 \cdot 1 \\
318 \cdot 2 \\
320 \cdot 0\end{array}$ & $\begin{array}{l}221 \\
222 \\
223 \\
224 \\
225 \\
226 \\
227 \\
228 \\
229 \\
230\end{array}$ & $\begin{array}{l}429 \cdot 8 \\
431 \cdot 6 \\
433 \cdot 4 \\
435 \cdot 2 \\
437 \cdot 0 \\
438 \cdot 8 \\
440 \cdot 6 \\
442 \cdot 4 \\
441 \cdot 2 \\
446 \cdot 0\end{array}$ \\
\hline $\begin{array}{l}21 \\
22 \\
2: 3 \\
24 \\
25 \\
26 \\
27 \\
28 \\
29 \\
20\end{array}$ & $\begin{array}{l}69 \cdot 8 \\
71 \cdot 6 \\
73 \cdot 4 \\
75 \cdot 2 \\
77 \cdot 0 \\
78 \cdot 8 \\
80 \cdot 6 \\
82 \cdot 4 \\
81 \cdot 2 \\
86 \cdot 0\end{array}$ & $\begin{array}{l}91 \\
9.9 \\
93 \\
9.4 \\
95 \\
560 \\
97 \\
918 \\
99 \\
100\end{array}$ & $\begin{array}{l}3.5 \cdot 8 \\
197 \cdot 6 \\
199 \cdot 4 \\
201 \cdot 2 \\
203 \cdot(1) \\
204 \cdot 8 \\
206 \cdot 6 \\
208 \cdot 4 \\
210 \cdot 2 \\
212 \cdot 0\end{array}$ & $\begin{array}{l}161 \\
162 \\
163 \\
164 \\
165 \\
166 \\
167 \\
168 \\
169 \\
170\end{array}$ & $\begin{array}{l}321 \cdot 8 \\
323 \cdot 6 \\
325 \cdot 4 \\
327 \cdot 7 \\
329 \cdot 0 \\
330 \cdot 4 \\
332 \cdot 6 \\
334 \cdot 4 \\
336 \cdot 2 \\
338 \cdot 0\end{array}$ & $\begin{array}{l}231 \\
232 \\
233 \\
231 \\
235 \\
236 \\
237 \\
238 \\
239 \\
240\end{array}$ & $\begin{array}{l}447 \cdot 8 \\
449 \cdot 6 \\
451 \cdot 4 \\
450 \cdot 0 \\
455 \cdot 0 \\
456 \cdot 4 \\
458 \cdot 6 \\
460 \cdot 4 \\
462 \cdot 2 \\
464 \cdot 0\end{array}$ \\
\hline 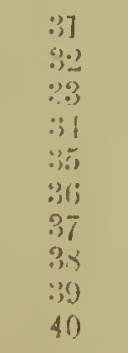 & 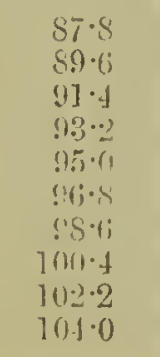 & $\begin{array}{l}101 \\
102 \\
10: 3 \\
101 \\
105 \\
106 \\
107 \\
1018 \\
109 \\
170\end{array}$ & 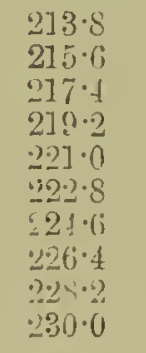 & $\begin{array}{l}171 \\
172 \\
173 \\
174 \\
175 \\
176 \\
177 \\
178 \\
179 \\
180\end{array}$ & $\begin{array}{l}339 \cdot 8 \\
341 \cdot 6 \\
343 \cdot 4 \\
345 \cdot 2 \\
347 \cdot 0 \\
348 \cdot 8 \\
350 \cdot 6 \\
352 \cdot 4 \\
354 \cdot 2 \\
356 \cdot 0\end{array}$ & $\begin{array}{l}241 \\
242 \\
243 \\
244 \\
245 \\
246 \\
247 \\
248 \\
249 \\
250\end{array}$ & $\begin{array}{l}465 \cdot 8 \\
467 \cdot 6 \\
469 \cdot 4 \\
471 \cdot 2 \\
473 \cdot 0 \\
474 \cdot 8 \\
476 \cdot 6 \\
478 \cdot 4 \\
480 \cdot 2 \\
482 \cdot 0\end{array}$ \\
\hline
\end{tabular}





\section{PHARMACOGRAPHIA.}




\section{CORRIGENTA.}

Pitge 55, th th line from toj, for 187. , and $186 \%$

" 141, th line from bottom, for Frit\%, real. Fit..

"213, 7t] line from top, aller formule thess

$$
2\left(\mathrm{C}^{12} \mathrm{H}^{21} \mathrm{O}^{31}\right) \mathrm{Pb}+2\left(\mathrm{C}^{112} \mathrm{H}^{29} \mathrm{O}^{11}\right) \text {. }
$$

., 344, 2th line from top, for Brnfnels, reed Binutels.

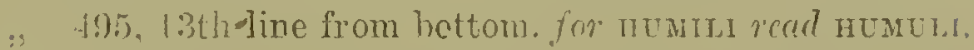

fior convenience of corpespondence, the postal adelicess of the unthoris

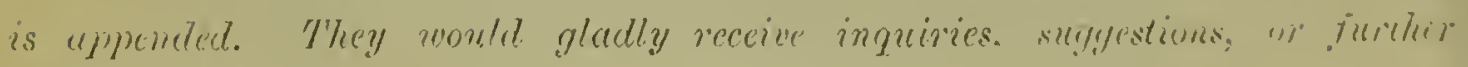
iniormation:-

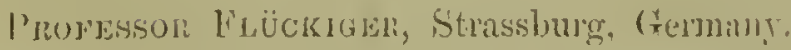

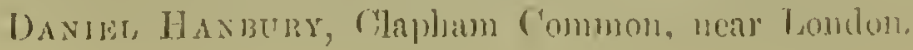




\title{
PHARMACOGRAPHIA.
}

\author{
I.-PII ANOGAMOUS OR FLOWERING PLANTS.
}

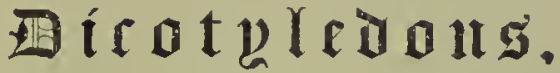

\section{RANUNCULACEA.}

\section{RADIX HELLEBORI NIGRI.}

Radix Ellebori nigri, Radix Melampodii; Blaek Hellebore Root; F. Raeine d'Ellebore noir; G. Schwarze Nieswurzel.

Botanical Origin-Helleborus niger L., a low perennial herb, mative of sub-alpine woods in Southern and Eastern Europe. It is found in Provence, Northern Italy, Salzburg, Bavaria, Austria, Bohemia, and Silesia, as well as, according to Boissier, ${ }^{1}$ in Continental Greece.

Under the name of Christmas Rose, it is often grown in English gardens on account of its handsome white flowers, which are put forth in mid-winter.

History-The story of the daughters of Prœtus, king of Argos, being cured of madness by the soothsayer and physician Melampus, who administered to them hellebore, has imparted great celebrity to the plant under notice. ${ }^{2}$

But admitting that the medicine of Melampus was really the root of a species of Helleborus, its identity with that of the present plant is extremely improbable. Several other species grow in Greece and Asia Ninor, and Schroff ${ }^{3}$ has endeavoured to show that of these, H. orientalis Larn. possesses medicinal powers agreeing better with the ancient accounts than those of $H$. niger $\mathrm{L}$. $\mathrm{H} \in$ has also pointed out that the ancients employed not the entire root but only the bark separated from the woody column; and that in $H$. niger and $H$. viridis the peeling of the rhizone is impossible, but that in $H$. orientalis it may be easily
effected.

1 Flora Orientalis, i. (1867) 61.

2 See the list of theses and niemoirs on Hellebore given by Mérat and De Lens Dict. iii. $472,473$.
3 Zeitschr. d. Gesellseh. d. Aerzte zu Wier. 1860, No. 25; Canstatt's Jahresberieht for 1859. i. $47 .-1860$. i. 55 . 
According to the sanc anthority the helfebores difler extremely in their medicinal aetivity. The most potent is $H$. oricnlalis Lann, then follow $H$. viridis $\mathrm{L}$. and $H$. foetidus $\mathrm{L}$. (natives of Britain), and $I I$. purpurascens Waldst. et Kit., a Hungarian species, while II. niger is the weakest of all. ${ }^{1}$

Description-Black Hellebore produces a knotiy, fleshy, brittle rhizome which creeps and branches slowly, forming in the course of years an entangled,interlacing mass, throwing ont an abundance of stout, straight roots. Botl rhizome and roots are of a blackish brown, but the younger roots are of lighter tint and are covered with a short woolly tomentum.

In commerce the rhizome is found with the roots more or less broken off and detached. It is in very knotty irregular pieces, 1 to 2 or 3 iuches long and about $\frac{2}{10}$ to $\frac{3}{10}$ of an inch in diameter, internally whitish and of a horny texture. If cut transversely (especially after maceration), it shows a circle of white woody. wedges 8 to 12 in number, surrounded by a thick bark. The roots are unbranched, scarcely $\frac{1}{10}$ of an inch in diameter. The younger when broken across exhibit a thick bark encircling a simple woody cord; in the older this cord tends to divide into converging wedges which present a stellate appearance, though not so distinctly as in Actcea. The drug when cut or broken has a slight odour like that of senega. Its taste is bitterish and slightly acrid.

Microscopic Structure-The cortical part both of the rhizome and the rootlets exhibits no distinct medullary rays. In the rootlets the woody centre is comparatively small and enclosed by a narrow zone somewhat as in sarsaparilla. A distinct pith occurs in the rhizome but not always in the rootlets, their woody column forming one solid bundle or being divided into several. The tissue contains small starch granules and drops of fatty oil.

Chemical Composition-The earlier investigations of Black Hellebore by Gmelin, and Feneulle and Capron, and of Riegel indicated only the presence of the more usual constituents of plants.

Bastick on the other hand in 1852 obtained from the root a peculiar, non-volatile, crystalline, chemically-indifferent substance which he named Helleborin. It is stated to have a bitter taste and to produce in addition a tingling sensation on the tongue; to be slightly soluble in water, more so in ether, and to dissolve freely in alcohol.

Marmé and A. Husemann extracted helleborin (186t) by treating with hot water the green fatty matter which is dissolved out of the root by boiling alcohol. After recrystallization from alcohol, it is obtainable in shining, colourless needles, llaving the composition $\mathrm{C}^{36} \mathrm{H}^{42} \mathrm{O}^{6}$. It is stated to be highly narcotic. Helleborin appears to be more abundant in $H$. viridis (especially in the older roots) than in $H$. niger, and yet to be obtainable only to the extent of 0.4 per mille. When it is boiled with dilute sulphuric acid, or still better witl solution of zinc chloride, it is converted into sugar and Helleboresin, $\mathrm{C}^{30} \mathrm{H}^{38} \mathrm{O}^{4}$.

Marmé and Husemann succeeded in isolating otler crystallized principles from the leaves and roots of $H$. niger and $H$. viridis, by precipitation with phospho-molybdic acid. They obtained firstly a 
slightly acid ghooside which they named Helleboreïn. It occurs only in very small proportion, but is rather more abundant in $H$. niger than in 1 . vividis. When boiled with a dilute acid, helleboreïn, $\mathrm{C}^{26} \mathrm{H}^{44} \mathrm{O}^{15}$, is resolved into Hcllcboretin, $\mathrm{C}^{1} \mathrm{H}^{20} \mathrm{O}^{3}$, of a fine violet colour, and sugar, $\mathrm{C}^{12} \mathrm{H}^{24} \mathrm{O}^{12}$. It is remarkable that helleboretin has no physiological action, though lielleborein is stated to be poisonous.

An organic acid accompanying helleborin was regarded by Bastick as probably aconitic (equisetic) acid. There is no tannin in hellebore.

Uses-Black Hellebore is reputed to be a drastic purgative. In British medicine its employment is nearly obsolete, but the drug is still imported from Germany and sold for the use of domestic animals.

Adulteration-Black Hellebore root as found in the market is not always to be relied on, and without good engravings, it is not easy to point out characters by which its genuineness can be made certain. In fact to ensure its recognition, some of the German pharmacopœias require that it should be supplied with leaves attached.

The roots with which it is chiefly liable to be confounded are the following :-

1. Helleborus viridis L.-Although a careful comparison of authenticated specimens reveals certain small differences between the roots and rhizomes of this species and of $H$. niger, there are no striking characters by which they can be discriminated. The root of $H$. viridis is far more bitter and acrid than that of $H$. niger, and it exhibits more numerous drops of fatty oil. In German trade the two drugs are supplied separately, both being in use; but as $H$. viridis is apparently the rarer plant and its root is valued at 3 to 5 times the price of that of $H$. niger, it is not likely to be used for sophisticating the latter.

2. Actcea spicatc L.-In this plant the rhizome is much thicker; the rootlets broken transversely display a cross or star. The drug has but little odour; as it contains tannin its infusion is blackened by a persalt. of iron, which is not the case with an infusion of Black Hellebore.

\section{RHIZOMA COPTIDIS.}

\section{Radix Coptidis; Coptis Root, Mishmi Bitter, Mishmi Tita.}

Botanical Origin-Coptis Teetc Wallich, a small herbaceous plant still but imperfectly known, indigenous to the Mishmi mountains, eastward of Assam. It was first described in 1836 by Wallich. ${ }^{1}$

History-This drug under the name of Mahmira is used in Sind for inflammation of the eyes, a circumstance which enabled Pereira ${ }^{2}$ to identify it with a substance bearing a nearly similar designation mentioned by the early writers on medicine and previously regarded as the root of Chelidonizm majus $\mathrm{L}$.

Thus we find that Paulus Agineta in tlie 7th century was ac-

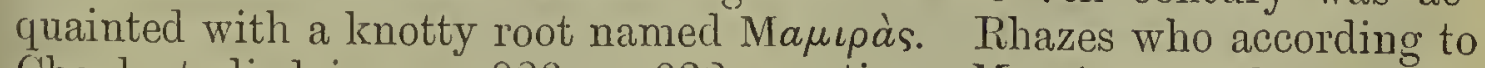
Choulant died in A.D. 923 or 932 , mentions Mamiran, and it is also noticed by Aviceuna a little later as a drug useful in diseases of the eye.

1 Trans. of Med. and Phys. Soc. of Calculla, viii. (1836) 85 .

2 Pharm. Jonrn. xi. (1852) 294. 
Ibn Baytar in the 1:3th century called the drug Mumiran and Uruk, and described it as a small yellow root like turneric, coming from China. Other writers of the middle ages allude to it under the name of Memeren.

Hajji Mahomed in the account of Cathay which he gave to Ramusio (cirea A.D. 15.50) says that the Mambroni chini, by which we understand the root in question, is found in the mountains of Succuir (Suh-cheu) where rhubarb grows and that it is a wonderful remedy for diseases of the eye. ${ }^{1}$ In an official report published at Lahore in 1862, ${ }^{2}$ Mamirani-chini is said to be brought from China to Yarkand.

The rhizome of Coptis is used by the Chinese under the names Hwoing-lien and Chuen-lien. ${ }^{3}$ It is enumerated hy cleyer ${ }^{4}$ (1682) as "radix pretiose amara," and was described in 1778 by Bergius "who received it from Canton.

More recently it was the subject of an interesting notice by Guibourt " who thought it to be derived from Ophioxylon serpentinum L., an apocyneous plant widely removed from Coptis. Its root was recommended in India by MacIsaac ${ }^{7}$ in 1827 and has been subsequently employed with success by many practitioners.

There is a rude figure of the plant in the Chinese herbal Pun-tsao.

Description-Tita, as the drug is called in the Mishmi country whence it is sent by way of Sudiya on the Bramaputra to Bengal, is a rhizome about the thickness of a quill occurring in pieces an inch or two in length. It often branches at the crown into two or three heads, and bears the remains of leafstalks and thin wiry rootlets, the stumps of which latter give it a rough and spiny appearance. It is nearly cylindrical, often contorted, and of a yellowish brown colour. The fracture is short, exhibiting a loose structure with large bright yellow radiating woody bundles. The rhizome is intensely bitter but not aromatic even when íresh.

It is found in the Indian bazaars in neat little open-work bags formed of narrow strips of rattan, each containing about half an ounce. We have once seen it in bulk in the London market. ${ }^{8}$

Microscopic Structure-Cut transversely the rhizome exhibits an inner cortical tissue, through which sclerenchymatous groups of cells are scattered. The latter are most obvious on account of their bright yellow colour. In the woody central column a somewhat concentric arrangement is found, corresponding to two or three periods of annual growth. The pith, not the medullary rays, begins to be obliterated at an early perior. The structure of the drug is, on the whole, very irregular on account of the branches and numerous rootlets arising from it.

The medullary rays contain small starch granules, while the bark as well as the pith are richer in albuminous or nucilaginous matters.

Chemical Composition-The colouring matter in which the

1 Yule, Cathay and the way thither (Hakluyt Soeiety) i. (1866) p. eexvi.

2 Davies, Report on the trade of the countrics on the N.W. boundary of India, Lahore, 1862.

3 Otherwise written Honglane, Chonlin, Chynlen, Chouline, Souline, die.

'Snceimen Medicina: Simica, Med. Sim]. No. 27.
5 Mat. Mcd. ii. (1778) 908.

6 Hist. des Drog. ii. (1S49) 526.

7 Trans. of Med. and Pliys. Soc. of Calculta, iii. (1827) 432 .

8 Two enses were offered for sale as olen or Mishmce by Messi's. Gruy and Clark, lirugbrokers, 25 Nov. $185 \mathrm{~S}$. 
rhizome of Coptis abounds, is quickly dissolved by water. If the yellow solution obtained by macerating it in water is duly concentrated, nitric acid will produce an abundant heavy precipitate of minute yellow crystals, which if redissolved in a little boiling water will separate again in stellate groups. Solution of iodine also precipitates a cold infusion of the root.

These reactions as well as the bitterness of the drug are due to a large proportion of Berberine, as proved by J. D. Perrins. The rhizome yielded not less than $8 \frac{1}{2}$ per cent., which is more than has been met with in any other of the numerous plants containing that alkaloid.

As pure berberine is scarcely dissolved by water, it must be combined in Coptis with an acid forming a soluble salt. Further researches are requisite to determine the nature of this acid. In some plants berberine is accompanied by a second basic principle: whether in the present instance such is the case, has not been ascertained.

Uses-The drug has been introduced into the Pharmacopceia of India as a pure, bitter tonic.

Substitutes-Thalictrum foliolosum DC, a tall plant common at Mussooree and throughout the temperate Himalaya at 5000-8000 feet, as well as on the Khasia Hills, affords a yellow root which is exported from Kumaon under the name Momiri. From the description in the Pharmacopceia of India, it would appear to much resemble the Mishmi Tita, and it is not impossible that some of the observations made under the head History (p. 3) may apply to Thalictrum as well as to Coptis.

In the United States the rhizome of Coptis trifolic Salisb., a small herb indigenous to the United States and Arctic America, and also found in European and Asiatic Russia, is employed for the same purposes as the Indian drug. It has been recently shown to contain berberine and another crystalline principle. ${ }^{2}$

\section{SEMEN STAPHISAGRI $Æ$.}

Stavesaere; F. Staphisaigre; G. Stephanskörner, Läuscsamen

Botanical Origin-Delphinium Staphisagria L.; a stout erect, biennial herb growing 3 to 4 feet high with palmate, 5 - to 9-lobed leaves, which as well as the rest of the plant are softly pubescent.

It is a native of Italy, Greece, the Greek Islands and Asia Minor growing in waste and shady places; it is now also found throughout the greater part of the Mediterranean regions and in the Canary Islands, but whether in all instances truly indigenous is questionable.

History-Stavesacre was well known to the ancients. It is the

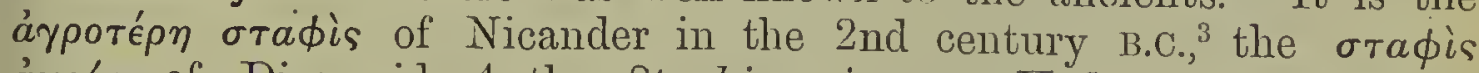
aypla of Dioscorides, ${ }^{4}$ the Staphisagria or Herba pedicularia of Scribonius Largus, ${ }^{5}$ the Astaphis agria or Staphis of Pliny. ${ }^{6}$ The lastnamed author mentions the use of the powdered seeds for destroying vermin on the head and other parts of the body.

1 Journ. of Chem. Soc. xv. (1862) 339.

${ }^{2}$ Gross in Am. Journ. of Pharm. May 1873. 193.

${ }_{271}^{3}$. S. Schneider, Nicandrca, Iips. 1856.
${ }^{4}$ De Mat. Med. lib. iv. c. 153. 166.

De Compositione Medicamentorum, c.

${ }^{6}$ Lib. xxiii. c. 13. 
The drug continued in use during the middle ages. P'ietro Cresecnzio ${ }^{3}$ who lived in the 13th century mentions the collection of the seeds in Italy; and Simon Jannensis," physician to P'ope Nicolas IV. (A.D. 1285-1292), describes then-"propter cxellentem operationem in caputpurgio."

Description-The fruit consists of three downy follicles, in each of which abont 12 seeds are closely packed in two rows. The seeds (which alone are found in commerce) are about 3 lines in length and rather less in width; they have the form of a very irregular 4-sided pyramid, of which one side, much broader than the others, is distinctly vaulted. They are sharp-angled, a little flattened, and very rough, the testa being both wrinkled and deeply pitted. The latter is blackishbrown, dull and eartly-looking, rather brittle, yet not hard. It encloses a soft, whitish, oily albumen with a minute embryo at its sharper end.

The seeds have a bitter taste and occasion a tingling sensation when chewed. Ten of them weigh about 6 grains.

Microscopic Structure-The epidermis of the seed consists of one layer of large cells, either nearly cubical or longitudinally extended: hence the wrinkles of the surface. The brown walls of these cells are inoderately thickened by seconctary deposits, which may be made very obvious by macerating thin sections in a solution of chromic acid, $1 \mathrm{p}$. in $100 \mathrm{p}$. of water. By this treatment numerous crystals after a short time make their appearance,- - without doubt the chromate of one of the alkaloids of staphisagria.

The outer layer of the testa is made up of thin-walled narrow cells, which become larger near the edges of the seed and in the superficial wrinkles. They contain a small number of minute starch granules and are not altered on addition of a salt of iron. The interior layer exhibits a single row of small, densely-packed cells. The albumen is composed of the usual tissue loaded with granules of albuminoid matter and drops of fatty oil.

Chemical Composition-The analyses of Brandes (1819), and of Lassaigne and Feneulle (1819) have shown this drug to contain a basic principle which has been named Delphinine or Delphine. Erdmann in 1864 assigned it the formula $\mathrm{C}^{24} \mathrm{H}^{35} \mathrm{NO}^{2}$; he obtained it to the extent of 1 per mille in small rhombohedric crystals fusing at $120^{\circ} \mathrm{C}$., soluble in ether, alcohol, chloroform, or benzol. Its salts, except the chromate, appear to be uncrystallizable. The alkaloid has an extremely burning and acrid taste, and is highly poisonous.

Couerbe ${ }^{3}$ in 1833 pointed out the presence in stavesacre of a second alkaloid separable from delphinine by ether in which it is insoluble. It is called Staphisaine and has the composition $\mathrm{C}^{16} \mathrm{H}^{23} \mathrm{NO}^{2}$.

The treatment of the shell of the seed with chromic acid, detailed above, shows that this part of the drug is the principal seat of the alkaloids; and the albumen indeed furnishes no crystals of any chromate. In confirmation of this view we exhausted about 400 granmes of the entire seeds with warm spirit of wine acidulated with a little acetic acid. The liquid was allowed to evaporate and the residue mixed with warm water. The solution thus obtained, separated from the resin, yielded on

1 Libro della Agricultura, Venet. (1511) lib. vi. c. 108.
2 Clavis Sanationis, Venet. 1510.

3. Inn. de Climie et de Phys. lii. (1\$33) 352. 
addition of chromic acid an abundant precipitate of chromate of delphinine. The same solution likewise furnished copious precipitates when bichloride of platinum, ${ }^{1}$ iodohydrargyrate of potassium or bichromate of potassium were added. We ascertained that pure acetate of delphinine gives the same reactions with these tests. By repeating the above treatment on a larger scale we obtained crystals of delphinine of considerable size, and also a second alkaloid, not soluble in ether, probably Couerbe's staphisaïne.

In 1864, Darbel in a thesis ${ }^{2}$ published at Montpellier, announced. the existence of a third alkaloid which he termed Staphisagrine-a name which unfortunately has been also applied to staphisaïne.

By exhausting stavesacre seeds with boiling ether, we got 27 per cent. of fatty oil, which continued fluid even at $-5^{\circ} \mathrm{C}$. It concreted by meaus of hyponitric acid, and is therefore to be reckoned among the non-drying oils.

The drug air-dry contains 8 per eent. of hydroscopic water. Dried at $100^{\circ} \mathrm{C}$., and incinerated it left 8.7 per. cent. of ash.

Nothing exact is known of the Delphinic acid of Hofschläger (about 1820) said to be crystalline and volatile.

Commerce-The seeds are imported from Trieste and from the south of France, especially from Nismes, near which city as well as in Italy (Puglia) the plant is cultivated.

Uses-Stavesacre seeds are still employed as in old times for the destruction of pediculi in the human subject, for which purpose they are reduced to powder which is dusted among the hair. Dr. Balmanno Squire ${ }^{3}$ having ascertained that prurigo senilis is dependent on the presence of pediculus, has recommended an ointment of which the essential ingredient is the fatty oil of stavesacre seeds extracted by ether. It is plain that such a preparation would contain delphinine. Delphinine itself has been used externally in neuralgic affections. Stavesacre seeds are largely consumed for destroying the pediculi that infest cattle.

\section{RADIX ACONITI.}

Tuber Aconiti; Aconite Root ${ }^{4}$; F. Racine d'Aconit; G. Eisenhutknollen, Sturmhutknollen.

Botanical Origin-Aconitum Napcllus L.-This widely-diffused and most variable species grows chiefly in the mountainous districts of the temperate parts of the northern hemisphere.

It is of frequent occurrence throughout the chain of the Alps up to more than 6500 feet, the Pyrenees, the mountains of Germany and Austria, and is also found in Denmark and Sweden. It has become naturalized in a few spots in the west of England and in South Wales. Eastward it grows throughout the whole of Siberia, extending to the mountain ranges of the Pacific coast of North America. It occurs in company with other species on the Himalaya at 10,000 to 16,000 feet above the sea-level.

The plant is cultivated for medicinal use and also for ornament.

1 'the platinic compound is in finc micro. scopic crystals.

${ }_{2}$ Recherches chimiques et physiologiques sur les alcaloüdes du Delphinium Staphisrygria.
3 Pharm. Journ. vi. (1865) 405.

4 We use the word root as most in accordance with the teaching of English botanists. 
History-The 'A אóvitoy of the Greeks and the Aconitum of the homans are held to refer to the genus muder notice, if not precisely to A. Nrupellus. The ancients were well aware of the poisonous properties of the nconites, though the plants were not more exactly distinguished until the close of the middle ages.

Aconite has been widely employed as an arrow-poison. It was used by the ancient Chinese, ${ }^{1}$ and is still in requisition among the less civilized of the lill tribes of India. Something of the same kind was in vogue among the aborigines of ancient Gaul. ${ }^{2}$

One of the most remarkable facts in the history of the species under notice is that in certain localities its poisonous qualities are not developed, and it is so entirely innocnous that it is used as a potherb! This was pointed out as long ago as 1671 by Martin Bernhard, ${ }^{3}$ an eminent Polish physician and botanist, and was confirmed by Linnæus ${ }^{4}$ so far as relates to Lapland, where the young shoots of one species are cooked and eaten. It is still more strange to find that while in certain districts of Northern India the roots are collected as a poison, there are others in which the same roots are eaten as "a pleasant tonic." 5

Störck of Vienna introduced aconite into medical practice about the year $1762 .^{6}$

Description-The herbaceous annual stem of aconite starts from an elongated conical tuberous root 2 to 4 inches long and sometimes as much as an inch in thickness. This root tapers off in a long tail, while numerous branching rootlets spring from its sides. If dug up in the summer it will be found that a second and younger root (occasionally a third) is attached to it near its summit by a very short branch, and is growing out of it on one side. This second root has a bud at the top which is destined to produce the stem of the next season. It attains its maximum development at the latter part of the year, the parent root meanwhile becoming shrivelled and decayed. This form of growth is therefore analogous to that of an orchis.

The dried root is more or less conical or tapering, enlarged and knotty at the summit which is crowned with the base of the stem. It is from 2 to 3 or 4 inches long and at top from $\frac{1}{2}$ to 1 inch thick. The tuberlike portion of the root is more slender, much shrivelled longitudinally, and beset with the prominent bases of rootlets. The drug is of a dark brown; when dry it breaks with a short fracture exhibiting a white and farinaceous, or brownish, or grey inner substance sometimes hollow in the centre. A transverse section of a sound root shows a pure white central portion (pith) which is many-sided and has at each of its projecting angles a thin fibro-vascular bundle.

In the fresh state the root of aconite has a sharp odour of radish which disappears on drying. Its taste which is at first sweetish soon becomes alarmingly acrid, accompanied with sensations of tingling and numbness.

Microscopic Structure-The tuberous root as seen in a transverse

1 F. Porter Smith, Mat. Med. and Nut. Hist. of China, Shanghai, 1871. 2, 3.

2 Pliny, lib. xxvii. c. 76 , also $\mathrm{xxv} .25$.

3 Napellus in Poloniâ non venenosus-

Ephem. Acad. Nat. Curios. Dec. i. ann. 2 (1671) 79 .
4 Flor. Lapponica, ed. 2. 1792. 157.

5 Munio, quoted by Hooker and Thomson, Flor. Ind. i. (1855) 58. 2nd part.

"Dc Stramonio, Hyoscyamo et Aconito, Vindob. 1762. 
section, consists of a central part enclosed by a delicate cambial zone. The onter part of this central portion exhibits a thin brownish layer made up of a single row of cells (kernscheide of the Germans). This is more distinctly obvious in the rootlets, which also show numerous, scattered, thick-walled cells of a yellow colour.

The fibro-vascular bundles of aconite root are devoid of true ligneous cells ; its tissue is for the largest part built up of uniform parenchymatous cells loaded with starch granules.

Chemical Composition - Aconite contains chemical principles which are of great interest on account of their virulent effects on the animal economy.

The first to be mentioned is Aconitine, discovered by Geiger and Hesse in 1833, and obtainable from the root to the extent of 3 or 4 per mille. Von Planta (1850) assigned to it the formula $\mathrm{C}^{30} \mathrm{H}^{47} \mathrm{NO}^{7}$; Duquesnel $^{1}$ (1871), whose analysis relates to erystallized aconitine (of $A$. Napellus) $\mathrm{C}^{54} \mathrm{H}^{40} \mathrm{NO}^{2}$. For many years it was only known in the form of a light, pulverizable, colourless, amorphous mass. In the London Exhibition of 1862, Morson, the well-known manufacturing chemist, whose aconitine had long been held in great repute, exhibited it in large well-defined crystals. On the same occasion small specimens of the crystallized alkaloid were shown by Groves of Weymouth, and also crystallized hydrochlorate, hydriodate, and nitrate, prepared two years previously by a process he afterwards described in print. ${ }^{2}$

About the year 1858 it became known to chemists that a substance was being sold under the name of Aconitinc, the properties of which were somewhat diverse from those held to be characteristic of that alkaloid, and there was much doubt and speculation as to its origin. It is now known that this body, which is named Pseud-aconitine, and has been also termed English Aconitine, Napelline (Wiggers), Nepaline (Flückiger), and Acraconitine (Ludwig), is derived from the aconite called in India Bish (see p. 12), which English manufacturing chemists have long preferred (whenever it could be obtained) to the aconite root of Europe.

With these facts in view, and a plentiful supply of each kind of aconite, Groves has re-examined the alkaloids of this drug; and his experiments, though not yet (January 1874) concluded, have established the following facts:-

European aconite root, derived from $A$. Napellus, affords aconitine in two forms,-crystalline and amorphous. Indian or Nepal aconite root, presumed to be obtained chiefly from $A$. ferox, yields a closely allied substance, Pseud-aconitine, also under two forms,-erystalline and amorphous. The characters by which these substances are distinguished have been thus recorded by Mr. Groves. ${ }^{3}$

Aconitine, whether crystalline or amorphous, does not fuse or soften in boiling water.

Crystalline Pseud-aconitine does not soften in boiling water, but if

1 Journ. de. Pharm. et de Chim. xiv. (1871) 94 ; De l'Aconitiné eristallisée et des prépurations d'aconit, quoted in Pharm. .Journ. Jan. 27, 1872. 602.

2 Pharm Journ. viii. (1867) 118.-The crystallized salt shows that the aconitine of Groves was that of A. Napellus. We camnot undertakc to say whether the crystallized aconitine of Morson was this alkaloid, or whether it was that now known as Pseud-aconitine.

3 Phorm. Journ. Oct. 11, 1873. 293-296. 
dissolved in an acid and then precipitated by annononia, the precipitate treated with boiling water coheres and becones plastic.

Amorphous Psend-aconiline, boiled in water, fuses, becones sticky, and adheres to the sides of the vessel.

Crystalline Aconitine is far more soluble in weak aqueous ammonia ${ }^{1}$ than its allied alkaloids. 'The proportions nay be roughly stated thus:cryst. aconitine, 1 part in 500 parts ; amorpli. aconitine, 1-1000; cryst. pseud-aconitine, 1 -2500; amorph. pseud-aconitine, $1-1500$.

Aconitine and pseud-aconitine are both deposited in crystals from aqueous ammoniacal solutions. Such a solution of crystalline aconitine speedily undergoes spontaneous decomposition; that of amorphous aconitine is more stable, while sinilar solutions of pseud-aconitine are but little prone to change.

Crystalline aconitine forms numerous crystallizable salts: crystalline pseud-aconitine appears incapable of affording crystallizable salts.

The crystals of aconitine are described by Groves as being entirely different in form from those of pseud-aconitine. According to Duquesnel those of the former are rhombic or hexagonal tables, sometimes short four-sided prisms.

Duquesnel who lias studied with attention the proporties of crystalline aconitine obtained from $A$. Napcllus grown in Europe, describes it as anlyydrous, nearly insoluble in water even at $100^{\circ} \mathrm{C}$. When obtained by precipitation from one of its salts, it is in the form of an amorphous, pulverulent hydrate. The crystals of the alkaloid dissolve in alcohol, ether, acetic ether, benzol, and especially in chloroform which is their best solvent; the solutions have an intensely-bitter taste followed by a sensation of pricking and tingling. Crystalline aconitine is freely soluble in dilute acids, easily affording crystallizable salts (especially a nitrate), provided the solution is perfectly neutral; it also forms crystalline compounds with iodine and bromine.

Pseud-aconitine is but. little soluble in ether (1 in 100), chloroform ( 1 in 230 ), or spirit of wine in the cold, but dissolves more freely in those liquids when heated, crystallizing in large prisms from boiling saturated solutions. Solution of pseud-aconitine has a burning but not a bitter taste.

In 1857, Hiibschmann ${ }^{2}$ announced the discovery in the root of $A$. Napellus of a new base which he called Napcllinc. It is described as a pulverulent, white, amorphous substance, having a bitter and burning taste, easily soluble in water, chloroform, or alcohol, but insoluble in ether or benzol. The substance has an alkaline reaction, and is a strong base. Hiibschmann subsequently (1S67) expressed his belief that napelline was identical with one of the alkaloids he had obtained in 1865 from the root of $A$. Lycoctonum L., ${ }^{3}$ and had described as Acolyctinc.

Groves (1873) has prepared a somewhat similar body from Nepal aconite, but has not yet determined its identity or otherwise with Hübschmann's napelline-in fact he has expressed the opinion that European and Indian aconite have each its own napelline.

Another alkaloid occurring in aconite was announced in 1864 by T. and H. Smith, of Edinburgh, ${ }^{4}$ who named it Aconclla, but afterwards

1 A solution containing $1 \frac{1}{\mathrm{pcr}}$ cent. of ammonia.

"Flückiger, in Pharm. Journ. Ang. 13, 1870. 121.

3 Hibschmanu's distinct and well-

marked, crystallizable alkaloid Lycoctonine obtained from that plant. is not known to occur in nny of the bluc-flowered aconites.

4 Pharm. Journ. ․ (1\&64) 317. 
showed it to be identical with nurcotine. So far as we know, it has not been met with by any other chemist;. Groves, ${ }^{1}$ in particular, was unable to find it.

The other constituents of aconite root are but imperfectly known. In the preparation of the alkaloids, a dark green mixture of resin and fat is obtained; it is much more abundant in European than in Nepal aconite (Groves). The root contains Mannite, as proved by T. and H. Smith (1850), togetherr with cane sugar, and another sugar which reduces cupric oxide even in the cold. Tannin is absent, or is limited to the corky coat. The absence of a volatile alkaloid in the root, as stated at page 12, was proved by Groves in 1866.

Uses-Prescribed in the form of tincture as an anodyne liniment; occasionally given internally in rheumatism.

Adulteration and Substitution-Aconite root, though offered in abundance in the market, is by no means always obtained of good quality. Collected in the mountainous parts of Europe by peasants occupied in the pasturing of sheep and cattle, it is often dug up without due regard to the proper season or even to the proper species, - a carelessness not surprising when regard is had to the miserable price which the drug realizes in the inarket. ${ }^{2}$

One of the species not unfrequent in the Alps, of which the roots are doubtless sometimes collected, is A. Störckcannm Reichenb. In this plant the tuberous roots are developed to the number of three or four, and have an anatomical structure slightly different from that of $A$. Napellus. ${ }^{3} \quad$ A. variegatumi L., A. Cammarum Jacq., and A. paniculatum Lam. are blue-flowered species having tuberous roots resembling those of $A$. Napellus, but according to Schroff somewhat less active.

The yellow-flowered $A$. Anthora L. and $A$. Lycoctonum L. produce roots which cannot be confounded with those of $A$. Napellus L.

\section{FOLIA ACONITI.}

Herba Aconiti; Aconite Leaves; F. Feuilles d'Aconit; G., Eisenhutkraut, Sturmhutkraut.

Botanical Origin-Aconitum Napellus L., see preceding article.

History-Aconite herb was introduced into medicine in 1762 by Störck of Vienna; and was admitted into the London Pharmacopoja in 1788 .

Description-The plant produces a stiff, upright, herbaceous, simple stem, 3 to 4 feet high, clothed as to its upper half with spreading, dark green leaves, which are paler on their under side. The leaves are from 3 to 5 or more inches in length, nearly half consisting of the channelled petiole. The blade, which has a roundish outline, is divided down to the petiole into three principal segments, of which the lateral are subdivided into two or even three, the lowest being smaller and less

'Phar'm. Journ. viii. (1867) 123.

2 Thus the continental druggists are able to offer it in quantity as low as $4 d$. to $5 d$. per lb., and a pound we find, contains fully 150 roots!

${ }^{3}$ See figure in Berg's Atlas zur pharm. Wrarchtiunde (1865) fig. 24. 
regular than the others. The segments, which are trifid, are finally cut into 2 to 5 strap-shaped pointed lobes. 'The leaves are usually glabrons, and are deeply impressed on their upper side by veins which run with but few branchings to the tip of every lobe. 'The uppermost leaves are more simple than the lower, and gradually pass into the bracts of the beautiful raceme of dull-blue helmet-shaped flowers which crowns the stem.

The leaves have when bruised a herby smell; their taste is at first mawkish but afterwards persistently burning.

Chemical Composition-The leaves contain aconitine in small proportion and also aconitic acid,- the latter in combination with lime.

Aconitic Acid, $\mathrm{C}^{6} \mathrm{H}^{6} \mathrm{O}^{6}$, discovered by Peschier in 1820 in somewhat considerable quantity in the leaves of aconite, occurs also in those of larkspur, and is identical with the Equisetic Acid of Braconnot and the Citridic Acid of Baup. ${ }^{1}$

Schoonbroodt ${ }^{2}$ (1867) on treating the extract with a mixture of alcohol and ether, obtained acicular crystals, which he thought were the so-called Aconella of Smith. He further found that the distillate of the plant was devoid of odour, but was acid, and had a burning taste. By saturation with an alkali he obtained from it a crystalline substance, soluble in water, and having a very acrid taste. Experiments made about the same time by Groves, ${ }^{3}$ a careful observer, led to opposite results. He distilled on different occasions both fresh herb and fresh roots, and obtained a ncutral distillate, smelling and tasting strongly of the plant, but entirely devoid of acridity. Hence he concluded that $A$. Napellus contains no volatile acrid principle.

In an extract of aconite that has been long kept, the microscope reveals crystals of aconitate of calcium, as well as of sal ammoniac.

The leaves contain a small proportion of sugar, and a tannin striking green with iron. When dried they yield ou incineration 16.6 per cent. of ash.

Uses-In Britain the leaves and small shoots are only used in the fresh state, the flowering herb being purchased by the druggist in order to prepare an inspissated juice,-Extractum Aconiti. This preparation, which is considered rather uncertain in its action, is occasionally prescribed for the relief of rheumatism, inflammatory and febrile affections, neuralgia, and heart diseases.

\section{RADIX ACONITI INDICA.}

\section{Bish, Bis or Biti, Indian Aconite Root, Nepal Aconite.}

Botanical Origin-The poisonous root known in India as Bish, $B i s$, or $B i k h^{4}$ is chiefly derived from Aconitun forox Wallich, a plant growing 3 to 6 feet high and bearing large, dull-blue flowers, native of

1 Gmelin, Chemistry xi. (1857) 402.

2 Wittstein's Vierteljahressehrift, xviii. (1869) 82.

3 Pharm. Journ. viii. (1867) 118.

4 The Arabic name Bish or Persian Bis is stated by Moodeen Sheriff in his Supple- ment to the Pharmacopocia of India (p. 265) to be more a correet designation than Bikh, which seems to be a eorruption of doubtful origin. We find that the Arabian writer Ibn Baytar gives the word as Bish (not $B i \hbar h)$. 
the temperate and sub-alpine regions of the Hinalaya at an elevation of 10,000 to 14,000 feet in Garwhal, Kumaon, Nepal and Sikkim. In the greater part of these districts, other closely allied and equally poisonous species occur, viz. A. uncinatum L., A. luridum H. f. et Th., A. palmatum Don, and also abundantly $A$. Napellus L., which last, as already mentioned, grows throughout Europe as well as in Northern Asia and America. The roots of these plants are collected indiscriminately according to Hooker and Thomson ${ }^{1}$ under the name of Bish or Bith.

History-The ancient Sanskrit name of this potent drug, Visha, signifies simply poison, and Ativisha, a name which it also bears, is equivalent to "summum venenum." Bish is mentioned by the Persian physician Alhervi ${ }^{2}$ in the 10th century as well as by Avicenna ${ }^{3}$ and many other Arabian writers on medicine,- - one of whom, Isa Ben Ali, calls it the most rapid of deadly poisons, and describes the symptoms it produces with tolerable correctness. ${ }^{4}$

Upon the extinction of the Arabian school of medicine this virulent drug seems to have fallen into oblivion. It is just named by Acosta (1578) as one of the ingredients of a pill which the Brahmin physicians give in fever and dysenter'y. ${ }^{5}$ There is also a very strange reference to it as "Bisch" in the Persian Pharmacopœia of Father Ange, where it is stated ${ }^{6}$ that the root though most poisonous when fresh, is perfectly innocuous when dried, and that it is imported into Persia from India, and mixed with food and condiments as a restorative! Ange was aware that it was the root of an aconite.

The poisonous properties of Bish were particularly noticed by Hamilton (late Buchanan) ${ }^{7}$ who passed several months in Nepal in 1802-3: but nothing was known of the plant until it was gathered by Wallich and a description of it as $A$. ferox communicated by Seringe to the Société de physique de Genève in 1822.8 Wallich himself afterwards gave a lengthened account of it in his Planta Asiaticce Rariores (1830). ${ }^{9}$

Description-Balfour whose figure of $A$. ferox is the only one that to our knowledge has been published, ${ }^{10}$ describes the plant from a specimen that flowered in the Botanical Garden of Edinburgh as- "liaving 2-3 fasciculated, fusiform, attenuated tubers, some of the recent ones being nearly 5 inches long, and $1 \frac{1}{2}$ inches in circumference, dark-brown externally, white within, sending off' sparse, longish branching fibres."

Aconite root has of late been imported into London from India in considerable quantity, and been offered by the wholesale druggists as Nepal Aconite. ${ }^{11}$ It is of very uniform appearance, and seems derived from a single species, which we suppose to be $A$. ferox. The drug consists

1 Flor. Ind. i. (1855) 54,57; and Introd. Essay, 3.

2 Abu Mansur Mowafik ben Ali Alherui, Liber Fundamcntorum Pharmacologia, i. (1830) 47. Selicrmann's edition.

3 Valgrisi edition, 1564. lib. ii. tract. 2. it. N. (p. 347.)

'Ibn Baytar, Sontheimer's transl. i (1840) 199 .

5 Clusius, Exotica, 289.

- Pharm. Persica, 1681. 1). 358, also 17 and 319. The word bisch is eorrectly given in Arabic characters, so that of its iclentity there ean bo no dispute.
7 Account of the Kingdom of $N$ cpal, Edin. 1819, 98.

${ }^{8}$ Musée Hclvétique d'Hist. Nat. Berne, i. (1823) 160 .

9 Yet strange to say confused the plant with $A$. Napollus, an Indian form of whieh he figured as $A$. ferox!

${ }_{10}$ Edinb. Ncw Phil. Joum. xlvii. (1849) 366, pl. 5 .

11 The first importation was in 1869 , when ten bags containing $1000 \mathrm{lb}$., said to be part of a much larger quantity netually in london, were offered for sale by a drughroker. 
of simple tuberous roots of an elongated conical form, 3 to 4 inches long, and $\frac{1}{2}$ to $1 \frac{3}{4}$ inches in greatest dianeter. Very often the roots have been broken in being dug up and are wanting in the lower ex. trenity: some are nearly as broad at one end as at the other. They are mostly flattened and not quite cylindrical, often arched, mnch shrivelled chiefly in a longitudinal direction, and marked rather sparsely with the scars of rootlets. 'J'he aerial stem lins becin closely cut away, and is represented only by a few short scaly rudiments. ${ }^{1}$

The roots are of a blackish brown, the prominent portions being often whitened by friction. In their normal state they are white and farinaceous within, but as they are dried by fire-heat and often even scorched, their interior is generally horny, translucent, and extremely compact and hard. 'The largest root we have met with weighed 55\% grains.

In the Indian bazaars, Bish is found in another form, the tuberous roots having been steeped in cow's urine to preserve them from insects. ${ }^{2}$ These roots which in our specimen ${ }^{3}$ are mostly plump and cylindrical, are flexible and moist when fresh, but become hard and brittle by keeping. They are externally of very dark colour, black and horny within, with an offensive odour resembling that of hyraceum or castor. Immersed in water, though only for a few moments, they afford a deep brown solution. Such a drug is wholly unfit for use in medicine, though not unsuitable perhaps for the poisoning of wild beasts, a purpose to which it is often applied in India. ${ }^{4}$

Microscopic Structure-Most of the roots fail to display any characteristic structure by reason of the heat to which they have been subjected. A living root sent to us from the Botanical Garden of Edinburgh exhibited the thin brownish layer which encloses the central part in A. Napellus, replaced by a zone of stone cells, - a feature discernible in the imported root.

Chemical Composition-The chemical constituents of Indian aconite have been noticed in the previous article.

Uses-The drug has been imported and used as a source of aconitine. It is commonly believed to be much more potent than the aconite root of Europe.

\section{RADIX ACONITI HETEROPHYLLI.}

Atís or Atees.

Botanical Origin-Aconitum heterophyllum. Wallich, a plant of 1 to 3 feet high with a raceme of large flowers of a dull yellow veined with purple, or altogether blue, and reniform or cordate, obscurely

I There is a rude woodent of the root in Pharm. Journ. i. (1871) 434.

2 A specimen of ordinary Bish in my possession for two or three years became much infested by a minute and active insect of the geuus Psocus. - D.H.

3 Obligingly sent to me in 1867 by Messrs. Rogers and Co. of Bombay, who say it is the only kind there procurable.-D. H.

4 According to Moodeen Sheriff (Surpplemont to Pharm. of India, pl. 25-32, 265) there are several kinds of aconite ront found in the Indian bazaars, some of them lighly poisonous, others imnocuous. The first or poisonous aconites he groups under the head Aconitum ferox, while the second, of which there are three varicties mostly known by the Arabic name Jadvar (Persian Zadrar), he refers to undetermined species of Aconitum.

'The surest and safest names in most parts of India for the poisonous aconite roots are Bish (Arnbic); Bis (Persiau); Singyk-bis, Mitha-ฉahar, Bachhnág(Hindustani); I'ashanavi (Tamil); Vasa-nabhi (Malyalime). 
5-lobed, radical leaves. It grows at elevations of 8000 to 13,000 feet in the temperate regions of the Western Himalaya, as in Simla, Kumaon and Kashmír.

History-We have not met with any ancient account of this drug, which however is stated by O'Shaughnessy ${ }^{1}$ to have been long celebrated in Indian medicine as a tonic and aphrodisiac. It has recently attracted some attention on account of its powers as an antiperiodic in fevers, and has been extensively prescribed by European physicians in India.

Description-The tuberous roots of $A$. heterophyllum are ovoid, oblong, and downward-tapering or obconical; they vary in length from $\frac{1}{2}$ to $1 \frac{1}{2}$ inches and in diameter from $\frac{3}{10}$ to $\frac{6}{10}$ of an inch, and weigh from 5 to 45 grains. They are of a light ash colour, wrinkled and marked with scars of rootlets, and have scaly rudiments of leaves at the summit. Internally they are pure white and farinaceous. A transverse section shows a homogeneous tissue with 4 to 7 yellowish vascular bundles. In a longitudinal section these bundles are seen to traverse the root from the scar of the stem to the opposite pointed end, here and there giving off' a rootlet. The taste of the root is simply bitter with no acridity.

Microscopic Structure-The tissue is formed of large angular thin-walled cells loaded with starch which is either in the form of isolated or compound granules. The vascular bundles contain numerous spiroid vessels which seen in transverse section appear arranged so as to form about four rays. The outer coat of the root is made up of about six rows of compressed, tabular cells with faintly brownish walls.

Chemical Composition-The root contains a well-defined alkaloid of intensely bitter taste recently discovered by Broughton, ${ }^{2}$ who assigns to it the formula $\mathrm{C}^{46} \mathrm{H}^{74} \mathrm{~N}^{2} \mathrm{O}^{5}$, obtained from concurrent analyses of a platinum salt. The absence in the drug of aconitine has been proved by medical experience. ${ }^{3}$

Uses-The drug is stated to have proved a valuable remedy in. intermittent and other paroxysmal fevers. In ordinary intermittents it may be given in powder in 20 -grain doses. As a simple tonic the dose is 5 to 10 grains thrice a day.

Substitutes-The native name $A$ t's is applied in India to several other drugs, one of which is an inert tasteless root commonly referred to Asparagus sarmentosus L. In Kunawar the tubers of Aconitum Napellus L. are dug up and eaten as a tonic, the name atís being applied to them as well as to those of $A$. heterophyllum. ${ }^{4}$

\section{RADIX CIMICIFUGE.}

Radix Actcece racemosce; Black Snakc-rout, Black Cohosh, Bugbane.

Botanical Origin-Cimicifuga racemosa Elliott (Actcea racemosa L.), a perennial leerb 3 to 8 feet high, abundant in rich woods in Canada and the United States, extending southward to Florida. It much

1 Bengal Dispensatory, 1842. 167.

2 Information communicater by Mr. B. in private letter, 10 Oct. 1873 .
3 Pharm. of India, 1868. 4. 434.

4 Hooker and Thomson (on the nutiority of Munro) Flor. Ind. 1855. 58. 
resembles Actoe spicata L., a plant widely spread over the northern parts of Europe, Asia, and America, occurring also in Britain; but it differs in having an elongated raceme of 3 to 8 inches in length and dry dehiscent capsules. A. spicata has a short raceme and juicy berries, usually red.

History - The plant was first made known by Plukenet in 1696 as Christophoriana Canadensis racomosa. It was recommended in 174.3 by Colden ${ }^{1}$ and named in 1749 by Limneus in his Matcria Medica as Actce raccmis longissimis. In 1823 it was introduced into medical practice in America by Garden; it began to be used in England about the year $1860 .^{2}$

Description-The drug consists of a very short, knotty, branching rhizome, $\frac{1}{2}$ an inch or more thick, having, in one direction, the remains of several stout aerial stems, and in the other, numerous brittle, wiry roots, $\frac{1}{20}$ to $\frac{1}{10}$ of an inch in diameter, emitting rootlets still smaller. The rhizome is of somewhat flattened cylindrical form, distinctly marked at intervals with the scars of fallen leaves. A transverse section exhibits in the centre a horny whitish pith, round which are a number of rather coarse, irregular woody rays, and outside them a hard, thickish bark. The larger roots when broken display a thick cortical layer, the space within which contains converging wedges of open woody tissue 3 to 5 in number forming a star or cross, - a beautiful and characteristic structure easily observed with a, lens. The drug is of a dark blackish brown; it lias a bitter, rather acrid and astringent taste, and a heavy narcotic smell.

Microscopic Structure-The most striking character is afforded by the rootlets, which on a transverse section display a central woody column, traversed usually by 4 wide medullary rays and often enclosing a pith. The woody column is surrounded by a parenchymatous layer separated from the cortical portion by one row of densely packed small cells constituting a boundary analogous to the nucleus-sheath (kernschcidc) met with in many roots of monocotyledons, as for instance in sarsaparilla. The parenchyme of cimicifuga root contains small starch granules. The structure of the drug is, on the whole, the same as that of the closely allied European Actaca spicata L.

Chemical Composition-Tilghmann ${ }^{3}$ in 1834 analysed the drug, obtaining from it gum, sugar, resin, starch and tannic acid, but no peculiar principle.

Conard ${ }^{4}$ extracted from it a neutral crystalline substance of intensely acrid taste, soluble in dilute alcohol, chloroform, or ether, but not in benzol, oil of turpentine, or bisulphide of carbon. The composition of this body has not been ascertained. The same chemist showed the drug not to afford a volatile principle, even in its fresh state.

The American practitioners called Eclctics prepare with Black Snakcroot in the same manner as they prepare podophyllin, an impure resin which they term Cimicifugin or Macrotin. The drug yields according to Parrish, $3 \frac{3}{4}$ per cent of this substance, which is sold in the form of scales or as a dark brown powider.

1 Acta Soc. Reg. Scicnt. Upsal. 1743. 131.

2 Bentley, Pharm. Joum. ii. (1861) 46i0.

4 Am. Journ. of Pharm. xliii. (1S71)

3 Quoted by Bentley. 
Uses-Cimicifuga nsually prescribed in the form of tincture (called Tinetura Actcece raeemosce) has been employed chiefly in rheumatic affections. It is also used in dropsy, the early stages of phthisis, and in chronic bronchial disease. A strong tincture has been lately recommended in America as an external application for reducing inflammation. ${ }^{1}$

\section{MAGNOLIACEA (tribe Winterece).}

\section{CORTEX WINTERANUS.}

Cortex Winteri, Cortex Magellanicus; Winter's Bark, Winter's Cinnamon; F. Ecoree de Winter; G. Wintersrinde, Magellanischer Zimmt.

Botanical Origin-Drimys ${ }^{2}$ Winteri Forster, a tree distributed throughout the American continent from Mexico to Cape Horn. It presents considerable variation in form and size of leaf and flower in the different countries in which it occurs, on which account it has received from botanists several distinct specific names. Hooker ${ }^{3}$ has reduced these species to a single type, a course in which he has been followed by Eichler in his recent monograph of the small order Winteraeece. ${ }^{4}$

History-In 1577 Captain Drake, afterwards better known as Sir Francis Drake, having obtained from Queen Elizabeth a commission to conduct a squadron to the South Seas, set sail from Plymouth with five ships; and having abandoned two of his smaller vessels, passed into the Pacific Ocean by the Straits of Magellan in the autumn of the following year. But on the 7th September, 1578, there arose a dreadful storm, which dispersed the little fleet. Drake's ship, the Peliean, was driven southward, the Elizabeth, under the command of Captain Winter, repassed the Straits and returned to England, while the third vessel, the Marigold, was heard of no more.

Winter remained three weeks in the Straits of Magellan to recover the health of his crew, during which period, according to Clusius (the fact is not mentioned in Hakluyt's account of the voyage), he collected a certain aromatic bark, of which, having removed the acridity by steeping it in honey, he made use as a spice and medicine for scurvy during his homeward voyage.

A specimen of this bark having been presented to Clusius, he gave it the name of Cortex Winteranus, and figured and described it in his Libri Exoticomum, published in 1605. He afterwards received a specimen with wood attached, which had been collected by the Dutch navigator Sebald de Weerdt.

Van Noort, another well-known Dutch navigator, who visited the Straits of Magellan in 1600, mentions cutting wood at Port Famine to

1 Yearbook of Pharmacy, 1872. 385.

2 From $\delta \rho \mu u$ s, acrid, biting.

3 Flora Antarctica, ii. (1847) 229.
4 Martius, Flor. Bras. fasc. 38 (1864) 134. Eichler however adnits five primcipal varieties, viz. a. Magellanica; $\beta$. Chitensis; $\gamma$. Gronatensis; $\delta$. revoluta; $\epsilon$. angustifotia. 
make a boat, and that the bark of the trees was hot and biting like pepper. It is stated by Murray that he also brought the bark tı Europe.

But although the Straits of Magellan were several times visited about this period, it is certain that no regular communication between that remote region and Europe existed either then or subsequently; and we may reasonably conclude that Winter's Bark became a drug of great rarity, and known to but fexv persons. It thus happened that, notwithstanding most obvious differences, the Canella alba of the West Indies, and another bark of which we shall speak further on, having been found to possess the pungency of Winter's Bark, xvere (owing to the scarcity of the latter) substituted for it, until at length the peculiar characters of the original drug came to be entirely forgotten.

The tree was figured by Sloane in 1693, from a specimen (still extant) brought from Magellan's Straits by Handisyd, a ship's surgeon, who had experienced its utility in treating scurvy.

Feuillée a French botanist, found the Winter's Bark-tree in Chili (1709-11), and figured it as Boigue cinncmomifera. It was, however, Forster, ${ }^{2}$ the botanist of Cook's second expedition round the world, who first described the tree accurately, and named it Drimys Winteri. He met with it in 1773 in Magellan's Straits, and on the eastern coasts of Tierra del Fuego, where it grows abundantly, forming an evergreen tree of 40 feet, while on the western shores it is but a shrub of 10 feet high. Specimens have been collected in these and adjacent localities by many subsequent botanists, among others by Dr. J. D. Hooker, who states that about Cape Horn the tree occurs from the sea-level to an elevation of 1000 feet.

Although the bark of Drimys was never imported as an article of trade from Magellan's Straits, it has in recent times been occasionally brought into the market from other parts of South America, where it is in very general use. Yet so little are drug dealers acquainted with it, that its true name and origin have seldom been recognized. ${ }^{3}$

Description-We have examined specimens of true Winter's Bark from the Straits of Magellan, Chili, Peru, New Granada, and Mexico, and find in each the same general characters. The bark is in quills or channelled pieces, often crooked, twisted or bent backwards, generally only a few inches in length. It is mostly extremely thick ( $\frac{1}{10}$ to $\frac{3}{10}$ of an inch) and appears to have shrunk very much in drying, bark a quarter of an inch thick having sometimes rolled itself into a tube only three times as much in external diameter. Young pieces have an ashygrey suberous coat beset with lichens. In older bark, the outer coat is sometimes whitish and silvery, but more often of a dark rusty brown, which is the colour of the internal substance, as well as of the surface next the wood. The inner side of the bark is strongly characterized by very rough striæ, or, as seen under a lens, by small short and sharp longitudinal ridges, with occasional fissures indicative of great contraction of the inner layer in drying. In a piece broken or cut trausversely, it is easy to perceive that the ridges in question are the ends of

1 Journ. des observations physiques, \&c. iv. $1714.10, \mathrm{pl} .6$.

2 Characteres Generum Plantarum, 1775. 42.
3 We have seen it offered in a drug sale at one time as "Pepper Bark," at another as "Cinchona." Even Mutis thought it a Cinchona, and called it "Kinkina urens" । 
rays of white liber which diverge towards the circumference in radiate order, a dark rusty parenchyme intervening between them. No such feature is ever observable in either Canella or Cinnamodendron.

Winter's Bark has a short, almost earthy fracture, an intolerably pungent burning taste, and an odour which can only be described as terebinthinous. When fresh its smell may be more agreeable.

Microscopic Structure-In full-grown specimens the most striking fact is the predominance of sclerenchymatous cells. The tissue moreover contains numerous large oil-ducts, chiefly in the inner portion of the large medullary rays. A fibrous structure of the inner part of the bark is observable only in the youngest specimens. ${ }^{1}$ Very small starch granules are met with in the drug, yet less numerous than in canella. The tissue of the former assumes a blackish blne colour on addition of perchloride of iron.

The wood of Drimys consists of dotted prosenchyme, traversed by medullary rays, the cells of which are punctuated and considerably larger than in Coniferce.

Chemical Composition-No satisfactory chemical examination has been made of true Winter's Bark. Its chief constituents, as already pointed out, are tannic matters and essential oil, probably also a resin. In a cold aqueous infusion, a considerable amount of mucilage is indicated by neutral acetate of lead. On addition of potash it yields a dark somewhat violet liquid. Canella alba is but little altered by the same treatment. By reasoll of its astringency the bark is used in Chili for tanning. ${ }^{2}$

Uses-Winter's Bark is a stimulating tonic and antiscorbutic, now almost obsolete in Europe. It is much used in Brazil and other parts of South America as a remedy in diarrhœa and gastric debility.

Substitute-False Winter's Bark-We have shown that the bark of Drimys or True Winter's Bark has been confounded with the pungent bark of Canella alba L., and with an allied bark, also the produce of Jannaica: The latter is that of $C$ innamodendron corticosum Miers, ${ }^{3}$ a tree growing in the higher mountain woods of St. Thomas-in-the-Vale and St. John, but not observed in any other of the West Indian islands than Jamaica. It was probably vaguely known to Sloane when he described the "Wild Cinamon tree, commonly, but falsely, called Cortex Winteranus," which, he says, has leaves resembling those of Lauro-cercasus; though the tree he figures is certainly Canella alba. ${ }^{4}$ Long ${ }^{5}$ in 1774, speaks of Wild Cinnamon, Canella alba, or Bastard Cortex Winteranus, saying that it is used by most apothecaries instead of the true Cortex Winteranus.

It is probable that both writers really had in view Cinnamodendron, the bark of which has been known and used as Winter's Bark, both in England and on the continent from an early period up to the present time. ${ }^{6}$ It is the bark figured as Cortex Winteranus by Goebel and Kunze ${ }^{7}$

1 The structure of Winter's Barl is beautifully figured by Eichler, loc. cit. tab. 32 . 113.

3 Annals of Nat. Hist., May 1858 ; also Miers' Contributions to Botany, i. 121, pl. 24.

${ }^{4}$ Phil. Trans. xvii for 1693. 465
5 Hist. of Jamaica, Lond. iii. (1774) 705 -also i. 495 .

${ }^{6}$ It is so labelled in the Museum of the Pharmaceutical Society, 28th April, 1873.

${ }^{7}$ Phar'm. Waarenkunde, 1827-29. i. taf. 3. 
and described by Mérat and De Lens, ${ }^{1}$ Pereira, and other writers of repute. Guibourt indeed pointed out in 1850 its great dissimilarity to the bark of Drimys and questioned if it could be derived from that genus.

It is a strange fact that the tree should have been confounded with Canella alba L., differing from it as it does in the most obvious manner, not only in form of leaf, but in having the flowers axillury, whereas those of $C$. alba are tcrminal. Although Cinnamodcndron corticosum is a tree sometimes as much as 90 feet high ${ }^{2}$ and must have been well known in Jamaica for more than a century, yet it had no botanical name until 1858 when it was described by Miers ${ }^{3}$ and referred to the. small genus Cinnamodendron which is closely allied to Canella.

The bark of Cinnamodendron has the general structure of Canella alba. There is the same thin corky outer coat (which is not removed) dotted with round scars, the sarne form of quills and fracture. But the tint is different, being more or less of a ferruginous brown. The inner surface which is a little more fibrous than in canella, varies in colour, being yellowish, brown, or of a deep chocolate. The bark is violently pingent but not bitter, and has a very agreeable cinnamon-like odour.

In microscopic structure it approaches very close to canella; yet the thick-walled cells of the latter exist to a much larger extent and are here seen to belong to the suberous tissue. The medullary rays are loaded with oxalate of calcium.

Cinnamodendron bark has not been analysed. Its decoction is blackened by a persalt of iron whereby it may be distinguished from Canella alba; and is coloured intense purplish brown by iodine, which is not the case with ₹ decoction of true Winter's Bark.

\section{FRUCTUS ANISI STELLATI.}

Semen Badiani ${ }^{4}$; Star-Anise ; F. Badiane, Anis étoilé ; G. Sternanis.

Botanical Origin-Illicium anisatum Loureiro (I. religiosum Sieb.). A small tree, 20 to 25 feet high, native of the south-western provinces of China; introduced at an early period into Japan by the Buddbists and planted about their temples.

Kämpfer in his travels in Japan towards the end of the 17th century discovered a tree called Somo or Skimmi ${ }^{5}$ which subsequent authors assumed to be the source of the drug Star-anise. The tree was also found in Japan by Thunberg ${ }^{6}$. who remarked that its capsules are not so aromatic as those found in trade. Von Siebold in 1825 noticed the same fact, in consequence of which he regarded the tree as distinct from that of Loureiro, naming it Illicium Japonicum, a name he afterwards changed to $I$. rcligiosum. Baillon who has recently investigated the subject ${ }^{7}$ while admitting certain differences between the fruits of the Chinese and

1 As shown by De Lens' own specimen kindly given to one of us by Dr. J. Léon Soubeiran. There are specimens of the same bark about a century old marked Cortex Winteranus verus in Dr. Burges's cabinct of drugs belonging to the Royal Collcge of Physicians.

2 Grisebach calls it a low shrubby tree, 10-15 feet high. Mr. N. Wilson, late of the Bath Botanic Garden, Jamaica, has in. formed me it grows to be $40-45$ in lieight, but that he has seen a specimen 90 feet high. (Letter 22 May, 1862.)-D. H.

3 Loc. cit.

4 From the Arabic Badiyan, anise.

5 Amonitates, 1712. 808.

- Flora Japonica, 1784. 235.

7 Adansonia, viii. 9 ; Hist. des Plantes, Magnoliacées, 1868. 154. 
Japanese trees, holds them to constitute but one species, and the same view is taken by Miquel.

The Star-anise of commerce is produced in the high mountains of Yunnan in South-western China where the tree, which attains a height of 12 to 15 feet, grows in abundance. ${ }^{1}$ The fruits of the Japanese variety of the tree are not collected, and the Chinese drug alone is in use even in Japan.

History-Notwithstanding its striking appearance, there is no evidence that star-anise found its way to Europe like other Eastern spices during the middle ages. Concerning its ancient use in China, the only fact we have found recorded is, that during the Sung dynasty, A.D. $970-1127$, star-anise was levied as tribute in the southern part of Kien-chow, now Yen-ping-fu, in Folien. ${ }^{2}$

Star-anise was brought to England from the Philippines by the voyager Candish, about A.D. 1588. Clusius obtained it in London from the apothecary Morgan and the druggist Garet, and described it in 1601. The drug appears to have been rare in the time of Pomet, who states (1694) that the Dutch use it to flavour their beverages of tea and "sorbec." 4 In those times it was brought to Europe by way of Russia, and was thence called Cardamomum Siberiense, or Anis de Sibérie.

Description-The fruit of Illicium anisatum is formed of 8 oneseeded carpels, originally upright, but afterwards spread into a radiate whorl and united in a single row round a short central column which proceeds from an oblique pedicel. When ripe they are woody and split longitudinally at the upturned ventral suture, so that the shining seed becomes visible. This seed, which is elliptical and somewhat flattened, stands erect in the carpel; it is truncated on the side adjoining the central column, and is there attached by an obliquely-rising funicle. The upper edge of the seed is keeled, the lower rounded. The boatshaped carpels, to the number of 8 , are attached to the column through their whole height, but adhere to each other only slightly at the base; the upper or split side of each carpel occupies a nearly horizontal position. The carpels are irregularly wrinkled, especially below, and are more or less beaked at the apex; their colour is a rusty brown. Internally they are of a brighter colour, smooth, and with a cavity in the lower half corresponding to the shape of the seed. The cavity is formed of a separate wall, $\frac{1}{2}$ nillim. thick, which, as well as the testa of the seed, distinctly exhibits a radiate structure. The small embryo lies next the hilum in. the soft albumen, which is covered by a dark brown endopleura. The seed, which is not aromatic, amounts to about one-fifth of the entire weight of the fruit.

Star-anise has an agreeable aromatic taste and smell, more resembling fennel than anise, on which account it was at first designated Foniculum Sinense. ${ }^{5}$ When pulverised it has a sub-acid after-taste.

Microscopic Structure-The carpels consist of an external, loose, dark-brown layer and a thick inner wall, separated by fibro-vascular bundles. The outer layer exhibits numerous large cells, containing pale

1 'Thorel, Notes médicales du voyage d'exploration du Mékong et de Cochinchine, Paris, 1870. 31.

2 Bretschneider in [Foochow] Chincse Recorder, Jan. 1871.
3 Rarior. Plant. Hist. 202.

4 Hist. des Drog. pt. i. liv. i. 43.

5 Redi, Experimenta, 1675, p. 172. 
yellow volatile oil. The imer wall of the carpels consists of woody pro. senchyme in those parts which are exterior to the seed-cavity, and especially in the shining walls laid bare by the splitting of the ventral suture. The inner surface of the carpel is entirely composed of sclerenchyme. A totally different structure is exhibited by this stony shell where it lines the cavity occupied by the seed. Here it is composed of a single row of cells, consisting of straight tubes exactly parallel to one another, more than $500 \mathrm{mkm}$. long and $70 \mathrm{mkm}$. in diameter, placed vertically to the seed cavity; their porous walls, marked with fine spiral striations, display splendid colours in polarized light. The seed contains albumin and drops of fat. Starch is wanting in star-anise, except a little in the fruit stalk.

Chemical Composition-The volatile oil amounts to 4 or 5 per cent. Its composition is that of the oils of fennel or anise; it usually solidifies below $2^{\circ} \mathrm{C}$. The oils of anise and star-anise, as distilled by one of us, possess no striking optical differences, both deviating very little to the left. We are unable to give characters by which they can be discriminated, although they are distinguished by dealers.

Star-anise is rich in sugar, which seems to be cane-sugar inasmuch as it does not reduce alkaline cupric tartrate. An aqueous extract of the fruit assumes, on addition of alcohol, the form of a clear mucilaginous jelly, of which pectin is probably a constituent. The seeds contain a large quantity of fixed oil.

Commerce-Star-anise is shipped to Europe and India from China. In 1872 Shanghai imported, mostly by way of Hongkong (but from what previous port we have failed to trace), 5273 peculs $(703,066 \mathrm{tb})$, a large proportion of which was re-shipped to other ports of China. ${ }^{1}$ The same drug, under the name of Bádiyáne-khatái (i.e. Chinese anise), is carried by inland trade from China to Yarkand and thence to India where it is much esteemed.

Uses-Star-anise is employed to flavour spirits, the principal consumption being in Germany, France, and Italy. It is not used in medicine, at least in England, except in the form of essential oil, which is often sold for oil of aniseed.

\section{E N I S E R M A C E E.}

RADIX CALUMBÆ.

Radix Columbo; Calumba or Colombo Root; F. Racine de Colombo; G. Kalumbawurzel, Columbowurzel.

Botanical Origin-Jateorhiza palmata Miers ${ }^{2}$ a diœcious perennial plant with large fleshy roots and herbaceous annual stems, climbing

1 Returns of Irade at the Treaty Ports in China for 1872, p. 4-8.

2 Synonyms - Nenispermum, palmatum Lamarck, Cocculus palmatus DC, Menispermum Columba Roxb., Jateorhiza Calumba Miers, J. Miersii Oliv., Chasmanthera Columba Baillon. As we thus suppress a species admitted in recent works, it is neeessary to give the following explanation. Menispernum palmatum of Lamarek, first described in the Eneyelopédic méthodique in 1797 (iv. 99), was divided by Miers into two species, Jateorhiza palmata and J. Calumba. Oliver in his Flora of Tropical Africa, $\mathrm{i}$. (1S68) 42, accepted the view taken by Miers, but to avoid confusion abolished the specifie name palmata, substituting for it that of Miersii. At the same time he noticed the close relationship of the two species, and suggested that further investigation might 

over bushes and to the tops of lofty trees. The leaves are of large size
and on long stalks, palmate-lobed and membranous. The male flowers are in racemose panicles a foot or more in length, setose-hispid at least in their lower part, or nearly glabrous. The whole plant is more or less hispid with spreading setæ and glandular hairs.

It is indigenous to the forests of Eastern Africa between Ibo or Oibo, the most northerly of the Portuguese settlements (lat. $12^{\circ} 20^{\prime} \mathrm{S}$.), and the banks of the Zambesi, a strip of coast which includes the towns of Mozambique and Quilimane. Kirk found it (1860) in abundance at Shupanga, among the hills near Morambala, at Kebrabasa and near Senna, localities all in the region of the Zambesi. Peters ${ }^{1}$ states that on the islands of Ibo and Mozambique the plant is cultivated. In the Kew Herbarium is a specimen from the interior of Madagascar.

The plant was introduced into Mauritius a century ago in the time of the French governor Le Poivre, but seems to have been lost, for after many attempts it was again introduced in 1825 by living specimens procured from Ibo by Captain Owen. ${ }^{2}$ It still thrives there in the Botanical Garden of Pamplemousses.

It was taken from Mozambique to India in 1805 and afterwards cultivated by Roxburgh in the Calcutta Garden, where however it has long ceased to exist.

History-The root is held in high esteem among the natives of Eastern Africa who call it Kalumb, and use it for the cure of dysentery and as a general remedy for almost any disorder.

It was brought to Europe by the Portuguese in the 17th century, and is first noticed briefly in 1671 by Francesco Redi an Italian physician of Arezzo, who speaks of $i^{3}$ as an antidote to poison deserving trial.

No further attention was paid to the drug for nearly a century, when Percival ${ }^{4}$ in 1773 re-introduced it as " a medicine of considerable efficacy not so generally known in practice as it deserves to be." From this period it began to come into general use. J. Gurney Bevan, a London druggist, writing to a correspondent in 1777 alludes to it as- "an article not yet much dealt in and subject to great fluctuation." It was in fact at this period extremely dear, and in Mr. Bevan's stock-books is valued in 1776 and 1777 at 30 s. per lb., in 1780 at 28s., 1781 at 64 s., 1782 at $15 s ., 1783$ at $6 s$. Calumba was admitted to the London Pharmacopocia in 1788 .

warrant their union. The characters supposed to distinguish them inter se are briefly thesc:-111 J. palmata, the lobes at the base of the leaf overlap, and the male inflorescence is nearly glabrous; whilc in $J$. Calumba, the basal lobes are rounded, but do not overlap, and the male inflorescence is setose-hispid " sparscly pilose" Miers). On careful examination of a large number of specimens, including those of Berry from Calcutta, and other's from Maurititis, Madagascal, and the Zambesi, togctler with the drawings of 'Telfair and Roxburgh, and the published figures and descriptions, I am convinced that the charactcrs in question are unimportant and do unt warrant the establishment of two species. In this view
I have the support of Mr. Holne of Mauritius, who at my request has made careful observations on the liviug plant and found that both forms of leaf occur on the same stem.-D. H.

1 Reise nach Mossambique, Botanik i. (1862) 172.

2 Hooker, Bot. Mag. lvii. (1830) tabb. 2970-71.

3 "Sono ancora da farsi nuove csperienze intorno alla radice di Calumbe, creduta un grandissimo alessifarmaco." - Espericnzo intorno a diverse cose naturali, ctc. Firenze, 1671. 125.

4 Essays, Medical and Experimental, Lond. ii. (1773) 3 . 
Collection-As to the collection and preparation of the drug for the market, the only account we possess is that obtained by Ir. Berry, ${ }^{1}$ which states that the roots are dug up in the month of March, which is the dry season, cut into slices and dried in the shade.

Description-The calumba plant produces great fusiform fleshy roots growing several together from a short head. Some fresh specimens sent to one of us (H.) from the Botanic Garden, Nauritius, in 1866 , and other's from that of Trinidad in 1868, were portions of cylindrical roots, 3 to 4 inclies in diameter, externally rough and brown, and internally firm, fleshy, and of a brilliant yellow. When sliced transversely, and dried by a gentle heat, these roots exactly resemble imported calumba except for being much fresher and brighter.

The calumba of commerce consists of irregular flattish pieces of a circular or oval outline, 1 to 2 inches or more in dianeter, and $\frac{3}{8}$ to $\frac{1}{2}$ an incli thick. In drying, the central portion contracts more than the exterior: hence the pieces are thinnest in the middle. The outer edge is invested with a brown wrinkled layer which covers a corky bark about $\frac{3}{8}$ of an inch thick, surrounding a pithless internal substance, from which it is separated by a fine dark shaded line. The pieces are light and of a corky texture, easily breaking with a mealy fracture. Their colour is a dull greenish yellow, brighter when the outer surface is shaved off with a knife. ${ }^{2}$ The drug has a weak musty odour and a rather nauseous bitter taste. It often arrives much perforated by insects, but seems not liable to such depredations here.

Microscopic Structure-On a transverse section the root exhibits a circle of radiate vascular bundles only in the layer immediately connected with the cambial zone; they project much less distinctly into the cortical part. The tissue of the whole root, except the cork and vascular bundles, is made up of large parenchymatous cells. In the outer part of the bark, some of them have their yellow walls thickened and are loaded with fine crystals of oxalate of calcium, whilst all the other cells contain very large starch granules, attaining as much as $90 \mathrm{mkm}$. The short fracture of the root is due to the absence of a proper ligneous or liber tissue.

Chemical Composition-The bitter taste of calumba, and probably likewise its medicinal properties, are due to three distinct substances, Columbin, Berbcrine, and Columbic Acid.

Columbin or Columba-Bitter was discovered by Wittstock in 1830 . It is a neutral bitter principle, crystallizing in colourless rhombic prisms, slightly soluble in cold alcohol or ether, but dissolving more freely iu those liquids when boiling. It is soluble in aqueous alkalis and in acetic acid.

The presence of Berberinc in calumba was ascertained in 1848 by Bödeker, who showed that the yellow cell-walls of the root owe their colour to it and (as we may add) to Columbic Acid, another substance discovered by the same chemist in the following year. Columbic acid is yellow, amorphous, nearly insoluble in cold water, but dissolving in alcohol and in alkaline solutions. It tastes somewhat less bitter than

1 A sialick Researches, x. (1808) 385; Ainslic, Mat. Med. of Ilindoosian, 298.
2 Wholesale druggists somotimes wash the drug to improve its colour. 
columbin. Bödeker surmises that it may exist in combination with the berberine.

Bödeker has pointed out a comnexion between the three bitter principles of calumba. If we suppose a molecule of ammonia, $\mathrm{NH}^{3}$, to be added to columbin $\mathrm{C}^{42} \mathrm{H}^{44} \mathrm{O}^{14}$, the complex molecule thence resulting will contain the elements of berberine $\mathrm{C}^{20} \mathrm{H}^{17} \mathrm{NO}^{4}$, columbic acid $\mathrm{C}^{22} \mathrm{H}^{24} \mathrm{O}^{7}$, and water $3 \mathrm{H}^{2} \mathrm{O}$.

Among the more usual constituents of plants, calumba contains (in addition to starch) pectin, gum, and nitrate of potassium, but no tannic acid. It yields when incinerated 6 per cent. of ash.

Commerce-Calumba root is shipped to Europe from Zanzibar, and from Bombay and other Indian ports.

Uses-It is much employed as a mild tonic, chiefly in the form of tincture or of aqueous infusion.

\section{PAREIRA BRAVA.}

\section{Radix Pareirce ; Pareira Brava ; F. Racinc de Butua ou de Pareirs- Brava; G. Grieswurzel.}

Botanical Origin-Chondodendron tomentosum Ruiz et Pav. (non Eichler) (Cocculus Chondodcndron DC., Botryopsis platyphylla Miers ${ }^{2}$ ). - It is a lofty climbing shrub with long woody stems, and leaves as much as a foot in length. The latter are of variable form but mostly broadly ovate, rounded or pointed at the extremity, slightly cordate at the base, and having long petioles. They are smooth on the upper side; on the under covered between the veins with a fine close tomentum of an ashy hue. The flowers are unisexual, racemose, minute, produced either from the young shoots or from the woody stems. The fruits are $\frac{3}{4}$ of an inch long, oval, black and much resembling grapes in form and arrangement. ${ }^{3}$

The plant grows in Peru and Brazil,-in the latter country in the neighbourhood of Rio de Janeiro, where it occurs in some abundance on the range of hills separating the Copacabana from the basin of the Rio de Janeiro. It is also found about San Sebastian further south.

History-The Portuguese missionaries who visited Brazil in the 17 th century became acquainted with a root known to the natives as Abutua or Butuc, which was regarded as possessing great virtues. As the plant affording it was a tall climbing shrub with large, simple, long-stalked leaves, and bore bunches of oval berries resembling grapes, the Portuguese gave it the name of Parrcira brava or Wild Vine.

The root was brought to Lisbon where its reputed medicinal powers attracted the notice of many persons, and among others of Michel Amelot, ambassador of Louis XIV., who took back some of it when he returned to Paris in 1688. Specimens of the drug also reached the botanist Tournefort, and one presented by him to Pomet was figured and

1 From the Portuguese parreira, signifying a vinc that grows against a wall (in French treille), and brava, wild.

${ }^{2}$ As figured by Eichler in Martius' Flor. Bras. fasc. 38. tab. 48. The C'issampclos
Abitria of Vellozo's Flora Flumincnsis, tom. x. tab. 140 appeal's to us the same plant.

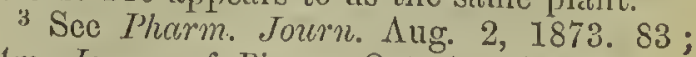
Am. Journ. of Pharm. Oct. 1, 1873. fig. 3. 
described by the latter in $1694 .{ }^{1}$ 'The drug was again brought to Paris by Louis-Raulin Rouillé, the successor to Amelot at Lisbon, together with a memoir detailing its numerous virtues.

Specimens obtained in Brazil by a naval officer named De la Mare in the early part of the last century, were laid before the French Academy, which body requested a report upon them from Geoffroy, professor of medicine and pharmacy in the College of France, who was already somewhat acquainted with the new medicine. He reported many favourable trials in cases of inflammations of the bladder and suppression of urine. ${ }^{2}$ The drug was a favourite remedy of Jean-Claude-Adrien Helvetius, ${ }^{3}$ physician to Louis XIV. and Louis XV., who administered it for years with great success.

Both Geoffroy and Helvetius were in frequent correspondence with Sloane ${ }^{4}$ who received from the former as well as from other sources specimens of Pareira Brava, which are still in the British Museum and have enabled us fully to identify the drug as the root of Chondodendron tomentosum.

Several other plants of the order Menispermacece have stems or roots employed in South America in the same manner as Chondodendron. Pomet had heard of two varieties of Pareira Brava, and two were known to Geoffroy. ${ }^{5}$ Lochner of Nuremberg who published a treatise on Pareira Brava in $1719^{6}$ brought forward a plant of Eastern Africa figured in 1675 by Zanoni, ${ }^{7}$ and supposed to be the mother-plant of the drug. A species of Cissampelos called by the Portuguese in Brazil Caapeba, Cipó de Cobras or Herva de Nossa Senhora described by Piso in $1648,{ }^{8}$ afterwards became associated with Pareira Brava on account of similarity of properties.

Thus was introduced a confusion which we may say was consolidated, when Linnæus in $1753,{ }^{9}$ founded a species as Cissampelos Pareira, citing it as the source of Pareira Brava,- - a confusion which has lasted for more than a hundred years. This plant is very distinct from that yielding true Pareira Brava, and though its roots and stems are used medicinally in the West Indies, ${ }^{10}$ there is nothing to prove that they were ever an object of export to Europe.

As Pareira Brava failed to realize the extravagant pretensions claimed for it, it gradually fell out of use ${ }^{11}$ and the characters of the true drug became forgotten. This at least seems to be the explanation of the fact that for many years past the Pareira Brava found in the shops and supposed to be genuine is a substance very diverse from the original drug,albeit not devoid of medicinal properties. More recently even this has become scarce and an inert Pareira Brava has been almost the sole

1 Hist. des Drog., Paris, 1694, part i., livre 2. cap. 14 .

2 Hist. de l'Aead. roy. des Scienecs, année 1710. 56 .

3 Traité des Maladies les plus fréquentes et des remèdes spécifiques pour les guérir, Paris, 1703. 98.

${ }_{4}$ In the volumes of Sloane MSS. No. 4045 and 3322 eontained in the British Museum, are a great many letters to Sloane from Etienne-François Geoffroy and from his younger brother Claude-Joseph, dating 1699 to 1744 .

${ }_{5}$ Tract. de Mat. Med. ii. (1741) 21-25.
- Schediasma de Parreira Brava, 1719. (ed. 2. auetior).

7 Istoria Botanica, 1675. 59. fig. 22.

8 Medicina Brasiliensis, 1648. 94.

9 Spceics Plantarum. Holmix, 1753 ; see also NFat. Med. 1749. No. 459.

10 Lunan, Hort. Jamaic. ii. (1814) 254; Deseourtilz, Flor. méd. des Antilles, iii. (1827) 231.

11 Thus it was omitted from the London pharmaeopoeias of 1809 and 1824 , and from many editions of the Edinburgh Dispensatory. 
kind obtainable. 'The true drug has however still at times appeared in the European market, and attention having been lately directed to it, ${ }^{1}$ we may hope that it will arrive in a regular manner.

The re-introduction of Pareira Brava into medical practice is due (so far as Great Britain is concerned) to Brodie ${ }^{2}$ who recommended it in 1828 for inflammation of the bladder.

Description-True Pareira Brava as derived from Chondodendron tomentosum is a long, branching, woody root, attaining 2 inches or more in diameter, but usually met with much smaller and dividing into rootlets no thicker than a quill or even than a horse-hair. It is remarkably tortuous or serpentine and marked with transverse ridges as well as with constrictions and cracks more or less conspicuous; besides which the surface is strongly wrinkled longitudinally. The bark is of a dark blackish brown or even quite black when free from earth, and disposed to exfoliate. The root breaks with a coarse fibrous fracture; the inner substance is of a light yellowish brown,-- sometimes of a dull greenish brown.

Roots of about an inch in diameter cut transversely exhibit a central column 0.2 to 0.4 of an inch in diameter, composed of 10 to 20 converging wedges of large-pored woody tissue with 3 or 4 zones divided from each other by a wavy light-coloured line. Crossing these zones are wedge-shaped woody rays, often rather sparsely and irregularly distributed. The interradial substance has a close, resinous, waxy appearance.

The root though hard is easily shaved with a knife, some pieces giving the impression when cut of a waxy, rather than of a woody and fibrous substance. The taste is bitter, well-marked but not persistent. The drug has no particular odour. Its aqueous decoction is turned inky bluish-black by tincture of iodine.

The aerial stems especially differ by enclosing a sinall but welldefined pitb.

Microscopic Structure-The most interesting character consists in the arrangement rather than in the peculiarity of the tissues composing this drug. The wavy light-coloured lines already mentioned are built up partly of sclerenchymatous cells. The other portions of the parenchyme are loaded with large starch granules, which are much less abundant in the stem.

Chemical Composition-From the examination of this dirug made by one of us in $1869,{ }^{3}$ it was shown that the bitter principle is the same as that discovered in 1839 by Wiggers in the drug hereafter described as Common False Pareira Brava, and named by him Pelosine. It was further pointed out that this body possesses the chemical properties of the Bibirine of Greenheart bark and of the Buxine obtained by Walz from the bark of Buxus sempervirens L. It was also obtained on the same occasion (1869) from the stens and roots of Cissampelos Pareira L. collected in Jamaica; but from both drugs in the very small proportion of about $\frac{1}{2}$ per cent.

Whether to Buxine (for by this name rather than Pelosine it should

¿ Hanbury in Pharm. Journ. Aug. 2-9, 1873 , pp. 81 and 102.

2 Lond. Med. Gazelte, Feb. 16, 1828 ;
Brodie, Lectures on Discases of the Urinary Organs, ed. 3. 1842. 108, 138.

3 Nenes Jahrb. f. Pharm. xxxi. (1869) 257 ; Pharm. Journ. xi. (1870) 192. 
be designated) is due the medicinal power of the druc may well be doubted. No further chemical examination of true Pareira Brava has been made.

Uses-The medicine is prescribed in chronic catarthal affections of the bladder and in calculns. From its extensive use in Brazil ${ }^{1}$ it seems deserving of trial in other complaints. Helvetius used to give it in substance, which in 5-grain doses was taken in infusion made with boiling water from the powdered root and not strained.

Substitutes - We have already pointed out how the name Pureira Brava has been applied to several other drugs than that described in the foregoing pages. We shall now briefly notice the more important

1. Stems and roots of Cissampelos Pareira L.-Owing to the diffculty of obtaining good Pareira Brava in the London market, the firm of which one of us was formerly a member (Messis. Allen and Hanburys, Plough Court, Lombard Street) caused to be collected in Jamaica under the superintendence of Mr. N. Wilson, of the Bath Botanical Gardens, the stems and root of Cissampelos Pareira L., of which it imported in 1866-67-68 about 300tb. It was found impracticable to obtain the root per se; and the greater bulk of the drug consisted of long cylindrical stems many of which had been decumbent and had thrown out rootlets at the joints. They had very much the aspect of the climbing stems of Clematis Vitalba L., and varied from the thickness of a quill to that of the forefinger, seldom attaining the diameter of an inch. The stems have a light brown bark marked longitudinally with shallow furrows and wrinkles, which sometimes take a spiral direction. Knots one to three feet apart, sometimes throwing out a branch, also occur. The root is rather darker in colour but not very different in structure from the stem.

The fracture of the stem is coarse and fibrous. The transverse section, whether of stem or root, shows a thickish, corky bark surrounding a light brown wood composed of a number of converging wedges (10 to 20 ) of very porous structure, separated by narrow medullary rays. There are no coneentric layers of wood, ${ }^{2}$ nor is the arrangement of the wedges oblique as in many other stems of the order. The drug is inodorous, but has a very bitter taste without sweetness or astringency.

2. Common False Pareira Brava-Under this name we designate the drug which for many years past has been the ordinary Pareira Brava of the shops, and regarded until lately as derived from Cissampelos Pareirc L. We have long endeavoured to ascertain, through correspondents in Brazil, from what plant it is derived, but without success. We only know that it belongs to the order Menispermacece.

'The drug consists of a ponderous, woody, tortuous stem and root, occurring in pieces from a few inches to a foot or more in length, and from 1 to 4 inches in thickness, coated with a thin, hard, dark brown

1 “Presentamente [Abutua] é reputarla diaphoretica, diuretiea e emenagoga, e usada interiormente na dóse de duas a quatro oitavas para uma libra de infusĩo ou eozimento, nas febres intermittentes, liydroîisias, e suspensũo de lochios."-Langraard,
Diccionario de Mcdicina domestica e popular, Rio de Janeiro, i. (1865) 17.

2 It is therefore entirely different to the wood figured as tlat of $C$. Parcira by liehler in Martius' Flor. Bras. xiii. pars. i. tab. 50. fig. 7 . 
bark. The pieces are cylindrical, four-sided, or more or less flattenedsometimes even to the extent of becoming ribbon-like. In transverse section, their structure appear's very remarkable. Supposing the piece to be stem, a well-defined pith will be found to occupy the centre of the first formed wood, which is a column about $\frac{1}{4}$ of an inch in diameter. This is succeeded by 10 to 15 or more concentric or oftener eccentric zones, $\frac{1}{10}$ to $\frac{2}{10}$ of an inch wide, each separated from its neighbour by a layer of parenchyme, the outermost being coated with a true bark. In pieces of true root, the pith is reduced to a mere point.

Sometimes the development of the zones has been so irregular that they have formed themselves entirely on one side of the primitive column, the other being coated with bark. The zones, including the layer around the pith (if pith is present), are crossed by numerous small medullary rays. These do not run from the centre to the circumference, but traverse only their respective zones, on the outside of which they are arched together.

The drug, when of good quality, has its wood firm, compact, and of a dusky yellowish brown hue, and a well-marked bitter taste. It exhibits under the knife nothing of the close waxy texture seen in the root of Chondodendron, but cuts as a tough, fibrous wood. Its decoction is not tinged blue by iodine. It was in this drug that Wiggers in 1839 discovered pelosine.

The drug just described which is by no means devoid of medicinal power, has of late years been almost entirely supplanted in the market by another sort consisting exclusively of stems which are devoid of bitterness and appear to be wholly inert. They are in the form of sticks or truncheons, mostly cylindrical. Cut transversely they display the same structure as the sort. last described, with a well-defined pith. The wood is light in weight, of a dull tint, and disposed to split. The bark which consists of two layers is easily detached.

3. Stems of Chondodendron tomentosum R. et P.-These have been recently imported from Brazil, and sold as Pareira Brava. ${ }^{1}$ The drug consists of truncheons about $1 \frac{1}{2}$ feet in length, of a rather rough and knotty stem, from 1 to 4 inches thick. ${ }^{2}$ The larger pieces, which are sometimes hollow with age, display, when cut transversely, a small number (5-9) nearly concentric woody zones. The youngest pieces have the bark dotted over with small dark warts.

The wood is inodorous, but has a bitterish taste like the root, of which it is probably an efficient representative. Some pieces have portions of root springing from them, and detached roots occur here and there among the bits of stem.

4. White Pareira Brava-Stems and roots of Abuta rufescens Aublet.-Mr. J. Correa de Méllo of Campinas has been good enough to send to one of us (H.) a specimen of the root and leaves ${ }^{3}$ of this plant marked Parreira Brava grande. The former we have identified with a drug received from Rio de Janeiro as Abutua Unha de Vaca, i.e. Cow-hooj

145 packages containing about $20 \mathrm{cwt}$. were offered for sale by Messrs. Lewis and Pent, drug-brokers, 11 Sept. 1873, but there had been earlier importations.

2 From these linots, whieh are at regular intervals and sometimes very protuberant, it wonld appear that the panicles of flower arise year after year.

3 I have compried these leaves wit Aublet's own speeimen in the. British Museum.-D. H. 
Abutua, and also with a similar drug found in the London market. Aublet ${ }^{1}$ states that the root of Alula rufcscons was, in the time of his visit to French Guiann, shipped from that colony to Europe as Purcira Brava blane (White Pareira Brava).

This name is well applicable to the drug before us, which consists of short pieces of a root, $\frac{1}{2}$ an inch to 3 inches thick, covered with a rough blackish bark, and also of bits of stem having a pale, striated, corky bark. Cut transversely the root displays a series of concentric zones of white amylaceous cellular tissue, each beautifully marked with narrow wedge-shaped medullary rays of dark, porous tissue. The wood of the stem is harder than that of the root, the medullary rays are closer together and broader, and there is a distinct pith.

The wood, neither of root nor stem, has any taste or smell. A decoction of the root is turned bright blue by iodine.

5. Yellow Pareira Brava-This drug of which a quantity was in the hands of a London drug-broker in 1873, is, we presume, the Pareira Brava jaune of Aublet-the bitter tasting stem of his "Abuta amara folio levi cordiformi ligno flavescente,"-a plant of Guiana unknown to recent botanists. That which we have seen consists of portions of a hard woody stem, from 1 to 5 or 6 inches in diameter, covered with a whitish bark. Tnternally it is marked by numerous regular concentric zones, is of a bright yellow colour and of a bitter taste. It probably contains berberine.

\section{COCCULUS INDICUS.}

\section{Fructus Cocculi; Cocculus Indicus; F. Coque du Levant; G. Kokkelskörner.}

Botanical Origin-Anamirta Cocculus Wight et Arnott (Menispermum Cocculus L.), a strong climbing shrub found in the eastern parts of the Indian peninsula from Concan and Orissa to Malabar and Ceylon, in Eastern Bengal, Khasia and Assam, and in the Malayan Islands.

History-It is commonly asserted that Cocculus Indicus was introduced into Europe through the Arabs, but the fact is difficult of proof; for though Avicenna ${ }^{2}$ and other early writers mention a drug having the power of poisoning fish, they describe it as a bark, and make no allusion to it as a production of India. Even Ibn Baytar ${ }^{3}$ in the 13th century professed his inability to discover what substance the older Arabian authors had in view.

Cocculus Indicus is not named by the writers of the School of Salernum. The first mention of it we have met with is by Ruellius, ${ }^{4}$ who alluding to the property possessed by the roots of Aristolochia and Cyclamon of attracting fishes, states that the same power exists in the little berries found in the shops under the name of Cocci Orientis, whicls when scattered on water stupefy the fishes, so that they may be captured by the hand.

Valerius Cordus, ${ }^{5}$ who died at Rome in 1543 , thought the drug which he calls Cuculi de Levantc, to be the fruit of a Solanum growing in Egypt.

1 Hist. des Plantes de la Guiane Françoise, i. (1775) 618. tab. 250.

- Tnlgrisi edition, 1564, lib. ii. tract. 2. cap. $48 \delta$.
3 Sontheimer's transl. ii. 460 .

- De Natura Stirpiun, Paris, 1536. lib. iii. c. 4 .

s Adnotationes, 1549. cap. 63 (p. 509). 
Dalechamps ${ }^{1}$ repeated this statement in 1586 , at which period and for long afterwards, Cocculus Indicus used to reach Europe from Alexandria and other parts of the Levant. Gerarde, ${ }^{2}$ who gives a very good figure of it, says it is well known in Fngland (1597) as Cocculus Indicus, otherwise Cocci vel Cocculce Orientales, and that it is used for destroying vermin and poisoning fish. In 1635 it was subject to an import duty of 2s. per lb., as Cocculus Indice. ${ }^{3}$

The use of Cocculus Indicus in medicine was advocated by Battista Codronchi, a celebrated Italian physician of the 16th century, in a tractate entitled De Baccis Orientalibus. ${ }^{4}$

The word Cocculus is derived from the Italian coccola, signifying a small, berry-like fruit. ${ }^{5}$ Mattioli remarks that as the berries when first brought from the East to Italy had no special name, they got to be called Coccole di Levante. ${ }^{6}$

Description-The female flower of Anamirta has normally 5 ovaries placed on a short gynophore. The latter, as it grows, becomes raised into a stalk about $\frac{1}{2}$ an inch long, articulated at the summit with shorter stalks, each supporting a drupe, which is a matured ovary. The purple drupes thus produced are 1 to 3 in number, of gibbous ovoid form, with the persistent stigma on the straight side, and in a line with the shorter stalk or carpodium. They grow in a pendulous panicle, a foot or more in length.

These fruits removed from their stalks and dried have the aspect of little round berries, and constitute the Cocculus Indicus of commerce. As met with in the market they are shortly ovoid or subreniform, $\frac{4}{10}$ to $\frac{5}{10}$ of an inch long, with a blackish, wrinkled surface, and an obscure ridge running round the back. The shorter stalk, when present, supports the fruit very obliquely. The pericarp, consisting of a wrinkled skin covering a thin woody endocarp, encloses a single reniform seed, into which the endocarp deeply intrudes. In transverse section the seed has a horse-shoe form; it consists chiefly of albumen, enclosing a pair of large, diverging lanceolate cotyledons, with a short terete radicle. ${ }^{7}$

The seed is bitter and oily, the pericarp tasteless. The drug is preferred when of dark colour, free from stalks, and fresh, with the seeds well preserved.

Microscopic Structure-The woody endocarp is built up of a peculiar sclerenchymatous tissue, consisting of branched, somewhat elongated cells. They are delisely packed, and run in various directions, showing but small cavities. The parenchyme of the seed is loaded with crystallized fatty matter.

Chemical Composition-Picrotoxin, $\mathrm{C}^{12} \mathrm{H}^{14} \mathrm{O}^{5}$, a crystallizable substance occurring in the seed to the extent of $\frac{2}{5}$ to 1 per cent., was observed by Boullay, as early as 1812, and is the source of the poisonous property of the drug. Picrotoxin does not neutralize acids. It dissolves in water and in alkalis; the solution in the latter reduces cupric oxide like the sugars, but to a much smaller extent than glucose. The alka-

1 Hist. Gen. Plant. 1586. 1722.

2 Herball, Lond. 1636. 1548-49.

3 The Rates of Marchandizes, Lond. 1635.

4 It forms part of his work De Christiance ac tuta medendi ratione, Ferrariæ, 1591.

- Frutto d'alcuni alberi, e d'alcune piante, o erbe salvatiche, come cipresso, ginepro, alloro, pugnitopo, e lentischio, e simili.Lat. bacca; Gr. ákpóspva.-Vocabolario degli A ccadcmici della Crusca.

${ }^{6}$ Quoted by J. J.von Tschudi, Die Kokkelskörner und das Pikrotoxin, St. Gallen, 1847.

7 The fruit should be macerated in order to examine its structure. 
line solution is not precipitated by chloride of ammonium. The aqucous solution of picrotoxin is not altered by any metallic salt, or by tannin, iodic acid, iodoliydrargyrate or bichromate of potassium-in fact by none of the reagents which affect the alkaloids. It may thus be easily distinguished from the bitter poisonoms alkaloids, although in its behaviour with concentrated sulphnric acid and bichromate of potassium it somewhat resembles strychnine, as shown in 1867 by Köhler.

Pelletier and Conerbe (1833) obtained from the pericarp of Cocculus Indicus two crystallizable, tasteless, non-poisonous substances, having the same composition, and terined respectively Menispermine and Paramenisperminc. These bodies, as well as the very doubtful amorphous Hypopicrotoxic Acid of the same chemists, require re-examination.

The fat of the seed which arnounts to about half its weight, is used in India for industrial purposes. Its acid constituent, formerly regarded as a peculiar substance under the name of Stecrophanic or Anamirtic Acid, was found by Heintz to be identical with stearic acid.

Commerce-Cocculus Indicus is imported from Bombay and Madras, but we have no statistics showing to what extent. The stock in the dock warehouses of London on 1st of December, 1873, was 1168 packages, against 2010 packages on the same day of the previous year. The drug is mostly shipped to the continent, the consumption in Great Britain being very small.

Uses-In British medicine Cocculus Indicus is only employed as an ingredient of an ointment for the destruction of pcdiculi. It has been discarded from the British Phurmacopceia, but has a place in that of India.

\section{GULANCHA.}

Caulis et radix Tinosporce.

Botanical Origin-Tinospora cordifolia Miers (Cocculus cordifolius DC.), a lofty climbing shrub found throughout tropical India from Kumaon to Assam and Burma, and from Concan to Ceylon and the Carnatic. It is called in Hindustani Gulancha.

History-The virtues of this plant which appear to have been long familiar to the Hindu physicians, attracted the attention of Europeans in India at the early part of the present century. ${ }^{1}$ According to a paper published at Calcutta in $1827,{ }^{2}$ the parts used are the stem, leaves, and root, which are given in decoction, infusion, or a sort of extract called pálo, in a variety of diseases attended with slight febrile symptoms.

O'Shaughnessy declares the plant to be one of the most valuable in India, and that it has proved a very useful tonic. Similar favourable testimony is borne by Waring. Gulancha was admitted to the Bcrgal Pharmacopoica of 1844, and to the Pharmacopcia of India of 1868.

Description-The stems are perennial, twining and succulent, running over the highest trees and throwing out roots many yards in length which descend like slender cords to the earth. They liave a thick corky bark marked with little prominent tubercles.

1 Fleming, Calal. of Indian Iiled. Plants and Irugs, Calcutta, 1810.27.
2 On the native ding called Gulancha by

Ram Comol Shen.-Trans. of Med. and Phys. Soc. of Calculta, iii. (1S27) 295. 
As found in the bazaars the drug occurs as short transverse segments of a cylindrical woody stem from $\frac{1}{4}$ of an inch up to 2 inches in diameter. They exhibit a shrunken appearance, especially those derived from the younger stens, and are covered with a smooth, translucent, shrivelled bark which becomes dull and rugose with age. Many of the pieces are marked with warty prominences and the scars of adventitious roots. The outer layer which is easily detached covers a shrunken parenchyme. The transverse section of the stem shows it to be divided by about 12 to 14 medullary rays into the same number of wedge-shaped woody bundles having very large vessels, but no concentric structure. The drug is inodorous but has a very bitter taste. The root is stated by $\mathrm{O}^{\prime}$ Shaughnessy ${ }^{1}$ to be large, soft and spongy.

Microscopic Structure-The suberous coat consists of alternating layers of flat corky cells and sclerenchyme, sometimes of a yellow colour. The structure of the central part reminds one of that of Cissampelos Parcira (p. 28), like which it is not divided into concentric zones. The woody rays which are sometimes intersected by parenchyme, are surrounded by a loose circle of arched bundles of liber tissue.

Chemical Composition-No analysis worthy of the name has been made of this drug, and the nature of its bitter principle is wholly unknown. We have had no material at our disposal sufficient for chemical examination.

Uses-Gulancha is reputed to be tonic, antiperiodic and diuretic. According to Waring ${ }^{2}$ it is useful in mild forms of intermittent fever, in debility after fevers and other exhausting diseases, in secondary syphilitic affections and chronic rheumatism.

Substitute-Tinospora crispa Miers, an allied species occurring in Silhet, Pegu, Java, Sumatra, and the Philippines, possesses similar properties, and is highly esteemed in the Indian Archipelago as a febrifuge

\section{BERBERIDE $A$.}

\section{CORTEX BERBERIDIS INDICUS.}

\section{Indian Barberry Bark.}

Botanical Origin-This drug is allowed in the Pharmacopacia of India to be taken indifferently from three Indian species of Berberis ${ }^{3}$ which are the following:-

1. Berberis aristata DC., a variable species occurring in the temperate regions of the Himalaya at 6000 to 10,000 feet elevation, also found in the Nilghiri mountains and Ceylon.

2. B. Lycium Royle, an erect, rigid shrub found in dry, hot situations of the western part of the Himalaya range at 3000 to 9000 feet above the sea-level.

3. B. asiatica Roxb.-This species has a wider distribution than the last, being found in the dry valleys of Bhotan and Nepal whence it

1 Bengal Dispensatory, 1842. 198.

2 Pharm. of Indica, 1868. 9.

3 For remarks on the Indian species of
Berberis, see Hooker and Thomson's Flora Indica (1855), also Hooker's Flora of British India, i. (1872) 108. 
stretches westward along the Himalaya to Garwhal, and occurs again in Affghanistan.

History-The medical practitioners of ancient Greece and Italy made use of a substance called Lycium ( $\lambda$ úkıov) of which the best kind was brought from India. It was regarded as a remedy of great value in restraining inflammatory and other discharges; but of all the uses to which it was applied the most important was the treatment of various forms of ophthalmic inflammation.

Lycium is mentioned by Dioscorides, Pliny, Celsus, Galen, and Scribonius Largus; by such later Greek writers as Paulus Egineta, IEtius, and Oribasius, as well as by the Arabian physicians.

The author of the Periplus of the Erythrean Sea who probably lived in the 1st century, enumerates dúkiov as one of the exports of Barbarike at the mouth of the Indus, and also names it along with Bdellium and Costus among the commodities brought to Barygaza:and further, lycium is mentioned among the Indian drugs on which duty was levied at the Roman custom house of Alexandria about A.D. $176-1800^{1}$

An interesting proof of the esteem in which it was held is afforded by some singular little vases or jars of which a few specimens are preserved in collections of Greek antiquities. ${ }^{2}$ These vases were made to contain lycium, and in them it was probably sold; for an inscription on the vessel not only gives the name of the drug but also that of a person who, we may presume, was either the seller or the inventor of the composition. Thus we have the Lycium of Jason, of Musceus, and of Heracleus. The vases bearing the name of Jason were found at Tarentum, and there is reason to believe that that marked Herccleus was from the same locality. Whether it was so or not, we know that a certain Heraclides of Tarentum is mentioned by Celsus ${ }^{3}$ on account of his method of treating certain diseases of the eye; and that Galen gives formulæ for ophthalmic medicines ${ }^{4}$ on the authority of the same person.

Innumerable conjectures were put forth during at least three centuries as to the origin and nature of lycium, and especially of that highly esteened kind that was brought from India.

In the year 1833, Royle ${ }^{5}$ communicated to the Linnean Society of London a paper proving that the Indian Lycium of the ancients was identical with an extract prepared from the wood or root of several species of Berberis growing in Northern India, and that this extract, well known in the bazaars as Rusot or Rasot, was in common use among the natives in various forms of eye disease. ${ }^{6}$ This substance attracted considerable notice in India, and though its efficacy $\mathrm{per}^{\mathrm{s}} \mathrm{se}^{7}$ seemed

1 Viucent, Commeree and Nuvigation of the Ansients in the Indian Oecan, ii. (1807) $390,410,734$.

2 Figures of theso vessels were publishod by Dr. J. Y. Simpson in an interesting paper entitled Notes on some aneient Greck medieal vases for containing Lyeium, of whieh we have mado free use.-Sce (Edinb.) Monthly Journal of Med. Seience, xvi. (1853) 24, also Pharm. Journ. xiii. (1854) 413.

3 Lib. vii. e. 7. - See also Cælius Aurelianus, De morbis chronicis (Haller's ed.) lib. i. c. 4 , lib. iii. c. 8 .
4 Cataplasmata lippientium quibus usus est Heraclides Tarentinus. -Galen, De Comp. Med. sec. locos, lib. iv. (p. 153 in Venieo edit. of 1625 ).

5 On the Lyeizm of Dioseorides. - Linn. Trans. xvii. (1837) 83.

6 It is interesting to find that two of the names for lyeium giren by Ibn Baytar in the 13 th century are preeisely those under which rusot is met with in the Indian bazars at the present day.

7 The natives apply it in eombination with alum and opium. 
yestionable, it was adninistered with benefit as a tonic and febrifuge. ${ }^{1}$ But the rusot of the natives being often badly prepared or adulterated, he bark of the root has of late been used in its place, and in consequence ' of its acknowledged efficacy has been admitted to the Pharmacopoeid, of India.

Description-In $B$. asiatica (the only species we have examined) the oots which are thick and woody, and internally of a bright yellow, are overed with a thin, brittle bark. The bark has a light-brown corky ayer, beneath which it appears of a darker and greenish-yellow hue, and omposed of coarse fibres running longitudinally. The inner surface as a glistening appearance by reason of fine longitudinal striæ. The ark is inodorous and very bitter.

Chemical Composition-Solly ${ }^{2}$ pointed out in 1843 that the rootbark of the Cey]on barberry $[B$. aristata $]$ contains the same yellow colouring matter as the barberry of Europe. L. W. Stewart ${ }^{3}$ extracted Berberine in abundance from the barberry of the Nilghiri Hills and Northern India, and presented specimens of it to one of us in 1865.

The root-bark of Berberis vulgaris L. was found by Polex (1836) to contain another alkaloid named Oxyacanthine, which forms with acids colourless crystallizable salts of bitter taste. ${ }^{4}$

Uses-The root-bark of the Indian barberries administered as a tincture has been found extremely useful in India in the treatment of fevers of all types. It has also been given with advantage in diarrhcea and dyspepsia, and as a tonic for general debility.

\section{RHIZOMA PODOPHYLLI.}

\section{Radix podophylli; Podophyllum Root.}

Botanical Origin-Podophyllum peltatum L., a perennial herb growing in moist shady situations throughout the eastern side of the North American continent from Hudson's Bay to New Orleans and Florida.

The stem about a foot high, bears a large, solitary, white flower, rising from between two leaves of the size of the hand composed of 5 to 7 wedge-shaped divisions, somewhat lobed and toothed at the apex. The vellowish pulpy fruit of the size of a pigeon's egg is slightly acid and is sometimes eaten under the name of May Apple. The leaves partake of the active properties of the root.

History-The virtues of the rhizome as an anthelmintic and emetic have been long known to the Indians of North America. The plant was figured in 1731 by Catesby ${ }^{5}$ who remarks that its root is an excellent emetic. Its cathartic properties were noticed by Barton in $1798^{6}$ and have been commented upon by many subsequent writers. In 1820 , podophyllum was introduced into the United States Pharmacopocia, and in 1864 into the British Pharmacopocia. Hodgson published in 1832 in the Journal of the Philadelphic College of Pharmacy ${ }^{7}$ the first chemical observations on the rhizome, which now furnishes one of the most

\footnotetext{
1 O'Shaughnessy, Bengul Dispensatory (1842) $203-205$.

2 Journ. of R. Asiat. Soc. vii. (1843) 74.

3 Pharm. Journ. vii. (1866) 303.

Gmelin, Chemistry, xvii. (1866) 197.
}

5 Nat. Hist. of Carolina, i. tab. 24.

- Collections for an Essay on Mat. Med. of U. S. Philad. 1798. 31.

7 Vol. iii. 273. 
popular purgatives, the so-called Podophyllin, manufactured on a large scalc at Cincinnati and in other places in Ancrica, as well as in England.

Description-The drug consists of the rhizome and rootlets. The former crecps to a length of several fcet, but as inported is mostly in somewhat flattenced picces of 1 to 8 inches in length and 2 to 4 lines in longest dianıcter; it is marked by knotty joints showing a depressed scar at intervals of a few inches which marks the place of a fallen stem. Each joint is in fact the growth of one year, the terminal bud being cnclosed in papery brownish sheaths. Somctimes the knots producc one, two, or even threc lateral buds and the rhizome is bi- or tri-furcate. The reddishbrown or grey surface is obscurely marked at intervals by oblique wrinkles indicating the former attachment of rudimentary leaves. The rootlcts are about $\frac{1}{2}$ a linc thick and arise from below the knots and adjaccnt parts of the rhizome, the internodal space being barc. They are brittlc, easily detached, and commonly of a palcr colour. The rhizome is mostly smooth, but some of the branched picces are dccply furrowed. Both rootstock and rootlets have a short, smooth, mcaly fracture; the transversc section is white, exhibiting only an extremely small corky layer and a thin simplc circle of about 20 to 40 ycllow, vascular bundles, enclosing a central pith which in the larger pieces is often 2 lines in diameter.

The drug has a heavy narcotic, disagreeable odour, and a bitter, acrid, nauseous taste.

Microscopic Structure-The vascular bundles are composed of spiral and scalariform vessels intermixed with cambial tissue. From each bundle a narrow-tissued, wedge- or crescent-shaped liber-bundle projects a little into the cortical layer. This, as well as the pith, exhibits large thin-walled cells. The rootlets are as usual of a different structure, their central part consisting of one group of vascular bundles more or less scattered. The parenchymatous cells of the drug are loaded with starch granules; some also contain stellate tufts of oxalate of calcium. Tannic matter is present in very small amount, as proved by perchloride of iron.

Chemical Composition-The active principles of podophyllum exist in the resin, which according to Squibb ${ }^{1}$ is best prepared by the process termed re-percolation. The powdered drug is exhausted by alcohol which is made to percolate through successive portions. The strong tincture thus obtained is slowly poured into a large quantity of water acidulated with hydrochloric acid (one measure of acid to 70 of water), and the precipitated resin dricd at a temperature not exceeding $32^{\circ} \mathrm{C}$. The acid is used to facilitate the subsidence of the pulverulent resin which according to Maisch scttles down but very slowly if precipitated by cold water simply, and if thrown down by hot water fuses into a dark brown cake which however has the advantage of being nearly free from berberine.

Resin of podophyllum thus prcpared is a light, brownish-yellow powder with a tinge of grecn, devoid of crystallinc appcarance, becoming darker if exposcd to a heat above $32^{\circ} \mathrm{C}$., and having an acrid, bittcr tastc. The drug yields $3 \frac{1}{2}$ to 5 pcr cent. of this resin which is very incorrectly called Podophyllin. The product is the same whether the rhizome or the

1 American Journ. of Pharm. xvi. (1868) 1-10. 
rootlets are exclusively employed. ${ }^{1}$ It is soluble in caustic, less freely in carbonated alkalis, and is precipitated, apparently without alteration, on addition of an acid. Ether separates it into two nearly equal portions, the one soluble in the menstruum, the other not, but both energetically purgative. From the statements of Credner ${ }^{2}$ it appears that if caustic lye is shaken with the ethereal solution, about half the resin combines with the potash while the other half remains dissolved in the ether. If an acid is added to the potassic solution, a red-brown precipitate is produced which is no longer soluble in ether nor possessed of purgative power. According to Credner, the body of greatest purgative activity was precipitated by ether from an alcoholic solution of crude podophyllin. It was however found after due purification to be soluble in ether.

F. F. Mayer ${ }^{3}$ of New York found podophyllum to contain beside the resin already mentioned, a large proportion of Berberine, and a colourless alkaloid, a peculiar (?) acid, an odoriferous principle which may be obtained by sublimation in colourless scales, and finally Saponin. From all these bodies the resin as prepared for pharmaceutical use by Squibb's process is free, provided that after precipitation, it is well washed with hot water to remove the berberine. An aqueous extract of podophyllum is devoid of cathartic power.

Uses-Podophyllum is only employed for the preparation of the resin (Resina Podophylli) which is now much prescribed as a purgative.

\section{PAPAVERACE无.}

\section{PETALA RHEADOS.}

lores Rhceados; Red Poppy Petals; F. Fleurs de Coquelicot; G. Klatschrosen.

Botanical Origin-Papaver Rhceas L.-The common Red Poppy or Corn Rose is an annual herb found in fields throughout the greater part of Europe often in extreme abundance. It almost always occurs as an accompaniment of cereal crops, frequently disappearing when this cultivation is given up. It is plentiful in England and Ireland, but less so in Scotland; is found abundantly in Central and Southern Europe and in Asia Minor, whence it extends as far as Palestine and the banks of the Euphrates. But it does not occur in India or in North America.

From the evidence adduced by De Candolle, ${ }^{4}$ it would appear that the plant is strictly indigenous to Sicily, Greece, Dalmatia, and possibly the Caucasus.

History-Papaver Rhoeas was known to the ancients, though doubtless it was often confounded with $P$. dubium $\mathrm{L}$. the flowers of which are rather smaller and paler. The petals were used in pharmacy in the time of Dodonæus (1550).

Description-The branches of the stem are upriglit, each terminating in a conspicuous long-stalked flower, from which as it opens the

75

2 Ueber Podophyllin (Dissertation), Giessen, 1869.
97.

${ }^{3}$ Am. Journ. of Pharmacy, xxxv. (1863)

4 Géogr, botanique, ii. (1855) 649. 
two sepals fall off. The delicate scarlet petals are four in number, transversely elliptical and attached below the ovary by very short, darkviolet claws. As they are broader than long, their edges overlap in the expanded flower. In the bud they are irrogularly crumpled, but when unfolded are smooth, lustrous, and unctuous to the touch. They fall off very quickly, shrink up in drying, and assume a brownish-violet tint even when dried with the utmost care. Although they do not contain a milky juice like the green parts of the plant, they have while fresh a strong narcotic odour and a faintly bitter taste.

Chemical Composition-'The most important constituent of the petals is the colouring matter, still but very imperfectly known. According to L. Meier (1846) it consists of two substances, Rhceadic and Papaveric Acids, neither of which could be obtained other than in an amorphous state. 'The colouring matter is abundantly taken up by water or spirit of wine but not by cther. The aquoous infusion is not precipitated by alum but yields a dingy violet precipitate with acetate of lead, and is coloured blackish-brown by ferric salts or by alkalis.

The alkaloids of opium cannot be detected in the petals. Attfield in particular has examined the latter (1873) for morphine but without obtaining a trace of that body.

The milky juice of the herb and capsules has a narcotic odour, and appears to cxert a distinctly sedative action. Hesse (1865) obtained from the plant a colourless, crystallizable substance, Rhoeadine, $\mathrm{C}^{21} \mathrm{H}^{21} \mathrm{NO}^{6}$, of weak alkaline reaction. It is tasteless, not poisonous, nearly insoluble in water, alcohol, ether, chloroform, benzol, or aqueous ammonia, but dissolves in weak acids. Its solution in dilute sulphuric or hydrochloric acid acquires after a time a splendid red colour, destroyed by an alkali but reappearing on addition of an acid.

Uses-Red Poppy petals are employed in pharmacy only for the sake of their fine colouring matter. They should be preferred in the fresh state.

\section{CAPSULAE PAPAVERIS.}

Frnctus Papaveris ; Poppy Capsules, Poppy Heads; F. Capsules ou Tétes
de Pavot; G. Mohnkapseln.

Botanical Origin-Papaver somniferum L. Independently of the garden-forms of this universally known annual plant, we may, following Boissier, ${ }^{1}$ distinguish three principal varietics, viz. :-

a. setigerum ( $P$. setigerum DC.), occurring in the Peloponnesus, Cyprus, Corsica and the islands of Hières, the truly wild form of the plant with acutely toothed leaves, the lobes sharp-pointed and each terminating in a bristle. The leaves, peduncles, and sepals are covered with scattered bristly hairs, and the stigmata are 7 or 8 in number.

B. glabrum-Capsule subglobular, stigmata 10 to 12 . Chiefly cultivated in Asia Minor and Egypt.

$\gamma$. album ( $P$. officinale Gmelin) - has the capsule more or less eggshaped and devoid of apertures. It is cultivated in Persia.

Besides the differences indicated above, the petals vary from white to red or violet, with usually a dark purplish spot at the base of each. ${ }^{2}$ The seeds also vary from white to slate-coloured.

1 Flora Orientalis, i. (1867) 116.

2 English growers prefer a white-flowcred poppr. 
History-The poppy has been known from a remote period throughout the easteru countries of the Mediterranean, Asia Minor, and Central Asia, in all which regions its cultivation is of very ancient date.

Syrup of poppies, a medicine still in daily use, is recommended as a sedative in catarrh and cough in the writings of the younger Mesue ( $o b$. A.D. 1015) who studied at Bagdad, and subsequently resided at Cairo as physician to the Caliph of Egypt. In the Ricettario Fiorentino said to be the earliest pharmacopoia published by authority, and of which the first edition was printed in 1498, a formula is given for the syrup as Siroppo di Papaveri semplici di Mesue; in the first pharmacopœia of the London College (1618), the medicine is prescribed as Syrupus de Meconio Mesuas.

Description-The fruit is formed by the union of 8 to 20 carpels, the edges of which are turned inwards and project like partitions towards the interior, yet without reaching the centre, so that the fruit is really one-celled. In the unripe fruit, the sutures of the carpels are distinctly visible externally as shallow longitudinal stripes.

The fruit is crowned with a circular disc, deeply cut into angular ridge-like stigmas in number equal to the carpels, projecting in a stellate manner with short obtuse lobes. Each carpel opens immediately below the disc by a pore, out of which the seeds may be shaken; but in some varieties of poppy the carpel presents no aperture even when fully ripe. The fruit is globular, sometimes flattened below, or it is ovoid; it is contracted beneath into a sort of neck immediately above a tumid ring at its point of attachment with the stalk. Grown in rich moist ground in England, it often attains a diameter of three inches, which is twice that of the capsules of the opium poppy of Asia Minor or India. While growing it is of a pale glaucous green, butat maturity becomes yellowish brown, often marked with black spots. The outer wall of the pericarp is smooth and hard; the rest is of a loose texture, and while green exudes on the slightest puncture an abundance of bitter milky juice. The interior surface of the pericarp is rugose, and minutely and beautifully striated transversely. From its sutures spring thin and brittle placentæ directed towards the centre and bearing on their perpendioular faces and edges a vast number of minute reniform seeds.

The unripe fruit has a narcotic odour which is destroyed by drying; and its bitter taste is but partially retained.

Microscopic Structure-The outer layer consists of a thin outicle exhibiting a large number of stomata; the epidermis is formed of a row of small thick-walled cells. Fragments of these two layers, which on the whole exhibit no striking peculiarity, are always found in the residue of opium after it has been exhausted by water.

The most interesting part of the constituent tissues of the fruit is the system of laticiferous vessels, which is of an extremely complicated nature inasmuch as it is composed of various lzinds of cells intimately interlaced so as to form considerable bundles. ${ }^{1} \quad$ The cells containing the milky juice are larger but not so much branched as in many other plants.

Chemical Composition-The analyses of poppy heads present discrepant results with regard to morphine. Merck and Winckler detected it in the ripe fruit to the extent of 2 per cent., and it has also been found by Groves (1854) and by Deschamps d'Avallon (1864). Other chemists have been unable to find it.

1 For particulars see Trécul, Ann. des Sciences Nat. r. (1866) 49. 
In recent pharmacopocias poppy heads are directed to be taken previous to complete maturity, and both Meurein and Aubergier have shown that in this state they are richer in morphine than when more arlvanced. Deschamps d'Avallon found them sometimes to contain narcotine. He also obtained mucilage perceptible lyy neutral acetate of lead, ammonium salts, meconic, tartaric, and citric acid, the ordinary mineral acids, wax, and lastly two new crystalline bodies, Paparevin, and Papaverosine. The former is not identical with Merck's alkaloirl of the same name; although nitrogenous and bitter, it has an acid reaction (?) yet does not combine with bases. It yields a blue precipitate with a solution of iodine in iodide of potassium.

Papaverosine on the other hand is a base to which sulphuric acid imparts a violet colour, changing to dark yellowish-red on addition of nitric acid.

In ripe poppy heads, Hesse (1866) found Rhceadine. Groves in 1854 somewhat doubtfully announced the presence of Cocleine. Ripe poppy capsules (seeds removed) dried at $100^{\circ} \mathrm{C}$. afforded 14.28 per cent. of ash, consisting chiefly of alkaline chlorides and sulphates, with but a small quantity of phosphate.

Production-Poppies are grown for medicinal use in many parts of England, mostly. on a small scale. The large and fine fruits (poppy heads) are usually sold entire; the smaller and less sightly are broken and the seeds having been removed, are supplied to the druggist for pharmaceutical preparations. The directions of the pharmacopœia as to the fruit being gathered when " nearly ripe" does not appear to be much regarded.

Uses-In the form of syrup and extract, poppy heads are in common use as a sedative. A hot decoction is often externally applied as an anodyne.

\section{OPIUM.}

Botanical Origin-Papaver somniferum L., see preceding article.

History-The medicinal properties of the milky juice of the poppy have been known from a remote period. Theophrastus who lived in the beginning of the 3rd century B.C. was acquainted with the substance in

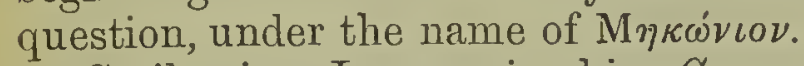

Scribonius Largus in his Compositiones Medieamentorum ${ }^{1}$ (eirca A.D. 40) notices the method of procuring opium, and points out that the true drug is derived from the capsules, and not from the foliage of the plant.

About the year 77 of the same century, Dioscorides ${ }^{2}$ plainly distinguished the juice of the capsules under the name of omós from an extract of the entire plant, $\mu \eta \kappa \omega v \epsilon \iota \nu$, which he regarded as much less active. He described exactly how the capsules should be incised, the performing of which operation he designated by the verb omi $\zeta_{\ell \iota \nu}$. We may infer from these statements of Dioscorides that the collection of opium was at that early period a branch of industry in Asia Minor. The same authority alludes to the adulteration of the drug with the milky juices of Glaueium and Laetuea, and with gum.

Pliny ${ }^{3}$ devotes some space to an account of Opion, of which he describes the medicinal use. The drug is repeatedly mentioned as 22.

1 Ed. Bernhold, Argent. 1786, c. iii. sect.

2 Lib. iv. c. 65.

3 Lib. $x x$. c. 76. 
Lacrima papaveris by Celsus in the 1st century, and more or less particularly by numerous later Lutin authors. During the classical period of the Roman Empire as well as in the early middle ages, the only sort of opium known was that of Asia Minor.

The use of the drug was transmitted by the Arabs to the nations of the East, and in the first instance to the Persians. From the Greek word ómós, juice, was formed the Arabic word Afyun, which has found its way into many Asiatic languages. ${ }^{1}$

The introduction of opium into India seems to have been comnected with the spread of Islamism and may have been favoured by the Mahommedan prolubition of wine. The earliest mention of it as a production of that country occurs in the travels of Barbosa ${ }^{2}$ who visited Calicut on the Malabar coast in 1511. Among the more valuable drugs the prices of which he quotes, opium occupies a prominent place. It was either imported from Aden or Cambay, that from the latter place being the cheaper, yet worth three or four times as much as camphor or benzoin.

Pyres $^{3}$ in his letter about Indian drugs to Manuel, king of Portugal, written from Cochin in 1516, speaks of the opium of Egypt, that of Cambay and of the kingdom of Coûs (Kus Bahár, S.W. of Bhotan) in Bengal. He adds that it is a great article of merchandize in these parts and fetches a good price; - that the kings and lords eat of it; and even the common people, though not so much because it costs dear.

Garcia d' Orta ${ }^{4}$ informs us that the opium of Cambay in the middle of the 16th century was chiefly collected in Malwa, and that it is soft and yellowish. That from Aden and other places near the Erythrean Sea is black and hard. A superior kind was imported from Cairo, agreeing as Garçia supposed with the opium of the ancient Thebaïd, a district of Upper Egypt near the modern Karnak and Luksor.

Prosper Alpinus ${ }^{5}$ who visited Egypt in 1580-83, states that opium or meconium was in his time prepared in the Thebaild from the expressed juice of poppy heads. Opium thebaïcum was however mentioned long before this, by Simon Januensis, ${ }^{6}$ physician to Pope Nicolas IV. (A.D. 1288-92), who also alludes to meconium as the dried juice of the pounded capsules and leaves. According to Unger's investigations (1857) Thebaic opium was not known to the ancient imhabitants of Egypt.

The German traveller Kämpfer who visited Persia about 1687 describes the various kinds of opium prepared in that country. The best sorts were flavoured with nutmeg, cardamom, cinnamon and mace, or simply with saffron and ambergris. Such compositions were called Theriakc and were held in great estimation during the middle ages and probably supplied to a large extent the place of pure opium. It was not uncommon for the sultans of Egypt of the 15th century to. send presents of Theriaka to the doges of Venice and the sovereigns of Cyprus. ${ }^{7}$

1 There are no ancient Chinese or Sanskrit names for opium. In the former language the drug is called 0 -fu-ynung from the Arabic. Two other names $Y a-p i e n$ and $O$-pien are adaptations to the Chinese idiom of our word opiam. 'There are several other designations which may be translated Smoking dirt, Forcign poison, Black commodity, \&c.

2 Coasts of East Africa and Malabar (Hakluyt Soc.), Lond. 1866. 206, 223.
3 Jorn. dc Soc. Pharm. Lusit. ii. (1838) 36.

4 Aromatum ... Historia, edit. Clusius, Antv. 1574. lib. i. c. 4.

5 De Medicina Aigyptionum, Lugd. Bat. 1719. 261.

6 Clavis Sanationis, Venet. 1510. 46.

7 De Mas Latrie, Hist. de Chyprc, iii. 406. 483; Muratori, Rcrum Italic. Scriptorcs, xxii. 1170 ; Amari, I diplomi Arabi del archivio Fiorentino. Firenze, 1863. 358. 
In medireval Europe opium seems not to have been reckoned among the more costly drugs; in the 16 th century we find it quoted at the same price as benzoin, and much cheaper than camphor, rhubarb, or manna. ${ }^{1}$

With regard to China it is supposed that opium was first brought thither by the Arabians, who are known to have traded with the southern ports of the empire as early as the 9th century. More recently, at least until the 16tl century, the Chinese imported the drug in their junks as a return cargo from India. At this period it was used ahmost exclusively as a remedy for dysentery, and the whole quantity imported was very small. It was not until 1767 that the importation reached 1000 chests, at which rate it continued for some years, most of the trade being in the hands of the Portuguese. T'he East India Company made a small adventure in 1773 ; and seven years later an opium depôt of two small vessels was established by the English in Lark's Bay, south of Macao.

The Chinese authorities began to complain of these two ships in 1793 but the traffic still increased, and without serious interruption until 1820 when an edict was issued forbidding any vessel having opium on board to enter the Canton river. This led to a system of contraband trade with the connivance of the Chinese officials, which towards the expiration of the East India Company's charter in 1834, had assumed a regular character. The political difficulties between England and China that ensued shortly after this event, and the so-called Opium War, culminated in the Treaty of Nanking (1842), by which five ports of China were opened to foreign trade, and opium was admitted as a legal article of commerce. ${ }^{2}$

The vice of opium-snoking began to prevail in China in the second half of the 17 th century, ${ }^{3}$ and in another hundred years had spread like a plague over the gigantic empire. The first edict against the practice was issued in 1796, since which there have been innumerable enactments and memorials, ${ }^{4}$ but all powerless to arrest the evil which is still increasing in an alarming ratio. Mr. Hughes, Commissioner of Customs at Amoy, thus wrote on this subject in his official Trade Report ${ }^{5}$ for the year 1870:- "Opiun-smoking appears here as elsewhere in China to be becoming yearly a more recognized habit,-almost a necessity of the people. Those who use the drug now do so openly, and native public opinion attaches no odium to its use, so long as it is not carried to excess. ... In the city of Amoy and in adjacent cities and towns, the proportion of opium-smokers is estimated to be from 15 to 20 per cent. of the adult population. ... In the country the proportion is stated to be from 5 to 10 per cent. ..."

Production-The poppy in whatever region it may grow always contains a milky juice possessing the same properties; and the collection of opium is possible in all temperate and subtropical countries where the rainfall is not excessive. But the production of the drug is limited by other conditions than soil and climate, among which the value of land and labour stands pre-eminent.

1 Fontanon, Edicts ct ordonnanccs des roys de France, ii. (1585) 347.

2 For more ample particulars on these momentous events, see S. Wells Williams's Middle Kingdom, vol. ii. (1848); British Almanac Companion for 1844, p. 77.

3 Pretschneider, Study of Chincse Bot. Works, 1870.47.

4 Chincse Ripositomy, vol. v. (1837) vi. \&c.

5 Addressed to the Inspector-General of Customs, Pekiu, and published at Shanghai, 1871. 
At the present day opium is produced on an important scale in Asia Minor, Persia, India, and China; to a small extent in Egypt. The drug has also been collected in Europe, Algeria, ${ }^{1}$ North America, ${ }^{2}$ and Australia, ${ }^{3}$ but more for the sake of experiment than as an object of commerce.

We shall describe the production of the different kinds under their several names.

1. Opium of Asia Minor; Turkey, Smyrna, or Constantinople Opium. * The poppy from which this most important kind of opium is obtained is Papaver somniferum, var. $\beta$. glabrum Boissier. The flowers are commonly purplish, but sometimes white, and the seeds vary from white to dark violet.

The cultivation is carried on throughout Asia Minor, both on the more elevated and the lower lands, the cultivators being mostly small peasant proprietors. The plant requires a naturally rich and moist soil, further improved by manure, not to mention much care and attention on the part of the grower. Spring frosts, drought, or locusts sometimes effect its complete destruction. The sowing takes place at intervals from November to March, partly to insure against risk of total failure, and partly in order that the plants may not all come to perfection at the same time.

The plants flower between May and July according to the elevation of the land. A few days after the fall of the petals the poppy head being about an inch and a half in diameter is ready for incision. The incision is made with a knife transversely, about half-way up the capsule, and extends over about two-thirds the circumference, or is carried spirally to beyond its starting point. Great nicety is required not to cut too deep so as to penetrate the capsule, as in that case some of the juice would flow inside and be lost. The incisions are generally made in the afternoon and the next morning are found covered with exuded juice. This is scraped off with a lnife, the gatherer transferring it to a poppy leaf which he holds in his left hand. At every alternate scraping, the knife is wetted with saliva by drawing it through the mouth, the object being to prevent the adhesion of the juice to the blade. Each poppy-head is, as a rule, cut only once; but as a plant produces several heads all of which are not of proper age at the same time, the operation of incising and gathering has to be gone over two or three times on the same plot of ground.

As soon as a sufficient quantity of the half-dried juice has been collected to form a cake or lump, it is wrapped in poppy leaves and put for a short time to dry in the shade. There is no given size for cakes of opium, and they vary in weight from a few ounces to more than two pounds. In some villages it is the practice to make the masses larger than in others. Before the opium is ready for the market, a meeting of buyers and sellers is held in each district, at which the price to be asked is discussed and settled,-the peasants being most of them in debt to the buyer's or merchants.

1 Plarm. Journ. xv. (1S:56) 348.

2 Am. Journ. of Phar. aviii. (1870) 124 ;

Jour'n. of Soe of Arts, Dec. 1, 1871.

3 Pharm. Journ. Oct. 1, 1870. 272.

4 Much information under this head has been derived from a paper On the production of Upium in Asia Minor by S. H. Maltass (Pharm. Journ. xiv. 1855. 395), and one On the Culture and Commeree in Opium in Asia Minor, by E. R. Heffler, of Smyrua (Pharm. Journ. x. 1869.434). 
'To the latter the opium is sold in a very soft but natural state. These dealers sometimes manipulate the soft drug with a wooden pestle into larger masses which they euvelope in poppy leaves and pack in cotton bags sealed at the mouth for transport to smyrna. According to another account, the opium as obtained from the grower is at once packed in bags tegether with a quantity of the little chaffy fruits of a dock (Rumex sp.) to prevent the lumps from sticking together, and so brought in baskets to Sinyrna, or ports farther north.

The opiun remains in the baskets (placed in cool warehouses to avoid loss of weight) till sold, and it is only on reaching the buyer's warehouse that the seals are broken and the contents of the bags exposed. This is done in the presence of the buyer, seller, and a public examiner, the last of whom goes through the process of inspecting the drug piece by piece, throwing aside any of suspicious quality. Heffler of Sinyma asserts that the drug is divided into three qualities, viz.-the prime, which is not so much a selected quality as the opium of some esteemed districts,- the current which is the nercantile quality and constitutes the great bulk of the crop,- and lastly the inferior or cluiginti. ${ }^{1}$ The opium of very bad quality or wholly spurious he would place in a fourth category. Maltass applies the name chiqinti (or chicantec) to opium of every degree of badness.

The examination of opium by the official expert is not conducted in any scientific method. His opinion of the drug is based on coleur, odour, appearance and weight, and appears to be generally very correct. Fayk Bey (1867) has recommended the Turkish government to adopt the more certain method of assaying opium by chemical means.

In A sia Minor the largest quantities of opium are now produced in the north-western districts of Karahissar Sahib, Balahissar, Kutaya, and Geiveh, the last on the river Sakariyeh which runs into the Black Sea. These centres of large production of opium send a superior quality of the drug to Constantinople by way of Izmid. Angora and Amasia are other places in the north of Asia Minor whence opium is obtained.

In the centre of the peninsula Afium Karahissar (literally opiumblack-castle) and Ushak are important localities for opium, which is also the case with-Isbarta, Buldur and Hamid farther south. The product of these districts finds its way to Smyrna, in the immediate neighbourhood of which but little opium is produced. The export from Smyrna in 1871 , in which year the crop was very large, was 5650 cases, valned at $£ 784,500 .^{2}$

Turkey Opium as it is generally called in English trade, occurs in the form of rounded masses which according to their softness become more or less flattened or many-sided, or irregular by mutual pressure in the cases in which they are packed. There appears to be no rule as to their weight ${ }^{3}$ which varies from an ounce up to more than $6 \mathrm{fb}$.; from $\frac{1}{2} 1 \mathrm{~b}$. to $2 \mathrm{ft}$. is however the most usual. The exterior is covered with the remains of poppy leaves strewn over with the Rumex chaff before alluded to, which together make the lumps sufficiently dry to be easily handled. The consistence is such that the drug can be readily cut with a knife, or moulded between the fingers. The interior is moist

1 Probably signifying refuse, - that whieh comes out.

2 Consul Cumberbatch, Trade Report for

3 The largest lump I have seen weighed $6 \mathrm{tb} .60 \%$, being part of 65 packages which I examined 2nd July, 1873.-D. H. 
and coarsely granular, varying in tint from a light ehestnut to a blackish brown. Fine shreds of the epidermis of the poppy capsule are perceptible even to the naked eye, but are still more evident if the residue of opium washed with water, is moistened with dilute chromic acid ( 1 to 100). The odour of Turkey opium is peculiar, and though commonly described as narcotic and unpleasant, is to many persons far from disagreeable. The taste is bitter.

The substances alleged to be used for adulterating Turkey opium are sand, pounded poppy capsules, pulp of apricots or figs, gum tragacauth or even turpentine. Bits of lead are sometimes found in the lumps, also stones and little masses of clay.

2. Egyptian Opium - though not so abundant as formerly is still met with in European commerce. It usually occurs in hard, flattish cakes about 4 inches in diameter covered with the remnants of a poppy leaf, but not strewn over with rumex-fruits. We have also seen it (1873) as freshly imported, in a soft and plastic state. The fractured surface of this opium (when hard) is finely porous, of a dark livercolour, shining here and there from imbedded particles of quartz or gum, and reddish-yellow points (of resin?). Under the microscope an abundance of starch granules is sometimes visible. The morphine in a sample from Merck amounted to 6 per cent.

According to Von Kremer who wrote in $1863,{ }^{1}$ there were then in Upper Egypt near Esneh, Kenneh, and Siout, as much as 10,000 feddan (equal to about the same number of English acres) of land cultivated with the poppy from which opium was obtained in March, and seed in April. Hartmann ${ }^{2}$ states that the cultivation is carried on by the government, and solely for the requirement of the sanitary establishments.

S. Stafford Allen in 1861 witnessed the collection of opium at Kenneh in Upper Egypt, ${ }^{3}$ from a white-flowered poppy. An incision is made in the capsule by running a knife twice round it transversely, and the juice scraped off the following day with a sort of scoop-knife. The gatherings are collected on a leaf and placed in the sun to harden. The produce appeared extremely small and was said to be wholly used in the country.

Gastinel, director of the Experimental Garden at Cairo, and government inspector of pharmaceutical stores, has shown (1865) that the poppy in Egypt might yield a very good product containing 10 to 12 per cent. of morphine, and that the present bad quality of Egyptian opium is due to an over-moist soil, and a too early scarification of the capsule, whereby (not to mention wilful adulteration) the proportion of morphine is reduced to 3 or 4 per cent.

In $1872,9636 \mathrm{Hb}$. of opium, value $£ 5023$, were imported into the United Kingdom from Egypt.

3. Persian Opium-Persia, probably the original home of the baneful practice of opium-eating, cultivates the drug chiefly in the central provinces where according to Boissier, the plant grown to furnish it is Papaver somniferum, var. $\gamma$ album ( $P$. officinale $\mathrm{Gm}$.) having ovate roundish capsules. Poppy heads from Persia which we

\footnotetext{
1 Aegypten, Forsehungen über Land und Volk während eines 10 jährigen Aufenthaltes, J.eiprig, 1863.

${ }^{2}$ Naturgesehiehtl. medicin. Skizze der Nilländer, Berlin, 1866. 353.

${ }^{3}$ Pharm. Joum. iv. (1868) 199.
} 
saw at the Paris Exhibition in 1867, had vertical incisions and contained white seeds.

The strongest opium called in Persia Teriak-e-Arabistani is obtained in the neighbourhood of Dizful and Shuster, east of the Lower Tigris. Good opium is likewise produced abont Sari and Balfarush in the province of Mazanderan, and in the southern province of Kerman. The lowest quality which is mixed with starch and other matters, is sold in light brown sticks; it is made at Shahabdulazim, Kashan, and Kum. ${ }^{1}$ A large quantity of opium appears to be produced in Khokan and Turkestan.

Persian opium is carried overland to China through Bokhara, Khokan and Kashgar; ${ }^{2}$ but since 1864 it has also been extensively conveyed thither by sea, and it is now quoted in trade reports like that of Malwa, Patna, and Benares. ${ }^{3}$ It is exported by way of Trebizond to Constantinople where it used to be worked up to imitate the opium of Asia Minor, and at the same time adulterated. ${ }^{4}$ Since 1870, Persian opium which was previously rarely seen as such in Europe, has been imported in considerable quantity. It occurs in various forms, the most typical being a short rounded cone weighing 6 to 10 ounces. We have also seen it in flat circular cakes, $1 \frac{1}{4} \mathrm{t}$. in weight. In both forms the drug was of firm consistence, a good opinm-smell, and internally brown of a comparatively light tint. The surface was strewn over with remnants of stalks and leaves. Some of it had been collected with the use of oil as in Malwa (see p. 48), which was apparent from the greasiness of the cone, and the globules of oil visible when the drug was cut. The best samples of this drug as recently imported, have yielded 8 to $10 \cdot 75$ per cent. of morphine, reckoned on the opium in its moist state. ${ }^{5}$

Carles, ${ }^{6}$ from a specimen which seems to have been adulterated with sugar, obtained 8.40 per cent. of morphine, and 3.60 of narcotine, the drug not having been previously dried.

Inferior qualities of Persian opium have also been imported. Some that was soft, black and extractiform afforded undried only 3 to $\frac{1}{2}$ per cent. of morphine (Howard); while some of very pale liue in small sticks, each wrapped in paper, yielded no more than 0.2 per cent.! (Howard). For futher details, see p. 57.

4. European Opium-From numerous experiments made during the present century in Greece, Italy, France, Switzerland, Germany, England, and even in Sweden, it has been shown that in all these countries a very rich opium, not inferior to that of the East, can be produced.

1 Polak, Persien, ii. (1865) 248, \&c.

2 Powell, Economic Products of the Punjab, i. (1868) 294.

3 Thus in the Trade Report for Foochow, for 1870, addressed to Mr. Hart, InspectorGeneral of Customs, Pekin, is the following table:

Imports of Opium in 1867 . . chests 2327

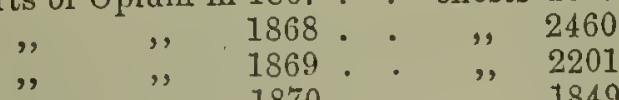

$\begin{array}{lcc}\text { Patna } & \text { Benares } & \text { Persian } \\ 1673 & 724 & 300 \\ 1257 & 377 & 544 \\ 1340 & 410 & 593 \\ 1283 & 245 & 630\end{array}$

4 Letter from Mr. M̈crck to Dr. F. 1863.

5 Information kindly given us (9th June, 1873) by Mr. W. Dillworth Howard, of the firn of Howard and Sons, Stratford. A morphinc manufacturer has no particular interest in asccrtaining the amount of watcr in the opium he purchases. All he requires to know is the perccntage of morphine which the drug contains. It is otherwisc with the pharnaceutist, whose prepalations have to be made with aried opium.

- Journ. de Pharm. xvii. (1873) 427. 
The most numerous attempts at opium-growing in Europe have been made in France. But although the cultivation was recommended in the strongest terms by Guibourt, ${ }^{1}$ who found in French opium the highest percentag'e of morphine yet observed (22.88 per cent.), it has never become a serious branch of industry.

Aubergier of Clermont-Ferrand has carried on the cultivation with great perseverance since 1844, and has succeeded in producing a very pure inspissated juice which he calls Affum and which is said to contain uniformly 210 per cent. of morphine. It is made up in cakes of 50 grammes, but is scarcely an article of wholesale commerce. ${ }^{3}$

Some careful and interesting scientific investigations relating to the production of opium in the neighbourhood of Amiens, were made by Decharme in 1855 to 1862 . $^{4}$ He found 14,725 capsules incised within 6 days to afford 431 grammes of milky juice, yielding 205 grammes (= $=47.6$ per cent.) of dry opium containing 16 per cent. of morphine. Another sample of dried opium afforded 20 per cent. of morphine. Decharme observed that the amount of morphine diminished when the juice is very slowly dried,-a point of great importance deserving attention in India. The peculiar odour of opium as observable in the oriental drug, is developed according to the same authority, by a kind of fermentation. Adrian ${ }^{5}$ even suggests that morphine is formed only by a similar process, inasmuch as he could obtain none by exhausting fresh poppy capsules with acidulated alcohol, while capsules of the same crop yielded an opium rich in morphine.

5. East Indian Opium-The principal region of British India distinguished for the production of opium is the central tract of the Ganges, comprising an area of about 600 miles in length, by 200 miles in width. It reaches from Dinajpur in the east, to Hazaribagh in the south, and Gorakhpur in the north, and extends westward to Agra, thus including the flat and thickly-populated districts of Behar and Benares. The amount of land here actually under poppy cultivation was estimated in $1871-72$ as 560,000 acres.

The region second in importance for the culture of opium consists of the broad table-lands of Malwa, and the slopes of the Vindhya Hills, in the dominions of the Holkar.

Beyond these vast districts, the area under poppy cultivation is comparatively small, ${ }^{6}$ yet it appears to be on the increase. Stewart ${ }^{7}$ reports (1869) that the plant is grown (principally for opium) throughout the plains of the Punjab, but less commonly in the north-west. In the valley of the Biás east of Isahore, it is cultivated up to nearly 7500 feet above the sea-level.

The manufacture of opium in these parts of India is not under any restriction as in Hindustan. Must districts, says Powell (1868), cultivate the poppy to a certain extent, and produce a small quantity of indifferent opium for local consumption. The drug however is

1 Journ. de Pharm. xli. (1862) 184, 201.

2 How this uniformity is ensured we know not.

3 Dorvault, Offieine, éd. 8. 1872. 648.

4 They are recorded in several pamphlets, for which we are indebted to the author, reprinted from the Mem. de l'Aead. du département de la Somme and the Mém. de l'Académie Stanislas.
5 Journ. de Pharm. vi. (1867) 222.

6 So we may infer from the fact that of the 39,225 chests which paid duty to Government at Bombay in 1872, 37,979 were Malwa opium, the remaining 1246 being reckoned as from Guzerat.- Statement of the Trade and Nav. of Bombay for 1871-72, p. xv.

7 Punjab Plants, Lahore, 1869. 10.

8 Op. cit. i. 294. 
prepared in the Hill States, and the opium of Kúlú (E. of Lahore), is of excellent quality, and forms a stiple article of trade in that region. Opium is also produced in Nepal, Basálíir and Rímpúr, and at Doda Kashtwar in the Jammú territory. ${ }^{1}$ It is exported from these districts to Yarkand, Khutan, Aksu, and other Chinese provinces,- - to the extent in 1862 of 210 maunds $(=16,890 t h)$. The Madras Presidency exports no opium at all.

T'he opium districts of Bengal, ${ }^{2}$ are divided into two agencies, those of Behar and Benares, which are under the control of officials residing respectively at Patna and Ghazipur. The opium is a government monoply :- that is to say, the cultivators are under an obligation to sell their produce to the government at a price agreed on beforehand; at the same time it is wholly optional with them, whether to enter on the cultivation or not.

The variety of poppy cultivated is the same as in Persia, namely, $P$. somniferum, var. $y$ album. As in Asia Minor, a moist and fertile soil is indispensable. ${ }^{3}$ The plant is liable to injury by insects, excessive rain, hail, or the growth on its roots of a species of Orobanche.

In Belrar the sowing takes place at the beginning of November, and the capsules are scarified in February or March (March or April in Nalwa). This operation is performed with a peculiar instrument, called a nushtur, having three or four two-pointed blades, bound together with cotton thread. ${ }^{4}$ In using the nushtur, only one set of points is brought into use at a time, the capsule being scarified vertically from base to summit. This scarification is repeated on different sides of the capsule at intervals of a few days, from two to six times. In many districts of Pengal, transverse cuts are made in the poppy-head as in Asia Minor.

The milky juice is scraped off early on the following morning with an iron scoop, which as it becomes filled is emptied into an earthen pot carried by the collector's side. In Malwa a flat scraper is used which, as well as the fingers of the gatherer, is wetted from time to time with linseed oil to prevent the adhesion of the glutinous juice. All accounts represent the juice to be in a very moist state by reason of dew, which sometimes even washes it away; but so little is this moisture of the juice thought detrimental that, as Butter states, ${ }^{5}$ the collectors in some places actually wash their scrapers in water, and add the washings to the collection of the morning !

The juice when brought home is a wet granular mass of pinkish colour; and in the bottom of the vessel in which it is contained, there collects a dark fluid resembling infusion of coffee, which is called paséwá. The recent juice strongly reddens litmus, and blackens metallic iron. It is placed in a shallow earthen vessel, which is tilted in such a manner that the paséwá may drain off as long as there is any of it to be separated. This liquor is set aside in a covered vessel. The residual mass is now exposed to the air, thongh never to the sun, and turned over every few days to promote its attaining the proper degree of

1 At the base of the Himalaya, S. and S.I. of Kashmir.

2 Much of what follows respecting Bengal opium is derived from a paper by Eatwell, formerly First Assistant and Opium Examiner in the Govermunent Factory at Ghazilmi.-Pharm. Journ. xi. (1852) 269, \&c.
3 It is said (1873) that the ground deroted to poppy-eulture in Bengal is becoming impoverished and that the plant no longer attains its nsual dimensions.

${ }_{4}$ For figures of the instrument, see

Pharm. Journ. xi. (1852) 207.

" Pharm. Journ. xi. (1852) 209. 
dryness, which according to the Benares regulations, allows of 30 per cent. of moisture. This drying operation occupies three or four weeks.

The drug is then taken to the Government factory for sale; previous to being sold it is examined for adulteration by a native expert, and its proportion of water is also carefully determined. Having been received into stock, it undergoes but little treatment beyond a thorough mixing, until it is required to be formed into globular cakes. This is effected in a somewhat complicated manner, the opium being strictly of standard consistence. First the quantity of opium is weighed out, and having been formed into a ball is enveloped in a crust of dried poppy petals, skilfully agglutinated one over the other by means of a liquid called léwá. This consists partly of good opium, partly of paséwá, and partly of opium of inferior quality, all being mixed with the washings of the various pots and vessels which have contained opium, and then evaporated to a thick fluid, 100 grains of which should afford 53 of dry residue. These various things are used to form a ball of opium in the following proportions :-

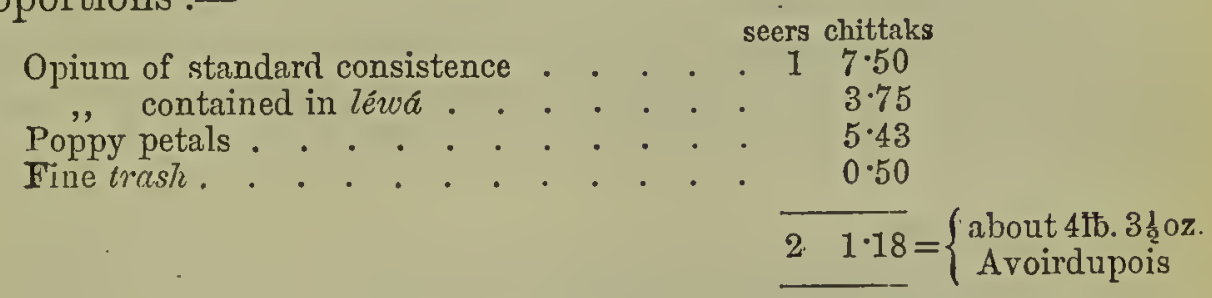

The finished balls usually termed cakes, which are quite spherical and have a diameter of 6 inches, are rolled in poppy trash which is the name given to the coarsely powdered stalks, capsules and leaves of the plant; they are then placed in small dishes and exposed to the direct influence of the sun. Should any become distended, it is at once opened, the gas allowed to escape, and the cake made up again. After three days the cakes are placed, by the end of July, in frames in the factory where the air is allowed to circulate. They still however require constant watching and turning, as they are liable to contract mildew which has to be removed by rubbing in poppy trash. By October the cakes have become perfectly dry externally and quite hard, and are in condition to be packed in cases ( 40 cakes in each) for the China market which consumes the great bulk of the manufacture.

For consumption in India the drug is prepared in a different shape. It is inspissated by solar heat till it contains only 10 per cent. of moisture, in which state it is formed into square cakes of $2 \mathrm{tb}$. each which are wrapped in oiled paper, or it is made into flat square tablets. Such a drug is known as Abkári Opium.

The Government opium factories in Bengal are conducted on the most orderly system. The care bestowed in selecting the drug, and in excluding any that is damaged or adulterated is such that the nierchants who purchase the commodity rarely require to examine it, although permission is freely accorded to open at each sale any number of chests or cakes they may desire. In the year 1871-72 the number of chests sold was 49,695 , the price being $£ 139$ per chest, which is $£ 26$ higher than the average of the preceding year. The net profit on each chest was $£ 90.1$

1 Statement exhibiting the moral and malerial progress and condition of India 
In Malwa the manufacture of opium is left entirely to private enterprise, the profit to Government being derived from an export duty of 600 rupees ( $£ 60$ ) per chest. ${ }^{1}$ As may readily be supposed, the drug is of much less miform quality than that which has passed through the Bengal agencies, and having no guarantee as to purity it commands less confidence.

Malwa opium is not made into balls, but into rectangular masses, or bricks which are not cased in poppy petals; it contains as much as 95 per cent. of dry opium. Some opimm sold in London as Malua Opium in 1870 had the form of rounded masses covered with vegetable remains. It was of firm consistence, dark colour, and rather smoky odour. W. D. Howard obtained from it (undried) 9 per cent. of morphine. Other importations afforded the same chemist $4 \cdot 8$ and 6 per cent. respectively.

The chests of Patna opium hold 120 catties or $160 \mathrm{Hb}$. Those of Malwa opium 1 pecul or $133 \frac{1}{3} l b$.

The quantity of opium produced in India cannot be ascertained, but the anount exported ${ }^{2}$ is accurately known. Thus from British India the exports in the year ending March 31, 1872, were 93,364 chests valued at $£ 13,365,228$. Of this quantity Bengal furnished 49,455 chests, Bombay 43,909 chests : they were exported thus:-

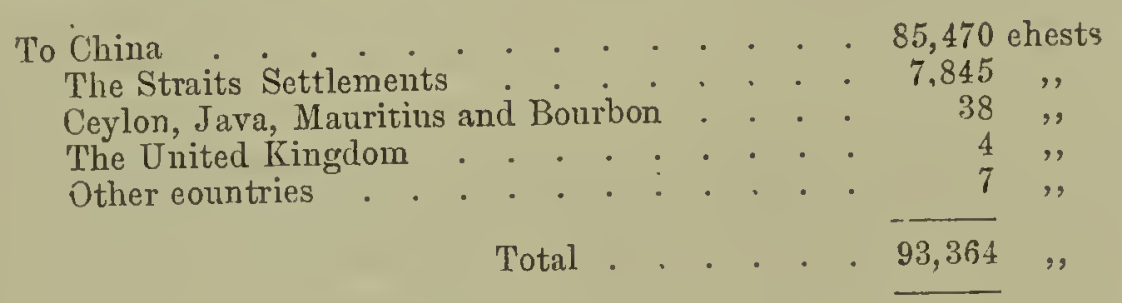

The net revenue to the Government of India from opium in the year $1871-72$ was $£ 7,657,213$.

6. Chinese Opium-China consumes not only nine-tenths of the opium exported from India, and a considerable quantity of that produced in Asia Minor, but the whole of what is raised in her own provinces. How large is this last quantity we shall endeavour to show.

The drug is mentioned as a production of Yunnan in a history of that province, of which the latest edition appeared in 1736. But it is only very recently that its cultivation in China has assumed such large proportions as to threaten serious competition with that in India. ${ }^{3}$

In a Report upon the Trade of Hankow for 1869, addressed to Mr. Hart, Inspector-General of Customs, Pekin, we find Notes of a journey through the opium districts of Szechuen, undertaken for the special purpose

1 The revenue by this duty upon opium exported from Bombay in the year 1871-72, was $£ 2,353,500$.

2 Annual Statement of the Trade and Navigation of British India with foreign countries, published by order of the GovernorGeneral, Caleutta, 1872. 52.

3 In the Report on the Trade of Hankow for 1869 addressed to Mr. Hart, InspeetorGeneral of Customs, Pekin, it is stated"The importation of opium is considerably short for the last two seasons, but this is not to be wondered at now that each o pium-shnpkeeper in this and the surround- ing distriets advertises native drug for sale."

W. H. Medhurst, British Consul at Shanghai, says - "The drug is now being so extensively prodnced by the Chinese upon their own soil as sensibly to affect the demand for the India-grown eommodity."-Foreigner in Far Cathay, Lond. 1872. 20.

The quantity of opium exported from Bombay in 1871-72 was less by 1719 ehests than that exported in $1870-71$, the deerease being attributed to the present large cnltivation in China. - Statement of the Trade and Nav. of Bombay for 1871-72, pp. xii. xri. 
of obtaining information about the drug. ${ }^{1}$ From these notes it appears that the estimated crop of the province for 1869 was 4235 peculs (=564,6667b.). This was considered small, and the Szechuen opium merchants asserted that 6000 peculs was a fair average. The same authorities estimated the annual yield of the province of Kweichow at 15,000 , and of I unnan at 20,000 peculs, making a total of 41,000 peculs or $5,466,666 \mathrm{lb}$.

Mr. Consul Markham states ${ }^{2}$ that the province of Shensi likewise furnishes important supplies. Mr. Edkins the well-known missionary has lately pointed out from personal observation ${ }^{3}$ the extensive cultivation of the poppy in the north-eastern province of Shantung.

Opium of very fair quality is now produced about Ninguta (lat. $44^{\circ}$ ) in north-eastern Manchuria, a region having a rigorous winter climate. Consul Adkins of Newchwang who visited this district in 1871, reports that the opium is inspissated in the sun until hard enough to be wrapped in poppy leaves, and that its price on the spot is equal to about $1 s$. per ounce. ${ }^{4}$

Shensi opium is said to be the best, then that of Yunnan. But Chinese consumers mostly legard home-grown opium as inferior in strength and flavour, and only fit for use when mixed with the Indian drug.

It must not be supposed that the growing of opium in China has passed unnoticed by the Chinese Government. Whatever may be the nature of the sanction now accorded to this branch of industry, it was "rigorously" prohibited, at least in some provinces, about ten years ago, the effect of the prohibition being to stimulate the foreign importations. Thus at Shanghai in 1865, the importation of Benares opium was 2637 peculs, ${ }^{5}$ being more than double that of the previous year, and Persian opium, very rarely seen before, was imported to the extent of 533 peculs, besides about 70 peculs of Turkish. ${ }^{6}$

Of the growth of the trade in opium between India and China, the following figures ${ }^{7}$ will give some idea : value of exports in
$1852-53-£ 6,470,915$.
1861-62—£9,704,972.
1871-72_£11,605,57\%.

Poppy cultivation in the south-west of China has been briefly described by Thorel, from whose remarks it would appear to be exactly like that of India. The poppy is white-flowered; the head is wounded with a three-bladed knife, in a series of 3 to 5 vertical incisions, and the exuded juice is scraped off and transferred to a small pot suspended at the waist. How the drug is finished off we know not. A Chinese account states simply that the best opium is sun-dried. But little is known of its physical and chemical properties. Thorel spealss of it as a soft substance resembling an extract. Dr. R. A. Jamieson ${ }^{9}$ describes a sample sub-

1 According to the French missionaries, the cultivation of the poppy in the great province of Szechuen was hardly known even so recently as 1840 .

2 Journ. of Soc. of Arts, Sept. 6, 1872. 838.

3 North China Herald, June 28, 1873.

4 Report of H.M. Consuls in China, 1871 (No. 3, 1872).

One pecul $=133 \frac{15}{15}$.
6 Reports on the Trade at the Treaty Ports in China for 1865. 125.

7 Taken from the Annual Statcment of the Trade and Navigation of British India with foreign countries, published by order of the Governor-General, Calcutta, 1872. 199.

8 Notes médicales du voyage d'exploration du Mékong et de Cochinchine, Paris, 1870. 32.

a Report on the Trade of Hankow, beforequoter.

E 2 
mitted to him as a flat cake enveloped in the sheathing petiole of bamboo; externally it was a blackish-brown, glutinous substance, dry and brittle on the outside. It lost by drying 18 per cent. of water, and afforded mpon incineration 7.5 per cent. of ash. In 100 grains of the (undried) drug, there were found 5.9 of morphine, and 7.5 of narcotine. (See also p. 58.)

The Chinese who prepare opium for use by converting it into an aqueous extract which they smoke, do not estimate the value of the drug according to its richness in morphine, but by peculiarities of aroma and degree of solubility. In China the preparation of opium for smoking is a special business, not beneath the notice even of Europeans. ${ }^{1}$

Description-The leading characteristics of each kind of opium have been already noticed. The following remarks bear chiefly on the microscopic appearances of the drug.

As will be presently shown, a more or less considerable part of the drug consists of peculiar substances which are mostly crystallizable and are many of them present in a crystalline state in the drug itself. All linds of opium appear more or less crystalline when a little in a dry state is triturated with benzol and examined under the microscope. The forms are various: opium from Asia Minor exhibits needles and short imperfect crystals usually not in large quantity, whereas Indian and still more Persian opium is not only highly crystalline but shows a variety of forms which become beautifully evident when seen by polarized light. In several kinds large crystals oecur which are doubtless sugar, either intentionally mixed or naturally present. The crystals seen in opium are not however sufficiently developed to warrant positive conclusions as to their nature, besides which the opium constituents when pure are capable under slightly varied circumstances of assuming very different forms. Hence the attempt to obtain from solutions crystals which shall be comparable with those of the same substances in a state of purity often fails. Some interesting observations in this direction were made by Deane and Brady in 1864-5.2

All opium has a peculiar narcotic odour and a sharp bitter taste.

Chemical Composition-Poppy-juice like analogous vegetable fluids is a mixture of several substances in variable proportion. With the commoner substances which constitnte the great bulk of the drug we are not yet sufficiently acquainted.

In the first place (independently of water) there is found mucilage distinct from that of gum arabic, also pectic matter, and albumin. These bodies, together with unavoidable fragments of the poppy-capsules, probably amount on an average to more than half the weight of the opium. ${ }^{3}$

In addition to these substances, the juice also contains sugar in solution,--in French opium to the extent of $6 \frac{1}{2}$ to 8 per cent. : according to Decharme it is uncrystallizable. Sugar also exists in other opium, but whether always naturally has not been determined.

1 In 1870, a British firm at Amoy opened an establishment for preparing opium for the supply of the Chinese in California and Australia.

2 Pharm. Journ. vi. 234 : vii. 183. with 4 beautilul plates representing the crystallizations from extract and tineture of opium

as well as from the pure opium constituents. When the juiee of tho poppy is prevented from rapid drying by the addition of a little glyeerin, crystals are developed in it.

3 Fliiekiger, in Pharm Journ. x. (1869) 208. 
Fresh poppy-juice contains in the form of emulsion, wax, pectin, albumin and insoluble calcareous salts. When good Turkey opium is treated with water these substances remain in the residue to the extent of 6 to 10 per cent.

Hesse has isolated the wax by exhausting the refuse of opium with boiling alcohol and a little lime. He thus obtained a crystalline mass from which he separated by chloroform Palmitate and Cerotate of Cerotyl, the former in the larger proportion.

Respecting the colouring matter and an extremely small quantity of a volatile body with pepper-like odour, we know but little. After the colouring inatter has been precipitated from an aqueous solution of opium by lead acetate, the liquid becomes again coloured by exposure to the air. As to the volatile body, it may be removed by acetone or benzol, but has not yet been isolated.

The salts of inorganic bases, chiefly of calcium, magnesium and potassium, contain partly the ordinary acids such as phosphoric and sulphuric, and partly an acid peculiar to the poppy.

Good opium of Asia Minor dried at $100^{\circ} \mathrm{C}$. yields 4 to 8 per cent. of ash.

Poppy-juice contains neither starch nor tannic acid, the absence of which easily-detected substances affords one criterion for judging of the purity of the drug.

The proportion of water in opium is very variable. In drying Turkey opium previous to pulverization and for other pharmaceutical purposes, the average loss is about $12 \frac{1}{2}$ per cent. ${ }^{1}$ Bengal opium which resembles a soft black extract is manufactured so as to contain 30 per cent. of water.

As the active constituents of opium, or at all events the morphine, can be completely extracted by cold water, the proportion of soluble matter is of practical importance. In good opium of Asia Minor previously dried, the extract (dried at $100^{\circ} \mathrm{C}$.) always amounts to between 55 and 66 per cent.,- - generally to more than 60,- thus affording in many instances a test of the pureness of the drug. Dried Indian opium yields from 60 to 68 per cent. of matter soluble in cold water. ${ }^{2}$

The peculiar constituents of opium are of basic, acid, or neutral nature. Some of these substances were observed in opium as early as the 17th or 18th century and designated Magisterium Opii. Bucholz in 1802 vainly endeavoured to obtain a salt from the extract by crystallization. In 1803 however, Charles Derosne, an apothecary of Paris, in diluting a syrupy aqueous extract of opium, observed crystals of the substance now called Narcotine, which he prepared pure. $\mathrm{He}$ believed that the same body was obtained by precipitating the mother liquor with an alkali, but what he so got was morphine. It is needless to pursue the further researches of Derosne. Ingenious as they were it was reserved for Friedrich Wilhelm Adam Sertiirner, apothecary of Eimbeck in Hanover (nat. 1783, ob. 1841) to discover their true interpretation.

Sertiurner had been engaged since 1805 with the chemical investigation of opium, and in 1816 he summarized his results in the statement

1 From the laboratory aceounts of Messrs. Allen and Hanburys, London, by which it appears that $2001 \mathrm{~b}$. of Turkey opium dried at various times in the eourse of 10 years lost in weight $25 \mathrm{rtb}$.

2 Calculated from official statements given by Eatwell in the paper quoted at p. 48. 
that he had enriched science (we now translate his own words ${ }^{1}$ )--" not only with the knowledge of a remarkable new vegetable acid [Mekonsëure (meconic acid) wlich he had made known as Opinmsüure in 1806], but also with the discovery of a new alkaline salifiable base, Morptium, one of the most renarkable substances and apparently related to ammonia." Sertiirner in fact distinctly recognized the basic nature and the organic constitution of morplinm (now called Morphine, Morphia, or Morphinum) and prepared a number of its crystalline salts. He likewise demonstrated the poisonous nature of these substances by experiments on himself and other's. Lastly he pointed out, though very incorrectly, the difference between morpline and the so-called Opium-salt (Narcotine) of Derosne. It is possible that this latter chemist may have had morphine in his hands at the same time as Sertiirner, or even earlier. "This honour seems also due to Séguin whose paper "Sur l'Opium" read at the Institute, December 24,1804 , was, strange to say, not published till 1814. ${ }^{2}$ To Sertiirner however undoubtedly belongs the merit of first making known the existence of organic alkalis in the vegetable kingdom,-a series of bodies practically interminable. As to opium, it still remains after nearly seventy years a nidus of new substances. ${ }^{3}$

Solutions of morphine in acids or in alkalis rotate the plame of polarization to the left.

The morphine in opium is combined with meconic acid and is therefore easily soluble in water. ${ }^{4}$ The Nareotine is present in the free state and can be extracted by chloroform, boiling alcohol, benzol, ether, or volatile oils, ${ }^{5}$ but not by water. It dissolves in 3 parts of chloroform, in 20 of boiling alcohol, in 21 of benzol, in 40 of boiling ether. Its alkaline properties are very weak, and it does not affect vegetable colours. If we examine opium by the microscope we cannot at once detect the presence of narcotine, but if first moistened with glycerin, numerous large crystals may generally be found after the lapse of some days. If the opium has been previously exhausted with benzol or ether, in order to remove the narcotine, no such crystals will be formed. Hence it follows that narcotine pre-exists in an amorphous state.

By decomposition with sulphuric acid, narcotine yields Cotarnine, an undoubted base, together with Opianic Acid and certain derivatives of the latter.

The discovery of another base, Codeine, was made in 1832 by Robiquet. It dissolves in 17 parts of boiling water forming a highly alkaline solution which perfectly saturates acids, and exhibits in polarized light a levogyre power. Codeine is also readily soluble at ordinary temperatures in 7 parts of amylic alcohol, and in 11 of benzol.

The codeine of commerce is in very large crystals containing 2 atoms $=5.66$ per cent. of water. By crystallization from ether the alkaloid may be obtained in small anhydrous crystals.

Since 1832 other alkaloids have been found in opium as may be seen in the following table, which includes all the sixteen now known.

1 Gilbert's Annalen der Physik.xxv. (1817) 57.

2 Annales de Chimie, xcii. (1814) 225.

3 The Institut de Franee on the 27 th June, 1831, awarded to Sertiirner a prize of 2000 francs-." pour avoir roeomu la nature alealine de la morphine, et avoir ainsi ouvert une voie qui a produit de grandes déeouvertes médieales."

4 There are exeeptional cases in which it is asserted that water does not take up the whole amount of morphine.

5 In large crystals by means of oil of turpentine. 
TABLE showing the NATURAL ALKALOHDS OH OPIUM and a few of their Artificial Derivatives.

DISCOVERED HY

Wöhler, $181 t$

Hesse, 1Sil

Mattliessen and)

Wright, $18: 1$. .

Wright, 1871

Sertuirner, 1816

Pclletier and Thibouméry, 1835 .

Matthiessen and Buruside, 1871. .

Wright, 1871

Robiquet, 1832 . .

Matthiessen and) Foster, 1868 . .)

Thibouméry, 1835 .

Hesse, 1870

Hesse, 1870

Hesse, 1S:1

Matthiessen and Foster, 1868 . .

Hesse, 1871 . .

Hesse, 1870

Hesse, 1870

Morck, 1848 . .

Hesse, 1865 . . .

Hesse, 1865

Arinstroug, $18 \% 1$.

Hesse, 1870

T. \& H. Smitlı, 1864

Hesse, 1871

Derosnc, 1803

Hesse, 1870

Pelletie 183
Cutarnine.

Formed by oxidizing narcotine; soluble in water

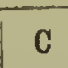

Crystallizable, alkalime, volatile at $100^{\circ}$.

From morphine, by holourless, amorphous, turning green by exposure to air; emetic.

DTSOYYMORPINE.

\section{MORPHINE.}

Crystallizable, alkaline, levogyre.

\section{PSEUDOMORPHINE .}

Crystallizes with $\mathrm{H}^{2} \mathrm{O}$; does not unite even witl acetic acid.

From codeine by chloride of zinc; anorphous, emetic. From coleine by chloride of zine; ainorphous, enietic.

\section{CODEINE}

Crystallizable, alkaline, soluble in water.

\section{Crystallizable, elkaline, isomeric with buxine. \\ 5. THEBAINE}

From thebaine or thebenine by lydrochloric acid.

Crystallizable, alkaline.

\section{PROTOPINE}

. . . . Methylnornarcotine .

Not yet isolated.

\section{. . . 7. LAUDANINE}

An alkaloid which, as well as its salts, forms large crystals ; turns orange by hydrochloric acid. Crystallizable, alkaline; ean be sublimed; bccomes green by nitric acid.

\section{PAPAVERINE}

Crystallizable, also its bydroehlorate; sulphate in sulphuric acid precipitated by water.

. . . . 10.ERHCEADINE . . . .

Crystallizable, not distinctly alkaline; can be sublined; occurs also in Papazer Rhocas.

. . . . . Rhoagenine

From rhœadine; crystallizable, alkaline.

DIMETHYLNORNARCOTINE

11. MECONIDINE

Amorphous, alkaline, melts at $58^{\circ}$, not stable, the salts also easily altered.

Crystallizable, alkaline; salts tend to gelatinize; hydrochlorate crystallizes in tufts.

13. LAUDANOSINE .

Crystallizable, alkaline.

\section{NARCOTINE}

Crytallizable, not alkaline; salts not stablc.

\section{LANTHOPINE}

Microscopic crystals not alkaline, sparingly solublc in hot or cold spirit of wine, ether or benzol.

\section{NARCEINE ${ }^{1}$}

Crystallizablc (as a lyydrate), readily soluble in boiling water or in alkalis, levogyre.

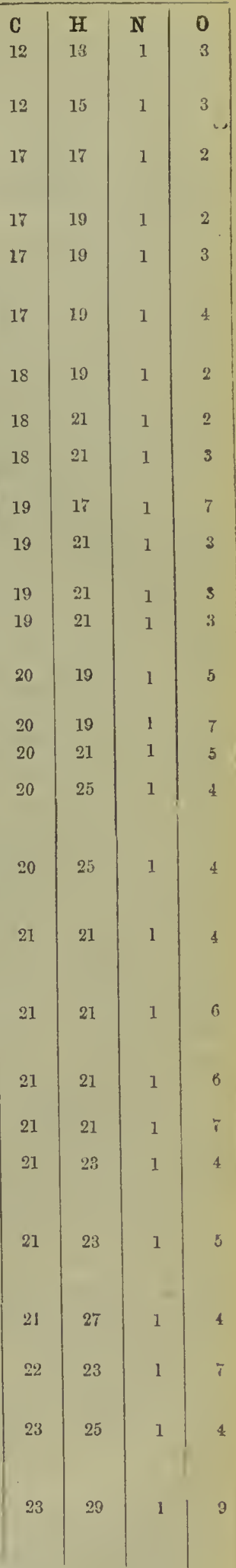

'In 1851 Hinterberger deseribed as a peculiar alknlold, Opianine; Dr. Hosse has lately e xumined Hinterborcer's specimen of this body. By a letterfrom him, dated 5 Oct. 1873 , we loarn that ho regards its existence as a definite substaure extrenel 
A large number of derivatives of several among them liave been prepared, of which we point out a few in smaller type. The molecular constitution of these opium alkaloids being not yet thoroughly settled we add only their empirical formulæ, which however exhibit unmistakeable connections.

Papavcrosine discovered by Deschamps in poppy-heads (p. 40) can hardly be absent from opiun. In some points it appear's to resemble cryptopine.

Among the peculiar non-basic constituents of opium, the first to call for notice is Meconic Acid, $\mathrm{C}^{7} \mathrm{H}^{4} \mathrm{O}^{7}$, discovered, as already observed, by Sertuirner in 1805. It is distinguished by the red colour which it produces with ferric salts. It dissolves in 4 parts of boiling water, but immediately gives off $\mathrm{CO}^{2}$, and the remaining solution instead of depositing micaceous crystalline scales of meconic acid, yields on cooling (but best after boiling with hydrochloric acid) hard granular crystals of Comenic Acid, $\mathrm{C}^{6} \mathrm{H}^{4} \mathrm{O}^{5}$.

Lactic Acid was discovered by T. and H. Smith in the opium-liquors produced in the manufacture of morphine. These chemists regarded it as a peculiar body, and under the name of Thebolactic Acid, exhibited it together with its copper and morphine salts at the London International Exhibition of 1862 . Its identity with ordinary lactic acid was ascertained by Stenhouse (whose experiments have not been published) and also by J.Y. Buchanan. ${ }^{1}$ T. and H. Smith consider it to be a regular constituent of Turkey opium; they obtained it as a calciumsalt to the amount of about 2 per cent., and have prepared it in this form and in a pure state to the extent of over 10017 . In our opinion it is not an original constituent of poppy-juice.

In the year 1826, Dublanc ${ }^{2}$ observed in opium a peculiar substance having neither basic nor acid properties which was afterwards (1832) prepared in a state of purity by Couerbe. It has been called Opianyl (by Couerbe Meconine). It has the composition $\mathrm{C}^{10} \mathrm{H}^{10} \mathrm{O}^{4}$ and crystallizes in six-sided prisms which fuse under water at $77^{\circ}$ C. or per se at $110^{\circ}$, and distil at $155^{\circ}$; it dissolves in about 20 parts of boiling water from which it may be readily crystallized. Opianyl may be formed by heating narcotine with nitric acid.

Proportion of peculiar constituents-The substances described in the foregoing section exist in opium in very variable proportion; and as it is on their presence, but especially that of morphine, that the value of the drug depends, the importance of exact estimation is evident.

Opium whether required for analysis or for pharmaceutical preparations has to be taken exclusively in the dry statc. The amount of water it contains is so uncertain that the drug must be reduced to a fixed standard by complete desiccation at $100^{\circ} \mathrm{C}$., before any given weight is taken.

Morphine-Guibourt ${ }^{3}$ who analysed a large number of samples of opium, and whose skill and care in such research are not disputed, obtained from a sample of French opium produced near Amiens, 22.88

1 Bcrichte d. Dcutsch. Chem. Gesellsch. $\approx u$ Berlin, iii. (1870)' 182.

2 Annales de Chimie ct de Physigue, xlix. (1832) 5-20. - The paper was read before the Acad. de Méd., 13th May, 1826.
3 Mémoirc sur le dosage de l'Opium et sur la quantité de morposinc que l'opiunn doit contenir, Paris, 1862. 
per cent. of morphine crystallized from spirit of wine. This percentage has not to our knowledge been ever exceeded. From another specimen produced in the same district he got 21.23 per cent., from a third 20.67. The lowest percentage from a French opium was 14.96 , -in each case reckoned on material previously dried.

Chevallier extracted from opium grown by Aubergier at Clermont in the centre of France, 17.50 per cent. of morphine. Decharmes from a French opium obtained $17 \cdot 6$ per cent., and Biltz from a German opium 20 per cent. Opium produced in Würtemberg sent to the Vienna Exhibition of 1873 afforded Hesse 12 to 15 per cent. of morphine; and opium from Silesia 9 to 10 per cent. ${ }^{1}$

A pure American opium collected in the State of Vermont yielded Procter 15.75 per cent. of morphine and 2 per cent. of narcotine. ${ }^{2}$

The opium of Asia Minor furnishes very nearly the same proportions of morphine as that of Europe. The maximum recorded by Guibourt is 21.46 per cent. obtained from a Smyrna opium sold in Paris. The mean yield of 8 samples of opium sent by Della Sudda of Constantinople to the Paris Exhibition of 1855 was 14.78 per cent. The mean percentage of morphine afforded by 12 other samples of Turkey opium obtained from various sources was 14.66.

Chevallier ${ }^{3}$ states that Smyrna, opium of which several cases were received by Merck of Darmstadt in 1845, afforded 12 to 13 per cent. of pure morphine reckoned upon the drug in its fresh and moist state.

Fayk Bey ${ }^{4}$ analysed 92 samples of opium of Asia Minor and found that half the number yielded more than 10 per cent. of morphine. The richest afforded $17 \cdot 2$ per cent.

From the foregoing statements we are warranted in assuming that good Smyrna opium deprived of water ought to afford 12 to 15 per cent. of morphine, and that if the percentage is less than 10, adulteration may be suspected.

Egyptian opium has usually been found very much weaker in morphine than that of Asia Minor. A sample sent to the Paris Exhibition of 1867 and presented to one of us by Figari Bey of Cairo, afforded us 5.8 per cent. of morphine and 8.7 of narcotine.

Persian opium appears extremely variable, probably in consequence of the practice of combining it with sugar and other substances. It is however sometimes very good. Séput ${ }^{5}$ obtained from four samples the respective percentages of $13.47,11.52,10.12,10.08$ of morphine, the opium being free from water. Mr. Howard as already stated (p. 46) extracted from Persian opium, not previously dried, from 8 to 10.75 per cent. of morphine.

East Indian opium is remarkable for its low percentage of morphine, a circumstance which we think is attributable in part to climate and in part to a method of collection radically defective. It is scarcely conceivable that the long period during which the juice remains in a wet state,-always three to four weeks,-does not exercise a destructive action on its constituents.

I. Schroff, Ausstellungsbericht, Ar:zneiwacaren, p. 31.

2 Am. Journ. of Pharm. xviii. (1870) 124.

${ }^{3}$ Notice historique sur l'opium indigène, 4. Monographie des Opiums de l'Empire
Ottoman envoyés à l'Exposition de Paris,
1867.
${ }_{5}^{5}$ Joum. de Phurm. xxxix. (1861) 163. Paris, 1852. 
According to Eatwell ${ }^{1}$ the percentage of morphine in the samples of Benares opium oflicially submitted for analysis gave the following averages :-

$\begin{array}{cccc}1845-46 & 1846-47 & 1847-48 & 1848-49 \\ 2 \cdot 48 & 2 \cdot 38 & 2 \cdot 20 & 3 \cdot 21\end{array}$

The same observer has recorded the results of the examination of freshly collected poppy-juice, which in three instances afforded respectively $1 \cdot 4,3.06$, and 2.89 per cent. of morphine, reckoned on the material deprived of water; but the conditions under which the experiments were made appear open to great objection. ${ }^{2}$

Such very low results are not always obtained from East Indian opium. In a sample from Khandesh furnished by the Indian Museum, we found 6.07 of morphine. Solly from the same kind obtained about 7 per cent.

Patna Garden Opium which is the sort prepared exclusively for medicinal use, afforded us 8.6 per cent. of purified morphine and 4 per cent. of narcotine. ${ }^{3}$ Guibourt obtained from such an opium 7.72 per cent. Christison from a sample sent to Duncan of Edinburgh in $1830,{ }^{4} 9 \cdot 50$ per cent. of hydrochlorate of morphine.

Samples from the Indian Museum placed at our disposal by Dr. $J$. Forbes Watson gave us the following percentages of morphine:Medical (Indian) Opium, 1852-53, portion of a square brick, 4:3; Garden Behar Opium, 4.6 ; Ablári Provision Opium, Patna, No. 5380, 3.5 ; Sind Opium, No. 28, 3.8; Opium, Hyderabad, Sind, 3.2 (and 5.4 of narcotine); Malwa Opium, $6 \cdot 1$.

With regard to the percentage of morphine in Chinese Opium, the following data have been obligingly furnished to us by Mr. T. TV. Sheppard, F.C.S., Opium Examiner to the Benares Opium Agency, of analyses made by himself from samples of the drug procured in China by Sir R. Alcock :-Szechuen opium, 2.2 ; Kweichow, 2.5; Yunnan, 41. Kansu, $5 \cdot 1$ per cent. Mr. S. informs us that Dr. Eatwell obtained in 1852 from Szechuen opium 3.3, and from Kweichow opium $6 \cdot 1^{5}$ per cent. - the opium in all instances being reckoned as dry. The samples examined by Mr. S. contained 86 to 95 per cent. of dry opium, and yielded (undried) 36 to 53 per cent. of extract soluble in cold water. The proportion of morphine in the sample of Chinese opium analysed by Dr. Jamieson (p. 51) was nearly 7.2 per cent. calculated on the dry drug.

Pseudomorphine-occurs only in very small quantity. Hesse found it in some sorts of opium to the extent of 0.02 per cent,-in others still less.

Codeine-has been found in Smyrna, French and Indian opium, but only to the extent of $\frac{1}{5}$ to $\frac{2}{5}$ per cent. T. and H. Smith give the proportion in Turkey opium as 0.3 per cent. ${ }^{6}$

Thebaine-which has likewise been obtained from French opium, amounts in Turkey opium according to Merck to about 1 per cent. In the latter sort T. and $H$. Smith found only about 0.15 per cent., but of

1 Pharm. Journ. xi. (1852) 361.

2 In one ease the juiee was allowed to stand in a basin from 23rd Feb. to 7th May, being "oceasionally stirred"!

3 'This drug made in 1838 eame from the A potheeary-General, Caleutta, and was presented by Christison to the Kew Museum.
It is in reetangular tablets $2 \frac{1}{\text { inehes square }}$ and $\frac{8}{4}$ of an ineh thiek, eased in wax.

${ }^{4}$ The actual specimen is in the Kew IIuscum.

5 This sample, the richest of all in morphine, is noted as of " 2 nd quality."

6 Pharm. Journ. vii. (1866) 183. 
Papaverinc-in the same drug, 1 per cent.

Narcotine-exists in opium in widely different proportions and often in considerable abundance. Thus Schindler obtained from a Smyrna opium yielding 10.30 per cent. of morphine, 1.30 per cent. of narcotine. Biltz analysed an oriental opium which afforded $9 \cdot 25$ per cent. of morphine and 7.50 of narcotine. Reveil obtained from Persian opium not rich in morphine, from half as much to twice as much narcotine as morphine. The utmost of narcotine was $9 \cdot 90$ per cent. We have found in German opium of indubitable purity ${ }^{1} 10.9$ per cent. of narcotine.

East Indian opium was found by Eatwell always to afford more narcotine than morphine,-frequently twice as much. The sample from Khandesh referred to on the opposite page, afforded us 7.7 per cent. of pure narcotine.

French opium collected from the Pavot ceillet sometimes affords neither narcotine, thebaine, or narceine. ${ }^{2}$

Narceine - Of this substance Couerbe found in opium 0.1 per cent.; T. and H. Smith 0.02 and Schindler $0 \cdot 71$.

Cryptopine-exists in opium in very small proportion. $T$. and $H$. Smith state that since the alkaloid first came under their notice, they have collected of it altogether about 5 ounces in the form of hydrochlorate, and this small quantity in operating on many thousands of pounds of opium. But they by no means assert that the whole of the cryptopine was obtained.

Rhoeadine - is also found only in exceedingly minute quantity.

Meconic Acid-If the average amount of morphine in opium be estimated at 15 per cent., and the alkaloid be supposed to exist as a tribasic meconate, it would require for saturation 3.4 per cent. of meconic acid. Wittstein obtained rather more than 3 per cent., T. and H. Smith 4 per cent., and Decharmes 4:33. The quantity of acid required to unite with the other bases assuming them to exist as salts can be but extremely small.

Estimation of Morphine in Opium-The practical valuation of opium turns in the first instance upon the estimation of the water present in the drug (p. 53) and in the second upon the proportion which the latter contains of inorphine. ${ }^{3}$

The first question is determined by exposing a known quantity of the drug divided into small slices or fragments to the heat of a waterbath until it cease to lose weight.

For the estimation of the morphine many processes have been devised, but none is perfectly satisfactory. That which we recommend is thus performed :-Take of opium previously dried at $100^{\circ} \mathrm{C}$., 7 to 10 grammes, mix it with thrice its weight of coarsely-powdered pumice, and pack the mixture in a percolation-tube. Then remove by boiling ether the narcotine together with wax and colouring matter. The residue should

${ }^{1}$ Colleeted by Biltz and obligingly placed at my disposal by his son.-F. A. F.

2 The statement of Biltz that an opium eolleeted by himself from poppies grown at Erfurt afforded 33 per cent. of nareotine is so eontrary to the experience of all other chemists that we eannot aeeept it as eertain. The same must be said of Christison's discovery of an opium yielding 8 per eent. of eodeine, and of Mulder's assertion respeeting an opium giving 6 to 13 per eent. of naleeine.

${ }^{3}$ In seleeting a sample for analysis, care should be taken that it fairly represents the bulk of the drug. Wo prefer to take a little piece from eaeh of several lumps, mix them in a mortar, and weigh from the mixed sample the required quantity. 
be next moistened (it may remin in the tube) with a very little spirit of wine $(0.822)$, and exhausted with water. 'The solution is usually a little acid: if otherwise, the water nsed should be very slightly acidulated with acetic acid. The solution should be equal to about 20 times the weight of the opium; it is to be mixed with ammonia, used as little in excess as possible. After a repose of a day or two, the inorphine will be found in crystals attached to the sides and botton of the glass. It may be dried and weighed as crude morphine, yet ought to be re-crystallized from boiling spirit of wine $(0.822)$, at least once.

There are three principal difficulties in this process:-1. It is not easy to remove the whole amount of narcotine and wax. 2. It is even less easy to extract the morphine with as little water as one would desire; and by using much water, the bulk of the solution is inconveniently increased and has then to be reduced by evaporation, which is better avoided. 3. The purification of the crude morphine is necessary yet occasions inevitable loss.

These sources of error should be kept in view and avoided as much as possible.

Commerce-By official statistics it appears that the quantity of opium imported into the United Kingdom in 1872 was 356,2117t., valued at $£ 361,503$. The imports from Asiatic and European Turkey are stated in the same tables thus:-

$\begin{array}{ccccc}1868 & 1869 & 1870 & 1871 & 1872 \\ 317,133 \mathrm{Hb} . & 203,546 \mathrm{Hb} . & 276,691 \mathrm{lb} . & 492,855 \mathrm{Hb} . & 325,572 \mathrm{Hb} .\end{array}$

It is thus evident that the drug used in Great Britain is chiefly Turkish. The import of opium from Persia has been very irregular. In $1871,21,894 \mathrm{tb}$. are reported as received from that country ; in 1872, none.

Except that a little Malwa opium has occasionally been imported, it may be asserted that the opium of India is entirely unknown in the English market, and that none of it is to be found even in London in the warehouse of any druggist.

Uses-Opium possesses sedative powers which are umiversally known. In the words of Pereira, it is the most important and valuable medicine of the whole Materia Medica; and we may add, the source by its judicious employment of more happiness and by its abuse of more misery than any other drug employed by mankind.

Adulteration-The manifold falsifications of opium have been already noticed, and the method by which its most important alkaloid may be estimated has been pointed out. Moreover as already stated, neither tannic acid nor starch ever occur in genuine opium; and the proportion of ash left upon the incineration of a good opium does not exceed 4 to 8 per cent. of the dried drug. Another criterion is afforded by the amount soluble in cold water which ought to exceed 55 per cent. reckoned on dry opium. Finally, if we are correct, the gum contained in pure opium is distinct from gum arabic, being precipitable by neutral acetate of lead. If we exhaust with water opium falsified with gum arabic, the mucilage peculiar to opium will be precipitated by nentral acetate of lead, the liquid separated from the precipitate, will still contain the gum arabic whicl may be thrown down by alcohol. If gum is present to some extent, an abundant precipitate is produced. 


\section{CRUCIFERAE.}

\section{SEMEN SINAPIS NIGRA.}

Black, Brown or Red Mustard; F. Moutarde noire ou grise; G.Schwarzer Senf.

Botanical Origin-Brassica nigra Koch (Sinapis nigra L.). Black Mustard is found wild over the whole of Europe excepting the extreme north. It also occurs in Northern Africa, Asia Minor, the Caucasian region, Western India, as well as in Southern Siberia. By cultivation, which is conducted on a large scale in many countries (as Alsace, Bohemia, Holland, England and Italy), it has doubtless been diffused through regions where it did not anciently exist. It has now become naturalized both in North and South America.

History-Mustard was well known to the ancients. Theophrastus

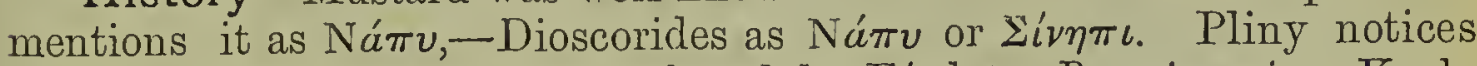
three kinds which have been referred by Fée ${ }^{1}$ to Brassica nigra Koch, B. alba Hook. f. et Th., and to a South European species, Diplotaxis erucoides DC. (Sinapis erucoides L.). The use of mustard seems up to this period to have been more medicinal than dietetic. But from an edict of Diocletian, A.D. $301^{2}$ in which it is mentioned along with alimentary substances, we must suppose it was then regarded as a condiment at least in the eastern parts of the Roman Empire.

In Europe during the middle ages mustard was a valued acconpaniment to food, especially to the salted meat which constituted a large portion of the diet of our ancestors during the winter. ${ }^{3}$ In household accounts of the 13th and 14th centuries, mustard under the name of Senapium is of constant occurrence.

Mustard was then cultivated in England, but not as it would seem very extensively. The price of the seed between A.D. 1285 and 1395 varied from $1 s$. $3 d$. to $6 s .8 d$. per quarter, but in 1347 and 1376 it was as high as 15s. and 16s. In the accounts of the abbey of St. Germaindes-Prés in Paris, commencing A.D. 800, mustard is specifically mentioned as a regular part of the revenue of the convent lands. ${ }^{5}$

Production-Mustard is grown in England only on the richest alluvial soils, and chiefly in the counties of Lincolnshire and Yorkshire. Very good seed is produced in Holland.

Description - The pod of Brassica nigra is smooth, erect, and closely pressed against the axis of the long slender raceme. It has a strong nerve on each of its two valves and contains in each cell from 4 to 6 spherical or slightly oval seeds. The seeds are about $\frac{1}{25}$ of an inch in diameter and $\frac{1}{50}$ of a grain in weight; they are of a dark reddish-brown. The surface is reticulated with minute pits, and often more or less covered with a whitish pellicle which gives to some seeds a grey colour. ${ }^{6}$

1 Botanique ct Matière Méd. de Pline, ii. (1833) 446.

2 Mommsen in Berichtc. . d. Gesell. d. Wissenschaften zu Leipzig, 1851. 1-80.

3 Fnelosed pasture land in England was rare, and there was but scanty provision for preserving stock through the winter, root erops being nuknown. Henee in November there was a general slanghtering of sheep and oxen, the flesh of which was salted for winter use.
4 Rogers, Hist. of Agricultur c and Prices in England, i. (1866) 223.

5 Guérard, Polyptique de l'Abbé Ir'minon, Paris, i. (1844) 715.

6 The grey colour of the seed which is attributed to rain during the ripening, is very detrimental to its value. The great aim of the grower is to produce seed of a bright reddish brown, with no grey seed intermixed. 
The testa which is thin, brittle and translucent encloses an exalbuminous embryo having two short cotyledons folded together longitudinally and forming a sort of trough in which the radicle lies bent up. The embryo thus coiled into a ball completely fills the testa; the outer cotyledon is thicker than the inner, which viewed in transverse section seems to hold the radicle as a pair of forceps. The seeds when pulverized have a greenish yellow hue. Masticated they have for an instant a bitterish taste which however quickly becomes pungent. When triturated witl water they afford a yellowish emulsion emitting a pungent acrid vapour which affects the eyes, and has a strong acid reaction. The seeds powdered dry liave no such pungency. When the seeds are triturated with solution of potash, the pungent odour is not evolved; nor when they are boiled in water. Neither is the acridity developed on triturating them with alcohol, dilute mineral acids, or solution of tannin, or even with water when they have been kept in powder for a long time.

Microscopic Structure-The whitish pellicle already mentioned, which covers the seed, is made up of hexagonal tabular cells. The epidermis consists of one row of densely packed brown cells, radially elongated and having strong lateral and inner walls. Their outer walls on the other hand are thin and not coloured they are not clearly obvious when seen under oil, but swell up very considerably in presence of water, emitting mucilage. Seeds immersed in water become therefore covered with a glossy envelope, levelling down the superficial inequalities, so that the wet seed appears smooth. The tissue of the cotyledons exhibits large drops of fatty oil and granules of albumin.

Chemical Composition-By distilling brown mustard with water, the seed having been previously macerated, the pungent principle, Essential Oil of Mustard, is obtained.

The oil, which has the composition $\mathrm{C}^{4} \mathrm{H}^{5} \mathrm{NS}$ or $\left.\mathrm{C}_{\mathrm{C}^{3} \mathrm{H}^{5}}^{\mathrm{C}}\right\} \mathrm{S}$ (allyl sulphocyanide), boils at $148^{\circ} \mathrm{C}$; ; it has a sp. gr. of 1.017 , no rotatory power, and is soluble without coloration or turbidity in three times its weight or more of cold strong sulphuric acid. To this oil is due the pungent smell and taste of mustard and its inflammatory action on the skin. As already pointed out, mustard oil is not present in the dry seeds but is produced only after they have been comminuted and mixed with water, the temperature of which should not exceed $50^{\circ} \mathrm{C}$.

The remarkable reaction whicl gives rise to the formation of mustard oil was explained by Will and Körner in 1863. They obtained from mustard a crystallizable substance, then termed Myronate of potassium, now called Sinigrin. It is to be regarded, according to the admirable investigations of these chemists, as a compound of

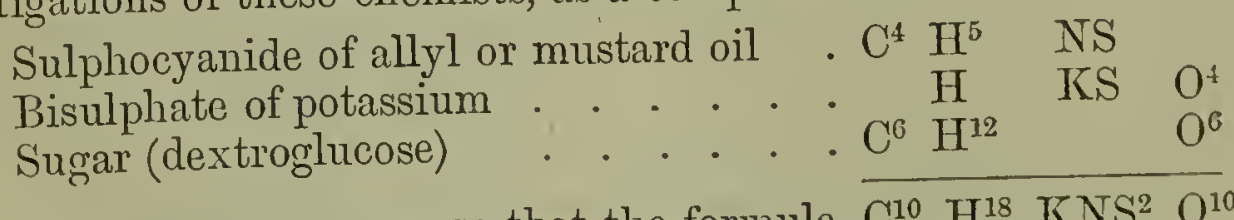

so that the formula $\mathrm{C}^{10} \mathrm{H}^{18} \mathrm{KNS}^{2} \mathrm{O}^{10}$

is that of sinigrin. It does in fact split into the above-mentioned three substances when dissolved in water and brought into contact witl Myrosin. 
This albuminous body discovered by Bussy in 1839, but the composition of which has not been made out, likewise undergoes a certain decomposition under these circumstances. Sinigrin may likewise be decomposed by alkalis and, according to Ludwig and Lange, by silver nitrate. These chemists obtained sinigrin from the seeds in the proportion of 0.5 per cent.; Will and Körner got 0.5 to 0.6 per cent. The extraction of the substance is therefore attended with great loss, as the minimum yield of volatile oil, 0.42 per cent. indicates 2.36 of potassium myronate.

The aqueous solution of myrosin coagulates at $60^{\circ} \mathrm{C}$. and then becomes inactive : hence mustard seed which has been heated to $100^{\circ} \mathrm{C}$. or has been roasted yields no volatile oil, nor does it yield any if powdered and introduced at once into boiling water. The proportion of myrosin in mustard has not been exactly determined. The total amount of nitrogen in the seed is 2.9 per cent. (Hoffmann) which would correspond to 18 per cent. of myrosin, supposing the proportion of nitrogen in that substance to be the same as in albumin, and the total quantity of nitrogen to belong to it. Sometimes black mustard contains so little of it, that an emulsion of white mustard requires to be added in order to develop all the volatile oil it is capable of yielding.

An emulsion of mustard or a solution of pure sinigrin brought into contact with myrosin, frequently deposits sulphur by decomposition of the allyl sulphocyanide, hence crude oil of mustard sometimes contains a considerable proportion (even half) of Allyl cyanide, $\mathrm{C}^{4} \mathrm{H}^{5} \mathrm{~N}$, distinguished by its lower sp. gr. $(0.839)$ and lower boiling point $\left(118^{\circ} \mathrm{C}\right.$.).

The seeds, roots, or herbaceous part of many other plants of the order Cruciferce yield a volatile oil composed in part of mustard oil and in part

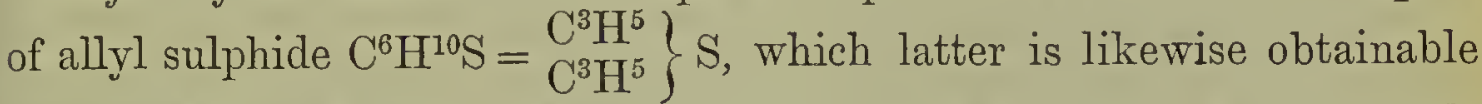
from the bulbs of garlic. Many Cruciferce afford from their roots or seeds chiefly or solely oil of mustard, and from their leaves oil of garlick. As to other plants, the roots of Reseda lutea L. and R. luteola L. have been shown by Volhard (1871) to afford oil of mustard. ${ }^{1}$

The artificial preparation of mustard oil was discovered in 1855 by Zinin, and at the same time also by Berthelot and De Luca.

Mustard submitted to pressure affords about 23 per cent. ${ }^{2}$ of a mildtasting, inodorous, non-drying oil, solidifying when cooled to $-17 \cdot 5^{\circ} \mathrm{C}$. and consisting of the glycerin compounds of stearic, oleic and Erucic or Brassic Acid. The last-named acid, $\mathrm{C}^{22} \mathrm{H}^{42} \mathrm{O}^{2}$, occurs also in the fixed oil of white mustard. and of rape, and is homologous with oleic acid. Darby (1849) has pointed out the existence of another body, Sinapoleic Acid, $\mathrm{C}^{120} \mathrm{H}^{38} \mathrm{O}^{2}$, which occurs in the fixed oil of both black and white mustard.

Mustard seed when ripe is devoid of starch; the mucilage which its epidermis affords amounts to 12 per cent. of the seed (Hoffmann). The ash-constituents amounting to 4 per cent. consist chiefly of the phosphates of calcium, magnesium, and potassium.

Uses-Black mustard is employed in the form of poultice as a powerful external stimulant; but it is rarely used in its pure state as the Flour of

1 See also Radix Armoracice, p. 68.

${ }^{2}$ I have obtained as much as 33.8 per cent. hy means of boiling ether.-F. A. F. 
Mustard prepared for the table, which contains in addition white mustard, answer's perfectly well and is at hand in every house. ${ }^{1}$

The essential oil of mustard dissolved in spirit of wine is occasionally prescribed as a liniment.

Substitute-Brassica juneca Hook. f. et Th. (Sinapis juneea L.) is extensively cultivated throughont India (where B. nigra is rarely grown), Central Africa, and generally in warm countries where it replaces $B$. nigra and is applied to the same uses. Its seeds constitute a portion of the mustard of Europe, as we may infor from the fact that British India exported in the year 1871-72, of "Mustard seed," 1418 tons, of which 790 tons were shipped to the United Kingdom, and 516 tons to France. ${ }^{2}$ $B$. juneea is largely grown in the south of Russia and in the steppes north-east of the Caspian where it appears to flourish particularly well in the saline soil. At Sarepta in the Government of Saratov, an establishment has existed since the beginning of the present century where this sort of mustard is prepared for use to the extent of 800 tons of seed annually. The seeds make a fine yellow powder employed both for culinary and medicinal purposes. By pressure they yield more than 20 per cent. of fixed oil which is used in Russia lite the best olive oil. The seeds closely resemble those of $B$. nigra and afford when distilled the same essential oil.

\section{SEMEN SINAPIS ALBAE.}

White Mustard; F. Moutarde blanehe ou Anglaise; G. Weisser Senf.

Botanical Origin-Brassiea alba Hook. f. et Th. (Sinapis alba L.) This plant appears to belong to the more southern countries of Europe and Western Asia. According to Chinese authors ${ }^{3}$ it was introduced into China from the latter region. Its cultivation in England is of recent introduction, but is rapidly extending. ${ }^{4}$ The plant is not uncommon as a weed on cultivated land.

History - White mustard was used in former times indiscriminately with the brown. In the materia medica of the London Pharmacopoia of 1720 the two sorts are separately prescribed. The important chemical distinction between them was first made known in 1831 by BoutronCharlard and Robiquet. ${ }^{5}$

Production-White mustard is grown as an agricultural crop in Essex and Cambridgeshire.

Description-Brassica alba differs from $B$. nigra in having the pods bristly and spreading. They are about an inch long, half the length being occupied by a flat veiny beak. Each pod contains 4 to 6 yellowish seeds about $\frac{1}{12}$ of an inch in diameter and $\frac{1}{10}$ of a grain in weight. The brittle, nearly transparent and colourless testa encloses an embryo of a bright pure yellow and of the same structure as that of black mustard.

1 The bost Flour of Mustard such as is made by the large manufacturcrs, contains nothing but brown and white mustard sceds. But the lower and chcaper qualities made by the same firms contain flour, turmcric, and capsicum. Unmixed flotl of Black Mustard is however kept for those who care ta

2 Ammal Statement of the Trade and $N^{\top}$ arigation of British India, Calcutta, 1872. 62.

3 Brctschncider, Study of Chinese Botan. Wortiss, 1870.17.

4 Morton's Cyelop. of Agriculture, ii. (1855) 440 .

5 Journ. de Pharm. xvii. (1831) ฉ79. purcliase it. 
The surface of the testa is likewise pitted in a reticulate nanner but so finely that it appears smootl except under a high magnifying power.

When triturated with water the seeds form a yellowish emulsion of very pungent taste, but it is inodorous and does not under any circumstances yield a volatile oil. The powdered seeds made into a paste with cold water act as a highly stimulating cataplasm. 'The entire seeds yield to cold water an abundance of mucilage.

Microscopic Structure-The epidermal cells of white mustard afford a good illustration of a mucilage-yielding layer such as is met with under many variations, in the seeds of numerous plants. The cuticle consists of large vaulted cells, exhibiting very regular hexagonal outlines when cut across. ${ }^{1}$ The inner layer of the epidermis is made up of thin-walled cells, which when moistened swell and give off the mucilage. In the dry state or seen under oil, the outlines of the single cells of this layer are not distinguishable. The tissue of the cotyledons is loaded with drops of fatty oil and with granular albuminoid matter; starch which is present in the seed while young, is altogether absent when the latter reaches maturity.

Chemical Composition-White mustard deprived of fatty oil yields to boiling alcohol colourless crystals of Sinalbin, an indifferent substance, readily soluble in cold water, but sparingly in cold alcohol. From the able investigations of Will (1870) it follows, that it is to be regarded as composed of three bodies, namely:

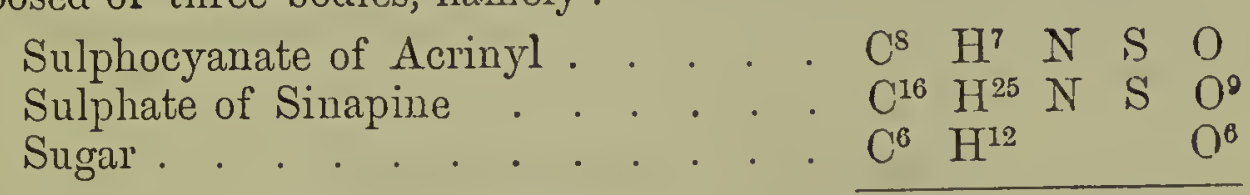

so that the formula $\mathrm{C}^{30} \mathrm{H}^{44} \mathrm{~N}^{2} \mathrm{~S}^{2} \mathrm{O}^{16}$

represents according to Will the composition of sinalbin. It is actualiy resolved into these three substances when placed at ordinary temperatures, in contact with water and Myrosin, the latter of which is a constituent of white mustard as well as of brown (p. 63). The liquid becomes turbid, the first of the above-named substances separates (together with coagulated albumin) as an oily liquid, not soluble in water, but dissolving in alcohol or ether. This Sulphocyanate of Acrinyl is the rubefacient and vesicating principle of white mustard. It does not pre-exist, as shown by Will, in the seed and cannot be ubtained by distillation. By treating it with a salt of silver, Will obtained crystals of cyanide of acrinyl, $\mathrm{C}^{8} \mathrm{H}^{7} \mathrm{NO}$ : by warming it (or sinalbin itself, or an alcoholic extract of the seed) with caustic potash, sulphocyanide of potassium is produced. The presence of the latter may be indicated by adding a drop of perchloride of iron, when a blood-red coloration will be produced. ${ }^{2}$

Sulphate of Sinapine imparts to the emulsion of white mustard, in which it is formed, au acid reaction. Sinapine is itself an alkaloid, which has not yet been isolated, as it is very liable to change. Thus its solution on addition of a trace of alkali immediately assumes a bright yellow colour indicating decomposition, and a similar colour is produced in an aqueous extract of the seed.

I An interesting object for the polarizing microscope.

2 The red compound thus formed with sulphocyanide is readily soluble in $t$ ther, yet in the case of uhite mustard we find it not to bo so. 
The above statements show, that the chemieal properties of sinalbin and its derivatives correspond closely with those of sinigrin (p. 62) and the substances which make their appearanee in an emulsion of blaek mustard.

'The other constituents of 'white mustard seed are nearly the same as those of blaek. The fat oil appears to yield in addition to the aeids mentioned at p. 63, Benic Acid, $\mathrm{C}^{22} \mathrm{H}^{44}()^{2}$. White mustard is said to be richer than black in myrosin, so that, as explained in the previous article, the pungeney of the latter may be often increased by an addition of white mustard. By burning white mustard dried at $100^{\circ} \mathrm{C}$., with soda-lime, we obtained from 4.20 to 4.30 per eent. of nitrogen, answering to about 28 per eent. of protein substances. ${ }^{1}$ The fixed oil of the seed amounts to 22 per eent. The mueilage as yielded by the epidermis is preeipitable by aleohol, neutral lead aeetate, or ferrie chloride, and is soluble in water after drying.

Erucin and Sinapic Aeid mentioned by Simon $(1838)^{2}$ as peeuliar eonstituents of white mustard are altogether doubtful, yet may deserve further investigation. The sinapic acid of Von Babo and Hirschbrunn ${ }^{3}$ (1852) is a produet of the deeomposition of sinapine.

Uses-White Mustard seeds reduced to powder and made into a paste with eold water act as a powerful stimulant when applied to the skin, notwithstanding that sucli paste is entirely wanting in essential oil. But for sinapisms they are actually used only in the form of the Flour of Mustard whieh is prepared for the table and which contains also Brown Mustard seed.

\section{RADIX ARMORACIÆ.}

\section{Horse-ratish; F. Raifort (i.e. racine forte), Cran de Bretagne; G. Meerrettig.}

Botanical Origin-Cochlearia Armoracia L., a common perennial with a stout tapering root, large coarse oblong leaves with long stalks, and ereet flowering raeemes 2 to 3 feet high. It is indigenous to the eastem parts of Europe, from the Caspian through Russia and Poland to Finland. In Britain and in other parts of Europe to the polar eircle, it oecurs cultivated or semi-wild.

History-The vernaeular name Armon is stated by Pliny ${ }^{4}$ to be used in the Pontie regions to designate the Ammoracia of the Romans, the Wild Radish ('paфavis árpia) of the Greeks, a plant whieh eannot be positively identified with that under notiee.

Horse-radish is called in the Russian language Chren, in Lithuanian Krenai, in Illyrian Kren, a name whieh has passed into several German dialeets, and as Cran or Cranson into Freneh.

From these and similar faets, De Candolle ${ }^{5}$ has drawn the eonelusion that the propagation of the plant has travelled from Eastern to Western Europe.

Both the root and leaves of horse-radish were eaten with food in Germany during the middle agges. ${ }^{6}$ But the use of the former was not

1 Experiments performed by Mr. Weppen in my laboratory, 1869 . F. A. F. 529.
3 Ibid. 521.

4 Lib. xix. c. 26. (Littré's translation.)

5Géographic Botanique, ii. (1855) 655.

- Meyer, Geschichtc der Botanik, iii. (1856) 
common in England until a much later period. The plant though known in England as Red-cole in the time of Turner, 1568, is not mentioned by him ${ }^{1}$ as used in food, nor is it noticed by Boorde, ${ }^{2} 1542$, in his chapter on edible loots. Gerarde ${ }^{3}$ at the end of the 16 th century remarks that horse-radish_" is commonly used among the Germanes for sauce to eat fish with, and such like meats, as we do mustard." Half a century later the taste for horse-radish had begun to prevail in England. Coles ${ }^{4}(1657)$ states that the root sliced thin and mixed with vinegar is eaten as a sauce with meat as among the Germans. That the use of horse-radish in France had the same origin is proved by its old French name Moutarde des Allemands.

The root to which certain medicinal properties had always been assigned, was included in the materia medica of the London Pharmacopœias of the last century under the name of Raphanus rusticanus.

Description-The root which in good ground often attains a length of 3 feet and nearly an inch in diameter, is enlarged in its upper part into a crown, usually dividing into a few short branches each surmounted by a tuft of leaves, and annulated by the scars of fallen folinge; below the crown it tapers slightly, and then for some distance is often almost cylindrical, throwing off here and there filiform and long slender cylindrical roots, and finally dividing into two or three branches. The root is of a light yellowish brown; internally it is fleshy and perfectly white, and has a short non-fibrous fracture. Before it is broken it is inodorous, but when conminuted it immediately exhales its characteristic pungent smell. Its well-known pungent taste is not lost in the root carefully dried and not kept too long.

A transverse section of the fresh root displays a large central column with a radiate and concentric arrangement of its tissues, which are separated by a small greyish circle from the bark, whose breath is from $\frac{1}{2}$ to 2 lines. In the root-branches there is neither a well-defined liber nor a true pith. The short leaf-bearing branches include a large pith surrounded by a circle of woody bundles. The bark adheres strongly to the central portion, in which zones of annual growth are easily perceptible, at least in older specimens.

Microscopic Structure-The corky layer is made up of small tabular cells as usual in suberous coats. In the succeeding zone of the middle bark, thick-walled yellow cells are scattered through the parenchyme, chiefly at the boundary line of the corky layer. In the root the cellular envelope is not strikingly separated from the liber, whilst in its leafy branches this separation is well marked by wedgeshaped liber bundles, which are accompanied by a group of the yellow longitudinally-elongated stone cells. The woody bundles contain a few short yellow vessels, accompanied by bundles of prosenchymatous, not properly woody cells. The centre, in the root, shows these woody bundles to be separated by the medullary parenchyma; in the branches the central column consists of an uniform pith without woody bundles, the latter forming a circle close to the cambium. The parenchyma

531 ; Pfeiffer, Buch dcr Natur von Konrad von Mlegenberg, Stuttgart, 1861. 418.

1 Ilerball, part 2. (1568) 111 .

2 Dyetary of Helth, Early English Text Society, 1870 . 278 .
3 Herball, edited by Johnson, 1636, 240.

4 Adam in Eden, or Nature's Prradise. Lond. 1657. chap. 256. 
of the whole root collected in spring is loaded with small starch granules.

Chemical Composition-Among the constituents of horseradish root (the chemical history of which is lowever far from perfect) the volatile oil is the most interesting. The fresh root subrnitted to distillation with water in a glass retort, yields about $\frac{1}{2}$ per mille of oil which is identical with that of Black Mustard as proved in 1843 by Hubatka. He combined it with ammonia and obtained crystals of thiosinammine, the composition of which agreed with the thiosinammine from mustard oil.

An alcoholic extract of the root is devoid of the odour of the oil, but this is quickly evolved on addition of an emulsion of Whitc Mustard. The essential oil does not therefore pre-exist, but only sinigrin (myronate of potassium) and an albuminoid matter (myrosin) by whose inutual reaction in the presence of water it is formed (p. 62). This process does not go on in the growing root, perhaps because the two principles in question are not contained in the same cells, or else exist together in some condition that does not allow of their acting on each other,-a state of things analogous to that occurring in the leaves of Lauro-cerasus. No crystals of sinigrin are visible in the tissue of horse-radish when examined under the microscope.

By exhausting the root with water either cold or hot, the sinigrin is decomposed and a considerable proportion of bisulphate is found in the concentrated decoction. Alcohol removes from the root some fatty matter and sugar (Winckler 1849). Salts of iron do not alter thin slices of it, tanuic matters being absent. The presence of myrosin which at present has been inferred rather than proved, ought to be further investigated.

Uses-An infusion or a distilled spirit of horse-radish is reputed stimulant, diaphoretic, and dinretic, but is not often employed.

Substitute-In India the root of Moringa pterygosperma Gärtn. is considered a substitute for horse-radish. It yields by distillation an essential oil of disgusting odour which Bronghton who obtained it in minute quantity, has assured us is not identical with that of mustard or of garlick.

\section{CANELLACE $A$.}

\section{CORTEX CANELLÆ ALBA.}

Canella Bark, Canella Alba Bark; F. Cannelle blanche; G. Canella-Rinde.

Botanical Origin-Canella alba Murray, a tree, 20 to 30 or even 50 feet in height, found in the south of Florida, the Bahama Islands (whence alone its bark is exported), Cuba, Jamaica, Ste. Croix, Gradaloupe, Martinique, Barbados and Trinidad.

History-The drug was first mentioned in 1605 by Clusius ${ }^{1}$ who remarks that it had been then newly brought to Europe and had received the name of Canella alba (White Cinnamon). It was afterwards known as Costus corticosus, Costus dulcis, Cassia alba, Cassia lignca Jamaicensis or Jamaica Wintcr's Bar\%. Dale ${ }^{2}$ writing in 1693 notices it as not
1 Exolica, 78.
2 Pharmacologia, 432. 
unfrequently sold for Winter's Bark. Pomet ${ }^{1}$ (1694) describes it as synonymous with Winter's Bark, and observes that it is common yet but little employed.

The drug is mentioned by most subsequent writers, some of whom like Pomet probably confounded it with the bark of Cinnamodendron (p. 19). It is usually described as produced in Jamaica or Guadaloupe, from which islands no Canella alba is now exported. On the other hand New Providence, one of the Bahamas whence the Canella alba of the present day is shipped, is not named. Nor do we find any allusion to the drug in the records of the Company $(1630-50)$ which was formed for the colonization of New Providence and the other islands of the group, though their staple productions are frequently enumerated. ${ }^{2}$

Canella alba Murr. was described and figured by Sloane (1707) and still better by Patrick Brown in 1789.

Collection-In the Bahamas where the drug is known as White Wood Bark or Cinnamon Bark, it is collected thus:-preparatory to being stripped from the wood, the bark is gently beaten with a stick which removes the suberous layer. By a further beating, the remaining bark is separated, and having been peeled off and dried, is exported without further preparation. ${ }^{3}$

Description-Canella bark occurs in the form of quills, more or less crooked and irregular, or in channelled pieces from 2 or 3 up to 6,8 , or more inches in length, $\frac{1}{2}$ an inch to 1 or 2 inches in width, and a line or two in thickness. The suberous layer which here and there has escaped removal is silvery grey, and dotted with minute lichens. Commonly the external surface consists of inner cellular layers (mesophlocum) of a bright buff, or light orange-brown tint, often a little wrinkled transversely, and dotted (but not always) with round scars. The inner surface is whitish or cinnamon-coloured, either smooth or with slight longitudinal striæ. Some parcels of canella show the bark much bruised and longitudinally fissured by the above-mentioned process of beating. The bark breaks transversely with a short granular fracture which distinctly shows the three, or in uncoated specimens the two, cortical layers, that of the liber being the largest and projecting by undulated rays or bundles into the middle layer, which presents numerous large and unevenly scattered oil-cells of a yellow colour.

Canella has an agreeable cinnamon-like odour and a bitter, pungent acrid taste. ${ }^{4}$ Even the corky coat is somewhat aromatic.

Microscopical Structure-The spongy suberous coat consists of very numerous layers of large cells with thin walls showing an undulated rather than rectangular outline. The next small zone is constituted of sclerenchymatous cells in a single, dorble, or triple row, or forming dense but not very extensive groups. This tissue is sometimes (in unpeeled specimens) a continuous envelope, marking the boundary between the corky layer and the middle portion of the cellular layer; but an in-

1 Hist. des Drog. part i. 130.

${ }^{2}$ Calendai of State Papers, Colonial Series, 1574-1660, Lond. 1860 .

3 Information communicated to me by the Hon. J. C. Lees, Chief-Justice of the Bahamas. The second beating would seem to be not always required.-D. H.
4 A specimen in Sloane's collection in the British Museum labelled "Cortex Winteranus of the Isles," but under the micruscope seen to be absolutely identical with canella alba, still retains its proper fragrance after nearly two centuries. -F. A. F. 
terruption in this thick-walled tissue often takes place when portions of it are enveloped and separated by the suberous layer.

The proper cellular envelope shows a narrow tissue with numerous very large cells filled with yellow essential oil. The liber forming the chief portion of the whole bark, exhibits thin prosenchymatous cells, which on transverse section form small bands of a peculiar horny or cartilaginous appearance, on which account they have been distinguished as horny liber (hornbast of German writers). ${ }^{1}$ The liber-fibres show reticulated marks due to the peculiar character of the secondary deposits on their cell walls. The oil-cells in the liber are less numerous and smaller; the medullary rays are not very obvious unless on account of the crystalline tufts of oxalate of calcium deposited in the latter. This crystalline oxalate retains air obstinately and has a striking dark appearance.

Chemical Composition-The most interesting body in canella is the volatile oil examined in 1843 under Wöhler's direction by Meyer and Von Reiche, who obtained it"in the proportion of 0.94 from 100 parts of bark. They found it to consist of four different oils, the first being identical with the Eugenic Acid of oil of cloves; the second is closely allied to the chief constituent of cajuput oil. The other oils require further examination. ${ }^{2}$

The bark of which we distilled 2017 ., afforded 0.74 per cent. of oil. This when distilled with caustic potash in excess was found to be composed of 2 parts of the acid portion and 1 part of the neutral hydrocarbon; the latter has an odour suggesting a mixture of peppermint and cajuput.

Meyer and Von Reiche evaporated the aqueous decoction of canella and removed from the bitter extract by alcohol 8 per cent. of mannite, which they ascertained to be the so-called Canellin described in 1822 by Petroz and Robinet.

The bark yielded the German chemists 6 per cent. of ash, chiefly carbonate of calcium. The bitter principle has not yet been isolated. An aqueous infusion is not blackened by a persalt of iron.

Commerce-Canella alba is collected in the Bahama Islands and shipped to Europe from Nassau in New Providence, the chief seat of trade in the group.

Uses-The bark is an aromatic stimulant, now but seldom employed. It is used by the West Indian negroes as a condiment.

\section{BIXINEA}

\section{SEMEN GYNOCARDI E.}

\section{Chaulmugra Seed.}

Botanical Origin-Gynocardia odorata R. Br. (Chaulmoogra Roxb. Hydnocarpus Lindl.), a large tree with a globular fruit of the size of a shaddock, containing numerous seeds immersed in pulp. It grows in the forests of the Malayan peninsula and Eastern India as far north as

2 First figured and described by Oude-

2 Gmelin, Chcmistry, xiv. (1S60) 210.

mans, - -Aanteckeningen op het.... Gedeelte

der Pharm. Ncerlandica, 1854-56, 469. 
Assam, extending thence along the base of the Himalaya westward to Sikkim.

History-The inliabitants of the south-eastern countries of Asia have long been acquainted with the seeds of certain trees of the tribe Pangiea (ord. Bixinece) as a remedy for maladies of the skin. In China a seed called Ta-fung-tsze is imported from Siam ${ }^{1}$ where it is known as Iuterabo and used in a variety of cutaneous complaints. The tree affording it, which is figured in the Pun-tsco (circa A.D. 1596), has not been reconnized by botanists, but from the structure of the seed it is obviously closely related to Gynocardia. ${ }^{2}$

The properties of $G$.odorctc were known to Roxburgh who Latinizing the Indian name of the tree, called it (1814) Chaulmoogra odorata. Of late years the seeds have attracted the notice of Europeans in India, and having been found useful in certain skin diseases, they have been admitted a place in the Pharmacopcia of India.

Description-The seeds, 1 to $1 \frac{1}{4}$ inches long and ahout half as much in diameter, are of irregular ovoid form, and more or less angular or flattened by mutual pressure; they weigh on an average about 35 grains each. The testa is very thin (about $\frac{1}{50}$ of an inch), brittle, smooth, dull grey; the copious oily albumen encloses a pair of large, plane, leafy, heart-shaped cotyledons with a stout radicle.

Microscopic Structure-The testa is chiefly formed of cylindrical thick-walled cells. The albumen exhibits large angular cells containing fatty oil, masses of albuminous matter and tufted crystals of calcium oxalate. Starch is not present.

Chemical Composition-No chemical examination of the seeds has yet been made.

Uses-The seeds are said to have been advantageously used as an alterative tonic in scrofula, skin diseases and rheumatism. They should be freed from the testa, powdered, and given in the dose of 6 grains gradually increased. Reduced to a paste and mixed with Simple Ointment, they constitute the Unguentum Gynocardia of the Indian Pharmacopceia, which, as well as an expressed oil of the seeds, may be employed externally in herpes, tinea, \&c.

Substitute-It has been suggested that the seeds of Hydnocarpus Wightiana $\mathrm{Bl}$. a tree of Western India, and of $H$. venenata Gärtn., native of Ceylon, might be tried where those of Gynocardia are not procurable. The seeds of both species of Hydnocarpus (formerly confounded together as $H$. inebrians Vahl) afford a fatty oil which the natives use in cutaneous diseases. ${ }^{3}$

1 The Commereial Report from H.M: Consul-General in Siam for the year 1871, presented to Parliament, Aug. 1872, states that 48 peeuls (64001b.) of Lukkkrabow Seeds were exported from Bangkok to China in 1871.
' 2 Hanbury, Notes on Chinese Mat. Med. (1862) 23.-Dr. Porter Smith assumes the Chinese drug to be derived from $G$. odorata, but as I have pointed out, the seeds have a much stronger testa than those of that tree. -D. H.

3 Waring, Pharm. of India, 1868. 27. 


\section{POLYGALEA.}

\section{RADIX SENEGA.}

Radix Senekce; Senega or Seneta Root; T. Racine de Polygala de Virginie; G. Senegawurzel.

Botanical Origin-Polygalce Senega L., a perennial plant with slender ascending stems 6 to 12 inches high, and spikes of dull white flowers resembling in form those of the Common Milkwort of Britain. It is found in British America as far north as the river Saskatchewan, and in the United States from New England to Wisconsin, Kentucky, Tennessee, Virginia and the upper parts of North Carolina.

The plant which frequents rocky open wools and plains, has become somewhat scarce in the Atlantic states, and as a drug it is now chiefly collected in the west.

History-The employment of this root among the Seneca Indians as a remedy for the bite of the rattle-snake attracted the notice of Tenment, a Scotch physician in Virginia; and from the good effects he witnessed he concluded that it might be administered with advantage in pleurisy and peripneumonia. The result of numerous trials made in the years 1734 and 1735 proved the utility of the drug in these complaints, and Tennent communicated his observations to the celebrated Dr. Mead of London in the form of an epistle, afterwards published together with an engraving of the plant then called the Seneec Rattle-snake Root. ${ }^{1}$ Tennent's practice was to administer the root in powder or as a strong decoction, or more oftcn infused in wine. The new drug was favourably received in Europe, and its virtues discussed in numerous theses and dissertations, one written in 1749 being by Linnæus. ${ }^{2}$

Description-Senega root is developed at its upper end into a knotty crown, in old roots as much as an inch in diameter, from which spring the numerous wiry aerial stems, beset at the base with scaly rudimentary leaves often of a purplish hue. Below the crown is a simple tap-root $\frac{2}{10}$ to $\frac{3}{10}$ of an inch thick, of contorted or somewhat spiral form, which usually soon divides into 2 or 3 spreading branches and smaller filiform rootlets.

The bark is light yellowish-grey, translucent, horny, shrivelled, knotted and partially annulated. Very frequently a keel-shaped ridge occurs, running like a shrunken sinew through the principal root; it has no connexion with the wood, but originatcs in a one-sided development of the liber-tissue. The bark encloses a pure white, woody column about as thick as itself. After the root has been macerated in water the bark is easily peeled off and the peculiar structure of the wood can then be studied. The latter immediately below the crown is a cylindrical cord, cleft however by numerous, fine, longitudinal fissures. Lower down these fissures increase in an irregular manner, causing a very abnormal development of the wood. Transverse sections of a root therefore differ greatly, the circular woody portion being either penetrated by clefts or wide notches, or one-half or even more is altogether wanting, the space 
where wood should exist being in each case filled up by uniform parenchymatous tissue.

Senega root has a short brittle fracture, a peculiar rancid odour, and a very acrid and sourish taste. When handled it disperses an irritating dust.

Microscopic Structure-The woody part is built up of dotted vessels surrounded by short porous ligneous cells; the medullary rays consist of one or two rows of the usual small cells. There is no pith in the centre of the root. The clefts and notches are filled up with an uniform tissue passing into the primary cortical tissue without a distinct liber; the large cells of this tissue are spirally striated. In the keelshaped ridge the proper liber rays may be distinguished from the medullary rays. The former are niade up of a soft tissue, hence the cortical part of the root brealzs short together with the wood.

Neither starch granules nor crystals of oxalate of calcium are present in this root; the chief contents of its tissue are albuminoid granules and drops of fatty oil.

Chemical Composition--The substance to which the drug owes its irritating taste was distinguished by the name of Senegin by Gehlen as early as 1804, and is probably the same as the Polygalic Acid of Quevenne (1836) and of Procter (1859). It appears to be closely allied to saponin, the decomposition-products of the two bodies being the same. Senegin is amorphous, insoluble in ether and in cold water ; it forms with boiling water a frothing solution possessing feebly acid properties, and dissolves in alkaline liquids with a greenish yellow colour. Like saponin it excites violent sneezing.

Dilute inorganic acids added to a warm solution of senegin throw down a flocculent jelly of Sapogenin, the liquid retaining in solution uncrystallizable sugar. Alkalis give rise to the same decomposition; but it is difficult to split up the senegin completely, and hence the formulas given for this process are doubtful. Even the formula of senegin itself is not definitely settled. According to Procter, the root yields $5 \frac{1}{2}$ per cent. of this substance; according to earlier authorities (who doubtless had it less pure) a much larger proportion.

Senega root contains a little volatile oil, traces of resin, also gum, salts of malic acid, yellow colouring matter, and sugar ( 7 per cent. according to Rebling). The Virginic Acid said by Quevenne to be contained in it, and the bitter substance Isolusin mentioned by Peschier, are doubtful bodies.

Uses-Senega is prescribed-as a stimulating expectorant and diuretic, useful in pneumonia, asthma and rheumatism. It is much esteemed in America.

Adulteration-The drug is not liable to be wilfully falsified, but through careless collecting there is occasionally a slight admixture of other roots. One of these is American Ginseng (Panax quinquefolium L.) a spindle-shaped root which may be found here and there both in senega and serpentaria. The rhizome of Cypripenium pubescens Willd. has also been noticed; it cannot be confounded with that of Polygala Senega. 


\section{RADIX KRAMERIAE.}

Radix Rutantice, Rhatantice v. Rathanias; Rhatany or Rhatania Root, Pernvian or Payla Rhatany; F. Racine de Ralantia ; G. Ratantiawurzel. ${ }^{1}$

Botanical Origin-Krameria triandra Ruiz et Pav., a sinalĩ woody shrub with an upright stem scarcely a foot high and thick decumbent branches 2 to 3 feet long. It delights in the barren sandy declivities of the Bolivian and Peruvian Cordilleras at 3000 to 8000 feet above the sea-level, often occurring in great abundance and adorning the ground with its red starlike flowers and silver-grey foliage.

The root is gathered chiefly to the north, north-east, and east of Lima, as at Caxatambo, Huanuco, Tarma, Jauja, Huarochiri and Canta; occasionally on the high lands about lake 'Titicaca. It appears likewise to be collected in the northern part of Peru, since the drug is now frequently shipped from Payta.

History-Hipolito Ruiz ${ }^{2}$ the Spanish botanist observed in 1784 that the women of Huanuco and Lima were in the habit of using for the preservation of their teeth a root which he recognized as that of Krameria triandra, a plant discovered by himself in 1779 . On his return to Europe he obtained admission for this root into Spain in 1796, whence it was gradually introduced into other countries of Europe.

The first supplies which reached England formed part of the cargo of a Spanish prize, and were sold in the London drug sales at the commencement of the present century. Some fell into the hands of Dr. Reece who recommended it to the profesşion. ${ }^{3}$

About 20 years ago there appeared in the European market some other kinds of rhatany previously unknown : of these the more important are noticed at p. 76 .

Description-The root which attains a considerable size in proportion to the aerial part of the shrub, consists of a short thick crown, sometimes much knotted and as large as a man's fist. This ramifies beneath the soil even more than above, throwing out an abundance of branching, woody roots (frequently horizontal) some feet long and $\frac{1}{4}$ to $\frac{1}{2}$ an inch thick. These long roots used formerly to be found in commerce; but of late years rhatany has consisted in large proportion of the more woody central part of the root with short stumpy branches, which from their broken and bruised appearance have evidently been extracted with difficulty from a hard soil.

The bark which is scaly and rugged, and $\frac{\pi}{10}$ to $\frac{1}{20}$ of an inch in thickness, is of a dark reddish brown. It consists of a loose cracked cork-layer, mostly smooth in the smaller roots, covering a bright brownred inner bark, which adheres though not very firmly to a brownish yellow wood. The bark is rather tough, breaking witli a fibrous fracture. The wood is dense, without pith, but marked with thin vessels arranged in concentric rings, and with still thinner, dark medullary rays. The taste of the bark is purely astringent; the wood is almost tasteless: neither possesses any distinctive odour.

1 Ruiz and Pavon state that the root is called at Huanuco ratanhio. The derivation of the word which is of the Quichua langrage is olsscure.
2 Mem. de la R. Acad. mút. dr Madrid. i. (1797) $319-366$.

3 Medical and Chivurgical Rericu . Lond. xiii. (1S06) cexivi.; also Reece, Dicl. of Domest HICd., 1808. 
Microscopic Structure-The chief portion of the bark is formed of liber, which in transverse section exhibits numerous bundles of yellow fibres separated by parenchymatous tissue and traversed by narrow brown medullary rays. The small layer of the primary bark is made up of large cells, the surface of the root of large suberous cells imbued with red matter. The latter also occurs in the inner cortical tissue and ought to be removed by means of ammonia in order to get a clear idea of the structure. Many of the parenchymatous cells are loaded with starch granules; oxalate of calcium occurs in the neighbourhood of the liber bundles. The woody portion exhibits no structure of particular interest.

Chemical Composition-Wittstein (1854) found in the bark of rhatany (the only part of the drug having active properties) about 20 per cent. of a form of tannin called Ratanhic-tannic Acid, closely related to catechu-tannic acid. It is an amorphous powder, the solution of which is not affected by emetic tartar, but yields with ferric chloride, a dark greenish precipitate. By distillation Eissfeldt (1854) obtained pyrocatechin as a product of the decomposition of ratanhia-tannic acid. The latter is also decomposed by dilute acids which convert it into crystallizable sugar and Ratantico-red a substance nearly insoluble in water, also occurring in abundance ready formed in the bark.

Grabowski (1867) showed that by fusing ratanhia-red with caustic potash, proto-catechuic acid and phloroglucin ${ }^{1}$ are obtained. Ratanhiared has the composition $\mathrm{C}^{26} \mathrm{H}^{22} \mathrm{O}^{11}$, the same according to Grabowski, as an analogous product of the decomposition of the peculiar tannic acid occurring (as shown by Rochleder in 1866) in the horse-chesnut. The same red substance may also be obtained, as stated by Rembold (1868), from the tannic acid of the root of tormentil (Potentilla Tormentilla L.).

As to rhatany root, Wittstein also found it to contain wax, gum and uncrystallizable sugar (even in the wood! according to Cotton ${ }^{2}$ ). Cotton further pointed out the presence in very minute quantity of an odorous, volatile, solid body, obtainable by means of ether or bisulphide of carbon; it occurs in a somewhat more considerable amount in the other sorts of rhatany. The root contains no gallic acid.

A dry extract of rhatany resembling kino used formerly to be imported from South America, but how and where manufactured we know not. It is however of some interest as containing a crystalline body which Wittstein who discovered it (1854) regards as Tyrosin, $\mathrm{C}^{9} \mathrm{H}^{11} \mathrm{NO}^{3}$, previously supposed to be exclusively of animal origin. ${ }^{3}$ Its identity with tyrosin has been called in question by Städeler and Ruge (1862), who assign to it a slightly different composition, $\mathrm{C}^{10} \mathrm{H}^{13} \mathrm{NO}^{3}$, and give it the name of Ratanhin. The same substance has been abundantly met with by Gintl (1868) in the natural exudation called Resina d'Angelim pedra which flows from the alburnum of Ferreirea speetabilis Allem., a large Brazilian tree of the order Leguminose (tribe Sophorec). Peckolt who first extracted it, named it Angelin; it forms colourless, neutral crystals yielding compounds both with alkalis and acids, which have been investigated by Gintl in 1869 and 1870 .

\footnotetext{
1 See art. Kino.

2 Etude sur le Genre Krameria (thèse),

3 Gmelin, Chemistry, xiii. (1859) 358. Paris, 1868. 83.
} 
Uses - Rhatany is a valuable astringent, but is not much employed in Great Britain.

Other sorts of Rhatany-Of the 20 to 25 other species of Krameria, all of them belonging to America, several have astringent roots which have been collected and used in the place of the rhatany of Peru. The most iniportant of these drugs is that known as-

Savanilla or New Granada Rhatany. 'The plant yielding it is Krameria tomentosa St. Hil. (Kr . Ixina var. $\beta$ granatensis Triana, $K r$. grandifolia Berg), a shrub 4 to 6 feet high covering large arid tracts in the valley of Jiron between Pamplona and the Magdalena in New Granada, in which locality the collection of the root was observed by Weir in 1864. ${ }^{1}$ According to Triana it also grows at Socorro, south of Jiron. The same plant is found near Santa Marta and Lio Hacha in north-easteru New Granada, in British Guiana, and in the Brazilian provinces of Pernambuco and Goyaz.

The stem or root-crown of Savanilla rhatany is never so knotty and irregular as that of the Peruvian drug, nor are the roots so long or so thick. Separate pieces of root of sinuous form, 4 to 6 inches long and $\frac{2}{10}$ to $\frac{3}{10}$ of an inch thick are most frequent. The drug is moreover well distinguished by its dull purplish brown colour, its thick smooth bark marked with longitudinal furrows, and here and there with deep transverse cracks, and by the bark not easily splitting off as it does in common rhatany.

The anatomical difference depends chiefly upon the more abundant development of the bark which in thickness is $\frac{1}{3}$ to $\frac{1}{4}$ the diameter of the wood. In Peruvian rhatany the cortical layer attains only $\frac{1}{8}$ to $\frac{1}{8}$ of the diameter of the woody column. The greater firmness of the suberous coat in Savanilla rhatany is due to its cells being densely filled with colouring matter.

Savanilla rhatany differs from the Peruvian root in its tannic matter. This becomes evident by shaking the powdered root (or bark) with water and iron reduced by hydrogen. The liquid filtered from the Savanilla sort and diluted with distilled water exhibits an intense violet colour, that from Peruvian rhatany a dingy brown; the latter turus light red by alkalis. Thin sections of the Peruvian root assume a greyish hue when moistened with a ferrous salt; Savanilla root by a similar treatment displays the above violet colour. The Savanilla root is richer in soluble matter and from the greater development of its bark may deserve to be preferred for medicinal use.

Parí Rhatany, - so called from having been shipped from Pará in Brazil. Berg who described it in 1865 termed it Brazitian Rhatany, Cotton in 1868, Ratanhia des Antilles. It is a drug nearly resembling the preceding, but of a darker and less purple hue; it is also in longer sticks which are remarkably flexible, and covered with a thick bark having numerous transverse cracks. ${ }^{2}$ It is apparently derived from the Krameria argentea of Martius, ${ }^{3}$ the root of which is collected in the dry districts of the provinces of Bahia and Minas Geraes.

1 Hanbury, Origin of Savanilla Rihatany, in Pharm. Journ. vi. (1865) 460.-In this paper I referred the drug to a variety of $K r$. Ixina which M. Cotton has shown to differ in no respect from St. Hilaire's $K r$. tomentosa, a conclusion in which, after careful reexamination of specimens, I fully agree.-D. H. 2 For further particulars, see Flückiger, Pharm. Journ., July 30, 1870. 84.

3 Syst. Mat. Mcd. Bras., 1843. 51 ; Langcaard, Diccionario de Medicina, Rio de Janeiro, iii. (1865) 384. 
A kind of rhatany attributed to Krameria secundiflora DC., a plant of Mexico, Texas and Arkansas, was furnished to Berg in 1854 by a Berlin druggist, but has not been in general commerce. Its anatomical structure has been described by Berg. ${ }^{1}$

$K^{\prime}$. cistoidea Hook, a plant scarcely to be distinguished from $K r$. triandra, affords in Chili a rhatany very much like that of Peru. . Its root was contributed to the Paris Exhibition of 1867.

\section{GUTTIFERAE.}

\section{CAMBOGIA.}

Gummi Gambogia, Gummi Gutti; Gamboge; F. Gomme Gutte; G. Gutti, Gummigutt.

Botanical Origin-Gareinia Morella Desrousseaux, var. $\beta$. pedicellata, a diœcious tree with handsome laurel-like foliage and small yellow flowers, found in Camboja, Siam (province of Chantibun and the islands on the east coast of the gulf of Siam), and in the southern parts of Cochin China. It was introduced about thirty years ago into Singapore where several specimens are still thriving (1873) on the estate of Dr. Jamie. The finest is now a tree of 20 feet high, with a trunk a foot in diameter, and a thick, spreading head of foliage.

History-The Chinese had intercourse with Camboja as early as the time of the Sung Dynasty (A.D. 970-1127); and a Chinese traveller who visited the latter country in 1295-97, describes gamboge and the method of obtaining it by incisions in the stem of the tree. ${ }^{2}$ The celebrated Chinese herbal Pun-tsao, written towards the close of the 16th century, mentions gamboge (Tang-hwang) and gives a rude figure of the tree. The drug is regarded by the Chinese as poisonous and is scarcely employed except as a pigment.

The first notice of the occurrence of gamboge in Europe is in the writings of Clusius $^{3}$ who describes a specimen brought from China by the Dutch Admiral Van Neck and given to him in 1603, under the name of Ghittaicmou. ${ }^{4}$ It appears that shortly after this time it began to be employed in medicine in Europe, for in a tariff of prices of the apothecaries of Schweinfurt printed in 1614, ${ }^{5}$ it is thus named:- "suecus Ghittaiemou, Indian. Purgiersaft, ein quintlein, 16 schilling." In the same year there was published at Leipzig a pamphlet by Michael Renden entitled De novo gummi purgante epistola, treating of gamboge. ${ }^{6}$

In 1615, a considerable quantity of garnboge was offered for sale in London by the East India Company. The entry respecting it in the Court Minute Books of the Company under date October 13, 1615, is to this effect:-Three chests, one rundlet, and a basket, containing 13, 14, or 15 hundredweights, more or less, of Cambogium " a drugge un-

3 Bot. Zeitung, 14th Nor. 1856. 797.

${ }^{2}$ Description de Camboge in $A$ bel-Remusat's Nouv. Mélanges Asiatiques, i. (1829) 134.The Chinese traveller ealls the exudation Kiang-hwang which is the name for turneric, but his deseription is unmistakeable.

3 Exotica (1605) 82.

4 Dr. R. Rost is of oniniou that this word derived from the Malay gătáh, gum, and the Javanese jamu signifying medicinal, such mixing of the two languages being of common oecurrence.

5 Valor sive Taxatio omnium materierum medicarum . . quce in officina pharmaceutica Swinphordiana venundantur, Giessen, 1614. 38. (Brit. Mus.)

6 We have only seen the second edition published at Leyden in 1625. 
known here," - the use of which was much commended as "a gentle purge," were offered for sale at 5 s. per lb., bnt met with no purchaser.

Parkinson ${ }^{1}$ who was an apothecary of London and wrote in 1640 speaks of "this Cambugio," called by some Catharticum aureum, as a drug of recent importation which arrived in the form of "wreatlues or roules" yellow within and without.

In the London Pharmacopocia of 1650 , gamboge is called Gutta Gamba ${ }^{2}$ or Ghitta jemon.

The place of production of the drug was first made known in 1658 by Bontius, ${ }^{3}$ a Dutch physician resident in Java; but the tree was not fully cxamined and figured until $1864 .{ }^{4}$

Secretion-We have examined a portion of a branch two inches in diameter of the gamboge-trec, ${ }^{5}$ and have found the yellow gum-resin to be contained chiefly in the middlc layer of the bark in numerous ducts like those occurring in the roots of Inula Helenium. A little is also secreted in the dotted vessels of the outermost layer of the wood, and in the pith. The wood which is white, acquires a bright ycllow tint when exposed to the vapour of ammonia or to alkaline solutions.

Production-At the commencement of the rainy season the gambogecollectors start for the forest in search of the trees which in some localities are plentiful. Having found one of full size thcy make a spiral incision in the bark round half the circumference of the trunk, and place a joint of bamboo to receive the sap which slowly exudes for several months. When it first issues from the tree, it is a yellowish fluid, which after passing through a viscid state hardens into the gamboge of commerce.

The trees grow both in the valleys and on the mountains and will yield on an average in one season enough to fill three joints of bamboo 20 inches in length by $1 \frac{1}{2}$ inches in diameter. The tree appears to suffer no injury provided the tapping is not more frequent than every other year. ${ }^{6}$

Description-The drug arrives in the form of sticks or cylinders 1 to $2 \frac{1}{2}$ inches in diameter, and 4 to 8 inches in length, striated lengthwisc with impressions from the inside of the bamboo. Often the sticks are agglutinated, or folded, or the drug is in compressed or in shapeless masses. It is when good of a rich brownish orange tint, dense and homogeneous, breaking easily with a conchoidal fracture, scarcely translucent even in thin splinters. Touched with water it instantly forms a yellow emulsion. Triturated in a mortar it affords a brilliant yellow powder, slightly odorous. Gamboge has a disagreeable acrid taste.

Much of the gamboge shipped to Europe is of inferior quality being of a brownish hue or exhibiting when broken a rough, granular, bubbly surface. Sometimes it arrives imperfectly dricd and still soft.

1 Theatrum Botanicum (1640) 1575.

2 This name is the Hindustani Gótaganba, signifying according to Moodeen Sheriff (Suppl. to Pharm. of India, s3) juice or extraet of rhubarb. It is still applied to gamboge.

3 Hist. nat. et mérl. Ind. Orient. 153, form- ing part of Piso's work De Indice re nnt. et med. 1658.

4 Hanbury in Trans. of Limn. Soe. xxiv. (1864) 487. tab. 50.

5 Obligingly sent to us by Dr. Jamie of Singapore.

6 Spenser St. John, Lifn in the Forests of the Far East, Lond. 1862. ii. 272. 
Chemical Composition-Gamboge consists of a mixture of resin with 15 to 20 per cent. of gum. The resin dissoltves easily in alcohol forming a clear liquid of fine yellowish-red hue, and neutral or very slightly acid reaction. It forms darker-coloured solutions with ammonia or the fixed alkalis, and a copious precipitate with basic acetate of lead. Perchloride of iron colours a solution of the resin deep blackish brown.

By fusing purified gamboge resin with potash, Hlasiwetz and Barth (1866) obtained together with fatty acids and other acids of peculiar nature, about one per cent. of Phloroglucin (see art. Kino).

The gum which we obtained to the extent of 15.8 per cent. by completely exhausting gamboge with alcohol and ether, was found readily soluble in water. The solution does not redden litmus and is not precipitated by neutral acetate of lead, nor by perchloride of iron, nor by silicate or biborate of sodium. It is therefore not identical with gum arabic.

Commerce-The drug finds its way to Europe from Camboja mostly by Singapore or Bangkok; it has of late been shipped also from Saigon. The exports from Bangkok in 1871 were 358 peculs $(47,73317$. value 17,759 dollars. ${ }^{1}$

Uses-Gamboge is a drastic purgative, seldom administered except in combination with other substances.

Adulteration-The Cambojans adulterate gamboge with rice flour, sand, or the pulverized bark of the tree, ${ }^{2}$ which substances may be easily detected in the residue left after exhausting the drug successively by spirit of wine and cold water.

Other Sources of Gamboge-Although the gamboge of European commerce appears to be exclusively derived from the plant named at the head of this article, the following species of Garcinia are capable of yielding a similar drug which is collected to some small extent for local use, but not for exportation.

1. G. Morella Desr.--The typical form of this tree having sessile male flowers grows in moist forests of Southern India and Ceylon, and is capable of affording good gamboge.

2. G. pictoria Roxb., a large tree of Southern India produces a sort of gamboge found by Christison (1846) essentially the same as that of Siam. It has been examined more recently by Broughton (1871) who states it to be quite equal to that of G. Morella.

3. G. Travancorica Beddome, a beautiful tree of the southern forests of Travancore and the Tinnevelly Ghats (3000 to 4500 feet). According to its discoverer Lieut. Beddome, ${ }^{3}$ it yields an abundance of bright yellow gamboge.

\section{OLEUM GARCINIÆ.}

\section{Concrete Oil of Mangosteen, Koleum Butter.}

Botanical Origin-Garcinia indica Choisy (G. purpurea Roxb. Brindonia indica Dup. Th.), an elegant tree with drooping branches and dark green leaves. It bears a smooth round fruit the size of a small

1 Report from H.M. Consul-General in Siam for 1871.

2 Spenser St. John, op. cil.

3 Flora Sylvatica, Madras, part xv. (1872) titb. 173. 
applè, containing an acid purple pulp in which are lodged as many as 8 seeds. The tree is a native of the coast region of Western India known as the Concan lying between Daman and Goa.

History-The fruit is mentioned by Garcia d'Orta (1563) as known to the Portuguese of Gor by the name of Brindones. Ile states that it has a pleasant taste though very sour, and that it is used in dyeing; and further that the peel serves to make a sort of vinegar. Several succeeding author's (as Bauhin and Ray) have contented themselves with repeating this account.

As to the fruit yielding a fatty oil, we find no reference to such fact till about the year 1830, when it was stated in an Indian newspaper ${ }^{2}$ that an oil of the seeds is well known at Goa and often used to adulterate ghee (liquid butter). It was afterwards pointed out as the result of some experiments that the oil was of an agreeable bland taste and well adapted for use in pharmacy. A short article on Kokum Butter was published by Pereira ${ }^{2}$ in 1851 . With the view of bringing the substance into use for pharmaceutical preparations in India, it has been introduced into the Pharmacopocia of India of 1868.

Preparation-The seeds are reniform, somewhat crescent-shaped or oblong, laterally compressed and wrinkled, $\frac{8}{10}$ to $\frac{8}{10}$ of an inch long by about $\frac{4}{10}$ broad. Each seed weighs on an average about eight grains. The thick cotyledons, which are inseparable, have a mild oily taste. Examination under the microscope shows them to be built up of large reticulated cells containing a considerable proportion of crystalline fat. readily soluble in benzol. In addition globular masses of albuminous matter occur which with iodine assume a brownish yellow hue. With perchloride of iron the walls strike a greenish-black.

The process followed by the natives of India (by whom alone the oil is prepared) has been thus described:-The seeds having been dried by exposure for some days to the sun are bruised, and boiled in water. The oil collects on the surface, and concretes when cool into a cake which requires to be purified by melting and straining.

Description-Kokum Butter is found in the Indian bazaars in the form of egg-shaped or oblong lumps about 4 inches long by 2 inches in diameter, and weighing about a quarter of a pound. It is a whitish substance, at ordimary temperatures, firm, dry, and friable, yet greasy to the touch. Scrapings (which are even pulverulent) when examined in glycerin under the microscope show it to be thoroughly crystalline. They have a mild oily taste, yet redden litmus if moistened with alcohol.

By filtration in a steam-bath, kokum butter is obtained perfectly transparent and of a light straw-colour, concreting again at $27.5^{\circ} \mathrm{C}$. into a white crystalline mass: some crystals appear even at $30^{\circ}$. Melted in a narrow tube, cnoled and then warmed in a water bath, the fat begins to melt at $42 \tilde{\sigma}^{\circ}$ C., and fuses entirely at $45^{\circ}$. The residue left after filtration of the crude fat is inconsiderable and consists chiefly of brown tannic matters soluble in spirit of wine.

When kokum butter is long kept it acquires an umpleasant rancid smell and brownish hue, and an efflorescence of shining tufted crystals appears on the surface of the mass.

1 Qnoted by Graham, Catal. of Bombay

2 Pharm. Journ. xi. (1852) 65.

Plants, 1839. 25. 
Chemical Composition - Purified kokum butter boiled with caustic soda yields a fine hard soap which when decomposed with sulphuric acid affords a crystalline cake of fatty acids weighing as much as the original fat. The acids were again combined with soda and the soap having been decomposed, they were dissolved in alcohol of about 94 per cent. By slow cooling and evaporation crystals were first formed which when perfectly dried, melted at $69.5^{\circ}$ C. : they are consequently Stearic Acid. A less considerable amount of crystals which separated subsequently had a fusing point of $55^{\circ} \mathrm{C}$. and may be referred to Myristic Acid.

A portion of the crude fat was heated with oxide of lead and water, and the plumbic compound dried and exhausted with ether, which after evaporation left a very small amount of liquid oil, which we refer to Oleic Acid.

Finally the sulphuric acid used at the outset of the experiments was saturated and examined in the usual manner for volatile fatty acids (butyric, valerianic, \&c.) but with negative results.

The fat of the seeds of $G$. indica was extracted by ether and examined chemically in 1857 by $\mathrm{J}$. Bouis and d'Oliveira Pimentel. ${ }^{1}$ It was obtained to the extent of 30 per cent., was found to fuse at $40^{\circ} \mathrm{C}$. and to consist chiefly of stearin (tristearin). The seeds yielded 1.72 per cent. of nitrogen. Their residue after exhaustion by ether afforded to alkaline solutions or alcohol a fine red colour.

Uses-The results of the experiments above-noted show that kokum butter is well suited for some pharmaceutical preparations. It might also be advantageously employed in candle-making, as it yields stearic acid more easily and in a purer state than tallow and most other fats. But that it is possible to obtain it in quantities sufficiently large for important industrial uses, appears to us very problematical.

\section{DIPTEROCARPE}

\section{BALSAMUM DIPTEROCARPI.}

\section{Balsamum Gurjuno; Gurjun Balsam, Wood Oil. ${ }^{2}$}

Botanical Origin-This drug is yielded by several trees of the genus Dipterocarpus, namely-

D. turbinatus Gärtn. f. (D. lavis Ham., D. indicus Bedd.), a native of Eastern Bengal, Chittagong and Pegu to Singapore.

D. incanus Roxb., a tree of Chittagong and Pegu.

D. culatus Roxb. growing in Chittagong, Burma, Tenasserim, the Andaman Islands and Siam.

$D$. Zeylanicus Thw. and D. hispidus Thw., indigenous to Ceylon.

$D$. trinervis Bl., a native of Java and the Philippines, and D. gracilis Bl.,

I Cumptes Rendus, xliv. (1857) 1355.

2 The liquid under nctice must not be confounded with the so-ealled Wood Oil of China, wlich is of a totally different nature. The latter is a fatty oil expressed from the seerls of Aleurites cordata Muill. Arg. (Dryandra cordata 'Thumb.), a tree of the order Euphorbiacer, found in China and Japan, and is an artiele of enormous eonsumption among the Chinese, who use it in the eaulking and painting of junks and boats, for preserving woodwork, varnishing furniture, and also in medieine. More than 38 million pounds valued at $£ 547,000$ were exported from Hankow alone dirring the year 1871 . 
D. littoralis B1., D. retusus B1. (D. Spronoghei B1.), trees of Java, supply a similar product which appenrs to be of less commercial importance.

The Gurjun tree is said by Hooker ${ }^{1}$ to be one of the most magnificent of the forests of Chittagong. It is conspicuous for its gigantic size. and for the straightness and graceful form of its tall unbranched trunk, and small symmetrical crown of broad glossy leaves. Many individuals are upwards of 200 feet high and 15 feet in girth.

History-Gurjun balsam was enumerated as one of the productions of Ava by Francklin ${ }^{2}$ in 1811, and in 1813 it was briefly noticed by Ainslie. ${ }^{3}$ Its botanical origin was first made known by Roxburgh who also described the method by which it is extracted.

The medicinal properties of Gurjun balsam were pointed out by O'Shaughnessy ${ }^{4}$ as entirely analogous to those of copaiba; and his observations were confirmed by many practitioners in India. This has obtained for the drug a place in the Pharmacopceic of India (1868).

Extraction-A recent account of the production of this drug is found in the Reports of the Jury of the Madras Extribition of 1855. It is there stated that Wood Oil, as the balsam is commonly called, is obtained for the most part from the coast of Burma and the Straits, and is procured by tapping the trees about the end of the dry season. Several cleep incisions are made with an axe into the trunk of the tree and a good-sized cavity scooped out. In this, fire is placed, and kept burning until the wood is somewhat scorched, when the balsam begins to exude and is then led away into a vessel of bamboo. It is afterwards allowed to settle when a clear liquid separates from a thick portion called the "guad." The oil is extracted year after year, and sometimes there are two or three holes in the same tree. It is produced in extraordinary abundance; from 30 to 40 gallons according to Roxburgh may sometimes be obtained from a single tree in the course of a season, during which it is necessary to remove from time to time the old charrea surface of the wood and burn afresh.

If a growing tree is felled and cut into pieces, the oleo-resin exudes and concretes on the wood, very much, it is said, resembling camphor (?) and having an aromatic smell.

Description-As Gurjun balsam is the produce of different trees as well as of different countries, it is not surprising to find that it varies considerably in its properties.

The following observations refer to a balsam of which $400 \mathrm{tb}$. were recently imported from Moulmein for a London drug firm. It is a thick and viscid fluid, exhibiting a remarkable fluorescence, so that when seen by reflected light it appears opaque and of a dingy greenish grey; yet when placed between the observer and strong daylight it is seen to be perfectly transparent and of a dark reddish-brown. It has a weak aromatic copaiba-like odour and a bitterish aromatic taste without the persistent acridity of copaiba. Its sp. gr. at $16.9^{\circ} \mathrm{C}$. is 0.964 .

I Himalayan Journals, cd. 2., ii. (1855) 332.

${ }^{2}$ Tracts on the Dominions of Ava, Lond.

3 Mat. Mcd. of Hindoostan, Madras, 1813. 186.

* Bengal Disponsatory, $18+2.222$.

1811. 26. 
With the following liquids Gurjun affords perfectly clear solutions which are more or less fluorescent, namely pure benzol (from benzoate of calcium), cumol, chloroform, sulphicle of carbon, essential oils. On the other hand, it is not entirely soluble in methylic, ethylic, or amylic alcohol, in ether, acetic ether, glacial acetic acid, acetone, phenol (carbolic acid), or in caustic potash dissolved in absolute alcohol. Many samples of commercial benzol also are not capable of dissolving the oleo-resin perfectly, but we have not ascertained on what constituent of such. benzol this depends. We have noticed however that that portion of petroleum which is known as Petroleum Ether, containing the most volatile hydrocarbons, does not wholly dissolve the oleo-resin, while the less volatile cumol $\left(\mathrm{C}^{9} \mathrm{H}^{12}\right)$ does so. One hundred parts of the balsam warmed and shaken with 1000 parts of absolute alcohol yielded on cooling a precipitate of resin amounting when dried to 18.5 parts. All concentrated solutions of the balsam are precipitated by amylic alcohol.

If the balsam is kept for a long time in a stoppered vessel at $100^{\circ} \mathrm{C}$. it simply becomes a little turbid; but at about $130^{\circ} \mathrm{C}$. it is transformed into a jelly, and on cooling does not resume its former fluidity. Balsam of copaiba heated in a closed glass tube to $220^{\circ} \mathrm{C}$. does not at all lose its fluidity, whereas Gurjun balsan becomes an almost solid mass.

Chemical Composition-Of the balsam 6.99 grammes dissolved in benzol and kept in a water bath until the residue ceased to lose weight, yielded $3 \cdot 80$ grammes of a dry, transparent, semi-fluid resin, corresponding to 54.44 per cent., and 45.56 of volatile matters expelled by evaporation.

By submitting larger quantities of the balsam to the usual process of distillation with water in a large copper still, 37 per cent. of volatile oil were easily obtained. The water passing over at the same time did not redden litmus paper. A dark, viscid, liquid resin remained in the still.

The essential oil is of a pale straw-colour and less odorous than most other volatile oils. Treated with chloride of calcium and again distilled, it begins to boil at $210^{\circ} \mathrm{C}$. and passes over at $260^{\circ} \mathrm{C}$., acquiring a somewhat empyreumatic smell and light yellowish tint. The purified oil has a sp. gr. of $0.915 ;{ }^{1}$ it is but sparingly soluble in absolute alcohol or glacial acetic acid, but mixes readily with amylic alcohol.

According to Werner (1862) this oil has the composition $\mathrm{C}^{40} \mathrm{H}^{32}$, like that of copaiba. He says it deviates the ray of polarized light to the left, but that prepared by one of us deviated strongly to the right, the residual resin dissolved in benzol being wholly inactive. The oil does not form a crystalline compound with dry hydrochloric acid, which colours it of a beautiful blue. ${ }^{2}$ De Vry $^{3}$ states that the essential oil after this treatment deviates the ray to the right.

The resin contains, like that of copaiba, a small proportion of a crystallizable acid which may be removed by warming it with ammonia in weak alcohol. That part of the resin which is insoluble even in absolute

10.944 according to Werner; 0.931 O'Shaughnessy; 0.928 De Vry (1857).
2 This magnificent colouring matter is no dissolved by ether.

${ }^{3}$ Pharm. Journ, xvi. (185i) 374 
alcohol, ${ }^{1}$ we found to be uncrystallizable. The Gurgunic Acid as the crystallized resinous acid is called by Werner, ${ }^{2}$ but whicls it is more correct to write Gurjunic, may consequently be prepared by extracting the resin with alcohol ( 838$)$ and mixing the solution with ammonia. From the ammoniacal solution gurjunic acid is precipitated on addition of a mineral acid, and if it is again dissolved in ether and alcolool it may be procured in the form of small crystalline crusts. From the specimen under examination we were not successfur in obtaining indubitable crystals.

Gurjunic acid, $\mathrm{C}^{44} \mathrm{H}^{08} \mathrm{O}^{8}$ according to Werner, melts at $220^{\circ} \mathrm{C}$., and concretes again at $180^{\circ} \mathrm{C}$. ; $^{\circ}$ it begins to boil at $260^{\circ} \mathrm{C}$., yet at the same time decomposition takes place. By assigning to this acid the formula $\mathbb{C}^{44} \mathrm{H}^{6.1} \mathrm{O}^{5}+3 \mathrm{H}^{2} \mathrm{O}$, which agrees well with Werner's analytical results, we may regard it as a hydrate of abietinic acid, the chemical behaviour of which is perfectly analogous. Gurjunic acid is soluble in alcohol 0.838 , but not in weak alcohol; it is dissolved also by ether, benzol, or sulphide of carbon (Werner).

In copaiba from Maracaibo, Strauss (1865) discovered Metacopaivic Acid which is probably identical with gurjunic; the former however fuses at $206^{\circ} \mathrm{C}$.

The amorphous resin forming the chief bulk of the residue of the distillation of the balsam, has not yet been subinitted to exact analysis. We find that after complete desiccation it is not soluble in absolute alcohol.

Commerce-Gurjun balsam is exported from Singapore, Moulmein, Akyab and the Malayan Peninsula, and is a common article of trade in Siam. It is likewise produced in Canara in Southern India. It is occasionally shipped to Europe. More than 20001tb were offered for sale in London under the name of East Indian Balsam Capivi, 4th October, 1855; and in October 1858 a no less quantity than 45 casks appeared in the catalogue of a London drug-broker. It is now not unfrequent in the London drug sales.

Uses-In medicine it has hitherto been employed only as a substitute for copaiba, and chiefly in the hospitals of India.

In the East its great use is as a natural varnish, either alone or combined with pigments; and also as a substitute for tar as an application to the seams of boats, and for preserving timber from the attacks of the white ant.

\section{MALVACEÆ.}

\section{RADIX ALTHÆ无.}

Marshmallow Root; F. Racinc de Guinauve; G. Eibischwurzel.

Botanical Origin-Althoca officinalis L., the marshmallow, grows in moist places throughout Europe, Asia Minor, and the temperate parts of Western and Northern Asia, but is by no means universally distributed. It prefers saline localities such as in Spain the salt marshes of Saragossa, the low-lying southern coasts of France near Montpellier, Southern Russia, and the neighbourhood of salt-springs in Central Europe.

I The sample of gurjun balsam examined

${ }^{2}$ Gmelin, Chemistry, xvii. 545. 
In Britain it occurs in the low grounds bordering the Thames below London, and here and there in many other spots in the south of England and of Ireland.

The cultivated marshmallow thrives as far north as. Throndbjem in Norway, and has been naturalized in North America (salt marshes of New England and New York) and Australia. It is largely cultivated in Bavaria and Würtemberg.

History-Marshmallow had inany uses in ancient medicine, and is described by Dioscorides as 'A $\lambda \theta$ cía, a name derived from the Greek verb $\grave{a} \lambda \theta \epsilon \iota v$, to heal.

The diffusion of the plant in Europe during the middle ages was promoted by Charlemagne who enjoined ${ }^{1}$ its culture (A.D. 812) under the name of "Mismalvas, id est alteas quod dicitur ibischa."

Description-The plant has a perennial root attaining about a foot in length and an inch in diameter. For medicinal use the biennial roots of the cultivated plant are chiefly employed. When fresh they are externally yellowish and wrinkled, white within and of tender fleshy texture. Previous to drying the thin outer and a portion of the middle bark are scraped off, and the small root filaments are removed. The drug thus prepared and dried consists of simple whitish sticks 6 to 8 inches long, of the thickness of the little finger to that of a quill, deeply furrowed longitudinally and marked with brownish scars. Its central portion which is pure white breaks with a short fracture, but the bark is tough and fibrous. The dried root is rather flexible and easily cut. Its transverse section shows the central woody colnmn of undulating outline separated from the thick bark by a fine dark line shaded off outwards.

The root has a peculiar though very faint odour and is of rather mawkish and insipid taste, and very slimy when chewed.

Microscopic Structure-The greater part of the bark consists of liber, abounding in long soft fibres, to which the toughness of the cortical tissue is due. They are branched and form bundles each containing from 3 to 30 fibres separated by parenchymatous tissue. Of the cortical parenchyme many cells are loaded with starch granules, others contain stellate groups of oxalate of calcium, and a considerable number of somewhat larger cells are filled with mucilage. The last-named on addition of alcohol is seen to consist of different layers.

The woody part is made up of pitted or scalariform vessels, accompanied by a few ligneous cells and separated by a parenchymatous tissue, agreeing with that of the bark. On addition of an alkali, sections of the ront assume a bright yellow hue.

Chemical Composition-The mucilage in the dry root amounts to about 25 per cent. and the starch to as much more. The former appears from the not very accordant analyses of Schmidt and of Mulder to agree with the formula $\mathrm{C}^{12} \mathrm{H}^{20} \mathrm{O}^{10}$, thus differing from the mucilage of gum arabic by one molecule less of water. It likewise differs in being precipitable by neutral acetate of lead. At the same time it does not show the behaviour of cellulose, as it does not turn blue by iodine when moistened with sulphuric acid, and it is not soluble in ammoniacal solution of oxide of copper. 'Pertz, Monumenta Germanice historica, Legum tom. i. (1835) 181.-16ischa from the
Greek ißíros. 
The root also contains pectin and sugar (cane-sugar according to Wittstock), and a trace of fatty oil. Tannin is found in very small quantity in the outer bark alone.

In 1826 Bacon, a pharnacien of Caen, obtained from althrea root crystals of a substance at first regarded as peculiar', but subsequently identified with Asparagin, $\mathrm{C}^{4} \mathrm{H}^{8} \mathrm{~N}^{2} \mathrm{O}^{3}, \mathrm{H}^{2} \mathrm{O}$. It had been previously prepared (1805) by Vauquelin and Robiquet from asparagus and is now known to be a widely-diffused constituent of plants. ${ }^{1}$ Marshmallow root does not yield more than 0.8 to 2.0 per cent. Asparagin crystallizes in large prisms or octohedra of the rhombic system; it is nearly tasteless and appears destitnte of physiological action. It is quite permanent whether in the solid state or dissolved, but is easily decomposed if the solution contains the albuminoid constituents of the root, which act as a ferment. Leguminous seeds, yeast or decayed cheese induce the same change, the final product of which is succinate of ammonium, the asparagin taking the elements of water and hydrogen set free by the fermentation, thus-

$$
\begin{aligned}
& \mathrm{C}^{4} \mathrm{H}^{8} \mathrm{~N}^{2} \mathrm{O}^{8}+\mathrm{H}^{2} \mathrm{O}+2 \mathrm{H}= \\
& \text { Asparagin } \\
& \text { Succinate of Ammonium } \\
& 2 \mathrm{NH}^{4}, \mathrm{C}^{4} \mathrm{H}^{4} \mathrm{O}^{4}
\end{aligned}
$$

Under the influence of acids or bases, or even by the prolonged boiling of its aqueous solution, asparagin is converted into Asparbate of Ammonium, $\mathrm{C}^{4} \mathrm{H}^{6}\left(\mathrm{NH}^{4}\right) \mathrm{NO}^{4}$, of which it contains the elements.

These transformations, especially the former, are undergone by the asparagin in the root, if the latter has been imperfectly dried, or has been kept long, or not very dry. Under such conditions, the asparagin gradually disappears, and the root then yields a yellow decoction, sometimes having a disagreeable odour of butyric acid. There is no doubt that a protein-substance here acts as a ferment.

The peeled root dried at $100^{\circ} \mathrm{C}$. and incinerated afforded us 4.88 of ash, rich in phosphates.

Uses-Althæa is taken as a demulcent; it is sometimes also applied as an emollient poultice. It is far more largely used on the continent than in England.

\section{FRUCTUS HIBISCI ESCULENTI:}

Capsulos Hibisci csculenti; Okro, Okra, Bendi-kai2 ; F. Gombo (in the
French Colonies).

Botanical Origin-Hibiscus esculentus L. (Abelmoschus esculentus Guill. ct Perr.) an herbaceous annual plant 2 to 3 feet high, indigenous to the Old World (Africa?), but now cultivated in all tropical countries.

History-The Spanish Moors appear to have been well acquainted with Hibiscus esculentus which was known to them by the same name that it has in Persian at the present day-Bámiyah. Abul-Abbas elNebáti, a native of Seville learned in plants, who visited Egypt in

I It plays an interesting part in the germination of the seeds of papilionaceous plants. It is abundant in the young plants, but in most it speedily disappear's. Its presence can be proved in the juice by means of the microscope and absolute alcohol, in which latter asparagin is insoluble. See
Pfeffer in Pringsheim's Jahrb. f. wiss. Bot. 1872. 533-564.

2 Okro or Okra are common names fur the plant in the East and West Indies. Bondi. Tai, a Canarese and Tamil word, is used by Europeans in the South of India. 
A.D. 1216 , describes ${ }^{1}$ in unmistakeable terms the form of the plant, its seeds and fruit, which last he remarks is eaten when young and tender with meat hy the Egyptians. The plant was figured among Egyptian plants in 1592 by Prosper Alpinus ${ }^{2}$ who mentions its uses as an external emollient.

It is noticed in the present work from the circumstance that it has a place in the Pharmacopcia of India.

Description-The fruit is a thin capsule, 4 to 6 or more inches long and about an inch in diameter, oblong, pointed, with 5 to 7 ridges correspouding to the valves and cells, each of which latter contains a single row of round seeds. It is covered with rough hairs and is green when fresh; it has a slightly sweet mucilaginous taste and a weak herbaceous odour. Like many other plants of the order, Hibiscus esculentus abounds in all its parts with insipid mucilage.

Microscopic Structure-A characteristic part for microscopic examination are the hairs of the fruit. They exhibit at the base one large cell, but their elongated and often slightly curved end is built up of a considerable number of small cells, without any solid contents. The middle and outer zone of the pericarp shows enormous holes filled up with colourless mucilage. In polarized light it is easily seen to be composed of successive layers.

Chemical Composition - It is probable that the fruits contain the same mucilage as Althoca, but we have had no opportunity of investigating the fact. Popp who examined them green in Egypt, states ${ }^{3}$ that they abound in pectin, starch and mucilage. He found that when dried they afforded 2 to 24 per cent. of nitrogen, and an ash rich in salts of lime, potash and magnesia. The ripe seeds gave $2.4-2.5$ per cent. of nitrogen; their ash 24 per cent. of phosphoric acid.

Uses-The fresh or dried, unripe fruits are used in tropical countries as a demulcent like marshmallow, or as an emollient poultice, for which latter purpose the leaves may also be employed. They are more important from an economic point of view, being much employed for thickening soups or eaten boiled as a vegetable. The root has been recommended as a substitute for that of Althoca. ${ }^{4}$ The plant yields a good fibre.

\section{STERCULIACE无.}

\section{OLEUM CACAO.}

Butyrum Cacao, Olcum Thcobromatis ; Cacao Butter, Oil of Theobroma; F. Beurre de Cacao; G. Cacaobutter, Cacaotaly.

Botanical Origin-Cacao seeds (from which Cacao Butter is extracted) are furnished by Theobroma Cacao L., and apparently also by Th. leiocarpum Bernoulli, Th. pentagonum Bern., and Th. Salzman-

1 Ibn Paytar, Sonthcimer's translation, i. 118 ; Wiistenfeld, Geschichte d. Arab. Aerzle etc. 1840.118.

27.
142.

${ }^{4}$ Della Sudda, Rép. de Pharm., Janvier, 1860. 229 . 
nianum Bern. ${ }^{1}$ These trees are found in the northern parts of South America and in Central America as far as Mexico, both in a wild state and in cultivation.

History-Cacao butter was prepared and described by Homberg ${ }^{2}$ as early as 1695 , at which time it appears to liave had no particular application.

An essay published at Tuibingen in $1735^{3}$ called attention to it as "novun atque commendatissimum medicamentum." A little later it is mentioned by Geoffroy ${ }^{4}$ who says that it is obtained either by boiling or by expressing the seeds, that it is recommended as the basis of cosmetic pomades and as an application to chapped lips and nipples, and to hæmorrhoids.

Production-Cacao butter is procured for use in pharrnacy from the manufacturers of chocolate who obtain it by pressing the warmed seeds. These in the shelled state yield from 45 to 50 per cent. of oil. The natural seeds consist of about 12 per cent. of shell (testa) and 88 of kernels (cotyledous).

Description-At ordinary temperatures cacao butter is a light yellowish, opaque, dry substance, usually supplied in the form of oblong tablets having somewhat the aspect of white Windsor soap. Though unctuous to touch, it is brittle enough to break into fragments when struck, exhibiting a dull waxy fracture. It has a pleasant odour of chocolate and melts in the mouth with a bland agreeable taste. Its sp. gr. is 0.961 ; its fusing point $29^{\circ}$ to $30^{\circ} \mathrm{C}$.

Examined under the microscope by polarized light, cacao butter is seen to consist of minute crystals. It is dissolved by 20 parts of boiling absolute alcohol, but on cooling separates to such an extent that the liquid retains not more than 1 per cent. in solution. The fat separated after refrigeration is found to have lost most of its chocolate flavour. Litmus is not altered by the hot alcoholic solution.

Cacao butter in small fragments is slowly dissolved by double its weight of benzol in the cold $\left(10^{\circ} \mathrm{C}\right.$.), but by keeping partially separates in crystalline warts.

Chemical Composition-The fat under notice is composed in common with others, of several bodies which by saponification furnish glycerin and fatty acids. Among the latter occurs in small proportion oleic acid, ${ }^{5}$ contained in that part of the cacao butter which remains dissolved in cold alcohol as above stated. In fact by evaporating that solution a soft fat is obtained. But the chief constituent of cacao butter appears to be stearin. Palmitin also occurs, and another compound of glycerin containing probably an acid of the same series richer in carbon,-perhaps arachic acid, $\mathrm{C}^{20} \mathrm{H}^{40} \mathrm{O}^{2}$.

Uses-Cacao butter which is remarkable for having but little tendency to rancidity, has long been used in continental pharniacy; it was

1 Bernoulli, Uebersicht der bis jetzt bekannten Arten von Theobroma.-Reprinted from Denkschriftcn der Sehweizerischen Gesellsehaft für Naturwissensehaften, xxiv. (Zürich 1869) 40.376.

2 IIist. d: l'Acad. Roy. des Sciences, tome ii. depuis 1686 jusqu'à 1699, Paris, 1733. p. 248.

3 B. D. Mauchart præside-dissertatio : Butyrum Cacao. Resp. 'Theoph. Hoffmann.

4 Tract. dc Mat. Mcd. ii. (1741) 409.

s See article Amygdala dulecs. 
introduced into England a few years ago as a convenient basis for suppositories and pessaries.

Adulteration-The descliption given of the drug sufficiently indicates the means of ascertaining its purity.

\section{LINEAE.}

\section{SEMEN LINI.}

Linseed, Flax Seed; F. Semence de Lin; G. Leinsamen, Flachssamen.

Botanical Origin-Linum usitatissimum L., Common Flax, is an annual plant, native of the Old World where it has been cultivated from the remotest times. It sows itself as a weed in tilled ground and is now found in all temperate and tropical regions of the globe. Heer regards it as a variety evolved by cultivation from the perennial $L$. angustifolium Huds.

History - The history of flax, its textile fibre and seed, is intimately connected with that of human civilization. The whole process of converting the plant into a fibre fit for weaving into cloth is frequently depicted on the wall-paintings of the Egyptian tombs. ${ }^{1}$ The graveclothes of the old Egyptians were made of flax, and the use of the fibre in Egypt may be traced back, according to Unger, ${ }^{2}$ as far as the 23rd century B.C. The old literature of the Hebrews ${ }^{3}$ and Greeks contains frequent reference to tissues of flax; and fabrics woven of flax have actually been discovered together with fruits and seeds of the plant in the rernains of the ancient pile-dwellings bordering the lakes of Switzerland."

The seed in ancient times played an important part in the alimentation of mall. Among the Greeks, Alcman in the 7 th century B.C., and the historian Thucydides, and among the Romans Pliny, mention linseed as employed for human food. The roasted seed is still eaten by the Abyssinians. ${ }^{5}$

Theophrastus (3rd century B.c.) expressly alludes to the mucilaginous and oily properties of the seed. Pliny and Dioscorides were acquainted with its medical application both external and internal. The latter, as well as Columella, exhaustively describes Hax under its agricultural aspect. In an edict of the Emperor Diocletian De pretiis rerum venalium ${ }^{6}$ dating A.D. 301, linseed is quoted 150 denarii, sesamé seed 200, hemp seed 80, and poppy seed 150, the modius castrensis, equal to about 880 cubic inches. ${ }^{7}$ The propagation of flax in Northern Europe as of so many other useful plants was promoted by Charlemagne. ${ }^{8}$

Description-The capsule which is globose splits into 5 carpels each containing two seeds separated by a partition. The seeds are of 1 Wilkinson, Ancient Egyptians, iii. (183\%)
138, \&c.

2 Sitzungsbericht der Wiener Akademic, Juni 1866.

3 Exod. ix. 31 ; Lev. xiii. 47,48 ; Isaiah xix. 9 . 87.

${ }^{4}$ Heer in Trimen's Journ. of Bot. i. (1872)
5 A. de Candolle, Géogr. Botanique, 835.

6 See p. 61, note 2.

7 The English iniperial gallon $=277 \cdot 27$ cubic inches.

8 For further historical information on flax in ancient times, we may lefer to Hehn, Kulturpflanien und Hausthic'c . . Berlin $1870.97,430$. 
flattened, elongated ovoid form with an acute edge, and a slightly oblique point blunt at one end. They liave a brown, glossy, polished surfaee which under a lens is seen to be marked with extremely fine pits. The hilum oeeupies a slight hollow in the edge just below the apex. The testa which is not very hard encloses a thin layer of albumen sur'rounding a pair of large cotyledons having at their pointed extremity a straight embryo. The seeds of different eountries vary from $\frac{1}{4}$ to $\frac{1}{6}$ of an inch in length, those produced in warm regions being larger than those grown in eold. We find that 6 seeds of Sicilian linseed, 13 of Black Sea and 17 of Arehangel linseed weigh respeetively onc grain.

When immersed in water, the seeds beeome surrounded by a thin, slippery, colourless, mueous envelope, which quiekly dissolves as a neutral jelly, while the seed slightly swells and loses its polish. The seed when mastieated has a mucilaginous oily taste.

Microscopic Structure-On examining the testa under almond oil or oil of turpentine, the outlines of the epidermal eells are not distinetly visible. But under dilute glycerin or in water the epidermis quickly swells up to 3 or 4 times its original thickness; on warming, the entire epidermis is resolved into mucilage, exeept a thin skeleton of eell-walls, whieh withstands even the aetion of eaustie lye. The formation of the mueilage may be eonveniently studied by the use of a solution of ferrous sulphate, with which thin seetions of the testa should be moistened. Other struetural peeuliarities may be seen if they are imbued with coneentrated sulphurie aeid, washed, and then moistened with a solution of iodine. The applieation of polarized light is also 'useful. By the latter means erystalloid granules of albuminoid matter beeome visible if the seetions are examined under oil. The tissue of the albumen and the eotyledons abounds in drops of fatty oil.

Chemical Composition-The constituent of chief importanee is the fixed oil whieh the seed eontains to about $\frac{1}{3}$ of its weight. The proportion obtained by pressure on a large seale is 20 to 30 per cent. varying with the quality of the seed. The oil when pressed without heat and when fresh has but little eolour, is without unpleasant taste, and does not solidify till eooled to $-20^{\circ} \mathrm{C}$. The commereial oil however is dark yellow and has a sharp repulsive taste and odour. On exposure to the air, espeeially after having been heated with oxide of lead, it quiekly dries up to a transparent varnish eonsisting ehiefly of Linoxyn $\mathrm{C}^{32} \mathrm{H}^{54} \mathrm{O}^{11}$. The erude oil increases in weight 11 to 12 per cent. although at the same time its glycerin is destroyed by oxidation.

By saponifieation, linseed oil yields glyeerin, and 95 per cent. of fatty aeids, consisting ehiefly of Linoleic A cid, $\mathrm{C}^{16} \mathrm{H}^{26} \mathrm{O}^{2},{ }^{1}$ aeeompanied by some oleie, palmitie, and myristie aeid. The aetion of the air transforms linoleic aeid into the resinoid Uxylinoleic Acid $\mathrm{C}^{16} \mathrm{H}^{26} \mathrm{O}^{5}$. Linoleie acid appears to be contained in all drying oils, notably in that of poppy seed. It is not homologous either with ordinary fatty aeids or with the oleie aeid of oil of almonds, $\left.\mathrm{C}^{18}\right]\left[{ }^{34} \mathrm{O}^{2}\right.$. The chemistry 1 Formula of Siissenguth $(1865) ; \mathrm{C}^{16} \mathrm{H}^{28} \mathrm{O}^{2}$ according to Mulder. 
of the drying oils, especially those of linseed and poppy, has been particularly investigated by Mulder. ${ }^{1}$

The viscid mucilage of linseed cannot be filtered till it has been boiled. It contains in the dry state more than 10 per cent. of mineral substances, when freed from which and dried at $110^{\circ} \mathrm{C}$. it corresponds like althra-mucilage, to the formula $\mathrm{C}^{12} \mathrm{H}^{20} \mathrm{O}^{10}$. The seeds by exhaustion with cold or warm water afford of it about 15 per cent. By boiling nitric acid it yields crystals of mucic acid. Its chemical relations are therefore those of gum and not of soluble cellulose.

Linseed contains about 4 per cent. of nitrogen corresponding to about 25 per cent. of protein-substances. After expression of the oil these substances remain in the cake so completely that the latter contains 5 per cent. of nitrogen, and constitutes a very important article for feeding cattle.

In the ripe state linseed is altogether destitute of starch, though this substance is found in the immature seed in the very cells which subsequently yield the mucilage. The latter may be regarded as in analogous cases to be a product of the transformation of starch.

The amount of water retained by the air-dry seed is about 9 per cent.

The mineral constituents of linseed, chiefly phosphates of potassium, magnesium, and calcium, amount on all average to 3 per cent., and pass into the mucilage. By treating thin slices of the testa and its adhering inter membrane with ferrous sulphate, it is seen that this integument is the seat of a small amount of tannin.

Production and Commerce-Flax is cultivated on the largest scale in Russia, from which country there was imported into the United Kingdom in 1872, linseed to the value of 3 millions sterling. The shipments were made in about equal proportion from the northern and the southern ports of Russia.

The imports from India in the same year amounted in value to $£ 1,144,942$, and from Germany and Holland to $£ 144,108$. The total import in 1872 was $1,514,947$ quarters, value $£ 4,513,842$.

The cultivation of flax in Great Britain appears to be declining. The area under this crop in 1870 was 23,957 acres; in $1871,17,366$ acres; in 1872, 15,357 acres; and in 1873, 14,683 acres. The last. named area reckoning the yield at 2 to $2 \frac{1}{2}$ quarters of seed per acre would represent a production of about 30,000 to 38,000 quarters.

In English price-currents, eight. sorts of linseed are enumerated, namely, English, Calcutta, Bombay, Egyptian, Black Sea and Azof, Petersburg, Riga, Archangel. The first three appear to fetch the highest prices.

Uses-In medicine, linseed is chiefly used in the form of poultice, which may be made either of the seed simply ground or of the pulverized cake. In either case the powder should not be long stored, as the oil in the comminuted seed is rapidly oxidized and fatty acids produced. An infusion of the seeds called Linseed $T e a$ is a common popular demulcent remedy.

1 His numerous investigations on this subjeet have been published in a separate paniphlet: of which we have before us a
German translation: G. J. Mulder, Die Chemic der austrocknenden Ocle. . Berlin, $1867, \mathrm{pp} .255$. 
Adulteration-Linseed is very iable to adulteration with other seeds, especially when the commodity is scarce. The admixture in question is due in part to careless harvesting and in part to intentional additions. In 1864 the impure condition of the linsced shipped to the English market had become so detrimental to the trade that the importers and crushers' founded an association called 'The Linsecd Association of London, by which they bound themselves to refuse all linseed containing more than 4 per cent. of foreign seeds, and this step very rapidly improved the quality of the article. ${ }^{1}$

As the rluggist has to purchasc linseed meal, he must of necessity rely to some extent on the character of the oil-presser from whom he derives his supplies. The presence of the seeds of Cruciferce (as rape and mustard) which is common, may be recognized by the pungent odour of the essential oil which they develope in contact with water. The introduction of cereals would also be easily discovered by iodine, which strikes no blue colour in a decoction of linseed. The microscope will also afford important aid in the examination of linseed cake or meal.

\section{ZYGOPHYLLEAE.}

\section{LIGNUM GUAIACI.} Lignum sanctum; Guaiacum Wood, Lignum Vita; F. Bois de Gayac;
G. Guaiakholz, Pockholz.

Botanical Origin-This wood is furnished by two West Indian species of Guciacum, namely :-

1. G. officincle L., a middle-sized or low evergreen tree, with light blue flowers, paripinnate leaves having ovate, very obtuse leaflets in 2, less often in 3 pairs, and 2-celled fruits. It grows in Cuba, Jamaica (abundantly on the arid plains of the south side of the island), Les Gonaives in the N.W. of Hayti (plentiful), St. Domingo, Martinique, St. Lucia, St. Vincent, Trinidad, and the northern coast of the South American continent. This tree affords the Lignum Vitæ of Jamaica (of which very little is imported), a portion of that shipped from the ports of Hayti, and probably the small quantity exported by the United States of Colombia.

2. G. sanctum L., a tree much resembling the preceding, but distinguishable by its leaves having 3 to 4 pairs of leaflets which are very obliquely obovate or oblong, passing into rhomboid-ovate, and mucronulate; and a 5-celled fruit. It is found in Southern Florida, the Bahama Islands, Key West, Cuba, St. Domingo (including the part called Hayti) and Puerto Rico, and is certainly the source of the small but excellent Lignum Vitæ exported from the Bahamas as well as of some of that shipped from Hayti.

History-There can be no doubt but that the earliest importatious of Lignum Vitæ were obtained from St. Domingo, of which island, Oviedo ${ }^{2}$ who landed in America in 1514 mentions the tree, under the name of Guayacan, as a native. He points out its fruits as yellow and

1 Greenish in Yeur-Book of Pharmacy, 1871. 590; Phurm. Journ: Sept. 9, 1871. 211. 
resembling two joined lupines, which could only be said with reference to $G$. offieincule and would not apply to the ovoid, five-cornered fruits of G. scuctum. Oviedo appears however to have been aware of two species, one of which he found in Española (St. Domingo) as well as in Nagrando (Nicaragua), and the other in the island of St. John (Puerto Rico), whence it was called Iignum sanctum.

The first edition of Oviedo was printed in 1526; but some years before this the wood must have been known in Germany, as is evident by the treatises written in 1517, 1518, and 1519 by Nicolaus Poll, ${ }^{1}$ Leonard Schmaus ${ }^{2}$ and Ulrich vou Hutten. ${ }^{3}$ The last which gives a tolerable description of the tree, its wood, bark, and medicinal properties was translated into English in 1533 by Thomas Paynel, canon of Merton Abbey, and published in London in 1536 under the title - " Of the wood called Guaideum that healeth the Frenehe Poekes and also helpeth the goute in the feete, the stoone, the palsey, lepree, dropsy, fallynge ouyll, and other dyseases." It was several times reprinted.

Description ${ }^{4}$ - The wood (always known in commerce as Lignum Vitce) as imported consists of pieces of the stem and thick branches, usually stripped of bark, and often weighing a hundredweight each. It is remarkably heavy and compact. Its sp. gr. which exceeds that of most woods is about $1 \cdot 3$.

Lignum Vitæ is mostly imported for turnery, ${ }^{5}$ and the chips, raspings and shavings are the only form in which it is commonly seen in pharmacy. A stem 7 to 8 inches in diameter cut transversely exhibits a light-yellowish zone of sapwood about an inch wide, enclosing a sharply defined heartwood of a dark greenish brown. Both display alternate lighter and darker layers, which especially in the sapwood are further distinguished by groups of vessels. In this manner are formed a large number of circles resembling annual rings, the general form of which is evident, though the individual rings are by no means well defined. More than 20 such rings may be counted in the sapwood of a log such as we have mentioned, and more than 30 in the heartwood. The pithless centre is usually out of the axis. The medullary rays are not visible to the naked eye but may be seen by a lens to be very numerous and equidistant. The pores of the heartwood may be distinguished as containing a brownish resin, while those of the outermost layer of sapwood are empty.

In the thickest pieces sapwood is wanting and even in stems of about a foot in diameter it is reduced to $\frac{1}{5}$ of an inch. It is of looser texture than the heartwood and floats on water, whereas the latter sinks. Both sapwood and heartwood owe their tenacity to a peculiar zigzag arrangement of the woody bundles. The sapwood is tasteless. The

1 De cura Morbi Gallici por Lignum Guxyacanum libcllus, printed in 1535 hut dated 19 Dee. 1517,8 pages $8^{\circ}$.

${ }^{2}$ De Morbo Gallico tractatus, Salisburgi, November 1518,-leprinted in the Aphro. disiacus of Luisinus, Lugd. Bat. 1728. 383.

-We have only seen the latter.

3 Ulrichi dc Hutten cquitis de Guaiaci medicina ct morbo gallico libcr unus, $4^{\circ}$. (26 ehapters) Moguntiæ, 1519.

${ }^{4}$ 'The Lignum Vitx of Jamaica ( $G$. officinalc) and that of the Bahamas (G. sanctum), of which authentie speeimens have been kivdly plaeed at our disposal by Mr. G. Shadbolt, display the same appearance as well as microseopie structure.

5 Lignum Vitæ is much used for the wheels (teelnically "shcaves") of ships' bloeks (pulleys) the circumference of which ought to eonsist of the white sapwood. It is also required fol caulking mallets, skittle balls and for the large balls used in American bowling alleys, for which purposes it should be as sound and homogeneous as possible. 
heartwood has a faintly aromatic and slightly irritating taste, and when heated or rubbed emits a wak agreeable odlour.

'The bark which was formerly officinal but is now almost obsolete, is very rich in oxalate of calcium and affords upon incineration not less than 23 per cent. of ash. It contains a resin distinct from that of the wood, and also a bitter acrid principle.

Microscopic Structure-The wood consists for the most part of pointed, not very long, ligneous cells (libriform), traversed by one-celled rows of medullary rays. There are also thin layer's of parenchymatous tissue, to which the zones apparent in a transverse section of the drug are due. The pitted vessels are comparatively large but not very numerous. The structure of the sapwood is the same as that of the leartwood, but in the latter the ligneous cells are filled with resin. The parenchymatous cells contain crystals of oxalate of calcium.

Chemical Composition-The only constituent of any interest is the resin which the heartwood contains to the extent of about a fourth of its weight. The sapwood afforded us 0.91 and the heartwood 0.60 per cent. of ash.

Commerce-Lignum Vitæ varies much in estimation, according to size, soundness, and the cylindrical form of the logs. The best is exported from the city of Santo Domingo whither it is brought from the interior of the island. The quantity shipped from this port during 1871 was 1494 tons. $^{1}$ That obtained from the Haytian ports of the same island is much less esteenied in the London market.

Some small wood of good quality comes from the Bahamas, and an ordinary quality, also small, from Jamaica. From the latter island, the quantity exported in 1871 was only 14 tons ${ }^{2}$ from the Bahamas in the same year 199 tons. $^{3}$ Lignum Vitæ was shipped from Santa Marta in 1872 to the extent of 115 tons. ${ }^{4}$

Uses-Guaiacum wood is only retained in the pharmacopoia as an ingredient of the Compound Decoction of Sarsaparilla. It is probably inert, at least in the manner in which it is now administered. ${ }^{.}$

Adulteration-In purchasing guaiacum chips it is necessary to observe that the non-resinous sapwood is absent, and still more that there is no admixture of any other woorl. A spurious form of the drug seems to be by no means rare in the United States. ${ }^{6}$

\section{RESINA GUAIACI.}

Guaiacum Resin; F. Résine de Gayac; G. Guaiakharz.

Botanical Origin-Guaiacum officinalc L., see preceding article.

History-Hutten ${ }^{7}$ in 1519 stated that guaiacum wood when set on fire exudes a blackish resin which quickly hardens, but of which he

1 Consular Reports presented to Parliament, Aug. 1872.

2 Blue Book-Island of Jamaica for 1871.

3 Blue Book for Colony of Bahamas for 1871.

${ }^{4}$ Consular Reports, Aug. 1873. 746.

5 The ancient treatment of syphilis by gnaincum which gained for the drug such immense reputation, consisted in the administration of vast quantities of the decoction, the patient being shut up in a warm room and kept in bed.

${ }^{6}$ Schulz, in the (Chicago) Pharmacist, Sent. 1873.

7 Op. cit. at 1. 93. 
knew no use. The resin was in fact introduced into medicine much later than the wood. The first edition of the London Pharmacopoeic in which we find the former named, is that of 1677.

Production ${ }^{1}$ - In the island of St. Domingo whence the supplies of guaiacum resin are chiefly derived, the latter is collected from the stems of the trees, in part as a natural exudation, and in part as the result of incisions made in the bark. In some districts as in the island of Gonave near Port-all-Prince, another method of obtaining it is adopted. A log of the wood is supported in a horizontal position above the ground by two upright bars. Each end of the $\log$ is then set on fire, and a large incision having been previously made in the middle, the melted resin runs out therefrom in considerable abundance.

The resin is collected chiefly from $G$. officinale, which affords it in greater plenty than G. sanctum.

Description-The resin occurs in globular tears $\frac{1}{2}$ an inch to 1 inch in diameter, but much more commonly in the form of large compact masses, containing fragments of wood and bark. The resin is brittle, breaking with a clean, glassy fracture ; in thin pieces it is transparent and appears of a greenish brown hue. The powder when fresh is grey, but becomes green by exposure to light and air. It has a slight balsamic odour and but little taste, yet leaves an irritating sensation in the throat.

The resin has a sp. gr. of about 12 , It fuses at $85^{\circ} \mathrm{C}$., emitting a peculiar odour somewhat like that of benzoin. It is easily soluble.in acetone, ether, alcohol, amylic alcohol, chloroform, creasote, caustic alkaline solutions, and oil of cloves; but is not dissolved or only partially by other volatile oils, benzol or bisulphide of carbon. By oxidizing agents it acquires a fine blue colour, well shown when a fresh alcoholic solution is allowed to dry up in a very thin layer and this is then sprinkled with a dilute alcoholic solution of ferric chloride. Reducing agents of all kinds, and heat produce decoloration. An alcoholic solution may be thus blued and decolorized several times in succession, but it loses at length its susceptibility. This remarkable property of guaiacum was utilized by Schönbein in his well-known researches on ozone.

Chemical Composition-The composition of guaiacum resin was ascertained by Hadelich (1862) to be as follows :-

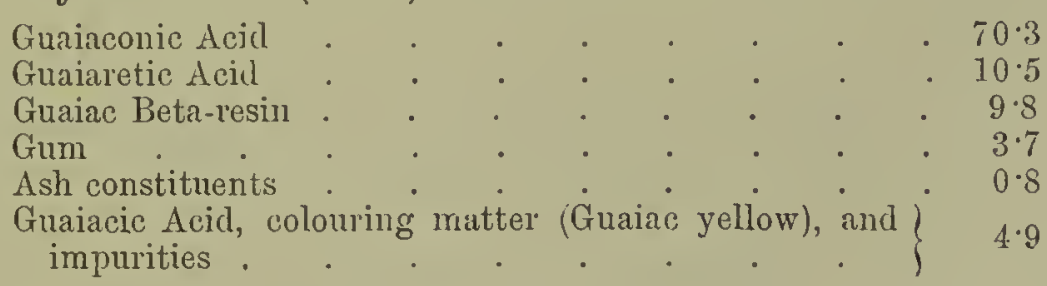

If the mother liquor obtained in the preparation of the potassium salt of guaiaretic acid (vide infra) is decomposed by hydrochloric acid, and the precipitate washed with water, ether will extract from the mass Guaiaconic Acid, a compound discovered by Hadelich, having the formula $\mathrm{C}^{38} \mathrm{H}^{40} \mathrm{O}^{10}$. It is a light brown, amorphous substance, fusing at $100^{\circ} \mathrm{C}$.

I We have to thank Mr. Eugène Nau of Port-an-Prince for the information given under this head, as well as for some interesting specimens. 
it is without acid reaction but decomposes alkaline carbonates, forming uncrystallizable salts casily soluble in watcr or alcohol. It is insoluble in water, benzol, or bisulphide of carbon, but dissolves in ether, chloroform, acctic acid or alcohol. With oxidizing agcnts it acruires a transient blue tint.

Guaiarctic Acid, $\mathrm{C}^{20} \mathrm{H}^{26} \mathrm{O}^{4}$, discovercd by Hlasiwetz in 1859 , may be extracted from the crucle resin by alcoholic potash or by quick lime. With the former it prodnces a crystalline salt; with the latter an amorphous compound: from cither, the liquid which contains chiefly a salt of guaiaconic acid, may bc easily decanted. Guaiarctic acid is obtained by decomposing onc of the salts rcferred to with hydrochloric acid, and crystallizing from alcohol. The crystals, which arc soluble also in cther, benzol, chloroform, carbon bisulphide or acetic acid, but neither in ammonia $110 r^{\circ}$ in water, mclt below $80^{\circ} \mathrm{C}$. and may be volatilized without decomposition. The acid is not coloured bluc by oxidizing agents.

After the extraction of the guaiaconic acid therc remains a substance insoluble in ether to which the name Guaiac Bcta-rcsin has been applied. It dissolves in alcohol, acetic acid or alkalis, and is precipitated by ether, benzol, chloroform or carbon bisulphide in brown flocks, the composition of which appears not greatly to differ from that of guaiaconic acid.

Guaiacic Acid, $\mathrm{C}^{12} \mathrm{H}^{16} \mathrm{O}^{6}$, obtained in 1841 by Thiel'y from guaiacum wood or from the resin, crystallizes in colourless needles. Hadelich was not able to obtain more than one part from 20,000 of guaiacum resin.

Hadelich's Guaiac-yellow, the colouring matter of guaiacum resin, first observed by Pelletier, crystallizes in pale yellow quadratic octohedra, having a bitter taste. Like the other constituents of the resin, it is not a glucoside.

The decomposition-products of guaiacum are of peculiar interest. On subjecting the resin to dry distillation in an iron retort and rectifying the distillate, Guaiacene (Guajol of Völckel), $\mathrm{C}^{5} \mathrm{H}^{8} \mathrm{O}$, passes over at $118^{\circ} \mathrm{C}$. as a colourless neutral liquid having a burning aromatic taste.

At $205^{\circ}-210^{\circ}$ C., there pass over other products, Guaiacol (or PyroAt $205^{\circ}-210^{\circ}$., thace prid -hydride), $\mathrm{C}^{7} \mathrm{H}^{8} \mathrm{O}^{2}$, and Kreosol, $\mathrm{C}^{8} \mathrm{H}^{10} \mathrm{O}^{2}$. Both
guaiacic Acid or Guaiacy thickish, aromatic, colourless liquids, which become green by caustic
are thalis, blue by alkaline earths, and are similar in their chemical relations alkalis, blue by alkaline earths, and are similar in their chemical relations to eugenic acid. Guaiacol has been prepared synthetically by GorupBesanez (1868) by combining iodide of methyl, $\mathrm{CH}^{3} \mathrm{I}$, with pyrocatechin, $\mathrm{C}^{6} \mathrm{H}^{6} \mathrm{O}^{2}$.

After the removal by distillation of the liquids just described, there sublime upon the further application of heat, pearly crystals of Pyroguaiacin, $\mathrm{C}^{38} \mathrm{H}^{44} \mathrm{O}^{6}$, an inodorous substance melting at $180^{\circ} \mathrm{C}$. The same compound is obtained together with guaiacol by the dry distillation of guaiaretic acid. Pyroguaiacin is coloured green by ferric chloride, and blue by warin sulphuric acid. The similar reactions of the crude resin are probably due to this substance (Hlasiwetz).

Beautiful coloured reactions are likewisc exhibited by two new acids which Hlasiwetz and Barth obtaincd (1864) in small quantity together with traces of fatty volatile acids, by mclting purified resin of guaiacum with potassium liydratc. Onc of them is isomeric with pyrocatechuic acid.

Uses-Guaiacum resin is reputcd diaphoretic and alterativc. It is frequently prescribed in cases of gout and rheumatism. 
Adulteration - The drug is sometimes imported in a very foul condition and largely contaminated with impurities arising from a careless method of collection.

\section{RU'TACE无.}

\section{CORTEX ANGOSTURE.}

Cortex Cusparia, Angostura Bark, Cusparia Bark, Carony Bark; F. Ecorce d'Angusturc; G. Angostura-Riinde.

Botanical Origin-Galipea Cusparia St. Hilaire (G. officinalis Hancock, Bonplandia trifoliata Willd.), a small tree, 12 to 15 feet high, with a trunk 3 to 5 inches in diameter, growing in abundance on the mountains of San Joaquin de Caroni in Venezuela, between $7^{\circ}$ and $8^{\circ}$ N. lat. According to Hancock, ${ }^{1}$ who was well acquainted with the tree, it is also found in the Missions of Tumeremo, Uri, Alta Gracia, and Cupapui, districts lying eastward of the Caroni and near its junction with the Orinoko. The bark is brought into commerce by way of Trinidad.

History-Angostura Bark is said to have been used in Madrid by Mutis as early as $1759^{2}$ (the year before he left Spain for South America), but it was certainly unknown to the rest of Europe until much later. Its real introducer was Brande, apothecary to Queen Charlotte, and father of the distinguished chemist of the same name, who drew attention to some parcels of the bark imported into England in $1788 .^{3}$ In the same year a quantity was sent to a London drug firm by Dr. Ewer of Trinidad who describes it ${ }^{4}$ as brought to that island from Angostura by the Spaniards. The drug continued to arrive in Europe either by way of Spain or England, and its use was gradually diffused. In South America it is known as Quina de Caroni and Cascarilla del Angostura.

Description - The bark occurs in flattish or chamnelled pieces, or in quills rarely as much as 6 inches in length and mostly shorter. The flatter pieces are an inch or more in width and $\frac{1}{5}$ of an inch in thickness. The outer side of the bark is coated with a yellowish-grey corky layer, often soft enough to be removeable with the nail, and then displaying a dark brown, resinous under surface. The inner side is light brown with a rough, slightly exfoliating surface indicating close adhesion to the wood, strips of which are occasionally found attached to it the obliquely cut edge also shows that it is not very easily detached. The bark has a short, resinous fracture and displays on its transverse edge sharply defined white points, due to deposits of oxalate of calcinm. It has a bitter taste and a nauseous musty odour.

Microscopic Structure-The most striking peculiarity is the great

1 Observations on the Orayuri or Angustura Bark Trec, - Trans. of Medico-Botanical Socicty, 1827-29.- Hancock endeavonred to prove his tree distinct from $G$. Cusparia St. Hil., but Farre and Don who subsequently - examined his specimens decided that the two were the same. With the assistance of Prof. Oliver, I also have examined (1871)
Hancock's plant, comparing it with his figure and other specimens, and have arrived at the conclusion that it is untenable as a distinct species.-D. H.

2 Martiny, Encylclopädic, i. (1843) 242.

3 Brande, Experiments and Obscrvations on the Angusture Bar\%. 1791. 2nd ed. 1798.

4 London MLd. Journ x. (1789) 154. 
number of oil-eells seattered through the tissue of the bark. They are not mueh larger than the neighbouring parenchymatous eells and are loaded with yellowish essential oil or small granules of resin. Numerous other eells eontain bundles of needle-shaped erystals of oxalate of ealcium or small starch granules. The liber exhibits bundles of yellow fibres, to whieh the foliaeeous fracture of the inner bark is due.

Chemical Composition-Angostura bark owes its peeuliar odour to an essential oil whieh it was found by Herzog ${ }^{1}$ to yield to the extent of $\frac{3}{4}$ per eent. Aeeording to this ehemist it has the composition $\mathrm{C}^{13} \mathrm{H}^{24} \mathrm{O}$; it is probably a mixture of a hydrocarbon $\left(\mathrm{C}^{10} \mathrm{H}^{8}\right)$ with an oxygenated oil. Its boiling point is $266^{\circ} \mathrm{C}$.

The bitter taste of the bark is attributed to a substance pointed out in 1833 by Saladin and named Crsparin. It is said to be erystalline, neutral, melting at $45^{\circ} \mathrm{C}$., soluble in alcohol, sparingly in water, precipitable by tannie aeid. The bark is stated to yield it to the extent of 1.3 per eent. Herzog endeavoured to prepare it but without suecess. A eold aqueous infusion of angostura bark yields an abundant redbrown preeipitate with ferrie ehloride. Thin sliees of the bark are not coloured by solution of ferrous sulphate, so that tannin appears to be absent.

Uses-Angostura bark is a valuable tonic in dyspepsia, dysentery and ehronie diarrhœe, but is falling into disuse.

Adulteration-About the year 1804, a quantity of a bark whieh proved to be that of Strychnos Nux Vomica reaehed Europe from India, and was mistaken for Cusparia. The error oeeasioned great alarm and some aceidents, and the use of angostura was in some countries even prohibited. The means of distinguishing the two barks (which are not likely to be again eonfounded) are amply eontained in the above-given deseriptions and tests.

\section{FOLIA BUCHU.} Folia Bucco; Buctu, Bucchu, Bucha or Buka Lcaves; F. Feuilles de
Bucco; G. Bukublätter.

Botanical Origin-The Buehu leaves of medieine are afforded by three speeies of Barosma. ${ }^{2}$ The latter are ereet shrubs some feet in height with glabrous rod-like branehes, opposite leaves furnished with conspieuous oil-eells on the toothed margin as well as generally on the under surface. The younger twigs and several parts of the flower are also provided with oil-cells. The white flowers with 5-partite ealyx, and the fruit formed of five ereet carpels, are often found, together with small leafy twigs, in the drug of eommeree.

The leaves of the three speeies referred to may be thus distinguished :-

1. Barosma crenulata Hook. (B. crenata Kunze).-Oblong, oval, or obovate, obtuse, narrowed towards the base into a distinet petiole; margin serrulate or erenulate; dimensions, $\frac{3}{4}$ to $1 \frac{1}{2}$ inehes long, $\frac{3}{10}$ to $\frac{4}{10}$ of an ineh wide.

1 Archiv d. Pharm. xciii. (1858) 146.

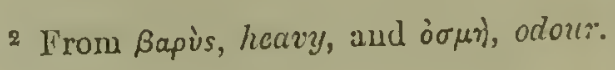


2. B. serratifolia Willd.-Linear-lanceolate, equally narrowed towards either end, three-nerved, apex truncate always furnished with an oil-cell; margin sharply serrulate; $1-1 \frac{1}{2}$ inches long by about $\frac{2}{10}$ of an inch wide.

3. B. betulina Bartling.-Cuneate-obovate, apex recurved; margin sharply denticulate, teeth spreading; $\frac{1}{2}$ to $\frac{3}{4}$ of an inch long by $\frac{3}{10}$ to $\frac{5}{10}$ wide. Substance of the leaf more harsh and rigid than in the preceding.

$B$. crenulata and $B$. betulina grow in the Divisions of Clanwilliam and Worcester, north and north-east of Cape Town, and the former even on Table Mountain close to the capital; $\bar{B}$. serratifolia is found in the Division of Swellendam further south.

History-The use of Buchu leaves was learnt from the Hottentots by the colonists of the Cape of Good Hope. The first importations of the drug were consigned to the house of Reece \& Co. of London, who introduced it to the medical profession in 1821. ${ }^{1}$ The species appears to have been $B$. crenulata.

Description-In addition to the characters already pointed out, we may observe that buchu leaves of either of the kinds mentioned are smooth and glabrous, of a dull yellowish-green hue, somewhat paler on the under side, on which oil-cells in considerable number are perceptible.

The leaves of $B$. crenulata vary in shape and size in different parcels, in some the leaves being larger and more elongated than in others, probably according to the luxuriance of the bushes in particular localities. Those of $B$. serratifolia and $B$. betulina present but little variation. Each kind is always imported by itself. Those of $B$. betulina are the least esteemed and fetch a lower price than the other's, yet appear to be quite as rich in essential oil.

Buchu leaves have a penetrating peculiar odour and a strongly. aromatic taste.

Microscopic Structure-The essential oil is contained in large cells close beneath the epidermis of the under side of the leaf. The oilcells are circular and surrounded by a thin layer of smaller cells; they consequently partake of the character of the oil-ducts in the aromatic roots of Umbelliferce and Compositc. The latter however are elongated.

The upper side of the leaf of Barosma exhibits an extremely interesting peculiarity. ${ }^{2}$ There is a colourless layer of cells separating the epidermis from the green inner tissue (mesophyllum). If the leaves are examined under alcohol or almond-oil the colourless layer is seen to be very narrow, and the thin walls of its cells shrunken and not clearly distinguishable. If the transverse sections are examined under water, these cells immediately swell up and beconie strongly distended, giving off an abundance of mucilage, the latter being afforded by the solution of the very cell-walls. The mucilage of buchu leaves thus originates in the same way as in flax seed or quince seed, but in the former the epidermis is thrown off without alteration. We are not aware that other mucilaginous leaves possess a similar structure, at least not those of Althcea officinalis and of Sesamum which we examined.

Chemical Composition-The leaves of $B$. betulina afforded us by

1 R. Reece, Monthly Gazctte of Health for Feb. 1821.799.
${ }^{2}$ Flückiger in Schweiz. Wochenschrift für Pharm. Dec. 1873 , with plate. 
distillation 1.56 per cent of volatile oil, ${ }^{1}$ which has the odour rather of peppermint than of buchu and deviates the ray of polarized light considerably to the left. On exposure to cold it furnishes a camphor which after re-solution in spirit of wine, crystallizes in needle-shaped forms. After repeated purification in this manner, the crystals of Barosma Camphor have an almost pure peppermint odour; they fuse at $85^{\circ} \mathrm{C}$. and begin to sublime at $110^{\circ} \mathrm{C}$. After fusion they again solidify only at $50^{\circ} \mathrm{C}$. Submitted to elementary analysis, the crystals yielded us 74.08 per cent. of carbon and from 9 to 10 per cent. of hydrogen. ${ }^{2}$ Barosma camphor is abundantly soluble in bisulphide of carbon.

The crude oil from which the camphor has been separated las a boiling point of about $200^{\circ} \mathrm{C}$., quickly rising to $210^{\circ}$ or even higher. That which distilled between these temperatures was treated with sodium, rectified in a current of common coal gas and submitted to elementary analysis, afforded us 77.86 per cent. of carbon and 10.58 of hydrogen. The formula $\mathrm{C}^{10} \mathrm{H}^{16} \mathrm{O}$ would require 78.94 of carbon and 10.53 of hydrogen.

On addition of perchloride of iron an aqueous infusion of buchu leaves assumes a dingy brownish green colour changing to red by an alkali. The infusion added to a concentrated solution of acetate of copper causes a yellow precipitate ${ }^{3}$ which dissolves in caustic potash, affording a green solution. This may be due to the presence of a substance of the quercitrin or rutin class.

When the leaves are infused in warm water, the mucilage noticed under the microscope may easily be pressed out. It requires for precipitation a large amount of alcohol, being readily miscible with dilute alcohol. Neutral acetate of lead produces a yellow precipitate in an infusion of the leaves; the liquid affords a precipitate by a subsequent addition of basic acetate of lead. The latter precipitate is (probably) due to the mucilage, that afforded by neutral acetate partly to mucilage and partly, we suppose, to rutin or an allied substance. Yet the mucilage of buchu leaves is of the class which is not properly dissolved by water, but only swells up like tragacanth.

The leaves of $B$. crenzlata afford apon incineration $4 \cdot 7$ per cent. of ash.

The Diosmin of Landerer ${ }^{4}$ is entirely unknown to as.

Commerce-The export of Buchu from the Cape Colony in 1872 was $379,125 \mathrm{Hb}$., about one-sixth of which quantity was shipped direct to the United States. ${ }^{5}$

Uses-Buchu is principally administered in disorders of the urinogenital organs. It is reputed diuretic and diaphoretic. In the Cape Colony the leaves are much employed as a popular stimulant and stomachic, infused in water, sherry or brandy. They are also extensively used in the United States, both in regular medicine and by the vendors of secret remedies.

1 Messrs. Allen and Hanburys operating on larger quautities obtained 1.63 per cent.

2 Our supply of the substance having been exhansted by two anlyses we caunot regard

3 It secms green as long as it is in the blue cupric liquid.

4 Gmelin's Chemistry, xviii. 194. the ahove figures as sufficient for the calcu-

- Blue, Book published at Cape Town, 1 si3. 
Substitutes-The leaves of Empleurum serrulatum Ait., a small shrub of the same order as Barosma and growing in the same localities, have been imported rather frequently of late and sold as Buchu. They have the same structure as regards mucilage, and nearly the same form as those of $B$. serratifolia, but are easily distinguished. They are still narrower, and often longer than those of $B$. serratifolia, and terminate in an acute point without an oil-duct; they have a bitterish taste and a different odour from buchu. The flowers of Empleurum are still more distinct, for they are apetalous and reddish brown. The fruit consisting of a single, compressed, oblong carpel, terminated by a flat sword-shaped horn, is quite unlike that of buchu.

The leaves of Barosma Eckloniana Berg (regarded by Sonder ${ }^{1}$ as a form of $B$. crenulata) have to our knowledge been imported on one occasion (1873). They are nearly an inch long, oval, rounded at the base, strongly crenate, and grow from pubeseent shoots.

We have seen other leaves which had been imported from South Africa and offered as buchu; but though probably derived from allied genera they were not to be mistaken for the genuine drug.

\section{RADIX TODDALIÆ.}

Botanical Órigin-Toddalia aeuleata Pers., a ramous prickly bush, often climbing over the highest trees, common in the southern parts of the Indian Peninsula as the Coromandel Coast, South Concans and Canara, also found in Ceylon, Mauritius, the Indian Archipelago and Southern China.

History-The pungent aromatic properties which pervade the plant but especially the fresh root-bark are well known to the natives of India and have been utilized in their medical practice. They have also attracted the attention of Europeans, and the root of the plant is now recognized in the Pharmacopceia of India.

It is from this and other species of Toddalia or from the allied gemus Zanthoxylum ${ }^{2}$ that a drug is derived which under the name of Lopez Root had once some celebrity in Europe. This drug which was more precisely termed Radix Indica Lopeziancs or Root of Juan Lopez Pigneiro, was first made known by the Italian physician Redi; ${ }^{3}$ who described it in 1671 from specimens obtained by Pigneiro at the mouth of the river Zambesi in Eastern Africa, - the very locality in which in our times Toddatia laneeolata Lam. has been collected by D.r. Kirk. ${ }^{4}$ It was actually introduced into European medicine by Gaubius ${ }^{5}$ in 1771 as a remedy for diarrhoea, and acquired so much reputation that it was admitted to the Edinburgh Pharmacopœia of 1792. The root appears to have been sometimes imported from Goa, but its place of growth and botanical origin were entirely unknown, and it was always extremely

1 Harvey and Sonder, Flora Capensis, i. (1859-60) 393.

2 'The root of a Zanthoxylum sent to us from Java by Mr. Binnendyk of the Buitenzorg. Botanic:al Garden has exactly the aspect of that of Toddalia. 'The root of $Z$. Bungei which we have examined in the fresh state is also completely similar. It is covered with a soft, corky, yellow bark having a very bitter taste with a strong pungency like that of pellitory.

3 Esperienze intorno a diverse cose natarali, Firenzc, 1671. 121.

307.

5 Adversaria, 80. 
rare and costly. ${ }^{1}$ It has long been obsolete in all countries except Holland, where until recently it was to be met with in the shops. 'Ihe Pharmacopoce Neerlandica of 1851 says of it "Origo botanica perguam, chbia.-Patria Malacea?"

Description-The specimen of the root of Toddalia aculeata which we have cxamined was collected for us by Dr. G. Jidie of Madras whose statements regarding the stimmlant and tonic action of the drug may be found in the Pharmacopeia of India, p. 442. It is a dense woody root in cylindrical, flexuous picces, which have evidently bccn of considerable length aud are from $\frac{1}{2}$ to $1 \frac{1}{2}$ inches in diameter, covered with bark $\frac{1}{10}$ to $\frac{1}{1}$ of an inch in thickness. The bark has a soft, dull yellowish, suberous coat, wrinkled longitudinally, bencath which is a very thin layer of a bright yellow colour, and still lowel and constituting twothirds or more of the whole, is the firm, brown middle cortical layer and liber which is the part chiefly possessing the characteristic pungency and bitterness of the drug. 'The yellow corky coat is however not devoid of bitterness. The wood is hard, of a pale yellow, and without taste and sinell. The pores of the wood which are rather large, are arranged in concentric order and traversed by numcrous narrow medullary rays.

In a lettcr which Frappier ${ }^{2}$ wrote to Guibourt from the island of Réunion where Toddalia aculeata is very common, he states that the roots of the plant are of enormous length (longueur incroyable) and rather difficult to get out of the basaltic rock into the fissures of which they penetrate. Mr. J. Horne of the Botanical Garden, Mauritius, has sent us a specimen of the root of this plant, the bark of which is of a dusky brown, with the suberous layer but little developed.

Microscopic Structure-We have examined the root for which we are indebted to Dr. Bidie, and may state that its cortical tissue is remarkable by the number of large cells filled with resin and essential oil; they are scattered through the whole tissuc, the cork excepted. The parenchymatous cells are loaded with small starch granules.or with crystals of oxalate of calcium. The vessels of younger roots abound in yellow resin.

Chemical Composition-None of the constituents of the Toddalia root of India have yet been satisfactorily examined. The bark contains an essential oil, which would be better extracted from fresh than from dry material. The tissue of the bark is but little coloured by salts of iron. In the aqueous infusion, tannic acid produccs an abundant precipitate, probably of an indifferent bitter principle rather than of an alkaloid. We have been unable to detect the presence in the bark of berberine.

Lopez root was examined in Wittstcin's laboratory by Schnitzer ${ }^{3}$ who found that the bark contains in addition to the usual substances a large proportion of resin, - a mixture probably of two or three different bodics. The esscntial oil afforded by the bark had an odour resembling cinnamon and melissa.

1 Our friend Dr. de Vry informs us that he remembers the price in Holland in 1828 being equivalent to about $24 s$. the ounce!

2 Journ. de Pharm. v. (1867) 403.
3 Wittstein's Vicrteljahresschrift fur jorat. Pharm. xi. (1S62) i.- The drug examined was the Lopez root sold at that period at Amsterdam. 
Uses-The drug has been introduced into the Pharmacopceia of Indic chiefly upon the recommendation of Dr. Bidie of Madras, who considers it of great value as a stimulating tonic. The bark rasped or shaved from the woody root is the only part that should be used.

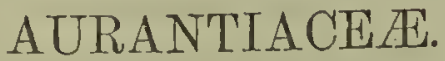

\section{FRUCTUS LIMONIS.}

\section{Lemon; F. Citron, Limon; G. Citrone, Limune.}

Botanical Origin-Citrus Limonum Risso ( $C$. medica var. $\beta$ Linn.), a small tree 10 to 15 feet in height, planted here and there in gardens in many sub-tropical countries, but cultivated as an object of industry on the Mediterranean coast between Nice and Genoa, in Calabria, Sicily, Spain and Portugal.

The tree which is supposed to represent the wild state of the lemon and lime, and as it seems to us after the examination of numerous specimens in the herbarium of Kew, of the citron (Citrus medica Risso) also, is a native of the forests of Northern India, where it occurs in the valleys of Kumaon and Sikkim.

The cultivated lemon-tree is of rather irregular growth; with foliage somewhat pallid, sparse, and uneven, not forming the fine, close head of deep green that is so striking in the orange-tree. The young shoots are of a dull purple; the flowers, which are produced all the year except during the winter and are in part herinaphrodite and in part unisexual, have the corolla externally purplish, internally white, and a delicate aroma distinct from that of orange blossom. The fruit is pale yellow, ovoid, usually crowned by a nipple.

History-The name of the lemon in Sanskrit is Nimbika; in Hindustani, Limbu, Limu, or Ninbu. From these sounds the Arabians formed the word Limun, which has passed into the languages of Europe.

The lemon was unknown to the inhabitants of ancient Greece and Rome; but it is mentioned in the Book of Nabathæan Agriculture, ${ }^{1}$ which is supposed to date from the 3rd or 4th century of our era. The introduction of the tree to Europe is due to the Arabians, yet at what precise period is somewhat doubtful. The geographer Edrisi, ${ }^{2}$ who resided at the court of Roger II., king of Sicily, in the middle of the 12 th century, mentions the lemon (limouna) as a very sour fruit of the size of an apple which was one of the productions of Mansouria on the Mahrân or Indus; and he speaks of it in a manner that leads one to infer it was not then known in Europe. This is the more probable from the fact that there is no mention either of lemon or orange in a letter written A.D. 1239 concerning the cultivation of the lands of the Emperor Frederick II. at Palermo, ${ }^{3}$ a locality in which these fruits are now produced in large quantity.

On the other hand the lemon is noticed at great length by Ibn Baytar of Malaga who flourished in the first half of the 13th century, but of its cultivation in Spain at that period there is no actual mention. ${ }^{4}$

\footnotetext{
1 Meyer, Geschichte der Botanik, iii. (1856) 68.

${ }^{2}$ Géographie d'Edrisi, traduite par Jaubert, i. (1836) 162.
}

3 Huillard-Bréholles, Historia diplomatica Fridcrici secundi, Paris, v. 571.

${ }^{4}$ Heil-und Nahrungsmittel von Ebn Baithar, übersetzt von Sontheimer, ii. (1842) 452. 
'There is distinct evidence that the tree was grown on the Riviera of Genoa about the middle of the 15 th century, since Limones and also Citri are mentioned in the manuscript Livre d'Administrution of the city of Sivona, under date $1468 .{ }^{1}$ The lemon was cultivated as early as 1494 in the Azores, whence the fruit used to be largely shipped to Ingland; but since the year 1838 the exportation has totally ceased. ${ }^{2}$

Description-The fruit of C'itrus Limonum as found in the shops ${ }^{3}$ is from about 2 to 4 inches in length, egro-shaped with a nipple more or less prominent at the apex; its surface of a pale yellow, is even or rugged, covered with a polished epidermis. 'The parenchyme within the latter abounds in large cells filled with fragrant essential oil. The roughness of the surface of the rind is due to the oil-cells. 'The peel which varies considerably in thickness but is never so thick as that of the citron, is internally white and fibrous, and is adherent to the paleyellow pulp. The latter is divided into 10 or 12 segments each containing 2 or 3 seeds. It abounds in a pale-yellow acid juice having a pleasant sour taste and a slight peculiar odour quite distinct from that of the peel. When removed from the pulp by pressure, the juice appears as a rather turbid yellowish fluid having a sp. gr. which varies from $1 \cdot 040$ to $1 \cdot 045$, and containing in each fluid ounce from 40 to 46 grains of citric acid, or about $9 \frac{1}{2}$ per cent. ${ }^{4}$ Lemon juice (Succus limonis) for administration as a medicine should be pressed as wanted from the recent fruit whenever the latter is obtainable.

The peel (Cortex limonis) cut in somewhat thin ribbons from the fresh fruit is used in pharmacy and is far preferable to that sold in a dried state.

Microscopic Structure of the peel.-The epidermis exhibits numerous stomata; the parenchyme of the pericarp encloses large oilcells, surrounded by sniall tabular cells. The inner spongy tissue is built up of very remarkable branched cells, separated by large intercellular spaces. A solution of iodine in iodide of potassium imparts to the cell-walls a transient blue coloration. The outer layer's of the parenchymatous tissue contain numerous yellowish lumps of a substance which assumes a brownish hue by iodine and yields a yellow solution if potash be added. Alkaline tartrate of copper is reduced by this substance, which probably consists of hesperidin. There also occur large crystals of oxalate of calcium, belonging to the monoclinic system. The interior tissue is irregularly traversed by small vascular bundles.

Chemical Composition-The peel of the lemon abounds in essential oil which is a distinct article of commerce, and will be described hereafter.

Lemons as well as other fruits of the genus Citrus contain a bitter principle, Hesperidin, our knowledge of which is still very imperfect. It was first obtained in 1827 by Lebreton, but not in a state of purity. He supposed the bitter taste of the needle-shaped crystals of his hesperidin to be due to an accompanying bitter principle; Lepage likewise stated hesperidin to be a tasteless body. Dehn in 1866 examined the products of decomposition of hesperidin, which were formed by boiling 1 Gallesio, Traité du Cilrus (1811) \$9, 105.

2 Consul Smallwood, in Consular Reports, Aug. 1873. 986.

' l'here ale many kinds of lemon as well

as of orange which are never seen in commerce. Risso and Poitean enumerate 25 varieties of the former and 30 of the latter. 203 , 
it with dilute sulphuric acid. He analysed the peculiar sugar, $\mathrm{C}^{12} \mathrm{H}^{24} \mathrm{O}^{10}+\mathrm{H}^{2} \mathrm{O}$, thus obtained, but not the other product of this reaction, nor hesperidin itself.

Brandes in 1841 also pointed out the existence of a bitter principle, to which he applied the name of Aurantiin. In 1840 Bernays obtained Limonin from kernels of lemons or sweet oranges, likewise a bitter principle, to which Schmidt (1844) assigned the formula $\mathrm{C}^{44} \mathrm{H}^{52} \mathrm{O}^{14}$. Lastly, J. E. de Vry in 1866 removed a crystallized bitter substance from the flowers of Citrus decumana L. grown in Java.

Whether these bodies are but one and the same is a question which remains to be investigated. Lebreton's hesperidin is soluble in ammonia with a greenish yellow colour. To it perhaps is due the fine yellow tint that is produced in the white parenchyme of the fruit when brought into contact with an alkali or with vapour of ammonia.

On addition of ferric chloride, thin slices of the peel are darkened, owing probably to a kind of tannic matter.

Lemon juice, some of the characters of which have been already noticed, is an important article in a dietetic point of view, being largely consumed on shipboard for the prevention of scurvy. In addition to citric acid it contains 3 to 4 per cent. of gum and sugar, and 2.28 per cent. of inorganic salts, of which according to Stoddart only a minute proportion is potash. Cossa ${ }^{1}$ on the other hand who has recently studied the products of the lemon tree with much care, has found that the ash of dried lemon juice contains 54 per cent. of potash, besides 15 per cent. of phosphoric acid.

Stoddart has pointed out the remarkable tendency of citric acid to $\mathrm{mn}-$ dergo decomposition, ${ }^{2}$ and has proved that in lemons kept from February to July this acid generally decreases in quantity, at first slowly but afterwards rapidly, until at the end of the period it entirely ceases to exist, having been all split up into glucose and carbonic acid. At the same time the sp. gr. of the juice was found to have undergone but slight diminution:- - thus it was 1.044 in February, 1.041 in May, and 1.027 in July, and the fruit had hardly altered in appearance. Lemon juice may with some precautions be kept unimpaired for months or even years. Yet it is capable of undergoing fermentation by reason of the sugar, gum, and albuminoid matters which it contains.

Commerce-Lemons are chiefly imported from Sicily, to a smaller extent from the Riviera of Genoa and from Spain. From the published statistics of trade, in which lemons are classed together with oranges under one head, it appears that these fruits are being imported in increasing quantities. The value of the shipments to the United Kingdom in 1872 (largely exceeding those of any previous year') was $£ 1,154,270$. Of this sum, $£ 986,796$ represents the value of the oranges and lemons imported from Spain, Portugal, the Canary Islands and Azores; $£ 155,3,30$ the shipments of the same fruit from Italy; and $£ 3,825$ those from Malta.

Uses-Lemon peel is used in medicine solely as a flavouring ingredient. Freshly prepared lemon juice is often administered with

1 Gazzetta Chimica Italiana, ii. (1872)

385 ; Journ. of Chem. Soc. xi. (1873) 402.

${ }^{2}$ Stoddart's statement that if potash be added to lemon juice, oxnlic acid may he detected in the mixture after a few dilys, is not supported by our observations. 
an alkaline bicarbonate in the form of an effervescing draught, or in a free state.

Concentrated lemon juice or lime juice is imported for the purpose of making citric acid; it is derived not only from the lemon, but also from the lime and bergamot.

\section{OLEUM LIMONIS.}

\section{Oleum Limonum; Essential Oil or Essence of Lemon; F. Essenee de Citron;} G. Citronenöl.

Botanical Origin-Citrus Limonum Risso (see p. 10.3).

History-The chemists of the 16 th century were well acquainted with the method of extracting essential oils by distillation. Besson in his work L'art et moyen parfaict de tirer huyles et eaux de tous medicaments simples et oleogineux published at Paris in 1571, mentions lemon(citron) and orange-peel among the substances subjected to this process. Giovanni Battista Porta, a learned Neapolitan writer, describes the method of preparing Oleum ex corticibus Citri to consist in removing the peel of the fruit with a rasp and distilling it so comminuted with water; and adds that the oils of lemon and orange may be obtained in the same manner. Essence of lemon of two kinds, namely expressed and distilled, was sold in Paris in the time of Pomet, 1692.

Production-Essential oil of lemon is manufactured in Sicily, at Reggio in Calabria, and at Mentone and Nice in France.

The lemons are used while still rather green and unripe, as being richer in oil than when quite mature. Only the small and irregular fruit such as is not worth exporting, is employed for affording the essence.

The process followed in Sicily and Calabria may be thus described ; ${ }^{2}$ it is performed in the months of November and December.

The workman first cuts off the peel in three thick longitudinal slices. leaving the central pulp of a three-cornered shape with a little peel at either end. This central pulp he cuts transversely in the middle, throwing it on one side and the pieces of peel on the other. The latter are allowed to remain till the next day and are then treated thus:- - the workman seated holds in the palm of his left hand a flattish piece of sponge, wrapping it round his fore-finger. With the other he places on the sponge one of the slices of peel, the outer surface downwards, and then presses the zest-side (which is uppermost) so as to give it for the moment a convex instead of a concave form. The vesicles are thus ruptured, and the oil which issues from them is received in the sponge with which they are in contact. Four or five squeezes are all the workman gives to each slice of peel, which done he throws it aside. Though each bit of peel has attached to it a small portion of pulp, the workman contrives to avoid pressing the latter. As the sponge gets saturated the workman wrings it forcibly, receiving its contents in a coarse earthen

1 Magice Naturatis libri $x x$. Neapoli, 1589. 188.

2 Throumh the kindness of Signor Mallandrino of Giampilieri near Messina, I had the pleasure of seeing how the essenee is made. Though the time of my visit
(13 May 1872) was not that of the manufaeture, Signor Mr. sent for one of his workmen, and having proeured a few lemons, set him to work on them in order that I might lave oeular demonstration of the process.-D. H. 
bowl provided with a spout; in this rude vessel which is capable of holding at least three pints, the oil separates from the watery liquid which accompanies it, and is then decanted.

The yield is stated to be very variable, 400 fruits affording 9 to 14 ounces of essence. The prisms of pulp and the exhausted pieces of peel are subinitted to pressure in order to extract from them lemon juice, and are said to be also subjected to distillation. The foregoing is termed the spongc-process; it is also applied to the orange. It appears rude and wasteful, but when honestly performed it yields an excellent product.

Essence of lemon is prepared at Mentone and Nice by a different method. The object being to set free and to collect the oil contained in the vesicles of the peel, an apparatus is employed which may be thus described:- a stout saucer or shalluw basin of pewter, about $8 \frac{1}{2}$ inches in diameter with a lip on one side for convenience of pouring. Fixed in the bottom of this saucer are a number of stout, sharp, brass pins standing up about half an inch; the centre of the bottom is deepened into a tube about an inch in diameter and five inches in length, closed at its lower end. This vessel which is called an écuelle à piquer, has therefore some resemblance to a shallow, dish-shaped funnel, the tube of which is closed below.

The workman takes a lemon in the hand, and rubs it over the sharp pins, turning it round so that the oil-vessels of the entire surface may be punctured. The essential oil which is thus liberated is received in the saucer whence it flows down into the tube; and as this latter becomes filled, it is poured into another vessel that it may separate from the turbid aqueous liquid that accompanies it. It is finally filtered and is then known as Essence de Citron au zeste. A small additional produce is sometimes obtained by immersing the scarified lemons in warm water and separating the oil which floats off.

A second kind of essence termed Essence de Citron distillée is obtained by rubbing the surface of fresh lemons, or of those which have been submitted to the process just described, on a coarse grater of tinned iron, by which the portion of peel richest in essential oil is removed. This grated peel is subjected to distillation with water and yields a colourless essence of very inferior fragrance which is sold at a low price.

Description ${ }^{1}$-The oil obtained by the sponge process and that of the écuelle $\grave{a}$ piquer are mobile liquids of a faint yellow colour, of exquisite fragrance and bitterish aromatic taste.

The different specimens which we have examined, are readily miscible with bisulphide of carbon but dissolve sparingly in spirit of wine $(0.830)$. An equal weight of the oil and of spirit of wine forms a turbid mixture. No peculiar coloration is produced by mixture with perchloride of iron.

The oils are dextrogyre, but differ in their rotatory power, as may be illustrated by the following results, which we obtained by examining thein in a column 50 millimetres long in the polaristrobometer of Wild.

1 For specimens of the Essence au zeste and of the Essence distillée of guaranteed purity we have to thank M. Médecin, distiller of essences, Mentone; and Messrs. G. Panuccio e figli for an authentic sample of the essenee made by the sponge process in their establishment at Reggio. We have also had a small quantity prepared by the ćcuelle by one of ourselres near Mentone, 15 June 1872 . - D. H. 
The oil of Signori Panuccio, due to the sponge-process (p. 107, note 1), deviated $20.9^{\circ}$, that of Monsieur Médicin (Éssenee de Citron au zeste) obtained by the écuelle ì piquer deviated $33^{\circ} 4^{\circ}$ and his distilled oil $28: 3^{\circ}$.

Chemical Composition-Most essential oils of the Aurantiaeca agree with the formula $\mathrm{C}^{10} \mathrm{H}^{16}$; the differences which they exhibit, chiefly concern their optical properties, odour and colour. The boiling point varies about from $170^{\circ}$ to $180^{\circ} \mathrm{C}$., the sp. gr. between 0.83 and $0 \cdot 88$. These oils are probably in many cases rather a mixture of isoneric hydrocarbons than individual substances. They also contain a small proportion of oxygenated oils, not yet well known; of these we may infer the presence either from analytical results or simply from the fact, that the crude oils are altered by metallic sodium. If they are purified by repeated rectification over that metal, they are finally no longer altered by it. Oils thus purified cease to possess their original fragrance, and often resemble oil of turpentine, with which they agree in composition and general chemical behaviour.

As to Essential oil of lemons it easily yields the crystalline compound $\mathrm{C}^{10} \mathrm{H}^{16}+2 \mathrm{HCl}$, when saturated with auhydrous hydrochloric gas, whereas by the same treatment oil of turpentine affords the compound $\mathrm{C}^{10} \mathrm{H}^{16}+\mathrm{HCl}$.

Essential oil of lemons when long kept deposits a greasy mass, from which we have obtained small crystals apparently of Bergaptene (p. 111).

Commerce-Essence of lemons is shipped chiefly from Messina and Palermo, packed in copper bottles called in Italian ramiere and by English druggists " jars," holding 25 to 50 kilo. or more; sometimes in tin bottles of smaller size. The quantity of essences of lemon, orange and bergamot exported from Sicily in 1871 was $368,800 \mathrm{Hb}$., valued at $£ 144,520$, of which about two-thirds were shipped to England. ${ }^{1}$

Uses-Essence of lemon is used in perfumery, and as a flavouring ingredient: and though much sold by druggists is scarcely employed in medicine.

Adulteration-Few drugs are more rarely to be found in a state of purity than essence of lemon. In fact it is stated that almost all that comes into the market is more or less diluted with oil of turpentine or with the cheaper distilled oil of lemons. Manufacturers of the essence complain that the demand for a cheap article forces them to this falsification of their product.

\section{OLEUM BERGAMOTT $\not$.}

Oleum Bergamii ; Essence or Essential Oil of Bergamot; F. Essenee de Bergamotte; G. Bergamottöl.

Botanical Origin-Citrus Bergania var. vulgaris Risso et Poiteau, ${ }^{2}$ a small tree closely resembling in flowers and foliage the Bitter Orange. Its fruit is $2 \frac{1}{2}$ to 3 inches in diameter, nearly spherical, or slightly pear-shaped, frequently crowned by the persistent style; it is of a pale golden yellow

1 Consul Dennis, On the Commerce \&c. of Sicily in 1869, 1870, 1871. (Reports from H.M. Consuls, No. 4. 1873.)

2 Iristoire naturelle des Orangers, Paris, 1818. p. 111. tab 53.-We accept the name

given by these authors for the sake of convenience and definiteness, and not because wo concur in their opinion that the Bergamot dcserves to be rankcd as a distinct botanical specics. 
like a lemon, with the peel smooth and thin, abounding in essential oil of a peculiar fragrance; the pulp is pale yellow, of rather acid and bitterish taste.

The tree is cultivated at Reggio in Calabria, and is unknown in a wild state.

History-The bergamot is one of the cultivated forms which abound in the genus Citrus, and which constitute the innumerable varieties of the orange, lemon and citron. Whether it is most nearly related to the lemon or to the orange is a point discussed as early as the beginning of the last century. Gallesio ${ }^{1}$ remarks that it so evidently combines the characters of the two that it should be regarded as a hybrid between them. The bergamot first appeared in the latter part of the 17th century. It is not mentioned in the grand work on orange trees of Ferrari, ${ }^{2}$ published at Rome in 1646 , nor in the treatise of Commelyn ${ }^{3}$ (1676), nor in the writings of Lanzoni (1690), ${ }^{4}$ or La Quintinie (1692). ${ }^{5}$ So far as we know, it is first noticed in a little book called Le Parfumeur François, printed at Lyons in 1693. The author who calls himself Le Sieur Barbe, parfumeur, says that the Essence de Cedra ou Berga-motte is obtained from the fruits of a lemon-tree which has been grafted on the stem of a bergamot pear; he adds that it is got by squeezing small bits of the peel with the fingers in a bottle or globe large enough to allow the hand to enter.

Volkamer of Nuremberg who produced a fine work on the Citron tribe in 1708, has a chapter on the Limon Bergamotta which he describes as gloria limonum et fruetus inter omnes nobilissimus. He states that the Italians prepare from it the finest essences which are sold at a high price. ${ }^{6}$

Production-The bergamot is cultivated at Reggio, on low ground near the sea, and in the adjacent villages. The trees are often intermixed with lemon and orange trees, and the soil is well irrigated and cropped with vegetables.

The essential oil (Oleum Bergamottce) is obtained from the full-grown but still unripe and more or less green fruits, gathered in the months of November and December. It was formerly made like that of lemon by the sponge-process, but during the last 20 years this method has been generally superseded by the introduction of a special machine for the extraction of the essential oil. In this machine the fruits are placed in a strong, saucer-like, metallic dish, about 10 inches in diameter, having in the centre a raised opening which with the outer edge forms a broad groove or channel; the dish is fitted with a cover of similar form. The inner surface both of the dish and cover is rendered rough by a series of narrow, radiating metal ridges or blades which are about $\frac{1}{4}$ of an inch high and resemble the backs of knives. The dish is also furnished with some small openings to allow of the outflow of essential oil ; and both dish and cover are arranged in a metallic cylinder, placed over a vessel to receive the oil. By a simple arrangement of cog-wheels moved by a handle, the cover which is very heavy is made to revolve rapidly

I Trcité du Citrus, 1811. 118.:

2 Hesperides, seu de malorum aurcorum cultura et usu.

${ }^{3}$ Nederlantze Hesperides, $\Lambda$ msterd. 1676.

fol. (an English translation in 1683).

4 Citrolugia, Ferrariæ, 1690.
5 Instruction pour les Jardins fruitiers . . avec un traité des Orangers, ed. 2, 1692.

6 Hesperides Norimbergenses, 1713. lib. 3. cap. 26. and p. $156 \mathrm{~b}$. (We quote from the Latin edition.) 
over the dish, and the fruit lying in the groove between the two is carried round, and at the same time is suljected to the action of the sharp ridges, which rupturing the oil-vessels, cause the essence to escape, and set it free to flow out by the small openings in the bottom of the dish. 'The fruits are placed in the machine 6,8 or more at a time, according to their size, and subjected to the rotatory action above described for about half a minute, when the machine is stopped, they are removed and fresh ones substituted. About 7,000 fruits can be thus worked in one of these machines in a day. The yield of oil is said to be similar to that of lemon, namely $2 \frac{1}{2}$ to 3 ounces from 100 fruits.

Essence of bergamot made by the machine is of a greener tint than that obtained by the old sponge-process. During some wecks after extraction it gradually deposits a quantity of white greasy matter (bergaptene), which after having been exhausted as much as possible by pressure, is finally subjected to distillation with water in order to separate the essential oil it still contains.

The fruits from which the essence has been extracted are submitted to pressure, and the juice, which is much inferior in acidity to lemon juice, is concentrated, and sold for the manufacture of citric acid. Finally, the residue from which both essence and juice liave been removed, is consumed as food by oxen.

Description-1 Essential oil of bergamot is a thin and mobile fluid of peculiar and very fragrant odour, bitterish taste, and slightly acid reaction. It has a pale greenish yellow tint, due to traces of chlorophyll as may be shown by the spectroscope. Its sp. gr. is 0.86 to 0.88 ; its boiling point varies from $183^{\circ}$ to $195^{\circ} \mathrm{C}$.

The oil is miscible with spirit of wine $(0.83 \mathrm{sp} . \mathrm{gr}$.), absolute alcohol, as well as with crystallizable acetic acid. Four parts dissolve clearly one part of bisulphide of carboul, but the solution becomes turbid if a larger proportion of the latter is added. Bisulphide of carbon itself is incapable of dissolving clearly any appreciable quantity of the oil. A mixture of 10 drops of the oil, 50 drops of bisulphide of carbon and one of strong sulphuric acid has an intense yellow hue. Perchloride of iron imparts to bergamot oil dissolved in alcohol a dingy brown colour.

Panuccio's oil of bergamot examined in the same way as that of lemon (p. 107) deviates $7^{\circ}$ to the right and has therefore a dextrogyre power very inferior to that of other oils of the same class. ${ }^{2}$ But it probably varies in this respect, for commercial specimens which we judged to be of good quality deviated from $8.8^{\circ}$ to $10.4^{\circ}$ to the right.

Chemical Composition-If essential oil of bergamot is submitted to rectification, the portions that successively distill over do not accord in rotatory power or in boiling point, a fact which proves it to be a mixture of several oils, as is further confirmed by analysis. It appears to consist of hydrocarbons, $\mathrm{C}^{10} \mathrm{H}^{16}$, and their hydrates, neither of which have as yet been satisfactorily isolated. Oil of bergamot, like that of turpentine, yields crystals of the composition $\mathrm{C}^{10} \mathrm{H}^{16}+3 \mathrm{H}^{2} \mathrm{O}$, if 8 parts are allowed to stand some weeks with 1 part of spirit of wine, 2 of nitric

1 The characters are taken from some Essence of Berganot presented to one of us (15 May 1872) as a type-sample by Messrs. $\mathrm{G}$. Panuceio e figli, manufacturers of essences at Reggio and also large cultivators of the bergamot orange.

¿ See however Oleum Neroli, p. 113. 
acid (sp. gr. 1.2) and 10 of water, the mixture being frequently shaken. No solid compound is produced by saturating the oil with anhydrous hydrochloric gas.

The greasy matter that is deposited from oil of bergamot soon after its extraction, 1 and in small quantity is often noticeable in that of commerce, is called Bergaptcne or Bergamot Camphor. We have obtained it in fine, white, acicular crystals, neutral and inodorous, by repeated solution in spirit of wine. Its composition according to the analysis of Mulder (1837) and of Ohme (1839) answers to the formula $\mathrm{C}^{9} \mathrm{H}^{6} \mathrm{O}^{3}$, which in our opinion requires further investigation. Crystallized bergaptene is abundantly soluble in chloroform, ether or bisulphide of carbon; the alcoholic solution is not altered by ferric salts.

Commerce-Essence of bergamot, as it is always termed in trade, is chiefly shipped from Messina and Palermo in the same kind of bottles as are used for essence of lemon.

Uses-Much employed in perfumery, but in medicine only occasionally for the sake of imparting an agreeable odour to ointments.

Adulteration-Essence of bergamot like that of lemon is extensively and systematically adulterated, and very little is sent into the market entirely pure. It is often mixed witl oil of turpentine, but a finer adulteration is to dilute it with essential oil of the leaves or with that obtained by distillation of the peel or of the residual fruits. Some has of late been adulterated with petroleum.

The optical properties as already mentioned may afford some assistance in detecting fraudulent admixtures, though as regards oil of turpentine it must be borne in mind that there are levogyre as well as dextrogyre varieties. This latter oil and likewise that of lemon is less soluble in spirit of wine than that of bergamot.

\section{CORTEX AURANTII.}

\section{Bitter Orange Peel; F. Ecorce ou Zestes d'Oranges amères; G. Pomeran- zenschale.}

Botanical Origin-Citrus vulgaris Risso (C. Aurantium var. a amara Linn., C. Bigaradia Duhamel).

The Bitter or Seville or Bigarade Orange, Bigaradier of the French, is a small tree extensively cultivated in the warmer parts of the Mediterranean region especially in Spain, and existing under many varieties.

Northern India is the native country of the orange tree. In Gurhwal, Sikkim and Khasia there occurs a wild orange which is the supposed parent of the cultivated orange, whether Sweet or Bitter.

The Bitter Orange reproduces itself from seed and is regarded, at least by cultivators, as quite distinct from the Sweet Orange, from which however it cannot be distinguished by any important botanical characters. Generally speaking it differs from the latter in having the fruit rugged on the surface, of a more deep or reddish-orange hue, with the pulp very sour and bitter. The peel as well as the flowers and leaves are more aromatic than the corresponding parts of the Sweet Orange, and the petiole is more broadly winged.

1 We are indebted to Mr. Robert Sanderson of Messina for placing at our disposal a

quantity of this deposit for chemical examination. 
History-The orange was unknown to the ancient Greeks and Romans; and its introduction to Europe is due to the Arabs wlio, according to Gallesio, ${ }^{1}$ appear to have established the tree first in Eastern Africa, Arabia and Syria, whence it was gradually conveyed to Italy, Sicily and Spain. In the opinion of the writer just quoted, the bitter oringe was certainly known at the commencement of the 10th century to the Arabian physicians, one of whom, Avicenna, ${ }^{2}$ employed its juice in medicine.

There is strong evidence to show that the orange first cultivated in Furope was the Bilter Orange or Bigarade. The orange tree at Rome said to have been planted by St. Dominic about A.D. 1200 and which still exists at the monastery of St. Sabina bears a bitter fruit; and the aricient trees standing in the garden of the Alcazar at Seville are also of this variety. Finally, the oranges of Syria (ab indigenis Orenges nuncupati) described by Jacques de Vitri, Bishop of Acon (ob. A.D. 1214) were acidi seu pontici saporis. ${ }^{3}$

The Sweet Orange began to be cultivated about the middle of the 15th century, having been introduced from the East by the Portuguese. It has probably long existed in Southern China, and may have been taken hence to India. In the latter country there are but few districts in which its cultivation is successful, and the Bitter Orange is hardly known at all. The name it has long borne of China ${ }^{4}$ or Portugal Orange indicates what has been the usual opinion as to its origin.

One of the first importations of oranges into England occurred in A.D. 1290, in which year a Spanish ship came to Portsmouth, of the cargo of which the queen of Edward I. bought one frail of Seville figs, one of raisins or grapes, one bale of dates, 230 pomegranates, 15 citrons and 7 oranges ("poma de orenge"). ${ }^{5}$

Description-The Bitter Orange known in London as the Seville Orange is a globular fruit resembling in size, form and structure the common Sweet Orange, but having the peel much rougher and when mature of ${ }^{\top}$ a somewhat deeper hue. The pulp of the fruit is filled with an acid bitter juice. The ripe fruit is imported into London; the peel is removed from it with a sharp knife in one long spiral strip, and quickly rlied, or it is sold in the fresh state. It is the more esteemed when cut thin, so as to include as little as possible of the white inner layer.

Well-dried orange peel should be externally of a bright tint and white on its inner surface; it should have a grateful aromatic smell and pitter taste. The peel is also largely imported into London ready dried, especially from Malta. We have observed it from this latter place of three qualities, namely in elliptic pieces or quarters, in broad curled strips, and lastly a very superior kind almost wholly free from the white zest, in strips less than $\frac{1}{8}$ of an iuch in width, cut apparently by a machine. Such needless subdivision as this last has undergone must greatly favour an alteration and waste of the essential oil. Foreign-dried orange peel fetches a lower price than that dried in England.

1 Traité du Citrus, Paris, 1811. 222.

2 Opera, ed. Valg. 1564. lib. v. sum. 1. tract. 6. p. 289. -The passage which is the iollowing sccms rather incollclusive:"6. succi acetositatis citri et succi acetosiuatis citranguli."
3 Vitriaco, Hist. orient. et occident., 1597. cap. $S 6$.

4 Hence the Dutch Sinarasappl or Appclsina and the German Apfelsine.

5 Mannors and Honschold Exponses of England in the 13 th and 15 th conturics, Lond. (Roxburghe ('lub) 1841. slviij. 
Microscopic Structure-There is no difference between the tissues of this drug and those of lemon peel.

Chemical Composition-The essential oil to which the peel of the orange owes its fragrant odonr, is a distinct article of commerce and will be noticed hereafter under a separate head. The other constituents of the peel probably agree with those of lemon peel. The substance mentioned under the name of Hesperidin (p. 104) appears to be particularly abundant in unripe bitter oranges.

Uses-Bitter orange peel is much used in medicine as an aromatic tonic.

\section{OLEUM NEROLI.}

Oleum Aurantii florum; Oil or Essence of Neroli; F. Essenee de Néroli; G. Neroliöl.

Botanical Origin-Citrus vulgaris Risso. (See page 111.)

History-Porta, the Italian philosopher of the 16th century referred to in connection with the essential oil of lemon (p. 106), was acquainted with the volatile oil of the flowers of the citron tribe ("Oleum ex eitriorum floribus") which he obtained by the usual process of distillation, and describes as possessing the most exquisite fragrance. That distilled from orange flowers acquired a century later $(1675-1685)$ the name of Essenee of Neroli from Anne-Marie de la Trémoille-Noirmoutier, second wife of Flavio Orsini, duke of Bracciano and prince of Nerola or Neroli. This lady employed it for the perfuming of gloves, hence called in Italy Guanti di Neroli. ${ }^{1}$ It was known in Paris to Pomet, who says ${ }^{2}$ the perfumers lave given it the name of Neroli, and that it is made in Rome and in Provence.

Production-Oil of Neroli is prepared from the fresh flowers of the Bigarade or Bitter Orange by the ordinary process of distillation with water, conducted in small copper stills. The water which distills over with the oil constitutes after the removal of the latter from its surface, the Orange Flower Water (Aqua aurantii florum vel Aqua Napha) of commerce. The manufacture is carried on chiefly in the south of France at Grasse, Cannes, and Nice.

Description and Chemical Composition-Oil of Neroli as found in commerce is seldom pure, for it generally contains an admixture of the essential oil of orange-leaf called Essenee of Petit, Grain.

By the kind assistance of Mr. F. G. Warrick of Nice, we have obtained a sample of Bigarade Neroli of guaranteed purity, to which the following observations relate. It is of a brownish hue, most fragrant odour, bitterish aromatic taste, and is neutral to test-paper. Its sp. gr. at $11^{\circ} \mathrm{C}$. is 0.889 . When mixed with alcohol, it displays a bright violet fluorescence, quite distinct from the blue fluorescence of a solution of quinine. In oil of Neroli the phenomenon may be shown most distinctly by pouring a little spirit of wine on to the surface of the essential oil, and causing the liquid to gently undulate. The oil is but turbidly miscible with bisulphide of carbon. It assumes a very pure, intense, and permanent crimson hue if shaken with a saturated solution

1 Menagio, Origini delle, Iingua Italiana, 168̄̃ ; Diel. de Trévoux, Paris, vi. (1771)

178. -The town of Nerola is about 16 miles north of Tivoli.

${ }^{2}$ Histoire des Droyucs, 1694. 234. ii. 
of bismlphite of sodium. Examined in a column of 100 mm., we observed the oil to deviate the ray of polarized light $6^{\circ}$ to the right.

Subjected to distillation, the larger part of the oil passes over at $185^{\circ}-195^{\circ} \mathrm{C}$. ; we found this portion to be colourless, yet to display in a marked manner the violet fluorescence and also to retain the odour of the original oil. The portion remaining in the retort was mixed with about the same volume of alcohol (90 per cent.) and some drops of water added, yet not sufficient to occasion turbidity. A very small amount of the crystalline Neroli Camploor then inade its appearance, floating on the surface of the liquid; by re-solution in boiling alcoliol it was obtained in crystals of rather indistinct form. The re-distilled oil gave no camphor whatever.

Neroli Camphor was first noticed by Boullay in 1828. According to our observations it is a neutral, inodorous, tasteless substance, fusible at $55^{\circ} \mathrm{C}$., and forming on cooling a crystalline mass. The crystallization sliould be effected by cooling the hot alcoholic solution, no good crystals being obtainable by slow evaporation or by sublimation. The pruduce was extremely small, about 60 grammes of oil having yiclded not more than 0.1 gramme. Perhaps this scantiness of produce was due to the oil being a year and a half old, for according to Plisson ${ }^{1}$ the camphor diminishes the longer the oil is kept. ${ }^{2}$ We were unable to obtain any similar substance from the oils of bergamot, petit grain, or orange peel.

Orange Flower Water is a considerable article of manufacture among the distillers of essential oils in the south of Europe, and is imported thence for use in pharmacy. According to Boullay ${ }^{3}$ it is frequently acid to litmus when first made,-is better if distilled in small than in large quantities, and if made from the petals per se, rather than from the entire flowers. He also states that only $2 \mathrm{Hb}$. of water should be drawn from $1 \mathrm{tb}$. of flowers, or $3 \mathrm{H}$. if petals alone are placed in the still. As met with in commerce, orange flower water is colourless or of a faintly greenish yellow tinge, almost perfectly transparent, with a delicious odour and a bitter taste. Acidulated with nitric acid, it acquires a pinkish hue more or less intense, which disappears on saturation by an alkali.

Uses-Oil of Neroli is consumed almost exclusively in perfumery. Orange flower water is frequently used in medicine to give a pleasant odour to mixtures and lotions.

Adulteration - The large variation in value of oil of Neroli as sliown by price-currents ${ }^{4}$ indicates a great diversity of quality. Besides being very commonly mixed, as already stated, with the distilled oil of the leaves (Essence de Petit Grainu), ${ }^{5}$ it is sometimes reduced by addition of the less fragrant oil obtained from the flowers of the Portugal or Sweet Orange. In some of these adulterations we must conclude that orange flower water participates : metallic contamination of the latter is not unknown.

1 Journ. de Pharm. xv. (1829) 152.

2 Yet we extracted it from an old sample labelled "Essence de Néroli Portugal Méro."

3 Bulletin de Pharm. i. (1809) 337-341.

4 Thus in the price-list of a firm at Grasse, Neroli is quoted as of four qualities, the lowest or "commercial " being less than half the price of the finest.

5 We have been informed on good authority that the Neroli eommonly sold contains $\frac{3}{8}$ of Essenee of Petit Grain. and $\frac{1}{8}$ of Essence of Bergamot, the remaining $\frac{4}{8}$ being true Neroli. 


\section{Other Products of the genus Citrus.}

Essence or Essential Oil of Petit Grain-was originally obtained by subjecting little immature oranges to distillation (Yomet$1692)$; but it is now produced, and to a large extent, by distillation of the leaves and shoots either of the Bigarade or Bitter Orange, or of the Portugal or Sweet Orange. The essence of the former is by far the more fragrant and commands double the price.

The leaves are obtained in the lemon-growing districts of the Mediterranean where the essence is manufactured. Lemon-trees being mostly grafted on orange-stocks, the latter during the summer put forth shoots, which are allowed to grow till they are often some feet in length. The cultivator then cuts them off, binds them in bundles, and conveys them to the distiller of Petit Grain. The strongest shoots are frequently reserved for walking-sticks. The leaves of the two sorts of orange are easily distinguished by their smell when crushed. Essence of Petit Grain which in odour lias a certain resemblance to Neroli, is used in perfumely and especially in the manufacture of Eau de Cologne.

According to Gladstone (1864) it consists mainly of a hydrocarbon probably identical with that from oil of Neroli.

Essential Oil of Orange Peel-is largely made at Messina and also in the south of France. It is extracted by the sponge-, or by the écuelle-process, and partly from the Bigarade and partly from the Sweet or Portugal Orange, the scarcely ripe fruit being in either case employed. The oil made from the former is much more valuable than that obtained from the latter, and the two are distinguished in price-currents as Essence de Bigarade and Essence de Portugal.

These essences are but little consumed in England, but are largely used in Germany. They are employed in liqueur-making and in perfumery. For what is known of their chemical nature, the reader can consult the works named at foot. 1

Essence of Cedrat-The true Citron or Cedrat tree is Citrus medica Risso, and is of interest as being the only member of the Orange tribe the fruit of which was known in ancient Rome. 'The tree itself which appears to have been cultivated in Palestine in the time of Josephus, was introduced into Italy in about the 3rd century. In A.D. 1003 it was much grown at Salerno near Naples, whence its fruits were sent as presents to the Norman princes. ${ }^{2}$

At the present day, the citron appears to be nowhere cultivated extensively, the more prolific lemon tree having generally taken its place. It is however scattered along the Western Riviera, and is also grown on a small scale about Pizzo and Paola on the western coast of Calabria, in Sicily, Corsica and the Azores. Its fruits which often weigh several pounds, are chiefly sold for being candied. For this purpose the peel. which is excessively thick, is salted and in that state shipped to England and Holland. The fruit has a very scanty pulp. ${ }^{3}$

1 Gmelin, Chemistry, xiv. (1860) 305. 306 ; Gladstone, Journ. of Chem. Soc. xvii. (1864) 1 ; Wright (and Piesse) in Ycarbook of Phar. macy, 1871. 546; 1873. 518; Journ. of Chem. S'oc. xi. (1873) 552, \&c.

2 Gallesio, Trailé du Citrus, 1811. 222.

Oribasius who lived in the second half of the 4th century and who was physician and friend of the emperor Julian the $A$ postate, accurately describes the citron as a fruit consisting of threc parts, namely a central acid pulp, a thick and fleshy zest and an aromatic outer coat.-Mcdicinalia collecta, lib. i. c. 64 . 
Essence of Cedrat which is quoted in some price-lists may be prepared from the scarcely ripe fruit by the sponge-process; but as it is more profitable to export the fruit salted, it is very rarely manufactured, and that which bears its name is for the most part fictitious.

\section{FRUCTUS BELAE.}

\section{Bela; Bacl Fruit, Indian Bacl, Bongal Quince.}

Botanical Origin-AEglc Marmelos ${ }^{1}$ Correa (Cratceva Marmelos L.), a tree found in most parts of the Indian peninsula, where it is often planted in the neighbourliood of temples, being esteened sacred by the Hindus. It is truly wild in the forests of the Coromandel Ghâts and of the Western Himalaya.

It attains a height of $30-40$ feet, is usually armed with strong sharp thorns and has trifid leaves, the central leaflet being petiolate and larger than the lateral. The fruit is a large berry, 2 to 4 inches in diameter, variable in shape, being spherical or somewhat flattened like an orange, ovoid, or pyriform, ${ }^{2}$ having a smooth hard shell; the interior divided into $10-15$ cells each containing several woolly seeds, consists of a mucilaginous pulp, which becomes very hard in drying. In the fresh state the fruit is very aromatic, and the juicy pulp which it contains has an agreeable flavour, so that when mixed with water and sweetened, it forms a palatable refrigerant drink. The fruit is never eaten as dessert, though its pulp is sometimes made into a preserve with sugar.

The fruit of the wild tree is described as small, hard, and flavourless. The bark of the stem and root, the flowers and the expressed juice of the leaves are used in medicine by the natives of India.

History-The tree under the name of Bilva ${ }^{3}$ is constantly alluded to as an emblem of increase and fertility in ancient Sanskrit poems, some of which as the Yajur Veda are supposed to have been written not later than 1000 B.C.

Garçia d'Orta who resided in India as physician to the Portuguese viceroy at Goa in the 16th century, wrote an account of the fruit under the name of Marmclos de Benguala (Bengal Quince) Çirifole or Beli, describing its use in dysentery.

In the following century it was noticed by Bontius, in whose writings edited by Piso ${ }^{5}$ there is a bad figure of the tree as Malum Cydonium. It was also figured by Rheede ${ }^{6}$ and subsequently under the designation of Bilack or Bilack tcllor by Rumphius. ${ }^{7}$ The latter states that it is indigenous to Gujarat, the eastern parts of Java, Sumbawa and Celebes, and that it has been introduced into Amboina.

But although Agle Marmclos has thus long been known and appreciated in India, the use of its fruit as a medicine attracted no

1 AEglc, one of the Hesperides. - Marmelos from the Portuguese marmclo, a quince.

2 In the Botanical Garden of Buitenzorer in Java, three varieties are grown, namelyfructibus oblongis, fructibus subglobosis, and macrocarpa.

3 We are indebted to Professor Monier Williams of Oxford for pointing out to us many references to Bilva in the Sanskrit writings.

4 Siri-phal and Bcl are Hindustani names.

5 De Indice re nat. ct mad. 1658 , lib. ri. c. 8 .

Hort. Malab. iii. (16s2) tab. $3 \bar{i}$ (Covalam).

7 IIcrb. Aanb. i. tab. 81. 
attention in Europe till about the year 1850. The dried fruit which has a place in the British Pharmacopceic is now not unfrequently imported.

Description-We have already described the form and structure of the fruit, which for medicinal use should be dried when in a half ripe state. It is found in commerce in dried slices having on the outer side a smooth greyish shell enclosing a hard, orange or red, gummy pulp in which are some of the 10 to 15 cells existing in the entire fruit. Each cell inchudes 6 to 10 compressed oblong seeds nearly 3 lines in length, covered with whitish woolly hairs. When broken the pulp is seen to be nearly colourless internally, the outside alone having assumed an orange tint. The dried pulp has a mucilaginous, slightly acid taste, without aroma, astringency or sweetness.

There is also iniported Bael fruit which has been collected when ripe, as shown by the well-formed seeds. Such fruits arrive broken irregularly and dried, or sawn into transverse slices and then dried, or lastly entire, in which case they retain some of their original fragrance resembling that of elemi.

Microscopic Structure-The rind of the fruit is covered with a strong cuticle and further shows two layers, the one exhibiting not very numerous oil-cells, and the other and inner made up of sclerenchyme. The tissue of the pulp, which treated with water swells into an elastic mass, consists of large cells with considerable cavities between them. The seeds when moistened yield an abundance of mucilage nearly in the same way as White Mustard or Linseed. In the epidermis of the seeds certain groups of cells are excessively lengthened and thus constitute the curious woolly hairs already noticed. They likewise afford mucilage in the same way as the seed itself.

Chemical Composition-We are unable to confirm the remarkable analyses of the drug alluded to in the Pharmacopeia of India; ${ }^{1}$ nor can we explain by any chemical examination upon what constituent the alleged medicinal efficacy of bael depends.

The pulp moistened with cold water yields a red liquid containing chiefly mucilage, and (probably) pectin which separates if the liquid is concentrated by evaporation. The mucilage may be precipitated by neutral acetate of lead or by alcohol, but is not coloured by iodine. It may be separated by a filter into a portion truly soluble (as proved by the addition of alcohol or acetate of lead) and another, comprehending the larger bulk, which is only swollen like tragacanth, but is far more glutinous and completely transparent.

Neither a per- nor a proto-salt of iron shows the infusion to contain any appreciable quantity of tannin, ${ }^{2}$ nor is the drug in any sense possessed of astringent properties.

Uses-Bael is held in high repute in Intlin as a remedy for dysentery and diarrhœa; at the same time it is said to act as a laxative where constipation exists.

Adulteration-The fruit of Feronia Elephantum Correa, which has

1 Edition 1868, pp. 46 and 441.

2 We are thus at variance with Collas of Pondichery, who attributes to the ripe fruit 5 per cent. of tannin.-Hist. nat. etc. du Bel, ou Vitra in Revue Coloniale, xvi (1856) 220-238. 
a considerable external resemblance to that of Eyle Mrumelos and is called by Luropenss Wool Apple, is sometimes supplied in India for bael. It may be easily distinguished: it is one-celled. with a large fivelobed cavity. (instcad of 10 to 15 cells) filled with nmmerous seeds. The tree his pinnate leaves with 2 or 3 pairs of leatlets. We have seen Iomegranate Peel offered as Indian Breel.1

\section{SIMARUBEA.}

\section{IIGNUM QUASSI $\not$.}

Quassia, Quassia Wood, Bitter Wood; F. Bois de Quassia de la Jamaique, Bois amer; G. Jamaica Quassiaholz.

Botanical Origin-Piercena excelsa Lindl. (Quassia exeelsa Swartz, Simaruba excelsa D C., Piercusma exeelsa Planchon), a tree 50 to 60 feet in height, somewhat resembling an ash and having inconspicuous greenish flowers and black shining drupes the size of a pea. It is common on the plains and lower mountains of Jamaica and is also found in the islands of Antigua and St. Vincent. It is called in the West Indies Bitter Wood or Bitter Ash.

History-Quassia wood was introduced into Europe about the middle of the last century. It was derived from Quassia amara L., a shrub or small tree with handsome crimson flowers, belonging to the same order, native of Panama, Venezuela, Guiana and Northern Brazil. It was subsequently found that the Bitter. Wood of Jamaica which Swartz and other botanists referred to the same genus, possessed similar properties, and as it was obtainable of much larger size, it has since the end "of the last century been generally preferred. The wood of $Q$ amarc called Surinam Quassica, is however still used in France and Germany. ${ }^{2}$

The first to give a good account of Jamaica quassia was John Lindsay, ${ }^{3}$ a medical practitioner of the island, who writing in 1791 described the tree as long known not only for its excellent timber, but also as a useful medicine in putrid fevers and fluxes. He adds that the bark is exported to England in considerable quantity- "for the purposes of the brewers of ale and porter."

Quassia, defined as the wood, bark, and root of Q. amara L., was introduced into the London Pharmacopøia of 1788 ; in the edition of 1809, it was superseded by the wood of Piercena excelsa. In the stockbook of a London druggist (J. Gurney Bevan, of Plough Court, Lombard Street) we find it first noticed in 1781 (as rasurce), when it was reckoned as having cost $4 s .2 d$. per $1 \mathrm{~b}$.

Description-The quassia wood of commerce consists of pieces of: the stem and larger branches, some feet in length and often as thick as a man's thigh. It is covered with bark externally of a dusky grey or blackish hue, white and fibrous within, which it is customary to strip off and reject. The wood which is of a very light yellowish tint is tough

140 bags in a drug sale, Sth May 1873.

2 The Pharmacopaia Germanica of 1872 expressly forbids the use of the wood of Picrena in place of Quassia.
3 Trans. Roy. Soc. Edinburgh, iii. (1794) 205. tab. 6. 
and strong, but splits easily. In transverse section it exibits numerous fine close medullary rays, which intersect the rather obscure and irregular rings resembling those of annual growth of our indigenous woody stems. The centre is occupied by a cylinder of pith of minute size. In a longitudinal section whether tangential or radial, the wood appears transversely striated by reason of the small vertical height of the nedullary rays.

The wood often exhibits certain blackish markings due to the mycelium of a fungus; they have sometimes the aspect of delicate patterns and at others appear as large dark patches.

Quassia has a strong, pure bitter taste, but is devoid of odour. It is always supplied to the retail druggist in the form of turnings or raspings, the former being obtained in the manufacture of the Bitter Cups, now often seen in the shops.

Microscopic Structure--The wood consists for the most part of elongated pointed cells (libriform), traversed by medullary rays, each of the latter being built up of about 15 vertical layers of cells. The single layers contain from one to three rows of cells. The ligneous rays thus enclosed by medullary parenchyme, are intersected by groups of tissue constituting the above-mentioned irregular rings. On a longitudinal section this parenchyme exhibits numerous crystals of oxalate of calcium and sometimes deposits of yellow resin. The latter is more abundant in the large vessels of the wood. Oxalate and resin are the only solid matters perceptible in the tissues of this drug.

Chemical Composition-The bitter taste of quassia is due to Quassiin, which was first obtained by Winckler in 1835 and analysed by Wiggers ${ }^{1}$ who assigned it the formula $\mathrm{C}^{10} \mathrm{H}^{12} \mathrm{O}^{3}$, now regarded as doubtful. According to the latter, quassiin is an irresolvable, neutral substance, crystallizable from dilute alcohol or from chloroform. It requires for solution about 200 parts of water, but is not soluble in ether; it forms an insoluble compound with tannic acid. Quassia wood is said to yield about $\frac{1}{10}$ per cent. of quassiin. A watery infusion of quassia, especially if a little caustic lime has been added to the drug, displays a slight fluorescence, due apparently to quassiin. Quassia wood dried at $100^{\circ} \mathrm{C}$. yielded us $7 \cdot 8$ per cent of ash.

Commerce-The quantity of Bitter Wood shipped from Jamaica in 1871 was $^{2} 6$ tons. $^{2}$

Uses-The drug is employed as a stomachic and tonic. It is poisonous to flies and is not without narcotic properties in respect to the higher animals.

Substitutes-The wood of Quassia amara L., the Bitter Wood of Surinam, bears a close resemblance, both external and structural, to the drug just noticed; but its stems never exceed 4 inches in diameter and are commonly still thinner. Their thin, brittle bark is of a greyish yellow and separates easily from the wood. The latter is somewhat denser than the quassia of Jamaica, from which it may be distinguished by its medullary rays being composed of a single or less frequently of a double row of cells, whereas in the wood of Picrana excelsa, they consist of two or three rows, less frequently of only one.

\footnotetext{
${ }^{1}$ Liebig's Annalend.Pharm. xxi.(1837)40.

2 Blue Rook, Island of Jamaica, for 1871.
} 
Suriman Quassia Wood is exported from the Dutch colony of Surinam. The quantity shipped thence during the nine months ending 30 Sept. 1872, was $264,(675) \mathrm{H} .{ }^{1}$

The bark of Samaldera indica Ciirtn., a tree of the same natural order owes its bitterness to a principle," which agrees perhaps with quassin.

\section{BURSERACEAE.}

\section{OLIBANUM.}

Gummi-resina Olibanum, Thus masculum;3 Olibanum, Frantoinecnse; F. Encens; G. Weihraueh.

Botanical Origin-Olibanum is obtained from the stem of several species of Boswellia, inhabiting the hot and arid regions of Eastern Africa near Cape Gardafui and of the southern coast of Arabia. Notwithstanding the recent elaborate and valuable researches of Birdwood ${ }^{4}$ the olibanum trees are still but imperfectly known, as will be evident in the following enumeration :-

1. Boswellia Carterii Birdw.-This includes the three following forms, which may be varieties of a single species, or may belong to two or more species, - a point impossible to settle until more perfect materials shall have been obtained.

a. Boswellia No. 5, Oliver, Flora of Tropieal. Afriea, I. (1868) 324, Mohr Madow of the natives.-Somali Country, growing a little inland in the valleys and on the lower parts of the hills, never on the range close to the sea. It yields the olibanum called Lubân Bedowi or Lubân Shcheri (Playfair).

b. Bosucllia No. 6, Oliver, op. eit., Birdwood, Linn. Trans. xxvii. tab. 29.-Sent by Playfair among the specimens of the preceding and with the same indications and native name.

c. Maghrayt d'sheehaz of the Maharas, Birdwood, 1. c. tab. 30. B. thurifera (?), Carter, Journ. of Bombay Branch of R. Asiat. Soc. ii. tab. 23 ; B. saera Fliickiger, Lehrbuch der Pharmakognosic des Pflanzenreiehes, 1867. 31. Ras Fartak, S. E. coast of Arabia, growing in the detritus of limestone cliffs and close to the shore, also near the village of Merbat (Carter, 1844-1846).

2. B. Bhau-Dajiana Birdw. 1. c.tab. 31.-Somali Country (Playfair); growing in Victoria Gardens, Bombay, where it flowered in 1 is68.

1 Consular Reports No. 3, presented to Parliament, July 1873.

2 Post vall Touningen, Jahresbericht of Wiggers (Canstatt) for 1858. 75 ; Pharm. Journ. ii. (1872) 644. 654.

3 The $\lambda$ ißavos of the Greeks, the Latin Olibanuin, as well as the Armbie Lubân, and the analogous sounds in otler lauguages, are all derived from the Hebrew Lcbonah signifying mills: and modern travellers who have seen the frankincense trees state that the fresh juice is milky, and hardens when exposid to the air. The word Thus on the other hand seems to be derived from the verb

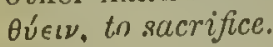

4 On the' Genus Boswellia, with deseriptions and fugures of three new species. - Linn. Trans. xxvii. (1871) 111. - The materials on which Dr. Birdwood's observations have been ehicfly founded, and to which we also liave had aecess, are,-1. Speeimens colleeted during an expedition to the Somali Coast made by Col. Playfair in 1862.-2. Growing plants at Bombay and Aden, raisel from euttings sent by Playfair--3. A speeimen obtained by H. J. Carter in 1846 near Ras Fartak on the soutli-east eoast of Arabia and still growing in Vietoria Gardens, Bonlbay; and figured by Carter in Journ. of Bombay Branch of $R$. Asiatic Soc., ii. (1S48) 380 , tab. 23. 
3. Boswellia No. 4, Oliver, op. cit.-Bunder Murayah, Somali Country (Playfair). Grows out of the rock, but sometimes in the detritus of limestone; never formd on the hills close to the sea, but further inland and on the highest ground. Yields Lubân Bedoui and L. Sheheri; was received at Kew as Mohr aud, a name applied by Birdwood also to B. Bhau-Dajiana.

In addition to the foregoing, from which indubitably the olibanum of cornmerce is collected, it may be convenient to mention also the following :-

B. papyrifera Richard (Plösslea floribunda Endl.), a tree of Sennaar and Abyssinia affords a resin like olibanum, which is not collected.

B. thurifera Colebr. (B. glabra et B. serrata Roxb.), the Salai tree of India, produces a soft odoriferous resin which is used in the country as incense but is not the olibanum of commerce.

B. Frereana Birdw. 1. c. tab. 32, a well-marked and very distinct species, native of the Somali Country, where it grows out of the smooth limestone rocks of the hills a few miles from the coast. The tree, which the natives call Yegaar, abounds in a highly fragrant resin collected and sold as Lubân Meyeti, or Lubân Matti, which we regard to be the substance originally known as Elemi.

History-The use of olibanum goes back to a period of extreme antiquity, as proved by the numerous references in the Mosaic writings of the Bible to incense, of which it was an essential ingredient. It is moreover well known that many centuries before Christ, the drug was one of the most important objects of the traffic which the Phœnicians ${ }^{1}$ and Egyptians carried on with Arabia.

Professor Ditimichen ${ }^{2}$ of Strassburg has discovered at the temple of Dayr el Báhri in Upper Egypt, paintings illustrating the traffic carried on between Egypt and Arabia as early as the 17th century B.c. In these paintings there are representations not only of bags of olibanum, but also of olibanum trees planted in tubs or boxes, being conveyed by ship from Arabia to Egypt. Inscriptions on the same building, deciphered by Professor D., describe with the utmost admiration the shipments of precious woods, heaps of incense, verdant incense-trees, ${ }^{3}$ ivory, gold, silver, apes, besides other productions not yet identified.

A detailed account of frankincense is given by Theophrastus ${ }^{4}$ (B.c. $370-285$ ) who relates that the commodity is produced in the country of the Sabrans, one of the most active trading nations of antiquity, occupying the southern shores of Arabia. It appears from Dicdorus that the Sabæans sold their frankincense to the Arabs, through whose hands it passed to the Phonicians who disseminated the use of it in the temples throughout their possessions, as well as among the nations with whom they traded. The route of the caravans from south-eastern Arabia

1 Movers, Dus phönizisehe Alterthum, iii. (1856) 99. 299.

${ }^{2}$ Diumichen (Joannes), The fleet of an E'gyptian Qucen from the 17 th century before our era, and ancient Egyptian militar? parade, represented on a monument of the sane age... after a eopy taken from the terraee of the temple of Der-el-Baheri, translated from the German by Amma Dümichen, Leipzig, 1868.
3 In one of the inscriptions they are referred to in terms which Professor D. has thus rendered:--Thirt y-one verdant incensetrees brought among the precious things from the land of Arabia, for the majesty of this god Amon, the lord of the terrestrial thrones. Never has anything similar been seen since the foundation of the world.

4 Hist. Plant. lib. iv. c. 7. 
to Gaza in Pilestine, lias recently (1866) been pointed out by Professon Sprenger. Plutarch relates that when Alexander the Great captured Caza, 500 talents of olibanum and 100 talents of myrrh were taken, and sent thence to Macedonia.

The libunophorous region of the old Sabrans is in fact the very country visited by Carter in 1844 and 1846, and lying as he states on the south coast of Arabia between long. $52^{\circ} 47^{\prime}$ and $52^{\circ} 23^{\prime}$ east. It was also known to the ancients, - at least to Strabo and Arrian, that the opposite African coast likewise produced olibanum, as it does extensively to the present day; and the latter states that the drug is shipped partly to Egypt and partly to Barbaricon at the mouth of the Tudus.

As exenplifying the great esteem in which frankincense was held by the ancients, the memorable gifts presented by the Magi to the infant Saviour will occur to every nind. A few other instances may be mentioned: Herodotus ${ }^{1}$ relates that the Arabians paid to Darius, king of Persia, an annual tribute of 1,000 talents of frankincense.

A remarkable Greek inscription brought to light in modern times ${ }^{2}$ on the ruins of the temple of Apollo at Miletus, records the gifts made to the shrine by Seleucus II., king of Syria (B.C. 246-227), and his brother Antiochus Hierax, king of Cilicia, which included in addition to vessels of gold and siver, ten talents of frankincense ( $\left.\lambda_{\iota} \Leftarrow a v \omega \tau o ̀ s\right)$ and one of myrrh.

The emperor Constantine made numerous offerings to the church under St. Silvester, bishop of Rome, A.D. 314-335, of costly vessels and fragrant drugs and spices, ${ }^{3}$ among which mention is made in several instances of Aromata and Aromata in incensum, terms under which olibanum is to be understood. ${ }^{4}$

With regard to the consumption of olibanum in other countries, it is an interesting fact that the Arabs in their intercourse with the Chinese, which is known to have existed as early as the 10th century, carried with them olibanum, myrrh, dragon's blood, and liquid storax, drugs which are still imported from the west into China. The firstnamed is called $J u$-siang i.e. mill-perfume, a curious allusion to its Arabic name Lubân signifying milk. In the year 1872 , Shanghai imported ${ }^{6}$ of this drug no less than 1,360 peculs $(181,333 \mathrm{Hb})$.

Collection-Cruttenden, ${ }^{7}$ who visited the Somali Country in 1843 , thus describes the collecting of olibanum by the Mijjertheyn tribe, whose chief port is Bunder Murayah (lat. $11^{\circ} 43^{\prime} \mathrm{N}$.) :-

"During the hot season the men and boys are daily employed in collecting gums, which process is carried on as follows :-A About the end of February or beginning of March, the Bedouins visit all the trees in succession and make a deep incision in each, peeling off a narrow strip of bark for about five inches below the wound. This is left for a month, when a fresh incision is made in the same place, but deeper. A third

1 Rawlinson's Herodotus, ii. (1858) 488.

2 Chishull, Antiquitales Asiatice, Lond. $1728 \quad 65-72$.

3 These remarkable gifts are enumerated by Vignoli in his Liber Pontificatis, Rome, 1724-55, and include beside Olibanum, Oleum nardinum, Oleum Cyprium, Bulsam, Storux Isaurica, Stacte, Aromata cassia, Saffron and Pepper.
${ }^{4}$ The ancient name of Cape Gardafui was Promontorium Aromatum.

5 Bretschueider, Ancient Chinesc, \&c. Loud. 1871. 19.

6 Returns of Trade at the Treaty Ports in Chine for 1872, p. 4.

121. 
month elapses and the operation is again repeated, after which the gum is supposed to have attained a proper degree of consistency. The monntain-rides are immediately covered with parties of men and boys, who scrape off the large clear globules into a basket, whilst the inferior quality that has run down the tree is packed separately. The gum when first taken from the tree is very soft, but hardens quickly. . . . . Every fortnight the mountains are visited in this manner, the trees producing larger quantities as the season advances, until the middle of September, when the first shower of rain puts a close to the gathering that year."

Carter, ${ }^{1}$ describing the collection of the drug in southern Arabia, writes thus:- "The gum is procured by making longitudinal incisions through the bark in the months of May and December, when the cuticle glistens with intumescence from the distended state of the parts beneath: the operation is simple, and requires no skill on the part of the operator. On its first appearance the gum comes forth white as milk, and according to its degree of fluidity, finds its way to the ground, or concretes on the branch near the place from which it first issued, from whence it is collected by men and boys, employed to look after the trees by the different families who possess the land in which they grow." According to Captain Miles, ${ }^{2}$ the drug is not collected by the people of the country, but by Somalis who cross in numbers from the opposite coast, paying the Arab tribes for the privilege. The Arabian Lubân, he says, is considered inferior to the African.

Description-Olibanum as found in commerce varies rather considerably in quality and appearance. It may in general terms be described as a dry gum-resin, consisting of detached tears up to an inch in length, of globular, pear-shaped, clavate, or stalactitic form, mixed with more or less irregular lumps of the same size. Some of the longer tears are slightly agglutinated, but most are distinct. The predominant forms are rounded,-angular fragments being less frequent, though the tears are not seldom fissured. Small pieces of the translucent brown papery bark are often found adhering to the flat pieces.

The colour of the drug is pale yellowish or brownish, but the finer qualities consist of tears which are nearly colourless or have a greenish hue. The smallest grains only are transparent, the rest are translucent and somewhat milky, and not transparent even after the removal of the white dust with which they are always covered. But if heated to about $94^{\circ} \mathrm{C}$., they become almost transparent. When broken they exhibit a rather dull and waxy surface. Examined under the polarizing microscope no trace of crystallization is observable.

Olibanum softens in the mouth; its taste is terebinthinous and slightly bitter, but by no means disagreeable. Its odour is pleasantly aromatic, but is only fully developed when the gum-resin is exposed to an elevated temperature. At $100^{\circ} \mathrm{C}$. the latter softens without actually fusing, and if the heat be further raised decomposition begins.

Chemical Composition-Cold water quickly changes olibanum into a soft whitish pulp, which when rubbed down in a mortar forms an emulsion. Immersed in spirit of wine, a tear of olibanum is not altered

1 Loc. cit.

2 On the neighbourhood of Bunder-Mara.

yah, in Journ. of R. Gcograph. Society, xlii. (1872) 65 . 
mueh in form, but it becomes of an almost pure opaque white. In the first case the water dissolves the gum, while in the seeond the aleohol removes the resin. We find that pure olibanum treated with spirit of wine leaves 27 to 35 per eent. of gum, the solution of whieh is preeipitated by pereliloride of iron as well as by silieate of sodiun, but not by nentral aectate of lead. It is consequently a guin of the same class as gum arabie, if not identical with it. Its solution contains the same amount of lime as gum arabie affords.

The resin of olibanm has been examined by Hlasiwetz (1867), aeenrding to whom it is a uniform substance having the composition $\mathrm{C}^{140} \mathrm{H}^{30} \mathrm{O}^{6}$. We find that it is not soluble in alkalis, nor have we sueeeeded in converting it into a erystalline body by the aetion of dilute aleohol. It is not uniformly distributed throughout the tears; if they are broken after having been aeted upon by dilute alcohol, it now and then happens that a elear stratification is pereeptible, showing a coneentrie arrangement.

Olibanum eontaius an essential oil, of which Braconnot (1.808) obtained 5 per cent., Stenhouse (1840) 4 per eent., and Kurbatow (1871) 7 per eent. Aeeording to Stenhouse it has a sp. gr. of $0 \cdot 866$, a boiling point of $179 \cdot 4^{\circ} \mathrm{C}$., and an odour resembling that of turpentine but more agreeable. Kurbatow separated this oil into two portions, the one of which has the formula $\mathrm{C}^{10} \mathrm{H}^{16}$, boils at $158^{\circ} \mathrm{C}$, and eombines with $\mathrm{HCl}$ to form Artifieial Camphor; the other eontains nxygen.

Olibanum submitted to destructive distillation affords no umbelliferone. Heated with strong nitrie acid it develops no peeuliar colour, but at length eamphresinic aeid, $\mathrm{C}^{20} \mathrm{H}^{14} \mathrm{O}^{7}$, is formed, which may be also obtained from many resins and essential oils if submitted to the same oxidizing agent.

Commerce-The olibanum of Arabia is shipped from several small plaees along the coast between Damkote and Al Kammar, but the quantity produeed in this distriet is much below that furnished liy the Somali Country in Eastern Afriea. The latter is brought to Zeyla, Berbera, Bunder Murayah, and many smaller ports, whence it is shipped to Aden or direet to Bombay. The trade is chiefly in the hands of Banians, and the great emporium for the drug is Bombay. A eertain portion is shipped through the straits of Bab-el-Mandeb to Jidda,- - Von Kremer ${ }^{1}$ says to the value of $£ 12,000$ annually. The quantity exported from Bombay in the year 1872-73 was 25,100 ewt., of which 17,446 ewt. were shipped to the United Kingdom, and 6,184 ewt. to China. ${ }^{2}$

Uses-As a medicine olibanum is nearly obsolete, at least in Britain. The great eonsumption of the drug is for the ineense used in the Roman Catholic and Greek Churehes.

\section{MYRRHA.}

Gummi-resina Myrrha; Myrrh; F. Myrrhe; G. Myrrha.

Botanical Origin-Ehrenberg who visited Egypt, Nubia, Abyssinia, and Arabia in the years 1820-26, brought home with him speeimens of

1 Aegypten, Forschungen über Land und Volk, Leipzig, 1863.

2 Statement of the Trade and Navigation of the Presideney of Bombay for 1872-i3, pt. ii. 78. 
the myrrh trees found at Ghizan (Gison), a town on the strip of coastregion called Tihâma, opposite the islands of Farsan Kebir and Farsan Seghir, and a little to the north of Lohaia, on the eastern side of the Red Sea; and also on the neighbouring mountains of Djara (or Shahra) and Kara. Here the nıyrrh trees form the underwood of the forests of Acacia, Moringa and Encphorbia. Nees von Esenbeck who examined these specimens, drew up from them a description of what he called Balsamodendron Alyrrtha, which he tigured in 1828.1

After Ehrenberg's herbarium had been incorporated in the Royal Herbarium of Berlin some years ago, Berg examined these specimens, and came to the conclusion that they consist of two species, namely that described and figured by Nees, and a second to which was attached (correctly we must hope) two memoranda bearing the following words :"Ipsa Myrrhce arbor ad Gison,-Martio," and "Ex huic simillima arbore ad Gison ipse Myprham effuentem legi. ${ }^{2}$ Hac specimina lecta sunt in montibus Djara et Kara Februario." This plant Berg named B. Ehrenbergianum. ${ }^{3}$ Oliver in his Flora of Tropical Africa (1868) ${ }^{4}$ is disposed to consider Berg's plant the same as B. Opobalsamum Kth., a tree or shrub yielding myrrh, found by Schweinfurth on the Bisharrin monntains in Abyssinia not far from the coast between Suakin and Edineb. But Schweinfurth himself does not admit the identity of the two plants. ${ }^{5}$ It is certain however that the myrrh of commerce is chiefly of African oligin.

It must be confessed that the botany of the myrrh trees is still encompassed with uncertainty, which will not be removed until the very localities in which the drug is collected shall have been well explored by a competent observer.

History-Myrrh has been used from the earliest times together with olibanum as a constituent of incense, ${ }^{6}$ perfumes and unguents. It was an ingredient of the holy oil used in the Jewish ceremonial as laid down by Moses; and it was also one of the numerous components of the celebrated Kyphi of the Egyptians, a preparation used in fumigations, medicine and the process of embalming, and of which there were several varieties.

In the previous article we have pointed out (p. 122) several early references to myrrh in connection with olibanum, in which it is observable that the myrrh (when weights are mentioned) is always in the sinaller quantity. Of the use of the drug in mediæval Europe there are few notices, but they tend to show that the commodity was rare and precious. Thus myrrh is recommended in the Anglo-Saxon Leechbooks ${ }^{7}$ to be used with frankincense in the superstitious medical practice of the 11th century.

In the Wardrobe accounts of Edward I. there is an entry under date 6 January, 1299, for gold, frankincense and myrrh, offered by the king

1 Planta Medicinales, Dïsseldorf, ii. (1828) tab. 355.

2 On applying in 1872 to Prof. Ehrenberg to know if it were possible that we eonld see this very speeimen, we reeeived the answer that it eould not be found.

${ }^{3}$ Berg u. Sehmidt, Drinstellung $и$. Beschreibuing. . . offizin. Gewïchse, iv. (1863) tab. xxix. d. ; also Bot. Zeitung, 16 Mai,
1862. 155 .

4 Vol. i. 326

5 Petermann, Geogr. Miltheilungen, 1868.

6 Cantie. iii. 6.

7 Coekayne, Lecchdoms \&.c. of Ear.ly England, ii. (1865) 295. 297. 
in his chapel on that day, it being the Feast of Epiphany. ${ }^{1}$ Myrrh agrin figures in the accounts of Geoffroi de Fleuri ${ }^{2}$ master of the wardrobe (aryentier) to Philippe le Long, king of France, where record is made of the purchase of - " 4 onces d'estorat calmite et mierre (myrrh) .... encenz et laudanon,"- - for the funeral of John, posthumous son of Loulis X., A.D. 1316.

Gold, silver, silk, precious stones, pearls, camphor, musk, myrrh and spices are enumerated ${ }^{3}$ as the presents which the Khan of Cathay sent to Pope Benedict XII. at Avignon about the year 1342 . The myrrh destined for this circuitous route to Europe ${ }^{4}$ was doubtless that of the Arabian traders, with whom the Chinese had constant intercourse during the middle ages. Myrrh in fact is still somewhat largely consumed in China. ${ }^{5}$

The name Myrrh is from the Hebrew and Arabic Mur, whence also the Greek $\sigma \mu u \dot{p} \nu a$. The ancient Egyptian Bola or Bal, and the Sanskrit Vola are preserved in the Persian and Indian words Bol, Bola and Hecra-bol, well-known names for myrrh.

Stacte $(\sigma \tau a \kappa \tau \grave{\eta})$, a substance often mentioned by the ancients, is said by Pliny to be a spontaneous liquid exudation of the myrrh tree, more valuable than myrrh itself. The author of the Periplus of the Erythrean Sea represents it as exported from Muza in Arabia ${ }^{6}$ together with myrrh. Theophrastus ${ }^{7}$ speaks of myrrl as of two kinds, solid and liquid. No drug of ntodern times has been identified with the stacte or liquid myrrh of the ancients: that it was a substance obtainable in quantity seems evident from the fact that 150 pounds of it, said to be the offering of an Egyptian city, were presented to St. Silvester at Rome, A.D. $314-335 .^{8}$

The myrrh of the ancients was not obtained exclusively from Arabia. The author of the Periplus ${ }^{9}$ who wrote about A.D. 64, records it to have been an export of Abalites, Malao, and Mosyllon (the last named, the modern Berbera), ancient ports of the African coast outside the straits of Bab-el-Mandeb; and he even mentions that it is conveyed by small vessels to the opposite shores of Arabia.

Secretion-Marchand ${ }^{10}$ who examined a branch of three years' growth of what he terms B. Myrrha, represents the gum-resin as chiefly deposited in the cortical layers, with a little in the medulla.

Collection-From the information given by Ehrenberg to Nees von Esenbeck, ${ }^{11}$ it appears that myrrh when it first exudes is of an oily and then of a buttery appearance, yellowish white, gradually assuming a golden tint and becoming reddish as it hardens. It exudes from the

- Liber quotidianus Contrarotulatoris Gardcroba... Edwardi I., Lond. 1787. pp. $\mathrm{xxxii}$ and $2 \%$. The custom is still observed by the sovereigns of Englaud, and the Queen's by the sovereigns of gold, frankineense and mylrh is still annually presented on the Feast of Epiphany in the Chapel Royal in Londou.

2 Doilet d'Areq, Comptes de l'Argenteric des rois de Franec, 1851. 19.

3 Yule, Cathay and the way thither, ii. 357.

4 For the costly presents in question nover reached their destinution, having been all plundered by the way!
5 Shanghai imported in 1872, 18,6001b. of Myirh. - Reports of Trade at the Treaty Ports in China for $1872, \mathrm{p} .4$.

6 Vineent, Commerce of the Ancionts, ii. (1807) 316 . Muza or Moosa is supposed to be identieal with a place still bearing that name lying about 20 miles east of Mokha.

7 Lib. ix. c. 4.

8 Vignolius, Liber Pontificalis, i. (1724) 95.

8ineent, o1. eit. ii. 127. 129. 135.

10 Baillon, Adansonia, vii. (1S66-7) 261. pl. 8 .

11 Op. cit. 
bark like cherry-tree gum and becomes dark and of inferior value by age. Although Ehrenberg says that the myrrh he saw was of fine quality, he does not mention it being gathered by the natives.

With regard to the localities ${ }^{1}$ in which the drug is collected, Cruttenden ${ }^{2}$ who visited the Somali coust in 1843, says that myrrh is brought from the Wadi Nogâl, south-west of Cape Gardafui, and from NIurreyhan, Ogahden and Agahora; and that some few trees are found on the mountains behind Bunder Murayah. Major Harris ${ }^{3}$ saw the myrrh tree in the Adel desert and in the jungle of the Háwash, on the way from Tajúra to Shoa.

Vaughan ${ }^{4}$ states that the Somali Country and the neighbourhood of Hur'ur (or Harar or Adari, $9^{\circ} 20^{\prime}$ N., $42^{\circ} 17^{\prime}$ E.) south-west of Zeila are the chief producing districts. It is generally brought to the great fair of Berbera held in November, December, and January, where it is purchased by the Banians of India and shipped for Bombay.

Myrrh trees abound on the hills about Shugra and Sureea in the territory of the Fadhli or Fudthli tribe, lying to the eastward of Aden; myrrh is collected from them by Somalis who cross from the opposite coast for the purpose and pay a tribute for the privilege. ${ }^{5} \quad$ But a sample of this drug received by one of us from Vaughan in 1852, and others we have since seen in London (and easily recognized) prove it to be somewhat different from typical myrrh, and it is probably afforded by another species than that yielding African inyrrh.

Description-Myrrh consists of irregular roundish masses, varying in size from small grains up to pieces as large as an egg, and occasionally much larger. They are of an opaque reddish brown with dusty dull surface. When broken they exhibit a rough or waxy fracture, having a moist and unctuous appearance especially when pressed, and a rich brown hue. The fractured, translucent surface often displays characteristic whitish marks which the ancients compared to the light mark at the base of the finger-nails. Myrrh has a peculiar and agreeable fragrance with an aromatic, bitter, and acrid taste. It cannot be finely powdered until deprived by drying of some of its essential oil and water ; nor when heated does it melt like colophony.

Water disintegrates myrrh forming a light brown emulsion, which viewed under the microscope appears made up of colourless drops, among which are granules of yellow resin. Alcohol dissolves the resin of myrrh leaving angular non-crystalline particles of gum and fragments of bark.

Chemical Composition - The gum which is dissolved when myrrh is treated with water amounts to between 40 and 50 per cent., or may even reach 67 per cent. ${ }^{6}$ It is partially precipitable by neutral acetate of lead, showing that it differs from gum arabic; but a portion (about a fourth) agrees with the latter in respect to action on acetate of lead.

The resin dissolves completely in chloroform or alcohol, and the colour of the latter solution is but slightly darkened by perchloride of

I Sue my paper with map in Ocean High. ways, April 1873, also Pharm. Journ. 19 A pril, 1873. 821.-D. H. 123.

2 Trans. Bombay Geogr. Soc. vii. (1846)

3 Irighlands of AEthiopia (1844) i. 426. ii. 414.
${ }^{4}$ Pharm. Journ. xii. (1853) 226.

5 Cant. S. B. Miles, in Journ. of $R$. Geo. graph. Soe. xli. (1871) 236.

6 Druggists who prepare large quantities of Tincture of Myrth may utilize this gum for making a common sort of mucilage.Pharm. Jourr. 10 June, 1871. 1001. 
iron. Tt is but partially soluble in alkalis or in bisulphide of carbon. Britckner ( 1867 ) found this portion to yield 75.6 per cent. of carbon and 9.5 of hydrogen. 'The resin which the bisulphide refuses to dissolve, is freely soluble in etler. It contains only $57 \cdot 4$ per cent. of carbon. The l'esin of myrih to which when moistened witl alcohol a small quantity of hydrochloric acid is added, assumes a violet hue, but far less brilliant than tlint displayed by resin of galbanum when treated in a sinnilar manner.

Myril yields on clistillation a volatile oil which in operating on $25 \mathrm{Hb}$. of the drug, we obtained to the extent of $\frac{3}{4}$ jer cent. 1 It is a yellowish, rather viscid liquid, neutral to litmms, liaving a powerful odonr of myrrh and sp. gr. 0.988 at $13^{\circ} \mathrm{C}^{2}$. In a column $50 \mathrm{inm}$. long, it cleviates a ray of light $30 \cdot 1^{\circ}$ to the left. By subrnitting it to distillation, we obtained before the oil boiled, a few drops of a strongly acid liquid having the smell of formic acid. Neutralized with ammonia, this liquid produced in solution of mercurous nitrate a whitish precipitate which speedily darkened, thus indicating formic acid, which is developed in the oil. Old myrrh is in fact said to yield an acid distillate. The oil begins to boil at about $266^{\circ} \mathrm{C}$, and chiefly distills over between $270^{\circ}$ and $290^{\circ}$.

On combustion in the usual way it afforded carbon 84.70 , hydrogen 9.98. Having been again rectificd in a current of dry carbonic acid, it had a boiling point of $262-263^{\circ} \mathrm{C}$, and now afforded ${ }^{3}$ carbon 84.70 , hydrogen $10^{\circ} 26$, which would nearly answer to the formula $\mathrm{C}^{22} \mathrm{H}^{32} \mathrm{O}$. The results of Ruickholdt's analysis (1945) of essential oil of myrrh assign it the formula $\mathrm{C}^{10} \mathrm{H}^{14} \mathrm{O}$, which is the same as that of carvol and thymol, and widely different from that indicated by our experiments.

The oil which we rectified displays a faintly greenish hue; it is miscible in every proportion with bisulphide of carbon, the solution exhibiting at first no peculiar coloration when a drop of nitric or sulphuric acid is added. Tet the mixture to which nitric acid $(\mathbf{1} \cdot 20)$ has been added, assumes after an hour or two a fine violet hue which is vely persistent, enduring even if the liquid is allowed to dry up in a large capsule. If to the crude oil dissolved in bisulphide of carbon bromine be added, a violet hue is produced; and if the solution is allowed to evaporate, and the residue diluted with spirit of wine, it assiumes a fine blue which disappears on addition of an alkali. The oil is not altered by boiling with alcoholic potash, nor does it combine with alkaline bisulphites.

Commerce-The drug is shipped to Europe chiefly by way of Bombay. The imports into that port in the year $1872-73$ amounted to $494 \mathrm{cwt}$, the exports to $546 \mathrm{cwt}$; of the latter quantity $493 \mathrm{cwt}$. were shipped to the United Kingdom. ${ }^{4}$

Uses-Myrrh though much used does not appear to possess any very important medicinal powers, and is chiefly employed on account of its bitter, aromatic properties.

Other varieties of Myrrh-Though the myrrh of commerce exhibits some diversity of appearance, the drug-brokers and druggists of

1 Ruiekholit got $2 \cdot 18$ per eent. ; Bley and Diesel $(1845)$ from $1 \cdot 6$ to $3 \cdot 4$ per cent. of an aeid oil.

2 Crladstone (1863) found the oil a little horvior than water.
3 Analyses performed in my laboratory by Dr. Buri, February 1874 - F. A. F.

4 Statement of the Trade and Narigatione of the Presidency of Bombay for 1st2-73, pt. ii. 34.78 . 
Loudon are not in the habit of applying any special designations to the different qualities. There are however two varieties which deserve notice.

1. Bissa Bôl (Bhesabol, Bysnbole), Hebbakhade of the Somalis, Myrrha Indica of Martiny, ${ }^{1}$ formerly called East India Myrrh.

This drug is of African origin, but of the plant which yields it, nothing is known. Vaughan ${ }^{2}$ who sent a sample from Aden to one of us in 1852, was told by the natives that the tree from which it is collected resembles that affording Heera Ból or true myrrh, but that it is nevertheless distinct. The drug is exported from the whole Somali coast to Mokha, Jidda, Aden, Makulla, the Persian Gulf, India and even China. $^{3}$ Bombay official returns show that the quantity imported thither in the year 1872-73, was 224 cwt., all shipped from Aden.

Bissa Bôl differs from myrrh chiefly in odour, which when once familiar is easily recognizable; in other respects it agrees with true myrrh : fine specimens have all the outward characters of real myrrh, and perhaps are passed off for it. The Bissa Bôl usually seen is however an impure and foul substance, which is regarded by London druggists as well as by the Banian traders in India as a very inferior dark sort of myrrh. Vaughan states that it is mixed with the food given to milch cows and buffaloes in order to increase the quantity and improve the quality of their milk, and that it is also used as size to impart a bright gloss to whitewashed walls.

2. Arabian Myrrh-This is the drug we have mentioned at p. 127 as collected to the eastward of Aden; and it is of interest as substantiating the statement of Theophrastus that both olibanum and myrrh grow in Southern Arabia.

The drug, which is not distinguished by any special name in English trade, is in irregular masses seldom exceeding $1 \frac{1}{2}$ inches long, and having a somewhat gummy-looking exterior. The larger lumps seem formed by the cohesion of small, rounded, translucent, externally shining tears or drops. The fracture is like that of common nuyrrh but wants the whitish markings. The odour and taste are those of the ordinary drug. Pieces of a semi-transparent papery bark are attached to some of the lumps. Finally the drug is distinguished by being more gummy, more brittle, and less motuous than common myrrh.

\section{ELEMI.}

\section{Resina Elemi; Elemi; F. Résine Elémi; G. Eleminarz.}

Botanical Origin-The resin known in pharmacy as Elemi is derived from a tree growing in the Philippines, which Blanco, ${ }^{5}$ a botanist of Manila, described in 1845 under the name of Icica Abilo, but which

' Encyklop. d. med.-pharm. Nat. u. Roh. waarenkunde, ii. (1854) 98, 101.

2 Pharm. Journ. xii. (1853) 227.

3 In 1865,10 packages of this drug containing abont $15 \mathrm{cwt}$. were consigned to me for sale in London by a friend in China, who had purchased the drug under the notion that it was true myrrh. The commodity was bad of its kind, and was sold with diffculty at 30 s. per cwt. - D. H.

4 Thus 100 grains powdered and then exhausted with spirit of wine left 75 grains of gummy residue, whereas in a parallel experiment with fine nyurrh of the usual sort, the same quantity left a residue of 53 graius.

F Flora de Fitipinas, segunda impresion, Mauila, 1S45. 256. 
is completely unknown to the botanists of Europe. Planco's description is such that, if correct, the plant cannot be placed in either of the old generil Icica or Elaphrium, comprehended by Pentham and Hooker in that of Burserca, nor yet in the allied genus Canrerium; in fact even the order to which it belongs is somewhat doubtful. ${ }^{1}$

The tree grows in the province of Batangas in the island of Luzon (south of Manila), where its name in the Tagrala language is abilo; the Spaniards call it Arbol a brea, i.e. pitch-tree, frum the circuntstance that its resin is used for the caulking of boats.

History-The explicit statements of Theophrastus in the 3rd century B.C. relative to olibanum have already been mentioned. The same writer narrates ${ }^{2}$ that a little above Coptus on the Red Sea, no tree is found except the acacia $(\dot{a} \kappa \dot{\alpha} \nu \theta)$ of the desert . . . but that on the

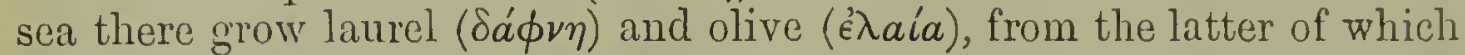
exudes a substance much valued to make a medicine for the stanching of blood.

This story appears again in Pliny ${ }^{3}$ who says that in Arabia the olive tree exudes tears which are an ingredient of the medicine called by the Greeks Enhwmon, from its efficacy in healing wounds.

Dioscorides ${ }^{4}$ briefly notices the Gum of the Ethiopian olive, which he likens to scammony; and the same substance is named by Scribonius Largus ${ }^{5}$ who practised medicine at Rome during the 1st century.

The writers who have commented on Dioscorides have generally adopted the opinion that the exudation of the so-called olive-tree of Arabia and Ethiopia was none other than the substance known to then as Elemi, though as remarked by Mattioli, ${ }^{6}$ the oriental drug thus called by no means well accords with the description left by that author.

As to that name, the earliest mention of it appears in the middle of the 15th century. Thus in a list of drugs sold at Frankfort about 1450, we find Gommi Elempnij.7 Saladinus ${ }^{8}$ who lived about this period, enumerates Gumi Elemi among the drugs kept by the Italian apothecaries, but we have not met with the name in any other writer of the school of Salerno. The Arbolayre, ${ }^{9}$ a herbal supposed to have been printed about 1485 , gives some account of Gomme Llempni, stating that it is the gum of the lemon tree and not of fennel as some think, -

1 On consulting Mr. A. W. Bennett who is now studying the Burseraeen of India, as to the proballe affinities of Blaneo's plant, we reccived from him the following remarks. "] liave little hesitation in pronouneing that from the deseription, Icied Abilo cannot be a Canarium, but what it is, is more difficult to say. The leaves having the lowest pair of leaflets smallest, seems at first sight very characteristic of Canarium; lont the following considerations tend the other way. 1. 'I'he opposite leaves whieh oceur nowhere in Burseracea except in Amyris, with which the plant does not agree in many ways. 2. The stipellce which are not found anywhere in the order. - 3. T'he quinate flowers. In all speries of Canarium the parts of the flower are in threes, inchuding $C$. commune which accorling to Miquel extends to the philiphines. The only exeeption is $C$.
(Seutinanthe Thwaites) brunneum, with whieh it does not agree in other respeets.

"The foregoing reasons almost equally exclnde Ieiea (Bursera); yet the fruit of Blaneo's plant seems so eminently that of a Burseracea, that 1 think it must belong to that order, but with some error in the de. seription of the leaves."

2 Hist. Plant. lib. iv. c. 7.

3 Lib. xii. e. 38.

4 Lib. i. e. 141.

5 Compositiones Medieament. cap. 103.

"Comm. in tib. i. Dioseoridis.

7 Flïekiger, Die Frankfurter Liste, Halle, 1873. 7. 16.

8 Compendium Aromatariorum, Bonon, 1488 .

9 This very rare volume is one of the treasures of the National Library of Paris. 
that it resembles Male ILcense,-and makes an excellent ointment for wounds.

The name Enhwmon ${ }^{1}$ of Pliny, also written Enhomi, is probably the original form of the word Animi, another designation for the same drug, though also applied as at the present day to a sort of copal. It is even possible that the word Elemi has the same origin. ${ }^{2}$

This primitive Elemi is in our opinion identical with a peculiar sort of olibanum known as Luban Meyeti, afforded by Boswellia Frereana Birdwood (p. 121). It has a remarkable resemblance both in external appearance and in odour to the substances in after-times imported from America, and which were likened to the elemi and animi of the old World.

The first reference to these drugs as productions of America conies from the pen of Monardes ${ }^{3}$ who has a chapter on Animi and Copal. He describes animi as of a more oily nature than copal, of a very agreeable odour, and in grains resembling olibanum but of larger size, and adds that it differs from the animi of the Old World in being less white and clear.

At a somewhat later period this resin and some similar substances began to be substituted for Elemi which had become scarce. ${ }^{4}$ Pomet $^{5}$ who as a dealer in drugs was a man of practical knowledge, laments that this American drug was being sold by some as Elemi, and by others as Animi or as Tacamaca. It was however introduced in great plenty, and at length took the place of the original elemi which became completely forgotten.

American Elemi was in turn discarded in favour of another sort imported from the Philippines. The first mention of this substance is to be found among the descriptions accompanied by drawings sent by Father Camelli to Petiver of London, of the shrubs and trees of Luzon ${ }^{6}$ in the year 1701. Camelli states that the tree, which from his drawing preserved in the British Museum appears to us to be a species of Canarium, is very tall and large, that it is called by the Spaniards Arbol de la brea, and that it yields an abundance of odorous resin which is commonly used for pitching boats. Living specimens of the tree together with samples of the resin were brought to Paris from Manila by the traveller Perrottet about the year 1820 . For the last twenty years the resin has been common, and is now imported in large quantities ${ }^{7}$ for use in the arts, so displacing all other kinds. It has been adopted as the Elemi of the British Pharmacopcia (1867), and is in fact the only variety of elemi now found in English commerce.

Description-Manila elemi is a soft, resinous substance, of granular consistence not unlike old honey, and when recent and quite pure is colourless; more often it is found contaminated with carbonaceous matter which renders it grey or blackish, and it is besides mixed with

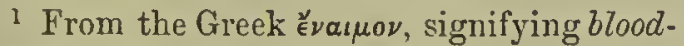
stopping.

2 Brassavola observes - "quandoque inclinavimus ut gummi olex Athiopicæ esset gumni elemi dicti, quasi enhomi." - Examen simplicium, Lugd. 1537. 386.

3 Libro de las cosas que se trren de nuestras Indias Occidentales, Sevilla, 1565.

4 Thus l'iso in $165 \mathrm{~s}$ describes the resin of an Ieica as exactly resembling Elemi and quite as good for wounds. - Hist. nat. et méd. Ind. Oce. 122 .

5 Histoire des Drogues, 1694, 261.

6 liay, Hist. Plant. iii. (1704), appendix, p. 67. No. 13. - Con pare also n. 60 , No. 10 .

7 Thus in a drug-sale, May 8, 1872 , thel e were offered 275 cases, - equal to about 480 ewt.

K 2 
chips and similar impurities. By exposure to the air it becomes harder and acquires a yellow tint. It has a strong and pleasant odour suggestive of fennel and lemon, yet withal somewhat terebinthinous. When moistened with spirit of wine, it disintegrates, and examined under the microscope is seen to consist of acicular crystals which may be easi]y separated to the extent of 20 per cent. At the heat of boiling water it soltens, and at a somewhat higher temperature fuses into a clear res n.

Chemical Composition-Manila elemi is rich in essential oil. On submitting $28 \mathrm{tb}$. of it to distillation with water, we obtained: $\mathrm{kb}$. $13 \mathrm{oz}$. (equivalent to $10 \mathrm{per}$ cent.) of a fragrant, colourless, neutral oil, o1 sp. gr. 0.861 at $15^{\circ} \mathrm{C}$. Observed in Wild's polaristrobometer we found it to be strongly dextrogyre. ${ }^{1} \quad H$. Ste Claire Deville ${ }^{2}$ on the other hand has examined an oil of elemi that was strongly levogyre. I'his discrepancy shows that there are among the oils of various kinds of elemi, differences similar to those existing in the oils of turpentine ind copaiba. By the action of dry hydrochloric acid gas, Deville obtailied from his oil of elemi a solid crystalline substance, $\mathrm{C}^{10} \mathrm{H}^{16}+2 \mathrm{HCl}$. IVe failed to produce any such compound from the oil of Manila elemi. () ur oil of elemi dissolves in bisulphide of carbon; when mixed with concentrated sulphuric acid, it becomes thick and assumes a deep orange colour.

By submitting the crude oil to fractional distillation, we separated it into six portions, of which the first five were dextrogyre in gradually diminishing degree, while the sixth displayed a weak deviation to the left. $^{3} \quad$ The first portion having been dissolved in four times its weight of strong sulphuric acid, washed and again distilled, exhibited a deviation to the left. ${ }^{4}$

Maujean ${ }^{5}$ a French pharmacien, examined Manila elemi as long ago as 1821 and proved it to contain two resins, the one soluble in cold, the other only in hot spirit of wine. Bonastre ${ }^{6}$ a little later made a nnore complete analysis, showing that the less soluble resin which he obtained to the extent of 25 per cent. is easily crystallizable, and apparently identical with a substance obtainable in a similar manner from whit he legarded as true elemi, which the Manila resin was not then held to be. Dumas analysed this crystalline resin of Manila elemi and found it tr contain 85.3 per cent. of carbon and 11.7 per cent. of hydrogen. ${ }^{7}$ Baup (1851)

1 I observed the following deviations :-

In a column of 25 inillimetres from $47^{\circ} \cdot 5$ to $70^{\circ} \cdot 5$ (deviation $23^{\circ}$ ).

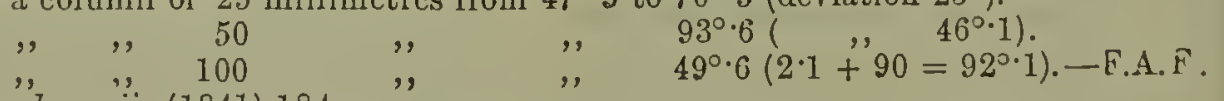

2 Comples Reñdus, xii. (1841) 184.

3 The following deviations were obscrved, in a column of 25 millimetres :-

1. Oil distilled at $172^{\circ}-180^{\circ} \mathrm{C}$. from $47^{\circ} \cdot 6$ to $74^{\circ} \cdot 5$; deviation $26^{\circ} \cdot 9$ to the right.

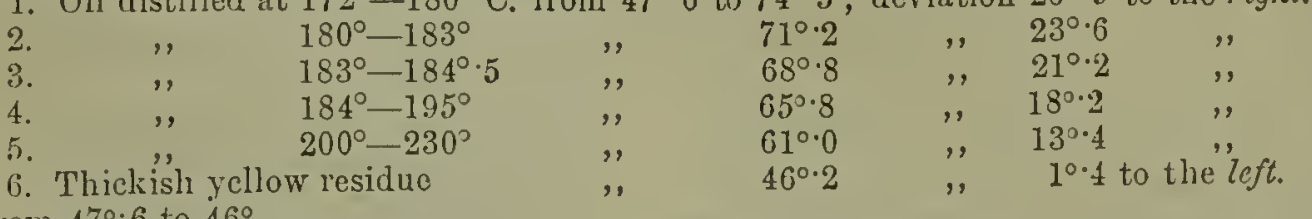

4 From $47^{\circ} 6$ to $46^{\circ}$.

5 Journ. de Pharm. ix. (1823) 45.47.

B Id. x. (1824) 199.

7 'Thic formula $\mathrm{C}^{40} \mathrm{H}^{66} \mathrm{O}$, assigned to the crystallized resin of elemi by the analyses of Rose, of Hess and of Johnston, requires $85^{\circ} 4$ carbon and 11.7 of hydrogen. These

chemists found from 84 to $84.45 \mathrm{pcr}$ sent of carbon,-results perhaps explicable liy the suggestion that the crystallized resiu still retaincl a little of the amorphous resin, whieh according to Jolmston and Rose is liss rich in carbon. 
give it the name of Amyrin. According to our experiments, it is readily isolated to the extent of 20 per cent. when Manila elemi is treated with cold spirit of wine, in which the crystals of amyrin are but slightly sciluble. If the elemi is pure, the amyrin may be thus obtained (by washing with spirit and pressure between bibulous paper) in a calie of slowy whiteness, which may be further purified by crystallization from builiug alcohol. The fusing point of the crystals is $171^{\circ} \mathrm{C}$.; by repeated crystallizations, it rises as high as $176^{\circ}$.

It is remarkable that other sorts of elemi (see p. 134) such as those of Mexico, Brazil and Mauritius, though afforded by very different trees, yit closely accord in chemical properties with the Manila drug. All consist of a crystalline and a non-crystalline resin, the former separating as a white magma when the crude resin is treated with cold spirit of wine, and both being perfectly neutral.

By allowing an alcoholic solution of the amorphous resin of Manila elemi ${ }^{1}$ to evaporate, Baup obtained in very small quantity crystals of $B$ réine, a substance fusing at $187^{\circ} \mathrm{C}$, which he considered to be distinct fr $)$ am amyin.

He likewise extracted from Manila elemi a crystallizable substance soluble in water to which he gave the name of Bryoidin, ${ }^{2}$ and in smaller qrantity a second also soluble in water which he called Bréidine. From the experiments of Baup it appears that bryoidin is soluble in 360 parts of water at $10^{\circ} \mathrm{C}$., and melts at $135^{\circ} \mathrm{C}$.; whereas bréicline requires for solution 260 parts of water and fuses at a temperature not inuch over $100^{\circ} \mathrm{C}$.

We have also obtained Bryoidin by operating in the following manner : the watery liquid left in the still after the distillation of $28 \mathrm{fb}$. of Manila elemi was poured off from the mass of hard resin, and having be en duly concentrated, it deposited together with a dark extractiform matter, colourless acicular crystals of bryoidin. The deposit in question hiving been drained and allowed to dry, the bryoidin may be separated by boiling water or by cold ether. We found the latter the more ccnvenient; it readily takes up the bryoidin contaminated only with a little resin. The ethereal solution should be allowed to evaporate and the residual crystalline mass boiled in water, wlien the solution (which is colourless), poured off from the resin, will deposit upon cooling brilliant tufts of acicular crystals of bryoidin. The boiling in water requires to be several times repeated before the whole of the bryoidin can be removed; the latter sometimes crystallizes as a mossy arborescent glowth. Bryoidin is a neutral substance, of bitter taste, scarcely coluble in cold water but dissolving easily in boiling water, or in alcohol or ether. When a little is placed in a watch-glass, covered with a plate of glass, and then gently heated over a lamp, it sublimes in delicate needles. To obtain it perfectly pure, it is best to sublime it in a current of dry carconic acid. Thus purified its fusing point is $133^{\circ} .5 \mathrm{C}$.; after fusion it concretes as a tramsparent, anorphous mass, which if immersed in glycerin and raiscd to the temperature of $135^{\circ} \mathrm{C}$., suddenly crystallizes.

1 I am indebted for a specimen of the material that Baup worked upon and which he called Resin of Arbol a brea, to M. Roux, pharmacien of Nyon. - F. A. F.
2 From the Greek Bpúo, in allusion to the moss-like aspect sometimes assumed by the crystals. 
We have observed that if the filtered mother-liquor of bryoidin after complete cooling and standing for a day or two is warmed, it becomes turbid and that in a few minutes there separate from it long white flocks like bits of paper or wool, which do not disappear either by warming or by cooling the liquid; under the microscope they are seen to consist partly of thread-like, partly of acicular crystals. It is possible this substance is Baup's Bréidine; we found it to fuse at $13.5^{\circ} \mathrm{C}$., to be neutral, and to crystallize from weak alcohol exactly like bryoidin. Both it and bryoidin look very voluminous in water, but are so sinall in weight that we have not yet obtained either in quantity sufficient for analysis.

Uses-Elemi is scarcely used in British nuedicine except in the form of an ointment, sometimcs prescribed as a stimulating application to old wounds.

\section{Other sorts of Elemi-1. Mexican Elemi, Vera Cruz Elemi-} This drug which used to be imported into London about thirty years ago, but which has now disappeared from commerce, is the produce of a tree named by Royle Amyris elemifera growing at Oaxaca in Mexico. ${ }^{1}$ It is a light yellow, or whitish, brittle resin occurring in semi-cylindrical scraped pieces, or in irregular fragments which are sometimes translucent but more often dull and opaque. It easily softens in the mouth so that it may be masticated, and has an agreeable terebinthinous odour. Treated with cold spirit of wine ( 838$)$, it breaks down into a white magma of acicular crystals (Amyrin?).

2. Brazilian Elemi-Was described as long ago as 1658 by the traveller Piso, as a substance completely resembling the elemi of the old World and applicable to the same purposes. It is the produce of several trees described as species of Icica, as I. Icicariba DC., I. heterophylla DC., I. heptaphylla Aubl., I. Guianensis Aubl., I. altissima Aubl.-In New Granada a similar exudation ${ }^{2}$ is furnished by $I$. Caranna H.B.K.

A specimen in our possession from Pernambuco ${ }^{3}$ is a translucent, greenish-yellow, fragrant, terebinthinous resin, which by cold spirit of wine may be separated into two portions, the one soluble, the other a mass of colourless acicular crystals. The resin spontaneously exuded and collected from the trunks, is often opaque and white, grey, or yellowish, looking not unlike fragments of old mortar. The microscope shows it to be made up of minute acicular crystals. ${ }^{4}$

3. Mauritius Elemi-Fine specimens of this substance and of Colophonia Mauritiana DC. the tree affording it, were sent to one of us (H.) in 1855 by Mr. Emile Fleurot of Mauritius. The resin accords in its general characters with Manila eleni, like which it leaves after treatment with cold spirit of wine, an abundance of crystals resembling amyrin.

1 Royle's very imperfect specimens of this plant are in the British Musenm.

${ }_{2}$ G. Planchon, Bulletin de la Soc. Bot. de France, xv. (1868) 16.

3 Given me by Mr. Manley late of Pernambuco. I have also an authentie speci- men of the resin of $I$. heterophylla DC. collected at Santarem, Pará, by Mr. H. W. Bates in 1853.-D. H.

${ }_{4}$ For some experiments on the resin of Icica, see Gmelin, Chemistry, xvi. (1866 421. 
4. Luban Meyeti ${ }^{1}$ or Lutben Matti.--This substance which we claim to be the Oriental or African Elcmi of the older writers, and also one of the resins anciently designated Animi ${ }^{2}$ is the exudation of Bosusellice Frereana Birdwood, a remarkable tree gregarious on the bare limestone hills near Bunder Murayah to the west of Cape Gardafui. The tree which is called Yegaar by the natives, is of small stature, and differs from the other species of Bosucllic growing on the same coast in having glabrous, glaucous leaves with obtuse leaflets, crisped at the margin. The bark is smooth, papery, and translucent, and easily stripped off in thin sheets which are used for writing ou. Though growing wild, the trees are said by Capt. Miles ${ }^{3}$ to be carefully watched and even sometimes propagated. The resin exudes after incision in great plenty, soon hardens, and is collected by the Somali tribes who dispose of it to traders for shipment to Jidda and ports of Yemen: occasionally a package reaches Iondon among the shipments of olibanum. It is used in the East for chewing like mastich.

Luban Meyeti occurs in the form of detached droppy tears and fragments, occasionally in stalactitic masses, 1 to 3 ounces in weight. It breaks very easily with a brilliant conchoidal fracture, showing an internal substance of a pale amber yellow and perfectly transparent. Externally it is more or less coated with a thin opaque white crust, which seen under the microscope appears non-crystalline. Many of the tears have pieces of the thin, brown, papery bark adhering to them. The resin has an agreeable odour of lemon and turpentine, and a mild terebinthinous taste.

Treated with spirit of wine (838) a large proportion of it is dissolved ; the indissolved portion is not erystalline. Subjected to distillation with water, we obtained from $20 \mathrm{tb}$., 10 ounces of a volatile oil ( $=3.1$ per cent.) having a fragrant odour suggestive of elemi and sp. gr. 0.856 at $16^{\circ} \mathrm{C}$. The oil examined in a column 50 millim. long, deviates the ray $2^{\circ} 5$ to the left. By fractional distillation we found it to consist of a dextrogyre hydrocarbon, $\mathrm{C}^{10} \mathrm{H}^{16}$, mixed with an oxygenated oil which we did not succeed in isolating; the latter is evidently levogyre, and exists in proportion more than sufficient to overcome the weak dextrogyre power of the hydrocarbon.

There is no gum in this exudation; it is therefore essentially different from olibanum, the product of closely allied species of Boswellia.

\section{MELIACE $\mathbb{E}$.}

\section{CORTEX MARGOS $A$.}

\section{Cortex Azadirachtce; Ním Bark, Margosa Bark.}

Botanical Origin-Melia indica Brandis (M. Azadirachta L., Azadirachta indica Juss.), an ornamental tree, 40 to 50 feet high and attain-

1 Luban is the general Arabic name for olibanurn : meyeti perhaps from Jebel Meyet, a mountain of 1200 feet on the Somali Coast in long. $47^{\circ} 10^{\prime}$.

2 By the assistauce of Professor G. Planchon, we have aseertained that it is identieally the same substance as deseribed by Guibourt under the name Tacamaque jaune huileuse, A.-Hist. des Drogues, iii. (1850) 483.

3 Journ. Geograph. Soc. xlii. (1872) 61. 
ing a considerable girth, rell known throughout India by its Hindustani name of Nim, or by its Portuguese appellation of Margosc. ${ }^{1}$ It is much planted in avenues, but occurs wild in the forests of Southern India, Ceylon and the Malay Archipelago.

The hard and heavy wood which is so bitter that no insect will attack it, the medicinal leaves and bark, the fruit which affords an acrid bitter oil used in medicine and for burning, the gum which exudes from the stem, and finally a sort of toddy obtained from young trees, cause the Ním to be regarded as one of the most useful trees of India.

MI. indica is often confounded with M. Azedarach L., a native of China ${ }^{2}$ and probably of India, now widely distributed throughout the warmer recions of the globe, and not rare even in the south of Europe. The former has an oval fruit (by abortion) one-celled and one-seeded, aud leaves simply pinnate. The latter has the fruit five-celled, and leaves bi-pinnate.

History-The tree under the Sanskrit name of Nimba is mentioned in the Ayurvedas (Systema Medicince) of Susruta, one of the most ancient of the Hindu medical writings.

In common with many other productions of India, it attracted the notice of Garçia d'Orta, physician to the Portuguese viceroy at Goa, and he published an account of it in his work on drugs in $1563 .{ }^{3}$ Christoval Acosta ${ }^{4}$ in 1578 supplied some further details and also a figure of the tree. The tonic properties of the bark, long recoguized by the native physicians of India, were successfully tested by Dr. D. White of Bombry in the beginning of the present century, and have since been generally aclmitted. ${ }^{5}$ The drug las a place in the Pharmacopacia of Inctia.

Description-The bark in our possession ${ }^{6}$ is in coarse fibrous pieces about $\frac{1}{5}$ of an inch thick and 2 to 3 inches wide, slightly channelled. The suberous coat is rough and cracked, and of a greyish rusty hue. The inner surface is of a bright buff and has a highly foliaceous structure. On making a transverse section three distinct layers may be observed:- firstly the suberous coat exhibiting a brown parenchyme interwoven with small bands of corky tissue,-secondly a dark cellular layer, and then the foliaceous liber. The dry bark is inodorous and has a slightly astringent bitter taste.

Microscopic Structure-The suberous coat consists of numerous . layers of ordinary corlk-cells, which cover a layer of nearly cubic sclerenchymatous cells. This latter however is not always met with, secondary bands of cork (rhytidoma) frequently taking its place. The liber is commonly'built up of strong fibre-bundles traversed by narrow medullary rays, and transversely separated by bands of parenchymatous liler tissue. Crystals of oxalate of calcium occur in the parenchyme more frequently than the small globular starch grains. The structure of the bark varies considerably according to the gradual development of the secondary cork-bands.

1 From amargoso, bitter.

2 It is mentioned in Chinese writings dating long prior to the Christian era.Bretschneider, Chinesc Botanical Works, 1870. 12.

3 Collonuios dos Simples, de., Groa, 1563.
- Tractado de las Drogas y Mcdicinas de las Indias Orientales, Burgos, 1578, eap. 43. 5 Waring, in Pharmacopaia of India, 1868. 443.

6 We are indebted for it to Mr. Broughton of Ootacamund. 
Chemical Composition-Margosa bark was chemically examined in India by Cornish ${ }^{1}$ (1856), who announced it as the source of a bitter alkaloid to which he gave the name of Margosine, but which he obtained only in minute quantity as a "double salt of Margosine and Soda," in long white needles.

From the bitter oil of the seeds he isolated a substance which he called Margosic Acid, and which he doubted to be capable of affording crystallizable salts. The composition neither of this acid nor of nargosine is known, nor have the properties of either been investigated.

The small sample of the bark at our disposal only enables us to add that an infusion produced with perchloride of iron a blackish precipitate, and that the infusion is not altered by tannic acid or iodohydrargyrate of potassium. If the inner layers of the bark are alone exhausted with water, the liquid affords an abundant precipitate with tannic acid; but if the entire bark is boiled in water, the tannic matter which it contains will form an insoluble compound with the bitter principle and prevent the latter being dissolved. It is thus evident that to isolate the bitter matter of the bark, it would be advisable to work on the liber or inner layers alone, which might readily be done, as they separate easily.

According to the recent researches of Broughton ${ }^{2}$ the bitter principle is an amorphous resin soluble in the usual solvents and in boiling solutions of fixed alkalies. From the latter it is precipitated by acids, yet, probably, altered. Broughton ascribes the forniula $\mathrm{C}^{36} \mathrm{H}^{50} \mathrm{O}^{11}$ to this bitter resin purified by means of bisulphide of carbon, ether and absolute alcohol; it fused at $92^{\circ} \mathrm{C}$. He obtained moreover a small quantity of a crystallized principle, which he believed to be a fatty body, yet its melting point of $175^{\circ} \mathrm{C}$. is not in favour of this suggestion.

Uses-In India the bark is used as a tonic and antiperiodic, both by natives and Europeans. Dr. Pulney Andy of Madras has found the leaves beneficial in small-pox.

\section{CORTEX SOYNIDAE.}

\section{Cortex Swietenioe; Rotun Bark.}

Botanical Origin-Soymida ${ }^{3}$ felrifuga Juss. (Swictenica febrifuga. Willd.), a tree of considerable size not uncommon in the forests of Central and Southern India. The timber called by Europeans Bastard Cedar is very durable and strong, and much valued for building purposes.

History-The introduction of Rohun Bark into the medical practice of Europeans is due to Roxburgh ${ }^{4}$ who recommended the drug as a substitute for Cinchona, after numerous trials made in India about the year 1791. At the same time he sent supplies to Edinburgh, where Duncan made it the subject of a thesis ${ }^{5}$ which probably led to it being introduced into the materia nedica of the Edinburgh Pharmacopœia of 1803, and of the Dublin Pharmacopeia of 1807.

1 Indian Annals of Mcdical Scicncc, Calcutta, iv. (1857) 104.

${ }^{2}$ Madras Monthly Journ. of IICd. Sciencc, quoted in Pharm. Journ. June 14, 1873, 992.
3 From Somida, the Telugu name of the tree ; Róhan is its name in Hindustani.

${ }^{4}$ Mcdical Facts and Ubscrvations, Lond. vi. (1795) 127.

5 T'cntamen inaugurale de Sivietenia Soymida, Edinb. 1794. 
Thongh thus officially recognized, it does not appear that the bark came much into nse or by any means fulfilled the expectations raised in its fivour. At present it is regarded simply as a useful astringent tonic, and as such it has a place in the Pharmacopceia of India (1868).

Description-Our specimen of liohun bark ${ }^{1}$ which is from a young tree, is in straight or somewhat curved, half-tubular quills, an inch or more in diameter and about $\frac{1}{5}$ of an inch in thickness. Externally it is of a rusty grey or brown, with a smoothish surface exhibiting no considerable furrows or cracks, but numerous small corky warts. These form little elliptic scars or rings, brown in the centre, and but slightly raised from the surface. The inner side and edges of the quills are of a bright redilish brown.

A transverse section exhibits a thin outer layer coloured by chlorophyll, and a middle layer of a bright rusty hue, traversed by large medullary rays and darker wedge-shaped rays of liber. The latter has a fibrous fracture, that of the outer part of the bark being rather corky or foliaceous. The whole bark when comminuted is of a rusty colour, becoming reddish by exposure to air and moisture. It has a bitter astringent taste with no distinctive odour. The older bark is very thick and fibrous, and according to Broughton, "as red as the reddest Cinchona."

Microscopic Structure-The bark presents but few structural peculiarities. The ring of liber is made up of alternating prosenchymatous and parenchymatous tissue. In the latter the larger cells are filled with mucilage, the others with starch. The prosenchymatous groups of the liber exhibit that peculiar form we have already described as hornbast (p. 70); it chiefly contains the tannic matter, besides stellate crystals of oxalate of calcium which are distributed through the whole tissue of the bark. The medullary rays are of the usual form, and contain starch granules. The corky coat is built up of a small number of vaulted cells.

Chemical Composition ${ }^{2}$-The bitter principle of the bark has been ascertained by Broughton ${ }^{3}$ to be a nearly colourless resinous substance, sparingly soluble in water but more so in alcohol, ether, or benzol. It does not appear to unite with acids or bases, and is less soluble in water containing them than in pure water. It has a very bitter taste, and refuses to crystallize either from benzol or ether. It contains no nitrogen. To this we may add that the bark is rich in tannic acid.

Uses-Rohun bark is administered in India as an astringent touic and antiperiodic, and is reported useful in intermittent fevers and general debility, as well as in the advanced stages of dysentery and in diarrhœa.

1 Kindly sent us by Mr. Broughton of Ootacamund.

2 The analysis alluded to in the Pharm. of India (p. 444) concerus Khaya (Swietenia) scnegalensis and not the present species, as my friend Dr. Overbeck has informed me.F. A. F.

3 Beddome, Flora Sylvatica, Madras, part i. (1869) 8,-also information communieated direct. 


\section{RHAMNACEE.}

\section{FRUCTUS RHAMNI.}

Bacce Rhamni, Bacce Spine cervince; Buckthorn Berrics; F. Baies de Ncrprun; G. Kreuzdornbecren.

Botanical Origin-Rhamnus cathartica L., a lobust diøcious shrub with spreading branches, the smaller of which often terminate in a stout thorn. It is indigenous to the greater part of Europe, and stretches eastward into Siberia. In England the buekthorn though generally distributed is abundant only in certain districts; in Scotland it occurs wild in but a single locality. Yet in Norway, Sweden, and Finland it grows much further north.

The fruit which ripens in the autumn is collected for use chiefly in the counties of Hertfordshire, Buckinghamshire and Oxfordshire.

History-The buckthorn was well known to the Anglo-Saxons and is mentioned as Hartsthorn or Waythorn in their medical writings and glossaries dating before the Norman conquest. As Spina Cervina it is referred to by Pietro Crescentio of Bologna ${ }^{1}$ about A.D. 1305.

The medicinal use of the berries was familiar to all the writers on botany and materia medica of the 16th century.

Description-The fruits, which are only used in the fresh state, are small, juicy, spherical drupes the size of a pea, black and shining, bearing on the summit the remnants of the style, and supported below by a slender stalk expanded into a disc-like receptacle. Before ripening, the fruit is green and distinctly 4-lobed, afterwards smooth and plump. It contains 4 one-seeded nuts ${ }^{2}$ meeting at right angles in the middle. The seed is erect with a broad furrow on the back: in transverse section the albumen and cotyledons are seen to be curved into a horse-shoe form with the ends directed outwards.

The fresh juice is green, has an acid reaction and a sweetish, afterwards disagreeably bitter taste, and repulsive odour. It is coloured yellow by alkalis, red by acids. According to Umney ${ }^{3}$ it should have a sp. gr. of 1.070 to 1.075 , but is seldom sold pure.

Microscopic Structure-The epidermis consists of snall tabular cells, followed by a row of large cubic cells and then by several layers of tangentially-extended cells rich in chlorophyll. This thick epicarp passes into the loose thin-walled and large-celled sarcocarp. Besides chlorophyll it exhibits numerous cells each containing a kind of sac, which may be squeezed out of the cell. These sacs are violet, turning blue with alkalis. Similar, yet much more conspicuous bodies occur also in the pulp of the Locust Bean (Ceratonia Sitiqua L.)

Chemical Composition-The berries of buckthorn and other species of Rhamnus contain interesting colouring matters, which have been the subject of much chemical research and controversy. Winckler, in 1849 extracted from the juice Rhamnocathartin, a yellowish un-

1 Trattato dall'Agricoltura, Milano, 1805, lib. iii. c. 58.
2 In $R$. Frangula L., the other British species, the fruit has 2 nuts.

2 Sharm. Journ. Nov. 23, 1872. 401. 
crystallizable bitter substance, soluble in water but not in ether. Allsalis colour it golden yellow; perchlericle of iron, dark greenish brown.

In 1840 Flemy, a phalmacien of Pontoise, discovered in buckthorn juice a yellow substance forming cauliflower-like crystals to which he gave the name of Khamnine. 'This body has been recently studied by Lefort, ${ }^{1}$ who identified it with the Rhamneline of Galletly (1.858) and the Chrysorhamnine of Schiitzenberger and Tierteche (1865). 'Though obtainable from the berries of all kinds of Rhamnus used in dyeing (including the common buckthorn), it is got most easily and abundantly from Persian Berries. When pure, and crystallized from absolute alcohol, it is described as forming minute yellow translucent tables. It is scarcely soluble in cold water, though colouring it pale yellow; is soluble in hot alcohol, insoluble in ether or bisulphide of carbon. It is very soluble in caustic alkalis, forming uncrystallizable reddish-yellow solutions. From alkaline solutions it is precipitated by a mineral acid in the form of a glutinous magma resembling hydrated silica. Lefort assigns to it the formula $\mathrm{C}^{12} \mathrm{H}^{12} \mathrm{O}^{5}+2 \mathrm{H}^{2} \mathrm{O}$.

This chemist has likewise found in the berries of Rhamnus, though not with certainty in those of $R$. cathartica, a neutral substance isomeric with rhamnine, to which he has given the name of Khamnegine. Unlike rhamnine it is very soluble in cold water, but in all other respects it agrees with that body in chemical and physical properties. The two substances have the same taste, almost the same tint, the same crystalline form, and lastly they give rise to the same reactions with chernical agents.

The conclusions of Lefort have been contested by Stein (1S68) and by Schützenberger (1\&68), the latter of whom succeeded in decomposing rhamnegine and proving it a glucoside having the formula $\mathrm{C}^{24} \mathrm{H}^{32} \mathrm{O}^{14}$. Its decomposition gives rise to a body named Rhamnetin, $\mathrm{C}^{12} \mathrm{H}^{10} \mathrm{O}^{5}$, and a crystallizable sugar isomeric with mannite. Schützenberger admits that the berries contain an isomeric modification of rhamnegine; but in addition another colouring matter insoluble in water, which appears to be the Rhamnine of Lefort, but to which he assigns a different formula, namely, $\mathrm{C}^{18} \mathrm{H}^{22} \mathrm{O}^{10}$. This is also a glucoside capable of being split into rhamnetin and a sugar. There are thus, according to Schützenberger, two forms of rhamnegine which may be distinguished as $a$ and $\beta$, and there is the substance insoluble in water, named by Lefort Rhamnine. .

The question of the purgative principles of buckthorn, it will be observed, has not been touched by all these researches.

Uses-From the juice of the berries is prepared a syrup having strongly purgative properties, much more used as a medicine for animals than for man. The pigment Sap Green is also made from the juice.

\section{AMPELIDE $\nexists$.}

\section{U V Æ PAS S}

Passula majores; Raisins; F. Raisins; G. Rosinen.

Botanical Origin-Vitis vinifera L., the Common Grape-vine. It appears to be indigenous to the Caucasian provinces of Russia, that is 1 Sur les graincs des Nermuns tincloriaux.-Journ. de Pharm. ir. (1866) 420 . 
to say, to the country lying between the eastern end of the Black Sea and the south-western shores of the Caspian; extending thence southward into Armenia. Under innmmerable varieties, it is cultivated in most of the warmer and drier countries of the temperate regions of both the northern and southern hemisplieres. Humboldt defines the area of the profitable culture of the vine, as a zone lying between $36^{\circ}$ and $40^{\circ}$ of north latitude.

History-The vine is among the oldest of cultivated plants, and is mentioned in the earliest Mosaic writings. Dried grapes as distinguished from fresh wele used by the ancient Hebrews, and in the Vulgate are translated Uva passa. ${ }^{1}$ During the middle ages, raisins were an article of luxury imported into England from Spain.

Description-The ovary of Vitis viniferce is 2-celled with 2 ovules in eacl cell ; it developes into a succulent, pedicellate ber'ry of spherical or ovoid form, in which the cells are obliterated and some of the seeds generally abortive. As the fruit is not articulated with the rachis or the rachis with the branch, it does not drop at maturity but remains attached to the plant, on which, provided there is sufficient solar heat, it gradually wither's and dries: suel fruits are called Raisins of the sun. Various methods are adopted to facilitate the drying of the fruit, such as dipping the bunches in boiling water or in a lye of wood ashes, or twisting or partially severing the stalk, - the effect of each operation being to arrest or destroy the vitality of the tissues. The drying is performed by exposure to the sun, sometimes supplemented by artificial heat.

The raisins commonly found in the shops are the produce of Spain and Asia Minor, and are sold either in entire bunches or removed from the stalk. The former kind, known as Muscatel Raisins and imported from Malaga, are dried and packed with great care for use as a dessert fruit. The latter kind, which includes the Valencia Raisins of Spain, and the Eleme, Chesme and stoneless Sultana Roisins of Smyrna, are used for culinary purposes. For pharmacy, Valencia raisins are generally employed.

Microscopic Structure-The outer layer or skin of the berry is made up of small tabular cells loaded with a reddish granular matter, which on addition of an alcoholic solution of perchloride of iron assumes a dingy green hue. The interior parenchyme exhibits large, thin-walled, loose cells containing an abundance of crystals (bitartrate of potassium and sugar). There are also some fibro-vascular bundles traversing the tissue in no regular order.

Chemical Composition-The pulp abounds in grape sugar and cream of tartar, each of which in old raisins may be found crystallized in nodular masses; it also contains gum and malic acid. The seeds afford 15 to 18 per cent. of a bland fixed oil, which is occasioually extracted. Fritz ${ }^{2}$ has shown that it consists of the glycerides of Erucic Acid, $\mathrm{C}^{22} \mathrm{H}^{42} \mathrm{O}^{2}$, stearic acid, and palmitic acid, the first-named acid largely prevailing. The crystals of erucic acid melt at $34^{\circ} \mathrm{C}$.; by manus of fused potash they may be resulved into arachic acid, $\mathrm{C}^{20} \mathrm{H}^{40} \mathrm{O}^{2}$, and acetic acid, $\mathrm{C}^{2} \mathrm{H}^{4} \mathrm{O}^{2}$.

1 Numbers vi. $3 ; 1$ Sam $x x v .18, x \times x$. $12 ; 2$ Sam. xvi. 1; 1 Chron. xii. 40.

2 Berichte d. Deutsch. Chem. Gesellsch. zu Berlin, iv. (1871) 442. 
The seeds further contain 5 to 6 per cent. of tannic acid, which also exists in the skin of the fruit. The latter is likewise the seat of chlorophyll and other colouring matter.

Commerce-The consumption of raisins in Great Britain is very large and is increasing. The imports into the United Kingdom have been as follows :-

$$
\begin{gathered}
1870 . \\
365,418 \text { ewt. } \\
\text { val. } 4593,527 .
\end{gathered}
$$

1871.
427,056 cwt.
val. $£ 707,344$.

1872.

617,418 cwt. val. $£ 1,149,337$.

Of the quantity last mentioned, 400,570 cwt. were shipped from Spain, 176,5010 ewt. from Asiatis Turkey, and the remainder from other countries. ${ }^{.}$

Uses-Raisins are an ingredient of Compound Tincture of Cardarnoms and of Tincture of Senna. They have no medicinal properties and are only used for the sake of the saccharine matter they impart.?

\section{ANACARDIACE $A$.}

\section{MASTICHE.}

\section{Mastix, Resina Masticho; Mastich ; F. Mastic; G. Mastix.}

Botanical Origin-Pistacia Lentiscus $\mathrm{L}$., the lentisk, is a diœcious evergreen, mostly found as a shrub a few feet high; but when allowed to attain its full growth, it slowly acquires the dimensions of a small tree having a dense head of foliage. It is a native of the Mediterranean shores from Syria to Spain, and is found in Portugal, Morocco and the -Canaries. In some parts of Ttaly it is largely cut for fuel.

Mastich is collected in the northern part of the island of Scio, which was long regarded as the only region in the world capable of affording it. Experiments made in 1856 by Orphanides ${ }^{3}$ have proved that excellent mastich might be easily obtained in other islands of the archipelago, and probably also in Continental Greece. The same botanist remarks that the trees yielding mastich in Scio are exclusively male.

History-Mastich has been known from a very remote period and is mentioned by Theophrastus ${ }^{4}$ who lived in the 4 th century before the Christian era. Both Dioscorides and Pliny notice it as a production of the island of Chio, the modern Scio.

Avicenna ${ }^{5}$ described (A.D. 1000-1037) two sorts of mastich, the white or Roman (i.e. Mediterranean or Christian), and the dark or Nabathæan, - the latter probably one of the Eastern forms of the drug inentioned at p. 145 .

Benjamin of Tudela ${ }^{6}$ who visited the island of Scio when travelling

1 Annual Statement of the Trade of the United Kingdam for 1872 .

2 The amount of this is very small. On macerating crushed raisins in proof spirit in the rroportion of $2 \mathrm{oz}$. to a pint, we found each fluid ounce of the tincture so obtained to afford by evaporation to dryuess 28 grains of a dark viscid sugary extract.
3 Heldreich, Nutzpflanzen Gricchenlands, Athen, 1862. 61 .

4 Hist. Plant. lib. ix. c. 1.

5 Lib. ii. c. 462.

6 Wright, Early Travels in Palestine. 1848. 77. (Bohu's series.) 
to the East about A.D. 1169-1173, also refers to it yielding mastich, which in fact has always been one of its most important productions, and from the earliest times intimately connected with its history.

In the middle ages, the mastich of Scio was held as a monopoly by the Greek emperors, one of whom, Michael Paleologus in 1261, permitted the Genoese to settle in the island. His successor Andronicus II. conceded in 1304 the administration of the island to Benedetto Zaccaria, a rich patrician of Genoa and the proprietor of the alum works of Fokia (the ancient Phocea), north-west of Smyrna, for ten years, renouncing all tribute during that period. The concession was very lucrative, a large revenue being derived from the Contrata del Mastico or Mastich district; and the Zaccaria family taking advantage of the weakness of the emperor determined to hold it as loug as possible. In fact they made theniselves the real sovereigns of Scio and of some of the adjacent islands, and retained their position until expelled by Andronicus III. in 1329.1

The island was retaken by the Genoese under Simone Vignosi in 1346 ; and then by a remarkable series of events became the property of an association called the Maona. Many of the noblest families of Genoa enrolled themselves in this corporation and settled in the island of Scio ; and in order to express the community of interest that governed their proceedings, some of them relinquished their family names and assumed the general name of Giustiniani. ${ }^{2}$ This extraordinary society played a part exactly comparable to that of the late East India Company. In Genoa it had its "Offcium Chii"; it had its own constitution and mint, and it engaged in wars with the emperors of Constantinople, the Venetians and the Turks, who in turn attacked and ravaged the mastich island and adjacent possessions.

The Giustinianis regulated very strictly the culture of the lentisk and the gathering and export of its produce, and cruelly punished all offenders. The annual export of the drug was 300 to 400 quintals, ${ }^{3}$ which were immediately assigned to the four regions with which the Maona chiefly traded. These were Romania. (i.e. Greece, Constantinople and the Crimea), Occidente (Italy, France, Spain and Germany), Vera Turchia (Asia Minor), and Oriente (Syria, Egypt and Northern Africa). In 1364, a quintal was sold for 40 lire; in 1417, the price was fixed at 25 lirc. In the 16 th century, the whole income from the drug was 30,000 ducats $(£ 13,750)^{4}$ a large sum for that period.

In 1566, the Giustinianis definitively lost their beautiful island, the Turks under Piali Pasha taking it by force of arms under pretext that the customary tribute was not duly paid. ${ }^{5}$ A few years before that

1 Friar Jordanus who visitcd Scio circa 1330 (?) noticed the production of mastich, and also the loss of the island by Martino Zaccaria. - Mirabitia deseripta, or Wonders of the East, edited by Col. Yule for the Hakluyt Society, 1863.

2 I'robably partly for the reason that the Giustiniani palace in Genoa had become the property of the Society.

${ }^{3}$ An incidental notice showing the value of the traclc occurs in the lcttcr of Columbus (himself a Genoese) announcing the result of his first voyage to the Indies. In stating what may be obtaincd from the island of Hispraniola, he mentions-gold and spices. and mastich, hitherto found only in Greece in the island of Scio, and which the Sig noria sells at its own price, as much as their Highnesses [Ferdinand and Isabella] shall command to be shipped. The letter bears date 15 Feb. 1493. - Letters of Christ. Columbus (Hakluyt Socicty) 1870. p. 15.

4 The ducat being reckoned at $9 s .2 d$.

5 For further particulars respecting the history of Scio, the Maona, and the trade of the Genoesc in the Levant, see Horf in Ersch and Gruber's Encyclopädic, vol. 68 (Leipzig 1859) art. Cinstiniani; also Heyd, Colonie commereiali degli Italiani in Oriente,
i. (1866). 
event, it was visited by the French naturalist Belon ${ }^{1}$ who testifies from personal observation to the great care with which the lentisk was cultivated by the inhabitants.

When Tournefort ${ }^{2}$ was at Scio in 1701 , all the lentisk trecs on the island were lield to be the property of the (irand Signor, and if any land was sold, the sale did not inchule the lentisks that might be growing on it. At that time the mastich villages, about twenty in number, were required to pay 286 chests of mastich ammally to the Turkish oflicers appointed to receive the revenue.

'The month of January, 1850, was memorable throughout Greece and the Archipelago for a frost of umparalleled severity which proved very destructive to the mastich trees of Scio, and occasioned a scarcity of the drug that lasted for many ycars."3

The disusc into which mastich has fallen makes it difficult to understand its ancicut importance; but a glance at the pharmacopœias of the 15th, 16th, and 17th centuries shows that it was an ingredient of a large number of compound medicines. ${ }^{4}$

Secretion-In the bark of the stems and branches of the mastich shrub, there are resin-ducts like those in the aromatic roots of Umbelliferce or Compositce. In Pislacia they may even be shown in the petioles. The wood is devoid of resin, ${ }^{5}$ so that slight incisions are sufficient to provoke the resinous exudation, the bark being not very thick, and liable to scale off:

Collection-In Scio incisions are made about the middle of June in the bark of the stems and principal branches. From these incisions, which are vertical and very close together, the resin speedily flows, and soon hardens and dries. After 15 to 20 days it is collected witl much care in little baskets lined with white paper or clean cotton wool. The ground below the trees is kept hard and clean, and flat pieccs of stone are often laid on it that the droppings of resin may be saved uninjurcd by dirt. There is also some spontaneous cxudation from the small branches which is of very fine quality. The operations are carried ou by women and children and last for a couple of months. A fine tree may yield as much as $S$ to 10 pounds of mastich.

The dealers in Scio distinguish three or four qualities of the drug, of which the two finer are called $\kappa v \lambda \iota \sigma \tau o$ and $\phi \lambda \iota \sigma \kappa x \rho i$, that collected from the ground $\pi \hat{\eta} \tau \tau a$, and the worst of all $\phi \lambda o \hat{v} \delta a{ }^{6}$

Description-The best sort of mastich consists of roundish tears about the size of small peas, together with pieces of an oblong or pearshaped form. They are of a pale yellow tint darkening by age, dusty and slightly opaque on the surface but perfectly transparent within.

\footnotetext{
1 Observations de plusieurs singularitez et choses mémorables tronvées en Grèce, etc. Paris, 1554. liv. i. ch. 8.

2 Voyage into the Levant, i. (1718) 285.

3 At Athens the mereury was for a short time at $-10^{\circ}$ C. $\left(14^{\circ} \mathrm{F}\right.$.) In Scio, where the frost was probably quite as serere, though we have no exaet data, the mischief to the lentisks varied with the loeality, trees exposerl to the north or growing at considerable elevations, being lilled down to
}

the base of the trunk, while those in more favoured positions suffered destruetion only in some of their branehes.

4 'Thus in the London Pharmacoparia of 1632 , mastieh enters into 24 of the 37 different kinds of pill, besides which it is prescribed in trouhes and ointments.

5 See Unger and Kotsehy, Die Insel Cypern, Wien, 1S65. 424.

Geldreicli (and Orphanides) Vutzpfarren Gricchenlands, A then, $1 \$ 6260$. 
The mastich of late imported has been washed; the tears are no longer dusty but have a glassy transparent appearance. Mastich is brittle, has a conchoidal fracture, a slight terebinthinous balsamic odour. It speedily softens in the mouth and may be easily masticated and kneaded between the teeth, in this respect differing from sandarac, a tear of which breaks to powder when bitten.

Inferior mastich is less transparent and consists of masses of larger size and less regular shape, often contaminated with earthy and vegetable impurities.

The sp. gr. of selected tears of mastich is about 1.06. They soften at $99^{\circ} \mathrm{C}$. but do not melt below $108^{\circ}$.

Mastich dissolves in half its weight of pure warm acetone and then deviates the ray of polarized light to the right. On cooling, the solution becomes turbid. It dissolves slowly in 5 parts of oil of cloves, forming even in the cold a clear solution; it is but little soluble in glacial acetic acid or in benzol.

Chemical Composition-Mastich is soluble to the extent of about 90 per cent. in cold alcohol ; the residue, which has been termed Masticin or Beta-resin of Mastich, is a translucent, colourless, tough substance, insoluble in boiling alcohol or in solution of caustic alkali, but dissolving in ether or oil of turpentine. According to Johnston, it is somewhat less rich in oxygen than the following.

The soluble portion of mastich called Alpha-resin of Mastich possesses acid properties, and like many other resins has the formula $\mathrm{C}^{20} \mathrm{H}^{32} \mathrm{O}^{3}$. Its. alcoholic solution is precipitated by an alcoholic solution of neutral acetate of lead. Mastich contains a very little volatile oil.

Commerce-Mastich still forms the principal revenue of Scio, from which isiand the export in 1871 was $28,000 \mathrm{Hb}$. of picked, and 42,000 $\mathrm{tb}$. of common. The market price of picked mastich was equal to $6 s .10 d$. per tb. - that of common $2 s .10 d$. The superior quality is sent to Turkey, especially Constantinople, also to Trieste, Vienna, and Marseilles, and a small quantity to England. The common sort is employed in the East in the manufacture of raki and other cordials. ${ }^{1}$

Uses-Mastich is not now regarded as possessing any important therapeutic virtues, and as a medicine is becoming obsolete. Even in varnish-making it is no longer employed as formerly, its place being well supplied by less costly resins, such for example as dammar.

Varieties-There is found in the Indian bazaars a kind of mastich which though called Mustagi-rumi (Roman mastich), is not imported from Europe but from Kábul, and is the produce of Pistacic Khinjuk Stocks, and the so-called P. Cabulica St., trees growing all over Sind, Belúchistán and Kábul. ${ }^{2}$ This drug of which the better qualities closely approximate to the mastich of Scio, sometimes appears in the European market under the name of East Indian or Bombay Mastich. We find that when dissolved in half its weight of acetone or benzol, it deviates the ray of light to the right.

The solid resin of the Algerian form of P. Terebinthus L., known as

1 Consul Cumberbatch, Report on Trade of Smyrna for 1871.
2 Powell, Economic Products of the Punjat, Roorkee, 1868. 411. 
P. Atlantica Desf., is collected and used as mastich by the Arab tribes of Northern Africa. ${ }^{1}$

\section{TEREBINTHINA CHIA.}

Terebinthina Cypria; Chian or Cyprian Turpcntinc; F. Térébcnthine ou Baume de Chio ou de Chypres; G. Chios Terpenthin, Cyprischer I'erpenthin.

Botanical Origin-Pistaeia Tcrebinthus L. (P. Atlantica Desf., $P$. Palastina Boiss., P. Cabulica Stocks), a tree 20 to 40 feet or more in height, in some countries only a shrub, common on the islands and shores of the Mediterranean as well as throughout Asia Minor, extending, as $P$. Palcestina, to Syria and Palestine; and eastward, as P. Cabulica, to Belúchistán and Afghanistan. It is found under the form called $P$. Atlantica in Northern Africa, where it grows to a large size, and in the Canary Islands.

These several forms are mostly regarded as so many distinct species; but after due consideration and the examination of a large number of specimens both dried and living, we have arrived at the conclusion that they may fairly be united under a single specific name. The extreme varieties certainly present great differences of habit, as anyone would observe who had compared Pistaeia Terebinthus as the straggling bush which it is in Languedoc and Provence, with the noble umbrageous tree it forms in the neighbourhood of Smyrna. But the different types are united by so many connecting links, that we have felt warranted in dissenting from the opinion usually held respecting them.

History-The terebinth was well known to the ancients; it is the $\tau \epsilon^{\prime} \rho \mu \iota \nu \theta_{0 s}$ of Theophrastus, $\tau \epsilon \rho \epsilon^{\prime} \beta \iota \nu \theta_{0}$ of other authors, and the Alah of the Old Testament. ${ }^{2}$ Among its products, the kernels were regarded by Dioscorides as unwholesome, though agreeable in taste. By pressing

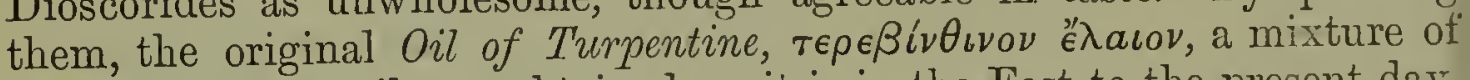
essential and fat oil was obtained, as it is in the East to the present day. The resinous juice of the stem and branches, the true, primitive turpentine, $\dot{\eta} \tau i \nu \eta \tau \epsilon \rho \mu \iota \nu \theta i \nu \eta$, was celebrated as the finest of all analogous products, and preferred both to mastich and the pinic resins. To the latter however the name of turpentine was finally applied. ${ }^{3}$

By the puncture of an hemipterous insect, Aphis Pistacion L., a hornshaped gall, often several inches in length, is produced on the branches; while a much smaller gall of different shape is formed (by the same insect ?) on the ribs of the leaves. The first named, called by pharmacological writers Galloe vel Folliculi Pistaeince, and in Italian Carobbe di Giudea, were formerly used in medicine and in dyeing. ${ }^{4}$

Collection-The resinous juice is secreted in the bark, according to Unger, ${ }^{5}$ in special cells precisely as mastich in $P$. Lentiscus. That found in commerce is collected in the island of Scio. To some extent it exudes spontaneously, yet in greater abundance after incisions made in

1 Guibourt, Hist. d. Drog. iii. (1850) 458; Armieux, Topographie médicale du Sahara, Paris, 1866. 58.

2 Genesis xii. 6, where the word is rendered in our version plain.

2 Further historical information on the
Terebinth may be found in Heln's Kulturpflanzen und Hausthicre. Berliu, 1870. 30\%. 4 Analysis by Martius may be found in Liebig's Ann. d. Pharm. xxi. (1S37) 179. 5 Unger u. Kotscliy, dic Insel Cypern, 1865. 361. 424. 
the stem and branches. This is done in spring, and the resin continues to flow during the whole summer; but the quantity is so small that not more than 10 or 11 ounces are obtained from a large tree in the course of a year. The turpentine, hardened by the coolness of the night, is scraped from the stem down which it has flowed, or from flat stones placed at the foot of the tree to receive it. As it is when thus collected, always mixed with foreign substances, it is purified to some extent by straining through small baskets, after having been liquefied by exposure to the sun.

When Tournefort ${ }^{1}$ visited Scio in 1701, the island was said to produce scarcely 300 okes $(850 \mathrm{fb}$.) annually, which is about the quantity it is supposed to yield at present. The trade is asserted to be almost exclusively in the hands of Jews, who dispose of the drug in the interior part of the Turkish Empire. ${ }^{2}$

Description-A specimen collected by Maltass near Smyrna in 1858 was after ten years, of a light yellowish colour, scarcely fluid though perfectly transparent, nearly of the same odour as melted colophony or mastich, and without much taste. We found it readily soluble in spirit of wine, amylic alcohol, glacial acetic acid, benzol, or acetone, the solution in each case being very slightly fluorescent. The alcoholic solution reddens litmus, and is neither bitter nor acrid. Two parts of this genuine turpentine dissolved in one of acetone deviate a ray of polarized light $7^{\circ}$ to the right, ${ }^{3}$ in a column $50 \mathrm{~mm}$. long.

Chian turpentine as found in commerce and believed to be genuine, is a soft solid, becoming brittle by exposure to the air; viewed in mass it appears opaque and of a dull brown hie. If pressed while warm between two slips of glass, it is seen to be transparent, of a yellowish brown, and much contaminated by various impurities in a state of fine division. It has an agreeable, mild terebinthinous odour and very little taste. The whitish powder with which old Chian turpentine becomes covered, shows no trace of crystalline structure when examined under the microscope.

Chemical Composition-Chian turpentine consists of resin and essential oil. The former is probably identical with the Alpha-resin of mastich. The Beta-resin or Masticin appears to be absent, for we find that Chian turpentine deprived of its essential oil by a gentle heat, dissolves entirely (impurities excepted) in alcohol sp. gr. 0.815 , which is by no means the case with mastich.

The essential oil which we obtained by distilling with water 64 ounces of Chian turpentine of authentic origin, amounted to nearly $14 \frac{1}{2}$ per cent. It has the odour of the drug; sp. gr. 0.869 ; boiling point $161^{\circ} \mathrm{C}$.; it deviates the ray of polarized light $12 \cdot 1^{\circ}$ to the right. In common with turpentine oils of the Coniferce, it contains a small amount of an oxygenated oil, and is therefore vividly attacked by sodium. When this reaction is over and the oil is again distilled, it boils at $157^{\circ} \mathrm{C}$. and has a sp. gr. of 0.862 . It has now a more agreeable odour, resembling a mixture of cajuput, mace, and camphor, and nearly the same rotatory power $\left(11 \cdot 5^{\circ}\right.$ to the right). By saturation with dry hydro-

1 Voyage into the Levant, i. (1718) 287.

2. Maltass, Pharm. Journ. xvii. (1858)
540 .
3 A solution of mastich made in the same proportion deviates $3^{\circ}$ to the right. 
chloric acid, it does not yicld a solid compound. After treatment with sodium and rectification, it was found ${ }^{1}$ to consist of $\mathrm{C} 88 \cdot 75, \mathrm{H} 11.40$ per cent., which is the composition of oil of turpentine.

Uses-Chian Turpentine appears to have exactly the properties of the pinic turpentines; in British medicine it is almost obsolete. In Greece it is sometimes added to wine or used to flavour cordials, in the same manner as turpentine of the pine, or mastich.

\section{LEGUMINOSA.}

\section{HERBA SCOPARII.}

Cacumina vel Summitates Scoparii; Broom Tops; F. Genêt d̀ balais; G. Besenginster, Pfriemenkraut.

Botanical Origin-Cytisus Scoparius Link (Spartium Scoparium L., Sarothannus vulgaris Wimmer), the Common Broom, a woody shrub, 3 to 6 feet high, grows gregariously in sandy thickets and uncultivated places throughout Great Britain, and Western and temperate Northern Europe. In continental Europe it is plentiful in the valley of the Rhine up to the Swiss frontier, in Southern Germany and in Silesia, but does not ascend the Alps, and is absent from many parts of Central and Eastern Europe. According to Ledebour, it is found in Central and Southern Russia and on the Eastern side of the Ural Mountains. In Southern Europe its place is supplied by other species.

History-From the fact that this plant is chiefly a native of Western, Northern and Central Europe, it is improbable that the classical authors were acquainted with it; and for the same reason the remarks of the early Italian writers may not always apply to the species under notice. With this reservation, we may state that broom under the name Genista, Genesta, or Genestra is mentioned in the earliest printed herbals, as that of Passau, ${ }^{2}$ 1485, the Hortus Sanitatis, 1491, the Great Herbal printed at Southwark in 1526, and others. Broom was used in ancient Anglo-Saxon medicine. ${ }^{3}$ It had a place in the London Pharmacopœia of 1618 , and has been included in nearly every subsequent edition. Hieronymus Brunschwyg (1515) gives directions for distilling a water from the flowers, - a medicine which Gerarde relates was used by King Henry VIII. "against surfets and diseases thereof arising."

Broom was the emblem of those of the Norman sovereigns of England descended from Geoffroy Plantagenet, count of Anjou, who died A.D. 1150 .

Description-The Common Broom has numerous straight ascending wiry branches, sharply 5 -angled and devoid of spines. The leaves, of which the largest are barely an inch long, consist of 3 obovate leaflets on a petiole of their own length. Towards the extremities of the twigs, the leaves are much scattered and generally reduced to a single ovate leaflet, nearly sessile. The leaves when young are clothed on

1 From an analysis performed in my laboratory by Dr. Kraushaar.-F. A. F. 316.

3 Cockayne, Lccchdoms, \&c. iii. (1866)

2 Herbcrius Patavie, 1485. 
both sides with long reddish hairs; these under the microscope are seen each to consist of a simple cylindrical thin-walled cell, the surface of which is beset with numerous extremely small protuberances.

The large, bright-yellow, odorous flowers, which become brown in drying, are mostly solitary in the axils of the leaves; they have a persistent campanulate calyx divided into two lips minutely toothed, and a long subulate style, curved round on itself. The legume is oblong, compressed, $1 \frac{1}{2}$ to 2 inches long by about $\frac{1}{2}$ an inch wide, fringed with hairs along the edge. It contains 10 to 12 olive-coloured albuminous seeds, the funicle of which is expanded into a large fleshy strophiole. They liave a bitterish taste, and are devoid of starch.

The portion of the plant used in pharmacy is the younger herbaceous branches, which are required both fresh and dried. In the former state they emit whell bruised a peculiar odour which is lost in drying. They have a nauseous bitter taste.

Chemical Composition-Stenhouse ${ }^{1}$ discovered in broom tops two interesting principles, Scoparin, $\mathrm{C}^{21} \mathrm{H}^{22} \mathrm{O}^{10}$, an indifferent or somewhat acid body, and the alkaloid Sparteine, $\mathrm{C}^{15} \mathrm{H}^{26} \mathrm{~N}^{2}$, the first soluble in water or spirit and crystallizing in yellowish tufts, the second a colourless oily liquid heavier than water and sparingly soluble in it, boiling at $288^{\circ} \mathrm{C}$.

To obtain scoparin, a watery decoction of the plant is concentrated so as to form a jelly after standing for a day or two. This is then washed with a small quantity of cold water, dissolved in hot water and again allowed to repose. By repeating this treatment with the addition of a little hydrochloric acid, the chlorophyll may at length be separated and the scoparin obtained as a gelatinous mass, which dries as an amorphous, brittle, pale yellow, neutral substance, devoid of taste and smell. Its solution in hot alcohol deposits it partly in crystals and partly as jelly, which after drying are alike in composition. Hlasiwetz showed (1866) that scoparin when melted with potash is resolved like kino or quercetin into Phloroglucin, $\mathrm{C}^{6} \mathrm{H}^{6} \mathrm{O}^{3}$, and Protocatechuic Acid, $2 \mathrm{C}^{7} \mathrm{H}^{6} \mathrm{O}^{4}$.

The acid mother-liquors from which scoparin has been obtained, when concentrated and distilled with soda, yield besides ammonia a very bitter oily liquid, Sparteine. To obtain it pure, it requires to be repeatedly rectified, dried by chloride of calcium, and distilled in a current of dry carbonic acid. It is colourless, but becomes brown by exposure to light; it has at first an odour of aniline, but this is altered by rectification. Sparteine has a decidedly alkaline reaction and readily neutralizes acids, forming crystallizable salts which are extremely bitter. Corine, nicotine, and sparteine are the only volatile alkaloids devoid of oxygen hitherto known to exist in the vegetable kingdom.

Mills ${ }^{2}$ extracted sparteine simply by acidulated water, which he concentrated and. then distilled with soda. The distillate was then saturated with hydrochloric acid, evaporated to dryness, and submitted to distillation with potash. The oily sparteine thus obtained was dried by prolonged heating with sodium in a current of hydrogen, and finally rectified per se. Mills succeeded in replacing one or two equivalents of the hydrogen of sparteine by one or two of $\mathrm{C}^{2} \mathrm{H}^{5}$ (ethyl). From $150 \mathrm{tb}$.

${ }^{1}$ Phil. Trans., 1851. 422-431.

2 Journ. of Chom. Soc. Xv. (1862) 1
Gmclin's Chem., xvi. (1864) 
of the (dried?) plant, he obtained 22 cubic centimetres ( $\mathrm{f} 3 \mathrm{vj}$.) of sparteine, which we may estimate as equivalent to about $\frac{1}{2}$ per mille.

Stenhouse ascertained that the amount of sparteine and scoparin depends much on external conditions, broom grown in the shade yielding less than that produced in open sunny places. He states that shepherds are well aware of the shrub possessing narcotic properties, from having observed their sheep to become stupified and excited when occasionally compelled to eat it.

The experiments of Reinsch (1846) tend to show that broom contains a bitter crystallizable principle in addition to the foregoing. It is well known that the seeds of the allied Cytisus Laburnum L. afford two highly poisonous alkaloids, Cytisine and Laburnine, discovered by A. Husemann and Marmé in 1865.

Uses-A decoction of broom tops, made from the dried herb, is used as a diuretic and purgative. The juice of the fresh plant preserved by the addition of alcohol, is also administered and is regarded as a very efficient preparation.

\section{SEMEN FCENI-GRACI.}

\section{Semen Fenugroci; Fenugreek; F. Semences de Fenugrec; G. Bocks- hornsamen.}

Botanical Origin-Trigonella Fronum-grcecum L., an erect, subglabrous, annual plant 1 to 2 feet high, with solitary, subsessile, whitish flowers; indigenous to the countries surrounding the Mediterranean, in which it has been long cultivated and whence it appears to have spread to India.

History-This plant was well known to the Roman writers on husbandry, as Porcius Cato (B.C. 234-149) who calls it Fcenum Groceum and directs it to be sown as fodder for oxen. Its mucilaginous seeds were valued as an aliment and condiment for man, and as such are still largely consumed in the East. They were likewise supposed to possess many medicinal virtues and had a place in the pharmacopoeias of the last century.

The cultivation of fenugreek in Central Europe was encouraged by Charlemagne (A.D. 812), and the plant was grown in English gardens in the 16 th century.

Description-The fenugreek plant has a sickle-shaped pod, 3 to 4 inches long, containing 10 to 20 hard, brownish-yellow seeds, having the smell and taste which is characteristic of peas and beans, with addition of a cumarin- or melilot-flavour.

The seeds are about $\frac{1}{8}$ of an inch long, with a rhomboid outline, often shrivelled and distorted; they are somewhat compressed, with the hilum on the sharper edge, and a deep furrow running from it and almost dividing the seed into two unequal lobes. When the seed is macerated in warm water its structure becomes easily visible. The testa bursts by the swelling of the internal membrane or endopleura, which like a thick gelatinous sac encloses the cotyledons and their very large hooked radicle.

Microscopic Structure-The most interesting structural peculiarity of this seed arises from the fact that the mucilage with which it 
abounds, is not yielded by the cells of the epidermis but by a loose tissue closely surrounding the embryo.

Chemical Composition-The cells of the testa contain tannin; the cotyledons a yellow colouring matter, but no sugar. The air-dried seeds give off 10 per cent. of water at $100^{\circ} \mathrm{C}$., and on subsequent incineration leave 7 per cent. of ash, of which nearly a fourth is phosphoric acid.

Ether extracts from the pulverized seeds 6 per cent. of a fœtid, fatty oil having a bitter taste. Amylic alcohol removes in addition a small quantity of resin. Alcohol added to a concentrated aqueous extract, forms a precipitate of mucilage, amounting when dried to 28 per cent. Burnt with soda-lime, the seeds yielded to Jahns ${ }^{1} 3 \cdot 4$ per cent. of nitrogen, equivalent to 22 per cent. of albumin. No researches have been yet made to determine the nature of the odorous principle.

Production and Commerce-Fenugreek is cultivated in Morocco, in the south of France near Montpellier, in Alsace, in a few places in Switzerland, and in some provinces of the German and Austrian empires, as Thuringia and Moravia. It is produced on a far larger scale in Egypt, where it is known by the Arabic name Helbeh, and whence it is exported to Europe and India.

Under the Sanskrit name of Methi which has passed into several of the modern Indian languages, fenugreek is much grown in the plains of India during the cool season. In the year 1872-73, the quantity of seed exported from Sind to Bombay was 13,646 cwt., valued at $£ 4,405 .{ }^{2}$ From the port of Bombay, there were shipped in the same year 9,655 cwt., of which only $1.00 \mathrm{cwt}$. are reported as for the United Kingdom. ${ }^{3}$

Uses-In Europe fenugreek as a medicine is obsolete, but the powdered seeds are still often sold by druggists for veterinary pharmacy and as an ingredient of curry powder. The chief consumption is however in the so-called Cattle Foods.

The fresh plant in India is commonly eaten as a green vegetable, while the seeds are extensively used by the natives in food and medicine.

\section{TRAGACANTHA.}

Gummi Tragacantha; Tragacanth, Gum Tragacanth; F. Gomme Adragante; G. Traganth.

Botanical Origin-Tragacanth is the gummy exudation from the stem of several species of Astragalus, belonging to the sub-genus Tragacantha. The plants of this group are low perennial shrubs, remarkable for their leaves having a strong, persistent, spiny petiole. As the leaves and shoots are very numerous and regular, many of the species have the singular aspect of thorny hemispherical cushions, lying close on the ground; while others, which are those furnishing the gum, grow erect with a naked woody stem, and somewhat resemble furze bushes.

1 Experiments performed in my laboratory in 1867.-F. A. F.

${ }^{2}$ Annwal Statemont of the Trade and
Nevigation of Sind, for the year 1872-73, printed at Karachi 1873. p. 36. 89. 
A few species occur in South-western Europe, others are found in Greece and 'Iurkey; but the largest number are inhabitants of the mountainous regions of Asia Minor, Syria, Armenia, Kurdistan and Persia. The tragacanth of commerce is produced in the last-named comntries, and chiefly, though not exclusively, by the following species ${ }^{1}:-$

1. Astragalus adscendens Boiss. et Haussk., a shrub attaining 4 feet in height, native of the mountains of South-western Persia at an altitude of 9,000 to 10,000 feet. According to Haussknecht, it affords an abundance of gum.

2. A. brachycalyx Fisch., a shrub of 3 feet high, growing on the mountains of Persian Kurdistan, likewise affords tragacanth.

3. A. gummifer Labil., a small shrub of wide distribution occurring on the Lebanon and Mount Hermon in Syria, the Beryt Dagh in Cataonia, the Arjish Dagh (Mount Argæus) near Kaisariyeh in Central Asia Minor, and in Armenia and Northern Kurdistan.

4. A. microcephalus Willd., like the preceding a widely distributed species, extending from the south-west of Asia Minor to the north-east coast, and to Turkish and Russian Armenia. A specimen of this plant with incisions in the stem, was sent some years ago to the Pharmaceutical Society by Mr. Maltass of Smyrna. We have lately received a large example of the same species, the stem of which is marked by old incisions, from the Rev. W. A. Farnsworth of Kaisariyeh, who states that tragacanth is collected from it on Mount Argæus.

5. A. pycnocladus Boiss. et Haussk., nearly related to A. microcephalus; it was discovered on the high mountains of Avroman and Shahu in Persia by Professor Haussknecht, who states that it exudes tragacanth in abundance.

6. A. stromatodes Bunge, growing at an elevation of 5,000 feet on the Akker Dagh range, near Marash in Northern Syria.

7. A. Kurdicus Boiss., a shrub 3 to 4 feet high, native of the mountains of Cilicia and Cappadocia, extending thence to Kurdistan. Professor Haussknecht has informed us that from this and the lastnamed species, the so-called Aintab Tragacanth is chiefly obtained.

8. A. Cylleneus Boiss. et Heldr., a small shrub found in abundance on the northern mountains of the Morea, is stated by Heldreich to be the almost exclusive source of the tragacanth collected about Vostizza and Patras.

History-Tragacanth has been known from a very early period. Theophrastus in the 3rd century B.c. mentioned Crete, the Peloponnesus and Media as its native countries. Dioscorides who as a native of South-eastern Asia Minor was probably familiar with the plant, describes it correctly as a low spiny bush. The drug is mentioned by the Greek physicians Oribasius, Aëtius, and Paulus AEgineta (4th to 7th cent.), and by many of the Arabian writers on medicine. During the middle ages it was imported into Europe through the trading cities of Italy, as shown in the statutes of Pisa, ${ }^{2}$ A.D. 1305 , where it is mentioned as liable to impost.

1 As described in Boissier's Flora Oricn. tatis, ii. (1872). We have to thank Professor Haussknecht of Weimar for revising our list of species, and for some valuable

information as to the localities in which the drug is produced.

${ }_{2}$ Bonaini, Statuti inediti della citta di Pisa dal xii. al xiv. sccolo, iii. (1857) 106. 114. 
Pierre Belon, the celebrated French naturalist and traveller, saw and described, about 1550, the collecting of tragacanth in the northern part of Asia Minor; and Tournefort in 1700 observed on Mount Ida in Candia the singular manner in which the gum is exuded from the living plant. ${ }^{1}$

Secretion-It has been shown by H. von $\mathrm{M}_{\mathrm{n}} \mathrm{hl}^{2}$ and by Wigand ${ }^{3}$ that tragacanth is produced by a metamorphosis of the cell membrane, and that it is not simply the dried juice of the plant.

The stem of a gum-bearing Astragalus cut transversely, exhibits concentric annual layers which are extremely tough and fibrous, easily tearing lengthwise into thin filaments. These inclose a central column, radiating from which are numerous medullary rays, both of very singular structure, for instead of presenting a thin-walled parenchyme, they appear to the naked eye as a hard transhucent gum-like mass, becoming gelatinous in water. Examined microscopically, this gummy substance is seen to consist not of dried mucilage, but of the very cells of the pith and medullary rays, in process of transformation into tragacanth. The transformed cells, if their transformation has not advanced too far, exhibit the angular form and close packing of parenchyme-cells, but their walls are much incrassated and evidently consist of numerous very thin strata.

That these cells are but ordinary parenchyme-cells in an altered state, is proved by the pith and medullary rays of the smaller branches which present no such unusual structure. Von Mohl was able to trace this change from the period in which the original cell-membrane could be still easily distinguished from its incrusting layers, to that in which the transformation had proceeded so far that it was impossible to perceive any defined cells, the whole substance being metamorphosed into a more or less uniform mucilaginous mass.

The tension under which this peculiar tissue is held in the interior of the stem, is very remarkable in Astragalus gummifer Labil., which one of us (H.) had the opportunity of observing on the Lebanon in 1860. On cutting off a branch of the thickness of the finger, there immediately exudes from the centre, a stream of soft, solid tragacanth, pushing itself
out like a worm, to the length of $\frac{3}{4}$ of an inch, sometimes in the course
of half an hour; while of half an hour; while much smaller streams (or none at all) are emitted from the medullary rays of the thick bark.

\section{Production-The principal localities in Asia Minor in which} tragacanth is collected are the district of Angora, the capital of the ancient Galatia; Isbarta, Buldur and Yalavatz, ${ }^{4}$ north of the gulf of Adalia; the range of the Ali Dagh between Tarsous and Kaisariyeh, and The drum is also gathered in ard as far as the valley of the Euphrates. Bingol Dagh south of for 500 miles in a south-rzerum; throughout Kurdistan from Mush Luristan in Persia, a direction as far as the province of Van, and west of lalke Urumiah. Inding the high lands south of lake farther east, over an area $300^{\prime}$ miles is likewise produced in Persia 43
${ }^{1}$ Voyage into the Levant, Lond., i. (1718)
Botanische Zeitung, 1857.33; Pharm.
Journ. x viii. (1859) 370 .
3 Pringsheim's Jahrbücher f wissenschaful. Bolanit, iii. (1861) 1]7.
- Pharm. Journ. xv. (1856) 18. 
between Gilpaigon and Kashan, southward to the Mahomed Senna range north-east of Shiraz, thus inclueling the lofty Bakhtiyari mountains.

As to the way in. which the gum. is obtained, it appears. from the statements of Maltass, that in July and August the peasants clear away the earth from around the stem of "the shrub and then make in the bark several incisions, from which during the following 3 or 4 days the gum exudes, and dries in flakes. In some localities they also puncture the bark with the point of a knife. Whilst engaged in these operations, they pick from the shrubs whatever gum they find exuded naturally.

Hamilton, ${ }^{1}$ who saw the shrub in 1836 on the hills about Buldur, says " the gum is obtained by making an incision in the stem near the root, and cutting through the pith, when the sap exudes in a day or two and hardens."

Formerly the peasants were content to collect the naturally exuded gum, no pains being taken to make incisions, whereby alone white flaky gum is obtained. We have in fact heard an old druggist state, that he remembered the first appearance of this fine kind of tragacanth in the London market. According to Professor Haussknecht, whose observations relate chiefly to Kurdistan and Persia, the tragacanth collected in those regions is mostly a spontaneous exudation.

Tragacanth is brought to Smyrna, which is a principal market for it, from the interior, in bags containing about 2 quintals each, by native dealers who purchase it of the peasants. In this state it is a very crude article consisting of all the gatherings mixed together. To fit it for the European markets, some of which have their special requirements, it has to be sorted into different qualities, as Flaky or Leaf Gum. Vermicelli and Common or Sorts; this sorting is performed almost exclusively by Spanish Jews.

Description-The peculiar conditions under which tragacanth exudes, arising from the pressure of the surrounding tissues and the power of solidifying a large amount of water, will account to some extent for the strange forms in which this exudation occurs.

The spontaneously exuded gum is mostly in mammiform or botryoidal masses from the size of a pea upwards, of a dull waxy lustre, and brownish or yellowish hue. It also occurs in vermiform pieces more or less contorted and very variable in thickness; some of them may have exuded as the result of artificial punctures. It is this form that bears the trade name of Vermicelli. The most valued sort is however the Flake Tragacanth, which consists of thin flattish pieces or flakes, $1,2,3$ or more inches in length, by $\frac{1}{4}$ to 1 inch in width. ${ }^{2}$ They are marked on the surface by wavy lines and bands, or by a series of concentric wave-marks as if the soft gum had been forced out by

1 Researches in Asia Minor, Pontus and Armenia, i. (1842) 492.

2 In the Museum of the Pharmaceutical Socicty in London, there is some Flakc Tragacanth remarkablc for its enormous size, but in other respects preciscly like the ordinary kind. The ribbon-like strips are as much as 2 inclies wide and $1^{3}$ of an inch thick, and the largest which is scveral inches long weighs $2 \frac{3}{4}$ ounces. Professor Haussknecht has informcd us that he has seen in Luristan, stems of Astragalus eriostylus Boiss. et Haussk. more than 6 feet in height and 5 inches in diameter, and bearing tragacanth. It is probable that the specimen of gum we have described was produced by some species attaining thesc extraordinary dimensions. Among the Kurdistan tragacanth, there occur curious cylindrical vermiform picces, about 1 of an inch in diameter, coatcd with a network of woody fibre. We are told by Professor H. that they arc picked out of the ccutre of cut-off pieces of stcm, split open by rapid drying in the sun. 
successive efforts. The pieces are contorted and altogether very variable in form and size. The gum is vilued in proportion to its purity and whiteness. The best, whether vermiform or tlaky, is dull-white, translucent, devoid of lustre, somewhat.flexible and horny, firm, and not easily broken, inodorous and with scarcely any or only a slight bitterish taste.

The tragacanth of Kurdistan and Persia shipped from Bagdad, which sometimes appears in the London drug sales under the incorrect name of Syrian Tragacanth, is in very fine and large pieces which are rather more translucent and ribbon-like than the selected tragacanth imported from Smyrna: in fact, the two varieties when seen in bulk are easily distinguishable.

The inferior kinds of tragacanth have more or less of colour, and are contaminated with bark, earth and other foreign substances.

Microscopic Structure-The transformation of the cells into tragacanth is usually not so complete, that every trace of the original tissue or its contents has disappeared. In the ordinary drug, the remains of cell-walls as well as starch granules may be seen, especially if thin slices are examined under oil or any other liquid not acting on the gum. Polarized light will then distinctly show the starch and the cell-walls. If a thin section is imbued with a solution of iodine in iodide of potassium and then moistened with concentrated sulphuric acid, the cell-walls will assume a blue colour as well as the starch.

Chemical Composition-When tragacanth is immersed in water it swells, and in the course of some hours disintegrates so that it can be diffused through the liquid. So great is its power of absorbing water that even with 50 times its weight, it forms a thick mucilage. If one' part of tragacanth is shaken with 100 parts of water and the liquid filtered, a neutral solution may be obtained which yields an abundant precipitate with acetate of lead, and mixes clearly with a concentrated solution of ferric chloride or of borax,-in these respects differing from a solution of gum arabic. On the other hand, it agrees with the latter in that it is thrown down as a transparent jelly by alcohol, and rendered turbid by oxalate of ammonium. The residue on the filter is a slightly turbid, slimy, non-adhesive mucilage, which when dried forms a very coherent mass. It has received the name of Bassorin, Traganthin or Adraganthin, and agrees with the formula $\mathrm{C}^{12} \mathrm{H}^{20} \mathrm{O}^{10}$.

The drug loses by drying about 14 per cent. of water, which it absorbs again on exposure to the air. Pure flake tragacanth incinerated
leaves 3 per cent. of ash.

Commerce-Tragacanth is shipped from Constantinople, Smyrna and the Persian Gulf. The annual export of the gum from Smyrna has been recently stated ${ }^{1}$ to be 4,500 quintals, value 675,000 Austrian florins $(£ 67,500)$; and the demand to be always increasing.

Uses-Though tragacanth is devoid of active properties, it is a very useful addition to many medicines. Diffused in water it acts as a demulcent, and is also convenient for the suspension of a heavy powder in a mixture. It is an important ingredient for imparting firmness to
lozenges and pill masses.

1 C. von Scherzer, Smyrna, Wien, 1873. 143. 
Adulteration-The fine quantities consisting of large distinet pieces are not liable to adulteration, but the small and the inferior kinds are often sophisticated. At Smyrma, tragacanth is mixed with gums termed respectively Mosul and Caramania Gum. The former appears to be simply very inferior tragacanth ; the latter which is sometimes called in the London market Hog Gum Traygacanth or Bassora Gum, ${ }^{1}$ is said to be the exudation of almond and pluin trees. It occurs in nodular masses of a waxy lustre and dull brown hue, which immersed in water gradually swell into a voluminous white mass. To render this gum available for adulteration, the lumps are broken into small angular fragments, the size of which is adjusted to the sort of tragacanth with which they are to be mixed. As the Caramania Gum is somewhat dark, it is usual to whiten it by white lead, previous to mixing it with Small Ieaf or Flake, or with the Vermicelli gum.

By careful examination the fraud is easily detected, angular fragments not being proper to any true tragacanth. The presence of lead may be readily proved by shaking suspected fragments for a moment with very dilute nitric acid, which will dissolve any carbonate present, and afford a solution which may be tested by the ordinary reagents.

\section{RADIX GLYCYRRHIZ Æ.}

Radix Liquiritice; Liquorice Root; F. Réglisse; G. Süssholz, Lakrizwurzel.

Botanical Origin-Glycyrrhiza glabra L., a plant which under several well-marked varieties, ${ }^{2}$ is found over an immense extent of the warmer regions of Europe, spreading thence eastward into Central Asia. The root used in medicine is derived from two principal varieties, namely :-

a. typica-Nearly glabrous, leaves glutinous beneath, divisions of the calyx linear-lanceolate often a little longer than the tube, corolla purplish blue, legume glabrous, $3-6$ seeded. It is indigenous to Portugal, Spain, Southern Italy, Sicily, Greece, Crimea, the Caucasian Provinces and Northern Persia; and is cultivated in England, France and Germany.

\%. glandulifera (G. glandulifera W. K.)-Stems more or less pubescent or roughly glandular, leaves often glandular beneath, legume sparsely or densely echinate-glandular, many-seeded, or short and 2-3 seeded. It occurs in Hungary, Galicia, Central and Southern Russia, Crimea, Asia Minor, Armenia, Siberia, Persia, Turkestan and Afghanistan.

G. glabra L. has long, stout, peremnial roots, and erect, herbaceous, annual stems. In var. a., the plant throws out long stolons which run horizontally at some distance below the surface of the ground.

History-Theophrastus ${ }^{3}$ in commenting on the taste of different roots (3rd cent. B.C.) instances the sweet Scythian root which grows in the neighbourhood of the lake Mæotis (Sea of Azov), and is good for asthma, dry cough and all pectoral diseases, - an allusion unquestionably to liquorice. Dioscorides ${ }^{4}$ who calls the plant $\gamma \lambda v \kappa v \rho j \rho ́ i \zeta a$, notices its glutinous leaves and purplish flowers, but as he describes the pods to be in balls resembling those of the plane, and the roots to be sub-austere (író

1 It is sometimes shipped from Bussorah.

2 We accept those adopted by Boissier in

3 Hist. Plant. lib. ix. c. 13.

his Flora Orientalis, ii. (1872) 202. 
as well as sweet, it is possible he had in view Glycyrrhiza echinata L. as well as G. glabra.

Roman writers as Celsus and Scribonius Largus, mention liquorice as Radix chulcis. Pliny who describes it as a native of Cilicia and Pontus, makes no allusion to it growing in Italy.

The cultivation of liquorice in Europe does not date from a very remote period, as we conclude from the absence of the name in early medirval lists of plants. It is for instance, not enumerated among the plants which Charlemagne ordered (A.D. 812) to be introduced from Italy into Central Europe; $;$ nor among the lierbs of the convent gardens as described by Walafridus Strabus, ${ }^{2}$ abbot of Reichenau, lake of Constance, in the 9th century; nor yet in the copious list of herbs contained in the vocabulary of Alfric, archbishop of Canterbury in the 10th century. ${ }^{3}$

On the other hand, liquorice is described as being cultivated in Italy by Pietro Crescentio ${ }^{4}$ of Bologna, who lived in the 13th century. The cultivation of the plant in the north of England existed at the close of the 16th century, but how much earlier we have not been able to trace.

The word Liquiritia whence is derived the English name Liquorice (Lycorys in the 13th century), is a corruption of Glycyrrtiza, as shown in the transitional mediæval form Gliquiricia. The Italian Regolizic and French Réglisse (anciently Requclice or Rccolice) have the same origin.

Cultivation, and habit of growth-The liquorice plant is cultivated in England at Mitcham and in Yorkshire, but not on a very extensive scale. The plants, which require a good deep soil, well enriched by manure, are set in rows, attain a height of 4 to 5 feet and produce flowers but not seeds. The root is dug up at the beginning of winter, when the plant is at least 3 or 4 years old. The latter has then a crown dividing into several aerial stems. Below the crown is a principal root about 6 inches in length, which divides into several (3 to 5 ) rather straight roots, running without much branching, though beset with slender wiry rootlets, to a depth of 3,4 or more feet. ${ }^{5}$ Besides these downward-running roots, the principal root emits horizontal runners or stolons, which grow at some distance below the surface and attain a length of many feet. These runners are furnished with leaf buds and throw up stems in their second year.

Every portion of the subterraneous part of the plant is carefully saved ; the roots proper are washed, trimmed, and assorted, and either sold fresh in their entire state, or cut into short lengths and dried, the cortical layer being sometimes first scraped off. The older runners distinguished at Mitcham as "hard," are sorted out and sold separately; the young, called "soft," are reserved for propagation. In Calabria, the singular practice prevails of growing the liquorice
among the wheat in the cornfields.

Description-Fresh liquorice (English) when washed is externally of a bright yellowish brown. It is very flexible, easily cut with a knife,

1 Pertz, Monumenta Germania historica, Legum, i. (1835) 186.

2 Migne, Patrologice Cursus, cxiv. 1122.

3 Wright, Volume of Vocabularies, 1857. 30.-This work contains several other early lists of plants.

4 Libro della Agrieoltura, Venet. 1511.

5 This form of root which reminds one of a whip with three or four lashes and a very short haudle, is probably due to the method of propagating adopted at Mitcham, where a short stick or monner is planted npright in
the ground. lib. vi. c. 62 . 
exhibiting a light yellow, juicy, internal substance which consists of a thick bark surrounding a woody column. Both bark and wood are extremely tough, readily tearing into long, fibrous strips. 'The root has a peculiar earthy odour, and a strong and characteristic sweet taste.

Dried liquorice root is supplied in commerce either with or without the thin brown coat. In the latter state it is known as peeled or decorticated. 'The English root, of which the supply is very limited, is usually offered cut into pieces 3 or 4 inches long, and of the thickness of the little finger.

Spanish Liquorice Root, also known as Tortosa or Alicante Iiquorice, is imported in bundles several feet in length, consisting of straight unpeeled roots and runners, varying in thickness from $\frac{1}{4}$ to 1 inch. The root is tolerably smooth or somewhat transversely cracked and longitudinally wrinkled; that from Tortosa is usually of a good external appearance, that from Alicante sometimes untrimmed, dirty, of very unequal size, showing frequently the knobby crowns of the root. Alicante liquorice root is sometimes shipped in bags or loose.

Russian Liquorice Root, which is much used in England, is we presume derived from $G$. glabra var. glandulifera. It is imported from Hamburg in large bales, and is met with both peeled and unpeeled. The pieces are 12 to 18 inches long with a diameter of $\frac{1}{4}$ of an inch to 1 or even 2 inches. Sometimes very old roots split down the centre and forming channelled pieces as much as $3 \frac{1}{2}$ inches wide at the crown end, are to be met with. This liquorice in addition to being sweet has a certain amount of bitterness.

Microscopic Structure-The root exhibits well-marked structural peculiarities. The corky layer is made up of the usual tabular cells; the primary cortical tissue of a few rows of cells. The chief portion of the bark consists of liber or endophloum, and is built up for the most part of parenchymatous tissue accompanied by elongated fibres of two kinds, partly united into true liber-bundles and partly forming a kind of network, the smaller threads of which deviate considerably from the straight line. Solution of iodine imparts an orange hue to both kinds of bast-bundles and well displays the structural features of the bark.

The woody column of the root exhibits three distinct forms of cell, namely ligneous cells (libriform) with oblique ends; parenchymatous, almost cubic cells; and large pitted vessels. In the Russian root, the size of all the cells is much more considerable than in the Spanish.

Chemical Composition-The root of liquorice contains in addition to sugar and albuminous matter, a peculiar sweet substance named Glycyrrhizin, which is precipitated from a strong decoction upon addition of an acid or solution of cream of tartar, or neutral or basic acetate of lead. When washed with dilute alcohol and dried, it is an amorphous yellow powder having a strong bitter-sweet taste and an acid reaction. It forms with hot water a solution which gelatinizes on cooling, does not reduce alkaline tartrate of copper, is not fermentable, and does not rotate the plane of polarization. From the analyses and experiments of GorupBesanez (1861), it appears that the most probable formula of glycyrrhizin is $\mathrm{C}^{24} \mathrm{H}^{36} \mathrm{O}^{9}$. By boiling glycyrrhizin with dilute hydrochloric acid, it is resolved into a resinous amorphous bitter substance named Glycyrretin, 
and an uncrystallizable sugar having the characters of glucose. The formula of glycyrretin has not yet been settled.

Allialies easily dissolve glycyrrhizin with a brown colour and emission of a peculiar odour. In the root it perhaps exists combined with ammonia, inasmuch as the aqueous extract evolves that alkali when warmed with potash. The deep yellow walls of the vessels and prosenchymatous cells appear to be the chief seat of the glycyrrhizin.

The sugar of liquorice root has not yet been isolated; the aqueous infusion of the dried root separates protoxide of copper from an alkaline solution of cupric tartrate. Yet the sugar as extracted from the fresh root by cold water, does not precipitate alkaline cupric tartrate at all in the cold, and not abundantly·even on prolonged boiling.

Asparagin was obtained from the root by Robiquet (1809) and by Plisson (1827). The former also found it to contain Malic acid. The presence of starch in abundance is shown by the microscope as well as by testing a decoction of the root with iodine. The outer bark of the root contains a small quantity of tannin.

Commerce-Liquorice root is imported into Great Britain from Germany, Russia and Spain, but there are no data for showing to what extent. France imported in 1872 no less than 4,348,789 kilogrammes (4282 tons), which was more than double the quantity imported the previous year. ${ }^{1}$

Liquorice root is much used in China, and is largely produced in some of the northern provinces. In $1870,6,954$ peculs (=927,200 ib.) were shipped from Chefoo, and 1,304 peculs (= 173,866 ib.) from Ningpo. ${ }^{2}$

Uses-Liquorice root is employed for making extract of liquorice and in some other pharmaceutical preparations. The powdered root is used to impart stiffness to pill masses and to prevent the adhesion of pills. Liquorice has a remarkable power of covering the flavour of nauseous medicines. As a domestic medicine, liquorice root is far more largely used on the Continent than in Great Britain.

\section{SUCCUS GLYCYRRHIZ $\approx$.}

Succus Liquiritia, Extractum Glycyrrhizce Italicum; Italian Extract of Liquorice, Spanish Liquorice, Spanish Juice; F. Jus ou Suc de Réglisse; G. Süssholzsaft, Lakriz. 156.

Botanical Origin-Glycyrrhiza glabra L., see preceding article, p.

History-Inspissated liquorice juice was known in the time of Dioscorides, and may be traced in the writings of Oribasius and Marcellus Empiricus in the latter half of the 4th century, and in those of Paulus Ægineta in the 7th. It appears to have been in common use in Europe during the middle ages. In A.D. 1264, "Liquorice" is charged in the Wardrobe Accounts of Henry III.; ${ }^{3}$ and as the article cost $3 d$. per tb., or the same price as grains of paradise and one-third that of cinnamon, we are warranted in supposing the extract and not the mere

1 Documents Statistiques réunis par l'administration des Douanes sur le commerce de la France, année 1872, Paris 1873.
2 Reports on Trade at the Treaty Ports in China for 1870, Shanghai, 1871. 13. 62.

3 Rogers, Hist. of Ayriculture and Prices, ii. $(1866) 543$ 
root is intended. Again, in the Patent of Pontage granted by Edward I., A.U. 1305, to aid in repairing London Bridge, permission is given to lay toll on various foreign commodities including Liquorice. ${ }^{1} \Lambda$ political song written in $1436^{2}$ makes mention of Liquorice as a production of Spain, but the plant is not named as an object of cultivation by Herrera the author of a work on Spanish agriculture in 1513.

Saladinus ${ }^{3}$ who wrote about the middle of the 15 th century, names it among the wares kept by the Italian apothecaries; and it is enumerated in a list of drugs of the city of Frankfort written about the year 1450.4

Dorsten ${ }^{5}$ in the first half of the 16th century, mentions the liquorice plant as abundant in many parts of Italy, and describes the method of making the Succus by crushing and boiling the fresh root. Mattioli ${ }^{6}$ states that the juice made into pastilli was brought every year from Apulia, and especially from the neighbourhood of Monte Gargano. Extract of liquorice was made at Bamberg in Germany, where the plant is still largely cultivated, as early as $15600^{7}$

Manufacture - This is conducted on a large scale in Spain, Southern France, Sicily, Calabria, Austria, Southern Russia (Astracan and Kasan), Greece (Patras) and Asia Minor (Sokia and Nazli, near Smyrna); but the extract with which England is supplied, is almost exclusively the produce of Calabria, Sicily and Spain.

The process of manufacture varies only by reason of the amount of intelligence with which it is performed, and the greater or less perfection of the apparatus employed. As witnessed by one of us (H.) at Rossano in Calabria in May, 1872, it may be thus described from notes made at the time. The factory employs about 60 persons, male and female. The root having been taken from the ground the previous winter, is stacked in the yard around the factory; it is mostly of the thickness of the fingers, with here and there a piece of larger size up to a diameter of nearly 2 inches; some of it is sprouting.

As required, the root is taken within the building and crushed under a heavy millstone to a pulp, water-power being employed. It is then transferred to boilers and boiled with water over a naked fire. The decoction is run off and the residual root pressed in circular bags like those used in the olive-mills. The liquor which is received into cisterns below the floor is then pumped up into copper pans, in which the evaporation is conducted also over the naked fire-even to the very last, care being taken by constant stirring to avoid burning the extract. The extract or pasta is removed from the pan while warm, and taken in small quantities to an adjoining apartment where a number of women are employed in rolling it into sticks. It is first weighed into portions, each of which the woman seated at the end of a long table tears with her hands into about a dozen pieces. These are passed to the women sitting next who roll them with their hands into cylindrical sticks, the table on which the rolling is done being of wood, and the pasta moistened with oil to prevent its adhesion to the hands. Near the further end of the table are some frames made of marble or metal, clean and bright, so

1 Chronicles of London Bridgc, 1827. 155.

2 Wright, Political Pocms and Songs (Master of the Rolls serics), ii. (1861) 160. 1488 .
4 Fliekiger, Dic Frankfurtcr Listc, Halle, 1873, page 10 , No. 204.

5 Botanicon, Francof. 1540. 175.

- Comm. in lib. Diosc., Basil. 1574. 485.

7 Gesner, Horti Germanici, Argent. 1561. $2.57,13$ 
arranged as to bring the sticks when rolled in them to the proper lengtli and thickness. When thus adjusted, they are carefully ranged on a board and a woman then stamps them with the name of the manufacturer. Lastly the sticks laid on boards are stacked up in a room to dry.

In some establishments the vacuum pan has been introduced for the inspissation of the decoction. At the great manufactory of $\mathrm{Mr}$. A. O. Clarke at Sokia near Smyrna, all the processes are performed by steam power.

Description-Liquorice juice of good quality is met with in cylindrical sticks stamped at one end with the maker's name or mark. They are of various sizes, but generally not larger than 6 to 7 inches long by about an inch in diameter. They are black, when new warm slightly flexible, but breaking when struck, and then displaying a sharpedged fracture, and shining conchoidal surface on which a few air-bubbles are perceptible; thin splinters are translucent. The extract has a special odour and dissolves in the mouth with a peculiar strong sweet taste. By complete drying, it loses from 11 to 17 per cent. of water.

Several varieties of Stick Liquorice are met with in English commerce, and command widely different prices. The most famous is the Solazzi Juice, manufactured at Corigliano, a small town of Calabria in the gulf of Taranto, at an establishment belonging to the sons of Don Onosato Gaetani, duke of Laurenzano and prince of Piedimonte d'Alife, who inherited the manufacture from his father-in-law, the Cavaliere Domenico Solazzi Castriota. The Solazzi Juice destined for the English market is usually shipped at Naples; it has for many years been wholly consigned to two firms in London, and in quantity not always equal to the demand. Of the other varieties we may mention Barracco, masufactured at the establishment of Messieurs Barracco at Cotrone on the eastern coast of Calabria; Corigliano produced at a factory at Corigliano, belonging to Baron Conrpagna. The sticks stamped Pignatelli are from the works of Vincenzo Pignatelli, prince of Strongoli, at Torre Cerchiara, where 300 to 400 workmen are employed.

The juice is also inmported in a block form, having while warm and soft been allowed to run iuto the wooden case in which it is exported. This juice, which is known as Liquorice Paste, is largely imported from Spain and Asia Minor, but on account of a certain bitterness is unsuited for use as a sweetmeat.

Chemical Composition-Hard extract of liquorice such as that just described, is essentially different in composition and properties from the Extract of Liquorice (Extractum Glycyrrhizo) of the British Pharmacopceic. ${ }^{1}$ The latter is a soft, hygroscopic substance, entirely soluble in cold water, whereas the so-called Spanish Juice when treated with cold water leaves a large residue undissolved.

It has been sometimes supposed that the presence of this residue indicates adulteration but such is far from being the fact, as was conclusively shown by the researches of a Frencli Commission arpointed subjected liquorice root to the successive action of cold water, boiling water, and lastly of steam. By the first menstrum 15 per cent., and by

1 Made by treating the crushed root with cold water.
2 Journ. de Pharm. xxx. (1850) 428 ; an abstract by Redwood in Pharm. Fourn. xvi.
(1857) 403 . 
the second an additional $7 \mathrm{~s}$ per cent., were obtained of a liygrescopice extraet much more soluble than commereial liquorice, and totally unsuitable for being moulded into sticks. The residne having been then exhausted by steam, 16 per cent. was obtained of an extract differing entirely from those of the previous operations. It was a dry firialle substance, cracking and falling to picces in the drying stove, having a sweet taste without acridity, not readily dissolving in the mouth, and very imperfectly soluble in cold water. This then was the substance required to give firmness to the more soluble matter, and to render possible the preparation of an extract possessing that degree of solubility and hardness which would render it an agreeable sweetneat, as well as a permanent and stable commodity. In fact, by treating the root at once with sten aceording to Delondre's process, the experimenters obtained 42 to 45 per cent. of extraet having all the qualities desired in good Italian or Spanish Juice.

When the latter substance is suspended in water undisturbed, the soluble matter may be dissolved out, the stick still retaining its original form. Glyeyrrhizin which is but slightly soluble in cold water, reniains to some extent in the residue, and by an alkaline solution may be afterwards extracted together with colouring matter and probably also pectin. The proportion of soluble matter whieh the best varieties of liquorice juice yield to eold water, varies from about 60 to 70 per cent. A sample of Solazzi Juice recently examined by one of us, lost $8 \cdot 4$ per cent. when dried at $100^{\circ} \mathrm{C}$; it was then exhausted by 60 times its weight of cold water used in successive quantities, by which means 66.8 per cent. of soluble matter were removed. The residue consisted of minute starch granules, fragments of the root, and colouring matter partially soluble in ammonia. Small shreds of copper were also visible to the naked eye. The dried juice yielded 6.3 per cent. of ash.

Corigliano liquorice treated in the same manner gave 71.2 per cent. of extract soluble in cold water; Barracco liquorice 64.9 .

The small liquorice lozenges known as Pontefract Cakes (Dunhill's), not previously dried, gave 71 per cent. of matter soluble in cold water.

Commerce-The value of the imports of Liquorice into the United Kingdom has been for the last five years as follows:-

$\begin{array}{ccccc}1868 & 1869 & 1870 & 1871 & 1872 \\ £ 89,482 & £ 83,832 & £ 70,165 & £ 55,120 & £ 75,991\end{array}$

The last named sum represents a quantity of 28,000 cwt., of which $11,170 \mathrm{cwt}$. were furnished by Italy, and the remainder by Turkey, France, Spain, and other countries.

The total exports of Liquorice Paste from Smyrna were estimated in $1872^{\circ}$ as 1,200 to 1,400 tons (24,000 to 28,000 cwt.) per annum.

Uses-Stick liquorice is sucked as a remedy for coughs, and by children as a sweetmeat. It is also used in lozenges, and in some pharmacopoias is admitted as the raw material from which to prepare soft extract of liquorice.

The block liquorice, of which a large quantity is imported, is chiefly used in the manufacture of tobacco for smoking and ehewing. 


\section{OLEUM ARACHIS.}

Ground-nut oil, Earth-nut oil, Arachis oil; F. Huilc d'Arachidc ou de Pistache de terre; G. Erdnussöl.

Botanical Origin-Arachis h? ppogad L., a diffuse herbaceous annual plant having stems a foot or two long, and solitary axillary flowers with an extremely long filiform calyx-tube. After the flower withers, the torus supporting the ovary becomes elongated as a rigid stalk, which bends down to the ground and forces into it the young pod, which matures its seeds some inches below the surface. The ripe pod is oblong, cylindrical, about an inch in length, indehiscent, reticulated, and contains one or two irregularly ovoid seeds.

The plant is cultivated for the sake of its nutritious oily seeds in all tropical and subtropical countries, but especially on the west coast of Africa. It is unknown in the wild state. De Candolle ${ }^{1}$ regards it as a native of Brazil, to which region the other species of the genus exclusively belong. But the opinion of one of us ${ }^{2}$ is strongly in favour of the plant being indigenous to Tropical Africa.

History-The first writer to notice the Ground Nut appears to be Monardes, ${ }^{3}$ who describes it as a nameless subterraneous fruit, found about the river Marañon and held in great esteem by both Indians and Spaniards. Some account of it and a figure were given in the following century by Marcgraf, who calls it by its Brazilian name of Mundubi.

It is only in very recent times that the value of the Ground Nut has been recognized in Europe. Jaubert, a French colonist at Gorée near Cape Verde, first suggested about 1840 its importation as an oil-seed into Marseilles, where it now constitutes one of the most important articles of trade. ${ }^{5}$

Description-The fat oil of Arachis as obtained by pressure without heat, is almost colourless, of an agreeable faint odour and a bland taste resembling that of olive oil. An inferior oil is obtained by warming the seeds before pressing them. The best oil has a sp. gr. of about 0.918 ; it becomes turbid at $3^{\circ} \mathrm{C}$., concretes at $-3^{\circ}$ to $-4^{\circ}$, and hardens at $-7^{\circ}$. On exposure to air it is but slowly altered, being one of the non-drying oils. At length it thickens considerably, and assumes even in closed vessels a disagreeable rancid smell and taste.

Chemical Composition-The oil consists of the glycerides of four different fatty acids. The common alcic Acid, $\mathrm{C}^{18} \mathrm{H}^{34} \mathrm{O}^{2}$, that is to say its glycerin compound, is the chief constituent of Arachis oil. Hypogceic Acid, $\mathrm{C}^{16} \mathrm{H}^{30} \mathrm{O}$, ${ }^{2}$ has been pointed out by Gössmann and Schevcn (1854) as a new acid, whereas it is thought by other chemists to agree with one of the fatty acids obtained from whale oil. The melting point of this acid from Arachis oil is $34-35^{\circ} \mathrm{C}$. The third acid afforded by the oil is ordinary Palmitic Acid, $\mathrm{C}^{16} \mathrm{H}^{32} \mathrm{O}^{2}$, with a fusing point of $62^{\circ} \mathrm{C}$.

1 Géorgraphic Botanique, ii. (1855) 963.

2 Flückiger, Ucber die Erdunss, - Archiv. der Pharmacic, 190. (1869) 70-84.

3 Las Cosas que se truen de muestras Indios Ocoidentales, Sevilla 1569 , part 2.

4 Hist. Rerum. Nat. Bras., 1648, 37.
5 Duval, Colonics ct politique coloniale de Ta France, 1864. 101.-Mavidal, Le Sénégal, son état préscnt, son avenir, Paris 1863, 171. - Carrère et Holle, La Sénégambic Frangrisc, 1855, 84.- Poitenu, in Annalcs des Sciences nat., Botanique, xix. (1853) 268. 
Arachic Acid, $\mathrm{C}^{20} \mathrm{H}^{40} \mathrm{O}^{2}$, the fourth constituent, has also been met with among the fatty acids of butter and olive oil, and, according to Oudemans $(1866)$, in the tallow of Nephclium lappaceum L., an Indian plant of the order Sapindacce.

When ground-nut oil is treated with hyponitric acid, which may be most conveniently evolved by heating nitric arid with a little starch, a solid mass is obtained, which yields by cirystallization from alcohol Elä̈dic and Gaidinic acids, the former isomeric with oleic, the latter with hypogæic acid.

Production and Commerce-The pods, or the seeds removed from them, are exported on an immense and ever increasing scale from the West Coast of Africa. From this region, not less than 66 inillions of kilogrammes, value 26 millions of francs $(£ 1,040,000)$, were imported in 1867 , almost exclusively into Marseilles.

The oil is exported from India where the ground-nut is also cultivated, though not on so large a scale as in Westem Africa. In Europe it is manufactured chiefly at Marseilles, London, Hamburg and Berlin. The yield of the seeds varies from 42 to nearly 50 per cent. The softness of the seeds greatly facilitates their exhaustion, whether by mechanical power or by the action of bisulphide of carbon or other solvent.

Uses-Good arachis oil may be employed in pharmacy in the same way as olive oil, for which it is a valuable substitute, though more prone to rancidity. It has been introduced into the Pharmacopeia of India, and is generally used instead of olive oil in the Indian Government establishments. Its largest application is for industrial purposes, especially in soap-making.

\section{RADIX ABRI.}

\section{Indian Liquorice; F. Liane à réglisse, Réglisse d'Amérique.}

Botanical Origin-Abrus precatorius L., a twining woody shrub indigenous to India, but now found in all tropical countries.

History-The plant is mentioned in the Sanskrit medical writings of Susruta, whence we may infer that it has long been employed in India. Its resemblance to liquorice was remarked by Sloane (1700), who called it Phaseolus glycyrrhites. As a substitute for liquorice, the root has been often employed by residents in the tropical countries of both hemispheres. It was introduced into the Bengal Pharmacopceia of 1844, and into the Pharmacopocia of India of 1868.

The seeds, of the size of a small pea, well known for their polish and beantiful black and red colours, have given their name of Retti to a weight ( $=2 \frac{3}{16}$ grains) used by Hindu jervellers and druggists.

Description-The root is long, woody, tortuous and branching. The stoutest piece in our possession is as thick as a man's finger, but nost of it is much more slender. The cortical layer is extrenely thin and of a light brown or almost reddish hue. The woody part breaks with a short fibrous fracture exhibiting a light yellow interior. The root has a peculiar, disagreeable odour, and a bitterish acrid flavour leaving a faintly sweet after-taste. When cut into short lengths it has a slight resemblance to liquorice, but may ensily be distinguished by means of the microscope. 
Mr. Moodeen Sheriff ${ }^{1}$ who says he has often examined the root of Abrus both fresh and dried, remarks that it is far from abounding in sugar as is generally considered; - that it does not possess any sweetness at all until it attains a certain size, and that even then its sweet taste is not always well marked. As it is often mixed in the Indian bazaars with true liquorice, he thinks the latter may have sometimes been mistaken for it.

Microscopic Structure-On a transverse section the bark exhibits some layers of cork cells, loaded with brown colouring matter and then, within the middle zone of the bark, a comparatively thick layer of sclerenchymatous tissue. Strong liber fibres are scattered through the interior of the cortical tissue, but are not distributed so as to form wedge-shaped rays as met with in liquorice. In the latter the sclerenchyme (thick-walled cells) is wanting. These differences are sufficient to distinguish the two roots.

Chemical Composition-The concentrated aqueous infusion of the root of Abrus has a dark brown colour and a somewhat acrid taste accompanied by a faint sweetness. When it is mixed with an alkaline solution of tartrate of copper, red cuprous oxide is deposited after a short time : hence we may infer that the root contains sugar. One drop of hydrochloric or other mineral acid mixed with the infusion produces a very abundant flocculent precipitate, which is soluble in alcohol. If the infusion of Abrus root is mixed with a very little acetic acid, an abundant precipitate is likewise obtained, but is dissolved by an excess. This behaviour is similar to that of glycyrrhizin (see p. 158).

Berzelius observed so long ago as 1827, that the leaves of Abrus contain a sweet principle similar to that of liquorice.

Uses-The root has been used in the place of liquorice, for which it is in our opinion a very bad substitute.

\section{SET $Æ$ MUCUNA.}

\section{Dolichi pubes vel setce; Cowhage, Cow-itch ${ }^{2}$ : F. Pois à gratter, Pois pouillieux; G. Juckborsten.}

Botanical Origin-Mucuna pruriens DC. (Dolichos pruriens L., Stizolobium pruriens Pers., Mucuna prurita Hook.), a lofty climbing plant with large, dark purple papilionaceous flowers, and downy legumes in size and shape not unlike those of a sweet pea, common throughout the tropical regions of both Africa, India and America.

History - The earliest notice we have found of this plant is that of Parkinson, who in his Theater of Plants published in 1640, names it "Phaseolus siliquâ hir'sutâ, the Hairy Kidney-Beane called in Zurrate [Surat] where it groweth, Couhagc." It was subsequently described by Ray (1686), who saw the plant raised from West Indian seeds, in the garden of the Hatton family in Holborn. ${ }^{3}$ Rheede figured it in the

1 Supplement to the Pharmacopceia of India, Madras, 1869, 17.- The author has kindly sent us specimens of the root. We are also indebted for authentic samples to Mr. Thwaites of the Royal Botanieal Garden, Ceylon, and to Mr. Prestoe of the Botanical Garden, 'Trinidad. The last named gentle- mall remarks - "I do not find any liquorice property in the root, even fresh, but it is very strong in the green leaves."

${ }^{2}$ These names and the following are also applied to the entire pods, or even to the plant.

${ }^{3}$ Hist. Mant. i. 887. 
Hortus Malabaricus, ${ }^{1}$ and it was also known to Rumphius and the other oller botinists.

'The employment of cowhage as a vermifilge originated in the West Indies, and is quite unknown in the Eist. In England the drug began to attract attention in the latter part of the last contury, when it was strongly recommended by Bancroft in his Natural History of Guiana (1769), and by Chamberlaine, a surgeon of London, who published an essay ${ }^{2}$ descriptive of its effects which went through many editions. It was introduced into the Edinburgh Pharmacopceia of 1783, and into the London Pharmacopoeia of 1809. At the present day it has been almost discarded from European medicine, but has been allowed a place in the Pharmacopaia of India (1868).

The name Cowhage is Hindustani, and in the modern way is written Kiwach; the corruption into Cow-itch is absurd. Mucuna is the Brazilian nane of another species mentioned in 1648 by Maregraf. ${ }^{3}$

Description-The pods are 2 to 4 inches long, about $\frac{4}{10}$ of an inch wide, and contain 4 to 6 seeds; they are slightly compressed and of a dark blackish brown. Each valve is furnished with a prominent ridge running from the apex nearly to the base, and is densely covered witl rigid, pointed, brown hairs measuring about $\frac{1}{10}$ of an inch in length. The hairs are perfectly straight and easily detached from the valves, out of the epidermis of which they rise. If incautiously touched, they enter the skin and occasion an intolerable itching.

Microscopic Structure-Under the microscope the hairs are seen to consist of a single, sharply pointed, conical cell, about $\frac{1}{40}$ of an inch in diameter at the base, with uniform brownish walls $5 \mathrm{mkm}$. thick, which towards the apex are slightly barbed. Occasionally a hair shows one or two transverse walls. Most of the hairs contain only air ; others show a little granular matter which acquires a greenish hue on addition of alcoholic solution of perchloride of iron. If moistened with chromic acid, no structural peculiarity is revealed that calls for remark. The walls however are somewhat separated into indistinct layers, the presence of which is confirmed by the refractive power displayed by the hairs in polarized light.

Chemical Composition-The hairs when treated with sulphuric acid and iodine assume a dark brown colour. Boiling solution of potash does not considerably swell or alter them. They are completely decolorized by concentrated nitric acid.

Uses-Cowhage is administered for the expulsion of intestinal worms especially Ascaris lumbricoides and $A$. vermicularis, which it effects by reason of its mechanical structure. It is given mixed with syrup or honey in the form of an electuary.

The root and seeds are reputed medicinal by the natives of some part of India. The pods when young and tender may be cooked and eatell.

1 Tom. viii. tab. 35, sub. nom. Näi Corana.

2 On the cficacy of Stizolobium or Couthage, Lond. 2nd el., 178 t.

3 Hist. Nat. Brasil. $1 \mathrm{~s}$. 


\section{SEMEN PHYSOSTIGMATIS.}

Faba Calabarica, Fuba Physostigmatis; Calabar Bean, Ordeal Bean of Old Calabar, Eseré Nut, Chop-nut; F. Fève de Calabar; G. Calabarbohne.

Botanical Origin-Physostigma venenosum Balfour, a perennial plant resembling the common Scarlct Runner (Phaseolus multiflorus, Lam.) of our gardens, but having a woody stem often an inch or two thick, climbing to a height of 50 fect or more. It grows near the mouths of the Niger and the Old Calabar River in the Gulf of Guinea.

The imported seeds germinate freely, but the plant though it thrives vigorously in a hothouse has not yet, we believe, flowered in Europe. It has already been introduced into India and Brazil. In the latter country Dr. Peckolt, late of Cantagallo, has raised plints which have blossomed abundantly, producing racemes of about 30 flowers each, pendent from the axils of the ternate leaves.

The flower, which is fully an inch across and of a purplish colour, has the form of Pluaseolus, but is distinguished from that genus by two special characters, namely that it has the style developed beyond the stigma backwards as a broad, flat, hooked appendage, ${ }^{1}$ and the seeds half surrounded by a deeply grooved hilum.

History-The pagan tribes of Tropical Western Africa compel persons accused of witchcraft to undergo the ordeal of swallowing some vegetable poison. One of the substances employed in this horrid custom is the seed under notice, which is administcred in substance or in the form of emulsion, or even as a clyster. It was first made known in England by Dr. W. F. Daniell about the year 1840, and subsequently alluded to in a paper rcad by him before the Ethnological Society in $1846 .{ }^{2}$ The highly poisonous effects of the bean were obscrved in 1855 by Christison ${ }^{3}$ in his own person, and in 1858 by Sharpey, who administered it to frogs.

Before the seed became an object of commerce, it was regarded by the natives with some mystery and was reluctantly parted with to Europeans. It was moreover customary in Old Calabar to destroy the plant whenever found, a few only being reserved to supply seeds for judicial purposes, and of these seeds the store was kept in the custody of the native chief. In 1859, the Rev. W. C. Thomson, a missionary on the West Coast of Africa, forwarded the plant to Professor Balfour of Edinburgh who described it as the type of a new genus. ${ }^{4}$

Fraser of Edinburgh (about 1863 or earlier) discovered the specific power of the seed in contracting the pupil, when the alcoholic cxtract is applied to the eye. These myotic effects, counteracting thosc of atropine and hyoscyamine, were further cxamined by G. Harley, A. von Gräfe, Robertson, Hulkc, Workman, Woolcott, Czermak, Wells and many other experimenters on mammals or birds. The action of the poison when

1 The name of the genus, from dúra, a bladder, was formed under the notion that this appendarge is hollow, which is not the fart.

2Edinb. Ncw Phil. Journ., xl. (1840) 313.
3 Edinb. Jonun. of Med. Scicnce, xx. (1855)

193 ; Pharm. Journ., xiv. (1855) 470.

4 Trans. Roy. Soc. of Edinb. xxii. (1861) 305. t. 16-17: see also Baillon, Hist. dcs Plantes, ii. 206. figg. 153-155. 
taken internally was found rapidly to affect the cardiac contractions and finally to paralyze the heart.

Description-The fruit of Physostigma is a dehiscent, oblong legume about 7 inches in length, containing 2 or '? seeds. The latter, commonly known as Culabar Beans, are 1 to $1 \frac{3}{8}$ inches long, about $\frac{8}{8}$ of an inch broad, and $\frac{4}{8}$ to $\frac{5}{8}$ of an inch in thickness, weighing on an averagc of twenty sceds, 67 grains eacl.

They have an oblong, subreniform outline, one side being straight or but slightly incurved, the other boldly arched. The latter is marked by a broad furrow, $\frac{1}{8}$ of an inch wide, bordered with raiscd edges, and running from the micropyle, which is a small fumbl-shaped depressiou, quite round the opposite end of the secd. In the middle of this r'cmarkable furrow the raphe is seen as a long raised suture running from end to end. The surface of the sced is somewhat rough but has a dull polish; it is of a deep chocolate brown, passing into a lighter tint on the ridges bordering the furrow. The latter is black, dull, and fincly rugose.

When the seed is broken the cotyledons are found adherent to the testa, with a large cavity between them. The air thus included causes the seeds to float on water, but they sink immediately when broken. After digestion for some hours in warm water, the testa having been previously cracked, the. whole seed softens and swells so that its structure may be easily studied. Each cotyledon is then seen to be marked on the hilum-side by a long shallow furrow, at one end of which, just below the micropyle, lies the plumule and radicle. A dark brown iuner membrane constituting part of the testa, surrounds the cotyledons.

The seeds have scarcely any taste, or not more than an ordinary bean; nor in the dry state have they any odour. After being boiled, or when their alcoholic tincture is evaporated, an odour suggesting cantharides is developed.

Microscopic Structure-The cotyledons are bnilt up of large globular or ovoid cells, those of the outermost layer being smaller and of rather cubic form. This parenchyme is loaded with starch granules, frequently as much as $50 \mathrm{mkm}$. in diameter. Their interior part is less distinctly stratificd than the outer; the hollow centre radiates in various directions around the axis of the ovate granule. Polarized light does not show a cross as in other more globular starch granules, but two elliptic curves approaching one another near the axis of the granule. Similar starch granules are commonly met with in the seeds of Leguminosce.

In the Calabar sceds the starch is accompanicd by numerous particles of albuminous natter becoming distinctly perceptible by addition of iodine, which imparts to them an orangc coloration.

The shell of the seed is built up of four different layers; the prevailing layer consists of very long, simply cylindrical cells, denscly packed so as to form only one radial row. Tison ${ }^{1}$ has endeavoured to ascertain in what anatomical structure of the seed the active principle is lodged; and he has arrived at the conclusion that its sent is the granular protoplasmic particles, which alone acquire an orange tint by the action of weak caustic alkalis.

1 Histoire de la Fìve de Calabar, Paris, 1873. 3S. 
Chemical Composition--.Jobst and Hesse ${ }^{1}$ proved in 1863 that the poisonous nature of Calabar bean depends upon an alkaloid, to which they gave the name Physostigmine. It is obtained by the method generally adopted for extracting analogous substances, that is, by precipitating one of its salts from an aqueous solution by bicarbonate of sodium, and dissolving out the base with ether or benzol. As extracted by these chemists, iphysostigmine is an amorphous mass of decidedly alkaline reaction, soluble in much water and in acids. On exposure to the air the solution soon becomes red, or sometimes intensely blue, a partial decomposition of the alkaloid taking place. The red coloration may even be observed in the aqueous infusion of a few cotyledons. It disappears by sulphuretted hydrogen or sulphurous acid, but returns if these reducing agents are allowed to evaporate.

Hesse ${ }^{2}$ ascertained (1867) that physostigmine consists of $\mathrm{C}^{30} \mathrm{H}^{21} \mathrm{~N}^{3} \mathrm{O}^{4}$; he now obtained it perfectly colourless and tasteless, softening at $40^{\circ} \mathrm{C}$., fusing at $45^{\circ} \mathrm{C}$., but not supporting a heat of $100^{\circ} \mathrm{C}$., without decomposition, which is manifested by a red coloration.

In 1865 , Vée and Leven ${ }^{3}$ by treating the powdered unpeeled seed in nearly the same way, prepared an alkaloid which they called Eserine. It differs from. Hesse's physostigmine in that it forms colourless, rhomboidal, tabular crystals ${ }^{4}$ of a bitter taste, melting at $90^{\circ} \mathrm{C}$. It dissolves easily in ether, alcohol, or chloroform, but very sparingly in water. The last named solution is alkaline, and reddens by exposure to the air. Eserine dissolves in acids and neutralizes them, forming soluble (crystalline?) salts. The sulphate dissolved in 200 parts of water affords a white precipitate with tannic acid or iodohydrargyrate of potassium, brown with ioduretted iodide of potassium and yellow with chloride of gold. The lastnamed precipitate rapidly turns brown, the solution acquiring a red tint.

It is assumed by some writers, as Tison, ${ }^{5}$ that eserine is only the pure form of physostigmine ; but at present we feel hardly warranted in admitting the identity of the two substances.

From the cotyledons per se, cold water extracts mucilage, precipitable by neutral acetate of lead. The watery infusion contains also albumin, which may be coagulated by heat or by alcohol. The infusion is colourless, does not redden litmus, nor does it contain sugar in appreciable proportion; a few drops of solution of potash cause it to assume an orange colour. An infusion of the shell of the seed is already of this colour, but the tint is intensified by caustic alkali.

The cotyledons yield to boiling ether $\frac{1}{2}$ to $\frac{1}{3}$ per cent. of fatty oil, and after exhaustion by ether and alcohol, afford to cold water 12 per cent. of albuminous and mucilaginous constituents. The proportion of starch according to Teich ${ }^{6}$ amounts to 48 per cent., the albuminous matter to

1 Liebig's Annalen der Chem. u. Pharm. $129(1864) 115$.

2 Ibid. 141 (186T) 82 ; Chcm. News, 22 Narch 1867, 149.

3 Comptss Rendus, lx. (1865) 1194.

4 F. F. Mayer of New York obtained the alkaloid of Calabar bean as an almost colourless mass capable of forming crystallizable salts. (American Jou'n. of Pharm., May $1865,173$.$) Hesse prepared the iodn-$ hydrargyrate of physostigininc in a crystallized statc.

5 Op. cit. chap. 2.
${ }^{6}$ Chemische Untersuchung der Calabarbohne. - Inauguralschrift, St. Petersburg 1S67. - Teich exhausted the kernels surcessively with ether, alcohol, and cold water, and then transformed the starch into sngar by means of hydrochloric acid. The proportion of sugar was then calculated according to the amomnt of protoxide of copper, which it scparated from an alkaline solution of tartrate of copper. We calculate the albuminous matters with refercnec to 'Teich's analysis, which proved the kernels to contain 3.65 per cent. of nitrogen. 
23 per cent. The entire seed furnishes 3 por eent. of ash, chiefly phosphate of potash. These eonstituents do not widely differ in proportion fion those fonnd in the common bean, whieh yields 23 to 25 per cent. of alluminous matters and 32 to 38 per cent. of starch, besides 1 to 3 per eent. of oil.

The shells of Calabar beall are stated by Fraser to be by no means devoid of aetive prineiple.

Vée asserts that if to a solution of eserine, a little potash, lime or earbonate of sodium be adder, there is developed a red eolour which rapidly increases in intensity. This colour is transient, passing into yellow, green and blue. If ehloroform is shaken with such eoloured solution, it takes up the colour ; ether on the other hand remains uneoloured.

Uses-Calabar bean has been hitherto ehiefly employed as an ophthalmic medieine, for the purpose of eontracting the pupil. It has however been oceasionally administered in tetanus and in neuralgic, rheumatie, and other diseases.

Adulteration-Other seeds are sometines fraudulently mixed with Calabar beans. We have notieed in particular those of a Mucuna and of the Oil Palm, Elceis Guincensis L. The slightest examination suffiees for their detection.

\section{KINO.}

Kino, Gum Kino, East Indian Kino; F. and G. Kino.

Botanical Origin-Pterocarpus Marsupium Roxb., a handsome tree 40 to 80 feet high, frequent in many parts of the Indian Peninsula and also in Ceylon, and affording a valuable timber. In the Goverument forests of the Madras Presideney, it is one of the reserved trees, the felling of whieh is placed under restrictions.

Pt. indicus Willd., a tree of Southern India, the Malayan Peninsula and the Indian and Philippine Islands, is eapable of yielding kino and is the souree of the small supplies of that drug that were formerly shipped from Moulmein.

Several other plants afford substanees bearing the name of Kino, whieh will be notieed at the eonelusion of the present artiele.

History-The introduetion of kino into European medicine is due to Fothergill, an eminent physieian and patron of economie botany of the last eentury. The drug whieh Fothergill examined, was brought from the river Gambia in West Africa as a rare sort of Dragon's Blood, and was deseribed by him in $1757^{1}$ under the name of Gummi rubrum astringens Gambiense. It had been noticed at least twenty years before as a production of the Gambia, by Moore, factor to the Royal African Company, who says that the tree yielding it, is called in the Mandingo language Kano. ${ }^{2}$ Speeimens of this tree were sent to England in 1805 by the eelebrated traveller Mungo Park, and recognized some years later as identieal with the Pterocarpus erinaceus of Poiret.

It seems probable that Afriean kino eontinued to reaeh England for some years, for we find "Gumni rubrum astringens" regularly valued in the stoek of a London druggist ${ }^{3}$ from 1776 to 1792.

1 Medical Observations and Inquivics, i. (1757) 358 .

2 Travels inlo the Inland Parts of Afriea, by Francis Moore, Joud. 1737. ll.' 160. 209.

3 J. Gurney Bevall, Plough Court, Loinbard Street. - The drug was priced in 1787 as having cost $16 \mathrm{~s}$, - - and in 1790-92, $21 \mathrm{~s}$. per $1 \mathrm{~b}$. 
Duncan in the Edinburgh Dispensatory of 1803, while asserting that "Fino is brought to us from Africa," admits that some, not distinguishable from it, is imported from Jamaica. In a later edition of the same work (1811), he says that the African drug is no longer to be met with, and alludes to its place being supplied by other kinds, as that of Jamaica, that imported by the East India Company, and that of New South Wales derived from Eucalyptus resinifera. It will thus be seen that at the commencement of the present century several substances, produced in widely distant regions, bore the name of Kino. That however which was principally used in the place of the old African drug, was East Indian Kino, the botanical origin of which was shown by Wight and by Royle ${ }^{1}$ (1844 46) to be Pterocarpus Marsupium Roxb.,-a tree which, curiously enough, is closely allied to the kino tree of Tropical Africa.

This is the drug which is recognized as legitimate kino in all the principal pharmacopœias of Europe. It appears to have been first prepared for the European market in the early part of the present century, on a plantation of the East India Company called Anjarakandy, a few miles from Tellicherry on the Malabar Coast; but as we learn from our friend Dr. Cleghorn, it was not grown there but on the ghats a short distance inland.

Extraction-Kino is the juice of the tree, dried without artificial heat. ${ }^{2}$ As it exudes, it has the appearance of red currant jelly, but hardens in a few hours after exposure to the air. In the Government forests of the Malabar Coast whence the supplies are obtained, permission to collect the drug is granted on payment of a small fee, and on the understanding that the tapping is performed skilfully and without damage to the timber. The method pursued is this :-A perpendicular incision with lateral ones leading into it, is made in the trunk, at the foot of which is placed a vessel to receive the ontflowing juice. This juice soon thickens, and when sufficiently dried by exposure to the sun and air, is packed into wooden boxes for exportation.

Description-Malabar kino ${ }^{3}$ consists of dark, blackish-red, angular fragments rarely larger than a pea, easily splitting into still smaller pieces which are seen to be perfectly transparent, of a bright garnet hue, and amorphous under the microscope. In cold water they sink, but partialiy dissolve by agitation forming a solution of very astringent taste, and a pale flocky residue. The latter is taken up when the liquid is made to boil, and deposited on cooling in a more voluminous form. Kino dissolves almost entirely in spirit of wine (.838) affording a dark reddish solution, acid to litmus paper, which by long keeping sometimes assumes a gelatinous condition. It is readily soluble in solution of caustic alkali, and to a large extent in a saturated solution of sugar.

Chemical Composition-Cold water forms with kino a reddish solution, which is at first not altered if a fragment of ferrous sulphate is added. But a violet colour is produced as soon as the liquid is cautiously neutralized. This can be done by diluting it with common water (containing bicarbonate of calcium) or by adding a drop of solution of slightly

1 Pharm. Jourin. v. (1846) 495.

${ }^{2}$ Cleghorn, Forests and Gardens of South India, 1861. 13. - also from information communicated by him orally.

${ }^{3}$ Our sample obtained from Pt. Harsu- pium Roxb. on the Sigúr Ghat, Feb. 1868 , was kindly transmitted to us by Mr. McIvor of Ootacamund. - We find it to agree with commercial Last Indian Jíno. 
alkaline acetate of potassimm. Yet the fact of kino developing an intense violet colour in presence of a protosalt of iron, may most evidently be shown by shaking it with water, and iron reduced by hydrogen. 'The filtered. liquid is of a brilliant violet and may be evaporated at $100^{\circ}$ without turning green; the dried residue even ngain forms a violet solution with water. By long keeping the violet liquid gelatinizes. It is decolorized by acids, and tnirns red on addition of an alkali, whether caustic or bicarbonated. Catechn, as well as crystallized catechin, show the same behaviour, but these solutions quickly turn green on exposure to air.

Solutions of acids, of inetallic or earthy salts, or of alkaline chromates prodnce copious precipitates in an aqneous solution of kino. Ferric chloride forms a dirty green precipitate, and is at the same time reduced to a ferrous salt. Dilute mineral acids or alkalies do not occasion any decided change of colour, but the former give rise to light brownishred precipitates of Kino-tannic Acid. By boiling for some time an aqueous solution of kino-tannic acid, a red precipitate, Kino-red, is separated.

Kino in its general behaviour is closely allied to Pegu catechu and yields by similar treatment the same products, that is to say, it affords Pyrocatechin when submitted to dry distillation, and Protocatechuic Acid together with Phloroglucin when melted with caustic soda or potash.

Yet in catechu the tannic acid is accompanied by a considerable amount of catechin, which may be removed directly by exhaustion with ether. Kino, on the other hand, yields to ether only a minute percentage of a substance, whose scaly crystals display under the microscope the character of Pyrocatechin, rather than that of catechin, which crystallizes in prisms. The crystals extracted from kino dissolve freely in cold water, which is not the case with catechin, and this solution assumes a fine green if a very dilute solution of ferric chloride is added, and turns red on addition of an alkali. This is the behaviour of catechin as well as of pyrocatechin; but the difference in solubility speaks in favour of the crystals afforded by kino being pyrocatechin rather than catechin.

Pyrocatechin having been met with in the fresh leaves of the. Virginian Creeper (Ampelopsis hederacea Mich.), we thought it must also occur in the mother-plant of kino, but this does not prove to be the case, no indication of its presence being perceptible either in the fresh bark or wood. ${ }^{1}$ Commercial kino yielded us 1.3 per cent. of ash.

Commerce-The quantity of true kino collected in the Madras forests is comparatively small, probably not exceeding a ton or two annually. The drug is often shipped from Cochin.

Uses-Kino is administered as an astringent. It is said to be used in the manufacture of wines, and it might be employed if cheap enough in tanning and dyeing.

1 We have to thank Mr. Broughton of the Cinchona Plantations, Ootreamund, for de. termining this point. In the bark almost saturated with fresh liquid kino, he utterly failed to obtain any indieation of pyrocatechin by the tests whieh he fourd to render it easily evident in dry kiro. 


\section{Other sorts of Kino.}

\section{Butea Kino, Butea Gum, Bengal Kino, Palas or Pulas Kino, Gum of the Palas or Dhak Tree.}

This is an exudation from Butea frondosa Roxb. (Leguminosca), a tree of India well known under the name of Palas or Dhak, and conspicuous for its splendid, large, orange, papilionaceous flowers. According to Roxburgh it flows during the hot season from natural fissures or from wounds made in the bark, as a red juice which soon hardens into a rubycoloured, brittle, astringent gum.

Authentic specimens of this kino have been placed at our disposal by Mr. Moodeen Sheriff of Madras and by Dr. J. Newton of Bellary. That received from the first-named gentleman consists of flattish, angular fraginents (the largest about $\frac{1}{2}$ an inch across) and small drops or tears of a very dark, ruby-coloured gum, which when held to the light is seen to be perfectly transparent. The flat pieces have been mostly dried on leaves, an impression of the veins of which, they retain on one side, while the other is smooth and shining. The substance has a pure astringent taste but no odour. It yielded us 1.8 per cent. of ash and contained 13.5 per cent. of water. Ether removes from it a small quantity of pyrocatection. Boiling alcohol dissolves this kino to the extent of 46 per cent.; the solution which is but little coloured, produces an abundant greyish-green precipitate with perchloride of iron, and a white one with acetate of lead. It may be hence inferred that a tannic acid, probably kino-tannic acid, constitutes about half the weight of the drug, the remainder of which is formed of a soluble mucilaginous substance which we have not isolated in a state of purity. By submitting the Butea kino of Mr. Moodeen Sheriff to dry distillation we obtained pyrocatechin.

The sample from Dr. Newton is wholly in transparent drops and stalactitic pieces, considerably paler than that just described but of the same beautiful ruby tint. The fragments dissolve freely and almost completely in cold water, the solution being neutral and exhibiting the same reactions as the former sample.

Butea kino, which in India is used in the place of Malabar kino, was long confounded with the latter by European pharmacologists, though the Indian names of the two substances are quite different. It is not obtained exclusively from $B$. frondosa Roxb., the allied $B$. superba Roxb. and $B$. parviflora Roxb. affording a similar exudation.

2. Afriecen or Gambia Kino-Of this substance we have a specimen collected by Daniell ${ }^{1}$ in the very locality whence it was obtained by Moore in 1733 (see p. 170), and by Park at the commencement of the present century. The tree yielding it, which still bears the Mandingo name Kano, and grows to a height of 40 to 50 feet, is Pterocarpus erinaceus Poiret, a native of Tropical Western Africa from Senegambia to
Angola. The juice exudes naturally from crevices in the bark, but much
more plentifully by incisions; it more plentifully by incisions; it soon coagulates, becoming deep bloodred and remarkably brittle. That in our possession is in very small, shining, angular fragments, which in a proper light appear transparent and of a deep ruby colour. In solubility and chemical characters, we can

${ }^{1}$ See his paper On the Kino Tree of West Africa, Pharm. Journ. xiv. (1855) 55. 
trace no difference between it and the kino of the allied Pt. Marsupium Roxb. 'This kino does not now find its way to England as a regular article of trade. From the statement of Welwitsch, it appears that the l'ortuguese of Angola employ it under the name of Singue de Drago. ${ }^{1}$

3. Arstralian, Botany Bay, or Eucalyptus Kino.-For some years past, the London drug market has been supplied with considerable quantities of kino from Australia; in fact at one period this kino was the only sort to be purchased.

As it is the prodnce of numerous species of Fuculyptus, it is not surprising that it presents considerable diversity of appearance. The better qualities closely agree with Pterocarpus kino. 'They are in dark reddish brown masses or grains, which when in thin fragments are seen to be transparent, of a garnet red hue and quite amorphous. The substance is mostly collected by the sawyers and wood-splitters. It is found within the trunks of trees of all sizes, in flattened cavities of the otherwise solid wood which are often parallel to the annual rings. In such place the kino which is at first a viscid liquid, becomes inspissated and subsequently hard and brittle. It may also be obtained in a liquid state by incisions in the stems of growing trees: such liquid kino has occasionally been brought into the London market; it is a viscid treacle-like fluid, yielding by evaporation about 35 per cent. of solid kino. ${ }^{2}$

Authentic specimens of the kino of 16 species of Eucalyptus sent from Australia by F. von Müller, have been cxamined by Wiesner of Vienna. $^{3}$ He found the drug to be in most cases readily soluble in water or in spirit of wine, the solution being of very astringent taste. The solution gave with sulphuric acid a pale red, flocculent precipitate of Kino-tannic Acid; with perchloride of iron (as in common kino) a dusky greenish precipitate,--except in the case of the kino of $E$. obliqua L'Hér. (Stringy-bark Tree), the solution of which was coloured dark violet.

Wiesner further states, that Eucalyptus kino contains 15 to 17 per cent. of water, - that it affords a mere trace of ash, and no sugar. In some sorts a little Catechin ${ }^{4}$ was present, and in all Pyrocatechin. It contains no pectinous matter, but in 'some varieties a gum like that of A cacia. In one sort, the kino of E. gigantea Hook., ${ }^{5}$ gum is so abundant that the drug is nearly insoluble in spirit of wine.

From this examination, it is evident that the better varieties of Eucrlyptus kino, such for instance as those derived from $E$. rostrata Schlecht. (Red or White Gum, or Flooded Gum of the colonists), E. corymbosa Sm. (Blood-wood) and E. citriodora Hook., possess all the useful properties of Pterocarpus kino and night with no disadvantage be substituted for it.

I Madeiras e Drogas medicinaes de Angola, Lisbon, 1862, 37.

2 Victoria Exhibition, 1861.-Jurors' Report on Class 3. p. 59.

3 Zeitschrift des österreieh. Apotheker-
Tereines ix. (1871) 497 ; Pharm. Journ.

Ang. 5, 1871. $\mathrm{i} 02$.

${ }_{4}$ In our opinion this is doubtful.

5 Bentham unites this species to $E$. obliqua L'Hér (Flor. Austr., iii. 204.) 


\section{LIGNUM PTEROCARPI.}

Lignum Santalinum murum, Santalum mubum; Red Sanders Wood, Ruby Wood; F. Bois de Santal rouge; G. Rothes Sandelholz.

Botanical Origin-Pterocarpus santalinus Linn. fil.-A small tree not often exceeding $3 \frac{1}{2}$ to 4 feet in girth and 20 to 25 feet in height; it is closely related to Pt. Marsupium Roxb., from which it differs chiefly in liaving broader leaflets always in threes. It is a native of the southern part of the Indian Peninsula, as Canara, Mysore, Travancore and the Coromandel Coast. The districts in which the wood is at present chiefly obtained are the forests of the southern portion of the Kurnool Hills, Cuddapah and North Arcot (W. and N.W. of Madras). The tree is now being raised in regular plantations. ${ }^{1}$

The wood is a staple article of produce, and the felling of the trees is strictly controlled by the forest inspectors. The fine trunk awood is highly valued by the natives for pillars in their temples and other buildings, as well as for tumery. The stumps and roots are exported to Europe as a dye-stuff, mostly from Madras.

History-It is difficult to tell whether the appellation Red Sandalwood used in connexion with Yellow and White Sandal-wood by some of the earlier writers on drugs, was intended to indicate the inodorous dyewood under notice or the aromatic wood of a species of Santalum. Yet when Marco Polo ${ }^{2}$ alludes to the sandal-wood imported into China, and to the red sandal ("Cendal vermeil") which grows in the island of Necuveran (Nicobar), it is impossible to doubt that he intended by this latter name some such substance as that under notice.

Garcia d'Orta who wrote at Goa in the middle of the 16th century, clearly distinguished the fragrant sandal of Timor from the red inodorous wood of Tenasserim and the Coromandel Coast. It is remarkable that the wood of Pt. santalinus is distinguished to the present day in all the languages of India by names signifying red-coloured sandal-wood, though it has none whatever of the peculiarities of the odorous wood of Santalum. Red Sanders Wood was formerly supposed to possess medicinal powers: these are now disregarded, and it is retained in use only as a colouring agent.

During the middle ages, it was used as well as alkanet for culinary purposes, such as the colouring of sauces and other articles of food. The price in England between 1326 and 1399 was very variable, but on an average exceeded $3 s$. per $1 \hbar .^{3}$ Many entries for the purchase of Red Sanders along with spices and groceries, occur in the accounts of the Monastery of Durham, A.D. 1530-34. ${ }^{4}$

Description-The wood found in English commerce is mostly that of the lower parts of the stem and that of the thickest roots. It appears in the market in ponderous, irregular logs, rarely exceeding the

1 [Beddome], Report of the Conservator of Forests, for 1869-70, Madras, $1870, \mathrm{pp} .3$. 39. 123 ; for figure of the tree, seo Flora Sylvatica of Southern India of the same author, tab. xxii.

"Pauthier, Livie de Mareo Polo, 580Pt. indicus Willd. grows in the adjacent Andarnan Islands.
3 Rogers, Agrieulture and Prices in England, 1866, i. 631, ii. 545, \&c.-The average price of a sheep during the same period was about $1 s .6 d$.

4 Durham Houschold Book, Surtees Soeiety, 1844, 215 ; also Pegge, Form of Cury, Lond.
1780, p. xv. 
thickness of a man's thigh and commonly much smaller, 3, 4 or 5 feet in length ; they are without bark or sapwood, and are externally of a dark colour. The internal wood is of a deep, rich, blood-red, exhibiting in transverse section, zones of a lighter tint, and taking a fine polish.

At the present day, druggists generally buy the wood rasped into small chips, which are of a deep reddish-brown hue, tasteless and nearly witlout odour.

Microscopic Structure-The wood is built up for the greater part of long pointed cells, having thick walls (libriforn). 'Through this ligneous tissue, there are scattered small groups of very large vessels. In a direction parallel to the circumference of the stem, there are less coloured small parenchymatous layers, running from one vascular bundle to another. The whole tissue is finally traversed by very narrow medullary rays, which are scarcely perceptible to the unaided eye. The parenchymatous cells are each loaded with one crystal of oxalate of calcium, which are so large that, in a piece of the wood broken longitudinally, they may be distinguished without a lens. The colouring matter is contained especially in the walls of the vessels and the ligneous cells.

Chemical Composition-Cold water or fatty oil (almond or olive) abstracts scarcely anything from the wood, and hot water but very little. On the other hand, ether, spirit of wine, alkaline solutions, or concentrated acetic acid, readily dissolves out the colouring matter. Essential oils of bitter almond or clove take up a good deal of the red substance; that of turpentine none at all. This resinoid substance termed Santalic Acid or Santalin, ${ }^{1}$ is said to form microscopic prismatic crystals of a fine ruby colour, devoid of odour and taste, fusing at $104^{\circ} \mathrm{C}$., insoluble in water but neutralizing allkalis and forming with them uncrystallizable salts.

Weidel (1870) exhausted the wood with boiling water, containing a little potash, and obtained by means of hydrochloric acid a red precipitate, which was redissolved in boiling alcohol and then furnished colourless crystals of Santal, $\mathrm{C}^{8} \mathrm{H}^{6} \mathrm{O}^{3}$. They are devoid of odour or taste, not soluble in water, benzol, chloroform, bisulphide of carbon, and but sparingly in ether. Santal yields with potash a faintly yellow solution which soon turns red and green. The wood afforded Weidel not more than 3 per mille of santal.

By exhausting the wood with ether, a red powder having a green hue in reflected light, is obtained, which, when melted with potash, produces Resorcin (see art. Galbanum) and Pyrocatechin (p.17\%). Red Sanders Wood yielded us of ash only 0.8 per cent.

Commerce-In the official year 1869-70, Red Sanderis Wood produced to the Madras Government a revenue of 26,015 rupees (£2,601). The quantity taken from the forests was reported as 1,161,799 $\mathrm{fb}$.

Uses-Red Sanders Wood is scarcely employed in pharmacy except for colouring the Compound Tincture of Lavender'; but it has numerous uses in the arts.

1 Gmelin, Chemistry, xvi. (1864) 259 ; the formula assigned to santalic acid $\left(\mathrm{C}^{15} \mathrm{H}^{14} \mathrm{O}^{5}\right)$ appear's to be doubtful. Weidel in proposing

the formula $\mathrm{C}^{14} \mathrm{H}^{12} \mathrm{O}^{4}$ points out that it may be allied to alizarin, $\mathrm{C}^{14} \mathrm{H}^{8} \mathrm{O}^{4}$. 


\title{
BALSAMUM TOLUTANUM.
}

\author{
Balsam of Tolu; F. Baume de Tolu; G. Tolubalsam.
}

Botanical Origin-Myroxylon Toluifera HBK. (Toluifera Batsamum Miller, Myrospermum toluiferum A. Rich.), ${ }^{1}$ an elegant and lofty evergreen tree with a straight stem, often as much as 40 to 60 feet from the ground to the first branch. It is a native of Venezuela and New Granada,-probably also of Ecuador and Brazil.

History - The first published account of Balsam of Tolu, is that of the Spanish physician Monardes, who in his treatise on the productions of the West Indies, which in its complete form first appeared at Seville in $1574,{ }^{2}$ relates how the early explorers of South America observed that the Indians collected this drug by making incisions in the trunk of the tree. Below the incisions they affixed shells of a peculiar black wax to receive the balsam, which being collected in a district near Cartagena called Tolu, took its name from that place. He adds that it is much esteemed both by Indians and Spaniards, that the latter bny it at a high price, and that they have lately brought it to Spain, where it is considered to be as good as the famous Balsam of Mecca.

A speoimen agreeing with this description, was given to Clusius in 1581 by Morgan, apothecary to Queen Elizabeth, but the drug was certainly not common till a much later period. In a price-list of drugs printed at Giessen in 1614, we find Balsamum Hispanicum and B. Indicum; and in a similar list emanating from the city of Basle in 1647, $B$. Indicum album, B. Peruvianum and B. siccum, - the last with the explanatory words-" trockner Balsam in der Kürbsen. ${ }^{3}$ Some of these names doubtless refer to the drug under notice.

As to the tree, of which Monardes figured a broken pod, leaflets of it marked 1758, exist in Sloane's herbarium. Humboldt and Bonpland saw it in several places in New Granada during their travels (17991804), but succeeded only in gathering a few leaves. Among recent collectors, Warszewiez, Triana, Sutton Hayes, and Seemann were successful only in obtaining leaves. Weir in 1863 was more happy, for by causing a large tree of nearly 2 feet diameter to be felled, he procured good herbarium specimens including pods, but no flowers. Owing to this tree having been much wounded for balsam, its foliage and fruits were singularly small and stunted, and its branehes overgrown with lichens.

That which botanists had failed to do, has been accomplished by an ornithologist, Mr. Anton Goering, who travelling in Venezuela to collect birds and insects, made it a special object at the urgent request of one of us (H.), to procure complete specimens of the Balsam of Tolu tree.

1 Professor Baillon is in favour of discarding the genus Mryroxylon for the older genus Toluifera, originally founded on very im. perfect materials but which recent investigatious have shown to be identical with it. Though the change of names may be justified by the strict rules of priority, we are of opinion that at present it would be fraught with more of inconvenience than advantage. ${ }^{2}$ II istoria de la cosas que se traen de nuestras Indias occidcntales, eap. del Balsamo
de Tolu.

3 The lists here referred to are Merlicinetariffs, and arc in the library of the British Museum, botund together in one volume $\left(\frac{777 . \text { c. }}{5}\right)$. They include Giessen (or Schwoinfurt?) 1614, Bremen 1644, Basle 1647, Rostock 1659, Quedlinburg 1665, Frankfor't on Main 1669 . 
By dint of much perseverance and by watching for the proper season, Mr. Goering obtained in December 1868, excellent flowering specimens and young fruits, and subsequently mature seeds from which plants have been raised in England, Ceylon and Java.

Extraction-The most authentic information we possess on this subject is derived from Mr. John Weir, plant collector to the Royal Horticultural Society of London, who when about to undertake a journey to New Granada in 1863, received instructions to visit the locality producing Balsam of Tolu. After encountering considerable diffculties, Mr. Weir succeeded in observing the manner of collecting the balsam in the forests near Plato, on the right bank of the Magdalena. Mr. Weir's information ${ }^{1}$ may be thus summarized:-

The balsam tree has an average height of 70 feet with a straight trunk, generally rising to a height of 40 feet before it branches. The balsam is collected by cutting in the bark two deep sloping notches, meeting at their lower ends in a sharp angle. Below this $V$-shaped cut, the bark and wood is a little hollowed out, and a calabash of the size and shape of a deep tea-cup is fixed. This arrangement is repeated, so that as many as twenty calabashes may be seen on various parts of the same trunk. When the lower part has been too much wounded to give space for any fresh incisions, a rude scaffold is sometimes erected, and a new series of notches made higher up. The balsam-gatherer goes from time to time round to the trees with a pair of bags of hide, slung over the back of a donkey, and empties into them the contents of the calabashes. In these bags the balsam is sent down to the ports, where it is transferred to the cylindrical tins in which it reaches Europe. The bleeding of the trees goes on for at least eight months of the year, causing then ultimately to become much exhausted, and thin in foliage.

In some districts, as we learn from another traveller, it is customary to let the balsam flow down the trunk into a receptacle at its base, formed of the large leaf of a species of Calathea.

From the observations of Mr. Weir, it appears that the balsam tree is plentifully scattered throughout the Montaña around Plato and other small ports on the right bank of the Magdalena. He states that he saw at least $1,500 \mathrm{lb}$. of the drug on its way for exportation. From another source, we know that it is largely collected in the valley of the Sinu, and in the forests lying between that river and the Cauca. None is collected in Venezuela.

Description-Balsam of Tolu freshly imported, is a light brown, slow-flowing resin, soft enough to be impressible with the finger, but not viscid on the surface. By keeping, it gradually hardens so as to be brittle in cold weather, but it is easily softened by the warmth of the hand. Thin layers show it to be quite transparent and of a yellowish brown hue. It has a very agreeable and delicate odour, suggestive of benzoin or vanilla, especially perceptible when the resin is warmed, or when its solution in spirit is allowed to evaporate on paper. Its taste is slightly aromatic with a barely perceptible acidity, though its alcoholic solution decidedly reddens litmus.

In very old specimens, such as those which during the last century reached Europe in little calabashes of the size and shape of an orange,

1 Journ. of the R. Hort. Soc., May 1864 ; Pharm. Journ. ri. (1865) 60. 
the balsam is brittle and pulverulent, and exhibits when broken a sparkling, crystalline surface. This old balsam is of a fine deep anıber tint and superior fragrance.

When balsam of Tolu is pressed between two warmed plates of glass so as to obtain it in a thin even layer, and then examined with a lens, it exhibits an abundance of crystals of cinnamic acid. Balsam of Tolu dissolves easily and completely in glacial acetic acid, acetone, alcohol, chloroform or solution of caustic potash; it is less soluble in ether, scarcely at all in volatile oils, and not in benzol or bisulphide of carbon. The solution in acetone is devoid of rotatory power in polarized light.

Chemical Composition-The balsam consists partly of an amorphous resin, not soluble in bisulphide of carbon, which is supposed to be the same as the dark resin precipitated by the bisulphide from balsain of Peru. Scharling (1856) assigned the formula $\mathrm{C}^{18} \mathrm{H}^{20} \mathrm{O}^{5}$, to that part of the balsam which is soluble in potash.

If Tolu balsam is boiled with water, it yields to it an acid which according to Carles ${ }^{1}$ is simply Cinnamie Acid, and not as was formerly supposed, a mixture of this acid with benzoic acid. The acid may also be removed by boiling bisulphide of carbon.

Upon distilling the balsam with water, it affords 1 per cent. of Tolene, $\mathrm{C}^{10} \mathrm{H}^{16}$, boiling at about $170^{\circ} \mathrm{C}$. This liquid rapidly absorbs oxygen from the air. By destructive distillation, the balsam affords the same substances as those obtainable from balsam of Peru, among which Phenol and Styrol have been observed. Cinnameïn and styracin are not present in balsam of Tolu.

Commerce-The balsam is exported from New Granada, packed in cylindrical tins holding about $10 \mathrm{Hb}$. each. The quantity shipped from Santa Marta in 1870 was 2,002 fb. ; in 1871, 2,183 tb. ; in 1872, 1,206 $\mathrm{tb}$.

Uses-Balsam of Tolu has no important medicinal properties. It is chiefly used as an ingredient in a pleasant-tasting syrup and in lozenges.

Adulteration-We have twice met with spurious balsam of Tolu, but in neither instance did the fraudulent drug bear any great resemblance to the genuine.

Colophony which might be mixed with the balsam, can be detected by bisulphide of carbon which dissolves it, but removes from the pure balsam only the cinnamic acid.

\section{BALSAMUM PERUVIANUM.}

\section{Balsamum Indicum nigrum; Balsam of Peru; F. Baume de Péron, Baume de San Salvador; G. Perubalsam.}

Botanical Origin-Myroxyton Pereirce Klotzsch (Myrospermum Pereirce Royle), ${ }^{2}$ a tree attaining a height of about 50 feet, and throwing out spreading, ascending branches at 6 to 10 feet from the ground. ${ }^{3}$

1 Journ. de Pharm. xix. (1874) 112.

2 The name "Myrospermum of Sonsonate" given to the tree provisionally by Percira (1850) because he could not identify his very poor specimens with any known spccics, has been translated "Myroxylon Sonsonatense," and used in some pliarmacological works; but it is not admitted by botanists.

3 We are not yet prepared to accept the opiniou of Prof. Baillon, that M. Pereirce is

$\mathrm{N} 2$ 
It is found in a small district of the State of Salvador in Central America (formerly part of Guatemala), lying between $13^{\circ} \cdot 35$ and $14^{\circ} \cdot 10$ N. lat., and $89^{\circ}$ and $89^{\circ} .40 \mathrm{~W}$. long., and known as the Costa del Balsamo or Balsam Coast. The trees grow naturally in the dense forests; those from which the balsam is obtained are, if in groups, sometimes enclosed, in other cases only marked, but all have their distinct owner's. 'They are occasionally rented for a term of years, or a contract is made for the produce of a certain number.

The principal towns and villages around which balsam is produced, are the following :-Juisnagua, Tepecoyo or Coyo, Tamanique, Chiltiuapan, Talnique, Jicalapa, Teotepeque, Comasagua and Jayaque. All the lands on the Balsam Coast are Indian Reservation Lands.

The Balsam of Peru tree was introduced in 1861 into Ceylon, where it flourishes with extraordinary vigour.

History-As in the case of Balsam of Tolu, it is to Monardes of Seville that we are indebted for the earliest description of the drug under notice. In a chapter headed Del Balsamo, ', he states that at the time he wrote $(1565)$ the drug was not new, for that it had been received into medicine immediately after the discovery of New Spain. As the conquest of Guatemala took place about 1524, we may conclude that the balsam was introduced into Europe soon afterwards.

Monardes further adds, that the balsam was in such high estimation that it sold for 10 to 20 ducats ( $£ 410$ s. to $£ 9$ ) the ounce; and that when taken to Rome, it fetched even 100 ducats for the same quantity. The inducement of such enormous prices brought plenty of the drug to Europe, and its value, as well as its reputation, was speedily reduced.

The description given by Monardes of extracting the balsam by boiling the chopped wood of the trunk and branches, raises a doubt as to whether the drug he had in view was exactly that now known; but he never was in America, and may have been misinformed. Evidence that our drug was in use, is afforded by Diego Garcia de Palacio, who in his capacity of Auditor of the Royal Audiencia of Guatemala, wrote an account to Philip II. king of Spain, describing the geography and productions of this portion of his majesty's dominions. In this interesting document, which bears date 1576 and has only recently been published, ${ }^{2}$ Palacio tells the king of the great balsam trees of Guaymoco and of the coasts of Tonala, ${ }^{3}$ and of the Indian method of promoting the exudation of the balsam by scorching the trunk of the tree. Prior to the conquest of the country by the Spaniards and for a short time after, balsam formed part

specifically identical with $M$. Toluifera, though we admit thcy are very closely related. According to our observations, the two trees exhibit the following differences :-

\section{Toluifera.}

Trunk tall and bare, branching at 40 to 60 feet from the ground, and forming a roundish crown of foliage.

Racemes dense, 3 to $4 \frac{1}{2}$ inches long.

Legume scarccly narrowed towards the stalk-end.

1 Occurring in the first book of the work quoted at p. 177 notc 2 , wlich was published separately at Seville in 1565 .

2 Squicr, Documents and Relations concerning the Diseovery and Conquest of America, New York, 1859.
M. Pereirco.

Trunk throwing off ascending branches at 6 to 10 feet from the ground.

Racemes loose, 6 to 7 inches long.

Lcgume much narrowed towards the stalk-end.

3 The ancicnt name of the Balsam Coast; Guaymoco is a village between Sonsonate and San Salvador. The pillars of wood of Myy'oxylon in the church, are perhaps, says Squier, the very samc as those mentioned with admiration by Palacio. 
of the tribute paid to the Indian chiefs of Cuscatlan, to whom it was presented in curiously ornainented earthen jar's.

The idea of great virtues attaching to the balsam, is shown by the fact that in consequence of representations made by missionary priests in Central America, Pope Pius V. granted a faculty to the Bishops of the Indies, permitting the substitution of the balsam of Guatemala for that of Egypt, in the preparation of the chrism used in the Roman Catholic Church. This document bearing date August 2, 1571, is still preserved in the archives of Guatemala. ${ }^{1}$

In the 16th century, the balsam tree grew in the warm regions of Panuco and Chiapan in Mexico, whence it was introduced into the famous gardens of Hoaxtepec near the city of Mexico, described by Cortes in his letter to Charles V. in $1522 .{ }^{2}$

A rude figure of the tree, certainly a Myroxylon and probably the species under notice, was published in the Thesaurus Rerum Medicarum. Novce Hispanice of Hernandez. ${ }^{3}$

The exports of Guatemala being shipped chiefly at Acajutla, were formerly carried to Callao, the port of Lima, whence they were transmitted to Spain. This circumstance led to the balsam acquiring the misleading name of Peru, and in part to the notion that it was a production of South America.

The history of Balsam of Peru was much amplified by a communication of the late Dr. Charles Dorat of Sonsonate, Salvador, in 1860 to the American Journal of Pharmacy, and by still further information accompanied by drawings and specimens, transmitted to one of us in $1863 .{ }^{4}$

Extraction of the Balsam-Early in November or December, or after the last rains, the stems of the balsam trees are beaten with the back of an axe, a hammer or other blunt instrument, on four sides, a similar extent of bark being left unbruised between the parts that are beaten. The bark thus injured soon cracks in long strips, and may be easily pulled off. It is sticky as well as the surface below it, and there is a slight exudation of fragrant resin but not in sufficient quantity to be worth collecting. To promote an abundant flow, it is customary five or six days after the beating, to apply lighted torches or bundles of burning wood to the injured bark, whereby the latter becomes charred. About a week later, the bark either drops or is taken off, and the stem commences to exude the balsam. This is collected by placing rags (of any kind or colour), so as entirely to cover the bare wood. As these rags in the course of some days become saturated with the exudation, they are collected, thrown into an earthen vessel of water, and gently boiled and stirred until they appear nearly clean, the balsam separating and sinking to the bottom. This process goes on for some hours, the exhausted rags being from time to time taken out, and fresh ones thrown in. As the rags are removed they are wrung out in a sort of rope bag, and the balsam so saved is added to the stock. When the boiler has cooled, the water is decanted, and the balsam is poured into tecomates or gourds, ready for the market.

The Indians work a tree a second year, by bruising the bark that was left untouched the previous year. As the bark is said to be renewed

${ }^{1}$ It may be found in extenso in the original Latin in Pharm. Journ. ii. (1861) 447

:Clavigero, Hist. of Mcxico, English trars., i. (1787) pp. 32.379.
3 Rome 1628 ; 2nd ed. 1651.

4 Hanbury in Pharm. Journ. v. (1864) 
in the short space of two years, it is possible to obtain from the same tree an annual yield of balsam for many years, provided a few years of rest be occasionally allowed. Clay or earth is sometimes smeared over the bared wood.

The trees sometimes exude spontaneously, a greenish gum-resin of slightly bitter taste, but totally devoir of balsamic odour. It has been analysed by Attfield (see opposite page).

Secretion of the Balsam - No observations have yet been made as to the secretion of the balsam in the wood, or the part that is played by the operation of scorching the bark. Neither the unscorched bark nor the wood, as we have received them, possesses any aromatic odour.

The old accounts speak of a very fragrant resin, far more valuable than the ordinary balsam, obtained by incisions. We have made many inquiries for it, but without the least success. Such a resin is easily obtainable from the trunk of $M$. Toluifera.

Description-Balsam of Peru is a liquid having the appearance of molasses but rather less viscid. In bulk it appears black, but when examined in a thin layer, it is seen to be of a deep orange brown and perfecrly transparent. It has a balsamic, rather smoky odour, which is fragrant and agreeable when the liquid is smeared on paper and warmed. It does not much affect the palate, but leaves a disagreeable burning sensation in the fauces.

The balsam has a sp. gr. of $1 \cdot 15$ to $1 \cdot 16$. It may be exposed to the air for years without undergoing alteration or depositing crystals. It is not soluble in water, but yields to it a little cinnamic and traces of benzoic acid ; from 6 to 8 parts of crystallized carbonate of sodium are required to neutralize 100 parts of the balsam. It is but partially and to a small extent dissolved by dilute alcohol, benzol, ether or essential or fatty oils, not at all by petroleum-ether. The balsam mixes readily with glacial acetic acid, anhydrous acetone, absolute alcohol or chloroform. Its rotatory power is very insignificant.

Chemical Composition-The peculiar process by which balsam of Peru is obtained, causes it to contain a variety of substances not found in the more natural resin of Myroxylon Toluifera; hence the two drugs though derived from plants most closely allied, possess very different properties.

Three parts of the balsam mix readily with one part of bisulphide of carbon, yet a further addition of the latter will cause the separation of a brown flocculent resin. If the balsam be mixed with thrice its weight of bisulphide, a coherent mass of dark resin, sometimes amounting to about 38 per cent. of the balsam, is precipitated. The bisulphide of carbon forms then a perfectly transparent brown liquid. If this solution is shaken with water, the latter rernoves Cinnamic and Benzoic acids. To separate them, ammonia is cautiously added, yet not in excess. ${ }^{1}$ The solution of cinnamate and benzoate thus obtained and duly concentrated, yields both these acids in white crystals on addition of acetic or hydroclloric acid.

The resin separated by means of bisulphide of carbon as above stated, is a black brittle amorphous mass, having no longer the specific odour of

1 By saturating the acid aqueous liquid with ammonia, it assumes a transicnt bright yellow huo; an excess of ammonia trans-

forms the whole mixture into an emulsion, from which the cinnameïn again separates but imperfectly. 
the balsam. It is soluble in caustic alkalies, also in alcohol; the solution in the latter which may be considerably purified by charcoal, reddens litmus, and is abundantly precipitated by an alcoholic solution of neutral acetate of lead. Kachler (1869) by melting this resin with potash obtained about $\frac{2}{3}$ of its weight of proto-catechuic acid. ${ }^{1}$ By destructive distillation, it furnishes benzoic acid, styrol $\mathrm{C}^{8} \mathrm{H}^{8}$, and toluol $\mathrm{C}^{7} \mathrm{H}^{8}$.

As to the solution obtained with bisulphide of carbon, it forms after the bisulphide has evaporated, a brownish aromatic liquid of about $1.1 \mathrm{sp}$. gr., termed Cinnameïn. This substance may also be obtained by distillation, yet less easily, on account of its very high boiling point, about $300^{\circ} \mathrm{C}$.

Cinnameïn, $\mathrm{C}^{16} \mathrm{H}^{14} \mathrm{O}^{2}$, is resolved by concentrated caustic lye into benzylic alcohol, $\mathrm{C}^{7} \mathrm{H}^{8} \mathrm{O}$, and cinnamic acid, $\mathrm{C}^{9} \mathrm{H}^{8} \mathrm{O}^{2}$, whence it follows that cinnameïn is Benzylic Cinnamate. This is, according to Kraut (1858, $1869,1870)$ and to Kachler $(1869,1870)$, the chief constituent of the balsam. The former chemist obtained from it nearly 60 per cent. cinnameïn. Kachler assigns to the balsam the following composition : 46 per cent. of cinnamic acid, 32 of resin, 20 of benzylic alcohol. These latter figures however are not quite consistent: 46 parts of cinnamic acid (equivalent $=148$ ) would answer to 73 parts of benzylic cinnamate; and 20 parts of benzylic alcohol require on the other hand only (equivalent $=108$ ) 27.4 parts of cinnamic acid in order to form benzylic cinnamate (equivalent $=238$ ).

Benzylic cinnamate prepared as above stated, is a thick liquid, miscible both with ether or alcohol, not concreting at $-12^{\circ} \mathrm{C}$., boiling at $305^{\circ} \mathrm{C}$., yet under ordinary circumstances not without decomposition. By exposure to air, it slowly acquires an acid reaction; by prolonged action of potash, especially in an alcoholic solution, toluol is also formed. In this process, cinnamate of potassium finally forms a crystalline mass, while an oily mixture of benzylic alcohol and toluol, the so-called "Peruvin," constitutes the liquid part of the whole.

Grimaux (1868) has artificially prepared benzylic cinnamate by heating an alkaline cinnamate with benzylic chloride. Thus obtained, that substance forms crystals, which melt at $39^{\circ} \mathrm{C}$, and boil at 225 to $235^{\circ} \mathrm{C}$. They consequently differ much from cinnameïn.

Delafontaine (1868) is of the opinion, that cinnamein contains besides benzylic cinnamate, cinnamylic cinnamate $\mathrm{C}^{36} \mathrm{H}^{32} \mathrm{O}^{4}$, the same substance as described under the name of styracin, in the article Styrax liquida. He states that he obtained benzylic and cinnamylic alcohol when he decomposed cinnameïn by an alkali. The two alcohols however were separated only by fractional distillation.

From the preceding investigations it must be concluded, that the bark of the tree contains resin and probably benzylic cinnamate. The latter is no doubt altered by the process of collecting the balsam, which is followed on the Balsam Coast. To this are probably due the free acids in the balsam and its dark colour.

Another point of considerable interest is the fact, that the tree exudes a gum-resin, containing according to Attfield $77 \cdot 4$ per cent. of resin, ${ }^{2}$ which is non-aromatic and devoid of cinnamic acid, and therefore entirely distinct from balsam of Peru.

\footnotetext{
1 Many other resins as benzoin, guaiacum, dragon's blood, myrrh, are capable of affording the same acid.
}

2 Pharm. Journ. v. (1864) 248. 
Commerce-The balsam is shipped chiefly at Acajutla. It used formerly to be packed in large earthenware jars, said to be Spanish wine-jars, which, wrapped in straw, were sewer up in raw hide. These packages have of late been superseded by metallic drums, which have the advantage of being much less liable to breakage. We have no recent statistics as to the quantity exported from Central America.

Uses-Occasionally prescribed in the form of ointment as a stimulating application to old sores, sometimes internally for the relief of asthrna and chronic cough. It is said to be also employed for scenting soap.

\section{Other sorts of Balsam of Peru.}

The value anciently set upon balsam for religious and medicinal uses, led to it being extracted from trees no longer employed for the purpose; and many of the products so obtained have attracted the attention of pharmacologists. ${ }^{1}$ Parkinson writing in 1640 observes that- "there have beene divers other sorts of liquours, called Balsamum for their excellent vertues, brought out of the West Indies, every one of which for a time after their first bringing was of great account with all men and bought at great prices, but as greater store was brought, so did the prices diminish and the use decay ..."

In a treatise on Brazil written by a Portuguese friar about 1570$1600,{ }^{2}$ mention is made of the "Cabueriba" (Cabure-iba), from which a much-esteemed balsam was obtained by making incisions in the stem, and absorbing the exudation with cotton wool, somewhat in the same way as Balsam of Peru is now collected in Salvador. This tree is Myrocarpus frondosus Allem., now called Cabriuva preta. The genus is closely allied to Myroxylon.

A fragrant balsamic resin is likewise collected, though in but very small quantity, from Myroxylon peruiferum Linn. f, a noble tree of New Granada, Ecuador, Peru, Bolivia, and Brazil. A fine sample of this substance, accompanied by herbarium and other specimens, was presented to one of us (H.) by Mr. J. Correa de Méllo of Campinas (Brazil); it is a resin having a general resemblance to Balsam of Tolu, but of somewhat deeper and redder tint, and greater hardness. Pressed between two slips of warmed glass, it does not exhibit any crystals.

In Salvador, the name Balsamo blanco (White Balsam) is applied to the soft resin contained in the large ducts of the legume of Myroxylon Pereirce. This when pressed out, forms a golden yellow, semi-fluid, granular, crystalline mass, hardening by age, having a rather unpleasant odour suggestive of melilot. Stenhonse (1850) obtained from it the neutral resin Myroxocarpin $\mathrm{C}^{24} \mathrm{H}^{34} \mathrm{O}^{3}$, in thin colourless prisms, an inch or more in length. We have succeeded in extracting it directly from the pods. This White Balsam, which is distinctly mentioned in the letter of Palacio in 1576 (see p. 180), is a scarce and valuable article, never prepared for the market. A large jar of it was sent to Pereira in $18500^{3}$

Another fragraut oleo-resin which has doubtless been confounded with that of a Myroxylon, is obtained in Central America from Liquidambar styracifua L., either by incision or by boiling the bark.

1 Guibourt, Hist. des Drog. iii. (1850) 440.

2 Purchas, His Pitgrimes, iv. (1025) 1308.

3 Pharm. Journ. x. (1851) 286. 


\section{SEMEN BONDUCELLEE.}

Scmon Guilandince; Bonduc Seeds, Grcy Nicker Seeds or Nuts; F. Graincs de Bonduc ou du Cniquier, Pois Quéniques, Pois Guénic.

Botanical Origin-Casalpinia Bonducella Roxb. (Guilandina Bonducclla L.), a prickly, pubescent, climbing shrub of wide distribution, occurring in Tropical Asia, Africa and America, especially near the sea. The compressed, ovate, spiny legume is 2 to 3 inches long, and contains one or two, occasionally three or four, hard, grey, globular seeds.

The plant is often confounded with C. Bonduc Roxb., a nearly allied but much rarer species, distinguished by being nearly glabrous, having leaflets very unequal at the base, no stipules, erect bracts, and yellow seeds.

History-The word Bunduk, occurring in the writings of the Arabian and Persian physicians, mostly signifies hazel-nut. ${ }^{1}$ One of these authors, Ibn Baytar ${ }^{2}$ who flourished in the 13th century, further distinguished a drug called Bunduk Hindi (Indian Hazel-nut), giving a description which indicates it plainly as the seed under notice. Both Bundute and Bunduk Hindi are enumerated in the list of drugs of Noureddeen Mohammed Abdullah Shirázy, ${ }^{3}$ physician to the Mogul emperor Shah Jehan, A.D. 1628-1661.

The pods of C. Bonducclla were figured by Clusius in 1605, under the name of Lobus ectinodcs, and the plant both by Rheede ${ }^{4}$ and Rumphius. Piso and Marcgraf (1648) noticed it in Brazil and gave some account of it with a bad woodcut, under the designation of Inimbóy (now Inimboja), or in Portuguese Silva do Praya.

In recent times, Bonduc seeds have been employed on account of their tonic and antiperiodic properties by numerous European practitioners in the East, and have been included in the Pharmacopocia of India, 1868.

Description-The seeds are somewhat globular or ovoid, a little compressed, $\frac{4}{10}$ to $\frac{8}{10}$ of an inch in diameter and weighing 20 to 40 grains. They are of a blueish or greenish grey tint, smooth yet marked by slightly elevated horizontal lines of a darker hue. The unbilicus is surrounded by a small, dark brown, semilunar blotch opposite the micropyle. The hard shell is from $\frac{1}{25}$ to $\frac{2}{25}$ of an inch thick, and contains a white kernel, representing from 40 to 50 per cent. of the weight of the seed. It separates easily from the shell, and consists of the two cotyledons and a stout radicle. When a seed is soaked for some hours in cold water, a very thin layer can be peeled from the surface of the testa. The kernel is bitter, but with the taste that is cormmon to most seeds of the family Leguminosce.

Microscopic Structure-The outer layer of the testa, the epidermis above alluded to, is composed of two zones of perpendicular, closely packed cells, the outer measuring about $130 \mathrm{mkm}$., the inner

1 The word also means a little ball or a round stone.

2 Sontheimer's translation i. 177.

3 Ulfaz Udwiych, translated by Gladwin, 1793. No. 542. 551 .

4 Hort. Malab. ii. (1679) tab. 22, sub nom. Caretti. 
$100 \mathrm{mkm}$. in length and only 5 to $7 \mathrm{mkm}$. in diameter. The walls of these cylindrical cells are thickened by secondary deposits, which in transverse section show usually four or more channels running down nearly perpendicularly throngh the whole cell.

The spongy parenchyme which is covered by this very distinct outer layer, is made up of irregular, ovate, subglobular or somewhat elongated cells with large spaces between them, loaded with brown masses of tannic matter, assuming a blackish hue when touched with perchloride of iron. The thick walls of these cells frequently exhibit, chiefly in the inner layers, undulated ontlines. The tissue of the cotyledons is composed of very large cells, swelling considerably in water and containing some mucilage (as may be ascertained when thin slices are examined in oil), small starch granules, fatty oil, and a little albuminous matter.

Chemical Composition-According to the medical reports alluded to in the Pharmacopeia of India (1868), Bonduc seeds, and still more the root of the plant, act as a powerful antiperiodic and tonic.

The active principle has not yet been adequately examined. It may perhaps occur in larger proportion in the bark of the root, which is said to be more efficacious than the seeds in the treatment of intermittent fever. ${ }^{\text {. }}$

In order to ascertain the chemical nature of the principle of the seeds, one ounce of the kernels ${ }^{2}$ was powdered and exhausted with slightly acidulated alcohol. The solution after the evaporation of the alcohol was made alkaline with caustic potash, which did not produce a precipitate. Ether now shaken with the liquid, completely removed the bitter matter and yielded it in the form of an amorphous white powder, devoid of alkaline properties. It is sparingly soluble in water, but readily in alcohol, forming intensely bitter solutions; an aqueous solution is not precipitated by tannic acid. It produces a yellowish or brownish solution with-concentrated sulphuric acid, which acquires subsequently a riolet hue. Nitric acid is without manifest influence. From these experiments, we may infer that the active principle of the Bonduc seed is a bitter substance not possessing basic properties.

Uses-The powdered kernels either per se, or mixed with black pepper (Pulvis Bonducelloe compositus $\mathrm{Ph}$. Ind.), are employed in India against intermittent fevers and as a general tonic.

The fatty oil of the seeds is sometimes extracted and used in India; it was shown at the Madras Exhibitions of 1855 and 1857.

\section{LIGNUM HÆMATOXYLI.}

Lignum Campechianum v. Campcseanum; Logwood, Pcachwood; F. Bois de Campèche, Bois d'Inde; G. Campecheholz, Blauholz.

Botanical Origin-Hwmatoxylon Campeetianum L., a spreading tree of moderate size, seldom exceeding 40 feet in height, native of the bay of Campeachy, Honduras and other parts of Central America. It

1 Waring, Bazaar Mcdicines, Travancoro,

Kindly furnished us by Dr. Waring. 1860. 18. 
was introduced into Jamaica by Dr. Barham ${ }^{1}$ in 171.5, and is now completely maturalized in that and other of the West India Islands.

History-Hernan Cortes in his letter to the Emperor Charles V. giving an account of his expedition to Honduras in $1525,{ }^{2}$ refers to the Indian towns of Xiculango and 'Tabasco as carrying on a trade in cacao, cotton cloth, and colours for dyeing,-in which last phrase there may be an allusion to logwood. We have songht for some more definite notice of the wood in the Historia de las Indias of Oviedo, ${ }^{3}$ the first chronicler of America, but without much success.

Yet the wood must have been introduced into England in the latter lialf of the 16th century, for in 1581, an act of parliament ${ }^{4}$ was passed abolishing its use and ordering that any found should be forfeited and burned. In this act, the obnoxious dye is described as " a certain kind of ware or stuff called Logwood alias Blockwood . . . of late years . . brought into this realm of England." The object of this measure was to protect the public against the bad work of the dyers who, it seems, were unable at that period to obtain durable colours by the use of logwood. Eighty years later, the art of dyeing had so far improved that logwood was again permitted, ${ }^{5}$ the colours produced by it being declared as lasting and serviceable as those made by any other sort of dyewood whatsoever.

The wood is mentioned by De Laet (1633) as deriving its name from the town of Campeachy, whence says he, it is brought in great plenty to Europe. ${ }^{6}$

As a medicine, logwood was not employed until shortly before the year 1746, when it was introduced into the London Pharmacopœia under the name of Lignum tinctile Campechense.

Description-The tree is fit to be felled when about ten years old; the dark bark and the yellowish sap-wood are chipped off, the stems cut into logs about three feet long, and the red heart-wood alone exported. By exposure to air and moisture, the wood acquires externally a blackish red colour; internally it remains brownish red. It splits well, although of a rather dense and tough texture.

The transverse section of a piece of logwood, exhibits to the naked eye a series of very narrow concentric zones, formed by comparatively large pores, and of small parenchymatous circles separated by the larger and darker rings of the proper woody tissue. The numerous medullary rays are visible only by means of a lens.

For use in pharmacy, logwood is always purchased in the form of chips, which are produced by the aid of powerful machinery. The chips have a feeble, seaweed-like odour, and a slightly sweet, astringent taste, better perceived in a watery decoction than by chewing the dry wood, which however quickly imparts to the saliva its brilliant colour.

Microscopic Structure.-Under a high magnifying power, the concentric zones are seen to run not quite regularly round the centre, but

1 Horlus Americanus, Kingston, Jamaica, 1794. 91.

${ }_{2}$ Fifth Letter of IIernan Cortes to the Emperor Charles V., Lond. (Hakluyt Society) 1868. 43.

3 The first edition bears date 1535 . We have used the modern one of Madrid, $1851-55,4^{\text {to }}$, and may refer in particular to tom. i. lib. ix. c. 15 , iii. lib. xxxi. c. 8 and c. 11.

423 Eliz. c. 9.

5 13-14 Car. ii. c. 11. sect. 26 (A.D. 166?), by which the act of Elizabeth was repealed.

${ }^{6}$ Novus Orbis, 1633, 274, and 265 ? 
in a somewhat undulating namer, because they do not correspond, as in our indigenous woods, to regular periods of annual growth. 'The vascular bundles contain only a few vessels, and are transversely united by small lighter parenchymatous hands. 'The latter are made up of large, cubic, elongated or polygonal cells, each loaded with a crystal of oxalate of calciun. The large punctuated vessels having frequently $150 \mathrm{mkm}$. diameter, are surrounded by this woody parenchyme, while the prevailing tissue of the wood is composed of densely packed prosenchyme, consisting of long cylindrical cells (libriform) witl thick, dark red-brown walls having small pores.

The medullary rays are of the usual structural character, running transversely in one to three straight rows; in a longitudinal section, the single rays show from 4 to 40 rows succeeding each other perpendicularly. No regular arrangement of the rays is obvious in a longitudinal section made in a tangential direction. The colouring matter is chiefly contained in the walls of the ligneous tissue and the vessels, and sometimes occurs in crystals of a greenish hue within the latter, or in clefts of the wood.

Chemical Composition-Logwood was submitted to analysis by Chevreul as early as the year $1810,{ }^{1}$ since which period all contributions to a knowledge of the drug, refer exclusively to its colouring principle Homatoxylin, which Chevreul obtained in a crystallized state and called Hématine. The very interesting properties of this substance have been chiefly examined by Erdmann (1842) and by O.Hesse(1858-59).

Erdmann obtained fron logwood 9 to 12 per cent. of crystallized hæmatoxylin, which he showed to have the formula $\mathrm{C}^{16} \mathrm{H}^{14} \mathrm{O}^{6}$ : In a pure state it is colourless, crystallizing with 1 or with 3 equivalents of water, and is readily soluble in hot water or in alcohol, but sparingly in cold water or in ether. It has a persistent sweet taste like liquorice. The crystals of hæmatoxylin acquire a red colour by the action of sunlight, as likewise their aqueous solution. They are decomposed by ozone but not by pure and dry oxygen. In presence of alkalies, hæmatoxylin exposed to the air, quickly yields dark purplish violet solutions, which soon acquire a yellowish or dingy brownish colour; hence in analytical chemistry hæmatoxylin is used as a test for alkalies.

By the combined action of ammonia and oxygen; dark violet crystalline scales of Hcemateïn, $\mathrm{C}^{16} \mathrm{H}^{12} \mathrm{O}^{6}+3 \mathrm{H}^{2} \mathrm{O}$, are produced. They show a fine green hue, which is also very commonly observable on the surface of the logwood chips of commerce. Hæmatein may again be transformed into hæmatoxylin by means of hydrogen or of sulphurous acid.

Hæmatoxylin separates protoxide of copper from an alkaline solution of the tartrate, and deviates the ray of polarized light to the right hand. It is not decomposed by concentrated hydrochloric acid; by melting hæmatoxylin with potash, pyrogallol (pyrogallic acid $\mathrm{C}^{6} \mathrm{H}^{6} \mathrm{O}^{3}$ ) is obtained. Alum and the salts of lead throw down precipitates from solutions of hrmatoxylin, the latter being of a blueish-black colour. Logwood affords upon incineration $3 \cdot 3$ per cent. of ash.

The colouring niatter being abundantly soluble in boiling water, an Extract of Logwood is also prepared on a large scale. It occurs in commerce in the form of a blackish brittle mass, taking the form of the wooden chest into which it is put while soft. The extract shares the 1 Annales de Chimic, lxxxi. (1812) 128. 
chemical properties of hæmatoxylin and hæmateïn: whether it also contains gum requires investigation.

Production and Commerce-The felling and shipping of logwood in Central America have been described by Morelet, ${ }^{\perp}$ who states that in the woods of Tabasco and Incatan the trade is carried on in the most irrational and reckless manner. By advancing money to the natives, or by furnishing them with spirits, arms, or tools, the proprietors of the woods engage them to fell a number of trees in proportion to their debts. This is done in the dry season, the rainy period being taken for the shipment of the logs, which are conveyed chiefly to the island of Carmen in the Laguna de Terminos in South-western Yucatan, and to Frontera on the mouths of the Tabasco river, at which places European ships receive cargoes of the wood.

Four sorts of logwood are found in the London market, namely Campeachy, quoted ${ }^{2}$ at $£ \$ 10$ s. to $£ 910$ s. per ton ; Honduras $£ 610$ s, to $£ 615 s$; St. Domingo £5 $15 s$. to $£ 6$; Jamaica £5 $2 s$. 6 d. to $£ 510$ s. The imports into the United Kingdom were valued in 1872 at $£ 233,035$. The quantities imported during that and the previous three years were as follows:-
1869 50,458 tons.
1870
62,187 tons.
1871
39,346 tons.
$18 \% 2$
46,039 tons.

Of the last mentioned quantity, the British West India Islands supplied 32,792 tons.

Uses-Logwood in the form of decoction is occasionally administered in chronic diarrhœa, and especially in the diarrhœa of children. Cases have occurred in which its use has been followed by phlebitis. Its employment in the art of dyeing is far more important.

Adulteration-The woods of several species of Cosalpinia imported under the name of Brazil Wood and used for dyeing red, bear an external resemblance to logwood, with which it is said they are sometimes mixed in the forn of chips. They contain a crystallizable colouring principle called Brasilin, $\mathrm{C}^{22} \mathrm{H}^{20} \mathrm{O}^{7}$, which affords with alkalies red and not blueish or purplish solutions. Brasilin may be considered as a compound of hæmatoxylin with phenol $\mathrm{C}^{6} \mathrm{H}^{6} \mathrm{O}$, and indeed yields trinitrophenylic acid (picric acid) when boiled with nitric acid, while hæmatoxylin yields oxalic acid only. The best source for brasilin is the wood of Cosalpinia Sappan L., a tree of the East Indies, well known as Brazil Wood, Lignum Brasile, Verzino of the Italians, an important object of commerce during the middle ages.

\section{FOLIA SENN $A$.}

\section{Senna Leaves; F. Fenilles de Séné; G. Sennesblätter.}

Botanical Origin-The Senna Leaves of commerce are afforded by two species of Cassia ${ }^{3}$ belonging to that section of the genus which I Voyage dans l'Amérique centrale, l'ile de Cuba, et le Yucatan, Paris 1857.

2 Publie Ledger, 28 Feb. 1874.

3 Some writers have removed these plant. from Cassic to a separate geuus named Senna, but such subdivision is repudiated by the prineipal botanists. The intricate synonymy of the senna plants has been well worked out by J. B. Batka in his memoir en-

titled Monographie der Cassien Gruppe Senna (Prag, I866), of which we have made free use. We have also had the advantage of the recent Revision of the Genus Cassia by Bentham (Linn. Trans., Xxvii. 1871. 503) and of the labours of Oliver on the same subject in his Flora of Tropieal Africa, ii.
(1871) 268-282. 
is distinguished by having leaves without glands, axillary racemes elongating as inflorescence advances, membranaceous bracts which in the young raceme conceal the flower buds but drop off during flowering, and a short, broad, llat leguine.

The senna plants are low perennial bushy shrubs, 2 to 4 feet high, having pari-pinnate leaves with leaflets unequal at the base, and yellow flowers. The pods contain 6 or inore seeds in each, suspended on alternate valves by long capillary funicles. These run towards the pointed end of the seed, but are curved at their attachment to the hilum just below. 'The seeds are compressed and of an obovate-cuneate or oblong form, beaked at the narrower end. ${ }^{1}$

The species in question are the following:-

1. Cassia acutifolia Delile ${ }^{2}$-a shrub about 2 feet high, with pale subterete or obtusely angled, erect or ascending branches, occasionally slightly zigzag above, glabrous at least below. Leaves usually 4-5-jugate; leaflets oval or lanceolate, acute, mucronate, usually more or less distinctly puberulous or at length glabrous, pale or subglaucous at least beneath, subsessile. Stipules subulate, spreading or reflexed, 1-2 lines long. Racemes axillary, erect, rather laxly many-flowered, usually. considerably exceeding the subtending leaf. Bracts membranous, ovate or obovate, caducous. Pedicels at length 2-3 lines. Sepals obtuse, membranous. Two of the anterior anthers much exceeding the rest of the fertile stamens. Legume flat, very broadly oblong, but slightly curved upwards, obliquely stipitate, broadly rounded at the extremity with a minute or obsolete mucro indicating the position of the style on the upper edge; $1 \frac{1}{2}-2 \frac{1}{4}$ inches long, $\frac{3}{4}-1$ inch broad; valves chartaceous, obsoletely or thinly puberulous, faintly transverse-veined, unappendaged. Seeds obovate-cuneate, compressed; cotyledons plane, extending the large diameter of the seed in transverse section. ${ }^{3}$

The plant is a native of many districts of Nubia (as Sukkot, Mahas, Dongola, Berber), Kordofan and Sennaar; grows also in Timbuktu and Sokoto, and is the source of Alexandrian Senna.

2. C. angustifolia Vahl ${ }^{4}$-This species is closely related to the preceding, the general description of which is applicable to it with the following exceptions. In the present plant the leaflets, which are usually 5-8-jugate, are narrower, being oval-lanceolate, tapering from the micldle towards the apex; they are larger, being from 1 to nearly 2 inches long, and are either quite glabrous or furnished with a very scanty pubescence. The legume is narrower (7-8 lines broad), with the base of the style distinctly prominent on its upper edge.

The plant abounds in Yemen and Hadramaut in Southern Arabia; it is also found on the Somali coast, in Sind and the Punjab. In some parts of India it is now cultivated for medicinal use.

The uncultivated plant of Arabia supplies the so-called Bombay Senna of commerce, the true Senna Mekki of the East. The cultivated and more luxuriant plant, raised originally from Arabian seeds, furnishes the Tinnevelly Senna of the drug market.

1 On the structure of the seed, see Batka, Pharm. Journ. ix. (1850) 30.

2 Synonyms-C. Senna $\beta$. Linn.; C. lanceolata Nectoux; C. lenitiva Bisch.; Sennu acutifolia Batra.
3 We borrow the above description from Prof. Oliver.

4 Synonyms-C. lanceolata Roxb.; C. elongata Lem. Lis.; Senna officinalis Roxb.; S. angustifolio Batta. 
History-According to the elaborate researches of Carl Martius, ${ }^{1}$ a knowledge of senna cannot be traced back earlier than the time of the Elder Serapion, who flourished in the 9th or 10th century; and it is in fact to the Arabian physicians that the introduction of the drug to Western Europe is due. Isaac Judæus ${ }^{2}$ who wrote probably about A.D. 850-900 and who was a native of Egypt, mentions senna, the best kind of which he says is that brought from Mecca.

Senna (as Ssinen or Ssenen) is enumerated among the commodities liable to duty at Acre in Palestine at the close of the 12th century. ${ }^{3}$ In France in 1542, a pound of senna was valued in an official tariff ${ }^{4}$ at 15 sols, the same price as pepper or ginger.

The Arabian and the medirval physicians of Europe used both the pods and leaves, preferring however the former. The pods (Folliculi Sennce) are still employed in some countries.

Cassia obovata Coll. ${ }^{5}$ was the species first known to botanists, and it was even cultivated in Italy for medicinal use during the first half of the 16th century. Hence the term Italian Senna used by Gerarde and others.

Production-According to Nectoux, ${ }^{6}$ whose observations relate to Nubia at the close of the last century, the peasants make two senna harvests annually, the first and more abundant being at the termination of the rains,- that is in September; while the other, which in dry seasons is almost nil, takes place in April.

The gathering consists in simply cutting down the shrubs, and exposing them on the rocks to the burning sun till completely dry. The drug is then packed in bags made of palm leaves holding about a quintal each, and conveyed by camels to Es-souan and Darao, whence it is transported by water to Cairo. By many travellers it is stated that Senna jebeli i.e. mountain senna, (C. acutifolia) finds its way to the ports of Massowah and Suakin, and thence to Cairo and Alexandria.

Cassia obovata which is called by the Arabs Senna baladi, i.e. indigenous or wild senna, grows in the fields of durra (Sorghum) at Karnak and Luxor, and in the time of Nectoux was held in such small esteem that it fetched but a quarter the price of the Senna jebeli brought by the caravans of Nubia and the Bisharrin Arabs. It is not now collected.

Description-Three kinds of senna are distinguished in English commerce :-

1. Alexandrian Senna-This is furnished by Cassia acutifolia and is imported in large bales. It used formerly always to arrive in a very mixed and dirty state, containing in addition to leaflets of senna,

1 Versuch ciner Monographie der Sennes. blätter, Lcipz., 1867.

2 Opera Omnia, Lugd., 1515, lib. 2 Prac. tices, c. 39 .

3 Recueil des Historiens des Croisades, Lois, ii. (1843) 177 .

4 Fontanon, Ediets et Ordonnances des Roys de France, ćd. 2, ii. (1585) 349.

5 It is a glancous shrub with obovate leaflets, broadly rounded and mucronulate, reniform legume terminated by persistent stylc, and marked along the middle of each valve by a series of crest-shaped ridges corresponding to the seeds. It is morc widely distributed in the Nile region than the other species, and is also found in India and (naturalized) in the West Indies. Its leaflets (also pods) may occasionally be picked out of Alexandrian Senna.

-Voyage dans la Haute Egypte . . avec des observations sur les diverses espèes de Séné qui sont répandues dans le commeree, Paris, 1808. fol. 
a variable proportion of leafstalks and broken twigs, pods and flowcrs; besides which there was almost invariably an accompaniment of thic leaves, flowers and fruits of Solenostemma Argel Hayne (p. 1.94), not to mention secds, stones, dust and heterogencous rubbish. Such a drug requircd sifting, fanning and picking, by which most of these impurities could be separated, leaving only the senna contaminated with leaves of argel. But Alcxandrian Scnna has of late becn shipped of much better quality. Some we have recently secn (1872) was, as taken from the original package, wholly composed of leaflets of $C$. acutifolia in a wellpreserved condition; and even the lower qualities of scnna arc never now contaminated with argel to the extcnt that was usual a few years ago.

The leaflets the gencral form of which has already been dcscribed (p. 190) are $\frac{3}{4}$ to $1 \frac{1}{4}$ inches long, rather stiff and brittle, gencrally a little incurled at the edges, conspicuously veined, the midrib being often brown. They are covered with a very short and finc pubcscence which is most dense on the midrib. The leaves have a peculiar opaque, light yellowish grecn hue, a somewhat agrccable tea-like odour, and a mucilaginous, not very marked taste, which however is sickly and nauseous in a watery infusion.

2. Arabian, Mola, Bombay or East Indian Senna-This drug is derived from Cassia angustifolia, and is produced in Southern Arabia. It is shipped from Moka, Aden and other Red Sea ports to Bombay, and thence reaches Europe.

Arabian senna is usually collected and dried without care, and is mostly an inferior commodity, fetching in London sometimes as low a price as $\frac{1}{2}$ to $\frac{1}{4} d$. per 7 b. Yet so far as we have observed, it is never adulterated, but consists wholly of senna leaflets, often brown and decayed, mixed with flowers, pods, and stalks. The leaflets have the form already described (p. 190); short adpresscd hairs are often visible on their under surface.

3. Tinnevelly Senna-Derived from the same species as the last, but from the plant cultivated in India, and in a state of far greater luxuriance than it exhibits in the drier regions of Arabia where it grows wild. It is a vcry superior and carefully collected drug, consisting wholly of the leaflets. These are lanceolate, 1 to 2 inches in length, of a yellowish green on the upper side, of a duller tint on the under, glabrous or thinly pubescent on the under side with short adpressed hairs. The leaflets are less rigid in texture than those of Alexandrian senna, and have a tea-like, rather fragrant smell with but little taste.

Tinnevelly senna has of late fallen off in size, and some recent importations (July, 1873) were not distinguishablc from Arabian senna, except from having been more carefully prepared. The drug is generally shipped from Tuticorin in the extreme south of India.

Chemical Composition-The analysis of scnna with a view to the isolation of its active principlc has engaged the attention of numerous chemists, but as yet the results of their labours are not quite satisfactory.

Ludwig (1864) treated an alcoholic extract of senna with charcoal, and obtained from the latter by means of boiling alcohol two bitter 
principles, Sennacrol, soluble in ether, and Sennapicrin, not dissolved by ether.

Dragendorff ${ }^{1}$ and Kubly (1866) have shown the active substance of senna to be a colloid body, easily soluble in water but not in strong alcohol. When a syrupy aqueous extract of senna is mixed with an equal volume of alcohol, and the mucilage thus thrown down has been removed, the addition of a further quantity of alcohol occasions the fall of a dark brown, almost tasteless, easily alterable substance, which is indued with purgative properties. It was further shown that this precipitate was a mixture of calcium and magnesium salts of phosphoric acid and a peculiar acid. The last named, separated by hydrochloric acid, has been called Cathartic Acid ; it is a black substance which in the mouth is at first insipid, but afterwards tastes acid and somewhat astringent. In water or strong alcohol it is almost insoluble, and entirely so in ether or chloroform; but it dissolves in warm dilute alcohol. From this solution it is precipitable by many acids, but not by tannic. Cathartic acid is dissolved by alkalis or their carbonates (in the latter case with disengagement of carbonic acid) forming a dark solution from which it may be precipitated unaltered by an acid. The neutral ammoniacal solution affords precipitates with salts of lead or silver, from which Dragendorff and Kubly have deduced for the acid the formula $\mathrm{C}^{180} \mathrm{H}^{192} \mathrm{O}^{82} \mathrm{~N}^{4} \mathrm{~S}$, which in our opinion is inadmissible.

Groves ${ }^{2}$ in 1868, unaware of the researches of Dragendorff and Kubly, arrived at similar results as these chemists, and proved conclusively that a cathartate of ammonia possesses in a concentrated form the purgative activity of the original drug.

The exactness of the chief facts relative to the solubility in weak alcohol of the active principle of semna set forth by the said chemists, was also remarkably supported by the long practical experience of $\mathrm{T}$. and H. Smith of Edinburgh. ${ }^{3}$

When cathartic acid is boiled with alcohol and hydrochloric acid, it is resolved into sugar and Cathartogenic Acid.

The alcoholic solution from which the cathartates have been separated, contains a yellow colouring matter which was called Chrysoretin by Bley and Diesel (1849), but identified as Chrysophan ${ }^{4}$ by Martius, Batka ind others. Dragendorff and Kubly regard the identity of the two ;ubstances as doubtful.

The same alcoholic solution which contains the yellow colouring matter just described, also holds dissolved a sugar which has been named Catharto-mannite. It forms warty crystals, is not susceptible of alcoholic fermentation, and does not reduce alkaline cupric tartrate. The formula assigned to it is $\mathrm{C}^{42} \mathrm{H}^{44} \mathrm{O}^{38}$

Senna contains tartaric and oxalic acids with traces of malic acid. The large amount of ash, 9 to 12 per cent., consisting of earthy and alkaline carbonates, also indicates the presence of a considerable quantity
of organic acids.

Commerce-Alexandrian Senna, the produce of Nubia and the regions further south, was formerly a monopoly of the Egyptian Govern-

1 Pharm. Zeitschr. f. Tussland, iv. (1866) 429465 ; all abstract in Wittstein's Vicrtcl. iahreschrift xvi. (1867) 92, and in Gmelin's Chemistry, xviii. (1871) 240 .

- Pharm. Joum. x. (1S69) 196

3 Ibid. 315.

* See Art. Radix Rhei. 
ment, the enjoyment of which was granted to individuals in return for a stipulated payment: hence it was known in continental trade as Séné de la palte, while the depots were terned palles and those who farmed the monopoly paltiers. ${ }^{1}$ All this has long been abolished, and the trade is now firee, the drug being shipped from Alexandria.

Arabian senna is bronght into commerce by way of Bombay. The quantity of semna imported thither from the Red Sea and Aden in the year 1871-72 was 4,195 cwt., and the quantity exported during the same period, 2,180 cwt. ${ }^{2}$

Uses-Senna leaves are extensively employed in medicine as a purgative.

Adulteration-The principal contamination to which senna is at present liable, arises from the presence of the leaves of Solenostemma Argel Hayne, a plant of the order Asclepiadece, 2 to 3 feet high, growing in the arid valleys of Nubia. Whether these leaves are used for the direct purpose of adulteration, or under the notion of improving the drug, or in virtue of some custom or prejudice, is not very evident. It is certain however that druggists have been found who preferred senna that contained a good percentage of ar'gel.

Nectoux, to whom we owe the first exact account of the argel plant, ${ }^{3}$ describes it as never gathered with the senna by accident or carelessness, but always separately. In fact he saw both at Esneh and Phile, the original bales of argel as well as those of senna : and at Boulak near Cairo at the beginning of the present century, the argel used to be regularly mixed with senna in the proportion of one to four.

The leaves of argel after a little practice are very easily recognized; but their complete separation from senna by hand-picking is a tedious operation. They are lanceolate, equal at the base, of the same size as senna leaflets but often larger, of a pallid, opaque, greyish-green, rigid, thick, rather crumpled, wrinkled and pubescent, not distinctly veined. They have an unmistakeably bitter taste. The small, white, star-like flowers, or more often the flower buds, in dense corymbs are found in plenty in the bales of Alexandrian senna. The slender, pear-shaped follicles, when mature $1 \frac{1}{2}$ inches long, with comose sceds are less frequent. It has been shown by Christison ${ }^{4}$ that argel leaves administered per se, have but a feeble purgative action though they occasion griping. It is plain therefore that their admixture with senna should be deprecated.

The leaves or leaflets of several other plants were formerly mixed occasionally with senna, as those of the poisonous Coriaria myrtifolia L., a Mediterranean shrub, of Colutea arborescens L., a native of Central and Southern Europe, and of the Egyptian Tephrosia Apollinea DC. We have never met with any of them. ${ }^{5}$

1 From the Italian appaltare, to let or farnı.

2 Statcment of the Trade and Navigation of the Presidency of Bombay for 1871-72, pt. ii. 21.98.
3 Op. cit. (See p. 191).

4 Dispensatory, ed. 2. 1848.850.

5 The reader will find figures of these leaves contrasted with Senna in Pereira's Elem. of Mat. Mcd. ii. part 2 (1853) 1866. 


\section{FRUCTUS CASSI E FISTULA.}

Cassia Fistula; Purging Cassia ; F. Casse, Canefice, Fruit du Caneficier ; G. Röhrencassie.

Botanical Origin-Cassia Fistula L. (Cathartocarpus Fistula Pers., Bactyrilobium Firstrula Willd.), a tree indigenous to India, but now cultivated or subspontaneous in Egypt, Tropical Africa, the West Indies and Brazil. It is from 20 to 30 feet high (in Jamaica even 50 feet) and bears long pendulous racemes of beautiful, fragrant, yellow flowers. Some botanists have established for this tree and its near allies a separate genus, on account of its elongated, cylindrical, indehiscent legume, but by most it is retained in the genus Cassia.

History-The name Casia or Cassia was originally applied exclusively to a bark related to cinnamon which, when rolled into a tube or pipe, was distinguished in Greek by the word $\sigma \dot{v} \rho \bullet \gamma \xi$, and in Latin by that of fistula. Thus Scribonius Largus ${ }^{1}$ a physician of Rome during the reigns of Tiberius and Claudius, with the latter of whom he is said to have visited Britain, A.D. 43, uses the expression "C'asice rufoe fistularum " in the receipt for a collyrium. Galen ${ }^{2}$ describing the different varieties of cassia, mentions that called $G i z i^{3}$ as being quite like cinnamon or even better; and also names a well-known cheaper sort, having a strong taste and odour, which is called fistula, because it is rolled up like a tube.

Oribasius, physician to the Emperor Julian in the latter half of the 4th and beginning of the 5th century, describes Cassia fistula as a bark of which there are several varieties, having pungent and astringent properties ("omnes cassice fistulce vires habent acriter excalfacientes et stringentes"), and sometimes used in the place of cinnamon. ${ }^{4}$

It is doubtless the same drug which is spoken of by Alexander

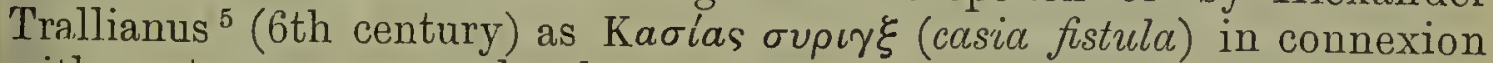
with costus, pepper and other aromatics; and named by other Greek

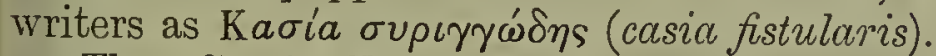

The Cassia Fistula of modern medicine is noticed by Joannes Actuarius, who flourished at Constantinople towards the close of the 13th century; and as he describes it with particular minuteness, ${ }^{6}$ it is evident that he did not consider it well known. The drug is also mentioned by several writers of the school of Salernum. It was a familiar remedy in England in the time of Turner, ${ }^{7} 1568$.

'The tree was figured in 1553 by the celebrated traveller Belon who

1 Compositiones Medicamentorum cap. 4. sect. 36 .

${ }^{2}$ De Antidot. i. c. 14

3 Noticed likewise among the commodities liable to duty at Alexandria in the 2 nd century.-Vincent, Commeree of the Aneients, ii. 712 .

4 Physica Hildegardis, Argent. 1533. 227.

5 Libri xii. J. Guinterio interprete, Basil., 1556 , lib. vii. c. 8.

6 "Quemadmodum si ventrem mollire fuerit animus, pruna, et præcipué Damas- cena adjicimus, atque quippiam ferè nigræ nominatæ casia. Est autem fructus ejus fistulosus et oblongus, nigrum intus humorem concretum gestans, qui haudquaquam una continuitate coaluit, sed ex intervallo tenuibus lignosisque membranulis dirimitur, habens ad speciei propagationem grana quadam seminalia, siliqux illi qux uobis innotuit, adsimilia." - Methodus Medendi, lib. v. c. 2.

7 Herball, part 3. 20. 
net with it in the gardens of Cairo, and in 1592 by Prosper Alpinus who also saw it in Egypt.

Description-The ovary of the flower is one-celled with numerous ovules, which as they advance towards maturity, become separated by the growth of intervening septa. The ripe legume is cylindrical, dark chocolate-brown, $1 \frac{1}{2}$ to 2 feet long, by $\frac{3}{4}$ to 1 inch in diameter, with a strong short woorly stalk, and a blunt end suddenly contracted into a point. The fibro-vascular column of the stalk is divided into two broad parallel seams, the dorsal and ventral sutures, running down the whole length of the pod. The sutures are smooth, or slightly striated longitudinally; one of them is formed of two ligneous bundles coalescing by a narrow line. If the legume is curved, the ventral suture commonly occupies its imner or concave side. The valves of the pods are inarked by slight transverse depressions (more evident in small specimens) corresponding to the internal divisions, and also by inconspicuous transverse veins.

Each of the 25 to 100 seeds which a legume contains, is lodged in a cell formed by very thin woody dissepiments. The oval, flattish seed, from $\frac{3}{10}$ to $\frac{4}{10}$ of an inch long, of a reddish-brown colour, contains a large embryo whose yellowish veined cotyledons cross diagonally, as seen on transverse section, the horny white albumen. One side is marked by a dark line (the raphe). A very slender funicle attaches the seed to the ventral suture.

In addition to the seeds, the cells contain a soft saccharine pulp which in the recent state fills them up, but in the imported pods appears only as a thin layer, spread over the septum, of a dark viscid substance of mawkish sweet taste. It is this pulp which is made use of in pharmacy.

Microscopic Structure-The bands above described running along the whole pod, are made up of strong fibro-vascular bundles mixed with sclerenchymatous tissue. The valves consist of parenchymatous cells, and the whole pod is coated with an epidermis exhibiting small tabular cells, which are filled with dark granules of tannic matter. A few stomata are also met with. The thin brittle septa of the pod are composed of long ligneous cells, enclosing here and there crystals of axalate of calcium.

The pulp itself, examined under water, is seen to consist of loose cells, not forming a coherent tissue. They enclose chiefly granules of albuminoid matters and stellate crystals of oxalate of calcium. The cell walls, assume on addition of iodine, a blue hue if they have been previously washed by potash lye. The seeds are devoid of starch, but yield a copious amount of thick mucilage, which surrounds them like a halo if they are macerated in water.

Chemical Composition-No peculiar principle is knowll to exist either in the woody or the pulpy portion of cassia fistula. The pulp contains sugar in addition to the commonly occurring bodies noticed in the previous section.

Uses-The pulp separated from the woody part of the pods by crushing the latter, digesting them in hot water, and evaporating the strained liquor, is a mild laxative in common domestic use in the 
South of Europe, ${ }^{1}$ but in England scarcely ever now administered except in the form of the well-known Lenitive Elcctuary (Confectio sennoe), of which it is an ingredient.

Commerce-Cassia fistula is shipped to England from the East and West Indies, but chiefly from the latter. The pulp per se has been occasionally imported, but it should never be employed when the legumes for preparing it can be obtained.

Substitutes-The pods of some other species of Cassia share the structure above described and have been sometimes imported.

Those of C. grandis L. f. (C. Brasiliana Lamarck), a tree of Central America and Brazil, are of much larger size, showing when broken transverely an elliptic outline, whose longer diameter exceeds an inch. The valves have very prominent sutures and transverse branching veins. The pulp is bitter and astringent.

The legumes of Cassia moschata H B K., ${ }^{2}$ a tree 30 to 40 feet high, growing in New Granada and known there as Cañafistola de purgar, bear a close resemblance to those of Cassia Fistula L, except that they are a little smaller and rather less regularly straight. They contain a sweetish astringent pulp of a bright brown hue. When crushed and exposed to the heat of a water-bath, they emit a pleasant odour like sandal-wood. The pulp is coloured dark blackish green by perchloride of iron.

\section{TAMARINDI PULPA.}

\section{Tamarindus, Fructus Tamarindi; Tamarinds; F. Tamarins ; G. Tamarinden.}

Botanical Origin-Tanarindus indica L.-The tamarind is a large handsome tree, growing to a height of 60 to 80 feet, and having abruptly pinnate leaves of 10 to 20 pairs of small oblong leaflets, constituting an abundant and umbrageous foliage. Its purplish flower buds and fragrant, red-veined, white blossoms, ultimately assuming a yellowish tinge, contribute to its beautiful aspect and cause it to be generally cultivated in tropical countries.

T. indica appears to be truly indigenous to Tropical Africa between $12^{\circ} \mathrm{N}$. and $18^{\circ} \mathrm{S}$. lat. It grows not only in the Upper Nile regions (Sennaar, Kordofan, Abyssinia), but also in some of the remotest districts visited by Speke, Grant, Kirk, and Stanley, and as far south as the Zambesi. According to F. von Muiller, ${ }^{3}$ it occurs in Tropical
Australia.

It is found throughout India, and as it has Sanskrit names it may even be really wild in at, least the southern parts of the peninsula. It grows in the Indian islands, and Crawfurd ${ }^{4}$ has adduced reasons to show authors describe it as growing in Ye of Java. The mediæval Arabian

1 Thus there were imported into Leghorn in 1871, 103 tons of Cassia Fistula and 'Tamarinds. - Consular Reports 1873, part i.

2 Hanbury in Linn. Trans. xxiv. 161. p. 26 ; Pharm. Journ. v. (1864) 348.

3 Exposition intercoloniale, - Notes sur la Végétation de l'Australie, Melbourue, 1866.

- Dict. of Indian Islands, 1856. 425. 
The tamarind has been naturalized in Brazil and Mexico. Hernandez ${ }^{1}$ who resicled in the latter country from 1571 to 1575 , speaks of it as "nuper... ad cas oras translata." It abounds in the West Indies where it was also introduced together with ginger by the Spaniards at an early period. The tree found in these islands bears shorter and fewer-seeded pods than that of India, and hence was formerly regarded as a distinct species, Tamarindus occidentalis Gärtn.

History-The tamarind was unknown to the ancient Greeks and Romans; nor have we any strong evidence that the Egyptians were acquainted with it, ${ }^{2}$ which is the more surprising considering that the tree appears indigenous to the Upper Nile countries, and that its fruit is held in the greatest esteem in those regions. ${ }^{3}$

The earliest mention of tamarind occurs in the ancient Sanskrit writings where it is spoken of monder several names. ${ }^{4}$ From the Hindus, it would seem that the fruit became known to the Arabians, who called it Tamare-hindi i.e. Indian Datc. Under this nane it was mentioned by Isaac Judæus, ${ }^{5}$ Avicenna, ${ }^{6}$ and the Younger Mesue, ${ }^{7}$ and also by Alhervi ${ }^{8}$ a Persian physician of the 10th century who describes it as black, of the flavour of a Damascene plum, and contrining fibres and stones.

It was doubtless from the Arabians that a knowledge of the tamarind, as of so many other eastern drugs, passed during the niddle ages into Europe through the famous school of Salernum. Oxyphonica ('O $\xi v-$ 申oiviкa) and Dactyli acetosi are names under which we meet with it in the writings of Matthæus Platearius and Saladinus, the latter of whom, as well as other authors of the period, considered tamarinds as the fruit of a wild palm growing in India.

The abundance of tamarinds in Malabar, Coromandel, and Java was reported to Manuel, king of Portugal, in 1516, in the letter of the apothecary Pyres ${ }^{9}$ on the drugs of India. A correct description of the tree was given by Garçia d'Orta about fifty years later.

Preparation-Tamarinds undergo a certain preparation before being brought into commerce.

In the West Indies, the tree matures its fruit in June, July and August, and the pods are gathered when fully ripe, which is known by the fragility of the outer shell. This latter which easily breaks between the finger and thumb, is then removed, and the pods deprived of shelly fragments are placed in layers in a cask, and boiling syrup is poured over them till the cask is filled. When cool, the cask is closed and is then ready for sale. Sometimes layers of sugar are placed between the fruits previous to the hot syrup being added.10

1 Nova plantarum, animalium et mineralium historia, Romæ 1651. 83.

" Sir Gardncr Wilkinson (Ancient Egyptians, i. 1841, 78) says that tamarind stones have been found in the tombs of Thebes; but on consulting Dr. Birch and the collections in the British Musem we have obtained no confirmation of the fact.

3 Barth speaks of it as an invaluable gift of Providence: Reisen und Entdeckungen in Nord-und Centralafriea, Gotha 1858. i. 614; iii. 334.400 ; iv. 173.
4 Sicsmitas Ayurvedas, ed. Hessler, i. (1844) 141, iii. (1850) 171.

5 Upera Omnia, Lugd. 1515, lib. ii. Practices, c. 41.

6 Opcra, Venet. 1564. ii. 339.

7 Upera, Venct. 1561. 52.

8 I'undamenta Phamacologia, ed. Selignianu, Vindob. 1830, 49.

9 Journ. de Soc. Pharm. Lusit. ii. (1\$3\$) 36.

10 Lunan, Hortus Jannaieensis, ii. (1S14)

224; Mracfadyen, Flora of Jamaiea, 1837. 335 . 
East Indian tamarinds are also sometimes preserved with sugar, but usually they are exported without such addition, the outer shell being removed and the fruits being pressed together into a mass.

In the Upper Nile regions (Darfur, Kordofan, Sennaar) and in Arabia, the softer part of tamarinds is, for the sake of greater permanence and convenience of transport, kneaded into flattened round cakes, 4 to 8 inches in diameter and an inch or two thick, which are dried in the sun. They are of firm consistence and quite black, externally strewn with hairs, sand, seeds and other impurities; they are largely consumed in Egypt and Central Africa, and sometimes find their way to the south of Europe as Egyptian Tamarinds.

Description-The fruit is an oblong, or linear oblong, slightly compressed, curved or nearly straight, pendulous legume, of the thickness of the finger and 3 to 6 inches in length, supported by a woody stalk. It has a thin but hard and brittle onter shell or epicarp, which does not split into valves or exhibit any very evident sutures. Within the epicarp is a firm, acid, juicy pulp, on the surface of which and starting from the stalk are strong woody ramifying nerves; one of these extends along the dorsal (or concave) edge, two others on either side of the ventral (or convex) edge, while between these two there are usually 2 , 3 , or 4 less regular and more slender nerves,-all running towards the apex and throwing out branching filaments.

The seeds, 4 to 12 in number, are each of them enclosed in a tough, membranous cell (endocarp), surrounded by the pulp (sarcocarp). They are flattened, and of irregular outline, being roundish, ovate, or obtusely four-sided, about $\frac{6}{10}$ of an inch long by $\frac{3}{10}$ thick, with the edge broadly keeled or more often slightly furrowed. The testa is of a rich brown, marked on the flat sides of the seed by a large scar or areole, of rather duller polish than the surrounding portion which is somewhat radially striated. The seed is exalbuminous, with thick hard cotyledons, a short straight included radicle, and a plumule in which the pinnation of the leaves is easily perceptible.

Tamarinds are usually distinguished in trade as West Indian and East Indian, the former being preserved with sugar, the latter without.

1. West Indian Tamarinds, Brown or Red Tamarinds.-A bright reddish-brown, moist, saccharine mass consisting of the pulpy internal part of the fruit, usually unbroken, mixed with more or less of sylup. It has a very agreeable and refreshing taste, the natural acidity of the pulp being tempered by the sugar. It is this form of tamarinds that is usually found in the shops.

2. East Indian Tamarinds, Black Tamarinds.-These differ from the last described in that they are preserved without the use of sugar. They are found in the market in the form of a firm clammy black mass, consisting of the pulp mixed with the seeds, stringy fibres and some remains of the outer shell. The pulp has a strong acid taste.

Notwithstanding the rather uninviting appearance of East Indian tamarinds, they afford a good pulp which may be satisfactorily used in making the Confectio Senno of pharmacy. In fact, on the continent this sort of tamarind alone is employed for medicinal purposes.

Microscopic Structure-The soft part of tamarinds consists of a 
tissue of thin-walled cells of considerable size, which is traversed by long fibro-vascular bundles. In the former, a few very small starehgranules are met with, and more numerous crystals which are probably bitartrate of potassium.

Chemical Composition-Water extracts from unsweetened tamarinds, sugar together with acetic, tartaric and citric acids, the acids being combined for the nost part with potash. The neutralized solution reduces alkaline cupric tartrate after a while without heat, and therefore probably contains grape sugar. On evaporation, crearn of tartar and sugar crystallize out. The volatile acids of the fatty series, the presence of which in the pulp has been pointed out by Gorup-Besanez, have not been met with by other chemists. Tanmin is absent as well as oxalic acid. We have ascertained that in East Indian tamarinds, citric acid is present in but small quantity. No peculiar principle to which the laxative action of tamarinds can be attributed is known.

The fruit-pulp diffused in water forms a thick, tremulous, somewhat glutinous and turbid liquid. It was examined as early as the year 1790 by Vauquelin under the name of "vegetable jelly," - the first described among the pectic class of bodies.

The hard seeds have a testa which abounds in tannin, and after long boiling is easily separated, leaving the cotyledons soft. These latter have a bland mucilaginous taste and are consumed in India as food during times of scarcity.

Commerce-Tamarinds are shipped in comparatively small quantities from several of the West Indian islands.

The export from the Bombay Presidency in the year 1871-72, was 6286 cwt., which quantity was shipped chiefly to the Persian Gulf, Sind, and ports of the Red Sea. ${ }^{1}$

Uses-In medicine, tamarinds are considered to be a mild laxative; they are sometimes used to make a refrigerant drink in fever. In hot countries, especially the interior of Africa, they are regarded as of the highest value for the preparation of refreshing beverages. The Black Tamarinds are said to be used in the manufacture of tobacco.

\section{BALSAMUM COPAIBA.}

Copaiba; Balsam of Copaiba ${ }^{2}$ or Copaiva, Balsam Capivi; F. Baume ou Oléo-résine de Copahu; G. Copaira-balsam.

Botanical Origin-The drug under notice is produced by trees belonging to the genus Copaifera, of which there are 10 or 11 species, natives of the warmer countries of South America. ${ }^{3}$ Some are found in moist forests, others exclusively in dry and elevated situations. They vary in height and size, some being umbrageous forest trees while others have only the dimension of shrubs; it is from the former alone that the oleo-resin is obtained.

1 Statement of the Trade and Navigation of the Presideney of Bombay for 1871-72, pt. ii. 65.

Wc see no good reason for discarding the popular term balsam, which was ori-

ginally applied to an oleo-resin of strictly analogous character.

3 'Three or four species are known from Tropical Africa. 
The following are reputed to furnish the drug, but to what extent each contributes is not fully known.

1. Copaifera officinalis L. (C. Jacquini Desf.), a large tree of the hot coast region of New Granada as far north as Panama, of Venezuela and the island of Trinidad.

2. C. Guianensis Desf., a tree of 30 to 40 feet high, very closely related to the preceding, native of Surinam, Cayenne, also of the Rio Negro between Manaos and Barcellos (Spruce.) According to Bentham it seems to be the same species as the C. bijuga of Hayne. ${ }^{1}$

3. C. coriacea Mart. (C. cordifolia Hayne), a large tree found in the caatingas or dry woods of the Brazilian provinces of Bahia and Piauhy.

4. C. Langsdorffi Desf. (C. nitida Hayne, C. Sellowii Hayne, ? C. Jussieri Hayne), a polymorphous species, varying in the form and size of leaflets, and also in dimensions, being either a shrub, a small bushy tree, or a large tree of 60 feet high. Bentham admits besides the type, three varie-

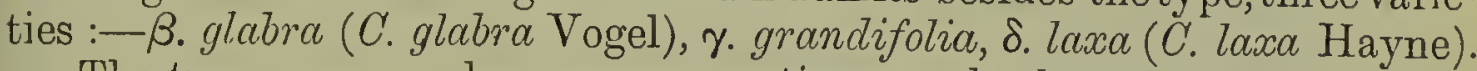

The tree grows on dry campos, caatingas and other places in the provinces of S. Paulo, Minas Geraes, Goyaz, Mato Grosso, Bahia and Ceará; it is therefore distributed over a vast area. According to Gardner, ${ }^{2}$ the Brazilian traveller, it yields an abundance of balsam.

In addition to these species, must be mentioned a tree described by Hayne and commonly cited under the name of Copaifera multijuga, as a special source of the drug shipped from Pará. ${ }^{3}$ As its name implies, it is remarkable for the number of leaflets (6 to 10 pairs) on each leaf. But it is only known from some leaves in the herbarium of Martius which Bentham, who has examined them, informs us are unlike those of any Copaifera known to him, though certainly the leaflets are dotted with oil-vessels as in some species. In the absence of flowers and fruits, there is no sufficient evidence to prove that it belongs even to the genus Copaifera. It is not mentioned by Martius in his Systema Materice Medice Brasiliensis (1843) as a source of the drug.

History-Among the early notices of Brazil, is a treatise by a Portuguese friar who had resided in that country from 1570 to 1600. The manuscript found its way to England, was translated, and was published by Purchas ${ }^{4}$ in 1625 . Its author notices many of the natural productions of the country, and among others Cupayba which he describes as a large tree from whose trunk, when wounded by a deep incision, there Hows in abundance a clear oil much esteemed as a medicine.

Father Acuña ${ }^{5}$ who ascended the Amazon from Pará arriving at Quito in 1638, mentions that the country affords very large cassia fistula, excellent sarsaparilla, and the oils of andirova and Copaiba,
as good as balsam for curing wounds.

Piso and Marcgraf ${ }^{6}$ who were physicians to the Count of Nassau,

1 Hayne (1827) enumerated and figured 15 species, some of them founded on very imperfect materials. Bentham in the Flora Brasitiana of Martius and Endlicher (fasc. 50, Leguminose ii. 1870. pp. 239-244) admits only 11, one of which is doubtful as to the genus.

2 MS. attached to specimens in the $\mathrm{K} \mathrm{ew}$ Herbarium.

${ }^{3}$ "Alle Arten geben mehr oder weniger
Balsain, und den meisten giebt die in der Provinz Para vorkommende Copaifera nultijuga."--Hayıe, Linnoca i. (1826) 429. 4 Pitgrimes and Pilgrimage, Lond. iv.
(1625) 1308.

5 Descubrimiento del gran Rio de las Amazonas, Madrid, 1641, No. 30.

Hist. Nat. Brasitia, 1648, Piso, 56, 
governor of the Dutch establishments in Brazil, each give an aceount of the Copaiba and the method of obtaining its oleo-resin. The former states that the tree grows in P'ernambuco and the island of Maranhon, whenee the balsam is conveyed in abundance to Europe.

The drug was formerly brought into Europenn commerce by the Portuguese, and used to be paeked in earthen pots pointed at the lower end; it often arrived in a very impure eondition. ${ }^{1}$ In the London Pharnnaeopœia of 1677, it was ealled Balsamum Capivi, whieh is still its most popular name.

Secretion-Karsten states that he observed resiniferous duets, frequently more than an inch in diameter, running through the whole stem. He is of the opinion, that the eell-walls of the neighbouring parenchyme are liquefied and transformed into the oleo-resin. ${ }^{2}$ We are not able to offer any argument in favour of this opinion.

Extraction-According to the testimony of the very few travellers who have given any aceount of the matter, the balsam is obtained by eutting out a wedge from the trunk of the tree near its base, reaehing to the very heart. From this great wound the balsam flows usually in sueh abundance that many pounds may be eolleeted in a few hours. If no flow takes place, the aperture is closed with wax or elay, and reopened after the lapse of some days when a copious exudation generally follows. Sometimes the required eavity is made by means of a large auger.

In the vessels already alluded to, the balsam sometimes eolleets in so large a quantity, that the trunk is unable to sustain the inward pressure, and bursts. This eurious phenomenon is thus referred to in a letter addressed to one of us by Mr. Spruee :- "I have three or four times heard what the Indians assured me was the bursting of an old eapivitree, distended with oil. It is one of the strange sounds that sometimes disturb the vast solitudes of a South American forest. It resembles the boom of a distant cannon, and is quite distinet from the erash of an old tree falling from deeay which one hears not unfrequently."

A similar phenomenon is known in Borneo. The trunks of aged trees of Dryobalanops aromatica eontain large quantities of oleo-resin or Camphor Oil, ${ }^{3}$ whieh appears to be sometimes seereted under sueh pressure that the vast trunk gives way. "There is another sound" says Spenser St. John " only heard in the oldest forests, and that is as if a mighty tree were rent in twain. I often asked the cause, and was assured it was the eamphor tree splitting asunder on aeeount of the aeeumulation of camphor in some partieular portion."

Balsam Capivi is colleeted by the Indians on the banks of the Orinoeo and its upper affluents, and carried to Ciudad Bolivar (Angostura); some of this balsam reaches Europe by way of Trinidad. But it is obtained mueh more largely on the tributaries of the Casiquiari and Pio Negro (the Siapa, Içanna, Uampés, \&e.) and is sent down to Pará. Most of the northern tributaries of the Amazon, as the Trombetas and Nhamunda, likewise furnish a supply. According to Spruee, in the Amazon valley it is the tall virgin forest, Caaguaçu of the Brazilians,

I Valmont de Bomare, Dict. d'Hist. Nat. i. $(1775) 387$.

2 Botanische Zeitung, xv. (1857) 316.
3 Motley in Hooker's Journ. of Botany, iv. (1852) 201.

${ }_{4}^{4}$ Lif? in the Forests of the Far East, ii. (1862) 152. 
Monte Alto of the Venezuelans, that yields most of the oils and gumresins, and not the low, dry caatingas, or the riparial forests. The same observant traveller tells us that in Southern Venezuela, capivi is known only as el Aceitc (the oil,) the name Balsamo being that of the so-called Sassafras Oil, obtained from a species of Nectandra.

Balsam Copaiba is also largely exported from Maracaibo where, according to Engel ${ }^{1}$ it is produced by $C$. officinalis, the Canime of the natives.

Description-Copaiba is a more or less viscid fluid, varying in tint from a pale yellow to a light golden brown, of a peculiar aromatic, not unpleasant odour, and a persistent, acrid, bitterish taste. Pará copaiba newly imported is sometimes nearly colourless and almost as fluid as water. ${ }^{2}$ T'he balsam is usually quite transparent, but there are varieties which remain always opalescent. Its sp. gr. varies from $0 \cdot 940$ to 0.993, according as the drug contains a greater or less proportion of volatile oil. Copaiba becomes more fluid by heat; if heated in a test-tube to $200^{\circ} \mathrm{C}$. for some time, it does not lose its fluidity on cooling. It is sometimes slightly fluorescent. It dissolves in several times its weight of ordinary spirit of wine, and generally in all proportions in absolute alcohol, ${ }^{3}$ acetone, or bisulphide of carbon, and is perfectly soluble in an equal volume of benzol. Glacial acetic acid readily dissolves the resin but not the essential oil.

Copaiba that is rich in resin of an acid character, unites with the alkaline earths to form a gradually hardening mass, provided a small proportion of water is present. Thus 8 to 16 parts of balsain will combine as a stiff compound when gently warmed with 1 part of moistened magnesia; and still more easily with lime or baryta.

Buignet has first shown (1861) that copaiba varies in its optical power. A sample from Trinidad examined by one of us was strongly dextrogyre, whereas we found Pará balsam to be levogyre. ${ }^{4}$

The Pará and Maranham balsams are regarded in wholesale trade as distinct sorts, and experienced druggists are able to distinguish them apart by odour and appearance, and especially by the greater consistence of the Maranham drug. Maracaibo balsam is reckoned as another variety, but is now rarely seen in the English market. West Indian copaiba is usually said to be of inferior quality, but except that it is generally opalescent, we know not on what precise grounds.

Chemical Composition-The balsam is a solution of resin in volatile oil, and therefore analogous to the fluid turpentines of the
Conifcro.

The volatile oil, Oleum Copaiba, constitutes about 40 to 60 per cent. of the balsam, according to the age of the latter and its botanical origin. It has the composition and general chemical properties of turpentine oil, but its boiling point is $245^{\circ} \mathrm{C}$. or even higher. It smells and tastes

I Zeitschrift der Gesellsehaft für Erdkunde zu Berlin, v. (1870) 435.

${ }^{2}$ We saw snch as this which had been imported into London in 1873; though re. garded by the dealers with suspicion, we are not of opinion that it was sophisticated.

${ }^{3}$ Such is the case with some very authentic specirnens collected for one of us in Central Ameriea by De Warszewiez, but other samples which we had no reason to suppose adulterated, ]eft a eertain amount of white residne when treated with twice their weight of alcohol sp. gr. $\cdot 796$.

4 Fliickiger in Wiggers and Husemann's Jahresbericht for 1867, 162, and for 1868 . 140. 
like the balsam, and dissolves in from 8 to 30 parts of spirit of wine. Most samples of copaiba oil turn the plane of polarization to the left, but in common with oil of turpentine, the oil exhibits isomeric modifications differing in optical as well as in other physical properties. The sp. gr. varies from about 0.88 to 0.91 .

After the oil of copaiba has been removed by distillation, there remains a brittle amorphous resin of an acid character, soluble both in benzol and amylic alcohol, and yielding only amorphous salts. Sometimes copaiba contains a small amount of crystallizable resin-acid, as first pointed out in 1829 by Schweitzer. By exposing a mixture of 9 parts of copaiba and 2 parts of aqueous ammonia (sp. gr. 0.95) to a temperature of $-10^{\circ} \mathrm{C}$., Schweitzer obtained crystals of the acid resin termed Copaivic Acid. They were analysed in 1834 by H. Rose, and exactly measured and figured by G. Rose. Hess (1839) showed that Rose's and his own analyses assign to copaivic acid the formula $\mathrm{C}^{20} \mathrm{H}^{32} \mathrm{O}^{2}$. It agrees with Maly's abietic acid from colophony in composition, but not in any other way. Copaivic acid is readily soluble in alcohol, and especially in warmed copaiba itself; much less in ether. We have before us crystals, probably of copaivic acid, which have been spontaneously deposited in an authentic specimen of the oleo-resin of Copaifera officinalis from Trinidad, which we have kept for several years. The crystals may be easily dissolved by warming the balsam; on cooling the liquid, they again make their appearance after the lapse of some weeks. After re-crystallization from alcohol they fuse at $116-117^{\circ}$ C., forming an amorphous transparent mass which quickly crystallizes if touched with alcohol.

An analogous substance, Oxycopaivic Acid, $\mathrm{C}^{20} \mathrm{H}^{28} \mathrm{O}^{3}$, was examined in 1841 by H. von Fehling, who met with it as a deposit in Pará Copaiba. And lastly, Strauss (1865) extracted Metacopaivic Acid, $\mathrm{C}^{22} \mathrm{H}^{34} \mathrm{O}^{4}$, from the balsam imported from Maracaibo. He boiled the latter with sodalye which separated the oil; the heavier subjacent liquid was then mixed with chloride of ammonium, which threw down the salts of the amorphous resin-acid, leaving in solution those of the metacopaivic acid. The latter acid was separated by hydrochloric acid and recrystallization from alcohol. We succeeded in obtaining metacopaivic acid by washing the balsam with a dilute solution of carbonate of ammonium, and precipitating by hydrochloric acid. The precipitate dissolved in dilute alcohol yields the acid in small crystals, but to the amount of only about one per cent.

These resin-acids have a bitterish taste and an acid reaction; their salts of lead and silver are crystalline but insoluble; metacopaivate of sodium may be crystallized from its watery solution.

Commerce-The balsam is imported in barrels direct from Para and Maranham, sometimes from Rio de Janeiro and less often from Trinidad, Demerara, Cartagena, and Angostura; it is also shipped from Maracaibo in Venezuela. It often reaches England by way of Havre or New York.

Uses-Copaiba is employed in medicine on account of its stimulant action on the mucous membranes, more especially those of the urinogenital organs.

Adulteration-Copaiba is not unfrequently fraudulently tampered with before it reaches the pharmaceutist; and owing to its naturally 
variable composition, arising in part from its diverse botanical origin, its purity is not always easily ascertained.

The oleo-resin usually dissolves in a small proportion of absolute alcohol : should it refuse to do so, the presence of some fatty oil other than castor oil may be surmised. To detect an admixture of this latter, one part of the balsam should be heated with four of spirit of wine (sp. gr. -838). On cooling, the mixture separates into two portions, the upper of which will contain any castor oil present, dissolved in alcohol and the essential oil. On evaporation of this upper layer, castor oil may be recognized by its odour; but still more positively by heating it with caustic soda and lime, when œnanthol will be formed, the presence of which may be ascertained by its peculiar smell. By the latter test an admixture of even one per cent. of castor oil can be proved.

The presence of fatty oil in any considerable quantity is likewise made evident by the greasiness of the residue, when the balsam is deprived of its essential oil by prolonged boiling with water.

It has been pointed out by Tomlinson, ${ }^{1}$ that the figure presented by a drop of copaiba balsam on the surface of water is extremely characteristic, and readily distinguishable from that of a mixture of the balsam and castor oil. We have not ascertained to what extent this test is capable of practical application.

The admixture of some volatile oil with copaiba can mostly be letected by the odour, especially when the balsam is dropped on a piece of warmed metal. Spirit of wine may also be advantageously tried for the same purpose. It dissolves but very sparingly the volatile oil of copaiba: the resins of the latter are also not abundantly soluble in it. Hence, if shaken with the balsarn, it would remove at once the larger portion of any essential oil that might have been added. For the recognition of Wood Oil if mixed with copaiba, see next page, note 1.

Substitutes-Under this head two drugs deserve mention, namely Gurjun Balsam or Wood Oil, described at p. 81, and

Oleo-resin of Hardwickia pinnata Roxb.-The tree which is of a large size belongs to the order Leguminosce and is nearly related to Copaifera. According to Beddome, ${ }^{2}$ it is very common in the dense moist forests of the South Travancore Ghats, and has also been found in South Canara. The natives extract the oleo-resin in exactly the same method as that followed by the aborigines of Brazil in the case of copaiba, - that is to say, they make a deep notch reaching to the heart of the trunk, from which after a time it flows out.

This oleo-resin which has the smell and taste of copaiba, but a much darker colour, was first examined by one of us in 1865, having been sent from the India Museum as a sample of Wood Oil; it was subsequently forwarded to us in more ample quantity by Dr. Bidie of Madras. It is a thick, viscid fluid, which, owing to its intense tint, looks black when seen in bulk by reflected light; yet it is perfectly transparent. Viewed in a thin layer by transmitted light, it is light yellowish-green, in a thick layer vinous-red,-hence is dichromic. It is not fluorescent, nor is it gelatinized or rendered turbid by being heated to $130^{\circ} \mathrm{C}$., thus differing

1 Pharm. Fourn. v. (1864) 387. 495. with
figures.
2 Flora Sylvatica for Southern India, Madras, part 24 (1872), 255. 
from Wood Oil. ${ }^{2}$ Broughton ${ }^{2}$ who has investigated it chemically, obtained by prolonged distillation with water an essential oil to the extent of 25 per cent. from an old specimen, and of more than 40 per cent., from one recently collected. The oil was found to have the same composition as that of copaiba, to boil at $225^{\circ} \mathrm{C}$., and to rotate the plane of polarization to the left. The resin is probably of two kinds, of which one at least possesses acid properties. Bronghton made many attempts, but without success, to obtain from the resin crystals of copaivic acid.

The balsam of Hardwickia has been used in India for gonorrhœa, and with as much success as copaiba.

\section{GUMMI ACACIEE.}

Gummi Arabicum; Gum Arabic; F. Gomme Arabique; G. Arabisches Gummi, Acacion-Gummi, Kordofan Gummi.

Botanical Origin-1. Acacia Verelc Guillemin et Perrottet, a small tree, not higher than 20 feet, growing abundautly on sandy soils in Western Africa, chiefly north of the river Senegal, where it constitutes extensive forests. It is called by the negroes Verek. The same tree is likewise found in Southern Nubia, Kordofan, and in the region of the Upper Atbara in Eastern Africa, where it is known as Hashab. The Verek has a greyish bark, the inner layers of which are strongly fibrous, small yellowish flowers densely arranged in spikes 2 to 3 inches long and exceeding the bipinnate leaves, and a broad legume 3 to 4 inches in length containing 5 to 6 seeds.

According to Schweinfurth, ${ }^{3}$ it is this tree exclusively that yields the fine white gum of the countries bordering the Upper Nile and especially of Kordofan.

2. A stenocarpa Hochst., a large tree of Southern Nubia, and Abyssinia, called Talch, Talha or Kakul, affords a brownish gum arabic which is extensively collected in the district of Gedaref, between the Blue Nile and the Upper Atbara (about $14^{\circ} \mathrm{N}$. lat.).

3. A Seyal Delile, var. Fistula (A. Fistula Schweinf.) a tree of 40 feet high called Soffar, the branches of which are covered with a very pale yellow bark ${ }^{4}$ beset with large milk-white spines, many of which are curiously dilated at the base by the puncture of an insect. It grows in Senuaar

1 It may be further distinguished from Wood Oil as well as from eopaiba, if tested in the following simple manner.-Put into a tube 19 drops of bisulphide of earbon and one drop of the oleo-resin, and shake them together. Then ald one drop of a mixture of equal parts of strong sulphurie and nitrie $(1.42)$ aeids. After a little agitation the appearance of the respeetive mixtures will be as follows :-

Copaiba-Colour faint reddish-brown, with deposit of resin ou sides of tube.

Wood Oil-Colour intense purplish-red, becoming violet after some minutes.

Oleo-resin of Hardwiekia-No pereeptible alteration; the mixture pale greenish yellow. By this test the presence in eopaibn of one-eighth of its volume of Wood Oil may be easily shown.

2 Beddoine, op. cit.

3 Aufzählung und Besehreibung der Acacien-Arten des Nilgebiets. - Linnoca i. (1867) 308-376, with 21 plates. Sehweinfurth's observations are strongly eonfirmed by a recent aceount of the commeree of Khartum in the Zeitschrift f. Erdkunde, ii. (1S67) 474. We have adopted in the matter of speeies the views takell by Oliver in his Flora of Tropical Africa ii. (18i1) 337.

4 The outer bark of the youngest branehes is of a rusty tint as in the eommon form of A. Seyal, but it soon exfoliates leaving the branches nearly white. 
and Southern Nubia, producing an inferior brownish gum of the same description as the preceding.

4. A. arabica Willd. (A.vora Willd., A. nilotica Delile). This tree under the form described by Delile as $A$. nilotica, distinguished by having the legumes glabrous instead of tomcntose, is largely planted in the valley of the Nile throughout the whole of Egypt and Nubia, where it is known by the name of Sont. On the banks of the White and Blue Nile and in Southern Nubia, it occurs in primæval forests. Schweinfurth, who regards it as a distinct species, states that it affords a very scanty amount of gum, which though collected for use in the country, is nowhere an article of trade.

The tree is widely distributed in Africa, occurring on the west side from Senegambia and the Niger to Angola; and on the east from the valley of the Nile to Abyssinia, Mozambique and Natal. ${ }^{1}$ It is supposed to be the source of the gum exported from Fezzan and Morocco.

A. arabica is the Kikar of the Punjab, the Babul or Babur of Central India. Cultivated or self-sown, it is found throughout the greater part of the peninsula, excepting the most humid coast-regions, and the extreme north-west beyond the Jhelam, where the winter frost is too severe. In some districts of Sindh and Guzerat where it forms entire forests, the tree supports the lac-insect. Gum is abundantly exuded from its bark, and with that of other trees, forms a portion of the East India Gum Arabic of commerce. ${ }^{2}$

5. A. horrida Willd. (A. Capensis Burch.) a large tree, the Doornboom, Wittcdoorn or Karródoorn of the Cape colonists, is the well-ascertained source of the chief portion of the South African gum arabic. It is the commonest tree of the lonely, deserts of South Africa.

A. pycnantha Benth.; A. dccurrens Willd. (A. mollissima Willd.), the Black or Grcen Wattle-tree of the colonists; $A$. dealbata Link, the Silver Wattle; and $A$. homalophylla A. Cunn., are the trees which furnish the gum arabic of Australia. ${ }^{3}$

History - The history of this drug carries us back to a remote antiquity. The Egytian fleets brought gum from Arabia as early as the 17th century B.C. Thus in the treasury of king Rhampsinit (Ramses III.) at Medinet $\mathrm{Abu}$, there are representations of gum-trees, together with heaps of gum. The symbol used to signify gum, is read.Kami-en-punt. i.e.gum from Arabia, and is of frequent occurrence in Egyptian inscriptions; sometimes mention is made of gum from Canaan. The word kami is the original of the Greek кó $\mu \mu \iota$, whence through the Latin our own word gum.

The Egyptians used gum largely in painting: all inscription exists which states that in one particular instance a solution of kami (gum) was used to render adherent the mineral pigment called chestcb, 5 the name applied to lapis lazuli or to a glass coloured blue by cobalt.

1 As var. B. Kraussiana Benth.-Harvey and Sonder, Flor. Capens. ii. (1861-2) 281.

2 Brandis, Forest Flora of North-Western and Central India, Lond. 1874.181.-It must however be borme in mind that a large proportion of the gum shipped from Bombay is the produce of Eastern Africa.

3 Victorian Exhibition, 1861.-Report on Class 3. (Indigenous Vegetable Substanccs),
Melbourne, 1862, 58.
We have to thank Professor Dümichen for most of the information relating to Egypt, which may be partly found in his own works, and partly in those of Brugsch, Ebers, and Lepsius.

5 Lepsius, Abhandl. der Akademie der Wissensch. zu Berlin for 1871, p. 77. 126. Metalle in den Acgyptischen Inschriften. 
Turning to the Greeks, we find that Theophrastus in the 3rd and 4 th century B.C. mentioned Kó $\mu \mu$ as a product of the E'gyptian" $A \kappa a v \theta a$, of which tree there was a forest in the Thiebaïs, of Upper Ecrypt. Strabo also, in describing the district of Arsinöe, the modern Fayûm, says that gum is got from the forest of the Thebaïc akanthe.

Celsus in the 1st century mentions Gummi acanthinum; Dioscorides and Pliny also describe Egyptian gum, which the latter values at 3 denarii [2s.] per lb.

Gun was employed by the Arabian physicians and by those of the school of Salerno, yet its utility in medicine was but little appreciated, and its value in the arts quite ignored nntil a much later period. During the middle ages, the small supplies that reached Europe were procured through the Italian traders, from Egypt and Turkey. Thus Pegolotti ${ }^{1}$ who wrote a work on commerce about A.D. 1340, speaks of gum arabic as one of the drugs sold at Constautinople by the pound, not by the quintal. Again in a list of drugs liable to duty at Pisa in $1305,{ }^{2}$ and in a similar list relating to Paris in $1349,{ }^{3}$ we find mention of gum arabic, It is likewise nanied by Pasi, ${ }^{4}$ in 1521, as an export from Venice to London.

Gum also reached Europe from Western Africa, with which region the Portuguese had a direct trade as early as 1449.

Production-Respecting the origin of gum in the tribe Acaciece, no observations have been made similar to those of $\mathrm{H}$. von Mohl on tragacanth.

It appears that gum generally exudes from the trees spontaneously, in sufficient abundance to render wounding the bark superfluous. The Somali tribes of East Africa however, are in the habit of promoting the outflow by making long incisions in the stem and branches of the tree. ${ }^{5}$ In Kordofan the lumps of gum are broken off with an axe, and collected in baskets.

The most valued product called Hashabi gum, from the province of Dejara in Kordofan, is sent northward from Bara and El Obeid to Dabbeh on the Nile, and thence down the river to Egypt; or it reaches the White Nile at Mandjara.

A less valuable gum known as Hashabi el Jesire, comes from Sennaar on the Blue Nile; and a still worse from the barren table-land of Takka, lying between the eastern tributaries of the Blue Nile and the Atbara and Mareb; and from the highlands of the Bisharrin Arabs between Khartum and the Red Sea. This gum is transported by way of Khartum or El Mekheir (Berber), or by Suakin on the Red Sea. Hence, the worst kind of gum is known in Egypt as Samagh Savakumi (Suakin Gum).

According to Munzinger, a better sort of gum is produced along the Samhara coast towards Berbera, and is shipped at Massowa. Some of it reaches Egypt by way of Jidda, which town being in the district of Arabia called the Hejaz, the gum thence brought receives the name of Samagh Hejazi; it is also called Jiddah or Gedda Gum. The gums of

1 Della Decima e di varie altre gravezze imposte dal commune di Firenze, iii. (1766) 18.

2 Bonaini, Statuli inediti della città di Pisa, Firenze, iii. (1857) 106. 114.
3 Ordonnances de Rois de France, ii. (1729) 318.

* Tariffa de pesi e misurc, Venet. 1521. 204.

-5 Vaughan (Drugs of Aden), Tharm. Journ. xii. (1853) 226. 
Zeila, Berbera and the Somali country about Gardafui, are shipped to Aden, or direct to Bombay. A little gum is collected in Southern Arabia, but the quantity is said to be insignificant. ${ }^{1}$

In the French colony of Senegal, gum, which is one of its principal productions, is collected chiefly iu the country lying north of the river, by the Moors who exchange it for European commodities. The gathering commences after the rainy season in November when the wind begins to set from the desert, and continues till the month of July. The gum is shipped for the most part to Bordeaux. The quantity imported into France in 1870 from Senegal, was 2,862,669 kilo. (107,116 cwt.), value 5,439,076 francs $^{2}(£ 217,563)$.

Description-Gum arabic does not exhibit any very characteristic forms like those observable in gum tragacanth. The finest white gum of Kordofan, which is that most suitable for medicinal use, occurs in lumps of various sizes from that of a walnut downwards. They are mostly of ovoid or spherical form, rarely vermicular, with the surface in the unbroken masses, rounded,-in the fragments, angular. They are traversed by numerous fissures, and break easily and with a vitreous fracture. The interior is often less fissured than the outer portion. At $100^{\circ} \mathrm{C}$. the cracks increase, and the gum becomes extremely friable. In moist air, it slowly absorbs about 6 per cent. of water.

The finest gum arabic is perfectly clear and colourless; inferior kinds have a brownish, reddish or yellowish tint of greater or less intensity, and are more or less contaminated with accidental impurities such as bark. The finest white gum turns black and assumes an empyreumatic taste, when it is kept for montlis at a temperature of about $98^{\circ} \mathrm{C}$., either in an open vessel, or enclosed in a glass tube, after having been previously dried over sulphuric acid or not.

An aqueous solution of gum deviates the plane of polarization $5^{\circ}$ to the left in a column $50 \mathrm{~mm}$. long; but after being long kept, it becomes strongly acid, the gum having been partly converted into sugar, and its optical properties are altered. An alkaline solution of cupric tartrate is not reduced by solution of gum even at a boiling heat, unless it contains a somewhat considerable proportion of sugar, extractable by alcohol, or a fraudulent admixture of dextrin.

We found the sp. gr. of the purest pieces of colourless gum dried in the air at $15^{\circ} \mathrm{C}$., to be 1.487 ; but it increases to 1.525 , if the gum is dried at $100^{\circ}$.

The foregoing remarks apply chiefly to the fine white gum of Kordofan, the Picked Turkey Gum or White Sennaar Gum of druggists. The other sorts which are met with in the London market are the following:-

1. Senegal Gum-As stated above, this gum is an important item of the French trade with Africa, but it is not much used in England. Its colour is usually yellowish or somewhat reddish, and the lumps, which are of large size, are often elongated or vermicular. Moreover Senegal gum never exhibits the numerous fissures seen in Kordofan gum, so that the masses are much firmer and less easily broken. In every other respect, whether chemical or optical, we find ${ }^{3}$ Senegal gum

1 Vaughan, 1.c."

2 Tableau général du Commorce de la France, 1870, published 1872 .
3 Fliickiger, in the Jahresbericht of Wiggers and Husemann, 1869. 149. 
and Kordofan gum to be identical; and the two, notwithstanding their different appearance, are produced by one and the same species of Acacia, narnely Acacia Veret.

2. Suation Gum, Talca or Talha Gum, yielded by Acacia stenocarpa, the Talch or Tallace of the Arabs, and by A. Seyal var. Fistula, is remarkable for its brittleness, which occasions much of it to arrive in the market in a semi-pulverulent state. It is a mixture of nearly colourless and of brownish gum, with here and there pieces of a deep reddishbrown. Large tears have a dull opaque look, by reason of the innumerable minute fissures which penetrate the rather bubbly mass. It is imported from Alexandria.

3. Morocco, Mogador or Brown Barbary Gurn-consists of tears of moderate size, often vermiform, and of a rather uniforn, light, dusky brown tint. The tears which are internally glassy become cracked on the surface and brittle if kept in a warm room; they are perfectly soluble in water.

Gums of various kinds, including the resin Sandrac, were exported from Morocco in the year 1872 to the extent of $5110 \mathrm{cwt}$., a quantity much below the average. ${ }^{1}$

4. Cape Gum-This gum which is uniformly of an amber brown, is produced in plenty in the Cape Colony, as a spontaneous exudation of Acacia horrida Willd. The Blue Book of the Cape Colony published in 1873 , states the export of gum in 1872, as 101,241 $\mathrm{Hb}$.

5. East India Gum-The best qualities consist of tear's of various sizes, sometimes as large as an egg, internally transparent and vitreous, of a pale amber or pinkish hue, completely soluble in water. This gum is largely shipped from Bombay, but is almost wholly the produce of Africa; the imports into Bombay from the Red Sea ports, Aden and the African Coast in the year 1872-73, were 14,352 cwt. During the same year the shipments from Bombay to the United Kingdom, amounted to 4,561 cwt. $^{2}$

6. Australian Gum, Wattle Gum-This occurs in large hard globular tears and lumps, occasionally of a pale yellow, yet more often of an amber or of a reddish-brown hue. It is transparent and entirely soluble in water; the mucilage is strongly adhesive, and said to be less liable to crack when dry than that of some other gums. The solution, especially that of the darker and inferior kinds, contains a little tannin evidently derived from the very astringent bark which is often attached to the gum. A variety of Australian Gum, unknown to us, is described as having "an amorphous white appearance," owing to the infinite multitude of cracks with which the tears are intersected.

Chemical Characters and Composition-At ordinary temperatures gum dissolves very slowly and without affecting the thermometer in an equal weight of water, forming a thick, glutimous, slightly o palescent liquid, having a mawkish taste and decidedly acid reaction. ${ }^{3}$

1 Consular Reports, August, 1873. 917.

2 Statement of the Trade and Navigation of the Presidency of Bombay for 1872-73, pt. ii, 34.77.

3 A sample of fine white gum was recently sent to us by a druggist on account of this which was glainy, like the mucilage of marshmallow, but in no other respect could we find that it differed from ordinary gum. On exposing it for some days to a temperature of $95^{\circ} \mathrm{C}$., it afforded a solution of the usual character. 
At higher temperatures the dissolution of gum is but slightly accelerated, and water does not take up a much larger quantity even at $100^{\circ} \mathrm{C}$. The finest gum dried at $100^{\circ} \mathrm{C}$., forms with 2 parts of water a mucilage of sp. gr. 1.149 at $15^{\circ} \mathrm{C}$.

This solution mixes with glycerin, and the mixture may be evaporated to the consistence of a jelly without any separation taking place. Solid gum in lumps on the contrary, is but little affected by concentrated glycerin. In other liquids, gum is insoluble or only slightly soluble, unless there is a considerable quantity of water present. Thus 100 parts of spirit of wine containing 22 volumes per cent. of alcohol, dissolve 57 parts of gum; spirit containing 40 per cent. of alcohol takes up 10 parts, and spirit of 50 per cent. only 4 parts. Aqueous alcohol of 60 per cent. no longer dissolves gum, but extracts from it a small quantity ( $\frac{1}{3}$ to $\frac{1}{2}$ per cent. according to the variety) of resin, colouring matter, glucose, calcium chloride, and other salts.

Neutral acetate of lead does not precipitate gum arabic mucilage; but the basic acetate forms even in a very dilute solution, a precipitate of definite constitution.

Soluble silicates, borates, and ferric salts render gum solution turbid, or thicken it to a jelly. It is not a compound of gum with any of these substances which is formed, but in the case of the first, basic silicates separate. No alteration is produced by silver salts, mercuric chloride or iodine. Ammonium oxalate throws down the lime contained in a solution of gum. Gum dissolves in an ammoniacal solution of cupric oxide. Acted upon by nitric acid, mucic acid is produced.

Small, air-dried lumps of gum lose by desiccation at $100^{\circ} \mathrm{C} ., 12$ to 16 per cent. of water. If gum independently of its amount of lime, be represented by the formula $\mathrm{C}^{12} \mathrm{H}^{22} \mathrm{O}^{11}, 3 \mathrm{H}^{2} \mathrm{O}$, the loss of 3 molecules of water will correspond to a decrease in weight of 13.6 per cent.; in carefully selected colourless pieces, we have found it to amount to $13 \cdot 14$ per cent. At a temperature of about $150^{\circ} \mathrm{C}$, gum parts with another molecule of water, and loses its solubility.

When gum arabic is dissolved in cold water and the solution. is slightly acidulated with hydrochloric acid, alcohol produces in it a precipitate of Arabin or Arabic Acid. It may be also prepared by placing a solution of gum (1 gum +5 water), acidulated with hydrochloric acid, on a dialyser, when the calcium salt will diffuse out, leaving behind a solution of arabin.

Solution of arabin differs from one of gum, in not being precipitated by alcohol. Having been dried, it loses its solubility, merely swelling in water, but not dissolving even at a boiling heat. If an alkali is added, it forms a solution like ordinary gum. Neubauer who observed these facts (1854-57), showed that gum arabic is essentially an acid calcium
salt of arabic acid.

A rabic Acid dried at $100^{\circ} \mathrm{C}$., has the composition $\mathrm{C}^{12} \mathrm{H}^{22} \mathrm{O}^{11}$, and gives. up $\mathrm{H}^{2} \mathrm{O}$ when it unites with bases. It has however a great tendency to form salts containing several equivalents of acid to one of base. An acid calcium arabate of the composition $\mathrm{C}^{12} \mathrm{H}^{20} \mathrm{CaO}^{11}, 6 \mathrm{C}^{12} \mathrm{H}^{22} \mathrm{O}^{11}$, would contain 1.63 per cent. of calcium, corresponding to $3 \cdot 4$ per cent. of calcium carbonate. Such salts have been prepared by Neubauer and also by
Heckmeijer.

The most carefully selected colourless pieces of gum arabic, yield from 
$2 \cdot 7$ to 4 per cent. of ash, consisting mainly of calcium carbonate, but containing also carbonates of potassium and magnesiun. Phosphoric acid appear's never to occur in gum.

Natural gum may therefore be regarded as a salt of arabic acid having a large excess of acid, or perhaps as a mixture of such salts of calcium, potassium and magnesium. It is to the presence of these bases, which are doubtless derived from the cell-wall from which the gum exuded, that gum owes its solubility.

It still remains unexplained why certain gums, not unprovided with mineral constituents, merely swell up in water without dissolving, thus materially differing from gum arabic. There is also a marked difference between gum arabic and many other varieties of gum or mucilage, which immediately form a plumbic compound if treated with neutral acetate of lead. The type of the swelling but not really soluble gums, is Bassora Gum $^{1}$ (p. 156); but there are a great many other substances of the same class. ${ }^{2}$

Commerce-The recent imports of Gum Arabic into the United Kingdom have been as follows :-

\section{6,136 cwt., value $£ 250,088$. $\quad 42,837$ cwt., value $£ 123,080$.}

The country whence by far the largest supplies are shipped, is Egypt.

Uses-Gum is employed in medicine rather as an adjuvant than as possessing any remedial powers of its own.

Substitutes-Feronia Gum. This is the produce of Feronia Elephantum Correa, a spiny tree, 50 to 60 feet high, of the order Auran-
tiacece, conmon throughout India from the hot valleys of the Himalaya to Ceylon, and also found in Java. There exudes from its bark, abundance of gum which appears not to be collected for exportation per se, but rather to be mixed indiscriminately with other gum, as that of Acacia.

Feronia gum sometimes forms small roundish transparent, almost colourless tears, more frequently stalactitic or knobby masses, of a brownish or reddish colour, more or less deep. In an authentic sample for which we are indebted to Dr. Thwaites of Ceylon, horn-shaped pieces about $\frac{1}{2}$ an inch thick and 2 inches long, also occur.

Dissolved in two parts of water, it affords an almost tasteless mucilage, of much greater viscosity than that of gum arabic made in the same proportions. The solution reddens litmus, and is precipitated like gum arabic by alcohol, oxalate of ammonium, alkaline silicates, perchloride of iron, but not by borax. Moreover, the solution of Feronia gum is precipitated by neutral acetate of lead or caustic baryta, but not by potash. If the solution is completely precipitated by neutral acetate of lead, the residual liquid will be found to contain a small quantity of a different gum, identical apparently with gum arabic, inasmuch as it is not thrown down by acetate of lead. If the lime is precipitated from the Feronia mucilage by oxalate of potassium, the gum partially loses its solubility and forms a turbid liquid.

From the preceding experiments, it follows that the larger portion of Feronia gum is by no means identical with gum arabic. The former

1 Guibourt, Hist. des Drogues, iii. (1850) 421.

2 For further informatiou, see Wiesner,

Gummiarten, Harze u. Balsame, Erlangen, 1869 ; Flïckiger, Pharm. Journ. x. (1869) 641 . 
when examined in a column of $50 \mathrm{~mm}$. length, deviates the ray of polarized light $0^{\circ} .4$ to the right, - not to the left as gum arabic. Gum arabic may be combined witl oxide of lead; the compound (arabate of lead) contains 30.6 per cent. of oxide of lead, whereas the plumbic compound of Feronia gum, dried at $110^{\circ} \mathrm{C}$, yielded us only 14.76 per cent. of $\mathrm{PbO}$. The formula, $\mathrm{C}^{12} \mathrm{H}^{9} \mathrm{PbO}^{11}+3 \mathrm{C}^{12} \mathrm{H}^{11} \mathrm{O}^{11}$, supposes 15 per cent. of oxide of lead. ${ }^{1}$

Feronia gum repeatedly treated with fuming nitric acid, produces abundant crystals of mucic acid. We found our sample of the gum to yield 17 per cent. of water, when dried at $110^{\circ} \mathrm{C}$. It left 3.55 per cent. of ash.

\section{CATECHU.}

Catechu nigrum; Black Catechu, Pegu Catechu, Cutch, Terra Japonica; F. Cachou, Cachou brun ou noir ; G. Catechu.

Botanical Origin-The trees from which this drug is manufactured are of two species, namely :-

1. Acacia Catechu Willd. (Mimosa Catechu L. fil., M. Sundra Roxb. ${ }^{2}$ ), a tree 30 to 40 feet high, with a short, not very straight trunk 4 to 6 feet in girth, straggling thorny branches, light feathery foliage, and dark grey or brown bark, reddish and fibrous internally.

It is common in most parts of India and Burma, where it is highly valued for its wood which is used for posts and for various domestic purposes, as well as for making catechu and charcoal, while the astringent bark serves for tanning. It also grows in the hotter and drier parts of Ceylon. A. Catechu abounds in the forests of Tropical Eastern Africa; it is found in the Soudan, Sennaar, Abyssinia, the Noer country, and Mozambique, but in none of these regions is any astringent extract manufactured from its wood.

2. A. Suma Kurz (Mimosa Suma Roxb.), a large tree with white bark, nearly related to the preceding but not having so extensive a geographical range. It grows in the Sonth of India (Mysore), Bengal, and Guzerat. The bark is used in tanning, and catechu is made from the heart-wood.

The extract of the wood of these two species of Acacia is Catechu in the true and original sense of the word, a substance not to be confounded with Gambier, which though very similar in composition, is widely diverse in botanical origin, and always regarded in commerce as a distinct article.

History-Barbosa in his description of the East Indies in $1514^{4}$ mentions a drug called Cacho as an article of export from Cambay to Malacca. This is the name for Catechu in some of the languages of
Southern India. ${ }^{5}$

About fifty years later, Garcia d'Orta gave a particular account of

1 We obtained $14: 56$ and $14 \cdot 96$ per cent. of $\mathrm{PbO} .-\mathrm{Pb}=207$.

2 Some Indian botanists, as Beddome, regard Mimosa (Acacia) Sundra as distinct from $A$. Catechu.

3 Brandis, Forest Flora of North-Western and Central India, Lond. 1874. 187, from

which excellent work we also borrow the description of $A$. Catcchu.

4 Published by the Hakluyt Society, Lond. 1866. p. 191.

${ }^{5}$ is Tamil and Canarese, in which according to modern spelling the word is

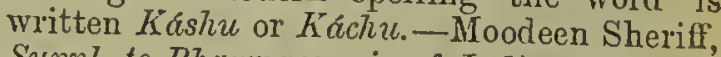
Suppl. to Phurmacopocia of India, 1869.96. 
the same dring ${ }^{1}$ under its Hindustani name of Kat, first describing the tree and then the method of preparing an extract from its wood. 'This latter substance was at that period made up with the flour of a cereal (Eleusinc correcana Gärtn.) into tablets or lozenges, and apparently not sold in its simple state: compositions of this lind are still met with in India. In the time of d'Orta the drug was an important article of traffic to Malacca and China, as well as to Arabia and Persia.

Notwithstanding these acconnts, catechu remained unknown in Europe until the latter half of the 17th century, when it began to be bronght from Japan. Schröder in the 4th edition of his Pharmacopocia Medieo-Chymica published at Lyons in 1654, briefly describes it as Catechu or Terra Japponiea,- "genus terrec exotice," of which he says a little bit had been given to him by the druggist, Matthew Bansa.

In 1671, catechu was noticed as a useful medicine by G. W. Wedel of Jena, ${ }^{2}$ who also called attention to the diversity of opinion as to its mineral or vegetable nature. Schröck ${ }^{3}$ in 1677 combated the notion of its mineral origin, and gave reasons for considering it a vegetable substance. A few years later, Cleyer ${ }^{4}$ who had a personal knowledge of China, pointed out the enorinous consumption of catechu for mastication in the East, - that it is imported into Japan,- that the best comes from Pegu, but some also from Surat, Malabar, Bengal, and Ceylon.

Catechu was received into the London Pharmacopoia of 1721, but was even then placed among "Terro medicamentosce."

The wholesale price in London in 1776 was $£ 16$ 16s. per cwt.; in $1780 £ 20$; in $1793 £ 1414 s$., from which it is easy to infer that the consumption could only have been very small. ${ }^{5}$

Manufacture-Cutch, commonly called in India $K a ́ t$ or $K u t$, is an aqueous extract made from the wood of the tree. The process for preparing it varies slightly in different districts.

The tree is reckoned to be of proper age when its trunk is about a foot in diameter. It is then cut down, and the whole of the woody part, with the exception of the smaller branches and the bark, is chopped into chips. Some accounts state that only the darker heart-wood is thus used. The chips are then placed with water in earthen jars, a series of which is arranged over a mud-built fire-place, usually in the open air. Here the water is made to boil, the liquor as it becomes thick and strong being decanted into another vessel, in which the evaporation is continued until the extract is sufficiently inspissated, when it is poured into moulds made of clay, or of leaves pinned together in the shape of cups, or in some districts on to a mat covered with the ashes of cowdung, the drying in each case being completed by exposure to the sun and air. The product is a dark brown extract, which is the usual form in which cutch is known in Europe.

In Kumaon in the north of India, ${ }^{6}$ a slight modification of the process affords a drug of very different appearance. Instead of evapo-

1 Aromatum Historia, ed. Clusius, 1574. 44. - He writes the word Cate.

2 Usus novus Catechu seu Terra Japoniea, -Ephemerides Nat. Cur., Dee. i. aun. 2 (1.671) 209.

3 Ibid. Dee. i. ann. 8 (1677) 88.

4 Ibid. Dec. ii. ann. 4 (1685). 6.
5 Pegu Cutch is quoted in a London pricecurrent, 21 Aug. 1S73, 1Ss. to 20s. per ewt.

6 Madden in Jourin. of Asiat. Soc. of Bengal, xvii. part i. (1S4S) 565 ; also private eommunieation aecompanied by specimens of tree, wood, and extraet from Mr. F. E. $G$. Matthews, of the Kumaon Iron Works, Nynee Tal. 
rating the decoction to the condition of an extract, the inspissation is stopped at a certain point and the liquor allowed to cool, "coagulate," and crystallize over twigs and leaves thrown into the pots for the purpose. How this drug is finished off we do not exactly know, but we are told that by this process there is obtained from each pot about $2 \mathrm{mb}$. of "Kath" or catechu, of an ashy whitish appearance, which is quite in accordance with the specimens we have received and of which we shall speak further on.

In Burma the manufacture and export of cutch form, next to the sale of timber, the most important item of forest revenue. According to a report by the Commissioner of the Prome Division, the trade returns of 1869-70, show that the quantity of cutch exported from the province during the year was 10,782 tons, valued at $£ 193,602$, of which nearly one-half was the produce of manufactories situated in the British territory. Vast quantities of the wood are consumed as fuel, especially for the steamers on the Irrawadi. ${ }^{1}$

Description-Cutch is imported in mats, bags, or boxes. It is a dark brown, extractiform substance, hard and brittle on the surface of the mass, but soft and tenacious within, at least when newly imported. The large leaf of Dipterocarpus tuberculatus Roxb., the Ein or Engben of the Burmese, is often placed outside the blocks of extract.

Cutch when dry breaks easily, showing a shining but bubbly and slightly granular fracture. When it is soft and is pulled out into a thin film, it is seen to be translucent, granular and of a bright orange-brown. When further moistened and examined under the microscope, it exhibits an abundance of minute acicular crystals, precisely as seen in gambier. We have observed the same in numerous samples of the dry drug when rendered pulpy by the addition of water, or moistened with glycerin and viewed by polarized light.

The pale cutch referred to as manufactured in the north of India, is in the form of irregular fragments of a cake an inch or more thick, which has a laminated structure and appear's to have been deposited in a roundbottomed vessel. It is a porous, opaque, earthy-looking substance of a pale pinkish brown, light, and easily broken. Under the microscope it is seen to be a mass of needle-sliaped crystals exactly like gambier, with which in all essential points it corresponds. We have received from India the same kind of cutch made into little round cakes like lozenges, with apparently no addition. The taste of cutch is astringent, followed by a sensation of sweetness by no means disagreeable.

Chemical Composition - Extractiform cutch, such as that of Pegu, which is the only sort comraon in Europe, when immersed in cold water turns whitish, softens and disintegrates, a small proportion of it dissolving and forming a deep brown solution. The insoluble part is Catechin or Catechuic Acid, in minute acicular crystals. If a little of the thick chocolate-like liquid made by macerating cutcli in water, is heated to the boiling point, it is rendered quite transparent (mechanical impurities being absent), but becomes turbid on cooling. Ferric chloride forms with this solution a dark green precipitate, immediately changing to purple if common water or a trace of free alkali be used; dilute acids throw down a precipitate.

I Pearson (G. F.) Report of the Administration of the Forest Department in the 
Ethcr extracts from cutch, catcchin. This substance has been shown by Rochleder (1869) to have the formula $\mathrm{C}^{13} \mathrm{H}^{12} \mathrm{O}^{5}$, and to be a compound of Phloroglucin, $\mathrm{C}^{6} \mathrm{H}^{6} \mathrm{O}^{3}$, and Ascylic Alcohol, $\mathrm{C}^{7} \mathrm{H}^{8} \mathrm{O}^{3}$, less $\mathrm{H}^{2} \mathrm{O}$. Catcchin dehydrated by drying over oil of vitriol, and then treated with an acid, loses $\mathrm{H}^{2} \mathrm{O}$ and is converted into brown, arnorphous Catcchurctin.

An aqueous solution of catechin does not precipitate a solution, either of gelatin, emetic tartar, or of a vcgetable alkaloid; but the prccipitation at least of the first-mentioned, takes place if the catcchin solution is previously boilcd for a long time, the result in this casc being duc to the partial conversion of the catcchin into Catcchu-tannic Acid. The lattcr substance is also extracted when cutch or gambicr is cxhausted with cold watcr, but from the difficulty of obtaining it frce from catechin it has not been thoroughly examined. ${ }^{1}$

Löwe $(1873)^{2}$ by exhausting cutch with cold water and then agitating the solution with ethcr, obtained upon the cvaporation of the latter, a ycllow crystalline substance which he ascertained to be Qucrcetin, $\mathrm{C}^{27} \mathrm{H}^{18} \mathrm{O}^{12}$. Its solubility in water is probably favoured by the presence of catechin, water having but very little action upon pure quercetin. The amount of quercetin in cutch is exceedingly small.

When either cutch or gambier is subjected to dry distillation it yields, in common with many other substances, Pyrocatcchin, $\mathrm{C}^{6} \mathrm{H}^{6} \mathrm{O}^{2}$.

Commerce-The importations of cutch into the United Kingdom from British India (excluding the Straits Settlements and Ceylon) were as under, almost the whole being from Bengal and Burma:-

$\begin{array}{cccc}1869 & 1870 & 1871 & 1872 \\ 2257 \text { tons. } & 5252 \text { tons. } & 4335 \text { tons. } & 5240 \text { tons. }\end{array}$

The total value of the cutch imported in 1872, was estimated at $£ 124,458$.

Uses-Cutch under the name of Catechu, which name it shares with gambier, is employed in medicine as an astringent.

Analogous Product-Areca-nut Catechu-The seeds of Areca Catechu L., the most elegant palm of India, are called Areca Nuts or Betel Nuts, and yield when boiled in water, an astringent extract which was once supposed to form part of the catechu of commerce; but there is no rcason to believe that any of it now finds its way to Europe. Drury ${ }^{3}$ states it to be a catechu of very inferior quality, one variety of which, called Cuttacamboo (Katta Kámbu) is chewed with lime and betel-leaf.

\section{ROSACEA}

\section{AMYGDALA DULCES.}

\section{Sweet Almonds; F. Amandes douccs; G. Süsse Mandeln.}

Botanical Origin-Prunus Amygdalus Baillon * var. $\beta$ dulcis (Amygdalus communis L. var. $\beta$ dulcis DC.) - The native country of the almond cannot be ascertained with precision. A. de Candollc ${ }^{5}$ after

1 Gmelin, Chemistry, xv. (1862) 515.

2 Fresenius, Zeitschrift für anal. Chemie, xii. (1873) 127.

3 Usiful Plants of India, 2nd ed., 1873. 48.
4 Hist. des Plantes (Monogr. des Rosackes, 1869) i. 415.

5 Gcographie Botanique, ii. (1S55) 888. 
reviewing the statements of various authors concerning the occurrence of the tree in an apparently wild state, arrives at the conclusion that its original area possibly extended from Persia, westward to Asia Minor and Syria, and even to Algeria.

At an early period the tree was spread throughout the entire Mediterranean region, and in favourable situations, far into the continent of Europe. It was apparently introduced into Italy from Greece, where according to Heldreich, ${ }^{1}$ the bitter variety is truly wild. The almondtree matures its fruit in the south of England, but is liable to destruction by frost in many parts of central Europe.

History-The earliest notice of the almond extant is that in the Book of Genesis, ${ }^{2}$ where we read that the patriarch Israel commanded his sons to carry with them into Egypt, a present consisting of the productions of Palestine, one of which is named as Almonds.

From the copious references to the almond in the writings of Theophrastus, one cannot but conclude that in his day it was familiarly known.

In Italy, M. Porcius Cato ${ }^{3}$ mentions towards the middle of the 2nd century B.C., Avellance Groecee which we know from later authors signified almonds. Columella who wrote about A.D. 60, calls them Nuces Grocece. Bitter almonds ("Amygdali amari") are named about this latter period by Scribonius Largus, a physician of Rome.

As to more northern Europe, almonds are mentioned together with other groceries and spices as early as A.D. 716, in a charter granted by Chilperic II. king of France, to the monastery of Corbie in Normandy. ${ }^{4}$ In the next century, Charlemagne ordered the trees (Amandalarii) to be introduced on the imperial farms. In the later middle ages, the cultivation of the almond was carried on about Speier and in the Rhenish Palatinate. We learn from Marino Sanuto ${ }^{5}$ that in the beginning of the 14th century, almonds had become an important item of the Venetian trade to Alexandria. They were doubtless in large part produced by the islands of the Greek Archipelago, then under Christian rule. In Cyprus for instance, the Knights Templar levied tithes in 1411, of almonds, honey and sesamé seed. ${ }^{6}$

The consumption of almonds in mediæval cookery was enormous. An inventory made in 1372, of the effects of Jeanne d'Evreux, queen of France, enumerates only $20 \mathrm{Hb}$. of sugar, but $500 \mathrm{lb}$. of almonds. ${ }^{7}$

In the Form of Cury, a manuscript written by the master cooks of King Richard II., A.D. 1390, are receipts for "Creme of Almand, Grewel of Almand, Cawdel of Almand Mylke, Jowt of Almand Mylke," \&c.8

Almonds were sold in England by the "hundred," i.e. $108 \mathrm{Hb}$. Rogers ${ }^{9}$ gives the average price between 1259 and 1350 as $2 d$., and between 1351 and 1400 as $3 \frac{1}{8} d$. per $1 \mathrm{~b}$.

67.

2 Ch. xliii. v. 11.

3 De Re Rustiea, cap. viii.

4 Pardessus, Diplomata, Charto, ctc. Paris, 1849. ii. 309.

${ }^{5}$ Liber Secretorum Fidelium, cd. Bongars, 1611. 24.

- De Mas Latrie, Hist. de l'île de Chypre, ii. (1852) 500 .
7 Leber, Appréeiation de la fortune privée au moyen-age, éd. 2, Paris, 1847. 95.

8 Published by Pegge, Lnnd. 1780.Boorde in his Dyetary of Helth, 1542, mentions Almon Mylke and Almon Butter, the latter " a commendable dysshe speeyallye in Lent."

9 Agrieulture and Priees in England, i. (1866) 641 . 
Description - The fruit of the almond-tree is a drupe, with a velvety sarcocarp which at maturity dries, splits, and drops off, leaving bare and still attached to the branch, an oblong, ovate, pointed stone, pitted with irregular holes. The seed, about an inch in length, is ovate or oblong, more or less compressed, pointed at the upper, blunt at the lower end, coated with a scurfy, cimnamon-brown skin or testa. It is connected with the stone or putamen by a broad funicle, which runs along its edge for more than a third of its length from the apex: hence the raphe passes downwards to the rounded end of the seed, where a scar marks the chalaza. From this, a dozen or more ranifying veins run up the brown skin towards the pointed end. After an almond has been macerated in warm water, the skin is easily removed, bringing with it the closely attached transhucent inner membrane or endopleura. As the seed is without albumen, the whole mass within the testa consists of embryo. This is formed of a pair of plano-convex cotyledons, within which lie the flat leafy plumule and thick radicle, the latter slightly projecting from the pointed or basal end of the seed.

Almonds have a bland, sweet, nutty flavour. When triturated with water, they afford a pure white, milk-like emulsion of agreeable taste.

Varieties-The different sorts of almond vary in form and size, and more particularly in the firmmess of the shell. This in some varieties is tender and easily broken in the hand, in others so hard as to require a hammer to fracture it. The form and size of the kernel likewise exhibit some variation. The most esteemed are those of Malaga, known in trade as Jordan Almonds. They are usually imported without the shell, and differ from all other sorts in their oblong form and large size. The other kinds of sweet almonds known in the London market, are distinguished in the order of value as Valencia, Sicily, and Barbary.

Microscopic Structure-Three different parts are to be distinguished in the brown coat of an almond. First, a layer of very large (as much as $\frac{1}{3} \mathrm{~mm}$. in diameter) irregular cells, to which the scurfy surface is due. If these brittle cells are boiled with caustic soda, they make a brilliant object for microscopic examination in polarized light. The two inner layers of the skin are made up of much smaller cells, traversed by small fibro-vascular bundles. The brown coat assumes a bluish hue on addition of perchloride of iron, owing to the presence of tannic matter.

The cotyledons consist of thin-walled parenchyme, fibro-vascular bundles being not decidedly developed. This tissue is loaded with granular albuminous matter, some of which exhibits a crystalloid aspect, as may be ascertained in polarized light. Starch is altogether wanting in almonds.

Chemical Composition-The sweet almond contains fixed oil extractable by boiling ether to the extent of 50 to 55 per cent. ${ }^{1}$ A produce of 50 per cent. by the hydraulic press is by no means uncommon. ${ }^{2}$

The oil (Oleum Amygdalce) is a thin, light yellow fluid, of sp. gr. 0.92, which does not solidify till cooled to between -10 and $-20^{\circ} \mathrm{C}$. When fresh, it has a mild nutty taste, but soon becomes rancid by exposure to

1 The result of 10 analyses - Vohl in Dingler's Polytechn. Journ. cc. (1871) 410.
2 Such was the experience in the Staatapotheke at Bern, where sweet almonds were often pressed.-F. A. F. 
the air ; it is not however one of the drying oils. It consists almost wholly of the glycerin compound of Oleic Acid, $\mathrm{C}^{18} \mathrm{H}^{34} \mathrm{O}^{2}$.

Almonds easily yield to cold water a sugar tasting like honey, which reduces alkaline cupric tartrate even in the cold, and is therefore in part grape-singar. Pelouze however (1855) obtained from almonds 10 per cent. of cane-sugar. The amount of gum appears to be very small; Fleury (1865) found that the total amount of sugar, dextrin and mucilage was altogether only 6.29 per cent.

The almond yields 3.7 per cent. of nitrogen, corresponding to about 24 per cent. of albuminoid matters. These have been elaborately examined by Robiquet (1837-38), Ortloff (1846), Bull (1849), and Ritthausen $(1872){ }^{1} \quad$ The experiments tend to show that there exist in the almond two different protein substances; Robiquet termed one of these bodies Synaptase, while others applied to it the name Emulsin. ${ }^{2}$ Commaille (1866) named the second albuminous substance Amandin; it is the Almond-legumin of Gmelin's Chemistry, the Conglutin of Ritthausen. Emulsin has not yet been freed from earthy phosphates which, when it is precipitated by alcohol from an aqueous solution, often amount to a third of its weiglit. Amandin may be precipitated from its aqueous solution by acetic acid. According to Ritthausen, these bodies are to be regarded as modifications of one and the same substance, namely vegetable casein.

Blanched almonds comminuted yield when slightly warmed with dilute potash, a small quantity of hydrocyanic acid and of ammonia; the former may be made manifest by means of Schönbein's test pointed out at p. 222.

The ash of almonds, amounting to from 3 to nearly 5 per cent., consists chiefly of phosphates of potassium, magnesium and calcium.

Production and Commerce-The quantity of almonds imported into the United Kingdom in 1872 , was 70,270 cwt., valued at $£ 204,592$. Of this quantity, Morocco supplied 33,500 cwt., and Spain with the Canary Islands 22,000 cwt., the remainder being made up by Italy, Portugal, France, and other countries. Almonds are largely shipped from the Persian Gulf: in the year 1872-73, there were imported thence into Bombay, 15,878 cwt., besides 3,049 cwt. from other countries. ${ }^{3}$

Uses-Sweet almonds may be used for the extraction of almond oil, yet they are but rarely so employed (at least in England) on account of the inferior value of the residual cake. The only other use of the sweet almond in medicine, is for making the emulsion called Mistura Amygdala.

\section{AMYGDAL $\#$ AMARAE.}

Bitter Almonds; F. Amandes amères; G. Bitter Mandeln.

Botanical Origin-Prunus Amygdalus Baillon var. a. amara Amygdalus communis L. var. a. amara DO.) The Bitter Almond tree

${ }^{1}$ Die Eiweisstcörper der Getreidearten, Iülsenfrüchte und Oelsamen. Bonn. 1872. 99.
2 Gmelin, Chemistry, xviii. (1871) 452.

3 Statement of the Trade and Navigation of Bombay for 1872-73, pt. ii. 31 . 
is not distinguished from the sweet by any permanent botanical character, and its area of growth appears to be the same (see p. 216).

History-See preceding article.

Description-Bitter almonds agree in outward appearance, form, and structure with sweet almonds; they exist under several varieties, but there is none so far as we know, that in size and form resembles the long sweet almond of Malaga. ${ }^{1}$ In general, bitter almonds are of smaller size than sweet. Triturated with water, they afford the same white emulsion as sweet almonds, but it has a strong odour of hydrocyanic acid and a very bitter taste.

Varieties-These are distinguished in their order of goodness, as French, Sicilian, and Barbary.

Microscopic Structure-In this respect, no difference between sweet and bitter almonds can be pointed out. If thin slices of the latter are deprived of fat oil by means of benzol, and then kept for some years in glycerin, an abundance of crystals is slowly formed, of what we suppose to be amygdalin.

Chemical Composition-Bitter almonds when comminuted and mixed with water, immediately evolve the odour of bitter almond oil. The more generally diffused substances are the same in both kinds of almond, and the fixed oil in particular of the bitter almond is identical with that of the sweet. Bitter almonds however contain on an average a somewhat lower proportion of oil than the sweet. In one instance that has come to our knowledge in which 28 cwt. of bitter almonds were submitted to pressure, the yield of oil was at the rate of $43 \cdot 6$ per cent. Mr. Umney, director of the laboratory of Messrs. Herrings and Co., where large quantities of bitter almonds are submitted to powerful hydraulic pressure, gives 44.2 as the average percentage of oil obtained during the years $1871-2$.

As early as the beginning of the present century, it was shown $b$ the experiments of Bohm of Berlin, that the aqueous distillate of bitter almonds contains hydrocyanic acid and a peculiar oil which cannot be obtained from sweet almonds. ${ }^{2}$

Robiquet and Boutron-Charlard in 1830, prepared from bitter almonds a crystalline substance, Amygdalin, and found that bitter almond oil and hydrocyanic acid can no longer be obtained from bitter almonds, the amygdalin of which has been removed by alcohol. Liebig and Wöhler in 1837 showed that it is solely the decomposition of this body (under conditions to be explained presently), that occasions the formation of the two compounds above named. Disregarding secondary products (ammonia and formic acid), the reaction takes place as represented in the following equation:

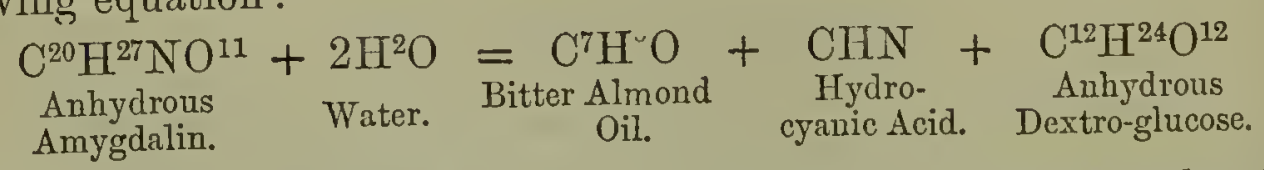

This memorable investigation first brought under notice a body of the glucoside class, now so mumerous.

1 Hence to avoid bitter almonds being used instead of swcet, the British Pharmacopceia directs that Jordan Almonds alone

2 J. B. Richter, Neucre Gegenstände d. shall be employcd for Confection of Almonds. Chymic, Breslau, xi. (1802) 65 . 
Amygdalin may be obtained crystallized with $2 \mathrm{H}^{2} \mathrm{O}$, when almonds deprived of their oil are boiled with alcohol of 84 to 94 per cent. The product amounts at most to $2 \frac{1}{2}$ or 3 per cent. Amygdalin per se dissolves in 15 parts of water at $8-12^{\circ} \mathrm{C}$., forming a neutral, bitter, inodorous liquid, quite destitute of poisonous properties.

When bitter almonds have been freed from amygdalin and fixed oil, cold water extracts from the residue chiefly emulsin and another albuminoid matter separable by acetic acid. The emulsin upon addition of alcohol, falls down in thick flocks, which, after draining, form with cold water a slightly opalescent solution. This liquid added to an aqueous solution of amygdalin, renders it turbid, and developes in it bitter almond oil. The reaction takes place in the same manner, if the emulsin has not been previously purified by acetic acid and alcohol, or if an emulsion of sweet almonds is used. But after boiling, an emulsion of almonds is no longer capable of decomposing amygdalin.

What alteration the emulsin itself undergoes in this reaction, or whether it suffers any alteration at all, has not been clearly made out. The reaction does not appear to take place necessarily in atomic proportions; it does not cease until the emulsin has decomposed about ten times its own weight of amygdalin, provided always that sufficient water is present to hold all the products in solution.

The leaves of Prunus Lauro-cerasus L., the bark of P. Padus L., and the organs of many allied plants, also contain emulsin or a substance analogous to it, not yet isolated. In the seeds of various plants belonging to natural orders not botanically allied to the almond, as for example in those of mustard, hemp, and poppy, and even in yolk of egg, albuminous substances occur which are capable of acting upon amygdalin in the same manner. Boiling dilute hydrochloric acid induces the same decomposition, with the simultaneous production of formic acid.

The distillation of bitter almonds is known to offer some difficulties on account of the large quantity present of albuminous substances, which gives rise to bumping and frothing. Michael Pettenkofer (1861) has found that these inconveniences may be avoided by immersing 12 parts of powdered almonds in boiling water, whereby the albuminous matters are coagulated, whereas the amygdalin is dissolved. On then adding an emulsion of only 1 part of almonds (sweet or bitter), the emulsin contained in it will suffice to effect the required decomposition at a temperature not exceeding $40^{\circ} \mathrm{C}$. In this manner, Pettenkofer obtained in some experiments performed with small quantities of almonds, as much as 0.9 per cent. of essential oil. In the case alluded to on the opposite page, in which $28 \mathrm{cwt}$. of almonds were treated, the yield of essential oil amounted to 0.87 per cent. From data obligingly furmished to us by Messrs. Herrings and Co. of London, who distill large quantities of almond cake, it appears that the yield of essential oil is very variable. The yearly averages as taken from the books of this firm, show that it may be as low as 0.74 , or as high as 1.67 per cent., which, assuming 57 pounds of cake as equivalent to 100 pounds of almonds, would represent a percentage from the latter of 0.42 and 0.95 per cent. respectively. Mr. Umney explains this enormous variation as due in part to natural variableness in the different kinds of bitter almond, and in part to their admixture with sweet almonds. He also states that the action of the 
emulsin ou the amygdalin when in contact with water, is exiremely rapid, and that 200 pounds of almond mare are thoroughly exhausted by a distillation of only threc hours.

In the distillation, the hydrocyanic acid and bittcr almond oil unite into an unstablc compound. From this, the acid is gradually set frec, and partly converted into cyanide of anmonium and formic acid. Supposing bitter almonds to contain $3 \cdot 3$ per ccnt. of anygdalin, they must yield 0.2 per cent. of hydrocyanic acid. Pettenkofer obtaincd by experiment as much as 0.25 per cent. Feldhaus (1863) 0.17 per cent.

Some manufacturcrs supply bitter almond oil deprived of hydrocyanic acid, but such purificd oil is very prone to oxidation, unless carefully deprived of water by being shaken with fused chloride of calcium. The sp. gr. of the original oil is $1.061-1.065$; that of the purified oil (according to Umncy) 1.049. The purification by the action of fcrrous sulphate and lime, and rc-distillation, as recommended by Maclagan (1853), occasions, we are informed, a loss of about 10 per cent.

Therc are a grcat number of plants which if crushed, moistcned with water, and submitted to distillation, yield both bitter almond oil and hydrocyanic acid. In many instances the amount of hydrocyanic acid is so extremely small, that its presence can only be revealed by the most delicate test, - that of Schönbein. ${ }^{1}$

Among plants capable of emitting hydrocyanic acid, probably always accompanied with bitter almond oil, the tribes Prunece and Pomece of the rosaceous order may be particularly mentioned.

The farinaceous rootstocks of the Bitter Cassava, Manihot utilissima Pohl, of the order Euphorbiacece, the source of tapioca in Brazil, have long been known to yield hydrocyanic acid.

A composite, Chardinia xeranthemoides Desf., growing in the Caspian regions, has been shown by W. Eichler also to emit hydrocyanic acid."
The same has been observed by the French in Gaboon ${ }^{3}$ with regard to the fruits of Ximenic Americanc L. of the order Olaeinece, and the fact lias been confirmed by Ernst of Caracas, ${ }^{4}$ near which place the plant abounds. Mr. Prestoe of the Botanical Garden, Trinidad, informs us (1874) that in that island a convolvulaceous plant, Ipomoea dissecte Willd., contains a juice with a strong prussic acid odour. According to Lösecke, a common mushroom, Agarieus Oreades Bolt., emits hydrocyanic acid. ${ }^{5}$

This acid is consequently widely diffused throughout the vegetable kingdom. Yet amygdalin has thus far only been isolated from a few plants belonging to the genus Prunus or its near allies. ${ }^{6}$ In all other plants in which hydrocyanic acid has bcen met with, we know nothing as to its origin. Ritthausen and Kreusler ${ }^{7}$ have proved the absence of amygdalin in the seeds of a Vicia, which yield bitter almond oil and hydrocyanic acid. These chemists followed the process which in the case of bitter almonds easily affords amygdalin.

Commerce--See preceding article.

1 Applied in the following manner :- Let bibulous paper be imbued with a fresh tineture of the wood or resin of guaiacum, and after drying, let it be moistened with a solution eomposed of one part of sulphate of copper in 2000 of water. Sueh paper moistened with water will assume an intense blue coloration in the presence of hydrocyanic acid.

2 Bull. de la Soc. imp. des nat. de Mroscon, xxxv. (1S62) ii. 444.

3 Exposition Univers. de 1867.-Produits des Colonics Françaises, 92.

4 Archiv der Pharmacic, 181 (1567) 222.

5 Johresberieht of Wiggers and Husemann for 1871.11.

6 Gmelin, Chemistry, vii. 359 ; xv. 422.

7 Chemisches Centralblatt, 1871, 3. 
Uses-Bitter almonds are used almost exclusively for the manufacture of Almond Oil, while from the residual cake is distilled Bitler Almond Oil. An emulsion of bitter almonds is sometimes prescribed as a lotion.

Adulteration-The adulteration of bitter almonds with sweet is a frequent source of loss and annoyance to the pressers of almond oil, whose profit largely depends on the amount of volatile oil they are able to extract from the residual cake.

\section{FRUCTUS PRUNI.}

\section{Prunes; F. Pruneaux à médecine.}

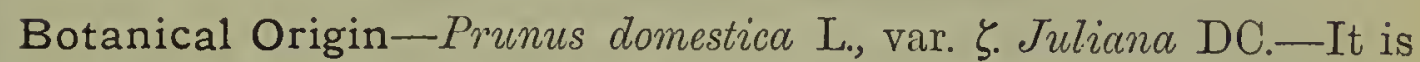
from this tree which is known as Prunier de St. Julien, ${ }^{1}$ that the true Medicinal Pruncs of English pharmacy are derived. The tree is largely cultivated in the valley of the Loire in France, especially about Bourgueil, a small town lying between Tours and Angers.

History-The plum-tree ( $P$. domestica L.) from which it is supposed the mumerous cultivated varieties have descended, is believed to occur in a truly wild state in Greece, the south-eastern shores of the Black Sea (Lazistan), the Caucasus, and the Elburz range in Northern Persia, from some of which countries it was introduced into Europe long before the Christian era. In the days of Pliny, numerous species of plum were already in cultivation, one of which afforded a fruit having laxative properties.

Dried prunes, especially those taking their name from Damascus (Pruna Damascena), are frequently mentioned in the writings of the Greek physicians, by whom as well as at a later period by the practitioners of the Schola Salerni, they were much employed.

In the older London pharmacopoias, many sorts of plum are enumerated, but in the reformed editions of 1746, 1788 and 1809, the French Prune (Prunum Gallicum) is specially ordered, its chief use being as an ingredient of the well-known Lonitive Electuary; and this fruit is still held by the grocers to be the legitimate prune. The same variety is regarded in France as the prune of medicine.

Description-The prune in its fresh state is an ovoid drupe of a deep purple hue, not depressed at the insertion of the stalk, and with a scarcely visible suture, and no furrow. The pulp is greenish and rather austere, unless the fruit is very ripe; it does not adhere to the stone. The stone is short $\left(\frac{7}{10}\right.$ to $\frac{8}{10}$ of an inch long, $\frac{5}{10}$ to $\frac{8}{10}$ broad), broadly rounded at the upper end and slightly mucronulate, narrowed somewhat stalk-like at the lower, and truncate; the ventral suture is broader and
thicker than the dorsal.

The fruit is dried partly by solar and partly by fire heat, - that is to say, it is exposed alternately to the heat of an oven and to the open air. Thus prepared, it is about $1 \frac{1}{4}$ inches long, black and shrivelled, but

1 Loiseleur-Deslongchanips et Michel, Noureau Duhamel, ou 'Traité des arbres et

arbustes que l'on cultive en France, v. (1812)
189, pl. 54. fig. 2, pl. 56. fig. 9. 
recovers its original size and form by digestion in warm water. The dried pulp or sarcocarp is brown and tough, with an acidulous, saccharine, fruity taste.

Microscopic Structure-The skin of the prune is formed of small, densely packed cells, loaded with a dark solid substance; the pulp consists of larger shrunken cells, containing a brownish amorphous mass which is probably rich in sugar. This latter tissue is traversed by a few thin fibro-vascular bundles, and exhibits here and there crystals of oxalate of calcium. By perchloride of iron, the cell walls as well as the contents of the cells, acquire a dingy greenish hue:

Chemical Composition-We are not aware of any analysis having been made of the particular sort of plum under notice, nor that any attempt has been made to discover the source of the medicinal property it is reputed to possess. Some nearly allied varieties have been submitted to analysis in the laboratory of Fresenius, and shown to contain saccharine matters to the extent of 17 to 35 per cent., besides malic acid, and albuminoid and pectic substances. ${ }^{1}$

Uses-The only pharmaceutical preparation of which the pulp of prunes is an ingredient, is Confectio Senna, the Electuarium lenitivum of the old pharmacopœias. The fruit stewed and sweetened, is often used as a domestic laxative.

Substitute-When French prunes are scarce, a very similar fruit known in Germany as Zwetschen or Quetschen, is iniported as a substitute. ${ }^{2}$ It is the produce of a tree which most botanists regard as a form of Prunus domestica L., termed by De Candolle var. Pruncauliana. K. Koch ${ }^{3}$ however, is decidedly of opinion that it is a distinct species, and as such he has revived for it Borkhausen's name of Prunus ceconomica. The tree is widely cultivated in Germany for the sake of its fruit, which is used in the dried state as an article of food, but is not grown in England.

The dried fruit differs slightly from the ordinary prune in being rather larger and more elongated, and having a thicker skin; also in the stone being flatter, narrower, pointed at either end, with the ventral suture much more strongly curved than the dorsal. The fruits seem rather more prone to become covered with a saccharine efflorescence.

\section{CORTEX PRUNI SEROTINAE.}

\section{Cortex Pruni Virginiano; Wild Black Cherry Bark.}

Botanical Origin-Prunus serotina Ehrhart (P. Virginiana Miller non Linn., Cerasus serotina DC.)-A shrub or tree, in favourable situations growing to a height of 60 feet, distributed over an immense extent of North America. It is found throughout Canada as far as $62^{\circ} \mathrm{N}$. lat, and from Newfoundland and Hudson's Bay in the east, to the valleys west of the Rocky Mountains. ${ }^{4}$ It is also common in the United States.

1 Liebig's Ann. der Chemie, ci. (1857) 228.

2 This was especially the case in the winter of 1873-74.
3 Dendrologie, part i. (1869) 94.

4 Hooker, Flora Boreali-Amerieana, i. (1833) 169. 
The tree is often confounded with $P$. Virginiana L., from which, indeed, it seems to be separated by no fixed character, though American botanists hold the two plants as distinct. It is also nearly allied to the well-known P. Padus. L. of Europe, the bark of which harl formerly a place in the Materia Medica. ${ }^{1}$

History-Experiments on the medicinal value of Wild Cherry Bark were made in America about the end of the last century, at which time the drug was supposed to be useful in intermittent fevers. ${ }^{2}$ The bark was introduced into the United States Pharmacopcia in 1820. An elaborate article by Bentley ${ }^{3}$ published in 1863 contributed to bring it into notice in this country, but it is still much more employed in America than with us.

Description-The inner bark of the root or branches is said to be the most suitable for medicinal use. That which we have seen, is evidently from the latter; it is in flattish or channelled pieces, $\frac{2}{10}$ to $\frac{1}{20}$ of an inch in thickness, $\frac{1}{2}$ an inch to 2 inches broad, and seldom exceeding 5 inches in length. From many of the pieces, the outer suberous coat has been shaved off, in which case the whole bark is of a deep cinnamon brown; in others the corky layer remains, exhibiting a polished satiny surface, marked with long transverse scar's. 'The inner surface is finely striated, or minutely fissured and reticulated. The bark breaks easily with a short granular fracture; it is nearly without smell, but if reduced to coarse powder and wetted with water it evolves a pleasant odour of bitter almonds. It has a decided but transient bitter taste.

The bark freshly cut from the stem is quite white, and has a strong odour of bitter almonds and hydrocyanic acid.

Microscopic Structure-The chief mass of the tissue is made up of hard, thick-walled, white cells, the groups of which are separated by a brown fibrous prosenchyme. The liber is crossed in a radial direction by numerous broad medullary rays of the usual structure. The parenchymatous portion is loaded both with very large single crystals, and crystalline tufts of calcium oxalate. There is also an abundance of small starch granules, and brown particles of tannic matters. Thin slices of the bark moistened with perchloride of iron, assume a blackish coloration.

Chemical Composition-The bitterness and odour of the fresh bark depend in part, according to Procter, ${ }^{4}$ on the presence of Amygclalin. Hydrocyanic acid and essential oil are produced when the bark is distilled with water, and must be due to the mutual action of amygdalin and some principle of the nature of emulsin. From the fact that an extract of the bark remained bitter although the whole of the amygdalin had been removed, Procter inferred the existence of another substance to which the tonic properties of the bark are perhaps due. The amygdalin, however, has not been isolated.

The fresh bark was found by Perot ${ }^{5}$ to yield $\frac{1}{2}$ per mille of hydrocyanic acid in April, 1 per mille in June, and 1.4 in October. The best time for collecting the bark is therefore the autumn.

\footnotetext{
I Martiny, Encyklopädic, i. (1843) 500 ;

Hayne, A rzncygerü̈chse, iv. (1816) 40.

2 Barton, Collcctions for Mat. Med. of

3 Pharm. Journ. v. (1864) 97.

1 Am. Joum. of Pharm. iv. (1839) 197

5 Ibid. xviii. (1\$52) 109.
}

Unitcd Statcs, Pnilad. 1798. 11. 
Uses-In Anerica, wild cherry bark is lield in high estimation for its mildly tonic and sedative properties. It is administered most appropriately in the form of cold infusion or syrup, the latter being a strong cold infusion, sweetened; in fluid extract and a dry resinoid extract are also in use. 'The bark is said to deteriorate by keeping, and shonld be preferred when recently dried.

\section{FOLIA LAURO-CERASI.}

\section{Common Laurel or Cherry-laurel Leaves; F. Feuilles de Laurier-cerise;} G. Kirsehlorbecrblëtter.

Botanical Origin-Prunus Lauro-cerasus L., a handsome everoreen shrub, growing to the height of 18 or more feet, is a native of the Caucasian provinces of Russia (Mingrelia, Imeritia, Guriel), of the valleys of North-western Asia Minor, and Northern Persia. It has been introduced as a plant of oinament into all the more temperate regions of Europe, and flourishes well in England and other parts, where the winter is not severe and the summer not excessively hot and dry.

History-Pierre Belon, the French naturalist, who travelled in the East between 1546 and 1550 , is stated by Clusius ${ }^{1}$ to have discovered the cherry-laurel in the neighbourhood of Trebizond. Thirty years later, Clusius himself obtained the plant through the Imperial ambassador at Constantinople, and distributed it from Vienna to the gardens of Germany. Since it is mentioned by Gerarde ${ }^{2}$ as a choice garden shrub, it must have been cultivated in England prior to 1597. Ray, who like Gerarde calls the plant Cherry-bay, states that it is not known to possess medicinal properties.

In 1731, Madden of Dublin drew the attention of the Royal Society of London ${ }^{4}$ to some cases of poisoning that had occurred by the use of a distilled water of the leaves. This water he states had been for many years in frequent use in Ireland among cooks, for flavouring puddings and creams, and also much in vogue with dram drinkers as an addition to brandy, without any ill effects from it having been noticed. The fatal cases thus brought forward occasioned much investigation, but the true nature of the poison was not understood till pointed out by Schrader in 1803. Cherry-laurel water, though long used on the Continent, has never been much prescribed in Great Britain, and had no place in any British Pharmacopoeia till 1839.

Description-The leaves are alternate, simple, of leathery texture and shining upper surface, 5 to 6 inches long by $1 \frac{3}{4}$ to 2 inches wide, oblong or slightly obovate, attenuated towards either end. The thick leafstalls, scarcely half an incl in length, is prolonged as a stout midrib to the recurved apex. The margin, which is also recurved, is provided with sharp but very short serratures, which become more distant towards the base. 'The under side, which is of a paler colour and dull surface, is marked by $\&$ or 10 lateral veins, anastomosing towards the edge. Below the lower of these and close to the midrib, are from two to four shallow

1 Rarionum Plantarum Ifistoria, 1601. 4.

2 Herball (1636), 1603.

3 Hist. Plant. ii. (1693) 1549.

* Phil. Trans. xxxvii. (for 1731-32) 84. 
depressions or glands, which in spring exude a saccharine matter, and soon assume a brownish colour:

The fresl leaves are inodorous until they are bruised or torm, when they instantly emit the smell of bitter almond oil and hydrocyanic acid. Whell chewed they taste rough, aromatic and bitter.

Microscopic Structure-The upper surface of the leaf is constituted of thin cuticle and the epidermis made up of large, nearly cubic cells. The middle layer of the interior tissue exhibits densely packed small cells, whereas the prevailing part of the whole tissue is formed of larger, loose cells. Most of them are loaded with chlorophyll; some enclose crystals of oxalate of calcium.

Chemical Composition-The leaves when cut to pieces and submitted to distillation with water, yield Bitter Almond Oil and Hydrocyanic Acid, produced it is supposed by the decomposition of Amygdalin (p. 220), which however has not been obtained from them. Moreover, the body which induces the decomposition is not known.

The proportion of hydrocyanic acid in the water has been the subject of many researches. Among the later are those of Broeker (1867), who distilled a given weight of the leaves grown in Holland under precisely similar circumstances, in each month of the year. The results proved that the product obtained during the winter and early spring, was weaker in the acid in the proportion of 17 to 24,28 , or 30 , the strongest water being that distilled in July and August. This chemist found that a stronger product was got when the leaves were chopped fine, than when they were used whole. According to Christison, the buds and very young leaves yield ten times as much essential oil as the leaves one year old.

The fresh unwounded leaves of the cherry-laurel in vigorous vegetation, have been recently found by Schaer, whose experiments were made at the request of one of us (F.), not to evolve naturally a trace of hydrocyanic acid, though they yield it on the slightest puncture. We are completely ignorant of the mode of distribution in the living tissue of the amygdalin and of the substance causing its decomposition, and how these two bodies are packed so as to prevent the slightest mutual reaction. The leaves may be even dried and powdered without the evolution of any odour of hydrocyanic acid, but the latter is at once developed by the addition of a little water.

Besides the substance concerned in the production of the essential oil, the leaves contain sugar which reduces cupric oxide in the cold, a small quantity of an iron-greening tannin, and a fatty or waxy substance.

Schoonbroodt (1868) treated the aqueous extract of the fresh leaves with alcoholic ether, which yielded $\frac{1}{4}$ per mille of bitter, acicular crystals; these quickly reduced cupric oxide, losing their bitterness.

Uses-The leaves are only employed for making cherry-laurel water (Aqua Lauro-cerasi), the use of which in England is generally superseded by that of the more definite hydrocyanic acid.

1 Dispensatory, 1842. 592. 


\section{FLORES KOSO.}

\section{Flores Brayerer, C'usso, Konsso, Kosso.}

Botanical Origin-Hugenice Abyssinica Lamarck (Brayera anthelminthica Kunth), a handsome tree growing to a height of 60 feet, found throughout the entire table-land of $\Lambda$ byssinia at an elevation of 3,000 to $\$, 000$ feet above the sea-level. It is remarkable for its abundant foliage and fine panicles of flowers, and is generally planted about the Abyssinian villages.

History-The celebrated Bruce ${ }^{1}$ during his journey to discover the source of the Nile, 1768-1773, found the koso tree in Abyssinia, observed the uses made of it by the natives, and published a figure of it in the narrative of his travels. It was also clescribed in 1811 by Lamarck, ${ }^{2}$ who called it Hagenia in honour of Dr. K. G. Hagen of Königsberg.

The anthelmintic virtues of koso were investigated by Brayer, a French physician of Constantinople, to which place parcels of the drus are occasionally brought by way of Egypt, and he published a small pamphlet on the subject. ${ }^{3}$ Several scattered notices of koso appeared in 1839-40-41, but no supply of it reached Europe until about 1850, when a Frenchman who had been in Abyssinia, obtained a large stock $(1,400 \mathrm{Hb}$., it was said), a portion of which he endeavoured to sell in London at 35s. per ounce! 'The absurd value set upon the drug produced the usual result: large quantities were imported, and the price gradually lell to $3 s$. or $4 s$. per th. Koso was admitted a place in the British Pharmacopœia of 1864.

Description-The flowers grow in broad panicles, 10 to 12 inches in length. They are unisexual, but though male and female occur on the same tree, the latter are chiefly collected. The panicles are either loosely dried, often including a portion of stalk and sometimes a leaf, or they are made into cylindrical rolls, kept in form by transverse ligatures. Very often the panicles arrive quite broken up, and with the flowers in a very fragmentary state. They have a herby, somewhat tea-like smell, and a bitterish acrid taste.

The panicle consists of a zigzag stalk, which with its many branches is clothed with shaggy simple hairs, and also dotted over with minute stalked glands; it is provided at each ramification with a large sheathing bract. At the base of each flower are two or three rounded veiny membranous bracts, between which is the turbinate hairy calyx, having ten sepals arranged in a double series. In the male, the outer series consists of much smaller sepals than the inner; in the female, the outer in the nltimate developement become enlarged, oborate and spreading, so that the whole flower measures fully $\frac{1}{2}$ an inch across. In both, the sepals are veiny and leaflike. The petals are minute and linear, inserted with the stamens in the throat of the calyx. These latter are 10 to $25 \mathrm{in}$ number, with anthers in the female flower, effete. The carpels are two,

I Travels, v. (1790) 73.

¿ Encyclopédic Méthodique, Bot., suppl. tome 2 (1811) 422 .

3 Nótice sur une nonvelle plante de la famille des Rosacées, employée contre le Tania, Paris, 1822. The reader should also consult the excellent notice by Pereira written when the drug was first oflered for sale in London. Pharm. Journ. x. (1S51) 15 ; reprinted in Pereiri's I:tum. of Ilat. Mcd. ii. Mart 2 (1853) 1815. 
included in the calycinal tube; and each surmounted by a hairy style. The fruit is an obovate one-seeded nut.

Koso as seen in commerce has a light brown hue, with a reddish tinge in the case of the female flowers, so that panicles of the latter are sometimes distinguished as Red Koso.

Chemical Composition-Wittstein (1840) found in koso, together with the substances common to most vegetables (wax, sugar and gum), 24 per cent. of tannin, and 6.25 of an acrid bitter resin, which was observed by Harms (1857) to possess acid properties.

The researches of Pavesi (1858), and still more those of Bedall of Munich, ${ }^{1}$ have made us acquainted with the active principle of the drug, which has been named Koussin or Kosin. It may be obtained by mixing the flowers with lime, exhausting them with alcohol and then with water; the solutions mixed, concentrated, and treated with acetic acid, deposit the kosin. We are indebted to Dr. Bedall for a specimen of it, which we tind to consist chiefly of an amorphous, resinoid substance, from which we got a few yellow crystals by means of glacial acetic acid.

Mr. Merck has lately favoured us with kosin prepared in his laboratory at Darmstadt. It is a tasteless substance of a yellow colour, forming fine crystals of the rhombic system,-readily soluble in benzol, bisulphide of carbon, chloroform or ether, less freely in glacial acetic acid, and insoluble in water. Of alcohol, sp. gr. 0.818, 1000 parts dissolve at $12^{\circ} \mathrm{C}$., only $2 \cdot 3$ parts of this kosin. It is abundantly soluble in alkalies, caustic or carbonated, yet has nevertheless no acid reaction, and may be precipitated from these solutions by an acid, without having undergone any alteration. It is then however a white amorphous mass, which yields the original yellow crystals by re-solution in boiling alcohol, in which it dissolves readily.

Kosin fuses at $142^{\circ} \mathrm{C}$, and remains after cooling an amorphous, transparent, yellow mass ; but if touched with the smallest drop of alcohol, it immediately assumes the form of stellate tufts of crystals. This striking phenomenon may be repeated at pleasure, kosin not being altered by
cautious fusion.

Kosin is not decomposed by boiling dilute acids. It dissolves in strong sulphuric acid, giving a yellow solution which becomes turbid by the addition of water, white amorphous kosin being thrown down. At the same time a well-marked odour exactly like that of Locust Beans, due probably to valerianic acid and amylic alcohol, is evolved; the same odour is emitted by kosin under many other circumstances. If the sulphuric solution is allowed to stand for a week, it gradually assumes a fine red; and then yields on addition of much water, an amorphous red mass which after drying is not soluble in bisulphide of carbon, and may thus be purified. We have not yet succeeded in obtaining this red derivative of kosin in a crystalline state. The analysis which we have performed of kosin, assigns it the formula $\mathrm{C}^{31} \mathrm{H}^{38} \mathrm{O}^{10}$. From experiments now (1874) being made at Giessen, it would appear that pure kosin is devoid of action on the animal economy; yet, in the opinion of Prof. Buchheim, it acquires medicinal activity when combined with some other principles existing in the drug.

Distillation with water separates from the flowers a stearoptene-likie

${ }^{1}$ Wittstein's Vierleljahlresschr. für pratet. Pharm. viii. (1859) 481 ; xi. (1862) 207. 
oil having the odour of koso, and traces of valerianic and acetic acid. No such body as the Hagenic Acid of Viale and Latini (1852), could be detected by Bedall.

Commerce-Koso is brought to England by way of Aden or Bombay; some appears also to reach Leghorn, probably carried thither direct from Egypt.

Uses-The drug is employed solely as a vermifuge, and is effectual for the expulsion both of I'ania solinm and of Bothriocephalus latus. The Abyssinian practice is to administer the flowers in substance in a very anple dose, which is sometimes attended with alarming and even fatal results.

The notion that the action of the drug is partially mechanical and due to the hairs of the plant, prevails in England, and has led to the use of an unstrained infusion of the coarsely powdered flowers. This remedy from the quantity of branny powder (2 to 4 drachms) that has to be swallowed, is far from agreeable; and as it occasions strong purgation and sometimes vomiting, it is not often prescribed. ${ }^{1}$

\section{PETALA ROSE GALLIC $F$.}

Flores Rosw murce; Red Rose Petals, Rose Leaves, True Provins Roses; F. Pétales de Roses rouges, Roses de Provins; G. Essigrosenblätter.

Botanical Origin-Rosa Gallica L., a low-growing bush, with a creeping rhizome throwing up numerous stems. The wild form with single flowers, occurs here and there in the warmer parts of Europe, ${ }^{2}$ including Central and Southern Russia, and Greece; also in Asia Minor, Armenia, and the Caucasus. But the plant passes into so many varieties, and has from a remote period been so widely cultivated, that its distribution cannot be ascertained with any exactness. As a garden plant it exists under a multitude of forms.

History - The use in medicine of the rose dates from a very remote period. Theophrastus ${ }^{3}$ who flourished in the 4 th and 3rd centuries B.C., speaks of roses being of many kinds, including some with double flowers which were the most fragrant; and he also alludes to their use in the healing art. Succeeding writers of every age down to a recent period, have discussed the virtues of the rose, ${ }^{4}$ which however is scarcely now admitted to possess any special medicinal property.

One of the varieties of $R$. Gallica is the Provins Rose, so called from having been long cultivated at Provins, ${ }^{5}$ a small town about 60 miles south-east of Paris, where it is said to have been introduced from the East by Thibaud VI. Count of Champagne, who died on his return from

" Johnston in his Travels in Southern Abyssinia (1844), speaking of koso, says its effects are "dreadfully severe."-Even in Abyssinia, he adds, it is harely tolcrated, and if any other remedy equally effieicnt for dislodging tapeworm were to be introduced, koso would be soon abandoned.

2 It has latcly bcen found in a quasi-wild state at Charlwood in Surrey. - Seemann's Journ. of Bot. ix. (1871) 273.

3 Hist. Plant. lib. vi. c. 6.

4 Consult in particular the lcarned essay of D'Orbessan contained in lis Mêlanges historiques, ii. (1768) 297-337.

5 Koch (Dendrologie, i. 1869. 250) asserts that the rose originally cultivated at Provins was a Damask Rose, but that in the sccond half of the 1Sth century its place was taken by a varicty of $T$. Galliea. This sccins very improbable: Pomet (1692) speaks of the roses of l'rovins being "hautes en coulcur, c'est à dire d'un rougre noir, velouté . ... très astringentes," - characters specially be. longing to $R$. Gallica. 
the Crusades, A.D. 1254. Be this as it may, Provins became much celebrated not only for its dried rose-petals, but also for the conserve, syrup and loney of roses made from them,-compositions which were regarded in the light of valuable medicines. ${ }^{1}$

It is recorded that when in A.D. 1310, Philippe de Marigny, archbishop of Sens, made a solemn entry into Provins, he was presented by the notables of the town with wine, spices, and Conserve of Roses; and presents of dried roses and of the conserve were not considered beneath the notice of Catherine de Medicis, and of Henry IV. ${ }^{2}$

We find that Charles Estienne, in 1536, mentions both the Rosw purpurece odoratissima, which he says are called Provinciales, and those known to the druggists as incarnatce, - the latter we presume a pale rose. $^{3}$ Rosce mubece are named as an ingredient of various compound medicines by 'Valerius Cordus. ${ }^{4}$

Production-The flowers are gathered while in bud and just before expansion, and the petals are cut off near the base, leaving the paler claws attached to the calyx. They are then carefully and rapidly dried by the heat of a stove, and having been gently sifted to remove loose stamens, are ready for sale. In some districts the petals are dried entire, but the drug thus produced is not so nice.

In England, the Red Rose is cultivated at Mitcham, though now only to the extent of about 10 acres. It is also grown for druggists' use in Oxfordshire and Derbyshire. At Mitcham, it is now called Damast: Rose, which is by no means a correct name. The Englisl dried roses command a high price.

There is a much more extensive cultivation of this rose on the continent at Wassenaar and Noordwijk in Holland; in the vicinity of Hamburg and Nuremberg in Germany, and in the villages round Paris and Lyons. Roses are still, we believe, grown for medicinal use at Provins, but are no longer held in great esteem.

There appears to be a considerable production of dried roses in Persia, judging from the fact that in the year 1871-72, $1163 \mathrm{cwt}$. were exported from the Persian Gulf to Bombay. ${ }^{5}$

Description-The petals adhere together loosely in the form of little cones, or are more or less crumpled and separate. When well preserved, they are crisp and dry, with a velvety surface of an intensepurplish crimson, a delicious rosy odour, and a mildly astringent taste. The white basal portion of the petals should be nearly absent. For making the confection, the petals are required in a fresh state.

Chemical Composition-Red rose petals impart to ether, without losing their colour, a soft yellow substance, which is a mixture of a solid fat and Quercitrin. Filhol has shown (1864) that it is the latter body, and not tannic acid, of which the petals contain but a trace, that produces the dark greenish precipitate with ferric salts. The same chemist found in the petals 20 per cent. (?) of glucose which, together with

1 Pomet, Hist. des Drogues, 1694, part i. 174-177.

2 Assier, Légendes, curiosités ct traditions de la Champagne el de la Brie, Paris, 1860. 191.
3 Stephanus (Carolns), De re hortensi libellus, Paris, 1536, 29. (in Brit. Mus.)

${ }^{4}$ Dispensatorinum, 1548. 39. 52.

5 Statement of the Trade and Navigation of the Presideney of Bombay for 1871-72, pt. ii. 43. 
colouring matter and gallic acid, is extracted by alcohol after exhaustion by ether. According to Rochleder (1867), the gallic acid in red roses is accompanied by quercitannic acid.

The colouring matter which is so striking a constituent of the petals, has not yet been isolated and studied in a satisfactory manner. ${ }^{1} \Lambda_{11}$ infusion of the petals is pale red, but becomes immediately of a deep and brilliant crimson if we add to it an acid, such as sulphuric, hydrochloric, acetic, oxalic, or tartaric. An alkali changes the pale red, or the deep crimson in the case of the acidulated infusion, to bright green.

Uses-An infusion of red rose petals, acidulated with sulpluric acid and slightly sweetened, is a very common and agreeable vehicle for some other medicines. The confection made by beating up the petals with sugar, is also in use.

\section{PETALA ROSA CENTIFOLI}

Florcs rosa pallida:v. incarnata; Provence Rose, Cabbage Rose; 1T. Pétales de Roses pâlcs; G. Centifolienrosen.

Botanical Origin-Rosa centifolia L.-This rose grows in a wild state and with single flowers in the eastern part of the Caucasus. ${ }^{2}$ Cultivated and with flowers more or less double, it is found under an infinity of varieties in all the temperate regions of the globe. The particular variety which is grown in England for medicinal use, is known in English gardens as the Cabbage Rose, but other varieties are cultivated for similar purposes on the Continent.

$R$. centifolia $\mathrm{L}$. is very closely allied to $R$. Gallica L.; though Boissier maintains the two species, there are other botanists who regard them as but one. The rose cultivated at Puteaux near Paris for druggists' use, and hence called Rose de Putcaux, is the Rose biferc of Redouté, placed by De Candolle though doubtfully under $R$. Damascena.

History-IVe are unable to trace the history of the particular variety of rose under notice. That it is not of recent origin, seems evident from its occurrence chiefly in old gardens. The Rosa pallida of the older Euglish writers on drugs ${ }^{3}$ was called Damask Rose, but that name is now applied at Mitcham to Rosa Gallica L., which has very deep-coloured flowers.

Production - The Cabbage Rose is cultivated in England to a very small extent, rose water which is made from its flower's, being procurable of better quality and at a lower cost in other countries, especially in the south of France. At Mitcham, whence the London druggists liave long been supplied, there are now (1873) only about 8 acres planted with this rose, but a supply is also derived from the market gardens of Putney, Hammersmith and Fulham.

Description-The Cabbage liose is supplied to the druggists in the fresh state, full blown, and picked off close below the calyx. A complete description is scarcely required: we need only say that it is a large and very double rose, of a beautiful pink colour and of delicious odour. The calyx is covered with short setre tipped with a fragrant, brown, viscid

1 Sec lowerer a paper by Filhol in Joum. de Pharm. xxxviii. (1960) 21 ; also Gmelin, Chemistry, xvi. (1864) 522 .
" Boissier, Flora Orientalis, ii. (IST?) 67 ( 6 .

" As Dale, Pharmacologia, 1693. 416. 
secretion. The petals are thin and delicate (not thick and leathery as in the Tea Roses), and turn brown on drying.

In making rose water, it is the custom in some laboratories to strip the petals from the calyx and to reject the latter; in others, the roses are distilled entire, and so far as we have observed, with equally good result.

Chemical Composition-In a chemical point of view, the petals of Li. contifolic agree with those of $R$. Gallica, even as to the colouring matter. Enz in 1867 obtained from the former, malic and tartaric acid, tamin, fat, resin, and sugar.

In the distillation of large quantities of the flowers, a little essential oil is obtained. It is a butyraceous substance, of weak rose-like, but not very agreeable odour. It contains a large proportion of inodorous stearoptene. For further particulars see remarks under the head Attur of Rose, p. 235.

Uses-Cabbage roses are now scarcely employed in pharmacy fur any other purpose than maling rose water. A syrup used to be prepared from them, which was esteemed a mild laxative.

\section{OLEUM ROS $Æ$.}

Attar or Otto ${ }^{1}$ of Rose, Rose Oil; F. Essence de Roses; G. Rosenöl.

Botanical Origin-Rosa Damascena Miller, var.-This is the rose cultivated in Turkey for the production of attar of rose; it is a tall shrub with semi-double, light-red (rarely white) flowers, of moderate size, produced several on a branch, though not in clusters. Living specimens sent by Baur ${ }^{2}$ which flowered at Tübingen, were examined by H. von Mohl and named as above. ${ }^{3}$

R. Damascena is unknown in a wild state. Kocl ${ }^{4}$ asserts that it was brought in remote times to Southern Italy, whence it spread northward.

History-Much as roses were prized by the ancients, no preparation such as rose water or attar of rose was obtained from them. The liquid

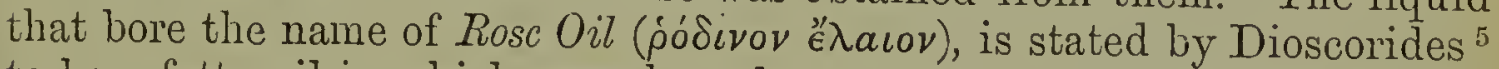
to be a fatty oil in which roses have been steeped. In Europe a similar preparation was in use down to the last century, Olcum rosarum, rosatum or rosaceum, signifying an infusion of roses in olive oil. ${ }^{6}$

The first allusion to the distillation of roses we have met with, is in the writings of Joannes Actuarius,? who was physician to the Greek emperors at Constantinople towards the close of the 13 th century. Rose water was distilled at an early date in Persia; and Nisibin, a town north-west of Mosul, was famous for it in the 14th century.s

Kämpfer speaks ${ }^{9}$ with admiration of the roses he saw at Shiraz $(1683-4)$, and says that the water distilled from them is exported to other parts of Persia, as well as to all India; and he adds as a singuliar fact, that there separates from it, a certain fat like butter, called $\mathscr{E} t t^{\circ}$

1 Attar or Otto is from the word itr. signifying porfume or odour; the oil is called in Turkish Ttr-yàghi i.e. Perfunc-oil, and also Ghyzùt-yághi i.e. Rosc-oil.

${ }^{2} A$ living plant followed by excellent herbarium specimens has been kindly given to me by Dr. Baur of Blaubeuren, the fatler of Prof. Dr. Baur of Constantinople, but it has not yet flowered (29 July 1873). - D. H.
3 Wiggers u. Husemamn, Jahocsucricht for 1867.350 .

\& Dendrologic, i. (1869) 250.

5 Lib. i. e. 53 .

- As in the London Plaa macoparia of 1721.

7 “. . . stillatitii rosarmm liquoris libna una."-Dc Methodo Medendi, lib. v. c. 4.

\& Voyage d'Tlne Bactoutah, trad. par Defirimery, ii. (1854) 140.

9 Amanitates, 1712. 373. 
gyl of the most exquisite odonr, and more valuable even than gold. The commerce to India, thongh much declining, still exists; and in the year $1872-73,20,100$ gallons of rose water, valued at 35,178 rupees $(£ 3,517)$, were imported into Bombay from the Persian Gulf. ${ }^{1}$

Rose water was much used in Europe during the middle arges, both in cookery and at table. In some parts of France, vassals were compelled to furnish to their lords so many bushels of roses, which were consumed in the distillation of rose water. ${ }^{2}$

The fact that a butyraceous oil of delicious fragrance is separable from rose water, was noticed by Geronimo Rossi ${ }^{3}$ of Ravenua in 1582 and by Giovanni Battista Porta ${ }^{4}$ of Naples in 1589: the latter in his work on distillation says-" Omnium difficillimæ extractionis est rosarum oleum atque in minima quantitate sed suavissimi odoris." 5 The oil was also known to the apothecaries of Germany of the 17th century, and is quoted in official drug-tariffs as early as $1614 .^{\circ}$ In Pomet's time (1694) it was sold in Paris, though, on account of its high price, only in very small quantity. The mention of it by Homberg ${ }^{7}$ in 1700 , and in a memoir by Aublet ${ }^{8}$ (1775) respecting the distillation of roses in the Isle of France, shows that the French perfumers of the last century were not unacquainted with true rose oil, but that it was a rare and very costly article.

The history of the discovery of the essence in India, is the subject of an interesting and learned pamphlet by Langlès, ${ }^{9}$ published in 1804 . He tells on the authority of oriental writers, how on the occasion of the marriage of the Mogul emperor Jehan Ghir with Nur-jehan, A.D. 1612 , a canal in the garden of the palace was filled with rose water, and that the princess observing a certain scum on the surface, caused it to be collected and found it of admirable fragrance, on which account it received the name of Atar-jehanghiri, i.e. perfume of Jehan Ghir. In later times, Polier ${ }^{10}$ has shown that rose oil is prepared in India by simple distillation of the flowers witl water. But this Indian oil has never been imported into Europe as an article of trade.

As already stated, the supplies at present come from European Turkey; but at what period the cultivation of the rose and manufacture of its oil were there introduced, is a question on which we are quite in the dark. There is no mention of attar in the account given by Savary ${ }^{11}$ in $\mathbf{1 7 5 0}$ of the trade of Constantinople and Smyrna.

In English commerce, attar of rose was scarcely known until the commencement of the present century. It was first included in the British Tariff in 1809, when the duty levied on it was $10 \mathrm{~s}$. per ounce. In 1813, the duty was raised to 11 s. $10 \frac{1}{2} d$.; in 1819 it was 6 s., and in 1828,2 s. per ounce. In 1832 it was lowered to $1 s$. 4 d. per 16 ., in 1842 to 1 s., and in 1860 it was altogether removed. ${ }^{12}$

1 Statement of the Trade and Navigation of the Presideney of Bombay for 1872-73,

part ii. 52. rles Françnis, ii. (1815) 250.

3 Hielonymi liubei Rav. De Destillatione, Ravennae, 1582. 102.

* Magiw Naburalis libri w., Neap. 158?. 188.

5 De Distillatione, Rom. (1608) 75.

6 As that printed at Giessen, referred to

7 Observations sur les huiles des plantesIrém. de l'Acad. Roy. res Seicners, 1700.206.

8 IIist. des Plantes de la Guiane fransoise, ii., Mémoires, p. 125.

"Irecherehes sur la déconurerte de l'Essence de Rose, Paris, $1 \mathrm{S0} 4$.

10 Asiatick licsearches, i. (17SS) 332.

1 Dict. de Commerce, iv. 54 S.

12 Information obligingly commmicated by Mr. Seldon of the Statistical Office of the Ciustom Honse. 
On searching a file of the London Price Current, the first mention of "Otto of Rose" is in 1813, from which year it is regularly quoted. The price (in bond) from 1813 to 1815 , varied from $\mathfrak{L 3}$ to $£ 55$ s. per ounce. The earliest notice of an importation is under date 1-8 July, 1813, when duty was paid on 232 ounces, shipped from Smyrna.

Production-The clief locality for attar of rose, and that by which European commerce is almost exclusively supplied, is a small tract of country on the southern side of the Balkan mountains in the Turkish province of Rumelia. The principal seat of the trade is the town of Kizanlik, in the fine valley of the Tunja. The other important districts are those of Philippopoli, Eski Zaghra, Yeni Zaghra and Tchirpan, which with Kizanlik were estimated in 1859 to include 140 villages, having 2,500 stills.

The rose is cultivated by Bulgarian and Turkish peasants in gardens and open fields, in which it is planted in rows as hedges, 3 to 4 feet high. The best localities are those occupying southern or south-eastern slopes. Plantations in high mountainous situations generally yield less, and the oil is of a quality that easily congeals. The flowers attain perfection in April and May, and are gathered before sunrise; those not wanted for immediate use are spread out in cellars, but are always used for distilling the same day. The apparatus is a copper still of the simplest description, comnected with a straight tin tube, cooled by being passed through a tub fed by a stream of water. The charge for a still is 25 to $50 \mathrm{Ht}$. of roses, from which the calyces are not removed. The first runnings are returned to the still; the second portion which is received in glass flasks, is kept at a temperature not lower than $15^{\circ} \mathrm{C} .\left(60^{\circ} \mathrm{F}\right.$. $)$ for a day or two, by which time most of the oil, bright and fluid, will have risen to the surface. From this, it is skimmed off by means of a small tin funnel having a fine orifice, and provided with a long liandle. There are usually several stills together.

The produce is extremely variable. According to Baur, ${ }^{1}$ whose interesting account of attar of rose is that of an eye-witness, it may be said to average 0.04 per cent. Another authority estimates the average yield as 0.037 per cent.

The harvest during the five years $1867-71$ was reckoned to average somewhat below 400,000 meticals, ${ }^{2}$ or $4,226 \mathrm{Hb}$. avoirdupois; that of 1873 which was good, was estimated at 500,000 meticals, value about $£ 70,000 .^{3}$

Roses are cultivated to a considerable extent about Grasse, Cannes and Nice in the south of France; and besicles much rose water, which is largely exported to England, a little oil is produced. The latter, which commands a high price, fuses less easily than the Turkish.

There is a large cultivation of the rose for the purpose of making rose water and attar, at Ghazipur on the Ganges, Lahore, Amritsar and other places in India, but the produce is wholly consumed in the country. 'The species thus cultivated is stated by Brandis ${ }^{4}$ to be $R$. Damasconc. Medinet Fayum, south-west of Cairo, supplies the great demand of Egypt for rose vinegar and rose water.

I Neres Jahrbuch f. Pharm. xxvii. (1867); Pharm. Journ. ix. (1868) 286.

2 Consular Reports prescnied to Parliament, May, 1872.-The metical, miskal. or midkcal is equal to about 3 dwt. troy.
3 Consular Reports mesented to Partia. ment, Aug. 1873. 1090.

4 Forest Flore of North-uestern and Central India, 1874. 200. 
Tumis has also some celebrity for similar products, which however do not reach Europe. A recent traveller ${ }^{1}$ states that the rose grown there, and from which attar is obtained, is hosa canina $\mathrm{L}$., which is extremely fragrant; $30 \mathrm{ft}$. of the flowers afford about $1 \frac{?}{2}$ drachms, worth $15 s$.

The butyraceous oil which may be collecter in distilling roses in Eirgland for rose water is of no value as a perfume.

Description-Oil of rose is a light-yellow liquid, of sp. gr. 0.87 to 0.89. By a reduction of temperature, it concretes owing to the separation of light, brilliant, platy crystals of a stearoptene, the proportion of which differ's with the country in which the roses have been grown, the state of the weather during which the flowers were gathered, and other circumstances less well ascertained. The oil produced in Turkey solidifies, according to Baur, at from 11 to $16^{\circ} \mathrm{C}$. In some experiments made by one of us ${ }^{2}$ in 1859 , the fusing point of true Turkish attar was found to vary from 16 to $18^{\circ} \mathrm{C}$; that of a sample from India was $20^{\circ} \mathrm{C}$.; of oil distilled in the south of France, 21 to $23^{\circ} \mathrm{C}$.; of an oil produced in Paris, $29^{\circ} \mathrm{C}$.; of oil obtained in distilling roses for rose water in London, 30 to $32^{\circ} \mathrm{C}$.

From these data, it appears that a cool northern climate is not conducive to the production of a highly odorous cil; and even in Turkey, experience shows that the oil of the mountain districts, holds a larger proportion of stearoptene than that of the lowlands.

Turkish oil of rose is stated by Baur to deviate a ray of polarized light $4^{\circ}$ to the right, when examiued in a column of $100 \mathrm{~mm}$. The oil from English roses which we examined, exhibited no rotation.

Chemical Composition-Rose oil is a mixture of a liquid constituent containing oxygen, to which it owes its perfume, and the solid hydrocarbon or stearoptene already mentioned, which is entirely destitute of odour. The proportion which these bodies bear to each other cannot be exactly determined, but is certainly extremely variable. From the Turkish oil, it may be obtained to the extent of 18 per cent., and from French and English to 35, 42, 60 or even 68 per cent.

Though the stearoptene can be entirely freed from the oxygenated oil, no method is known for the complete isolation of the latter. As obtained by Gladstone, ${ }^{3}$ it liad a sp. gr. of 0.881 and a boiling point of $216^{\circ} \mathrm{C}$.

With regard to the stearoptene of rose oil, the analyses of Théodore de Saussure (1820) and Blanchet (1833), long since showed its composition to accord with the formula $\mathrm{C}^{\mathrm{n}} \mathrm{H}^{2 u}$. The experiments of one of us ${ }^{4}$ confirm this striking fact, which assigns to the stearoptene in question a very exceptional place among the hydrocarbons of volatile oils, all of which are less rich in hydrogen.

Rose stearoptene separates when attar of rose is mixed with spirit of wine. We have isolated it also from oil obtained from Mitcham roses, by dissolving the oil in chloroform and precipitating with spirit of wine, the process being several times repeated. The stearoptene was lastly

1 Von Maltzan, Reise in den Riegcitschaften I'unis und Trinotis, Leipzig, 1870.

" Hanbury, Pharm. Journ. xviii. (1859)
504-509; Wittstein's Vicrleljahressehr. fiir malit. Pharm. ix. (1860) 55.

3 Joum. of Chom. Soc., x. (1872) 12.

${ }^{4}$ Fliickiger, Pharm. Joun'n. x. (1S69) 147. 
inaintained for some days at $100^{\circ} \mathrm{C}$.; thus obtained, it is inodorous, but when heated evolves an offensive smell like that of heated wax or fat. At $32.5^{\circ} \mathrm{C}$. it melts; at $150^{\circ} \mathrm{C}$. vapours are evolved; at $272^{\circ} \mathrm{C}$. it begins to boil, soon after which it turns brown and then blackish. Stains of the stearoptene on paper, do not disappear by the heat of the water-bath under a lapse of some days.

If cautiously melted by the warmth of the sun, the stearoptene forms on cooling microscopic crystals of very peculiar shape. Most of them have the form of truncated hexahedral pyramids, not however belonging to the rhombohedric system, as the angles are evidently not equal; many of them are oddly curved, thus \$. Examined under the polarizing microscope, these crystals from their refractive power make a brilliant object.

Rose stearoptene is a very stable body, yet by boiling it for some Jays with fuming nitric acid, it is slowly dissclved, and converted into various acids of the homologous series of fatty acids, and into oxalic acid,-perhaps likewise partly into fumaric acid. Among the former, we detected butyric and valerianic. The chief product is however succinic acid, which we obtained in pure crystals, showing all the wellknown reactions.

The same products are obtained even much easier, by treating paraffin with nitric acid; it yields however less of succinic acid. The general behaviour and appearance of paraffin is in fact nearly the same as that of rose stearoptene. But what is called paraffin, is by no means always one and the same body, but rather a series of extremely similar hydrocarbons, the separation of which has not yet beell thoroughly effected. They may as well answer to the formula $\mathrm{C}^{\mathrm{n}} \mathrm{H}^{2 \mathrm{n}+2}$ as to that adopted hitherto, mamely $\mathrm{C}^{\mathrm{n}} \mathrm{H}^{2 \mathrm{n}}$ ( $n$ being usually supposed equal to 20 ). The same consideration applying to rose stearoptene, the above-mentioned anaytical results can be regarded as in accordance with either of these formulæ.

The fusion point of the different kinds of paraffin generally ranges from 42 to $60^{\circ} \mathrm{C}$., yet one sort from the bituminous shale of Autun, prepared and examined by Laurent, ${ }^{1}$ melts at $33^{\circ} \mathrm{C}$, and in this respect agrees with our stearoptene. It is therefore probable that the latter actually belongs to the paraffin series.

Commerce-Formerly attar of rose came into commerce by way of Austria; it is now shipped from Constantinople. From the interior, it is transported in flattened round tin bottles called hunkumas, holding from 1 to 10 fb., which are sewed up in white woollen cloth. These sometimes reach this country, but more commonly the attar is transferred at Constantinople to small white glass bottles, ornamented with gilding, imported from Germany.

Uses-Attar of rose is of no medicinal importance, but serves occasionally as a scent for ointments. Riose water is sometimes made with it, but is not so good as that distilled from the flowers. Attar is much used in perfumery, but still more in the scenting of snuff.

Adulteration-No drug is more subject than attar of rose to adulteration, which is principally effected by the addition of the volatile oil of an Indian grass, Andropogon Schananthus L. This oil, which is 
ealled in Turkish Idris yàghi, and also Entershah, and is more or less known to Europeans as Gercunium Oil, is imported into 'Turkey for this express purpose, and even snbmitted to a sort of purification before being used. ${ }^{1}$ It was formerly added to the attar only in Constantinople, but now the mixing takes place at the seat of the manufaeture. It is said that in many places, the roses are absolutely sprinkled with it before being placed in the still. As grass oil does not solidify by eold, its admixture with rose oil renders the latter less disposed to crystallize. Hence arises a preference among the dealers in 'Turkey for attar of the mountain districts, which, having a good proportion of stearoptene, will bear the larger dilution with grass oil without its tendeney to crystaliize beeoming suspiciously small. Thus, in the circular of a eommereial house of Constantinople, dated from Kizanlik, oceur the phrases—“Extra strong oil,"- " Good strong confealing oil,""Strong good freezing oil" ;-while the 3rd quality of attar is spoken of, as a "not eongealing oil." The same eircular states the belief of the writers, that in the season in which they wrote, "not a single metieal of unadulterated oil " would be sent away.

The chief criteria, according to Baur, for the purity of rose oil are:-1. Temperature at whieh erystallization takes plaee: a good oil should eongeal well in five minutes at a temperature of $12.5^{\circ} \mathrm{C} .\left(55^{\circ} \mathrm{F}\right.$.) 2. Manner of erystallizing.-The crystals should be light, feathery, shining plates, filling the whole liquid. Spermaceti, whieh has been sometimes used to replace the stearoptene, is liable to settle down in a solid eake, and is easily reeognizable. Furthermore, it melts at $50^{\circ} \mathrm{C}$., and so do most varieties of paraffin. The microseopic crystals of the latter are somewhat similar to those of rose stearoptene, yet they may be distinguished by an attentive eomparative examination.

\section{FRUCTUS ROSÆ CANIN $Æ$.}

\section{Cynosbata; Fruit of the Dog-rose, Hips; F. Fruits de Cynorrthodon; G. Hagebutten.}

Botanical Origin-Rosa canina L., a bush often 10 to 12 feet ligh, found in hedges and thiekets throughout Europe except Lapland and Finland, and reaching the Canary Islands, Northern Africa, Persia and Siberia; universally dispersed throughout the British Islands. ${ }^{2}$

History-The fruits of the wild rose, including other species besides R. canina L., have a scanty, orange, acid, edible pulp, on account of which they were colleeted in ancient times when garden fruits were few and searce. Galen ${ }^{3}$ mentions them as gathered by country people in his day, as they still are in Europe. Gerardc in the 16tl century remarks that the fruit when ripe- "maketh most pleasant meats and banqueting dishes, as tarts and such like." Though the pulp of hips preserved with sugar which is here alluded to, is no longer brought to

1 For particulars, sec Baur (p. 235, note 1).

2 Baker, Journ. of Limn. Soc. Bot. xi. (1869) 226.

${ }^{3}$ Dc Alimentorum facultatibus, ii. c. 14.
In the Amur country a nuch larger and better fruit is aftorded by $h_{\text {. acicularis }}$ Lindl. and $R$. cimamomea L. Maximowicz, Primitice Florec Amurensis, 1859, 100. 453. 
table, at least in this country, ${ }^{1}$ it retains a place in pharmacy as a useful ingredient of pill-masses and electuaries.

Description-The fruit of a rose consists of the bottle-shaped calyx, become dilated and succulent by growth, and sometimes crowned with 5 leafy segments, enclosing numerous dry carpels or achenes, containing each one exalbuminous seed. The fruit of $R$. eaninc called a hip, is ovoid, about $\frac{3}{4}$ of an inch long, with a smooth, red, shining surface. It is of a dense, fleshy texture, becoming on maturity, especially after frost, soft and pulpy, the pulp within the shining skin being of an orange colour, and of an agreeable sweetish subacid taste. The large interior cavity contains numerous, hard achenes, which as well as the walls of the former, are covered with strong short hairs.

For medicinal use, the only part required is the soft orange pulp, which is separated by rubbing it through a hair sieve.

Microscopic Structure-The epidermis of the fruit is made up of tabular cells containing red granules, which are much more abundant in the pulp. The latter, as usual in many ripe fruits, consists of isolated cells no longer forming a coherent tissue. Besides these cells, there occur small fibro-vascular bundles. Some of the cells enclose tufted crystals of oxalate of calcium; most of them however are loaded with red granules, either globular or somewhat elongated. They assume a bluish hue on addition of perchloride of iron, and are turned blackish by iodine. The latter coloration reminds one of that assumed by starch granules under similar circumstances; yet, on addition of a very dilute solution of iodine, the granules always exhibit a blackish, not a blue tint, so that they are not to be considered as starch granules. The hairs of the pulp are formed of a single, thick-walled cell, straight or sometimes a little crooked.

Chemical Composition-The pulp examined by Biltz (1824) was found to afford nearly 3 per cent. of citric acid, 7.7 of malic acid, besides citrates, malates and mineral salts, 25 per cent. of gum, and 30 of uncrystallizable sugar.

Uses-Hips are employed solely on account of their pulp, which mixed with twice its weight of sugar, constitutes the Confeetio Rose canina of pharmacy.

\section{SEMEN CYDONIE.}

\section{Quince Seeds, Quince Pips; F. Semenees ou Pepins de Coings; G. Quittensamen.}

Botanical Origin-Pirus Cydonia I. (Cydonia vulgaris Pers.), the quince tree, is supposed to be a true native of Western Asia, from the Caucasian provinces of Russia to the Hindu Kush range in Northeru India. But it is now apparently wild also, in many of the countries which surround the Mediterranean basin.

In a cultivated state, it flourishes throughout temperate Europe, but is far more productive in southern than in northern regions. Quinces ripen in the south of England, but not in Scotland.

1 In Switzerland and Alsace a very agrecable confiture of hips is still in use. 
History - The quince was held in high esteem by the ancients, who considered it an emblem of happiness and fertility; and as such, it was dedicated to Venus, whose temples it was uscd to decoratc. Some antiquarians maintain that quinces were the Goldcn Apples of the Hesperides.

Porcins Cato in his graphic description of the managenent of a Roman farmhouse, alludes to the storing of quinces both cultivated and wild; and there is much other evidence to prove that from an early pcriod the quince was abundantly grown throughout Italy. Charlcmagne, A.D. 812, enjoined its cultivation in central Europe. ${ }^{1}$ At what period it was introduced into Britain is not evident, but we have observed that Baked. Quinccs are mentioned among the viands served at the famous installation feast of Nevill, archbishop of York in $1466 .^{2}$

The use of mucilage of quince seeds has come to us through the Arabians.

Description-The quince is a handsome fruit of a golden yellow, in shape and size resembling a pear. It has a very agrecable and powerful smell, but an austere, astringent taste, so that it is not eatable iu the raw state. In structure, it differs from an apple or a pear in having nuany seeds in each cell, instead of only two.

The fruit is, like an applc, 5-celled, with each cell containing a double row of closely-packed seeds, 8 to 14 in number, cohering by a soft mucilaginous membrane with wbich each is surrounded. By drying, thcy become hard, but remain agghtutinated as in the cell. The seeds have an ovoid or obconic form, rather flattened and 3-sided by mutual pressure. From the hilum at the lower pointed end, the raphe passes as a straight ridge to the opposite extremity, which is slightly beaked and marked with a scar indicating the chalaza. The edge opposite the raphe is more or less arched, according to the position of the individual seed in the cell. The testa encloses two thick, veined cotyledons, having a straight radicle directed towards the hilum.

Quince seeds have a mahogany-brown colour, and when unbroken a simply mucilaginous taste. But the kernels have the odour and taste of bitter almonds, and evolve hydrocyanic acid when comminuted and mixed with water.

Microscopic Structure-The epidermis of the seed consists of one row of cylindrical cells, the walls of which swell up in the presence of water and are dissolved, so as to yield an abundance of mucilage. This process can easily be observed, if thin sections of the seed are examined under glycerin, which acts on them but slowly.

Chemical Composition-The mucilage of the epidermis is present in such quantity, that the seed easily coagulates forty times its reight of water. By complete exhaustion, the seeds afford about 20 per cent. of dry mucilage, having the composition $\mathrm{C}^{12} \mathrm{H}^{20} \mathrm{O}^{10}$, and thereforc corresponding with that of linseed. The mucilage of quince seeds contains considerable quantities of calcium salts and albuminous matter, of which it is not easily deprived. When treated with uitric acid, it yiclds oxalic acid. After a short treatment with strong sulphuric acid it is coloured blue by iodine.

1 Pertz, Monumenta Germanice historica, Logum, i. (1835) 187.
: Leland, Derebus Britannicis Collectance, vi. $(1774) 5$. 
Quince mucilage has but little adhesive power, and is not thickened by borax. That portion of it which is really in a state of solution and which may be separated by filtration, is precipitable by metallic salts or by alcohol. The latter precipitate after it has been dried, is no longer dissolved by water either cold or warm. Quince mucilage is, on the whole, to be regarded as a soluble modification of cellulose.

Commerce-Quince seeds reach England from Hamburg; and are frequently quoted in Hamburg price-currents as Russian; they are also brought from the South of France and from the Cape of Good Hope. They are largely imported into India from the Persian Gulf, and by land from Afghanistan.

Uses-A decoction of quince seeds is occasionally used as a demulcent external application in skin complaints. It is also sometimes added to eye-lotions. Quince seeds are in general use among the natives of India as a demulcent tonic and restorative. They have been found useful by Europeans in dysentery.

\section{HAMAMELIDE无。}

\section{S T Y R A X L I Q U I D A.}

\section{Balsamum Styracis; Liquid Storax; F. Styrax liquide; G. Flüissiger Storax.}

Botanical Origin - Liquidambar orientalis Miller ( $L$. imberbe Aiton), a handsome, umbrageous tree resembling a plane, growing to the height of 30 to 40 feet or more, ${ }^{1}$ and forming forests in the extreme south-western part of Asia Minor. In this region the tree occurs in the district of Sighala near Melasso, about Budrum (the ancient Halicarnassus) and Moughla, also near Giova and Ullà in the Gulf of Giova, and lastly near Marmorizza and Isgengak opposite Rhodes. It also grows in the valley of the El-Asi (the ancient Orontes), as proved by a specimen in the Vienna herbarium, collected by Gödel, Austrian Consul at Alexandretta. In this locality it was seen by Kotschy in 1835 , but mistaken for a plane. The same traveller informed one of us that he believed it to occur at Narkislik, a village near Alexandretta.

The tree is not known to grow in Cyprus, Candia, Rhodes, Kos, or indeed, in any of the Greek or Turkish islands of the Mediterranean. ${ }^{2}$

History-Two substances of different origin have been known from a remote period under the name of Styrax or Storax, namely the resin of Styrax officinalc L. (p. 246), and that of Liquidambar orientalis Miller, the latter commonly distinguished as Liquid Storax.

According to Krinos of Athens, who has carefully investigated the history of the drug, ${ }^{3}$ the earliest allusions to Liquid Storax occur. in the

1 For a good figure of $L$. oricntatis, see Hooker's Iconcs Plantarum (3rd series, 1867) pl. 1019.

2 'The fine old trees existing at the convent of Antiphoniti on the north coast of Cyprus, and at that of Neophiti near Papho, specimens of which were distributed by Kotsehy as Liquidambar imberbe Ait., agree in all points with the Ameriean L. styraciflua L., and not with the Asiatic plant. Kotschy has told me that they have cortainly been planted, and that no otler examples cxist in the island. - D. H.

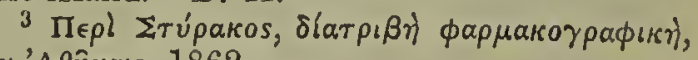
$\epsilon \nu$ 'A $\theta \hat{\eta} \nu$ als, 1862. 
writings of Aetins and of Paulus AEgineta, ${ }^{1}$ who name both Storas and

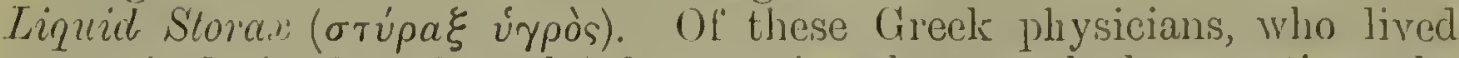
respectively in the 6th and 7 th centuries, the second also mentions the resin of Zuria, which is regarded by Krinos as synonymous with the latter substance. ${ }^{2}$

Ve find in fact the term Sigia frequently mentioned by Filiazes (10th century) as signilying Liquid Storax. This and other Arabian physicians were also familiar with the same substance under the name of Mitu (may'a) and also knew how and whence it was obtained. ${ }^{3}$

A curious account of the collecting of Liquid Storax from the tree Zygia and from another tree called Stourika, is given in the travels through Asia Minor to Palestine of the Russian abbot of Tver in A.I. 1113-111.5.4

The widle exportation and ancient use of Liquid Storax are very remarkable: even in the first century, as appears by the author of the Periplus of the Erythrean Sea, Storax, by which term there can be but little doubt Liquid Storax was intended, was exported by the Red Sea to India. Whether the Storax and Storax Isaurica offered to the Church of Rome under' St. Silvester, A.D. 314-335, by the emperor Constantine, ${ }^{5}$ was Liquid Storax or the more precious resin of Styrax officinale L., is a noint we cannot determine. That the Chinese used the drug was a fact known to Garcia d'Orta (1535-63): Bretschneider ${ }^{6}$ has recently shown from Chinese sources that together with olibanum and myrrh, it was imported by the Arabs into China during the Ming dynasty, A.D. 1368-1628. This trade is still carried on : the drug is conveyed by way of the Red Sea to Bombay, and thence shipped to China. Official returns show that the quantity thus exported from Bombay in the year 1856-57 was $13,328 \mathrm{fb}$. In the time of Kämpfer (1690-92), Liquid Storax was one of the most profitable articles of shipment to Japan. ${ }^{7}$

Liquid Storax is known in the East, at least in the price-currents and trade statistics of Europeans, by the strange-sounding name of Rose MTalloes (Rosa MTallas, Rosum Alloes, Rosmal), a designation for it in use in the time of Garcia d'Orta. Clusius ${ }^{8}$ considered it to be Arabic, which however the scholars whom we have consulted do not allow. Others identify it with Rasamala, the Malay name for Altingia cxcelsa.

The botanical origin of Liquid Storax was long a perplexing question to pharmacologists. It was correctly determined by Krinos, but his information on the subject published in a Greek newspaper in 1841, and repeated by Kosté in $1855,{ }^{9}$ attracted no attention in Western Europe. The question was also investigated by one of the authors of the present work, whose observations together with a figure of Liquidambar orientale Miller, was published in $1857 .{ }^{10}$

1 Nediece Artis Principes post'Hippocratem et Galcnum, Par. 1567.- Aëtii tetr. 4. serm. 4. c. 122 ; P. Egineta, De re med. vii. 20.

2 The foliage of the Liquidambar melı resembles that of the common maple ( $A$ cer campestre I.) ; hence the two trees as well as the plane (Platanus oricnialis L.) are confounded under onc name,-Zvyós or Zuvla. So Styrax oficinale L. from the rescmblance of its leaves to those of Pims Cydonia L., is

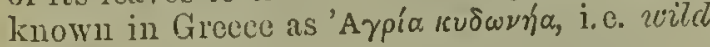
quince.

"I Ibn Baytar; Sontheimer's transl. ii. 539.

4 Noroff, Pélerinage on T'erre Sainte de l'Igoumenc russe Danicl, St. Pétersb. 1864.

$4^{\circ}$. - The passase has been kindly abstracted for us by Professor Heyd of Stuttgart.

5 Vignolius, Liber Pontificalis, Rome, i. (1724) 94.-The ancient Isamia was in Cilicia, the country of Styrax officinale L.

6 On the knowledge possesscd by the Chinese of the Arabs, \&e., Lond. 1571. 19.

7 Hist. of Japan, ed. Sehenchzer. i. 353.

s Exoticonum. Libri, 245.

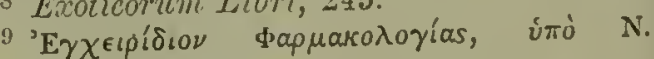
К $\omega \sigma \tau \hat{\eta}, 1855.356$.

10 Hanbury, Pharm. Joun. xvi. (1S5\%) 417. 461; Boinplandia, 1 Mai 1557; Journ. de Pharm. xxi. (1857) 198; also Pharm. Journ. iv. (1863) 436. 
Method of Extraction-The extraction of Liquid Storax is carried on in the forests of the south-west of Asia Minor, chicfly by a tribe of wandering 'Turcomans called Yuruks. The process has becn described on the authority of Maltass and McCraith of Smyrna, and of Campbell, British Consul at Rhodes. ${ }^{1}$ The outer bark is said to be first removed from the trunk of the tree and rejected; the iuncr is then scraped off witl a peculiar iron knife or scraper, and thrown into pits until a sufficient quantity has been collected. It is then boilcd with water in a large copper, by which process the resin is separated, so that it can be slimmed off. The boiled bark is put into hair bags and squeezed under a rude lever, hot water bcing added to assist in the separation of the resin, or as it is termed yagh, i.e. oil. Maltass states that the bark is pressed in the first instance per se, and afterwards treated with hot water. In either case the prodncts obtained are the opaque, grey, semi-fluid resin known as Liquid Storcux, and the fragrant cakcs of foliaceous, brown bark, once common but now rare in European pharmacy, called Cortex Thymiamatis.

We are indebted to M. Felix Sahut of Montpellier for a specimen of the bark of Liquidambar oricntalis, cut from the trumle of a fine tree on his property at the neighbouring village of Lattes. The bark which is covered with a very thick corky layer and soaked in its own fragrant resin, shows no tendency to exfoliate. The investigations of Unger² in Cyprus are consequently to us inexplicable; he asserts that the bark scales off, like that of the plane, by continued exfoliation, which is not the case with that of MI. Sahut's tree.

Description-Liquid Storax is a soft viscid resin, usually of the consistence of honey, heavier than water, opaque and greyish brown. It always contains water, which by long standing rises to the surface. In onc sample that had been kept more than 20 years, the resin at the bottom of the bottle formed a transparcnt layer of a pale golden brown. When liquid storax is heated, it bccomes by the loss of water, dark brown and transparent, the solid impurities settling to the bottom. Spread out in a very thin layer, it partially dries, but does not wholly lose its stickiness. When frce from water (whicl reddens litmus) it dissolves in alcohol, spirit of wine, chloroform, ether, glacial acetic acid, bisulphide of carbon, and most of the essential oils, but not in the most volatile part of petrolcum ("petroleum ether"). It has a pleasant balsamic smell, espccially after it has been long kept; when recent, it is contaminated with an odour of bitumen or naphthalin that is far from agrceable. Its taste is sharply pungent, burning and aromatic.

Whon the opaque resin is subjected to microscopic examination, small brownish granules are observed in a viscid, colourless, transparcnt liquid, besides which large drops of a mobile watery liquid may be distinguished. In polarized light, numerous minute crystalline fragments with a few larger tabular crystals are obvious. But when thin layers of the resin are left on the object-glass in a warm place, feathery or spicular crystals (styracin) shoot out on the edge of the clear liquid, while in the large, sharply-defined drops above mentioned, rectangular tables and short prisms (cinnanic acid) make their appearance. On applying more warmth after the water is evaporated, all the substances unite into a

1 Hanbury, 1.c.

2 Unger u. Liotschy, Die Insel Cypern. Wien, $1865,410$. 
transparent, dark-brown, thick liquid, which exhibits no crystalline structure on cooling, or only after a very long time. Among the fracments of the bark occurring in the crude resin, liber fibres are frequently observable.

Chemical Composition-The most remarkable constituent of Liquid Storax is a liydrocarbon, ${ }^{8} \mathrm{H}^{8}$, first prepared by Simon in 1839 , which exists in the resin as a liquid, and also in a modified form as a solid. The former called Styrol, Cinnamone, or Cinnamol, has a sp. gr. of 0.924 , and a boiling point of $146^{\circ} \mathrm{C}$. It is a colourless, mobile liquid which may be obtained by distilling with water liquid storax, the odour and burning taste of which it possesses. When heated for a considerable time to $100^{\circ} \mathrm{C}$., or for a shorter period to $200^{\circ} \mathrm{C}$., it is converted without change of composition into the cclourless, transparent solid, Metastyrol, which unlike styrol, is not soluble in alcohol or ether. It has a sp. gr. of $1 \cdot 054$, and may be cut with a knife. By prolonged heating, it can be converted into its original liquid form.

Styrol absorbs oxygen, forming an acid, the composition of which has not yet been determined.

If all the styrol obtainable by distillation with water is removed from liquid storax, the residue when submitted to dry distillation yields, as Berthelot has shown (1869), a further quantity. Styrol has also been artificially formed by the same chemist, who regurds it (1867) as a condensed Acetylcne, namely Tetracetylcnc, $4\left(\mathrm{C}^{2} \mathrm{H}^{2}\right)$. Artificial styrol is devoid of rotatory power, whereas that obtained from liquid storax deviates, according to Berthelot, a ray of polarized light. We have ascertained that a solution of storax-resin in acetone has no such effect.

Of the other constituents of liquid storax, Cinnamic Acid and Styracin belong to the radical $\mathrm{C}^{9} \mathrm{H}^{7} \mathrm{O}$ (cinnamyl). The first, $\mathrm{C}^{9} \mathrm{H}^{8} \mathrm{O}^{2}$, is easily extracted from the drug by boiling it in water with carbonate of sodium and lime, by which is obtained cinnamate of sodium, easily decomposable by acids. The process yields from 6 to 12 per cent,according to Löwe as much as 23 per cent., of crystallized cinnamic acid. The acid dissolves abundantly in ether, alcohol, or hot water, slightly in cold water; it is inodorous but has an acrid taste. It fuses at $129^{\circ} \mathrm{C}$., and at a dull red heat is resolved into carbonic acid and styrol, which latter is therefore related to it in the same manner as benzene to benzoic acid.

Styracin ${ }^{1}$ or Cinnamylic Cinnamatc, $\left.{ }_{\mathrm{C}^{9} \mathrm{H}^{9}}^{\mathrm{C}^{9} \mathrm{O}}\right\} \mathrm{O}$, discovered by Bonastre in 1827, can be removed by ether, benzol or alcohol, after the separation from the resin of the styrol and cinnamic acid; for it is insoluble in water, and volatile only in super-heated steam. It crystallizes in tufts of long rectangular prisms, which melt at $38^{\circ} \mathrm{C}$., but it frequently does not solidify in a crystalline form, or only after a long time, or remains as an oily liquid. In its purest state it is inodorous and tasteless. By concentrated solution of potash, it is resolved into a cinnamate, and styprone, $\mathrm{C}^{9} \mathrm{H}^{10} \mathrm{O}$, which latter is not present in Liquid Storax.

Laubenheimer ${ }^{2}$ has shown, that probably Bcnzylic Alcohol, $\mathrm{C}^{7} \mathrm{H}^{8} \mathrm{O}$, boiling at $206^{\circ} \mathrm{C}$, likiewise occurs in Liquid Storax. The cinnamic acid

1 Gmelin, Chomistry, xiii. (1859) 286.

2 Ann.d. Chem. und Pharm. $16 \pm$ (1S72) 2 S9. 
exists dissolved, partly in the water, but to a larger extent in the styrol. Its crystallization and that of the styracin is promoted by exposure to the air.

By the action of oxidizing agents, as nitric or chromic acids, or peroxide of lead, the styrol and cimnamyl compounds are easily reduced, carbonic acid and water being evolved; and at the same time benzoic acid, bitter almond oil, and hydrocyanic acid are produced. These compounds are in fact abundantly evolved when 6 parts of Liquid Storax are gently warmed with $1 \mathrm{p}$. of caustic soda, and then mixed with $3 \mathrm{p}$. of permanganate of potassium dissolved in $20 \mathrm{p}$. of water.

We have examined several samples of Liquid Storax of average quality, and found by exposure of small quantities to the heat of the steam bath, that it lost from 10 to 20 per cent. of water. The remainder treated with alcohol, yielded a residue amounting to 13 to 18 per cent., consisting chiefly of fragments of bark and inorganic impurities. The percentage of the drug soluble in alcohol, to which is due its therapeutic value, thus amounts to 56 to 72 . This part, as may be inferred from the foregoing statements, consists of styrol, metastyrol, cinnamic acid, styracin and, doubtless for a large part, also of resin, the amount of which has not yet been ascertained nor its properties investigated.

Commerce-The annual production of Liquid Storax was estimated by Campbell in 1855 as about $490 \mathrm{cwt}$. for the districts of Giova and Ullà, and $300 \mathrm{cwt}$. for those of Marmorizza and Isgengak. The drug is exported in barrels to Constantinople, Smyrna, Syra and Alexandria. Some is also packed with a certain proportion of water in goat-skins, and sent either by boats or overland to Smyrna, where it is transferred to barrels and shipped mostly to Trieste.

The chief consumption of Liquid Storax would appear to be in India and China. In the fiscal year 1866-67, Bombay imported $319 \mathrm{cwt}$. from the Red Sea. Liquid Storax is seldom seen in the London drug-sales.

Uses-Liquid Storax, which the British Pharmacopceia directs to be purified by solution in spirit of wine, is an ingredient in a few oldfashioned preparations but is hardly ever prescribed on its own account. It is stated to be expectorant and stimulant, and useful in chronic bronchial affections. It has lately been recommended (1865) as an external application for the cure of scabies, for which purpose it is mixed with linseed oil.

Adulteration-The drug is occasionally mixed with sand, ashes and other substances; these would be detected by solution in spirit of wine, as well as by the microscope.

\section{Allied Substances.}

Styrax Calamita (Storax en pain Guibourt)-The substance that now bears this name is by no means the Styrax Calamita of ancient times, but is an artificial compound made by mixing the residual Liquidambar bark called Cortex Thymiamatis (p. 243), coarsely powdered, with Liquid Storax in the proportions of 3 to 2 . It is at first a clammy mass, acquiring after a few weelzs an appearance of mouldiness, due to minute silky crystals of styracin. It is usually imported in wooden drums, and has a very sweet smell. When the bark is scarce, common sawdust is substituted for it, while qualities still inferior are made up 
with the help of olibanum, honey, and earthy sulustanees. This drug is manufactured at Trieste, Veniee and Marseillcs.

Several other odoriferous eompounds of which Liquid Storax appear's to be the chief ingredient, are made in the East and may still be found in old drug warchouses. ${ }^{2}$

Resin of Styprex officincte I.; True Storrax-This was a solid resin somewhat resembling benzoin, of fragrant, balsamic odour, held in great estimation from the time of I)ioseorides and Illiny down to the close of the last eentury. It was obtained from the stem of Styras, officinale L. (Stypecece), a native of Greeee, Asia Minor and Syria, now found also in Italy and Southern Franee. This plant when permitted to grow freely for scveral years, forms a small tree, in whieh state alone it appears to be eapable of affording a fragrant resin. But in most localities it has been reduced by ruthless lopping to a mere bush, the young stems of whieh yield not a trace of exudation. True storax has thus utterly disappeared, and genuine specimens of it are searcely to be found even in museums.

Professor Krinos of Athens has informed us (1871), that about Adalia on the southern eoast of Asia Minor, a sort of solid storax obtained from $S$. officincule is still used as ineense in the ehurehes and mosques. The speeimen of it whieh he has been good enough to send us, is not however resin, but sawdust; it is of a pale einnamon-brown, and pleasant balsamie odour. By keeping, it emits an abundance of minute aeicular erystals (styraein?). 'The substance is interesting in connexion with the statement of Dioseorides, that the resin of Styras is adulterated with the sawdust of the tree itself, and the faet that the region where this sawdust is still in use, is one of the loealities for the drug (Pisidia) whieh he mentions.

Resin of Liquidambar styraciflua L.- - large and beantiful tree, native of North America from Connectieut and Illinois sonthward to Mexico and Guatemala. In the United States, where it is called Succt Gum, the tree yields from natural fissures or by ineision, small quantities of a balsamic resin. In Central Ameriea this exudation is far more freely produeed; an authentie speeimen from Guatemala in our possession, is a pale yellow, opaque resin of honey-like eonsistenee, beeoming transparent, amber-eoloured and brittle by exposure to the air. It has a rather terebinthinous, balsamie odour. In the moutl it softens like benzoin or mastich, and has but little taste. Another speeimen also from Guatemala, is a thiek, fluid oleo-resin, perfeetly transparent and of a golden brown hue.

The resin of $L$. styracifuc $L$. has been ascertained by Procter to contain einnamie, but not benzoie aeid. Whether it is eapable of yielding styrol is not known.

Resin of Liquidambar Formosana Hance-This tree, which we suppose may be the Styrax liquida folio minore whieh Ray names ${ }^{2}$ as oceurring in a eollection of plants from $\Lambda$ moy, is a native of Formosa and Southern China, where it affords a dry terebinthinous resin, of agreeable fragrance when heated. Of this resin, which is used by the Chincse, a speeimen colleeted in Formosa by $\mathrm{Mr}$. Swinhoe has been presented to 
us by Dr. Hooker. A tree figured under the name of Frung-lieang in the Pun-tsco ${ }^{1}$ is, we presume, this species.

Resin of Altingic excelsa Noronha (Liquidambar Altingiana Bl.), Rascmalce of the Javanese and Malays-The Rasamala is a magnificent tree of the Indian Archipelago, Burma, and Assam. In Java it yields by incisions in the trunk an odorous resin, yet only very slowly and in very small quantity; this resin is not collected. ${ }^{2}$ In Burma, on the other hand, the tree affords a fragrant balsam, of which according to Waring ${ }^{3}$ there are two varieties, the one pellucid and of a light yellowish colour, obtained by simple incision; the other thick, dark, opaque, and of terebinthinous odour, procured by boring the stem and applying fire around the trunk.

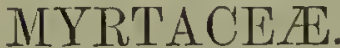

\section{OLEUM CAJUPUTI.}

\section{Oil of Cajuput, Kayu-puti Oil ; F. Essenee de Cajeput; G. Cajeputöl.}

Botanical Origin-Melaleued Leueadendron I., a tree often attaining a considerable size, with a thick spongy bark peeling off in layers, and slender, often pendulous branches. It is widely spread, and abundant in the Indian Archipelago and Malayan peninsula, and is also found in Northern Australia, Queensland and New South Wales.

The tree, according to Bentham, ${ }^{4}$ varies exceedingly in the size, shape, and texture of the leaves, in the young shoots being silky, and the spikes silky-villous or woolly, or the whole quite glabrous, in the short and dense, or long and interrupted spikes, in the size of the flower, and in the greenish-yellow, whitish, pink, or purple stamens, so that it is difficult to believe all can be forms of a single species. Yet upon examination, none of these variations are sufficiently constant or so combined, as to allow of the definition of distinct races.

The variety growing in Bouro, where the oil of cajuput has been distilled ever since the time of Rumphius, and known as M. minor Smith, is described by Lesson who visited the island in 1823, as a tree resembling an aged olive, with flowers in little globose white heads, and a trunk the stout bark of which is composed of numerous satiny layers.

History-Rumphius who passed nearly fifty years in the Dutch possessions in the East Indies, and died at Amboyna in 1702, is the first to give an account of the oil under notice, and of the tree from which it is obtained. ${ }^{5}$ From what he says, it appears that the aromatic properties of the tree were well known to the Malays and Javanese, who were in the habit of steeping its leaves in oil which they then impregnated with the smoke of benzoin and other aromatics, so obtaining. an odorous liquid for anointing their heads. They likewise used cushions stuffed with the leaves, and also laid the latter in cliests to keep away insects.

The fragrance of the foliage having thus attracted the attention of the

1 Chap. 34. sect. 5. 1. Aromalic Trecs.For a modern fig., sec Hooker's Teones Plont. 3ril series, i. tab. 1020.

" De Vry, in letter to D. Manbury, dated Dec. 1. 1859 .
3 Pluam. of Inclia, 1863, SS.

4 Jilore A ustruliensis, iii. (1S66) 142.

5 1Icrb. Amboinense, ii. (1741) cap. 26. 
Dutch, probably suggested submitting the leaves to distillation. Rumphius narrates how the oil was obtained in very small quantities, and was regarded as a powerful sudorific.

The oil was first in the liands of the Amsterdam druggists about the year $1727,{ }^{1}$ soon after which period it took the name of Oleum Wittnebianum, from the recommendations bestowed on it by M. von Wittneben, a German clergyman long resident in Batavia.2 IIn France and England, it was however scarcely known till the commencement of the present century, though it had a place in the Edinburgh Pharmacopœia of 1788. In the London Price Current, we do not find it quoted earlier than 1813, when the price given is $3 s$. to $3 s$. $6 d$. per ounce, with a duty of $2 s .4 \frac{1}{2} d$. per ounce.

Manufacture-In the island of Bouro, in the Molucca Sea, the leaves of the Kayu-puti or White-wood trees are submitted to distillation with water, the operation being conducted in the most primitive manner. Bickmore, ${ }^{3}$ an American traveller who passed three months in the island in 1865 , states that it produces about 8,000 bottles of the oil annually, and that this is almost its only export. The Trade Returns of the Straits Settlements published at Singapore, show that the largest quantity is shipped from Celebes, the great island lying west of Bouro.

Description-Oil of Cajuput is a transparent mobile fluid, of a light blueish-green hue, a fragrant camphoraceous odour, and bitterish aromatic taste. It has a sp. gr. of 0.926 , and remains liquid even at $13^{\circ} \mathrm{C}$. It deviates the ray of polarized light to the left.

Chemical Composition-The researches of Schmidl (1860) and of Gladstone (1872) have shown that cajuput oil consists chiefly of $B i$ hydrate of Cajuputene or Cajuputol, $\mathrm{C}^{10} \mathrm{H}^{16}, \mathrm{H}^{2} \mathrm{O}$, which may be obtained from the crude oil by fractional distillation at $174^{\circ} \mathrm{C}$. If it is repeatedly distilled from anhydrous phosphoric acid, Cajuputene, $\mathrm{C}^{10} \mathrm{H}^{16}$, passes over at $160-165^{\circ} \mathrm{C}$; it has an agreeable odour of hyacinths. After the cajuputene, Isocajuputene distils at $177^{\circ}$, and Paracajuputene at $310-$ $316^{\circ}$, both agreeing in composition with cajuputene.

Like most essential oils having the formula $\mathrm{C}^{10} \mathrm{H}^{16}$, crude cajuput oil is capable of forming the crystallized compound $\mathrm{C}^{10} \mathrm{H}^{16}, 3 \mathrm{H}^{2} \mathrm{O}$. This we have obtained by adding to the oil double its weight of dilute sulphuric acid, about sp. gr. 1·09, and shaking the two liquids togetler occasionally during a few weeks. Various crystallime compounds of cajuputene with chlorine, bromine and iodine have also been obtained. ${ }^{4}$

By the action of concentrated boiling nitric acid, cajuput oil yields according to Schwanert, chiefly camphretic acid and not camphoric.

The remarkable green tint of the oil is due in part to copper, a minute proportion of which metal is usually present in all that is imported. ${ }^{5}$ It may be made evident by agitating the oil with dilute hydrochloric acid. To the acid, after it has been put into a platimum capsule, a little zinc should be added, when the copper will be immediately deposited

1 Schendus van der Beck, De India rarioribus, Act. Nat. Cur. i., appendix (1725) 123.

2 Goetz, Olei Caicput historin-Commercium Littcrarium, 1731. 3; Martini, De Oleo Willnebiano disscrtatio, 1751.
3 Trarels in the East Indian Archipelago, Lond. 196S. 252.

4 Gmelin, Chemistry, xiv. (1S60) 514. 804. 
on the platinum. The liquid may be then poured off and the copper dissolved and tested. When the oil is rectified, it is obtained colourless, but it readily becomes green if in contact for a short time with metallic copper. Guibourt ${ }^{1}$ has lowever proved by experiment, that the volatile oil obtained by the distillation of the leaves of several species of Melaleuca, Mctrosideros and Eucalyptus, has naturally a fine green hue. It is not improbable that this hue is transient, and that the contamination witl copper is intentional in order to obtain a permanent green.

Commerce-The oil is imported from Singapore and Batavia, packed in glass beer or wine bottles. From official statements ${ }^{2}$ it appears that the imports into Singapore during 1871 were as under :-

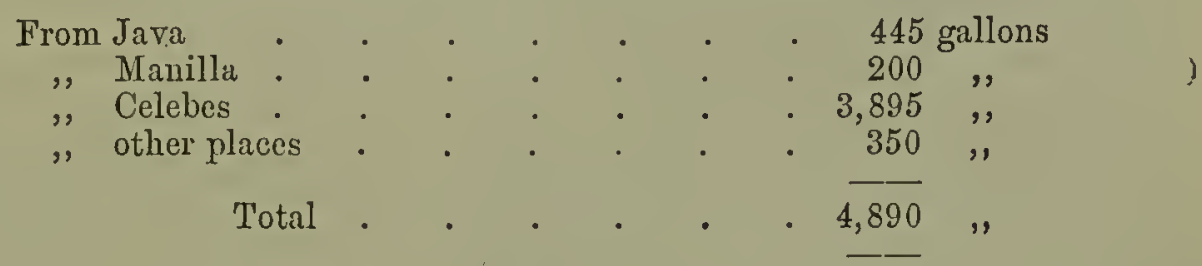

Of this large quantity, the greater portion was re-shipped to Bombay, Calcutta, and Cochin China.

Uses-Cajuput oil is occasionally administered internally as a stimulant, antispasmodic and diaphoretic: externally as a rubefacient it is in frequent use.

Substitutes-The oil of Encalyptus oleosa F. Muell. has, we find, the odour of cajuput; and according to Gladstone it agrees, as well as the oils of Melalenea ericifolia Sm. and M. linariifolia Sm., almost entirely with cajuput oil, except in optical properties. The same is probably the case with the oil of Eucalyptus globulus Labil., which Cloez (1870) states to be dextrogyre.

\section{CARYOPHYLLI.}

Cloves; F. Girofles, Clous de Girofles; G. Gewürznelken.

Botanical Origin-Eigenia caryophyllata Thunberg (Caryophyllus cromaticus L.), a beautiful evergreen tree, 30 to 40 feet high, resembling a gigantic myrtle, bearing numerous flowers grouped in small terminal trichotomous cymes. The flower has an inferior ovary about $\frac{1}{2}$ an inch long, cylindrical, of a crimson colour, dividing at the top into 4 sepals; and 4 round concave petals larger than the calyx, imbricated in the bud like a globe, but at length spreading and soon dropping off.

The clove-tree is said to be strictly indigenous only in the five small islands constituting the proper Moluccas, namely Tarnati, Tidori, Mortir, Makiyan and Bachian. ${ }^{3}$ These form a chain on the west side of the large island of Jilolo, where, strange to say, the tree appears not to exist in a wild state (Crawfurd). According to Rumphins, it was introdnced into

1 Hist. des Drog. iii. (1869) 278.

2 Blue Book of the Colony of the Straits Settlements for 1871, Singapore 1872.
3 Though these are the original Moluceas or Clove Islands, the name has been extended to all islands east of Celebes and west of New Guinea. 
Amboyna before the arrival of the Portugnese, and is still cultivated there and in the neighbouring islands of Harukn, Saparua and Nusalaut, also in Sumatra and Penang. It is likewise now found in Malacca, the Mascarene Islands, the islands of Zanzibar and Temba on the eastern coast of Africa, and the West Indies.

The tree whiels is grown for the spice appears to be a cultivated variety, of lower stature and more aromatic than the wild form.

History-The Greek name Kapvó $\phi \nu \lambda \lambda o v$ is supposed to refer to the ball-like petals of the bud, which as above deseribed, might be compared to a small nut (кápvov). But the name is very variably written, as

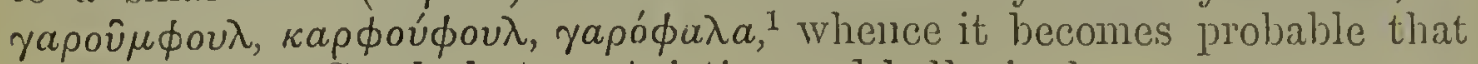
it is not really Greek, but an Asiatic word hellenized.

Cloves have been long known to the Chinese. Mr. Mayers, late Chinese Seeretary to the British Legation at Pekin, has communicated to us the interesting faet that they are inentioned by several Chinese writers as in use under the Han dynasty, B.C. 266 to A.D. 220, during which period it was eustomary for the offieers of the eourt to hold the spice in the mouth before addressing the sovereign, in order that their breath might have an agreeable odour. ${ }^{2}$

The first European author to mention Caryophyllon is Pliny, who describes it after pepper, as a grain resembling that spiee but longer and more brittle, produeed in India, and imported for the sake of its odour. It is doubtful whether this description really refers to cloves.

By the 4th century, cloves must have become well known in Europe, if eredenee can be plaeed in a remarkable record preserved by Vignoli, ${ }^{3}$ which states that the emperor Constantine presented to St. Silvester, bishop of Rome, A.D. 314-335, numerous vessels of gold and silver, incense and spices, among which last were 150 pounds of Clores, - a vast quantity for the period.

Cosmas Indicopleustes ${ }^{4}$ in his Topographica Christicna written about A.D. 547, states in the aceount of Taprobane (Ceylon) that silk,

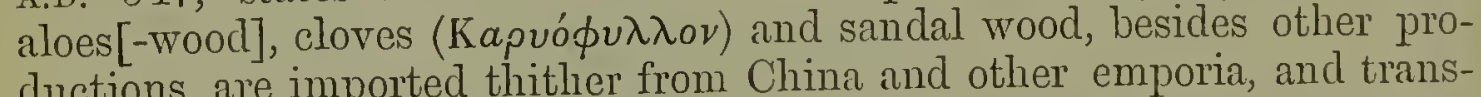
ductions, are imported thither from China and other emporia, and trans-
mitted to distant regions. A century later, Paulus \#gineta ${ }^{5}$ distinctlydescribed cloves as Caryophyyllon-cx India, veluti flores exjusctam arboris . odorati, acres. . . and much used for a condiment and in medicine.

In the beginning of the Sth century, the same spice is noticed by Benedictus Crispus, ${ }^{6}$ archbishop of Milan, who calls it Cariophylus ater; and in A.D. 716, it is enumerated with other commodities in the diploma granted by Chilperic II. to the monastery of Corbie in Normandy. ${ }^{7}$

We find cloves among the wares on which duty was levied at Acon (the modern Acre) in Palestine at the end of the 12th century, at which period that eity was a great emporium of Mediterranean trade. ${ }^{s}$ They

1 Langkavel, Botaniti cler späteren Gricetion, Berlin, 1866. 19.

${ }_{2}$ At this period, the clove was ealled $K i$ shête hiang, i.e. foucl's tongue spice. The modern name Ting hiang, i.c. nail-scent, or -spice, was in use in the 5th or 6th century of our era.

3 Liber Pontifeculis, scu dr. Gestis liomanonum Pontificum, Tioms, i. (1724) 94.
4 Migne, Patrologice Cursus, serjes Greca. lxxxriii. (1s60) 446.

5 De re nedica, lib. vii. c. 3.

- Posmatium Nedicum-Nigne, Patrologiu Cursus, lxxxix. (1850) 374.

- Pardessus, Diplomate, Chuile; ete., ii. (1849) 309.

s Pecucil aes Ifistoricas des Croisader, Lois, ii. (1843) 173. 
are likewise enmmerated in the tariff of Marseilles of A.D. 1228, ${ }^{1}$ in that of Barcelona of $1252^{2}$ and of Paris, $1296 .^{3}$

These facts show that the spice was a regular object of commerce at this period. But it was very costly: the Household Book of the Countess of Leicester A.D. $1265^{4}$ gives its price as 10 s. to 12 s. per $1 \mathrm{~b}$., exactly the same as that of saffron. Several other examples of the high cost of the spice might be adduced.

Of the place of growth of cloves, the first distinct notice seems to be that of the Arabian geographer Ibn Khurdádbah, ${ }^{5}$ A.D. 869-885, who names the spice, with cocoa-nuts, sugar, and sandal-wood as produced in Java. Doubtless he was misinformed, for the clove-tree had not come so far west at that period. Marco Polo ${ }^{6}$ made the same mistake four centuries later: finding the spice in Java, he supposed it the growth of the island.

Nicolo Conti, ${ }^{7}$ a Venetian merchant who reached the Indian Archipelago in the middle of the 15th century, learned that cloves are brought to Java from the island of Banda, fifteen days' sail further east. With the arrival of the Portuguese at the commencement of the 16th century, more accurate accounts of the Spice Islands began to reach Europe; and Pigafetta, ${ }^{8}$ the companion of Magellan, gave a very good description of the clove-tree as he observed it in 1521.

The Portuguese had the principal share in the clove trade for nearly a century. In 1.605 they were expelled by the Dutch, who took exclusive possession of the Moluccas and adopted extraordinary measures for keeping the traffic in their own hands. Yet notwithstanding this, large supplies of cloves reached England direct. In 1609 a ship of the East India Company called the Consent, arrived with $112,000 \mathrm{fb}$. the duty on which amounted to $£ 1400$ and the impost to as much more. The spice ungarbled was sold at 5s. $6 \mathrm{~d}$. and $5 \mathrm{~s}$. $9 \mathrm{~d}$. per $\mathrm{tb}$. - of course, in bond. ${ }^{9}$

To effect their purpose, the Dutch endeavoured to extirpate the clovetree from its native islands, and even instituted periodical expeditions for the purpose of destroying any young trees that might have accidentally sprung up. This policy the object of which was to confine the growth of the spice to a group of small islands of which Amboyna is the largest, has but very recently been abandoned: though the cultivation of the spice was free in all other localities, the clove parks of the Amboyna islands remained the property of the Dutch Government. The original Moluccas or Clove Islands now produce no cloves at all.

The enterprise of Poivre, the French governor of Mauritius and Bourbon, so far eluded the vigilance of the Dutch, that both clove- and nutmeg-trees were introduced into those islands in the year $1770 .{ }^{10}$ The

1 Méry et Guindon, Irist. des Actes . . . . do la municipalité de Marscille, 1841. 373.

2 Capmany, Mlcmorias sobrc la marine (ic. de Burcelona, iii. 170 .

3 Douet d'Areq, Revuc archéologique, ix. (1852) 213.

* IFanners and Houschold Experises in England (Toxburgh Club), 1841. lii.

5 Le Livre des routes at des movinces, traduit par C. Jiarbier de Meyuard, Journ. A siat. sér. 6. tome v. (1805) 227.

(s Yule, Marco Polo, ii. (1871) 217.-It should however be borne in mind that the nume Java was applied in a gencral sense by the Arab geographers to the islands of the Archipelago.

7 Kunstmann, Dic Kcnntniss Indicns im XVten Jahrhundert, München 1863. 46.

\& Ramusio, Delle navigationi ct viaygi, Venctia 1554, fol. 4046.

"Calcudar" of State Papers, Colonial scrics, East Indics, 1562. 181.

10 T'essicr, Sur l'importation du Girotlicr des Moluques aux Îsles de France, de Boivbon et de Sechelles, et de ces îsles it. Conyenne.Obscrinativis sur la physsique, Paris, Juillet, 1779 . 
clove-tree was carried thence to Cayenme in 1773 , and to Zanzibar about the end of the century.

Crawfurd ${ }^{1}$ in an excellent article of which wc have made free usc, aptly remarks that it is difficult to understand how the clove first came to the notice of foreign nations, considcring the wcll-ascertained fact that it has never been used as a condiment or in 'any other way, by the inliabitants of the islands of which it is a native. We may obscrve however that there wcre some singular superstitions among the islanders with regard to the so-callcd Royal Clove (p. 255), a tree of which on the island of Makiyan was long supposed to be unique.

Collection-The flower-buds of the clove-tree when young are nearly white, but afterwards bccome green and lastly bright red, when they must at oncc be gathered. This in Zanzibar is done by hand; cach clove is picked singly, a moveable stagc the height of the trec bcing used to enable the labourers to reach the upper branches. The buds are then simply dricd in the sun, by which thcy acquire the familiar dark brown tint of the commercial article. The gathering takes place twice a ycar; in the Moluccas where the harvest occurs in June and Decembcr, the cloves are partly gathered by hand, and partly beaten off the trce by bamboos on to cloths spread beneath. The annual yield of a good tree is about $4 \frac{1}{2}$ pounds, but sometimes reaches doublc that quantity.

Description-Cloves are about $\frac{8}{10}$ of an inch in length, and consist of a long cylindrical calyx dividing above into 4 pointed sprcading scpals which surround 4 petals, closely imbricated as a globular bud about $\frac{2}{10}$ of an inch in diameter.

The petals which are of lighter colour than the rest of the drug and somewhat translucent from numerous oil-cells, spring from the base of a 4-sided epigynous disc, the angles of which are directed towards the lobes of the calyx. The stamens which are very numerous, are inserted at the base of the petals and are arched over the style. The latter wnich is short and subulate, rises from a depression in the centre of the disc. Immediately below it and united with the upper portion of the calyx is the ovary, which is 2 -celled and contains many ovules. The lower end of the calyx (hypanthium) has a compressed form; it is solid but has its internal tissue far more porous than the walls. The whole calyx is of a deep rich brown, has a dull wrinkled surface, a dense fleshy texture, and abounds in essential oil which exudes on simple pressure with the nail. Cloves have an agreeable spicy odour, and a strong biting aromatic taste.

The varieties of cloves occurring in commerce do not cxhibit any structural differences. Inferior kinds are distinguished by being less plump, less bright in tint, and less rich in essential oil. In London price-currents, cloves are enumerated in the order of value thus: Penang, Bencoolen, Amboyna, Zanzibar.

Microscopic Structure-A transverse section of the lower part of a clove shows a dark rhomboid zone, the tissue on cither side of which is of a lighter hue. 'The outcr layer beneath the epidermis cxhibits a large number of oil-cells, frequently as much as $300 \mathrm{mkm}$. in diametcr. About 200 oil-cells may be counted in onc transverse scction, so that the

1 Dictionary of the Indian Istands, 1856, article Clorc. 
large amount of essential oil in the drug is well shown by its microscopic character's. The above-mentioned zone is chiefly made up of about 30 fibro-vascular bundles, another stronger buudle traversing the centre of the clove. The fibro-vascular bundles as well as the tissue bordering the oil-cells, assume a greenish black hue by alcoholic perchloride of iron.

Chemical Composition-Few plants possess any organ so rich in essential oil as the drug under consideration. The oil known in pharmacy as Oleum Caryophylli, which is the most important constituent of cloves, is obtainable to the extent of 16 to 18 per cent. But to extract the whole, the distillation must be long continued, the water being returned to the same material.

The oil is a colourless or yellowish liquid with a powerful odour and taste of cloves, sp. gr. 1.046 to 1.058, and no rotatory power. It is a mixture of a hydrocarbon, and an oxygenated oil called E'ugenol, in variable proportions. The former which is sometimes termed light oil of cloves and comes over in the first period of the distillation, has the composition of oil of turpentine, a sp. gr. of 0.91 , and boils at $251^{\circ} \mathrm{C}$. It therefore agrees better with the oils of copaiba and cubebs, to which we assign more correctly the formula $\mathrm{C}^{20} \mathrm{H}^{32}$ than $\mathrm{C}^{10} \mathrm{H}^{16}$. Eugenol which. on account of its acid properties is commonly called Eugenie Acid, has a sp. gr. of 1.068 and possesses the full taste and smell of cloves. Its boiling point is about $252^{\circ}$ ( $242^{\circ}$ Stenhouse). With alkalis, especially ammonia and baryta, it yields crystallizable salts. Eugenic acid, $\mathrm{C}^{10} \mathrm{H}^{12} \mathrm{O}^{2}$, is isomeric with cuminic acid, but it partakes in several respects of the chemical behaviour of phenol, as for instance in not reddening litmus. It is likewise a constituent of the volatile oils of pimento, cinnamonleaf, cannella alba, and Brazilian clove-bark (Dicypellium caryophyllatum Nees).

The water distilled from cloves contains in addition to the essential oil, another body, Eugenin, which sometimes separates after a while in the form of tasteless, crystalline laminæ, liaving the same composition as eugenic acid. ${ }^{1}$ We have never met with it.

Scheuch (1863) showed that oil of cloves also contains Salicylic Acid, $\mathrm{C}^{7} \mathrm{H}^{7} \mathrm{O}^{3}$, probably in the form of an ether. It may be removed by shaking the oil with a solution of carbonate of ammonium. To the presence of this acid, the reactions of the oil with iron are probably due. Crude oil of cloves indeed assumes a greenish-blue hue when mixed with an alcoholic solution of perchloride of iron, and an intense violet if shaken with reduced metallic iron.

Caryophyllin, $\mathrm{C}^{10} \mathrm{H}^{18} \mathrm{O}$, is a neutral, tasteless, inodorous substance, isomeric with common camphor, crystallizing in needle-shaped prisms. We have obtained it in small quautity, by treating with boiling ether cloves, which we had previously deprived of most of their essential oil by small quantities of alcohol. E. Mylius (1873) obtained from it by nitric acid, crystals of Caryophyllinic Acid, $\mathrm{C}^{20} \mathrm{H}^{32} \mathrm{O}^{6}$.

Carmufellic Acid obtained by Muspratt and Danson after digesting an aqueous extract of cloves with nitric acid, is a product of this treatment and not a natural constituent of cloves.

Cloves contain a considerable proportion of gum; also a tannic acid not yet particularly examined. 
Production and Commerce-Of late years the principal locality for the production of cloves has been the islands of Zanzibar and Pentua on the east coast of Africa, which until very recently were capable of producing a maximum crop of $10 \frac{1}{2}$ millions of pounds in a single scasun. On the 15th April, 1872, 'Zanzibar' was visited by a hurricane of extraordinary violence, by which about five-sixths of the clove-trees in the island were destroyed; and although the plantations "are being renewed, many years must elapse before the crop can resume its former inportance. Pemba which is distant from Zanzibar 25 miles, and produced about half as much of the spice as that island, did not appreciably suffer from the storm.

The crop on these islands fluctuates, a good year alternating with a bad one. 'This is partly shown in the imports of Bombay, the great nart of Zanzibar produce, which have been as follows :-

$\begin{array}{cccc}1869-70 & 1870-71 & 1871-72 & 1872-73 \\ 45,642 \mathrm{cwt} . & 21,968 \mathrm{cwt} . & 43,891 \mathrm{cwt} . & 25,185 \mathrm{cwt} .\end{array}$

The quantity of cloves shipped from Bombay to the United Kingdom is comparatively small, being in 1871-72, 3279 cwt.; in 1872-73, 3271 civt.

Cloves are also largely shipped direct from Zanzibar to the United States and Hamburg. A small amount is taken in native vessels to the Red Sea ports; these are packed in raw hides. Those for the European and American markets are shipped in mat bags made of split cocoa-nut leaf.

The clove trade of the Moluccas has been for many years in the hands of the Dutch Government, which by its restrictive policy, assumed practically the position of growers, disposing of their produce through the Netherlands Trading Company at auctions held in Holland twice a year. This system which was abolished in 1872, has proved disastrous to the trade it was designed to protect, and to such a degree that the produce of cloves in the Moluccas is but a tenth of what it was in the early days of their intercourse with Europe. The crop of the four islands, Amboyna, Haruku, Saparua, and Nusalaut, the only Moluccas in which the tree is cultivated, was reckoned in 1854 as 510,912 $\mathrm{fb}$.

The export of cloves from Java in 1871, was 1397 peculs $^{1}$ $(186,266 \mathrm{1b}$.). The French island of Réunion which thirty or forty years ago used to produce as much as 800,000 kilogrammes $(1,764,571 \mathrm{fb}$.), now yields almost none, partly by reason of change of climate and partly from political causes.

Uses-As a remedy, cloves are unimportant, though in the form of infusion or distilled water, they are useful in combination with other medicines. The essential oil which sometimes relieves toothache, is a frequent ingredient of pill-masses. The chief consumption of cloves is as a culinary spice.

Substitutes-1. Clove Stallis-Festuca vel Stipites Caryophylli, in French Griffes de Girofle, in German Nelkensticle, were an article of import into Europe during the middle ages, when they were chiefly known by their low Latin name of fusti. Thus under the statutes of Pisa, ${ }^{2}$ A.D. 1305 , duty was levied not only on cloves (garofali), but also

1 Consular Reports, Aug. 1873. 952.

- Bonaini, Statuti incditi della ciltì di Pisc dal xii. al xiv. sccolo, iii. (1S57) 106. 
on Folic et fusti garofalorum. Pegolotti ${ }^{1}$ a little later, names both as being articles of trade at Constantinople. Clove Leaves are enumerated ${ }^{2}$ as an import into Palestine in the 12 th century; they are also mentioned in a list of the drugs sold at Frankfort ${ }^{3}$ about the year 1450: we are not aware that they are nsed in modern times.

As to Clove Stalks, they are still a considerable object of trade, especially from Zanzibar, where they are called by the natives Vikunicu. They taste tolerably aromatic, and yield 4 'to 5 per cent. of volatile oil; they are used for adulterating the Ground Cloves, sold by grocers. Such an admixture may be detected by the microscope, especially if the powder after treatment with potash, be examined in glycerin. If clove stalks have been ground, thick-walled or stone-cells will be found in the powder; such cells do not occur in cloves. Powdered allspice is also an adulterant of powdered cloves; it also contains stonecells, but in addition numerous starch-granules which are entirely wanting in cloves.

2. Mother Cloves, Anthophylli,-are the fruits of the clove-tree, and are ovate-oblong berries about an inch in length and much less rich in essential oil than cloves. Though occasionally seen in the London drug sales in some quantity, they are not an article of regular import. ${ }^{4}$ As they contain very large starch-granules, their presence as an adulteration of ground cloves would be revealed by the microscope.

3. Royal Cloves-Under this name or Caryophyllum regium, a curious monstrosity of the clove was formerly held in the highest reputation, on account of its rarity and the strange stories told respecting it. ${ }^{5}$ Specimens in our possession show it to be a very small clove, distinguished by an abnormal number of sepals and large bracts at the base of the calyx-tube, the corolla and internal organs being imperfectly developed.

\section{FRUCTUS PIMENTA.}

Semen Amomi; Pimento, Allspice, Jamaiea Pepper; F. Poivre de la Jamä̈que, Piment des Anglais, Toutc-épiee; G. Nelkenpfeffer, Nelkenköpfe, Neugewü̈z.

Botanical Origin-Pimenta oficinclis Lindley ${ }^{6}$ (Myrtus Pimenta L., Eugenia Pimenta DC.), a beautiful evergreen tree, growing to about 30 feet in height, with a trunk 2 feet in circumference, common throughout the West India Islands. In Jamaica, it prefers limestone hills near the sea, and is especially plentiful on the morth side of the island.

History-The high value placed on the spices of India, sufficiently explains the interest with which aromatic and pungent plants were regarded by the early explorers of the New World; while the eager clesire to obtain these lucrative commodities is shown by the names

1 See p. 208, note 1.

2 liecucil nes Itislorions des Croisades, Lois, ii. (1843) 173.

3 Fliiekiger, Die Frankfurter Liste, Halle, 1873. 11. 38.

4 We find in the fortnightly priee current of a London drust-broker under date Nov. 27, 1873, the announeement of the sale of 1,050 bags of Mother Cloves at $2 d$. to $3 d$. per 1b., besides 4,200 packages of Clove Stalks at $3 d$. to $4 d$. per 16 .

5 Rumphius, Herb. Amb. ii. 11. tab. 2.See! also Hasskarl, Neucr Schlüssel $\approx u$ Rumpli's Herb. Amb., Halle, 1866; Berg, Linnoe, 1854. 137; 'Valmont de Bomare, Diet. d'Hist. Nat. iii. (1775) 70.

${ }^{6}$ Colleclanea Botanica, 1821, sub. tab. 19. 
Pepper, Cinnamon, Balsam, Melegueta, Amomum, bestowed on productions totally distinct from those originally so designated.

Among the spices thins brought to the notice of Europe, wcre the little dry berries of certain trecs of the myrtle tribe, which had some resenblance in shape and flavour to peppercorns, and hence were named Pimienta, ${ }^{1}$ corrupted to Pimenta or P'imento. It was doubtless a drug of this kind, if not our veritable allspice, that was given to Clusius in 1601 by Garret, a druggist of London, and described and figured by the former in his Liber Exoticorum. ${ }^{2}$ A few ycars later it began to be imported into England, being as Parkinson ${ }^{3}$ says- "obtruded for Amomum" (Round Cardamom), so that "some more audacious than wise ... put it in their compositions instead of the right." Sloane ${ }^{4}$ states (1691) that it was commonly sold by druggists for Carpobalsamum. Ray (1693) distinguished the spice as a production of Jamaica under the name of Sweet-seented Jamaiea Pepper or All-spice, and states it to be abundantly importcd into England, and in frequent use as a condiment, though not employcd in medicine. The spice had a place in the London Pharmacopœia as early as 1721 .

The consumption of pimento has been enormous. In the year 1804-5, the quantity shipped from the British West Indies was $2,257,000 \mathrm{Hb}$., producing in import duty, a net revenue of $£ 38,063 .^{5}$

Production and Commerce-The spice found in commerce is furnished wholly by the island of Jamaica. A plantation, there called a Pimento walk, is a piece of natural woodland stocked with the trees, which require but little attcntion. The flowers appear in June, July, and August, and are quickly succeeded by the berries, which are gathered when of full size but still unripe. This is performed by breaking off the small twigs bearing the bunches. These are then spread out, and exposed to the sun and air for some days, after which the stalks are removed, and the berries are fit for being packed.

By an official document ${ }^{6}$ it appcars that in the year 1871, the amount of land in Jamaica cropped with pimento was 7,178 acres. In that year the island exported of the spice $6,857,838 \mathrm{fb}$., value $£ 28,574$. Of this quantity Great Britain took 4,287,551 1b., and the United States 2,266,950 1b.

Description-Allspice is a small, dry, globular berry, rather variable in size, measuring $\frac{3}{10}$ to less than $\frac{2}{10}$ of an inch in diameter. It is crowned by a short style, scated in a depression, and surrounded by 4 short thick sepals; generally however the latter have been rubbed off, a scar-like raised ring marking their formerr position. The berry has a woody shell or pericarp, easily cut, of a dark ferruginons brown, and rugose by reason of minute tubercles filled with essential oil. It is twocelled, each cell containing a single, reniform, exalbuminous seed having a large spirally curved embryo. The seed is aromatic, but less so than the pericarp.

Allspicc has an agreeable, pungent, spicy flavour, much resembling that of cloves.

1 Pimienta, the Spanish for pepper is derived from pigmentum, a general name in medixeval Latin for spicery.

2 Lib. i. c. 17.

3 Theatrum Dotanieum (1640) 1567.
4 Description of the Pimienta or Jamaica Pepper-trec. - Phil. Trans, xvii. No. 192.

5 Parliamentary Return, March 1505, quoted in Young's IV $c s t$-India Common-place Book, 1807. 79.

${ }_{6}$ Blue Book for Jamaica, printed 1872 . 
Microscopic Structure-The outer layer of the pericarp immediately beneath the epidermis, contains numerous large cells filled with essential oil. The parenchyme further exhibits thick-walled cells loaded with resin, and smaller cells enclosing crystals of oxalate of calcium. The whole tissue is traversed by small fibro-vascular bundles. The seeds are also provided with a small number of oil-cells, and contain starch granules.

Chemical Composition-The composition of pimento resembles in many points that of cloves. The berries yield to the extent of 3 to $4 \frac{1}{2}$ per cent., ${ }^{1}$ a volatile oil, sp. gr. 1.037 (Gladstone), having the characteristic taste and odour of the spice, and known in the shops as Oleum Pimentce. We have found it to deviate the ray of polarized light $2^{\circ}$ to the left, when examined in a column of $50 \mathrm{~mm}$. The rotatory power depends upon the presence of a hydrocarbon, the eugenic acid being optically inert.

Oeser (1864), whose experiments have been confirmed by Gladstone (1872), has shown that oil of pimento has substantially the same composition as oil of cloves. When it is heated in a retort, the first portion that distills over is a hydrocarbon lighter than water, the second is eugenic acid, wholly soluble in alkalis and giving crystalline salts (p. 253). Salicylic acid has not been found. Pimento is rich in tannin, striking with a persalt of iron an inky black. Its decoction is coloured deep blue by iodine, showing the presence of starch. Dragendorff (1871) pointed out the existence in allspice of an extremely small quantity of an alkaloid.

Uses-Employed as an aromatic lkie cloves; a distilled water (Aqua Pimento) is frequently prescribed. The chief use of pimento is as a culinary spice.

Substitutes-According to Berg ${ }^{2}$ the Mexican spice called Pimienta de Tabasco (? Piment Tabago, Guibourt) which is somewhat larger and less aromatic than Jamaica allspice, is derived from a variety of Pimenta officinalis. Analogous products are afforded by Pimenta acris Wight and P. Pimento Griseb.

\section{GRANATEÆ.}

\section{CORTEX GRANATI FRUCTUS.}

\section{Cortex Granati; Pomegranate Peel; F. Ecorce de Girencedes; G. Granatschalen.}

Botanical Origin-Punica Granatum L., a shrub or low tree, with small deciduous foliage and handsome scarlet flowers. It appears to be indigenous to North-western India, and the countries south and south-

1 From information kindly given $u s$ by Messrs. Herrings and Co., London, it appears that $3756 \mathrm{Hb}$. of pimento distilled in the course of several years, yielded $120 \mathrm{lb}$. $2 \mathrm{oz}$ of oil, equivalent to $3 \cdot 19$ per cent. -
Mr. Whipple distilled in the laboratory of Messrs. Barron and Co., $896 \mathrm{It}$., getting the exceptionally large yield of 4.6 per cent.

- Pharmazeutische Waarcnkunde 1869.394. 
west of the Caspian to the Persian Gulf and Palestine. But it has long been cultivated, and is now found throughout the warm jarts of Europe and in the subtropical recrions of both hemispheres.

History-The porncgranate has been higlily prized by mankind from the remotest antiquity, as is shown by the references to it in the Mosaic writings ; ${ }^{1}$ and by the numerous representations of the fruit in the sculptures of Perscpolis and Assyria, ${ }^{2}$ and on the ancient monuments of Egypt. ${ }^{3}$ It was probably introduced into the south of Italy by Greek colonists, and is raincd as a common fruit-tree by Porcius Cato ${ }^{4}$ in the 3rd century B.C. The peel of the fruit was recognized as medicinal by the ancients, and among the Romans was in common use for tanning leather.

Description-The fruit of the pomegranate trec is a spherical, somewhat flattened and obscurely six-sided berry, of the size of a common orange and often much larger, crowned by the thick, tubular, 5 - to 9-toothed calyx. It has a smooth, hard, coriaceous skin, which when the fruit.is ripe, is of a brownish yellow tint, often finely shaded with red. Membranous dissepiments about 6 in number meeting in the axis of the fruit, divide the upper and larger portion into equal cells. Below these, a confused conical diaphragmseparates the lower and smaller half, which in its turn is divided into 4 or 5 irregular cells. Fach cell is filled with a large number of grains, crowded on thick spongy placentæ, which in the upper cells are parietal but in the lower appear to be central. The grains, which are about $\frac{1}{2}$ an inch in length, arc oblong or obconical and manysided, and consist of a thin transparent vesicle containing an acid, saccharine, red, juicy pulp, surrounding an elongated angular seed.

The only part of the fruit used medicinally is the peel, Cortex Granati of the druggists, which in the fresh state is leathery. When dry, as imported, it is in irregular, more or less concave fragments, some of which have the toothed, tubular calyx still enclosing the stamens and style. It is $\frac{1}{20}$ to $\frac{1}{10}$ of an inch thick, easily breaking with a short corky fracture; externally it is rather rough, of a yellowish brown or reddish colour. Internally it is more or less brown or yellow, and honey-combed with depressions left by the seeds. It has hardly any odour, but has a strongly astringent taste.

Microscopic Structure-The middle layer of the peel consists of large thin-walled and elongated, somctimes even branched cells, among which occur thick-walled cells and fibro-vascular bundles. Both the outer and the inner surface are made up of smaller, nearly cubic and densely packed cells. Small starch granules occur sparingly throughout the tissue, as well as crystals of oxalate of calcium.

Chemical Composition-The chief constituent is tannin, which in an aqueous infusion of the dried peel, produces with perchloride of iron an abundant dark blue precipitate. The peel also contains sugar and a little gum. Dried at $100^{\circ} \mathrm{C}$. and incinerated, it yiclded us 5.9 per cent. of ash.

1 Exodus xxviii. 33, 34, Numbers xx. 5, Deut. viii. 8.

${ }_{2}$ Layard, Nineveh and its Remains, ed. 2, ii. (1849) 296.
3 Wilkinson, Ancient Egyptians, ii. (183i) 142.

${ }_{4}^{4}$ Nisard's edition, Paris, 1864, capp. 7. 127. 133 . 
Uses-Pomegranate peel is an excellent astringent, now almost obsolete in British medicine. Waring ${ }^{1}$ asserts that when combined with opium and an aromatic, as cloves, it is a most useful remedy in the chronic dysentery of the natives of India, as well as in diarrhœa.

\section{CORTEX GRANATI RADICIS.}

\section{Pomegranate-root Bark; F. Ecorce de racine de Grenadier ; G. Granatwurzelrinde.}

Botanical Origin-Punica Granatum L., see p. 257.

History-In addition to the particulars regarding the pomegranate tree given in the preceding article, the following which concern the drug under notice may be stated.

A decoction of the root of the pomegranate was recommended by Celsus, ${ }^{2}$ Dioscorides, ${ }^{3}$ and Pliny ${ }^{4}$ for the expulsion of tape-worm; but the remedy had fallen into complete oblivion, until its use among the Hindus attracted the notice of Buchanan ${ }^{5}$ at Calcutta about the year 1805. This physician pointed out the efficacy of the root-bark, which was further shown by Fleming and others. Pomegranate root is known to have been long used for a similar purpose by the Chinese. ${ }^{6}$

Though the medicine is admitted to be efficient, and is employed with advantage in India where it is easily procured both genuine ard fresh, it is hardly ever administered in England, the extract of malefern being generally preferred; but it has a place in several continental pharmacopoias.

Description-The bark occurs in rather thin quills or fragments, 3 to 4 inches long. Their outer surface is yellowish grey, sometimes marked with fine longitudinal striations or reticulated wrinkles, but more "often furrowed by bands of cork, running together in the thickest pieces into broad flat conchoidal scales. The inner surface which is smooth or marked with fine strix and is of a greyish yellow, has often strips of the tough whitish wood attached to it. The bark breaks short and granular ; it has a purely astringent taste, but scarcely any odour.

Microscopic Structure-On a transverse section, the liber is seen to be the prevailing part of the cortical tissue. The former consists of alternating layers of two kinds of cells-one of them loaded with tufted crystals of oxalate of calcium, the other filled with starch granules and tannic matter. The bark is traversed by narrow medullary rays, and very large sclerenchymatous cells are scattered through the liber. Touched with a dilute solution of a persalt of iron, the bark assumes a dark blackish blue tint.

Chemical Composition-The bark contains according to Wackenroder (1.824), more than 22 per cent. of tannic acid, which Rembold (1867) has ascertained to consist for the most part of a peculiar variety called Punico-tannic Acid, $\mathrm{C}^{20} \mathrm{H}^{16} \mathrm{O}^{13}$; when boiled with dilute sulphuric acid, it is resolved into Ellagic Acid, ${ }^{14}{ }^{14} \mathrm{H}^{6} \mathrm{O}^{8}$, and sugar. Punico-tannic

1 Plarm. of India, 1868. 93. 447.

2 De Medicina, lib. iv. c. 17.

3 Lib. i. c. 153.

4 Lib. xxiii. c. 60.
5 Edinb. Ned. and Surg. Journ, iii. (1807) 22.

6 Debeaux, Pharmacie et Mat. Aréd. des Chinois, 1865. 70 . 
acid is accompanied by common tannic acid, yielding by means of sulphuric acid, gallic acid, which appears sometimes to pre-exist in the bark. If a decoction of pomerranate bark is precipitated by acetate of lead, and the lead is separated from the filtered liquid, the latter on evaporation yields a considerable amount of mannite. This is probably the Punicin or Granatin of former observers. Among the substances hitherto detected in pomegranate bark, it will be seen that there is none which explains its trenicide power.

Uses-A decoction fullowed by a purgative, is stated by Waring ${ }^{1}$ and others to be most efficient for the expulsion of tape-worm. The fresh bark is said to be preferable to the dried.

Adulterations-The commercial drug frequently consists partly or entirely of the bark of the stem or branches, characterised by its less abundant cork-formation, which exlibits longitudinal bands or ridges of light brownish cork, but not conchoidal exfoliations. The middle cortical layer is somewhat more developed, and contains in the outer cells deposits of chlorophyll. The cambial zone is not distinctly observable. Such bark is reputed to be less active than that of the root, but we are not a ware that the fact has ever been proved.

The bark of Buxus sempervirens and of Berberis vulgaris are somewhat similar to the drug nuder notice, but their decoctions are not affected by salts of iron.

\section{CUCURBITACEA.}

\section{FRUCTUS ECBALLII.}

Fructus Ellaterii ; Elaterium Fruit, Squirting Cucumber, Wild Cucumber ; F. Concombre purgatif ou Sauvage; G. Springgurke.

Botanical Origin-Ecballium ${ }^{2}$ Elaterium A. Richard (Momordica Elaterium L.), a coarse, hispid, fleshy, decumbent plant without tendrils, having a thick white perennial root. It is common throughout the Mediterranean region, extending eastward as far as Southern Russia and Persia, and westward to Portugal. It succeeds well in Central Europe, and is cultivated to a small extent for medicinal use at Mitcham and Hitchin in England.

History-Theophrastus mentions the plant under notice by the

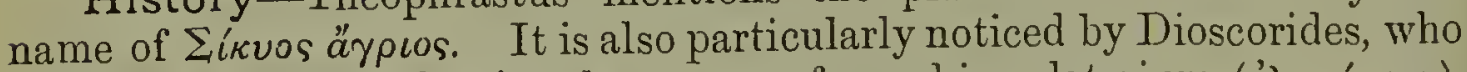

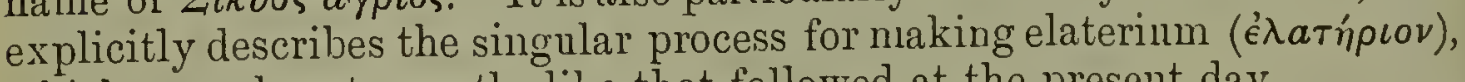
which was almost exactly like that followed at the present day.

The Wild or Squirting Cucumber was well known and cultivated in gardens in England as early as the middle of the 16th century. ${ }^{3}$

Description-The fruit is ovoid-oblong, nodding, about $1 \frac{1}{2}$ inch long, hispid from numerous short fleshy prickles terminating in white elongated points. It is attached by a long scabrous peduncle, is fleshy and green while young, becoming slightly yellowish when mature; it is

Indian Annals of Med. Seience, vi. (1859): Pharmacopaia of India, 1868. 93.

2 Eicullium from é $\beta{ }_{u}^{\prime} \lambda \lambda \omega, 1$ expel, in allusion to the expulsion of the seeds : often erroneously written Ecbalium.

3 'Iurner's Herbull, 1568, part i. 180. 
3-celled and contains numerous oblong seeds lodged in a very bitter succulent pulp. The fruit when ripe separates suddenly from the stalk, and at the same moment the seeds and juice are forcibly expelled from the aperture left by the detached peduncle. This interesting phenomenon is due to the process of exosmosis, by which the juice of the outer part of the fruit gradually passes through the strong contractile tissue which lines the central cavity, until the pressure becomes so great that the cell gives way at its weakest point. This point is that at which the peduncle is articulated with the fruit; and it is the sudden and powerful contraction of the elastic tissue when relieved from pressure, that occasions the violent expulsion of the contents of the central cavity.

For the preparation of the officinal elaterium, the fruit has to be employed while still somewhat immature, for the simple reason that it would be impossible to gather it so as to retain its all-important juice, if left till quite ripe. When it is sliced longitudinally as in making elaterium, some of the juice is expelled by virtue of the endosmotic action already described, as can easily be seen on examining the contracted lining of the sliced fruit.

Pereira observes ${ }^{1}$ that if the juice of a fruit is received on a plate of glass, it is seen to be nearly colourless and transparent. In a few minutes however, by exposure to the air, it becomes slightly turbid, and small white coagula are formed in it. By slow evaporation, minute rhomboidal crystals make their appearance: these are claterin.

Hot, dry weather favours the development of the active principle of the drug.2

Microscopic Structure-The middle layer of the fruit is built up of large somewhat thick-walled cells, traversed by a few fibro-vascular bundles. The former abound in small starch grains, and also contain granules of albuminous matter.

Chemical Composition-The experiments of Clutterbuck (1819) proved that the active properties of the elaterium plant reside chiefly, though not exclusively, in the juice that surrounds the seeds; and it is to this juice and to the medicinal product which it yields, that the attention of chemists has been hitherto directed.

The juice obtained by lightly pressing the sliced fruits, is at first, greenish and slightly turbid. After having been set aside a few hours, it yields a deposit, which has to be collected on calico, rapidly drained with gentle pressure between layers of bibulous paper and porous bricks, and dried in a warm place. The substance thus obtained is the Elaterium of pharmacy. ${ }^{3}$ The method recommended by Clutterbuck ${ }^{4}$ involves no pressing. The juice of the sliced fruit is saved, and the pulp scooped out by the thumb of the operator, is thrown on a sieve and slightly washed with pure water. From these liquors, elaterium is deposited.

Elaterium occurs in irregular cake-like fragments, light, friable, and opaque; when new, of a bright, pale green, becoming by age greyish and exhibiting mimute crystals on the surface. It has a herby tea-like

1 Elem. of Mat. Med. ii. (1853) 1745.

2 Having liad to procure elaterium finits at Mitcham in the very fine summer of 1868 , I was told that the preople ocenvicd in slicing the fruits had never suffered so scverely from their work as in that year:D. H.

3 There is a genus of Cumpritacere fommded by Linnæus, also called Elatrrium.

${ }^{4}$ Lond. Ited. Repository, xii. (1820) 1. 
odour and a very bitter taste. 'The produce is extremely small : $240 \mathrm{Ht}$. of fruits gathered at Mitcham, 10 August 1868, yielded $4 \frac{5}{8}$ ounces of elatcrium $=0.123$ per cent.

Elaterium consists, nccording to Pcreira, of Elaterin, to which the activity of the drug is due, contaninated with grecn colouring matter, cellular tissue, and starch, togcther with a little of the residue of the bitter liquor from which these substances were depositcd. Yct, in our opinion this description is not applicable to the best varicties of elaterium. We have examined elaterium carefully prepared in the laboratory of Messrs. Allen and Hanburys, London, and a fine specimen imported from Malta. Both are devoid of starch, as wcll as of cellular-tissue, but wcre seen to be largely madc up of crystals. The first sample contained 12 per cent. of water, and yielded aftcr drying, 8.4 per cent. of ash.

The most interesting principle of elaterium is Elaterin, $\mathrm{C}^{20} \mathrm{H}^{28} \mathrm{O}^{5}$, discovered about the year 1831 by Morries, and independently by Henncll. The best method of obtaining it, according to our cxpcrience, is to exhanst elaterium with chloroform. From this solution, a white crystalline deposit of elaterin is immediately separatcd by addition of ether. It should be washed with a little ether, and recrystallized from chloroform. We have thus obtained 33.6 per cent. of purc elatcrin from the above-mentioned elaterium of London, and 27.6 per cent. from that of Malta. Elaterin crystallizes in hexagonal scales or prisms; it has an extremely bitter, somewhat acrid taste. It is readily soluble in boiling alcohol, amylic alcohol, bisulphide of carbon, or chloroform. Its alcoholic solutions are neutral and are not precipitated by tannin, nor by any metallic solution. It is but very little coloured by cold concentrated sulphuric acid.

Elaterin is the drastic principle of Ecballium; if to its boiling alcoholic solution, solid caustic potash is added, the liquid thus obtained, is stated by Buchheim (1872), to be no longer prccipitable by water. The elaterin is then in fact converted into an acid body, which may be separated by supersaturating the solution with a mineral acid. The principle thus obtained has been found by Buchheim to be devoid of drastic power.

The fresh juice of the fruits was found by Köhler (1869) to contain 95 per cent. of water, 3 to 3.5 of organic and 1 to 1.6 of inorganic constituents. The same chemist observed that the perccntage of elaterin gradually diminished as the season advanced, until in the month of September he was unable to obtain any of it whatever.

Walz (1859) found in the juice of the fruits and herb of Ecballium as well as in that of Cucumis Prophetarum L., a second crystallizable bitter principle, Prophetin, and the amorphous substances Ecballin or Elateric Acid, Hydro-elaterin, and Elateride, all of which require further examination. ${ }^{1}$ Prophetin is a.glucoside,- not so the other principles. The four together constitute according to Walz, 8.7 per cent. of clatcrium, which moreover contains about the same percentage of pcctic matter.

Uses-Squirting cucumbers are only employed for making claterium, which is a very powerful hydragoguc cathartic. ${ }^{2}$ Elaterin is not employed in medicine, but sceing how much elaterium is liable to vary from climate or season, it might probably be introduced into use with advantage.

^ Goolin's Chemistry, xvii. (1866) 365-367.

2 Clutter'suck says $\frac{1}{8}$ of a grain purges violently. 


\section{FRUCTUS COLOCYNTHIDIS.}

\section{Colocynth, Coloquintida, Bitter Applc; F. Coloquinte; G. Coloquinthe.}

Botanical Origin-Citrullus Colocynthis Schrader (Cucumis Colocynthis L.)-The colocynth gourd is a slender scabrous plant with a perennial root, native of warm and dry regions in the Old World, over which it has an extensive area.

Commencing eastward, it occurs in abundance in the arid districts of the Punjab and Sind, in sandy places on the Coromandel coast, in Ceylon, Persia as far north as the Caspian, in Arabia (Aden), Syria, and in some of the Greek islands. It is found in immense quantities in Upper Egypt and Nubia, and throughout North Africa to Morocco and Senegambia, in the Cape de Verd Islands, and on maritime sands in the south-east of Spain. Finally, it is said to liave been collected in Japan.

History-Colocynth was familiar to the Greek and Roman, as well as to the Arabian physicians; and if we may judge by the mention of it in an Anglo-Saxon herbal of the 11th century, ${ }^{1}$ was not then unknown in Britain. 'The drug was collected in Spain at an early period, as is evident from an Arabic calendar of A.D. 961, lately published together with an ancient Latin version. ${ }^{2}$

The plant has been long cultivated in Cyprus, and its fruit is mentioned in the 14th century as one of the more important products of the island. ${ }^{3}$

Description-The colocynth plant bears a gourd of the size and shape of an orange, having a smooth, marbled-green surface. It is sometimes imported simply dried, in which case it is of a brown colour; but far more usually it is found in the market, peeled with a knife and dried. It then forms light, pithy, nearly white balls, which consist of the dried internal pulp of the fruit with the seeds imbedded in it. This pulp is nearly inodorous, but has an intensely bitter taste, perceptible by reason of its dust when the drug is slightly handled. The balls are generally more or less broken; when dried too slowly they have a light brown colour.

The seeds are disposed in vertical rows on 3 thick parietal placentæ, which project to the centre of the fruit, then divide and turn back, forming two branches directed towards one another. Owing to this structure, the fruit easily breaks up vertically into 3 wedges in each of which are lodged 2 rows of dark brown seeds. The seeds, of which a fruit contains from 200 to 300 , are of flattened ovoid form, $\frac{3}{10}$ of an inch long by $\frac{2}{10}$ broad, not bordered. The testa which is hard and thick, having its surface minutely granulated, is marked on each side of its more pointed end by two furrows directed towards the hilum. The seed, as in other Cucurbitacece, is exalbuminous, and has thick oily cotyledons, enclosing an embryo with short straight radicle directed towards the hilum.

Colocynth fruits are mostly supplied by wholesale druggists, broken up and having the seeds removed, the drug in such case being called Colocynth I'ulp or Pith.

Microscopic Structure-The pulp is made up of large thin-walled

1 Cockayne, Lecchdoms, \&c. i. (1864) 325.

2 Le Calendrier de C'ordoue, publié par $\mathrm{R}$. Dozy, Leyde, 1873. 92.
$3 \mathrm{D}$ s Mas Latrie, Hist. de l'ile de Chypre, iii. $(1852-61) 4$ G 8 . 
parenchymatous cells, their outer layer consisting of rows of smaller cells more densely packed. The tissue is irregularly traversed by fibrovascular bundles, and also exhibits numerous large intercellular spaces. The cells contain but an insignificant amount of minute granules, to which neither iodine nor' a persalt of iron imparts any coloration. 'The tissue is not much swollen by water, although one part of the pulp easily retains from 10 to 12 parts of water like a sponge.

Chemical Composition-The bitter principle has been examined by Walz (1858). He treated alcoholic extract of colocynth with water', and mixed the solution firstly with neutral acetate of lead and subsequently with basic acetate of lead. From the filtered liquid the lead was separated by means of sulphuretted hydrogen, and then tannic acid added to it. The latter caused the colocyuthin to be precipitated; the precipitate washed and dried was decomposed by oxide of lead, and finally the colocynthin was dissolved out by ether.

Walz thus obtained about $\frac{1}{4}$ per cent. of a yellowish mass or tufts, which he considered as possessing crystalline structure and to which he gave the name Colocynthin. He assigns to it the formula $\mathrm{C}^{56} \mathrm{H}^{84} \mathrm{O}^{23}$, which in our opinion requires further investigation. Colocynthin is a violent purgative.

Colocynthin is decomposed according to Walz by boiling dilute hydrochloric acid, and then yields Colocyntheïn, $\mathrm{C}^{44} \mathrm{H}^{64} \mathrm{O}^{13}$, and grape sugar.

The same chemist termed Colocynthitin that part of the alcoholic extract of colocynth which is soluble in ether but not in water. Purified with boiling alcohol, colocynthitin forms a tasteless crystalline powder.

The pulp perfectly freed from seeds and dried at $100^{\circ} \mathrm{C}$., afforded us 11 per cent. of ash; the seeds alone yield only 2.7 per cent. They have, - even when crushed, but a faint bitter taste and contain 17 per cent. of fat oil.

Commerce-The drug is imported from Mogador, Spain and Syria.

Uses-In the form of an extract made with weak alcohol, and combined with aloes and scammony, colocynth is much employed as a purgative. The seeds roasted or boiled, are the miserable food of some of the poorest tribes of the Sahara. ${ }^{1}$

Substitutes-Cucumis trigonus Roxb. (C. Pscudo-colocynthis Royle), a plant of the plains of Northern India, with spherical or elongated, sometimes obscurely trigonous, bitter fruits, prostrate rooting stems and deeply divided leaves, resembles the colocynth gourd and has been mistaken for it. Another species named by Royle C. Hardwickii and known to the natives of India as Hill Colocynth, has oval oblong bitter fruits, but leaves entirely unlike those of Citrullus Colocynthis.

\section{UMBELLIFERA.}

\section{HERBA HYDROCOTYLES.}

\section{Indian Hydrocotyle, Indian Pennywort; F. Bevilacqua.}

Botanical Origin-Hydrocotyle asiatica L., a small creeping herb,

$\checkmark$ See my paper on Cucumis Colocynthis considered as a nutritive plant in the
Archin der Phasmacic, 201 (2872) 235.-

F. A. F. 
with slender jointed stems, conmon in moist places throughout tropical Asia and Africa, occurring also in America from South Carolina to Valdivia, in the West Indies, the islands of the Pacific, New Zealand, and Australia.

History - The plant was linown to Rheede ${ }^{I}$ by its Malyalim name of Codagam (or Kutakan), and also to Rumphius. ${ }^{2}$ It has been long used medicinally by the natives of Java and of the Coromandel coast. In 1852, Boileau, a French physician of Mauritius, pointed out its virtues in the treatment of leprosy, ${ }^{3}$ for which disease it was largely tried in the hospitals of Madras by Hunter ${ }^{4}$ in 1855 . It has since been admitted to a place in the Pharmacoperia of India.

Description ${ }^{5}$ - The peduncles and petioles are fascicled; the latter are frequently $2 \frac{1}{2}$ inches long; the peduncles are shorter and bear a 3 or 4-flowered simple umbel with very short rays. The leaves are reniform, crenate, $\frac{1}{2}$ to 2 inches in longest diameter, 7 -nerved, glabrous, or when young somewhat hairy on the under side. The fruit is laterally compressed, orbicular, acute on the back; the mericarps reticulated, sometimes a little hairy, with 3 to 5 curved ribs; they are devoid of vittæ. The main root is an inch or two long, but roots are also thrown out by the procumbent stem.

When fresh, the herb is said to be aromatic and of a disagreeable bitter and pungent taste; but these qualities appear to be lost in drying.

Chemical Composition-An analysis of hydrocotyle has been made by Lépine, a pharmacien of Pondicherry, ${ }^{6}$ who found it to yield a somewhat peculiar body which he called Vellarin, fiom Vallárai, the Tamil name of the plant, and regarded as its active principle. Vellarin, which is said to be obtainable from the dry plant to the extent of 0.8 to 1.0 per cent., is an oily, non-volatile liquid with the smell and taste of fresh hydrocotyle, soluble in spirit of wine, ether, caustic ammonia, and partially also in hydrochloric acid. These singular properties do not enable us to rank vellarin in any well-characterised class of organic compounds.

By exhausting 3 ounces of the dried herb with rectified spirit, we did not obtain anything like vellarin, but simply a green extract almost entirely soluble in warm water, and containing chiefly tannic acid which produced an abundant green precipitate with salts of iron. With caustic potash, neither the herb nor its extract evolved any nauseous odour. The dried plant afforded Lépine 13 per cent. of ash.

Uses-As an alterative tonic, hydrocotyle is allowed to be of some utility, but the power claimed for it by Boilean of curing leprosy is generally denied. Dorvault ${ }^{7}$ regards it as belonging to the class of narcotico-acrid poisons such as hemlock, but we see no evidence to warrallt such an opinion. Besides being administered internally, it is sometimes locally applied in the form of a poultice. Boileau says that the entire plant is preferable to the leaves alone. ${ }^{\mathrm{S}}$

1 Hort. Aral. x. tab. 46.

- Herb. Amboin. v. 169.

"Bouton, Med. Plants of Mauritius, $185773-83$.

4 Medical licports, Madras, 1855. 356.

$\checkmark$ Drawn up from Indian specimens.
- Joum. de Pharm. xxviii. (1855) 47.

7 L'Officine (1872) 554.

8 It is probably by oversight that the lenes alone are ordered in the Pharma. copocia of India. 
Substitutes (?)-H. rotundifolic Roxb., another species common in India, may be known from $I$. asiatica by having 10 or more flowers in an umbel and much smaller fruits. The turopean $H$. vulgaris L., easily distinguishable from the allied tropical species just described, by having its leaves orbicular and peltate (not reniform), is said to possess deleterious properties.

\section{FRUCTUS CONII.}

\section{Hemlock fruits; F. Fruits dc Ciguë; G. Schicrlingsfrucht.}

Botanical Origin-Conium maculatum L., an erect biennial herbaceous plant, flourishing by the sides of fields and streams, and in neglected spots of cultivated ground, throughout temperate Europe and Asia. It occurs in Asia Minor and the Mediterranean islands, and has been naturalized in North and South America. But the plant is very unevenly distributed, and in many districts is entirely wanting. It is found in most parts of Britain from Kent and Cornwall to the Orkneys.

History-The Cicuta of the Romans and Kwvelov of the Greeks was the plant under notice. The famous hemlock potion of the latter, by which criminals were put to death, was essentially composed of the juice of this plant. The old Roman name Cicuta was subsequently applied to Cicuta virosa L., another umbelliferous plant which is altogether wanting in Greece and in Southern Europe generally, and does not contain any poisonous alkaloid.

Hemlock was used in Anglo-Saxon medicine. It is mentioned as early as the 10th century in the vocabulary of Alfric, archbishop of Canterbury, as "Cicuta, hemlic." I Its use in modern medicine is due chiefly to the recommendation of Störck of Vienna, since whose time (1760) the plant has been much employed. The extreme uncertainty and even inertness of its preparations, which had long been known to physicians and had caused its rejection by many, have been recently investigated by Harley. ${ }^{2}$ The careful experiments of this physician show what are the real powers of the drug, and by what method its active properties may be utilized.

Description-The fruit has the structure usual to the order; it is broadly ovoid, somewhat compressed laterally, and constricted towarids the commissure, attenuated towards the apex, which is crowned with a depressed stylopodium. As met with in the shops, it consists of the separated mericarps which are about $\frac{1}{8}$ of an inch long. The dorsal surface of these has 5 prominent longitudinal ridges, the edges of which are marked with little protuberances giving them a jagged or crenate outline, which is most conspicuous before the fruits are fully ripe. The furrows are glabrous but slightly wrinkled longitudinally; they are devoid of vitto. When a mericarp is cut transversely, the seed exhibits a reniform outline, due to a deep furrow in the albumen on the side of the commissure.

The fruits of hemlock are dull greenish grey, and have but little taste and smell; but when triturated with a solution of caustic alkali they evolve a strong and offensive odour.

Microscopic Structure-Hemlock fruits differ from other fruits

1 Volume of Vocabularies, edited by

2 Pharm. Journ. viii. (1967), ix. (1868).

Wright, 1857. 31. 
of the order by the absence of vittr. In the endocarp, there is a peculiar layer of small nearly cubic cells surrounding the albumen. The cells of the endocarp are loaded with a brown liquid consisting chiefly of conine and essential oil.

Chemical Composition-The most important constituent of the fruits of hemlock is Conine or Conic, $\mathrm{C}^{8} \mathrm{H}^{15} \mathrm{~N}$, a limpid colourless oily fluid, of sp. gr. 0.88 , having poisonous properties; it has a strong alkaline reaction, and boils without decomposition at $163^{\circ} .5 \mathrm{C}$. It was first observed by Giseke in 1827, recognized as an alkaloid by Geiger in 1831, and more amply studied by Wertheim in 1856 and 1862 . In the plant, it is combined with an acid (malic?), and accompanied by ammonia as well as by a second less poisonous crystallizable base called Conhydrine, $\mathrm{C}^{8} \mathrm{H}^{17} \mathrm{NO}$, which may be converted into conine by abstraction of the elements of water. From these alkaloids a liquid, non-poisonous, hydrocarbon, Conylene, $\mathrm{C}^{8} \mathrm{H}^{14}$, has been separated by Wertheim. Even in nature one hydrogen atom of conine is frequently replaced by methyl, $\mathrm{CH}^{3}$; and commercial conine commonly contains, as shown by $\mathrm{A}$. von Planta and Kekulé, methyl-conine $N\left\{\begin{array}{l}\mathrm{C}^{8} \mathrm{H}^{14} \\ \mathrm{CH}^{3}\end{array}\right.$ Lastly there is present in hemlock fruits, a third alkaloid having probably the composition $\mathrm{C}^{7} \mathrm{H}^{13} \mathrm{~N}$.

As to the yield of conine, it varies according to the development of the fruits, but is at best only about $\frac{4}{5}$ per cent. According to Schroff (1870), the fruits are most active just before maturity, provided they are gathered from the biennial plant. At a later stage, conine is probably partly transformed into conhydrine, which however is present in but very small proportion,- -about $1 \frac{1}{4}$ per mille at most.

In its deleterious action, conine resembles nicotine, but is much less powerful.

Schiff (1871-1872) has artificially produced an alkaloid partalking of the general properties of conine, and having the same composition; but it is optically indifferent. Conine on the other hand, we find turns the plane of polarization from $47^{\circ} \cdot 7$ to $61^{\circ} .4$, that is to say $13^{\circ} .7$ to the right, when examined in a column $25 \mathrm{~mm}$. long. ${ }^{1}$

. The fruits of hemlock contain also a volatile oil which appears devoid of poisonous properties; it exists in but small quantity and has not yet been fully examined.

Uses-The fruits of hemlock are the only convenient source of the alkaloid conine. They were introduced into British medicine in 1864, as a substitute for the dried leaf in making the tincture. But it has been shown that a tincture, whether of leaf or fruit, is a preparation of very small value, and that it is far inferior to the preserved juice of the herb. It has however been pointed out by W. Manlius Smith ${ }^{2}$ and his observations have been confirmed by Harley, ${ }^{3}$ that the green unripe fruits possess more than any other part the peculiar energies of the plant, and that they may even be dried without loss of activity. A medicinal fluid extract of considerable power has been made from them by Squibb of New York.

1 The counine thus cxamined had been prepared by Merck, of Darmstadt, and was colourless.
2 Trans. of the New York Statc Medical Society for 1867.

3 The Old Vegetable Nenrotics, Lond. 1869. 


\section{FOLIA CONII.}

\section{Hcmlock Leanes; F. F'euilles de Ciguë; G. Schierlingsblätter.}

Botanical Origin-Conium maculatum L., see p. 266.

History-See 1. 266.

Description-Hemlock in its first year produces only a tuft of leaves, but in its second a stout erect stem which often grows to the height of 5 or 6 feet, is much branched in its upper part, and terminates in small umbels, each having about 12 rays. The lower leaves, often a foot in length, have a triangular outline, and a hollow stalk as long as the lamina, clasping the stem at its base with a membranous sheath. Towards the upper portion of the plant, the leaves have shorter stalks, are less divided, and are opposite or in cohorts of 3 to 5 . The involucral bracts are lanceolate, reflexed, and about $\frac{1}{4}$ of an inch long. Those of the partial umbel are turned towards the outside, and are always 3 in number. The larger leaves are twice or thrice pinnate, the ultimate segments being ovate-oblong, acute, and deeply incised.

The stem is cylindrical and hollow, of a glaucous green, generally marked on its lower part with reddish-brown spots. The leaves are of a dull dark green, and like the rest of the plant quite glabrous. They lrave when bruised a disagreeable fotid smell.

For medicinal purposes the plant should be taken when in full blossom. ${ }^{1}$

Chemical Composition-The leaves of hemlock contain, though in exceedingly small proportion, the same alkaloids as the fruits. Geiger obtained from the fresh herb not so much as one ten-thousandth part of conine. It is probable however that the active constituents vary in proportion considerably, and that a dry and sunny climate promotes their development.

The same observer as well as Pereira, has pointed out that hemlock leaves when dried are very frequently almost devoid of conine, and the observation is supported by the more recent experiments of Harley (1867). It has also been shown by the last-named physician, that the inspissated juice known in pharmacy as Extractum Conii usually contains but a mere trace of alkaloid, the latter having in fact been dissipated by the heat employed in reducing the juice to the required consistence. On the other hand, Harley has proved that the juice of fresh hemlock preserved by the addition of spirit of wine, as in the Succus Conii of the Pharmacopœia, possesses in an eminent degree the poisonous properties of the plant.

The entire amount of nitrogen in dried hemlock leaves was estimated by Wrightson (1845) at 6.8 per cent.; the ash at 12.8 per cent. The latter consists mainly of salts of potassium, sodium, and calcium, especially of sodium chloride and calcium phosphate.

A ferment-oil may be obtained from Conium; it is stated to lave an odour unlike that of the plant and a burning taste, and not to be poisonous. ${ }^{2}$

1 The London herhalists often collect it while much of the inflorescenee is still in bud, in which state it affords far more of the latter condition that the plant is to be preferred.

leaf than when well matured; but it is in

2 Gmelin, Chemistry, xiv. 40 s. 
Uses-Hemlock administered in the form of Succus Conii, has a peculiar sedative action on the motor nerves, on account of which it is occasionally prescribed. It was formerly much more employed than at present, although the preparations used were so defective that they could rarely liave produced the specific action of the medicine.

Plants liable to be confounded with Hemlock-Several common plants of the order Umbelliferce have a superficial resemblance to Conium, but can be discriminated by characters easy of observation. One of these is Ethusa Cynapium L. or F'ool's Parsley, a common annual garden weed, of much smaller stature than hemlock. It may be known by its primary umbel having no involucre, and by its partial umbel having an involucel of 2 or 3 linear pendulous bracts. The ridges of its fruit moreover are not wavy or crenate as in hemlock, nor is its stem spotted.

Chcerophyllum Anthriscus L. (Anthriscus vulgaris Pers.) and two or three other species of Chcerophyllum have the lower leaves not unlike those of hemlock, but they are pubesccnt or ciliated. The fruits too are linear-oblong, and thus very dissimilar from those of Conium.

The latter plant is in fact clearly distinguished by its smooth spotted stem, the character of its involucral bracts and fruit, and finally by the circumstance that when triturated with a few drops of solution of caustic alkali, it evolves conine (and anmonia), easily observable as a white fume when a rod moistened with strong acetic acid is held over the mortar.

\section{FRUCTUS AJOWAN.}

Semen Ajave val Ajouain; Ajowan, True Bishop's ueed.

Botanical Origin-Ammi Copticum L. (Ptychotis Coptica et Pt. Ajowan DC.) - an erect annual herb, cultivated in Egypt and Persia, and especially in India where it is well known as Ajván or Omam.

History-The minute spicy fruits of the above-named plant have been used in India from a remote period, as we may infer from their being mentioned in Sanskrit writings, suclı as the Ayurvedas of Susruta.

Owing to their having been confounded with some other very small umbelliferous fruits, it is difficult to trace them precisely in many of the older writers on materia medica. It is however probable that they are the Ammi cdore origaini of Anguillara (1549) and the Ammi perpusillum of Lobel (1571), in whose time the drug was imported from Egypt. Dale ${ }^{1}$ who says it is brought from Alexandria, reports it as very scarce in the London shops. Under the name of Ajava Sceds, the drug was again brought into notice in 1773 by Percival, ${ }^{2}$ who received a small quantity of it from Malabar as a remedy for cholic; and still more recently, it has been favourably spoken of by Fleming, Ainslie, Roxburgh, O'Shaughnessy, Waring and other writers who have treated of Indian materia medica.

Description-Ajowan fruits, like those of other cultivated Umbelliferce, vary somewhat in size and form. The largest kind much resemble those of parsley, being of abont the same shape and weight. The length of the large fruits is about $\frac{x}{10}$, of the smaller form scarcely $\frac{1}{10}$ of an inch.

${ }^{1}$ Pharmacolngica, 1693. 211.

2 Essays, metical and experimental, ii. (17 73$) 226$. 
The fruits are greyish brown, plump, very rough on the surfice, owing to numerous minute tubercles (fructus muriculatus). Each mericarp has five prominent ridges, the intervening channels being dark brown, with a single vitta in each. The commissural side bears two vittce. 'The fruits when rubbed exhale a strong odour of thyme (Thymus vulgaris L.), and have a biting aromatic taste.

Microscopic Structure-The oil-ducts of ajowan are very large, often attaining a diameter of $200 \mathrm{mknn}$. The ridges contain numerous spiral vessels; the blunt tubercles of the epidermis are of the same structure as those in anise, but comparatively larger and not pointed. The tissue of the albumen exhibits numerous crystalloid granules of albuminous matter (aleuron), distinctly observable in polarized light.

Chemical Composition-The fruits according to Stenhouse (1855) yield 5 to 6 per cent. ${ }^{1}$ of an agreeably aromatic, volatile oil, sp. gr. $0 \cdot 896 .{ }^{2}$ At the same time there collects on the surface of the distilled water, a crystalline substance, which is prepared at Oojein and elsewhere in Central India, by exposing the oil to spontaneous evaporation at a low temperature. This stearoptene, sold in the shops of Poona and other places of the Deccan, under the name of Ajwain-ka-phul, i.e. flowers of ajwain, was first made known by Stocks, and was examined by Stenhouse and by Haines, who showed its identity with Thymol; $\mathrm{C}^{10} \mathrm{H}^{14} \mathrm{O}$.

We obtained it by exposing oil of our own distillation, first rectified from chloride of calcium, to a temperature of $0^{\circ} \mathrm{C}$., when the oil deposited 36 per cent. of thymol in superb tabular crystals, an inch or more in length. The liquid portion even after long exposure to a cold some degrees below the freezing point, yielded no further crop. We found the thymol thus obtained, began to melt at $44^{\circ} \mathrm{C}$., yet using somewhat larger quantities, it appeared to require fully $51^{\circ} \mathrm{C}$. for complete fusion. On cooling, it continues fluid for a long time, and only recrystallizes when a crystal of thymol is projected into it.

Thymol may be distilled in a current of carbonic acid; it has a sp. gr. of 1.028 , and the odour of oil of ajowan. Its identity with the Thymol of thyme was at one time doubtful, Stenhouse having stated that the alcoholic solution of the former is precipitated by water, and that it is not soluble in caustic alkalis. But H. Miiller ${ }^{3}$ has recently showed, that thymol from either source is soluble in caustic alkalis; he has even extracted it by this means from the oil of ajowan.

The liquid part of the essential oil, which according to Stenhouse boils at $172^{\circ} \mathrm{C}$., may be separated by rectification from the stearoptene which, as it commences to boil only at $218^{\circ} \mathrm{C}$, remains in the still as a crystalline mass. The liquid oil according to the same chemist is isomeric with oil of turpentine and has a different odour to the stearoptene. Haines (1856) regards this oil as Cymol (cymene) $\mathrm{C}^{10} \mathrm{H}^{14}$, which also occurs in cumin, Cicuta virosa and in Thymus vulgaris. Miiller has proved the correctness of this statement; he obtained a compound of it with sulphuric acid. Some hydrocarbon of the formula $\mathrm{C}^{10} \mathrm{H}^{16}$ may nevertheless be also present.

1 In a small experiment made with an old sample of the drug, 1 got 3.12 per cent. of essential oil.-D. H.

2 The fruits examined by Stonhouse were of the small variety before alluded to, as I

know by an anthentic specimen.-F. A. F.

3 Beriehte d. Dentschen Chemischen Gesellschaft, ii. (1869) 130 ; also Jahresbericht of Wiggers and Husemann, 1869. 86. 
We have found that neither the thymol, nor the liquid part of ajowan oil possesses any rotatory power.

Uses-Ajowan is much used by the natives of India as a condiment. ${ }^{1}$ The distilled water which has been introduced into the Pharmacopreia of India, is reputed to be carminative and a good vehicle for nauseous medicines. It has a powerful burning taste and would seem to require dilution. The volatile oil may be used in the place of oil of thyme, which it closely resembles.

Substitutes - Under the name Semen Ammi, the very small fruits of Ammi majus L. and of Sison A momum L. have been often confounded with those of Ammi Copticum I.; but the absence of minute tubercles on the two former, not to mention some other differences, is sufficient to negative any supposition of identity.

The seeds of Hyoscyamus niger L. being called in India Khorásániajwán, a confusion might arise between them and true ajowan; though the slightest examination would suffice to show the difference. ${ }^{2}$

\section{FRUCTUS CARUI.}

Semen Carui vel Carvi; Caraway Fruits, Caraway Seeds, Caraways; F. Fruits ou Semences de Carvi; G. Kümmel.

Botanical Origin-Carum Carvi L., an erect annual or biennial plant not unlike a carrot, growing in meadows and moist grassy land over the northern and midland parts of Europe and Asia, but to what extent truly wild cannot be always ascertained.

It is much cultivated in Iceland and is also apparently wild. ${ }^{3}$ It grows throughout Scandinavia, in Finland, Arctic, Central and Southern Russia, and in Siberia. It appears as a wild plant in many parts of Britain (Lincolnshire and Yorkshire), but is also cultivated in fields, and may not be strictly indigenous. The caraway is found throughout the eastern part of France, in the Pyrenees, Spain, Central Europe, Armenia and the Caucasian provinces; and it grows wild largely in the high alpine region of Lahul in the Western Himalaya. ${ }^{4}$

But the most curious fact in the distribution of Carum Carvi, is its occurrence in Morocco, where it is largely cultivated about El Araiche, and round the city of Morocco. ${ }^{5}$ The plant differs somewhat from that of Europe; it is an annual with a single erect stem, 4 feet high. Its foliage is more divided, and its flowers larger, with shorter styles and on more spreading umbels than the common caraway, and its fruit is more elongated. ${ }^{6}$

History-The opinion that this plant is the Kápos of Dioscorides and that, as Pliny states, it derived its name from Caria (where it has never been met with in modern times) has very reasonably been doubted. ${ }^{7}$

Caraway fruits were known to the Arabians, who called them

1 Roxburgh, Flor. Ind. ii. (1832) 91.

${ }^{2}$ To such a mistake may probably be referred the statement of Irvine (Account of the Mat. Med. of Patna, 1848, p. 6) that the seeds of henbane are "used in food as carminative and stimulant"!

3 Babington in Journ. of Linn. Soc., Bot., xi. (1871) 310 .
${ }^{4}$ Aitehison in Journ. of Linn. Soc., Bot., x. (1869) 76. 94.

5 Leared in Pharm. Journ., Feb. 8, 1873. 623.

6 I have cultivated the Moroeco plant during two years by the side of the common form.-D. H.

7 Dierbach, Flora Apiciana, 1831. 53. 
Karawya, a name they still bear in the East, and the original of our words caraway and carui, as well as of the Spanish alcarahueya. In the Arab writings quoted by Ibn Maytar,' himself a Mauro-Spaniard of the 13 th century, caraway is compared to cumin and anise. The spice probably came into use about this period. It is not noticed by St. Isidore, archbishop of Seville in the 7th century, though he mentions fennel, dill, coriander, anise, and parsley; nor is it named by St. Hildegard in Germany in the 12th century. Neither have we found any reference to it in the Anglo-Saxon Herbarium of Apuleius, written circa A.D. 1050," or in other works of the same period, though cumin, anise, fennel, and dill are all mentioned.

On the other hand, in two German medicine-books of the $12 \mathrm{~h}$ and 13 th centmries ${ }^{3}$ there occurs the word Cumich, which is still the popular name of caraway in Southern Germany; and Cumin is also mentioned. Caraway was certainly in use in England at the close of the 14th century, as it figures with coriander, pepper and garlick in the Form of Cury, a roll of ancient English cookery compiled by the master-cooks of Richard II. about A.D. 1390.

The oriental names of caraway show that as a spice it is not a production of the East:- thus we find it termed Roman (i.e. European), Armenian, mountain, or foreign Cumin ; Persian or Andalusian Caraway; or foreign Anise. And though it is now sold in the Indian bazaars, its name does not occur in the earlier lists of Indian spices.

Cultivation 4-In England, the caraway is cultivated exclusively in Kent and Essex, on clay lands. It was formerly sown mixed with coriander and teazel seed, but now with the former only. The plant which requires the most diligent and careful cultivation, yields in its second year a crop which is ready for harvesting in the beginning of July. It is cut with a hook at about a foot from the ground, and a few days afterwards may be thrashed. The produce is very variable, but may be stated at 4 to $8 \mathrm{cwt}$. per acre.

Description-The fruits which in structure correspond to those of other plants of the order, are laterally compressed and ovate. The mericarps which hang loosely suspended from the arms of the carpophore, are in the English dring about $\frac{1}{6}$ of an inch in length and $\frac{1}{20}$ in diameter, subcylindrical, slightly arched, and tipped with the conical, shrivelled stylopodium. They are marked with 5 pale ridges, nearly half as broad as the shining, dark brown furrows, each of which is furnished with a conspicuous vitta; a pair of vittæ separated from each other by a comparatively thin fibro-vascular bundle, occurs on the commissure.

Caraways are somewhat horny and translucent; when bruised they evolve an agreeable fragrance resembling that of dill, and they have a pleasant spicy taste. In the Lonclon market, they are distinguished as English, Dutch, German, and Mogarlor, the first sort fetching the lighest price. The fruit varies in size, tint and flavour; the English is shorter and plumper than the others; the Mogador is paler, stalky and elongated, - often $\frac{3}{10}$ of an inch in length.

1 Sontheiner's translation, ii. 368.

2 Leechdoms, dic. of Early England, i. (1864).

${ }_{3}$ Pfeiffer, Zwei dentsehe Arzneibücher aus dem xii. und xiii. Jahthundert, Wien 1863. 14.

4 Morton, Cyclop. of Agriculture, i. (1855) 
Microscopic Structure-Caraways are especially distinguished by their enormous vitta, which in transverse section display a triangular ontline, the largest diameter, i.c. the base of the triangle, often attaining as much as $300 \mathrm{mkm}$. Even those of the commissure are usually not smaller.

Chemical Composition-Caraways contain a volatile oil, which the German drug affords to the extent of about 4 per cent., though variations from 3 to 6 , or even exceptionally to 9 per cent., have been observed. It appears that a nortlerly or elevated locality tends to render the plant more productive in essential oil. The position and size of the vittre account for the fact that conminution of the fruits previous to distillation, does not increase the yield of oil.

Oil of caraway according to the experiments of Schweizer and of Völckel, ${ }^{1}$ is a mixture of Carvol, $\mathrm{C}^{10} \mathrm{H}^{14} \mathrm{O}$, a mobile liquid boiling at $227^{\circ} \mathrm{C}$. (Gladstone), and Carvene, which latter constitutes more than a third of the crude oil. Carvene boils at $173^{\circ} \mathrm{C}$., and has the formula $\mathrm{C}^{10} \mathrm{H}^{16}$. It has been ascertained by us that each of these constituents has a dextrogyrate power, that of carvene being considerably the stronger. Carvol is isomeric according to Gladstone, ${ }^{2}$ with the menthol of spearmint, myristicol and the carvol of dill; with the last it is probably identical. It is also isomeric with thymol, but does not like that body unite with alkalis. It easily forms large acicular crystals, $2\left(\mathrm{C}^{10} \mathrm{H}^{14} \mathrm{O}\right)+\mathrm{H}^{2} \mathrm{~S}$, when treated with alcoholic sulphide of ammonium.

Oil of caraway of inferior quality is obtained from the refuse of the fruit; we find it less dextrogyrate than the oil from the fruits alone. The former is of less agreeable odour, but is good enough to be used for the scenting of soap. The oil distilled in England from home-grown caraways is preferred in this country. On the Continent, that extracted from the caraways of Halle and of Holland, is considered to be of finer flavour than the oil obtained from those of Southern Germany.

The immature fruit of caraway is rich in tannic matter, striking blue with a salt of iron. It occurs abundantly in the tissue around the oilducts, where the presence of sugar may be also detected by alkaline tartrate of copper. Sugar occurs likewise in the embryo, but not in the albumen, in which latter protein substances predominate.

Production and Commerce-Caraways are exported from Finmark, the most northerly province of Norway; from Finland and Russia. In Germany, the cultivation, recommended by , Gleditsch in 1776, is now largely carried on in Moravia, and in Prussia, especially in the neighbourhood of Halle. The districts of Erfurt and Merseburg, also in Prussia, are stated to yield annually about $30,000 \mathrm{cwt}$. Dutch caraways are produced in the provinces of North Holland, Gelderland and North Brabant, in the latter two from wild plants. ${ }^{3}$ Caraways are frequently shipped from the ports of Morocco; the quantity exported thence in 1872 was 952 civt. $^{4}$

The import of caraways into the United Kingdom in 1870, amounted to 19,160 cwt., almost all being from Holland. 283.

1 Gmelin, Chemistry xiv. (1860) 416. 414.

${ }^{2}$ Journ. of Chem. Soc. x. (1872) 9; Pharm. Journ., Harch 1872. 746 .
3 Oudemans, Aanteckeningen, \&c., Rotterdam, 1854-1856. 351.

- Consular Reports, August 1873. 917. 
The essential oil is manufactured on a large scale. According to a statement of the Chamber of Commerce of Lcipzig, ${ }^{1}$ four establishments of that district produced in 1872 , no less a quantity than 30,955 kilo. $(68,277 \mathrm{Hb}$.), valucd at $£ 24,000$.

Uses-Caraway in the form of cssential oil or distilled water is used in medicinc as an aromatic stimulant, or as a flavouring ingredient. But the consumption in Europe is far more important as a spicc, in brcad, cakes, chcese, pastry, confectionary, sauces, \&c., or in the form of oil as an ingredient of alcoholic liquors. The oil is also used in perfumery.

\section{FRUCTUS FEENICULI.}

Fennel Fruils, Fennel Seeds ; F. Fruits de Fenouil ; G. Fenchel.

Botanical Origin-Fcenieulum vulgare Gärtn. (Anethum Foniculum L.), an erect, branching plant with an herbaceous stcm and percnnial rootstock, growing to the height of 3 or 4 feet, having lcaves 3 or 4 times pimnate with narrow linear segments.

It appears to be truly indigenous to the countries bordering the Mediterranean, but is also found apparently wild, over a large portion of Western Europc as far as the British Isles, especially in the vicinity of the sea. It grows in the country bordering the western side of the Caspian Sen, and as a doubtful native in many parts of Central and Southern Russia.

Fennel is largely cultivated in the central parts of Europe, as Saxony, Franconia and Wurtcmberg, also in the south of France about Nimes, and in Italy. It is extensively grown in India and China. The Indian plant is an annual of somewhat low stature. ${ }^{2}$

The plant varies in stature, foliage, and in the size and form of its fruits; but all the forms belong apparently to a single species.

History-Fennel was used by the ancient Ronans, as weli for its seedlike aromatic fruits, as for its edible succulent shoots. It was also employed in Northern Europe at a remote period, as it is constantly mentioned in the Anglo-Saxon medical receipts, which date as early at least as the 11th century. The diffusion of the plant in Central Europe was stimulated by Charlemagne, who enjoined its cultivation on the imperial farms. Fennel shoots (turiones fonuculi), fennel water, and fennel seed, as well as anise, are all mentioned in an ancient record ${ }^{3}$ of Spanish agriculture, dating A.D. 961.

Description-The fonnel fruits of commerce, commonly called Fennel Seeds, are of several kinds and of very different pecuniary value. The following are the principal sorts:-

1. Sweet Fennel,--known also as Roman Fennel, is cultivated in the neighbourhood of Nimes in the south of France. The plant is a tall perennial with large umbels of 25 to 30 rays. ${ }^{4}$ As the plants grow old, the fruits of each succeeding season gradually change in shape and diminish in size, till at the end of 4 or 5 years they are hardly to be

1 Pharmaceutische Zeitung, 15 April, 1874.

- It is an annual even in England, ripening seeds in its first year, and then dying.

Le Calendrier de Cordoue de l'annéc 961, publié par R. Dozy, Leyde, 1873.

- The Nímes fennel has been usually re-

ferred to Foniculum dulce DC., lut that plant has the stem compressed at the base, and only $6^{\circ}$ to 8 rays in the umbel: and is the fennel which is eaten as a vegetable or as 2 silad. 
listinguished from those of the wild fennel growing in the same district. This curious fact, remarked by Tabernæmontanus (1588), was experimentally proved by Guibourt. ${ }^{1}$

The fruits of Sweet Femmel as found in the shops, are oblong, cylindrical, about $\frac{4}{10}$ of an inch in length by $\frac{1}{10}$ in diameter, more or less arched, terminating with the two-pointed base of the style, and smooth on the surface. Each mericarp is marked by 5 prominent ridges, the lateral being thicker than the dorsal. Between the ridges lie vittæ, and there are two vittix on the commissural surface,-_all filled with dark oily matter. The fruits seen in bulk have a pale greenish hue; their odour is aromatic, and they have a pleasant, sacrharine, spicy taste.

2. German Fennel, Saxon Fennel, produced especially near Weissenfels in the Prussian province of Saxony; the fruits are $\frac{2}{10}$ to $\frac{1}{4}$ of an inch long, ovoid-oblong, a little compressed laterally, slightly curved, terminating in a short conical stylopodium; they are glabrous, of a deep brown, each mericarp marked with 5 conspicuous pale ridges, of which the lateral are the largest. Seen in bulk, the fruits have a greenish brown hue; they have an aromatic saccharine taste, with the peculiar smell of fenuel.

3. Wild or Bitter Fennel (Fenouil amer), collected in the south of France, where the plant grows without cultivation. They are smaller and broader than those of the German Fennel, being from $\frac{1}{5}$ to $\frac{2}{8}$ of an inch long by about $\frac{1}{15}$ of an inch wide. They have less prominent ridges and at maturity are a little scurfy in the furrows and on the commissure. Their taste is bitterish, spicy, and strongly fenuel-like. The essential oil (Essence de F'enouil amer) is distilled from the entire herb.

4. Indian Fennel.-A sample in our possession from Bombay resembles Sweet Fennel, but the fruits are not so long, and are usually straight. The mother-plant of this drug is $F$. Panmorium DC., now regarded as a simple variety of $F$. vulgare Gärtn.

Microscopic Structure-The most marked peculiarity of fennel is exhibited by the vittæ, which are surrounded by a brown tissue. The latter is nuade up of cells resembling the usual form of cork-cells. In Sweet Fennel the vittæ are smaller than in the German fruit; in the transverse section of the latter, the largest diameter of these ducts is about $200 \mathrm{mkm}$.

Chemical Composition-The most important constituent of fennel fruits is the volatile oil, which is afforded both by the Sweet and the German fennel to the extent of about $3 \frac{1}{2}$ per cent.

Oil of femnel from whatever variety of the drug obtained, consists of Anethol or Anise-camphor, $\mathrm{C}^{10} \mathrm{H}^{12} \mathrm{O}$, and variable proportions of a liquid, isomeric with oil of turpentine. Anethol is obtainable from fennel in two forms, the solid and the liquid; crystals of the former are deposited when the oil is subjected to a somewhat low temperature; the liquid anethol may be got by collecting the portion of the crude oil passing over at $225^{\circ} \mathrm{C}$. The crystals of anethol fuse between 16 and $20^{\circ} \mathrm{C}$; the liquid form of anethol remains fluid even at $-10^{\circ} \mathrm{C}$. By long keeping, the crystals slowly become liquid and lose their power of reassuming a crystalline form. Three varieties of oil of fennel are found in commerce, namely the oils of Sweet Fennel and Bitter Fennel offered by the drug-

'Hist. des Drogues, iii. (1869) 233. 
houses of the south of France; their money value is as 3 to 1 , the oil of sweet fenuel, which has a decidedly sweet taste, being by far the most esteemed. The third variety is obtained from Saxon fennel, especially by the manufacturers of I)resden and Leipzig. $\quad$ We have been supplied with type-specimens of the first two oils by the distillers, Messr's. J. Sagnier, fils, \& Cie., Nîmes; a specimen of the third has been distilled in the laboratory of one of ourselves.

Oil of fennel differ's from that of anise by displaying a considerable rotatory power. We found the above-mentioned specimens, examined in a column $50 \mathrm{~mm}$. long, to deviate the ray of polarized light to the right thus :-

Oil of Swect Fennel
" Bitter ,
, German ,"

The rotatory power is due to the hydrocarbon contained in the oil; we ascertained that anethol from oil of anise is devoid of $i$.

Fennel fruits contain sugar, yet their sweetness or bitterness depends on the essential oil rather than on the presence of that body. The albumen of the seed contains fixed oil, which amounts to about 12 per cent. of the fruit.

Uses-Fennel fruits are used in medicine in the form of distilled water and volatile oil, but to no considerable extent. The chief consumption is in cattle medicines, and of the oil in the manufacture of eordials.

\section{FRUC'TUS ANISI.}

Anise, Aniseed; F. Fruits d'Anis vert; G. Anis.

Botanical Origin-Pimpinella Anisum L., an annual plant, indigenous to Asia Minor, the Greek Islands and Egypt, now cultivated in many parts of Europe where the summer is hot enough for ripening its fruits, as well as in India and South Anerica. It is not grown in Britain.

History-Anise, which the ancients obtained chiefly from Crete and Egypt, is among the oldest of medicines and spices. ${ }^{2}$ It is mentioned by Theophrastus, and by the later writers Dioscorides and Pliny. In Europe we find that Charlemagne (A.D. 812) commanded that anise should be cultivated on the imperial farms in Germany. The AngloSaxon writings contain frequent allusions to the use of dill and cumin, but we have failed to find in them any reference to anise.

The Patent of Pontage granted by Edward I. in 1305 to raise funds for repairing the Bridge of London, ${ }^{3}$ enumerates Anise (anisium) among the commodities liable to toll. There are entries for it under the name of Annis vert, in the account of the expenses of John, king of France, during lis abode in Eugland, 1359-604 ; and it is one of the spices of which the Grocers' Company of London had the weighing and oversight

1 'The Leipzig Chamber of Conmerec reports the quantity made by four establishments in 1872 , as 4350 kilo. (9594 th.).

2 On the Anise of the Bible, see note 1, p. 292.
3 [Thomson, R.], Chronicles of London Bridge, 1827. 155.

4 Doiiet d'Areq, Comptes de l'Argentcrie des Rois de France, 1851. 206. 220. 
from 1453.' By the Wardrobe Accounts of Edward IV., A.D. 1480,2 it appears that the royal linen was perfumed by means of "lytill baggres of fustian stuffed with ireos and anncys."

Anise seems to have been grown in England as a potherb prior to 1542, for Boorde in his Dyctary of Helth, printed in that year, ${ }^{3}$ says of it and fennel,_- " these herbes be seldome vsed, but theyr seedes be greatly occinpycle."

In common with all other foreign commodities, anise was enormously taxed during the reign of Charles I., the dnties levied upon it amounting to 7 iss. per $112 \mathrm{Hb}^{4}{ }^{4}$

Description-Anise fruits which lhave the usual characters of the order, are about $\frac{2}{10}$ of an inch in length, mostly undivided and attached to a slender pedicel. They are of ovoid form, tapering towards the summit which is crowned by a pair of short styles, rising from a thick stylopode; they are nearly cylindrical but a little constricterl towards the commissure. Each fruit is marked by 10 light-coloured ridges which give it a prismatic form; these as well as the rest of the surface of the fruit, are clothed with short rough hairs. The drug has a greyish brown hue, a spicy saccharine taste, and an agreeable aromatic smell.

Microscopic Structure-The most striking peculiarity of anise fruit is the large number of oil-ducts or vittæ it contains; each half of the fruit exhibits in transverse section, nearly 30 oil-ducts, of which the 4 to 6 in the commissure are by far the largest. The hairs display a simple structure, inasmuch as they are the elongated cells of the epidermis a little rounded at the end.

Chemical Composition-The only important constituent of anise is the essential oil (Oloum Anisi), which the fruits afford to the extent of nearly 2 per cent. ${ }^{5}$ This oil is a colourless liquid, having an agreeable odour of anise and a sweetish aromatic taste; its sp. gr. varies from 0.977 to 0.983 . At $10^{\circ} \mathrm{C}$. to $15^{\circ} \mathrm{C}$., it solidifies to a hard crystalline mass, which does not resume its fluidity till the temperature rises to about $17^{\circ} \mathrm{C}$.

Dil of anise resembles the oils of fennel, star-anise, and tarragon, in that it consists almost wholly of Anethol or Anise-cumphor, described in the previous article (p. 275). This fact explains the rotatory power of oil of anise being inferior to that of fennel. Oil of Gernan anise, distilled by one of us, examined under the conditions stated on the opposite page, deviated only $1^{\circ} \cdot 7$, but to the left. Franck (1868) found oil of Saxon anise deviating $1^{\circ} \cdot 1$ to the right.

Production and Commerce-Anise is prodnced in Malta, about Alicante in Spain, in Touraine and Guienne in France, in Puglia (Southern Italy), in several parts of Northern and Central Germany, Bohemia and Moravia. The Russian provinces of Tula and Orel, south of Moscow, also produce excellent anise, and in Southern Russia, Charkow is likewise known for the production of this drug. In Greece, anise is largely

I Herbert, Hist. of the truclve Great Livery Companics of Lomilon, 1834. 310. 131.

2 Fditerl by N. H. Nicolas, Loud. 1830.

3 Reprintel for the Early English Text Society, 1870.281.
4 Rates of Marchandizes, 1635.

5 Thus $5126 \mathrm{tb}$. of aniscert distilled in the course of three yenrs in the laboratory of Messis. Herrings of London, afforded $95 \mathrm{tt}$. $5 \mathrm{oz}$. of essential oil, equal to 1.85 per cent. 


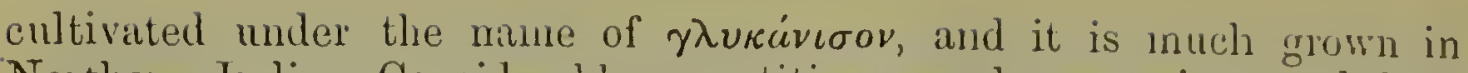
Northern India. Considerable quantities are also now imported from Chili.

Uses-Anise is an aromatic stimnlant and carminative, usually administered in the form of essential oil as an adjunct to other medicines. It is also used as a cattle medicine. The essential oil is largely consumed in the manulacture of cordials, chiefly in France, Spain, Italy, and South Anierica.

Adulteration-The fruits of anise are sometimes mixed with those of hemlock, but whether by design or by carelessness we know not. Careful inspection with a lens will reveal this dangerous adulteration. We have known poudercd anise also to contain hemlock, and have detected it by trituration in a mortar with a few drops of solution of potash, a sample of pure anise for comparison being tried at the same time.

The essential oil of aniseed may readily be confounded with that of Star-anise, which is distilled from the fruits of the widely different Iilicium anisatum. As stated at p. 22, these oils agree so closely in their chemical and optical properties, that no scientific means are known for distinguishing them.

\section{RADIX SUMBUL.} Sumbul Root; F. Racine de Sumbul, Sambola ou Sambula; G. Moschus-
wurzel.

Botanical Origin-Euryangium Sumbul Kauffmamn, ${ }^{1}$ a tall perennial plant closely resembling a Ferula, discovered in 1869 , by a Russian traveller, Fedschenko, in the mountains of Maghian ${ }^{2}$ near Pianjakent, a small Russian town, eastward of Samarkand. A living plant transmitted thence to the Botanical Garden of Moscow flowered there in 1871.

History-The word sumbul, which is Arabic and signifies an ear or spitie, is used as the designation of various substances, but especially of Indian Nard, the rhizone of Nardostachys Jatamansi DC. Under what circumstances, or at what period, it came to be applied to the drug under notice, we know not. Nor are we better informed as to the history of sumbul root, which we have been unable to trace by means of any of the works at our disposal. All we can say is, that the drug was first introduced into Russia about the year 1835 as a substitute for musk, that it was then recommended as a remedy for cholera, and that it began to be known in Germany in 1840, and ten years afterwards in England. It was admitted into the British Pharmacopreia in 1867.

Description-The root as found in commerce, consists of transverse slices, 1 to 2 inches, rarely as much as 5 inches in diameter, and an inch or more in thickness ; the bristly crown, and tapering lower portions,

1 Nouv. Mém. de la Soc. imp. des Nat. de Moscou, xii. (1871) 253 . tabb. 24. 25.

2 Maghian or Magian is a town situated on a river of the same name, rising on the northern side of the Shehri Sebztan range of mountaius, lying S.. $\mathrm{E}$ of Samarkand. 'l'ho Maghian tlowing north, falls into the Zaraf- shan about 40 miles eastward of Samarkand. Pianjakent or Pentschakend, 3393 feet above the sea, is on the left bauk of the Zarafshan, i little to the west of the point at which that river is joined by the Maghian. For further particulars, see Journ. of $k$. Goograph. Soc. Il. (1870) 448 . 
often no thicker than a quill, are also met with. The outside is covered by a dark papery bark; the imner surface of the slices is of a dirty brown, marbled with rhite, showing when viewed witl a lens an abundant resinous exudation, especially towards the circumference. The interior is a spongy, fibrous, farinaceous-looking substance, having a pleasant musky odour and a bitter aromatic taste.

We are not acquainted with the Indian Sumbul Root described in Pereira's Elements of Materia Medica. ${ }^{1}$ That imported some years since from China and noticed in the sane work, appears to us to be a root different from sumbul.

Microscopic Structure-The interior tissue of sumbul root is very irregularly constructed of woody and medullary rays, while the cortical part exhibits a loose spongy parenchyme. The structural peculiaricy of the root becomes obvious, if thin slices are moistened with solution of iodine, when the medullary rays assume by reason of the starch they contain, an intense blue. The structure of the root reminds one by its irregularity of rhubarb, though the latter wants the large balsam-ducts observable in the roots of this as well as of other Umbelliferce. ${ }^{2}$

Chemical Composition-Sumbul root yields about 9 per cent. of a soft balsamic resin soluble in ether, and a very small proportion of essential oil. The resin has a musky smell,not fully developed until after contact with water. According to Reinsch (1848), it dissolves in strong sulphuric acid with a fine blue colour, but in our experience with a crimson brown. The same chemist states that when subjected to dry distillation, it yields a blue oil.

Solution of potash is stated to convert the resin of sumbul into a crystalline potassium salt of Sumbulamic Acid, which latter was obtained in a crystalline state by Reinsch in 1843 , but has not been further examined. Sumbulamic acid, which smells strongly of musk, appears to be a different substance from Sumbulic or Sumbulolic Acid, the potassium salt of which may be extracted by water from the above-mentioned alkaline solution. Kicker and Reinsch (1848) assert that the last-mentioned acid, of which the root contains about $\frac{3}{4}$ per cent., is none other than Angclie Acid, accompanied as in angelica root, by a little valerianic acid. All these substances require further investigation, as well as the body called Sumbulin, which was prepared by Murawjeff (1853), and is said to fornı with acids, crystalline salts.

Sommer has shown (1859) that by dry distillation, sumbul resin yields Umbelliferone, which substance we shall further notice when describing the constituents of galbanum.

Uses-Prescribed in the form of tincture as a stimulating tonic.

1 Vol. ii. $(1850-53) 2284$.

2 The structure and growth of Sumbul root have been elaborately studied by Tchistiakoft; of whose observations first published in Russian in 1870; an Italian translation with two plates has appeared in the Nuovo Giornale Botanico for Oct. 1873. 298. 


\section{ASAFCETIDA.}

Gummi-resinu Asafatida vel Assafatida; Asafotida; F. Ase-foetidre; G. Asunt, Stinkasant.

Botanical Origin-Two perennial umbelliferous plants are now generally cited as the source of this drug; but though they are looth capable of affording a gum-resin of strong alliaceous odour, it has not been proved that either of them furnishes the asafoctida of commerce. The plants in question are :-

1. Narthex ${ }^{1}$ Asa-foetida Falconer (Ferula Narthex Boiss.), a gigantic herbaceous plant, having a large root several inches in thickness, the crown of which is clothed with coarse bristly fibres; it has an erect stem attaining 10 feet in height, throwing out from near its base upwards a regular series of branches bearing compound umbels, each branch proceeding from the axil of a large sheathing inflated petiole, the upper of which are destitute of lamina. The radical leaves, $1 \frac{1}{2}$ feet long, are bipinnate with broadly ligulate obtuse lobes. It has a large flat fruit with winged margin. When wounded, the plant exudes a milky juice having a powerful smell of asafoctida. It commences to grow in early spring, rapidly throwing up its foliage which dies away at the beginning of summer. It does not flower till the root has acquired a considerable size and is several years old.

N. Asa-foetida, which now exists in several botanic gardens and has flowered twice in that of Edinburgh, was discovered by Falconer in 1838 , in the valley of Astor or Hasora $\left(35^{\circ} \mathrm{N}\right.$. lat., $74^{\circ} \cdot 30 \mathrm{E}$. long.) north of Kashmír. ${ }^{2}$

2. Scorodosma fatidum Bunge.-In form of leaf, in the bristly summit of the root, and in general aspect, this plant resembles the preceding; but it has the stem ( 5 to 7 feet high) nearly naked, with the umbels which are very numerous, collected at the summit; and the few stem-leaves have not the voluminous sheathing petioles that are so striking a feature in N $N^{\top}$ rthex. In Narthex, the vittæ of the fruit are conspicuous,-in Scorodosma almost obsolete; but the development of these crgans in feruloid plants varies considerably, and has been rejected by Bentham and Hooker as affording no important distinctive character. Scorodosma is apparently more pubescent than Narthex.

S. foetidum. was discovered by Lehmann in 1841, in the sandy deserts eastward of the Sea of Aral, and also on the hills of the Karatagh range south of the river Zarafshan,--that is to say, south-east of Samarkand. In 1858-59, it was observed by Bunge about Herat. At nearly the sanre period, it was afresh collected between the Caspian and Sea of Aral, and in the country lying eastward of the latter, by Borszczow, a Russian botanist, who has made it the subject of an elaborate and valuable memoir. ${ }^{3}$

1 The Genera $N a r t h c x$ and Scorodosma are held by Beutham and Hooker (Gencra Plantarum, i. 918) as in nowise distingnishable from Ferula, and they have accordingly been suppressed by these botanists. Without questioning the propriety of this course, we retain for the present to ensure distinctness the designations bestowed by Falconer and by Bunge.

2 We iefrain from citing localities in Tibet, Beluchistan and Persia, where plants supposed to agree with that of Fulcollel have been found by other collectors.

3 Dic Pharmaccutisch-uichtigen Frerulucems dcr. Aralo-Caspischun I'üsto, St. l'etersb. IS60, pp. 40, eight plates. 
Ferula alliacea Boiss. ${ }^{1}$ ( $F$ : Asafoetidla Boiss. et Buhse, non Limn.) discovered in 1850 by Buhse, and observed in 1858-59 by Bunge in many places in Persia, is said to exhale a strong odour of asafoctida and to be known in Khorassan as angriza, the same name that is applied to Scorolosma. F'. teterrima Kir. et Kar., a plant of Somngaria, is likewise remarkiable for its intense alliaceons smell; but neitler plant is known as the source of any commercial prodnct. ${ }^{2}$

The most detailed account of the asafœetida plant we possess, is that of the German traveller Engelbert Kämpfer, who in 1687 observed it in the Persian province of Laristan, between the river Shúr and the town of Kongún, also in the neighbourhood of the town of Dusgun or Disgun, in which latter locality ${ }^{3}$ alone he saw the gum-resin collected. $\mathrm{He}$ states that he found the plant also growing near Herat. Kämpfer has given figures of his plant which he calls Asa fretida Disgunensis, and his specimens consisting of remnants of leaves, a couple of mericarps (in a bad state) and a piece of the stem a few inches long, are still preserved in the British Museum.

These materials have been the subject of much study, in order to determine which of the asafœtida plants of modern botanists should be identified with that of Kämpfer, Falconer and Borszczow have arrived in turns at the conclusion that his own plant accords with Kämpfer's. But Kämpfer's fignres agree well neither with Narthex nor with Scoroclosma. The plant they represent does not form, it would seem, the branching pyramid of the Narthex (as it flowered at Edinburgh), nor has it the multitude of umbels seen in Borszczow's figure of Scorodosma. ${ }^{4}$

Whether Kämpfer's plant is really identical with either of those we have noticed, and whether the discrepancies observable are due to careless drawing or to actual difference, are points that cannot be settled without the examination of more ample specimens.

Great allowance must be made for the period of growth at which these plants have been observed. Kämpfer saw his plant when quite mature, and not when its stem was young and flowering. Narthex is scarcely known except from specimens grown at Edinburgh, those obtained by Falconer in Tibet having been gathered when dry and withered. Even Borszczow's plant appear's never to have been seen by any botanist while its flower-stem was in a growing state.

History-Whether the substance which the ancients called Laser was the same as the modern Asafoetida, is a question that has been often discussed during the last three hundred years, and it is one upon which we shall attempt to offer no further evidence. Suffice it to say that Laser is mentioned along with products of India and Persia, among the articles on which duty was levied at the Roman Custom House of Alexandria in the 2 nd century.

Asafotida was certainly known to the Arabian and Persian geographers and travellers of the middle ages. One of these, Ali Tstakhri, a native of Istakr, the ancient Persepolis, who hived in the 10th century, states $^{5}$ that it is produced abundantly in the desert between Sistan and

1 Flora Orientalis, ii. (1872) 995.

2 Borszczow, op. cit. $13-14$.

3 Which we cannot find on any map.

4 Känıfer figures his plant with about 6 mubels on a stalk, while Scorodosma, as represented by Borszczow, has at least 25 .

5 Buch der Länder, translated by Mordtmann, Hamburg, 1845. 111 . 
Makran, and is much used by the people as a condiment. The region in question comprises a portion of Beluchistan.

The geographer Edrisi, ${ }^{1}$ who wrote about the middle of the 12 th century, asserts that asafortida, called in Arabic Hillit, is collected largely in a district of Afghanistan near Kaleh Bust, at the junction of the Helmand with the Arghundab, a locality still producing the drug. Other Arabian writers as quoted by Ibn Baytar, ${ }^{2}$ describe asafoctida in terms which show it to have been well known and much valued.

Matthæus Platearius of Salerno, who flourished in the second half of the 12 th century, mentions asafotida in his work on simple medicines, known as Circa instans, which was held in great esteem during the middle ages. It is also named a little later by Otho of Cremona, ${ }^{3}$ who remiarks that the more foetid the drug, the better its quality. Like other productions of the East, asafoetida found its way into European commerce during the middle ages through the trading cities of Italy. It is worthy of remark that it is much less frequently mentioned by the older writer's than galbanum, sagapenum and opopanax.

Collection-The collecting of asafotida on the mountains about Dus-

gun in Laristan in Persia, as described by Kämpfer, ${ }^{4}$ is performed thus :-
The peasants repair to the localities where the plants abound, about the middle of April, at which time the latter have ceased growing, and their leaves begin to show signs of withering. The soil surrounding the plant is removed to the deptl of a span, so as to bare a portion of the root. The leaves are then pulled off, the soil is replaced, and over it are laid the leaves and other herbage, with a stone to keep them in place, the whole being arranged in this way to prevent injury to the root by the heat of the sin.

About forty days later, that is towards the end of May, the people return, the men being armed with knives for cutting the root, and broad iron spatulas for collecting the exuded juice. Having first removed the leaves and earth, a thinnish slice is taken from the fibrous crown of the root, and two days later the juice is scraped from the flat cut surface. The root is again sheltered, care being taken that nothing rests on it. This operation is repeated twice in the conrse of the next few days, a very thin slice being removed from the root after each scraping. The product got during this first cutting is called shirr, i.e. mill, and,is thinner and more milky and less esteemed than that obtained afterwards. It is not sold in its natural state, but is mixed with soft earth (terra limosa) which is added to the extent of an equal, or even double, weight of the gum-resin, according to the softness of the latter.

After the last cutting, the roots are allowed to rest 8 or 10 days, when a thicker exudation called pispaz, more esteemed than the first, is obtained by a similar process carried on at intervals during June and July, or even later, until the root is quite exhausted.

The only recent account of the production of asafœetida that we have met with, is that of Staff-surgeon H. W. Bellew, who witnessed the collection of the drug in 18.57 in the neighbourhood of Kandahar.

1 Géographicd' Edrisi, traduite par Jaubert, i. (1836) 450 .

2 Sontheimer's transl. i. (1840) 84.

3 Choulant, Mlacer Floridus, Lips. 1832. 159.
4 Ambuitales Furolica, Lemgoria, 1712. $535-552$.

5ourinal of a Mission to Afghanistan, Lond. 1562. 270 . 
The frail withered stem of the previous year with the cluster of newlyspronted leaves, is cut away from the top of the root, around which a trench of 6 inches wide and as many deep, is dug in the earth. Several deep incisions are now made in the upper part of the root, and this operation is repeated every 3 or 4 days as the sap continues to exude, which goes on for a week or two according to the strength of the plant. The juice collects in tears about the top of the root, or when very abundant flows into the hollow around it. In all cases as soon as incisions are made, the root is covered with a bundle of loose twigs or herbs, or even with a heap of stones, to protect it from the drying effects of the sun. The quantity of gum-resin obtained is variable; some roots yield scarcely half an ounce, others as mucl as two pounds. Some of the roots are no larger than a carrot, others attain the thickness of a muan's leg. The drug is said to be mostly adulterated before it leaves the country, by admixture of powdered gypsum or flour. The finest sort, which is generally sold pure, is obtained solely "from the node or leafbud in the centre of the root-head." At Kandahar, the price of this superior drug is equivalent to from $2 s$. $8 d$. to $4 s$. $8 d$. per $7 b$., while the ordinary sort is worth but from $1 s$. to $2 s$.

During a journey from North-western India to Teheran in Persia, through Beluchistan and Afghanistan, performed in the spring of 1872, the same traveller observed the asafotida plant in great abundance on many of the elevated undulating pasture-covered plains and hills of Afghanistan, and of the Persian province of Khorassan. He states that the plant is of two kinds, the one called Kamá-i-gawi which is grazed by cattle and nsed as a potherb, and the other known as Kamá-i-angriza which affords the gum-resin of commerce. The collecting of this last is almost exclusively in the hands of the western people of the Kákarr tribe, one of the most numerous and powerful of the Afghan clans, who when thus occupied, spread their camps over the plains of Kandahar to the confines of Herat. ${ }^{\text {? }}$

Wood, in his journey to the source of the Oxus, found asafoetida to be largely produced in a district to the north of this, namely the mountains around Saigan or Sykan (lat. $35^{\circ} 10$, long. $67^{\circ} 40$ ), where, says he, the land affording the plant is as regularly apportioned out and as carefully guarded as the cornfields on the plain. ${ }^{2}$

Description-The best asafoetida is that consisting chiefly of agghntinated tears. Freshly imported, it forms a clammy yet hard yellowishgrey mass, in which opaque, white or yellowish milky tears sometimes an inch or two long, are more or less abundant. By exposure to air, it acquires a bright pink and then a brown hue. The perfectly pure tears display when fractnred a conchoidal surface, which changes from milky white to purplish pink in the course of some hours If a tear is touched with nitric acid, sp. gr. 122, it assumes for a short time a fine green colour.

When asafœetida is rubbed in a mortar with oil of vitriol, then cliluted with water and neutralized, the slightly coloured solution exhibits a bluish fluorescence. The tears of asafoetida when warmed become adhesive, but by cold are rendered so brittle that they may be powdered. With water they easily form a white emulsion. The drug has a powerful and persistent alliaceous odour and a bitter acrid alliaceous taste.

1 Bellew, From the Indus to the Tigris, Jondon. 1874. 101. 102. 286. 321. Eec.
Wood, Journcy to the Source of the River Oxus, now ed., 1872. 131. 
Sometimes asafeetida has been imported as a fluid honey-like mass, apparently pure. We presume that such is that of the first gathering, which Kiimpler says is called milk. The drug is often adulterated with earthy matter which renders it very ponderous. This earthy or stony asafnetida constitutes at Bombay, a distinct article of commerce under the name of Himgre, the purer drug being called Hing.

Among the natives of Bombay, a third form of asafretida is in use that communds a much higher price than those just described, and is therefore never brought into European trade. ${ }^{1}$ It forms a dark brown, transluccent, brittle mass, of extremely fotid alliaceous odour, containing many pieces of the stem with no admixture of earth. Guilsourt by whom it was first noticed ${ }^{2}$ was convinced that it had not been obtained from the root, but had been cut from the stem. He remarks that Theophrastus alludes to asafœetida (as lie terms the Silphium ${ }^{3}$ of this author) as being of two kinds, - the one of the stem, the other of the root; and thinks the former may be the sort under notice. Vigier ${ }^{4}$ who calls it Asa. faetida nauséeux, found it to consist in 100 parts, of resin and essential oil 37.50 , gum 23.75 , remains of stalks 38.75 . This drug appears to be the superior sort alluded to by Bellew.

Chemical Composition-Asafotida consists of resin, gum and essential oil, in varying proportions, but the resin generally amounting to more than one half. Malic acid, so generally diffused in umbelliferons plants, is also present; and the watery distillate contains acetic, formic, and valerianic acids.

The volatile oil amounts to between 3 and 5 per cent. It contains sulphur, and must therefore be distilled from glass vessels. It is light yellow, has a repulsive, very pungent odour of asafotida, tastes at first inild, then irritating, but does not stimulate like oil of mustard when applied to the skin. It is neutral, but after exposure to the air acquires an acid reaction and different odour; it evolves sulphuretted hydrogen. In the fresh state, the oil is free from oxygen; it begins to boil at $135^{\circ}$ to $140^{\circ} \mathrm{C}$., but with continued evolution of hydrogen sulplide, so that even Hlasiwetz did not succeed in preparing it of constant composition, the amount of sulphur varying from 20 to 25 per cent. It appears to be a mixture of sulphur-compounds of the radical $\mathrm{C}^{6} \mathrm{H}^{11}$, the possible relations of which to allyl $\mathrm{C}^{3} \mathrm{H}^{5}$ (p. 63) require further investigation. To this however, the insufferable odour of the crude oil is a serious obstacle.

Oil of asafœetida when treated with oxydizing agents, yields besides oxalic acid, acids of the fatty series up to valerianic acid. Potassium decomposes it with evolution of gas, forming potassium sulphide; the residual oil is found to have the odour of cimnamon.

The resin of asafoetida is not wholly soluble in ether or chloroform, but dissolves with decomposition in warm concentrated nitric acid. It contains Ferulaic Acid, $\mathrm{C}^{10} \mathrm{H}^{10} \mathrm{O}^{4}$, discovered by Hlasiwetz and Barth in 1866 , crystallizing in iridescent needles soluble in boiling water; it is homologous with Eugetic Acid, $\mathrm{C}^{11} \mathrm{H}^{12} \mathrm{O}^{4}$. Fused with potash, ferulaic acid yields oxalic and carbonic acids, fatty acids, and likewise

I A large specimen of it was kindly pre. sented to one of us (H.) by Mr. D. S. Kemp of Bombay. We have also examined the same irug in the India Museum.
= Hisl. acs Dromes, iii. (1850) 223.

3 Hist. Plantanum, l. vi. c. 3.

4 Gommes-résines des Ombellifêres (thièsc). Paris, $186 ? 32$. 
protocatechuic acid. The resin itself treated in like namner after it has been previously freed from gum, yields resorcin ; and by dry distillation, oils of a green, blue, violet or red tint, besides about $\frac{1}{4}$ per cent. of Umbelliferone, $\mathrm{C}^{9} \mathrm{H}^{6} \mathrm{O}^{3}$.

Commerce-The drug is at the present day produced exclusively in Afghanistan. Much of it is shipped in the Persian Gulf for Bombay whence it is conveyed to Europe; it is also brought into India by way of Peshawur, and by the Bolan pass in Beluchistan.

In the year 1872-73, there were imported into Bombay ${ }^{1}$ by sea, chiefly from the Persian Gulf, $3367 \mathrm{cwt}$. of asafœetida, and $4780 \mathrm{cwt}$. of the impure form of the drug called Hingra. The value of the latter is scarcely a fifth that of the genuine kind known as Hing. The export of asafotida fron Bombay to Europe is very small in comparison with the shipments to other ports of India.

Uses-Asafoetida is reputed stimulant and antispasmodic. It is in great demand on the Coutinent, but is little employed in Great Britain. Among the Malommedan as well as Hindu population of India, it is generally used as a condiment, and is eaten especially with the various pulses known as dál. In regions where the plant grows, the fresh leaves are cooked as an article of diet.

Adulteration-The systematic adulteration chiefly with earthy matter already pointed out, may be easily estimated by exhausting the drug with solvents and incinerating the residue.

\section{GALBANUM.}

\section{Gummi-resinu Galbanum; Galbanum; F. Galbanum; G. Mutterharz.}

Botanical Origin-The uncertainty that exists as to the plants which furnish asafotida, hangs over those which produce the nearly allied drug Galbanum. Judging from the characters of the latter, it can scarcely be doubted that it is yielded by umbelliferous plants of at least two species, which are probably the following :-

1. Ferula galbaniflua Boiss. et Buhse, ${ }^{3}$ - a plant witl a tall, solid stem, 4 to 5 feet high, greyish, tomentose leaves, and thin flat fruits, 5 to 6 lines long, 2 to 3 broad, discovered in 1848 at the foot of Demawend in Northern Persia, and on the slopes of the sane mountain at 4,000 to 8,000 feet, also on the mountains near Kuschkäk and Churchurä (Jajarúd ?). Bunge collected the same plant at Subzawar. Buhse says that the inhabitants of the district of Demawend collect the gum resin of this plant which is Galbanum; the tears which exude spontaneously from the stem, especially on its lower part and about the bases of the leaves, are at first milk-white but become yellow by exposure to light and air. It is not the practice, so far as he observed, to wound the plant for the purpose of causing the

1 Statement of the Trade and Navigation of Bombay for the year $1872-73$, pt. 1i. 26 . 95.

i The following in addition have at various times been supposed to afford galbanum:-fierulago galbunifera Koch, a native of the Mediterranean region and Sonthern Russia;
Opoidia galbaniferu Lindl., a Persian plant of duubtful genus; Bubon Galbanum L., a shrubby umbellifer of South Africa.

${ }^{3}$ Anfzällung der in einer Reise durch Transkaukasien und Persien gesammelten Pflanzen.-Nouv. Mem. de la Soc. imp. des Nat. de Moscont, xii. (1860) 99. 
juice to exude more freely, nor is the gathering of the gum in this district any special object of industry. ${ }^{1}$ The plant is called in Persian Khassuih, and in the Mazanderan dialect Boridsheh.

2. F. rubricaulis Boiss. ${ }^{2}(F$. erubesccns Boiss. ex parte, Aucher exsicc.n. 4614, Kotschy n. 666).- This plant was collected by Kotschy in gorges of the Kuh Dinar range in Southern Persia, and probably by Aucher-Eloy un the mountain of Dalmkuh, in Northern Persia. Borszczow, ${ }^{3}$ who regards it as the same as the preceding (though Boissier ${ }^{4}$ places it in a different section of the genns), says on the authority of Buhse, that it occurs locally throughont the whole of Northern Persia, is found in plenty on the slopes of Elwund near Hamadan, here and there on the edge of the great central salt-desert of Persia, on the mountains near Subzawar, between Ghurian and Kháf, west of Herat, and on the desert plateau west of Kháf. He states, though not from personal observation, that its gum-resin which constitutes Persian Galbanum, is collected for commercial purposes around Hamadan. F. rubricaulis Boiss. has been beautifully figured by Berg ${ }^{5}$ under the name of $F$. crubescens.

History-Galbanum, in Hebrew Chelbenah, was an ingredient of the incense used in the worship of the ancient Israelites, ${ }^{6}$ and is mentioned by the earliest writers on medicine as Hippocrates and Theophrastus.? Dioscorides states it to be the juice of a Narthex growing in Syria, and describes its characters, and the method of purifying it by hot water exactly as followed in modern tines. We find it mentioned in the 2nd century among the drugs on which duty was levied at the Roman custom house at Alexandria. ${ }^{8}$ Under the name of Kinnah it was well known to the Arabians, and through them to the physicians of the school of Salerno.

In the journal of expenses of John, king of Frunce, during his captivity in England, A.D. 1359-60, there is an entry for the purchase of $1 \mathrm{tb}$. of Galbanum which cost 16s., 1 fb. of Sagapenum (Sercpin) at the same time costing only $2 s .^{9}$ In common with other products of the East, these drugs used to reach England by way of Venice and are mentioned among the exports of that city to London in $1503 .^{10}$

An edict of Henry III. of France promulgated in 1581, gives the prices per $\mathrm{Hb}$. of the gum-resins of the Umbelliferce as follows :-Opopanax 32 sols, Sagapenum 22 sols, Asafœtida 15 sols, Galbanum 10 sols, Ammoniacum 6 sols 6 deniers. ${ }^{11}$

Description-Galbanum is met with in drops or tears, adhering inter se into a mass, usually compact and hard, but sometimes found so soft as to be fluid. The tears are of the size of a lentil to that of a hazel-nut, translucent, and of various shades of light brown, yellowish

1 Buhse, 1. c. ; also Bulletin de la Soc. imp. des Nat. de Moscou, xxiii. (1850) 548.

${ }^{2}$ Diagnoses Plantarum novarum prasertion orientalium, ser. ii. fasc. 2 (1856) 92.

3 Op. cit. 36 (see p. 280, note 3 ).

- Flora Orientalis, ii. (1872) 995.

5 Berg. u. Schmidt, Offizinelle Gewächse, iv. (1863) tab. $31 b$.

is Exodus xxx. 34.-In imitation of the ancient Jewish custom, Galbanum is a component of the incense used in the Irvingite chapels in London.

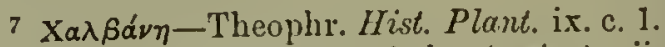

$s$ Vincent, Commerce of the Aneients, ii. (1807) 692 .

" Doilet d'Arcq, Comptes de l'Argenterie des Rois de France (1S51) 236. -Tho prices must be multiplied by 3 to give a notion of present value.

${ }_{10}$ Pasi, Tariffa de Pesi e Misure, Venet. 1521. 204 (1st edition, 1503).

11 Fontanou, Edicts et Ordonnances dis $R$ is de Franes, ii. (1585) 389. 
or faintly greenish. The drug has a peculiar, not unpleasant, aronatic odour, and a disagreeable, bitter, alliaceous taste.

In one variety, the tears are dull and waxy, of a light yellowish tint when fresh, but becoming of an orange-brown by keeping; they are but little disposed to run together, and are sometimes quite dry and loose, with an odour that somewhat reminds one of savine. In recent importations of this form of galbanum, we have noticed a considerable admixture of thin transverse slices of the root of the plant, an inch or more in diameter.

Chemical Composition-Galbanum contains volatile oil, resin an mucilage. The first, of which 7 per cent. may be obtained by distillation with water, is a colourless liquid, boiling at $160-165^{\circ} \mathrm{C}$., and having the odour of the Urug; it deviates the ray of polarized light to the right, and yields when treated with dry hydrochloric acid, a crystalline compound, $\mathrm{C}^{10} \mathrm{H}^{16}, \mathrm{HCl}$.

The resin, which we find to constitute about 60 per cent. of the drug, is very soft, and dissolves in ether or in alkaline liquids, even in milk of lime, but only partially in bisulphide of carbon. When heatea for sone time at $100^{\circ} \mathrm{C}$. with hydrochloric acid, it yields about 0.8 per cent. of Umbelliferone, $\mathrm{C}^{9} \mathrm{H}^{6} \mathrm{O}^{3}$, which may be dissolved from the acid liquid by ineans of ether or chloroform; it is obtained on evaporation in colourless acicular crystals. Umbelliferone is soluble in water; its solution exhibits, especially on addition of an alkali, a brilliant blue fluorescence which is destroyed by an acid. If a small fragment of galbanum is immersed in water, no fluorescence is observed, but it is immediately produced by a drop of amnionia. ${ }^{1}$ The same phenomenon takes place with asafoetida, and in a slight degree with ammoniacum ; it is probably due to traces of umbelliferone pre-existing in those drugs.

Umbelliferone is also produced from many other aromatic umbelliferous plants, as Angclica, Levisticum, and Meum, when their respective resins are submitted to dry distillation. According to Zwenger (1860) it may be likewise obtained from the resin of Daphne Mezereum L. The yield is always small; it is highest in galbanum, but even in this, does not inuch exceed 0.8 per cent. reckoned on the crude drug.

By submitting galbanum-resin to dry distillation, Mössmer (1861) obtained a thick oil of an intense and brilliant blue, ${ }^{2}$ which was noticed as early as 1751 by Caspar Neumann of Berlin. It is a liquid having a slightly aromatic odour and a bitter acrid taste. Kachler (1871) found that it could be resolved by fractional distillation into a colourless oil having the formula $\mathrm{C}^{10} \mathrm{H}^{16}$, and a blue oil to which he assigned the composition $\mathrm{C}^{10} \mathrm{H}^{16} \mathrm{O}$, or perhaps more correctly $\mathrm{C}^{40} \mathrm{H}^{64} \mathrm{O}^{4}$, boiling at $289^{\circ} \mathrm{C}$. As to the hydrocarbon, it boils at $240^{\circ} \mathrm{C}$., and therefore differs from the essential oil obtained when galbanum is distilled with water. The blne oil, after due purification agrees, according to Kachler, with the blue oil of the flowers of Matricaria Chamomilla L. Each may be transformed

\footnotetext{
1 This remarkable property of umbelliferowe may be beautifully shown by dipping some bibulous paper into water which has stood for an hour or two on lumps of gal. banum, and drying it. A strip of this paper placer 11 a test tube of water with a drop of ammonia, will give a superb bluc solutuon,
}

instantly lusing its colour on the adrlition of a drop of hydrochloric neid.

2 We have fonnd it best to mix tho galbaunn-resin with coarsely powdered pumicestone ; the oil is then ensily and abundantly obtainahle. 
by means of potassium into a colourless hydrocarbon, $\left({ }^{10} \mathrm{H}^{16} ;{ }^{1}\right.$ or by anhydride of phosphoric acid into another produce, ${ }^{10} \mathrm{H}^{14}$, likewise colourless. The latter, as well as the former hydrocarbon, if difuted witl ether, and bromine be added, assumes for a noment a fine blue tint.

The blue oil, $\mathrm{C}^{10} \mathrm{H}^{16} \mathrm{O}$, is not the only product of the dry distillation of galbanum-resin. We have observed that acids are also abundantly tormed, which may be separated from the oil by washing it with water.

When cooled, the crude blue oil sometimes deposits crystals of unbelliferone, which are also obtained if the acidulous water just inentioned is concentrated, and then shaken with chloroform.

By fusing galbanum-resin with potash, Hlasiwetz and Barth (1864) obtained crystals (about 6 per cent.) of Resorcin, together with acetic and volatile fatty acids. The empirical formula of resorcin, $\left(^{6} \mathrm{H}^{6} \mathrm{O}^{2}\right.$, is likewise that of pyrocatechin and hydrokinone. Resorcin has a disagreeable sweet taste; it is soluble in water, alcohol, ether, bisulphide of carbon, or chloroform. It melts at $104^{\circ} \mathrm{C}$. and distills at $272^{\circ} \mathrm{C}$. Resorcin, which is a very interesting body from a theoretical point of view, is more abundantly produced if the crystalline portion of the extracts of Sapan Wood (Ccesalpinia Sappan L.) or of Brazil Wood (C. echinata Lam.), is submitted to dry distillation, or melted with potash.

Galbanum-resin treated with nitric acid, yields Camphretic Acid and Styphnic Acid. ${ }^{2}$

If galbanum, or still better its resin, is warmed with concentrated hydrochloric acid, a red hue is developed, which turns violet or bluish if spirit of wine is slowly added. Asafotida treated in the same way assumes a dingy greenish colour, and ammoniacum is not altered at all. This test probably depends upon the formation of resorcin, which in itself is not coloured by hydrochloric acid, but assumes a red or blue colour if sugar or mucilage or certain other substances are present. It is remarkable that ammoniacum, though likewise yielding resorcin when fused with potasll, assumes no red colour when warmed with hydrochloric acid. The mucilage of galbanum has not been minutely examined.

Commerce-Galbanum is we believe, brought into commerce chiefly from Eastern Europe. It is stated that considerable quantities reach Russia by way of Astrachan and Orenburg.

Uses-Galbanum is adıninistered internally as a stimulating expectorant, and is occasionally applied in the form of plaster to indolent swellings.

\section{AMMONIACUM.}

Gummi-resina Ammoniacum; Ammoniacum or Gum Ammoniacum;

F. Gomme-résine Ammoniaque; G. Ammoniak-gummihaiz.

Botanical Origin-Dorema Ammoniacum Don (Diserneston gummiferum Jaub. et Spach), a pereminial plant, with a stout, erect, leafless Hower-stem, 6 to 8 feet high, dividing towards its r.pper part into

1 Probably identical with that obtained

2 Gmelin's Chemistry, xi. 228.

by fractional distillation, as previously men-

tioned. 
numerous ascending branches, along which are disposed on thick short stalks, ball-like simple umbels, scarcely half an inch across, of very small flowers. 'The aspect of the full-grown plant is therefore very unlike that of Fcrula. The Doremia has large compound leaves with broad lobes. The whole plant in its young state is covered with a tomentum of soft, stellate hairs, which give it a greyish look, but which disappear as it ripens its fruits. The withered stems long remain erect, and occurring in immense abundance and overtopping the other vegetation of the arid desert, have a striking appearance. ${ }^{1}$

The plant occurs over a wide area of the barren regions of which Persia is the centre. According to Bunge and Bienert, its north-western limit appears to be Shahrud (S.E. of Asterabad), whence it extends eastward to the deserts south of the Sea of Aral and the Sir-Daria. The most southern point at which the plant has been observed, is Basiran, a village of Southern Khorassan in N. lat. $32^{\circ}$, E. long. $59^{\circ}$.

Of the three or four other species of Dorcma, D. Aucheri Boiss. affords very good ammoniacum, as we know by an ample specirnen of the gum deposited together with the plant in the British Museum by Mr. W. K. Loftus, who in 1851 collected both at Kirrind in Western Persia, where the plant is called in Kurdish Zuh. Boissier ${ }^{2}$ includes as $D$. Aucheri another plant, called by Loftus D. robustum, the gum of which is certainly different from ammoniacum. Of the plant itself, there are only fruits in the British Museum.

History-The first writer to mention ammoniacum is Dioscorides, who states it to be the juice of a Narthex growing about Cyrene in Libya, and that it is produced in the neighbourhood of the temple of Ammion. He says it is of two sorts, the one like frankincense in pure, solid tears, the other massive, and contaminated with earthy impurities. Pliny gives essentially the same account.

The succeeding Greek and Latin authors on medicine throw but little light on the drug, which however is mentioned by most of them as used in furnigation. Hence we find such terms as Ammoniacum thymiama, Anmoniacum suffimen, Thus Libycum.

The African origin assigned to the drug by Dioscorides has long perplexed pharmacologists; but it is now well ascertained that in Morocco a large species of Ferula (according to Lindley $F$. Tingitana L.), yields a milky gum-resin having some resemblance to ammoniacum, and still an object of traffic with Egypt and Arabia, where it is employed, like the ancient drug, in fumigations. There can be but little doubt we think, that the ammoniacum of Morocco is identical with the ammoniacum of the ancients; it may well have been imported by way of Cyrene from regions lying further westward. ${ }^{3}$

Persian ammoniacum or the ammoniacum of European commerce, may also have been known in very remote times, though we are unable to trace it back earlier than the 10th century, at which period it is mentioned by Isaac Judæus ${ }^{4}$ and by the Persian physician Alhervi. ${ }^{5}$ Both

1 Fraser, Journey into Khorasän, 1825. 118 ; Polak, Persien, das Land und seine Leute, ii. (1865) 282.

2 Flora, Orientalis, ii. (1872) 1009.

${ }^{3}$ Hanbury, Pharm. Journ. March 22, 1873. 741 .
1 Opera Omnia, Lugd. 1515, lib. ii. practices c. 44

5 Seligmann, Liber Fundamentorum Pharmacologioe, Vindob. 1830. 55 . 
these writers designate it $U$ shak, a nane which it bears in Persia to the present day.

Collection-The stem of the plant abounds in a milky juice which flows out on the slightest puncture. The agent which occasions the exudation is a beetle, multitudes of which pierce the stem. The gum, the drops of which speedily harden, partly remains adherent to the stem and partly falls to the ground; it is gathered about the end of July by the peasants, who sell it to dealer's for conveyance to Tspahan or the coast. ${ }^{\prime}$

Young roots, 3 to 4 years old, are according to Jorszczow, extremely rich in millky juice which sometimes exudes into the surrounding soil in large drops; there is also an exudation from the fibrous crown of the root of a dark inferior sort of ammoniacum. The gum-resin appear's to be collected in quantity only in Persia. One of the chief localities for it are the desert plains about Yezdikhast, betwcen Ispahan and Shiraz.

Description-Ammoniacum occurs in dry grains or tears of roundish form, from the size of a small pea to that of a cherry, or in norlular lumps. They are externally of a pale creamy yellow, opaque and milky-white within. By long kceping, the outer colour darkens to a cinnamon-brown. Ammoniacum is brittle, showing when broken a dull waxy lustre, but it easily softens with warmth. It has a bitter acrid taste, and a peculiar, characteristic, non-alliaceous odour. It readily forms a white emulsion when triturated with water. It is coloured yellow by caustic potash. Hypochlorites, as common bleaching powder, give it a bright orange hue, while they do not affect the Morocco drug.

Ammoniacum is obtaincd from the mature plant, the ripe mericarps of which, $\frac{3}{8}$ of an inch in length, are often found sticking to the tears. By pressure the tears agglutinate into a compact mass, which is the Lump Ammoniacum of the druggists. It is generally less pure than the detached grains, and fetches a lower price.

Chemical Composition-Ammoniacum is a mixture of volatile oil with resin and gum. The greater or less softness of the drug is partly due, as in all analogous substances, to the proportion of water present.

The volatile oil, which is lighter than water and has the precise odour of the drug, contains according to our experiments, no sulphur; a similar observation was made by Przcciszewski. ${ }^{2}$ Vigier, ${ }^{3}$ who obtained the oil to the extent of 1.8 per cent. by distilling the gum-resin witl water, asserts that it blackens silver, and that after oxidation with nitric acid, he detected in it sulphuric acid. He states that with hydrochloric acid, the oil acquires a fine violet tint passing by all shades to black; we failed in obtaining this coloration.

The resin in ammoniacum usually amounts to about 70 per cent. It is separable according to Przeciszewski, into two substances, - - the one a resin having acid propertics, the other an indifferent resin. He asserts that the indifferent resin when heated yields sulphuretted hydrogen. Our own experiments failed to show the presence of sulphur in the

I Johnson, Journey from India to England throngh P'ersia, \&c., 1818.93. 94; Hart, quoted by Don, Linn. Trans. xvi. (1833) 605.

${ }^{2}$ Pharmakologisehe Untersuchungen über
Ammoniaerm, Sagapenum und Opopanax, Dorinat, 1861.

3 Gommes-résines des Ombelliferes (Thèse), Paris, 1869. 93. 
crude drug; and the same negative result has been more recently obtained in some careful experiments by Moss. ${ }^{1}$

Unlike the gum-resin of allied plants, ammoniacum yields no umbelliferone. When melted with caustic potash it affords a little resorcin. Przeciszewski found the gum to agree with that of acacia.

Commerce-Ammoniacum is shipped to Europe from the Persian Gulf by way of Bombay. The exports from the latter place in the year 1871-72 were 453 cwt., all shipped to the United Kingdom. The quantity imported into Bombay in 1872-73 was $1671 \mathrm{cwt}$., all from the Persian Gulf. ${ }^{2}$

Uses-The drug is administered as an expectoraut and is also used in certain plasters.

\section{Allied Gum-resins.}

Sagapenum-This is a gum-resin which, when pure, forms a tough softish mass of closely agglutinated tears. It is nearly related to asafœetida, but differs from that substance in forming brownish (not milk-white) tears, which when broken do not acquire a pink tint; also in not having so powerful an alliaceous odour.

Sagapenum, which in medirval pharmacy was often called Serapinum, is so frequently mentioned by the older writers that it must have been a plentiful substance. At the present day it can scarcely be procured genuine even at Bombay, whither it is sometimes brought from Persia. The botanical origin of the drug is unknown.

Opopanax-A gum-resin occurring in hard, nodular, brittle, earthylooking lumps of a bright orange-brown hue, and penetrating offensive odour, reminding one of crushed ivy-leaves. It is commonly attributed to Upopanax Chironium Koch, a native of Mediterranean Europe. We liave never seen a specimen known to have been obtained from this plant; but can say that the gum-resin of the nearly allied Opopanax Persicum Boiss., as collected by Loftus at Kirrind in Western Persia in 1851 , has neither the appearance nor the characteristic odour of officinal opopanax. Powell, ${ }^{3}$ who has recently endeavoured to trace the origin of the drug, regards it as a product of Persia.

Opopanax was very common in old pharmacy, but has fallen out of use, and is now both rare and expensive. ${ }^{4}$

\section{FRUCTUS ANETHI.}

\section{Semen Anethi; Dill Fruits, Dill Seeds; F. Fruits d'Ancth; G. Dillfrüchtc.}

Botanical Origin-Anethum ${ }^{5}$ graveö̈ens L., an erect, glaucous annual plant, with finely striated stems usually 1 to $1 \frac{1}{2}$ feet high, pinnate leaves with setaceous linear segments, and yellow flowers.

1 Pharm. Journ. Mareh 29, 1873. 761.

2 Statement of the Trade and Navigation of the Presidency of Bombay, 1871-72, and $1872-73$.

3 Economic Products of the Prinjab, i. (1868) 402.

"Further partienlars regarding Sagapenum and Opopanax, may be found in the theses of Przeciszewski (1861) and Vigier (1869), notieed in our article on Ammoniaeum.

5 Bentham and Hooker (Gen. Plant. i. 919) suppress the genus Anethum, uniting its one solitary speeies with Peuccdanum. 
It is indigenous to the Mediterranean region, Southern Russia and the Caucasian provinces, but is found as a cornfield weed in many other countries, and is frequently cultivated in gardens.

Dill, under the Hindustani name of Suvà or Sóyjah, is largely grown in various parts of India, where the plant though of but a few months duration, grows to a height of 2 to 3 feet. On account of a slight peculiarity in the fruit, the Indian plant was regarded by Roxburgh and De Candolle as a distinct species, and called Anethum Sowa, but it possesses no botanical characters to warrant its separation from $A$. graveolens.

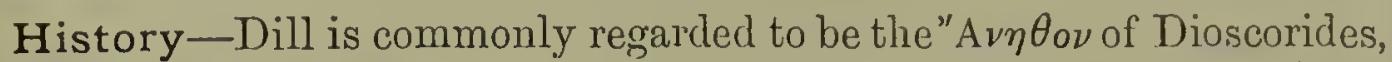
the Anethum of Palladius and other ancient writers, as well as of the New Testament. ${ }^{1}$ In Greece the name "A $\nu \eta \theta 0 \nu$ is at present applied ${ }^{2}$ to a plant of very similar appearance, Carum Ridolfu Benth. et Hook.

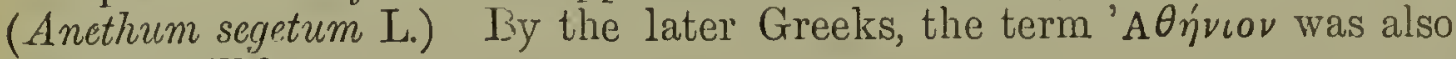
used for dill. ${ }^{3}$

Dill, as well as coriander, fennel, cumin, and ammi, was in frequent requisition in Britain in Anglo-Saxon times. ${ }^{4}$ The name is derived according to Prior ${ }^{5}$ from the old Norse word dilla, to lull, in allusion to the reputed carminative properties of the drug. However this may be, we find the word occurring in the 10th century in the Vocabulary of Alfric, archbishop of Canterbury. ${ }^{6}$ The words dill and till, undoubtedly meaning this drug, were also used in Germany and Switzerland as early as A.D. 1000.

Description-The fruit which has the characters usual to Umbelliferce, is of ovoid form, much compressed dorsally, surrounded with a broad flattened margin. The mericarps about $\frac{1}{10}$ of an inch wide, are mostly separate; they are provided with 5 equidistant, filiform ridges, of which the two lateral lose themseives in the paler, broad, thin margin. The three others are sharply keeled; the darker space between them is occupied by a vitta and two occur on the commissure. In the Indian drug, the mericarps are narrower and more convex, the ridges more distinct and pale, and the border less winged. In other respects it accords with that of Europe. The odour and taste of dill are agreeably aromatic.

Microscopic Characters-The pericarp is formed of a small number of flattened cells, which in the inner layer are of a brown colour; the ridges consist as usual of a strong fibro-vascular bundle. The vittæ in a transverse section present an elliptic outline $\frac{1}{140}$ of an inch or less in diameter. The margin of the mericarp is built up of porous, parenchymatous tissue. The albumen as in the seeds of all umbellifers, consists of somewhat thick-walled, angular cells, loaded with fatty oil, and globular grains of albuminors matters which present a dark cross when examined by polarized light. In dill, these grains are about 3 to $5 \mathrm{mkm}$. in diameter.

1 Matt. xxiii. 23,-where it has been rendererl anise by the English translators from Wicklif (1380) downwards. But in other versions, the word is corrcetly translated.

2 Heldreich, Nutzpfanzen Griechenlands (1862) 40 .

3 Langkavel, Botanik d. späteren Griechen, Berlin, 1866. 39.

4 Lecchdoms, \&c., edited by Cockayne, 186 $4-66$, - see especially Herbarium Apuleii, dating about A.D. 1050, in Vol. i. pp. 219. 235. 237. 281. 293.

5 Popular Names of British.Plants, 1570.

6 Volume of Vocabularies, edited by Wright, 1857.30 . 
Chemical Composition-Dill fruits yield on all average 2.8 per cent. (3.7 per cent. Pereira) of an essential oil, a large proportion of which was found by Gladstone (1864-1872) to be a hydrocarbon, $\mathrm{C}^{10} \mathrm{H}^{18}$, to which lie gave the name Ancthene. This substance has a lemon-like odour, sp. gr. 846 , and boils at $173^{\circ} \mathrm{C}$. It deviates a ray of polarized light strongly to the right.

Oil of dill also contains an oxygenated oil, $\mathrm{C}^{10} \mathrm{H}^{14} \mathrm{O}$, regarded by Gladstone as identical with carvol. It may be obtained as this chemist states ${ }^{1}$ either by fractional distillation (an imperfect method), or by taking advantage of the fact that oils of this group form crystalline bodies with hydrosulphuric acid, which can be easily purified and which yield the original oil when decomposed by an alkali. The oxidised oil from dill has the same odour as that from caraway, and likewise forms a crystalline compound when treated with sulphide of ammonium. in alcohol. It has a sp. gr. of 956 , and rctates the polarized ray to the right. Nothing is known of the other constituents of dill fruits.

Uses-The distilled water of dill is stomachic and carminative, and frequently prescribed as a vehicle for more active medicines. The seeds are much used for culinary and medicinal purposes by the people of India, but are little employed in Continental Europe.

\section{FRUCTUS CORIANDRI.}

\section{Semen Coriandri: Coriander Fruits, Coriander Seeds, Corianders;} F. Fruits de Coriandre; G. Koriander.

Botanical Origin-Coriandrum sativum L., a small, glabrous, annual plant, apparently indigenous to the Mediterranean and Caucasian regions, but now found as a cornfield weed throughout the temperate parts of Europe and Asia. It is cultivated in many countries, and has thus found its way even to Paraguay. In England the cultivation of coriander has long been carried on, but only to a very limited extent.

History-The plant owes its names Kópıov, Kopiavvov, and Kopıáv$\delta \rho o \nu$ to the offensive odour it exhales when handled, and which reminds one of bugs, -in Greek Kópıs. This character caused it to be regarded in the middle ages as having poisonous properties. ${ }^{2}$ The ripe fruits which are entirely free from the foetid smell of the growing plant, were used as a spice by the Jews and the Romans, and in medicine from a very early period. Cato, who wrote on agriculture in the 3rd century B.C., notices the cultivation of coriander. Pliny states that the best is that of Egypt.

Coriander, or as sometimes called Coliander, was well known in Britain prior to the Norman Conquest, aud often employed in ancient English medicine and cookery.

Cultivation-Coriander, called by the farmers Col, is cultivated in the eastern counties of England, especially in Essex. It is sometimes sown with caraway, and being an annual is gathered and harvested the first year, the caraway remaining in the ground. The seedling plants

\footnotetext{
1 Journ. of Chemical Society, x. (1872) 9 ; Pharm. Journ. March 1872. 746.

2 P. de Abbano, Tract. de Voncnis, $14 i 3$, capp. 25. 46 .
} 
are hoed so as to leave those that are to remain, in rows 10 to 12 incless apart. The plant is cut with sickles, and when dry the seed is thrashed out on a cloth in the centre of the ficld. On the best land, 15 cwt. jer acre is reckoned an average crop. ${ }^{1}$

Description-The fruit of coriander consists of a pair of hemispherical mericarps, firmly joined so as to form an almost regular globe, measuring on an average about $\frac{1}{5}$ of an inch in diameter, crowned by the stylopodium and calycinal teeth, and sometines by the slender diverging styles. The pericarp bears on each half, 4 perfectly straight sharpish ridges, regarded as secondary (juga seeundaria); two other ridges, often of darker colour, belonging to the mericarps in common, the separation of which takes place in a rather sinuous line. The shallow depression between each pair of these straight ridges, is occupied by a zigzag raised line (jugum primarium), of which there are therefore 5 in each mericarp. It will thus be seen that each mericarp has 5 (zigzag) so-called primary ridges, and 4 (keeled and more prominent) secondary, besides the lateral ridges which mark the suture or line of separation. There are no vittæ on the outer surface of the pericarp. Of the 5 teeth of the calyx, 2 often grow into long, pointed, persistent lobes: they proceed from the outer flowers of the umbel.

Though the two mericarps are closely united, they adhere only by the thin pericarp, enclosing when ripe a lenticular cavity. On each side of this cavity, the skin of the fruit separates from that of the seed, displaying the two brown vittæ of each mericarp. In transverse section, the albumen appears crescent-shaped, the concave side being towards the cavity. The carpophore stands in the middle of the latter as a column, connected with the pericarp only at top and bottom.

Corianders are smooth and rather hard, in colour buff or light brown. They have a very mild aromatic taste, and when crushed a peculiar fragrant smell. When unripe, their odour, like that of the fresh plant, is offensive. The nature of the chemical change that occasions this alteration in odour has not been made out.

The Indian corianders shipped from Bombay are of large size and of elongated form.

Microscopic Structure-The structural peculiarities of coriander fruit chiefly refer to the pericarp. Its middle layer is made up of thickwalled ligneous prosenchyme, traversed by a few fibro-vascular bundles which in the zigzag ridges vary exceedingly in position.

Chemical Composition-The essential oil of coriander has a composition indicated by the formula $\mathrm{C}^{10} \mathrm{H}^{18} \mathrm{O}$, and is therefore isomeric with borneol. If the elements of water are abstracted by phosphoric anhydride, it is converted according to Kawalier (1852) into an oil of offensive odour, $\mathrm{C}^{10} \mathrm{H}^{16}$.

The fruits yield of volatile oil about $\frac{1}{2}$ per cent.; as the vittæ are well protected by the woody pericarp, corianders should be bruised before being submitted to distillation. Trommsdorff found the fruits to afford 13 per cent. of fixed oil.

'The fresh herb distilled in July when the fruits were far from ripe, yielded to one of us (F.) from 0.57 to 1.1 per mille of an essential oil possessing in a high degree the disagreeable odour already alluded to. ${ }^{1}$ R. Baker, in Morton's Cyclopedia of Agriculture, i. (1855) 545. 
This oil was found to deviate the ray of polarized light $1 \cdot 1^{\circ}$ to the right when examined in a column $50 \mathrm{~mm}$. long. The oil distilled by us from ripe commercial fruit deviated $5 \cdot 1^{\circ}$ to the right.

Production and Commerce-Coriander is cultivated in various parts of Continental Europe, and as already stated, to a small extent in England. It is also produced in Northern Africa and in India. In $1872-73$, the export of coriander from the province of Sind ${ }^{1}$ was 948 cwt. from Bombay ${ }^{2}$ in the same year 619 cwt. From Calcutta ${ }^{3}$ there were shipped in 1870-71, 16,347 cwt.

Uses-Coriander fruits are reputed stimulant and carminative, yet are but little employed in medicine. They are however used in veterinary practice, and by the distillers of gin, also in some countries in cookery.

\section{FRUCTUS CUMINI.}

Fructus vel Semen Cymini; Cumin or Cummin ${ }^{4}$ Fruits, Cummin Seeds F. Graines dc Cumin; G. Mutterkümmel, Kreuzkümmel, Langer oder Römischer Kümmel, Mohrentümmel.

Botanical Origin-Cuminum Cyminum L., a small annual plant, indigenous to the upper regions of the Nile, but carried at an early period by cultivation to Arabia, India and China, as well as to the countries bordering the Mediterranean. The fruits of the plant ripen as far north as Southern Norway; but in Europe, Sicily and Malta alone produce them in quantity.

History-Cumin was well known to the ancients; it is alluded to by the Hebrew prophet Isaiah, ${ }^{5}$ and is mentioned in the gospel of Matthew ${ }^{6}$ as one of the minor titheable productions of the Holy Land.

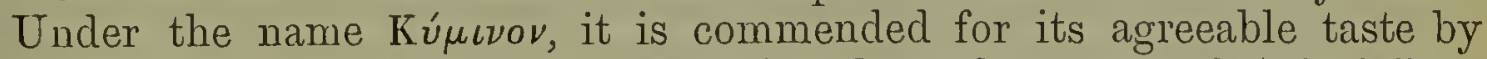
Dioscorides, in whose day it was produced on the coasts of Asia Minor and Southern Italy. It is named as Cuminum by Horace and Persius.

During the middle ages, cumin was one of the spices in most common use. Thus in A.D. 716, an annual provision of $150 \mathrm{tb}$. of cumin for the monastery of Corbie in Normandy, was not thought too large a supply. ${ }^{7}$ It was in frequent use in England, its average price between 1264 and 1400 , being a little over $2 d$. per $15 .{ }^{8}$ Cumin is enumerated in the Liber albus $^{9}$ of the city of London, compiled in 1419, among the merchandize on which the king levied the impost called scavage; and is mentioned 10 in 1453 as one of the articles of which the Grocers' Company had the weighing and oversight.

Description-The fruit, the colour of which is brown, has the usual

1 Statement of the Trade and Navigation of Sind for the year 1872-73, Karachi, 1873. 36 .

2 Ditto for Bombay, 1872-73. ii. 90.

3 Annual Volume of Trade, de. for the Bengal Presideney, 1870-71. 121.

4 Comyne in Wieklif's Bible (1380), Common in Tyndale's (1534), Commyn in Cranmer's (1538), C'ummine in the Authorized Version (1611), Cumin in Gerarde's Herbal (1636) and Paris's Pharmaeolngia (1822),
Cummin, Ray (1693) and in modern tradelists and price-currents.

5 Ch. xxviii. 25-27.

6 Ch. xxiii. 23.

7 Pardessus, Diplomata, etc., Paris, 1849. ii. 309 .

8 Rogers, Hist. of Agrieulture and Prices in England, 1866. i. 631, ii. 543-547.

9 Munimenta Gildhalloe Londoniensis, edited by Riley, i. (1859) 224.

10 Herbert, Hist. of the Great Livery Companies of London, 1834. 114. 
structure of the order; it is of an elongated ovoid form, tapering towards each end, and somewhat laterally compressed. The mericarps which do not readily separate from the carpophore, are about $\frac{1}{4}$ of an inch in length and $\frac{7}{10}$ of an inch in greatest breadth. Lach lins 5 primary ridges which are filiform, and scabrous or muriculate, and 4 secondary covered with rough hairs. Between the primary ridges is a single elongated vitta, and 2 vittre occur on the commissural surface. A transverse section of the seed shows a reniform outline. There is a form of C. Cyminum in cultivation, the fruit of which is perfectly glabrous.

Cumin has a strong aromatic taste and smell, analogous to but far less agreeable than that of caraway.

Microscopic Structure-The hairs are rather brittle, sometimes $\frac{1}{2} \mathrm{~mm}$. in length, formed of cells springing from the epidermis. The larger consist of groups of cells, vertically or laterally combined, and enclosed by a common envelope; the smaller of but a single cell ending in a rounded point. The whole pericarp is rich in tannic matter, striking with salts of iron a dark greenish colour.

The tissue of the seed is loaded with colourless drops of a fatty oil ; the vittæ with a yellowisls-brown essential oil. But the most striking contents of the parenchyme of the albumen consist of transparent, colourless, spherical grains, 7 to $5 \mathrm{mkm}$. in diameter, several of which are enclosed in each cell. Under a high magnifying power, they show a central cavity with a series of concentric layers around it, frequently traversed by radial clefts. Examined in polarized light, these grains display exactly the same cross as is seen in granules of starch, although their behaviour with chemical tests at once proves that they are by no means that substance; in fact iodine does not render them blue, but intensely brown. Grains of the same character, assuming sometimes a crystalloid form, occur in most umbelliferous fruits, and in many seeds of other orders. All these bodies are composed of albuminous and fatty matters; the more crystalloid form as met with in the seeds of Ricinus and in the fruit of parsley, is the body called by Hartig Aleuron.

Chemical Composition-Cumin fruits yielded to Bley (1829) $7 \cdot 7$ per cent. of fat oil, 13 per cent. of resin (?), 8 of mucilage and gum, $15 \cdot 5$ of albuminous matter, and a large amount of malates. Their peculiar, strong, aromatic smell and taste, depend on the essential oil of which they afford about 3 per cent. Trapp ${ }^{1}$ has shown that the fruits of Cicuta virosa $\mathrm{L}$. contain the same oil to the extent of about $1 \frac{1}{4}$ per cent. Oil of cumin is a mixture of Cymol or Cymene, $\mathrm{C}^{10} \mathrm{H}^{14}$, having sp. gr. 0.867 and boiling point $177^{\circ} \mathrm{C}$; and Cuminol or Cuminaldenydc, $\mathrm{C}^{10} \mathrm{H}^{12} \mathrm{O}$, of sp. gr. 0.972 , boiling point $236^{\circ} \mathrm{C}$., the proportion of the latter in the crude oil being about 56 per cent. It also contains the hydrocarbon $\mathrm{C}^{10} \mathrm{H}^{16}$, according to Warren (1865), and Beilstein and Kupffer (1873).

Cuminol possesses the smell and taste of cumin, while the odour of cymol more resembles that of lemons. Oil of cumin deviates a ray of polarized light $10 \cdot 2^{\circ}$ to the right: the optical power of each of its constituents is nearly the same, that of cuminol being the less strong. Cymol may also be obtained by submitting coal-tar to dry distillation, or by distilling camphor with anhydrous phosphoric acid or dry clloride

1 Ann. der Chem. u. Pharm. criii. (1858) 386. 
of zinc. Oppenheim (1872) has showed ${ }^{1}$ that oil of turpentine is to be considered as a hydride of cymol, and has indeed transformed terpin, the crystallized hydrate of the former into cymol. In the oil of Thymus vulgaris L., cymol exists ready formed.

Cuminol manifests the chemical properties of an aldehyde, inasmuch as it combines with alkaline bisulphites, and is easily transformed by oxidizing agents into the crystallizable Cuminic or Cumic Acid, $\mathrm{C}^{10} \mathrm{H}^{12} \mathrm{O}^{2}$. It also slowly oxidizes under the influence of air and water, yielding the same product. ${ }^{2}$

Commerce-Cumin is shipped to England from Mogador, Malta and Sicily. In Malta there were in 1863, 140 acres under cultivation with this crop; in 1865,730 acres, producing 2766 cwt. $^{3}$

The export of cumin from Morocco ${ }^{4}$ in 1872 was 1657 cwt. ; that from Bombay in the year 1872-73 was $6766 \mathrm{cwt}$. ${ }^{5}$ and 20,040 cwt. from Calcutta ${ }^{6}$ in the year $1870-71$.

Uses-Cumin is sold by druggists as an ingredient of curry powders, but to a much larger extent for use in veterinary medicine.

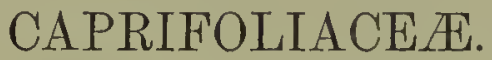

\section{FLORES SA M B U CI.}

\section{Elder Flowers; F. Fleurs de Sureau; G. Holunderblüthe, Fliederblumen.}

Botanical Origin-Sambucus nigra L.-a large deciduous shrub or small tree, indigenous to Southern and Central Europe, Western Asia, the Crimea, the regions of the Caucasus and Southern Siberia. It is believed to be a native of England and Ireland, but not to be truly wild in Scotland. In other northern parts of Europe, as Norway and Sweden, the elder appears only as an introduced plant.

History-The Romans, as we learn from Pliny, made use in medicine of the plant under notice as well as of the Dwarf Elder ( $S$. Ebulus L.) Both kinds were employed in Britain by the ancient English and Weish leeches, ${ }^{7}$ and in the medicine of the school of Salernum.

Description-The elder produces in the early summer, conspicuous, many-flowered cymes, 4 to 5 inches in diameter, of which the long peduncle divides into 5 branches, which subdivide once or several times by threes or fives, ultimately separating by repeated forking into slender, furrowed pedicels about $\frac{1}{4}$ of an inch long, each bearing a single flower. In the second or third furcations, the middle flower remains

1 Berichte der Deutsehon Chem. Gesellseh. 18 18. 97.

2 Fol further information on this oil see Gmelin, Chemistry, xiii. (1859) 8. 13 ; xiv. (1860) 143. 144. 148. 183.

3 Stalistieal Tables relating to the Colonial and other possessions of the United Kingdom, xi. 618.619 .

4 Consular Reports, Ang. 1873. 917.

5 Statement of the Trade and Navigntion of the Presideney of Bombay for 1872-73. pt. ii. 90.
${ }^{6}$ Annual Volume of Tranle, \&e. for the Bengal Presideney for 1870-71. 121.

7 Leechdoms, dee. of EarTy Englanch, edited by Coekayne, iii. (1866) 324. 347. According to the Rev. Edward Gillett (p. xxxii.), S. Ebulus is believed to have been brought to England by the Danes and planted on the battle-fields and graves of their countrymen. In Norfolk it still bears the name of Danewort and blood hilder (blood elder); also Physieians of Myddvai, tramslated by Pughe, Llandovery, 1851. 
short-stalked or sessile, and opens sooner than the rest. In like manner, on the outermost small forks only one of the florets is usually longstalked. The whole of this inflorescence for'ns a flattish umbelliform cyme, perfectly glabrous and destitute ol' bracts.

The calyx is combined with the ovary and bordered with 4 or 5 small teeth. The corolla, which is of a creamy white, is monopetalous with a very short tube and 5 spreading ovate lobes. The stamens which are about as long as the divisions of the corolla and alternate with them, are inserted in the tube of the latter. The yellow pollen which thickly powders the flower's, appears under the microscope 3 -pored. The projecting ovary is crowned by a 2 - or 3-lobed sessile stigma.

For use in pharmacy, the part of the flower most desirable is the corolla, to obtain a good proportion of which the gathered cymes are left for a few hours in a large heap ; the mass slightly heats, the corollas detach themselves, and are separated from the green stalks by shaking, rubbing, and sifting; they require to be then rapidly dried. 'This done, they become much shrivelled and assume a dull yellow tint. When fresh, they have a sweet faint smell, which becomes stronger and somewhat different by drying, and is quite unlike the repulsive odour of the fresh leaves and bark. Dried elder flowers have a bitterish, slightly gummy flavour. On the Continent they are sold with the stalks, i.e. in entire cymes.

Chemical Composition-Elder flowers yield a very small percentage of a butter-like essential oil, lighter than water, and smelling strongly of the flowers; it is easily altered by exposure to the air. ${ }^{1}$ The oil is accompanied by traces of volatile acids.

Uses-Elder flowers are only employed in British medicine for making an aromatic distilled water, and for communicating a pleasant odour to lard (Unguentum Sambuci). The leaves are sometimes used for giving a fine green tint to oil or fat, as in the Oleum viride and Unguentum Sambuci foliorum of the shops. The bark once much employed, is now obsolete.

\section{RUBIACEA.}

\section{GAMBIER.}

Catechu pallidum, Extractum Uncaria ; Gambier, Pale Catechn, Gambicr Catechu, Terra Japonica; F. Gambir, Cachou jaune; G. Gambir.

Botanical Origin-1. Uncaria Gambier Roxb. (Nauclea Gambir Hunter), a stout climbing shrub, supporting itself by means of its flowerstalks which are developed into strong recurved hooks. It is a native of the countries bordering the Straits of Malacca, and especially of the numerous islands at their eastern end; but according to Crawfurd ${ }^{2}$ it does not seem indigenous to any of the islands of the volcanic band. It also grows in Ceylon, where however no use is made of it.

2. U. acida Roxb., a plant nearly related to the preceding, and grow-

1 For further information, see Gmelin, Chemistry, xiv. (1860) 368.

2 Dictionary of the Indian Istands, 1856. 142. 
ing in the Malayan islands, appear's to be used in exactly the same manner.

History-Gambicr is one of the substances to which the name of Catcchu or Tcrrec Japonica is often applied; the other is Cutch, which has been alrealy described (p. 213). By druggists and pharnaceutists the two articles are frequently confounded, but in the great world of commerce they are reckoned as quite distinct. In many price-currents and tradelists, Catcchu is not found under that name, but only appears under the terms Cutch and Gambior.

Crawfurd asserts that gambier has been exported from time immemorial to Java from the Malacca Straits. This statement appears highly questionable. Rumphius, who resided in Amboyna during the second lialf of the 17th century, was a merchant, consul and naturalist; and in these capacities became thoroughly conversant with the products of the Malay Archipelago and adjacent regions, as the six folio volumes of his Hcrbarinm A mboinense illustrated by 587 plates, amply prove.

Among other plants, he figures ${ }^{1}$ Uncaria Gambier, which he terms Funis uncatus, and states to exist under two varieties, the one with broad, the other with narrow leaves. The first form, he says, is called in Malay Daun Gatta Gambir, on account of the bitter taste of its leaves, which is perceptible in the lozenges (trochisci) called Gatta Gambir, so much so that one might suppose they were made from these leaves, which however is not the case. He further asserts that the leaves have a detergent, drying quality by reason of their bitterness, which is mevertheless not intense but quite bearable in the mouth: that they are masticated instead of Pinong [Betel nut.] with Siri [leaf of Piper Betle] and lime: that the people of Java and Bali plant the first variety near their houses, for the sake of its fragrant flowers; but though they chew its leaves instead of Pinang, it must not be supposed that it is this plant from which the lozenges Gatta are compounded, or that indeed, is quite different.

Thus, if we may credit Rumphius, it would seem that the important manufacture of gambier had no existence at the commencement of the last century. As to "Gatta Gombir," his statements are scarcely in accord with those of more recent writers. We may however remark that that name is very like the Tamil Katta Kámbu, signifying Catechu, which drug is sometimes made into little round cakes, and was certainly a large export from India to Malacca and China as early as the 16th century (p. 213).

That gambier was unknown to Europeans long after the time of Rumphius, is evident from other facts. Stevens, a merchant of Bombay, in his Compleat Guide to the East India Trade, published in 1766, quotes the prices of goods at Malacca, but makes no allusion to gambier. Nor is there any reference to it in Savary's Dictionnaire dc Commerce (edn . of 1750), in which Malacca is mentioned as the great entrepôt of the trade of India with that of China and Japan.

The first account of gambier known to us, was communicated to the Batavian Society of Arts and Sciences in 1780 , by a Dutch trader named Couperus. This person narrates ${ }^{2}$ how the plant was introduced into

1 Herb. Amb. v. 63. tab. 34.

2 Verhandetingen van het Bataviaasch Genootschap, ii. (derde druk) 217-234. 
Malacca from Pontjan in 1758, and how gambier is made from its leaves; and names several sorts of the drug, and their prices.

In 1807, a description of - " the drug called Gutta Gambeer," and of the tree from which it is made, was presented to the Linnean Society of London. ${ }^{1}$ 'The writer, William Hunter, well known for scientific observations in comection with India, states that the substance is made chiefly at Malacca, Siak and Rhio, that it is in the form of small squares, or little round cakes almost perfectly white, and that the finer sorts are used for chewing with betel leaf in the same manner as catechu, while the coarser are shipped to Batavia and China for use in tanning and dyeing.

Manufacture-The gambier plant is cultivated in plantations. These were commenced in 1819 in Singapore, where there were at one time 800 plantations; but owing to scarcity of fuel, without an abundant supply of which the manufacture is impossible, and dearness of labour, gambier-planting was in 1866 fast disappearing from the island. ${ }^{2}$ The official Blue Book printed at Singapore in 1872, reports it as " much increased." It is largely pursued on the mainland (Johore), and in the islands of the Rhio-Lingg'a Archipelago, lying south-east of Singapore. On the island of Bintang, the most northerly of the group, there were in 1854 , 1,250 gambier-plantations.

The plantations are often formed in clearings of the jungle, where they last for a few years and are then abandoned ${ }^{3}$ owing to the impoverishment of the soil and the irrepressible growth of the lalang grass (Imperata Konigii P. de B.), which is more difficult to eradicate than even primæval jungle. It has been found profitable to combine with the cultivation of gambier that of pepper, for which the boiled leaves of the gambier form an excellent manure.

The gambier plants are allowed to grow 8 to 10 feet high, and as their foliage is always in season, each plant is stripped 3 or 4 times in the year. The apparatus and all that belongs to the manufacture of the extract, are of the most primitive description. ${ }^{4}$ A shallow cast-iron pan about 3 feet across, is built into an earthen fireplace. Water is poured into the pan, a fire is kindled, and the leaves and young shoots, freshly plucked, are scattered in, and boiled for about an hour. At the end of this time, they are thrown on to a capacious sloping trough, the lower end of which projects into the pan, and squeezed with the hand so that the absorbed liquor may run back into the boiler. The decoction is then evaporated to the consistence of a thin syrup, and baled out into buckets. When sufficiently cool, it is subjected to a curious treatment:-instead of simply stirring it round, the workman pushes a stick of soft wood in a sloping direction into each bucket; and placing two such buckets before him, he works a stick up and down in each. The liquid thickens round the stick, and the thickened portion being constantly rubbed off, while at the same time the whole is in motion, it gradually sets into a mass, a result which the workman affirms would never be produced by simple stirring round. ${ }^{5}$ Though we are not prepared to concur in the workman's

1 Linn. Trans. ix. (1808) 218-224.

2 Collingwood, Journ. of Limn. Soc, Bot., x. (1869) 52 .

3 This abuse of land has been repressed in Singapore.
4. We borrow the following account, which is the best we have met with, from Jagor's Singapore, Malacca, und Java, Berlin, 1 \&66. 64.

$s$ Whether the kind of rood used for 
opinion, it is reasonable to suppose that his manner of treating the liquor favours the crystallization of the catechin in a more concrete form than it might otlerwise assume. The thickened mass, which is said by another writer to resemble soft yellowish clay, is now placed in shallow square boxes, and when somewhat hardened, is cut into cubes and dried in the slrade. The leaves are boiled a second time, and finally washed in water, which water is saved for another operation.

A plantation with five labourers, contains on an average 70,000 to 80,000 shrubs, and yields 40 to 50 catties $\left(1\right.$ catty $\left.=1 \frac{1}{3} \mathrm{7b}\right)$ of gambier daily.

Description-Gambier is an earthy-looking substance of light brown hue, consisting of cubes about an inch each side, more or less agglutinated, or it is in the form of entirely compact masses. The cubes are externally of a dark reddish brown and compact, internally of a pale cinnamon hue, dry, porous, friable, devoid of odour, but with a bitterish astringent taste, becoming subsequently sweetish. Under the microscope, the cubes of gambier are seen to consist of very small acicular crystals.

Chemical Composition-In a chemical point of view, gambier agrees with cutch, especially with the pale variety made in Northern India (p. 214). Both substances consist mainly of Catechin or Catechuic Acid; this may be obtained in the hydrated state as slender colourless needles, by exhausting gambier with cold water, and crystallizing the residue from 3 or 4 parts of hot water. Gambier, like cutch, dissolves in hot water, forming a liquid which on cooling deposits a copious precipitate. Ferric chloride strikes with this solution much diluted, a green tint. Alkaline cupric solutions throw down from a decoction of gambier a red powder, which however does not appear to consist of cuprous oxide.

The yellowish colouring matter of gambier was determined by Hlasiwetz (1S67) to be Quercetin, which is also a constituent of cutch. Some fine gambier in regular cubes which we incinerated, left 2.6 per cent. of ash, consisting mainly of carbonates of calcium and magnesium. As many species of Nauclea contain, according to De Vry, Quincvic Acid, it is probable that substance may be detected in gambier.

Commerce-Singapore, which is the great emporium for gambier, exported in 1871 no less than 34,248 tons, of which quantity 19,550 tons had been imported into the colony chiefly from Rhio and the Malayan Peninsula. ${ }^{2}$

The quantity imported into the United Kingdom in 1872 was 21,155 tons, value $£ 451,737$, almost the whole being from the Straits Settlements.

Uses-Gambier, under the name of Catechu, is used medicinally as an astringent, but the quantity thus consumed is as nothing in comparison with that employed for tanning and dyeing.

stirring, influences the setting of the liquid, is doubtful; but the effect is described by Secmann as extraordinary. The wood which Jagor saw used, was that of Artocarpus incisa, but he was told that any sort of soft wood would answer as well.
1 Pharm. Journ. vi. (1865) 18.

2 Blue Book of the Colony of the Straits Settlements for 1871 . 


\section{CORTEX CINCHONÆ.}

\section{Cortex Peruvianus, Cortex Chine; Cinehona Bark, Peruvian Bark; F. Eeoree de Quinquina; G. Chinarinde.}

Botanical Origin-The genus Cinchona from which the drug under notice is derived, constitutes together with several nearly allied genera, the well-characterised tribe Cinchonea of the order Rubraeea. This tribe consists of shrubs or trees with opposite leaves, 2-celled ovary, capsular fruit, and numerous minute, vertical or ascending, peltate, winged, albuminous seeds.

(A). Remarks on the genus.-The genus Cineliona is distinguished by deciduous stipules, flower's in terminal panicles, 5 -toothed superior calyx, tubular corolla expanding into 5 lobes fringed at the margin. The corolla is of an agreeable odour, and of a rosy or purplish hue or white.

The fruit is a capsule of ovoid or subcylindrical form, dehiscing from the base (the fruitstalk also splitting) into two valves, which are held together at the apex by the thick permanent calyx. The seeds, 30 to 40 in number, are imbricated vertically; they are flat, winged all round by a broad membrane, which is very irregularly toothed or lacerated at the edge.

The Cinchonas are evergreen, with finely-veined leaves, traversed by a strong midrib. The thick leafstalk often of a fine red, is sometimes a sixth the length of the whole leaf, but usually shorter. The leaves are ovate, obovate, or nearly circular; in some species lanceolate, rarely cordate, always entire, glabrous or more rarely hirsute, often variable as to size and form in the same species.

Among the valuable species, several are distinguished by small pits called scrobieuli, situated on the under side of the leaf, in the axils of the veins which proceed from the midrib. These pits sometimes exude an astringent juice. In some species they are replaced by tufts of hair. The young leaves are sometimes purplish on the under side; in several species the full-grown foliage assumes before falling, rich tints of crimson or orange.

The species of Cinchona are so much alike that their definition is a matter of the utmost difficulty, and only to be accomplished by resorting to a number of characters which taken singly are of no great importance. Individual species are moreover frequently connected together by wellmarked and permanent intermediate forms, so that according to the expression of Howard, the whole form a continuous series, the terminal members of which are scarcely more sharply separated from the allied genera, than from plants of their own series.

As to the number and value of the species known, there is some diversity of view. Weddell, in 1870, enumerated 33 species and 18 sub-species, besides numerous varieties and sub-varieties. Bentham and Hooker, ${ }^{1}$ in 1873, estimated the species as about 36.

(B). A rea, Climate and Soil.-The Cinchonas are all natives of Sonth America, where they occur exclusively on the western side of the conti- 
nent between $10^{\circ} \mathrm{N}$. lat. and $22^{\circ} \mathrm{S}$. lat.,-an area which includes portions of Venezuela, New Granada, Ecuador, Peru, and Bolivia.

The plants are found in the mountain regions, no species whatever being known to inhabit the low alluvial plains. In Peru and Bolivia, the region of the Cinchona forms a belt, 1300 miles in length, occupying the eastern slope of the Cordillera of the Andes. ${ }^{1}$ In Ecuador and New Granada, the tree is not strictly limited to the eastern slopes, but occurs on other of the Andine ranges.

The average altitude of the cinchoniferous region, is given by Weddell as 5,000 to 8,000 feet above the sea-level. The highest limit, as noted by Karsten, is 11,000 feet. One valuable species, C. succirubra; occurs exceptionally as low as 2,600 feet. Generally, it may be said that the altitude of the Cinchona zone decreases in proportion as it recedes from the equator, and that the most valuable sorts are not found lower than 5,000 feet.

The climate of the tropical mountain regions in which the Cinchonas flourish, is extremely variable,-sunshine, showers, storms, and thick mist, alternating in rapid succession, yet with no very great range of temperature. A transient depression of the thermometer even to the freezing point, and not unfrequent hail-showers, may be borne without detriment by the more hardy species. Yet the mean temperature most favourable for the generality of species, appears to be 12 to $20^{\circ} \mathrm{C}$. (54 to $68^{\circ} \mathrm{F}$.)

Climatic agencies appear to influence the growth of Cinchona far more than the composition of the soil. Though the tree occurs in a great variety of geological formations, there is no distinct evidence that these conditions control in any marked manner, either the development of the tree or the chemical constitution of its bark. Manure on the other hand, though not increasing perceptibly luxuriance of growth, has a decided effect in augmenting the richness of the bark in alkaloids. ${ }^{2}$

(C). Species yielding officinal barks. - The Cinchona Barks of commerce are produced by about a dozen species; of these barks the greater number are consumed solely in the manufacture of quinine. Those admitted for pharmaceutical use, are afforded by the following species :-

1. Cinchonc officinalis Hooker ${ }^{3}-\mathrm{A}$ native of Ecuador and Peru, existing under several varieties. It forms a large tree, having lanceolate or ovate leaves, usually pointed, glabrous and shining on the upper surface, and scrobiculate on the under. The flowers are small, pubescent and in short lax panicles, and are succeeded by oblong or lanceolate capsules, $\frac{1}{2}$ an inch or more in length.

2. C. Caliscrya Weddell-Discovered by Weddell in $1847,{ }^{4}$ although its bark had been an object of commerce since the latter half of the previous century.

The tree inhabits the warmest woods of the declivities which border the valleys of Bolivia and South-eastern Peru, at an altitude of 5,000 to 6,000 feet above the sea-level. More precisely, the chief localities for

1 That is to say the enstern Cordillera, the western and lower range being caller the Cordillera of the Coast; no Ciwchonas grow on the latter.

2 Broughton, in Pharm. Journ. Jan 4, 1873. 521 .
3 Figured in Bot. Magazine, vol. 89 (1\&63) tab. 5364, including C. Condaminea Humb. et Bonpl. and C. Uritusinga Pavon.

${ }_{4}$ Ann. des Sciences nat., Bot. x. (1848) 6, and Hist. nat. des Quinquinas, 1849, tah. 3, figttred in Botenical Magazine, 1873. 6052. 
the tree are the Bolivian provinces of Enquisivi, Yungas de la Paz, Larecaja or Sorata, Caupolican or Apolobamba, and Muñecas: thence it passes northward into the Peruvian province of Carabaya, suddenly ceasing on the confines of the valley of Sandia, although as Weddell observed, the adjacent valleys are to all appearance precisely similar.

When well grown, C. Calisaya has a trunk often twice as thick as a man's body, and a magnificent crown of folinge overtopping all other trees of the forest. It has ovate capsules of about the same length ( $\frac{1}{2}$ an inch) as the elegant pinkish flowers, which are in large pyramidal panicles. The leaves are 3 to 6 inches long, of very variable form, but usually oblong and obtuse, rarely acute.

A variety named after Joseph de Jussieu who first noticed it, $\beta$. Josephiana, but known in the country as Ichu-Cascarilla or Cascarilla del Pajonal, differs from the preceding in that it is a shrub, 6 to 10 feet high, growing on the borders of mountain meadows and of thickets in the same regions as the larger form.

Other forms known in Bolivia as Calisaya zamba, morada, verde or alta, and blanca, have been distinguished by Weddell as varieties of $C$. Calisaya.

3. C. succirubra Pavon, ${ }^{1-a}$ magnificent tree, 50 to 80 feet high, formerly growing in all the valleys of the Andes which debouch in the plain of Guayaquil. The tree is now almost entirely confined to the forests of Guaranda on the western declivities of Chimborazo, at 2,000 to 5,000 feet above the level of the sea.

The bark appears to have been appreciated in its native country at an early period, if we may conclude that the Red Bark mentioned by La Condamine in 1737, was that under notice. It would seem, however, to have scarcely reached Europe earlier than the second half of the last century. ${ }^{2}$ The tree has broadly oval leaves, attaining about a foot in length, nearly glabrous above, pubescent beneath, large terminal panicles of rosy flowers, succeeded by oblong capsules, 1 to $1 \frac{1}{4}$ inches long.

The other species of Cinchona, the bark of which is principally consumed by the manufacturers of quinine, will be found briefly noticed together with the foregoing, in the conspectus at page 318 .

History-The early native history of Cinchona is lost in obscurity. No undoubted proofs bave been handed down, to show that the aborigines of South America had any acquaintance with the medicinal properties of the bark. But traditions are not wanting.

William Arrot, ${ }^{3}$ a Scotch surgeon who visited Peru in the early part of the last century, states that the opinion then current at Loxa, was that the qualities and use of the barks of Cinchona were known to the Indians before any Spaniard came among them. Condamine, as well as Jussieu, heard the same statements, which appear to have been generally prevalent at the close of the 17 th century.

It is noteworthy on the other hand, that though the Peruvians tenaciously adhere to their traditional customs, they make no use at the present day of Cinchona bark, but actually regard its employment with repugnance.

1 Figured in Howard's Nueva Quinologia, art. Chinchona succirubra.
${ }^{3}$ Howard, l.c. p. 9.

3 Phil. Trans. xl. for $173 ;-38$. 51 . 
Humboldt ${ }^{1}$ declares that at Loxa, the natives would rather die than have recourse to what they consider so dangerous a remedy. Pöppig ${ }^{2}$ (1830) found a strong prejudice to prevail among the people of Huanuco against Cinchona as a remedy for fevers, and the sane fact was observed farther north by Spruce ${ }^{3}$ in 1861 . The latter traveller narrates, that it was impossible to convince the cascarilleros of Ecuador that their Red Bark could be wanted for any other purpose than dyeing cloth; and that even at Guayaquil there was a general dislike to the use of quinine.

Markham ${ }^{4}$ notices the curious fact that the wallets of the native itinerant doctors, who from father to son have plied their art since the days of the Incas, never contain cinchona bark.

Although Peru was discovered in 1513, and had submitted to the Spanish yoke by the middle of the century, no mention has been found of the febrifuge bark with which the name of the country is connected, earlier than the commencement of the 17th century.

Joseph de Jussieu, ${ }^{5}$ who visited Loxa in 1739 , relates that the use of the remedy was first made known to a Jesuit missionary, who being attacked by intermittent fever, was cured by the bark administered to him by an Indian cacique at Malacotas, a village near Loxa. The date of this event is not given. The same story is related of the Spanish corregidor of Loxa, Don Juan Lopez de Canizares, who is said to have been cured of fever in 1630 .

Eight years later, the wife of the viceroy of Peru, Luis Geronimo Fernandez de Cabrera y Bobadilla, fourth count of Chinchon, having been attacked with fever, the same corregidor of Loxa sent a packet of powdered bark to her physician Juan de Vega, assuring him of its efficacy in the treatment of "tcrtiana." The drug fully bore out its reputation, and the countess Ana was cured. ${ }^{6}$ Upon her recovery, she caused to be collected large quantities of the bark, which she used to give away to those sick of fever, so that the medicine came to be called Polvo de la Condesa, i.e. The Countess' Powder. It was certainly known in Spain the following year (1639), when it was first tried at Alcala de Henares near Madrid. ${ }^{7}$

The introduction of Peruvian Bark into Europe is described by Chifflet, physician to the archduke Leopold of Austria, viceroy of the Netherlands and Burgundy, in his Pulvis Febrifugus Orbis Americani ventilatus, published at Brussels in 1653. He says that among the wonders of the day, many reckon the tree growing in the kingdom of Peru, which the Spaniards call Palo de Calenturas, i.e. Lignum febrium. Its virtues reside chiefly in the bark, which is known as China febris, and which taken in powder drives off the febrile paroxysms. He further states, that during the last few years the bark has been imported into Spain,

1 Der Gescllsch. naturf. Freunde zu Berlin Magaz. i. (1807) 60.

${ }_{2}$ Reise in Chile, Peru, etc. ii. (1836) 222.

3 Blue Book - East India Chinchona Plant, 1863. 74. 75 .

4 Travels in Peru and India, 1862. 2.

5 Qunted by Weddell in his Hist. res Quinquinas, p. 15, from De Jussien's unpublished MS. - The town of Loxa or Loja was founded by the Spaniards in 1546 .

6 'The cireumstanees are fully narrated by
La Condamine (Mém. de l'Acad. royale des Sciences, année 1738). But the cure of the conntess was known in Europe much before this, for it is mentioned by Sebastiano Bado in his Anastasis, Corticis Peruvio, seu Chince Chince defensio, published at Genoa in 1663. When Pado wrote, it was a debated question whether the bark was introduced to Europe by the eount of Chinchon or by the Jesuit Fathers.

7 Villerobel, quoted by Bado, op. cit. 202. 
and thence sent to Cardinal Joannes de Lugo $^{1}$ at Rome. Chifflet adds, that it has been carried from Italy to Belgium by the Jesuit Fathers going to the election of a general, but that it was also brought thither direct from Peru by Michael Belga, who had resided some years at Lima.

Chifflet, thongh candidly admitting the efficacy of the new drug when properly used, was not a strong advocate for it; and his publication started an acrimonious controversy, in which Honoratius Faber, a Jesuit (1655), Fonseca physician to Pope Innocent X., Sebastiano Bado ${ }^{2}$ of Genoa (1656 and 1663), and Sturm (1659) appeared in defence of the febrifuge; while Plempius (1655), Glantz an imperial physician of Ratisbon (1653), Godoy physician to the king of Spain (1653), René Moreau (1655), Arbinet and others contended in an opposite sense.

From one of these disputants, Roland Sturm, a doctor of Louvain, who wrote in $1659,{ }^{3}$ we learn that four years previously, some of the new febrifuge had been sent by the archduke Leopold to the Spanish ambassador at the Hague, and that he (Sturm) had been required to report upon it. He further states, that the medicine was known in Brussels and Antwerp, as Pulvis Jesuiticus, because the Jesuit Fathers were in the habit of administering it gratis to indigent persons suffering from quartan fever; but that it was more commonly called Pulvis Peruanus or Peruvianum Febrifugum, while at Rome it bore the name of Pulvis eminentissimi Cardinalis de Lugo, because Cardinal de Lugo used to give it away to the poor:- that it was very scarce:- that in 16.58, he saw 20 doses sent to Paris which cost 60 florins. He gives a copy of the handbill ${ }^{4}$ which the apothecaries of Rome used to distribute with the powder.

The drug began to be known in England about 1655.5 The Mereurius Politicus, one of the earliest English newspapers, contains in several of its numbers for $1658,{ }^{6}$ a year remarkable for the prevalence in England of an epidemic remittent fever, advertisements offering for sale- "the exelllent powder known by the name of the Jesuits' Powder"-brought over by James Thompson, merchant of Antwerp.

Brady, professor of physic at Cambridge, prescribed bark about this

I The cardinal belonged to a family of Seville, which town had the monopoly of the trarle with America.

2 Bado in his Anastasis, lib. 3, quotes the opinion of many persons as coinciding with his own.

3 Febrifugi Peruviani Vindiciarum pars prior-Pulveris Historiam complectens ejusque vires et proprictates . . exhibens, Delphis, 1659 . $12^{\circ}$.

4 It is in these words :-Modo di adoprare la Corteccia chiamata della Febre.-Questa Corteccia si porta dal Regno di Peru, e si chiama China, o vero China della febre, laquale si adopra per le febre quartaua, e tcrzana, che venga con freddo: s'adopra in questo modo, cioe :

Se ne piglia dramme due, e si pista fiua, con passarla per setaccio; c trc liore prima incirca, che debba venir la febre si mette in infusione in un bicchiero di villo bianco gagliardissimo, e quando il freddo com- mincia d̀ venire, ò si sente qualche minimo principio, si prende tutta la presa preparata, e si mette il patiente in letto.

Avertasi, si potrà dare detta Corteccia nel modo sudetto nella febre terzana, quaudo quella sia fermata ill stato di molti giorui.

L'esperienza continua, hà liberata quasi tutti quelli, che l'hanno presa, purgato prima bene il corpo, e per quattro giorni doppo non pigliar' niuna sorte di medicamento, ma auvertasi di uou darla se non con licenza delli Sig. Medici, acciò giudicauo so sia in tempo à proposito di pigliarla.

5 So says Sir G. Baker, who has traced the introduction of Cinchona in a very able paper published in the Medical Transactions of the College of Physicians of Loudon, ii. (1785) 141-216.

6 Namely No. 422. Jnne 24-July 1 ; No. 426. July 22-29; No. 439. Oct. 21-2s; No. 545. Dec. 9-16. - We lave cramined the copy at the British Muscum. 
time; and in 1660, Willis, a physician of great eminence, reported it as coming into daily use.

Among those who contributed powerfully to the diffusion of the new medicine, was Robert Talbor atias Tabor. This singular personage having been apprenticed to an apothecary of Cambridge, settled in Essex where he practised medicine with much success. He afterwards came to London, and in 1672 published a small book called Pyretologia, $a$ rational account of the cousc and cure of agucs (London, $12^{\circ}$ ). In this work, he by no means intimates that his method of cure depends on the use of bark. On the contrary, he cautions his readers against the dangerous effects of Jesuits' Powder, when administered by unskilful persons, yet admits that properly given, it is a "noble and safe medicine."

Talbor's reputation increasing, he was appointed in 1678, physician in ordinary to Charles II., and on $27 \mathrm{July}$ of the same year, received the honour of knighthood at Whitehall. But he was not a member of the College of Physicians; and to save him from attack, the king caused a letter to be written restraining that body from interfering with him in his medical practice. ${ }^{2}$ The following year, the king being ill of tertian fever at Windsor, Talbor cured him by his secret remedy.3

The same year Talbor visited France and Spain ${ }^{4}$; and in the former country had the good fortune to cure the Dauphin of an attack of fever, and also treated with success other eminent persons. ${ }^{5}$ These happy results brought him into favour with Louis XIV., who induced him in consideration of a sum of 2,000 louis d'or and an annual pension of 2,000 livres, to explain his mode of treatment, which proved to consist in the administration of considerable doses of cinchona bark infused in wine. ${ }^{6}$

Talbor did not long enjoy his prosperity, for he died in 1681, aged about 40 years. ${ }^{7}$ Upon his death, Louis XIV. ordered the publication of Talbor's method of cure, which accordingly appeared in 1682 in a small volume by Nicolas de Blegny, surgeon to the king. ${ }^{8}$ This was im-

1 This appointment marle in eonsideration of- "good and aceeptable serviees performed," led to the issuing of a patent under the Privy Seal, dated 7 August, 1678, granting to Sir Robert Talbor, an annuity of if 100 per annum, together with the profits and privileges appertainiug to a physician in ordinary to the sovereign.

2 Baker, l.c. - The physieians both in England and France were exeeedingly jealous of the suecesses of an irregular practitioner like Talbor, and averse to admit the merits of his praetiee. Yet D'Aquin, first physician to Louis XIV., preseribed Vin dc Zuinquina, as well as powdered bark, for the King in 1686. - See J. A. le Roi, Journal de la santé du roi Louis XIV., Paris, 1862. 171. 431.

3 Recueil des'nouvcllcs etc. pendant l'année 1679 (Paris, 1780) 466.-This ineludes the Gazctte dc France, 23 Sept. 1679.-In the Recueil of the following year (p. 275), the King is said to have had anotlier attack of fever at Windsor, for which he took "du Quinquina préparé," which again eured him. 4 IIis journey to the latter country was made in the suite of the young queen of Spain, Louise d'Orléans, niece of Louis XIV., of whom he is described as premier médecin.
During Talbor's absenee, his praetice in London was carried on by his brother, Dr. John Talbor, as is proved by an advertisement in the True News or Nercurius Anglicus, January 7-10, 1679.

5 Lettres de Madame de Sévigné, nouv. éd. tome $\nabla$. (1862) 559 ; also tome vi., letters of 15 and 29 Sept. and 6 Oet. 1679 .

6 Les admirables qualitez du Kinkina con. firmées par plusieurs expériences, Paris, 1689. $12^{\circ}$.

7 He was buried in Trinity Church, Cambridge, where a monumental inseription deseribes him as-"Febrium malleus" -and physician to Charles II., Louis XIV., and the Dauphin of France. In Talbor's will, proved by his widow Dame Elizabeth, 18 Nov. 1681, and preserved at Doctors' Commons, mention is made of an only son, Philip Louis.

8 Le Rcmède anglois pour la guérison des fievres, publić par ordrc du Roy, avcc les observations de Monsieur lc premicr Médccin de sa Majesté, sur la composition, les vertus, et l'usage de ce remiède, par Nieolas de Blegny, Chirurgien ordinaire du eorps de Monsieur, et Direeteur de l'Académie des nouvelles dé. couvertes de Médecino, Paris, 1862. $12^{\circ}$. 
mediately translated into English, under the title of The English Remedy: or, Talbor's WVonderful Secrel for Cureing of Ayues and Feavcrs. - Sald by the Author Sir Robert Talbor to the most Christian King, and since his Death, ordered by his Majesty to be mublished in French, for the benefet of his sulijects, and now translated into English fur Problick Good (Iond. I (182).

Cinchona bark was now accepted into the domain of regular medicine, though its efficacy was by 110 means universally acknowledged. It first appeared in the London Pharmacopoia in 1677, under the name of Cortex Peruanus.

For the first accurate information on the botany of Cinchona, science is indebted to the French. ${ }^{1}$

Charles-Marie de la Condamine, while occupied in common with Bouguer and Godin, as an astronomer fron 1736 to 1743 , in measuring the arc of a degree near Quito, availed himself of the opportunity to investigate the origin of the famous Peruvian Bark. On the 3rd and

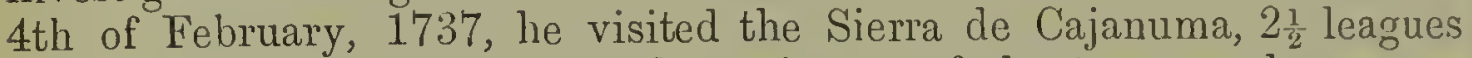
from Loxa, and there collectcd specimens of the tree now known as Cinchona offieinalis var. a. Condaminea. At that period, the very large trecs had already become rare, but there were still specimens having trunks thicker than a man's body. Cajanuma was the home of the first cinchona bark brought to Europe; and in early times it enjoyer such a reputation, that certificates drawn up before a notary were provided, as proof that parcels of bark were the produce of that favoured locality. ${ }^{2}$

Joseph de Jussieu, botanist to the French expedition with which La Condamine was connected, gathered, near Loxa in 1739, a second Cinchona subsequently named by Vahl, C. pubescens, a species of no medicinal value.

In 1742, Linnæus established the genus Cinchona, ${ }^{3}$ and in 1753 first described the species $C$. officinalis, recently restored and exactly characterised by Hooker, aided by specimens supplied to him by Mr. Howard.

The cinchona trees were believed to be confined to the region around Loxa, until 1752 when Miguel de Santisteban, superintendent of the mint at Santa Fé, discovered some species in the neighbourhood of Popayan and Pasto.

In 1761, José Celestino Mutis, physician to the Marquis de la Vega, viceroy of New Granada, arrived at Carthagena from Cadiz, and immediately set about collecting materials for writing a Flora of the country. This undertaking he carried on with untiring energy, especially from the year 1782 until the end of his life in 1808,first for seven years at Real del Sapo and Mariquita at the foot of the Cordillera de Quindiu, and subsequently at Santa Fé de Bogotá.

I Sur l'arbre de Quinquina par M. de la Condamine-Mém. de l'Aeadémic royale des Scienees pour l'année 1738. pp. 226-243, with two plates.

2 This elassic spot in the history of Cinchona, was visited in September 1861 by Robert Cross, who sueeeeded in bringing therefrom an abundant supply of the seeds of $C$. offieinalis var. Condaminea, which in February of the year following, germinated freely at Ootacamund in India.
3 Markham has vigorously contended that the Linnxan name Cinchona should be altered to Chinchona as more in aeeordanee with the derivation of the word, and as better commemorating the serviees of the eountess of Chinchoul. But the ineonvenienee of ehanging so well-established a name and its many derivatives, has outweighed these eonsiderations; and $M$ r. Markham's proposal has not met with general aeeeptance either by botanists, pharmaeeutists or ehemists. 
Mutis gave up his medical appointment in 1772, for the purpose of entering a religions order, and ten years later was entrusted by the Govermment with the establishment and direction of a large museum of natural history, first at Mariquita, afterwards at Santa Fé.

A position similar to that of Mutis in New Granada, had also been conferred in 1777 on the botanists Hipolito Ruiz and José Pavon with regard to Southern Peru, whence originated the well-known Flora Peruviana et Chilensis, ${ }^{1}$ as well as most important direct contributions to our knowledge on the subject of Cinchona.

About the same time (1776), Renquizo (Renquifo or Renjifo) found cinchona trees in the neighbourhood of Huanuco, in the central tract of Peru, whereby the monopoly of the district of Loxa was soon broken up.

Numerous and important quinological discoveries were subsequently made by Mutis, or rather by his pupils Caldas, Zea, and Restrepo, ${ }^{2}$ as well as on the other hand by Ruiz and Pavon, and their successors Tafalla and Manzanilla. Mutis did not bring his labours to any definite conclusion, and his extensive botanical collections and 5,000 coloured drawings, were sent to Madrid only in 1817, and there remained in a lamentable state of neglect.

Some of his observations first appeared in print in 1793-94, under the title of El Areano de la Quina in the Diario, a local paper of Santa Fé, and were reprinted at Madrid in 1828 by Don Manuel Hernandez de Gregorio. The botanical descriptions of the cinchonas of New Granada, forring the fourth part of the Areano, remained forgotten and lost to science until rescued by Markham and published in 1867.3 The drawings belonging to the descriptions were photographed and engraved a little later, and form part of Triana's Nouvelles Etudes sur les Quinquinas, which appeared in 1870 .

The two Peruvian botanists succeeded somewhat better in securing their results. Ruiz in 1792, in his Quinologia, ${ }^{4}$ and in 1801 conjointly with Pavon in a supplement thereto, ${ }^{5}$ brought together a portion of their important labours relating to cinchona. But an essential part called Nueva Quinologia, written between 1821 and 1826, remained unpublished ; and after an oblivion of over thirty years, it came by purchase into the hands of Mr. John Eliot Howard who published it, and with rare liberality enriched it with 27 magnificent coloured plates, mostly taken from the very specimens of Pavon lying in the herbarium of Madrid.

Between the pupils of Mutis on the one hand, and those of Ruiz and Pavon on the other, there arose an acrimonious controversy regarding their respective discoveries, which has been equitably summarized by Triana in the work just mentioned.

Production-The hardships of bark-collecting in the primeval forests of South America are of the severest kind, and undergone only by the half-civilized Indians and people of mixed race, in the pay of speculator's or companies located in the towns. Those who are engaged

1 Published at Madrid, 1798-1802, in 4 volumes folio, with 425 plates.

2 “. Mutis u'avait qu'une notion inexacte et confuse du genre Cinchona et de ses véritables caraetèr''s ; c'est en définitive qu'ancune de ses espèces, dans lo sens strict du mot, n'a été reconnue ni déeouvertc par hui."-'Triana, Nouv. Etudes, p. 8.
3 Markhnm, Chinchona Species of New Granada, Lond. 1867.

${ }_{4}$ Quinologia, 6 tratado del arbol de la Quina ó Cascarilla, Madrid, 1792. $4^{\circ}$. Pl. 103.

5 Supplemento a la Quinologia, Madrid, 1801. $4^{\circ}$. pp. 154. 
in the business, especially the collectors themselves, are called Cascarilleros or Cascadures, from the Spanish word Cascara, bark. A majordomo at the hend of the collector's, directs the proceedings of the several bauds in the forest itself, where provisions and afterwards the produce are stowed away in huts of slight construction.

Arrot in 1736, and Weddell and Karsten in our own day, have given from personal observation, a striking pictnle of these operations.

'The cascarilleto having found his tree, has usually to free its stem from the luxuriant chimbing and parasitic plants with which it is encircled. This done, he begins in most cases at once to remove after a previous beating, the sapless layer of outer bark. In order to detach the valuable inner bark, longitudinal and transverse incisions are made as high as can be reached on the stem. The tree is then felled, and the peeling completed. In inost cases, but especially if previously beaten, the bark separates easily from the wood. In many localities it has to be dried by a fire made on the floor of a hut, the bark being placed on hurdles above, - a most imperfect arrangement. In Southern Peru and Bolivia however, according to Weddell, even the thickest Calisaya bark is dried in the sun without requiring the aid of fire.

The thinner bark as it dries, rolls up into tubes or quills called canutos or canutillos, while the pieces stripped from the trunks are made to dry flat by being placed one upon another and loaded with weights, and are then known as plancha or tabla. The bark of the root was formerly neglected, but is now in several instances brought into the market.

After drying, the barks are either assorted, chiefly according to size, or all are packed without distinction in sacks or bales. In some places, as at Popayan, the bark is even stamped, in order to reduce its bulk as much as possible. The dealers in the export towns enclose the bark in serons ${ }^{1}$ of raw bullock-hide, which, contracting as it dries, tightly compresses the contents (1.00 $\mathrm{tb}$. or more) of the package. In many places however, wooden chests are used for the packing of bark.

Conveyance to the Coast and Commercial Statistics-The ports to which bark is conveyed for shipment to Europe, are not very numerous.

Guayaquil on the Pacific coast is the most important for the produce of Ecuador. The quantity shipped thence in 1871 was 7,859 quintals. ${ }^{2}$ Pitayo bark is largely exported from Buenaventura in the Bay of Chocó further north.

Payta the most northerly port of Peru, and Callao the port of Lima likewise export bark, the latter being the natural outlet for the barks of Central Peru from Huanuco to Cusco.

Islay, and more particularly Arica, receive the valuable barks of Carabaya and of the high valleys of Bolivia. The barks of Pern and Bolivia now find an outlet also by the Amazon and its tribntaries, and are shipped to Europe from ports of Brazil. Howard ${ }^{3}$ has given an interesting account of one of the first attempts to utilize this eastern route, made by Senr. Pedro Lada in 1868.

There is a large export of the barks of New Granada, principally

1 From zurrón, the Spanish name for a pouch or game-bag.

- Consular Rcports, presented to Parliament, July 1872 .

3 Seemanu's Journ. of Bot. vi. (1S6S) 328. 
from Santa Marta, whence the shipments ${ }^{1}$ in 1871 were 3,415,149 $\mathrm{Hb}$. ; and in $1872,2,758,991 \mathrm{tb}$. From the neighbouring port of Savanilla which represents the sity of Barranquilla, the sea-terminus of the navigation of the Magdalena, the export of bark in 1871 was $1,043,835 \mathrm{Hb}$., value $£ 38,7152^{2}$ Some Cinchona bark is also shipped from Venezuela by way of Puerto Cabello.

The quantity of bark appearing in the Annual Statement of Trade, as "Peruvian Bark," imported into the United Kingdom in 1872, was 28,451 cwt., valued at $£ 285,620$; of which, $11,843 \mathrm{cwt}$. was shipped from New Granada, 4,668 cwt. from Ecuador, and 5,829 cwt. from Peru, the remainder being entered as from the ports of Chili, Brazil, Central America and other countries.

Cultivation-The reckless system of bark-cutting in the forests of South America, which has resulted in the ntter extermination of the tree from many localities, has aroused the attention of the Old World, and has at length prompted serious efforts to cultivate the tree on a large scale in other countries.

The idea of cultivating Cinchonas out of their native regions was advanced by Ruiz in 1792, and by Fée of Strassburg in 1824. ${ }^{3}$ Royle ${ }^{4}$ pointed out in 1839, that suitable localities for the purpose might be found in the Neilgherry Hills and probably in many other parts of India, and argued indefatigably in favour of the introduction of the tree.

The subject was also urged in reference to Java in 1837 by Fritze, director of medical affairs in that island; in 1846 by Miquel, and subsequently by other Dutch botanists and chemists. ${ }^{5}$

Living Cinchonas had been taken to Algeria as early as 1849 , by the intervention of the Jesuits of Cusco, but their cultivation met with no success.

Weddell in 1848, brought cinchona seeds from South America to France, and strenuously insisted on the importance of cultivating the plant. His seeds, especially those of $C$. Calisaya, germinated at the Jardin des Plantes in Paris, and in June 1850, living seedlings were sent to Algeria ; and in April 1852, throngh the Dutch Government, to Java.

The first important attempts at cinchona-cultivation were made by the Dutch. Under the auspices of the Colonial Minister Pahud, afterwards Governor-General of the Dutch East Indies, the botanist Hasskarl was despatched to Peru for the purpose of obtaining seeds and plants. His mission was so far successful, that a collection of plants contained in 21 Wardian cases, was shipped in August 1854 from Callao, in a frigate sent expressly to receive them. Notwithstanding every care, the plants did not reach Java in good condition; and when Hasskarl resigned his appointment in 1856, he bequeathed to his successor Junghuhn, only 167 young cinchonas, though 400 specimens had been shipped from South America.

An impulse to the project of cinchona-planting was given in 1852 by Royle. in a report addressed to the East India Company, in which he pointed out, that the Government of India were then spending more than

1 Consular Reports, August 1873. 743.

2 Ibid. August 1872.

3 Cours d'Itist. nat. pharmaceutique, ii. (1828) 252.
1 Mlustrations of the Bot. of the Himalayan Mountains, i. (1839) 240.

s Aceording to Van Gorkom, suggestions to the same end were made to the Dutch Governnent as early ns 1829 hy Reinwarit. 
$£ 7,000$ a year for Cineliona bark, in addition to about $£ 25,000$ for quinine. ${ }^{1}$

After some unsatisfactory endeavour's on the part of the British Govermment to obtain plants and seeds throngh the intervention of H. M. Consuls in South America, Mr. Clements Lobert Markliam offered his services, which were aceepted. Mr. Markham, though not a professed botanist, was well qualified for the task by a previous acquaintanee with the country and people of Pcru and Bolivia, and by a knowledge of the Spanish and Quichua languages, - and even more so by a rare amount of zeal, intelligenee, and forethought. Being fully aware of the difficulties of the undertaking, he earnestly insisted that nothing should be negleeted which could ensure suecess; and in particular made repeated demands for a steam-vessel to eonvey the young plants across the Pacifie to India, whieh unfortunately were not eomplied with. He further urged the desirableness of not eonfining operations to a single district, but of endeavouring to proeure by different eollectors all the more valuable species.

The prudence of this latter suggestion was evident, and Markham was enabled to engage the serviees of Richard Spruce, the distinguished botanist, then resident in Ecuador, who expressed lis readiness to undertake a search for the Red Bark trees (C. succirubra) in the forests of Chimiborazo. He also secured the eo-operation of G. J. Pritchett for the neighbourhood of Huanuco, and of two skilful gardeners, John Weir and Robert Cross. The last-named was employed in 1861 to procure seeds of C. officinalis from the Sierra de Cajanuma near Loxa, and in 1863-64 those of C. Pitayensis from the provinee of Pitayo in Eeuador. ${ }^{2}$

Markham reserved for himself the border-lands of Peru and Bolivia, in order to obtain C. Calisayc ; and for this purpose started from Islay in March 1860. Arriving in the middle of April by way of Arequipa and Puno, at Crucero, the eapital of the provinee of Carabaya, he made his way to the village of Sandia, near which he met with the first speeimens of Cinchona in the form of the shrubby variety of C. Calisaya, termed Josephiana. He afterwards found the better variety a. vera, and also C. ovata R. et P., C. micrantha R. et P., and C. pubescens Vahl. Of. these sorts, but chiefly of the first three, 456 plants were shipped at Islay in June 1860.

In eonsequence of the hostile attitude of the people, and the jealousy of the Bolivian Government, lest an important monopoly should be broken up, added to the diffieulties arising from insalubrious climate and the want of roads, the obstacles eneountered by Markham were very great, and no attempt eould be made to wait for the ripening of the seeds of the Calisaya, which takes place in the month of August. ${ }^{3}$

The expedition of Spruce was successful, but was also attended with much diffieulty and danger, of which there are vivid pietures in the

1 In 1870 , the Indian Govcrnment purchased no less than 81,600 ounces of sulphate of quinine, besides 8,832 ounces of the sulphates of cinclionine, cinchonidine and quinidine. The quantitics bought in subsequent year's have becn much sinaller until the present year (1874).

${ }_{2}$ Report on the Expedition to procure sceds of C. Condaminea [1862]; also Report to the
Under Secretary of State for India on the Pitayo Chinchona, by Robt. Cross, 1865 .

3 Great difficulty was at first experienced in successfully conveying living Cinclona plants to India, even in Wardian cases; and the collections formed by Hasskarl, Markham, and Pritehctt almost all perished after reaching their destination (Markham's letter, 26 Feb. 1861). But the propagation by seed lias proved rery rapill. 
interesting narratives by limself and by Cross, published in the Parliamentary Returns of 1863 and $1866 .^{1}$

The service entrusted to Pritchett was also efficiently performed; and he succeeded in bringing to Soutlampton, six coses containing plants of $C$. micranthe and $C$. nitida, besides a large supply of seeds.

Some important supplies of plants and seed for Pritish India have likewise been obtained from the Dutch plantations in Java. Seeds of C. lancifolia, the tree affording the valuable bark of New Granada, were procured through J). Karsten.

Those of all excellent variety of C. Calisaya, obtained in the Bolivian province of Caupolican in 1865 by Mr. Charles Ledger, ${ }^{2}$ have afforded trees which in Java have yielded bark of extraordinary goodness. It is probable that this variety will henceforth be very largely cultivated, especially in the Dutch plantations.

Previously to the arrival in India of the first consignment of plants, careful inquiries were instituted from a meteorological and geological point of view, as to the localities most adapted for the cultivation. This resulted in the selection for the first trial, of certain spots among the Neilgherry (or Nilgiri) Hills on the south-west coast of India and in the Madras Presidency. Of this district, the chief town is Ootacamund (or Utakanand), situated about 60 miles south of Mysore and the same distance from the Indian Ocean. Here the first plantation was established in a woody ravine, 7,000 feet above the sea-level, a spot pronounced by Mr. Markham to be exceedingly analogous, as respects vegetation and climate, to the Cinchona valleys of Carabaya. Other plantations were formed in the same neighbourhood, and so rapid was the propagation, that in September 1866, there were more than $1 \frac{1}{2}$ millions of Cinchona plants on the Neilgherry Hills alone. ${ }^{3}$ The species that grows best there is $C$. officinalis.

The number was stated to be in $1872,2,639,285$, not counting the trees of private planters. The largest are about 30 feet ligh, with trunks over 3 feet in girth. The area of the Government plantations on the Neilgherry Hills is 950 acres. $^{4}$

Plantations liave also been made in the coffee-producing districts of Wynaad, and in Coorg, Travancore and Tinnevelly, in all instances we believe, as private speculations.

Cinchona plantations have been established by the Government of India in the valleys of the Himalaya in British Sikkim, ${ }^{5}$ and some have been started in the same region by private enterprise. In the former there were on the $31 \mathrm{March}$, 1870, more than $1 \frac{1}{2}$ millions of plants permanently placed, the species growing best being $C$. succirubra and C. Calisaya. The Cinchona plantation of Rungbi near Darjiling (British Sikkim) covered in 1872, 2,000 acres. In the Kangra valley of the Western Himalaya, plantations have been commenced, as well as in the Bombay Presidency, and in British Burma.

1 Correspondence relating to the introduetion of the Chinchona Plant into India, ordered by the House of Commons to be printed $20 \mathrm{Narch}, 1863$ and 18 June, 1866.

2 Phurm. Journ., July 12, 1873. 25.

3 Bluc Book (Chinchona Cultivation) 1870. p. 30. - A name that must always be remembered in connection with the Neilgherry plantations, is that of William
Graham McIvor, who by his rare practical skill and sagacity in the eultivation and management of the tree, has rendered most signal services in its propagation in India.

4 Moral and material progress and eondition of India during 1871-72, presented to Parliament 1873. p. 33.

5 The first annual Report dates from 1862 to 1863 . 
Ceylon offers favourable spots for the cultivation of Cinchona, in the mountain region which occupies the centre of the island, as at Hakgalle near Nenera-Fllia, 5,000 feet above the sea, where a plantation was formed by Govermment in 1861. 'The production of bark has been taken up with spirit by the coffee-planters of Ceylon.

The Govermment of 'India has acted with the greatest liberality in distributing plants and seeds of Cinchona, and in promoting the cultivation of the tree among the people of India; $;^{1}$ and it has freely granted sipplies of seed to other countries.

The plantations of Java coinmenced by Hasskarl, increased under Jungliulm's management to such an extent, that in December 1862 there were 1,360,000 seedlings and young trees, among which however, the more valuable species, as C. Calisaya, C. lancifolia, C. micrantha and $C$. succimubra, were by far the least numerous, whereas C. Pahudiana of which the utility was by no means well established, amounted to over a million. The disproportionate multiplication of this last was chiefly due to it quickly yielding an abundance of seeds, and to its rapid and vigorous growth. Another defect in the early Dutch system of cultivation arose from the notion that the Cinchona requires to be grown in the shade of other trees, and to a less successful plan of multiplying by cuttings and layers.

These and other matters were the source of animated and often bitter discussions, which terminated on the one hand by the death of Junghuhn in 1864, and on the other by the skilful investigations of De Vry.

This eminent chemist was despatched by the Government of Holland in 1857 to Java, that he might devote his chemical knowledge to the investigation of the natural productions of the island, including the then newly introduced Cinchona. In connexion with the latter, De Vry did not confine his attention to Java, but visited the plantations of Ceylon and Ootacamund, thereby gathering information that was utilized to the best advantage. In fact under K. W. van Gorkom, who was appointed superintendent in 1864, the Dutch plantations have assumed a very prosperous state. They are now rich in C. Calisaya, which thrives there better than $C$. officinalis; while the propagation of C. Pahudiana has been abandoned since the year $1862 .^{2}$

The history of the transplantation of the Cinchona has been made the subject of an exhaustive report laid before the Société d'Acclimatation of France, by Delondre and Soubeiran, ${ }^{3}$ in which are recorded the attempts that have been made to introduce the tree into Brazil, Mexico, the West Indies, and even into the warmer parts of Europe.

Cinchona Bark from the Indian plantations began to be brought into the London market in $1867,{ }^{4}$ and now arrives in constantly increasing quantities.

Description-(A). Of Cinchona Barks generally. - In the development of their bark, the various species of Cinchona exhibit considerable

1 Up to January 1870 , more than 178,000 plants had been distributed from the Neilgherry plantations to private individuals.

2 Yct the plantations are maintained, and the bark, which is of good appcarance, is brought in somc quantity into the European market. 'Though poor in alkaloids, it is rich in cincho-tanuic acid.

${ }^{3}$ De l'introduction et de l'acclimatation des Cinchonas dans les Indes neclaxdaises et anglaiscs, Paris IS68.

${ }_{4}$ When I was in London, in August 1867, I went to Finsbury Place, to meet $\mathrm{Mr}$. Spruce, and was happy enough to find there also Mr. Howard, who prescuted Mr. S. and myself with markct samples of the first importation of $C$. succirubra, from Deuison plantation, Ootacamund.-F. A. F. 
diversity. Many are distinguished from an early stage by an abundant exfoliation of the outer surface, while in others this takes place to a smaller degree, or only as the bark becomes old. The external appearance of the barks varies therefore very much, by reason of the greater or less development of the suberous coat. The barks of young stems and branches, lave a greyish tint more or less intense, while the outer bark of old wood displays the more characteristic shades of brown or red, especially after removal of the corky layers.

In the living bark, these colours are very pale, and only acquire, their final hue by exposure to the air, and drying. Some of them however are characteristic of individual species, or at least of certain groups, so that the distinctions originated by the bark-collectors of pale, yellow, red, \&c. ${ }^{1}$ and adopted by druggists, are not without reason.

In texture, the barks vary in an important manner by reason of diversity in anatomical structure. Their fracture especially, depends upon the number, size and arrangement of the liber fibres, as will be shown in our description of their microscopic characters.

The taste in all species is bitter and disagreeable, and in some there is in addition a decided astringency. Most species have no marked odour, at least in the dried state. But this is not the case in that of $C$. officinalis, the smell of which is characteristic.

(B). Of the Bartes used in pharmacy.-For pharmaceutical preparations as distinguished from the pure alkaloids and their salts, the Cinchona barks employed are chiefly of three kinds.

1. Pale Cinchona Bark, Loxa Bark, Crown Bark. ${ }^{2}$-This bark, which previous to the use of quinine and for long afterwards was the ordinary Peruvian Bark of English medicine, is only found in the form of quills, which are occasionally as much as a foot in length, but are more often only a few inches or are reduced to still smaller fragments. The quills are from $\frac{3}{4}$ down to $\frac{1}{8}$ of an inch in diameter, often double, and variously twisted and shrunken. The thinnest bark is scarcely stouter than writing paper; the thickest may be $\frac{1}{10}$ of an inch or more. ${ }^{3}$ The pieces have a blackish brown or dark greyish external surface, variously blotched with silver-grey, and often beset with large and beautiful lichens. The surface of some of the quills is longitudinally wrinkled and moderately smooth; but in the majority it is distinctly marked by transverse cracks, and is rough and harsh to the touch. The inner side is closely striated and of a bright yellowish brown.

The bark breaks easily with a fracture which exhibits very short fibres on the inner side. It has a well-marked odour sui generis, and an astringent bitter taste. Though chiefly afforded by $C$. officinalis, some other species occasionally contribute to furnish the Loxa Bark of commerce, as shown in the conspectus at p. 318.

2. Calisaya Bark, Yellow Cinchona Bark. ${ }^{4}$-This bark, which is the most important of those commonly used in medicine, is found in fla ${ }^{+}$

1 The following are eommon terms in reference to the barks of Peru:-Amarilla (yellow), blanea (whitc), colorada or roja (red), naranjada (orange), negrilla (brown).

2 Cortex Cinchonce pallida; F. Quinquina Loxa; G. Loxachina. The term Crown Bark was originally restricted to a superior sort of Loxa Bark, shipped for the usc of the royal family of Spain.

${ }^{3}$ In the old eollections of the Royal College of Physicians, there arc specimens of very thiek Loxa Bark, of a quality quite uriknown there at the present day. "They are doubtless the produce of aneient trees, such as were notieed by La Condamine.

${ }^{4}$ Cortex Cinchona Alava, Cortex China: regius; F. Quinquina Calisaya; G. Königschina. 
pieces $\left(a_{\text {. }}\right.$ ), and in quills ( $\beta$.), both afforded by C. Calisaya Wedd., thonghl usually imported separately.

a. F'lut Calisayn-is in irregular flat pieces, a foot or more in length by 3 to 4 inches wile, but usuilly smatler, and $\frac{2}{T^{2}}$ to $\frac{4}{10}^{4}$ of an inch in thickness; devoid of suberous layer and consisting almost solely of liber, of uniform texture, compact, and ponderons. Its colonr is a rusty orange-brown, with darker stains on the onter surface. The latter is ronghened with shallow longitudinal depressions, sometimes called cligital furrons. The inner side has a wavy, close, fibrous texture. The bark breaks transversely with a fibrons fracture; the fibres of the broken ends are very short, easily detached, and with a lens are seen to be many of them faintly yellowish and translucent.

A well-marked variety known as Bolivian Calisaya, is distinguished for its greater thinness, closer texture, and for containing mumerous laticiferous ducts which are wanting in comnon flat Calisaya bark.

3. Quill Calisaya-is found in tubes $\frac{3}{4}$ to $1 \frac{1}{2}$ inch thick, often rolled up at both edges, thus forming double quills. They are always coated with a thick, rugged, corky layer, marked with deep longitudinal and transverse cracks, the edges of which are somewhat elevated. This suberous coat which is silvery white or greyish, is easily detached, leaving its impression on the cinnamon-brown middle layer. The imner side is dark brown and finely fibrous. The transverse fracture is fibrous but very short. The same bark also occurs in quills of very small size, and is then not distinguishable with certainty from Loxa bark.

3. Red Cinchona Bark. - Though still retaining a place in the British Pharmacopœia, this is by far the least important of the Cinchona barks employed in pharmacy. But as the tree yielding it (C. succirubra), is now being cultivated on a large scale in India, the bark may probably come more freely into use.

Red Bark of large stems, which is the most esteemed kind, occurs in the form of flat or channelled pieces, sometimes as much as $\frac{1}{2}$ an inch in thickness, coated with their suberous envelope which is rugged and warty. Its outermost layer in the young bark has a silvery appearance. The inner surface is close and fibrous and of a brick-red hue. The bark breaks with a short fibrous fracture. ${ }^{2}$

Some very fine Red Bark recently imported from Ceylon (1873), is in stout channelled or quilled pieces 20 inches long, internally of a reddish brown. It is stated to be rich in alkaloids, two-fitths of which are quinine and quinidine; and has been sold in London at a high price.

(C). Of the Barks not used in pharmacy.-Among the non-officinal barks, the most important are afforded by Cinchona lancifolia Mutis and C. Pitayensis Wedd., natives of the Cordilleras of Columbia.

These barks are largely imported and used for making quinine, the former under the names of Columbian, Carthagena, or Caqucta bark. It varies much in appearance, but is generally of an orange-brown; the corky coat, which scales off easily, is shining and whitish. The barks of $C$. lancifolia often occur in fine large quills or thick flattish pieces. Their anatomical structure agrees in all the varieties which re have examined, in the remarkable number of thick-walled and tangentially

i From the notion that they resemble the marks left by drawing the fingers over wet clay.
2 Thick Red Bark that happens to hare a very deep and brilliant tint, is eagerly bought at a high price for the Paris market. 
extended cells of the middle cortical layer and the medullary rays. In percentage of alkaloids, Carthagena barks are liable to great variation.

The Pitayo Barks are restricter to the south-western districts of Columbin, ${ }^{1}$ and are usnally inported in short flattish fragments, or broken quills, of brownish rather than orange colour, mostly covered with a dull greyish or internally reddish cork. The middle cortical layer exhibits but few thick-walled cells; the liber is traversed by very wide medullary rays, and is provided with but a small number of widely scattered liber fibres, which are rather thinner than in most other Cinchona barks. The Pitayo barks are usually rich in alkaloids, quinine prevailing. Cinchona Pitaycnsis is one of the hardiest species of the valuable Cinchonas, and is therefore particularly suitable for cultivation, which however has not yet been carried out as largely as that of either C. officinalis or C. succirubra.

In the Conspectus on the next page, we have arranged the principal species of Cinchona, with short indications of the barks which some of them afford. ${ }^{2}$

Microscopic Structure-The first examination of the minute structure of Cinchona barks is due to Weddell, whose observations have been recorded in one of his beantiful plates published in $1849 .{ }^{3}$ Since that time numerous other observers have laboured in the same field of research.

General Characiers.-These barks as contrasted with those of other trees, do not exhibit any great peculiarities of structure; and their features may be comprehended in the following statements. The cpidcrmis in the anatomical sense, occurs only in the youngest barks, which are not found in commerce. The corky layer which replaces the epidermis, is constructed of the usual tabular cells. In some species as C. Calisaya, it separates easily, at least in the older bark, whereas in others as C. succirubra, the bark even of trunks is always coated with it. In several species the corky tissue is not only found on the surface, but strips of it occur also in the inner substance of the bark. In this case the portions of tissue external to the inner corky layers or bands, are thrown off as bork-scales (periderm of Weddell). This peculiar form of suberous tissue ${ }^{4}$ was first examined (not in cinchona) in 1845 by $\mathrm{H}$. von Mohl, who called it rhytidoma (Borke of the Germans). In C. Calisayc it is of constant occurrence, but not so in $C$. succirnbra and some others; the rhytidoma therefore affords a good means of distinguishing several barks.

The inner portion of the bark exhibits a middle or primary layer (mesopllcoum), ${ }^{5}$ made up of parenchyme; and a second inner layer or libcr (endophlonm) ${ }^{6}$ displaying a much more complicated structure. The primary layer disappears if rhytidoma is formed: barks in which this is the case are therefore at last exclusively composed of liber, of which Flat Calisaya Bark is a good example.

The liber is traversed by modullary rays, which in cinchona are

1 Pitayo is an Indian village eastward of Popayan, see map of the country between Pasto and Bogrotá in Blue Book (East India Chinchona Plant) 1866. 257.

${ }^{2}$ Two species ineluded by Weddell in his recent Noles sur les Quinquinas, namely $C$. Chometiana Wedd. and C. (?) Barbacoensis Karst., have been omitted, as not in our opinion belonging to tho genus.
${ }^{3}$ Hist. nat. des Quinquinas, tab. ii.

${ }^{4}$ Fliickiger, Grundlagen, Berlin, 1872.61. fig. 48.

5 Enveloppe ou tunique cellulaire of Weddell ; Mittelrinde of the Germans.

6 In German Bast, or Phloëm of modern Ger'man botany. 


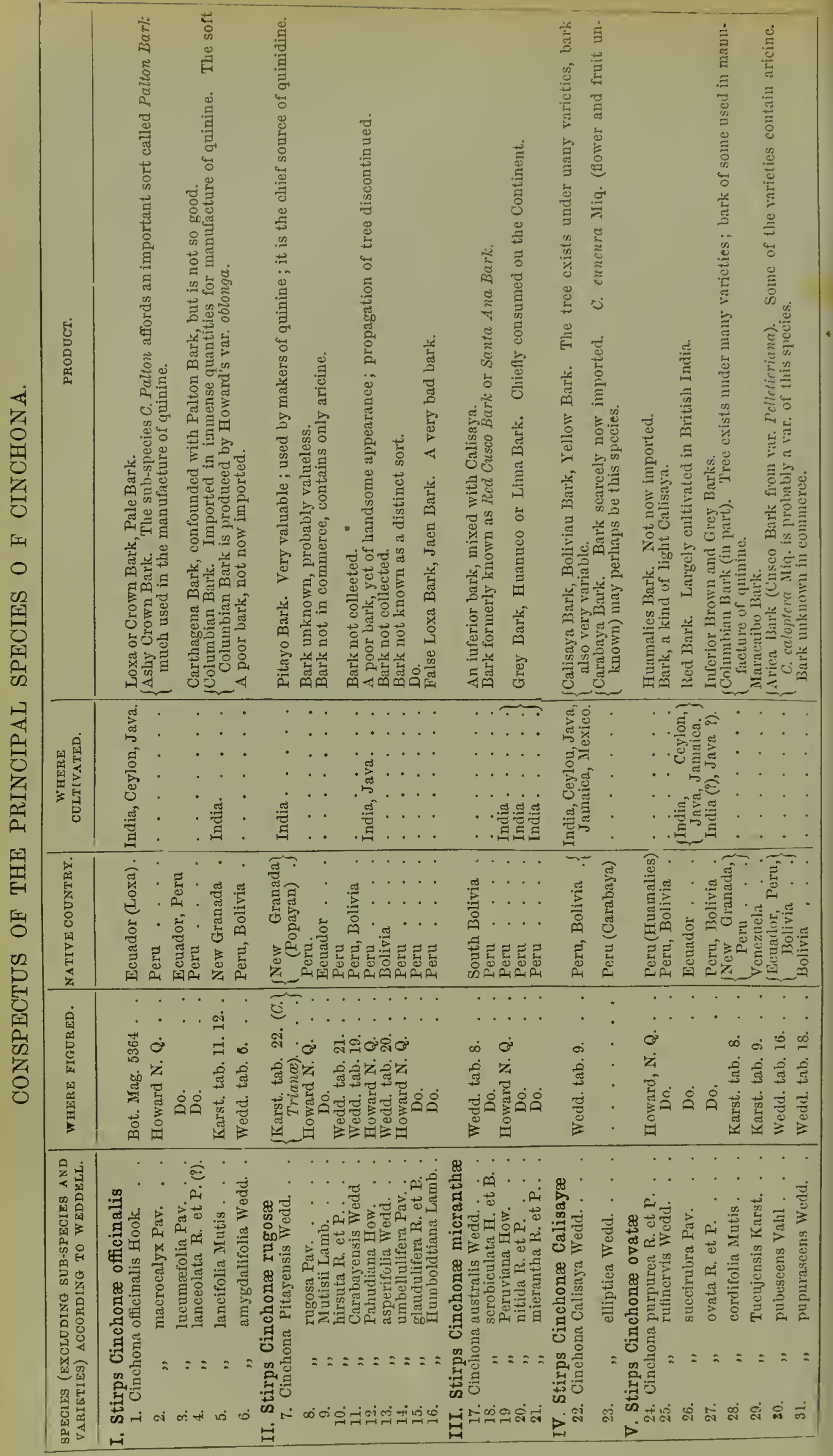


mostly very obvious, and project more or less distinctly into the middle cortical tissue. The liber is separated by the medullary rays into wedges, ${ }^{1}$ which are constituted of a parenchymatous part and of yellow or orange fibres. The number, colour, shape, and size, but chiefly the arrangement of these fibres, confer a certain character common to all the barks of the group under consideration.

The liber-fibres ${ }^{2}$ are elongated and bluntly pointed at their ends but never branched, mostly spindle-shaped, straight or slightly curved, and not exceeding in length 3 millimetres. They are consequently of a simpler structure than the analogous cells of most other officinal barks. They are about $\frac{1}{4}$ to $\frac{1}{3} \mathrm{~mm}$. thick, their transverse section exhibiting a quadrangular rather than a circular outline. Their walls are strongly thickened by numerous secondary deposits, the cavity being reduced to a narrow cleft, a structure which explains the brittleness of the fibres. The liber-fibres are either irregularly scattered in the liberrays, or they form radial lines transversely intersected by narrow strips of parenchyme, or they are densely packed in short bundles. It is a peculiarity of cinchona barks that these bundles consist always of a few fibres (3 to 5 or 7 ), whereas in many other barks (as cinnamon), analogous bundles are made up of a large number of fibres. Barks provided with long bundles of the latter kind, acquire therefrom a very fibrous fracture, whilst cinchona barks from their short and simple fibres, exhibit a short fracture. It is rather granular in Calisaya bark, in which the fibres are almost isolated by parenchymatous tissue. In the bark of $C$. scrobiculata, a somewhat short fibrous fracture ${ }^{3}$ is due to the arrangement of the fibres in radial rows. In $C$. pubescens, the fibres are in short bundles and produce a rather woody fracture.

Besides the liber-fibres, there are some other cells contributing to the peculiarity of individual cinchona barks. This applies chiefly to the laticiferous ducts or vessels ${ }^{4}$ which are found in many sorts; they are scattered through the tissue intervening between the middle cortical layer and the liber, and consist of soft, elongated, unbranched cells, mostly exceeding in diameter the neighbouring parenchymatous cells.

As to the contents of the tissue of cinchona barks, crystallized alkaloids are not undoubtedly visible. Howard has published figures representing minute rounded aggregations of crystalline matter in the cells, which he supposes to be kinates of the alkaloids; and also distinct acicular crystals which he holds to be of the same nature. These remarkable appearances are easily observable, yet only after sections of the bark have been boiled for a minute in weak caustic alkali and then washed with water; it may well be doubted whether they are strictly natural.

The greater number of the parenchymatous cells are loaded with small starch granules, or in young and fresh barks with chlorophyll. In several barks, as in that of C. lancifolia Mutis, numerous cells of the middle cortical layer and even of the medullary rays, are provided with somewhat thick walls, and contain either a soft brown mass or crystalline oxalate of calcium. These cells have therefore been called resin-cells and crystal-cells; they are mostly isolated, not forming

a Baststrahlen or Phloëmstrahlen of the Germans.

2 Fibres corticales of Weddell; Baströhren or Bastzellen in German.
3 Fracture filandreuse, Weddell ; fädiger Bruch of the Germans.

4 Vaisseaux laticiferes of Weddell; Milchsaftschläuche in German. 
extensive groups or zones, and their walls are not strongly thickened as in true sclerenchymatoms tissue. If thin sections of the barks are, moistened with dilute alcoholic perehloride of iron, the walls of the cells, except the fibres and the cork, assmme a blackish-green due to cincho. tannic acid; this applies even to the stareh grianules.

Characters of particulur sorts. - The modilications of general structure just described, are sulficient to impart a special cliaracter to the bark of many species of Cinchona, provided the bark is exannined at its full development, the structural peculiarities being far from well-marked in young barks.

Thus, it is not possible to point out any distinctive features for the Loxa Barl of commerce, because it is mostly taken from young wood. We may say of it, that neither resin-cells nor crystal-cells occur in its middle layer, that its laticiferous vessels become soon obliterated, and have indeed disappeared in the older quills; and that the liber-fibres form interrupted, not very regular, radial rows.

The quills of $C$. Calisaya display large laticiferous ducts, which are wanting in the flat bark. There is a peculiar sort of the latter called Bolivian Calisaya (already mentioned at p. 316), the flat pieces of which still possess very obvious laticiferous vessels. As to the liber-fibres of Calisaya bark, they are as before stated (p. 319), scattered throughout the parenchymatous tissue or endophloum. In the bark of $C$. scrobiculata, which might at first sight be confounded witl Calisaya bark, the liber-fibres form radial, less interrupted rows. The microscope affords therefore the means of distinguishing these two barks.

The barks of $C$. succimbra are particularly rich in laticiferous ducts, mostly of considerable diameter, in which the formation of new parenchyme may not unfrequently be observed. The orange liber-fibres occurring in this bark are less numerous, more scattered, and of smaller size than in Calisaya. The fracture of Ped Bark, especially the flat sort, is therefore more finely granular and not so coarse as that of Calisaya.

The structural characters of Cinchona barks may lastly be fully appreciated by examining barks of the allied genera Buena, Cascarilla and Ladenbergia, which were formerly known under the name of False Cinchona Barks. The microscope shows that the liber-fibres of the latter are soft, branched and long, densely packed into large bundles, imparting therefore a well-marked fibrous structure. The external appcarance of these barks is widely different from that of true cinchona barks; none of them it would appear is now collected for the purpose of adulteration.

Chemical Composition-The most important and at the same time peculiar principles of Cinchona bark are the Alkaloids,-enumerated in the following table:-

Cinchonine

Cinchonidine (Quinidine of many writers).

Quinine

Quinidine (Conquinine of Hesse)

Quillamine.

$\mathrm{C}^{20} \mathrm{H}^{24} \mathrm{~N}^{2} \mathrm{O}$ sane formula. $\mathrm{C}^{20} \mathrm{H}^{24} \mathrm{~N}^{2} \mathrm{O}^{2}$. same formula. $\mathrm{C}^{20} \mathrm{H}^{26} \mathrm{~N}-\mathrm{O}^{2}$.

Gomes ${ }^{1}$ of Lisbon first succeeded in obtaining active principles of cinchona, by treating an alcoholic extract of the bark with water, adding

1 Ensaio sobre o Cinchonino, e sobre sua influencia no virtude da quina e d'outras cascas. - Mem. da Acad. R. das Scicncias de lisboa, iii. (1812) 202-217. 
to the solution caustic potash, and crystallizing the precipitate from alcohol. The basic properties of the substance thus obtained, which Gomes called Cinehonino, were observed in the laboratory of Thénard by Houtou-Labillardière, and communicated to Pelletier and Caventou. ${ }^{1}$ Shortly before that time, Sertïrner had asserted the existence of organic alkalis: and the Frencli chernists guided by that brilliant discovery, were enabled to show that the Cinchonino of Gomes belonged to the same class of substances. Pelletier and "Caventou however, speedily pointed out that it consisted of two distinct alkaloids, one of which they named Quinine, the other Cinchonine.

Cinchonidine (thus called by Pasteur) was first obtained and characterized under the name of Quinidine in 1847, by F. L. Winckler of Darmstadt, from Maracaibo Bark (C. Tucujensis Karst.); and in 1852 it was more closely studied in Liebig's laboratory by Leers, still under the name of quinidine.

Quinidine is the name applied in 1833 by Henry and Delondre to an alkaloid they obtained from the bark called Quinquina Carthagène rosé d'Ocaña, afforded by Howard's Cinchona rosulenta, a tree which Weddell regards as a sub-species of $C$. suceirubra. The peculiar nature of quinidine was not clearly proved until 1853, when Pasteur examined it and showed its identity with the Betc-quinine extracted in 1849 by Van Heijningen from commercial quinoidin. ${ }^{2}$ The name quinidinc having been since applied to different basic substances more or less pure, Hesse has proposed to replace it by that of Conquininc, which however has not met with general acceptance. The alkaloid is especially characteristic of the Pitayo barks.

Quinaminc was discovered in 1872 by Hesse, in bark of C. suceirubra cultivated at Darjiling in British Sikkim.

Paricine is another basic substance discovered in 1845 by Winckler, in the bark of Buench hexandra Pohl. Hesse detected it along with quinamine in the bark of C. succirubra; its composition is not yet known.

The names Aricine, Cinchovatinc, Cuseonine, ${ }^{3}$ have been given to alkaloids obtained from certain barks of inferior value, especially that of C. pubesccns var. Pcllctieriana, which has not been imported for several years. The composition and properties of these substances remain obscure.

Pitoyine was pointed out by Peretti (1837), but Hesse has shown (1873) that the bark called China bieolorata, T'ccamez ${ }^{*}$ or Pitoya Bark from which it was obtained, is altogether destitute of alkaloid.

By heating for a length of time solutions of the cinchona alkaloids with an excess of sorne mineral acid, Pasteur (1853) obtained amorphous modifications of the natural bases. Quinine thus afforded Quinieine, 292.

1 Ann. the Clizm. et to Phys. xv. (1820)

2 'Ihe identity of the original quinidine of Henry and Delondre with that studied twenty years later by Pasteur though not doubted by many chemists, is nevertheless not susceptible of actual proof, no specimen we believe of the original substance cxisting for comparison.

"Consult Gmelin, Chemistry: xvii. (1866)

568 ; Husemanu, Pflanzeristofje, 1870. 346. 349. 350 . It is almost eertain that eincleovetine is identical with cinchonidine.

4 So called from Tecamez or Tacames, i small port of Eeuador in about lat. $1^{\circ} \mathrm{N}$. The bark which was first noticed in Lanlbert's Description of the Gonus Cinchona, 1797. 30. tab. ii., is of nuknown botanical origin. See also Guibourt, Ilist. des Lrogues. iii. (1869) 190 (Quinquina bicolore). 
having the same composition; cinchonine and cinchonidine furnished Cinchonicine, likewise agreeing in composition with the alkaloids from which it originates. These amorphous products may also be obtained by heating the natural bases in glycerin at $200^{\circ} \mathrm{C}$., wherl a red substance is also formed. In quinine manufactories, amorphous alkaloids are constantly met with, being partly produced in the course of the manipulations to which the materials are subjected. Yet cinchona barks also afford amorphous alkaloids at the very outset of analysis, whence we must infer their existence in the living plant.

Lastly may be mentioned Paytine, $\mathrm{C}^{21} \mathrm{H}^{24} \mathrm{~N}^{2} \mathrm{O}+\mathrm{H}^{2} \mathrm{O}$, a crystallizable alkaloid discovered in 1870 by Hesse in a white bark of uncertain origin. It is allied to quinamine and quinidine, but has not been met with in any known cinchona bark.

The name.Quinoidinc (or rather "Chinioüdin") was applied by Sertiimer (1829) to an uncrystallizable basic substance, which he prepared from cinchona barks and thought to be a peculiar alkaloid. The term has subsequently been bestowed upon a preparation which has found its way into commerce and medical practice, in the form of a dark brown brittle extractiform mass, softening below $100^{\circ} \mathrm{C}$., and having usually a slight alkaline reaction. It is obtained in quinine factories by precipitating the brown mother-liquors with anmonia, and consists chiefly of the amorphous alkaloids just mentioned. Recently it has been purified by a process not yet made public, and can be obtained as a sulphate or hydrochlorate in the form of a slightly coloured powder.

The alkaloids under consideration have not been met with in any appreciable amount in other parts of the cinchonas than the bark, nor' has their presence been ascertained in other plants than those of the tribe Cinchonece.

\section{Characters of the Cinchona Alkaloids.}

1. Quinine.--It is obtained from alcoholic solutions, in prisms of the composition $\mathrm{C}^{20} \mathrm{H}^{24} \mathrm{~N}^{2} \mathrm{O}^{2}+3 \mathrm{H}^{2} \mathrm{O}$, fusing at $57^{\circ} \mathrm{C}$. The crystals may be deprived of water by warming or exposure over oil of vitriol, and then fuse at $177^{\circ} \mathrm{C}$. The anhydrous alkaloid is likewise crystallizable; it requires about 21 parts of ether for solution, but dissolves more readily in chloroform or absolute alcohol. These solutions deviate the ray of polarized light to the left, and so do likewise solutions of the salts of quinine. Yet one and the same quantity of alkaloid exhibits a very different rotatory power according to the solvent used, though the rolume of the solution remain the same. Even the common sulphate differs in this respect from the two other sulphates of quinine. The same remark applies to the optical power of the other alkaloids.

If ten volumes of a solution of quinine, or of one of its salts, are inixed in a test tube with one volume of chlorine water, and a drop of ammonia is added, a brilliant green colour makes its appenrance. In solutions rich in quinine, a green precipitate, Thalleioquin or Dallciochine is produced; in solutions containing less than $\frac{7}{1000}$ of quinine, no precipitate is formed, but the fluid assumes a green even more beautiful tlian in a stronger solution. The test succeeds with a solution containing

1 Flückiger in Nones Jahrb. fïr Pham. xxxv. (1871) 291 ; Wiggers and Husemann, .Jahrcsbericht for 1872.132 . 
only one part of quinine in 5000; and in a solution containing not more than $\frac{1}{20000}$ of quinine, if bromine is used instead of chlorine. ${ }^{1}$

The bitter taste of quinine is not appreciable in solutions containing less than one part in 100,000. The blue fluorescence displayed by a solution of quinine in dilute sulphuric acid, is observable in solutions containing much less than one part in 200,000 of water; yet it is not apparent in very strong solutions.

Besides the common medicinal sulphate, $2 \mathrm{C}^{20} \mathrm{H}^{24} \mathrm{~N}^{2} \mathrm{O}^{2}+\mathrm{SH}^{2} \mathrm{O}^{4}+8 \mathrm{H}^{2} \mathrm{O}$, quinine forms two other crystallizable sulphates, namely, the so-called neutral or soluble sulphate of pharmacy, $\mathrm{C}^{20} \mathrm{H}^{24} \mathrm{~N}^{2} \mathrm{O}^{2}+\mathrm{SH}^{2} \mathrm{O}^{4}+7 \mathrm{H}^{2} \mathrm{O}$, and a third having the composition, $\mathrm{C}^{20} \mathrm{H}^{24} \mathrm{~N}^{2} \mathrm{O}^{2}+2 \mathrm{SH}^{2} \mathrm{O}^{4}+7 \mathrm{H}^{2} \mathrm{O}$.

Herapath showed in 1852 that quinine forms with sulphuric acid and iodine a peculiar compound, Iodo-sulphatc of Quinine, having the composition $4\left(\mathrm{C}^{20} \mathrm{H}^{24} \mathrm{~N}^{2} \mathrm{O}^{2}\right)+3\left(\mathrm{H}^{2} \mathrm{SO}^{4}\right)+6 \mathrm{I}+3 \mathrm{H}^{2} \mathrm{O}$. As this substance possesses optical properties analogous to those of tourmaline, it was called by Haidinger, Herapathite. It may be easily obtained by dissolving sulphate of quinine in 10 parts of weak spirit of wine containing 5 per cent. of sulphuric acid, and adding an alcoholic solution of iodine until a black precipitate is no longer formed. This precipitate is collected on a filter and washed with alcohol; then dissolved in boiling spirit of wine and allowed to crystallize. The tabular crystals thus obtained, are extremely remarkable on account of their dichroïsm and polarizing power, as well as for their sparing solubility, since they require 1000 parts of boiling water for solution; the latter property may be utilized for separating quinine from the other cinchona alkaloids and estimating its quantity.

2. Quinidine (Conquinine of Hesse)-forms crystals having the composition, $\mathrm{C}^{20} \mathrm{H}^{24} \mathrm{~N}^{2} \mathrm{O}^{2}+2 \mathrm{H}^{2} \mathrm{O}$; the anhydrous alkaloid melts at $168^{\circ} \mathrm{C}$., and requires about 30 parts of ether for solution. Its solutions are strongly dextrogyre; it agrees with quinine as regards bitterness, fluorescence and the thalleioquin test, and forms a neutral and an acid sulphate. The most striking character of quinidine is afforded by its hydriodate, the crystals of which require for solution at $15^{\circ} \mathrm{C} ., 1250$ parts of water or 110 parts of alcohol sp. gr. 834 . Quinidine may therefore be separated from the other alkaloids of bark, by a solution of iodide of potassium which will precipitate the hydriodate. According. to Hesse (1873), quinidine is further characterized by the fact that its sulphate is soluble in 20 parts of chloroform at $15^{\circ} \mathrm{C}$., the sulphates of the other cinchona-alkaloids being far less soluble in that liquid. The, common medicinal sulphate of quinine, e.g., requires for solution 1000 parts of chloroform.

3. Cinchonine.-This alkaloid forms crystals which are always anhydrous; they fuse at $257^{\circ} \mathrm{C}$., and require about 400 parts of ether and 120 of spirit of wine for solution. Cinchonine further differs from quinine by its dextrogyre power, its want of fluorescence, and its nonsusceptibility to the thalleioquin test. Its hydriodate is readily soluble in water, and still more so in alcohol whether dilute or strong.

4. Cinchonidine-forms anhydrous crystals melting at $206^{\circ} \mathrm{C}$., soluble in 76 parts of ether, or 20 of spirit of wine, then affording levogyre

${ }^{1}$ Pharm. Journ., May 11, 1872. 901. 
liquids, levoid of fluorescence, ${ }^{1}$ and not acquiring a green colour (thalleioquin) by means of chlorine water and ammonia. Iydrochlorate of cinchonidine forms pyranidal crystals of the monoclinic system, very different from the hydrochlorates of the allied alkaloids.

5. Quinaminc.-The crystals are anliydrous, fuse at $172^{\circ} \mathrm{C}$., and forn at a temp. of $20^{\circ}$, with 32 parts of ether or 100 parts of spirit of wine, i dextrogyre solution. Quinamine is even to some extent soluble in boiling water, and abundantly in boiling ether, benzol, or petroleum ether. The solutions of quinamine do not stand the thalleioquin test, nor do they display fluorescence; in acid solution, the alkaloid is liable to be transformed into an amorphous state. Quinannine moistened with concentrated nitric acid, assumes like paytine, a yellow coloration. Its hydriodate is readily soluble in boiling water, but very sparingly in cold water, especially in presence of iodide of potassium, in which respect it is allied to quinidine as well as to paytine.

The more important properties of the Cinchona-alkaloids may be summarized as follows:-

a. Hyclrated crystals are formed by . : . Quinine, Quinidine, (Paytine).

No hydratcd crystals by . . . . . Cinehonine, Cinchonidine, Quinamine.

b. Abrendantly soluble in ether ... $\left\{\begin{array}{c}\text { Quinine, Quinidine, Quinamine, (Paytine), } \\ \text { and the amorphous alkaloids. }\end{array}\right.$

Sparingly solnble in etler . . . . Cinehonidine.

Almost insoluble in ether . . . . . Cinchonine.

c. Levogyre solutions afforded by . . . . Quinidine, Cinchonidine, (Paytine).

Dcxtrogygre solutions by . . . . $\left\{\begin{array}{c}\text { Cinchonine, Quinidine, Quinamine, and } \\ \text { the amorphons alkaloids. }\end{array}\right.$

d. Thallcioquin is formed by . . . . Quinine, Quinidine, and also by Quinicine.

Thalleioquin cannot be obtained from $\cdot\left\{\begin{array}{c}\text { Cinehonine, Cinehonidine, Quinamine, nor } \\ \text { from Cinchonicine. }\end{array}\right.$

e. Flnoresecnec is displayed by solutions of Quinine, Quinidine.

No fluorescenec in solutions of pure . Cinchonine, Cinehonidine, Quinamine.

Proportion of Alkaloids in Cinchona Barks-This is liable to very great variation. We know from the experiments of Hesse (1871), that the bark of $C$. pubeseens Vahl is sometimes devoid of alkaloid.Similar observations made near Bogota upon C. Pitayensis Wedd., C. corymbosa Karst., and C. lancifolia Mutis, are due to Karsten. He ascertained $^{3}$ that barks of one district were sometimes devoid of quinine, while those of the same species from a neighbouring locality, yielded $3 \frac{1}{2}$ to $4 \frac{1}{2}$ per cent. of sulphate of quinine.

Another striking example is furnished by De $\mathrm{Vr}^{*}{ }^{\star}$ in his examination of quills of $C$. officinalis grown at Ootacamund, which he found to vary in percentage of alkaloids, from 11.96 (of which $9 \cdot 1$ per cent. was (quinine) down to less than 1 per cent.

Among the innumerable published analyses of cincliona bark, there are a great number showing but a very small percentage of the useful principles, of which quinine, the most valuable of all, is not seldom altogether wanting. The highest yield on the other hand hitherto

I De Vry unaintains that einelonidine is not totally devoid of fluoreseence.

: Berichle der Deutschen chem. Gesellsch.,

3 Dio med. Chinarinden Nou-Granada's, 17. 20.39 .

Berlin, 1871. \$1S. 
observed, was obtained by Broughton ${ }^{2}$ from a bark grown at Ootacamund. This bark afforded not less than $13 \frac{1}{2}$ per cent. of alkaloids, among which quinine was predominant.

The few facts just mentioned, show that it is impossible to state even :pproximately any constant percentage of alkaloids in any given bark. We may horrever say that good Flat Calisaya Bart; as offered in the lrug trade for pharmaceutical preparations, contains at least 5 to 6 per cent. of quinine.

As to Croun or Loxa Burk, the Cortex Cinchone pallides of pharmacy, its merits are to say the least very uncertain. On its first introduction in the 17 th century, when it was taken from the trunks and large branches of full-grown trees, it was doubtless an excellent medicinal bark; but the same cannot be said of much of that now found in commerce, which is to a large extent collected from very young wood. ${ }^{2}$ some of the Crown Bark produced in India is however of extraordinary excellence, as shown by the recent experiments of De Vry. ${ }^{3}$

As to Red Bark, the thick flat sort contains only 3 to 4 per cent. of alkaloids, but a large amount of colouring, matter. The quill Red Bark of the Indian plantations is a much better drug, some of it yielding 5 to 10 per cent. of alkaloids, more than a third of which is quinine and a fourth cinchonidine, the remainder being cinchonine and quinidine.

The variation in the amount of alkaloids relates not merely to their total percentage, but also to the proportion which one bears to another. Quinine and cinchonine are of the most frequent occurrence; cinchonidine is less usual, while quinidine is still less frequently met with and never in large amount. The experiments performed in India ${ }^{4}$ liave already shown, that external influences contribute in an important namner to the formation of this or that alkaloid; and it may even be loped that the cultivator's of cinchona will discover methods of promoting the formation of quinine and of reducing, if not of excluding, that of the less valuable alkaloids.

Acid principles of Cinchona Barks - Count Claude de la Garaye ${ }^{5}$ observed (1746) a crystalline salt deposited in extract of cinchona bark, which salt was known for some time in France as Sel essenticl de la Garaye. Hermbstädt at Berlin (1785) showed it to be a salt of calcium, the peculiarity of whose acid was pointed out in 1790 by C. A. Hoffmann, ${ }^{6}$ in apothecary of Leer in Hanover, who termed it Chinasäure. The composition of this substance, which is the Kinic Acid of English chemists, was ascertained by Liebig to be $\mathrm{C}^{7} \mathrm{H}^{12} \mathrm{O}^{6}$. The acid forms large tabular crystals, fusible at $161^{\circ} \mathrm{C}$, of a strong and pure acid taste, soluble in two parts of water, also in spirit of wine, but hardly in ether. The solutions are levogyre. Kinic acid appears to be present in every species, and also to occur in barks of allied genera; and in fact to be of somewhat wide distribution in the vegetable kingdom. ${ }^{7}$ By heating. it or a kinate, interesting derivatives are obtained; thus, by means of peroxide of nianganese and sulphmric acid, we get yellow crystals of Kinone

1 Plue Book- "Eash India Chinchona 7lant," 1870.282; Yearbook of Pharmacy, ¿S71. 85 .

2 See Howard's analyses and observations, Ihnom. Journ. xiv. (1855) 61-63.
3 Pharm. Journ. Scpit. 6, 1873. 184.

4 J3lue Book, 1870. 116. 188. 205.

5 Chimic hydrantique, Paris, 1746. 114

6 Crell's Chem. Annalen, 1790, ii. 314-317.

7 Gmelin, Chemistry, xvi. (1864) 222. 
or Quinone, $\mathrm{C}^{6} \mathrm{H}^{4} \mathrm{O}^{2}$, - a reaction which may be used for ascertaining the presence of kinic acid. Kinic acid is devoid of any noteworthy physiological action.

Cincho-tannic Acid-is precipitated from a decoction of bark by acetate of lead, after the decoction has been freed from cinchona-red by means of magnesia. The cincho-tamate of lead decomposed by sulpluretted hydrogen, and the solution cautiously cvaporated in vacuo, yiclds the acid as an amorphous, hygroscopic substance, readily soluble in water, alcohol, or ether. The solutions, especially in presence of an alkali, are quickly decomposed, a red flocculent matter, Cinchona-red, being produced. Solutions of cincho-tannic acid assume a greenish colour on addition of a ferric salt. By destructive distillation, cincho-tannic acid affords pyrocatechin.

Quinovic (or ('hinovic) Aeid, $\mathrm{C}^{24} \mathrm{H}^{38} \mathrm{O}^{4}$, crystallizcs in hexagonal scales which are tasteless, sparingly soluble in cold alcohol, more readily in boiling alcohol, but not dissolved by water, ether, or chloroform. It occurs in cinchona barks, and has been met with by Rembold (1868) in the rhizome of Potentilla Tormentilla Sibth.

Other Constituents of Cinchona Barks-Quinovic acid is accompanicd by Quinovin (or Chinovin), $\mathrm{C}^{30} \mathrm{H}^{48} \mathrm{O}^{8}$, an amorphous bitter substance, first obtained (1821) by Pelleticr and Caventou under the name of Kinic Acid, from China nova in which it occurs combined with lime. Quinovin in alcoholic solution, was shown in 1859 by Hlasiwetz, to be resolved by means of hydrochloric gas into quinovic acid, $\mathrm{C}^{24} \mathrm{H}^{38} \mathrm{O}^{4}$, and an uncrystallizable sugar, Mannitan, $\mathrm{C}^{6} \mathrm{H}^{12} \mathrm{O}^{5}$, with subtraction of $\mathrm{H}^{2} \mathrm{O}$. The formation of quinovic acid takes place more easily, if quinovin is placed in contact with sodium amalgam and spirit of wine, when after 12 hours, mannitan and quinovate of sodium are formed (Rochleder, 1867).

Quinovin, although an indifferent substance, may be removed from cinchona barks by weak caustic soda, from which it is precipitable by hydrochloric acid, together with quinovic acid and cinchona-red. Milk of lime then dissolves quinovin and quinovic acid, but not the red substance. Quinovic acid and quinovin again precipitated by an acid, may be separated by chloroform in which the latter only is soluble.

Quinovin dissolves in boiling water, and more abundantly in spirit of wine; its solutions, as well as those of quinovic acid, are dextrogyre. Quinovin seems to be a constant constituent of almost every part of the cinchonas and the allied Cinchonec, although the amount of it in barks does not apparently exceed 2 per cent. It is accompanied by quinovic acid: both substances are stated to have tonic properties.

Cinchona-red, an amorphous substance to which the red hue of cinchona barks is duc, is produced as shown by Rembold (1867), when cincho-tannic acid is boiled with dilute sulphuric acid, sugar being formed at the samc time. By fusing cinchona-red with potash, protocatechuic acid, $\mathrm{C}^{7} \mathrm{H}^{6} \mathrm{O}^{4}$, is produced. Cinchona-red is sparingly soluble in alcohol, abundantly in alkaline solutions, but neither in water nor in ether. Thick Red Bark in which it is abundant, affords it to the extent of over 10 per cent.

The Cinchona barks yicld but a scanty percentage of ash, not

1 The bark of Buena magnifolia Wedd., a tree with fragrant flowers and magnifieent nsed to appear occrsionally in the London foliage, yielding a worthless bark which market. 
exceeding 3 per cent., a fact well according with the small amount they contain of oxalate of calcium.

Estimation of the Alkaloids in Cinchona Bark-The microscope will enable us, as already shown, to ascertain whether a given bark is derived from Cinchona, but it can furnish no exact information as to the actual value of such bark as a drug.

Yet there is a very simple test by which the presence of a cinchonaalkaloid may be demonstrated. These alkaloids heated in a glass tube in the presence of a volatile acid or of substances capable of producing a volatile acid, evolve heavy vapours of a beautiful crimson colour. Every bark, even the smallest fragment, containing traces of a cinchonaalkaloid affords these red vapours, as was shown in 1858 by Grahe of Kasan. On the other hand the reaction fails with all other barks, and even with true cinchona barks which are destitute of alkaloid.

But to ascertain the real value of a cinchona bark, a quantitative estimation of the alkaloids is necessary. A good process for this operation has lately been given by De Vry. ${ }^{1}$ It is as follows:-Mix 20 grammes of pordered bark, dried at $100^{\circ} \mathrm{C}$., with milk of lime ( $5 \mathrm{grm}$. slaked lime to $50 \mathrm{grm}$. water), dry the mixture slowly, and then boil it with 200 cubic centimetres of strong alcohol. Pour the liquid on to a small filter, and afterwards the residual bark and lime mixed with 100 cub. cent. more alcohol. Wash the powder on the filter with 100 cub. cent. of spirit. From the mixed liquids, now nearly 400 cub. cent., separate the sulphate of calcium by a few drops of weak sulphuric acid. Filter, distill off the spirit and pour into a capsule the residual liquid,- to which add the distilled spirit and the water with which the distilling apparatus has been rinsed out. Let the capsule be now heated on a water-bath until all the spirit shall have been expelled; and let the remaining liquor which contains all the alkaloids in the form of acid sulphates, be filtered. There will remain on the filter quinovic acid and fatty substances, which must be washed with slightly acidulated water. The filtrate and washings reduced to about 50 cub. cent., should be treated while still warn with caustic soda in slight excess. ${ }^{2}$ The precipitate should be washed with the smallest quantity of water, pressed between folds of blotting paper, removed therefrom and dried. The weight multiplied by 5 will indicate the percentage of mixed alkaloids in the bark.

To separate the alkaloids from each other, treat the powdered mass. with ten times its weight of ether. This will resolve it into two portions, - (a) insoluble in ether, (b) soluble in ether.

(a). This should be converted into neutral sulphates, and to the solution there should be added iodide of potassium, which will separate quinidine. After removal of the latter (if present), add solution of tartrate of potassium and sodium; which will throw down in a crystalline form tartrate of cinchonidine; from the mother-liquor, cinchonine may be precipitated by caustic soda.

(b). The ether having been evaporated, the residue is to be dissolved in ten times its weight of weak spirit of wine $(0.915)$ at $15^{\circ} \mathrm{C}$., to which

1 Pharm. Journ., Sent. 27, 1873. 241.

2 De Vry has recently pointed out that this acid filtrate may contain a little quinovic acid or an allied substance, accompanying the alkaloids. Tn get rid of this, he would precipitate the latter with a good cxcess of canstic lye, decauting it off from the precipitate, and then add water to the latter before throwing it on to a filtcr. 
dilnte sulphurie acid ( The solution should be filtered, gently warmed, and tincture of indine added so long as herapathite (p. 323) is formed. Of this compound, 100 parts dried at $100^{\circ} \mathrm{C}$., eontain 56.5 parts of Quinine.

After adrling a few drops of sulphurous aeir, the aleohol should now be evaporated from the fluid from whiel the crystals of herapathite have been removed, and caustie lye adiled, by whieh the amorphous alkaloids will be precipitated, including quinamine if present.

Uses-Cinehona bark enjoys the reputation of being a most valuable remedy in fevers. But the uncertainty of its eomposition and its inconvenient bulk render it a far less eligible form of medieine than the alkaloids themselves. It is nevertheless mueh used as a general tonie in various pharmacentical preparations.

As to the alkaloids, the only one whieh is in general use is quinine. The negleet of the others is a regrettable waste, whieh the result of reeent investigations ought to obviate. In the year 1866, the Madras Government appointed a Medieal Commission to test the respeetive efficaey in the treatment of fever, of Quinine, Quinidine, Cinehonine and Cinchonidine. Of the sulphates of these alkaloids, a due supply, speeially prepared under Mr. Howard's superintendence, was plaeed at the disposal of the Commission. From the report ${ }^{1}$ it appears that the number of eases of paroxysmal malarious fevers treated, was 2472 ,-namely 846 with Quinine, 664 with Quinidine, 569 with Cinehonine, and 403 with Cinchonidine. Of these 2472 eases, 2445 were eured, and 27 failed. The difference in remedial value of the four alkaloids, as deduced from these experiments, may be thus stated:-

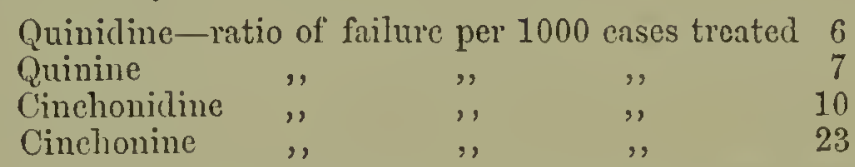

The Indian Government, acting on the recommendation of $\mathrm{Mr}$. Howard, has officially advised (Dec. 16, 1873) the more free use in India of einehona alkaloids other than quinine, and espeeially of sulphate of cinchonidine, whieh is procurable in abundanee from Red Bark. ${ }^{2}$ Quinidine on the other hand, whieh has proved the most valuable of all, is only obtainable from a few barks and in very limited amount.

Adulteration - There is not now any frequent importation of spurious cinchona barks, but the substitution of bad varieties for good is suffieiently common. To diseriminate these in a positive manner by aseertaining the pereentage of quinine, whieh is the ehief criterion of value, reeourse must be had to chemieal analysis, a method of performing whieh has been described.

\section{Modern Works relating to Cinchona.}

The following enumeration has been drawn up for the sake of those desiring more ample information than is contained in the foregoing pages, but it has no pretension to be a complete list of all publieations that have lately appeared on the subject.

] Blue Book-licst India Chinchona Cultivatim, 1870. pp. 156-172.-T'he report contains vory interesting and important medieal details. See also Dongall in Edinz.

2 We hear (April 1S74) that the Gorernment has lately purchased by tender between 300 and 400 th. of einelionidine. 
Berg (Otto), Chinarinden der pharmakognostischen Sammlung au Berlin. Berlin, $1865,4^{\circ} .48$ pages and 10 plates showing the microscopic structure of barks.

Bergen (Heimrich von), Monographic der China. Hamburg, 1826, $4^{\circ}$. 348 pages and 7 coloured plates representing the following barks :China rubra, Huanuco, Calisaya, flava, Hurmalies, Loxa, Jaen. An exhaustive work for its period in every direction.

Blue-books-East Indic (Chinchona Plant). Folio.

a. Copy of Correspondenec relating to the introduetion of the Chinehona Plant into India, and to proccedings connected with its cultivation, from March 1852 to March 1863. Ordered by the House of Commons to be printed, 20 March, 1863. 272 pages.

Contains correspondence of Royle, Markham, Spruce, Pritchett, Cross, McIvor, Anderson and others, illustrated by 5 maps.

b. Copy of further Correspondence relating to the introduction of the Chinehona Plant into India, and to proceedings connceted with its cultivation, from April 1863 to April 1866. Ordered by the House of Commons to be printed, 1s June, 1866. 379 pages.

Contains Monthly Reports of the plantations on the Neilgherry Hills; Annual Reports for 1863-64, 1864-65, with details of method of propagation and cultivation, barking, mossing, attacks of insects, illustrated by woodcuts and 4 plates; report of Cross's journey to Pitayo, with map ; Cinchona cultivation in Wynaad, Coorg, the Pulney Hills and Travancore, with map; in British Sikkim, the Kangra Valley (Punjab), the Bombay Presidency, and Ceylon.

c. Copy of all Correspondenec between the Secretary of State for India and the Governor-General, and the Governors of Madras and Bomban, relating to the cultivation of Chinchona Plants, from April 1866 to April 1870. Ordered by the House of Commons to be printed, 9 August, 1870.

Contains reports on the Neilgherry and other plantations, with map; appointment of Mr. Broughton as analytical chemist, his reports and analyses; reports on the relative efficacy of the several cinchona alkaloids, on cinchona cultivation at Darjiling and in British Burma.

Delondre (Augustin Pierre) et Bouchardat (Apollinaire), Quinologie. Paris, $1854,4^{\circ} .48$ pages, and $23 \mathrm{good}$ coloured plates exhibiting all the barks then met with in commerce.

Forkom (K. W. van), Die Chinacultur auf Java. Leipzig, 1869, 61 pages. An account of the management of the Dutch plantations.

Howard (John Eliot), Illustrations of the $\Lambda^{\top}$ ueva Quinologia of Pavon. London, 1862, folio, 163 pages and 30 beautiful coloured plates.Figures of Cinchona mostly taken from Pavon's specimens in the herbarium of Madrid, and 3 plates representing the structure of several barks:

IToward (John Eliot), Quinology of the Fast Indian Plantations. London, 1869 , folio $x$. and 43 pages, with 3 coloured plates exhibiting structural peculiarities of the barks of cultivated Cinctuone.

Karsten (Hermann), Die medicinisehen Chinarinden Neu-Granada's. Berlin, $1858,8^{\circ}$. 71 pages, and 2 plates showing microscopic structure of a few barks. An English translation prepared under the supervision of Mr. Markham, has been printed by the India Office, under 
the title of Notes on the Medicinal Cinehona Barls of NTor Granade by H. Karsten, 1861. The plates liave not been reproduced.

Karsten' (Hermamn), Flora: Colnembie lerrarum rue adjacentiun specimina selecte. Berolini, 1858, folio. lieautiful coloured figures of various plants including Cinchona, under which name are several species usually referred to other genera. Only the first 3 parts lave been published.

Markham (Clements Robert), I'he Chinchone Species of Now Grenada, containing the botanical deseriptions of the specics examincd by Drs. Mretis and Karsten; with some account of those botanists, and of the results of thcir labours. London, $1867,8^{\circ} .139$ pages and 5 plates. The plates are not coloured, yet are good reduced copies of those contained in Karsten's Flora Columbia; they represent the following:-Cinchona corymbosa, C. Triance, C. lancifolia, C. cordifolic, C. Treoujensis.

Miquel (Friedrich Anton Wilhelm), De Cinchonce spccicbus quibusclam, adjectis iis qua in Java colnentur. Commentatio ex Annalibus Musci Botanici Lugduno-Batavi cxseripta. Amstelodami, 1869, 4. ${ }^{\circ} 0$ pages.

Phoebus (Philipp), Die Delondrc-Bouchardat'schen China-Rinden. Giessen, $1864,8^{\circ} .75$ pages and a table. The author gives a description without figures, of the microscopic structure of the type-specimens figured in Delondre and Bouchardat's Quinologie.

Planchon (Gustave), Dcs Quinquinas. Paris et Montpellier, 1864, 8. 150 pages. A description of the cinchonas and their barks. An English translation has been issued under the superintendence of Mr. Markham by the India Office, under the title of Pcruvian Barks by Gustavc Planchon. London, printed by Eyre and Spottiswoode, 1866. Soubeiran (J. Léon) et Delondre (Augustin), Dc l'introduction ct de l'acclimatation des Cinchonas dans lcs Indes nécrlandaises ct dans lcs Indes britanniques. Paris, $1868,8^{\circ} .165$ pages.

Triana (José), Nouvclles études sur les Quinquinas. Paris, 1870, folio, 80 pages and 33 plates. An interesting account of the labours of Mutis, illustrated by uncoloured copies of some of the drawings prepared by him in illustration of his unpublished Quinologia de Bogotá, especially of the several varieties of Cinchona lancifolia; also an enumeration and short descriptions of all the species of Cinchona, and of New Granadian plants (chicfly Cascarillce) formerly placed in that genus.

Vogl (August), Chinarinden des Wiener Grosshandcls und der Wiener Sammlungen. Wien, 1867, 8․ 134 pages, no figures. A very exhaustive description of the microscopic structure of the barks occurring in the Vienna market, or preserved in the museums of that city.

Weddell (Hugh Algernon), Histoire naturelle des Quinquinas, ou monographie du genre Cinchona, suivic l'une description du genre Cascarilla et de quelques autrcs plantes de la môme tribu. Paris, 1849, folio, 108 pages, 33 plates, and map. Excellent uncoloured figures of Cinchona and some allied genera, and beautiful coloured drawings of the officinal barks. Plate I. exhibits the anatomical structure of the plant; Plate II. that of the bark.

Weddell (Fugh Algernon), Notes sur les Quinquinas, extrait des Annales 
des Seicnees naturelles, $5^{\circ}$ série, tomes xi. et xii. Paris, $1870,8^{\circ}$. 75 pages. A systematic arrangement of the genus Cinehona, and description of its (33) species, accompanied by useful remarks on their barks. An English translation has been printed by the India Office with the title-Notes on the Quinquinas by H. A. Weddell, London, $1871,8^{\circ} .64$ pages. A German edition by Dr. F. A. Fliickiger has also appeared under the title Uebersieht der Cinchonen von $H$. A. $W^{\top}$ eddcll. Schaffhausen and Berlin, 1871, 8. 43 pages, with additions and indexes.

\section{RADIX IPECACUANHA.}

\section{Ipeeaenanta Root, Ipeeaeuan; F. Raeine d'Ipéeaeuanta annelée;} G. Breehwurzel.

Botanical Origin-Cephaëlis Ipeeaeuanha A. Richard-This is a small shrub, 8 to 16 inches high, with an ascending, afterwards erect, simple stem, and somewhat creeping root, growing socially in moist and shady forests of South America, lying between $8^{\circ}$ and $22^{\circ} \mathrm{S}$. lat., especially in the Brazilian provinces of Pará, Maranhão, Pernambuco, Bahia, Espiritu Santo, Minas, Rio de Janeiro, and São Paulo. Within the last half century, it has been discovered in the vast interior province of Matto Grosso, chiefly in that part of it which forms the valley of the Rio Paraguay. From information given to Weddell, ${ }^{1}$ it would seem probable that the plant extends beyond the frontiers of Brazil to the Bolivian province of Chiquitos.

The root which is brought into commerce, is furnished chiefly by the region lying between the towns of Cuyabá, Villa Bella, Villa Maria, and Diamantina in the province of Matto Grosso; but to some extent also by the woods in the neighbourhood of the German colony of Philadelphia on the Rio Todos os Santos, a tributary of the Mucury, north of Rio de Janeiro.

Prof. Balfour of Edinburgh, who has paid much attention to the propagation of ipecacuanha, finds that the plant exists under two varieties of which he has published figures $;^{2}$ they may be thus distinguished:-

a. Stem woody, leaves of firm texture, elliptic or oval, wavy at the edges, with but few hairs on surface and margin. Long in cultivation : origin unknown.

b. Stem herbaceous, leaves less firm in texture, more hairy on margin, not wavy. Grows in the neighbourhood of Rio de Janeiro.

The plant cultivated in India seems disposed to run into several varieties, but according to the experience gained in Edinburgh, the diversity of form apparent in young plants, tends to disappear with age.

History-In an account of Brazil written by a Portuguese friar, who, it would seem, had resided in that country from about 1570 to

1 Ann. des Scicnces nat., Bot., xi. (1849) $193-202$.

2 Trans. of Roy. Soc. of Edinb. xxvi. (1572) 781. plates 31-32. 
1600, and published by Purchas, ${ }^{1}$ mention is made of threc remedies for the bloody flux, one of which is called Igpecaya or Pigaya; the drug herc spoken of is probably that under notice.

Piso and Maregraf ${ }^{2}$ in their scicntific exploration of Brazil, unct with ipecacuanha, of which they described the virtucs; they also figured the plant, noticing its cxistence under two varieties.

The introdnction of the drug to Europe is thus narrated by Sprengel, Mérat, Virey, Hcrzog, and others:-Although well known from the accounts given by Piso and Marcgraf and in common use in Brazil, ipccacuanha was not employed in Europe prior to the year 1672. At that date a pliysician named Legras brought from South America a quantity of the root to Paris, but administering it in too large doses, damaged rather than aidcd the reputation of the new drug. A few ycars later, namcly in 1686, a merchant of Paris named Grenier or Garnicr, became possessed of $150 \mathrm{lt}$. of ipccacuanha, the valuable properties of which in dysentery he vaunted to his medical attendant Afforty, and to Jcan-Claudc-Adrien Helvctius, pupil of the latter. Grenicr on his convalesccnce made a present of some of the new drug to Afforty, who attached to it but little importance. Helvetius on the other hand was induced to prescribe it in cases of dysentery, which he did with the utmost success. It is said he even caused placards to be affixed to the corners of the streets, amnouncing his successful treatment with the new drug, supplics of which he obtained through Grenier from Spain, and sold as a sccret medicine. The fame of the cures cffected by Helvctius reached the French Court, and caused some trials of the drug to be made at the Hôtel Dieu. These having been fully successful, Louis XIV. accorded to Helvetius the sole right of vending his remedy. Subsequently several great personages, including the Dauphin of France, having expericnced its benefit, the king consulted his physician D'Aquin and his confessor, and through them negotiated the purchase from Helvetius of his secret, for 1000 louis-d'or, and made it public. The right of Helvetius to this payment was disputed in law by Grenier, but maintained by a decision of the Châtelet of Paris.

The botanical source of ipecacuanha was the subject of much disputc until finally settled by Gomez, a physician of the Portuguese navy, who brought authentic specimens from Brazil to Lisbon in the year $1800{ }^{6}$

Collection ${ }^{7}$-The ipecacuanha plant, Poaya of the Brazilians, grows in valleys, yet prefers spots which arc rather too mucl raised to be inundated or swampy. Here it is found under the thick shade of ancient trees, growing mostly in clumps. In collecting the root, the poaycro, for so the collector of poaya is called, grasps in one handful if he can, all the stems of a clump, pushing under it obliquely into the soil a pointed stick to which he gives a see-saw motion. A lump of carth inclosing the roots is thus raised; and, if the operation has becn well performed, those of the whole clump are got up almost unbroken. The proaycro shakes off adhering soil, places the roots in a large bag which he carries

1 Purchas, His Pilgrimes, Lond. iv. (1625), -a treatise of Brasill, written by a Portugall which had long lived there, p. 1311.

Hist. nat. Brasil. 1648. Piso p. 101, Marcgraf p. 17.

3 IIistoire de la Médecine, Paris, $v$
4 Dict. de DIat. Mréd. iii. (1S31) $64 t$.

5 De Ipecacuanhâ disscrtatio, Lips. 1 S26.

6 Trans. of Linn. Soc. vi. (1S01) $13 \%$.

- Abstracted from the interesting cyewitness account of Weddell, 7.c. 
with him, and goes on to seek other clumps. A good collector may thus get as much as $30 \mathrm{Hb}$. of roots in the day; but generally a daily gathering does not exceed 10 or $12 \mathrm{tb}$, and there are many who scarcely get 6 or $8 \mathrm{Ht}$. In the rainy season, the ground being lighter, the roots are removed more easily than in dry weather. The poayeros, who work in a sort of partnership, assemble in the evening, unite their gatherings, which having been weighed, are spread out to dry. Rapid drying is advantageous: the root is therefore exposed to sunshine as much as possible, and if the weather is favourable, it becomes dry in two or three days. But it has always to be placed under cover at night on account of the dew. When quite dry, it is broken into fragments, and shaken in a sieve in order to separate adherent sand and earth, and finally it is packed in bales for transport.

The harvest goes on all the year round, but is relaxed a little during the rains, on account of the difficulty of drying the produce. As fragments of the root grow most readily, complete extirpation of the plant in any one locality does not seem probable. The more intelligent poayeros of Matto Grosso, are indeed wise enough intentionally to leave small bits of root in the place whence a clump has been dug, and even to close over the opening in the soil.

Cultivation-The importance in India of ipecacuanha as a remedy for dysentery, and the increasing costliness of the drug, ${ }^{1}$ have occasioned active measures to be taken for attempting its cultivation in that country. Though known for several years as a denizen of botanical gardens, the ipecacuanha plant has always been rare, owing to its slow growth and the difficulty attending its propagation.

It was discovered in 1869 by M'Nab, curator of the Botanical Garden of Edinburgh, that if the annulated part of the root of a growing ipecacuanha plant be cut into short pieces, even only $\frac{1}{16}$ of an inch thick, and placed in suitable soil, each piece will throw out a leafbud and become a separate plant. Lindsay, a gardener of the same establishment, further proved that the petiole of the leaf is capable of producing roots and buds, a discovery which has been utilized in the propagation of the plant at the Rungbi Cinchona plantation in Sikkim.

In 1871, well-formed fruits were obtained from the ipecacuanha plants growing in the Edinburgh Botanic Garden: this was promoted by artificial fertilization, especially when the flowers of a plant producing long styles, were fertilized with the pollen of one having short styles,for Ccphaëlis like Cinchono has dimorphic flowers.

With regard to the acclimatization of the plant in India, much difficulty has been encountered, and successful results are still problematical. The first plant was taken to Calcutta by Dr. King in 1866, and by 1868 had been increased to nine; but in 1870-71, it was reported that notwithstanding every care, the plants could not be made to thrive. Three plants which had been sent to the Rungbi plantation in 1868, grew rather better; and by adopting the method of root-propagation, they

1 The following are the average prices at which the drug was purchased wholesale, in london during three pcriods of ten years cach :-

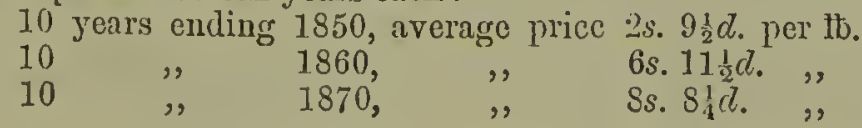


were increased by August 1871, to 300. Three consignments of plants, numbering in all 370, were received from Scotland in 1871-72, besides a smaller number from the Royal Gardens, Kew. From these various collections, the propagation has been so extensive, that on the 31 March, 1873 , there were 6,719 young plants in Sikkim, in addition to about 500 in Calcutta.

The ipecacuanha plant in India has been tried under a variety of conditions as regards sun and shade, but thus far with only a moderate amount of success. The best results are those that have been obtained at Rungbi, 3000 feet above the sea, where the plants, placed in glazed frames, were reported in May 1873, as in the most healthy condition. ${ }^{\text {I }}$

Description-The stem creeps a little below the surface of the soil, emitting a small number of slightly branching contorted roots, a few inches long. These roots when young are very slender and threadlike, but grow gradually knotty, and become by degrees invested with a very thick bark, transversely corrugated or ringed. Close examination of the dry root, shows that the bark is raised in narrow warty ridges, which sometimes run entirely round the root, sometimes encircle only half its circumference. The whole surface is moreover, minutely wrinkled longitudinally. The rings or corrugations of a full-sized root number about 20 in an inch; not unfrequently they are deep enough to penetrate to the wood.

The root attains a maximum diameter of about $\frac{2}{10}$ of an inch; but as imported, a large proportion of it is much smaller. The woody central part is scarcely $\frac{1}{20}$ of an inch in diameter, sub-cylindrical, sometimes striated, and devoid of pith.

Ipecacuanha is of a dusky grey hue, occasionally of a dull ferruginous brown. The root is hard, breaks short and granular (not fibrous), exhibiting a resinous, waxy, or farinaceous interior, white or greyish. The bark, which constitutes 75 to 80 per cent. of the entire root, may be easily separated from the less brittle wood. It has a bitterish taste and faint, musty smell; when freshly dried it is probably much more odorous. The wood is almost tasteless. In the drug of commerce the roots are always much broken, and there is often a considerable separation of bark from wood; portions of the non-annulated, woody, subterraneous stem are always present.

During the last few years there has been imported into London, a variety of ipecacuanla, distinguished as Carthagena or New Granada Ipecaeuanha, and differing from the Brazilian drug chiefly in being of larger size. Thus, while the maximum diameter of the amulated roots of Prazilian ipecacuanha is about $\frac{2}{10}$ of an inch, corresponding roots of the New Granada variety attain nearly $\frac{3}{10}$. The latter moreover, has a distinct radiate arrangement of the wood, due to a greater developement of the medullary rays, and is rather less conspicuously annulated. Lefort (1869) has shown that the New Granada drug is a little less rich in emetine than the ipecacuantia of Brazil.

Mr. R. B. White, of Medellin in the valley of the Cauca, New Granada, near which place the drug has been collected, has been good 
enough to send us herbarium specimens of the plant with roots attached; they agree entirely with Cephaielis Ipecacuanha.

Microscopic Structure-The root is coated witl a thin layer of brown cork cells; the interior cortical tissue is made up of a uniform parenchyme, in which medullary rays cannot be distinguished. In the woody column they are obvious; the prevailing tissue consists of short pitted vessels. The cortical parencliyme and the medullary rays are loaded with small starch granules. Some cells of the interior part of the bark, contain however only bundles of acicular crystals of oxalate of calcium.

Chemical Composition-The peculiar principles of ipecacuanha are Emetine and Ipecacuantic Acid, together with a minute proportion of a foetid volatile oil. The activity of the drug appears to be due solely to the alkaloid, which taken internally is a potent emetic.

Emetine, discovered in 1817 by Pelletier and Magendie, is a bitter, inodorous, colourless substance with distinct alkaline reaction, amorphous in the free state as well as in most of its salts. Reich (1863) alone appears to have obtained crystals of the hydrochlorate. The same chemist found emetine not to be decomposed by boiling hydrochloric acid. The root yields of the alkaloid less than 1 per cent.; the numerous higher estimates that have been given, relate to impure emetine, or have been arrived at by some defective methods of analysis. ${ }^{1}$

The formula assigned to emetine by Reich, $\mathrm{C}^{20} \mathrm{H}^{30} \mathrm{~N}^{2} \mathrm{O}^{5}$, differs from that of quinine by containing in addition 3 molecules of $\mathrm{H}^{2} \mathrm{O}$. Lefort however (1869) gires the formula of emetine as $\mathrm{C}^{30} \mathrm{H}^{44} \mathrm{~N}^{2} \mathrm{O}^{8}$. He obtained the alkaloid by exhausting with chloroform, the fluid alcoholic extract of the root, to which some potash had been added. Emetine is abundantly soluble in chloroform, sparingly in ether. It melts at $70^{\circ} \mathrm{C}$. The nitrate of emetine is a soft resin-like mass, and requires no less than 100 parts of water for solution ; the tannate is still less soluble. Lefort obtained from the root, 1.3 per cent. of nitrate or 1.4 of tannate.

The above reactions may be easily shown thus:-Take 10 grains of powdered ipecacuanha and mix them with 3 or 4 grains of quick-lime and a few drops of water. Allow the mixture to dry, and transfer it to a vial containing 2 fluid drachms of chloroform : agitate frequently, then filter into a capsule containing a minute quantity of acetic acid, and allow the chloroform to evaporate. Two drops of water now added will afford a nearly colourless solution of emetine, which, placed in a watch-glass, will readily give the characteristic precipitates upon addition of a saturated solution of nitrate of potassium, or of tannic acid, or of a solution of mercuric iodide in iodide of potassium.

If the rood separated as exactly as possible from the bark, is used and the experiment performed in the same way, the solution will reveal only traces of emetine. By addition of nitrate of potassium, no precipitate is then produced, but tannic acid or the potassico-mercuric iodate afford a slight turbidity. This experiment confirms the observation that the bark is the seat of the alkaloid, as might indeed be inferred from the fact, that the wood is nearly tasteless.

I See the results obtained by Richard and Parmel, by Magendie and Pelletier, and by Attfield, as recorded by the last-nameil chemist in Procecdings of the British Pharmaceutical Conference for 1569. 37-39. 
Ipecceuanhic Acid, regarded by Pelletier as gallic acid, but recognized as a peculiar substance by Willigk, ${ }^{1}$ is reddish-brown, anorphous, bitter, and very hygroscopic. It is related to caffetannic and kinic acids; Reicli lias shown it to be a ghucoside.

Ipecacuanha contains also, according to Keich, small proportions of resin, fat, albumin, and fermentable and crystallizable sugar'; also gum and a large quantity of pectin. The bark yielded about 30 per cent., and the wood more than 7 per cent. of starch.

Commerce-The imports of ipecacuanha into the United Kingdom in 1870 amounted to $62,952 \mathrm{Hb}$., valued at $£ 16,639 .{ }^{2}$

Uses-Ipecacuanha is given as an emetic, but much more often in small doses as an expectorant and diaphoretic. In India it has proved of late a most important remedy for dysentery. Since the year 1858 when the administration of ipecacuanha in large (30 grains) doses began to be adopted, the mortality in the cases treated for this complaint has greatly diminished. ${ }^{3}$

Adulteration and Substitutes-It can hardly be said that ipecacuanha as at present imported is ever adulterated. Although it may contain an undue proportion of the woody stems of the plant, it is not fraudulently admixed with other roots. But it very often arrives muchl deteriorated by damp : we have the authority of an experienced druggist for saying that at least three packages out of every four offered in the London drug sales, have either been damaged by sea-water or by damp' during their transit to the coast.

Several roots have been described as False Ipecaeuanta, but we know not one that would not be readily distinguished at first sight by any druggist of average knowledge and experience.

In Brazil, the word Poaya is applied to emetic roots of plants of at least six genera, belonging to the orders Rubicaeew, Violariea, and Polygalea; while in the same country, the name Ipeeacuantha is used for various species of Ionidium ${ }^{4}$ as well as for Cephaëlis.

Some of these roots, which are occasionally brought to Europe under the notion that they may find a market, have been described and figured by pharmacologists. We shall notice only the following:-

1. Large Striated Ipecacuanha.-This is the root of Psychotric emetica Mutis (Rubiacece), a native of New Granada. It is considerably stouter than true ipecacuanha, but consists like the latter of a woody column covered with a thick brownish bark. The latter though marked here and there with constrictions and fissures, is not annulated like ipecacuanha, but has very evident longitudinal furrows. But its most remarkable character is that it remains soft and moist, tough to the hnife, even after many years; and the cut surface has a dull violet hue. The

1 Gmeliu, Chemistry, xv. (1862) 523.

2 Annual Statcment of the Tradc and Navigation of the U.K. for 1870 . - The more recent issues of this return have been simplified to such an extent that drugs are for the oreater part included under one hearl.

3 In the Madras Presidency, the deathrate from dysentery was 7.1 jer 1000 eases treated: under the new method of trentment, it has been reduced to $13 \cdot 5$. lin
Bengal, it has fallon from $88 \cdot 2$ to $28 \cdot 8$ per 1000. - Supplement to the Garclle of Indie, January 23, 1869.

${ }^{4}$ As Ionidium Ipecacuanlua Vent., I. Poaye St. Hil., I. parviflornem Vent., the first of which affords the Poaya branca or Whitc Ipccacuantha of the Brazilians. - See C. F. P. von Martius, Specimen Mat. MCd. Bras. 1824; $\Lambda$. de St. Hilaire, Plantci usuclles des Brasilicus, 1827-28. 
root has a sweetish taste and abounds in sugar; ${ }^{1}$ its decoction is not rendered blue by iodine, nor is any starch to be detected by means of the microscope. The drug occasionally appears in the London market.

2. Small Striated Ipecacuanha-This drug in outward appearance closely resembles the preceding, but is usually of smaller size,-_sometimes much smaller and in short pieces tapering torvards either end. It also differ's in being brittle, abounding in starch, and having its woody column provided with numerous pores, easily visible under a lens. Prof. Planchon ${ }^{2}$ of Paris, who has particularly examined both varieties of Striated Ipecacranha, is of opinion that the drug under notice may be derived from some species of Richardsonia.

3. Undulated Ipecacuanha-The root thus called is that of Richardsonia scabra L., a plant of the same order as Cephaëlis, very common in Brazil, where it grows in cultivated ground and sandy places, or by roadsides, and even in the less frequented streets of Rio de Janeiro. Authentic specimens have been forwarded to us by Mr. Glaziou of Rio de Janeiro, and Mr. J. Correa de Méllo of Campinas; and we have also had an ample supply of the plant cultivated by one of us near London.

The root in the fresh state is pure white, but by drying becomes of a deep iron-grey. In the Brazilian specimens, there is a short crown emitting as many as a dozen prostrate stems; below this there is generally, as in true ipecacuanha, a naked woody portion, which extends downwards into a thicker root, $\frac{2}{10}$ of an inch in diameter, and six or more inches long. This part of the root is marked by deep fissures on alternate sides, which give it a knotty, sinuous, or undulating outline. It has a brittle, very thick bark, white and farinaceous within, surrounding a strong flexible slender woody column. The root has an earthy odour not altogether unlike that of ipecacuanha, and a slightly sweet taste. It affords no evidence of emetine when tested in the manner described at p. 335 .

\section{VALERIANACEA.}

\section{RADIX VALERIAN $Æ$.}

\section{Valerian Root; F. Racine de Valériane; G. Baldrianwurzel.}

Botanical Origin-Valeriana officinalis L, an herbaceous perennial plant, growing throughout Europe from Spain to Iceland, the North Cape and the Crimea, and extending over Northern Asia to the coasts of Manchuria. The plant is found in plains and uplands, ascending even in Sweden to 1200 feet above the sea-level.

In England, valerian is cultivated in many villages ${ }^{3}$ near Chesterfield in Derbyshire, the wild plant which occurs in the neighbourhood not being sufficiently plentiful to supply the demand.

In Vermont, New Hampshire and New York, as well as in Holland,

1 Attfield in Pharm. Jorm. xi. (1870) 140. 19.

Journ. de Pharm. xri. (1872) 404 ; xvii.

3 Namely Ashover, Woolley Moor, Mor- ton, Stretton, Higham, Shirland, Pilsiey, North and South IVingfield, and Brackenfield. From the produce of these villages, one wholesale dealer in Chesterfield obtained in 1872 about 6 tons $(13,44016$.) of root. 
the plant is grown to some extent. It is propagated by separating the young plants which are developed at the end of rumners emitted from the rootstock.

The wild plant, according to the situation it inluabits, exhibits several divergent forms. Among eight or more varicties noticed by botanists, ${ }^{1}$ we may especially distinguish a. major with a comparatively tall stem and all the leaves toothed, and $\beta$. minor ( $V$. angustifotia Tausch) with entire or slightly dentate leaves.

History-The plant which the Greeks and Romans called Фov or Phu, and which Dioscorides and Pliny describe as a sort of wild nard, is usually held to be some species of valerian. ${ }^{2}$

The word Valeriana is not found in the classical authors. We first meet with it in the 9th or 10th century, at which period and for long afterwards, it was used as synonymous with $P h u$ or $F^{r} u$.

Thus in the writings of Isaac Judæus ${ }^{3}$ an Egyptian physician, who died at an advanced age, A.D. $932^{4}$ occurs the following:- "Fru id est valeriana, melior rubea ct tenuis et qua venit de Armenia et est diversa in sua complexione. . .."

Constantinus Africanus ${ }^{5}$ who ended his life in 1087, as a monk at Monte Casino where he taught medicine, says- " Fu, id . est valerianc. Naturam habet sicut spiea nardi. . . ."

The word Valeriane occurs in the recipes of the Anglo-Saxon leeches written as early as the 11th century. ${ }^{6} \quad$ Valeriana, Amantilla and $F u$ are used as synonymous in the Alphitc, a inediæval vocabulary of the school of Salernum. ${ }^{7}$

Saladinus ${ }^{8}$ of Ascoli in Italy, directs (eirece A.D. 1450) the collection in the month of August of "radiees fu id est valeriance."

Valerian was anciently called in English Sctwall, a name properly applied to Zedoary; and the root was so much valued for its medicinal virtues, that as Gerarde ${ }^{9}$ (1567) remarks, the poorer classes in the north of England esteemed "no broths, pottage, or physicall meats" to be worth anything without it. Its odour now considered intolerable, was not so regarded in the 16 th century, when it was absolutely the custom to lay the root among clothes as a perfume ${ }^{10}$ in the same way as those of Valcriana Celtica $\mathrm{L}$. and the Himalayan valerians are still used in the East.

Some of the names applied to valerian in Norther'l and Central Europe are remarkable. Thus in Scandinavia we find Velandsrot, Velamsrot, Vändelrot (Swedish); Vendelród, Venderód, Vendingsród (Norwegian); and Velandsint (Danish) - names all signifying Vandals' root. ${ }^{11}$ Valerian is also called in Danish Danmarks gros. Among the German-speaking population of Switzerland, a similar word to the last, namely Tannmark,

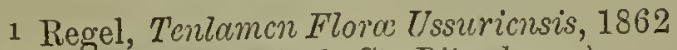
(Mém. de $l^{2}$ Académie de St. Pétersbourg).

$2 V$. offeinalis L. and nine other species, oceur in Asia Minor ('Tehiliateheff').

3 Opera Omnia, Lugd. 1515, cap. 45.-It must be remembered that this is a translation from the Arabie. How the word in question stands in the original we have no means of knowing.

4 Choulant, Handl. dcr Bücherkunde fir die ältere Medicin, Leipz. 1841. 347.

5 De Omnibus medico cognilu necessariis, Basil. 1539. 348.
6 Lcechdoms, Worteunning and Starercift of carly England, iii. (1866) 6. 136.

7 S. de Renzi, Collectio Srtemritana, iii. (1854) 271-322.

8 Compondium Aromatarorium, Bonon. 1488 .

9 Herball, 1636, 1078.

10 Turner's Herball, part 3 (1568) 76 Langham, Gavden of Health, 1633. 598.

11 H. Jenssen-Tuseh, NordiskicPlantenarine, Kjöbenliavu, 1867. 25s. 
is applied to valerian. The Dencmarcha mentioned by St. Hildegard, ${ }^{1}$ about A.D. 1160, is the same. These names seem to point to some connexion with Northern Europe which we are wholly unable to explain.

Description-The valerian root of the shops consists of an upright rhizome of the thickness of the little finger, emitting a few short horizontal branches, besides numerous slender rootlets. The rhizome is naturally very short, and is rendered still more so by the practice of cutting it in order to facilitate drying. The rootlets which are generally 3 to 4 inches long, attain $\frac{1}{10}$ of an inch in diameter, tapering and dividing into slender fibres towards their extremities. They are shrivelled, very brittle, and, as well as the rhizome, of a dull, earthy brown. When broken transversely, they display a dark epidermis forming part of a thick white bark which surrounds a slender woody column. The interior of the rhizome is compact, firm and horny, but when old becomes hollow, a portion of the tissue remaining however in the form of transverse septa.

The drug has a peculiar, somewhat terebinthinous and camphor-like odour, and a bitterish, aromatic taste. The root when just taken from the ground has no distinctive smell, but acquires its characteristic odour as it dries.

Microscopic Structure ${ }^{2}-$ In the rhizome as well as in the rootlets, the cortical part is separated from the central column by a dark cambial zone ; the medullary rays are not distinctly obvious. In old rootstocks, sclerenchymatous cells are met with in the cortical tissue.

The parenchyme of the drug is loaded with small starch granules, brownish grains of tamnic matter and drops of essential oil.

Chemical Composition-Volatile oil is contained in the dry root to the extent of $\frac{1}{2}$ to 2 per cent. This variation in quantity is partly explained by the influence of locality, a dry, stony soil yielding a root richer in oil than one that is moist and fertile. According to Zeller, the oil appears to be more abundant in autumn than in spring. But Schoonbroodt ${ }^{3}$ has shown that the most important influence is the recent condition of the root. He states that if the root is submitted to distillation while perfectly fresh, it yields a neutral water and a large quantity of essential oil. The latter has but a very faint odour, but by exposure to the air it slowly acidifies, especially if a little alkali is added, and acquires a strong smell. Valerianic Acid which is thus formed, amounts to 6 per mille of the fresh root. The dried root yields a distillate of decided valerian odour, containing valerianic acid, but in proportion not exceeding 4 per mille of the root calculated as fresll. Thus, by the operation of drying, the essential oil is oxidized in the root itself, and furnishes the acid and resinoid secondary products. Bouchardat ${ }^{4}$ is of opinion that even the essential oil does not exist in the living plant, but that it is formed by a reaction similar to that which takes place in the production of oil of bitter almonds.

1 Physica, Argent. 1533. 62.

2 The structure of the rhizomes and roots of the differcnt species of valerian has reeently becn discussed by Joannes Chatin in his Etudes sur les Valérianécs, Paris, 1872, illustrated by 14 beautiful plates.
3 Journ. de Médecine de Bnwaxelles, 1867 and 1868; Wittstein's Vicrteljahressehrift $f$. prakt. Pharm. zviii. (1869) 73.

290. Manuel de Matière Mlédicale, i. (1865)
(18) 
Oil of valerian as obtained from the dried root, is a mixture of valerianic acid (about 5 per cent.), Valerene or Borneene $\mathrm{C}^{10} \mathrm{H}^{16}$ (about 25 per cent.) and 70 per cent. of oxygenated compounds, partly crystallizing at $0^{\circ} \mathrm{C}$., and easily resinifying. 'The nature of these compounds has not yet been distinctly made out; among them have been found Valerol, $\mathrm{C}^{6} \mathrm{H}^{10} \mathrm{O}$, and a camplor, $\mathrm{C}^{10} \mathrm{H}^{18} \mathrm{O}$, identical with Borneol or Dryobalanops Camphor. Valerene much resembles oil of turpentine. 'The composition of the neutral oil yielded by the fresh root is doubtless simpler, and ought to be ascertained.

Valerianic Acid, $\mathrm{C}^{5} \mathrm{H}^{10} \mathrm{O}^{2}$, was discovered in valerian root by Pent? in 1819, and more fully examined by Grote in 1830. In composition and most of its properties, it is the same as the valerianic acid produced by the oxidation of amylic alcohol; but in certain other points, these acids do not agree. ${ }^{1}$

After distillation of the oil, there is found a strongly acid residue containing malic acid, resin, and sugar, - the last capable, according to Schoombroodt, of reducing cupric oxide.

Uses-Valerian is employed as a stimulant and antispasmodic.

Substitute-The less aromatic and now disused root of Valeriana Phu L., consists of a thicker rhizome which lies in the earth obliquely; it is less closely annulated and rooted at the bottom only.

\section{COMPOSIT Æ.}

\section{R A D I X I N ULÆ.}

\section{Radix Enulce, Radix Helenii; Elecampane ; ${ }^{2}$ F. Racine d'Aunée; G. Alantwurzel.}

Botanical Origin-Inula Helenium L.-This stately perennial plant is very widely distributed, occurring scattered thronghout the whole of central and southern Europe, and extending eastward to the Cancasus, Southern Siberia and the Himalaya. It is found here and there apparently wild in the south of England and Ireland, as well as in Southerin Norway and in Finland (Schübeler).

Elecampane was formerly cultivated in gardens as a medicinal and culinary plant, and in this manner has wandered to North America. In Holland and some parts of England and Switzerland, it is cultivated on a somewhat larger scale.

History - The plant was known to the ancients as Celsus, Columella, Dioscorides, and Pliny, in wloose time it was used both as a medicine and a condiment. Marcellus Empiricus in the 5th century, and St. Isidore in the begiming of the 7th, name it as Inula, the latter adding - "quam Alam rustici vocant." It is frequently mentioned in the Anglo-Saxon writings on medicine, current in England prior to the Norman Conquest; and was generally well known during the middle ages. Not only was its root much employed as a medicine, but it was also candied and eaten as a siveetmeat.

1 Sehorlemmer, Chemistry of the Carbon Compounds, 1874. pp. 162-165.
2 A corruption of Enula Campana, the latter word referring to the growth of the plant in Campania (Italy). 
Description-For pharmaceutical use, the root is taken from plants two or three years old; when more advanced, it becomes too woody. The principal mass of the root is a very thick short crown, dividing below into several fleshy branches of which the larger are an inch or two in diameter, covered with a pale yellow bark, internally whitish and juicy. The smaller roots are dried entire; the larger are variously sliced, whicli occasions them to curl up irregularly. When dried, they are of a light grey, brittle, horny, smooth-fractured. Cut transversely, the young root exhibits an indistinct radiate structure, with a somewhat darker eambial zone separating the thick bark from the woody nucleus. The pith is not sharply defined, and is often porous and hollow. In the older roots the bark is relatively much thimner, and the internal substance is nearly uniform. Elecampane root has a weak aromatic odour suggestive of orris and camphor, and a slightly bitter, not unpleasant, aromatic taste.

Microscopic Structure--The medullary rays, both of the woody column and the inner part of the bark (endophloum), exhibit large balsam-ducts. In the fresh root they contain an aromatic liquid, which as it dries deposits crystals of helenin, probably derived from the essential oil. The parenchymatous cells of the drug are loaded with inulin in the form of splinter-like fragments, devoid of any peculiar structure.

Chemical Composition-It was observed by Le Fèbrre ${ }^{1}$ as early as 1660, that when the root of elecampane is subjected to distillation with water, a colourless crystallizable substance collects in the head of the receiver, from which it speedily passes on as the operation proceeds. The same substance may also be observed after carefully heating a thin slice of the root, and it is even found as a natural efflorescence on the surface of root that has been long kept. It has a faint odour and aromatic taste, is fusible at $72^{\circ} \mathrm{C}$., and readily soluble in alcohol, but not in water. Until recently it lias been considered a distinct body under the name of Helenin ; ${ }^{2}$ but from the investigations of Kallen, ${ }^{3}$ it would appear to be a compound of two substances, both crystallizable, the one of which he calls Helenin and the other Alantcamphor. Kallen assigus to his helenin the formula $\mathrm{C}^{6} \mathrm{H}^{8} \mathrm{O}$; and describes the substance is fusible at $110^{\circ} \mathrm{C}$. and devoid of odour and taste. Alantcamphor (i.e. (ccampane-camphor) has probably the formula $\mathrm{C}^{10} \mathrm{H}^{16} \mathrm{O}$; it melts at $64^{\circ} \mathrm{C}$., and in taste and smell is suggestive of peppermint. It is very difficult entirely to remove helenin from alantcamphor, these substances being soluble to nearly the sarue extent in alcohol or ether. By disfilling the second of them with pentasulphide of phosphorus, Cymol, $\because \mathrm{H}^{14}$, was obtained. Volatile oil appears to be present in elecampane.

The substance most abundantly contained in elecampane root is Inulin, discovered in it by Valentine Rose in 1804. It has the same composition as starch, $\mathrm{C}^{10} \mathrm{H}^{20} \mathrm{O}^{10}$, but stands to a certain extent in opposition to that substance, 'which it replaces in the root-system of Composita. Inulin has not yet been detected with certainty in plants of any
w)ther tribe.

${ }^{1}$ Apoticaire ordinaire du lioy, distillateur. Hymique de sa Najesté - Troité de la (jhymic, Taris, i. (1660) $375-377$.
2 Gmelin, Chemistry, xvii. (1866) 522.

3 Berichle der Deutschen Chemischen Gesellsehisit, 1874. 1506. 
In living plants, inulin is dissolved in the watery juice, and on drying is deposited within the cells in amorphous masses, which in polarized light are inactive, and are not coloured by jodine. There are various other characters, by which inulin differs from starch. Thus for instance, iunlin readily dissolves in about 3 parts of boiling water; the solution is perfectly clear and fluid, not paste-like; but on cooling deposits nearly all the inulin. The solution is levogyre and is easily transformed into uncrystallizable sugar. With nitric acid, inulin affords no explosive compound as starch does.

Sachs showed in 1864, that by immersing the roots of elecampane or Dahlia variabilis or of many other perennial Composita, in alcohol or glycerin, inulin may be precipitated in a crystalline form. Its globular aggregates of needle-shaped crystals ("sphæro-crystals") then exhibit under the polarizing microscope, a cross similar to that displayed by starch grains.

The amount of inulin varies according to the season, but is most abundant in the autumn. Of the various sources for it, the richest appears to be elecampane; Dragendorff, who has made it the subject of a very exhaustive treatise, ${ }^{1}$ obtained from the root in October not less than 44 per cent., but in spring only 19 per cent.

In the roots of the Compositce, inulin is accompanied according to Popp, ${ }^{2}$ by two closely allied substances, Synanthrose, $\mathrm{C}^{12} \mathrm{H}^{22} \mathrm{O}^{11}+\mathrm{H}^{2} \mathrm{O}$, and Inuloüd, $\mathrm{C}^{6} \mathrm{H}^{10} \mathrm{O}^{5}+\mathrm{H}^{2} \mathrm{O}$. Synanthrose is soluble in dilute alcohol, devoid of any rotatory power, and deliquescent. Inuloïd is much more readily soluble in water than inulin. Both these substances are probably present in elecampane.

Uses-Elecampane is an aromatic tonic, but as a medicine is now obsolete. It is chiefly sold for veterinary practice. In France and Switzerland (Neuchâtel), it is employed in the distillation of Absinthe.

\section{RADIX PYRETHRI.}

\section{Pellitory Root, Pellitory of Spain, F. Pyrèthre salivaire; G. Bertram-} wurzel.

Botanical Origin-Anacyclus Pyrethrum DC. (Anthemis Pyrethrum L.), a low perennial plant with small, much divided leaves, and a radiate flower resembling a large daisy. It is a native of Algeria, growing on the high plateaux that intervene between the fertile coast regions and the desert.

History-The $\pi \dot{u} \rho \epsilon \theta \rho \nu$ of Dioscorides was an umbelliferous plant, the determination of which must be left to conjecture. The pellitory of modern times was familiar to the Arabian writers on medicine, one of whom, Ibn Baytar (ob. A.D. 1248), describes it very correctly from specimens gathered by himself near the city of Constantine in Algeria. The mens gathered by her called by the Berbers sandasab, is found nowhere but in
plant, says he, callor from which region it is carried to other countries. ${ }^{3}$
Western Africa, from

Pellitory root is a favourite remedy in the East, and has long been

1 Materiaticn $\approx u$ cincr Monographic des Inutins, St. Petersburg, 1870.141 pages. - See also Prenll's paper on Inulin, as abstracted in Pharm. Journ. Sept. 1871.262.
2 Wiggers and Huscmann, Jahresbricht for 1870.68 .

3 Sontleimer's translation, ii. (1S42) 179 
an article of export by way of Egypt to India. An Arabic name for it is Aáqurqurhú or Aluiliarce, a word which under slight variations, is found in the principal languages of India. In Germany, pellitory was known as early as the 12 tl century; it is named in the oldest printed works on materia medica.

Description-The root as found in the shops is simple, 3 to 4 inches long by $\frac{3}{8}$ to $\frac{4}{8}$ of an inch thick, cylindrical, or tapering, sometimes terminated at top by the bristly remains of leaves, and having only a few hair-like rootlets. It has a brown, rough, shrivelled surface, is compact and brittle, the fractured surface being radiate and destitute of pith. The bark, at most $\frac{1}{25}$ of an inch thick, adheres closely to the wood, a narrow zone of cambium intervening. The woody column is traversed by large medullary rays in which, as in the bark, numerous dark resin-ducts are scattered. The root has a slight aromatic smell, and a persistent, pungent taste, exciting a singular tingling sensation, and a remarkable flow of saliva. The drug is very liable to the attacks of insects.

Microscopic Structure-The cortical part of this root is remarkable on account of its suberous layer, which is partly made up of sclerenchyme (thick-walled cells). Balsam-ducts (oil-cells) occur as well in the middle cortical layer as in the medullary rays. Most of the parenchymatous cells are loaded with lumps of inulin; pellitory in fact is one of those roots most abounding in that substance.

Chemical Composition-Pellitory has been analysed by several chemists, whose labours have shown that its pungent taste is due in great part to a resin, not yet fully examined. The root also contains a little volatile oil, besides sugar, gum, and a trace of tannic acid. The so-called Pyrethrin is a mixed substance.

Commerce-The root is collected chiefly in Algeria and is exported from Oran and to a smaller extent from Algiers. But from the information we have received from Colonel Playfair, British Consul-General for Algeria, and from Mr. Wood, British Consul at Tunis, it appears that the greater part is shipped from Tunis to Leghorn and Egypt. Mr. Wood was informed that the drug is imported from the frontier town of Tebessa in Algeria into the regency of Tunis, to the extent of 500 cantars $(50,000 \mathrm{tb}$.) per annum.

Bombay imported in the year 1871-72, 740 cwt. of this drug, of which more than half was shipped to other ports of India. ${ }^{1}$

Uses-Chiefly employed as a sialogogue for the relief of tooth-ache, occasionally in the form of tincture as a stimulant and rubefacient.

Substitute - In Germany, Russia and Scandinavia, African pellitory is replaced by the root of Anacyclus officinarum Hayne, an annual herb long cultivated in Prussia and Saxony. ${ }^{2}$ Its root of a light grey is only half as thick as that of $A$. Pyrethrum, and is always abundantly provided with adherent remains of stalks and leaves. It is quite as pungent as that of the perennial species.

I Statement of the Trade and Navigation of the Presidency of Bombay in 1871-72, pt. ii. 19. 98.
2 For further information ou the medicinal specics of Anacyclus, sce a paper by Dr. P. Aseherson in Bonplandia, 15 April, $185 \mathrm{~S}$. 


\section{FLORES ANTHEMIDIS.}

\section{Chamomile Flowers; I: Fleurs te Camomille Iiomaine; G. Römisehe Kamillen.}

Botanical Origin-Anthemis notitis L., the Common or lioman Chamomile, a small creeping perennial plant, throwing up in the latter part of the summer, solitary flower-heads.

It is abundant on the commons in the neighloumhood of London, and generally throughout the south of England; and extends to Ireland, lut is not a native of Scotland. It is plentiful in the west and centre of France, Spain, Portugal, Italy and Dalmatia; and occurs as a doubtful native in Soutliern and Central Russia.

History-The identification of the chamomile in the classical and other ancient authors seems to be impossible, on account of the large number of allied plants liaving similar inflorescence.

The chamomile has been cultivated for centuries in English gardens, the flowers being a common domestic medicine. The double variety was well known in the 16 th century.

The plant was introduced, according to Gessner, into Germany from Spain about the close of the middle ages. Tragus first designated it Chamomilla nobilis, ${ }^{1}$ and Joachim Camerarius, who had observed its abundance near Rome, gave it the name of Roman Chamomile.

Production-The chamomile is cultivated at Mitcham, near London, the land applied to this purpose being in 1864 about 55 acres, and the yield reckoned at about 4 cwt. per acre. The flowers are carefully gathered, and dried by artificial heat; and fetch a high price in the market. ${ }^{2}$

The plant is grown on a large scale at Kieritzsch, between Leipzig and Altenburg, and near Zeiz and Borna, all in Saxony; and likewise to some extent in Belgium and France.

Description-The chamomile flowers found in commerce are never those of the wild plant, but are produced by a variety in which the tubular florets have all, or for the greater part, been converted into ligulate florets. In the flowers of some localities, this conversion has been less complete, and such flowers having a somewhat yellow centre, are called by druggists Single Chamomiles; while those in which all the florets are ligulate and white, are known as Double Chamomiles.

Cliamomile flowers have the general structure found in the order Compositce. They are $\frac{1}{2}$ to $\frac{3}{4}$ of an inch across, and consist of a hemispherical involucre about $\frac{3}{8}$ of an inch in diameter, composed of a number of nearly equal bracts, scarious at the margin. The receptacle is solid, conical, about $\frac{7}{4}$ of an inch in height, beset with thin, concave, blunt, narrow, chaffy scales, from the bases of which grow the numerous florets. In the wild plant, the outer of these to the number of 12 or more, are white, narrow, strap-shaped, and slightly toothed at the apex. The central or disc florets are yellow and tubular, with a somewhat bell-

1 De Stirpium ..., 1552. 149.-In Germany the epithet edel $(=$ nobilis $)$ is frequently used in popular botany to designate nseful or remarkable plants. Tragus may have been inducel to bestow it on the sprecies under notice, on aceount of its superiority to Matricaria Chamomilla, the so-ealled Common Chamomile of the Germans.

$2 \Lambda$ bout $£ 9$ per cwt. Foreign Chamomiles being worth from $£ 3$ to $£ 4$. 
shaped summit from whieh project the two reflexed stigmas. In the eultivated plant, the ligulate florets predominate, or replace entirely the tubular. The florets which are wholly destitute of pappus are reflexed, so that the capitulum when dried has the aspeet of a little white ball. Ninute oil-glands are sparingly scattered over the tubular portion of the florets of either kind. The flower's of ehamomile as well as the green parts of the plant, have a strong aroma, and a very bitter taste.

In trade, dried elamomile flowers are esteemed in proportion as they are of large size, very double, and of a good white-the last named quality being due in great measure to fine dry weather during the flowering period. Flowers that are buff or brownish, or only partially double, command a lower priee.

Chemical Composition-Chamomile flowers yield about $\frac{1}{5}$ per eent. of essential oil, whiel is at first of a pale blue, but beeomes yellowish-brown in the course of a few months. The reeent researehes. of Demarçay (1873) show that this oil is to be regarded as a mixture of butylic and amylic angelate and valerate, whieh bodies are easily deeomposed by the action of eaustic alkali. In faet, by gently warming for a moment 6 parts of the oil with 5 parts of potash, Jaffé (1865) obtained angelate of potassium which, treated with dilute sulphuric acid, afforded Angelic Acicl, fusible at $45^{\circ} \mathrm{C}$. The whole amount of angelie acid is not thus isolated in a erystalline form; but this may be aecomplished if a current of nitrous aeid is condueted through the liquid, in whieh ease the angelie acid floats on the surfaee as an oily layer. By this treatment, 50 parts of erude angelic aeid or 30 of the pure acid, may be obtained from every 100 parts of oil used.

At Mitcham, oil of ehamomile is usually distilled from the entire plant, after the best flowers have been gathered. The oil has a shade of green, to remove whieh it is exposed to sunlight; it thus acquires a brownish-yellow colour, at the same time throwing down a considerable deposit.

Camboulises (187.1) extraeted from double eliamomiles, a bitter acid forming needle-like prisms, but in too small quantity to allow of analysis; he regarded it as identieal with the Anthcmic Acid, obtained by Pattone (1859) from Anthcmis arvonsis. He was unable to diseover in ehamomile the Anthcminc of the latter ehemist, or any other alkaloid. We have performed some experiments in order to isolate the bitte. principlc, but have not suceeeded in obtaining it in a satisfaetory state of purity; it forms a brown extraet, apparently a glucoside. We can also eonfirm the statement that no alkaloid is present.

Uses-An infusion or an extraet of ehamomile is often used as a bitter stomaehie and tonie.

Adulteration and Substitution-The flower-heads of Matricaria C'hamomilla L., designated in Germany Common Chamomilcs (gcmcine Kamillon), are sometinies asked for in this eountry. In aspeet as well as in odour, they are very different from the chamomiles of English pharmaey; they are quite single, not bitter, and have the receptaele devoid of seales and hollow.

A cultivated variety of (hryssanthemum I'urthenium Pers., or Fercrfew, with the florets all ligulate, and some seales on the receptacle (not 
having the receptacle naked, as in the wild form), common in gardens, ${ }^{1}$ lias flower-heads exceedingly like double chamomiles. But they may be distinguished from the latter by their conves or nearly flat receptacle, with the scales lanceolate and acute, and less membranous.

The chamomiles of the Indian bazaars which are brought from Persia and known as Búbuncle, are (as we infer from the statement of Royle) the flowers of Matricaria suaveolens L., a slender form of M. C'luanomilla, growing in Southern Russia, Persia, Southern Siberia, also in North America.

The fresh wild plant of Anthemis notilis L., pulled up from the ground, is sold in London for making extract, a proceeding highly reprehensible supposing the extract to be sold for medicinal use.

\section{SANTONICA.}

Flores Cince, Semen Cinc, ${ }^{2}$ Semen Santoniece, Semen Zedoaria, Semen Contra, Semen Sanetum; Wormseed; F. Semen-eontra, Semeneine, Barbotine; G. Wurmsamen, Zitwersamen.

Botanical Origin-Artemisia maritima, var. a. Stechmanniana Besser $^{3}$ (A. Lereheana Karel. et Kiril. in Herbb. Kew. et Mus. Brit.; A. maritima var. a. pauciflora Weber, quoad Ledebour, Flor. Ross. ii. 570).

Artemisice of the section Seriphidium assume great diversity of form ${ }^{4}$ : they have been the object of attentive study on the part of the Russian botanists Besser (1834-35) and Ledebour (1844-46), whose researches have resulted in the union of many supposed species, under the head of the Linnæan Artemisia maritima. This plant has an extremely wide distribution in the northern hemisphere of the old world, occurring mostly in saltish soils. It is found in the salt marshes of the British Islands, on the coasts of the Baltic, of France and the Mediterranean, and on saline soils in Hungary and Podolia; thence it extends eastward, covering immense tracts in Southern Russia, the regions of the Caspian, and Central Siberia, to Chinese Mongolia.

The particular variety which furnishes at least the chief part of the drug, is a low, shrubby, aromatic plant, distinguished by its very small, erect, ovoid flowerheads, having oblong, obtuse, involucral scales, the interior scales being scarious. The stem in its upper half is a fastigiate, thyrsoid panicle, crowded with flowerheads. The localities for the plant are the ncighbourhood of the Don, the regions of the lower Volga near Zarepta and Zaritzya, and the Kirghiz deserts.

The drug, which consists of the minute, unopened flowerheads, is collected in large quantities, as we are informed by Björklund (1867), on

1 Is not this plant the Anthcmis? porthenioicles Bernh., of which De Candolle says (Prod. vi. 7) -". . . simillima Mlal. Parinenio, sed paleis inter flores instructa. Ferè semper plena in hortis occurrit, et forte ideo palere receptaculi ex luxuriante statu orte nt paler receptaculi indico el sincnsi . . ."?

2 From the Italian semenzina, the diminutive of semen:a (seed).

3 W. S. Besser in Bulletin de Ta Soc. imp. des Naturalistes de Moseou, vii. (1S34) 31. $\Lambda$ specimen of the plant in question labelled in Besser's handwriting, with a memorandum that it is eollected for medicinal use, is in the Herbarium of the Royal Gardens, $\mathrm{K} \mathrm{cr}$. It completely agrees with the Semen Cino of Russian and German commerce. This remark also applies to a specimen of $A$. Lorcheana Karel, et Kiril. in the same herbarium.

4 "Si alix Artemisixe multum variant, Seriphlidia ineonstantiâ formarum omnes superant. . ."-Besser. 
the vast plains or steppes of the Kirghiz, in the northern part of Turkestan. It was formerly gathered about Zarepta, a thriving German colony in the Government of Saratov, but from direct information we have lately (1872) reccived, it appears to bc obtained thcre no longer.

The eniporium for wormseed is the great fair of Nishnei-Novgorod, whence the drug is conveyed to Moscow, St. Petersburg, and Western Europe.

Wormseed is found in the Indian bazaars. A spccimen received by us from Bombay does not matcrially differ in form from the Russian drug, but is slightly shaggy and mixed with tomentose stalks. It is probably brought from Afghanistan and Cabul. ${ }^{1}$

Wilkomm ${ }^{2}$ has lately described as mother-plant of wormseed, an Artemisia which he calls $A$. Cina. It was obtained in Turkestan by Prof. Petzholdt, who received it from the people gathering the drug. The specimen kindly communicated to us by Prof. Wilkomm, has flowerheads which do not entirely resemble the wormseed of trade, in that they have fewer scalcs.

History-Several species of Absinthium are mentioned by Diosco-

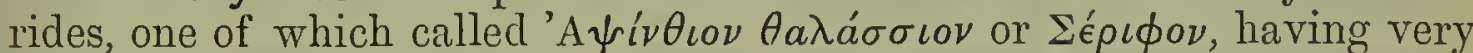
small seeds (capitules), and growing in Cappadocia, he states to be taken in honey as a remedy for ascarides and lumbrici : one can hardly doubt but that this is the modern wormseed. Another species is described by

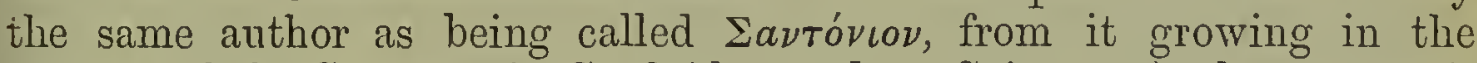
country of the Santones in Gaul (the modern Saintonge); he asserts it to resemble $\sigma$ '́ $\rho \iota \phi \nu$ in its properties.

In an epistle on intestinal worms attributed to Alexander Trallianus, ${ }^{3}$ who practised medicine with great success at Rome in the 6th century, the use is recommended of Absinthium marinum $(\theta a \lambda a \sigma \sigma i a$ a' $\psi(\nu \theta \eta)$, as a cure for ascarides and round worms.

Semen sanctum vel Alexandrinum is mentioned as a vermifuge for children by Saladinus about. A.D. 1450, and by Ruellius, Dodonæus, the Bauhins, and other naturalists of the 16th century. Its ancient reputation has been fully maintained in modern times, and in the form partly of Santonin, the drug is still extcnsively employed.

Description-Good samples of the drug consist almost exclusively of entire, unopened flowerheads or capitules, which are so minute that it requires about 90 to make up the wcight of one grain. In samples less pure, there is an admixture of stalks, and portions of a small pinnate leaf. The flowerheads are of an elliptic or oblong form. about $\frac{1}{10}$ of an inch long, greenish yellow when new, brown if long kept; they grow singly, less frequently in pairs, on short stalks, and are formed of about 18 oblong, obtuse, concave scales, closcly imbricated. This involucre is much narrowed at the base in consequence of the lowermost scales being considerably shorter than the rest. The capitule is sometimes associated with a few of the upper leaves of the stem, which are short, narrow, and simple. Notwithstanding its compactness,

1 Artemisia No. 3201, Herb. Griffith, Afghanistan, in the kew Herbarium has capitules preciscly agrecing with this Bombay drug.
2 Bot.Zcitung, 1 März, 1872.130; Phar'm. Journ. 23 March, 1872. 762 (abstract).

3 Contained in a work by Hieronymus Mcrcurialis, entitled Variarum Lectionum libri quatuor, Venet. 1570. 
the capitule is somewhat ridged and angular, ${ }^{1}$ from the involucral scales having a strong, central nerve or kecl. 'The middle portion of each scale is covered with minute, yellow, sessile glands, which are wanting on the transparent scarious edge. The latter is marked with extremely fine stric and is quite glabrous; in the young state the keel bears a few woolly colourless hairs, but at maturity the whole flowerhead is shining and nearly glabrous. ${ }^{2}$ The florets number from 3 to 5 ; they have (in the bud) an ovoid corolla, glandular in its lower portion, a little longer than the ovary, which is destitute of pappus.

Wormseed when rubbed in the hand exhales a powerful and agreeable odour, resembling cajuput oil and camphor; it has a bitter aromatic taste.

Chemical Composition-Wormseed yiclds about 1 per cent. of essential oil, having its characteristic smell and taste. The oil boils at $175^{\circ} \mathrm{C}$.; it consists mainly, as the investigations of Kraut (1862-3) have shown, of Hirzel's Cinabene-Camphor, $\mathrm{C}^{10} \mathrm{H}^{18} \mathrm{O}$, which when distilled, easily gives off $\mathrm{H}^{2} \mathrm{O}$, so that part of the oil is resolved into $\mathrm{C}^{10} \mathrm{H}^{16}$ and water, which latter produces a turbidity in the previously dehydrated oil. The hydrocarbon has no action on polarized light, but the crude oil is slightly lævogyrate. The latter also originally contains a possibly different, isomeric hydrocarbon, Hirzel's Cincebene, Völckel's Cincne or Cynene.

The water which distils over, carries with it volatile acids of the fatty series, also (as in the case of Anthemis nobilis L.) Angelie Acid.

The substance to which the remarkable action of wormseed on the human body ${ }^{3}$ is due, is Santonin, $\mathrm{C}^{15} \mathrm{H}^{18} \mathrm{O}^{3}$. It was discovered in $1830 \mathrm{l} \mathrm{y}$ Kahler, an apothecary of Düsseldorf, who gave a very brief notice of it in the Archiv der Pharmacie of Brandes (xxxiv. 318). Immeaiately. afterwards Augustus Alms, a druggist's assistant at Penzlin in the grand duchy of Mecklenburg-Schwerin, knowing nothing of Kahler's discovery, obtained the same substance and named it Santonin. Alms recommended it to the medical profession, pointing out that it is the anthelmintic principle of wormseed. ${ }^{4}$ Santonin constitutes from $1 \frac{1}{2}$ to 2 per cent. of the drug, but appears to diminish in quantity very considerably as the Howers open. It is easily extracted by milk of lime, for, though not an acid and but sparingly soluble in water even at a boiling heat, it is capable of combining with bases. It is inodorous, but has a bitter taste, especially when dissolved in chloroform or alcohol. ${ }^{5}$

Santonin forms colourless rectangular tabular crystals, which when exposed to daylight, or to the blue or violet rays, but not to the other colours of the spectrum, assume a yellow hue, and split into irregular fragments. It has not been proved that this change, which takes place even under water, alcohol, or ether, is accompanied by any chemical

I Maceration in water, whieh restores the matural shape of the flowerheads, shows that this shrunken, angular form is not found in the growing plant.

2 Yet too inuch stress must not be laid on this character, for as Besser remarks"perietinii squame in uno loco tomento brevi plus minusve eana, in aliis nucla, ino nitides."

${ }^{3} \Lambda$ s the affeeted vision, so that objects :
Other eflects are reeorded by Stillé (Therapentics and Mat. MTed. ii. 641).

${ }_{4}$ The paper of Alms being eontained in the vory same periodical (p. 319) as that of Kahler (and further in rol. xxxix. 190), affords additional evidence of the independenee of the diseovery.

5 Its ready solubility in 3 or 4 parts of ehloroform, renders its estimation easy when mixed with sugn, as in a santonin lozenge. 
aiteration. Yet Sestini (1865) has asserted that the yellow santonin or "Photo-santonin" has a different composition, namely $\mathrm{C}^{23} \mathrm{H}^{34} \mathrm{O}^{6}$, and a lower fusing point. The behaviour of santonin when exposed to light, resembles that of erythrocentaurin, $\mathrm{C}^{27} \mathrm{H}^{24} \mathrm{O}^{8}$. The latter has been obtained by means of ether, from the alcoholic extract of Erythroca Centaurium, and of some other Gcntianacco. Méhn (1866) has shown that the colourless crystals of that substance when exposed to sunlight, assume a brilliant red colour, without undergoing any chemical alteration. The colourless solutions of this body in chloroform or alcohol yield the original substance. With due precautions, santonin may be sublimed unchanged.

According to Hesse (1873), it appears that santonin is the anhydride of a crystallizable body which he calls Santoninic Acid, $\mathrm{C}^{15} \mathrm{H}^{20} \mathrm{O}^{4}$; when this acid is heated to $120^{\circ} \mathrm{C}$, it is resolved into santonin and water. Cannizzaro and Sestini have shown (1873) that when santonin is heated with an alkali, it may be converted into Santonic Acid, a substance isomeric with santoninic acid, but not resolvable like the latter into santonin and water.

Wormseed contains in addition to the two bodies just described, resin, sugar, waxy fat, salts of calcium and potassium, and malic acid; when carefully selected and dried, it yielded us 6.5 per cent. of ash, rich in silica.

Commerce-Ludwig of St. Petersburg has stated that the imports of wormseed into that city were about as follows:-In 1862, $7400 \mathrm{cwt}$. in 1863, 10,500 cwt; in 1864, 11,400 cwt. The drug was brought fron the Kirghiz steppes by Semipalatinsk and by Orenburg.

Uses-The drug is employed exclusively for its anthelmintic properties, partly in the form of santonin. It proves of special efficacy for the dislodgement of Ascaris lumbricoides.

\section{RADIX ARNICAE.}

Ainica Root; F. Racine d'Arnica; G. Arnicawurzel.

Botanical Origin-Ainica montana L., a perennial plant growing: in meadows throughout the northern and central regions of the northern hemisphere, but not reaching the British Islands. In western and central Europe, it is an inhabitant of the mountains, but in colder countries it grows in the plains.

In high latitudes, as in Arctic Asia and America, a peculiar form of the plant distinguished by narrow, almost linear leaves has been named A. angustifolia Vahl; but numerous transitional forms prove its identity with the ordinary $A$. montance of Europe.

History-The older botanists as Matthiolus, Gessner, Camerarius, Tabernæmontanus, and Clusius were acquainted with arnica and had some knowledge of its medicinal powers. It appear's to have been a popular remedy in Germany at an early period, but was only introduced into regular medicine about 1712, on the recommendation of Johann Michael Fehr of Schweinfurt and of several other physicians. But for enthusiastic laudation of the new remedy, all these writers fall far short of Collin of Vienna, who imagined that in arnica he had found a Euro- 
peau plant possessing all the virtues of Peruvian Bark. ${ }^{1}$ In his hands, fevers and agues gave way under its use, and more than 1000 patients in the Paznlan Hospital were alleged to have been eured of intermittents by an eleetuary of the Howers, between 1771 and 1774! Such happy results were not obtained by other physieians.

Arnica (herba, flos, radix) had it plaee in the London Pharmaeopceia of 1788 , but it soon fell out of notiee, so that Woodville writing in 1790 , remarks that he had been unable to proeure the plant from any of the London druggists. Of late years it has gained some popular notoriety as an application in the form of tineture, for preventing the blaekness of bruises, but in England it is rarely prescribed internally.

Description-The arniea root of pharmaey consists of a slender, contorted, dark-brown rootstoek, an inch or two long, emitting from its under side an abundance of wiry simple roots, 3,4 or more inehes in length; it usually bears the remains of the rosette of eharaeteristic, ovate, eoriaceous leaves, whieh are 3- to 5-nerved, ciliated at the margin, and slightly pubeseent on their upper surfaee. It has a faintly aromatic, herby smell, and a rather aerid taste.

Microscopic Structure-On a transverse section, the rootstoek exhibits a large pith surrounded by a strong woody ring. In the innermost part of the cortieal layer, large oil-duets are found corresponding to the fibro-vascular bundles. Neither starch granules, inulin, or oxalate of caleium are visible in the tissue. The rootlets are of a different struetural eharaeter, but also eontain oil-duets.

Chemical Composition-Several chemists have oeeupied themselves in endeavouring to isolate the aetive principle of arniea. Bastick described (1851) a substanee which he obtained in minute quantity from the flowers and named Arnicine. He states it to possess alkaline properties, to be non-volatile, slightly soluble in water, more so in alcohol or ether; when neutralized with hydroehloric acid, it forms a crystalline salt.

The Amicin extracted by Walz (1861) both from the root and flowers of arniea is a different substance; it is an amorphous yellow mass of aerid taste, slightly soluble in water, freely in aleohol or ether, and dissolving also in alkaline solutions. It is precipitable from its alcoholic solution by tammic aeid or by water. Walz assigns to arnicin the formula $\mathrm{C}^{20} \mathrm{H}^{30} \mathrm{O}^{4}$; other ehemists that of $\mathrm{C}^{35} \mathrm{H}^{51} \mathrm{O}^{7}$. Arnicin has not yet been proved a glueoside, although it is deeomposed by dilute acids.

Sigel $^{2}$ obtained from dried arnica root about $\frac{1}{2}$ per cent. of essential oil, and 1 per eent. from the fresh ; the oil of the latter had a sp. gr. of 0.999 at $18^{\circ} \mathrm{C}$. The eomposition of the oil is represented by the formula $\mathrm{C}^{6} \mathrm{H}^{9} \mathrm{O}$; but it was found to be a mixture of various bodies, the princijal being Dimethylic Ether of Thymohydroquinone. The water from which the oil separated, eontains Isobutyric Acid, probably also a little Angelic
and Formic Acid; but neither eapronic nor caprylic aeid, which had been pointed out by Walz.

Arniea root eontains Inulin, whieh Dragendorff extracted from it to the extent of about 10 per eent.

Uses-Arniea is used ehiefly in the form of tineture as a popular appli-

1 Arnicce, in fobribus et aliis morbis putridis vircs, -in the Anni Madici of Störck 
cation to bruises and chilblains; internally it is occasionally prescribed as a stimulant and diaphoretic.

Adulteration-Arnica root has recently been met with ${ }^{1}$ adulterated with the root of Goum urbanum L., a common herbaceous plant of the order Rosacew. The latter is thicker than the rhizome of arnica, being $\frac{3}{10}$ to $\frac{4}{10}$ of an inch in diameter; it is a true root, furnished on all sides with rootlets, and has an astringcnt taste. The leaves of Geum are pinnate, and quite unlike those of arnica.

\section{Flores Arnicæ.}

Arnica montana produces large, handsome, orange-yellow flowers, solitary at the summit of the stem or branches. The involucral scales of the capitulum (20 to 24) are of equal length, but are imbricated, forming a double row. They are very hairy, the shorter hairs being tipped with viscid glands. The receptable is chaffy, $\frac{1}{4}$ of an inch in diameter, with about 20 ligulate florets, and of tubular a much larger number. The ligulate florets, an inch in length, are oblong, toothed at the apex, and traversed by about 10 parallel veins. The achenes are brown and hairy, crowned by pappus consisting of a single row of whitish barbed hairs.

Arnica flowers have a weak, not unpleasant odour ; they were formerly used in making the tincture, but as the British Pharmacopœia now directs that preparation to be made with the root, they have almost gone out of use, at least in Great Britain. They appear to be rather richer in arnicin than the root, and are said to be fully equal if not superior to it in medicinal powers; yet the essential oil they contain is not the same.

\section{RADIX TARAXACI.}

\section{Dandelion Root, Taraxacum Root; F. Pisscnlit; G. Löwenzahnwurzel.}

Botanical Origin-Taraxacum officinalc Weber ( $T$. Dens-leonis Desf., Leontodon Taraxacum L.), a plant of the northern hemisphere, found over the whole of Europe, Central and Northern Asia, and North America, extending to the Arctic regions. It varies under a considerable number of forms, several of which have been regarded as distinct species. In many districts it is a troublesome weed.

History-Though the common Dandelion is a plant which must have been well known to the ancients, no distinct reference to it can be traced in the classical authors of Greece and Italy. The word Taraxacum is however usually regarded as of Greek origin ; ${ }^{2}$ we have first met with it as Taraklishay $\bar{n} n$, in the works of the Arabian physicians, who speak of it as a sort of Wild Endive. It is thus mentioned by Rhazes in the 10th, and by Avicenna in the 11th century.

The name Dens Lconis, an equivalent of which is found in nearly all the languages of Europe, is stated in the herbal of Johann von Cube ${ }^{3}$ to have been bestowed on this plant by one Wilhelm, a surgeon, who held it in great esteem; but of this personage and of the period during which he lived, we have sought information in vain. Dandelion was

1 Holmes in Pharm. Journ. April 11. 1874. 811 .

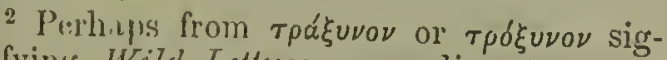
nifying Wild, Letluce; according to somc, from $\tau u$ pakıs, a diseasc of the eye which the plant was used to cure, or from tho verb $\tau \nless \rho \alpha \sigma \sigma \omega, I$ dislurb.

3 Herbarius zu teutseh und von aller handt kreuleren, Augspurg, 1488. cap. clii. 
much valued as a medicine in the tine of Cerarde and Parkinson, and is still extensively employed.

Collection-In England, taraxacum root is considered to be in perfection for extract in the month of November, the juice at that period affording an ampler and better product than at any other. Bentley contends that it is more bitter in March, and most of all in July, and that at the former period at least, it should be preferred.

Description-The root is perennial, and tapering, simple, or slightly branched, attaining in a good soil a length of a foot or more, and half an inch to an inch in diameter. Old roots divide at the crown into several heads. 'T'he root is fleshy and brittle; externally of a pale brown, internally white, and abonnding in an inodorous milky juice of bitter taste. It shrinks very much in drying, losing in weight about 76 per cent. ${ }^{1}$

Dried dandelion root is half an inch or less in thickness, dark brown, shrivelled with wrinkles rumning lengthwise often in a spiral direction; when quite dry, it breaks easily with a short corky fracture, showing ? very thick white bark, surrounding a woody column. The latter is yellowish, very porous, without pith or rays. A rather broad but indistinct cambium-zone separates the wood from the bark, which latter exhibits numerous well-defined concentric layers. The root is inodorous but has a bitterish taste.

Microscopic Structure-On the longitudinal section, especially in a tangential direction, the brownish zones are seen to contain laticiferous vessels, only about $2 \mathrm{mkm}$. in diameter. These traverse their zones in a vertical direction, giving off numerous lateral branches, which however remain always confined to their zone. Within each of these zones, the laticiferous vessels form conseqnently an anastomosing net. We may say that the root is thus vertically traversed by about 10 to 20 concentric rings of laticiferous vessels. ${ }^{2}$ They may be made beautifnlly evident by means of anilin-blue, with which a thin longitudinal section of the fresh root may be moistened. The root must be allowed to partially dry but only till the milky juice coagulates; the thin slice then energetically absorbs the colouring matter. ${ }^{3}$

The tissue of the dried root is loaded with inulin, which does not occur in the solid form in the living plant. The woody part of taraxacum root is made up of large scalariform vessels, accompanied by parenchymatous tissue, the former much prevailing.

Chemical Composition-The fresh milky juice of dandelion is bitter and neutral, but it soon acquires an acid reaction and reddish brown tint, at the same time coagulating with separation of masses of what has been called by Kromayer (1864), Leontodonizm. This chemist, by treating this substance with hot water, obtained a bitter solution yielding an active (?) principle to animal charcoal, from which it was removed by means of boiling spirit of wine. After the evaporation of the alcohol, Kromayer purified the liquid by addition of basic acetate of lead, satri-

1 Thus 5496 th. of the washed root, afforded of dry only $1277 \mathrm{tb}$., or $23.2 \mathrm{per}$ cent. - Information corrmmicated by ILessis. Allen and Hanburys, London.:

2 For further particular's about them, see Vogrl, Silazngsber. der IVicner Alectemie, vi.
(1863) 608 with plate; Hanstein, Milchsaftrcfässe und rervecundte Organe der Rinde, Berlin, 186t. 72. 73. pl. ix.

3 The reader who is not familiar with this process may refer to a paper by p'ocklington in Pharm. Jouril. April 13, 1872.822. 
ration of the filtered solution with sulphuretted hydrogen and evaporation to dryness. The residue then yielded to ether an acrid resin, and left a colourless amorphous mass of intensely bitter taste, named by Kromayer Taraxaein. Polex (1839) obtained apparently the same principle in warty crystals; he simply boiled the milky juice with water and allowed the concentrated decoction to evaporate.

The portion of the "Leontodonium" not dissolved by water, yields to alcohol a crystalline substance, Kromayer's Taraxacerin, $\mathrm{C}^{8} \mathrm{H}^{16} \mathrm{O}$. It resembles lactucerin and has in alcoholic solution an acrid taste. How far the medicinal value of dandelion is dependent on the substances thus extracted, is not yet known.

Dragendorff (1870) obtained from the root gathered near Dorpat in October and dried at $100^{\circ}$ C., 24 per cent. of Inulin and some sugar. The root collected in March from the same place, yielded only 1.74 per cent. of inulin, 17 of uncrystallizable sugar and 18.7 of Levulin. The last-named substance, discovered by Dragendorff, has the same composition as inulin, but dissolves in cold water; the solution tastes sweetish, and is devoid of any rotatory power. Inulin is often to be seen as a glistening powder when extract of taraxacum is dissolved in water.

T. and H. Smith of Edinburgh (1849) have shown that the juice of the root by a short exposure to the air, undergoes a sort of fermentation which results in the abundant formation of Mannite, not a trace of which is obtainable from the perfectly fresh root. Sugar which readily underwent the vinous fermentation, was found by the same chemists in considerable quantity.

The leaves and stalks of dandelion (but not the roots) were found by Marmé (1864) ${ }^{1}$ to afford the peculiar sugar named Inosite, $\mathrm{C}^{12} \mathrm{H}^{24} \mathrm{O}^{12}$.

The root collected in the meadows near Bern immediately before flowering, carefully washed and dried at $100^{\circ} \mathrm{C}$., yielded us $5 \cdot 24$ per cent. of ash, which we found to consist of carbonates, phosphates, sulphates, and in smaller quantity also of chlorides.

Uses-Taraxacum is much employed as a mild laxative and tonic, especially in hepatic disorders.

Adulteration-The roots of Leontodon hispidus L. (Common Hawkbit) have occasionally been supplied by fraudulent herb-gatherers in place of dandelion. Both plants have runcinate leaves, but those of hawkbit are hairy, while those of dandelion are smooth. The (fresh) root of the former is tough, breaking with difficulty and rarely exuding any milky juice. ${ }^{2}$

The dried root of dandelion is exceedingly liable to the attacks of maggots, and should not be kept beyond one season.

\section{HERBA LACTUCA VIROSAE.}

Priekly Lettuce; F. Laitue vireuse; G. Giftlattieh.

Botanical Origin-Laetuea virose L., ${ }^{3}$ a tall herb occurring on stony ground, banks and roadsides, throughout Western, Central and

1 Gmelin, Chemistry, xv. (1862) 351.

${ }^{2}$ Giles, Pharm. Journ. xi. (1852) 107.

3 Bentham unites this plant with $L$.
Scariola L., but in most works on botany they are maintained as distinct species. 
Southern Europe. It is abundant in the Spanish Peninsula and in France, but in Britain is only thinly scattered, reaching its northern. limit in the south-eastern Highlands of Scotland.

History-The introduction of this lettuce into modern medicine is due to Collin, a celebrated physician of Vienna, who about the year 1771 recommended the inspissated juice in the treatment of dropsy. In longstanding cases, this extract was given to the extent of half an ounce a day.

The College of Physicians of Edinburgh inserted Lactuca virosa $\mathrm{L}$. in their pharmacopœia of 1792, while in England its place was taken by the Garden Lettuce, L. sativa I. The authors of the British Pharmasopaic of 1867 have discarded the latter, and directed that Extractum lactuca shall be prepared by inspissating the juice of $L$. virosa.

Description-The plant is biennial, producing in its first year depressed obovate undivided leaves, and in its second a solitary upright stem, 3 to 5 feet high, bearing a panicle of small, pale yellow flowers, resembling those of the Garden Lettuce. The stem which is cylindrical and a little prickly below, has scattered leaves growing horizontally; they are of a glaucous green, ovate-oblong, often somewhat lobed, auricled, clasping, with the margin provided with irregular spinescent teeth, and midrib white and prickly. The whole plant abounds in a bitter, milky juice of strong, unpleasant, opiate smell.

Chemical Composition-We are not aware of any modern chemical examination having been made of Lactuca virosa. The more important constituents of the plant are doubtless those found in Lactucarium, to the article on which the reader is referred.

Uses-The inspissated expressed juice of the fresh plant is reputed narcotic and diuretic, but is probably nearly inert.

\section{LACTUCARIUM.}

Lactucarium, Lettucc Opium, Thridace; ${ }^{1}$ F. and G. Lactucarium.

Botanical Origin-The species of Lactuca from which lactucarium is obtained are three or four in number, namely-

1. Lactuca virosa L., described in the foregoing article.

2. L. Scariola L., a plant very nearly allied to the preceding and perhaps a variety of it, but having the foliage less abundant, more glaucous, leaves more sharply lobed (?), much more erect and almost parallel with the stem. It has the same geographical range as L. virosa.

3. L. altissima Bieb., a native of the Caucasus, now cultivated in Auvergne in France for yielding lactucarium. It is a gigantic herb, having when cultivated, a height of 9 feet and a stem $1 \frac{1}{2}$ inches in diameter. Prof. G. Planchon believes it to be a mere variety of $L$. Scariola L.

4. L. sativa L., the common Garden Lettuce. ${ }^{2}$

1 The term Thridace is also applied to Extract of Lettuce.

2 'The authors of the French Codex of 1866 , name as the sourco of lactucarium, that form of the garden lettuce which has beell called by De Candolle Latuca capitata. Naisch has obtaincd lactucarium from $L$. clongata Mühl. (Am. Journ. of Pharm. 1869. 148.) 
History-Dr. Coxe of Philadelphia was the first to suggest that the juice of the lettuce collected in the same manner as opium is collected from the poppy, might be usefully employed in medicine. The result of his experiments on the juice which he thus obtained from the garden lettuce (L. sativa L.), and called Lettuce Opium, were published in 1799. ${ }^{1}$

The experiments of Coxe were continued some years later by Duncan, Young, Anderson, Scudamore and others in Scotland, and by Bidault de Villiers and numerous observers in France. The production of lactucarium in Auvergne was commenced ${ }^{2}$ by Aubergier, pharmacien of Ulermont-Ferrand, about 1841.

Secretion-All the green parts of the plant are traversed by a system of vessels, which when wounded, especially during the period of flowering, instantly exude a white milky juice. The stem at first solid and fleshy but subsequently hollow, owes its rigidity to a circle of about 30 fibro-vascular bundles, each of which includes a cylinder of cambiurn. At the boundary between this tissue and the primary cortical parenchyme, is situated the system of milk-vessels, exhibiting on transverse section a single or double circle of thin-walled tubes, the cavities of which contain dark brown masses of coagulated juice. In longitudinal section, they appear branched and transversely bound together, as in the milk-vessels of taraxacum. The larger of these tubes, $35 \mathrm{mkm}$. in diameter, correspond pretty regularly in position with the vascular bundles. Each of the latter is also separated from the pith by a band or arch of cambium, in the circumference of which isolated smaller milk-vessels occur.

The system of milk-vessels ${ }^{3}$ is therefore double, belonging to the pith on the one side, and to the bark on the other, the two being separated by juiceless wood. The millk-vessels of the bark are covered by only 2 to 6 rows of parenchyme cells of the middle bark, rapidly decreasing in size from within outwards, and these are protected by a not very thick-walled epidermis. Hence it is easy to understand how the slightest puncture or incision may reach the very richest milk-cells.

The drops of milky juice when exposed to the air, quickly harden to small yellowish-brown masses, whitish within.

Collection and Description-Lactucarium has been especially collected since about the year 1845, in the neighbourhood of the small town of Zell on the Mosel, between Coblenz and Trèves in Rhenish Prussia. The introduction of this industry is due to Mr. Goeris, apothecary of that place, to whom we are indebted for the following information and for some further particulars to Mr. Meurer of Zell.

The plant is grown in gardens, where it produces a stem only in its second year. In May just before it flowers, its stem is cut off at about a foot below the top, after which a transverse slice is taken off daily until September. The juice, which is pure white but readily becomes brown on the surface, is collected from the wounded top by the finger, and transferred to hemispherical earthen cups, in which it quickly hardens

1 Inquiry into the comparative effects of the Opium officinarum, extracted from the Papaver somnifcrum or White Poppy of Linnæus, and that procured from the Lactuce sativa or Common cultivatcd Lettucc of the same author.-Transact. of the $A$ merican Philosophical Society, iv. (1799) 387.
\& Comptcs Rondus, xv. (1842) 923.

3 Beantifully delincatcd by Hanstein in the work referred to at p. 352, note 2 ; see also Trécul, Ann. acs Scicnccs nat., Bot. v. (1866) 69 ; Dippel, Entstehung der Nilchsaftycfässe. Rotterdam 1865. tab. 1. fig. 17. 
so that it can be tumed out. It is then dried in the sunshine until it can be eut into four pieees, when the drying is completed by exposure to the air for some weeks on frames.

At Zell, 300 to 400 kilogrammes (661 to $882 \mathrm{H}$.) of laetucarium are anmually produeed; the whole district furnishes at best but 20 quintals ammally. The priee the drug fetches on the spot varies from 4 to 10 thalers per kilogramme (about $6 s$. to $14 s$. per $1 \mathrm{~b}$.) In the Eifel district where laetuearium was formerly eolleeted, none is now produced.

As found in trade, German lactucarium consists of angular pieceis formed as already deseribed, but rendered more or less shrunken and irregular by loss of moisture and by fracture. Externally they are of a dull reddish brown, internally opaque and wax-like, and when recent, of a ereamy white. By exposure to the air, this white becomes yellow and then brown. Lactuearium has a strong unpleasant odour, suggestive of opium, and a very bitter taste.

The laetuearium produced by Aubergier of Clermont-Ferrand is of exeellent quality, but does not appear to differ from that obtained on the Mosel, except that it is in circular eakes about $1 \frac{1}{2}$ inches in diameter, instead of in angular lumps.

Seoteh laetucarium, which was formerly the only sort found in the market, is still (1872) met with. Mr. Fairgrieve, who produces it in the neighbourhood of Edinburgh, colleets the juiee into little tin vessels, in which it quiekly thiekens; it is then turned out and dried with a gentle heat, the drug being broken up as the proeess of drying goes on. It is thus obtained in irregular earthy-looking lumps of a deep brown hue, of which the larger may be about an ineh in length. In smell, it exactly resembles the drug collected on the Continent. ${ }^{1}$

We are unaequainted with Russian Lactucarium which has been quoted at a very high priee in some continental lists.

Chemical Composition-Lactucarium is a mixture of very different organic substances, together with 8 to 10 per eent. of inorganic matter. It is not completely taken up by any solvent, and when heated merely softens but does not melt.

By exhausting with boiling alcohol, it yielded us 58.7 per cent. of Lactuccrin or Lactucone, $\mathrm{C}^{16} \mathrm{H}^{26} \mathrm{O}$, depositing it in crystals which when duly purified have the form of slender colourless needles, fusing at about $185^{\circ} \mathrm{C}$. to an amorphous mass. Lactucerin is an inodorous, tasteless, nentral substance, insoluble in water, but dissolving in ether and in oils both fixed and volatile, not quite so readily either in benzol, or in bisulphide of carbon. It appears to be closely allied to Euphorbon, witl which it ought to be accurately compared.

Cold alcohol as well as boiling water, take out of lactucarium abont 0.3 per eent. of a crystallizable bitter substance, Lactucin, $\mathrm{C}^{11} \mathrm{H}^{12} \mathrm{O}^{3}, \mathrm{H}^{2} \mathrm{O}$, which although it reduees alkaline cupric tartrate, is not a glucoside. Laetucin forms white pearly scales, readily soluble in acetic acid, but insoluble in ether. It loses its bitterness when treated with an alkali.

From the mother-liquors that have yielded lactucin, Ludwig obtained Lactucic Acid, as an amorphous light yellow mass, becoming crystalline after long standing. Lastly lactucarium has further afforded in small

I We arc indebted to Mr. H. C. Baildou for a specimen of Scotch lactucarium col-

T. and H. Smith for a recent sample of MIr. for a specimen of Scoted labout tho year 1844, and to Messrs. Fairgrieve's article. 
quantity, an amorphous substance named Lactucopicrin, $\mathrm{C}^{44} \mathrm{H}^{84} \mathrm{O}^{21}$, apparently produced from lactucin by oxidation; it is stated by Kromayer (1862) to be soluble in water or alcohol, and to be very bitter.

Of the widely diffused constituents of plants, lactucarium contains resin, albumen, gum, oxalic, citric, malic and succinic acids, sugar, mannite, and asparagin, together with potassium, calcium and magnesium salts of nitric and phosphoric acids. We obtained crystals of nitrate of potassium by concentrating the aqueous decoction of lactucarium. On distillation with water, a volatile oil having the odour of lactucarium, passes over in very small quantily.

Uses-The soporific powers universally ascribed in ancient times to the lettuce, are supposed to exist in a concentrated form in lactucarium. Yet numerous experiments have failed to show that this substance possesses more than very slight sedative properties, if indeed it is not absolutely inert. ${ }^{1}$

\section{LOBELIACEA.}

\section{HER B A L O B E L I}

Lobelia, Indian Tobacco; F. Lobélie enflée; G. Lobeliakraut.

Botanical Origin-Lobelic inflata L., an annual herb, 9 to 18 inches high, with an angular upright stem, simple or more frequently branching near the top, widely diffused throughout the eastern part of North America from Canada to the Mississippi, growing in neglected fields, along roadsides, and on the edges of woods, and thriving well in European gardens.

History-Lobclic inflata was described and figured by Linnæus ${ }^{2}$ from specimens cultivated by him at Upsala about 1741, but he does not attribute to the plant any medicinal virtues.

The aborigines of North America made use of the herb, which from this circumstance and its acrid taste, came to be called Indian Tobacco. In Europe it was noticed by Schoepf $^{3}$ but with little appreciation of its powers. In America it has long been in the hands of quack doctors, but its value in asthma was set forth by Cutler in 1813. It was not employed in England until about 1829, when with several other remedies, it was introduced to the medical profession by Reece. ${ }^{4}$

Description-The leaves are 1 to 3 inches long, scattered, sessile, ovate-lanceolate, rather acute, obscurely toothed, somewhat pubescent. The edge of the leaf bears small whitish glands, and between them isolated hairs which are more frequent on the under than on the upper surface. They are usually in greater abundance on the lower and middle portions of the stem.

The stem of the growing plant exudes when wounded a small quan-

'Stillé, Therupeutics and Mat. Med. i. (1868) 756. Garrorl (Med. Times and, (fazelte, 26 March, 1864), gave lactucarium in drachm doses, repeated 3 or 4 times a day, without being able to perceive that it had any effect either as an anodync or hypnotic.
2 Aeta Soc. Reg. Scient. Upsal. 1746. 23.3 Mat. Med. Amerieana, Exlangæ, 1787.

4 Treatise on the Bladder-podded Lobelia, Lond. 1829. 
tity of acrid milky juice, contained in laticiferous vessels running also into the leaves. The inconspicuous blossoms are arranged in a manyflowered, terminal, leafy raceme. The five-cleft, bilabiate corolla is blneish with a yellow spot on the under lip, its tube being as long as the somewhat divergent limb of the calyx.

The capsule is ovoid, inflated, ten-ribbed, crowned by five, elongated sepals which are half as long as the ripe fruit. The latter is two-celled and contains a linge nmmber of ovate-oblong seeds about $\frac{1}{50}$ of an inch in length, having a reticulated, pitted surface.

The herb found in commerce is in the form of rectangular cakes, 1 to $1 \frac{3}{4}$ inches thick, consisting of the yellowish-green chopped herl, compressed as it would seem while still moist, and afterwards neatly trimmed. The cakes arrive wrapped in paper, sealed up and bearing thr label of some American druggist or herb-grower.

Lobelia has a herby smell and, after being chewed, a burning, acrid taste resembling that of tobacco.

Chemical Composition-Lobelia has been examined chemically by Procter (1838-1841), Pereira (1842), Reinsch (1843), Bastick (1851), also by F. F. Mayrer. ${ }^{1}$ The first-named chemist ${ }^{2}$ traced the activity of the plant to a liquid, volatile alkaloid which he termed Lobelina, and his observations were confirmed some years later by the independent experiments of Bastick. ${ }^{3}$ From the labours of these chemists it appears that lobelina is an oily, viscid, transparent fluid with a strong alkaline reaction, especially when in solution. In the pure state, it smells slightly of the plant, but more strongly when mixed with ammonia. Its taste is pungent and tobacco-like, and when taken in minute doses, it exercises in a potent manner the poisonous action of the drug. Lobelina is volatile, but does not evaporate entirely unchanged. It dissolves in water, but more readily in alcohol or ether, the latter of which is capable of removing it from its aqueous solution. Caustic alkalies decompose it rearlily. It neutralizes acids forming with them crystallizable salts, solnble in water or alcohol. The hydrochlorate is described as forming colourless, transparent, well-defined acicular crystals; a sulphate, nitrate, and oxalate have been also obtained.

The herb likewise contains traces of essential oil (the Lobclianin of Pereira?), resin and gum. The seeds afforded Procter about 30 per cent. of fixed oil, sp. gr. $\cdot 940$, which was found to dry very rapidly. The Lobeliin of Reinsch appears to be an indefinite compound.

In 1871, Enders at our request performed some researches on lobelia in order to isolate the acrid substance, to which the herb owes its taste. He exhausted the drug with spirit of wine and distilled the liquid in presence of charcoal, which then retained the acrid principle. The charcoal was washed with water, and then treated with boiling alcohol. This on evaporation yielded a green extract, which was further purified by means of chloroform. Warty tufts were thus finally obtained, yet always of a brownish colour. The tufts are readily soluble in ether and chloroform, but ouly slightly in water; they possess the acrid taste of lobelia. This substance, which we may term Lobclacrin, is decomposed if merely 'boiled with water' by the influence of alkalis or acids it is

1 American Journ. of Pharm. xxxvii. (1866) 209; also Jahresbericht of Wiggers and Husemann, 1866. 252.
${ }^{2}$ Am. Jonn. of Pharm. iii. (1S3\$) !s: vii. (1841) 1 ; Plarm. Journ. x. (1S51) 4 .io.

3 Pharm. Jourm. x. (1S51) 270. 
resolved into sugar and Lobclic Acid. The latter is soluble both in water and alcolol, and is non-volatile; it yields a soluble salt with barium oxide, whereas its plumbic salt is insoluble in water.

Uses-Lobelia is a powerful nauseating emetic; in large doses an acro-narcotic poison. It is prescribed in spasmodic asthma.

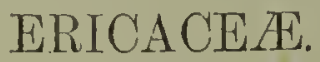

\section{FOLIA UVAE URSI.}

\section{Bearberry Leaves; F. Fcuilles de Busserole; G. Bärcntraubenblätter.}

Botanical Origin-Arctostaphylos Ura-ursi Sprengel (Arbutus Uva-ursi L.), a small, procumbent, evergreen shrub, distributed over the greater part of the northern hemisphere. It occurs in North America, Iceland, Northern Europe and Russian Asia, and on the chief mountain chains of Central and Southern Europe. In Britain, it is confined to Scotland, the north of England and Ireland.

History-The bearberry" previously described by Clusius in 1601, was recommended for medicinal use in 1763, by Gerhard of Berlin and others. ${ }^{1}$ It had a place in the London Pharmacopœia for the first time in 1788 .

Description-The leaves are dark green, $\frac{3}{4}$ to 1 inch in length by $\frac{2}{8}$ to $\frac{3}{8}$ of an inch in breadth, obovate, rounded at the end, gradually narrowed into a short petiole. They are entire, with the margin a little reflexed, and in the young state slightly pubescent, otherwise the whole leaf is smooth, glabrous, and coriaceous; the upper surface shining, deeply impressed with a network of veins; the under minutely reticulated with dark veins. The leaves have a very astringent taste, and when powdered, a tea-like smell.

Chemical Composition-Karvalier (1852) has shown that a decoction of bearberry treated with basic acetate of lead, yields a gallate of that metal, thus proving that gallic acid exists ready-formed in the leaves. When the filtrate, freed from lead by sulphuretted hydrogen, is properly concentrated, it deposits acicular crystals of Arbutin, $\mathrm{C}^{24} \mathrm{H}^{32} \mathrm{O}^{14}, \mathrm{H}^{2} \mathrm{O}$, a bitter neutral substance, easily soluble in hot water, less so in cold, dissolving in alcohol, but sparingly in ether. ${ }^{2}$

By contact for some days with emulsin, or by boiling with dilute sulphuric acid, arbutin is resolved into Hydrolinone, $\mathrm{C}^{6} \mathrm{H}^{6} \mathrm{O}^{2}$ (Kawalier's Arctuvin), and glucose. The action of peroxide of manganese and dilute sulphuric acid, on the other hand, converts arbutin into Kinone, $\mathrm{C}^{6} \mathrm{H}^{4} \mathrm{O}^{2}$, and formic acid (p. 325). If a concentrated decoction of the leaves is allowed to stand for some months, a decomposition of the arbutin takes place, and a certain quantity of hydrokinone can be isolated by shaking the liquid with ether.

Hydrokinone was likewise found by Uloth (1859) among the products of the distillation of an aqueous extract of bearberry leaves, together

\footnotetext{
1 Murrny, Apparahus Medicaminum, ii. 2 Ginclin, Chomistry, xv. (1862) 419.
} (1794) 64-81. 
with the isomeric substance Pyroeatechin (p. 172). Arbutin itself also yields hydrokinone by means of dry distillation. Hydrokinone forms colourless crystals, melting at $177^{\circ} .5 \mathrm{C}$.; kinone crystallizes in brilliant yellow scales, melting at $115^{\circ} .7 \mathrm{C}$. and then evolving a peculiar odour. The vapour strongly irritates the eyes, and the watery solution imparts a yellow colour to the skin.

In the mother-liquor from which the arbutin has crystallized, there remains a small quantity of the very bitter substance called Ericolin, occurring in greater abundance in other Invicacece. Irricolin, $\mathrm{C}^{144} \mathrm{H}^{56} \mathrm{O}^{21}$, is an anorphous yellowish mass, softening at $100^{\circ} \mathrm{C}$. and resolved, when heated with dilute sulphuric acid, into sugar and Erieinol, a colourless, quickly resinifying oil, isomeric with the camphor of the Laurinea." It has a peculiar, not disagreeable odour.

H. Trommsdorff in 1854, obtained from bearberry leaves by exhausting them with ether (in which however it is but slightly soluble) the colourless and tasteless crystallizable neutral substance Ursone, $\mathrm{C}^{20} \mathrm{H}^{32} \mathrm{O}^{2}$. It melts at $200^{\circ} \mathrm{C}$., and sublimes apparently unchanged. Tonner (1866) met with it in the leaves of an Australian Epacris, a plant of the same order as the bearberry.

Lastly tannic acid is present in the leaves under notice; their aqueous infusion is nearly colourless, but assumes a violet hue on addition of ferrous sulphate. After a short time a reddish precipitate is produced, which quickly turms blue. By using ferric chloride, a bluish black precipitate immediately separates.

Adulteration-The leaves of Vaceinium Vitis-idaa L. called Red Whortleberry or Cowberry, have been confounded with those of bearberry, which in form they much resemble. But they are easily distinguished by being somewhat crenate toward the apex, dotted and reticulate on the under surface and more revolate at the margin.

Uses-An astringent tonic used chiefly in affections of the bladder.

\section{EBENACEÆ.}

\section{FRUCTUS DIOSPYRI.}

Botanical Origin-Diospyros Embryopteris Pers. (Embryopteris glutinifera Roxb.), a middle-sized or large evergreen tree, native of the western coast of India, Ceylon, Bengal, Burma, Siam and also Java. ${ }^{2}$

History-The tree, which has a Sanskrit name, was known to Rheede and was figured in his Hortus Malabaricus. ${ }^{3}$. The circumstance that the unripe fruit abounds in an astringent viscid juice which is used by the natives of India for daubing the bottoms of boats, was communicated by Sir William Jones to Roxburgh in 1791. The introduction of the fruit into medicine which is due to O'Shaughnessy, ${ }^{4}$ has been followed by its admission to the Pharmacopoia of India, 1868.

Description-The fruit is usually solitary, subsessile or pedunch-

I Gnelin, Chemistry, xvi. (1864) 28.

$\because \Lambda$ very complete account of the tree, is well as of the whole order, will be found in Hiern's Monograph of Ebenacea, published in the Transactions of the Cambridge Philusophical Socicty, xii. part i. 1873.

3 Tom. iii. tab. 41.

4 Bengal Dispensalory, Calcuttr, 1842.428. 
late, globular or ovoid, $1 \frac{1}{2}$ to 2 inches long, surrounded at the base by a large and deeply 4-lobed calyx. It is of a yellowish colour, covered with a rusty tomentum; internally it is pulpy, 6- to 10-celled, with thin flat solitary seeds. The pulp is excessively astringent when unripe, but loses this quality at maturity so far as to become eatable. The fruit is used only in the unripe and fresh state.

Chemical Composition-No satisfactory analysis has been made of this fruit, but there can be no doubt that in common with that of other species of Diospyros, it is when immature, rich in tannic acid. Charropin (1873), ${ }^{1}$ who has examined the fruit of the American $D$. Virginiana L., found it to contain a tannic acid which he considered identical with that of nutgalls, besides an abundance of pectin, glucose, and a yellow colouring matter insoluble in water but dissolving freely in ether.

Uses-The inspissated juice has been recommended as an astringent in diarrhœa and chronic dysentery.

\section{STYRACE E.}

\section{RESINA BENZÖ̈.}

\section{Benzoïnum ; Benzoin, Gun Benjamin ; F. Benjoin ; G. Benzoëharz. ${ }^{2}$}

Botanical Origin-Styrax Benzoin Dryander, a tree of moderate height, with stem as thick as a man's body and beautiful crown of foliage, indigenous to Sumatra and Java, in the first of which islands benzoin is produced.

The tree yielding the superior benzoin of Siam, though commonly referred to this species, has never been examined botanically, and is actually unknown. The French expedition for the exploration of the Mekong and Cochin China (1866-68), reported the drug to be produced in the cassia-yielding forests on the eastern bank of the river in question in about $\mathrm{N}$. lat. $19^{\circ}$. Whether any benzoin is obtained from S. Finlaysonianum Wall, as conjectured by Royle, we know not.

History-There is no evidence that the Greeks and Romans, ${ }^{3}$ or even the earlier Arabian physicians, had any acquaintance with benzoin; nor is the drug to be recognized among the commodities which were conveyed to China by the Arab and Persian traders between the 10th and 13 th centuries, though the camphor of Sumatra is expressly named.

The first mention of benzoin known to us, occurs in the travels of Ibn Batuta, who having visited Sumatra during his journey through the East, A.D. 1325-49, notes that the island produces Java Frantincense and camphor. The word Java was at that period a designation of Sumatra, or was even used by the Arabs to signify the islands and

1 Etude sur le Plaqueminier (Diospyros), thèse, Paris, 1873. 28-30.

2 Benzoin in Malay and Javanese is termed Kamañan, Kamiñan, and Kamayan, abbreviated to mânan and miñan (Crawfurd); it is called in Siamese kom-yan or kar-yan; in Chinese ngan-si-hiang.

The name Benzoin is also applied to a beautiful crystalline substance obtained by treating Bitter Almond Oil with an alcoholic solution of potash. It has the formula $\mathrm{C}^{14} \mathrm{H}^{12} \mathrm{O}^{2}$ (Scliorlemmer).

3 Crawfiurd suggests that the Malabathrum of the ancients is possibly benoin.-Dict. of Indian Islands, 50.

4 Voygages d'Ton Batoutah, traduit par Defrémery et Sanguinetti, Paris, 1853-59. iv. 228.240. 
productions of the Archipelago generally. ${ }^{1}$ Hence came the Arabic name Lubain Jíwi, i.e. Juva Franlinecuse, corrupted into 'Banjuwi, Benjui, Benzui, Ben:oë and Benzoinn, and into the still nore vulgar English Benjamin.

We have 110 further information about the drug until the latter half of the following century, when we find a record that in 1.461, the sultan of Egypt, Melech Elmaydi, sent to Pasquale Malipiero, doge of Venice, a present of 30 rotoli of Benzoi, 20 rotoli of Alocs Wood, two pairs of Carpets, a small flask of Balsam (of Mecca), 15 little boxes of Theriaka, 42 loaves of Sugar, 5 boxes of Sugar Candy, a horn of Civet, and 20 pieces of Porcelain. ${ }^{2}$ Agostino Barberigo, another doge of Venice, was presented in a similar manner in 1490 by the sultan of Egypt with 35 rotoli of Aloes Wood, the same quantity of Benzui and 100 loaves of Sugar."

Among the precious spices sent from Egypt in 1476 to Catarina Cornaro, queen of Cyprus, were $10 \mathrm{lt}$. of Aloes Wood and $15 \mathrm{lb}$. of Benzui. ${ }^{4}$ 'T'hese notices indicate the high value set upon the drug when first brought to Europe.

The occurrence of benzoin in Siam is noticed in the journal of the voyage of Vasco da Gama, ${ }^{5}$ where in enumerating the kingdoms of India, it is stated that Xarnauz $\left(\right.$ Siam $^{6}$ ) yields much benzoin worth 3 cruzados, and aloes worth 25 cruzados per farazola. According to the same record, the price of benzoin (bcijoim) in Alexandria was 1 cruzado per arratcl, half the value of aloes wood.

The Portugnese traveller Barbosa visited in 1511, Calicut on the Malabar Coast, and found Benzui to be one of the more valuable items of export, one farazola (22 Hb. 6 oz.) costing 65 to 70 fanocs; camphor fetched nearly the same price, and mace only 25 to 30 fanoes. From other sources we gather that benzoin was an article of Venetian trade in the beginning of the 16th century.

Garcia d'Orta, writing at Goa (1534-63), was the first to give a lucid and intelligent account of benzoin, detailing the method of collection, and distinguishing the drug of Siam and Martaban from that produced in Java and Sumatra.

In the early part of the 17 th century, there was direct commercial intercourse between England and both Siam and Sumatra, an English factory existing at Ayuthia (Siam) until 1623; and benzoin was doubtless one of the commodities imported. The import duties levied upon it in England in 1635 , amounted to 10 s. per $16 .{ }^{7}$ ). Benzoic acid was described as early as 1617 by Blaise de Vigenère. ${ }^{8}$

Production-Benzoin is collected in Northerl and Eastern Sumatra, especially in the Batta country, lying soutliward of the state of Achin. ${ }^{9}$ The tree grows in plenty also in the highlands of Palembang in the soutl,

1 Yule, Book of Ser Mareo Polo, ii. (1871) 228.

2 Muratori, Rerum Italicarum Seriptores, xxii. (1733) $1170 .-100$ rotoli $=175 \mathrm{H}$. Avoirdupois.

3 L. de Mas Latrie, Hist. de l'île de chypre, ete. iii. (1861) 483.

4 Ibid. iii. 406.

5 Roteiro da Viagem de Vaseo da Gana m 1497, yar Hereulano e o Bario Castello de Paira, segrunda edição, Lisboa, 1861. 109. G Yule, op. eit. ii. 222.
7 The Rates of Marehandizcs, Lond. 1635.

8 Traicté du Feu et du Sel, Paris, 1622. 91. There is said to be an elition of $160 \mathrm{~s}$, which we have not seen.

9 Niquel, Prodromus Florec Sumatrana, 1860. 72 ; Marsden, Hist. of Sumatra, lond. it 33.123 . - The latter author resided at Bencoolen eight years, as an offieial of the English Government. His specimens of benzoin are now in the muscum of the Phamaceutical Soeiety.

The statement of Crawfurd (Dict. of the 
and its resin is collected. It is ehiefly on the coast regions that considerable plantations are found. Teysmann saw the eultivation in the tracts of the river Batang Leko, the trees being planted about 15 feet apart. The benzoin from the interior is mostly from wild trees, which occur at the foot of the mountaius at an elevation of 300 to 1000 feet.

The trees, which are of quick growth, are raised from seeds sown on the [edges of?] rice-fields; they require no particular attention beyond being kept elear of other plants, until about 6 or 7 years old, when they have trunks 6 to 8 inches in diameter, and are capable of yielding the resin. Ineisions are then made in their stems, from which there exudes a thiek, whitish, resinous juiee, which soon hardens by exposure to the air, and is carefully scraped off with a knife.

The trees continue to yield at the rate of about three pounds per annum for 10 or 12 years, after which period they are cut down. The resin which exudes during the first three years, is said to be fuller of white tears and therefore of finer quality, than that.whieh issues snbsequently, and it is termed by the Malays Head Benzoin. That whieh flows during the next 7 or 8 years, is browner in colour and less valuable, and is known as Belly Benzoin; while a third sort ealled Foot, is obtained by splitting the tree and seraping the wood; this last is mixed with much bark and refuse. ${ }^{1}$

Benzoin is brought for sale to the ports of Sumatra in large eakes called Tampangs, wrapped in matting. These have to be broken, and softened either by the heat of the sun or by that of boiling vater, and then paeked into square eases which the resin is made to fill.

The only account of the colleetion of Siam Benzoin is that given by Sir R. H. Schomburgk, for some years British Consul at Bangkok. ${ }^{2}$ He represents that the bark is gashed all over, and that the resin which exudes, eollects and hardens between it and the wood, the former of whieh is then stripped off. This account is confirmed by the aspect of some of the Siam benzoin of commeree as well as by that of pieces of bark in our possession; but it is also evident that all the Siam drug is not thus obtained. Schomburgk adds, that the resin is muel injured and broken during its eonveyance in small baskets on bullocks' backs to the navigable parts of the Menam, whence it is brought down to Bangkok. ${ }^{3}$

Whether benzoin owes its original fluidity to a volatile oil holding the resin in solution, and its solidifieation to the volatilization of this oil, or whether the resin itself hardens by oxidation,--what occasions the remarkable diversity of aspect between the opaque and milk-like, and the completely transparent resin, are questions to be investigated by some future observer.

\section{Description-Benzoill (always termed in English eommeree Gum}

Indian Islands, 1856.50) that benzoin is colleeted in Bornco "on the northern coast in the territory of Brunci" is to us inexplieable. Mr. St. John, British Consul in Bornco, in an official report on the trade of Brmai, daterl from that place 29 . January, 1858 , cnumcrates the various productions of the district, but does not name benzoin.

1 The terms Ilead, Belly and Foot, equivalent to our words supcrior, medium and inferior, are used in the East to distinguish the qualities of many other eommodities, as Borneo Camphor, Esculent Birds'-nests, Cardanoms, Galbanum, \&e.

2 This account must have been derivel from others, for Sir R. H. Schomburgk certainly never visited the region producing benzoin.

3 Pharm. Journ. iii. (1802) 126. 
Benjamin) is distinguished as of two kinds, Siam and Sumatra. Each sort occurs in various degrees of purity, and under considerable differences of appenrance.

1. Siam Ben:oin-The most esteemed sort is that which consists entirely of flattened tears or drops, an inch or two long, of an opaque, milk-like, white resin, loosely agglutinated into a mass. More fiequently the mass is quite compact, consisting of a certain proportion of white tears of the size of an almond downwards, imbedded in a deep, rich amber-brown, translucent resin. Occasionally the translucent resin preponderates, and the ivhite tear's are almost wanting. In some packages, the tears of white resin are very small, and the whole mass has the aspect of a reddish-brown granite. There is always a certain admixture of bits of wood, bark, and other accidental impurities.

The white tears when broken, display a stratified structure with layers of greater or less translucency. By keeping, the white milky resin becomes brown and transparent on the surface, but from some experiments made by one of us (F.) it does not appear that the opacity is due to water, but rather to a peculiar molecular (semi-crystalline?) state of the resin.

Siam benzoin is very brittle, the opaque tears showing a slightly waxy, the transparent a glassy fracture. It easily softens in the mouth and may be kneaded with the teeth like mastich. It has a delicate balsamic, vanilla-like, fragrance but very little taste. When heated it evolves a more powerful fragrance, together with the irritating fumes of benzoic acid; its fusing point is $75^{\circ} \mathrm{C}$. The presence of benzoic acid nay be shown by the microscopical examination of splinters of the resin under oil of turpentine.

Siam benzoin is imported in cubic blocks, which take their form from the wooden cases in which they are packed while the resin is still soft.

2. Sumatra Benzoin-Prior to the renewal of direct commercial intercourse with Siam in 1853, this was the sort of , benzoin most cominonly found in commerce.

It is imported in cubic blocks exactly like the preceding, from which it differs in its generally greyer tint. The mass however, when the drug is of good quality, contains numerous opaque tears, set in a translucent, greyish-brown resin, mixed with bits of wood and bark. When less good, the white tears are wanting, and the proportion of impurities is greater. We have even seen samples consisting almost wholly of bark. In odour, Sumatra benzoin is both weaker and less agreeable than the Siam drug, and generally falls short of it in purity and handsome appearance,- - and hence commands a much lower price ${ }^{1}$ The greyish-brown portion melts at $95^{\circ}$, the tears at $85^{\circ} \mathrm{C}$.

A variety of Sumatra benzoin is distinguished by the London druglrokers as Penang Benjamin or Storax-smelling Benjamin. We have seen it of very fine quality, full of white tears (some of them two inches long), the intervening resin being greyish. ${ }^{2}$ The odour is very agreeable, and perceptibly different from that of Siam benzoin, or the usual Sumatra sort. Whether this drug is produced in Sumatra and by Styrax Benzoin we

1 In the Public Ledacr, May 2, 1874, the prices are quoted thus :- Siam Gum Benjamin, 1st and 2 nd qualities, $£ 10$ to $£ 28$ per cwt. : Sumatra, 1st and 2nd, £7 10s. to £12.

2 There were 8 cases of this drug offered at Public Sale, 13 April, 1871. 
know not; but it is worthy of note that $S$. subdenticulatum Miq. occurring in Western Sumatra, has the same native name (Kajoe Këminjan) as $S$. Benzoin, and that Miquel remarks of it-" An etiam benzoiferum?"1

Chemical Composition-Benzoin consists mainly of amorphous resins perfectly soluble in alcohol and in potash, having slightly acid properties, and differing somewhat in their behaviour to solvents, whence they have been designated alpha-resin, beta-resin, \&c. But they nevertheless appear to agree in their essential properties. When benzoin is fused with potash, it is partly decomposed and then according to Hlasiwetz and Barth, yields among other products, protocatechuic acid (more than 5 per cent.), para-oxybenzoic acid, $\mathrm{C}^{7} \mathrm{H}^{6} \mathrm{O}^{3}$, and pyrocatechin.

Subjected to dry distillation, benzoin affords as chief product, Benzoic Aeid, $\mathrm{C}^{7} \mathrm{H}^{6} \mathrm{O}^{2}$, together with empyreumatic 'products, among which Berthelot has proved the presence (in Siam benzoin) of Styrol (p. 244). The benzoic acid exists ready-formed to the extent of 14 to 18 or more per cent. Although the acid readily dissolves in twelve parts of boiling water, the resin in which it is imbedded, precludes its complete extraction by this means. It is however easily accomplished by the aid of an alkali,-most advantageously by milk of lime, which does not combine with the amorphous resins.

Benzoin is not manifestly acted on by bisulphide of carboil, but if kept in contact with it for a month or two, very large colourless crystals of benzoic acid make their appearance. Brought into a warm room, the crystals quickly dissolve, but are easily reproduced by exposure to cold.

Most pharmacopœias require not the inoderous acid obtained by a wet process, but that afforded by sublimation, which contains a small amount of fragrant empyreumatic products. The resin when repeatedly subjected to sublimation, affords as much as 14 per cent. of benzoic acid. It has long been known that the opaque white tears of benzoin are less rich in benzoic acid than the transparent brown resin in which they lie. From the latter, S. W. Brown (1833) extracted 13 per cent. of impure acid, but from the former scarcely $8 \frac{1}{2}$ per cent. We are by no means sure that such difference is constant.

Bitter almond oil, which by oxidation yields benzoic acid, is wanting in benzoin. Very little volatile oil is in fact to be got; half a pound of the best Penang benzoin yielded us by distillation with water, only a few drops of an extremely fragrant oil (styrol ?).

Ferric chloride imparts to alcoholic solution of benzoin, a dark brownish green, which is not acquired under the same circumstances by the aqueous decoction of the powdered resin: hence the reaction does not proceed from tannin. Benzoin dissolves in cold oil of vitriol, forming a solution of splendid carmine hue, from which water separates crystals of benzoic acin.

Kolbe and Lautemann in 1860, discuvered in Siam and Penang benzoin together with benzoic acid, an acid of different constitution which in 1861, they recognized as Cinnamic Aeid, $\mathrm{C}^{9} \mathrm{H}^{9} \mathrm{O}^{2}$. Aschoff $(1861)$ found in a sample of Sumatra benzoin, cinnamic acid only, of which he got 11 per cent.; and in amygdaloid Siam and Penang benzoin only benzoic acid. In some samples of the latter, one of us (F.) has likewise met with cinnamic acid. On triturating this sort with peroxide of lead, and

1 Prod. Florec Sumatrana, 1860. 474. 
boiling the nixture with water, the odour of bittcr-almond oil, due to the oxidation of cimnamic acid, is evolved.

The simultancous occurrence of benzoic and cinnamic acids, or the absence of one or other of them in benzoin, is due to circumstances at present unexplained.

Commerce-The statistics of Singapore, ${ }^{1}$ the grcat emporium of the commerce of the Indian Archipelago, show the imports of Gum Benjamin in 1871 as 7442 cwt., of which quantity 6185 cwt. had been shipped from Sumatra and $405 \mathrm{cwt}$. from Siam. Penang, which is also a mart for this drug; appears from the same authority to have received from Sumatra for trans-shipment, 4959 crvt. of Gum Benjamin.

Padang in Sumatra exported in 1870, 4.303 piculs (5122 cwt.); and in 1871,4064 piculs $\left(4838\right.$ cwt.) of benzoin. ${ }^{2}$

The imports of Gum Benjamin into Bombay in the year 1871-72 were no less than $5975 \mathrm{cwt}$., and the exports $1043 \mathrm{cwt}^{3}$

Uses-Benzoin appears to be nearly devoid of medicinal properties and is but little employed. It is chiefly imported for use as incense in the service of the Greek Church.

\section{OLEACE E.}

\section{MANNA.}

Manna; F. Manne; G. Manna.

Botanical Origin-Fraxinus Ornus L. (Ornus Europaca Pers.), the Manna-ash, is a small tree found in Italy, whence it extends northwards as far as the Canton of Tessin in Switzerland and the Southern Tyrol. It also occurs in Hungary (Buda) and the eastern coasts of the Adriatic, in Greece, Turkey (Constantinople), in Asia Minor about Smyrna and at Adalia on the south coast. It grows in the islands of Sicily, Sardinia and Corsica, and is found in Spain at Moxente in Valencia. ${ }^{4}$ As an ornamental tree it has been introduced into Central Europe, where it is often seen of greater dimensions, sometimes acquiring a height of about 30 feet. It blossoms in early summer, producing numerous feathery panicles of dull white flowers which give it a pleasing appearance. The foliage exhibits great variation in shape of leaflets, even where the tree is uncultivated; and the fruits also are very diverse in form.

In some districts of Sicily, a little manna is obtained from the Common Ash, F. excelsior L.

History-The name Manna, though originally applied to the aliment miraculously provided for the sustenance of the ancient Israelites during their journey to the Holy Land, has been used to designate other substances of distinct nature and origin. Of these, the best known and most important is the saccharine exudation of Fraxinus Ornus L., which constitutes the Manna of European medicine.

From recent rescarches ${ }^{5}$ it appears evident that previous to the 15 th

1 Blue Book for the Colony of the Straits Settlements, Singapore, 1872.

${ }_{2}$ Consular Reports, August 1873. 953.

3 Statement of the Trade and Navigation of the Presidency of Bombay for 1871-72. pt. ii. 26.79.
4 Fraxinus Bungeana DC., a tree of Northern China, appears to be hardly distinct from $F$. Ormus.

5 Hanbury, Historical Notes on Manna, pharm. Journ. xi. (1870) 326. 
century, the manna used in Europe was imported from the Last and was not that of the ash. Raffaele Maffei, called also Volaterranus, a writer who flourished in the second half of the 15th century, states that manna began to be gathered in Calabria in his time, but that it was inferior to the oriental. ${ }^{1}$ At this period, the manna collected was that which exuded spontaneously from the leaves of the tree, and was termed Manna di foglia or Manna di fronda: that which flowed from the stem bore the name of Manna di eorpo and was less esteemed. All such manna was very dear.

About the middle of the 16th century, the plan of making incisions in the trunk and branches was resorted to, and although it was strenuously opposed even by legislative enactment, the more copious supplies which it enabled the collectors to obtain, led to it being generally adopted. Manna di foglia became in fact utterly unknown, so that Cirillo of Naples writing in 1770 , expresses doubt whether it ever had any existence. ${ }^{2}$

With regard to the history of manna-production in Sicily, there is this curious fact,- that near Cefalù there exists an eminence in the Madonia range, called Gibelman or Gibelmanna, which in Arabic signifies manna-mountain. This name is not of modern origin, but is found in a diploma of the year 1082, concerning the foundation of the bishopric of Messina; and it has been held to indicate that manna was there collected during the Saracenic occupation of Sicily, A.D. 827 to 1070 . We have not been successful in finding any evidence whether this supposition is well founded. On the other hand, it is remarkable that no vriter, so far as we know, mentions manna as a production of Sicily, before Paolo Boccone of Palermo, who after naming many localities for the drug in continental Italy, states that it is also obtained in Sicily. ${ }^{3}$

Manna was also produced until recently in the Tuscan Maremma, but neither from that locality, nor from the States of the Church, where it was collected in the time of Boccone, is any supply now brought into commerce, though the name of Tolfa, a towu near Civita Vecchia, is still used to designate an inferior sort of the drug.

The collection of manna in Calabria which was important up to the end of the last century, has now almost entirely ceased. ${ }^{4}$

Production-The manna of commerce is collected at the present day exclusively in Sicily. The principal localities producing the drug are the districts around Capaci, Carini, Cinisi, and Favarota, small towns 20 to 25 miles west of Palermo near the shores of the bay of Castellamare; also the townships of Geraci, Castelbuono, and other places in the district of Cefalù, 50 to 70 miles eastward of Palermo.

The manna-ash, in the districts whence the best manna is obtained, does not at the present day form natural woods, but is cultivated in regular plantations called frassinetti. The trees, which attain a height of from 10 to 20 feet, are planted in rows and stand about 7 feet apart, the soil between being at times loosened, kept free from weeds, and enriched by manure. After a tree is 8 years old and when its stem is at least 3 inches

1 Commentarii Urbani, Paris. 1515. lib. 38. f. 413 .

2 Phil. Trans. lx. (1771) 233.

${ }^{3}$ Museo di Fisica, Venet. 1697. Obs. xiv, $-\mathrm{xy}$.
${ }^{4}$ Hanbury in Giornale Botanico Ilaliano, Ottobre 1872. $267 ;$ Plarm. Journ. Nov. 30.
1872. 421. 
in thickness, the gathering of manna may begin; and may continue for 10 or 12 years, when the stem is usually cut down, and a young one brought up from the same root takes its place. The same stump thus has often two or three stems rising from it.

To obtain manna, transverse cuts from $1 \frac{1}{2}$ to 2 inches long and 1 inch apart, are made in the bark, just reaching to the wood. One cut is made daily, beginning at the bottom of the tree, the second directly above the first, and so on while dry weather lasts. In the following year, cuts are made in the mintouched part of the stem, and in the same way in succeeding seasons. When after some years, the tree has been cut all round and is exhausted, it is felled. Pieces of stick or straws are inserted in the incisions, and become encrusted with the very superior manna, called Mannce a cannolo, which however, is unknown in commerce as a special sort. The fine manna ordinarily seen, appears to have hardened on the stem of the tree. The manna which flows from the lower incisions, and is often collected on tiles or on a cup-shaped piece of the stem of the prickly pear (Opuntia), is less crystalline, and more gummy and glutinous, and is regarded of inferior quality.

The best time for notching the stems is in July and August, when the trees have ceased to push forth more leaves. Dry and warm weather is essential for a good harvest. The manna after removal from the tree, is laid npon shelves in order that it may dry and harden before it is packed. The masses left adhering to the stem after the finer pieces have been gathered, are scraped off and form part of the Small Manne. of commerce. ${ }^{1}$

Secretion-We have examined microscopically the bark of stems of Fraxinus Ornus that had been incised for manna at Capaci. It exhibits no peculiarity explaining the formation of manna, or any evidence that the saccharine exudation is due to an alteration of the cell-walls as in the case of tragacanth. The bark is poor in tannic matter; it contains starch, and imparts to water a splendid fluorescence due to the presence of Fraxin.

Description - Varions terms have been used by pharmacological writers to designate the different qualities of manna, but in English commerce they are not now employed; and the better kinds of the drug are called simply Flake Manna, while the smaller pieces, usually loosely agglutinated and sold separately, are termed Small Manna or Tolfa Manna.

Owing to the gradual exudation of the juice and the deposition of one layer over another, manna has a stalactitic aspect. The finest pieces are mostly in the form of three-edged sticks, sometimes as much as 6 to 8 inches long and an inch or more wide, grooved on the inner side, which is generally soiled by contact with the bark; of a porous, crystalline, friable structure and of a pale brownish yellow tint, becoming nearly pure white in those parts which have been most distant from the bark of the tree. The pieces which are of deeper colour and of an unctuous or gummy appearance, are less esteemed. Good manua is crisp

1 Our account of the production of manna has been derived from the observations of Stettner, who visited Sicily in the summer of 1847 (Archiv der Pharm. iii. 194 ; also Wiggers' Jahresbericht, 1848. 35 ; Ilooker's

Journ. of Bot. i. 1849. 124), from those of Cleghorn (Trans. of the Bot. Soc. of Edinburgh, x. 1868-69. 132), and from personal investigations made by one of us in the neighbourhood of Palermo in May 1872. 
and brittle, and melts in the mouth with an agreeable, honey-like sweetness, not entirely devoid of traces of bitterness and acridity. Its odour may be compared to that of honey or moist sugar.

Manna of the best quality dissolves at ordinary temperatures in about six parts of water, forming a clear, neutral liquid. It contains besides mannite, a small proportion of sugar and gum.

The manna which exudes from the older stems and from the lower parts of even young trees, contains more or less considerable quantities of gum and fermentable sugar, as ${ }^{2} w e l l$ as extraneous impurities. The less favourable weather of the later summer and autumn promotes an alteration in the composition of the juice, and impairs its property of concreting into a crystalline mass.

Chemical Composition-The predominant constituent of mamna, at least of the better sorts, is Manna-sugar or Mannite, $\mathrm{C}^{6} \mathrm{H}^{14} \mathrm{O}^{6}$, which likewise occurs, though in much smaller quantity, in many other plants besides Fraximus. Artificially, it is produced by treating glucose, $\mathrm{C}^{6} \mathrm{H}^{12} \mathrm{O}^{6}$, with sodium-amalgam, and indirectly in the fermentation of glucose or of cane-sugar. It is isomeric with dulcite or melampyrin ; crystallizes in shining prisms or tables, belonging to the rhombic system ; melts at $165^{\circ} \mathrm{C}$, and in very small quantity may by careful heating, be sublimed undecqmposed. It dissolves in 6 parts of water at ordinary temperature, less freely in aqueous alcohol, very sparingly in absolute alcohol, and not in ether. The solution has an extremely weak rotatory power, and is not altered by boiling with dilute acids or alkalis, or with alkaline cupric tartrate.

Berthelot has shown that mannite is susceptible of fermentation, though not so easily as sugars belonging to the group of carbo-hy'drates. When mixed with moist platinum-black, it becomes very hot, and yields uncrystallizable Mannitie Acid, $\mathrm{C}^{6} \mathrm{H}^{12} \mathrm{O}^{7}$, and Mannitose, $\mathrm{C}^{6} \mathrm{H}^{12} \mathrm{O}^{6}$, a kind of sugar resembling grape-sugar and probably isomeric therewith, but optically inactive and not yet shown to be crystallizable.

With nitric acid, mannite yields neither tartaric nor mucic acid, but sugar together with a certain quantity of racemic acid. By dry distillation, it affords acrolein, formic acid and other products. All the chemical reactions of mannite show it to belong to the class of alcohols, and among these it is most nearly related to glycerin. The quantity of mannite in the best manna varies from 70 to 80 per cent.

When a solution of manna is mixed with alkaline cupric tartrate, rapid reduction to cuprous hydrate takes place even in the cold. This effect is due to the presence of a sugar which, according to Backhaus, consists of ordinary dextro-glucose. It may amount to as much as 16 per cent., and is found in the best flake manna, but most abundantly in the unctuous varieties. Buignet ${ }^{1}$ has pointed out that the rotatory power of this sugar being inconsiderable, it probably consists of a mixture of Cane-sugar and Levulose. He found however that an aqueous solution of manna deviates powerfully to the right, a fact which he considers due to the presence of a large proportion of Dcatrin. The best kinds of manna, according to Buignet, contain about 20 per cent. of dextrin; the inferior much more. With nitric acid, the dextrin

1 Journ. de Pharm. vii. (1867) 401 ; viii.(1868) 5 . 
does not furnish mucic acid; its solution is not precipitated even by bissic acetate of lead, but is thrown down by alcohol.

In our experiments, we have not succeeded in isolating either dextrin, or cane-sugar. There is present, even in the finest manna, a small amount of a dextrogyre mucilage, which is precipitated ly neutral acctate of lead and yields mucic acid when boiled witl concentrated nitric acid.

Ether extracts from an aqueous solution of manna a very small quantity of red-brown resin, having an offensive odour and sub-acrid taste; logether with traces of an acid which reduces silver-salts and appears to be easily resinified. The quantity of water in the inferior kinds of manna often amounts to 10 or 15 per cent. The finest manna affords about 3.6 per cent. of ash.

The greenish colour of certain pieces of manna was formerly attributed to the presence of copper, till Gmelin on account of the fluorescence of the solution, ascribed it to Esculin. It is in reality produced by a body much resembling resculin, namely Fraxin, $\mathrm{C}^{16} \mathrm{H}^{18} \mathrm{O}^{10}$, occurring in the bark of the manna-ash and of the common ash, and together with resculin, in that of the horse-chestnut. Fraxin crystallizes in colourless prisms, easily soluble in hot water and in alcohol, and having a faintly astringent and bitter taste. By dilute acids, it is resolved into Fraxetin, $\mathrm{C}^{10} \mathrm{H}^{8} \mathrm{O}^{5}$, and Glucose, $\mathrm{C}^{6} \mathrm{H}^{12} \mathrm{O}^{6}$. The presence of fraxin in manua, especially in the inferior sorts, is made apparent by the faint fluorescence of the alcoholic manna solution.

Commerce-The exports of manna from Sicily ${ }^{1}$ (chiefly from Palermo) have been as follows :-
1869
1564 crtt., val. $£ 10,220$.
$25 \pm 6$ cwt., val. $£ 15,972$.
3038 cwt., val. $£ 19,528$.

About half the quantity is sent to France. Italian commercial statistics represent the export of manna in 1870 thus:-in canelli 58,691 kilo. (1155 cwt.), in sorte 186,664 kilo. (3676 civt.) The United Kingdom imported in the year $1870,230 \mathrm{cwt}$. of manna, valued at $£ 4447.3$

Adulteration - It can hardly be said that mamna is subject to adulteration, though attempts to introduce a spurious mamna made of glucose have been recorded. But considerable skill and ingenuity have been expended in converting the inferior sorts of manna into what has the aspect of fine natural Flake Manna, the manufacturers admitting however the factitiousness of their product. The artificial Flake Manna has the closest superficial resemblance to very fine pieces of the natural drug, but differs in its more uniform colour, and in being uncontaminated with the slight impurities, from which natural manna is never wholly free. It differs also in that when broken, no crystals of mannite are to be seen in the interstices of the pieces, and it wants the peculiar odour and slightly bitter flavour of natural manna. If one part of it is boiled with four of alcohol ('\$38), a viscid honey-like residue will be obtained, whereas natural manna leaves undissolved a hard substance. Histect ${ }^{ \pm}$

1 Reprorl by Consul. Incunis on the Cominerece and Arevigation of Sicily in 1869,1870 rind 1871 .

2 Direzione generale delle Gabelle-Moviinculo commereiale de7 vegno d'Itatianel 1870 , Jilano 1871.
3 Ammat Statement of the Trade and Narigatim of the U.K. for 1S70. p. 102.

\& On arlificial. Flakic Manna, in Pharin. Joum. xi. (1570) 6:9. 
found it to afford about 40 per cent. of mannite, while fine manna similarly treated yielded 70 per cent.

Uses-A gentle laxative, much less frequently employed in this country than formerly, but still largely consumed in South America. ITannite which possesses similar properties, is often prescribed in Italy.

\section{Other sorts of Manna.}

Various plants besides Fraxinus afford under certain conditions, saccharine exudations some of which constituted the Oriental Manna used in Europe in early times. So far as is known, they differ from officinal manna in containing no mannite.

Alhagi Manna; Turanjabin (Arabic); is afforded by Alhayi Camelorum Fisch., a small spiny plant of the order Legruminosce found in Persia, Afghanistan and Beluchistan. Excellent specimens of the manna, kindly obtained for us in the north-west of India by Dr. E. Burton Brown and Mr. T. W. H. Tolbort, show it as a substance in little roundish, hard, dry tears, varying from the size of a mustard-seed to that of a hemp-seed, of a light brown colour, agreeable saccharine taste, and senna-like smell. According to Ludwig ${ }^{1}$ it contains crystalline tears or grains of cane-sugar, some dextrin, a sweetish mucilaginous substance and a very little starch. The leaflets, spines and pods of the plant, mixed with the grains of this manna, are characteristic and easily recognizable.

Alhagi Manna is collected near Kandahar and Herat, where it is found on the plants at the time of flowering. It is imported into India from Kabul and Kandahar to the extent of about 25 maunds (2000 1b.) annually; its value is reckoned at 30 rupees per seer, $=30$ s. per $16 .{ }^{2}$

Gaz-anjabin (Arabic); Tamaristi Manna (in part). In the months of June and July, the shrubs of tamarisk (Tamarix gallica var. Mannifera Ehrenb.) growing in the valleys of the peninsula of Sinai, especially in the Wady es Sheikh, exude from their slender branches, in consequence of the puncture of an insect (Cocens manniparus Ehrenb.) little honey-like drops, which in the coolness of early morning are found in a solid state. This substance is Tamarisk Manna: it is collected by the Arabs, and by them sold to the monks of St. Katharine, who dispose of it to the pilgrims visiting the convent. Tamarisk Manna is also produced (but is perhaps no longer collected?) in Persia, where it is called Gaz-angabin $;^{3}$ and probably likewise in the Punjab, ${ }^{4}$ from which regions it may have been brought to Europe in ancient times.

A specimen of tamarisk manna brought from Sinai, examined in 1861 by Berthelot, had the appearance of a thick yellowish syrup, contaminated with vegetable remains. It was found to consist of canesugar, inverted sugar (levulose and glucose), dextrin and water, the last constituting one-fifth of the whole. ${ }^{5}$

Although the name Gaz-angabin signifies tamarisk-honey, it is used according to Haussknecht ${ }^{6}$ at the present time in Persia, to designate

1 Archiv der Pharmacic, 193 (1870) 32-52.

2 Stewart, Punjal Plants, Lahore (1869) p. 57 ; Davies, Report on the trade and resources of the conntries on the N.W. boundary of British Indic, Lahore, 1862.
3 Angelus, Pham. Persica (1681) 359.

4 Stewart, opr. cit. 1) 92.

5 Comptes Rendus, liii. (1861) 583 ; Pham. Tou?n. iii. (1862) 274.

"Archiv d. Pharmacic, 192 (1870) 246. 
certain round cakes, common in all the bazaars, of which the chief constituent is a manna collected in the mountain districts of Chahar-Mahal and Faraidan, and especially about the town of Khonsar, south-west of Ispahan, from Astragalus florulentus Boiss. et Haussk, and $A$. adscentens Boiss. et Hanssk. The best sorts of this manna, which are termed $G a z$ Alefi or Gaz Khonsuri, are obtained in August by shaking it from the branches, the little drops finally sticking torgether and forming a dirty, greyish-white, tough mass. The commoner sort got by scraping the stem, is still more impure. The specimen of it brought by Haussknecht yielded to Ludwig ${ }^{1}$ dextrin, uncrystallizable sugar and orgauic acids.

Shir-lihisht-Ancient writers on materia medica as Carcia d'Orta (1563) mention a sort of manna known by this name. The substance is still found in the bazaars of North-western India, being imported in small quantity from Afghanistan and Turkistan. ${ }^{2}$ Haussknecht in his paper on Oriental Manna already quoted, states that it is the exudation of Cotoneaster nummularia Fisch. et Mey. (Rosacece), also of Atraphaxis spinosa L. (Polygonacece), and that it is brought chiefly from Flerat. We have to thank Dr. E. Burton Brown of Lahore, and Mr. Tolbort for specimens of this manna, which, from fragments it contains, is without doubt derived from a Cotoncaster. It is in irregular roundish tears, from about $\frac{1}{4}$ up to $\frac{3}{4}$ of an inch in greatest length, of an opaque dull white, slightly clammy, and easily kneaded in the fingers. It has a manna-like smell, a pure sweet taste and crystalline fracture. With water, it forms a syrupy solution with an abundant residue of starch granules.

Shír-khisht was found by Ludwig to consist of an exudation analogous to tragacanth, but containing at the same time two kinds of gum, an amorphous levogyre sugar, besides starch and cellulose.

Oak Manna-The occurrence of a saccliarine substance on the oak is noticed by both Ovid and Virgil, and it is also mentioned by the Arabian physicians, as Ibn Baytar ${ }^{3}$ and Elluchasem Elimithar." ${ }^{4}$ The last named who died A.D. 1052, states that the exudation appears upon the oaks in the region of Diarbekir. At the present day, it is the object of some industry among the wandering tribes of Kurdistan, who according to Haussknecht, collect it from Quereus Vallonca Kotschy and $Q$. Persica Jaub. et Spach. These trees are visited in the month of August by immense numbers of a small white Coceus, from the puncture of which a saccharine fluid exudes, and solidifies in little grains. The people go out before sunrise, and shake the grains of manna from the branches on to linen cloths, spread out beneath the trees. The exudation is also collected by dipping the small branches on which it is formed, into vessels of hot water, and evaporating the saccharine solution to a syrupy consistence, which in this state is used for sweetening food, or is mixed with flour to form a sort of cake.

A fine specimen of the Oak Manna of Diarbekir was sent to the London International Exhibition of 1862 . It constituted a moist soft mass of agglutinated tears, much resembling an inferior sort of ashmanna, and had an agreeable saccharine taste.

1. c. "

Davies in the work quoted at page 371 , note 2.
3 Ed. Sontheimer, Bd. i. 375.

4 Tacuini Sanifatis, Argent. (1531) 24. 
A less pure form of this manna occurs as a compact, greyish, saccliarine mass, sometimes hard enough to be broken with a hammer. It consists of sugary matter, mixed with abundance of small fragments of wreen leaves, and has a herby smell and pleasant sweet taste. A sample of it brought from Diarbekir examined by one of us, yielded 90 per cent. of dextrogyre sugar, which could not be obtained in a crystalline state, though it exists in such condition in the crude drug. Starch and dextrine were entirely wanting. ${ }^{1}$

A specimen furnished to Ludwig $^{2}$ by Haussknecht afforded much mucilage, a small amount of starch, about 48 per cent. of dextrogyre grape-sugar, with traces of tannic acid and chlorophyll.

Briancon Manna-This is a white saccharine substance which in the height of summer and in the early part of the day, is found adhering in some abundance to the leaves of the larch (Pinus Larix L.), growing on the mountains about Briançon in Dauphiny. It was formerly collected for use in medicine, but only to a very limited extent, for it was rare in Paris in the time of Geoffioy (1709-1731), ancl at the present day has quite disappeared from trade, though still gathered by the peasants. A specimen collected for one of us near Briançon in 1864, consists of small, detached, opaque, white tears, many of them oblong and channelled, and encrusting the needle-like leaf of the larch ; they have a sweet taste and slight odour. Under the microscope they exhibit indistinct crystals.

Briançon manna has been examined by Berthelot, who detected in it a peculiar sugar termed Meleaitose. ${ }^{3}$

Several other saccharine exudations have been observed by travellers and naturalists; but as most of them are unknown to us, we shall simply enumerate the more remarkable, referring the reader for further information to the original notices.

Pirus glabre Boiss. affords in Luristan a sulstance which, according to Haussknecht, is collected by the inhabitants, and is extremely like Oak Manna. It is stated by the same traveller that Salix firagilis L., and Scrophularia frigida Boiss., likewise yield in Persia saccharine exudations. A kind of manna was anciently collected from the cedar, Pinus Cedrus L. ${ }^{4}$ Mamna is vielded in Spain by Cistus ladaniferus L." Austratian Manna, which is in small rounded, opaque, white, dry masses, is found on the leaves of Encalyptus viminalis Labil. It contains a kind of sugar called Melitose, ${ }^{6}$ has a sweet taste, is devoid of medicinal properties and is not collected for use. ${ }^{7}$

The substance named Tigala (corrupted into Trehala), from which a peculiar sugar has been obtained, 8 is the coccoon of a beetle, and not properly a saccharine exudation. ${ }^{9}$

The Lerp Manna of Australia is also of animal origin. ${ }^{10}$ It consists

3 For furtler particulars, see Fliickiger, Veber rice Eichenmanna un Kurdistan, in Archiv der Pharmacic, 200 (1872) 159.

2 1.c. T. 35.

3 Gmelin, Ciumistry, xr. 298; Journ. de 7harm. xxxiv. (1858) 292.

4 Creofroy, Mat. Med. ii. (1741) 584.

"Dillon, T'rarels throush Spain (1780) 1. 127

"Gmelin, Chenistry, xi. 296.

7 Pharm. Joun. iv. (1863) 108.
8 Comptes Ronches, xlvi. (1858) 1276 ; Gmelin, Chemistry, xv. 299.

9 Belon, Singularites (1554) 1. 2. cap. 91 ; Guibourt, Comptes Rendus, 21 Juin 1858, p. 1213 ; Hanbury, Journ. Linn. Soc., Zoology, iii. (1859) 178.

10 Dobson, Procecdings of lioyal Socicty of Tran Dicmen's Land, i. (1851) 234; Plharm. Joun. iv. (1863) 108; Fliickiger, Wittstein's Ticrtcljahresschr. xvii. (1868) 161; Archiv der Pliarmacic, 196 (1871) 7; abstracted in the Ycarbook of Pharmacy, 1871. 188. 
of water 14, white threadlike portion 33, sugar 53 parts. The threads possess some of the characteristic properties of starch, from which they differ entirely by their form and unalterability even in boiling water: Yet in sealed tubes, they dissolve in 30 parts of water at $135^{\circ} \mathrm{C}$. The sugar is dextrogyre; it impregnates the threads as a soft brown amorphous mass. In the purfified state it does not crystallize, even after a long time. By means of dilute sulphuric acid, the threads are converted into crystalline grape-sugar.

\section{OLEUM OLIVAE.}

\section{Olive Oil; Salad Oil; F. Huile d'Olives; G. Olivenöl; Baumöl; Provencer Oel.}

Botanical Origin-Olea Europcea L., an evergreen tree, seldom exceeding 40 feet in height yet attaining extreme old age, abundantly cultivated in the countries bordering the Mediterranean, up to an elevation of about 2000 feet above the sea-level. ${ }^{1} \quad$ O. euspidata Wall, a tree abundant in Afghanistan, Beluchistan and Western Sind, has been supposed to be a wild form of 0 . Europeca, but is regarded by Brandis ${ }^{2}$ as a distinct species. It is not known to have been ever cultivated, yet its fruit which is of small size and but sparingly produced, is capable of affording a good oil.

History-According to the elaborate investigations of Ritter ${ }^{3}$ and of A. De Candolle, ${ }^{4}$ there can be no doubt that the olive-tree is a native of Palestine, and perhaps of Asia Minor and Greece. Schweinfurth ${ }^{5}$ regards it as undoubtedly wild on the mountains of Elbe and Soturba in lat. 22 $\mathrm{N}$. on the western shores of the Red Sea, a locality which he visited in 1868. The olive would appear to have been introduced at a very remote period into Northern Africa and Spain. It was plentiful in the Cyrenaica as early as the time of Theophrastus, 3rd century B.C.

At the present day, it is largely cultivated in Algeria, Spain, Portugal, Southern France, Italy, the Greek Peninsula and Asia Minor. In the Crimea, the tree grows well, but does not afford good fruit. It was carried to Lima in Peru about 1560 and still flourishes there, and in great plenty in the coast valleys further south as far as Santiago in Chili. ${ }^{6}$

Olive oil is mentioned in the Bible so frequently that it must have been an important object with the ancient Hebrews. It held an equally prominent place among the Greeks and Romans, ${ }^{7}$ whose writers on agriculture and natural history treat of it in the most circumstantial manner. Olive fruits preserved in brine were used by the Romans as

1 Grisebaeh states the elevation above the sea of olive-cultivation thus :- Portugal ( 1 lsarve) 1400 feet; Sierra Nevada 3000 ; do., southern slope 4200 ; Nice 2400 ; Etna 2200; Macedonia 1200 ; Cilicia 2000.-Dic Vegeletion der Erde nach ihrer Klimalologischen Anordnung, i. (1872) 262. 283. 342.

2 Forest Flora of North-western and ConIral Tudice, 1874.

3 Erdkunde von Asicn, vii. (jart 2. 1844) 516-537.
4 Géographic Botaniquc (1855) 912.

5 Bot. Zitung, 1868. 860 .

6 Perez-Rosales, Essai sur 7c Chili, Hambonrg, 1857. 133.

7 Hehn, Kullurplañen und Hausthicre in ihrom Ucbergange aus Asicn nach Gricchenland und Italicn, Berlin, 1870. 44-60,-an interesting account of the importance of the olive in ancient times. 
an article of food, and were an object of eommeree with Northern Europe as early as the 8 th centrury. ${ }^{1}$

Production-In eommon with many important eultivated plants, the olive oceur's under several varieties differing more or less from the wild form, the finer of which are propagated by grafting. It is also increased by the suckers which old trees throw up from their naked roots, and which are easily made to develope into separate plants. ${ }^{2}$ The fruit, an oval drupe, half an ineh to an ineh or more in length, and of a deep purple, is remarkable for the large amount of fat oil eontained in its pulpy portion (sareocarp). The latter is most riel in oil when ripe, containing then nearly 70 per cent., besides 25 per cent. of water. The unripe fruit as well as other parts of the plant, abounds in mannite, whieh disappears in proportion as the oil increases. The ripe olive contaius no mannite, it having probably been transformed into fatty oil. ${ }^{3}$

The process for extraeting olive oil varies slightly in different eountries, but consists essentially in subjeeting the erushed pulp of the ripe fruit to moderate pressure. The olives, whieh are gathered from the trees, or collected from the ground, in November, or during the whole winter and early spring, are erushed under a millstone to a pulpy mass. This is then put into eoarse bags, which, piled upon one another, are subjected to moderate pressure in a serew-press. The oil thus obtained, is eonducted into tubs or cisterns eontaining water, from the surfaee of whieh it is skimmed with ladles. This is called Virgin Oil. After it has eeased to flow, the contents of the bags are shovelled out, mixed with boiling water, and submitted to stronger pressure than before, by whieh a seeond quality of oil is got. If the fruit is left for a eonsiderable time in heaps it undergoes deeomposition, yielding by pressure a very inferior quality of oil called in French Huile fermentée. The worst oil of all, obtained from the residues, has the name of Huile toumante or Huile d'enfer.

It is said that in some districts, the millstones are so mounted as to crush the pulp without breaking the olive-stones, and that thus the oil of the pulp is obtained unmixed with that of the kernels. ${ }^{4}$ We have made many inquiries in Italy and France as to this method of oil-making, but cannot find that it is anywhere followed.

The fixed oil of the kernels of ripe olives has been extraeted and examined by one of us (F.) Though the kernels have a bitterish taste, the oil they yield is quite bland; by exposure to the vapour of hyponitric acid, it concretes like that of the pulp. If the whole of it were extraeted in making olive oil, it would only be about as 1 part of oil of the kernel, to 40 parts of oil of the pulp.

Description-Olive Oil is a pale yellow or greenish yellow, somewhat viscid liquid, of a faint agreeable smell and of a bland oleaginous taste, leaving in the throat a slight sense of acridity. ${ }^{5}$ Its specific gravity on an average is 0.916 at $17.5^{\circ} \mathrm{C}$. In eold weather, olive oil loses its

1 Diploma of Chilperie, A.D. 716.-Pardessus, Diplomala, Chrerice, ete., Paris, ii. (1849) 309.

2 Winter, in Pharm. Jonum. Sept. 7, 1872.

3 De Luea in Journ. de Pharm. xlv. (1863) 65.- Some further resenrelies by Harz on the formation of olive oil may be found in Wittstein's Vierleljahresschrifl für prakl. Pharm. xix. (1870) 161.
4 The Grocer, $\Lambda$ pril 25, 1868, supplement; Tereira, Elcm. of Mat. Mid. ii. (1850) 1505.

5 This recording to our experienee is the case even with oil as it runs from the pulp and therefore in the freshcst eondition; but the aerid after-taste is more perceptible in oil which lias been long kept. 
transparency by the separation of a crystalline fatty body. The deposition takes plince at a few degrees above the freezing point of water, and in some oils even at $10^{\circ} \mathrm{C} .\left(50^{\circ} \mathrm{F}\right.$.) If the oil is allowed to contgeal perfectly, and is then subnitted to strong pressure, about onethird of its weight of solid fat may be separated. After repeated crystallizations, this fat melts at 20 to $28^{\circ} \mathrm{C}$. The fluid part or Olein, contimes fluid at $-4^{\circ}$ to $-10^{\circ} \mathrm{C}$. Olive oil belongs to the class of the less alterable, non-drying oils.

The foregoing description does not apply to the inferior sorts of oil, which eongeal more easily, are more or less deep-coloured, have a disagreeable odlour and taste, and quickly turn rancid. 'These inferior oils have their special applications in the arts.

Chemical Composition-The chief constituent of olive oil is Olein or more correetly Triolein, ${ }^{3} \mathrm{H}^{5} \mathrm{O}^{3}, \cdot 3 \mathrm{C}^{18} \mathrm{H}^{33} \mathrm{O}$, identical so far as at present ascertained, with the fluid part of all oils of the non-drying class. The proportion of olein in olive oil, as well as in other oils, is liable to variation, the result partly of natural circumstances and partly of the processes of manufacture. The best oils are eomparatively rich in olein.

As to the solid part of olive oil, Chevreul believed it to be constituted of Margarin, which he first examined in 1820. But Heintz (1852 and later) slowed margarin to be a mixture of palmitin with other compounds of glycerin and fatty acids. Collett in 1854 isolated Palmitic Acicl, $\mathrm{C}^{16} \mathrm{H}^{32} \mathrm{O}^{2}$, from olive oil; and Heintz and Krug (1857) further proved that Tripalmitin is the ehief of the solid constituents of olive oil. They also met with an acid melting at $71 \cdot 4^{\circ} \mathrm{C}$, which they regarded as Arachic Acid (p. 164). As to stearic acid, Heintz and Krug did not fully succeed in evidencing its presenee in olive oil.

Lastly, Benecke discovered in olive oil a small quantity of Cholesterin, $\mathrm{C}^{26} \mathrm{H}^{44} \mathrm{O}$. It may be removed by means of glaeial acetic acid or alcohol, which dissolve but very little of the oil.

Commerce-Various sorts of olive oil are distinguished in the English market, as Florenee, Gallipoli, Gioja, Spanish (Malaga and Seville), Sicily, Myteline, Corfu and Mogador.

Olive oil was imported into the United Kingdom in the year 1872,

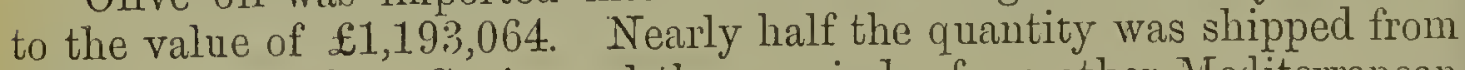
Italy, one-fifth from Spain, and the remainder from other Mediterranean eountries.

The average annual production in Italy is estimated at upwards of $1,500,000$ liectolitres (33 million gallons), representing a value of $£ 8,000,000$ sterling, but the quantity exported does not exceed in value $£ 2,800,000$. ${ }^{1}$

The statistics of the French Govermment indicate the annual production of olive oil in France to be not more than 250,000 hectolitres, equivalent in value to 30 millions of francs $(\$ 1,200,000){ }^{2}$

Uses-The uses of olive oil in medicine and its immense consumption in the warmer parts of Europe as an article of food, are too well known to require more than a passing allusion.

1 Journ. of Soc. of Airts, May 22, 1 S68.

2 Exposition de 1867 il Paris, Rapports die Jury Internationat, xi. 108. 
Adulteration-Olive Oil is the subject of various fraudulent admixtures with less costly oils, the means of detecting which has engaged much attention. Of the various methods by which chemists have endeavoured to asccrtain the purity of olive oil, the following are the more noteworthy :-

a. Drying oils (such as the oils of poppy and walnut) may be distinguished by their not being converted into solid crystallizable elaidin by hyponitric acid or concentrated solution of nitrate of protoxide of mercury. Olive oil which contains any considerable proportion of one of these oils, no longer solidifies if cxposcd for a moment to one of the above-mentioned reagents. This test however is not of sufficient delicacy for small amounts of drying oils.

b. Olive oil being one of the lighter oils, the specific gravity may to some degree indicate admixture with a heavier oil. To malie use of this fact, Gobley and other chemists have invented an instrument called an elciometer, for taking the specific gravity of oils.

c. Olive oil, when mixed with concentrated sulphuric acid, sets free less caloric than many other oils similarly treated. An exact estimation of the amount of caloric, requires a thorough proficiency in physical experiments, so that in a practical point of view this method of testing is of no great utility.

d. Observation of the Cohesion-figure.-This test, proposed by Tornlinson in $1864,{ }^{1}$ depends on the forces of cohesion, adhesion, and diffusion. Thus, if a drop of any oil hanging from the end of a glass rod is gently deposited upon the surface of chemically clean water, contained in a clean glass, a contest takes place between the forces in question the moment the drop flattens dowu by its gravity upon the surface of the water. The adhesion of the liquid surface tends to spread out the drop into a film, the cohesive force of the particles of the drop strives to prevent that extension, and the resultant of these forces is a figure which Mr. Tomlinson believes to be definite for every independent liquid. The figure thus produced is named the colcesion-figure. A series of careful and patient experiments with materials of known purity, is requisite in order to ascertain the practical applicability of this method of testing as applied to olive oil. From the wroodcuts given by Mr. Tomlinson, there is, we fear, not much hope of it being effectual for the detection of sesamé oil, unless the latter be in very large proportion.

So far as our experience goes, the processes hitherto recommended for testing olive oil (and there are scveral that we have not mentioned) are only available in cases where the adulteration is considerable, and are quite insufficient for discovering a small admixture of other oils. How littlc they are appreciated, may be inferred from the fact that the Chamber of Commerce of Nice ${ }^{2}$ has recently offered a reward of 15,000 francs $(£ 600)$ for a simple and easy proccss for making cvident an admixturc with olive oil of 5 per cent. at least, of any seed-oil.

1 Pharm: Joum. v. (1864) 387. 495, with figures.
2 Anuales de Chimic et de Physique, March, 1869. 309 . 


\section{APOCYNEA:}

\section{CORTEX ALSTONIÆ.}

\section{Corlex Alstonia: scholaris; Alstonia Bark.}

Botanical Origin-Alslonia ${ }^{1}$ scholaris R. Brown (Echilcs scholaris L.), a handsome forest tree, 50 feet or more in height, common throughout the Indian Peninsula from the sub-Himalayan region to Ceylon and Burma ; found also in the Philippines, Java, Timor and Eastern Australia, likewise in Tropical Africa. It has oblong obovate leaves, in whorls of 5 to 7 , and slender pendulous pods a foot or more in length.

History-Rheede ${ }^{2}$ in 1678 and Rumphius ${ }^{3}$ in 1741 described and figured the tree, and inentioned the use made of its bark by the native practitioners. Rumplius also explained the trivial name scholuris as referring to slabs of the close-grained wood which are used as schoolslates, the letters being traced upon them in sand. The tonic properties of the bark were favourably spoken of by Graham in his Calalugue of. Bombay Plants (1839), and further recommended by Dr. Alexander Gibson in 1853." The drug has a place in the Pharmacopceia of India, 1868.

Description-The drug; as presented to one of us by the late $\mathrm{Dl}$. Gibson and by Mr. Bronghton of Ootacamund, consists of irregular fragments of bark, $\frac{1}{8}$ to $\frac{1}{2}$ an inch thick, of a spongy texture, easily breaking with a short, coarse fracture. The external suriace is very uneven and rough, dark grey or brownish, sometimes with blackish spots; the interior substance and inner surface (liber) is of a bright buff. A transverse section shows the liber to be finely marked by numerous small medullary rays. The bark is almost inodorous; its taste is purely bitter and neither aromatic nor acrid.

Microscopic Structure-The cortical tissue is covered with a thin suberous coat; the middle layer of the bark is built up of a thin-walled parenchyme, through which enormous, hard, thick-walled cells are scattered in great numbers and are visible to the naked eye, as they form large irregular groups of a biight yellow colour. Towards the inner part, these stone-cells disappear, the tissue being traversed by undulated medullary rays, loaded with very small starch grains; many of the other parenchymatous cells of the liber contain crystals of calcium oxalate. The longitudinal section of the liber exhibits large but not very numerous laticiferous vessels, as elongated simple cells with perforated transverse walls (sieve-cells), containing a brownish mass, the concrete milk-juice in which all parts of the tree abound.

Chemical Composition-Gruppe, ${ }^{5}$ a pharnacien of Manila, has obtained from the bark an uncrystallizable bitter substance which he calls Ditain ${ }^{6}$ and to which he ascribes the febrifuge powers of the drug.

From the chemical examination of the bark of an allied Australian tree, Alstonia constricta F. v. Miiller, it may be presumed that the bitter

1 So named in honour of Chirles Alston, Professor of Botany and Materia Medica (1740-1760) in the University of Edinburgh.

2 Hortus Malabaricus, i. tab. 45.

3 Herb. Ambrin. ii. tab. 82.
4 pharm. Joum. xii. (1553) 422.

5 Zeitschrift d.Oestcrercich. Apoth.-Foreincs 1873. 249.

6 From Dita, the name of the tree in the island of Luzon. 
substance of $A$. scholaris is not an alkaloid. The Australian bark analys ed by Palm in Wittstein's laboratory, yielded an amorplous resinous bitter body, soluble in alcohol but very sparingly in ether or water, an essential oil of camphoraceous odour, and tanuic matter striking a green hue with salts of iron. Palm ascertained that the bitter principle is not of a basic nature. The Australian bark, a specimen of which has been presented to us by Dr. Wittstein, is quite different from that of $A$. scholaris in its structural characters.

Uses-The bark has been recommended as a tonic and antiperiodic; but has not yet been employed in Europe. ${ }^{2}$

\section{ASCLEPIADEAE.}

\section{RADIX HEMIDESMI.}

\section{Hemidesmus Root, Nunnari Root, Inclian Sarsaparilla.}

Botanical Origin-Hemidesmus indicus R. Brown (Periploca indica Willd., Asclepias Pserdo-sarsa Roxb.), a twining shrub, growing throughout the Indian Peninsula and in Ceylon. The leaves are very diverse, being narrow and lanceolate in the lower part of the plant and broadly ovate in the upper branches.

History-The root under the name of Nannari or Ananto-múl has long been employed in medicine in the southern parts of India. ${ }^{3}$ Ashburner in 1831, was the first to call the attention of the profession in Europe to its medicinal value. ${ }^{4}$ In 1864 it was admitted to a place in the British Pharmacopceic, but its efficiency is by no means generally acknowledged.

Description ${ }^{5}$ - The root is in pieces of 6 inches or more in length; it is cylindrical, tortuous, longitudinally furrowed, fron $\frac{2}{10}$ to $\frac{7}{10}$ of an inch in thickness, mostly simple or provided with a few thin rootlets, emitting slender, branching, woody aerial stems, $\frac{3}{10}$ of an inch or less thick. Externally it is dark brown, sometimes with a slight violet-grey hue, which is particularly obvious in the sunshine. The transverse section of the hard root, shows a white mealy or brownish or somewhat violet cortical layer, not exceeding $\frac{1}{10}$ of an inch in thickness, and a yellowish woody column, separated by a narrow dark undulated cambial line. Neither the wood nor the cortical tissue present a radiate structure in the stout pieces; in the thinner roots, medullary rays are obvious in the woody part. The extremely thin corky layer easily separates from the bark, which latter is frequently marked transversely by large cracks. The root whether fresh or dried, has an agreeable odour resembling tonka bean or melilot. The dried root has a sweetish taste with very slight acridity. The stems are almost tasteless and inodorous. The root found in the English market is often of very bad quality.

1 Vicrtcljahresschrift für pratit. Pharm. xii. (1863) 161 .

2 It has been reeently extravagantly praised in Manila as a substitute for quinine.

3 There is an Indian root figured as Palo de Culebra by $\Lambda$ costa (Tractado de las Drogas - de las Indias Oricntalcs, 1578 , cap. Iv.) which is astonishingly like the drug in question. He describes it moreover, as having a sweet smell of melilot. The plant. he says is called in Canarese Duda sali. The figure is reprodueed in Antoine Colin's translation, but not in that of Clusius.

4 Lond. Med. and Phys. Jounn. Ixv. 189.

5 Takeu from cxcellent specimens obligingly sent to us from India by Dr. L. WT. Stewart and Mr. Broughton. 
Microscopic Structure-All thie proper cortical tissue shows a uniform parenchyme, not distinctly separated into liber, medullary rays and mesopll1neum. On making a longitudinal section however, one can observe some elongated laticiferous ressels filled with the colourless concrete milky juice. In a transverse section, they are sean to be irregularly scattered through the bark, ehiefly in its inner layers, yet even here in not very considerable number. They are frequently $30 \mathrm{mkm}$. in diameter and not branched.

The wood is traversed by small medullary rays, which are obvious only in the longitudinal section. The parenchymatons tissue of the ront is loaded with large, ovoid starch granules. Tannic matters do not occur to any considerable amount, except in the outermost suberous layer.

Chemical Composition-The root lias not been submitted to any adequate chemical examination. Its taste and smell appear not to depend on the presence of essential oil, so far as may be inferred from microscopic examination; and it is probable the aroma is due to a body of the cumarin class. According to Scott, ${ }^{1}$ the root yields by simple distillation with water, a stearoptene, which is probably the substance obtained by Garden in 1837, and supposed to be a volatile acid.

Uses-The drug is reputed to be alterative, tonic, diuretic and diaphoretic, but is rarely employed, at least in England.

\section{CORTEX MUDAR.}

\section{Cortcx Cálotropidis; Mudar; F. Ecoree de racine de Mudar.}

Botanical Origin-The drug under notice is furnished by two nearly allied species of Calotropis, occupying somewhat distinct geographical areas, but not distinguished from each other in the native languages of India. These plants are:-

1. Calotropis procera R. Brown (C. Hamiltonii Wight), a large shruh, fi or more feet high, with dark green, oval, opposite leaves, downy beneath, abounding in an acrid milky juice.

It is a native of the drier parts of India, as the Deccan, the Upper Provinces of Bengal, the Punjab and Sind, but is quite unknown in the southern provinces; it also extends to Persia, Palestine, the Sinnitic Peninsula, Arabia, Egypt, Nubia, Abyssinia, the oases of the Saliara, and Sudan. Lastly it has been naturalized in the West Indies.

2. C. gigantca R. Brown (Asclcpias giganted Willd.), a large erect shrub, 6 to 10 feet high, with stem as thick as a man's leg, much resembling the preceding, indigenous to Lower Bengal and the southern parts of India, Ceylon, the Malayan Peninsula, and the Moluccas.

Both species are extremely common in waste ground over their respective areas. ${ }^{3}$

History-Mudar is frequently mentioned in the writings of Susruta,

1 Pharm. of India, 457; also Chem. Growette, 1843. 378.

${ }_{2}$ Henee the specific name giggutec.

3 The botanical distinctions between the two speeies may be stated thus :-

C. procerc, corolla eup-shapal, petals some what ercet, flowerbuds spherieal, appendaces of corona with a blunt upward point. C. yiganted, eorolla opening flat, flowerhuds bluntly eonical or oblong, appendages of corona rounded. 
and must therefore have been in use in India prior to the Christian ern; and it was well known to the Arabian physicians. ${ }^{1}$

C. procerc was observed in Egypt by Prosper Alpinus (1580-84), and upon his return to Italy was figured, and some account given of its medicinal properties. ${ }^{2}$

C. gigantca was figured by Rheede ${ }^{3}$ in 1679 , and in our own day by TVight. ${ }^{*}$

The medicinal virtues of mudar, though so long esteemed by the natives of India, were not investigated experimentally by Europeans until the present century, when Playfair recommended the drug in elephantiasis, and its good effects were afterwards noticed by Vos (1826), Cumin (1827), and Duncan (1829). The last-named physician also performed a chemical examination of the root-bark, the activity of which he referred to an extractive matter which he termed Mudarine. ${ }^{5}$

Description-The root-bark of $C$. procera, as we have received it, ${ }^{6}$ consists of short, arched, bent, or nearly flat fragments, $\frac{1}{8}$ to $\frac{1}{5}$ of an inch thick. They have outwardly a thickish, yellowish-grey, spongy cork, more or less fissured lengthwise, frequently separating from the middle cortical layer; the latter consists of a white mealy tissue, traversed by narrow brown liber-rays. The bark is brittle and easily powdered; it has a mucilaginous, bitter, acrid taste, but no distinctive odour. The light-yellow, fibrous wood is still attached to many of the pieces.

The roots of $C$. gigantca are clothed with a bark which seems to be undistinguishable from that of $C$. procera just described. The wood of the root consists of a porous, pale-yellow tissue, exhibiting large vascular bundles, and very numerous small medullary rays, consisting of 1 to 3 rows of the usual cells. ${ }^{7}$

Microscopic Structure-In the root-bark of C. procera, the suberous coat is made up of large, thin-walled, polyhedral, or almost cubic cells; the middle cortical layer, of a uniform parenchyme, loaded with large starch granules, or here and there containing some thick-walled cells (sclerenchyme) and tufts of oxalate of calcium. The large medullary rays are built up of the usual cells, having porous walls and containing starch and oxalate. In a longitudinal section, the tissue chiefly of the middle cortical layer, is found to be traversed by numerous laticiferous vessels, containing the dry milk juice ${ }^{8}$ as a brownish granular substance not soluble in potash.

The microscopic characters of the root-bark of $C$. gigantec agree with those here detailed of $C$. procerc. The stems of Calotropis are distinguished by strong liber fibres, which are not met with in the roots.

Chemical Composition-By following the process of Duncan above

1 Ebn Baithar, translated by Sontheimer, ii. (1842) 193.

${ }^{2}$ De Plantis AEgypti, Venet. 1592. eap. xxv.

3 Ilortus Malabaricus, ii. tab. 31.

* Illustrations of Indian Botany, Madras, ii. (1850) tab. 155. - C. procera is figured by the same author in his Icones Plantarum Indiox Oricntalis, iv. tab. 1278.

5 Edinb. Hed. and, Surq. Journ. xxxii. (1829) 60

"We are indeuted for an authentic speeimen to Dr. E. Burton Brown of Lahore.
7 Roots of $C$. gigantea kindly supplied to us by Dr. Bidie of Madras consist of light, woody truneheons, $\frac{1}{2}$ to $2 \frac{1}{4}$ inehes in diameter.

8 It is evidently with a view to the retention of this juice, that the Pharmacopocia of India orders the bark to be stripped from the roots when the latter are half-dried. Moodeen Sheriff remarks of $C$. gigantea, that although it is frequently used in medieine, no part of it is sold in the bazaars, -no doubt from the circumstanee that the plant is everywhere found wild and cam be eollected as required. 
illucled to, 200 grammes of the powdered bark of $C$. gigantea yielded us nothing like his Mularine, but 2.4 grammes of as acrid resin, soluble in ether as well as in alcohol. The latter solution reddens litmus; the former on evaporation yields the resin as all almost colourless mass. If the aqueous liquid is separated from the crude resin, and much absolute alcohol added, an abundant precipitate of mucilage is obtained. The liquid now contains a bitter principle, which after due concentration may be separated by means of tannic acid.

We obtained similar results by exhausting the bark of $C$. procerc with dilute alcohol. The tannic compound of the bitter principle was mixed with carbonate of lead, dried and boiled with spirit of wine. This after evaporation furnished an amorphous, very bitter mass, not soluble in water, but readily so in absolute alcohol. The solution is not precipitated by an alcoholic solution of acetate of lead. By purifying the bitter principle with chloroform or ether, it is at last obtained colourless. This bitter matter is probably the active principle of Calotropis; we ascertained by. means of the usual tests, that no alkaloid occurs in the drug. The large juicy stem, especially that of $C$. gigantea, ought to be submitted to an accurate chemical and therapeutical examination. ${ }^{1}$

Uses-Mudar is an alterative tonic, and diaphoretic,-in large doses emetic. By the natives of India who employ it in venereal and skin complaints, almost all parts of the plant are used. According to Moodeen Sheriff, ${ }^{2}$ the bark of the root and the dried milky juice are the most efficient; the latter is however somewhat irregular and unsafe in its action. The same writer remarks that he has found that the older the plant, the more active is the bark in its effects. He recommends that the corky outer coat which is tasteless and inert, should be scraped off before the bark is powdered for use : of a powder so prepared, 10 to 50 grains suffice as an emetic.

The stems of $C$. gigantea afford a very valuable fibre which can be spun into the finest thread for sewing or weaving. ${ }^{3}$

\section{FOLIA TYLOPHORÆ.}

\section{Country or Indian Ipecacuanha.}

Botanical Origin-Tylophora asthmatica Wight et Arnott (Asclepias asthmatica Roxb.), a twining perennial plant, common in sandy soils throughout the Indian Peninsula and naturalized in Mauritius. It may be distinguished from some of its congeners by its reddish or dull pink flowers, with the scale of the staminal corona abruptly contracted into a long sharp tooth.

History-The employment of this plant in medicine is well known to the Hindus, who call it Antamúl and use it with considerable success in dysentery. During the last century, it attracted the attention of Roxburgh ${ }^{4}$ who made many observations on the administration of the

1 List's A sclcpione (Gmelin's Chomistry, xvii. 368) might then be sought for.

2 Sicpilement to the Pharmacopaia of India, Madras, 1869. 364; for further information on the therapeutic uses of mudar, see also Pharm. of India, 455.

3 Drury, Useful Plants of Iindia, 2 nd ed. 1873. 101.

4 Flore Indica, ed. Carey, ii. (1832) 33. 
root, while physician to the General Hospital of Madras from 1776 to 1778. It was also used very successfully in the place of ipecacuanha by Anderson, Physician-General to the Madras army. In inore recent times, the plant lias been prescribed by O'Shaughnessy, who pronounced the root an excellent substitute for ipecacuanha if given in rather larger loses. $^{2}$ Kirkpatrick ${ }^{3}$ administered the drug in at least a thousand cases, and found it of the greatest value; he prescribed the dried leaf, not only because superior to the root in certainty of action, but also as being obtainable without destruction of the plant. The drug has been largely given by many other practitioners in India. Tylophorc is also employed in Mauritius, where it is known as Ipéea sanvage or Ipéca du, pays. It has a place in the Bengal Pharmacopceia of 1844, and in the Pharmacopocia of India of 1868.

Description ${ }^{4}$-The leaves are opposite, entire, from 2 to 5 inches long, $\frac{3}{ \pm}$ to $2 \frac{1}{2}$ inches broad, somewhat variable in outline, ovate or subrotund, usually cordate at the base, abruptly acuminate or almost mucronate, rather leathery, glabrous above, more or less downy beneath with soft simple hairs. The pedicel which is channelled, is $\frac{1}{2}$ to $\frac{3}{4}$ of an inch in length. In the dry state the leaves are rather thick and harsh, of a pale yellowish green; they have a not unpleasant herbaceous smell, with but very little taste. ${ }^{5}$

Chemical Composition-A concentrated infusion of the leaves has a slightly acrid taste. It is abundantly precipitated by tannic acid, by neutral acetate of lead or caustic potash, and is turned greenish-black by perchloride of iron. Broughton of Ootacamund (India) has informed us (1872) that from a large quantity of the leaves he obtained a small amount of crystals, -insufficient for analysis. Dissolved and injected into a small dog, they occasioned purging and vomiting.

Uses-Employed in India, as already mentioned, as a substitute for ipecacuanha; "chiefly in the treatment of dysentery. The dose of the powdcred leaves as an emetic is 25 to 30 grains, as a diaphoretic and expectorant 3 to 5 grains.

Radix Tylophorce - This root is met with in the Indian bazaars, and has been employed as before stated, as much or more than the leaf. It consists of a short, knotty, descending rootstock, about $\frac{2}{8}$ of an inch in thickness, emitting 2 to 3 acrial stems, and a considerable number of wiry roots. These roots are often 6 inches or more in length by $\frac{1}{2}$ a line in diameter and are very brittle. The whole drug is of a pale yellowish brown; it has no considerablc odour, but a sweetish and subsequently acrid taste. In general appearance it is suggestive of valerian, but is somewhat stouter and larger.

Examincd microscopically, the parenchymatous cnvclope of the rootlets is seen to consist of two layers, the inner forming a small

1 Fleming, Catalogne of Indian Plants and Drugs, Calcutta, 1810. 8.

2 Bengal Dispensalory (1842) 455.

3 Catalogue of Madras bixhibition of 1855 , - list of Mysore drugs; also Pharm. of India, 458.

* Drawn up from an ample spccimcn kindly presented to us together with one of the root, by Mr. Moodeen Sheriff of Madras.

5 A figure of the leaves may be found in a paper on Unto-mool by M. C. Cooke, Pharm. Journ. Ang. 6, 1870.105; and one of the whole plant in Wight's Iconcs Plantanum Indice Oricutalis, iv. (1850) tab. 1277. 
nuclens sheath. 'The outer portion is built up of large cells, loaded with starch granules and tufted crystals of oxalate of calcium. Salts of iron do not alter the tissue.

\section{LOGANIACEA.}

\section{NUX VOMICA.}

Semon Nucis Vomica; Nux Vomica; F. Noix vomique; G. Brechnüsse.

Botanical Origin-Stryctenos Nux-vomica L., a inoderate sized tree, with shiort, thick, often crooked stem, and small, greenish-white, tubular flowers ranged in terminal corymbs. It is indigenous to most parts of Iudia, especially the coast districts, and is found in Burmall, Siam, Cochin China and Northern Australia.

The ovary of $S$. Nux-vomica is bi-locular, but as it advances in growth, the dissepiment becomes fleshy and disappears. The fruit, which is an indehiscent berry of the size and shape of a small orange, is filled with a bitter, gelatinous white pulp, in which the seeds, 1 to 5 in number, are placed vertically in an irregular manner. 'The epicarp forms a thin, smooth, somewhat hard shell, which at first is greenish, but when mature, of a rich orange-yellow. The pulp of the fruit contains strychnine ${ }^{1}$ yet it is said to be eaten in India by birds. ${ }^{2}$ The wood, which is hard and durable, is very bitter.

History-Nux Vomica, which was unknown to the ancients, is thouglit to have been introduced into medicine by the Arabians. But the notices in their writings which have been supposed to refer to it, are far from clear and satisfactory. We have no evidence moreover that it was used in India at an early period. Garcia d' Orta, an observer thoroughly acquainted with the drugs of the west coast of India in the middle of the 16th century, is entirely silent as to nux romica. Fleming ${ }^{3}$ writing at the beginning of the present century, remarks that nux vomica is seldom, if ever, employed in medicine by the Hindus, but this statement does not hold good now.

The drug was however certainly made known in Germany in the 16 th century. Valerius Cordus ${ }^{4}$ wrote a description of it about the year 1540, which is remarkable for its accuracy. Fuchs, Bauhin and other's

1 Roxburgh's assertion that the pulp "sccms perfectly innocent," indueed us to examine it ehemieally, which we rere emabled to do through the kindness of $\mathrm{Dr}$. Thwaites, of the Royal Botanieal Gardens, Ceylon. The inspissatcd pulp reecived from Dr. T., diluted with water, formed a very consistent jelly having a slightly aeid reaetion and very bitter taste. Some of it was mixed with slaked lime, dried, and then exhausted by boiling ehloroform. 'I'he liquid left on evaporation, a yellowish resinoid mass, which was warmer with aeetie aeid. The eolourless solution yielded a perfeetly white, erystalline residue, whieh was dissolved in water, and preeipitated with biehromate of potassium. The preeipitate dried, and moistened with strong sulphuric acid, exhibited the violet hue charaeteristic of strychnine.

'To eonfirm this experiment, we obtained through the obliging assistance of Dr. Bidie of Madras, some of the white pulp taken with a spool from the interior of the ripe fruit, and at onee immersed por se in spirit of wine. The aleoholie fluid gave abundant evidenee of the presenee of stryehnine.

2 Aceording to Cleghorn by the hornbill (Buccros malabaricus); aeeording to Roxburgh by " mally sorts of bird." Beddome (Flora S'ylvatica, Madras, 1S72. 243) says the pulp is quite liarmless, and the farourite food of many birds.

3 Catalogne of Indian Med. Plants and Drugs, Caleutta, 1\$10. 37.

4 Ilist. Stirpium, edited by C. Gesner, Argentorat. 1561. lib. iv. e. 21. 
noticed it as Nux Metella, a mane taken from the Methel of Avicenna and other Arabian authors. ${ }^{1}$

It was found in the English shops in the time of Parkinson (1640), who remarks that its chief use is for poisoning dogs, cats, crows and ravens, and that it is rarely given as a medicine.

Description-Nux Vomica is the seed, removed from the pulp and shell. It is disc-like, or rather irregularly orbicular, a little less than an inch in diameter, by about a quarter of an inch in thickness, slightly concave on the dorsal, convex on the ventral surface, or nearly flat on either side, often furnished with a broad, thickened margin so that the central portion of the seed appears depressed. The outside edge is rounded or tapers into a keel-like ridge. Each seed has on its edge a small protuberance, from which is a faintly projecting line (raphe) passing to a central scar which is the hilum or umbilicus; a slight depression marks the opposite side of the seed. The seeds are of a light greyish hue, occasionally greenish, and have a satiny or glistening aspect, by reason of their being thickly covered with adpressed, radiating hairs. Nux vomica is extremely compact and horny, and has a very bitter taste.

After having been softened by digestion in water, the seed is easily cut along its outer edge, then displaying a mass of translucent, cartilaginous albumen, divided into two parts by a fissure in which lies the embryo. This latter is about $\frac{3}{10}$ of an inch long, having a pair of delicate, 5 - to 7-nerved, lreart-shaped cotyledons, with a club-shaped radicle, the position of which is indicated on. the exterior of the seed by the small protuberance already named.

Microscopic Structure-The hairs of nux vomica are of remarkable structure. They are formed as usual of the elongated cells of the epidermis, and have their walls thickened by secondary deposits, which are interrupted by longitudinally extended pores; they are a striking object in polarized light. The albumen is made up of large cells, loaded with albuminoid matters and oily drops, but devoid of starch. In water, the thick walls of this parenchyme swell up and yield some mucilage; the cotyledons are built up of a narrow, much more delicate tissue, traversed by small fibro-vascular bundles.

The alkaloids are not directly recognizable by the microscope; but if very thin slices of nux vomica are kept for some length of time in glycerin, they develope feathery crystals, doubtless consisting of these bases.

Chemical Composition-The bitter taste and highly poisonous action of nux vomica, are chiefly due to the presence of Strychninc and Brucine. Strychnine, $\mathrm{C}^{21} \mathrm{H}^{22} \mathrm{~N}^{2} \mathrm{O}^{2}$, was first met with in 1818 by Pelletier and Caventou in St. Ignatius' Beans, and immediately afterwards in nux vomica. It crystallizes from an alcoholic solution in large anhydrous prisms of the orthorhombic system. It requires for solution about 6700 parts of cold or 2500 of boiling water ; the solution is of decidedly alkaline reaction, and an intensely bitter taste which may be distinctly perceived though it contain no more than $\frac{1}{50000}$ of the alkaloid. The best solvents for strychnine are spirit of wine or chloroform; it

1 Clusius and others held the opinion that the Nus methel of the Arabs was the fruit of a Datura, and an Indian species was accordingly named by Linneus, $D$. Metel. 
is but very sparingly soluble in absolute alcohol, benzol, amylic alcohol, or ether. The alcoholic solution deviates the ray of polarized light to the left.

Strychmine is not restricted to the fruil of the plant under notice, but also occur's in the wood. ${ }^{1}$ It is moreover found in the wood of the root of Strychnos colubrina L., and in the bark of the root of Strychnos Tiente Lesch., both species indigenous to the Indian Archipelago.

The discovery of Brucine was made in 1819 by the sane cliemists, in nux vomica bark, then supposed to be derived from Brucea ferruginca. Its presence in mx vomica and St. Ignatius' Bean, was pointed out by them in 1824. Brucine, dried over sulphuric acid, has the formula $\mathrm{C}^{23} \mathrm{H}^{26} \mathrm{~N}^{2} \mathrm{O}^{4}$, but it crystallizes from its alcoholic solution with $4 \mathrm{H}^{2} \mathrm{O}$. It readily neutralizes acids, forming crystalline salts. In bitterness and poisonous properties, as well as in rotatory power, it closely resembles stryclmine, differing however in the following particulars:-it is soluble in about 150 parts of boiling water, melts without alteration a little above $100^{\circ} \mathrm{C}$. In common with its salts, it acquires a dark red colour when moistened with concentrated nitric acid. By heating brucine with hydrochloric or sulphuric acid in sealed tubes, it is entirely decomposed, and then, according to Baudrimont (1869), yields among other products sugar.

The proportion of strychnine in nux vomica appears to vary from $\frac{1}{4}$ to $\frac{1}{2}$ per cent. That of brucine is variously stated to be 0.12 (MIerck), .0 .5 (Wittstein), 1.01 (Mayer) per cent.

A third crystallizable base, called Igasurine, was discovered in 1853 by Desnoix, in the liquors from which strychnine and brucine had been precipitated by lime. Schuitzenberger has stated (1858) that the substance thus obtained consists of as many as nine distinct bases, not even belonging to one and the same homologous series, which he has distinguished by letters ( $a$-Igasurine, $b$-Igasurine, \&c.) They differ from each other in composition, in solubility, and in the proportion of water which they lose when heated to $130^{\circ} \mathrm{C}$. Igasurine has the bitter taste and poisonous properties of the other strychnos alkaloids. ${ }^{2}$

According to Schuitzberger, even strychnine itself is not a definite substance, but is a mixture of three different bases. All these statements respecting igasurine and strychnine require in our opinion to be confirmed by further researches.

In nux vomica, as well as in St. Ignatius' Beans, the alkaloids, according to their discoverers, are combined with Strychnic or Igasuric Acid; Ludwig (1873) who prepared this body from the latter drug, describes it as a yellowish-brown amorphous mass, having a strongly acid reaction and a sour astringent taste; and striking a dark green with ferric salts.

Nux vomica dried at $100^{\circ} \mathrm{C}$. yielded us when burnt with soda-lime 1.822 per cent. of nitrogen, indicating about 11.3 per cent. of protein substances. By boiling ether, we removed from the seeds $t \cdot 14$ per cent. of fat; they also contain mucilage and sugar. The latter, which

1 It is remarkable that parasitic plants of she order Loranthacew growing on Stryychnos Nux-vomicu, acquire the poisonnus properties of the latter.... Pharm. of Indice, 1868. 108.

2 For further information on igasurine, consult Gmelin, Chemistry, xvii. (1866) 589; Watts, Dictionary of Chemistry, iii. (1865) 243; Pharm. Journ. xviii. (1859) 432. 
according to Rebling (1853) exists to the extent of 6 per cent., reduces cripric oxide without the aid of heat. When macerated in water, the seeds easily undergo lactic fermentation, not however attended with decomposition of the alkaloids. The stability of strychnine is remarkable, even after ten years of contact with putrescent animal substances.

Commerce-Large quantities of nux vomica are brought into the London market from British India. ${ }^{1}$ The export from Bombay in the year 1S71-72 was $3341 \mathrm{cwt}$, all shipped to the United Kingdom. ${ }^{2}$ Madras in 1869-70 exported 4805 cwt.; and Calcutta in 1865-66, 2801 cwt. The quantity imported into the United Kingdom in $1870^{3}$ was 5534 civt.

Uses-Tincture and extract of nux vomica, and the alkaloid strychnine, are frequently administered as tonic remedies in a variety of disorders.

\section{SEMEN IGNATII.}

Faba Sancti Ignatii; St. Ignatius' Bcans; F. Fèves de Saint-Ignace, Noix Igasur; G. Ignatiusbohncn. ${ }^{4}$

Botanical Origin - Strychnos Ignatii Bergius ${ }^{5}$ (S. Phitippensis Blanco, Ignaticuna Philippinica Loureiro), a large climbing shrub, growing in Bohol, Samar, and Cebu, islands of the Bisaya group of the Philippines, and according to Loureiro in Cochin China, where it has been introduced. The inflorescence and foliage are known to botanists only from the descriptions given by Loureiro ${ }^{6}$ and Blanco. ${ }^{7}$ The fruit is spherical, or sometimes ovoid, 4 inches or more in diameter, and consists of a smooth brittle shell enclosing seeds to the number of about 24. G. Bennett, who saw the fruits at Manila sóld in the bazaar, says they contain from 1 to 12 seeds, imbedded in a glutinous blackish pulp.9

History-It is stated by Murray ${ }^{10}$ and later writers, that this seed was introduced into Europe from the Philippines by the Jesuits, who, on account of its virtues, bestowed upon it the name of Ignatius, the founder of their order. However this may be, the earliest account of the drug appears to be that communicated by Camelli, Jesuit missionary at

1 We have seen 1136 paekages offered in a single drug-sale (30 March, 1871).

${ }^{2}$ Statement of the Trade and Navigation of Bombay for 1871-72, pt. ii. 62 .

3 No later returns are aeessible.

4 The plant and seeds are known in the Bisaya language by the names of pangegreason, agruason, eanlara, mananciog, daneagay, catalonga or igasur ; in the islands of Bohol and Cebu, where the seeds are prodneed, by that of coycucoy, and by the Spaniards of the Philippines as Pepite de Bisaya or Pepita de Catbalogan (Clain, Remedios Fuciles, Manila, 1857. p. 610). The name St. Ignalines' Bean applied to them in Europe, is employed in South Amerien to designate the seeds of several medieinal Cucurbitacew, as those of feuillea trilobata 1., IYypanthera. Guapeva Manso and Anisosperma Passiflor'a Manso.
5 Materia Nediea, Stoekholm, 1778. i. 146.--Te onit eiting the Limnean Ignatia cmarcc, as it has been shown by Bentham. that the plant so named by the younger Limmaus is Posoqueria longitlor a Aubl. of the order Rubicuece, a native of Guiana.

6 Flore Cochinchinensis, ed. Willd. i. (1793) 155.

7 Flore de Filipinas, ed. 2. 1845. 61.

8 London Med. cund Phys. Joum., January 1832.

9) The ouly speeimen of the furit I have seell was in the possession of iny late friend Mr. Morson. It measured exaetly 4 inehes in dianeter, and when opened (15 January 1872) was found to eontain 17 mature, well. formed seeds, with remuants of dried pulp. $\Lambda$ s figured on the authority of Camelli, the fruit is ovoid, $6 \frac{9}{4}$ inelies long by $4 \frac{1}{4}$ in diameter.-D. H.

10 Apparalus Medicaminum, vi. (1792) 26. 
Manila, to Ray and Petiver, and by them laid before the Royal Society of London in 1699.' Camelli proclained the seed to be the $N^{\prime}$ ux Vomirn, legitima of the Arabian physician Serapion, who flourished in the !th century, but in our opinion there is no warrant whatever for sipposing it to liave been known at so remote a period." Camelli states that the seed, which he calls Nux Pepita seu Falu Suncti Ignatii, is much esteemed as a remedy in various disorders, though he was well aware of its poisonous properties when too freely administered. In Ciermany, St. Ignatius' Bean was made known about the same period by Bohn of Leipzig. ${ }^{3}$

The drug is found in the Indian bazaars under a name which is evidently corrupted from the Spanish pepita. It is met witl in the drugshops of China as Lerc-sung-hwo, i.e. Luzon fruit.

Description-St. Ignatius' Beans are about an inch in length; their form is ovoid, yet by mutual pressure it is rendered very irregular, and they are 3-, 4-, or 5-sided, bluntly angular, or flattish, with a conspicuous hilum at one end. In the fresh state, they are covered with silvery adpressed hairs: portions of a shaggy brown epidermis are here and there perceptible on those found in commerce, but in the majority, the seed shows the dull grey, gramular surface of the albumen itself.

Notwithstanding the different outward appearance, the structure of St. Ignatius' Beans accords with that of mux vomica. The radicle however is longer, thicker, and frequently somewliat bent, and the cotyledons are more pointed. The horny brownish albumen is translucent, very hard, and difficult to split. The whole seed swells considerably by prolonged digestion in warm water, and has then a heavy, earthy smell. 'The beans are intensely bitter and highly poisonous.

Microscopic Structure-The hairs of the epidermis are of an analogous structure but more simple than in nux vomica. The albumen and cotyledons agree in structural features with those of the same parts in nux vomica.

Chemical Composition-Strychnine exists to the extent of about 1.5 per cent.; the seed also contains 0.5 per cent. of brucine. Dried over sulphuric acid and burnt with soda-lime, it yielded us an average of 1.78 per cent. of nitrogen, which would answer to about 10 per cent. of albuminoid matter.

Commerce-We have no information as to the collection of the drug. The seeds are met with irregularly in English trade, being sometimes very abundant, at others scarcely obtainable.

Uses-The same as those of mux vomica. When procurable at a moderate price, the seeds are valued for the manufacture of strychmine.

1 Phil. Trans. xxi. (1699) 44. 87 ; Ray, Hist. Plant. iii. lib. 31. 118.

2 the Philipliues were wholly unknown to the Europeans of antiquity or of the Nidale $\Lambda$ sres. They were discovered by Magellan in 1521, but their conquest by the Spaniards was not eflectually commenced until 1:65. Previous to the Spanish occupation, they were governed by petty chiefs: and were frequented for the purposes of commerce by Japanese, Chinesr, and Malays.

3 Martigny, Encyllopädic d. Rohucaurent: i. (1813) 576 . 
RADIX SPIGELIAE.

\section{Fiadir Spigelice MLarilandiea; Indian Pink Root, Carolina Pink Root, Spigelia. ${ }^{1}$}

Botanical Origin-Spigelia Marilandiea L., an herbaceous plant about a foot high, indigenous in the woods of North America, from l'ennsylvariia to Wisconsin and southward. According to Wood and Bache, it is collected cliefly in the Western and South-western States.

History-The anthelmintic properties of the root, discovered by the Indians, were bronght to notice in Europe about the year 1754, by Linning, Garden, and Chalmers, physicians of Charleston, South Carolina. The drug was admitted to the London Pharmacopœia in 1788.

Description-Pink root has a near resemblance to serpentary, consisting of a short, knotty, dark brown rhizome emitting slender wiry roots. It is quite wanting in the peculiar odour of the latter drug, or indeed in any aroma ; in taste it is slightly bitter and acrid. Sometimes the entire plant with its quadrangular stems a foot high is imported. It has opposite leaves about 3 inches long, sessile, ovate-lanceolate, acuminate, smooth or pubescent.

Microscopic Structure-The transverse section of the rhizome, ubout $\frac{2}{10}$ of an inch in diameter, shows a small woody zone enclosing a large pith of elliptic outline, consisting of thin-walled cells. Usually the central tissue is decayed. In the roots, the middle cortical layer predominates; it swells in water, after which its large cells display fine spiral markings. The nucleus-sheath observable in serpentary, is wanting in spigelia.

Chemical Composition-Not satisfactorily known : the vessels of the wood contain resin, the parenchyme starch; in the cortical part of the rhizome, sone tannic matters occur, but not in the roots. Feneulle (1.82:3) asserts that the drug yields a little essential oil. The experiinents of Bureau ${ }^{2}$ show that spigelia acts on rabbits and other animals as a narcotico-acrid poison.

Uses-Spigelia has long been repnted a most efficient medicine for the expulsion of Ascaris lumbricoides, but according to Stillé, ${ }^{3}$ its real value for this purpose las probably been over-estimated. This author speaks of it as possessing alterative and tonic properties. In England, it is rarely prescribed by the regular practitiomer, but is used as a household merlicine in some districts. It is much employed in the United States.

\section{GENTIANEA.}

\section{RADIX GENTIAN FE.}

\section{Gentian Root; F. Racine de Gentiane; G. Enzianvourzel.}

Botanical Origin-Gentiana lutea L., a handsome perennial lierb, spowing $?$ feet high, indigenous to open grassy places on the mountains

1 Pinl; Root, is sometimes erroneously latinized in price-lists, "Radix caryophylli." " Je la fumitle des Loganiacées, 1856. 130.
3 Therepeutics and Matiric Mcdica, Pliiladelphia, ii. (1868) 651. 
of Middle and Southern Europe. It occurs in Portugal, Spain, the Pyrenees, in the islands of Sardinia and Corsica, in the Apennines, the mountains of Auvergne, the Jura, the Tosges, the J3lack Forest. and throughout the chain of the $\mathrm{Al} p \mathrm{~s}$ as far as Bosnia and the Danubian Principalities. Among the mountains of Ciemony, it is found on the Suabian $A$ lps near Wiir further north, nor does it occur in the British. Islands.

History-The name Gentiana is said to be derived from Gentius, a king of the Tllyrians, living B.c. 180-167, by whom according to both Pliny and Dioscorides, the plant was noticed. Whether the species thus mamed was Gentiana lutea is doubtful. During the middle ages, gentian was commonly employed for the cure of discase, and as an antidote to poison. Tragus in 1552, mentions it as a means of dilating wounds, an application which has been resotred to in modern medical practice.

Description-The plant has a cylindrical, fleshy, simple root, of pale colour, occasionally almost as much as 4 feet in length by $1 \frac{1}{2}$ inches in thickness, producing 1 to 4 aerial stems.

The dried root of commerce is in irregular, contorted pieces, several inches in length, and $\frac{1}{2}$ to 1 inch in thickness; the pieces are much wrinkled longitudinally, and marked transversely, especially in their upper portion, with numerous rings. Very often they are split to facilitate drying. They are of a yellowish brown; internally of a more orange tint, spongy, with a peculiar, disagreeable, heavy odour, and intensely bitter taste. The crown of the root, which is somewhat thickened, is clothed with the scaly bases of leaves. The root is tougl and flexible,-brittle only immediately after drying. We found it to lose in weight about 18 per cent. by complete drying in a water-bath; it regained 16 per cent. by being afterwards exposed to the air.

Microscopic Structure-A transverse section shows the bark separated by a dark cambial zone from the central column; the radial arrangement of the tissues is only obvious in the latter part. In the bark, liber fibres are wanting; and in the centre there is no distinct pith. The fibro-vascular bundles are devoid of thick-walled ligneous prosenchyme; this may explain the consistence, and the short even fracture of the root. It is moreover remarkable on account of the absence both of starch and oxalate of calcium; the cells appear to contain chiefly sugar and a little fat oil.

Chemical Composition-The bitter taste of gentian is due to a substance called Gentiopierin or Gentian-bitter. ${ }^{1}$ Several chemists, as Henry, Caventou, Trommsdorff, Leconte, and Dulk have described the bitter principle of gentian in an impure state, under the name of Gontianin, but Kromayer in 1862 first obtained it in a state of purity.

Gentiopicrin, $\mathrm{C}^{20} \mathrm{H}^{30} \mathrm{O}^{12}$, is a neutral body crystallizing in colourless needles, which readily dissolve in water. It is soluble in spinit of wine, but in absolute alcohol only when aided by lieat; it does not dissolve in ether. A solution of caustic potash or soda forms with it a Jellow solution. Under the influence of a dilute mineral acid, gentiopicrin is resolved into glucose, and an amorphous, yellowish-brown, neutral sub-

1 Gmelin, Chemistry, xvi. (1864) 193. 
stance, named Gentiogenin. Fresh gentian roots yield somewhat more than $\frac{1}{10}$ per cent. of gentiopicrin; from the dried root it could not be obtained in a crystallized state. The medicinal Tincture of Gentian, mixed with solution of caustic potash, loses its bitterness in a few days, probably in consequence of the destruction of the gentiopicrin.

Another constituent of gentian root is Gcntianic Acid, $\mathrm{C}^{14} \mathrm{H}^{10} \mathrm{O}^{5}$, a tasteless substance, forming pale yellow, silky crystals, which may be sublimed if cautiously heated. It is but very slightly soluble in water, whether cold or hot, or in ether, but dissolves in hot strong alcohol, from which it may be crystallized. It also dissolves in aqueous alkalis, forming crystallizable compounds. Gentianic acid appears to be without action on the organism.

Gentian root abounds in pectin ; it also contains to the extent of 12 to 15 per cent., an uncrystallizable sugar, of which advantage is taken in Southern Bavaria and Switzerland, for the manufacture by fermentation and distillation of a potable spirit. ${ }^{1}$ This use of gentian and its consumption in medicine, have led to the plant being almost extirpated in some parts of Switzerland where it formerly abounded.

Commerce-Gentian root finds its way into English commerce through the German houses; and some is shipped from Marseilles. The quantity imported into the United Kingdom in 1870, was $1100 \mathrm{cwt}$.

Uses-Gentian is much used in medicine as a bitter tonic. Ground to powder, the root is an ingredient in some of the compositions sold for feeding cattle.

Substitutes-It can hardly be said that gentian is adulterated, yet the roots of several other species possessing similar properties are occasionally collected; of these we may name the following:-

1. Gentiana purpurea L.-This species is found in Alpine meadows: of the Apennines, Savoy and Switzerland, in Transylvania, and in Southern.Norway; a'variety also in Kamtchatka. ${ }^{2}$ The root is frequently collected; it attains at most 18 inches in length and a diameter of about 1 inch at the summit, from which arise 8 to 10 aerial stems, clothed below with many scaly remains of leaves. The top of the root has thus a peculiar branched appearance, never found in the root of $G$. lutec, with which in all other respects that of $G$. purpurea agrees. The latter is perhaps even more intensely bitter.

2. G. punctatc L.-Nearly the same description applies to this species, which is a native of the Southern Alps, extending eastward to Austria, Hungary and Roumelia.

3. G. Pannonica Scop.-a plant of the mountains of Austria, unknown in the Swiss Alps, has a root which according to Vogl,$^{3}$ does not attain the length or the thickness of the root of $G$. purpurea, with which it agrees in other respects. It is officinal in the Austrian Pharmacopœia.

I Th. Martius, Pharm. Journ. xii. (1858) 371.

2 Grischach (Die Vegctation der Ercle, i. 1872. 223) gives very interesting particulas relating to the area of glowth of Genciune jnerpurea, $G$. munctala and $G$. Pennonica. He is decidedly of the opinion that they are listinct species.

3 Commenin) zun österrecichischicn PharmaKropiör, i. (1869) 345 . 
HERBA CHIRAT AE.

\section{Herba Chiretla necl Chirayler; Chiretta or Chirayta.}

Botanical Origin-Ophelia Chirata Grisebach (Gentiana Chirayita Roxb.) an ammal herb of the mountainous regions of Northern India. from Simla through Kumaon to the Murung district in South-eastern Nepal.

History-Chiretta has long been held in ligh esteem by the Hindus, and is frequently mentioned in the writings of Susruta. It is called in Sanscrit Kirâta-tikta, which means the bitler plant of thc Kircitas, the Kirîtas being an outcast race of mountaineers in the north of India. In Fngland, it began to attract some attention about the year 1829 ; and in 1839 was introduced into the Edinburgh Pharmacopoia. The plant was first described by Roxburgh in 1814.

Chiretta was regarded by Guibourt as the Calamus aromaticus of the ancients, but the improbability of this being correct was well pointed out by Fée ${ }^{2}$ and by Royle, and is now generally arlmitted.

Description-The entire plant is collected when in flower, or more commonly when the capsules are fully formed, and tied up with a slip of bamboo into flattish bundles of about 3 feet long, ${ }^{3}$ each weighing when dry from $1 \frac{1}{2}$ to $2 \mathrm{fb}$. The stem, $\frac{2}{10}$ to $\frac{3}{10}$ of an inch in thickness, is of an orange-brown, sometimes of a dark purplish colour; the tapering simple root, often much exceeding the stem in thickness, is 2 to 4 inches long and up to $\frac{1}{2}$ an inch thick. It is less frequently branched, but always provided with some rootlets. In stronger specimens, the root is somewhat oblique or geniculate; perhaps the stem is in this case the product of a second year's growth and the plant not strictly annual. Each plant usually consists of a single stem, yet occasionally two or more spring from a single root. The stem rises to a height of 2 to 3 feet, and is cylindrical in its lower and middlc portion, but bluntly quadrangular in its upper, the four edges being each marked with a prominent decurrent line, as in Erythroe Centaurium and many other plants of the order. The decussate ramification resembles that of other gentians; its stems are jointed at intervals of $1 \frac{1}{2}$ to 3 or 4 inches, bearing opposite semiamplexicaul leaves or their cicatrices. The stem consists in its lower portion of a large woody column, coated with a very thin rind, and enclosing a comparatively large pith. The upper parts of the stem and branches contain a broad ring of thick-walled woody parenchyme. The numerous slender axillary and opposite branches are elongated, and thus constitute a dense umbellate panicle. They are smooth and glabrous, of a greenish or brownish grey colour.

The leaves are ovate-acuminate, cordate at the base, entire, sessile, the largest 1 inch or more in length, 3-to 5-or 7 -nerved, the midrib being strongest. At each division of the panicle there are two small bracts. The yellow corolla is rotate, 4-lobed, with glandular pits above the base; the calyx is one-third the length of the petals, which are about half an inch long. The one-celled, bivalved capsule contains numerous seeds.

I 'Oфє́ $\lambda \lambda \in \iota \nu$, to hless, in allusion to the merlical virtues of the herb.

2 Cours d' Histoire nat. pharmaccutique, ii.

3 The other kinds of chiretta to be uamed presently are usually much shorter.

(1828) 395 . 
The flowers share the intense bitterness of the whole drug. The wood of stronger stems is devoid of the bitter principles.

Chemical Composition-A chemical examination of chiretta lias been made at our request under the direction of Professor Ludwig of Jena, by his assistant Mr. Höhn. The chief results of this careful and elaborate investigation may be thus described. ${ }^{1}$

Among the bitter principles of the drug, Ophelie Acid, ${ }^{1}{ }^{13} \mathrm{H}^{20} \mathrm{O}^{10}$, occurs in the largest proportion. It is an amorphous, viscid, yellow substance, of an acidulous, persistently bitter taste, and a faint gentianlike odour. With basic acetate of lead, it produces an ahundant yellow precipitate. Ophelic acid does not form an insoluble compound with tannin; it dissolves in water, alcohol and ether. The first solution causes the separation of protoxide of copper from an alkaline tartrate of that metal.

A second bitter principle, Chiratin, $\mathrm{C}^{26} \mathrm{H}^{48} \mathrm{O}^{15}$, may be removed by means of tannic acid, with which it forms an insoluble compound. Chiratin is a neutral, not distinctly crystalline, light yellow, hygroscopic powder, soluble in alcohol, ether and in warm water. By boiling hydrochloric acid, it is decomposed into Chiratogenin, $\mathrm{C}^{13} \mathrm{H}^{24} \mathrm{O}^{3}$, and ophelic acid. Chiratogenin is a brownish, amorphous substance, soluble ir alcohol but not in water, nor yielding a tannic compound. No sugar is formed in this decomposition.

These results exhibit no analogy to those obtained in the analysis of the European gentians. Finally, Höhn remarked in chiretta, a crystallizable, tasteless, yellow substance, but its quantity was so minute that no investigation of it could be made.

The leaves of chiretta, dried at $100^{\circ} \mathrm{C}$., afforded 7.5 per cent. of ash ; the stems 3.7 ; salts of potassium and calcium prevailing in both.

Uses-Chiretta is a pure bitter tonic, devoid of aroma and astringency. In intense bittermess, it exceeds gentian, Erythroea and other European plants of the same order. It is much valued in India, but is not very extensively used in England, and not at all on the Continent. It is said to be employed when cheap, in place of gentian, to impart flavour to the compositions now sold as Cattle Foods.

Substitutes and Adulteration-Four other species of Ophelia, namely $O$. angustifolic Don, $O$. densifolia Griseb., O. elegans Wiglit, and O. multiflora Dalz., two or three species of Exacum, besides Andrographis paniculata Wall. (p. 424), are more or less known in the Indian bazaars by the name of Chiretta ${ }^{2}$ and possess to a greater or less degree the bitter tonic properties of that drug. Another Gentianacea, Slevogtic orientalis Griseb., is called Chota Chiretta, i.e. small chiretta. It would exceed due limits were we to describe each of these plants: we have therefore giren a somewhat detailed description of the true chiretta, which will suffice for its identification. We have frequently examined the chiretta found in the English market, but have never met with any
sther than the legitimate sort.

I For full details, see Archiv der Pharmcecie, 189 (1869) 229.

"Moodccin Sheriff, Suppl. to the Pharma. copceice of India, 1869. 1). 138. 189.-C'onsult also Phamacopaia of India, 1868. pl.
${ }^{3} \mathrm{Mrr}$. F. $\Lambda$. Webb has pointed out a case of false-packing in which the ronts of luctice cordifolia L. (Munjit) had been enclosed in
the bundles of chiretta. 


\section{CONVOT,VUT,ACEA:}

\section{SCAMMONIUM.}

\section{Scammony; T. Sccemmonée; G. Scammonium.}

Botanical Origin - Convolvulus Scammonice L, a twining plant nuch resembling the common C. arvensis of Europe, but differing from it in being of larger size, and having a stont tap-root. It occur's in waste bushy places in Syria, Asia Minor, Greece, the Greek Islands, extendingr nortliward to the Crimea and Southern Russia, but appears to be wanting in Northern Africa, Italy, and in all the western parts of the Mediterranean basin.

History-The dried milky juice of the scammony plant has been known as a medicine from very ancient times. Theophrastus in the 3rd century B.C. was acquainted with it; it was likewise familiar to Dioscorides, Pliny, Celsus, and Rufus of Ephesus, each of whom has given some account of the manner in which it was collected. The Arabian physicians also knew scammony and the plant from which it is derived. The drug was used in Britain in the 10th and 11th centuries, and would appear to be one of the medicines recommended to King Alfred the Great, by Helias, patriarch of Jerusalen. ${ }^{1}$ It is repeatedly named in the medical writings in use prior to the Norman conquest (A.D. 1066), in one of which, directions are given for recognizing the goodness of the drug by the white emulsion it produces when wetted.

The botanists of the 16th and 17th centuries, as Brufnels, Gesner, Matthiolus, Dodonæus, and the Bauhins described and figured the plant, partly under the name of Scammonia Syriaca. The collecting of the drug was well described by Russell, an English physician of Aleppo $(1752)$, whose account ${ }^{2}$ is accompanied by an excellent figure representing the plant and the means of obtaining its juice.

Scammony was formerly distinguished by the names Aleppo and Smyrna, the former sort being twice or thrice as costly as the latter; at the present day, Aleppo scammony has quite lost its pre-eninence.

Localities producing the drug-Scammony is collected in Asia Minor, from Brussa and Boli in the north, to Macri and Adalia in the south, and eastward as far as Angora. But the most productive localities within this area, are the valley of the Mendereh, south of Smyrna; and the districts of Kirkagach and Demirjik, north of that town. The neighbourhood of Aleppo likewise affords the drug. A little is obtained further south in Syria, from the woody hills and valleys about the lake of Tiberias and Mount Carmel.

Production-The scammony plant has a long woody root, which throws off downwards a few lateral branches, and produces from its knotty summit, numerous twining stems which are persistent and woody-

1 Such is the opinion expressed by the Rev. O. Coekayne. The letter of Helias to Alfred is imperfect, and mentions only balsam, petroleum, theriaka, and a white stone used as a charm. But from the reference to these four articles in another part of the MS., in connexion with scammony, ammoniacum, trugacanth, and galbanum, there is ground for believing that the lattor (Syrian and
Persian) drugs were included in the lost part of the patriarch's letter.-See Lecehdoms, Wortcunning and Stercraft of Ear. Iy England. edited by Cockaync (Naster of the Rolls Series), vol. ii. pages xxir. 2S9. 175, also 273. 281.

2 Medicat Observations and Inquiries, i. (1757) 12. 
at the base. In plants of three or four years old, the root may be an inch or more in diameter; in older specimens it sometimes acquires a diameter of three or four inches. In length, it is from two to three feet, according to the deptli of soil in which it grows. When the root is wounded, there exudes a milky juice which dries up to a golden-brown, transparent, gummy-looking substance:- this is pure scammony. ${ }^{\text {I }}$

The method followed in collecting scammony for use, appears to be nearly the same in all localities. It has been thus described to us by two eye-witnesses, both long resident in the East. ${ }^{2}$ Operations commence by clearing away the bushes among which the plant is commonly found; the soil around the latter is then removed, so as to leave 4 or 5 inches of the root exposed. This is then cut off in a slanting direction at 2 to 4 inches below the crown, and a mussel-shell is stuck into it just beneath the lowest edge, so as to receive the milky sap which instantly flows out. The shells are usually left till evening, when they are collected, and the cut part of the root scraped with a knife, so as to remove any partially dried drops of juice. These latter are called by the Smyrna peasants, kaimak or cream, the softer contents of the shell being called galu or milk.

Sometimes the scammony is allowed to dry in the shell, and such must be regarded as representing the drug in its ntmost perfection. But scammony in shells is not brought into commerce, though a little of it is reserved by the peasants for their own nse.

The contents of the shells and the scraped-off drops are next emptied into a covered copper pot or a leathern bag, carried home, made homogeneous by mixing with a knife, and at once allowed to dry. In this way, a form of scammony is obtained closely approaching that dried in the shell. But it is a quality of exceptional gondness. Usually the peasant does not dry off the juice promptly, but allows his daily gatherings to accumulate; and when he has collected a pound or two, he places it in the sunshine to soften, and then kneads it, sometimes with the addition of a little water, into a plastic mass, which he lastly allows to dry. By this long exposure to heat, and retention in a liquid state, the scammony juice undergoes fermentation, acquires a strong cheesy odour and dark colour, and when finally dried, exhibits a more or less porous or bubbly structure, never observable in shell scammony.

Scammony is very extensively adulterated. The adulteration is often performed by the peasants, who mix foreign substances into the drug while it is yet soft; and it is also effected by the dealers, some of whom purchase it of the peasants in a half-dried state. The substances used for sophistication are numerous, the commonest and most easily detected being, according to our experience, carbonate of lime and flour. Woodashes, earth (not always calcareous), gum arabic, and tragacanth are also employed ; more rarely, wax, yolk of egg, pounded scammony roots, rosin, or black-lead.

Description-The pure juice of the root, simply dried by exposure to the sun and air, is an amorphous, transparent, brittle substance, of

1 Named probably from $\Sigma$ sá $\mu \mu a$, a trench or pit, in allusion to the excavation made around the root.

2 'The one was the late Mr. S. H. Maltass of Sinyma, whose interesting paper may be found in Pharm. Jounn. xiii. (1854) 264; the other is Mr. Edward T. Rogers, formerly of Caiffa, now (1874) British Consul at Cairo. 
resinous aspect, a yellowish-brown colour, and glossy fracture. Scammony possessing these characters is occasionally met with in the form of flattish irregular masses, about to to of an inch in thickness, very brittle by renson of internal fissures, yet witl but few air-cavities. In mass, it is of a chestnut-brown, but in small fragments it is seen to be very pale yellowish-brown and transparent, with the freshly fractured surface, vitreous and slining. When powdered, it is of a very light buff. Rubbed with the moistened finger, it forms a white emulsion. Treated with etlicr, it yields 88 to 90 per cent. of solnble matter, and a nearly colomrless residuum. This scammony as well as the pure juice in the shell, is very liable to become mouldy; but besides this, it throws out if long kept, a white, mammillated, crystalline efflorescence, the nature of which we have not been able to determine. But if scammony is kept quite dry, neither mouldiness nor efflorescence makes its appearance.

The ordinary fine scammony of commerce, known as Virgin Scammony, is also in large flat pieces or irregnlar flattened lumps and fragments, which in mass have a dark-grey or blackish hre. Viewed in thin fragments, it is seen to be translucent and of a yellowish-brown. It is very easily broken, exhibits a shining fracture, gives an ashy grey powder, and has a peculiar cheesy odour. Some of the pieces have a porous, bubbly structure, indicative of fermentation; the more solid, often show the efflorescence already mentioned. Scammony has not much taste, but leaves an acrid sensation in the throat.

Chemical Composition-Scammony owes its active properties as a medicine, to a resin shown (1860) by Spirgatis to be identical with that found in the root of the Mexican Ipomoca Orizabensis, known in commerce as Male Jalap: this resin called Jalapin will be described in the next article. The other constituents of pure scammony are not well known. One of them is the substance which, as already stated, makes its appearance as small masses of cauliflower crystals on the surface of pure scammony, when the latter is kept in air not perfectly dry.

Whether the odour observable in commercial scammony is due to a volatile fatty acid developed by fermentation, is a question still to be investigated.

Commerce-The export of scammony from Smyrna amounted in 1871 , to 278 cases, valued at $£ 8320$; in 1872 to 185 cases value $£ 6100$. According to a report of Consul Skene on the trade of Northern Syria, 737 cases of scammony were exported from the province of Aleppo in 1872, -six-sevenths of the quantity being for England.

Uses-Employed as an active cathartic, often in combination with colocynth and calomel.

Adulteration-Scammony is very often imported in an adulterated state, but the adulteration is so clumsily effected, and is so easily discoverable by simple tests, or even by ocular examination, that druggists have but little excuse for accepting a bad article.

We have already named the substances used in the sophistication of scammony: of these, the most frequent are carbonate of lime and farinaceous matter. The first miny generally be recognized by examining the fractured surface of the drug with a good lens, when the white particles

1 Presented to Palliament, July 1873. 
of the carbonate will be perceived. If the surface is then touched (while still sub lentc) with hydrochloric acid, effervescence will prove the presence of a carbonate. Other earthy adulterants can be discovered by incineration, or by examining the residue of the drug after treatment with ether. Starchy substances, the presence of which may be surmised by the scammony being difficult to break, are detectable by the microscope or by solution of iodine, a cold decoction of scammony not being affected by that reagent. Scammony that is ponderous, dull and clayey, not casily broken in the fingers, or which when broken cloes not exhibit a clean, glossy surface, or which does not afford at least 80 per cent. of matter soluble in ether, should be rejected. That which is made up in the form of hard, dark, circular cakes is widely different from pure scammony.

Scammony may be distinguished from Resin of Scammony by its property of forming an emulsion when wetted. The resin is also more glossy and almost entirely soluble in ether.

\section{Radix Scammoniæ.}

The frauds commonly practised on the scammony of commerce, have given rise to varions scheines for obtaining the drug in a purer form, as well as at a more moderate price. ${ }^{1}$

So far back as 1839, the Edinburgh College prescribed a Resina Scammonii, which was prepared by exhausting scammony with spirit of wine, distilling off the spirit, and washing the residue with water. Such an extract was manufactured by the late Mr. Maltass of Smyrna, and occasionally shipped to Londorr.

In consequence of a suggestion made by Mr. Clark, manufacturer of liquorice at Sochia near Scala Nuova, a patent was taken out (1856) by Prof. A. W. Williamson of London, for preparing this resin directly from the dried root by means of alcohol. The same chemist shortly afterwards devised an improved process, which consists in boiling the roots first with water and then with dilute acid, so as to deprive them of all matters soluble in those menstrua, and afterwards extracting the resin by alcohol.

Resin of Scammony, obtained either from scammony or from the dried root, is ordered in the Britisin Pharmacopocia of 1867, and is manufactured by a few lrouses. It is a brown, translucent, brittle substance of resinous fracture, entirely soluble in ether, and not forming inl emulsion when wetted with water.

Scammony root is occasionally brought into the London market, sometimes in rather large quantity, ${ }^{2}$ but it is not generally kept by druggists, nor do we find it quoted in price-curients. Its collection is even opposed in some parts of Turkey by the local authorities."

The root consists of stout, woody, cylindrical pieces, often spirally twisted, 2 to 3 inches in diameter, covered with a rough, furrowed, greyish-brown bark. They are internally pale brown, tough and resinous, with a faint odour and taste resembling jalap. A good sample yielded us $\tilde{5} \frac{1}{2}$ per. cent. of resin.

1 Scammony is quoted in a London prieecurrent, $A$ pril, 1874 , at $8 s$. to 36 s. per $1 \mathrm{~b}$..liesin of Seammony at $14 s$. per $1 b$.

2 Thus 100 bales wero offered in a drug sale, 3 July, 1873.
3 Such was the case at Aleppo, as wo know by a private letter from Mr. Consul Skene.-I). H. 


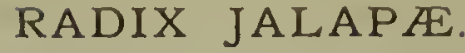

Truber Jalaper; Jalap, Vere C'rus Jalap; F. Racine de Jalap; G. Jalape.

Botanical Origin-Ipoméce J'urga Hayne (Convolvulus Purga Wenderoth, Exxogonium P'urya Benthin), a tuberous-rooted plant, throwing out herbaceons, twining stems, clothed with cordate-acuminate, sharply auricled leaves, and bearing elegant salver-shaped, deep pink flowers. It grows naturally on the eastern declivities of the Mexican Andes, at an elevation above the sea of 5000 to $\$ 000$ feet, especially about Chiconquiaco and the adjacent villages, and also around San Salvador on the eastern slope of the Cofre de Perote. In these localities where rain falls almost daily, and where the diurnal temperature varies from $15^{\circ}$ to $24^{\circ} \mathrm{C}$. $\left(60^{\circ}\right.$ to $75^{\circ} \mathrm{F}$.), the plant occurs in shady woods, flourishing in a deep rich vegetable soil.

The jalap grows freely in the south of England, if planted in a sheltered border, but its flowers are produced so late in autumn that they rarely expand, and the tubers which develope in sone abundance, are liable to be destroyed in winter unless protected from frost.

The plant has been introduced on the Neilgherry Hills in the south of India; it succeeds there remarkably well, ${ }^{1}$ and might be extensively propagated if there were any adequate inducement.

History-The use as a purgative of the tuber of a convolvulaceous plant of Mexico, was made known by the early Spanish voyagers; and so highly was the new drug esteemed that large quantities of it reached Europe during the 16th century.

Monardes writing in 1565 , says the new drug was called Ruybarbo de las Indias or Ruybarbo de Mechoacan, the latter name being given in allusion to the province of Michoacan whence the supplies were derived. Some writers have advanced the opinion that mechoacan root was the modern jalap, but in this we do not concur, for the description given of mechoacan and the place of its production do not apply well to jalap. Both drugs were moreover well known about 1610 ; they were perfectly distinguished by Colin an apothecary of Lyons (1619), who mentions jalap ("racine dc Ialap") as then newly brought to France." They were however often confounded, or at least only distinguished by their difference of tint. Thus jalap which at that period used to be imported cut into transverse slices, ${ }^{3}$ was termed from its darker colour, Black Mcchocucan; and on the other hand, the paler mechoacan was in later times known as White Jalap.

Mechoacan root is now known to consist (at least in part) of the large thick tuber of Ipomcea Jalapa Pursh (Batatas Jalapa Chois.), a plant of the Southern United States and Mexico. As a drug, it has been long obsolete in Europe, having given place to jalap which is a more autive and efficient purgative.

The botanical source of jalap was not definitely ascertained until. about the year 1829, when Dr. Coxe of Philadelphia published a descrip-

1 Thus at Ootacamund, Mr. Brougliton, iu a letter to one of us (15 January, 1870), speaks of reciving "a cluster of tubers" plant jrows as casily as a yam.
- Monardes, IIist. des Mćdicamens, trid. par Colin, cd. 2. 1619.131.- The first clition of this work scems to be unkmown.

3 Hill, Mistory of the Mat. MLcl., Lond. 1751. 549. 
tion and coloured figure, taken from living plants sent to him two years previously from Mexico. ${ }^{1}$

Manner of Growth-Though we have cultivated the jalap plant for many years, we have had no opportunity of examining the seedling, but judging from analogy suppose that it has at first a small tap-root which gradually thickens after the manner of a radish. A root of jalap, called by some tuber and by others tubercule, throws out in addition to aerial stems, slender, prostrate, underground shoots which emit roots at intervals. These roots while but an inch or two long, become thickened and carrot-shaped, gradually enlarging into napiform tuber-like bodies, which emit a few rootlets from their surface and taper off below in long, slender ramifications. The thickened roots have no trace of leaf-organs; the aerial stem grows from the shoot from which they originated.

Fresh jalap roots (tubers) are externally rough and dark brown, internally white and fleshy.

Collection-Jalap is said to be dug up in Mexico during the whole year. $^{2}$ The smaller roots are dried entire; the larger are cut transversely, or are gashed so that they may dry more easily. As drying by sun-heat would be almost impracticable owing to the wetness of the climate, the roots are placed in a net, and suspended over the almost constantly burning hearth of the Indian's hut, where they gradually dry, and at the same time often contract a smoky smell. Much of the jalap that has of late arrived, has been more freely sliced than usual, and has obviously been dried with less difficulty.

According to Schiede, whose account was written in $1829,^{3}$ the Indians of Chiconquiaco were at that period commencing the cultivation of jalap in their gardens.

Description-The jalap of commerce consists of irregular, ovoid roots, varying from the size of an eggy to that of a hazel-nut, but occasionally as large as a man's fist. They are usually pointed at the lower end, deeply wrinkled, contorted and furrowed, and of a dark-brown hue, dotted over with numerous little, elongated, lighter coloured scars, running transversely. The large roots are incised lengthwise, or cut into halves or quarters, but the smaller are usually entire. Some of the small roots are spindle-shaped or cylindrical; others can be found which are nearly globular, smooth and pitchy-looking, but these latter are seldom solid. Good jalap is ponderous, tough, hard and often horny, becoming brittle when long kept, and breaking with a resinous, nonfibrous fracture ; internally it is of a pale dingy brown or dirty white. It has a faint smoky, rather coffee-like odour, and a mawkish taste followed by acridity.

Microscopic Structure-Seen in transverse section, jalap exhibits no radiate structure, but numerous small concentric rings, which in many pieces are very regularly arranged. They are due to the laticiferous cells, differing from the surrounding parenchyme only by their

1 American Journal of Med. Sciences, $\nabla$. (1829) 300. pl. 1-2.

2 It is plain that such a procesding is irrational. The roots should be ciug up when the aerial stems have died down.
3 Linnac, iii. (1830) 473 ; Pharnn. Jounn. viii. (1867) 652 . - We are not aware of any more recent account. 
contents and rather larger size. These laticiferons cells traverse the tissue in a vertical direction, constituting vertical bands, as may be observed on a longitudinal section; the single cells are simply placed one on the other, and do not form peculiar ducts as in Lactuca or Taraxacum.

'The fibro-vascular bundles of jalap are neither numerous nor large ; they are accompanied by thin-walled cells, so that firnı woody rays do not occur. Purenchymatous cells are abundant, and, on a longitudinal fracture especially if subsequently moistened, are seen to constitute concentric layers. The laticiferous cells are always found in the outer part of each layer. The snberous coat with which the drug is covered, is made ip of the usual tabular cells.

The pareuchyme of jalap is loaded with starch grains; in the pieces which have been submitted to heat in order to dry them, the starch appear's as an amorphous mass, and the drug then exhibits a horny consistence and greyish fracture, instead of being mealy. Crystals of calcium oxalate are frequently met with. The laticiferous cells contain the resin of jalap in a semi-fluid state, even in the dry drug; drops of the resinous emulsion flow out of the cells, if thin slices are moistened by any watery liquid.

Chemical Composition-Jalap owes its medicinal efficacy to a resin, which is extractable by exhausting the drug with spirit of wine, concentrating the alcoholic solution to a small bulk, and pouring it into water. The resin precipitated in this manner is then washed and dried; it is contained in jalap to the extent of 12 to 18 per cert. ${ }^{1}$

Fron this crude resin, which is the Resinc jalapee of the pharmacopceias, ether or chloroform extracts 5 to 7 (12, Umney) per cent. of a resin which, according to Kayser ${ }^{2}$ partially solidifies when in contact with water in crystalline needles. We can by no means confirm Kayser's statement. The residue (insoluble in ether) is one of the substances to which the name Jalapin has been applied. ${ }^{3}$ W. Mayer, 1852-1855, who designated it Convolvulin, ${ }^{4}$ found it to have the composition, $\mathrm{C}^{31} \mathrm{H}^{50} \mathrm{O}^{16}$. When purified, it is colourless; it dissolves easily in the fixed alkalis, and is not re-precipitated by acids, having been converted by assumption of water into amorphous Convolvulic Acid, which is readily soluble in water. Both convolvulin and convolvulic acid are resolved by moderate heating with dilute acids, or with emulsin, into crystallizable Convolvulinol, $\mathrm{C}^{26} \mathrm{H}^{50} \mathrm{O}^{7}$, and sugar. Convolvulinol in contact with aqueous alkalis, is converted into Convoliulinolic Acid, $\mathrm{C}^{26} \mathrm{H}^{48} \mathrm{O}^{6}$, which is slightly soluble in water and crystallizable.

When convolvulin or its derivatives is treated with nitric acid, there is produced, together with oxalic acid, a body which lias been termed Ipomoic Acid, $\mathrm{C}^{10} \mathrm{H}^{18} \mathrm{O}^{4}$, isomeric with sebacic acid.

Convolvulin (dry) melts at $150^{\circ} \mathrm{C}$, but a small amount of water renders

1 Guibourt obtainel of it 17 per cent., Ummey $21^{\circ} 5$, Squib 11 to 16 , "I. and $\mathrm{H}$. Smith "not more than 15," D. Hambury 11 to $15 \cdot 8$. Jalap grown in Ponn, afforded to Marquart 12 per cent. ; a root cultivated at Munich gavs Widnmann 22 yer cent.; from plants produeed in Dublin, W. G. Sunith rot 9 to 12 per cent.; and fine tubers from Ootacannund in India yielded to one of us 18 per cent. of resin. Bronghton is of opinion that exposure of the sliced tuber to the air in the process of drying, farours the formation of resin, by the oxidation of a hydrocarbon.

2 Gmelin, Chemistry, xvi. (1\&6t) 159.

3 As by Pereira, Elem. of Mat. Micd. ii. (1850) 1463.

4 Grinclin, op. cit. xri. 154. 
it fusible below $100^{\circ} \mathrm{C}$. It is insoluble in oil of turpentine and in ammonia. It dissolves in dilute nitric acid without becoming coloured or evolving gas. Convolvulin possesses in a high degree the purgative property of jalap, but this is not the case with convolvulinol.

The other constituents of jalap include starch, uncrvstallizable sugar, gum, and colouring matter. The sugar according to Guibourt, exists to the extent of 19 per cent.

Commerce-We have no means of knowing to what extent jalap is produced in Mexico. The imports of the drug into the United Kingdom, amounted in 1870 to $169,951 \mathrm{tb}$. Very considerable quantities liave of late (1873) appeared in the London drug-sales.

Uses-Jalap is employed as a brisk cathartic.

\section{Other kinds of Jalap.}

Besides true jalap, the roots of certain other Convolvulacece of Mexico have been employed in Europe, either in the form of jalapin, or as adulterants of the more costly, legitimate drug. The two following have been extensively imported and have been traced to their botanical source; but there are others, of more occasional occurrence, the origin of which has not been ascertained. ${ }^{1}$

1. Light, Fusiform, or Woody Jalap, Male Jalap, Orizaba Root, Jalap Tops or Stalks, Purgo macho of the Mexicans.

This drug is derived from Ipomoea Orizxbensis Ledanois, ${ }^{2}$ a plant of Orizaba, which is but imperfectly known. It is described as a pubescent climber, having a spindle-shaped root about 2 feet long, of woody and fibrous texture. The drug occurs in irregular, rectangular, or block-like pieces, evidently portions of a very large root, divided transversely and longitudinally. Sometimes it is more like true jalap, being in entire roots, of smaller size, spindle-shaped, not spherical. It has a somewhat lighter colour than jalap, and much deeper longitudinal wrinkles. The larger pieces cften exhibit deep cuts from an axe or knife; transverse slices are of rare occurrence. Although generally less ponderous than jalap, the Orizaba drug is nevertheless of a compact and often horny texture. From jalap it is easily distinguished by its radiated transverse section, and the numerous thick bundles of vessels which project as woody fibres from the fractured surface.

In chemical constitution, Orizaba rcot is closely parallel to jalap. The resin was named by Mayer Jalapin ; ${ }^{3}$ it is the Julapin of Gmelin's Chemistry (xvi. 405), and perhaps the jalapin of English pharmacy. ${ }^{4}$

In the pure state, it is a colourless amorphous translucent resin, dissolving perfectly in ether, thus differing from convolvulin the corresponding resin of jalap. We find that it is readily soluble also in acetone, amylic alcohol, benzol and phenol, not in bisulphide of carbon. It has the composition $\mathrm{C}^{34} \mathrm{H}^{56} \mathrm{O}^{16}$, so that it is homologous with convolvulin; the decomposition-products of jalapin obtained by sinilar treatment,

1 For information about some of these, consult Guibourt, Histoire des Drogues, ii. (1869) 523.

2 Journ. de Chimie méd. x. (1834) 1-22. pl. 1. 2.

3 The name is ill-ehosen and misleading, but having been adopted in stindard works, it might occasion greater confusion to attempit to supersede it, and its several derivatives.

* It is at least a fact, that of numerons samples of jalapin that we have examined (1871), every one is completely solnule in ether. 
namely jalapic acid, jalapinol, and jalapinolic acid, are likewise homologous with the corresponding substances obtained from convolvulin. All these bodies when treated with nitric acid, yield iponøic acid. Jalapin has the same fusing point as convolvulin, and behaves in the same manner with alkalis.

The root afforded us 11.8 per cent. of resin dried at $100^{\circ} \mathrm{C}$. When perfectly washed, decolorized and dissolved in two parts of alcohol, this resin turned the plane of polarization of a ray of light $9.8^{\circ}$ to the left, in a column of $50 \mathrm{~mm}$. long. Convolvulin under the same conditions turned it only $5.8^{\circ}$. The resin of Orizaba root is held by chemists to be identical with that of scammony, of which it has the drastic action.

2. Tampico Jalap,-_Purga de Sierra Gorda of the Mexicans.-The plant whish affords this drug has been described by one of us (1869) under the name of Ipomoea simulans. ${ }^{1}$ It is closely related to I. Purga Hayne, from which by its foliage it cannot be distinguished, but it has a bell-shaped corolla and pendulous flowerbuds, which are very different. I. simulans Hanbury, grows in Mexico along the mountain range of the Sierra Gorda in the neighbourhood of San Luis de la Paz, from which town and the adjacent villages, its roots are carried down to 'Tampico. It has also been found on the lofty Cordillera near Oaxaca, but whether there collected we know not.

The drug, to which in trade the name Tampico Jalap is commonly applied, has been imported during the last few years in considerable quantities. In appearance it closely approaches true jalap, but the roots are generally smaller, more elongated or finger-like, more shrivelled and corky-looking, wanting in the little transverse scars that are plentifully scattered over the roots of true jalap. Many pieces occur however which it is impossible to distinguish by the eye from true jalap, with which it agrees also in odour and taste.

Tampico jalap yielded to one of us, 10 per cent. of purified resin, entirely soluble in ether. Umney ${ }^{2}$ obtained 12 to 15 per cent. of resin almost wholly soluble in ether; Evans got 13 per cent., but found only about half of this to be soluble in ether. ${ }^{3}$ According to Andouard ${ }^{4}$ the resin of Tampico jalap is not deficient in purgative powers.

\section{SEMEN KALADAN Æ.}

\section{Semen Pharbitidis; Kaladana.}

Botanical Origin-Pharbitis Nil ${ }^{5}$ Choisy (Convolvulus $N i$ L.), a twining annual plant, with a large blue corolla, much resembling the Major Convolvulus (Pharbitis hispida Chois.) of English gardens, but having three-lobed leaves. It is found throughout the tropical regions of both hemispheres, and is common in India, ascending the mountains to a heiglit of 5000 feet.

1 Hanbury, On a species of Ipomoen, affording Tampico Jalap, Journ. of Linn. Soc., Bot. xi. (1871) 279, tab. 2 ; Pharm. Journ. xi. (1870) 848; American Journ. of Pharm. xviii. (1870) 330.

'Pharm. Journ. ix. (1868) 282.
3 Ibid. ix. (1868) 330.

- Etude sur les Convolvulacées purgatives (thèse) Paris, 1864. 31.

3 Pharbitis from $\Phi a \rho \beta \eta$ colour, in allusion to the flower. In Hindustani $N i$ signifies blue, and Kala-dana, black seed. 
History-The seeds of this plant were employed in medicine by the Arabian physicians under the name Habbun-níl; and they have probably been long in use anıong the natives of Hindustan. In recent times they have been recommended by O'Shaughnessy, Kirkpatrick, Bidie, Waring ${ }^{1}$ and many other European practitioners in India, as a safe and efficient cathartic.

Description-The shape of the seeds is that which would result if a nearly spherical body were divided perpendicularly around its axis into 6 or 8 almost equal segments, only that the back is less regularly vanlted. The seeds are $\frac{1}{4}$ of an inch high and nearly as much broad; 100 of them weigh on an average about 6 grammes. There is a smaller variety imported from Calcutta, of which 100 seeds weigh but little over 3 grammes; in every other respect the two sorts are identical. Both are of a dull black, excepting at the umbilicus which is brown and somewhat hairy. The adjacent parts of the thin shell (testa) crack in various directions, if the seed is kept for a short time in cold water. If it is removed from the upper part of the vaulted back, the radicle becomes visible, surrounded by the undulated folds of the cotyledons, which join perpendicularly, but cannot be easily unfolded by reason of the thiu seminal integument. Cut transversely, the cotyledons show the same curled structure. Throughout their tissue, small bright glands in considerable number are observable, even without a lens. The kernel, which is devoid of albumen, has at first a nutty taste, with subsequently a disagreeable persistent acridity. When bruised in a mortar, the seeds evolve a heavy earthy smell.

Microscopic Structure-The seed is covered with a dark blackish cuticle, formed of a densely packed tissue, the cells of which show zigzag outlines. The dark brown epidermis is composed of very close cylindrical cells, about $70 \mathrm{mkm}$. in length and 5 to $7 \mathrm{mkm}$. in diameter; they require to be treated with chromic acid in order that their structure may be distinctly seen.

The tissue of the kernels is made up of thick-walled cells. Between this tissue and the shell, there is a colourless layer, about $70 \mathrm{mkm}$. thick, of thin-walled corky parenchyme. The cotyledons contain in their narrow tissue, numerous granules of albuminous matter, mucilage, a little tannic acid, crystals of oxalate of calcium, and a few starch granules. The glands or hollows, before alluded to as occurring throughout the tissue of the cotyledons, are about $70 \mathrm{mkm}$. in diameter, and contain an oily liquid.

Chemical Composition-By exhausting the seeds dried at $100^{\circ} \mathrm{C}$. with boiling ether, we obtained a thick light-brownish oil having an acrid taste and concreting below $18^{\circ} \mathrm{C}$. The powdered seeds yielded of this oil 14.4 per cent. Water removes from the seeds a considerable amount of mucilage, some albuminous matter and a little tannic acid. The first is soluble to some extent in dilute spirit of wine, and may be precipitated therefrom by an alcoholic solution of acetate of lead.

The active principle of kaladana is a resin, soluble in alcohol, but neither in benzol nor in ether. From the residue of the seeds after exhaustion by ethes, treatment with absolute alcohol removed a pale yellowish resin in quantity equivalent to 8.2 per cent. of the seed.

\footnotetext{
1 Pharm. Journ. vii. (1866) 496.
} 
Kaladana resin, which has been introduced into medical practice in India under the nane of Pharbitisin, ${ }^{1}$ lhas a nauseous acrid taste and an unpleasint odour, especially when heated. It melts about $160^{\circ} \mathrm{C}$. The following liquids dissolve it more or less freely, namely, spirit of wine, absolute alcohol, acetic acid, glacial acetic acirl, acetone, acetic ether, methylic and anylic alcohol, and alkaline solutions. It is on the other hand insoluble in ether, benzol, chloroform, and sulphide of carbon. With concentrated sulphuric acid, it forns a brownisli yellow solution, quickly assuming a violet hue. This reaction however requires a very small quantity of the powclered resin. If a solution of the resin in ammonia, after having been kept a short time, is acidulated, no precipitate is formed; but the solution is now capable of separating protoxide of copper from an alkaline solution of the tartiate, which originally it did not alter. Heated with nitric acid, the resin affords Mayer's Ipomaic Acid.

From these reactions of kaladana resin, we are entitled to infer that it agrees with the resin of jalap or Convolvulin. To prepare it in quantity, it would probably be best to treat the seeds with coinmon acetic acid, and to precipitate it by neutralizing the solution. We have ascertained that the resin is not decomposed when digested with glacial acetic acid at $100^{\circ} \mathrm{C}$, , even for a week.

We have had the opportunity of examing a sample of kaladana resin manufactured by Messis. Rogers and Co., chemists of Bombay and Poona, which we found to agree with that prepared by ourselves. It is a light yellowish friable mass, resembling purified jalap resin, and like it, capable of being perfectly decolorized by treatment with animal charcoal.

Uses-Kaladana seeds have cathartic powers like jalap. Besides the resin, an extract, tincture and compound powder have been introduced into the Pharmacopocia of India. In many parts of India the natives take the roasted seeds as a purgative.

\section{SOLANACE正.}

\section{STIPES DULCAMARÆ.}

Caules Dulcamarce; Bitter-swect, Dulcamara, Woody Nightshade; F. Doucc amère, Morelle grimpante; G. Bittersüss.

Botanical Origin-Solanum Dulcamara L., a perennial shrubby plant, having small purple flowers and red berries, occurring throughout Europe, except in the extreme north. It is also found in Northern Africa, and in Asia Minor, and has become naturalized in North America. It is common in moist, shady hedges and thickets."

History-The stalks of bitter-sweet were introduced into medical practice by the German physicians and botanists of the 16th century, one of whom, Tragus (1552), has figured and described it, under the name of Dulcis amara or Dulcamarum.

1 Pharmacopocia of India, 1868. 156.

2 Solanum nigrum L. which slightly resembles dulcamara, is a low-growing aunual or biennial, with herbaccous stems, and berries usually black. 
Description-The older stems are woody; the upper and younger are soft and green, long and straggling, attaining by the support of other plants, a height of 6 feet or more, and dying back in the winter. For medicinal use, the shoots of a year or two old should be gathered, either late in the year, or early in the spring before the leaves come out. These shoots are several feet long, by about $\frac{1}{5}$ of an inch thick, of a light greenish-brown, sometimes cylindrical, at others indistinctly 4- or 5-sided, slightly furrowed longitudinally, or somewhat warty.

The thin, shining cork-bark easily exfoliates, showing beneath it the mesophloum which is rich in chlorophyll. The stalks are mostly hollow, and partially filled with a whitish pith. The wood when dried is about half or one-third as broad as the hollow centre, and the green bark considerably narrower than the wood; the latter has a radiate structure, and in older stems exhibits two or three sharply-defined annual rings. The stems are usually cut into short lengths before being dried for use.

The odour which is rather foetid and unpleasant, is to a great extent dissipated by drying. The taste at first slightly bitter, is afterwards sweetish. The bitter appears to be more predominant in the spring than in the autumn.

Microscopic Structure-The epidermis of younger shoots consists of tabular thick-walled cells, many of them being elevated from the surface as short blunt hairs. The older stems are covered with the usual suberous envelope. The boundary between the mesophloum and the endophlœum is marked by a ring of strong liber fibres, some of which also occur in the pith. The woody part is rich in large vessels. In the parenchymatous tissue of bitter-sweet, small crystals of oxalate of calcium, not of a well-defined outline, and minute starch granules are deposited.

Chemical Composition-The taste of bitter-sweet appears due, according to Schoonbroodt (1867), to a bitter principle yielding by decomposition, sugar and Solanine,-the latter in very small amount. Solanine is an alkaloid; it was first prepared in 1820 by Desfosses from the berries of Solanum nigrum L., and was snbsequently detected by the same chemist in the leaves and stalks of $S$. Dulcamara, and by Peschier in the berries. Winckler (1841) observed that the alkaloid of dulcamara stems can be obtained only in an amorphous state, and that it behaves to platinic and mercuric chlorides differently from the solanine of potatoes. Moitessier (1856) confirmed this observation, and obtained only amorphous salts of the solanine of bitter-sweet.

Zwenger and Kind on the one hand, and O. Gmelin on the other (1859 and 1858), found that solanine, $\mathrm{C}^{43} \mathrm{H}^{69} \mathrm{NO}^{16}$, is a conjugated compound of sugar and a peculiar crystallizable alkaloid, Solanidine, $\mathrm{C}^{25} \mathrm{H}^{39} \mathrm{NO}$. The latter, under the influence of strong hydrochloric acid, gives up water, and is converted into the amorphous and likewise basic compound, Solanicine, $\mathrm{C}^{50} \mathrm{H}^{76} \mathrm{~N}^{2} \mathrm{O}$.

Lastly, Wittstein (1852) detected in the stems of bitter-sweet another amorphous alkaloid, Dulcamarine, which has a bitter-sweet taste, but differs in its reactions both from the solanine of potatoes and from that obtained by Winckler from dulcamara. It exists to the extent of scarcely $\frac{1}{10}$ per cent.

Uses-Dulcamara is occasionally given in the form of decoction, in 
rheumatic or cutaneous affections; but its real action, according to Garrod, is unknown. This physician remarks' that it does not dilate the pupil or produce dryness of the throat like helladonna, henbane or stramonium. He has given to a patient 3 pints of the decoction per diem without any marked action, and has also administered as much as half a pound of the fresh berries with no ill effect.

\section{FRUC'TUS CAPSICI.}

Pod Pepper, Red Pepper, Guinea Pepper, Chillies, Capsicum; F. Piment ou Corail des Jardins, Poivre d'Inde ou de Guinée; G. Spanischer Pfeffer.

Botanical Origin-The plants, the fruits of which are known as Pod Pepper, have for a long period been cultivated in tropical countries, and are now found in such numerous varieties, that an exact determination of the original species is a point of great difficulty. Of several species having pungent fruits, the two following are those which supply the spice found in British commerce :-

1. Capsicun fastigiatum Blume, ${ }^{2}$ a small ramous shrub, with 4 -sided, fastigiate, diverging branclies; fruit-bearing peduncles sub-geminate, slender, erect; fruit very small, subcylindrical, oblong, straight, with calyx obconical and truncate. It occurs apparently wild in Southern India, and is extensively cultivated in Tropical Africa and America.

Roxburgh, who describes this plant under the name C. minimum, terms it East Indian Bird Chilly or Cayenne Pepper Capsicum. Wight says that it is consumed by the natives of India, but that it is not the sort preferred. It is this species that the authors of the British Pharmacoporia have cited as the source of the Fructus Capsici to be used in medicine, and it certainly furnishes the greater part of the Pod Pepper now found in the London market.

2. C. annuนm L., an herbaceous (sometimes shrubby?) plant, with fruit extremely variable in size, form and colour, in some varieties erect, in others pendulous. According to Naudin, in whose opinion we concur, C. longum DC. ${ }^{3}$ and C. grossum Willd. are not specifically distinct from this plant. It furnishes the larger kinds of Pod Pepper and, as we believe, much of the Cayenme Pepper which is imported in the state of powder.

History-All species of Capsicum appear to be of American origin: no ancient Sanskrit or Chinese name for the genus is known, and the Latin and Greek names that have been referred to it, are extremely doubtful. ${ }^{4}$

The earliest reference to the fruit as a condiment that we have met with, occurs in a letter written in 1494 to the Chapter of Seville by Chanca, physician to the fleet of Columbus in his second voyage to the

1 Essentials of Materia Medica, 1855. 196.

2 Wight. Icones Plant. Indice Orient. iv. (1850) tab. 1617 ; Capsicum. minimum Roxb. Flor. Ind. i. (1832) 574 . Farre has ascertained that this is the Capsicum frutescens of the Sprcies Plantarum of Linniens, but not that of the Hortus Cliffortianus of the sime botanist, to which latter the name $C$. fruteseens is usually applicd.

3 The chief distinction between $C$. ennu $u$ su and $C$. longum, is that the folmer has an ereet, the latter a pendulous fruit.

+ Dunal in De Cand. Frodromus, xiii. $\mathrm{i}$. 112. 
West Indies. The writer in noticing the productions of Hispaniola, remarks that the natives live on a root called Age, which they season with a spice they term Agi, also eaten with fish and meat. ${ }^{1}$ The first of these words signifies yam, the second is the designation of Red Pepper, and still the common name for it in Spanish. Capsicum and its uses are more particularly described by Gonzalo Fernandez de Oviedo, who reaclied Tropical America from Spain in A.D. 1514. ${ }^{2}$

In the Historia Stirpium of Leonhard Fuchs, published at Basle in 1542, may be found the first and excellent figures of Capsicum longum DC. under the name of Siliquastrum or Calicut Pepper; the author states that the plant had been introduced into Germany from India a few years previonsly. From this might be inferred an Indian origin; but on the other hand, Clusius asserts that the plant was brought from Pernambuco by the Portuguese, whose conimercial intercourse with India would easily explain it being carried thither at an early period. $\mathrm{He}$ further states, that the American capsicum had been generally introduced into the gardens of Castille, and that it was used all the year round, green or dried, as a condiment and as pepper. He also saw it cultivated in abundance at Briinn in Moravia in $1585 .^{3}$

Capsicum longum DC. was grown in England by Gerarde (1597 et antec), who spealss of the pods as well known, and sold "in the shops at Billingsgate by the name of Ginnie Pepper."

Description-As already indicated, the Pod Pepper of commerce is of two kinds, namely :-

1. Fruits of Capsicum fastigiatum-These are $\frac{1}{2}$ to $\frac{3}{4}$ of an inch in length, by about $\frac{2}{10}$ of an inch in diameter, of an elongated, sub= conical form, tapering to a blunt point, and slightly contracted towards the base. The calyx, which is not always present, is cup-shaped, 5 -toothed, 5-sided, supported on a slender, straight pedicel, $\frac{3}{4}$ to 1 inch long. The fruits, which are somewhat compressed and shrivelled by drying, and also brittle when old, have a leathery, smooth, shining, translucent, thin, dry pericarp, of a dull orange-red, enclosing about 18 seeds, attached in two cells to a thin central partition. The seeds have the form of roundish or ovate discs, about $\frac{1}{8}$ of an inch in diameter, somewhat thickened at the edges; the embryo is curved, almost into a ring. The taste of the pericarp, and likewise of the seeds, is extremely pungent and fiery. The dried fruit has an odour by no means feeble, which we cannot compare to that of any other substance.

2. Fruits of Capsicum annum of the commonest variety, resemble those of C.fastigiatum, except that they are of larger size, being from 2 to 3 or more inches in length, often rather more tapering towards the extremity. The seeds scarcely surpass in size those of C. fastigiatum.

Microscopic Structure-The pericarp consists of two layers, the outer being composed of yellow thick-walled cells. The inner layer is twice as broad and exhibits a soft shrunken parenchyme, traversed by thin fibro-vascular bundles. The cells of the outer layer especially are

1 Letters of Christopher Columbus, translated by Major (Hakluyt Society), 1870. 68. ${ }^{2}$ Oviedo, Historia de las Indios Madrid, i. (1851) 275
3 Caroli Clnsii Curce posteriores, Antverp., 1611. 95 . 
the seat of the fine granular colonring natter. If it is removed by an alcoholic solution of potash, a cell-nucleus and drops of fat oil nake their appearance. The structural details of this fruit afford interesting subjects for microscopical investigation.

Chemical Composition-Bncholz in 1816, and about the same time Braconnot, traced the acridity of capsicum to a substance called Capsicin. It is obtained by treating the alcoholic extract with ether, and is a thick yellowisl red liquid, but slightly soluble in water. When gently leated, it becomes very fluid, and at a higher temperature is dissipated in fumes which are extremely irritating to respiration. It is evidently a mixed substance, consisting of resinous and fatty matters.

Felletár in 1869, exhausted capsicum fruits with dilute sulphuric acid, and distilled the decoction with potash. The distillate, which was strongly alkaline and smelt like conine, was saturated with sulphuric acid, evaporated to dryness, and exhausted. with absolute alcoliol. The solution after evaporation of the alcohol, was treated witl potash, and yielded by distillation a volatile alkaloid having the odour of conine.

From experiments made by one of us (F.) we can fully confirm the observations of Felletár. We have obtained the volatile base in question, and find it to have the smell of conine. It occurs both in the pericarp and in the seeds, but in so small proportion that we were unsuccessful in isolating it in sufficient quantity to allow of accurate examination.

Dragendorff states (1871) that petroleum ether is the best solvent for the alkaloid of capsicum; he obtained crystals of its hydrochlorate, the aqueous solution of which was precipitated by most of the usual tests, but not by tannic acid.

The colouring matter of capsicum fruits is sparingly soluble in alcohol, but readily. in chloroform. After evaporation, an intensely red soft mass is obtained, which is not much altered by potash.

The fruits of Capsicum fastigiatum have a somewhat strong odour; on distilling consecutively two quantities, each of $50 \mathrm{tb}$., we obtained a scanty amount of flocculent fatty matter, which possesses an odour suggestive of parsley. Both this matter, as well as the distilled water, were neutral to litnus paper, and the water tasteless. We separated the latter and exposed the remaining greasy mass to a temperature of about $50^{\circ} \mathrm{C}$., when it for the most part melted. The clear liquid on cooling solidified, and now consisted of tufted crystals, which we further purified by recrystallization from alcohol. Thus about 2 centigrammes were obtained of a neutral white stearoptene, having a decidedly aromatic, not very persistent taste, by no means acrid, but rather like that of the essential oil of parsley. The crystals melted at $38^{\circ} \mathrm{C}$. On keeping them for: some days at the temperature of the water-bath, covered with a watch-glass, some drops of essential oil were volatilized, which had the same taste and did not solidify; the crystals were consequently accompanied by a liquid oil. When kept for some days more in that condition, the crystals themselves began to: be volatilized, and the part remaining behind acquired a brownish hue. This no doubt points out another impurity, as we ascertained by the following experiment. With, boiling solution of potash, the stearoptene prodnces a kind of soap, which on cooling yields a transparent jelly. If this is dissolved and diluted, it beconies turbid, by addition of an acid. This probably 
depends upon the presence of a little fatty natter, a suggestion which is confirmed by the somewhat offensive smell given off by our stearoptene if it is heated in a glass tube.

Commerce-Chillies or Pod Pepper are shipped from Zanzibar, Westem Africa and Natal, but no general statistics of the quantity imported into Great Britain are accessible:

The exports from Sierra Leone in 1871 reached $7258 \mathrm{fb}^{1}{ }^{1}$ The colony of Natal which produces Cayenne Pepper in the county of Victoria, where sugar-cane and coffee are also grown, shipped in the same year $9072 \mathrm{tb} .^{2}$

Official returns ${ }^{3}$ show that in 1871 Singapore imported $1071 \mathrm{cwt}$. $(119,952 \mathrm{mb}$.) of chillies, chiefly from Penang and Pegu. The spice is largely consumed by the Chinese.

Bombay imported of dried chillies in the year 1872-3, $5567 \mathrm{cwt}$. $(623,504 \mathrm{tb}$.) principally from the Madras Presidency, and exported. 3323 cwt. $^{4}$

Uses-Capsicum on account of its pungent properties, is. often administered as a local stimulant in the form of gargle, and occasionally as a liniment; and internally to promote digestion. In all warm countries, it is much eniployed as a condiment.

\section{RADIX BELLADONNÆ.}

\section{Belladonna Root; F. Racine de Belladone; G. Belladonnawurzel.}

Botanical Origin - Atropa Belladonna L., a tall, glabrous or slightly downy herb, with a perennial stock, native of Central and Southern Europe, where it grows in the clearings of woods. The plant extends eastward to the Crimea, Caucasia and Northern Asia Minor. In Britain, it is chiefly found in the southern counties, but even of these it is a doubtful native.

In a few localities in England and France as well as in North America, the plant is cultivated for medicinal use.

History-Although a plant so striking as belladonna can hardly have been unknown to the classical author's, it cannot with certainty be identified in their writings.

Saladinus of Ascoli, ${ }^{5}$ who wrote an enumeration of medicinal plants about A.D. 1450, names the leaves of both Solatrum furiale and Solatrum minus, the former of which is probably Belladonna. However this may be, the first indubitable notice of it that we have rnet with, is in the Grand Herlier printed at Paris, probably about 1504. ${ }^{6}$ The plant is also mentioned about this period as Solatrum mortale or Dolwurtz, in the writings of Hieronymus Brunschwyg.?

1 Blue Brok of the Colony of Sierra Leone for 1871 .

2Do. of Natal for 1871 .

3 Do. of the Straits Settlements for 1871.

4. Statement of the Trude and Navigation of Jiombay for 1872-73, pt. ii. 58. 91 .

- Compendium Aromatariorum, 1488.
- Le Grand Herbier en franeoys, contenät les qualites, vertus et proprietez des. herbes, \&e., Paris (no date) $4^{\circ}$. cap. De Solastro rustico.

7 Das destillier Buch (sub. voce Nachtsehet. Wasser ). Strassb. 1515. But there are earlier editions. 
In $15+2$, belladonna was well figured as Solanum somniferum or Dollkraut, by the German botanist Leonhard Fuchs, who fully rccognized its poisonons properties. ${ }^{1}$ Yet it was confounded by other writers of this pcriod, as 'Trngus," who reproduced Fuchs' figure as "Solanum hortense!"

Matthiolus (1548), who terms the plant Solanum majus, states that it is called by the Venetians Herba Bella donna, from the circumstance of the Ttalian ladies using a distilled water of the plant as a cosmetic. The introduction of the root of belladonna into British medicine is of rccent date, and is due to Mr. Peter Squire of London, who recommended it as the basis of a useful anodync liniment, about the year 1860 .

Description-Belladomna has a large, fleshy, tapering root, 1 to 2 inches thick, and a foot or more in length, from which diverge stout branches. Externally the fresh roots are of an earthy brown, rough with cracks and transverse ridges. The bark is thick and juicy, and as well as the more fibrous central portion, is internally of a dull creamy white. A transverse section of the main root shows a distinct radiate structure. The root has an earthy smell with but very little taste.

Dried root of Belladonna is sold in rough irregular pieces of a dirty greyish colour, whitish internally, breaking easily with a short fracture, and having an earthy smell not unlike that of liquorice root. Roots not exceeding the thickness of the finger should be preferred. The drug is for the most part imported from Germany, and is often of doubtful quality. English-grown root purchased in a fresh state (the large and old being rejected), then washed, cut into transverse segments and dried by a gentle heat, furnishes a more reliable and satisfactory article.

Microscopic Structure-There is a considerable structural difference between the main root and its branches, the former alone containing a distinct pith. This pith is included in a woody circle, traversed by narrow medullary rays. In the outer part of the woody circle, parenchymatous tissue is more prevalent than vascular bundles. The transverse section of the branches of the root, exhibits a central vascular bundle instead of a medullary colnmn. The outer vascular bundles show no regular arrangement; and medullary rays are not clearly obvious in the transverse section.

The woody parts, both of the main root and its branches, contain very large dotted vesscls accompanied by a prosenchymatous tissue. The cells of the latter, however, are always thin-walled; the absence of propcr so-called ligneous tissue explains the easy fracture of the root. Sometimes the prosenchyme in which the vessels are imbedded, assumes a brownish hue and a waxy appearance, and such parts exhibit a very irregular structure.

In the cortical portion of belladonna root, many of the cells of the middle laver, and likewise some of the central parts of the root, are loaded with extremely small octahedric crystals of calcium oxalate. But most of the parenclymatous cells arc filled up with small starch granules.

1 Historia Stirpium, Basil. 1542. 683.

= Dc Stivpium, 1. 301. 
Chemical Composition-In 1833, Mein prepared from the root, and Geiger and Hesse from the herb, the crystallizable alkaloid Atropine, $\mathrm{C}^{17} \mathrm{H}^{23} \mathrm{NO}^{3}$. The researches of Lefort $(1872)$ have proved that the ronts contain it in very variable proportions, the young being mush richer in alkaloid than the old. ${ }^{1}$ The maximum proportion obtained was 0.6 per cent.; this was from root of the thickness of the finger. Large old roots, 7 or 8 years of age, afford from 0.25 to 0.31 per cent. They have besides a smaller proportion of bark than young roots, and it is chiefly in the bark that the alkaloid appears to reside. Manufacturers of atropine employ exclusively the root.

Lndwig and Pfeiffer (1861) by decomposing atropine with potassium chromate and sulphuric acid, obtained benzoic acid and propylamine. Other products are formed when atropine is treated with strong hydrochloric acid, baryta water or canstic soda, thus-Atropine, $\mathrm{C}^{17} \mathrm{H}^{23} \mathrm{NO}^{3}$ $+\mathrm{H}^{2} \mathrm{O}=$ Tropic Acid, $\mathrm{C}^{9} \mathrm{H}^{10} \mathrm{O}^{3}+$ Tropine, $\mathrm{C}^{8} \mathrm{H}^{15} \mathrm{NO}$.

Tropic acid crystallizes, and is easily resolved into Atropic Acid and Isatropic Acid, each corresponding to the formula $\mathrm{C}^{9} \mathrm{H}^{8} \mathrm{O}^{2}$, but otherwise reniakably dissimilar. Tropine is a strongly alkaline body, readily soluble both in water and alcohol, and furnishing tabular crystals by the evaporation of its solution in ether. Neither tropine nor tropic acid, it is stated by Kraut (1863), is present in the leaves and root of belladonna.

Huibschmann (1858) detected in belladonna root a second but uncrystallizable alkaloid, called Belladonnine; it has a resinous aspect, is distinctly alkaline, and when heated emits, like atropine, a peculiar odour.

The root further contains according to Richter (1837) and Hübschmann, a fluorescent substance, as well as a red colouring matter called Atrosin. ${ }^{2}$ The latter occurs in greatest abundance in the fruit, and would probably repay further investigation.

Uses-Belladonna root is chiefly used for the preparation of atropine, which is employed for dilating the pupil of the eye. A liniment made with belladomna root is used for the relief of neuralgic pains.

FOLIA BELLADONN $Æ$.

\section{Belladonna Leaves; F. Fenilles de Belladone; G. Tollkraut.}

\section{Botanical Origin-Atropa Belladonna L. (p. 409).}

History-Belladonna Leaves and the extract prepared from them were introduced into the London Pharmacopœia of 1809 . For further particulars regarding the history of belladonna, see the preceding article.

Description-Belladonna or Deadly Nightshade produces thick, smooth herbaceous stems, which attain a height of 4 to 5 feet. They are simple in their lower part, then usually 3 -forked, and afterwards 2 . forked, producing in their upper branches an abundance of bright green leaves, arranged in unequal pairs, from the bases of which spring the

1 For Iefort's process for estimating atrorine, sec $[3 . \$ 12$.

2 Gunclin, Chemistry, xvii. (1866) 1. 
solitary, pendulous, purplish, bell-shaped llowers, and large shining black herries.

The leaves are 3 to 6 inches long, stalked, broadly ovate, acuminate, attenuated at the base, soft and juicy; those of barren reots are alternate and solitary. 'The young shoots are clothed with a soft, short pubescence, which on the calyx is sonewhat more persistent, assuming the character of viscid, glandular hairs. If bruised, the leaves emit a somewhat offensive, herbaccous odour which is destroyed by drying. When dried, they are thin and friable, of a brownish green on the upper surface and greyish beneath, with a disagreeable, faintly bitter taste. Of fresh leaves, $100 \mathrm{fb}$. yield $16 \mathrm{fb}$. of dried (Squire).

Chemical Composition-The important constituent of belladonna leaves is Atropine. Lefort $(1872)^{1}$ estimated its amount by exhausting the leaves previously dried at $100^{\circ} \mathrm{C}$. by means of dilute alcohol, concentrating the tincture, and throwing down the alkaloid with a solution of iodo-hydrargyrate of potassium. The precipitate thus obtained was calculated to contain 33.25 per cent. of atropine. Lefort examined leaves from plants both cultivated and growing wild in the environs of Paris, and gathered either before or after flowering. He found cultivation not to affect the percentage of alkaloid,-that the leaves of the young plant were rather less rich than those taken at the period of full inflorescence,-and that the latter (dried) yielded 0.44 to 0.48 per cent. of atropine.

Belladonna herb yields Asparagine, which according to Biltz (1839) crystallizes out of the extract after long keeping. The crystals found in the extract by Attfield (1862) were however, chloride and nitrate of potassium. 'The same chemist obtained by dialysis of the juice of belladonna, nitrate of potassium, and square prisms of a salt of magnesium containing some organic acid; the juice likewise affords ammonia. ${ }^{2}$ The dried leaves yielded us 14.5 per cent. of ash consisting mainly of calcareous and alkaline carbonates.

Uses-The fresh leaves are used for making Extractum Bclladonnce, and the dried for preparing a tincture. They should be gathered while the plant is well in flower.

\section{HERBA STRAMONII.}

Stramonium, Thornapple; F. Herbe de Stramoine; G. Steehapfelblätter.

Botanical Origin-Datura ${ }^{3}$ Stramonium L., a large, quick-growing, upright annual, with white flowers like a convolvulus, and ovoid spiny fruits. It is now found as a weed of cultivation in almost all the temperate and warmer. regions of the globe. In the south of England it is often met with. in rich waste ground, chiefly near gardens or habitations.

1 Journ. de Pharm. xv. (1872) 269. 341.

2. The fresh juice kept for a few days has been known to evolve red vapours (nitrous reid?) when the vessel containing it was
opened.-H. S. Evans in Pharm. Journ. ix. (1850) 260.

\& Dature from the Sanskrit name D'husturra, applied to $D$. fastuose $\mathrm{L}$. The origin of the word Stramonizm is not known to us. 
History-The question of the native country and early distribution of D. Stramonium has been much discussed by botanical writers. Alphonse De Candolle, who has ably reviewed the arguments advanced in favour of the plant being a native respectively of Europe, America or Asia, enounces his opinion thus:-that D. Stramonium L. appears to be indigenous to the Old World, probably the borders of the Caspian Sea or adjacent regions, but certainly not of India; that it is very doubtful if it existed in Europe in the time of the ancient Roman Empire, but that it appears to have spread itself between that period and the discovery of America.

Stramonium was cultivated in London towards the close of the 16th century by Gerarde, who received the seed from Constantinople and freely propagated the plant, of the medicinal value of which he had a high opinion. Its use in more recent times is due to the experiments of Störck. ${ }^{2}$

Description-Stramonium produces a stout, upright, herbaceous green stem, which at a short distance from the ground, throws out spreading forked branches, in the axil of each fork of which, arises a solitary white flower, succeeded by an erect, spiny, ovoid capsule. At each furcation and directed outwards, is a large leaf. This arrangement of parts is repeated, and as the plant grows vigorously, it often becomes much branched and acquires in the course of the summer a considerable size.

The leaves of stramonium have long petioles, are unequal at the base, oval, acuminate, sinuate-dentate with large irregular pointed teeth or lobes, downy when young, glabrous at maturity. When fresh, they are somewhat firm and juicy, emitting when handled a disagreeable fœitid smell. The larger leaves of plants of moderate growth, attain a lengtl of 6 to 8 or more inches.

For medicinal purposes, the entire plants are pulled up, the leaves and younger shoots are stripped off, quickly dried, and then broken and cut into short lengths, so as to be conveniently smoked in a pipe, that being the method in which the drug is chiefly consumed in England. The offensive smell of the fresh plant is lost by drying, being replaced by a rather agreeable tea-like odour. The dried herb has a bitterish saline taste.

Chemical Composition-The leaves of stramonium contain in common with the seeds, the alkaloid Daturine (see p. 414), but in extremely small proportion, not exceeding in fact, $\frac{2}{10}$ to $\frac{3}{10}$ per mille. They are rich in saline and earthy constituents; selected leaves dried at $100^{\circ} \mathrm{C}$. yielded us 17.4 per cent. of ash.

Uses-Scarcely employed in any other way than in smoking like tobacco, for the relief of asthma.

Substitute-Datura Tatula L.-This plant is closely allied to $D$. Stramonium L., propagating itself on rich cultivated ground with nearly the same facility; but it is not so generally diffused.

De Candolle is of opinion that it is indigenous to the warmer parts of America, whence it was imported into Europe in the 16th

1 Géographic Botanique, ii. (1855) 731.

2 Libellus quo demonstratur Stramonium, Hyoscyamum, Aconitum . . . esse remedia
Vindob. 1762 . 
century, and naturalized first in Italy, and then in South-Western Europe. By many botanists, it has been united to D. Stramonium, but Naudin ${ }^{2}$ who has studied both plants with the greatest attention, especially with reference to their hybrids, is decidedly in favour of considering them distinct. D. Tatula differs from D. Stramonium, in having stem, petiole, and nerves of leaves, purplish instead of green; and corolla and anthers of a violet colour instead of white,-characters which, it must be admitted, are of very smali botanical value.

D. Tatula has been recommended for smoking in cases of asthma, on the ground of it being stronger than D. Stramonium; but we are not aware of any authority as to the comparative strength of the two species.

\section{SEMEN STRAMONII.}

\section{Stramonium Seeds; F. Semences de Stramoine; G. Stechapfelsamen.}

Botanical Origin-Datura Stramonium L., see preceding article.

Description-The spiny, ovoid capsule of stramonium, opens at the summit in four regular valves. It is bilocular, with each cell incompletely divided into two, and contains a large number (about 400) of flattened, kidney-shaped seeds. The seeds are blackish or dark brown, about 2 lines long and $\frac{1}{2}$ a line thick, thinning off towards the hilum which is on the straighter side. The surface of the seed is finely pitted, and also marked with a much coarser series of shallow reticulations or rugosities. A section parallel to the faces of the seed, exhibits the long, contorted embryo, following the outline of the testa, and bedded in the oily white albumen. The cylindrical form of the embryo is seen in a transverse section of the seed.

The seeds have a bitterish taste, and when bruised, a disagreeable odour. When the entire seeds are digested in spirit of wine, they afford a tincture displaying a green fluorescence.

Microscopic Structure-The testa is formed of a row of radially extended, thick-walled cells. They are not of a simply cylindrical form, but their walls are sinuously bent in and out in the direction of their length. Viewed in a direction tangential to the surface, the cells appear as if indented one into the other. Towards the surface of the seed, the cell-walls are elevated as dark brown tubercles and folds, giving to the seed its reticulated and pitted surface. The albumen and embryo exhibit the usual contents, namely fatty oil and albuminoid substances.

Chemical Composition-The active constituent of stramonium seeds, is the highly poisonous alkaloid Daturine, of which they afford only about $\frac{1}{10}$ per cent., while the leaves and roots contain it in still smaller proportion. $^{2}$ Daturine was discovered in 1833 , by Geiger and Hesse, and regarded as identical with atropine by A. vou Planta (1850), who found it to have the same composition as that alkaloid. The two bodies exhibit the same relations as to solubility and fusing point $\left(88-90^{\circ} \mathrm{C}\right.$.) ; and they also agree in crystallizing easily. The experiments of Schroff (1852) tending to show that although daturine and atropine act in the 
same manner, the latter has twice the poisonous energy of the former, raised a further question as to the identity of the two alkaloids. From the observations of Erliard (1866), it would appear that the crystalline form of some of their salts is different. In stramonium seeds, daturine appears to be combined with malic acid. The seeds yielded to Cloëz (1865) 2.9 per cent. of ash and 25 per cent. of fixed oil.

Uses-Stramonium seeds are prescribed in the form of extract or tincture, as a sedative or narcotic.

\section{SEMEN ET FOLIA DATURA ALBÆ.}

\section{Seeds and Leaves of the Indian or White-flowered Datura.}

Botanical Origin-Datura alba Nees, a large, spreading annual plant, 2 to 6 feet high, bearing handsome, tubular, white flowers 5 to 6 inches long. The capsules are pendulous, of depressed globular form, rather broader than high, covered with sharp tubercles or thick short spines. They do not open by regular valves as in $D$. Stramonium, but split in different directions and break up into irregular fragments.

$D$. alba appears to be scarcely distinct from D. fastuosa L. Both are common in India, and are grown in gardens in the south of Europe. ${ }^{1}$

History - The mediæval Arabian physicians were familiar with Datura alba, which is well described by Ibn Baytar ${ }^{2}$ under precisely the same Arabic name (Jouz-masal) that it bears at the present day; they were also fully aware of its poisonous properties.

Garcia d'Orta ${ }^{3}$ (1563) observed the plant in India and has narrated that its flowers or seeds are put into food, to intoxicate persons it was designed to rob. It was also described by Christoval Acosta, who in his book on Indian drugs, ${ }^{4}$ mentions two other varieties, one of them with yellow flowers, the seeds of either being very poisonous and often administered with criminal intent, as well as for the cure of disease. Graham ${ }^{5}$ says of the plant that it possesses very strong narcotic properties, and has on several occasions been fatally used by Bombay thieves, who have administered it in order to deprive their victims of the power of resistance.

The seeds and fresh leaves have a place in the Pharmacopceia of India, 1868.

Description-The seeds of $D$. alba are very different in appearance from those of $D$. Stramonium, being of a light yellowish brown, rather larger size, irregular in shape and somewhat shrivelled. Their form has been likened to the human ear ; they are in fact obscurely triangular or flattened-pearshaped, the rounded end being thickened into a sinuous,

1 Seeds of $D$. alba sent to us from Madras by Dr. Bidie, were sown by our friend M. Naudin of Collioure (Pyrénées Orientales), and produced the plant under three forms, viz. -1 . The true $D$. alba as figured in Wight's Icones. -2 . Plants with flowers, violet without and nearly white within $(D$. fastrosa).--3. Plants with double corollas of

large size and of a yellow colour.

Sontheimer's translation, i. 269.

3 Aromatum historia, 1574, lib. 2. c. 24.

4 Tractado de la Drogas. . . de las Indias Orientales, Burgos, 1578. 85.

${ }^{5}$ Catalogue of Bombay Plants, 1839. 141. 
convoluted, triple ridge, while the centre of the seed is somewhat depressed. T'he hilum runs from the pointed end, nearly half-way up the length of the seed. The testa is marked with minnte rugosities, but is not so distinctly pitted as in the seed of the D. Stramonium; it is also more developed, exhibiting in section large intercellular spaces to which are dne its spongy texture. 'The seeds of the two species agree in internal structure as well as in taste; but those of $D$. alba do not give a fluorescent tincture.

The leaves, which are only employed in a fresh state, are 6 to 10 inches in length, with long stalks, ovate, often unequal at the base, acuminate, coarsely dentate with a few spreading teeth. They evolve an offensive odour when handled.

Microscopic Structure-The testa is built up of the same tissues as in D. Stramonium, but the thick-walled cells constituting the spongy part are far larger, and distinctly show numerous secondary deposits, making a fine object for the microscope.

Chemical Composition-Neither the seeds nor the leaves of $D$. alba have yet been examined chemically, but there can scarcely be any doubt that their very active properties are due to Daturine, for the preparation of which the former would probably be the best source.

Uses-The seeds in the form of tincture or extract have been employed in India as a sedative and narcotic, and the fresh leaves, bruised and made into a poultice with flour, as an anodyne application.

\section{FOLIA HYOSCYAMI.}

\section{Henbane Leaves; F. Feuilles de Jusquiame; G. Bilsentrraut.}

Botanical Origin-Hyoseyamus niger L., a coarse, erect herb, with soft, viscid, hairy foliage of unpleasant odour, pale yellowish flowers elegantly marked with purple veins, and 5-toothed bottle-shaped calyx. It is found throughout Europe from Portugal and Greece to Central Norway and Finland, in Egypt, Asia Minor, the Caucasus, Persia, Siberia and Northern India. As a weed of cultivation, it now grows also in North America ${ }^{1}$ and Brazil. In Britain, it occurs wild chiefly in waste places near buildings; and is cultivated for medicinal use.

Henbane exists under two varieties, known as annual and bicnnial, but scarcely presenting any other distinctive character.

Bicnnial Henbane (Hyoseyamus niger var. a.biennis) is most esteemed for pharmaceutical preparations. It is raised by seed, the plant producing the first year, only a rosette of luxuriant stalked leaves, 12 or more inches in length. In the second, it throws up a flower stem of 2 to 3 feet in height, and the whole plant dies as the finit matures.

Annual Henbane (H. niger var. $\beta$ annuc, vel agrestis) is a smaller plant, coming to perfection in a single season. It is the usual wild form, but it is also grown by the herbalists. ${ }^{2}$

1 It had become naturalized in North Anerica prior to 1672 , as we find it mentioned by Josselyn in his Noro England's Rarities discovered (Lond. 1672) anoug the plants "sprung up since the English planted, and kept cattle in New England."

2 Pharm. Journ. i. (1860) 414 . 
History-Hyoscyamus, under which name it is probable the nearly allied South European species, $H$. albus L., was generally intended, was medicinal among the ancients, and particularly commended by I)ioscorides.

In Furope, henbane has been employed from remote times. Benedictus Crispus, archbishop of Milan, in a work written shortly before A.D. 681, notices it under the name of Hyoseyamus and Symphoniaca. ${ }^{1}$ In the 10th century, its virtues were particularly recorded by Macer Floridus ${ }^{2}$ who called it Jusquiamus.

Frequent mention is made of it in the Anglo-Saxon works on medicine of the 11th century, ${ }^{3}$ in which it is called Henbell, and sometimes Belene, the latter word perhaps traceable in Biגıvovvтía, which Dioscorides ${ }^{4}$ gives as the Gallic designation of the plant.

The word Hennebone, with the Latin and French synonyms Jusquiamus and Chenille, occurs in a vocabulary of the 13th century; and Hennebane in a Latin and English vocabulary of the 15th century. ${ }^{5}$ In the Arbolayre, a printed French herbal of the 15 th century, ${ }^{6}$ we find the plant described as Hanibane or Hanpbane with the following explanaation-" Elle est aultrement appeler cassilago et aultrement simphoniaca. La semence prpprement a nom jusquiame ou hanebane, et herbe a noun cassilago. .." Both Hyoseyamus and Jusquiamus are from the Greek

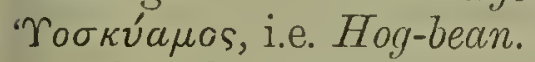

Thongh a remedy undeniably potent, henbane in the first half of the last century had fallen into disuse. It was omitted from the London pharmacopocias of 1746 and 1788, and restored only in 1809. Its re-introduction into medicine was chiefly due to the experiments and recummendations of Störck.?

Description-The stems of henbane, whether of the annul or biennial form, are clothed with soft, viscid, hairy leaves, of which the upper constitute the large, sessile, coarsely-toothed bracts of the unilateral flower-spike. The middle leaves are more toothed and subamplexicaul. The lower leaves are stalked, ovate-oblong, coarsely dentate, and of large size. The stems, leaves, and calyces of henbane are thickly beset with long, soft, jointed hairs; the last joint of many of these hairs exudes a riscid substance occasioning the fresh plant to feel clammy to the touch. In the cultivated plant, the hairiness diminishes.

After drying, the broad light-coloured midrib becomes very conspicuons, while the rest of the leaf shrinks much and acquires a greyish green hue. The drug derived from the flowering plant as found in cominerce, is usually much broken. The fotid, narcotic odour of the fresh leaves is greatly diminished by drying. The fresh plant has but little taste.

Dried henbane is sold under three forms, which are not however generally distinguished by druggists. These are 1. Annual plant, foliage and green tops. 2. Biennial plant, leaves of the first year. 3. Biennial plant, foliage and green tops. The third form is always regarded as the

IS. de Renzi, Collectio Solermitono, Naroli, i. (1852) 74. 84.

De Firibus Herburum, elited by Chouint, Lips. 1832. J08.

${ }^{3}$ Tacelderms, dec of Ererly Englrind, iii. (1866) 813.
4 Lib. iv. c. 69. (ed. Sprengel).

5 Wright, Folume of Vocrbularies, 1857. 141. 265 .

"See T. J30. note 9, also Brunet, FIanue

du. Libreire, i. $(1860) 377$.

7 Sin p. 413, note 2. 
hest, but 110 attempt has becn marle to deternine with accuracy the relative merits of the three sorts.

Chemical Composition-Hyoscyamine, the most important anong the constituents of hembane, was obtained in an inpuse state lyy Geiger and Hesse in 1833. Höhn in 1871 first isolated it from the seeds, which are far richer in it than the leaves. 'I'he seeds are deprived of the fatty oil (26 per cent.) and treated with spirit of wine containing sulpliuric acid, which takes out the lyoscyamine in the form of sulphate. The alcohol is then evaporated and tamic acid added; the precipitate thus obtained is mixed with lime and exhausted with alcohol. The hyoscyamine is again converted into a sulphate, the aqueous solution of which is then precipitated with carbonate of sodium, and the alkaloid dissolved by means of ether. After the evaporation of the ether, hyoscyamine remains as an oily liquid which after some time concretes into wart-like tufted crystals, soluble in benzol, chloroforn, ether, as well as in water. Höhn and Reichardt assign to hyoscyamine the formula, $\mathrm{C}^{15} \mathrm{H}^{23} \mathrm{NO}^{3}$. The seeds yield of it only 0.05 per cent.

Hyoscyamine is easily decomposed by caustic alkalis. By boiling with baryta in aqueous solution, it is split into Hyoscine, $\mathrm{C}^{6} \mathrm{H}^{13} \mathrm{~N}$, and Hyoscinic Acid, $\mathrm{C}^{9} \mathrm{H}^{10} \mathrm{O}^{3}$. The former is a volatile alkaloid; hyoscinic acid, a crystallizable substance having an odour resembling that of empyreumatic benzoic acid. ${ }^{2}$

Attfield ${ }^{3}$ has pointed out, that extract of henbane is rich in nitrate of potassium and other inorganic salts. In the leaves, the amount of nitrate is, according to Thorey, ${ }^{4}$ largest before flowering, and the same ohservation applies to hyoscyamine.

Uses-Henbane in the form of tincture or extract is administered as a sedative, anodyne or hypnotic. 'The impropriety of giving it in conjunction with free potash or soda which render it perfectly inert, has been demonstrated by the experiments of Garrod. ${ }^{5}$ Hyoscyamine, like atropine, powerfully dilates the pupil of the eye.

Substitutes-Hyoscyamus albus L., a more slender plant than $H$. niger $L_{\text {. }}$, with stalked leaves and bracts, a native of the Mediterranean region, is sometimes used in the south of Europe as medicinal henbane. $H$. insanus Stocks, a plant of Beluchistan, is mentioned in the Pharmacopceic of India as of considerable virulence, and sometimes used for sinoking.

\section{FOLIA TABACI.}

\section{Herba Nicotiane; Tobacco; F. Tabac; G. Tabahblättcr.}

Botanical Origin-Nicotiann Tabacum L-The common Tobacco plant is a native of the New World, though not now known in a wild

1 From the experiments of Schoonbroodt (1868), there is leason to believe that the active rinciple of hembane can be mowe easily extractel from the fresh than from the dived plant.

2 I have had the opportunity of examining the above sulustances as prepared by the said chemists. - F. A. F., July 1971.

3 pharm. Journ. iii. (1S62) 447 .

4 Wiggers and Husemaun, Jahresbericht 1869. 56 .

5 Pharm. Journ. xrii. (1853) 462 ; xrii. (1859) 17 . 
state. Its cultivation is carried on in most temperate and sub-tropical colutries.

History-It is stated by Von Martius ${ }^{1}$ that the practice of smoking tobacco has been widely diffused from time immemorial anong the natives of Soutl America, as well as among the inhabitants of the valley of the Mississippi as far north as the plant can be cultivated.

The Spaniards became acquainted with tobacco when they landed in Cuba in 1492, and on their return introduced it into Europe for the sake of its medicinal properties. The custom of inlaling the sinoke of the herb was learnt from the Indians, and by the end' of the 16th century had become generally known throughout Spain and Portugal, whence it passed into the rest of Europe, and into Turkey, Egypt, and India, notwithstanding that it was opposed by the severest enactments both of Christian and Mahommedan governments. It is commonly beliered that the practice of smoking tobacco was much promoted in England, as well as in the north of Europe generally, by the example of Sir Walter Raleigh and his companions.

Tobacco was introduced into China, probably by way of Japan or Manila, during the 16th or 17th century, but its use was prohibited by the emperors both of the Ming and Tsing dynasties. It is now cultivated in most of the provinces, and is universally employed. ${ }^{2}$

The first tolerably exact description of the tobacco plant is that given by Gonzalo Fernandez de Oviedo y Valdés, governor of St. Domingo, in his Historia general de las Indias, ${ }^{3}$ printed at Seville in 1535 . In this work, the plant is said to be smoked through a branched tube of the shape of the letter $Y$, which the natives call Tabaco.

It was not until the middle of this century that growing tobacco was seen in Europe,-first at Lisbon, whence the French ambassador, Jean Nicot, sent seeds to France in 1560 as those of a valuable medicinal plant, which was even then diffused throughout Portugal. ${ }^{4}$

Monardes ${ }^{5}$ writing in 1571, speaks of tobacco as brought to Spain a few years previonsly, and valued for its beauty and for its nedicinal virtues. Of the latter he gives a long account, noticing also the methods of smoking and chewing the herb, prevalent among the Indians. He also supplies a small woodcut representing the plant, which he states to lave white flowers, red in the centre.

Jacques Gohory ${ }^{6}$ who cultivated the plant in Paris at least as early as 1572 , describes its flower's as shaded with red, and enumerates various medicinal preparations made from it.

In the Maison Rustique of Clarles Estienne, edition of 158:3, the author gives a "Discours sur la Nicotiane ou Petum mascle," in which he claims for the plant the first place anong medicinal herbs, on account of its singular and almost divine virtues.

1 Beiträge zur Ethnographic und Sprachenl.unde Amerieas, zumal Brasiliens, i. (1867) 719.

2 Mayers in Hong Kong Notes and Queries, May $1867 ;$ F. P. Smith, Mnt. Med. and Trit. Hist. of rinina, 1871.219.

3 Lib. v. c. '2.

4 Nicot, Thićsor de la langue Francoyse, Paris, 1606.429 .
5 Segunda parte del libro de las cosas que se treven de nuestras Indias occidentales, que simen al uso de mecticina. J)o se trata clel Tabaco..., Sevilla, 1571. 3.

"Instruction sur l'herbe Petum ditte en France l'herbe de la Royne on Médicés. Paris, 1572. 
The cultivation of tobacco in England, except on a very small scale in a physic garden, has been prohibited by law ${ }^{1}$ since 1660 .

Description-Anongst the various species of Nicotiana cultivated for the manufacturing of smoking tobacco and suuff, $N$. Tabacum is by far the most frequent, and is almost the only one named in the pharmacopœias as medicinal. Its simple stem, bearing at the smmmit a panicle of tubular pink flowers, and growing to the height of a man, has oblong, lanceolate, simple leaves, with the margin entire. The lower leaves, more broadly lanceolate and about 2 feet long by 6 inches wide, are shortly stalked. The stem-leaves are semi-amplexicaul, and decurrent at the base. Cultivation sometimes produces cordate-ovate forms of leaf, or a margin more or less uneven, or nearly revolute.

All the lerbaceous parts of the plant are clothed with long soft hairs, made up of broad, ribbon-like, striated cells, the points of which exude a glutinous liquid. Small sessile glands are situated here and there on the surface of the leaf. The lateral veins proceed from the thick midrib in straight lines, at angles of $40^{\circ}$ to $75^{\circ}$, gently curving upwards only near the edge. In drying, the leaves become brittle and as thin as paper, and always acquire a brown colour. Even by the most careful treatment of a single leaf, it is not possible to preserve the green hue.

The smell of the fresh plant is narcotic; its taste bitter and nauseous. The claracteristic odour of dried tobacco is developed during the process of curing.

Chemical Composition-The active principle of tobacco, first isolated in 1828 by Posselt and Reimann, is a volatile alkaloid termed Nicotine, $\mathrm{C}^{10} \mathrm{H}^{14} \mathrm{~N}^{2}$. It is easily extracted from tobacco by means of alcohol or water, as a malate, from which the alkaloid can be separated by shaking it with caustic lye and ether. The ether is then expelled by warming the liquid, which finally has to be mixed with slaked lime and distilled in a stream of hydrogen, when the nicotine begins to come over at about $200^{\circ} \mathrm{C}$.

Nicotine is a colourless oily liquid, of sp. gr. 1.027 at $15^{\circ} \mathrm{C}$.; it boils at $250^{\circ} \mathrm{C}$., and does not concrete even at $-10^{\circ} \mathrm{C}$. It lias a strongly alkaline reaction, an unpleasant odour, and a burning taste. It quickly assumes a brown colour on exposure to air and light; and appears even to undergo an alteration by repeated distillation in an atmosphere deprived of oxygen. Nicotine dissolves in water, but separates on addition of caustic potash. Most salts of nicotine crystallize with difficulty; its hydrochlorate forms with cliloride of zinc a compound obtainable in crystals of colnsiderable size. Nicotine is the highly poisonous principle of tobacco; it occurs in the dried leaves to the extent of about. 6 per cent., but is subject to great variation. It has not been met with in tobacco-smoke by Vohl and Eulenberg (1S71), though other chemists assert its occurrence. The vapours were found by the former, to contain numerous basic substances of the picolinic series, and ceded to caustic potash, hydrocyanic acid, sulphuretted hydrogen, several volatile fatty acids, phenol and creasote. There was further observed in

112 Car. 11. c. $34 ; 15$ Car. II. c. $7 .-$ For further information on the history of tobacco, see Tieciemann, Geschichle des Ta. baks, Frankfurt, 185 t. 
the imperfect combustion of tobacco, the formation of laminæ fusible at $94^{\circ} \mathrm{C}$. and having the composition $\mathrm{C}^{10} \mathrm{H}^{18}$.

Tobacco leaves, whether fresh or dried, yield when distilled with water, a turbid distillate in which, as observed by Hermbstidt in 1823, there are formed after some days, crystals of Nicotianin or Tobacco Camphor. According to J. A. Barral, nicotianin contains 7.12 per cent. of nitrogen (?). By submitting 4 kilogrammes of good tobacco of the previous year to distillation with much water, we obtained nicotianin, floating on the surface of the distillate, in the form of minute acicular crystals, which we found to be devoid of action on polarized light. The crystals have no peculiar taste, at least in the small quantity we tried; they have a tobacco-like smell, perhaps simply due to the water adhering to them. When an attempt was made to separate them by a filter, they entirely disappeared, being probably dissolved by an accompanying trace of essential oil. The clear water showed an alkaline reaction partly due to nicotine; this was proved by adding a solution of tannic acid, which caused a well-marked turbidity.

Among the ordiuary constituents of leaves, tobacco contains albumin, resin and gum. In smoking, these substances as well as the cellulose of the thick midrib, would yield products not agreeable to the consumer. The manufacturer therefore discards the midrib, and endeavours by further preparation to ensure at least the partial destruction of these unwelcome constituents, as well as the formation of certain products of fermentation (ferment-oils), which may perhaps contribute to the aroma of tobacco, especially when saccharine substances, liquorice, or alcoliol, are added in the maceration to which tobacco is subjected.

Tubacco leaves are remarkably rich in inorganic constituents, the proportion varying from 16 to 27 per cent. According to Boussingault, they contain when dry about 1 per cent. of phosphoric acid, and from 3 to 5 per cent. of potash, together with $2 \frac{1}{2}$ to $4 \frac{1}{2}$ per cent. of nitrogen partly in the form of nitrate, so that to enable the tobacco plant to flourish, it must have a rich soil or continual manuring.

The lime amounting to between a quarter and a half of the entire quantity of ash, is in the leaf combined with organic acids, especially malic, perhaps also citric. The proportion of potash varies greatly, but may amount to about 30 per cent. of the ash.

Commerce-There were imported into the United Kingdom in the year $1872,45,549,700 \mathrm{Hb}$. of Unmanufactured Tobacco, rather more than half of which was derived from the United States of America. The total value of the commodity thus imported was $£ 1,563,882$; and the duty levied upon the quantity retained for home consumption, amounted to $£ 6,694,037$.

Uses - Tobacco has some reputation in the removal of alvine obstructions, but it is a medicine of great potency and is very
rarely used.

Substitutes - Of the other species of Nicotiana cultivated as Tobacco, $N$. mustica L. is probably the most extensively grown. It is easily distinguished by its greenish yellow flowers, and its stalked ovate leaves. In spite of their coarser texture, the leaves dry more easily than those of $N$. Tabacum, and with some care may even be made to retain 
their green colour. N. rustica furnishes Liast Indiun I'obacco, also the kinds known as Latakic and T'urkish '́ubacco.

N. Persica Lindl. yields the tobacco of Shinaz. N. quadrivalvis Pursh, $N$. multivalvis Lindl. and $N$. repanda Willd. are also cultivated plants, the last named, a plant of Havana, being used in the manufacture of a much valued kind of cigar.

\section{SCROPHULARIACEAE.}

\section{FOLIA DIGITALIS.}

\section{Foxglove Leaves; F. Feuilles de Digitale; G. Fingerhutblütter.}

Botanical Origin-Digitalis purpurea L., an elegant and stately plant, common throughout the greater part of Europe, but preferring siliceous soils and generally absent from limestone districts. It is found on the edges of woods and thickets, on bushy ground and commons, becoming a mountain plant in the warm parts of Europe. It occurs in Central and Southern Spain, Northern Italy, France, Germany, the British Isles and Southern Sweden, and in Norway as far as $62^{\circ} \mathrm{N}$. lat.; it is however very unequally distributed, and is altogether wanting in the Swiss Alps and the Jura. ${ }^{1}$ As a garden plant it is well known.

History-We are acquainted with no very ancient accounts of the use of foxglove in medicine. Fuchs ${ }^{2}$ and Tragus $^{3}$ about the middle of the 16th century figured the plant; the former gave it the name Digitalis, remarking that up to the time at which he wrote, there was none for the plant in either Greek or Latin. At that period it was regarded as a violent medicine. It had a place in the London Pharmacopoia of 1650 and in several subsequent editions. The investigation of its therapeutic powers $(1776-9)$ and its introduction into modern practice are chiefly due to Withering, a well-known English botanist and physician."

The word forglove is said to be derived from the Anglo-Sixion Foxesglew, i.e. fox-music, in allusion to an ancient musical instrument consisting of bells hung on an arched support. ${ }^{5}$

Description-Foxglove is a biennial or perennial, the leaves of which ought to be taken from the plant while in full flower: The lower leaves are ovate with the lamina running down into a long stalk; those of the stem become gradually narrower, passing into ovate-lanceokate with a short broadly-winged stalk, or are sessile. All have the margin crenate, crenate-dentate, or sub-serrate, are more or less softly pubescent or nearly glabrous on the upper side, much paler and densely pubescent on the under, which is marked with a prominent network of veins. The principal veins diverge at a very acute angle from the midrib, which is thick and fleshy. The lower leaves are often a foot or more long, by 5 to 6 inches broad; those of the stem are smaller.

1 Dr. R. O. Cunningham found (1868) Digitalis purpurea completely naturalized about San Carlos in the Island of Chiloe in Southern Chili.

2 De Hist. Stirpium, 1542. 892.
3 . Dc stirpium . . . nomenclaturis, etc. 1552- "Campanula sylvestris seu Digitatis."

4 Withering (William), Account of the Foxglore, Birningham, 1785. $8^{\circ}$.

5 Prior. Popular Names of British Plants, ed. 2. 1870.84 . 
When magnified, the tip of each crenatmre or serrature of the leaf, is reen to be provided with a small, shining; wart-like gland. The hairs of the lower surface are simple, and composed of jointed cells which flatten in drying; those of the upper surface are shorter.

In preparing foxglove for medicinal use, it is the custom of some druggists to remove the whole of the petiole and the thicker part of the midrib, retaining only the thin lamina, which is dried with a gentle heat. ${ }^{1}$ The fresh leaf has when bruised an umpleasant herbaceous smell, which in drying becomes agreeable and tea-like. The dried leaf has a very bitter taste.

Chemical Composition-Since the beginning of the present century, numerous attempts have been made to prepare the active principle of foxglove, and the name Digitalin has been sticcessively bestowed on widely different substances.

Among the investigators engaged in these researches, we may especially point out Walz (1846-1858), Kosmann (1845-46, 1860), Homolle partly with Quévenme (1845-61), and O. A. Nativelle (1872).

The Digitalin of Walz, first called Digitasolin, has the formula $\mathrm{C}^{28} \mathrm{H}^{48} \mathrm{O}^{14}$. It is amorphous, sparingly soluble in cold, more readily in hot water, and easily dissolved by alcohol. By dilute acids it is resolved into sugar, Digitaliretin and Paradigitaletin, the last two amorphous.

The Digitalin of Kosmann is described as being in crystalline scales, sparingly soluble in water, freely in alcohol, not in ether.

The Digitalin of Homolle (Digitaline of Homolle and Quevenne) which is that adopted in the British Pharmacopaia, as well as in the French Codex, is described by Gmelin as a colourless substance in "warty masses or fine scales" " "porons mammillated masses or small scales" - Brit. Pharm.) -inodorous, extremely bitter, discolving easily in spirit of wine, very slightly soluble in water or ether; soluble in acids, but not forming with them neutral compounds. Its solution in hydrochloric acid, at first pale yellow, rapidly becomes green. This substance is not now regarded by chemists as of perfectly definite composition.

The Digitalin of Nativelle-The researches on digitalis of this chemist, for which the Orfila prize of 6000 francs was awarded in 1872, have resulted in the extraction of a crystallized digitalin, possessing active medicinal properties. It may be obtained by the following process :-

The leaves previously exhausted by water, are extracted by means of alcohol, sp. gr. 930 . The tincture is concentrated mutil its weight is equal to that of the leaves used, and then diluted by adding thrice its weight of water. A pitch-like deposit is then formed; digitaléin and other substances remaining in solution. The deposit dried on blotting paper is boiled with double its weight of alcohol, sp. gr. 907 ; on cooling, crystals are slowly deposited during some days. They should be washed with a little diluted alcohol ( 958 ) and dried: to purify them, they should be first recrystallized from chloroform, and subsequently from boiling alcohol sp. gr. 828 , some charcoal being used at the same time. Digitalin is thus obtained in colourless needle-shaped crystals. It assumes an

1 This methor of preparing the leaf was lireeted in the London Pharmaeopoia of 851, but it had long been in use. No partieular directions are given in the British Pharmacopœia. 
intense emerald green colour when moistened with hydrochloric acid, and has an cxtremely bitter taste. On the animal econony, it displays all the peculiar effects of digitalis, the dose of a milligramme taken by an adult person once or twice a day occasioning somewhat alarming symptoms, but smaller doses exhiliting the sedative power of the herb.

Lastly, we may mention a Digitalin prepared from the seeds of Digitalis by Prof. Delffs of Heidelberg, to whom we are indehted for a specinen. It is a nentral, colourless, crystalline substance, readily soluble in alcohol, ether, or chloroform; not coloured by concentrated mineral acids, or by bromine. Prof. Delffs finds it to be a glucoside, having the composition $\mathrm{C}^{17} \mathrm{H}^{30} \mathrm{O}^{7}$.

What relation these substances bearing the name of Digitalin have to one another, is a question that must be left for further investigation. Another body occurring in foxglove is the crystallizable sugar called Inosite, which was detected by Marmé in the leaves, as well as in those of dandelion (p. 353).

Uses-Foxglove is a very potent drug, having the effect of reducing the frequency and force of the heart's action, and hence is given in special cases as a sedative; it is also employed as a diuretic.

Adulteration-The dried leaves of some other plants have occasionally been supplied for those of foxglove. Such are the leaves of Verbascum, which are easily recognized by their thick coat of branched stellate hairs; of Inula Conyzu DC. and I. Helenium L., which have the margin almost entire, and in the latter plant, the veins diverging nearly at a right angle from the midrib; in both plants the under side of the leaf is less strongly reticulated than in foxglove. But to avoid all chance of mistake, it is desirable that druggists should purchase the fresh flowering plant, which cannot be confounded with any other, and strip and dry the leaves for themselves.

\section{ACANTHACER.}

\section{HERBA ANDROGRAPHIDIS.}

\section{Kariyát or Creyat.}

Botanical Origin-Andrographis ${ }^{1}$ paniculata Nees ab E. (Justicia Burm.), an annual herb, 1 to 2 feet high, common throughout India, growing under the shade of trees. It is found likewise in Ceylon and Java, and has been introduced into the West Indies. In some districts of India it is cultivated.

History - It is probable that in ancient Hindu medicine, this plaint was administered indiscriminately with chiretta, which with several other species of Ophclia, is known in India by nearly the same vernacular names. Ainslie asserts that it was a component of a famous bitter tincture called by the Portuguese of India Droga amara; but on consulting the authority he quotes ${ }^{2}$ we find that the bitter employed in that medicine was calumba. Andrographis is known in Bengal as

1 Andrograplis from ávijp and $\gamma p \alpha \phi l s$, in allusion to the brush-like anther and filament.
- 2 Paolinn da San Bartolomeo, Voyage to the East Indies (1776-1789), translated from the German, Lond. 1800. pp. 14. 40 . 
Maha-tita, literally king of bitters, a title of which it has been thought so far deserving, that it has been adnitted to a place in the Pharmacopoia of India.

Description-The straight, knotty, branched stems are obtusely quadrangular, about $\frac{1}{4}$ of an inch thick at the base, of a dark green colour and longitudinally furrowed. The leaves are opposite, petiolate, lanceolate, entire, the largest $\frac{1}{2}$ an inch or more wide and 3 inches long. Their upper surface is dark green, the under somewhat lighter, and as seen under a lens finely granular. The leaves are very thin, brittle, and iike the stems, entirely glabrous.

In the well-dried specimen before us, for which we are indebted to Dr. G. Bidie of Madras, flowers are wanting and only a few roots are present. The latter are tapering and simple, emitting numerous thin rontlets, greyish externally, woody and whitish within. The plant is inodorous and hås a persistent pure bitter taste.

Chemical Composition-The aqueous infusion of the herb exhibits a slight acid reaction, and has an intensely bitter taste, which appears due to an indifferent, non-basic principle, for the usual reagents do not indicate the presence of an alkaloid. Tannic acid on the other hand produces an abundant precipitate, a compound of itself with the bitter principle. The infusion is but little altered by the salts of iron; it contains a considerable quantity of chloride of sodium.

Uses-Employed as a pure bitter tonic like quassia, gentian, or chiretta, with the last of which it is sometimes confounded.

\section{SESAMEA.}

\section{OLEUM SESAMI.}

Sesamé Oil, Gingeli, Ginyili or Jinjili Oil, Til or Teel Oil, Benné Oil; F. Huile de Sésame; G. Sesamöl.

Botanical Origin-Sesamum indicum DC., an erect, pubescent, annual herb, 2 to 4 feet high, indigenows to India, but propagated by cultivation throughout the warmer regions of the globe. In Europe, Sesamum is only grown in some districts of Turkey and Greece, and on a small scale in Sicily and in the islands of Malta and Gozo. It does not succeed well even in the South of France.

History-Sesamé is a plant which we find on the authority of the most ancient dociments of Sanskrit, Greek, and Roman literature, has been used by mankind for the sake of its oily seeds from the earliest times. In the days of Pliny, the oil was an export from Sind to Europe by way of the Red Sea, precisely as the seeds are at the present day.

During the middle ages the plant, then known as Suseman or Sempsen, was cultivated in Cyprus, Egypt and Sicily. In later times, sesamé oil gave way to that of olives, yet at present it is an article which, if not so renowned, is at least of far greater consumption.

The word Sescumé is derived from Simsim, the Arabic name of the 
plant. The Lndim languages have their own terms for it, the Hindustani T'il, from the Simskrit Tilaha, being one of the hest known. ${ }^{1}$

Production-The plant comes to perfection withing or 4 months; its capsule contrins numerous flat seeds, which are about $\frac{20}{10}$ of an inch long by $\frac{1}{2}$ thick, and weigh on an average $\frac{1}{16}$ of a "yrain. To collect them, the plant when mature is cut down, and stacked in heaps for a few days, after which it is exposed to the sun during the day but collected again into heaps at night. By this process the capsules gradually ripen and burst, and the seeds fall out. ${ }^{2}$

The plant is fonnd in several varieties affording respectively white, yellowish, reddish, brown or black seeds. The dark seeds may be deprived of a part of their colouring matter by washing, which is sometimes done with a view to obtain a paler oil. ${ }^{3}$

We obtained from yellowish seeds, 56 per cent. of oil; on a large scale, the yield varies with the variety of seed employed and the process of pressing, from 45 to 50 per cent.

Description-The best kinds of sesamé oil have a mild agreeable taste, a light yellowish colour, and scarcely any odour; but in these respects the oil is liable to vary with the circumstances already mentioned. The white seeds produced in Sind are reputed to yield the finest oil.

We prepared ${ }^{4}$ some oil by means of ether, and found it to have a sp. gr. of 0.919 at $2: 3^{\circ} \mathrm{C}$.; it solidified at $5^{\circ} \mathrm{C}$., becoming rather turbid at some degrees above this temperature. Yet sesamé oil is more fluid at ordinary temperatures than gromend-nut oil, and is less prone to change by the influence of the air. It is in fact when of fine quality, one of the less alterable oils.

Chemical Composition-The oil is a mixture of olein, stearin and other compounds of glycerin with acids of the fatty series. We prepared with it in the nisual way a lead plaster, and treated the latier with ether in order to remove the oleate of lead. The solution was then decomposed by sulphuretted hydrogen, evaporated, and exposed to hyponitric vapours. By this process we obtained $72 \cdot 6$ per cent. of Elaïdic Acid. The specimen of sesamé oil prepared by ourselves, consequently contained $76^{\circ}$ per cent. of olein, inasmuch as it must be supposed to be present in the form of triolein. In commercial oils, the amount of olein is certainly not constant.

As to the solid part of the oil, we succeeded in removing fatty acids, freely melting after repeated crystallizations, at $67^{\circ} \mathrm{C}$., which may consist of stearic acid mixed with one or more of the allied homologous acids, as palnitic and myristic. By precipitating with acetate of magnesium,

1 We know not the origin of the word Gingeli, which Roxburgh remarks was (as it is now) in common use amoug Europeans. No such name occurs in the copions lists collected by Moodeen Sheriff and published in the Supplement to the Pharm. of India. The word Benné is, we believe, of West African origin, and has no connexion with Ben, the name of Moringa.

2 For further particulars, see Buchanan, Journey from IIadras through Mysore, de.

3 This curious process is described in the Reports of Juries, Hadras Exhibition, 1856 , p. 31. - That the colouring matter of the seeds is actually soluble in water is confirmed by Lépine of Pondicherry as wc have learnt from his manuscript notes presented to the Mlusée des Prodnits des Colonies de Frauce at Paris. The seeds may even be used as a dye.

4 'The experiments narrated in this article were performed by 1)r. $\mathrm{k}$. 
as proposed by Heintz, we finally isolated acids melting at 52.5 to $53^{\circ} \mathrm{C}$., 62 to $63^{\circ} \mathrm{C}$, and $69.2^{\circ} \mathrm{C}$., which correspond to myristic, palmitic ind stearic acids.

The small proportion of solid matter which separates from the oil on congelation, cannot be removed by pressure, for even at many degrees below the freezing point, it remains as a soft magma. In this respect, sesamé oil cliffers from that of olive.

Sesamé oil contains an extremely small quantity of a substance, perhaps resinoid, which has not yet been isolated. It may be obtained in solution by repeatedly shaking 5 volumes of the oil with one of glacial acetic acid. If a cold mixtme of equal weights of sulphuric and nitric acids is added in like volume, the acetic solution acquires a greenish yellow hne. The same experiment being made with spirit of wine substitnted for acetic acid, the mixture assumes a blue colour, quickly changing to greenish yellow. The oil itself being gently shaken with snlphuric and nitric acids, takes a fine green hne, as shown in $1 S 52$ by Behrens, who at the same time pointed out that no other oil exhibits this reaction. It takes place even with the bleached and perfectly colourless oil. Sesamé oil added to other oils, if to a larger extent than 10 per cent., may be recognized by this test. The reaction ought to be observed with small quantities, say 1 gramme of the oil and 1 gramme of the acid mixture, previonsly cooled.

Commerce-The commercial importance of Sesamé may be at once illustrated by the fact that France imported in 1870, 83 millions; in $1871,57 \frac{1}{2}$ millions; and 1872,50 millions of kilogrammes $(984,693$ cwt.) of the seed. ${ }^{1}$

The quantity shipped from British India in the year 1871-72 was 565,854 cwt., of wlich France took no less than 495,414 cwt. ${ }^{2}$ The imports of the seed into the United Kingdom in 1870 , were to the value of only about $£ 13,000$.

Sesamé is extensively prodnced in the Chinese island of Formosa, which in 1869, exported the exceptionally large quantity of 46,000 peculs $^{3}$ ( 1 pecul $=133 \mathrm{tb}$.) Zanzibar also furnishes consiclerable quantities of sesamé, whilst on the West Const of Africa, the staple oil-seed is Ground-nut (Arachis hypogce L.) The chief place for the manufacture of sesamé oil is Mar'seilles.

Uses-Good sesamé oil might be employed without disadvantage for all the purposes for which olive oil is used. ${ }^{4}$ As its congealing point is some degrees below that of olive oil, it is eren more fitted for cool climates. Sesamé seeds are largely consumed as food both in India and Tropical Africa. The foliage of the plant abounds in mucilage, and in the United States is sometimes nsed in the form of poiltice.

1 Documents Statistiques réunis par l'Administration des Dousunes sur le commerce de la Fronce, année 1872.

2 Statement of the Trade and Navigation of British India with Forcign Countries, Calcutia, 1872. 62.
3 Repnots on Trade at the Treaty Ports in China for 1870, Shanghai, 1871.81.

4 For pharmaceutical uses, the larger proportion of olein and consequent lesser tendency to solidify, should be remembered. 


\section{LABLA'T E.}

\section{FLORES LAVANDULAE.}

\section{Lavender Flowers; F. Fleurs de Lavande; G. Lavendelllumen.}

Botanical Origin-Lavandula verce DC., a shrubby plant growing in the wild state from 1 to 2 feet high, but attaining 3 feet or more under cultivation. It is indigenous to the mountainous regions of the countries bordering the western half of the Mediterranean basin. Thus it occur's in Eastern Spain, Southern France (extending northward to Lyons and Dauphiny), in Upper Italy, Corsica, Calabria and Northern Africa,-on the outside of the olive region. ${ }^{1}$ In cultivation, it grows very well.in the open air throughout the greater part of Germany and as far north as Norway and Livonia.

History-There has been much learned investigation in order to identify lavender in the writings of the classical authors, but the result has not been satisfactory, and no allusion has been found which unquestionably refers either to $L$. vera or to $L$. Spica. ${ }^{2}$

The earliest mention of lavender that we have observed, occurs in the writings of the abbess Hildegard, ${ }^{3}$ who lived near Bingen on the Phine during the 12 th century, and who in a chapter De Lavendula alludes to the strong odour and many virtues of the plant. In a poem of the school of Salerno entitled Flus Medieince ${ }^{4}$ occur the following lines:-

"Salvia, castoreum, lavendula, primula veris,

Nasturtium, athanas hæc sanant paralytica membra."

Lavender was well known to the botanists of the 16th century.

Description-The flowers of Common Lavender are produced in a lax terminal spike, supported on a long naked stalk. They are arranged in 6 to 10 whorls (verticillasters), the lowest being generally far remote from those above it. A whorl consists of two cymes, each having when fully developed, about three flowers, below which is a rhomboidal acuminate bract, as well as several narrow smaller bracts belonging to the particular flowers. The calyx is tubular, contracted towards the mouth, marked with 13 nerves and 5-toothed, the posterior tooth much larger than the others. The corolla of a violet colour is tubular, twolipped, the upper lip with two, the lower with three lobes. Both corolla and calyx as well as the leaves and stalks, are clothed with a clense tomentum of stellate hairs, amongst which minute shining oil-glands can' be seen by the aid of a lens.

The flowers emit when rubbed a delightful fragrance, and have a pleasant aromatic taste. The leaves of the plant are oblong linear, or lanceolate, revolute at the margin and very hoary when young.

For pharmaceutical use or as a perfume, lavender flowers are stripped from the stalks and dried by a gentle heat. They are but seldom

I On Mont Ventoux near Avignon, the region of Lavandula vera is comprised according to Martins, between 1500 and 4500 feet above the sea-level. - Ann. des Se. Nat., Bot. x. (1838) 145. 149.

${ }_{2} \mathrm{~F}$. de Gingins-Lassaraz, Hist. des Lavandes, Genève et Paris, 1826. - Lavandula
Stcechas L. is however distiuctly referred to both by Dioscorides and Pliny.

3 Operce Ommia, accurante J. P. Migne, Paris, 1855. 1143.

${ }_{4}$ S. de Renzi, Collectio Salernitana, Na. poli, i. 417-516. 
liept in the shops, being grown almost entirely for the sake of their essential oil.

Production of Essential Oil-Lavender is cultivated in the parishes of Mitcham, Carshalton and Beddington and a few adjoining localities, all in Surrey, to the extent of about 300 acres. It is also grown at Market Deeping in Lincolnshire, and at Hitchin in Hertfordshire, at which latter place there were in 1871 about 50 acres so cropped.

The plants which are of small size, and grown in rows in dry open fields, flower in July and August. The flowers are usually cut with the stalks of full length, tied up in mats, and carried to the distillery there to await distillation. This is performed in the same large stills that are used for peppermint. The flowers are commonly distilled with the stalks as gathered, and either fresh, or in a more or less dry state. A few cultivators distil only the flowering heads, thereby obtaining a superior product. Still more rarely, the flowers are stripped from the stalks, and the latter rejected in toto. According to the careful experiments of Bell, ${ }^{1}$ the oil made in this last method is of exceedingly fine quality. The produce he obtained in 1846 , was $26 \frac{1}{2}$ ounces per $100 \mathrm{tb}$. of flowers, entirely freed from stalks ; in 1847, $25 \frac{1}{2}$ onnces; and in 1848, 20 ounces: the quantities of flowers used in the respective years were 417 , 633 , and $923 \mathrm{tb}$. Oil distilled from the stalks alone, was found to have a peculiarly rank odour. In the distillation of lavender, it is said that the oil which comes over in the earlier part of the operation is of superior flavour.

We have no accurate data as to the prodnce of oil obtained in the ordinary way, but it is universally stated to vary extremely with the season. Warren ${ }^{2}$ gives it as 10 to $12 \mathrm{fb}$., and in an exceptional case as much as $24 \mathrm{lb}$. from the acre of ground under cultivation. At Hitchin, ${ }^{3}$ the yield would appear to approximate to the last-named quantity. The experiments performed in Bell's laboratory as detailed above, show that the flowers deprived of stalks afforded on an average exactly $1 \frac{1}{2}$ per cent. of essential oil.

Oil of Lavandula verce is distilled in Piedmont, and in the mountainous parts of the South of France, as in the villages about Mont Ventoux near Avignon, and in those some leagues west of Montpellier (St. Guilhen-le-désert, Montarnaud and St. Jean de Fos),in all cases from the wild plant. This foreign oil is offered in commerce of several qualities, the highest of which commands scarcely one-sixth the price of the oil produced at Mitcham. ${ }^{4}$ The cheaper sorts at least are obtained by distilling the entire plant.

Chemical Composition-The only constituent of lavender flowers that has attracted the attention of chemists, is the essential oil (Oleum Lavandulce). It is a pale yellow, mobile liquid, varying in sp. gr. from 0.87 to 0.94 (Zeller), having a very agreeable odour of the flowers and a strong aromatic taste. The oil distilled at Mitcham (1871) we find to rotate the plane of polarization $4.2^{\circ}$ to the left, in a columm of $50 \mathrm{~mm}$.

Oil of lavender is a mixture in rariable proportions of a hydro-

J Pharm. Journ. viii. (1849) 276.

: Ibid. vi. (1865) 257.

${ }^{3}$ Ibid. i. (1860) 278. Tho statement is that an acre of land yielus "about 6 Winchester quarts" of oil.

4 The Mitcham oil fetches 30 s. to $60 s$. per 
carbon, $\mathrm{C}^{10} \mathrm{H}^{18}$, and stearoptene, the first of which boils at $200^{\circ}-210^{\circ} \mathrm{C}$. The stearoptene is identical according to I) umas, with common camplor. In some samples it is said to exist to the extent of one-half. It is sometimes deposited from the oil in cold weather'; we have not however been able to ascertain this fact.

Commerce-Dried lavender flowers are the object of some trade in the south of Europe. According to the official Tablcau général du Commcrce de la France, Lavender and Orange Flowers (which are not separated) were exported in 1870 to the extent of 110,958 kilo. $(244,741 \mathrm{tb}$.), - chiefly to the Barbary States, Turkey and Anerica. There are no data to show the amount of oil of lavender imported into England.

Uses-Lavender flowers are not prescribed in modern English medicine. The volatile oil has the stimulant properties common to bodies of the same class and is much nsed as a perfume.

\section{Other Species of Lavender.}

1. Lavandula Spica DC. is a plant having a very close resemblance to $L$. vera, of which Linnæus considered it a variety, though its distinctness is now admitted. It occurs over much of the area of $L$. vera, but does not extend so far north, nor is it found in such elevated situations, or beyond the limit of the olive. It is in fact a more southern plant and more susceptible to cold, so that it cannot be cultivated in the open soil in Britain except in sheltered positions. In Languedoc and Provence, it is the common species from the sea-level up to about 2000 feet, where it is met by the more hardy I. vera. ${ }^{1}$

Lavandula Spica is distilled in the sonth of France, the flowering wild plant in its entire state being used. The essential oil which is termed in French Esscnce d'Aspic, is known to English druggists as Oleum Lavandulce spica, Oleum Spica, or Oil of Spikc. It resembles true oil of lavender, but compared with that distilled in England, it has a much less delicate fragrance. ${ }^{2}$ In chemical composition, it agrees with oil of Lavandula verce. Oil of Spike is used in porcelain painting and in veterinary medicine.

2. Lavandula Stoechas L.-This plant was well known to the ancients; Dioscorides remarks that it gives a name to the Stochades, the modern isles of Hières near Toulon, where the plant still abounds. It has a wider range than the two species of Lavandula already described, for it is found in the Canaries and in Portugal, and eastward throughout the Mediterranean region to Greece and Asia Minor. It may at once be known from the other lavenders by its flower-spike being on a short stalk, and terminating in 2 or 3 conspicuous purple bracts.

The flowers, called Flores Stcerhados or Stoechas Arabica, ${ }^{3}$ were formerly kept in the shops, and had a place in the London Pharmacopœia down

1 On the high land betwcen Nicc and Turbia, I have observed the two species crowing together, and that $J_{\text {. }}$. vera is in flower two or three weeks earlier than $L$. spice. D. H.

\& Yet we find that flowers of the two plants (L. vero and $L$. Spica) grown side by side in an English garden, are hardly distinguishable in fragrance.

3 The incorrectuess of the term Aribien is noticed by Pomet. How it camc to be applicd we know not. 
to $17+6$. We are not aware that they are, or ever were, distilled for essential oil, though they are stated to be the source of True Oit of Spike. ${ }^{1}$

\section{HERBA MENTHAE VIRIDIS.}

Spearmint.

Botanical Origin-Mentha viridis $\mathrm{L}$. is a fragrant perennial plant, chietly known in Europe, Asia and North America, as the Common Mint of gardens, and only found apparently wild in countries where it has loug beell cultivated. It occur's occasionally in Britain under such circumstances. ${ }^{2}$

Mentha viridis is regarded by Bentham as not improbably a variety of $M$. silvestris L., perpetuated through its ready propagation by suckers. J. G. Baker remarks, that while these two plants are sufficiently distinct as found in England, yet continental forms occur which bridge over their differences. ${ }^{3}$

History-Mint is mentioned in all early medixval lists of plants, and was certainly cultivated in the convent gardens of the 9th century. Turuer, who has been called "the father of English botany," states in his Herball that the garden mint of his time was also called "Spere Mynte." We find spearmint also described by Gerarde who terms it Mentha Romana vel Sarraenica, or Common Garden Mint, but his statement that the leaves are white, soft, and hairy does not well apply to the plant as now found in cultivation.

Description-Spearmint has a pereminal root-stock which throws out long runners. Its stem 2 to 3 feet ligh is erect, when luxuriant branched below with short erecto-patent branches, firm, quadrangular, naked or slightly hairy beneath the nodes, often brightly tinged with purple. Leaves sessile or the lower slightly stalled, lanceolate or ovatelanceolate, rounded or even cordate at the base, dark green and glabrous above, paler and prominently veined with green or purple beneath, rather thickly glanduiar, but either quite naked or hairy only on the midrib and principal veins, the point narrowed out and acute, the teeth sharp but neither very close nor deep, the lowest leaves measuring about 1 inch across by 3 or 4 inclies long. Inflorescence a panicled arrangement of spikes, of which the main one is 3 or 4 inches long by $\frac{3}{8}$ inch wide, the lowest whorls sometimes $\frac{1}{2}$ an inch from each other and the lowest bracts leafy. Bracteoles linear-subulate, equalling or exceeding the expanded flowers, smooth or slightly ciliated. Pedicels about $\frac{3}{4}$ line long, purplish glandular, but never hairy. Calyx also often purplish, the tube campanulato-cylindrical, $\frac{3}{8}$ line long, the teeth lanceolatesubulate, equalling the tube, the flower part of which is naked, but the teeth and often the upper part clothed more or less densely with erectopatent hairs. Corolla reddisli-purple, about twice as long as the calyx, naked both within and without. Nut smooth.

1 Pereira, Elem. of Mut. Mect. ii. (1850) 1368. - Nor do we know if L. lanata Boiss. a very fragrant speries closely allied to $\mathrm{L}$. Sproce DC., and a native of Spain, is distilleal iil that countiy.

2 Benthan, Handbook of the Bl ilish Flora, 1558. 413.-Parkinsinl (1610) remarks of
Sperire Mine that it is "onely found planted iu garlens with us."

3 Seemanus's . Journ. of Bot. Aug. 1S65. 1)

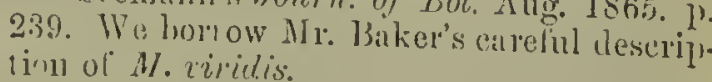

+ Vart 2. (1568) 54 
The plant varies slightly in the shape of its leaves, elongation of spike and hairiness of calyx. The entire plant enits a most fragrant odour when rubbed, and has a pungent aromatic taste.

Production-Spearmint is grown in kitchen gardens, and more largely in market gardens. A few acres are under cultivation with it at Mitcham, cliefly for the sake of the herb, which is sold mostly in a dried state.

The cultivation of spearmint is carried on in the United States in precisely the same manner as that of peppermint, but on a much smaller scale. Mr. H. G. Hotclikiss of Lyons, Wayne County, State of New York, has informed us that his manufacture of the essential oil amounted in 1870 to $1162 \mathrm{lb}$. The plant he employs appears from the specimen with which he has fuvoured us, to be identical with the spearmint of English gardens, and is not the Curled Mint (Mentha crispa) of Germany.

Chemical Composition-Spearmint yields an essential oil (Oleum Menthe viridis) in which reside the medicinal virtues of the plant. Kane ${ }^{1}$ who examined it, gives its sp. gr. as 0.914 , and its boiling point as $160^{\circ} \mathrm{C}$. The oil yielded him a considerable amount of stearoptene. Gladstone $^{2}$ found spearmint oil to contain a hydrocarbon almost identical with oil of turpentine in odour and other pliysical properties, mixed with an oxidized oil to which is due the peculiar smell of the plant. The latter oil boils at $225^{\circ} \mathrm{C}$.; its sp. gr. is 0.951 , and it was found to be isomeric with carvol, $\mathrm{C}^{10} \mathrm{H}^{14} \mathrm{O}$.

Uses-Spearmint is used in the form of essential oil and distilled water, precisely in the same nuanuer as peppermint. In the United States, the oil is also employed by confectioners and the manufacturers of perfumed soap.

Substitutes-Oil of spearmint is now rarely distilled in England, its high cost ${ }^{3}$ causing it to be nearly unsaleable. The cheaper foreign oil is offered in price-currents as of two kinds, namely American and German. Of the first we have already spoken: the second termed in German Krausemünzöl, is the produce of Mentha aquatica L. var. y crispa Bentham, a plant cultivated in Northern Germany.

\section{HERBA MENTHAE PIPERITAE.}

\section{Peppermint; F. Menthe poivrée; G. Pfefferminze.}

Botanical Origin-Mentha piperita Hudson (non Linn.), an erect, usually glabrous perennial, much resembling the Common Spearmint of the gardens, but differing from it in having the leaves all stalked, the flowers larger, the upper whorls of flower's somewhat crowded together, and the lower separate. In the opinion of Bentham it is possibly a mere variety of $M$. hirsutc L., with which it can be connected by numerous intermediate forms.

Peppermint rapidly propagates itselî by rumers, and is now found in wet places in several parts of England, as well as on the Continent.

1 Philosophical Magazine, xiii. (1838) 444. 11 .

3 Price from 1524 to 1539 , 40s, to $45 s$. pel to. 
It is cultivated on the large scale in England, France, Germany, and North Amelica.

History-Mentha pipcrita was first observed in Hertfordshire by Dr. Eales and communicated to Ray, who in the second edition of his Synopsis Stirpium Britannicamem, 1696, noticed it under the name of Mentha spicis brevioribus et habitioribus, foliis Menthe fusce, sapore fervido piperis; and in his Historia Plantarum" as "Mentha palustris . . . Peper-Mint." 2 Dale who found the plant in the adjoining county of Essex, states ${ }^{3}$ that it is esteemed a specific in renal and vesical calculus; and Ray in the third edition of his Synopsis, declares it superior to all other mints as a remedy for weakness of the stomach and for diarrhœea. Peppermint was admitted to the London Pharmacopœia in 1721, under the designation of Mentha piperitis sapore.

The cultivation of peppermint at Mitcham in Surrey, dates from about $1750,{ }^{4}$ at which period only a few acres of ground were there devoted to medicinal plants. At the end of the last century, above 100 acres were cropped with peppermint. But so late as 1805 there were no stills at Mitcham, and the herb had to be carried to London for the extraction of the oil. Of late years the cultivation has diminished in extent, by reason of the increased value of land and the competition of foreign oil of peppermint.

In Germany, peppermint became practically known in the latter half of the last century, especially through the recommendation of Knigge. ${ }^{5}$

Description-The rootstock of peppermint is peremnial, throwing out rumners. The stem is erect, 3 to 4 feet high, when luxuriant somewhat branched below with erecto-patent branches, firm, quadrangular, slightly hairy, often tinged with purple. Leaves all stalked, the stallks of the lower $\frac{1}{2}$ to $\frac{3}{4}$ of an inch long, naked or nearly so, the leaf lanceolate, narrowed or rather rounded towards the base, the point narrowed out and acute, the lowest 2 to 3 inches long by about $\frac{3}{4}$ of an inch broad, naked and dull green above, paler and glandular all over, but only slightly hairy upon the veins beneath; the teeth sharp, fine, and erecto-patent. Inflorescence in a loose lanceolate or acutely conical spike, 2 to 3 inches long by about $\frac{3}{4}$ of an inch broad at the base, the lowest whorls separate, and usually the lowest bracts leaf-like. Bracteoles lanceolate acuminate, about equalling the expanded flowers, slightly ciliated. Pedicels 1 to $1 \frac{1}{2}$ lines long, purplish, glandular but not hairy. Calyx often purplish, the tube about 1 line long and the teeth $\frac{1}{2}$ a line, the tube campanulate-cylindrical, purplish, not hairy, but dotted over with prorninent glands; the teeth lanceolate subulate, furnished with short erecto-patent hairs. Corolla reddish purple about twice as loug as the calyx, naked both within and withont. Nut smooth ${ }^{6}$ (rugose, according to onr observation). The odour and taste are strongly arumatic.

1 Tomus iii. (1704) 284.

2 I have examined the original specimen still preserved anong Ray's plants in the British Museum and find it to agree perfectly with the plant now in cultivation.I). I1.

2 Pharmacologia Supplementum. Lond. 1705.117. 254.

4 Lysons, Environs of London, i. (1800)

5 De Mentha Piperitide Commentalio, Erlangæe, 1780.

6 This description is borrowed from Mr. Baker's paper on the English Mints, referred to at p. 431, note 3 . 
In var. 2. vulgaris of Sole, $M$. piperitu $\beta$. Sunith, the plant is more hairy, with the spikes broader and shorter, or even bluntly capitate.

Chemical Composition-The constitnent for the salie of which peppermint is cultivated, is the essential oil, Oleum Menthe piperita, a colourless, pale yellow, or greenish liquid, of sp. wr. varying from 0.84 to 092. It has a strong and agreeable odour, with a powerful aromatic taste, followed by a sensation of cold when air is drawn into the mouth. We find that the Mitcham oil examined by polarized light in a column $50 \mathrm{~mm}$. longr, deviates $14 \cdot 2^{\circ}$ to the left.

When oil of peppermint is cooled to $-4^{\circ} \mathrm{C}$., it sometimes deposits colourless hexagonal crystals of Peppermint Camphor, $\mathrm{C}^{10} \mathrm{H}^{18}+\mathrm{H}^{2} \mathrm{O}$, called also Menthol. This camphor (the deposit of which in the oil we have not observed) boils at $210^{\circ} \mathrm{C}$. and possesses the odour of the crude oil; it deviates the ray of polarized light to the left. 'The proportion of inenthol contained in oils of different origin is very variable. Pure crystallized menthol is sometimes found in commerce under the name of Chinese Oil of Peppermint. ${ }^{1}$

The liquid part of the oil of peppermint has not yet been chemically investigated.

Oil of peppermint is not uniform in constitution, nor in its flavour and chemical behaviour. Accurate means of ascertaining its value and purity are wanting.

If 50 to 70 drops of peppermint oil are shaken with one drop of nitric acid, sp. gr. about $1 \cdot 2$, the mixture changes from faintly yellowish to brownish and, after an hour or two, exhibits a bluish, violet or greenish colour; in reffected light, it appears reddish and not transparent. The colour thus produced lasts a fortnight. We have thus examined the various samples of peppernint oil at our command, and may state that the finest among them assume the most beautiful coloration and fluorescence, which however shows very appreciable differences. An inferior oil of American origin was not coloured; and a very old sample of an originally excellent Linglish oil was likewise not coloured by the test. Menthol, that is to say the Chinese oil of peppermint, is not altered when similarly treated. ${ }^{2}$ The nitric acid test is not capable of revealings adulterations of peppermint oil, for the coloration takes place with an oil, to which a considerable quantity. of oil of turpentine has been added.

Remarkable colorations of a different hue are also displayed by the various kinds of oil of peppermint if other chemical agents are mixed with it. Thus green or brownish tints are produced by means of anhydrous chloral; the oil becomes bluish or greenish or rose-coloured if shaken with a concentrated solution of bisulphite of sodium. It is worthy of note that oils of different origin, which camnot be distiugruished by means of nitric acid, exhibit totally different colorations if inixed with either of the liquids just named. This behaviour may be of some use in the examination of commercial sorts of peppermint oil.

As to bisulphite of sodium, it yields a solid compound with certain kinds of peppermint oil, which we have not yet examined.

1 It is distilled at Canton from a plant whish aljpear's to be Mentha arvensis L. var. Javanica (.K. Juvanica Bl.) The oil was exported from Canton in 187 , to the extent of $800 \mathrm{tb}$; it was valued at about 30 s. per 1b. - See also Fliickiger in Pharm. Jon Oet. 14, 1871.321.

$\because$ Phurm. Journ. Feb. 25, 1871. 652. 
Production and Commerce-ln several parts of Europe as well as in the United States, peppermint is cultivated on the large scale as a medicinal plant.

In England the culture is carried on in the neighbourhood of Mitchan in Surrey, near Wisbeach in Cambridgeshire, Market Deeping in Lincolnshire, and Hitchin in Hertfordshire.

At Mitchan in 1850, there were about 500 acres under cultivation: in 1864 only about 219 acres. $^{1} \quad$ At Market Deeping there were in 1871 about 150 acres cropped with peppermint. The usual produce in oil may be reckoned at 8 to $12 \mathrm{fb}$. per acre. The fields of peppermint at Mitcham are level, with a rich, friable soil, well manured and naturally retentive of moisture. The ground is kept free from weeds, and in other respects is carefully tilled. The crop is cut in August, and the herb is usually allowed to dry on the ground before it is consigned to the stills. These are of large size, holding 1000 to 2000 gallons, and heated by coal; each still is furnished with a condensing worm of the usual character, which passes out into a small iron cage secured by a padlock, in which stands the oil separator. The distillation is conducted at the lowest possible temperature. The water that comes over with the oil is not distilled with another lot of herb, but is for the most part allowerl to run away, a very little only being reserved as a perquisite of the workmen. The produce is very variable, and no facilities exist for estimating it with accuracy. ${ }^{2}$ It is however stated that a ton of dried peppermint yields from $2 \frac{1}{2}$ to $3 \frac{1}{2}$ pounds of oil, which equals 0.11 to 0.15 per cent. But we have been assured by a grower at Mitcham that the yield is as much as 6 pounds from a ton, or $0 \cdot 26^{\circ}$ per cent.

At Mitcham and its neighbourhood, two varieties of peppermint are at present recognized, the one being known as White Mint, the other as Black Mint, but the differences between the two are very slight. The Black Mint has purple stems; the White Mint, green stems, and as we have observed, leaves rather more coarsely serrated than those of the Black. The Black Mint is more prolific in essential oil than the White, and hence more generally cultivated; but the oil of the latter is superior in delicacy of odour and commands a higher price. White Mint is said to be principally srown for drying in bundles, or as it is termed "bunching."

Peppernint is grown on a vastly larger scale in America, the localities where the cultivation is carried on being Southern Michigan, Westeru New York, and Ohio. In Michigan where the plant was introduced in 1835 , there were in 1858 about 2100 acres devoted to its growth, all with the exception of about 100 acres being in the county of St. Joseph. The average produce of this district was estimated in 1858, at $15,000 \mathrm{tb}$; but the yield fluctuates enormously, and in the exceptionally fine season of 1855 , it was reckoned at $30,000 \mathrm{ft}$. We nust suppose that it is now much larger, for we have been informed by Mr. H. G. Hotchkiss, of Lyons, Wayne County, State of New York, one of the most wellknown distillers, in a letter under date Oct. 10, 1871, that the quantity

1 Phurm. Journ. x. (1851) 297. 340; also Warren in Pharm. Journ. vi. (1865) 257. 'T'o these plapers and to jersonal inquiries we are indebted for most of the partieular's relating to peppermint eulture at Mitchan.

* Unly the larger growers have stills.
These they let to smaller cultivators who pay' so much for distilling a charge, i.c. whatever the still can be made to contain, without reference to weight. Hence the dried herb is preferred to the fresh, as a larger quantity can be distilled at one time. 
sent ont by him in the previous year, reached the enormous amount of 57,365 th. From the statistics quoted by Stearns ${ }^{1}$ it would appear that the produce of oil per acre is somewhat higher than in England, but from various canses, information on this head cannot be very reliable.

l'eppermint is cultivated at Sens in the department of the Yonne in lirance ${ }^{2}$ and in Saxony, and very recently it has been tried in the Neilgherry Hills in Southern India.

Peppermint oil varies greatly in commercial value, that of Mitcham commanding twice or three times as high a price as the finest American. Even the oil of Mitcham is by no means uniform in quality, certain plots of ground affording a product of superior fragrance. A damp situation or badly drained ground, is well known to be unfavourable both to the quantity and quality of oil.

The presence of weeds among the peppermint is an important cause of deterioration to the oil, and at Mitcham some growers give a gratuity to their labourers to induce them to be careful in throwing out other plants when cutting the herb for distillation. One grower of peppermint known to us was compelled to abandon the cultivation, owing to the enormous increase of Mentha arvensis L. which could not be separated, and which whell distilled with the peppermint ruined the flavour of the latter. In America great detriment is occasioned by the growth of Erigeron Canadense L. Newly cleared ground planted with peppermint, is liable to the intrusion of another plant of the order Composita, lirechtites hieracifolic Raf., which is also highly injurious to the quality of the oil. ${ }^{3}$

Uses-A watery or spiritnous solution of oil of peppermint is a grateful stinulant, and is a frequent adjunct to other medicines. Oil of peppermint is extensively consumed for flavouring sweetmeats and cordials.

\section{HERBA PULEGII.}

Pennyroyal ${ }^{4}$; F. Menthe pouliot, Pouliot vulgaire; G. Polei.

Botanical Origin-Mentha Pulegium L., a small peremial aromatic plant, common thronghout the south of Europe and extending northward to Sweden, Demmark, England and Ireland, eastward to Asia Minor and Persia, and sonthward to Abyssinia, Algeria, Madeira and Teneriffe. It has been introduced into North ${ }^{5}$ and South America. For medicinal use it is cultivated on a small scale.

History-Pennyroyal was in high repute among the ancients. Both Dioscorides and Pliny describe its numerous virtues. In Northern Europe it was also much esteemed, as may be inferred from the frequent reference to it in the Anglo-Saxon works on medicine.

I To whose paper On the Peppermint Plantations of Michigan in the Proccedings of the Americ. Pharm. Assocn. for 1858, we owe the fow particulars for which we can here afford spaee.

2 Journ. de Pharm. viii. (1868) 130.Abstract from Roze, La Menthe poiverér, sa culture en France, ses moduits, falsifications de l'essence et moy'us de les reconnaitre, Paris 1868. 43 juiges.
3 Maiscli, American Journ. of Pharm., March 1870. 120.

+ Pennyroyal, in old lierbals Putiol ronal. is derived from Puleium reqium, an ohl Latin name given from the suplosed efticacs of the plant in destroying fleas (Prior).

5 The native Pennyroyal is however a different plant, namely Hedema melegivides Pers. 
Crerarle considered the plant to be "so exceedingly well linown to all our English nation" that it neerled no description. In his time (circa 1590), it used to be collected on the commons round London, whence it was brought in plenty to the London markets. At the present day pennyroyal has fallen into neglect, and is not named in the British Pharmacopœia of 1867.

Description-The plant has a low, decumbent, branching stem, which in Howering rises to a height of about 6 inches. Its leaves, scarcely an inch in length and often much less, are petiolate, ovate, bhunt, crenate at the margin, dotted with oil-glands above and below. The flowers are arranged in a series" of dense, globose whorls, extending for a considerable distance up the stem. The iwhole plant is more or less hairy. It has a strong fragrant odour, less agreeable to most persons than that of peppermint or spearmint. Its taste, well perceived in the distilled water, is highly aromatic.

Chemical Composition-The most important constituent of pennyroyal is the essential oil, known in pharmacy as Oleum Pulegii, to which is due the odour of the plant. It has been examined by Kane, ${ }^{1}$ according to whom it has a sp. gr. of 0.927 . Its boiling was fonnd to fluctuate between $183^{\circ}$ and $188^{\circ} \mathrm{C}$. The formula assigned to it by this chemist is $\mathrm{C}^{10} \mathrm{H}^{16} \mathrm{O}$.

Production-Pennyroyal is cultivated at Mitcham and is mostly sold dried; occasionally the herb is distilled for essential oil. The oil found in commerce is however chiefly French or German, and far less costly than that produced in England.

Uses-The distilled water of pennyroyal is carminative and antispasmodic, and is used in the same manner as peppermint water.

\section{HERBA THYMI VULGARIS.}

\section{Garden Thyme; F. Thym iulgaire; G. Thymiankraut.}

Botanical Origin-Thymus vulgaris L., a small, erect, woody shrub reaching 8 to 10 inches in height, gregarions on sterile uncultivated ground in Portugal, Spain, Southern France and Italy, and in the mountainons parts of Greece. On Mont Ventoux near Avignon, it reaches an elevation above the sea of $3700 \mathrm{ft}$. (Martins). It is commonly cultivated in English kitchen gardens as a sweet herb. ${ }^{2}$

History-Garden thyme was commonly cultivated in England in the 16th century, and was well figured and described by Gerarde. It is even said to have been formerly grown on a large scale for medicinal use in the neighbourhood of Deal and Sandwich in Kent. ${ }^{3}$ Thymol or the Camphor of Thyme was described by Neumann, apothecary to the

Description-The plant produces thin, woody, branching stens, bearing sessile, linear-lanceolate, or ovate-lanceolate leaves. 'Thiese are

1 Phit. Mag. xiii. (1838) 442 .

2 In many of the references to thyme,

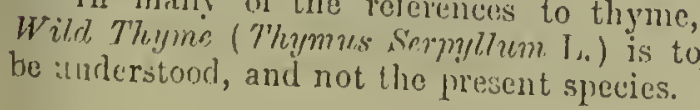
3 Booth in Trecusury of Botun!y. ii. (1S60)
1149.

${ }^{4}$ Phit. Trans. No. 389. 
about $\frac{1}{2}$ of an inch longr, revolute at the margin, morc or less hoary, especially on the under side, and dotted with shining oil-glands. The sinall purple flowers are borue on round tcrminal heads, with sometimes a few lower whorls. The entire plant has a greyish tint by reason of a short white pubescence. It is extremely fragrant when rubbed, and has a pungent aromatic taste. ${ }^{1}$

Production of Essential Oil-'Though cultivated in gardens for culinary usc, common thyme is not grown in England on a large scale. Its essential oil (Oleum Thymi), for which alone it is of intercst to the druggist, is distilled in the sonth of France. In the ncighbourhood of Nimcs, where we have observed the proccss, the entirc plant is nsed, and the distillation is carried on at two periods of the ycar, namely in May and June when the plant is in flower, and again late in the antumn. The oil has a deep, reddish-brown colour, but becomes colourless though rather less fragrant by re-distillation. The two sorts of oil, termed respectively Huile rouge de Thym and Huile blanche de Thym, are found in commerce.

Oil of thyme is frequently termed in English shops Oil of Origanum, which it in no respect resembles, aud which was never, so far as we know, found in conmerce. ${ }^{2}$

Chemical Composition-The only constituent of the herb that has attracted any attention is the above-named essential oil. This liquid by fractional distillation, is resolved into two portions; the first, more volatile and boiling between $178^{\circ}$ and $180^{\circ} \mathrm{C}$., is a mixture of two hydrocarbons, Cymene $\mathrm{C}^{10} \mathrm{H}^{14}$, and Thymene $\mathrm{C}^{10} \mathrm{H}^{16}$.

The second named Thymol, $\mathrm{C}^{10} \mathrm{H}^{14} \mathrm{O}$, is a solid crystalline substance, having a strong aroniatic smell, not quite like that of the crude oil, and -a sharp burning taste. It is optically inert; it boils at $230^{\circ} \mathrm{C}$.; dissolves in about 330 parts of water, and very readily in alcohol, ether, or glacial acetic acid. It also dissolves in and combines with aqueous ailkaline solutions. Thymol is homologous with phenol or phenyl-alcohol (carbolic acid), and isomeric with cuminic alcohol, carvol and carvacrol. ${ }^{3}$

Uses-Oil of thyme is an efficient external stimulant, and is sometimes employed as a liniment. Its chief consumption is in veterinary medicine. Thymol has been proposed as a disinfectant in the place of carbolic acid, in cases in which the odour of the latter is objectionable. The herb is not used in modern English mcdicine, but is often employed on the Continent.

\section{HERBA ROSMARINI.}

\section{Herba Anthos; Rosemary; F. Romarin; G. Rosmarin.}

Botanical Origin-Rosmarimus offeinalis $\mathrm{L}_{\text {.. }}$, an evergreen shrub, attaining a height of :3 to 4 feet or more, abundant on dry rocky hills of the Mediterranean region, from the Spanish peninsula to Greece and Asia Minor: It gcnerally prefers the neighbonrhood of the sea, but

1 This deseription is from wild specimens: as seen in Euglish gardens, the plant is more luxuriant, greener and far less tomentos?.

2 For a note on True Oil of Oriynnum. see Pharm, .Tonm. x. (1851) 324.

3 For further information consult frmelin's Chemistry, xiv. (1860) 183. 311. 409 : also our article on $A$ jowan, at page 270 . 
occurs even in the Sahara, where it is collected and conreyed by camvans to Central Africi."

History-Rosemary ${ }^{2}$ is mentioned by Pliny, who ascribes to it numerous virtnes. It was also familiar to the Arab physicians of Spain, one of whom, Ilm Baytar (13th cent.), states it to be an object of trade among the vendors of aromatics. ${ }^{3}$ In the middle ages, rosemary was doubtless much esteemed, as may be inferred from the fact that it was one of the plants which Charlemagne ordered to be grown on the imperial farms. John Philip de Lignamine, ${ }^{4}$ a writer of the 15th century, describes it as the usual condiment of salted meats. It was probably in cultivation in Britain prior to the Norman Conquest, as it is recommended for use in an Anglo-Saxon herbal of the 11th century. ${ }^{5}$ The essential oil was distilled by Raymundus Lullius ${ }^{6}$ about A.D. 1330 .

Description-Rosemary has sessile, linear, entire, opposite leaves about an inch in length, revolute at the inargin; they are of coriaceous texture, green and glabrons above, densely tomentose and white beneath. Examined under a lens, the tomentum both of the leaves and young shoots is seen to consist of white stellate hairs; in that of the shoots which is less dense, minute oil-glands are discernible. These glands are of two kinds, large and small, and probably do not yield one and the same oil. The flowers have a campanulate 2-lipped calyx, and a pale blue and white corolla, the upper lip of which is emarginate and erect, the lower 3-lobed with the central lobe concave and pendulous. The whole plant has a very agreeable smell and a strong aromatic taste. It flowers in the early spring.

Production of Essential Oil-Rosemary is cultivated on a very small scale in English herb-gardens, and thongh a little oil has been occasionally distilled from it, English oil of rosemary is an article practically unknown in commerce. That with which the market is supplied, is produced in the south of France and on the contiguous coast of Italy. The plant which is plentifully found wild, is gathered in summer not while in flower) and distilled, the operator being sometimes an itinerant herbalist who carries his copper alembic from place to place, erecting it where herbs are plentiful, and where a stream of water enables him to cool a condenser of primitive construction.

Oil of rosemary is also produced on a somewhat large scale in the island of Lesina, south of Spalato in Dalmatia, whence it is exported by way of Trieste, even to France and Italy, to the extent of 300 to 350 quintals annually. ${ }^{7}$

Some of the French manufacturers of essences offer oil of rosemary at a superior price as drawn from the flower's, by which we presume is meant the flowering tops, for the separation of the actual flowers would be impracticable on a large scale. The great bulk of the oil found in commerce is however that distilled from the entire plant. 187.

1 Duveyrier, Les Touarcys du Nord, 1864.

: From ros and marinus, - literally morine dev. Various opinions have been lield as to the allusion conteyed by the name.

3 Sonthesinfer's trauslation, i. 73.

4 Conssivalorium Sunitalis, cap. 81.
"IImbarium, Apmiei-Lceclidoms a'c. of Err.ly Englenu, i. (1861) 185.

${ }^{6}$ Mingot, Bibliothece chemica curiose, fe:nevæ, i. (1702) 829.

- Lnger, Der liosmarin und soine Tranndung in Dulmatien-Sizungsberichto der Wicner Akarlemir, 1vi. (1867) 586. 
Chemical Composition-The peculiar odour of rosemary depends on the essential oil, which is the only constituent of the plant that has afforded matter for chemical research. This oil is a yellowish liquid of variable sp. gr. $\left(0.908\right.$, Gladstone), which boils at $1665^{\circ}-168^{\circ} \mathrm{C}$. (Kane) and turns the plane of polarization to the right. Gladstone (1864) found it to consist ahmost wholly of a hydrocarbon, resembling that from Myptus communis, $\mathrm{C}^{10} \mathrm{H}^{10}$. Tallemand by fractional distillation, resolved oil of rosentury into two liquids, - the one a mobile hydrocarbon boiling at $165^{\circ} \mathrm{C}$. and turning the plane of polarization to the left; the other boiling between $200^{\circ}$ and $210^{\circ} \mathrm{C}$., deposits when exposed to a low temperature, a large quantity of camphor, resembling in all respects common cimluphor except that it has rather less dextro-rotatory power. ${ }^{1}$ Oil of rosemary, acted ujon by bichromate of potassium and sulphuric acid, gives rise to Limettic Acid, $\mathrm{C}^{11} \mathrm{H}^{8} \mathrm{O}^{6}$, a colourless crystalline substance.

Uses-The flowering tops and dried leaves are kept by the herbalists, but are not used in regular medicine. The volatile oil is employed as an external stimulant in liniments, and also as a perfume. Rosemarv is popularly supposed to promote the growth of the hair.

\section{PLAN'TAGINEA.}

\section{SEMEN ISPAGHULAE.}

\section{Ispaghúl Seeds, Spogel Seeds.}

Botanical Origin-Plantago decumbens Forsk. (P. Ispaghula Roxb.), ${ }^{2}$ a plant of variable aspect, from an inch to a foot in height, erect or decumbent, with linear lanceolate leaves which may be nearly glabrous, or covered with shaggy hairs. The flower-spikes differ according to the luxuriance of the plant, being in some specimens cylindrical and $1 \frac{1}{2}$ inches long, in others reduced to a globular head. The plant has a wide range, oceurring in the Canary Islands, Egypt, Arabia, Beluchistan, Afghanistan, and North-western India. Stewart ${ }^{3}$ says it is common in the Peshawar valley and Trans-Indus generally up to 2000 feet; also on the plains and lower hills of the Punjab, but that he has never seen it cultivated in the latter region. It is said to be cultivated at Multan and.Lahore, also in Bengal and Mysore.

History - The seeds which are found in all the bazaars of India and are held in great esteem, are generally designated by the Persian word Ispaghúl; but they also bear the Arabic name Bazre-qatúná, under which we find them mentioned by the Persian physician Alhervi ${ }^{4}$ in the 10 th century, and about the same period or a little later, by Avicenna. ${ }^{5}$ Several other Oriental writers are quoted by Ibn Baytar ${ }^{6}$ as referring to a drug of the same name, which may possibly lave included the seeds

1 Gnelin, Chomistry, xiv. (1860) 397.

2 After the examination of numerons specimens, we adopt the course taken by J)r. Aitchison (Catalogue of the Plants of the Prenjab and Sindh, Lond. 1869) of uniting $P$. Ispaghula to $P$ '. decumbens. 'The union of species in this group may probalily be carried still further.
3 Punjab Plants, Lahore 1869. 174-also MS. note attached to specimens in Herb. Kew.

4 Liber Fundamentorum Pharmacologia, ed. Seligmann, Vindobnuse, 1\$30. 40.

5 Lib. ii. tract. 2. c. 541. (V 156t. i. 357.$)$

o Sentheimer's transl, i. (1840) 132. 
of other species, as Plantago Psyllium L., and P. Cynops L., having similar properties, and known to have been used from an early period.

The Indian Ispaghíl attracted the notice of Europeans towards the close of the last century, ${ }^{1}$ and has been often prescribed as a demulcent in dysentery and diarrhœea. It was admitted to the Pharmacopceice of India of 1868.

Description-The seeds, like those of other species of Plantago, are of boat-shaped form, the albumen being deeply furrowed on one side and vaulted on the other. They are a little over $\frac{1}{10}$ of an inch in length and nearly half as broad, and so light that 100 weigh scarcely three grains. Their colour is a light pinkish grey with an elongated brown spot on the vaulted back, due to the embryo, which at this point is in close contact with the translucent testa. From this brown spot, the thick radicle runs to the top of the seed. The hollow side of the seed is also brown and partially covered with a thin white membrane.

The seeds are highly mucilaginous in the mouth, but have neither taste nor odour. Those of the allied P. Psyllium have nearly the same form, but are shining and of a dark brown hue.

Microscopic Structure-This can be best investigated by immersing the seed in benzol, as in this medium the mucilage is insoluble. When thus examined, the whole surface is seen to consist of polyhedral cells, separated by a very thin brown layer from the albumen, which on the back of the seed is only $70 \mathrm{mkm}$. thick. The albumen is made up of thick-walled cells, loaded with granules of matter which acquires an orange hue on addition of iodine. The two cotyledons arlhere in a direction perpendicular to the bottom of the furrow; their tissue is composed of thin-walled smaller cells, containing also albuminous granules and drops of fatty oil.

If the seed is immersed in water, the cells composing the epidermis instantly swell and elongate, and soon burst, leaving only fragments of their walls. When examined under glycerin, the change is more gradual, and the outer walls of the cells yielding the mucilage display a series of thin layers, which slowly swell and disappear by the action of water. The mucilage is consequently not contained within the cells, but is formed of the secondary deposits on their walls, as in linseed and quince pips.

Chemical Composition-Mucilage is so abundantly yielded by these seeds, that one part of them with 20 parts of water, forms a thick tasteless jelly. On addition of a larger quantity of water and filtering, but little mucilage passes, the greater part of it adhering to the seeds. The mucilage separated by straining with pressure, does not redden litınus, is not affected by iodine, nor precipitated by borax, alcohol or ferric chloride. The fat oil and albuminous natter of the seed, have not been examined.

Uses-A decoction of the seeds ( 1 p. to $70 \mathrm{p}$. of water) is employed in India as a cooling, demulcent drink. The seeds powdered and mixed with sugar, or made gelatinous with water, are sometimes given in
chronic diarrhoea.

1 J'leming, Calal. of Indian Med. Plonts and Druys, Calcutta, 1810. 31. 


\section{POIYGONACEA.}

\section{RADIX RHEI. \\ Rhubarb; F. Rhubarbe; G. Rhabarber.}

Botanical Origin-Rheum officinale Baillon, a perennial plant resembling the Common Garden Rihubarb, but of larger size. It differ's from the latter in several particulars: the leaves spring from a distinct crown rising some inches above the surface of the gronnd; they have a sub-cylindrical petiole, which as well as the veins of the under side of the lamina is covered with a pubescence of short crect hairs. The lamina, the outline of which is orbicular, cordate at the base, is shortly כ- to 7-lobed, with the lobes coarsely and irregularly dentate; it attains 4 to $4 \frac{1}{3}$ feet in length and rather more in breadth.

The plant was discovered in South-eustern Tibet, where it-is said to be often cultivated for the sake of its medicinal root; but it is supposed to grow in various parts of Western and North-western China, whence the supplies of rhubarb are derived. It was obtained by the French missionaries about the year 1867 for Dabry, French Consul at Hankow, who transmitted specimens to Soubeiran of Paris. From one of these which flowered at Montmorency in 1871, a botanical description was drawn up Baillon. ${ }^{1}$

Whether the rhubarb of commerce is derived exclusively from this plant is not known. But that the latter is a true source of the drug is supported by the fact, that there is at least no important discrepancy between it and the accounts and figures, scanty and imperfect thongh they are, given by Chinese authors and the old Jesuit missionaries; and still more by the agreement in structure which exists between its root and the Asiatic rhubarb of commerce. ${ }^{2}$

History-The Chinese appear to have been acquainted with the properties of rhubarb from a period long anterior to the Christian era, for the drug is treated of in the herbal called Pen-king, which is attributed to the Emperor Shen-nung, the father of Chinese agriculture and medicine, who reigned about 2700 B.c. ${ }^{3}$

As regards Western Asia and Europe, we find a root called $\dot{\rho} a ̂$ or $\hat{\rho}$ pov, mentioned by Dioscorides as brought from beyond the Bosphorus. The same drug is allucled to in the fourth century by Ammianus Marcellinus, ${ }^{4}$ who states that it takes its name from the river Rha (the modern Volga), on whose banks it grows. Pliny describes a root termed Rhacoma, which when pounded, yielded a colour like that of wine but inclining to saffron, and was brought from beyond Pontus.

The drug thus described, is usually regarded as rhubarb, or at least as the root of some species of Rhoum, but whether produced in the regions of the Euxime (Pontus), or merely received thence from remoter countries, is a question that cannot be solved.

${ }_{1}$ Adansonia, x. 246 ; Association Frangaise poncr l'avancement de la Ścience, Comptes Rendus de la $1^{\text {re }}$ Session, 1872. 514-529. pl. $x$.

2 We hare particularly examined the very large root of a plaut of $h^{2}$. officinale cultivated by one of us at Clapham Common near Lundon.

3 Bretschneider, Chiness Bolanical Horks, Foo:how, 1970.2.

+ Seriptures Historice tomance latini re. teres, ii (1it3) 511 (Amm. Marc. xaii. c. 3.) 
It is however certain that the name Radix pontica or Rha ponticum, used by sicribonius Largus ${ }^{1}$ and Celsus, ${ }^{2}$ was applied in allusion to the region whence the drug was received. Lassen has shown that trading caravans from Shensi in Northern China arrived at Bokliara as early as the year 114 B.c. Goods thus transported might reach Europe either by way of the Black Sea, or by conveyance down the Indus to the ancient port of Barbarike. Vincent suggests ${ }^{3}$ that the $r h a$ imported by the first route would naturally be termed rha-ponticum, while that brought by the second night be called rha-barbarnm.

We are not prepared to accept this plausible hypothesis. It receives no support from the author of the Periplus of the Erythrean Sea (circe A.D. 64), whose list of the exports of Barbarike ${ }^{4}$ does not include rhubarb: nor is rhubarb named among the articles on which duty was levied at the Roman custom-house of Alexandria (A.D. 176-180). ${ }^{5}$

The terms Rhcum barbarum vel barbaricum ol Reu barbarum occur in the writings of Alexander Trallianus ${ }^{6}$ about the middle of the 6 th century, and in those of Benedictus Crispus, ${ }^{7}$ archbishop of Milan, and Isidore $^{8}$ of Seville, who both flourished in the 7 th century. Among the Arabian writers on medicine, the younger Mesue, in the early part of the 11th century, mentions the rlubarb of China as superior to the Barbaric or Turkish. ${ }^{9}$ Constantinus Africanus ${ }^{10}$ about the same period, speaks of Indian and Pontic Rheum, the former of which he declares to be preforable.

Rhubarb in the 12 th century was probably inported from India, as we may infer from the tariff of duties levied at the port of Acon in Syria, in which document ${ }^{11}$ it is enumerated along with many Indian drugs. A sinilar list of A.D. 1271, relating to Barcelona, mentions Rubarbo. ${ }^{12}$ In a statute of the city of Pisa called the Breve Fundacariorum, dating 1305, rhubarb (ribarbari) is classified with commodities of the Levant and India. ${ }^{13}$

The first and almost the only European who has visited the rhubarbyielding countries of China, is the famous Venetian traveller, Marco Polo, ${ }^{14}$ who speaking of the province of Tangut says-" . . et par toutes les montagnes de ces provinces se treuve le reobarbe en grant habondance. Et illec l'achatent les marchans et le portent par le monde."

A sketch of the history of rhubarb would be incomplete without some reference to the various routes by which the drug has been conveyed to Europe from the western provinces of the Chinese Empire,

1 De Compositione Mcdicarnentorum, c. 167.

2 De Medicinâ, lib. v. c. 23.

3 Vincent, Commerce and Navigation of the Ancicuts, ii. (1807) 389.

4 Ihid., op? cit. ii. 390.

5 Ibid., op. eit. ii. 686 .

G Lib. viii. c. 3 (Haller's edition.)

7 Migne, Patrologice Cursus, Ixxxix. 37t.

8 Migne, op cit., lxxxii. 623 . The explanation given by Isidore is this :- "licubrr. barum, sive Reuponticum : illud quod trans Danubium in solo barbarico; istud quod circa Pontum colligitur, nominatum est. heu all. tem radix dicitur. Rcubarbam ergo, quasi radix barbara Rereponticum quasi radir. pontica." Put Isidne was fond of snch derivations.
9 Ravedsceni, Raved barbarum, and Raved Turclicum are the terms used in the Isatin translation we have consulted.

${ }_{10}$ De omnibus medico cognitu necessariis, Basil. 1539. 354 .

11 Assiscs dc Jérusalcm eontained in the Rcculeil des Historiens des Croisades, Lois, ii.
(1843) 176.

12 Capmany, Mcmorias de . . Bareelona, i. (1779) 44 .

13 Bonaini, Statuti incditi dclla città di Piss dal xii al xiv sccolo, iii. (Filenze, 1857)
106. 115.

14 Pauthier, Le Live de Marco Polo... rédigé en frangais sons sa dictéc en 1298 par Rusticien de Pise, i. (1865) 165. ii. 490 .'The ancient kingdom of Tangut is partially included in the modern province of Kansuh. 
and which have given rise to the fimniliar designations of Russiun, T'urkey and Chince lihuluerb.

The first route is that over the barren steppes of C'entral Asia by Yarkand, Kashyar, 'Turkestan, and the Caspian to Russia; the second by the Indus or the Persian Gull to the lied Sea and Alexandria, or by Persia to syria and Asia Minor; and the third by way of Canton, the only port of the Chinese Empire which previous to the year 1842, held direct commmnication with Furope.

In 165:3, China first permitted Russia to trade on her actual fronticr's. The traffic in Chinese goods wits therenpon diverted from the line of the Caspian and Black Sea finther north, taking its way from Tangut across the steppes of the ligh Gobi, and through Siberia by 'Tobulsk to Moscow. Thas it is mentioned in 1719, that Urga on the north edge of the Gobi desert, was the principal depôt for rhubarb. From the earliest times, Bncharian merchants appear to have been agents in this traffic, the producers of the drug never concerning themselves about its export.

Consequent on the rectitication of frontier in 1728, a line of customhonses was established by treaty between Russia and China, whereby the commerce, previously nnrestricted, was limited to the government caravans which passed the frontier only at Kiachta and at Zuruchaitu, south of Nerchinsk. The latter place always remained unimportant, while Kiachta and the opposite Chinese town of Maimatchin became the staple depôts of rhubarb.

The root was subjected to special control as early as 1687-1697 by the Russian Government, who finally monopolized the trade about 1704 . Caravans fitted out by the Crown, alone bronght the drug to Moscow, until 1762, when the caravan-trade was for a while thrown open. It was not until this period that the export of rhubarb became considerable, although the stringent regulations established in 1736, were still maintained. The surveillance of rhubarb was exercised at Kiachta in a special court or office called the Brake, ${ }^{1}$ under instructions from the liussian Minister of War, by an apothecary appointed for six years, the object being to remove from the rhubarb brought for inspection, all inferior or spurious pieces, and to improve the selected dring by trimming, paring and boring. It was then carefully dried, and packed in chests, which were sown up in linen and rendered impervions to wet, by being pitched and then covered with hide. The drug was dispatched, but only in quantities of 1000 muds $(40,000 \mathrm{Bb}$.), once a year by way of Lake Baikal and Irkntsk to Moscow, whence it was transmitted to St. Petersburg, to be there delivered to the Crown apothecaries and in part to be sold to druggists.

We are indebted for these accounts chiefly to Calau, ${ }^{2}$ an apothecary appointed to supervise the examination of rhubarb, and who resided a long time at Kiachta. An exact account of the remarkable policy of the Russian Govermment in relation to that drug, was also given by $T^{\top} \mathrm{on}$ Schröders ${ }^{3}$ in 1864.

So long as China kept all her ports closed to foreign commerce, except Canton in the extreme south, a large supply of fine rhubarb

1 From the German word Bracke, the name applied to persous appointed for the examination of merchandize brought to the ports of the Baltic.
2 Gruger's Rep. fiur Pharm. and Chcmie, 1842. 452-457; Pham. .Jonrn. ii. (1S43) 6.5. 3 Canstatt's Jahresbericht for 1564. i. $35-42$. 
found its way to Europe by way of Russia. But the unpleasant iccompaniments of the liussian supervision, which was exercised with unsparing severity, ${ }^{1}$ and the extreme tediousness of the land-transport, made the Clinese very ready to accept an easier ontlet for their goods. Accordingly we find that the opening of a number of ports in the north of China, exerted a very depressing influence on the trade of Kiachta, which was augmented by the rebellion that raged in the interior of China for some year's from 1852 .

On these accounts, Russia in 1855 removed certain restrictions on the trade, though without abandoning the Rhubarb Office. She withdrew in 1860, the custom-houses to Irkutsk, and declared Kiachta a free port, while by the treaty with China of November 1860, she insisted on that country abandoning all restrictions on trade.

But the over-land rhubarb trade had already been destroyed: the Chinese termpted by the increased demand occasioned by the new tradingports, became less careful in the collection and curing of the root, while the Russians insisted with the greatest strictness on the drug being of the accustomed quality. Hence it happened that from 1860, hardly any rhubarb was delivered at Kiachta, either for the government use or to private traders; and in 1863, the Rhubarb Office was abolished.

Thus, the so-called Russian or Muscovitic or Crown Rhubarb, fumiliarly known in England as Trurkey Rhubarb, a drug which for its uniformly good quality long enjoyed the highest repntation, has beconie a thing of the past, which can only now be found in museum collections. It began to appear in English commerce at the commencement of the last century. Alston, ${ }^{2}$ who lectured on botany and materia medica at Edinburgh in 1720 , speaks of rhubarb as brought from Turkey and the East Indies,- " and of late, likewise from Muscovy."

It has been shown (p. 443) that rhubarb was shipped from Syria in the 12 th century. Vasco da Gama ${ }^{3}$ mentions it in 1497, among the exports of Alexandria. In fact, the drug was carried from the far east to Persia, whence it was brought by caravans to Aleppo, Tripoli, Alexandria, and even to Smyma. From these Levant ports it reached Europe, and was distributed as Turkey Rhubarb; while that which was shipped direct from China, or by way of India, became known as China, Canton, or East India Rhubarb. The latter was already the more common sort in England as early as $1640 .^{4}$

As the rhubarb of the Levant disappeared from trade, that of Russia took not only its place but likewise its name, until the term "Turkey Rhubarb" cane to be the accepted designation of the drug imported from Riussia. This strange confusion of terms was not however prevalent on the Continent, but was chiefly limited to British trade.

The risk and expense of the enormous land-transport over almost the whole breadth of Asia, caused rhubarb in ancient times to be one of the very costly drugs. Thus at Alexandria in 1497, it was valued at twelve times the price of benzoin. In France in 1542,5 it was worth ten times as mucli as cinnamon, or more than four times the price of

1 Thus in 1860, the Russians compelled the Chinese to burn $6000 \mathrm{tb}$. of rhubarb, on the pretext that it was too small!

2 Lectures on the Mat. Med. i. (1770) 502.

- Rolevio da viagem ile Fresion da Game. par A. Helculano e o Barão de Castello de Paiva, ed. 2. Lisbon, 1861. 115.

4 l'arkinson, Theatrum Botanicum, 1640. 155 .

5 Taber, Appréeiation de la forlune mivée an troyen ruge, éd. 2. 1847. 308-9. 
saffiron. At Uhn in 1596,' it was more costly than opium. A German price-list of $1614,{ }^{2}$ shows Radix Rha Barbari to be six times as dear as fine myrrh, and more tham twice the price of opium. An official English list ${ }^{3}$ giving the price of drugs in 1657 , quotes opium as 6 s. per $1 \mathrm{~b}$., scammony $12 s$, and rhubarb $16 s$.

Production and Commerce-The districts of the Chinese Empire which produce rhubarb, extend over a vast area. They are comprised in the four northern provinces of China Proper, known as Chihli, Shansi, Shensi, ${ }^{4}$ and Honan; the immense north-western province of Kansul, formerly partly included in Shensi, but now extending across the desert of Gobi and to the frontiers of Tibet; the province of T'sing-hai inhabited by Mongols, which includes the great salt lake of Koko-nor and the districts of Tangut, Sifan, and Turfan; and lastly the mountains of the wester'n province of Szechuen. The plant is found on the pasturages of the high plateaux, growing particularly well on spots that have been enriched by encampments.

What little we further know regarding the production of rhubarls and its preparation for the market, is due partly to Chinese authorities and partly to Catholic missionaries, ${ }^{5}$ and is of a rather meagre and unsatisfactory character. The root is dug up at the beginning of autumn when the vegetation of the plant is on the decline, and the operation is probably continued for a few months, or in some districts for the whole winter. It is cleaned, its cortical part sliced off, and the root cut into pieces for drying. This is performed either by the aid of fire heat, or by simple exposure to sun and air, or the pieces are first partially dried on a hot stone, and them strung on a cord and suspended until the desiccation is complete.

Rhubarb is now purchased for the European market chiefly at Hankow on the upper Yaugtsze, whither it is brought from the provinces of Shensi, Kansuh, and Szechuen. From Hankow it is sent down to Shanghai, and there shipped for Europe. The exports from Hankow are thus stated in official documents. ${ }^{6}$

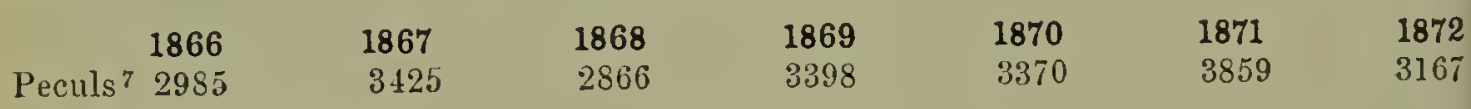

Much smaller quantities (55t peculs in 1872) are shipped from Tientsin; and there are occasional exportations from Canton, Anoy, and Foochow. The imports of rhubarb into the United Kingdom in 1870 , amounted to $343,306 \mathrm{lb}$., the estimated value of which was $£ 62,716 .^{8}$

Description-China Rhubarb as imported into Europe, ${ }^{9}$ consists of portions of a massive root which display considerable diversity of form,

1 Reichard, Beiträge zur Geseluichte der A pothekcn, Ulm, 1825. 208.

2 See 1. 177, note 3 .

9 Book of the Values of Derehanclize imported, aceording to which, Exeize is to be paid by the First Buyer, Lond. 1657.

4 According to Consul Hushes of Hankow, San-yuan in Shensi (north of Singanful) is one of the principal marts for rhubarb.

5 Farle in Pharm. Journ vii. (1866) 375 ; Chauveau, Vicar A prostolic of Tibet (1870) and Biet a French missionary both quoted by Collin in his thesis Des Fhubarbes, Paris, 1871. 22.24.

6 Reports on Trade at. the Treaty Ports of China for 1870; Commercial Reports from her Majesty's Consuls in China, 1872. No. 3. 1). 57 .

$7 \mathrm{l} \cdot$ pecul $=133 \mathrm{lt}$.

8 Annual Statement of the Trade and $\mathrm{Na}$. viyation of the Unitcd Kingdom for 1S70. 79.

9 It is now often trimmed by wholesale dinggists to simulate the old Russinn rhy. barb. 
arising from the various operations of paring, slicing and trimming, to which they have been subjected. Thus some pieces are cylindrical or rather bar'rel-shaped, other's conical, while a large proportion are planoconvex, and others again are of no regular shape. These forms are not all found in the same package, the drug being usually sorted into round and flat rhubarb. In dimensions we find 3 to 4 inches the commonest length, though an occasional piece 6 inches long or more, may be met with. 'The width may be stated at 2 to 3 inches. The outer surface of the root is somewhat shrivelled, often exhibiting portions of a dark bark that have not been pared away. Many pieces are pierced with a hole, in which may be found the remains of a cord used to suspend the root while drying. 'The drug is dusted over' with a bright brownish-yellow powder, on removal of which the outer side of the root is seen to have a rusty-brown hue, or viewed with a lens to be marked by the medullary rays, which appear as an infinity of short broken lines of deep brown, traversing a white ground.

The character which most readily distinguishes the rhubar'b of China, is that well-developed pieces, broken transversely, display these dark lines arranged as an internal ring of star-like spots. Although this character is by no means obvious in every piece of Chinese rhubarb, it is of some utility from the fact that in European rhubarb, such spots are generally wholly wanting, or at most occur only sparingly and in an isolated namner.

In jurging of rlubarb, great stress is laid upon the appearance of the root when broken, and the circumstance of the fractured surface presenting no symptoms of decay, discoloration, or sponginess. ${ }^{2}$. In good rhubarb, the interior is found to be compact, and beautifully veined with reddish-brown and white, sometimes not mumixed with iron-grey. The root when chewed tastes gritty, by reason of the crystals it contains of oxalate of calcium; but it is besides bitter, astringent and nauseous. The odour is peculiar, and except by the druggist, is mostly regarded as very disagreeable.

Microscopic Structure-The tissue of rhubarb is made up of a white parenchyme, brown medullary rays and a few irregularly scattered very large fibro-vascular bundles, which are devoid of ligneous cells.

On a transverse fracture of specimens, which are not too much peeled, a narrow dark cambial zone may be distinguished. In that part of the root, only the medullary rays display the usual radial arrangement, and in the interior of the root no regular structure is met with. There is no well-marked pith, but the central portion of the tissue shows a mixture of white parenchyme and brown medullary rays running in every direction. In full-grown roots, the central part is separated from the cambial zone by the band of stellate patches already mentioned.

As to the contents of the white cells, they are loaded either with starch or tufted crystals of oxalate of calcium, the amount of the latter being especially liable to variation. Scheele, after having discovered the oxalic acid, pointed out in 1784, that the crystals under notice consist

1 The quality and appearance of rhubarb are far more regarded in England than on the Continent. To insure a line powder of brilliant hue, the drug is most carefully prepared, each root being split open, and any dark or decayed portion removed with a chisel or file, while the operator is not allowed to handle the drug except with leather gloves. 
of that acid in eombination with lime. The medullary rays contain the substancus peculiar to rhubarb, lut none of them occur in a crystalline state.

Chemical Composition-The active constituent of the root las long been supposed to reside in the yellowish red contents of the inedullary rays. Sclirader as early as 1807 , prepared a Rluubarb-Bitter, to which he attributed the medicinal power's of the drug. Since then, several substances of the same kind have been separated by various methorls, and described under different names: such are the Rhabarkerstoff of 'T'rommsdorff, the Rileumin of Iornemam, the Rhabarberin of Buchner and Herberger, the Rhubarb-Yellow or Rheïn, and the Rhabarbic Acid of Brandes.

Schlossberger and Döpping in 1844, first recognized anong the abovenamed substances, a definite chemical body named Chrysoplean or Clerysophanic Acid, $\mathrm{C}^{14} \mathrm{H}^{8} \mathrm{O}^{4}$, which had been previously found by Rochleder and Heldt in the yellow lichen, Parmelia parietina. It partly forms the yellow contents of the medullary rays of rhubarb, and when isolated, crystallizes in golden yellow needles or in plates. It dissolves in ether, alcohol, or benzol; though scarcely soluble in water, it is nevertheless extracted from the root to some extent by that solvent, probably by reason of some accompanying substances. Alkalis dissolve it, forming fine dark red solutions.

By precipitating alcoholic solutions of extract of rhubarb with ether, Schlossberger and Döpping obtained together with chrysophan, three resinous bodies which they named Aporetin, Phooretin, and Errythroretin.

De la Rue and Miller (1857) extracted from rhubarb in addition to chrysophan, an allied substance, Emodin, which crystallizes in ornngecoloured prisms, sometimes as much as two inches long. Its conpuosition was found to agree with the formula $\mathrm{C}^{40} \mathrm{H}^{30} \mathrm{O}^{13}$.

The latest researches on this difficult subject are those of Kubly, who has obtained from rhubarb the following constituents:-

1. Rheo-tannic Acid, $\mathrm{C}^{26} \mathrm{H}^{26} \mathrm{O}^{14}$, a yellowish powder abundantly present in rhubarb, soluble in water or alcohol, not in ether. Its solutions produce blackish-green precipitates with persalts of iron, and greyish ones slowly turning blue, with protosalts of the same.

2. Rlucumic Acid (Rheumsäurc), $\mathrm{C}^{20} \mathrm{H}^{16} \mathrm{O}^{9}$, obtained as a reddishbrown powder, by boiling rheo-tannic acid with a dilute mineral acid, a fermentable sugar being developed at the same time. Rheumic acid exhibits nearly the same reactions as rheo-tamnic acid, but is very sparingly soluble in cold water. It partly pre-exists in rhubarb.

3. Nentral colourless substance, sparingly soluble in hot water, and separating from the latter in prismatic crystals of the formula $\mathrm{C}^{10} \mathrm{H}^{12} \mathrm{O}^{4}$; no name has yet been given to it.

4. Phooretin, $\mathrm{C}^{16} \mathrm{H}^{16} \mathrm{O}^{7}$, agreeing with the substance thus named by Schlossberger and 10öpping. It is a brown powder, soluble in alcohol or in acetic acid, but not in ether, chloroform or water.

5. Chrysophan, described above; it agrees in composition with Alizarin.

A pectic matter, which abounds in rhubarb, has not yet been satisfactorily examined. As to the mineral constituents, their amount is

1 Pharm. Zcitschrift.f. Russland, vi. (1867) 603-627; abstract in Wiggers and Husemann's Jahresbericht for $186 \%$. 40 . 
exceedingly variable. Two samples of good China Rhubarb dried at $100^{\circ} \mathrm{C}$. and incinerated, yielded respectively 12.9 and 13.87 per cent of ash. Another sample which we had particularly selected on account of its pale tint, afforded no less than 43.27 per cent. of ash. The ash consists of carbonates of calcium and potassium. English rhubarb from Banbury (portions of a large specimen) left after incineration 10.90 per cent. of ash.

From a practical point of view the chemical history of rhubarb is far from satisfactory, for we are still ignorant to what principle the drug owes its therapeutic value, or what the pharmaceutical preparations in which the active matter may be most appropriately exhibited. Chrysophan is said to act as a purgative, but less powerfully than rhubarb itself.

Uses-Rhubarb is one of the commonest and most valuable purgatives; it is also taken as a stomachic and tonic.

Substitutes-These are found in the roots of the various species of Rherm, cultivated in Europe. In most countries, the cultivation of rhubarb for medicinal use has at some time been attempted. Yet in but few instances has it been persistently carried on; and though the drug produced has often been of good appearance and by no means devoid of the characteristic properties of Asiatic rhubarb, it has failed to gain the confidence of medical men, and to acquire much importance in the drug-market.

These results are doubtless owing in large measure to the species of Rheum cultivated, which has never been that which yields the finest Chinese rhubarb. Now that the true kind has been obtained, a much greater success may be anticipated. ${ }^{1}$ The European rhubarb most interesting from our point of view is

English Rhubarb-So early as 1535, Andrew Boorde, an English Carthusian monk and practitioner of medicine, obtained seeds of rhubarb, which he sent as " a grett tresure" to Sir Thomas Cromwell, Secretary of State to Henry VIII.; but as he says they "come owtt of barbary," we must be allowed to hold their genuineness as doubtful. ${ }^{2}$

In the following century, namely about the year 1608, Prosper Alpinus of Padua cultivated as the True Rhubarb, a plant which is now linown as Rheum Rhaponticum L., a native of Southern Siberia and the regions of the Volga. ${ }^{3}$ From this stock, Sir Matthew Lister, physician to Charles I, procured seeds when in Italy, and gave them to Parkinson, ${ }^{4}$ who raised plants from them.

Collinson obtained rhubarb plants from seeds procured in Tartary, and sent to him in 1742, by Professor Siegesbeck of St. Petersburg. ${ }^{5}$

About 1777, Hayward, an apothecary of Banbury in Oxfordshire, commenced the cultivation of rhubarb, with plants of Rh. Rhaponticum, raised from seeds sent from Russia in 1762. The drug he produced was so good that the Society of Arts awarded him in 1789, a silver medal and in 1794 a gold medal. ${ }^{\circ}$ The Society also awarded medals about the same time (1789-1793) to growers of rhubarb in Somersetshire, Iorkshire

1 Mr. Usher of Bodieott near Banbury has already (1873) eommenced the cultivation of Rhcum officinale Baillon.

2 Boorde's Introduction and Dyctary, reprinted by the Early English Text Socicty,
1870. 56 .
3 Prosper Alpinus, De Rhapontico, Lugd. Bat. 1718

4heatrum Botanicum, 1640. 157.

5 Dillwyn, Hortus Collinsonianus, 1843. 45.

6 Trans. of Soc. of Arts, viii. (1790) 75 ; xii. (1794) 225. 
and Middlesex, some of whom, it appears, cultivated $R /$. palmatum. On the deatl of Hayward in 1811, his rhubarb plants came into the possession of Mr. P. Usher, by whose descendants, Mr. R. Usher and sons, they are still cultivated at Bodicott, a village near Banbury.

We had the plensure of inspecting the rhubarb fields of Messis. Usher on Sept. 4. 1872, and of seeing the whole process of preparing the root for the market. ${ }^{1}$ The land under cultivation is about 17 acres, the soil being a rich friable loam. The roots are taken from the ground during the autumn up to the month of November. It is considered advantageous that they should be 6 or 7 years old, but they are seldom allowed to attain more than 3 or 4 years. The clumps of root as removed from the ficld to the yard, where the trimming takes place, are of huge size, weighing with the earth attached to them, as much as 60 or $70 \mathrm{Ht}$. They are partially cleaned, the smaller roots are cut off, and the large central portion is rapidly trimmed into a short, cylindrical mass the size of a child's head. This latter subsequently undergoes a still further paring, and is finally shiced longitudinally; the other and loss valuable roots are also pared, trimmed, and assorted according to size. The fresh roots are fleshy, easily cut, and of a beautiful deep yellow. All are dried in buildings constructed for the purpose and heated by flues. The drying occupies several weeks. The root after drying has a shrivelled, unsightly appearance, which may be remedied by paring and filing. The finished drug has to be stored in a warm dry place.

When well prepared, Banbury rhubarb is of excellent appearance. The finest pieces, which are semi-cylindrical, are quite equal in size to the drug of China. The colour is as good, and the fractured surface exhibits pink markings not less distinct and brilliant. Even the smaller roots which are dried as sticks, have internally a good colour and afford a fine powder. But the odour is somewhat different from that of Chinese rhubarb; the taste is less bitter but more mucilaginous and astringent, and the root is of a more spongy, soft, and brittle texture. The structure is the same as that of the Chinese rhubarb, except that, as already stated, the star-like spots, if present, are isolated, and not arranged in a regular zone.

The drug commands but a low price, and is chiefly sold, it is said, for exportation in the state of powder. It is not easily purchased in London.

French and German Rhubarb-The cultivation of rhubarb was commenced in France in the latter half of the last century, and has been pursued with some enthusiasm in various localities. The species grown were Rhcum palmatum L., Rh. undulatum L., Rh. compactum L. and Rh. Rhaponticum L. The first was thought by Guibourt" to afford a root more nearly approaching than any other, the rhubarb of China; but it is that which is cultivated the least readily, the central root being liable to premature decay. Both this plant and $R h$. undulatum, were formerly cultivated by order of the Russian Government on a large scale at Kolywan and Krasnojarsk in Southern Siberia, but the culture has, we believe, been long abandoned. ${ }^{3}$

1 No nse is made of the leaves.

2 Mistoire des Drogues, ii. (1849) 398.

3 T'welve ehests of this rhubarb said to be of the erop of 1793 , which liad been lying in the Russian Goverument warehouses, were

offered for sale in London, Dec. 1, 1853. Samples of the drug now 80 years old, are in my possession and still sound and good. $-\mathrm{D} . \mathrm{H}$. 
As to France, it appears from inquiries we have lately made (1873), that except in the neighbourhood of Avignon and in a few other scattered localities, the cultivation has now ceased.

Rherm Rhaponticum is the source of the rhubarb which is produced at Austerlitz and Auspitz in Moravia, and at Ilmitz, Kremnitz and Frauenkirchen in Hungary. Some rhubarb is also produced in Silesia from Rh. Emodi Wall. (R/. australe Don.)

\section{MYRISTICEAE.}

\section{Y R I S T I C A.}

Nuclei Mryristice, Semen Mypistice, Nux moschata; Nutmeg; F. Muscade, Noix de Muscade; G. Muskatnuss.

Botanical Origin-Myristica fragrans Houttuyn ( $M$. moschatce Thunb., M. officinclis Linn. f.), a handsome, bushy, evergreen tree, with dark shining leaves, growing in its native islands to a height of 40 to 50 feet. It is found wild in Jilolo, Ceram, Amboyna, Bouro, the western peninsula of New Guinea, and in many of the adjacent islands, including the very small volcanic group of Banda, south of Ceram; but it is not indigenons to any of the islands westward of these, or to the Philippines (Crawfurd).

The nutmeg-tree has been introduced into Bencoolen on the west coast of Sumatra, Malacca, Bengal, the islands of Singapore and Penang, as well as Brazil and the West Indies; but it is only in a very few localities that the cultivation has been attended with success.

In its native countries, the tree comes into bearing in its ninth year, and is said to continue fruitful until 60 or even 80 years old, yielding annually as many as 2000 fruits. It is diocious, and one male tree furnishes pollen sufficient for twenty female.

History-It has been generally believed that neither the nutmeg nor mace was known to the ancients. C. F. Ph. von Martius ${ }^{1}$ however maintains that mace was alluded to in the comedies of Plautus, ${ }^{2}$ written about two centuries before the Christian era.

The words Macer, Macar, Machir or Macir, occurring in the writings of Scribonius Largus, Dioscorides, Galen, and Pliny are thought by Von Martius to refer in each instance to mace. But that the substance designated by these names was not mace, but the bark of a tree growing in Malabar, was pointed out by Acosta nearly three centuries ago, and by niany subsequent writers, and as we think, with perfect correctness. ${ }^{3}$

Nutmegs and mace were imported from India at an early date by the Arabians, and thus passed into western countries. Aëtius, who was resident at the court of Constantinople about the year 540, appears to have been acquainted with the nutmeg, if that at least is intended by the term Nuces Indicce, prescribed together with cloves, spikenard, costus, calamus aromaticus and sandal wood, as an ingredient of the Sruffumiginum

1 Flora Erasilicnsis, fasc. 11-12. 133 ; also in Buchner's licpertorium für Pharmacie, ix. (1860) 529-538.

2 Pscudolus, act. iii. scena 2.

3 Mérat et Do Lens, Dict. de Mal. Mécl.

${ }^{4}$ Aëtius,'tetrabiblos iv.serm. 4. c. 122. - It must however be admitted that Nux Indica in medixval authors usually signifies the Coco-nut. 
Masudi ${ }^{1}$ who appears to have visited India in A.D. 916-920, pointed out that the nutmeg, like cloves, areca nut and sandal wood, was a product of the eastern islands of the Indian Archipelago. The Arabian geographer Edrisi, who wrote in the middle of the 12th century, mentions both nutmegs and mace as articles of import into Aden; ${ }^{2}$ and again "Nois mouscades" are among the spices on which duty was levied at Acre in Palestine, circa A.D. $1180 .^{3}$ About a century later, anothes: Arabian author, Kazwini, ${ }^{4}$ expressly named the Moluccas as the native country of the spices under notice.

One of the earliest references to the use of nutmegs in Europe, occurs in a poem written about 1195 , by Petrus d'Ebulo ${ }^{5}$ describing the entry into Rome of the Emperor Henry VI., prior to his coronation in April, 1191. On this occasion, the streets were fumigated with aromatics, which are enumerated in the following line:-

"Balsama, thus, aloë, myristica, cynnama, nardus."

By the end of the 12th century, both nutmegs and mace were found in Northern Europe,- - even in Denrnark, as may be inferred from the allusion to them in the writings of Harpestreng. ${ }^{6}$ In England, mace though well known, was a very costly spice, its value between A.D. 1284 and 1377 being about $4 s$. $7 d$. per $1 \mathrm{~b}$, while the average price of a sheep during the same period was but $1 s, 5 d$., and of a cow $9 s$. $5 d .{ }^{7}$ It was also dear in France, for in the Compte de l'cxécution of the will of Jeanne $d^{\prime}$ Evreux, queen of France, in 1372, six ounces of mace are appraised per ounce; at 3 sols 8 deniers, equal to about $8 s$. $3 d$. of our present money.

The use of these spices was diffused throughout Europe long before the Portuguese in 1512 had discovered the mother-plant in the isles of Banda. The Portuguese held the trade of the Spice Islands for about a century, when it was wrested from them by the Dutch, who pursued the same policy of exclusiveness that they had followed in the case of cloves and cinnamon. In order to secure their monopoly, they endeavoured to limit the trees to Banda and Amboyna, and to exterminate them elsewhere, which in fact they did at Ceram and the small neighbouring islands of Kelang and Nila. So completely was the spice trade in their hands, that the crops of sixteen years were said to be at one time in their warehouses, those of recent years being never thrown on the market. Thus the crop of 1744 was being sold in 1760 , in which year an immense quantity of nutmegs and cloves was burned at Amsterdam lest the price should fail too low. ${ }^{9}$

During the occupation of the Spice Islands by the English from 1796 to 1802, the culture of the nutmeg was introduced into Bencoolen

1 Les Prairics d'or, i. (1861) 341.

2 Géographic, trad. par Jaubert, i. (1836)

51.

3 In the work quoted at p. 250 , note 8 .

4 Kosmographic, ubersetzt von Ethé, i. (1869) 227.

5 Carmen de motibus siculis, Basil., 1746. 23. - A new edition of this work by Prof. Winklemann is now (1874) in the press.

- Danslic Lacgebog, quoted by Meyer, Gcsehichte dcr Botanik, iii. (1856) 537.

7 Rosers, Ilist. of Agriculture and Prices in England, i. (1866) 361-362. 628. - It is remarkable that uutmegs are not nientioned, though macc is named repeatedly.

8 Leber, Appréciation dc la fortune privé au mousu âgc, éd. 2, 1847. 95.

9 Valmont de Bomare, Dict. d'Histoirc Nat. iv. (1775) 297.-This anthor writes as an eye-witness of the destruction he has recorded:-“Le 10 Juin 1760, j'en ai vu à Amsterdam, près de l'Amirauté, un feu dont l'aliment étoit estimé huit millions argent do France: on devoit en bruler autant le lendemain. Ises pieds des speetateurs baignoient dans l'huile essentielle de ees substances ..." 
and Penang, and many years afterwards into Singapore. Extensive plantations of nutmeg-trees were formed in the two islands last named, and by a laborious and costly system of cultivation were for many years highly productive. ${ }^{2}$ In 1860 , the trees were visited by a destructive blight which the cultivators were powerless to arrest, and which ultimately ${ }_{\text {er }}^{*}$ led to the ruin of the plantations, so that in 1867 , there was no such thing as nutmeg cultivation either in Penang or Singapore. ${ }^{3}$

Though so long valued in Europe and Asia, neither nutmegs nor mace are ever employed as a condiment in the islands where they are indigenous. ${ }^{4}$

Collection and Preparation-Almost the whole surface of the Banda Isles, observes Mr. Wallace, ${ }^{5}$ is planted with nutmeg-trees, which thrive under the shade of the lofty Canarium commune. The light volcanic soil, the shade, and the excessive moisture of these islands, where it rains more or less every month in the year, seem exactly to suit the nutmeg-tree, which requires no manure and scarcely any attention.

In Bencoolen, ${ }^{6}$ the trees bear all the year round, but the chief harvest takes place in the later months of the year, and a smaller one in April, May and June. The fruit as it splits, is gathered by means of a hook attached to a long stick, the pericarp removed, and the mace carefully stripped off. The nuts are then taken to the drying house (a brick building), placed on frames, and exposed to the gentle heat of a smouldering fire, with arrangements for a proper circulation of air. This drying operation lasts for two months, during which time the nutmegs are turned every second or third day. At the end of this period, the kernels are found to rattle in the shell, an indication that the drying is complete. The shells are then broken with a wooden mallet, the nutmegs picked out and sorted, and finally rubbed over with dry sifted lime. In Banda the smaller and less sightly nutmegs are reserved for the preparation of the expressed oil.

The old commercial policy of the Dutch originated the singular practice of breaking the shell, and immersing the kernel of the artificially dried seed in milk of lime, - sometimes for a period of three months. This was done with a view to render impossible the germination of any nutmegs sent into the market. The folly of such a proceeding was demonstrated by Teijsmann, who proved that mere exposure to the sun for a week is sufficient to destroy the vitality of the seed. By immersion in milk of lime, many nutmegs are spoiled and the necessity is incurred of a second drying. Lumsdaine has also shown that even the $d r y$ liming process is, to say the least, entirely needless.

1 How tempting the enltivation must have appeared, may be julged from the priee of maee, which we find quoted on the 3 January, 1806, in the London Pricc Current (which gives only import prices), as $85 \mathrm{~s}$. to 90s. per tb. ; - to these rates must be added the duty of $7 \mathrm{~s} .1 \mathrm{l}$. per $1 \mathrm{~b}$.

2 Seemann, Hooker's Journ. of Bot. iv. (185,2) 83.

${ }^{3}$ Collingwood in Journ. of Linnean Society, Bot., x. (1869) 45.
4 Crawfurd, Dictionary of the Indian Islands, 1856. 304.-Mueh additional information will be found in this work.

5 The Malay Arehipclago, i. (1869) 452.See also Biekmore, Travels in the East Indian Arehipelago, 1868. 225.

- Lumsdaine, Pharm. Journ. xi. (1852) 516. For further information on the management of nutmeg plantations in Simatra, consult the original paper. 
Nutmegs are well preserved in their natural shell, in which state the Clinese have the good sense to prefer them.

The process of liming nutmegs is however still largely followed; and the prejudice in favour of the spice thus prepared is so strong in certain countries, that nutmegs not limed abroad, have sometimes to be limed in London to fit them for exportation. Penang nutmegs are always imported in the natural state,- that is, un-limed.

Description-The fruit of Myristiea fragrans is a pendulous, globose drupe, about 2 inches in diameter, and not unlike a small round pear. It is marked by a furrow which passes round it, and by which at maturity its thick fleshy pericarp splits into two pieces, exhibiting in its interior a single seed, enveloped in a fleshy foliaceous mantle or arillus, of fine crimson hue, which is maee. The dark brown, shining, ovate seed is marked with impressions corresponding to the lobes of the arillus; and on one side, which is of paler hue and slightly flattened, a line indicating the raphe may be observed.

The bony testa does not find its way into European commerce, the so-called nutmeg being merely the kernel or nucleus of the seed. Nutmegs exhibit nearly the form of their outer shell with a corresponding diminution in size. The London dealers esteem them in proportion to their size, the largest which are about one inch long by $\frac{8}{10}$ of an incl broad, and four of which will weigh an ounce, fetching the highest price. If not dressed with lime, they are of a greyish brown, smooth yet coarsely furrowed and veined longitudinally, marked on the flatter side with a shallow groove. A transverse section shows that the inner seed coat (endopleura) penetrates into the albumen in long, narrow brown strips, reaching the centre of the seed, thereby imparting the peculiar marbled appearance familiar in a cut nutmeg.

At the base of the albumen and close to the hilum, is the embryo, formed of a short radicle with cup-shaped cotyledons, whose slit and curled edges penetrate into the albumen. The tissue of the seed can be cut with equal facility in any direction. It is extremely oily, and has a delicious aromatic fragrance, with a spicy rather acrid taste.

Microscopic Structure-The testa consists mainly of long, thin, radially arranged, rigid cells, which are closely interlaced and do not exhibit any.distinct cavities. The endopleura which forms the adhering coat of the kernel and penetrates into it, consists of soft-walled, redbrown tissue, with small scattered bundles of vessels. In the outer layers the endopleura exhibits small collapsed cells; but the tissue which fills the folds that dip into the interior, consists of much larger cells. The tissue of the albumen is formed of soft-walled parenchyme, which is densely filled with conspicuous starch-grains, and with fat, partly crystallized. Among the prismatic crystals of fat, large thick rhombic or six-sided tables may often be observed. Witl these are associated grains of albuminoid matter.

Chemical Composition-After starch and albuminoid matter, the principal constituent of nutmeg is the fat, which makes up about a fourt.ly of its weight, and is known in commerce by the incorrect name of 0 il of Mace (see p. 456).

The volatile oil, to which the smell and taste of nutmegs are chiefly 
due, amounts to between 2 and 3 per cent, ${ }^{1}$ and consists, according to Cloëz (1864), almost entirely of a hydrocarbon, $\mathrm{C}^{10} \mathrm{H}^{16}$, boiling at $165^{\circ} \mathrm{C}$., which Gladstone ${ }^{2}$ who assigus it the same composition, calls Myristiccne. The latter chemist found in the crude oil, an oxygenated oil, Myristicol, of very difficult purification and possibly subject to change during the process of rectifying. It has a high boiling point (about $220^{\circ} \mathrm{C}$. ?) and the characteristic odour of nutmeg; unlike carvol and menthol with which it is isomeric, it does not form a crystalline compound with hydrosulphuric acid.

Oil of nutmegs, distilled in London by Messrs. Herrings and Co., examined in a column $200 \mathrm{~mm}$. long, we found to deviate the ray of polarized light, $15^{\circ} \cdot 3$ to the right; that of the Long Nutmeg (Myristica fatuc Houtt.), furnished to us by the same firm, deviated $28^{\circ} \cdot 7$ to the right.

From the facts recorded by Gmelin, ${ }^{3}$ it would appear that oil of nutmeg sometimes deposits a stearoptene called Myristicin. We are not acquainted with such a deposit; yet we have been kindly furnished by Messrs. Herrings with a crystalline substance which they obtained during the latter part of the process of distilling both common and long nutmegs. It is a greyish greasy mass, which by repeated crystallizations from spirit of wine, we obtained in the form of brilliant, colourless scales, fusible at $54^{\circ} \mathrm{C}$, and still possessing the odour of nutmeg. The crystals are readily soluble in benzol, bisulphide of carbon or chloroform, sparingly in petroleum ether; their solution in spirit of wine has a decidedly acid reaction, and is devoid of rotatory power. By boiling them with alcohol, sp. gr. $0 \cdot 843$, and anhydrous carbonate of sodium, we obtained a solution which after removal of the alcohol, left a residuum perfectly soluble in boiling water, forming a jelly on cooling. By adding hydrochloric acid to the warm aqueous solution, the original crystallizable substance again made its appearance, yet almost devoid of odour. It is in fact nothing else than Myristic Acid (see next page).

Production and Commerce-The nutmegs and mace now brought into the market are to a large extent the produce of the Banda Islands, ${ }^{4}$ of which however only three, namely Lontar or the Great Banda, Pulo Ai, and Pulo Nera, have what are termed Nutmeg Parks. According to official statements of the Dutch, the first-named island possessed in 1864 , about 266,000 fruit-bearing trees ; Ternate on the western coast of Jilolo, 46,000; Menado in the island of Celebes, 35,000, and Amboyna, only 31,000. The nutmegs of the Banda Islands are shipped to Batavia. The quantity exported from Java in 1871 (all, we believe, from Batavia, and therefore the produce of the Banda Islands) is stated as 8107 peculs $(1,080,933 \mathrm{fb}$.), of which 2300 peculs $(306,666 \mathrm{ft}$.) were shipped to the United States, and a rather larger quantity to Singapore. ${ }^{5}$ The lastnamed port also shipped in the same year a very large quantity $\left(310,576 \mathrm{1b}\right.$.) of nutmegs to North America. ${ }^{6}$

I Messrs. Herrings \& Co. of London have informed us, that $2874 \mathrm{tb}$. of nutmegs distilled in their laboratory, afforded $67 \mathrm{lb}$. of essential oil, i.e. $2 \cdot 33$ per cent.

2 Journ. of C'hemical Soc. x. (1872) i.

3 Chemistry, xiv. (1860) 389.

4 Some idea of tho extremely small area of these famous islands may be gathered from the fact that the Great Banda, the largest of them, is but about 7 miles long by 2 miles broad; while the entire group occupies no more than $17^{\circ} 6$ geographical square iniles.

5 Consular Reports, August 1873. 952-3.

(i) Blue Book for the Colony of the Straits Settlements for 1871, Singapore, 1872. 
Nutmegs were exported from Padang in Sumatra in the year 1871, to the extent of 2766 peculs $(368,800 \mathrm{tb}$.), chiefly to America and Singapore. The quantity imported into the United Kingdom in 1870 , was $537,978 \mathrm{tb}$.

Uses-Nutmeg is a grateful aromatic stimulant, chiefly employed for flavouring other medicines. It is also in constant use as a condiment, though less appreciated than formerly.

\section{Oleum Myristicæ expressum.}

Olcum Macidis ; Balsamum vcl Olcum Nucista ; Expresscd Oil of Nutmogs, Nutmeg Butter, Oil of Macc; F. Bcurre de Muscadc; G. Mustcatbutter, Muskatnussöl.

This article reaches England chiefly from Singapore, in oblong, rectangular blocks, about 10 inches long by $2 \frac{1}{2}$ inches square, enveloped in a wrapper of palm leaves. It is a solid unctuous substance of an orange-brown colour, varying in intensity of shade, and presenting a mottled aspect. It has a very agreeable odour and a fatty aromatic taste.

In operating on $2 \mathrm{lb}$. of nutmegs, first powdered and heated in a waterbath and pressed while still hot, we obtained 9 ounces of solid oil, equivalent to 28 per cent. This oil, which in colour, odour and consistence does not differ from that which is imported, melts at about $45^{\circ} \mathrm{C}$.; and dissolves perfectly in two parts of warm ether or in four of warm alcohol sp. gr. $\cdot 800$.

Nutmeg butter contains the volatile oil already described, to the extent of about 6 per cent., besides several fatty bodies. One of the latter, termed Myristin, $\mathrm{C}^{45} \mathrm{H}^{86} \mathrm{O}^{6}$, may be obtained by means of benzol, or by dissolving in ether that part of the butter of nutmeg which is insoluble in cold spirit of wine. The crystals of myristin melt, according to Playfair (1841), at $31^{\circ} \mathrm{C}$. By saponification, they furnish glycerin, and Myristic Acid, $\mathrm{C}^{14} \mathrm{H}^{28} \mathrm{O}^{2}$, the latter fusing at $53^{\circ} .8 \mathrm{C} .^{1}$ Myristin also occurs in spermaceti as well as, according to Mulder, in small quantity, in the fixed oils of linseed and poppy seed. Nutmegs according to Comar (1859) yield 10 to 12 per cent. of myristin.

That part of nutmeg butter, which is more readily soluble in spirit of wine or benzol, contains another fat, which however has not yet been investigated. It is accompanied by a reddish colouring matter.

\section{MACIS.}

Macc; F. Macis; G. Macis, Muskatblüthc.

Botanical Origin-Myristica fragrans Houttuyn (see p. 451). The seed which deprived of its hard outer shell or testa, is known as the nutmcg, is enclosed when fresh in a fleshy net-like envelope, somewhat resembling the husk of a filbert. This organ which is united though not very closely, at the base of the stony shell both with the hilum and the contiguous portion of the raphe, of which parts it is an expansion, is termed arillus, ${ }^{2}$ and when separated and dried, constitutes the mace of

^ Gmelin, Chemistry, xvi. (1864) 209.

sec Baillon, Ifist. des Plantes, ii. (1870)

2 On the nature and origin of this organ, 199. 
the shops. In the fresh state it is fleshy, and of a beautiful crimson; it envelopes the seed completely only at the base, afterwards dividing itself into broad flat lobes, which branch into narrower strips overlapping one another towards the summit.

History-Included in that of the mutmeg (see preceding article).

Description-The mace separated from the seed by hand, is dried in the sun, thereby losing its brilliant red hue and acquiring an orangebrown colour. It has a dull fatty lustre, exudes oil when pressed with the nail, and is horny, brittle and translucent. Steeped in water it swells rather considerably. The entire arillus compressed and crumpled by packing, is about $1 \frac{8}{4}$ inches long with a general thickness of about $\frac{1}{20}$ of an inch or even $\frac{1}{10}$ at the base. Mace has an agreeable aromatic smell nearly resembling that of nutmeg, and a pungent, spicy, rather acrid taste.

Microscopic Structure-The uniform, small-celled, angular parenchyme, is interrupted by numerous brown oil-cells of larger size. The inner part of the tissue contains also thin brown vascular bundles. The cells of the epidermis on either side are colourless, thick-walled, longitudinally extended, and covered with a peculiar cuticle of broad, flat, riband-like cells, which cannot however be remored as a continuous film. The parenchyme is loaded with small granules, to which a red colour is imparted by Millon's test (solution of mercurous nitrate) and an orange hue by iodine. The granules consequently consist of albuminous matter, and starch is altogether wanting.

Chemical Composition-The nature of the cliemical constituents of mace may be inferred from the following experiments performed by one of us:-17 grammes of finely powdered mace were entirely exhausted by boiling ether, and the latter allowed to evaporate. It left behind $5.57 \mathrm{grm}$., which after drying at $100^{\circ} \mathrm{C}$. were diminished to 4.17 . The difference, 1.40 grammes, answers to the amount of essenticll oil, of which consequently 8.2 per cent. had been present.

The residue, amounting to 24.5 per cent., was a thickish aromatic balsam, in which we have not been able to ascertain the presence of fat; it consisted of resin and semi-resinified essential oil. Alcohol further removed 14 per cent. of an uncrystallizable sugar, which reduced cupric oxide.

The drug having been thus treated with ether and with alcohol, yielded almost nothing to cold water, but by means of boiling water $1 \cdot 8$ per cent. of a mucilage was obtained, which turned blue by addition of iodine, or reddish violet if previously dried. This substance is not soluble in an ammoniacal solution of cupric oxide; it appears rather to be an intermediate body between mucilage and starch." ${ }^{-}$The composition of mace is therefore very different from that of nutmeg.

As to the volatile oil, of which several observers have obtained from 7 to 9 per cent., ${ }^{2}$ it is a fragrant colourless liquid which we found, when examined in a column $200 \mathrm{~mm}$. long, deviated the ray $18^{\circ} .8$ to the right. Its greater portion consists according to Schacht (1862) of Macene, $\mathrm{C}^{10} \mathrm{H}^{16}$, a hydrocarbon boiling at $160^{\circ} \mathrm{C}$, and distinguished from oil of

1 See my paper: Ueber Stürle und Cellulose in Archiv der Pharm. 196 (1871) 31.-
2 In an actual experiment (1868) in the laboratory of Messrs. Herrings \& Co., London, $23 \mathrm{tb}$ of mace yielded 23 ozs. of volatile oil, whieh is equivalent to $6 \frac{1}{4}$ per cent. 
turpentine by not forming a crystalline hydrate when mixed with alcohol and nitric acid. Koller (1.865) states that macene is identical with the hydrocarbon of oil of nutmeg (myristicene), yet the latter is said by Cloëz to yield no solid compound when treated with hydrochloric gas. Macene on the other hand furnishes crystals of $\mathrm{C}^{10} \mathrm{H}^{16}, \mathrm{HCl}$. Crude oil of mace contains like that of nutmeg, an oxygenated oil, the properties of which appear to have been not yet investigated.

Commerce-Mace, mostly the produce as it would appear of the Banda Islands, was shipped from Java in 1871, to the extent of 2101 peculs $(282,133 \mathrm{Hb}$.) ; and from Padang in Sumatra (excluding shipments to Java) to the amount of 457 peculs $\left(60,933 \mathrm{lb}\right.$.). ${ }^{1}$ 'The spice is exported principally to Holland, Singapore, and the United States.

Uses-Mace is but rarely employed in medicine. It is chiefly consumed as a condiment.

\section{LAURACEAE.}

\section{A M P H O R A.}

\section{Camphor, ${ }^{2}$ Common Camphor, Laurel Camphor; F. Camphre;} G. Campher.

Botanical Origin-Cinnamomum Camphora Fr. Nees et Ebermaier (Laurus Camphora L., Camphora officinarum C. Bauh.), the Camphor tree or Camphor Laurel, is widely diffused, being found throughout Central China and in the Japanese Islands. In China, it abounds principally in the eastern and central provinces, as in Chekiang, Fokien and Kiangsi. It is likewise plentiful in the island of Formosa, where it covers the whole line of mountains from north to south, up to an elevation of 2000 feet above the level of the sea. It flourishes in tropical and subtropical countries, and forms a large and handsome tree in sheltered spots in Italy as far north as the Lago Maggiore. The leaves are small, shining, and glaucous beneath, and have long petioles; the stem affords excellent timber, much prized on account of its odour for making clothes' chests and the drawers of cabinets.

Camphor is obtained from other plants besides the camphor laurel, the most remarkable being Dryobalanops aromatica, a noble tree of the Indian Archipelago, further described at p. 464.

History-The two kinds of camphor afforded by the two trees just named, have always been regarded by the Chinese as perfectly distinct substances, and in considering the history of camphor this fact must be borme in mind.

On perusing the accounts of Laurel Camphor given by Chinese writers ${ }^{3}$ the remarkable fact becomes apparent, that although the tree was evidently well known in the 6th century, and probably even earlier,

1 Consular Reports, August 1873. 952-3.

2 The word Camphor, generally written by old Latin authors Caphura, and by English Comphire, is derived from the Arabie $K a$ far, whiel in turn is supposed to come from the Sanskrit Karpurc, signifying white.
3 Passages from several have been translated and kindly plaeed at our disposal by Mr. A. Wylie. Dr. Bretsehneider of Pekin has also been good enough to aid us in the same mauner. 
and is specially noticed on account of its valuable timber, no mention is made in connexion with it of any such substance as camphor.

Le-she-chin, the author of the celebrated herbal Pun-tsao-7oang-mun, written in the middle of the 16th century, was well acquainted with the two sorts of camplior,- - the one produced by the camphor laurel of his own country, the other imported from the Malay islands; and he narrates how the former was prepared by boiling the wood, and refined by repeated dry sublimations.

Marco Polo, towards the end of the 13th century, saw the forests of Fokien in South-eastern China, in which, says he, are many of the trees which give camphor. ${ }^{1}$ It would thus appear that Laurel Camphor was known as early as the time of Marco Polo, yet it is certain that the more ancient notices which we shall now quote, have reference to the much valued Malay Camphor, which remains up to the present day one of the most precious substances of its class.

There is no evidence that camphor reached Europe during the classical period of Greece and Rome. The first mention of it known to us, occurs in one of the most ancient monuments of the Arabic language, the poems of Imru-l-Kais, ${ }^{2}$ a prince of the Kindal dynasty, who lived in Hadramaut in the beginning of the 6th century. Nearly at the same period, Aëtius of Amida (the modern Diarbekir) used camphor medicinally, but from the manner in which he speaks of it, it was evidently a substance of some rarity. ${ }^{3}$

In fact for many centuries subsequent to this period, camphor was regarded as one of the most rare and precious of perfumes. Thus, it is mentioned in A.D. 636, with musk, ambergris, and sandal wood, among. the treasures of Cliosroes II., of the Sassanian dynasty of kings of Persia, in the palace at Madain on the Tigris, north of Babylon. ${ }^{4}$

Among the immense mass of valuables dispersed at Cairo on the downfall of the Fatimite Khalif Mostanser in the 11th century, the stores of Camphor of Kaisur, and the figures of melons in camphor adorned with gold and jewels, besides vast quantities of musk and aloes wood, are noticed with astonishment by Arabian historians. ${ }^{5}$ It is also on record that about A.D. 642, Indian princes sent camphor as tribute or a gift to the Chinese Emperors ; ${ }^{6}$-further, that in the Teenpaou period (A.D. 742-755), the Cochinchinese brought to the Chinese court a tribute of Barus camphor said by the envoy to be found in the trunks of old trees, the like of which for fragrance was never seen again. ${ }^{7}$ Masudi, ${ }^{8}$ four centuries later, mentions a similar present from an Indian to a Chinese potentate, when 1000 menn ${ }^{9}$ of aloes wood were accompanied by 10 menn of camphor, the choice quality of the latter being indicated by the remark that it was in pieces as large or larger than a pistachio-nut.

1 Ynle, Book of Scr Marco Polo, ii. (1871) 185.

. In the deseription of Arabia by Ibn Hagik el Hamdany, fol. 170 of the MS. at Aden (Prof. Sprenger).

${ }^{3}$ He direets two ounecs of camphor to be added to a ecrtain preparation, provided camphor is sufficiontly abundant.-Tetr. iv. sermo 4. e. 114.

4 G. Weil, Geschichte der Chalifon, i. (Mannheim, 1846) 75 .
`Quatremère, Mrém. sur l’ Egyptc, ii. (1811) $366-375$. - It is interesting to find that $K a$. furc-kaisuri, i.e. Kaisur Camphor is a term still known in the Indian bazaars.

${ }^{6}$ Känffer, Gicschichtc ron Ostasicn, ii. (1859) 491.

7 Translation from the Chinese communieated by Mr. A. Wylie.

8 Lcs Prairics d'or, i. (Paris, 1861) 200.

9 The Arabian mona or menn is equal to $2 \frac{1}{6}$ pounds Troy. 
Again, between A.D. 1342 and 1352, an embassy left Pekin bearing a letter from the Great Khan to Pope Benedict XII., accompanied by presents of silk, precious stones, camphor, musk, and spices. ${ }^{1}$

Ibn Batuta, the celebrated traveller, relates that after having visited the King of Sumatra, he was presented on leaving (A.D. 1347) with aloes-wood, camphor, cloves, and sandal-wood, besides provisions.

Ishâk ibn Amrîn, an Arabian physician living towards the end of the 9th century, and Ibn Khurdidbah, a geographer of the same period, were among the first to point out that camphor is an export of the Malayan Archipelago; and their statements are repeated by the Arabian writers of the middle ages, who all assert that the best camplor is produced in Fansúr. This place, also called Kansúr or Kaisúr, was visited in the 13 th century by Marco Polo, who speaks of its camphor as selling for its weight in gold; Yule ${ }^{2}$ believes it to be the same spot as Barus, a town on the western coast of Sumatra, still giving a name to the camphor produced in that island.

From all these facts and many others that might be adduced, ${ }^{3}$ it undoubtedly follows that the camphor first in use was that found native in the trunk of the Sumatran Dryobalanops aromatica, and not that of the Camphor Laurel. At what period and at whose instigation the Chinese began to manufacture camphor from the latter tree, are not known.

Camphor was known in Europe as a medicine as early as the 12th century, as is evident from the mention of it by the abbess Hildegard ${ }^{4}$ (who calls it ganphora), Otho of Cremona, ${ }^{5}$ and the Danish canon Harpestreng (ob. A.D. 1244).

Garcia d'Orta states (1563) that it is the camphor of China which alone is exported to Europe, that of Borneo and Sumatra being a hundred times more costly, and all consumed by eastern nations. Kämpfer, ${ }^{6}$ who resided in Japan in 1690-92, and who figured the Japanese camphor tree under the name Laurus eamphoriferc, expressly declares the latter to be entirely different from the camphor tree of the Indian Archipelago. He further states that the camphor of Borneo was among the more profitable commodities imported into Japan by the Dutch, whose homeward cargoes included Japanese camphor to the extent of 6000 to $12,000 \mathrm{Hb}$. annually. ${ }^{7}$ This camphor was refined in Holland by a process long kept secret, and was then introduced into the market. In Pomet's time (1694 and earlier), crude camphor was common in France, but it had to be sent to Holland for purification.

It is doubtful whether at that period, or even much later, any camphor was obtained from Formosa. Du Halde ${ }^{8}$ makes no allusion to it as a production of that island; nor does he mention it among the commodities of Emouy (Amoy), which was the Chinese port then in most active communication with Formosa.

Production-The camphor of European commerce is produced in

1 Yule, Cathay and the way thither, ii. 357.

2 The Book of Ser Marco Polo, ii. 244.

3 For further historieal details, compare my paper in the Schweizerische Wochensehrift f. Pharmacie, 27 Sept., 1 and 11 Oet. 1867, and in Buchuer's Repertorium $f$. Pharmacic xvii. (1868) 28.-F. A. F.
4 S. Hildegardis Opera Omnia, accurante J. P. Migne, Paris, 1855. 1145.

5 Choulant, Nracer Floridus, Lips. 1832. 161.

- Amoenitates exotica (1712) 770.

7 Hist. of Japan, translated by Scheuchzer, i. (1727) 353. 370 .

\& Description de la Chinc, i. (1735) 161. 
the island of Formosa and in Japan. Wc have no evidence that any is manufactured at the present day in China.

In Formosa, the camphor-producing districts lic in the narrow belt of debateable ground, which separatcs the border Chincse settlements from the territory still occupicd by the aboriginal tribes. The camphor is prepared from the wood, which is cut into small chips from the trces, by means of a gouge with a long handle. In this process there is great waste, many trees bcing cut and then left with a large portion of valuable timber to perish. The next operation is to expose the wood to the vapour of boiling water, and to collect the camphor which volatilizes with the steam. For this purpose, stills are constructed thus: - a long wooden trough, frequently a hollowed trunk, is fixed over a furnace and protected, by a coating of clay. Water is poured into it, and a board perforated with numerous small holes is luted over it. Above these holes, the chips are placed and covered with earthen pots. A fire having been lighted in the furnace, the water becomes heated, and the steam passing through the chips, carries with it the camphor, which condenses in minute white crystals in the upper part of the pots. From these it is scraped out every few days, and is then very pure and clean. Four stills, each having ten pots placed in a row over one trough, are generally arranged under one shed. These stills are moved from time to time, according as the gradual exhaustion of timber in the locality renders such transfer desirable. A considerable quantity of camphor is however manufactured in the towns, the chips being conveyed thither from the country.

Camphor is brought from the interior to Tamsui, the chief port of Formosa, in baskets holding about half a pecul each $\left(1\right.$ pecul $=133 \frac{1}{3} 17$. $)$, lined and covered with large leaves. Upon arrival, it is stored in vats holding from 50 to 60 peculs each, or it is packed at once in the tubs, or lead-lined boxes, in which it is exported. From the vats or tubs, there drains out a yellowish essential oil known as Camphor Oil, which is used by the Chinese in rheumatism. ${ }^{1}$

Kämpfer in his account ${ }^{2}$ of the manufacture of camphor in the Japanese province of Satzuma and in the islands of Gotho, describes the boiling of the chips in an iron pot covered with an earthen head containing straw in which the camphor collects. He does not mention any draining of the product from essential oil.

Purification - Camphor as it arrives in Europc requires to be purified by sublimation. The crude drug consists of small crystalline grains, which cohere into irregular friable masses, of a greyish white or pinkish hue. Dissolved in spirit of wine, it leavcs from 2 to 10 per cent. of impurities consisting of gypsum, common salt, sulphur, or vegetable fragments.

In Europe, crude camphor is sublimed from a little charcoal or sand, iron filings or quick-lime, and scnt into the markct as Refined Camphor in the form of large bowls or concave cakes, about 10 inches in diametcr, 3 inches in thickness, and weighing from 9 to $12 \mathrm{Hb}^{3}$ Each bowl has a

1 The foregoing particulars are chiefly extracted from the Trade Report of Tamsui by L. C. Taintor, Acting Commissioner of Customs, published in the Reports on I'rede at the Treaty Porls in China for 1869, Shanghai, 1870.
2 Op. cit. p. 772.

3 These are the dimensious of the cakes manufactured in the laboratory of Messrs. Howards of Stratford, but it is obvious that they may rary with different maker's. 
large round hole at the bottom, corresponding to the aperture of the vesscl in which the sublimation has becn conducted. This operation is performed in peculiar glass flasks termed bomboloes, in the upper half of which the purc camphor concretes. These flasks having becn charged and placed in a sand-bath, arc rapidly licated to about $120^{\circ}-190^{\circ} \mathrm{C}$. in order to remove the water. Afterwards the temperaturc is slowly increased to about $204^{\circ} \mathrm{C}$, and maintained during 24 liours. The flasks are finally broken.

As camphor is a ncutral substance, the addition of lime probably serves merely to retain traces of resin or cmpyrcumatic oil. Iron would kcep back sulphur were any prescnt.

The refining of camplior is carricd on to a large extent in England, Holland, Hamburg, and Paris. It is a process requiring grcat care on account of the inflammability. of the product. The temperature must also be nicely regulated, so that the sublimate may be deposited not merely in loose crystals, but in compact cakes. In India where the consumption of camplior is very large, the natives effect the sublimation in a copper vessel, the charge of which is $1 \frac{1}{2}$ maunds $(42 \mathrm{lt}$.): fire is applied to the lowcr part, the upper being kept cool. ${ }^{1}$

Description - Purified Camphor forms a colourless crystalline, translucent mass, travcrsed by numerous fissures, so that notwithstanding a certain toughness, a mass can readily be broken by repeatcd blows. By spontaneous and extremely slow cvaporation at ordinary temperatures, camphor sublimes in lustrous hexagonal plates or prisms, having but little hardness. If triturated in a.mortar, camplior adhercs to the pestle, so that it cannot be powdered per se. But if moistened with spirit of wine, ether, chloroform, methylic alcohol, glycerin, or an essential or fatty oil, pulverization is effected without difficulty. By keeping a short time, the powder acquires a crystalline form. With an equal weight of sugar, camphor may also be easily powdered.

Camphor melts at $175^{\circ} \mathrm{C}$., boils at $205^{\circ} \mathrm{C}$., and volatilizes somewhat rapidly even at ordinary temperatures. To this latter property, combined with slight solubility, must be attributed the curious rotatory motion which small lumps of camphor (as well as barium butyrate, stannic bromide, and a few other substances) exhibit when thrown ou to water.

The solubility of camphor in water is very small, 1300 parts dissolving about one; but even this small quantity is partially separated on addition of some alkaline or earthy salt, as sulphate of magnesium. Alcohols, ethers, chloroform, carbon bisulphide, volatile and fixed oils and liquid hydrocarbons, dissolve camphor abundantly.

The sp. gr. of camphor at $0^{\circ} \mathrm{C}$. and up to $6^{\circ} \mathrm{C}$. is the same as that of water; yet at a somewhat higher tcmpcrature, camphor cxpands more quickly, so that at $10^{\circ}$ to $12^{\circ} \mathrm{C}$. its sp. gr. is only 0.992 .

In concentrated solution or in a state of fusion, camplior turns the plane of polarization strongly to the right. Officinal solution of camphor (Spiritus Camphorec) is too weak, and does not deviate the ray of light to a considerable amount. ${ }^{2}$ Crystals of camphor are devoid of rotatory power. ${ }^{3}$

1 Mattheson, England to Delhi, Lond. 1870. 474 .

2 Pharn. Journ. 18 April, 1874. 830.
3 Des Cloizeaur, Comples Rendus, lxx. (1870) 1209. 
The taste and odour of camphor are sui generis, or at least are common only to a group of nearly allied substances. Camphor is not altered by exposure to air or light. It burns easily, affording a brilliant smoky flame.

Chemical Composition-Camphor, $\mathrm{C}^{10} \mathrm{H}^{16} \mathrm{O}$, by treatment with various reagents, yields a number of interesting products: thus when repeatedly distilled with chloride of zinc or anhydrous phosphoric acid, it is converted into $\mathrm{Cymol}, \mathrm{C}^{10} \mathrm{H}^{14}$, a body contained in many essential oils, or obtainable therefrom.

Camphor, and also camphor oil, when subjected to powerful oxidizing agents, absorbs oxygen, passing gradually first into crystallized Camphoric Aeid, $\mathrm{C}^{10} \mathrm{H}^{16} \mathrm{O}^{4}$, and afterwards into Camphretic Aeid, ${ }^{1} \mathrm{C}^{10} \mathrm{H}^{14} \mathrm{O}^{7}$, water and carbonic acid being at the same time eliminated. Many essential oils, resins and gum-resins likewise yield these acids when similarly treated.

By means of less energetic oxidizers, camphor may be converted into Oxy-eamphor, $\mathrm{C}^{10} \mathrm{H}^{16} \mathrm{O}^{2}$, still retaining its original odour and taste (Wheeler, 1868). ${ }^{2}$

Commerce-Two kinds of crude camphor are known in the English market, namely :

1. Formosa or China Camphor, imported in chests lined with lead or tinned iron, and weighing about 1 cwt. each; it is of a light brown, small in grain, and always wet, as the merchants cause water to be poured into the cases before shipment, with a view, it is pretended, of lessening the loss by evaporation. The exports of this camphor from Tamsui in Formosa ${ }^{3}$ in the years $1870-71-72$ were as follows :-

1870

1871

1872

14,481 peculs $(1,930,800 \mathrm{lb}$. $) \quad 9691$ peculs $(1,292,133$ ib. $) \quad$ 10,281 peculs $(1,370,800 \mathrm{lb}$. $)$

The shipments of camphor from Takow, the other open port of Formosa, are of insignificant amount. Planks of carmphor wood are now exported in some quantity from Tamsui.

2. Japan Camphor is lighter in colour and occasionally of a pinkish tint; it is also in larger grains. It arrives in double tubs (one within the other) without metal lining, and hence is drier than the previous sort; the tubs hold about 1 cwt. It fetches a somewhat higher price than the Formosa camphor.

Hiogo and Osaka exported in 1871, 7089 peculs (945,200 $\mathrm{ft}$.), and Nagasaki 745 peculs $\left(99,333 \mathrm{lb}\right.$.), the total value being 116,718 dollars. ${ }^{4}$ The imports of Unrefined Camphor into the United Kingdom amounted in 1870 to 12,368 cwt. $(1,385,216$ 1b.); of Refined Camphor in the saine year to 2361 cwt. $^{5}$

1 Schwancrt in Licbig's Annulen, 128 (1863) 77. - Kachler (1871) has disputed the existence of this acid.

${ }^{2}$ For information respecting the muncrous other compounds of camphor, consult Gmclin, Chemistry, xiv. (1860) 338; Watts, Dict. of Chemistry, i. (1863); Schorlemmer, Carbon Compounds, 1874. 303.
3 Returns of Trade at the Treaty Ports in Chine for 1872 , part. 2. p. 124

* Conmercicil Reports from H. MI. Consuls in Jepan, No. 1, 1872.-The returns for Hiogo and Osaka are upon the authority of the Chamber of Commcrec.

5 Statement of the Trade and Navigution of the United Kingdom for 1870. p. 61-no later returns accessible. 
Camphor is largely consumed by the natives of India; the quantity of the crude drug imported into Bombay in the year 1872-73, was 3801 cwt. $^{1}$

Uses-Camphor has stimulant properties and is frequently used in medicine both internally and externally. It is largely consumed in India.

\section{Other kinds of Camphor; Camphor Oils.}

\section{Barus Camphor, Borneo Camphor, Malayan Camphor, Dryo-} balanops Camphor:- This, as already explained, is the substance to which the earliest notices of camphor refer. The tree which affords it is Dryobalanops aromatica Gärtn. (D. Camphora Colebrooke), of the order Dipterocarpece, one of the most majestic objects of the vegetable kingdom. The trunk is very tall, round, and straight, furnished near the base with huge buttresses; it rises 100 to 150 feet without a branch, then producing a dense crown of shining foliage, 50 to 70 feet in diameter, on which are scattered beautiful white flowers of delicious fragrance. ${ }^{2}$ The tree is indigenous to the Dutch Residencies on the north-west coast of Sumatra, between $0^{\circ}$ and $3^{\circ} \mathrm{N}$. lat., from Aycr Bangis to Barus and Singkel, and to the northern part of Borneo, and the small British island of Labuan.

The camphor is obtained from the trunk, in longitudinal fissures of which it is found in a solid crystalline state, and extracted, by laboriously splitting the wood. It can only be got by the destruction of the entire tree; - in fact, many trees afford none, so that to avoid the toil of useless felling, it is now customary to try them by cutting a hole in the side of the trunk, but the observation so made is often fallacious. Spenser St. John, British Consul in Borneo, was told that trees in a state of decay often contain the finest camphor. ${ }^{3}$ The camphor when collected is carefully picked over, washed and cleaned, and then separated into three qualities, the best being formed of the largest and purest crystals, while the lowest is greyish and pulverulent.

It is difficult to state how much camphor is usually obtained from a single tree, but Colebrooke's statement that a tree should produce about $11 \mathrm{Hb}$. is, we suspect, near the truth. ${ }^{4}$

A good proportion of the small quantity produced is consumed in the funeral rites of the Batta princes, whose families are often ruined by the lavish expense of providing the camphor and buffaloes which the custom of their obsequies requires. The camphor which is exported, is eagerly bought for the China market, but some is also sent to Japan, Laos, Cochin China, Cambodia, and Siam.

I Statement of the Trade and Navigation of Bombay for 1872-73. ii. 27.

2 For some recent observations on the botany of Dryobalanops, see paper by W.T. Thiselton Dyer in Trimen's Jounn. of Botany, April 1874. 98.

3 Life in the Forests of the Far East, ii. (1862) 272 .

${ }^{4}$ De Vriese and Motloy in Hooker's Journ. of Bot. iv. (1852) 33.202. Do Vriese declares this to be quite exiggerated, and that the
- thiekest and oldest trees rarely contain more than 2 ounees! If the latter statement were true, it would require at least 1000 trees to yield'a single peeul of camphor. Mliquel (Prod. Florce Sumatrana, 66.) confirms Colebrooke, in stating that $100 \mathrm{it}$. was said to be the produce of 9 trees. Another report which he quotes, is to the effeet that a single tree yields only a few entties ( 1 eatty $=13 \mathrm{Hb}$. or 604 grammes). 
The quantity annually shipped from Borneo was reckoned by Mot̂ley in 1851 to be about 7 peculs $(933 \mathrm{tb}$.). The export from Sumatra was estimated by De Vriese at 10 to 15 quintals per annum. ${ }^{1}$ The quantity imported into Canton in 1872 was returned as $23 \frac{7}{10}$ peculs (3159 Hb.), value 42,326 taels, equivalent to about $80 \mathrm{~s}$ : per $\mathrm{Hb} .^{2}$ In the Annual Statement of the Trade of Bombay for the year 1872-3, 2 cwt. of Malayan Camphor is stated to have been imported; it was valued at 9141 Rs. (£914). The price in Borneo in 1851 of camphor of fine quality, was 30 collars per catty, or about $95 \mathrm{~s}$. per $1 \mathrm{~b}$. : consequently the drug never finds its way into European commerce.

Borneo Camphor, also termed by chemists Borneol or Camphyl Aleohol, is somewhat harder than common camphor, also a little heavier so that it sinks in water. It is less volatile, and does not crystallize on the interior of the bottle in which it is kept; and it requires for fusion a higher temperature, namely $198^{\circ} \mathrm{C}$. It has a somewliat different odour, resembling that of common camphor with the addition of patchouli or ambergris. The composition of borneol is represented by the formula $\mathrm{C}^{10} \mathrm{H}^{18} \mathrm{O}$. It may be converted by the action of nitric acid into common camphor, which it nearly resembles in most of its physical properties. Conversely, as Berthelot (1S5S) has shown, borneol ${ }^{3}$ may be prepared from common camphor by heating the latter with alcoholic potash; or, according to Baubjgny (1866) by treating a solution of camphor in toluol with sodium.

Camphor Oil of Borneo-Besides camphor, the Dryobalanops furnishes another product, a liquid termed Camphor Oil, which must not be confounded with the camphor oil that drains out of crude laurel camphor. This Bornean or Sumatran Camphor Oil is obtained by tapping the trees, or in felling them (see also p. 202). In the latter way, Motley in cutting down a tree in Labuan in May 1851, pierced a reservoir in the trunk from which about five gallons of camphor oil were obtained, though much could not be caught. ${ }^{4}$ The liquid was a volatile oil holding in solutiou a resin, which after a few days' exposure to the air, was left in a syrupy state. This camphor oil, which is termed Borncenc, is isomeric with oil of turpentine, $\mathrm{C}^{10} \mathrm{H}^{16}$; yet in the crude state, holding in solution borneol and resin. By fractional distillation, it may be separated into two portions, the one more volatile than the other but not differing in composition.

Camphor Oil of Formosa, which has been already referred to as draining out of the crude camphor of Cinnamomum Camphora, is a brown liquid holding in solution an abundance of common camphor, which it speedily deposits in crystals when the temperature is slightly reduced. From Borneo Camphor Oil, it may be distinguished by its odour of sassafras. We find no optical difference in the rotatory power. of the oils; both are dextrogyre to the same extent, whicl is still the case if the camphor from the lauraceous camphor oil is separated by

1 In Milburn's time (Oriental Commerce, ii. 1813. 308), Sumatia was reckoned to export 50 peculs, and Borneo 30 peculs a year. Pondot's statement that China imports of Barus camphor about 800 peculs ammunlly is plainly erroneous.
2 Returns of Trade at the Treaty Ports in China for 1872, p. 30 .

3 More correctly a substance of the same. composition yct differing in optieal power, and therefore termol Camphor.

* Ibn Khurdádbah in the 9th eentury, mentions it as being obtnined in this way. 
cooling. Borneo camphor oil, for a sample of which we are indebted to Prof. de Vriese, deposits no camphor cven when kept at $-15^{\circ} \mathrm{C}$.

Ngai Camphor, Blumea Camphor-It has been known for many year's that the Chinese are in the habit of using a third variety of camphor, having a pecuniary value intermediate between that of common camphor and of Borneo camphor. Tt has been lately shown (1874) that this substance is manufinctured at Canton, the plant from which it is obtained being Blumea balsamifera DC., a tall herbacerous Composita called in Chinese Ngai, abundant in Tropical Eastern Asia.

The drng has been supplied to us ${ }^{1}$ in two forms,-crude and pure,the first being in crystalline grains of a dirty white, contaminated with vegetable remains; the second in colourless crystals as much as an inch in length. By sublimation, the substance may be obtained in distinct, brilliant crystals, agreeing preciscly with those of Jornen camphor, which they also resemble in odour and hardness, as well as in being a little heavier than water and not so volatile as common camphor.

The chemical examination of Ngai camphor, performed by Plowman, ${ }^{2}$ under the direction of Prof. Attfield, has proved that it has the composition $\mathrm{C}^{10} \mathrm{H}^{18} \mathrm{O}$, like Borneo camphor. But the two substances differ in optical properties, ${ }^{3}$ an alcoholic solution of Ngai camphor being levogyre in about the same degree that one of Borneo camphor is clestrogyre. By boiling nitric acid, Borneo camphor is transformed into common (dextrogyre) camphor, whereas Ngai camphor affords a similar yet lcvogyre camphor, in all probability iclentical with the stearoptene of Chrysanthemum Parthonium Pers.

As Ngai camphor is about ten times the price of Formosa camphor, it never finds its way to Europe as an article of trade. In China, it is consumed partly in medicine and partly in perfuming the fine kinds of Chinese ink. The export of this camphor by sea from Canton, is valued at about $£ 3,000$ a year.

\section{CORTEX CINNAMOMI.}

Cortex Cinnamomi Zcylaniei; Cinnamon; F. Cannelle de Ceylan; G. Zimmt, Ceylon Zimmt, Kaneel.

Botanical Origin-Cinnamomum Zeylanicum Breyne,-a small evergreen tree, richly clothed with beautiful, shining leaves usually somewhat glaucous beneath, and having panicles of greenish flowers of disagreeable odour.

It is a native of Ceylon, where, according to Thwaites, it is generally distributed through the forests up to an elevation of 3000 feet, and one variety even to 8000 feet. It is exceedingly variable in stature, and in the outline, size and consistence of the leaf; and several of the extreme forms are very unlike one another and have received specific names. But there are also numerous intermediate forms; and in a large stite of specimens, many occur of which it is impossible to determine whether they should be referred to this species or to that.

1 Through the eourtesy of Alr. T. H. Ewer, of the Imperial Maritime Customs, Canton.
¿ Pharmn. Journ., Mineh 7, 1874. 710.

3 Fluickiger in Pharm. Joum., April 1s, 1874.829. 
Thwaites ${ }^{1}$ is of opinion that some still admitted species, as $C$. obtusifolium Nees and $C$. incrs Reinw., will prove on further investigation to be mere forms of $C$. Zcylanicum.

Beddome, ${ }^{2}$ Conservator of Forests in Madras, remarks that in the moist forests of South-western India, there are 7 or 8 well-marked varieties which might easily be regarded as so many distinct species, but for the fact that they are so connected inter sc by intermediate forms, that it is impossible to find constant characters worthy of specific distinction. They grow from the sea level up to the highest elevations and, as Beddome thinks, owe their differences chiefly to local circumstances, so that he is disposed to class them simply as forms of C. Zeylanicum.

History-Cinnamon was held in high esteem in the most remote times of history. In the words of the learned Dr. Vincent, Dean of Westminster, ${ }^{3}$ it seems to have been the first spice sought after in all oriental voyages. Both cinnamon and cassia are nuentioned as precious odoriferous substances in the Mosaic writings and in the Biblical books of Psalms, Proverbs, Canticles, Ezelziel and Revelations, also by Theophrastus, Herodotus, Galen, Dioscorides, Pliny, Strabo and many other writers of antiquity: and from the accounts which have thus come down to us, there appears reason for believing that the spices referred to were nearly the same as those of the present day. That cinnamon and cassia were extremely analogous, is proved by the remark of Galen, that the finest cassia differs so little from the lowest quality of cinmamon, that the first may be substituted for the second, provided a double weight of it be used.

It is also evident that both were regarded as among the most costly of aromatics, for the offering made by Seleucus II., king of Syria, and his brother Antiochus Hierax, to the temple of Apollo at Miletus, B.c. 246-227, consisting chiefly of vessels of gold and silver, included

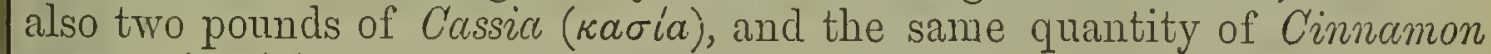
$\left(\kappa \iota \nu \nu a \mu \omega_{\mu}^{\prime} о \nu\right){ }^{4}$

In connexion with this subject there is one remarkable fact to be noticed, which is that none of the cinnamon of the ancients was obtained from Ceylon. "In the pages of no author," says Tennent, " European or Asiatic, from the earliest ages to the close of the thirteenth century, is there the remotest allusion to cinnamon as an indigenous production, or even as an article of commerce in Ceylon." Nor do the anmals of the Chinese, between whom and the inhabitants of Ceylon from the 4th to the 8th centuries, there was frequent, intercourse and exchange of commodities, name Cinnamon as one of the productions of the island. The Sacred Books and other ancient records of the Singhalese are also completely silent on this point.

Cassia under the name of $K w e i$, is mentioned in the earliest Chinese herbal, - that of the emperor Shen-nung, who reigned about 2700 B.C., in the ancient Chinese Classics, ${ }^{6}$ and in the $R h-y a$, a herbal dating from

1 Enumeratio Plantarum Zeylania, 1864. 252.-Consult also Mcissner in De Cand. Prad. xv. sect. i. 10. 262.

Flora, Sylvatica for Souttern India, 1872.

Commeree and Navigation of the An. cicnis in the Indian Oceane, ii. (1807) 512.
4 Chishull, Antiquitates Asiatica, 1728. $65-72$.

5 Ceylon, i. (1859) 575.

6 We are indebted to Dr. Bretschneider of Pekin for these references to Chinese literature. For information about some of the worles quoted, see his pamplilet On the Studly unul Velue of Chincse Botanical Works, 1870. 
1200 B.c. In the Hai-ycto-pentn-ls'av, written in the 8th century, mentior is made of I'icn-chu lowci. Tien-chu is the ancient name for India: perhaps the allusion may be to the cassia bark of Malabar.

In comexion with these extrenely early references to the spice, it may be stated that a bark supposed to be eassic is mentioned as imported into Egypt together with gold, ivory, frankincense, precious woods, and apes, in the 17 th century B.c. ${ }^{1}$

The accounts given by Dioscorides, Ptolemy and the author of the Periplus of the Erythrean Sen, indicate that cinnamon and cassia were obtained from Arabia and Eastem Africa; and we further know that the importers were Phœnicians, who traded by Egypt and the Red. Sea with Arabia. Whether the spice under notice was really a production of Arabia or Africa, or whether it was imported thither from Southern China (the present source of the best sort of cassia) is a question which has excited no small amount of discussion.

We are in favour of the second alternative,-firstly, because no substance of the nature of cinnamon is known to be produced in Arabia or Africa; and secondly, because the commercial intercourse which was undoubtedly carried on by China with India and Arabia, and which alsa existed between Arabia, India and Africa, is amply sufficient to explain the importation of Chinese produce. ${ }^{2}$ That the spice was a production of the far East, is moreover implied by the name Darehini (from dar, wood or bark, and Chini, Chinese), given to it by the Arabians and Persians.

If this view of the case is admissible, we must regard the ancient cinnamon to have been the substance now known as Chinese Cassia lignea or Chinese Cinnamon, and cassia as one of the thicker and perhaps less aromatic barks of the same group, such in fact as are still found in commerce.

Of the circumstances which led to the collection of cinnamon in Ceylon, and of the period at which it was commenced, nothing is known. That the Chinese were concerned in the discovery is not an unreasonable supposition, seeing that they traded to Ceylon, and were in all probability acquainted with the cassia-yielding species of Cinnamomum of Southern China, a tree extremely like the cinnamon tree of Ceylon.

Whatever may be the facts, the early notices of cinnamon as a production of Ceylon are not prior to the 13 th century. The very first according to Yule, ${ }^{3}$ is a mention of the spice by Kazwini, an Arab writer of about A.D. 1275 , very soon after which period it is noticed by John of Montecorvino, a missionary friar who visited India. This man, in a letter under date 1292 or 1293, still extant in the Medicean library at Florence, says that the cinnamon tree is of medium bulk, and

1 Dümichen, Flcet of an Egyptian Quecn, Leipzig, 1868, p. 1.

2 ". . That there was an ulterior commerce beyond Ceylon is indubitable; for at Ceylon the trade from Nalacea and the Golden Chersonese, met the mereliants from Arabia, Persia and Egypt. This miglit possibly have been in the hands of the Malnys or event the Chinese, who seem to have been navigators in all ages as universally as the Arabians. . . " Vineent, op. eit. ii. 284. 285.-In the time of Mareo Polo, the trade of China westward, met the trade of the Red Sea, no longer in Ceylon, but on the coast of Malabar, apparently at Calieut, where the Portuguese found it on their first arrival. Here, says Mareo, the ships from Aden obtained their lading from the East, and earried it into the Red Sea for Alexandria, whence it passed into Europe by means of the Yenetians.-See also Yule, Book of Sir Marco Polo, ii. (1Si1) 325. 32\%.

3 Op, cit. ii, 255. 
in trunk, bark and foliage, like a lamrel, and that great store of its bark is carried forth from the island which is near by Milabar. ${ }^{1}$

Again, it is mentioned by the Mahomedan traveller Ibn Batuta about A.D. $13 \pm 0,{ }^{2}$ and a century later by the Venetian merchant Nicolo di Conti, whose description of the tree is very correct. ${ }^{3}$

The circumnavigation of the Cape of Good. Hope led to the real discovery of Ceylon by the Portuguese in 1505 , and to their permanent occupation of the island in 1536, chiefly for the sake of the cinnamon. It is from the first of these dates that more exact accounts of the spice began to reach Europe. Thus in 1511, Barbosa distinguished the fine ciunamon of Ceylon from the inferior Cannella trista of Malabar. Garcia d'Orta about the middle of the same century, stated that Ceylon cinnamon rras forty times as dear as that of Malabar. Clusius, the translator of Garcia, saw branches of the cimnamon-tree as early as 1571, at Bristol and in Holland.

At this period, cinnamon was cut from trees growing wild in the forests in the interior of Ceylon, the bark being exacted as tribute from the Singhalese kings by the Portnguese. A peculiar caste called chalias, who are said to have emigrated from India to Ceylon in the 13th century, and who in after-times became cinnamon-peelers, delivered the bark to the Portugnese. The cruel oppression of these chatias was not mitigated by the Dutch, who from the year 1656 were virtually masters of the whole seaboard, and conceded the cinnamon trade to their East India Company as a profitable monopoly, which the Company exercised with the greatest severity. ${ }^{4}$ The bark previous to shipment was minutely examined by special officers, to guard against frauds on the part of the chalias.

Abnut 1770, De Koke conceived the happy idea, in opposition to the universal prejudice in favour of wild-growing cinnamon, of attempting the cultivation of the tree. This project was carried out under Governors Falck and Van der Graff with extraordinary success, so that the Dutch were able independently of the kingdom of Kandy, to furnish about 400,000 $\mathrm{ib}$. of cinnamon annually, thereby supplying the entire Emropean demand. In fact, they completely ruled the trade, and would even burn the cinuamon in Holland, lest its unusual abundance should reduce the price.

After Ceylon had been wrested from the Dutch by the English in 1796, the cinnamon trade became the monopoly of the English East India Company, who then obtained more cinnamon from the forests, especially after the year 1815, when the kingdom of Kandy fell under Pritish rule. But though the chalias had much increased in numbers, the yearly production of cinnamon does not appear to have exceeded $500,000 \mathrm{Ht}$. The condition of the unfortunate chalias was not ameliorated until 1833, when the monopoly granted to the Company was finally abolished, and Government ceasing to be the sole exporters of cinnamon, permitted the merchants of Colombo and Galle to share in the trade.

Cinnamon however was still burdened with an export duty equal to a third or a half of its value, in consequence of which and of the com-

1 Yule, Cathay and the way thither, i. 213. 2 Travels of The Batuta, translated by Iee, Lond. 1829. 184

${ }^{3}$ Ramusio, Riaccolta delle Navigntioni et
Viaggi, i. (1563) 339 ; Krunstmann, Kenntniss Indiens im fünfïchnten Jahrhundert,
1863. 39.

* Tennent, op. eit. ii. 52. 
petition with cinnamon raised in Java, and with cassia from China and other places, the cultivation in Ceylon began to suffer. This duty was not removed until 1853 .

The earliest notice of cimnamon in comnexion with Northern Furope that we have met with, is the diploma granted lyy Chilperic II., king of the Franks, to the monastery of C'orbie in Normandy, A.D. 716, in which provision is made for a certain supply of spices and grocery, including 5 tb. of Cimnamon. ${ }^{1}$

The extraordinary value set on cinnamon at this period is remarkably illustrated by some letters written from Italy, in which mention is liere and there incidentally made of presents of spices and incense. ${ }^{2}$ Thus in A.D. T45, Gemmulus, a Roman deacon, sends to Poniface, archibishop, of Mayence ("cum magnấ reverenticâ "), 4 ounces of Cinnamon, 4 ounces of Costus, and 2 pounds of Pepper. In A.D. 748, Theophilacias, a Roman archdeacon, presents to the same bishop similar spices and incense. Lullus, the successor of Boniface, sends to Ladburga, abbatissa Thanetensis," cirea A.D. 732-751- "unum graphizum argenterm et sloracis et cinnamomi partem aliquace "; and about the same date, another present of cinnamon to archbishop Boniface is recorded. Under date A.D. 732-742, a letter is extant of three persons to the abbess Cuneburga, to whom the writers offer-" turis et piperis et cimnamomi permodica xenia, sed omni mentis affectione destinata."

Of the pecuniary value of this price in England, there are many notices from the year 1264 downwards. ${ }^{*}$ In the 16th century it was probably not plentiful, if we may judge from the fact that it figures among the New Year's gifts to Philip and Mary (1556-57), and to Queen Elizabeth (1561-62). ${ }^{5}$

Production and Commerce ${ }^{6}$ - The best cinnamon is produced, according to Thwaites ${ }^{7}$ from a cultivated or selected form of the tree (var. a.), distinguished by large leaves of somewhat irregular shape. But the bark of all the forms possesses the odour of cimnamon in a greater or less degree. It is not lowever always possible to judge of the quality of the bark from the foliage, so that the peelers when collecting from uncultivated trees, are in the habit of tasting the bark before commencing operations, and pass over some trees as unfit for their purpose. The bark of varieties B. multiflorum and $\gamma$. ovalifolium is of very inferior quality, and said to be never collected unless for the purpose of adulteration.

The best variety appears to find the conditions most favourable to its culture, in the strip of country; 12 to 15 miles broad, on the south-west coast of Ceylon, between Negumbo, Colombo and Matura, where the tree is grown up to an elevation of 1500 feet. A rery sandy clay soil, or fine white quartz, with a good sub-soil and free exposure to the

1 Pardessus, Diplomate, etc., Paris 1819. ii. 309 .

¿ Jaffé, Bibliothecr Rrmun Cermanicuinm, Berlin, iii. (1866) 154. 199. 214. 216-8. 109.

3 Doubtless Eadburh, third abbess of Minster in the 1sle of 'Thanet in Fent. She died A.D. 751 .

4 Eden, State of the Poor, ii. (1797) appendix; liogers, Hist. of Agriculture and Prices in England, ii. (1866) 543.
5 Nicholls, Progresses and Processions of Q. Elizabcth, i. (1823) xxxiv. 118.

6 Additional information may be found in two papers by Marshall, in Thomson's Annals of Philosophy, x. (1S17) 241 and 346 ; sec also Leschenault de la Tour, Mém. cil Muséc d'Ifist. nat. viii. (1 S22) 436-446.

; Op. cit. 252-253. 
sun and rain, are the circumstances best adapted for the cultivation. The management of the plantations resembles that of oak coppice in England. The system of pruning checks the plant from becoming a tree, and induces it to form a stool from which four or five shoots are allowed to grow; these are cut at the age of $1 \frac{1}{2}$ to 2 years, when the greyish-green epidermis begins to turil brown by reasoll of the formation of a corky layer. They are not all cut at the same time, but only as they arrive at the proper state of maturity; they are then 6 to 10 feet ligh and to 2 inches thick. In some of the cinnamon gardens at Colombo, the stools are very large and old, dating back it.is supposed, from the time of the Dutch.

In consequence of the increased flow of sap which occurs after the heavy rains in Nay and June, and again in November and Deccmber, the bark at those seasons is easily separated from the wood, so that a principal harvest takes place in the spring, and a smaller one in the latter part of the year.

The shoots having been cut off by means of a long sickle-shaped hook called a catty, and stripped of their leaves, are slightly trimmed with a knife, the little pieces thus removed being reserved and sold as Cinnamon Chips. The bark is next cut through at distances of about a foot, and slit lengthwise, when it is casily and completely removed by the insertion of a peculiar knife termed a mama, the separation being assisted if necessary, by strongly rubbing with the handle. The pieces of bark are now carefully put one into another, and the compound sticks firmly bound together into bundles. Thus they are left for 24 hours or more, during which a sort of "fcrmcntation" (?) goes on which facilitates the subsequent removal of the exterior part. This is accomplished by placing each quill on a stick of rood of suitable thickness, and carefully scraping off with a knife the outer and middle cortical layer. In a few hours after this operation, the peeler commences to place the smaller tubes within the larger, also inserting the small pieces so as to make up an almost solid stick, of about 40 inches in length. The cimnamon thus prepared is liept one day in the shade, and then placed on wicker trays in the sun to dry. When sufficiently dry, it is made into bundles of about $30 \mathrm{th}$. each. ${ }^{1}$

The cinnamon gardens of Ceylon were estimated in 1860-64, to occupy anl area of about 14,400 acres. $^{2}$ At present the cultivation of coffee is displacing that of cinnamon. Mr. Horne of the Botanical Garden of Mauritius, writing in 1866, observes that no new plantations are now laid out, and that many of the old ones are going to ruin. The exports of cinnamon from Ceylon have been as follows:-

1871

$1,359,327 \mathrm{tb}$., value $\mathfrak{E} 67,966$.

\section{2}

$1,267,953 \mathrm{lb}$., value $£ 64,747$.

Of the last named quantity, $1,179,510 \mathrm{mb}$. were shipped to the United Kingdom, 53,439 1t. to the United States of North America, and 10,000 1b. to Hamburs. Besides the above-named exports of cinnamon, the official

1 Formerly called fardelo or fardello, a name signifying in the Romance languages bundle or packeage. The word fardel having the same meaning, is found in old English writers.

2 Yel the cultivation was far more exten. sive in the earlier part of the eentury, as we may judge by the statement that the five princiual einnamon gardens around $\mathrm{Ne}$ gumbo, Colombo, Barberyn, Galle, and Matura, were cach from 15 to 20 miles in circumfircnce ('Tennent's Cey]nn, ii, 163). 
statistics "record the export of "Cinnamon Barl\%"-884.6 17. in 1871 $23,449 \mathrm{lb}$. in 1872. This name includes two distinct articles, namely C'innamon Chips, and a very thick bark derived from old steins. The Cinnamon Chips which, as explained on the previous page, are the first trimmings of the shoots, are very aromatic; they used to be considered worthless, and were thrown away. The second article, to which in the London drug sales the name "Cinnamon Bark" is restricted, is in flat or" slightly chamnelled framents, which are as much as $\frac{4}{10}$ of an inch in thickness, and remind one of New Granada cinchona bark. It is very deficient in aromatic qualities, and quite unfit for use in pliarmacy.

In most other countries into which C'inncomomum Zeylanicum has been transplanted, it has been found that, partly from its tendency to pass into new varieties and partly perhaps from want of careful cultivation and the absence of the skilled cinnamon-peeler, it yields a bark appreciably different from that of Ceylon. Of other cimnamon-producing districts, those of Southern India may be mentioned as affording the Malabar or Tinnevelly, and the Tellicherry Cinnamon of commerce, the latter being almost as good as the cinnamon of Ceylon. ${ }^{2}$ The cultivation in Java commenced in 1825. The plant according to Miquel is a variety of $C$. Zeylanicum, distinguished by its very large leaves which are frequently 8 inches long by 5 inches broad. The island exported in 1870 , 1109 peculs $\left(147,866 \mathrm{lb}\right.$.) ; in 1871 only 446 peculs $\left(59,466 \mathrm{lt}\right.$.). ${ }^{3}$

Cinnamon is also grown in the French colony of Guyana and in Brazil, but on an insignificant scale. The samples of the bark from those countries. which we have examined are quite unlike the cinnamon of Ceylon. That of Brazil in particular has evidently been taken from stems several years old.

The importations of cinnamon into the United Kingdom from Ceylon are declining, as the following figures will show :-

$\begin{array}{cccc}1869 & 1870 & 1871 & 1872 \\ 2,611,473 \mathrm{lb} . & 2,148,405 \mathrm{lb} . & 1,430,518 \mathrm{lt} . & 1,015,461 \mathrm{ft} .\end{array}$

During $1872,56,000 \mathrm{th}$. of cinnamon were imported from other countries.

Description-Ceylon cinnamon of the finest description, is imported in the form of sticks, about 40 inches in length and $\frac{3}{8}$ of an inch in thickness, formed of tubular pieces of bark about a foot long, dexterously arranged one within the other, so as to form an even rod of considerable firmness and solidity. The quills of bark are not rolled up as simple tubes, but each side curls inwards so as to form a channel with in-curving sides, a circumstance that gives to the entire stick a somewhat flattened cylindrical form. The bark composing the stick is extremely thin, measuring often no more than $\frac{1}{100}$ of an inch in thickness. It has a light brown, dull surface, faintly marked with shining wavy lines, and bearing here and there scars or holes at the points of insertion of leaves or twigs. The inner surface of the bark is of a darker hue. The bark is brittle and splintery, witl, a fragrant odour, peculiar to itself and the allied barks of the same genus. Its taste is saccharine, pungent, and aromatic.

The bales of cinnamon which arrive in London are always re-packed

1 Ceylon Bluc Books for 1871 and 1872 , nrinted at Colombo.

2 Some of it however is very thick, thougli neatly quilled.

3 Consular Reports, Aus. 1873. 952. 
in the dock warehouses, in doing which a certain anount of breakage occurs. The spice so injured is kept separate and sold as S'mall Cinnamon, and is very generally used for plaruaceutical purposes. It is often of excellent quality.

Microscopic Structure-By the peeling above described, Ceylon cimmamon is deprived of the suberous coat and the greater part of the middle cortical layer, so that it almost consists of the mere liber (endophloum). Three different layers are to be distinguished on a transverse section of this tissue:-

1. The external surface which is composed of one to three rows of large thick-walled cells, forming a colherent ring; it is only interrupted by bundles of liber-fibres, which are obvious even to the unaided eye; they compose in fact the wavy lines mentioned in the last page.

2. The middle layer is built up of about ten rows of parenchymatous thin-walled cells, interrupted by nuch larger cells containing deposits of mucilage, while other cells, not larger than those of the parenchyme itself, are loaded with essential oil.

3. The innermost layer exhibits the same thin-walled but smaller cells, yet intersected by narrow, somewhat darker, medullary rays, and likewise interrupted by cells containing either mucilage or essential oil.

Instead of bundles of liber-fibres, fibres mostly isolated are scattered through the two inner layers, the parenchyme of which abounds in small starch granules accompanied by tannic matter. On a longitudinal section, the length of the liber-fibres becomes more evident, as well as the oil-ducts and gum-ducts.

Chemical Composition-The most interesting and noteworthy constituent of cinnamon is the essential oil, which the bark yields to the extent of $\frac{1}{2}$ to 1 per cent., and which is distilled in Ceylon, - very seldom in England. It was prepared by Porta ${ }^{1}$ of Naples, who mentions it as early as 1589. In the latter part of the last century, it used to be brought to Europe by the Dutch. During the five years from 1775 to 1779 inclusive, the average quantity annually disposed of at the sales of the Datch East India Company was 176 ounces. The wholesale price in London between 1776 and 1782 , was $21 \mathrm{~s}$. per ounce; but from 1785 to 1789 , the oil fetched $63 s$. to $68 s$., the increase in value being doubtless occasioned by the war with Holland commenced in 1782. The oil is now largely produced in Ceylon, from which island the quantity exported in 1871 was 14,796 ounces; and in 1872, 39,100 ounces. ${ }^{2}$ The oil is shipped chiefly to England.

Oil of cinnamon is a golden-yellow liquid, having a sp. gr. of 1.035 , a powerful cinnamour odour, and a sweet and aromatic but burnimg taste. It deviates a ray of polarized light a very little to the left. The oil consists chiefly of Cinnamic Aldehyde, $\mathrm{C}^{0} \mathrm{H}^{8} \mathrm{O}$, together with a variable proportion of hydrocarbons. At a low temperature it becomes turbid by the cleposit of a camphor, which we lave not examined. The oil easily absorbs oxygen, becouring thereby contaminated with resin and cinnamic acid.

Cinnamon contains sugar, manuite, starch, nucilage, and tannic acid. The Cinnamomin of Martin (1868) hus been shown by Wittstein to be 184.

1. Magiae Naturalis libri xx. Nean. $1589 . \quad$ a Ceylon Dlue Boolis for 1871 and 1872. 
very probably merely mamnite. The effect of iodine on a decoction of eimnamon will be notieed under the head of Cassia Lignea. Cinnamon afforded to Schätzler (1862) 5 per cent, of ash consisting chiefly of the carbonates of ealciun and potassinm.

Uses-Cimnomon is used in medicine as a cordial and stimulant, but is muel more largely eonsumed as a spiee.

Adulteration-Cassia lignea being much cheaper than cimnamon, is very commonly substituted for it. So long as the bark is entire, there is no difficulty in its reeognition, but if it should lave been reduced to powder, the case is widely different. We have found the.following tests of some service, when the spice to be examined is in powder:--Make a deeoetion of powdered einnamon of known genuineness; and one of similar strength of the suspeeted powder. When eool and strained, test a fluid oumee of eaeh with one or two drops of tincture of iodine. A decoction of cinnamon is but little affeeted, but in that of cassia a deep blue-black tint is immediately produeed (see p. 479). The eheap kinds of cassia known as Cassice vera, may be distinguished from the more valuable Chinese Cassia as well as from cinnamon, by their riehness. in mueilage. This ean be extracted by cold water as a thick glairy liquid, giving dense ropy precipitates with eorrosive sublimate or neutral aeetate of lead, but not with alcohol.

\section{Other products of the Cinnamon 'Tree.}

Essential Oil of Cinnamon Leaf (Oleum Cinnamomi folionum)This is a brown, viscid, essential oil, of elove-like odour, which is sometimes exported from Ceylon. It has been examined by Stenhouse (1854), who found it to have a sp. gr. of 1.053, and to consist of a mixture of Eugenic Acid (p. 253) with a neutral hydroearbon having the formula, $\mathrm{C}^{10} \mathrm{H}^{16}$. It also contains a small quantity of benzoic aeid.

Essential Oil of Cinnamon Root (Oleum Cinnamomi radicis)A yellow liquid, lighter than water, having a mixed odour of camphor and cinnamon, and a strong camphoraceous taste. Botli this oil and that of the leaf were deseribed by Kämpfer (1712) and by Seba in 1731, and perhaps by Garcia d'Orta so early as 1563. Solid camphor may also be obtained from the root. A water distilled from the flowers, and a fatty oil expressed from the fruits are likewise notieed by old writers, but are unknown to us.

\section{CORTEX CASSI $\not$ LIGNE $\not E$.}

\section{Cassia Lignea, Cassia Bark.}

Botanical Origin-Various species of Cinnamomum occurring in the warm countries of Asia from India eastward, afford what is termed in commerce Cassia Bark. The trees are extremely variable in foliage, inflorescence and aromatic properties, and the clistinetness of several of the species laid down even in recent works is still uncertain.

The bark whicl bears par cxeellence the name of Cassia or Cassic lignea, and which is distinguished on the Contiuent as Chinese Cinnamon. is a production of the provinees of Kwangsi and Kweiehau in Southeru

1 Phil. Trans. xxxvi. (1731) $10 \%$. 
China. The Frenel expedition of Lieut. Garnier for the exploration of the Mekong and of Cochin Clina (1866-68) found eassia growing in about $\mathrm{N}$. lat. $19^{\circ}$ in the forests of one of the affluents on the left bank of the MIekong near the frontiers of Annam. 'A part of this eassia is earried by land into China, while another part is conveyed to Bangkok. ${ }^{1}$ Although it is customary to refer it without hesitation to a tree named Cinnchmomum C'assia, we find no warrant for sueh reference: no eompetent observer has visited and deseribed the eassia-yielding distriets of China proper, and brought therefrom the specimens requisite for aseertaining the botanical origin of the bark."

Cassia lignea is also produced in the Khasya mountains in Eastem Bengal, whenee it is brought down to Caleutta for shipment. ${ }^{3}$ In this region there are three speeies of Cinnamomum, growing at 1000 to 4000 feet above the sea-level, and all have bark with the flavour of cimnamon, more or less pure: they are $C$. obtusifolium Nees, $C$. panciflorum Nees, and C. Tamala Fr. Nees et Eberm.

Cinnamomum iners Reinw., a very variable species oceurring in Continental India, Ceylon, Tavoy, Java, Sumatra and other islands of the Indian Archipelago, and possibly in the opinion of Thwaites a mere variety of $C$. Zcylanicum, but according to Meissner weil distinguished by its paler, thinner leaves, its nervation, and the eharacter of its aroma, wouldfappear to yield the cassia bark or wild cinnamon of Southern India. ${ }^{ \pm}$

C. Tamala Fr. Nees et Ebern., which besides growing in Khasya is found in the contiguous regions of Silhet, Sikkim, Nepal, and Kumaon, and even reaches Australia, probably affords some eassia bark in Northern India.

Large quantities of a thick sort of cassia have at times been imported from Singapore and Batavia, mueh of which is produeed in Sumatra. In the absence of any very reliable information as to its botanical sourees, we may suggest as probable mother-plants, C. Cassia Bl. and C. Burmanni Bl., var. a, Chincnsc, both stated by Teijsmann and Binnendijk to be eultivated in Java. ${ }^{5}$ The latter speeies growing also in the Philippines, most probably affords the eassia bark which is shipped from Manila.

History-In the preeeding article, we have inclicated (p. 467) the remote period at whieh eassia bark appears to have been known to the Chinese; and have stated the reasons that lead us to believe the einnamon of the aneients was that substance. It must, however, be observed that Theophrastus, Dioseorides, Pliny, Strabo and others, as well as the remarkable inseription on the temple of Apollo at Miletus, represent cinnamon and eassia as distinet, but nearly allied substances. While on the other hand, the author of the Periplus of the Erythrean Sea, in enumerating the produets shipped from the various

1 Thorel, Notes médicales ctu Voyage d'Exploration du Nékong et de Cochinchine, Paris, 1870. 30. .

2 The greatest market in China for cassia and eimnamon according to Dr. F. Porter Smith, is Taiwu in Ping-nan hion (Sin-chau fu), in Kwangsi provinee.-Mal. Mccd. and Nat. II ist. of China, 1871. 52. - The canital of Kwangsi is Kweilin fu, literally CassicForcst.
${ }^{3}$ Hooker, Himalayan Jununals, el. 2. ii. (1855) 303

4 A specimen of the stem-bark of $C$. incrs from Travaneore, presented to us by $\mathrm{Dr}$. Waring, has a delightful odour', bnt is quite devoil of the taste of cimnamon.

"Catalogres Plantarum qua ine IIorto Botanico Bogorionsi coluntur, Batavia, 1866. 92. 
commercial ports of Eastern Africa ${ }^{1}$ in the firstecntury, mentions Cussice

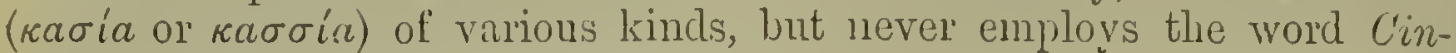

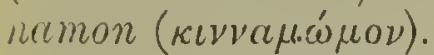

In the list of productions of India on which duty was levied at the Roman custom house at Alexandria, circe A.D. 176-180, Cimnamomum is mentioned as well as Cassia turiana, Xylocassia and Xylocinnamomum. ${ }^{2}$ Of the distinction here drawn between cinnamon and cassia, we can give no cxplanation; but it is worthy of note that twigs and lranches of a Cinncemomum are sold in the Chinesc drug shops, and may not improbably be the xylocassia or xylocinnamon of the ancicnts. ${ }^{3}$ The name Cassialignce would seem to have been originally bestorved on some such substance, rather than as at present, on a mere bark. The spicc was also undoubtedly called Cassia syrinx and Cassice fislularis (p. 195),names which cvidently refer to a bark which had the form of a tube. In fact there may well have bcen a diversity of qualities, some perhaps very costly. It is remarkable that such is still the case in China, and that the wealthy Chinese cmploy a thick variety of cassia, the price of which is as much as 18 dollars per catty, or about 56s. per $\mathrm{1b}^{4}{ }^{4}$

Whether the Aromatc Cassio, which were presented to the Church at Rome under St. Silvester, A.D. 314-335, was the modern cassia bark, is rather doubtful. The largest donation, $200 \mathrm{Hb}$., which was accompanied by pepper, saffron, storax, cloves, and balsam, would appear to have arrived from Egypt. ${ }^{5}$ Cassia-seems to have been known in Western Europe as early as the 7 th century, for it is mentioned with cinnamon by St. Isidorc, archbishop of Seville. ${ }^{6}$ Cassia is named in one of the Leech-books in use in England prior to the Norman conquest. ${ }^{7}$ The spice was sold in London as Canel, in 1264, at 10d. per 17., sugar being at the same time $12 d$., cumin $2 d$, and ginger $18 d .{ }^{8}$ In the Boke of Nurture ${ }^{9}$ written in the 15 th century by John Russell, chamberlain to Humphry, duke of Gloucester, cassia is spoken of as resembling cinnamon, but cheaper and commoner, exactly as at the present day.

Production - We have no information whether the tree which affords the cassia bark of Southern China is cultivated, or whether it is exclusively found wild.

The Calcutta cassia bark collected in the Khasya mountains and

1 Vincent, Commerce and Navigation of the Ancients in the Indian Oeean, ii. (1507) 130.134. 149. 150.157.-That the ancients should confound the different kinds of cassia is really no matter for surprise, when $\pi \mathrm{C}$ moderns, whether botanists, pharmaeolosrists, or spice-dealers, are unable to point out charaeters by which to distinguish the barks of this group, or cren to give definite mames to thosc found in our wareliouses.

2 Vincent, op. cit. ii. 701-716.

3 In 1872 , no less than $456,533 \mathrm{lb}$. of this rood of eassic or Cassic Twigs, were shipped from Canton, for the most part to other Chinese ports.-Reticrns of Trads at the Treaty Ports in China for 1872, p. 34.

4 Very fimo spccimens of this costly bark have been kindly supplicd to us by Dr. H. F. Hance, British Vice-Consul at Whampoa.
5 Vignolius, Liber Pontificalis, Roma i. (1721) 94. 95 .

6 Migne, Patrologice Cursus, lxxxii. (1550) 622. - St. Isidore evidently quotes Galen, but his remarks imply that both spiees were known at the period when he wrote.

7 Cockayne, Lecehdoms, de., of Enrily Eilgland, ii. (1865) 143.

s Rogers, ITist. of Agriculture and Prices in Enciland, ii. (1S66) 543.

9 The book lias been reprinted for the Early English Text Society, 1S63.-Russell says:-- "Looke that your stikkes of symamome be thy $\overline{1}$, bretille and fayre in colewr ... for canclle is not so good in this erafte and cure."-And in his directions "how: to make Ypoeras," he prescribes symamome in that "for"lordes," but "canelle" iu that for "commyn paple." 
brought to Calcutta is afforded by wild trees of small size. Dr. Hooker who visited the district with Dr. Thomson in 1850 , observes that the trade in the bark is of recent introduction. ${ }^{1}$ The bark which varies much in thickness, has been scraped of its outer layer.

Cassia is extensively produced in Sumatra, as may be inferred from the fact that Padang in that island, exported of the bark in 1871, 6128 peculs $\left(817,066 \mathrm{tb}\right.$.), a large proportion of which was shipped to America. ${ }^{2}$ Regarding the collection of cassia on the Malabar coast, in Java and in the Philippines, no particular account has, so far as we know, been published. Spain imported from the Philippines by way of Cadiz in $1871,93,000 \mathrm{tb}$. of cassia. ${ }^{3}$

Description - Chinese Cassia lignea, otherwise called Chinese Cinnamon, which of all the varieties is that most esteemed, and approaching most nearly to Ceylon cinnamon, arrives in small bundles about a foot in length and a pound in weight, the pieces of bark being held together with bands of bamboo.

The bark has a general resemblance to cinnamon, but is in simple quills, not inserted one within the other. The quills moreover are less straight, even and regular, and are of a darker brown; and though some of the bark is extremely thin, other pieces are much stouter than fine cinnamon, - in fact, it is much less miniform. The outer coat has been removed with less care than that of Ceylon cinnamon, and pieces can easily be found with the corky layer untouched by the knife.

Cassia bark breaks with a short fractmre. The thicker bark cut transversely, shows a faint white line in the centre rumning parallel with the surface. Good cassia in taste resembles cinnamon, than which it is not less, sweet and aromatic, though it is often described as less fine and delicate in flavour.

An unusual kind of cassia lignea has been recently (1870) imported from China and offered in the London market as China Cinnamon, though it is not the bark that bears this name in continental trade. The new drug is in unseraped quills which are mostly of about the thickness of ordinary Chinese cassia lignea; it has a very saccharine taste and pungent cinnamon flavour.

The less esteemed kinds of cassia bark, which of late years have been poured into the market in vast quantity, are known in commerce as Cassia lignea, Cassia vera or Wild Cassia, and are further distinguished by the names of the localities whence shipped, as Calcutta, Java,
Timor, \&c.

The barks thus met with, vary exceedingly in colour, thickness and aroma, so that it is vain to attempt any general classification. Some have a pale cinnamon hue, but most are of a deep rich brown. They present all variations in thickness, from that of cardboard to more than a quarter of an inch thick. The flavour is more or less that of cimnamon, often with some unpleasant addition suggestive of insects of the genus Cimex. Many, besides being aromatic, are highly mucilaginous, the mucilage being freely imparted to cold water. Finally, we have met

1 Hooker, op. cit.

${ }^{2}$ Consular Reporls; Angust 1873. 953.

3 Consul Reade, Rieport on the Trude, dic. of Cadiz for 1871, where the spice is ealled "cinnamon."
${ }_{4}$ Messis. Dalton and Young of Cullum Street have obligingly supplied us with a sample of this bark. See also Flücliger in Wirgers and Husemaun's Jahresbcricht for
1372 . 52 . 
with some thick cassia bark of good appearnnce that was distinguished by astringency and the almost entire absence of aroma. ${ }^{1}$

Microscopic Structure-A transverse section of such pieces of Chincse Cassice lignea as still bear the suberous envelope, exlibits the following character's. 'The external surface is made up of several rows of the usual cork-cells, loaded with brorvn colouring matter. In pieces from which the cork-cells have been entirely scraped, the surface is formed of the mesopliloeum, yet by far the larger part of the bark belongs to the liber or endophlowum. Isolated liber-fibres and thick-walled cells (stone-cells) are scattered even through the outer layers of a transrerse section. " In the middle zone they are numerous, but do not form a coherent sclerenchymatous ling as in cinnamon (p. 473). The innermost part of the liber shares the structural character of cinnamon with differences due to age, as for instance the greater developinent of the medullary lays. Oil-cells and gum-ducts are likewise distributed in the parenchyme of the former.

The "Chinc Cinnamon" of 1870 (p. 477) comes still nearer to Ceylon cinnamon, except that it is coated. A transverse section of a quill, characterizing that bark. The sclerenchymatous ring is covered by a parenchyme rich in oil-ducts, :So that it is obvious that the flavour of this drug could not be improved by scraping. The corky layer is composed of the usual tabular cells. The liber of this drug in fact agrees with that of Ceylon cimmamon.

In Cassia Barlis of considerable thichness, the same arrangement of tissues is met with, but their strong development causes a certain dissimilarity. Thus the thick-walled cells are more and more separated one from another, so as to form only small groups. The same applies also to the liber-fibres, which in thick barks are surrounded by a parenchyme, loaded with considerable crystals of oxalate of calcium. The gum-ducts are not larger, but are more. mumerous in these barks, which swell considerably in cold water.

Chemical Composition-Cassia bark owes its aromatic properties to an essential oil, large quantities of which are shipped from Canton. In a chemical point of view, no difference can be pointed out between this oil and that of Ceylon cinnamon. The flavour of cassia oil is somewhat less agreeable, and as it exists in the less valuable sorts of cassia, decidedly different in aroma from that of cinnamon. We find the sp. gr: of a Chinese cassia oil to be 1.066 , and its rotatory porver in a columm $50 \mathrm{~mm}$. long, only $0^{\circ} \cdot 1$ to the right, differing consequently in this respect from that of cinnamon oil (p. 473 ).

Oil of cassia sometimes deposits a stearoptene, which when purified, is a colourless, inodorous substance, crystallizing in shining brittle prisms.? We have never met with it.

If thin sections of cassia bark are moistened with a dilute solutiou of perchloride of iron, the contents of the parenchymatous part of the whole tissue assume a dingy brown colour; in the outer layers the starch

1 It is a bark of this lind that the late Professor Guibourt considered to be the true Cassia lignea and to which he restrictel tho name. - II ist. des Drogues, ii. (1849) 380.
2 Rochleder and Schwarz in Gmelin's Chomistry, xvii. 395. 
granules cven are coloured. Tannic matter is consequently onc of the chief constituents of the bark; the very cell-walls are also imbued with it. A decoction of the bark is turned blackish green by a per-salt of iron.

If cassia bark (or Ceylon cinnamon) is exhausted by cold water, the clear liquid becomes turbid on addition of iodine; the same occurs if a concentrated solution of iodide of potassium is added. An abundant precipitate is produced by addition of iodine dissolved in the potassium salt. The colour of iodine then disappears. There is consequently a substance present, which unites with iodine; and in fact, if to a decoction of cassia or cinnamon, the said solution of iodine is added, it strikes a bright blue coloration, due to starch. But the colour quickly disappears, and becomes permanent only after much of the test has been added. We have not ascertained the nature of the substance that thus modifies the action of iodine: it can hardly be tannic matter, as we have found the reaction to be the same when we used bark that had been previously repeatedly treated with spirit of wine and then several times with boiling ether.

The mucilage contained in the gum-cells of the thinner quills of cassia is easily clissolved by cold water, and may be precipitated together with tannin, by neutral acetate of lead, but not by alcohol. In the thicker barks it appears less soluble, merely swelling into a slimy jelly.

Commerce-Cassia lignea is exported from Canton in enormous and increasing quantities. The shipments which in 1864 amounted to 13,800 peculs, reached 40,600 in $1869,{ }^{1} 61,220$ in 1871, and 76,464 peculs $\left(10,195,200 \mathrm{lb}\right.$.) value $£ 267,703$, in $1872 .^{2}$ A very large proportion of the cassia bark imported into England is reshipped to other countries.

Oil of cassia was shipped from the south of China to the United Kingdom, to the extent in 1869, of $47,517 \mathrm{17}$.; - in 1870, of $28,389 \mathrm{lb}^{3}$

Uses-The same as those of cinnamon.

\section{Allied Products.}

Cassicu Buds-These are the immature fruits of the trec yielding Chinese cassia lignea, and have been used in Europe since the middle ages. In the journal of expenses (A.D. 1359-60) of John, king of France, when a prisoner at Somerton Castle in England, there are several entries for the spice under the name of Flor de Canclle; it was very expensive, costing from 8 s. to $13 \mathrm{~s}$. per lb., or more than double the price of mace or cloves. On one occasion two pounds of it had to be obtained for the king's use from Bruges." From the Form of Cury ${ }^{5}$ written in 1390, it appears that cassia buds ("Flo de oueyncl") were used in preparing the spiced wine called Hippocress.

Cassia buds are shipped from Canton, but the exports have much declined. Rondot, writing in $1848,{ }^{6}$ estimated them as averaging 400

I Canton Troude Report for 1869.

9 Commercial Reports from $H . i \Gamma$. Consuls in China, presented to Parliment 1873 , (Consul Robertson).

${ }^{3}$ Annual Statement of the Trade and Naviyalion of the Uniled, Kinurdom for 1870 . 290. - No later returns accessible.
* Doüet l'Al'cq, Comptes le l'Argenterie des liois de Fronec, 1851. 206. 218. 222. 239 \&c.

5 See 1). 217, note 8.

'Commerec d'exportation de la Chine, 45. 
pecnls $(53,333 \mathrm{1b}$.) a year. In 1866 , there were shipped from Canton, only 233 peculs $\left(31,066 \mathrm{ftb}\right.$.); in 1867,165 peculs $(22,000 \mathrm{Ht} \text {. })^{1}$ The quantity of Cassia Buds imported into the United Kingdom in 1870, was $29,321 \mathrm{tb} . ;^{2}$ the spice is sold chiefly by grocers.

In Southern 1 ndia, the more mature fruits of one of the varieties of Cinnamomum incrs Reinw. are collected for use, but are very inferior to the Clinese cassia buds.

Folice Malabath $i$-is the name given to the dried, aromatis, leaves of certain Indian species of Cinnamomum, formerly employed in European medicine, but now obsolete. Under the name Taj-pat, the leaves are still used in India; they are collected in Mysore from wild trees.

Istepingo-This is the designation in Quito of the calyx of a tree of the laurel tribe, used in Ecuador and Peru in the place of cinnamon. Though but little known in Europe, it has a remarkable history.

The existence of a spice-yielding region in South America, having come to the ears of the Spanish conquerors, was regarded as a matter of such high importance that an expedition for its exploration was fitted ont. The direction of the enterprise was confided to Gonzalo Pizarro, who with 340 soldiers, and more than 4000 Indians, laden with supplies, quitted the city of Quito on Christmas Day, 1533. The expedition, which lasted two years, resulted in the most lamentable failure, only 130 Spaniards surviving the hardships of the journey. In the account of it given by Garcilasso de la Vega, the cinnamon tree is described as having large leaves like those of a laurel, with fruits resembling acorns growing in clusters. ${ }^{3}$ Oviedo ${ }^{4}$ has also given some particulars regarding the spice, together with a figure fairly representing its remarkable form: and the subject has been noticed by several other Spanish writers, including Monardes. ${ }^{5}$

Notwithstanding the celebrity thus conferred on the spice, and the fact that the latter gives its name to a large tract of country, ${ }^{6}$ and is still the object of a considerable traffic, the tree itself is all but unknown to science. Meissner places it doubtfully under the genus Ncctandra, with the specific name cinnamomoides, but confesses that its flowers and fruits are alike unknown. ${ }^{7}$

The spice, for an ample specimen of which we liave to thank Dr. Destruge, of Guayaquil, consists of the enlarged and matured roody calyx, $1 \frac{1}{2}$ to 2 inches in diameter, having the shape of a shallow funnel, the open part of which is a smooth cup (like the cup of an acom), surrounded by a broad, irregular margin, ustually recurved. The outer surface is rough and veiny, and the whole calyx is dark brown, and has a strong,

I Reports on Trade at the Treaty Ports in China for 1867, Shanghai, 1868. 94.

2 A munal Statement of the Trade and Nevigation of the U.K. for 1870. 101.

3 Travels of Pedro de Cieza de Leon, A.D. 1532-50, translated by Markham (Hakluyt Soeiety) Lond. 1864 . chap. 39-40; also Eixpedition of Gonzalo Pizarro to the Land of Cinnamon, by Garcilasso Inea de la Vega, forming part of the same volume.

4 Iristoria de las Indias, Madrid, i. (1851) 357. (lib. ix. e. 31).

- De la Canela de muestras Indias. - Historia de las cosas que so traen de mucstras
Indias oecidentales, Sevilla, 1574. 98.

6 The village of San José de Canclos, which may be eonsidered as the centre of the einnamon region, was determined by Mfr. Spruce to be in lat. $1^{\circ} 20 \mathrm{~S}$., long. $77^{\circ} 45 \mathrm{~W}$., and at an altitude above the sea of 1590 fect. The Forest of Canclos, he tells us, has no definite boundaries; but the term is popularly assigned to all the upper region of the Pastasa and its tributaries, from a height of 4000 to 7000 feet on the slopes of the Andes, down to the Amazonian plain, and the conflnenee of the Bombonasa and Pastasa.

7 De Candolle, Prodromus, xr. sect. i. 167. 
sweet, aromatic taste, like cimnamon, for which in Ecuador it is the common substitute.

Dr. Destruge has also furnished us with a specimen of the bark, which is in very small uncoated quills, exactly simulating true cinnamon. We are not aware whether the bark is thus prepared in quantity.

\section{CORTEX BIBIRU.}

\section{Cortex Nectandra; Greenheart Bark, Bibiru or Bebeeru Bark.}

Botanical Origin-Neetandra Rodicei Schomburgk-The Bibiru or Greenheart is a large forest tree, growing on rocky soils in British Guiana, twenty to fifty miles inland. It is found in abundance on the hill sides which skirt the rivers Essequibo, Cuyuni, Demerara, Pomeroon and Berbice. The tree attains a height of So to 90 feet, with an undivided erect trunk, furmishing an excellent timber which is ranked in England as one of the eight first-class woods for shipbuilding, and is to be had in beams of from 60 to 70 feet long.

History-In 1769, Bancroft, in his History of Guiana, called attention to the excellent timber afforded by the Greenheart or Sipeira. About the year 1835, it became known that Hugh Rodie, a navy surgeon who had settled in Demerara some twenty years previously, had discovered an alkaloid of considerable efficacy as a febrifuge, in the bark of this tree. ${ }^{1}$ In 1843, this alkaloid to which Rodie had given the name Bebeerine, was examined by Dr. Douglas Maclagan; and the following year, the tree was described by Schomburgk under the name of Neetandra Rodicei. ${ }^{2}$

Description-Greenheart bark occurs in long heavy flat pieces, not unfrequently 4 inches broad and $\frac{3}{10}$ of an inch thick, externally of a light greyish brown, with the inner surface of a more uniform cinnamon hue and with strong longitudinal strix. It is hard and brittle; the fracture coarse-grained, slightly foliaceous, and only fibrous in the inner layer. The grey suberous coat is always thin, often forming small warts, and leaving when removed longitudinal depressions analogous to the digital furrows of Flat Calisaya Bark (p. 316), but mostly longer. Greenheart bark has a strong bitter taste, but is not aromatic. Its watery infusion is of a very pale cinnamon brown.

Microscopic Structure-The general features of this bark are very uniform, almost the whole tissue having been changed into thickwalled cells. Even the cells of the corky layer show secondary deposits; the primary envelope has entirely disappeared, and no transition from the suberous coat to liber is obvious.

The prevalent forms of the tissue are the stone-cells and very short liber-fibres, intersected by small medullary rays and crossed transversely by parenchyme or small prosenchyme cells with walls a little less thickened, so as to appear in a transverse section as irregular squares or groups. The only cells of a peculiar character are the sharp-pointed

1 Halliday, On the Bebecru tree of British Guiana, and Sulphate of Bebecrine, the former a substitute for Cinchona, the latter for Sulphate of Quinine.-Edinburgh $M$ ed. and Surg. Journ. vol. xl. 1835.

Hooker's Journ. of Bot., 1844. 624. 
libres of the inner liber, which are euriously saw-shaped, being provided with numerous protuherances and sinuosities.

'The very small lumen of the thick-walled cells contains a dark brown mass which is coloured grcenish-black by sulphate of iron; the same coloration takes place thronghout the less dense tissuc surrounding the groups of stone-cells, and may in cach case be due to tannic matter.

Chemical Composition-Giccuhenrt bark contains an alkaloid which has long been regarded as peculiar, under the nanc of Bibirine or Bebirine. It was however shown by Walz in 1860 to be apparently identical with Buxine, a substance discovercd as early as 1830 in the bark and leaves of the Comrnon Box, Buxus sempervirens L. In 1869, the observation of Walz was to some cxtent confirmed by onc of us, ${ }^{1}$ who furthcr demonstrated that Pelosine, an alkaloid occurring in the stems and roots of Cissampelos Pareirce L. and Chondodendron tomentosum Riniz et Pavon (p. 27), is undistinguishable from the alkaloids of greenheart and box.

The alkaloid of bibiru bark, which may be convenicntly prepared from the crudc sulphate used in medicine under the name of S'ulphate of Bitirine, is a colourless amorphous substance, the composition of which is indicated by the formula, $\mathrm{C}^{18} \mathrm{H}^{21} \mathrm{NO}^{3}$. It is soluble in 5 parts of absolute alcohol, in 13 of ether, and in 1400 (1800) Valz) of boiling water, the solution in each case having a decidedly alkaline reaction on litmus. It dissolves readily in bisulphide of carbon, as wcll as in dilute acids. The salts hithcrto known are uncrystallizable. The solution of a neutral acetate affords an abundant white precipitatc on the addition of an alkaline phosphate, nitratc or iodide, of iodo-hydrargyrate or platino-cyanide of potassium, perchloride of mercury, or of nitric or iodic acid.

Maclagan, one of the earliest investigators of greenheart, has recently obtained in co-operation with Gamgee ${ }^{2}$ certain alkaloids from the wood of the tree, to one of which, these chemists have assigned the formula ${ }^{120} \mathrm{H}^{23} \mathrm{NO}^{4}$ and the name Nectandria. Two other alkaloids, the characters of which have not yet becn fully investigated, are stated to have been obtained from the same source.

Bitiric Aeid, which Maclagan obtained from the sceds, is described as a colourless, crystalline, deliqucscent substance, fusing at $150^{\circ} \mathrm{C}$. and volatile at $200^{\circ} \mathrm{C}$., then forming needle-shaped groups.

Commerce-The supplics of greenheart bark are extremely uncertain, and the drug is scarccly to be found in the market. It has been imported in barrels containing 80 to $84 \mathrm{th}$. each, or in bags holding $\frac{1}{2}$ to $\frac{3}{4} \mathrm{cw}$.

Uses-The bark has been recommended as a bitter tonic and f'cbrifuge, but is hardly ever employcd exccpt in the form of what is called Sulphate of Bibirine, which, as wc have said, is crulc Sulphate of Buxine. ${ }^{3}$ It is a dark amorphous substance which, laving while in a syrupy state becn spread out on glazed platcs, is obtained in thin transluccnt lamina. We find it to yield scarccly one-third of its weight of thic pure alkaloid.

1 Hliickiger, Neues Jahrbuch für Pharmucic, xxxi. (1869) 257 ; Pharm. Jonrn. xi. (1870) 192.

2 Plurm. Journ. xi. (1870) 19.

3 Mr. W. H. Camplell, of Georgetown. Demerara, lias assured me that neither the bark nor its alkali is held in esteem in the colony.-D. H. 


\section{RADIX SASSAFRAS.}

\section{Sassafras Root; F. Bois de Sassafras, Lignum Sassafras; G. Sassafrasholz.}

Botanical Origin-Sassafras officinale Nees (Launus Sassafras L.), a tree growing in North America, from Canada, southward to Florida and Missouri. In the north, it is only a shrub, or a small tree 20 to 30 feet high, but in the Middle and Souther'n United States, and especially in Virginia and Carolina, it attains a height of 40 to 50 feet. The leaves are of different forms, some being ovate and entire, and other's two- or three-lobed, the former it is said, appearing earlier than the latter.

History-Monardes relates that the French during their expedition to Florida, about the year 1562 , cured their sick with the wood and root of a tree called Sassafras, the use of which they had leamt from the Indians. ${ }^{1}$ Laudonnière, who diligently set forth the wonders of Florida, observes that among oforest trees, the most remarkable for its timber and especially for its fragrant bark, is that called by the savages Pavame, and by the French Sassafra. ${ }^{2}$

In 1610, a paper of instructions from the Government of England to that of the new colony of Virginia, mentions among commodities to be sent home, "Small Sassafras Rootcs," which are "to be drawen in the winter and dryed and none to be medled with in the soner; -and yt is worthe $£ 50$ and better per tonne." 3 The shipments were afterwar'ds much overdone, for in 1622, complaint is made that other things than tobacco and sassafras ${ }^{4}$ were neglected to be shipped.

The sassafras tree had been introduced into England in the time of Gerarde (circa 1597), who speaks of a specimen growing at Bow. At that period, the wood and bark of the root were used chiefly in the treatment of ague.

Description-Sassafras is imported in large branching logs, which often include the lower portion of the stem, 6 to 12 inches in diameter. 5 The roots proper, which diminish in size down to the thickness of a quill, are covered with a dull, rough, spongy bark. This bark has an inert, soft corky layer, beneath which is a firmer inner bark of brighter lue, rich in essential oil, The wood of the root is light and easily cut, in colour of a dull reddish brown, and with a fragrant odour and spicy taste similar to that of the bark but less strong. It is usually sold in the shops, rasped into shavings.

The bark, of the root (Cortex Sassafias) is a separate article of commerce, but not intich used in England. It consists of channelled, flattish, or curled, irregular fragments, seldom exceeding 4 inches long by 3 inches broad and generally nuch smaller, and from $\frac{1}{10}$ to $\frac{1}{4}$ of an inch in thickness. The inert outer layer has been carefully removed, leaving a scarred, exfoliating surface. The inner surface is finely striated

II istoria medicinal de las cosas que se traen de nuestras Indias oecidentales, 1574. 51.

2 De Lact, Novus Orbis, 1633. 215.

3 Colonial Papers, vol. i. No. 23 (MS. in the Record Office, London).
${ }^{4}$ Colonial Papers, vol. ii No. 4.

5 'The sassafras logs met with in English trade often include a considerable portion of trunk-wood, which, as well as the bark that covers it, is inert, and should be sawn ull and rejected before the wood is rasped. 
and exhibits very minnte shining crystals. 'The bark has a short, corky fracture, and in colour is a bright cimmanon brown of various shades. It has a strong and agrecable smell, with an astringent, aromatic, bitterish taste.

Microscopic Structure-The woor of the root exlibits in transverse section, concentric rings traversed by narrow medullary rays. Each ring contains a number of large vessels in its inner part, and more densely packed cells in its outer. The prevailing part of the wood consists of prosenchyme cells. Globular cells, loaded with yellow essential oil, are distributed among the woody prosenchyme. The latter as well as the inedullary rays abounds in starch.

The bark is rich in oil-cells and also contains cells fillerd with mucilage; it owes its spongy appearance and exfoliation to the formation of secondary cork bands (irhytidoma) within the mesophloum and even in the liber. The cortical tissue abounds in red colouring matter and further contains stareh and, less abundantly, oxalate of calcium.

Chemical Composition-The wood of the root yields 1 to 2 per cent. of volatile oil, ${ }^{1}$ and the root-bark twice as mucl. The stem and leaves of the tree contain but a very small quantity. The oil, which as found in commerce is all manufactured in America, has the specific odour of sassafras, and is colourless, yellow, or reddish-brown, according, as the distillers assert, to the character of the root employed. As the colour of the oil does not affect its flavour and market value, no effort is made to keep separate the different varicties of root.

Oil of Sassafras has a sp. gr. of 1.087 to 1.094, increasing somewhat by age (Procter). When cooled in a freezing mixture, it deposits crystals of Sassafras Camphor. This body which may be obtained in the form of hard, four- or six-sided prisms with the odour of sassafras, has the composition, $\mathrm{C}^{10} \mathrm{H}^{10} \mathrm{O}^{2}$; it has a sp. gr. of 1.245 , or 1.11 when melted at $12^{\circ} \mathrm{C}$. The liquefied crystals solidify at $7^{\circ} \mathrm{C}$. and boil at $232^{\circ} \mathrm{C}$. The rescarches of Grimaux and Ruotte ${ }^{2}$ show the oil to contain nine-tenths of its weight of Safrol, $\mathrm{C}^{10} \mathrm{H}^{10} \mathrm{O}^{2}$, a liquid boiling between about $230^{\circ}$ and $233^{\circ} \mathrm{C}$. and having a sp. gr. of 1.114 at $0^{\circ} \mathrm{C}$. Safrol has a fennel-like odour and is devoid of rotatory power ; it is not soluble in caustic alkalis. Treated with bromine, it yields crystals having the formula, $\mathrm{C}^{10} \mathrm{H}^{5} \mathrm{Br}^{5} \mathrm{O}^{2}$, melting at $170^{\circ} \mathrm{C}$. Safrol according to these chemists does not solidify even at $-20^{\circ} \mathrm{C}$. As the composition and boiling point of sassafras camphor agree with those of safrol, we suppose that the latter may by time acquire the faculty of concreting on exposure to cold, so that in fact these substances are identical.

Another constituent of sassafras oil has been termed by Grimaux and Puotte, Safrene; it boils at $155^{\circ}$ to $157^{\circ} \mathrm{C}$., has a sp. gr. of 0.834 , and the formula $\mathrm{C}^{10} \mathrm{H}^{16}$. It has the same odour as safrol, but deviates the ray of polarized light to the right.

It was further found by the same observers, that the crude oil contains an extremely snall quantity of a substance of the phenol class, which can be removed by caustic lye and separated by an acid. The oily liquid

1 According to information obtained by Procter, 11 bushels of chips (the charge of a still) yields from 1 to $5 \mathrm{lt}$. of oil, the amount varying with the quality of the root, and

Procter, Essay on Sassafras in the Procecdof the American Pham. Association, 1800. 217. the froportion of bark it may contain.-

2 Comples Rendus, Ixrii. (1869) 92s. 
thus obtained, assumes a green hue on addition of perchloride of iron, and separates silver from a boiling solntion of its nitrate. The Sosscurubin and Sassafrin of Hare (18.37) are impure products of the decomposition of sassafras oil by means of sulphuric acid.

The bark and also to some extent the wood, in both cases of the root, contain tannic acid which produces a blne colour with persalts of iron. By oxidation, we must suppose, it is converted into the red colouring matter deposited in the bark and, in smaller quantity, in the heart-wood of old trees. The young wood is nearly white. The said red substance probably agrees with that, to which. Reinsch in 1845 and 1846 gave the name of Sassafrid, and is doubtless analogous to cinchona-red and ratanhia-red. Reinsch obtained it to the extent of $9 \cdot 2$ per cent.

Production and Commerce-Baltimore is the chief mart for sassafras root, bark and oil, which are brought thither from within a circuit of 300 miles. The roots are extracted from the ground by the help of levers, partly barked and partly sent untouched to the market, or are cut up into chips for distillation on the spot. Of the bark, as much as $100,000 \mathrm{tb}$. were received in Baltimore in 1866 . The quantity of oil annually produced previous to the war, is estimated at 15,000 to $20,000 \mathrm{lb}$. There are isolated small distillers in Pennsylvania and West New Jersey, who are allowed by the owners of a "scissafras wilderness," to remove from the ground the roots and stumps without charge. Sassafras root is not medicinal in the United States, the more aromatic root-bark being reasonably preferred. ${ }^{1}$

Uses-Sassafras is reputed to be sudorific and stimulant, but in British practice it is only given in combination with sarsaparilla and guaiacum. Shavings of the wood are sold to make Sassafras Tea.

In America, the essential oil is used to give a pleasant flavour to effervescing drinks, tobacco and toilet soaps. ${ }^{2}$

Substitutes-The odour of sassafras is common to several plants of the order Lauracece. Thits the bark of Mespilodaphne Sassafras Meissn., a tree of Brazil, resembles in odour true sassafras. We have seen a very thick sassafras bark brought from India, the same we suppose as that which Mason ${ }^{3}$ describes as abundantly produced in Burma.

The large separate cotyledons of two lauraceous trees of the Rio Negro, doubtfully referred by Meissner to the genus Nectandra, furnish the so-called Sassafras Nuts or Puehury or Pichurim Beans of Brazil, occasionally to be met with in old drug warehouses.

On the Orinoko and in Guiana, a liquid called Sassafras Oil is obtained by boring into the stem of Orcodaphne opifora Nees, which sometimes contains a cavity holding a large quantity of this fluid. A similar oil (Aceite de Sassafras) is afforded on the Rio Negro by Nectandra Cymzarum Nees. ${ }^{4}$

1 Besides this, the pith of sassafras is also there used as a popular remedy; it is entirely devoid of odour and taste, and is very slightly mucilaginous.

${ }^{2}$ American Journ. of Pharm. 1871. 470.
3 Bur'mah, its people and natural productions, 1860. 497 .

${ }^{4}$ Spruce in Hooker's Journ. of Bot. vii. (1855) 278. 


\section{THYMELEA.}

\section{CORTEX MEZEREI.}

\section{Mezeron Bark; F. Ecorec de Mézéréon; G. Seidellust-Rinde.}

Botanical Origin-Daphne Mezerenm L., an erect shrub, 1 to $:$ feet high, the branches of which are crowded with purple flowers in the early spring before the full expansion of the oblong, lanceolate, deciduous leaves. The flowers are succeeded by red berries. It is a native of the hilly parts. of almost the whole of Europe, from Italy to the Arctic regions, and extends eastward to Siberia. In Britain, it occurs here and there in a few of the southern and midland counties, and even reaches Yorkshire and Westmoreland, but there is reason to think it is not truly indigenous. Gerarde, who was well acquainted with it, did not regard it as a Pritish plant.

History-The Arabian physicians used a plant called Mazariyún, the effects of which they compared to those of euphorbium; it was probably a species of Daphne. D. Mezereum was known to the early botanists of Europe, as Daphnoides, Chamoloca, Thymelca, or Channedaphne. Tragus described and figured it in 1546, under the name of Mezereum Germanicum.

Description-Mezereon has a very tough and fibrous bark easily removed in long strips which curl inwards as they dry; it is collected in winter and made up into rolls or bundles. The bark, which rarely exceeds $\frac{1}{20}$ of an inch in thickness, has an external greyish or reddish-brown corky coat which is easily separable from a green inner layer, white and satiny on the side next the wood. That of younger branches is marked with prominent leaf-scars. The bark is too tough to be brokeu, but easily tears into fibrous strips. When fresh, it has an unpleasant odour which is lost in drying; its taste is persistently burning and acrid. Applied in a moist state to the skin, it occasions after some hours, redness and even vesication,

Microscopic Structure-The cambial zone is formed of about ten rows of delicate mnequal cells. The liber consists chiefly of simple fibres alteruating with parenchymatous bundles, and traversed by medullary rays. The fibres are very long,--frequently more than $3 \mathrm{~mm}$., and from 5 to $10 \mathrm{mkm}$. in diameter, their walls being always but little thickened. In the outer part of the liber, there occur bundles of thick-walled basttubes, while chlorophyll and starch granules appear generally throughout the middle cortical layer. The suberous coat is made up of about 30 dense rows of thin-walled tabular cells, which examined in a tangential section, have an hexagonal outline. Small quantities of tannic matter are deposited in the cambial and suberous zones.

Chemical Composition-The acrid principle of mezereon is a resinoid substance contained in the inner bark: it has not yet been examined. The fruits were found by Martius (1862) to contain more than 40 per cent. of a fatty, vesicating oil, which appears to be likenise present in the bark.

The name Daphnin has been given to a crystallizable substance obtained by Vauquelin in 1808, from Daphne alpina, and afterwards detected by C. G. Gmelin and Baer in the bark of D. Mcscreum. Zwenger 
in 1860 , ascertained it to be a non-volatile glucoside of bitter taste, having the composition, $\mathrm{C}^{31} \mathrm{H}^{34} \mathrm{O}^{19}$.

When daphnin is boiled with dilute hydrochloric or sulphuric acid, it furmishes Daphnetin, $\mathrm{C}^{19} \mathrm{H}^{14} \mathrm{O}^{9}$, described by Zwenger as crystallizing in colourless prisms. By dry distillation of an alcoholic extract of mezereon bark, the same chemist obtained Umbelliferone (p. 287).

Uses-Mezereon taken internally is supposed to be alterative and sudorific, and useful in venereal, rheumatic and scrofulous complaints ; but in English medicine it is never now given except as an ingredient of the Compound Decoction of Sarsaparilla. An ethereal extract of the burk has been introduced (1867) as an ingredient of a powerful stimulating liniment. On the Continent, the bark itself, soaked in vinegar and water, is applied with a bandage as a vesicant.

Substitutes-Owing to the difficulty of procuring the bark of the root of $D$. Mezereum, the herbalists who supply the London druggists have been long in the habit of substituting that of $D$. Laureola L., an evergreen species, not uncommon in woods and hedge-sides in several parts of England. The British Pharmaeopocia (1864 and 1867) permits Cortex Mezerei to be obtained indiscriminately from either of these species, and does not follow the London College in insisting on the bark of the root alone. That of the stem of $D$. Laureola corresponds in structure with the bark of the true mezereon, but wants the prominent leaf-scars that mark the upper branches of the latter; it is reputed to be somewhat less acrid than mezereon bark. The mezereon bark of English trade is now mostly imported from Germany, and seems to be derived from D. Mezеreum.

In France, use is made of the stem-bark of D. Gnidium L., a shrub growing throughout the whole Mediterranean region as far as Morocco. The bark is dark grey or brown, marked with numerous whitish Jeaf-scars which display a spiral arrangement, at least in the younger stems. The leaves themselves, some of which are occasionally met with in the drug, are sharply mucronate and very narrow. As to structural peculiarities, the bark of $D$. Gnidium has the medullary rays more obvious and more loaded with tannic matters than those of $D$. Mezereum; but the middle cortical layer is less developed. The bark, which is called. Ecorcc de Garou, is employed as an epispastic.

\section{ARTUCARPACE无.}

\section{CARIC $A$.}

Fruetus Curice, Fici; Figs; F. Figues; G. Feigen.

Botanical Origin-Ficus Carica L., a deciduous tree, 15 to 20 feet in height, with large rough leaves, forming a handsome mass of foliage.

The native country of the fig stretches from the steppes of the Eastern Aral, along the south and south-west coast of the Caspian Sea (Ghilan, Mazanderan and the Caucasus) through Kurdistan, to Asia Minor and Syria. In these countries, the fig-tree ascends into the mountain region, growing undoubtedly wild in the Taurus at an elevation of 1800 feet. ${ }^{1}$

1 Ritter, Erolkunde, von Asirn, vii. (184.1) 2. ã4t. 
The fig-tree is repeatedly mentioned in the Scriptures, where with the vine, it often stands as the symbol of peace and plenty. Neither fig nor vine was known in Greece, the Archipelago and the neighbouring consts of Asia Minor during the Homeric age, though both were very common in the time of Plato. The fig-tree was early introduced into Italy, whence it reached Spain and Gaul. Charlemagne (A.D. 768-81.4) orlered its cultivation in Central Europe. It was brought to England in the reign of Henry VIII. by Cardinal Pole, whose trees still exist in the garden of Lambeth Palace. But it had certainly been in cultivation at a muclı earlier period, for the historian Matthew Paris relates ${ }^{1}$ that the year 1257 was so inclement that apples and pears were scarce in England, and that figs, cherries and plums totally failed to ripen.

At the present day, the fig-tree is found cultivated in most of the temperate countries both of the old and new world. Its fruit can only be preserved in those regions where the summer and autumn are very warm and dry.

History-Figs were a valued article of food among the ancient Hebrews ${ }^{2}$ and Greeks, as they are to the present day in the warmer countries bordering the Mediterranean. ${ }^{3}$ In the time of Pliny many varieties were in cultivation. The Latin word Carica was first used to designate the dried fig of Caria, a strip of country in Asia Minor opposite Rhodes, an esteemed variety of the fruit corresponding to the Smyrna fig of modern times.

In a diploma granted by Chilperic II., king of the Franks, to the monastery of Corbie, A.D. 716, mention is made of "Karigas," in connexion with dates, almonds and olives, by which we think dried figs (Caricce) were intended.4 Dried figs were a regular article of trade during the middle ages, from the southern to the northern parts of Europe. In England, the average price between A.D. 1264 and 1398, was about $1 \frac{3}{4} d$. per 16 ., raisins and currants being $2 \frac{3}{4} d .^{5}$

Description-A fig consists of a thick, fleshy, hollow receptacle of a pear-shaped form, on the inner face of which grow a multitude of minute fruits. This receptacle, which is provided with an orifice at the top, is at first green, tough and leathery, exuding when pricked a milky juice. The orifice is surrounded and almost closed by a number of thick, fleshy scales, near which and within the fig; the male flowers are situated, but they are often wanting or are not fully developed. The female flowers stand further within the receptacle, in the body of which they are closely packed; they are stalked, have a 5-leafed perianth and bipartite stigma. The ovary which is generally one-celled, becomes when ripe, a minute, dry, hard nut, popularly regarded as a seed.

As the fig advances to maturity, the receptacle enlarges, becomes softer and more juicy, a saccharine fluid replacing the acrid milliy sap. It also acquires a reddish hue, while its exterior becomes purple, brown or yellow, though in some varieties it continues green. The fresh fig has

1 English History, Bohn's cdition, iii. (1854) 255 .

2 See in partieular 1 Sam. xxv. 18 and 1 Chron. xii. 40 ; where we read of large supplies of dried figs being provided for the use of fighting men.
3 On the Riviera of Genoa, dried figs eaten with bread are a common winter food of the peasantry.

\& Pardessus, Diplomata, Charta, etc., ii. (1849) 309.

5 Rogers, Hist. of Agriculturc and Prices in England, i. (1866) 632 . 
an agreeable and extremely saccharine taste, but it wants the juiciness and refreshing acidity that characterize many other fruits.

If a fig is not gathered, its stalk loses its firmness, the fruit hangs pendulous from the branch, begins to shrivel and become more and more saccharine by loss of water, and ultimately if the climate is favourable, it assumes the condition of a dried fig. On the large scale however, figs are not dried on the tree, but are gathered and exposed to the sun and air in light trays till they acquire the proper degree of dryness.

Dried figs are termed by the dealers, either natural or pulled. The first are those which have not been compressed in the packing, and still retain their original shape. ${ }^{1}$ The second are those which after drying have been made supple by squeezing and kneading, and in that state packed with pressure into drums and boxes.

Snyrna figs, which are the most esteemed sort, are of the latter kind. They are of irregular, flattened form, tough, translucent, covered with a saccharine efflorescence; they have a pleasant fruity smell and luscious taste. Figs of inferior quality, as those called in the market Greek Figs, differ chiefly in being smaller and less pulpy.

Microscopic Structure-The outer layer of a dried fig is made up of small, thick-walled and densely packed cells, so as to form a kind of skin. The inner lax parenchyme consists of larger thin-walled cells, traversed by vascular bundles and large, slightly branched, laticiferous vessels. The latter contain a granular substance not soluble in water. In the parenchyme, stellate crystals of oxalate of calcium occur, but in no considerable number.

Chemical Composition.-The chemical changes which take place in the fig during maturation are important, but no researches have yet been made for their elucidation. The chief chemical substance in the ripe fig is grape sugar, which constitutes from 60 to 70 per cent. of the dried fruit. Gum and fatty matter appear to be present only in very small quantity. We have observed that unripe figs contain starch.

Production and Commerce-Dried figs were imported into the United Kingdom in 1872, to the amount of $141,847 \mathrm{cwt}$., of which 91,721 cwt. were shipped from Asiatic Turkey, the remainder being from Portugal, Spain, the Austrian territories and other countries. The value of the total imports is estimated at $£ 231,571$.

Uses-Dried figs are thought to be slightly laxative, and as such are occasionally recommended in habitual constipation. They enter into the composition of Confectio Sennce.

\section{MORACE 2 .}

\section{FRUCTUS MORI.}

Bacece Mori, Mora; Mulberries; F. Mures; G. Naulbeeren.

Botanical Origin-Morus nigra L., a handsome bushy tree, about 30 feet in height, growing wild in Northern Asia Minor, Armenia, and the southern Caucasian regions as far as Persia. In Italy, it was em-

1 The word Eleme applied in the London hops to dried figs of superior quality

("Eleme Figs") is probahly a corruption of the Turkish cllémé, signifying hand-piclscel. 
ployed for feeding the silkworm until about the year 14:34, when $M$. allue L. was introduced from the Levant, ${ }^{1}$ and has ever since been commonly preferred. Yet in Greece, in many of the Greek islands, Calabria and C'orsica, the species planted for the silkworm is still M. nigra.

The inulberry tree is now cultivated throughout kiurope, yet excepting in the regions named, by no means abmndantly. It ripens its fruit in England, as well as in Southern Sweden and Gottland, and in favourable summers even in Christiania (Schiibeler).

History - The mulberry tree is mentioned in the Old 'Testament, ${ }^{2}$ and by most of the early Greek and Roman writers. Among the large number of useful plants ordered by Charlemagne (A.D. 812) to be cultivated on the imperial farms, the mulberry tree (Morurius) did not escape notice. ${ }^{3}$ We meet with it also in a plan sketched A.D. 820, for the gardens of the monastery of St. Gall in Switzerland. ${ }^{4}$ The cultivation of the mulberry in Spain is implied by a reference to the preparation of Symup of Ainulberries, in the Calendar of Cordova ${ }^{5}$ which dates from the year 961 .

A curious reference to mulberries, proving them to have been far more esteemed in ancient times than at present, occurs in the statutes of the abbey of Corbie in Normandy, in which we find a Brevis de Melle, showing how much honcy the tenants of the monastic lands were required to pay annually, followed by a statement of the quantity of Mulberrics which each farm was expected to supply. ${ }^{6}$

Description-The tree bears unisexual catkins; the female, of an ovoid form, consists of numerous flowers with green four-lobed periantlis and two linear stigmas. The lobes of the perianth overlapping each other become fleshy, and by their lateral aggregation forn the spurious berry, which is shortly stalked, oblong, an inch in length, and, when ripe, of an intense purple. By detaching a single fruit, the lobes of the former perianth may be still discerned. Each fruit encloses a hard lenticular nucule, covering a pendulous seed with curved embryo and fleshy albumen.

Mulberries are extremely juicy and have a refreshing, subacid, saccharine taste; but they are devoid of the fine aroma that distinguishes many fruits of the order Rosceece.

Chemical Composition-In an analysis made by H. van Hees (1857) mulberries yielded the following constituents :-

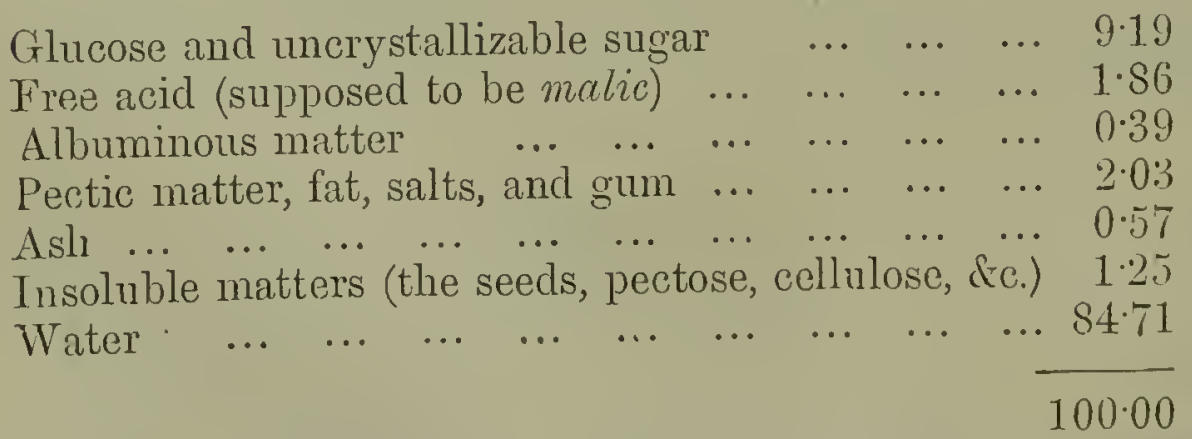

1 A. De Candolle, Géogr. botaniquc, ii. (1855) 856 .

22 Sam. จ. $23,24$.

3 Pertz, Monumenta Gormanice historica (Leges) iii. (1835) 181.
$4 \mathrm{~F}$. Keller, Bauriss des Klosters $S$. Gallen, facsimile, Ziirich, 1544.

5 Le Calendrier de Cordone de l'annéc 961 , publié par R. Dozy, Iseyde, 1873. 67.

6 Gnérard, Polyplizue ds l'albbé Irminon, Paris, ii. 335. 
With regard to the results of researches on other edible fruits, made about the same time in the laboratory of Frescnius, it would appear that the mulberry is one of the most saccharine, being only surpassed by the cherry $\left(10 \cdot 79\right.$ of sugar) and grape $(10 \cdot 6$ to $19 \cdot 0) .^{1}$ Tt is richer in sugar than the following, nanely :-

Raspberries, yielding 4 per cent. of sugar and 1.48 of (nalic) acid.

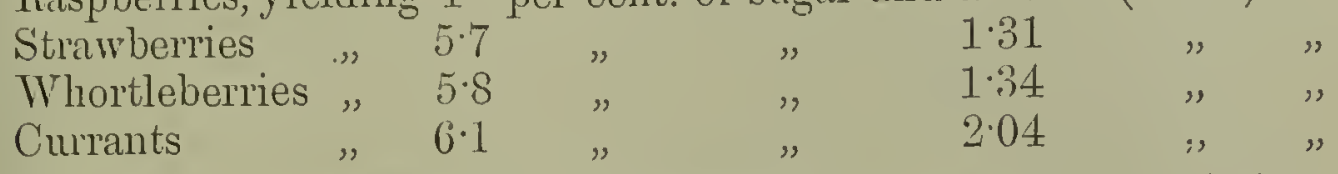

The amount of free acid in the mulberry is not small, nor is it excessive. The small proportion of insoluble matters is worthy of notice in comparison, for instance, with the whortleberry which contains no less than 13 per cent. The colouring matter of the mulberry has not been examined. The acid is probably not simply malic, but in part tartaric.

Uses-The sole usc in medicine of mulberries is for the preparation of a syrup, employed to flavour or colour other medicines. In Greece, the fruit is submitted to fermentation, thereby furnishing an inebriating beverage.

\section{UANNABINEE.}

\section{HERBA CANNABIS.}

Cannabis Indica: Indian Hemp; F. Chanvre Indien; G. Hanfkraut.

Botanical Origin-Cannabis sativa L., Common Hemp, an annual diøcious plant, native of Western and Central Asia, cultivated in temperate as well as in tropical countries.

It grows wild luxuriantly on the banks of the lower Ural and Volga near the Caspian Sea, extending thence to Pcrsia, the Altai range, and Northern and Western China. It is found in Kashmir and on the Himalaya, growing 10 to 12 feet high, and thriving vigorously at an elevation of $60 n 0$ to 10,000 feet. It likewise occurs in Tropical Africa, on the eastern and western coasts as well as in the central tracts watered by the Congo and Zambesi, but whether truly indigenous is doubtful. It has been naturalized in Brazil, north of Rio de Janeiro, the seeds having been brought thither by the negroes from Western Africa. The cultivation of hemp is carried on in many parts of continental Europe, but especially in Central and Southern Russia.

The hemp plant grown in India, exhibits ccrtain differences as con. trasted with that cultivated in Europe, which were noticed by Rumphius in the 17th century, and which, at a later date, induced Lamarck to clain for the former plant the rank of a distinct species, under the name of Cannabis indica. But the variations observed in the two plants are of so little botanical importance and are so inconstant, that the maintenance of $C$. indica as distinct from $C$. sativa has been abandoned by general consent.

In a medicinal point of view, there is a wide dissimilarity between hemp grown in India and that produced in Europe, the former being vastly more potent. Yct even in India therc is much variation, for according to Jameson, the plant grown at altitudes of 6000 to 8000

\footnotetext{
1 The fig excepted, which is much more saccharine than any.
} 
feet, affords the resin known as Charus, which cannot be obtained from that cultivated on the plains. ${ }^{1}$

History-Hemp las been propagated on account of its textile fibre and oily seeds from a remote period.

The ancient Chinese herbal called $R h_{-} y a$, written about the 5 th century B.C., notices the finct that the hemp plant is of two kinds, the one producing seeds, the other flowers only. ${ }^{2}$ In the writings of Susiuta on Hindu medicine, supposed to date some centuries before the Christian era, hemp (B'hangá) is mentioned as a remedy. Herodotus states that hemp grows in Scythia both wild and cultivated, and that the Thracians make garments from it which can liardly be distinguished from linen. Te also describes how the Scythians expose themselves as in a bath to the vapour of the seeds thrown on hot coals. ${ }^{3}$

The Greeks and Romans appear to have been unacquainted with the medicinal power's of hemp, unless indecd the care-destroying $N \eta \pi \epsilon \nu \theta$ és should, as Royle has supposed, be referred to this plant. According to Stanislas Julien, ${ }^{4}$ anæsthetic powers were ascribed by the Chinese to preparations of hemp as early as the commencement of the $3 \mathrm{rd}$ century.

The employment of hemp both medical and dictetic, appears to have spread slowly through India and Persia to the Arabians, anongst whom the plant was used in the early middle ages. The famous heretical sect of Mahomedans, whose murderous deeds struck terror into the hearts of the Crusaders during the 11 th and 12 th centuries, derived their name of Hashishin or, as it is commonly written, assassins, from hashish the Arabic for hemp, ${ }^{5}$ which in certain of their rites, they used as an intoxicant. ${ }^{6}$

The use of hemp (bhang) in India was particularly noticed by Garcia d'Orta $^{7}$ (1563), and the plant was subsequently figured by Rheede, who described the drug as largely used on the Malabar coast. It would seem about this time to have been imported into Europe, at least, occasionally, for Berlu in his Treasury of Drugs, 1690, describes it as coming from Bantam in the East Indies, and "of an infatuating quality and pernicious use."

It was Napoleon's expedition to Egypt that was the means of again calling attention to the peculiar properties of hemp, by the accounts of De Sacy (1809) and Rouger (1810). But the introduction of the Indian drug into European medicine is of still more recent date, and is chiefly due to the experiments made in Calcutta by O'Shaughnessy in 1838-39."

I Journ. of the Agrie. and Hortic. Soc. of India, viii. 167.

2 Bretschneider, On Chinese Botanieal Works, 1870. 5. 10. Part of the Rh-ya was written in the 12 th cent. B.C.

3 Rawlinson's translation, iii. (1859) book 4, chap. 74-5.

4 Comptes Rendus, xxviii. (1849) 195.

5 Hence the words assassin and assassinele. Weil, however, is of opinion that the word assassin is nore probably derived from sikkin, a dagger.-Geschichte der Chatifen, iv. $(1860) 101$.

6 The iniscreant who assassimated Justice Norman at Calcutta, 20 Sept. 1871 , is said to have aeted under the influenco of hashish. Bellew (Indus to the I'igris, 1874. 218) states that the Afglian chief who murdered Dr. Forbes in 1842 , had for some days previously been more or less intoxicated with Charas or Bhang.

'Colloquios dos simples e drogas e cousas medicinaes da India, ed. 2, Lisboa, 1S72, $2 \mathrm{f}$.

8 For a notice of them, see O'Shauglunessy, On the preparation of the Indian IIcm? or Gunjah, Calcutta, 1839 ; also Bengal Dispensatory, Calcutta, 1S42. 579-604. An immense number of references to writers who have touehed on the medicinal properties of hemp, will be found in the elaborate essay entitled Studien über den Hanf, by Dr. G. Martius (Erlaugen, 1855). 
Although the astonishing effects produced in India by the administration of preparations of hemp are seldom witnessed in the cooler climate of Britain, the powers of the drug are sufficiently manifest to give it an established place in the pharmacopœia.

Production-Though hemp is grown in many parts of India, yet as a drug, it is chiefly produced in a limited area in the districts of Bogra and Rájsháhi, north of Calcutta, where the plant is cultivated for the purpose in a systematic manner. The retail sale, like that of opium and spirits, is restricted by a license, which in 1871-2, produced to the Government of Bengal about $£ 120,000$, while upon opium (chiefly consumed in Assanl), the amount raised was $£ 310,000{ }^{1}$ Bhang is one of the principal conmodities imported into India from Turkestan.

Description-The leaves of hemp have long stalks with small stipules at their bases, and are composed of 5 to 7 lanceolate-acuminate leaflets, sharply serrate at the margin. The loose panicles of male flowers, and the short spikes of female flowers, are produced on separate plants, from the axils of the leaves. The fruits, called Hemp-seeds, are small grey nuts or achenes, each containing a single oily seed. In common with other plants of the order, hemp abounds in silica which gives a roughness to its leaves and stems. In European medicine, the only hemp employed is that grown in India, which occurs in two principal forms, namely:-

1. Bhang, Siddhí or Sabzi (Hindustani); Hashísh or Qinnab (Arabic). This consists of the dried leaves and small stalks, which are of a dark green colour, coarsely broken, and mixed with here and there a few fruits. It has a peculiar but not umpleasant odour, and scarcely any taste. In India, it is smoked either with or without tobacco, but more commonly it is made up with flour and various additions, into a sweetmeat or majun, ${ }^{2}$ of a green colour. Another form of taking it, is that of an infusion, made by immersing the pounded leaves in cold water.

2. Ganja (Hindustani); Qinnab (Arabic); Guaza ${ }^{3}$ of the London drug-brokers. These are the flowering or fruiting shoots of the fernale plant, and consist in soine samples of straight, stiff, woody stems some inches long, surrounded by the upward branching flower-stalks; in others of more succulent and much shorter shoots, 2 to 3 inches long, and of less regular form. In either case, the shoots have a compressed and glutinous appearance, are very brittle and of a brownishgreen hue. In odour and in the absence of taste, ganja resembles bhang. It is said that after the leaves which constitute bhang have been gathered, little shoots sprout from the stem, and that these picked off and dried, form what is called ganja. ${ }^{4}$

Chemical Composition - The most interesting constituents of hemp from a medical point of view, are the resin and volatile oil.

The former was first obtained in a state of comparative purity by T. and H. Smith in $1846 .^{5}$ It is a brown amorphous solid, burning with a bright white flame and leaving no ash. It has a very potent action

1 Blue Book quoted at p. 49, note 1 .

2 Father Ange, in his Phurmacopaia Persica, 1681, gives numerous formulæ for eleetuaries under the name of magi-oun.
3 This name is not used in India, but seems to be a corruption of ganja.

4 Powell, Economic Products of the Punjab, Roorkee, i. (1868) 293.

"Pharm. Journ. vi. (1847) 171. 
when taken internally, two-thirls of a grain acting as a powerful narcotic, and one grain producing complete intoxication. From the experiments of Messis. Smith, it seems to us impossible to doubt that to this resin the energetic eflects of cammabis are mainly due.

When water is repentedly distilled from considerable quantities of hemp, fresh lots of the latter being used for each operation, a volatile oil lighter than water is obtained, together with ammonia. 'This oil according to the observations of Persome (1857), is amber-coloured, and has an oppressive hemp-like smell. It sometimes deposits an abundance of small crystals. With due precautions it nuy be separated into two bodies, the one of which named by Personne Cannabene, ${ }^{1}$ is liquid and colourless, with the formula $\mathrm{C}^{18} \mathrm{H}^{20}$; the other which is called Iydride of Cannabene, is a solid, separating from alcohol in platy crystals to which Persoune assigns the formula $\mathrm{C}^{18} \mathrm{H}^{22}$. He asserts that camnabene has indubitably a physiological action, and evell claims it as the sole active principle of hemp. Its vapour he states to produce when breathed, a singular sensation of shuddering, a desire of locomotion, followed by prostration and sometimes by syncope. ${ }^{2}$ Bohlig in 1840, observed similar effects from the oil, which he obtained from the fresh herb just after flowering, to the extent of 0.3 per cent.

The other constituents of hemp are those commonly occurring in other plants. The leaves yield nearly 20 per cent. of ash.

As to the resin of Indian hemp, Bolas and Francis in treating it with nitric acid, converted it into Oxycannabin, $\mathrm{C}^{20} \mathrm{H}^{20} \mathrm{~N}^{2} \mathrm{O}^{7}$. This interesting substance may, they say, be obtained in large prisms from a solution in methylic alcohol. It melts at $176^{\circ} \mathrm{C}$. and then evaporates without decomposition; it is neutral. ${ }^{3}$ One of us (F.) has endeavoured to obtain it from the purified resin of charas but without success.

Uses-Hemp is employed as a soporific, anodyne, antispasmodic, and as a nervous stimulant. It is used in the form of alcoholic extract, administered either in a solid or liquid form. In the East it is consumed to an enormous exteut by Hindus and Mahomedans, who either smoke it with tobacco, or swallow it in combination with other substances. ${ }^{4}$

\section{Charas.}

No account of hemp as a drug would be complete without some notice of this substance, which is regarded as of great importance by Asiatic nations.

Charas or Churrus is the resin which exudes in minute drops from the leaves and branches of the plant. It is collected in several ways :one is by rubbing the tops of the plant in the hands when the seeds are

1 Joum. de Pharm. xxxi. (1857) 4S; Canstatt's Jahresbericht for 1857 , i. 28.

2 Personne, thongh he admits the actirity of the resin prepared by Smith's proeess, contends that it is a mixed body, and that a further purification deprives it of all vulatile matter and renders it inert This is not astonishing when one finds that the "purification" was effeeted by treatment with catstie lime or soda-lime, and exposmle to a temperature of $300^{\circ} \mathrm{C} .\left(572^{\circ} \mathrm{F}.\right)$ ! That the resin of the Edinburgh ehemists loes not owe its aetivity to volatile matter, is proved by their own experiment of exposing a small quantity in a very thin layer to $82^{\circ} \mathrm{C}$. for 8 homrs : the medieinal action of the resin so treated was found to be m. impaired.

3 Chemical Neus, xxiv. (1871) 77.

4 For further information, cousult Cooke's Srren. Sisters of Stcep, Lound., will. Xr.xvii. 
ripe, and scraping from the fingers the adhering resin. Another is thus performed:-men clothed in leather garments walk about among growing hemp, in doing which the resin of the plant attaches itself to the leather, whence it is from time to time scraped off. A third method consists in collecting, with many precautions to avoid its poisonous effects, the dust which is raised when heaps of dry bhang are stirred about. ${ }^{1}$

By whichever of these processes obtained, charas is of necessity a foul and crude drug, the use of which is properly excluded from civilized medicine. As before remarked (p. 492) it is not obtainable from hemp grown indiscriminately in any situation even in India, but is only to be got from plants produced at a certain elevation on the hills.

The best charas, which is that brought from Yarkand, is a brown, earthy-looking substance, forming compact yet friable, irregular masses of considerable size. Examined under a strong pocket lens, it appears to be made up of minute, transparent grains of brown resin, agglutinated with short hairs of the plant. It has a hemp-like odour, with but little taste even in alcoholic solution. A second and a third quality of Yarkand charas represent the substance in a less pure state. Charas viewed under the microscope, exhibits a crystalline structure, due to inorganic matter. It yields from $\frac{1}{4}$ to $\frac{1}{3}$ of its weight of an amorphous resin, which is readily dissolved by bisulphide of carbon or spirit of wine. The resin does not redden litmus, nor is it soluble in caustic potash. It häs a dark brown colour, which we have not succeeded in removing by animal charcoal. The residual part of charas yields to water a little chloride of sodium, and consists in large proportion of carbonate of calcium and peroxide of iron. These results have been obtained in examining samples from Yarkand." Other specimens which we have also examined, have the aspect of a compact dark resin.

Charas is imported from Yarkand ${ }^{3}$ and Káshgar, the first of which places exported during 1867, 1830 maunds (146,400 10.) to Lê, whence the commodity is carried to the Punjab and Kashmír. Smaller quantities are annually imported from Kandahar and Samarkand. ${ }^{4}$. The drug is mostly consumed by smoking with tobacco; it is not found in European commerce.

\section{STROBILI HUMILI.}

\section{Humulus vel Lupulus; Hops; F. Houblon; G. Hopfen.}

Botanical Origin-Humulus Lupulus L., -a dinecious perennial plant, producing long annual twining stems which climb freely over trees and bushes. It is found wild, especially in thickets on the banks of rivers, throughout all Europe, from Spain, Sicily and Greece to Scandinavia; and extends also to the Cancasus, the South Caspian region, and

1 Powell, Economic Products of the Punjab, Roorkee, 1868. 293.

2 Obtained by Colonel H. Strachey, and now in the Kew Museum. It is by no means evident by what process they were collected.

3 Forsyth, Correspondence on Mission io
Farkand, ordered by the House of Commons to be printed, Feb. 28, 1871 ; also Henderson and Hume, Lahore to Tarkand, Lond. 1873. 324.

4 Stewart, Punjab Plants, Lahore, 1869. 
through Central and Southern Siberia to the Altai mountains. It has becn introduced into North America, Brazil (Rio Grande do Sul), and Australia.

History-Hops have been used from a remote period in the brewing of becr, of which they are now regarded as an indispensable ingredient. IIop gardens, under the name humularia or luumuleta, are mentioned as existing in France and Germany in the 8th and 9th ccuturies; and Bohemian and Bavarian hops have becn known as an cstecmed kind since the 11th century. A grant alleged to have been made by Willian the Conqueror in 1069, of hops and hop-lands in the county of Salop ${ }^{1}$ would indicatc, wcre it free from doubt, a very early cultivation of the hop in England.

As to the usc made of hops in these early times, it would appear that they were regarded in somewhat of a medicinal aspect. In the Herbarium of Apuleius, ${ }^{2}$ an English manuscript written about A.D. 1050, it is said of the hop (hymele) that its good qualities arc such that men put it in their usual drinks; and St. Hildegard, ${ }^{3}$ a century latcr, states that the hop (hoppho) is added to beverages, partly for its wholesone bitterncss, and partly becausc it makes thern keep.

Hops for brewing were among the produce which the tenants of the abbey of St. Germain in Paris ${ }^{4}$ had to furnish to the nonastery in the beginning of the 9th century; yet in the middlc of the 14th ccntury, beer without such addition was still brewed in Paris.

The brewsters, bakers and millers of London werc the subject of a mandate of Edward I. in A.D. 1298; but there is no reason for inferring that the manufacture of malt liquor at this period involved the use of hops. It is plain indced that somewhat later, hops were not generally used, for in the 4th year of Henry VI. (1425-26), an information was laid againist a person for putting into beer " an unwholesome weed called an hopp;" 5 and in the samc reign, Parliament was petitioned against "that wicked wced called hops."

But it is evident that hops were soon found to possess good qualities, and that though their use was denounced, it was not suppressed. Thus in the regulations for the household of Henry VIII. (1530-31), there is an injunction that the brewer is " not to put any hops or brimstone into the ale" $;^{6}$ while in the very same year (1530), hundreds of pounds of Flemish hops wcre purchased for the use of the noble family of L'Estranges of Hunstanton. ${ }^{7}$

In 1552, the cultivation of hops in England was distinctly sanctioned by the 5th and 6th of Edward VI. c. 5, which directs that land formerly in tillage should again bc so cultivated, excepting it should have been set with hops or saffron. Notwithstanding these facts, hops were for a long period hardly rcgarded an essential in brewing, as may be gathered from the remark of Gerarde (ob. A.D. 1607), who speaks of them as used "to season" beer or ale, explaining that notwithstanding their manifold virtues, they

I Blount, Tenures of Land and Customs of Manors, edited by Hazlitt, 1874. 165.

2 Leechdoms, Wortcunning and Starcraft of Early England, edited by Cockayne, i. (1864) 173 ; ii. (1865) ix.

3 Opera Omnia, accurante J. P. Migne, Paris, 1855. 1153.
4 Guérard, Polyptique dc l'abbé Irminon, i. (1844) 714.896 .

5 The authority for this statement is an isolated memorandum in a MS. rolume ( $\mathrm{No}$. 980) by Thomas Gybbons, preserved in the Harleian collection in the British Museum.

6 Archocologin, iii. (1786) 157.

7 Ibid. xxy. (1834) 505 . 
"rather make it a physical drinke to keepe the body in health, than an ordinary drinke for the quenching of our thirst." In reality, other herbs were for a long period employed to impart to malt liquor a bitter or aromatic taste, as Ground Ivy (Nepeta Glechoma Benth.) anciently called Ale-hoof or Gill; Alecost (Balsamita vulgaris I.) ; Sweet Gale (Myrica Gale L.); and Sage (Salvia officinalis L.). Even Long Pepper and Bay Berries were used for the same purpose, ${ }^{1}$ but in addition to hops.

Though English hops were esteemed superior to foreign, and were extensively grown as early as 1603 , as shown by an act of James I., Flemish hops continued to be imported in considerable. quantities down to 1693.

Structure-The inflorescence of the male plant constitutes a large panicle; that of the female is less conspicuous, consisting of stalked catkins which by their growth develope large leafy imbricating bracts, ultimately forming an ovoid cone or strobile, which is the officinal part. This catkin consists of a short central zigzag stalk, bearing overlapping rudimentary leaflets, each represented by a pair of stipules. Between them are 4 female florets, each supported by a bract. After flowering, the stipules as well as the bracts are much enlarged, and then form the persistent, yellowish-green, pendulous strobile. At maturity, each bract infolds at its base a small lenticular elosed fruit or nut, $\frac{1}{10}$ of an inch in diameter. The nut is surrounded by a membranous, one-leafed perigone, and contains within its fragile, brown shell, an exalbuminous seed. These fruits, as well as the axis and the base of all the leaflike organs, are beset with numerous shining, translucent glands, to which the aromatic smell and taste of hops are due.

Description-Hops as found in commerce, consist entirely of the fully developed strobiles or cones, more or less compressed. They have, a greenish yellow colour, an agreeable and peculiar aroma, and a bitter aromatic burning taste. When rubbed in the hand they feel clammy, and emit a more powerful odour. By keeping, hops lose their greenish colour and become brown, at the same time acquiring an unpleasant odonr, by reason of the formation of a little valerianic acid. Exposure to the vapour of sulphurous acid retards or prevents this alteration. For medicinal use, hops smelling of sulphurous acid should be avoided, though in reality the acid speedily becomes innocuous. Liebig has refuted the objections raised by brewers to the sulphuring of hops.

Chemical Composition-Besides the constituents of the glands which are described in the next article, hops contain 3 to 5 per cent. of a tannin, stated by Wagner to resemble Morintannic Acid; also chlorophyll, gum, from 5 to 9 per cent. of ash constitnents, chiefly potassinm salts, and about 12 per cent. of water.

Siewert (1870) has analysed six specimens of hops grown in Germany in which he found the resin soluble in alcobol, to vary from 9.7 to 18.4 per cent.

The odour of hops resides in an essential oil, of which the yield is from 1 to 2 per cent. Personne found the oil to contain Valerol, $\mathrm{C}^{6} \mathrm{H}^{10} \mathrm{O}$, which passes into valerianic acid; the latter in fact occurs in

1 Holinshed, Chronicles, vol. i. book 2. cap. 6.

21 James I. (anno 1603) cap. 18. 
the glands, yet according to Méhu ${ }^{1}$ only to the extent of 0.1 to 0.17 per cent. When distilled from the fresh strobiles the oil has a greenish colour, but a reddish-brown when old hops have been employed. We find it to be devoid of rotatory power, neutral to litmus paper, and not striking any remurkable coloration with concentrated sulphuric acid.

Griessniayer (1874) has shown that hops contain I'rimethylamine, and in sinall proportion, a liquid volatile alkaloid not yet analysed, which he terms Lupuline. The latter is stated to have the odour of conine, and to assume a violet hue when treated with chromate of potassium and sulphuric acid.

Production and Commerce-England was estimated as having in $1873,63,276$ acres under hops. The chief district for the cultivation is the county of Kent, where in that year 39,040 acres were devoted to this plant. Hops are grown to a much smaller extent in Sussex, and in still diminished quantity in Herefordshire, Hampshire, Worcestershire and Surrey. The other counties of England, and the principality of Wales produce but a triffing amount, and Scotland none at all.

In continental Europe, hops are most largely produced in Bavaria and Wurtemberg, Belgium and France, but in each on a smaller scale than in England. France in 1872 is stated to have 9223 acres under hops. ${ }^{2}$

Notwithstanding the extensive production of hops in England, there is a large importation from other countries. The importation in 1872 ,

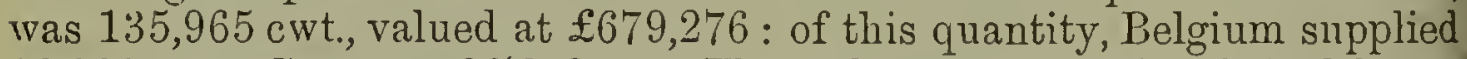
66,930 cwt., Germany 36,612 cwt., Holland 16,675 cwt., the United States $10,414 \mathrm{cwt}$., France $5328 \mathrm{cwt}$. During the same period, hops were exported from the United Kingdom to the extent of $31,215 \mathrm{cwt}^{3}$

Uses-Hops are administered medicinally as a tonic and sedative, chiefly in the form of tincture, infusion or extract.

\section{GLANDULA HUMULI.}

Lupulina; Lupulin, Lupulinic Grains; F. Lupuline; G. Hopfendrüsen, Hopfenstaub.

Botanical Origin-Humulus Inpulus L. (see preceding article). The minute, shining, translucent glands of the strobile, constitute when detached therefrom, the substance called Lupulin.

History-The glands of hop were separated and chemically examined by L. A. Planche, a pharmacien of Paris, whose observations were first briefly described by Loiseleur-Deslongchamps in 1819.4 In the following year, Dr. A. W. Ives of New York published ${ }^{5}$ an account of his experiments upon hops and their glands, to which latter he applied the name of Lupulin. Payen and Chevallier, Planche and others, made further experiments on the same subject, endorsing the recommendation of Ives that lupulin (or, as they preferred to call it, Lupuline) might be advantageously used in medicine in place of hops.

Production-Lupulin is obtained by stripping off the bracts of hops,

1 Thìse, Montpellier, 1867.

2 Agricultural Returns of Great Britain, \&c., 1873, presented to Parliament, 48. 49. 70. 71 .

3 Annual Statement of the Trade of the United Kingdom for 1872. 49. 93.
4 Manuel des Plantes usuelles et indigìnes, 1819. ii. 503.

5 Silliman's Journ. of Scicnce, ii. (1820) 302. 
and shaking and rubbing them; and then separating the powcler by a sieve. The powder thus detached, ought to be washed by decantation, so as to remove from it the sand or earth with which it is always contaminated; finally it should be dried, and stored in well-closed bottles. From the clried strobiles, 8 to 12 per cent. of lupulin may be obtained.

Description-Lmpulin seen in quantity appears as a yellowishbrown grauular powcler, having an agreeable odour of hops and a bitter aromatic taste. It is gradually wetted by water, instantly by alcoliol or ether, but not by potash or sulphuric acid. By trituration in a mortar, the celis are ruptured so that it may be worked into a plastic mass. Thrown into the air and then ignited, it burns with a brilliant flame like lycopodium.

Microscopic Structure-The lupnlinic gland or grain, like the generality of analogous organs, is formed by an intumescence of the cuticle of the nucule and bracts of hop (see p. 497). Each grain is originally attached by a very short stalk, which is no longer perceptible in the drug. The gland, exhausted by ether and macerated in water, is a globular or ovoid thin-walled sac. ineasuring from 140 to $240 \mathrm{mkm}$. It consists of two distinct, nearly hemispherical parts ; that originally provided with the stalk is built up of tabular polyhedric cells, whilst the upper hemisphere shows a continuous delicate membrane. This part therefore easily collapses, and thus exhibits a variety of form, the greater also as the grains turn pole or equator to the observer. ${ }^{1}$

The hop gland is filled with a thick, dark brown or yellowish liquid, which in the drug is contracted into one mass occupying the centre of the gland. It may be expelled in minute drops when the wall is made to burst by warming the grain in glycerin. The colouring matter, to which the wall owes its fine yellow colour, adheres more obstinately to the thinner hemisphere, and is more easily extracted from the thicker part by means of ether.

Chemical Composition-The odour of lupulinic grains resides in the essential oil, described in the previous article. The bitter principle formerly called Lupulin or Lupulite was first isolated by Lermer (1863) who called it the bitter acid of hops (Hopfenbittersüure). It crystallizes in large brittle rhombic prisms, and possesses in a high degree the peculiar bitter taste of beer, in which however it can be present only in very small proportion, it being nearly insoluble in water though easily dissolved by many other liquids. The composition of this acid, $\mathrm{C}^{32} \mathrm{H}^{50} \mathrm{O}^{7}$, appears to approximate it to absinthiin; it is contained in the glands inl. but small proportion. Still smaller is the amount of another crystallizable constituent, regarded by Lermer as an alkaloid.

The main contents of the hop gland consist of $\max$ (Myricylic palmitate, according to Lermer), and resins, one of which is crystalline and unites with bases.

A good specimeu of German lupulin, dried over sulphuric acirl, yielded us 7.3 per cent. of ash. The same drug exhausted by boiling ether, afforded 76.82 per cent. of an extremely aromatic extract, which on exposure to the steam bath for a week, lost 3.03 per cent., this loss corre-

1 For a full account of the formation of the glands, seo Trécul, Annales des Sciences Nut., Bot., i. (1854) 299. An abstrinct may be found in Méhu's Etude rlu Houbion el du Lupulin, Montpeilier, 186\%. 
sponding to the volatile oil and acids. The residual part was soluble in glacial acetic acirl and could therefore contain but very little fatty matter.

Uses-The drug has the properties of hops, but with less of astringency. It is not often preseribed.

Adulteration-lupulin is apt to contain sand, and on incineration often leaves a large amount of ash. Other extraneous matters which are uot unfrequent, may be easily recognized by means of a lens. As the essential oil in lupulin is soon resinified, the latter should be preferred fresh, and should be kept excluded from the air.

\section{UT,MACEAS.}

\section{CORTEX ULMI.}

Elm. Bark; F. Eeoree d'Orme; G. Ulmenrinde, Rüsterrinde.

Botanical Origin-Ulmus campestris Smith, the Common Elm, a stately tree, widely diffused over Central, Southern and Eastern Europe, extending in Norway to $66^{\circ} \mathrm{N}$. lat.; southward to Northern Africa and Asia Minor, and eastward as far as Amurland, Northeru China, and Japan. It is probably not truly indigenous to Great Britain; but the Wych Elm, U. montana With., is certainly wild in the northern and western counties. ${ }^{1}$

History-The classical writers, and especially Dioscorides, were fimiliar with the astringent properties of the bark of $\pi \tau \epsilon \lambda \lambda^{\prime} a$, by which name Ulmus campestris is understood. Imaginary virtues are ascribec by Pliny to the bark and leaves of Ulmus. Elm bark is frequently prescribed in the English Leech Books of the 11th century, at whicl period a great many plants of Southern Europe had already beer introduced into Britain. ${ }^{2}$ Its use is also noticed in Turner's Herla (1568) and in Parkinson's Theater of Plants (1640), the author of the latter remarking, that "all the parts of the Elme are of much use ir Physicke."

Description-Elm bark for use in medicine should be removed from the tree in early spring, deprived of its rough corky outer coat, and ther dried. Thus prepared, it is found in the shops in the form of broac flattish pieces, of a rusty yellowish colour, and striated surface especiall: on the inner side. It is tough and fibrous, nearly inodorous, and has : woody, slightly astringent taste.

Microscopic Structure-The liber which is the only officinal part consists of thick-walled, tangentially extended parenchyme, in whicl there are some larger cells filled with mucilage, while the rest contain red-brown colouring matter. The mueilage forms a stratified deposi within the cell. Large bast-bundles arranged in irregular rows, alternat with the parenchyme and are intersected by narrow, reddish, nedullar: rays consisting of 2 or 3 rows of cells. The bast-bundles contai

1 On the word elm, Dr. Prior remarks that it is nearly identical in all the Germanic and Scandinavian dialects, yet does not find its root in any of them, but is an adantatione of the Latin UTmus. - Promular Names of British Plants, ed. 2 1870. 71.
2 Lepchidoms, Wortcunning and Starcra. of Farly Eingland, edited by Rev. i Cockayne, ii (1865) pp. 53. 67. 79.99. 1 : and 1 \% xii.- - In the Anglo-Saxon reeipes, bot EIm and Wych Elm are niamed. 
numerous long tubes about 30 mkin. thick, with narrow cavities; and besides these, somewhat larger tubes with porous transverse walls (cribriform vessels). Each cubic cell of the neighbouring bast-parenchyme, encloses a large crystal, seldom well defined, of oxalate of calcium.

Chemistry-The chief soluble constituent of elm bark is mucilage with a small proportion of tannic acid. The concentrated decoction yields a browu precipitate with perchloride of iron; the dilute assumes a green coloration with that test. Starch is wanting, or only occurs in the middle cortical lnyer which is usually rejected.

Elms in summè-time frequently exude a gum which, by contact with the air, is converted into a brown insoluble mass, called Ulmin. This name has been extended to various decomposition-products of organic bodies, the nature and affinities of which are but little known. ${ }^{1}$

Uses-Elm bark is prescribed in decoction as a weak mucilaginous astringent, but is almost obsolete.

\section{CORTEX ULMI FULVA.}

\section{Slippery Elm Bark.}

Botanical Origin-Ulmus fulva Michaux, the Red or Slippery Elm, a small or middle-sized tree, seldom more than 30 to 40 feet high, growing on the banks of streams in the central and northern United States from Western New England to Wisconsin and Kentucky, and found also in Canada.

History - The Indians of North America attributed medicinal virtues to the bark of the Slippery Elm, which they used as a healing application to wounds, and in decoction as a wash for skin diseases. Bigelow writing in 1824, remarks that the mucilaginous qualities of the inner bark are well known.

Description-The Slippery Elin Bark used in medicine consists of the liber only. It forms large flat pieces, often 2 , to 3 feet long by several inches broad, and usually $\frac{1}{20}$ to $\frac{2}{20}$ of an inch thick, of an extremely tough and fibrous texture. It has a light reddish-brown colour, an odour resembling that of fenugreek (which is common to the leaves also), and a simply mucilaginous taste.

In collecting the bark the tree is destroyed, and no effort is made to replace it, the wood being nearly valueless. Thus, the supply is diminishing year by year, and the collectors who formerly obtained large quantities of the bark in New York and other eastern states, have now to go westward for supplies. ${ }^{2}$

Microscopic Structure-The transverse section shows a series of undulating layers of large yellowish bundles of soft liber fibres, alterllating with small brown parenchymatous bands. The whole tissue is traversed by numerous narrow medullary rays, and interrupted by large intercellular mucilage-ducts. In order to examine the latter, longitudinal sections ought to be moistened with benzol, aqueous liquids causing to be 70 to $100 \mathrm{mkm}$. long, and to contain colourless masses of mucilacge,

' Gimelin, Chemistry, xvii. (1866) 458.

2 Proceedings of the American Phurina. ccutical Association for 1873 , xxi. 435. 
distinctly showing a series of layers. Crystals of calcium oxalate, as well as small starch grains, are very plentiful throughout the surrounding parenchyme, but not in the nucilage-ducts.

Chemical Composition-The most interesting constituent of the bark is the nucilage, which is imparted to either cold or lot water but loes not form a trine solution. I'he bark moistened vith 20 parts of water swells considerably, and becomes enveloped by a thick neutial mucilage, which is not altered either loy iodine or perchloride of iron. 'This nucilage when dilnted even with a triple volune of water, will vield only a tew drops when thrown on a papper tilter. The liquid which ilrains out is precipitable by neutral acetate of lead. By addition of absolute alcohol, the concentrated inucilage is not rendered turbid, but lorms a colourless transprarent fluid deposit.

Uses-Slippery EM Bark is a demulcent like althæa or linseed. The powder ${ }^{1}$ is much used in America for making poultices; it is said to preserve lard from rancidity, if the latter is melted with it and kept in contact for a short time.

\section{EUPHORBIACEE.}

\section{EUPYORBIUM.}

Eunhorbium, Gum Euphortium; F. Gonnc-résine d'Euphorbe; G. Euphortiurn.

Botanical Origin-Euphortia resinifera Berg, a leafless, glaucous, peremial plant resembling a cactus, and attaining 6 or more f'eet in height. Its stems are ascending, fleshy and quadrangular, each side measuring about an inch. The angles of the stem are furnished at intervals with pairs of divergent, horizontal, straight spines about $\frac{1}{4}$ of an inch long, and confluent at the base into ovate, subtriangular discs. These spines represent stipules: above each pair of them is a depression, indicating a leaf-bud. The inflorescence is arranged at the summits of the branches, on stalks each bearing three flowers, the two outer of which are supported on pedicels. The fruit is tricoccous, $\frac{3}{10}$ of an inch wide, with each carpel slightly conpressed and keeled.

The plant is a native of Morocco, growing on the lower slopes of the Atlas in the southern province of Suse. Dr. Hooker and his fellow travellers met with it in 1870, at Imsfuia, south-east of the city of Morocco, which appears to be its westward limit.

History - Euphorbium was known to the ancients. Dioscorides ${ }^{2}$ and Pliny ${ }^{3}$ both describe its collection on Mount Atlas in Africa, and notice its extreme acridity. According to the latter writer, the drug received its name in honour of Euphorbus, physician to Juba II., king of Mauritania. This monarch, who after a loug reign died about A.D. 18, was clistinguished for lis literary attaimments, and was the author of several books ${ }^{4}$ which inchded treatises on opium and euphorbium. The latter work was apparently extant in the time of Pliny.

Euphorbium is mentioned by numerons other early writers on medi-

1 That sold in America is somctimes adultcraterl with farinaccous substalicus.

Lib. iii. c. 86 .

3 I.il. v. c. 1 ; lib. xxv. c. 38.

4 Smith, Dict. of freck and Roman Liv. gra $\left.a_{i}\right)$, ii. (is46) 630 . 
cine, as Rufus Ephesins, who probably flourished during the reign of Trajan, by Galen in the 2nd century, and by Vindicianus and Oribasius in the 4th. Aëtius and Paulus AEgineta, who lived respectively in the 6 th and 7 th centuries, were likewise acquainted with it; and it was also known to the Arabian school of medicine. The drug has a place in all the early printed pharmacopoias.

The plant yielding euphorbium was first described at the beginning of the present century, by an English merchant named Jackson, who had resided many years in Morocco. From the figures he published, ${ }^{1}$ the species was doubtfully identified with Euphorbia Canariensis L., a large cactus-like shrub, abounding on scorched and arid rocks in the Canary Islands.

In the year 1849, it was pointed out in the (Admiralty) Manual of Scientific Enquiry, that the stems of which fragments are found in commercial euphorbium, do not agree with those of $E$. Canariensis. Berg carried the comparison further', and finally from the fragments in question, drew up a botanical description which with an excellent figure, he published ${ }^{2}$ as Euphorbia resinifera. The correctness of his observations has been fully justified by specimens ${ }^{3}$ which were transmitted to the Royal Gardens, Kew, in 1870, and now form flourishing plants.

Collection-Euphorbium is obtained by making incisions in the green fleshy branches of the plant. These incisions occasion an abundant exudation of milky juice which hardens by exposure to the air, encrusting the stems down which it flows; it is finally collected in the latter part of the summer. So great is the acridity of the exudation, that the collector is obliged to tie a cloth over his mouth and nostrils, to prevent the entrance of the irritating dust. The drug is said to be collected in districts lying east and south-east of the city of Morocco.

Description-The drug consists of irregular pieces, seldom more than an inch across and mostly smaller, of a dull yellow or brown waxylooking substance, among which, portions of the angular spiny stem of the plant may be met with. Many of the pieces encrust a tuft of spines or a flower-stalk or are hollow. The substance is brittle and translucent; splinters examined under the microscope exhibit no particular structure, even by the aid of polarized light; nor are starch granules visible. The odour is slightly aromatic, especially if heat is applied; but $10 \mathrm{lb}$. of the drug which we subjected to distillation, afforded no essential oil. Euphorbium has a persistent and extremely acrid taste; its dust excites violent sneezing, and if inhaled, as wheu the drug is powdered, occasions alarming symptoms.

Chemical Composition-An analysis of euphorbium performed by one of us, ${ }^{4}$ showed the composition of the drug to be as follows:-

I Account of the Empire of Mroroceo and the district of Suse, Lond. 1809. 81. pl. 7.The plate represents an cntire plant, anil also what purports to be a portion of it branch of the natural sizc. The latter is really the figure of a different species, apparently that which has bcen recently named by Cosson, Euphorbia Beaumierana.

2 Berg und Schmidt, Offizinclle Gewächse, iv. (1863) xxxiv. d.
3 They were procured by $\mathrm{Mr}$. William Grace, and forwarded to England by $\mathrm{Mr}$. C. F. Carstensen, British Vice-Consul at Mogador.

${ }^{4}$ Fliickiger in Wittstein's Vierteljahresschrift für prakt. Pharmacie, xvii. (1868) 82-102.-The drug analysed consisted of sclected fragments, fice from extraneous substances. 


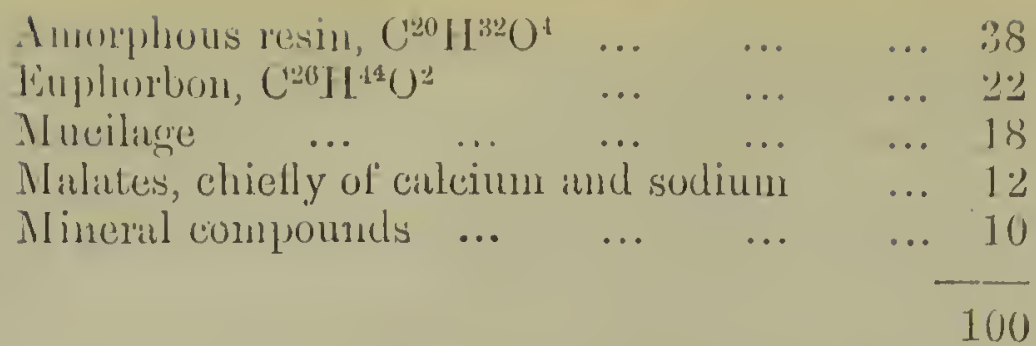

The annorphous resin is readily soluble in cold spirit of wine containing ubout 70 per cent. of alcohol.' 'The solution has no acid reaction, but an extremely bmrning acrid taste: in fact it is to the amorphous indilferent resin that euphorbium owes its intense acridity.

This constituent having been removed, ether takes up the Euphorbon, which may be obtilined in eolourless, although not very distinct crystals, which are at first not free from acrid taste. But by repeated crystallizations and finally boiling in a weak solution of permanganate of potassium, they may be so far purified as to be entirely tasteless. Euphorbon is insoluble in water; it requires about 60 parts of spirit of wine, sp. gr. 0.830 , for solution at the ordinary temperature. In boiling spirit of wine, euphorbon dissolves abundantly, also in ether, benzol, amylic alcohol, chloroform, acetone, or glacial acetic acid.

Euphorbon melts at $116^{\circ}$ C., without emitting any odour. By dry distillation, a brownish oily liquid is obtained, which claims further exanination. If euphorbon dissolved in alcohol is allowed to form a thin film in a porcelain capsule, and is then moistened with a little oil of vitriol, a fine violet hue is produced in contact with strong nitric acid slowly added by means of a glass rod. The same reaction is displayed by Lactueerin (p. 356), to which in its general characters euphorbon is closely allied.

As to the mucilage of euphorbium, it may be obtained from that portion of the drug which has been exhausted by cold alcohol and by ether. Neutral acetate of lead, as well as silicate or borate of sodiun, precipitate this mucilage, which therefore does not agree with gum arabic.

If an aqueous extract of euphorbium is mixed with spirit of wine, and t'. Iiquid evaporated, the residual matter assumes a somewhit crystalline appearance and exhibits the reactions of Malic Acid. Subjected to dry distillation, white scales and acicular crystals of Maleic and Fumaric Acids, produced by the decomposition of the malic acid, are sublimed into the neck of the retort. A sublimate of the same kind may sometimes be obtained directly by lieating fragments of eiphorbium. Among the mineral constituents of the drug, chloride of sodium and calcium are noticeable; scarcely any salt of potassium is present.

Commerce-The drug is shipped from Mogador. The quantity imported into the United Kingdom in 1870, is given in the Anmual Statement of Trade, as 12 cwt.

Uses-Euphorbium was formerly employed as an emetic and purgative, but as an internal remedy it is completely obsolete. We have been told that it is now in some demand as an ingredient of a paint for the preservation of ships' bottonis. 


\section{CORTEX CASCARILLEE.}

Cortex Elcutheria; Casearilla Bail, Swet Wood Bark, Eleuthera Bark ${ }^{1}$; F. Ecorec de Casearille; G. Cusearill-Rinde.

Botanical Origin-Croton Eluteria Bennett, ${ }^{2}$ a shrub or small tree, native of the Bahama Islands.

History-It is not improbable that cascarilla bark was imported into Europe in the first half of the 17th century, as there was much intercourse subsequent to the year 1630 between England and the Bahamas. ${ }^{3}$

Be this as it rnay, the earliest notice of the bark with which we are acquainted, is that of Stisser, a physician and professor of Helmstedt in Brunswick, who relates that he received the drug innder the name of Cortex Eleuterii from a person who had returned fron England, in which country he was assured, it was customary to mix it with tobacco for the sake of correcting the smell of the latter when smoked. He also mentions that it had been confounded with Peruvian Bark, from which however it was very distinct in odour, \&c. ${ }^{4}$

Both Stisser, and Apinus a physician of Hersbruck near Nuremberg, as well as other's, prescribed this bark as a febrifuge; and soon afterwards it began to be confounded with cinchona bark and to be used in the place of that then rare medicine. ${ }^{5}$ Hence the name easearilla, signifying in Spanish little bark, which was the customary designation of Peruviau Bark, was erroneously applied to the Bahama bark, until at last it quite superseded the original and more correct appellation. ${ }^{6}$ The bark was first introduced into the London Pharmacoporia in 1746, as Eleutherië Cortex, which was its common name among druggists down to the end of the last century. In the Bahamas, the iame eascarilla is still hardly known, the bark being there called either Sucet Wood Bark, or Elerutherce Bark.

The plant affording cascarilla las been the subject of much discussion; arising chietly from the circumstance that several nearly allied West Indian species of Croton, yield aromatic barks resembling more or less the officinal drug. Catesby in 1754, figured a Bahama plant, Croton Casearilla Benuett, from which the original Elcuthera Bark was probably derived, though it certainly affords none of the cascarilla of modem commerce. Woodville in 1794, and Lindley in 1838, both investigated the botany of the subject, the latter having the advantage

1 Fron Eleuthera, one of the Bahama Islands, so named from the Greek éं $\dot{\lambda} \in \dot{v} \theta \in$ epos, signifying free or independent.

2 Journal of Proecedings of Linn. Soc. iv. (1860) Bot. 29.

${ }^{3}$ In that year, a patent was granter by Charles I. for the incorporation of a Company for colonizing the Pahama Islands, and a complete record is extant of the proceedings of the Comprany for the first elcven years of its existcnce. In some of the documents, particular mention is made of the introduction, actual or attempited, of useful plints, as cotton, tobacco, fig, pepper, pomegranate, palma Christi, mulberry, flax, indigo, madder, and jâlap; and there is also frequent allusion to the iniportation of the produce of the islands, but no mention of Casearilla. See Calendar of Slate Papers. Colonial Series, 1574-1660, edited by Sainsbury, I $\mathrm{I}_{411}$. 1860 . pp. 146. 148. 149. 164. 168. 185 , \&c.

4 Stisser (J. A.), Aetornum Laboratorii Chemici speeimen secundum, Helmcstadi, 1693. c. ix.

${ }_{5}^{5}$ Geoffroy, Traet. de MIat. Ned., ii. (1741)

6 Murray, Apmaralns Medieaminucm, iv. (1787) 128 ; Martiny, Eneyklopädie der Róhwararinkuinde, i. (1843) 271. 
of authentic specinens communicaled hy the Hon. J. C. Lees of New Providence, to whom one of us is also indebted for a similar favour. The question was not however, finilly set at rest until 1859 , when J. J. Bennett by the aid of specimens collected in the Balnamas by Daniell in 1857-8, drew up lucid diannoses of the several plants which had been confounded, and disentangled their intricate synouymy.

Description-Cascarilla occur's in the form of tribular or channelled pieces of is dull brown colour, somewhat rough and integular, rarely exceeding $t$ inches in length by $\frac{1}{2}$ an inch in diameter. The chief bulk of that at present inported, is in very small thin quills and fragments, often scarcely an inch in length, and evidently stripped from very young wood. The younger bark has a thin suberous coat easily detached, blotched or entirely covered with the silvery-white growth of a minute lichen (Verrucaria albissimu Ach.), the peritheciun of which appears as small black dots. The older bark is more rugose, irregularly tessellated by longitudinal cracks and less numerous transverse fissures. Beneath the corky envelope, the bark is greyish-brown.

'The bark breaks readily with a short fracture, the broken surface displaying a resinous appearance. It has a very fragrant odour, especially agreeable when several pounds of it are reduced to coarse powder and placed in a jar; it has a nauseous bitter taste. Whell burned, it emits an aromatic smell, and hence is a common ingredient in fumigating pastilles.

Microscopic Characters-The suberous coat is made up of numerous rows of tabular cells, the outermost having their exterior walls much thickened. The mesophioum exhibits the usual tissue, containing starch, chlorophyll, essential oil, crystals of oxalate of calcium and a brown colouring matter. The latter assumes a dark bluish coloration on addition of a persalt of iron. The liber consists of parenchyme and of fibrous bundles, intersected by small medullary rays. On the transverse section, the fibrous bundles show a wedge-shaped outline; they are for the most part built up, not of true liber fibres, but of cylindrical cells having their transverse walls perforated sieve-like (vasa cribriformic). The contents of the parenchymatous part of the liber are the same as in the mesophloum; as to the oxalate of calcium, the variety of its crystals is remarkable.

Chemical Composition-Cascarilla contains a volatile oil, which it yields to the extent of $\frac{3}{4}$ to 1 per cent. According to Völckel, the first portion which comes over is colourless, mobile and refractive, the next yellowish and rather viscid, and the last of all, very thick. 'This chemist regards the crude oil as a mixture of at least tivo oils, the more volatile of which is probably free from oxygen. ${ }^{2}$ Gladstone (1872) assigns to the hydrocarbon of cascarilla oil, the cumposition of oil of turpentine. Rectified oil of cascarilla, distilled by one of us some years ago, deviates the ray of polarized light $2 \cdot 9^{\circ}$ to the left, when observed in a columm 50 inm. lons.

The bark afforded to 'lrommsdorff', 15 per cent. of resin consisting of two portions, - the one acil (i.e. solnble in alkulis), the other indifferent. It appears to contain gum in about the same proportion.

1 Rennett, 1.c. ; also Daniell in Pharn.

2 Gmelin, Chumistry, xiv. (1860) 363.

I Rennatt, 1.c. ; also Danith figures.
Juuric. iv. (1563) 144.226 , with 
The bitter principle was isolated in $18+5$ by Duval, and called Cascarillin. C. and E. Mylius (1873) have obtained it from a deposit in the officinal extract, in microscopic prisms readily soluble in ether or hot alcohol, very sparingly in water, chloroform or spirit of wine. It melts at $205^{\circ} \mathrm{C}$, is not volatile, nor a glucoside. Its composition answers to the formula $\mathrm{C}^{12} \mathrm{H}^{18} \mathrm{O}^{4}$.

Commerce-The bark is shipped from Nassau, the chief town of New Providence (Bahamas). and is usually packed in sacks. The quantity imported into the United Kingrdom in 1870 was 12,261 cwt., valued as $£ 16,48$.

Uses-Cascarilla is prescribed as a tonic, usually in the form of tincture or infusion.

Adulteration-A spurious cascarilla bark has lately been noticed in the London market; it was imported from the Bahamas mixed with the genuine, to which it bears a close sinilarity. The quills of it resemble the larger quills of cascarilla; though covered with a lichen, the latter has not the silvery whiteness of the Verrucaric of cascarilla. The spurious bark has a suberous coat that does not split off; its inner surface is pinkish-brown, and distinctly striated longitudinally. In micruscopic structure the bark may be said to resemble cascarilla and still more copalchi. But it is at once distinguishable by its numerous roundish groups of sclerenchymatous cells, which become very evident when thin sections are moistened with ammonia, and then with solution of iodine in iodide of potassium. The bark has an astringent taste, without bitterness or aroma; its tincture is not rendered milky by addition of water, but is darkened by ferric chloride,-in these respects differing from a tincture of cascarilla. Mr. Holmes ${ }^{1}$ suggests that this spurious cascarilla is probably the bark of Croton lucidus L.

\section{Copalchi Bark.}

This drug is derived from Croton nivens Jacquin (C. Pseudo-China Schlecht.), a shrub growing 10 feet high, native of the West Indian Islands, Mexico, New Granada and Venezuela. It has occasionally been imported into Europe, in quills a foot or two in length, usually much stouter and thicker than those of cascarilla, to which in odour and taste it nearly approximates. The bark has a thin, greyish, papery, suberous layer, which when removed shows the surface marked with minute transverse pits, like the lines made by a file; it has a short fracture.

Copalchi bark was examined by J. Eliot Howard, ${ }^{2}$ and found to contain a minute proportion of a bitter alkaloid soluble in ether, which resembled quinime in yielding a deep green colour when treated witl chlorine and ammonia, though it did not afford any characteristic comfound with iodine. Mauch ${ }^{3}$ who alsu anlalysed the bark, could not obtain from it any organic base. He extracted by distillation the essential oil, which he found to consist of a hydrocarbon and an organic acid,latter not examined; he likewise got from the bark an uncrystallizable vitter principle, which proved to be reve a ghticoside.

1 Pharm. Journ. April 1], 1874.810.

2 Hharm. Jưri, xiv. (18Ei) $31 \%$
${ }^{3}$ Wittstein's Tierteljahresschrift für prakt. Pharin., xviii. (1869) 161. 


\section{SEMEN TIGLII.}

Soncen Crotonis; Croton Seeds; Tr. Graines de Tilly on des Molurques, Petits P'ignons d'Inde; G. Puryinliörner, Grunalill.

Botanical Origin-Cioton 'Tiglium I. (Tiglium offrinale Klotzsch), a small tree, 15 to 20 feet high, indigenous to the Malinisal Coast and Tavoy, cultivated in gardens in many parts of the last, from Maurilius to the Indian Archipelago. The tree las small inconspicuous flowers, and brown, capsular, three-celled fruits, each cell contanining one seed. The leaves have a disagreeable sniell and nauseous taste.

History-In Europe, the seeds and wood of the tree were first described in $157 \mathrm{~s}$ by Christoval Acosta,-the forner, with a figure of the plant, appearing' muder the name of Piñones de Nuluco. ${ }^{1}$ 'The plant was also described and figured by Rheede $(1679)^{2}$ and Riunphius (1743). ${ }^{3}$ The sceds, whicl were officinal in the 17 th century but had becone obsolete, were recommended about 1812 , by Lughish medical officers in India, ${ }^{4}$ and the expressed oil by Perry, Frost, Conwell and others about 1821-2t. The oil then in use was imported from India, and was often of doubtful purity, so that some druggists felt it uecessary to press the seeds for themselves. ${ }^{5}$

Description-Croton seeds are about half an inch long, by uearly $\frac{2}{5}$ of an inch broad, ovoid or bluntly oblong, divided longitudinally into two unequal parts, of which the nore arched constitutes the dorsal and the flatter the ventral side. From the hilum, a fine raised line (raphe) passes, to the other end of the seed, terminating in a darker point inclicating the chalaza. The surface of the seed is more or less covered with a bright cinnamon-brown coat, which when scraped shows the thin, hrittle, black testa filled with à whitish, oily kernel, invested with a delicate seed-coat. The kernel is easily split into two halves consisting of oily albumen, between which lie the larye, veined, leafy cotyledons and the radicle. The taste of the seed is at first merely oleaginous, but soon beconies unpleasantly and persistently acrid.

Microscopic Structure-The testa consists of an outer lajer of radially arranged, much elongated and thick-walled cells; the imner parenchymatons layer contains small vascular bundles. The soft tissive of the albumen is loaded with drops of fatty oil. If this is removed by means of ether and weak potash lye, there remain small graniles of albuminoid matter, the so-cilled Alewron, and crystals of uxalate of calciunn.

Chemical Composition-The principal constituent of croton seeds is the fiatty oil, the Oleum Crotonis or Olen'n I'iglii of pharmacy, of

1 Tractado de las drogas y medicinas de las Indias Orientales, Burgos, 1578. e. 48.After spealing of the virtues of the secds, he alds-"tambien las buenas mugeres de aquellas partes, amigas de sus mariclos, les dĩ hasta ruatro destós por la boca, pára embiar a los pobretos al otro muirto."

2 Ilortus Nalabnricus, ii. tab. 33.

\& livbarium Amboinense, iv. tab. 42.
4 Ainslie, Mrat. Med. of Hindoostan, 1813. 292.

5 The oil was very expensive. I find by the books of Messi's Allen aud Hauburys, that the seeds cost in 1824,10 s., and in 1827 , 18s. pier 1b. The oil was purchased in 1826 hy the saine house at $S s$. to $10 s$. $1^{1 e 1}$ oulce.D. $\mathrm{H}$. 
which the kernels afford from 50 to 60 per cent. That used in England is for the most part expressed in London, and justly regarded as more reliable than that imported from India, with which the market was formerly supplied. It is a transparent, sherry-coloured, viscid liquid, slightly fluorescent, and having a slight rancid smell and an oily, acrid taste. Its solubility in alcohol (794) appears to depend in great measure on the age of the oil, and the greater or less freshness of the seeds from which it was expressed,-oxidized or resinified oil dissolving the most readily. ${ }^{1}$ We found the oil which one of us had extracted by means of bisulphide of carbon, to be levogyre.

Although croton oil does not solidify in contact with nitrons acid, and thickens somewhat upon exposure to the air, it does not appear to contain the fatty acid of a true drying oil such as that of linseed. It contains however in the form of glycerides, sereral of the members of the fatty acids series $\left(\mathrm{C}^{\mathrm{u}} \mathrm{H}^{2 \mathrm{n}} \mathrm{O}^{2}\right)$, such as stearic, palmitic, myristic and lauric acids ; also largely the more volatile acids, as acetic, butyric and valerianic. The volatile part of the acids yielded by croton oil, contains moreover about a third of its weight of an acid which was regarded by Schlippe (1858) as angelic acid, but which has been shown by Geuther and Frölich (1869) to be a peculiar body, metameric with angelic acid, melting at $64^{\circ} \mathrm{C}$. and boiling at $201^{\circ} \mathrm{C}$. This constituent of croton oil is called by the latter chemists, Tiglinic Acid; it has the formula. $\mathrm{C}^{5} \mathrm{H}^{8} \mathrm{O}^{2}$.

Schlippe also found in croton oil a peculiar liquid acid termed Crotonic Acid, $\mathrm{C}^{4} \mathrm{H}^{6} \mathrm{O}^{2}$. According to Geuther and Frölich however, an acid of this formula does not occur at all in croton oil, but may be obtained artificially by means of perchloride of phosphorus and ethyldiacetic acid. They give it the name of Quartenylic Acid, instead of crotonic acid. The latter name has been bestowed upon a crystallizable acirl, melting at $72^{\circ} \mathrm{C}$. and boiling at $187^{\circ} \mathrm{C}$, which has been artificially produced by Will aud Körner (1863), Wislicenus (1869), and other chemists.

The drastic principle of croton oil lias not yet been isolated. It appears to exist not only in the seeds, but also in the wood and leaves of the plant, from which latter it may possibly be more readily extracted. Schlippe asserts that he has separated the vesicating matter of croton oil : according to his statements, if the oil be agitated with alcoholic soda, and afterwards with water, the supernatant liquor will be found quite free from acridity, while the alcoholic solution will yield, on addition of hydrochloric acid, a small quantity of a dark brown oil, called Crotonol, $\mathrm{C}^{18} \mathrm{H}^{28} \mathrm{O}^{4}$, possessing strong vesicating properties. In its purest state it is described to be a viscid, non-volatile, yellowish liquid, of faint peculiar odour, miscible with alcohol or ether, and decomposable by acids as well as by alkalis. We have not succeeded in obtaining it, nor, so far as we know, has any other chemist except its discoverer.

The shells of the seeds (testa) yield upon incineration 266 per cent. of ash; the kernels dried at $100^{\circ}$ C. $3 \cdot 0$ per cent.

Commerce-The shipments of croton seeds arrive chiefly from

1 Warrington, Pharm. Journ. vi. (1865) 382-387. 
Cochin or Bombay, packed in cases, bales or robbins; but there are no statistics to show the extent of the trade.

Uses-Croton seeds are not administered. The oil is given internally as a powerful cathartic, and is applied externally as a rubefacient.

Substitutes-The seeds of Croton Prowan Hamilton, a native of Ava and Camrup (Assam), and those of C'. oblonyifolizus Roxb., a small tree common about Calcutta, are said to resemble those of $C$. Tiglium I., but we have not compared them. Those of Baliospermum montanum Miill. Arg. (Croton polyandmum Roxb.) partalse of the nature of croton seeds, and according to Roxburgh, are used by the natives of India as a purgative.

\section{SEMEN RICINI.}

Semen Cataputice majoris ; Castor Oil. Seedls, Palma Christi Seeds; F. Semence de Ricin; G. Ricinussanen.

Botanical Origin-Ricinus communis L., the castor oil plant, is a native of India where it bears sevcral ancient Sanskrit names. ${ }^{1}$ By cultivation, it has been distributer through all the tropical and many of the temperate countries of the globe. In the regions most favourable to its growth, it attains a height of 40 feet. In the Azores, and the warmer Mediterranean countries as Algeria, Egypt and Greece, it becomes a small tree, 10 to 15 feet high; while in France, Germany and the south of England, it is an annual herb of noble foliage, growing to a height of 4 or 5 feet. In good summers, it ripens sceds in England and even as far north as Christiania in Norway.

Ricinus communis exhibits a large number of varicties, several of which have been described and figured as distinct species. Miiller, after a careful examination of the whole series, maintains them as a single species, of which he allows 16 forms, more or less well marked. ${ }^{2}$ Baillon ${ }^{3}$ follows the same course.

History-The castor oil plant was known to Herodotus who calls it Ki $\kappa$, and states that it furnishes an oil much used by the Egyptians. At the period when he wrote, it would appear to have been already introduced into Greece, where it is cultivated to the present day under the same ancient name. ${ }^{4}$ The Kitajon of the Book of Jonah, rendered by the translators of the English Bible, gourd, is believed to be the same. plant. Kik $i$ is also mentioned by Strabo as a production of Egypt, the oil from which is used for burning in lamps and for unguents.

Theophrastus and Nicander give the castor oil plant the name of

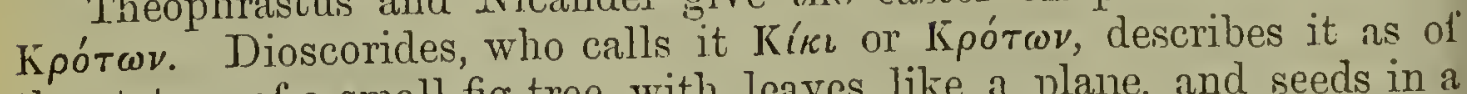
the stature of a small fig-tree, with leaves like a plane, and seeds in a prickly pericarp, observing that the name Kót $\omega_{\nu}$ is applied to the seed on account of its resemblance to an insect [Ixodes Ricinus Latr.], known by that appellation. He also gives an account of the process

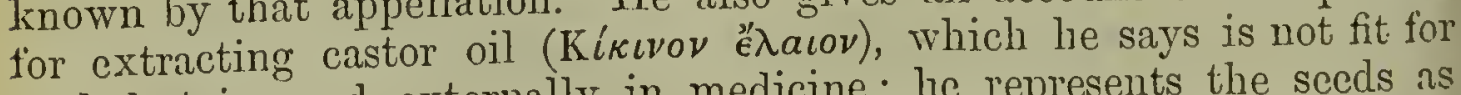
food, but is used externally in medicine; he represents the sceds is

1 The most usual is Eranda or Teranda, which passes into several other languages.

2 De Caudolle, Prodromas, xv. sect. 2. 1017.
\& Hist. des Plantes; Euptorbiaceses (1S74) 110.

+ Heldreich, Nutzpfanzen Griectuntands. Athen, 1862. 58. 
extremely purgative. There is a tolerably correct figure of Ricinus in the famous M[S. Dioscorides which was executed for the Empress Juliana Anicia in A.D. 505, and is now preserved in the Imperial Library at Vienna.

The castor oil plant was cultivated by Alberius Magnus, Bishop of Ratisbon, in the middle of the 13 th century. ${ }^{1} \quad$ It was well known as a garden plant in the time of Turner (1568), who mentions the oil as Olcum cicinum vel ricininum. ${ }^{2}$ Gerarde at the end of the same century, was familiar with it under the name of Ricinus or $K i k$. The oil he says is called Oleum cicinum or Oleum de Cherua, and used externally in skin diseases.

After this period the oil seems to have fallen into complete neglect, and is not even noticed in the comprehensive and accurate Pharmacologia of Dale (1693). In the time of Hill (1751) and Lewis (1761) Palma Christi seeds were rarely found in the shops, and the oil from them was scarcely known. ${ }^{3}$

In 1764, Peter Canvane, a pliysician who liad practised many years in the West Indies, published a "Dissertation on the Oleum Palmo Christi, sive Oleum Ricini; or (as it is commonly call'd) Castor Oil," 4 strongly recommending its use as a gentle purgative. This essay which passed through two editions and was translated into French, was followed by several others, ${ }^{5}$ thus thoroughly drawing attention to the value of the oil. Accordingly we find that the seeds of Ricinus were admitted to the London Pharmacopœia of 1788, and directions given for preparing oil from them. Woodville in his Medical Botany (1790) speaks of the oil as having "lately come into frequent use."

At this period and for several years subsequently, the small supplies of the seeds and oil required for European medicine, were obtained from Jamaica. ${ }^{6}$ This oil was gradually displaced in the market by that produced in the East Indies: the rapidity with which the consumption increased, may be inferred from the following fignres, representing the value of the Castor Oil shipped to Great Britain from Bengal in three several years, namely $] 813-14, \mathfrak{£} 610 ; 1815-16, £ 1269 ; 1819-20$, $£ 7102 .^{7}$

Description-The fruit of Ricinus is a tricoccous capsule, usually provided with weak prickles, containing one seed in each of its three cells. The seeds attain a length of $\frac{3}{10}$ to $\frac{b}{10}$, and a maximum breadth of $x^{4} v$ of an inch, and are of a compressed ellipsoid form. The apex of

1 De Vegetabitimus, ed. Jcssen, 196\%. 347 .

Turner's Herbal, nt. ii. 116.

${ }^{3}$ Hill, Hist. of the Mat. Med., Lond. 1751. 537.-Lewis, Hist. of the Mrat. Med., Lond. 1761. 468 .

4 The word castor in connection with the sceds and oil of Ricinus, has come to us from Jamaica, in which island, by some strange mistake, the plant was once called Agnus Castus. The tric Agmus Castus (Vitex Agnus-astus I.) is a native of the Mediterranean countries and not of the West Indies.

5 For a list of which consult Miérat et De Lens, Dict. de MTat. Méd., vi. (1834) 95.

- How small was the trafic in Castor Oil in those days, may be judged from the froct that the stock in 17\%7, of a London whole. sale druggist (Joseph Gurney Bevan, predecessor of Allen and Hanburys) was 2 Bottles ( 1 Bottle $=18$ to 20 ounces) valued at $8 s$. per bottle. The accounts of the same house show at stocktaking in 1782,23 Bottles of the oil, which had cost $10 \mathrm{~s}$. ner bottle. In 1799, Jamaica exported 236 Casks of Castor Oil and 10 Casks of seeds (Renny, Hist. of Jamaica, 1807.235).

7 H. H. Wilson, Review of the External Commerec of Bengal from 1813 to 1828 , Calcutta 1830, tables pp. 14-15. (Wc have reduced the value from Sicca rupces to sterling.) 
the seed is prolonged into a short heak, on the inner sille of which is a large tumid curuncle: from this latter proceeds the raplue as far as the lower end of the ventral surface, where it forks, its porint of disappearance through the testa being marked hy a minnte protuberance. If the carmole is broken off, a black scar formed of two little depressions, remains.

The shining grey epidermis is benutifully marked with brownish bands and spots, and in this respect exhibits a great varicty of colour's and markings. Tt camnot be rubbed off, but may after maceration be pecled off in leathery strips. The black testa, grey within, is not thicker than in croton sced, but is much more brittle. 'The kernel or mucleus fills the testa completely, and is easily separated, still covered by the soft white inner membranc.

'The kernel in respect to structure and situation of the embryo, agrees exactly with that of Croton Tiglium (p. 508), excepting that the somewhat gaping cotyledons of Ricinus are proportionately broader, and have their thick midrib provided with 2 or 3 pairs of lateral veins. If not rancid, the kernel lias a bland taste, with but very slight acridity.

Microscopic Structure - The thin epidermis consists of pentagonal or hexagonal porous tabular cells, the walls of which are penetrated in certain spots by brownish colouring matter, whence the singular markings on the seed. It is these cells only that become blackened when a thin tangential slice is saturated with solution of ferric chloride in alcohol.

Beneath these tabular cells, there is found in the unripe seed ${ }^{1}$ a row of encrusted colourless cells, deposited in a radial direction on the testa. In the mature seed this layer of cells is not perceptible, and therefore appears to perish as the seed ripens. The testa itself is built up of cylindrical, densely packed cells, 300 to $320 \mathrm{mkm}$. long, and 6 to 10 mkm. in diameter. The kernel shares the structure of that of $C$. Tiglium, but is devoid of crystals of oxalate of calcium. If the endopleura of Ricinus is moistened with dilute sulphuric acid, acicular crystals of sulphate of calcinm separate from it after a few hours.

When thin slices of the kernel are examined under concentrated glycerin, no drops of oil are visible, notwithstanding the abundance of this latter; and it becomes conspicuous only by addition of mucli water. Hence it is probable that the oil exists in the seed as a kind of compound with its albuminoid contents. ${ }^{2}$ As to the latter, they partly form in the albumen of Ricinus, beautiful octohedra or tetrahedra, which are also found in many other seeds.

Chemical Constitution-The most important constituent of the seed is the fixed oil, called Castor Oil, of which the pecled kcrnels afford at most, half of their weight.

The oil, if most carefully prepared from peeled and winnowed seeds by pressure without heat, has but a slightly acrid taste, and contains only a very small proportion of the still unknown drastic constitnent of

1 Gris, Annales des Scionces Nat., Bot., xv. (1861) $5-9$.

2 Sachs, Lelurbuch der Botanit, 1870. 53.

3 For further particulars. see 'l'rérnl, Anm. des Sc. Nat., Bot., x. (1858) 355; Radlkolier,
Krystalle mentcinartiger Körper, I,eipzig, 185961 . and tah. 2 fig. 10 ; Pfeffer, Proteinkiömer in Pringsheim's Jahrbücher für "wissenschufuliche Botnnik, viii. (18i2) is?. 464. 
the seeds. Hence, the seeds themselves, or an emulsion prepared with them, act much more strongly than a corresponding quantity of oil. Castor oil, extracted by absolute alcohol or by bisulphide of carbon, likewise purges much more vehemently than the pressed oil.

The castor oil of commerce has a sp. gr. of about 0.96 , usually a pale yellow tint, a viscid consistence, and a very slight yet rather mawkish odour and taste. Exposed to cold, it does not in general entirely solidify until the temperature reaches $-18^{\circ} \mathrm{C}$. In thin layers it dries up to varnish-like film.

Castor oil is distinguished by its power of mixing in all proportions with glacial acetic acid or absolute alcohol. It is even soluble in four parts of spirit of wine ( 838 ) at $15^{\circ} \mathrm{C}$., and mixes without turbidity with an equal weight of the same solvent at $25^{\circ} \mathrm{C}$. The commercial varieties of the oil however, differ considerably in these as well as in some other respects.

The optical properties of the oil demand further investigation, as we have found that some samples deviate the ray of polarized light to the right and others to the left.

By saponification, castor oil yields several fatty acids, one of which appears to be Palmitic Acid. Another acid (peculiar to the oil), is Ricinoleic Acid, $\mathrm{C}^{18} \mathrm{H}^{34} \mathrm{O}^{3}$; it is solid below $0^{\circ} \mathrm{C}$.; does not solidify in contact with the air by absorption of oxygen, and is not homologous with oleic or linoleic acid, neither of which is found in castor oil. ${ }^{1}$ Castor oil is nevertheless thickened if 6 parts of it are warmed with 1 part of starch and 5 of nitric acid (sp. gr. 1.25), Ricinelä̈din being thus formed. From this, Ricinelaz̈dic Acid may easily be obtained in brilliant crystals.

As to the albuminoid matter of the seed, Fleury (1865) obtained 3.23 per cent. of nitrogen which would answer to about 20 per cent. of such substances. The same chemist further extracted $46 \cdot 6$ per cent. of fixed oil, $2 \cdot 2$ of sugar and mucilage, besides 18 per cent. of cellulose.

According to Bower, ${ }^{2}$ the seeds contain a protein substance and a body resembling amygdalin, by the mutual reaction of which in the presence of water, there is produced in very small quantity, a fœtid poisonous substance which strongly attacks the digestive organs. These statements require investigation.

Tuson in 1864, by exhausting castor oil seeds with boiling water, obtained from them an alkaloid which he named Ricinine. He states that it crystallizes in rectangular prisms and tables, which when heated fuse, and upon cooling solidify as a crystalline mass; the crystals may even be sublimed. Burnt on platinum foil, they leave no residue. Ricinine dissolves readily in water or alcohol, less freely in ether or benzol. Concentrated sulphuric acid dissolves it without coloration. With mercuric chloride, it combines to form tufts of silky crystals, soluble in water or alcohol. Heated with potash, it evolves ammonia. Picinine is said to have but little taste, and not to be the purgative principle of the seeds. Werner (1869) on repeating Tuson's process on $30 \mathrm{tb}$. of Italian castor oil seeds, also obtained a crop of crystals, which in appearance and solubility had many of the characters ascribed to ricinine, but differed in the essential point that when incinerated they

1 Gmelin, Chemistry, xvii. (1860) 131-114. 2 Am. Joum. of Pharm.xxvi. (1854) $20 \%$. 
left a residuum of magnesia. When heated with potash, they gave off no ammonia; Werner regarded them as the magnesium salt of a new acid. 'I'uson ${ }^{1}$ repudiates the suspieion that ricinine may be identieal with Werner's magnesium eompound. I. S. Wayne of Cincinnati has reeently (1874) found in the leaves of Ricinus, a substance apparently identical with Tuson's ricinine; but he consider's that it has no elaim to be called an alkaloid.

The testa of eastor oil seeds afforded us 10.7 per eent. of ash, one tenth of whieh we found to eonsist of silica. 'The ash of the kernel previously dried at $100^{\circ} \mathrm{C}$., amounts to only 3.5 per eent.

Production and Commerce-Castor oil is most extensively produeed in India, where two varieties of the seeds, the large and the small, ire distinguished, the latter being considered to yield the better produet. In manufacturing the oil, the seeds are gently erushed between rollers, and freed by hand from husks and unsound grains. At Caleutta, 100 parts of seed yield on an average 70 parts of eleaned kernels, whieh by the hydraulie press afford 46 to 51 per cent. of their weight of oil; the oil is afterwards subjected to a very impcrfeet proeess of purifieation by leating it with water. ${ }^{2}$

The exports of castor oil from Caleutta ${ }^{3}$ in the year 1870-71, amounted to 654,917 gallons, of which 214,959 gallons were shipped to the United Kingdom. The total imports of eastor oil into the United Kingdom ${ }^{4}$ in the year 1870, were returned as 36,986 ewt. (about 416,000 gallons), valued at $£ 82,490$. Of this quantity, British India (chiefly Bengal) furnished about two-thirds ; and Italy 11,856 cwt. (about 133,000 gallons), while a small remainder is entered as from "other parts."

Italian Castor Oil, which has of late risen into some celebrity, is pressed from the seed of plants grown ehicfly about Verona and Legnago, in the north of Italy. The manufactory of Mr. Bellino Valeri at the latter town produeed in the year 1873,1200 quintals of castor oil, entirely from Italian seed. Two varieties of Ricinus are cultivated in these localities, the black-seeded Egyptian and the red-seeded American; the latter yields the larger pereentage, but the oil is not so pale in colour. The seeds are very earefully deprived of thcir integuments, and having beein erushed, are submitted to pressure in powerful hydraulie presses, placed in a room which in winter is heated to about $21^{\circ} \mathrm{C}$. The outflow of oil is further promotcd by plates of iron warmed to $32-38^{\circ} \mathrm{C}$., being placed betwecn the press-bags. The peeled seeds yield about 40 per cent. of oil. ${ }^{5}$

All the eastor oil pressed in Italy is not pressed from Italian seed. By an official return ${ }^{6}$ it appears that in the year's $1872-73$, there were exported from Bombay to Genoa $1350 \mathrm{cwt}$. of castor oil seeds, besides 2452 gallons of castor oil. There are no data to show what was exported from the other presidencics of India in that year:

Uses-Castor oil is much valued as a mild and safe purgative; while

1 Chemical Ncus, xxii. (1870) 229.

2 Marlres Eshluibition of liaw Products, cte. of Southern India, -Reports by the Juries, IIndras, 1856. 2S.

3 Anmual Volume of Trade and Nerigation for the Bengal Presillency for 1s70-71, Calcutta, 1871. 119.
* Anmual Statement of the Trade, de. of the U.K. for 1870 . - No later returns.

5 H. Groves, Pharm. Journ. riii. (1S67) 250 .

"Amuchl statcment of the Trade and Navigation of the Presidensy of Bombay for 1872-73, part ii. 87.88 . 
the commoner qualities are used in soap-making, and in India for burning in lamps. The seeds are not now administered. The leaves of the plant applied in decoction to the breasts of women, are said to promote or even to occasion the secretion of milk. This property which has long been known to the inhabitants of the Cape Verd Islands ${ }^{1}$ was particularly observed by Dr. McTVilliam about the year 1850. It has even been found that the galactagogue powers of the plant are exerted when the leares are administered interually.

\section{KAMALA.}

\section{Kamelc, Glandulce Rottlerce.}

Botanical Origin-Mallotus Philippinensis Miill. Arg. (Croton Philippense Lam., Rottlera tinctoria Roxb., Echinus Philippinensis Baillon), a large shrub, or small tree, attaining 20 or 30 feet in height, of very wide distribution. It grows in Abyssinia and Southern Arabia, throughout the Indian peninsulas, ascending the mountains to 5000 feet above the sea-level, in Ceylon, the Malay Archipelago, the Philippines, Eastern China and in North Australia, Queensland and New South Wales.

The tricoccous fruits of many of the Euphorbicacece are clothed with prickles, stellate hairs, or easily removed glands. This is especially the case in the several species of Mallotus, most of which have the capsules covered with stellate hairs, together with small glands. In that under notice, the capsule is closely beset with ruby-like glands which, when removed by brushing and rubbing, constitute the powder known by the Bengali name of Kancula. These glands are not confined to the capsule, but are scattered over other parts of the plant, especially among the dense tomentum with which the under side of the leaf is covered.

History-This drug is mentioned by some of the Arabian physicians ${ }^{2}$ as early as the 10th century, under the name of Kanbil or Wars. Ibn Khurdádbah, an Arab geographer, living A.D. 869-885, states that from Yemen come striped silks, ambergris, wars, and gum. ${ }^{3}$ It is described to be a reddish yellow powder like sand, which falls on the ground in the valleys of Yemen, and is a good remedy for tapeworm and cutaneous diseases. One writer compares it to powdered saffron; another spealks of two kinds,-an Abyssinian which is black (or violet), and an Indian which is red. Abul-Abbas el-Nebáti, who was a native of Spain, remarks that the drug is known in the Hejaz and brought from Yemen, but that it is unknown in Andalusia and does not grow there.

In modern times, we find Niebuhr ${ }^{4}$ speaks of the same substance (as "uars") stating it to be a dye-stuff, of which quantities are conveyed from Mokha to Oman. The drug must have been long known in India, for it has several Sanskrit names: one of these is Kapila, which as well as the Telugu Kápila-podi, is sometimes used by Europeans, though not

1 Frezier, Foyage to the South Sces, Lond. 1717. p. 13.-Tumer in his Herbal (1568) gives the plant an opposite eharaeter, for the bruised leaves, says he, "swage the brestes or pappes swellinge wyth to muche plenty of milke."
2 Quoted by Ibn Baytar, - see Sontheimer's translation, ii. (1842) 326. 585.

${ }^{3}$ Ibu Khordadbeh, Livre des routes ot des mrorinces, trad. par Barbier de Meynard.Journ. A siatique, V. (1865) 295.

4 Description de l'Arabie, 1774. 133. 
so frequently as the word Kamala or Kamela, which belongs to the Hindustani, Bengali and Guzratti languages.

It does not appear that as a drug the glandular powder of Mallotus, or as it is more conveniently called, Kamula, attracted any particular notice in Europe until a very recent period, though it is named by Ainslie, Roxburgh, Royle and Buchanan, the last of whom gives an interesting account of its collection and uses. ${ }^{1}$ In 1852, specimens of it as found in the bazaar of Aden under the old Arabic name of Wars, were sent to one of us by Port-Surgeon Vaughan, with information as to its properties as a dye for a silk and as a remedy in cutaneous diseases. ${ }^{2}$ But the real introduction of the drug as a useful medicine is due to Mackinnon, surgeon in the Bengal Medical Establishment, who administered it successfully in numerous cases of tapeworm. Anderson of Calcutta, C. A. Gordon, and Corbyn in India, and Leared in London, confirmed the observatious of Mackinnon, and fully established the fact that kamala is an efficient tænifuge. ${ }^{3}$ It was introduced into the British Pharmacopeia in 1864.

Production-Kamala is one of the minor products of the Government forests in the Madras Presidency, but is also collected in many other parts of India. The following particulars have been communicated to us by a correspondent ${ }^{4}$ in the North-west Provinces:-

“. . Enormous quantities of Rottlerc tinctoria are found growing at the foot of these hills, and every season numbers of people, chiefly women and children, are engaged in collecting the powder for exportation to the plains. They gather the berries in large quantities and throw them into a great basket in which they roll them about, rubbing them with their hands so as to divest them of the powder, which falls through the basket as through a sieve, and is received below on a cloth spread for the purpose. This powder forms the Kamala of commerce, and is in great repute as an anthelmintic, but is most extensively used as a dye. The adulterations are chiefly the powdered leaves, and the fruit-stalks with a little earthy matter, but the percentage is not large. The operations of picking the fruit and rubbing off the powder commence here in the beginning of March and last about a month.

The powder is collected in a similar manner in Southern Arabia, whence it is shipped to the Persian Gulf and Bombay. It is also brought under the name of Wars, from Hurrur, a town in Eastern Africa, which is a great trading station between the Galla countries and Berbera. ${ }^{5}$

Description-Kamala is a fine, granular, mobile powder, consisting of transparent, crimson granules, the bright colour of which is mostly somewhat deadened by the admixture of grey stellate hairs, minute fragments of leaves and similar foreign matter. It is nearly destitute of taste and smell, but an alcoholic solution poured into water emits a melon-like odour. Kamala is scarcely acted on by water, even at a boiling heat; on the other hand, alcohol, ether, chloroform or benzol extract from it a splendid red resin. Neither sulphuric nor nitric acid

1 Joninucy through Mysore, Canara, etc., Jond. 1807 , i. 168. 211 , ii. 343.

2 Pharm. Joum. xii. (1853) 386. 589.

3 Tlia. xvii. (1858) 408.

4 F. E. G. Matthews, Esq., of Naince "Y'l.

5 Burton, Journ. of R. Gcogr. Suci "l, xxv. (1855) 146. 
acts upon it in the cold, nor does oil of turpentine become coloured by it mlnless warmed. It floats on water, but sinks in oil of turpentine. When sprinkled over a flame, it ignites after the manner of lycopodium. Heated alone, it emits a slight aromatic odour; if pure, it leaves after incineration, about 1.37 per cent. of a grey ash.

Microscopic Structure-The granules of kamala are irregular spherical glands, 50 to: $60 \mathrm{mkm}$. in diameter; they have a wavy surface, are somewhat flattened or depressed on one side, and enclose within their delicate yellowish membrane, a structureless yellow mass in which are imbedded numerous, simple, club-shaped cells containing a homogeneous, transparent, red substance. These cells are grouped in a radiate manner arolnd the centre of the flattened side, so that on the side next the observer, 10 to 30 of them may easily be counted, while the entire gland may contain 40 to 60 . In a few cases, a very short stalk-cell is also seen at the centre of the base.

When the glands are exhausted by alcohol and potash, and broken by pressure between flat pieces of glass, they separate into individual cells which swell up slightly, while the membranous envelope is completely detached, and appears as a simple coherent film. After this treatment the cells, but not their membranous envelope, acquire by prolonged contact with strong sulphuric acid and iodine water, a more or less brown or blue colour: the walls of the cells alone correspond therefore to cellulose. Vogl (1864) supposes that a cell of the epidermis of the fruit first developes a young cellule, which by partition is resolved into the stalk-cell and the true mother-cell of the small clavate resincellules. At first, the contents of the latter do not cliffer from the mass in which they are imbedded, and perhaps pass gradually into resin by metamorphosis of the cellular substance.

The glands of kamala are always accompanied by colourless or brownish, thick-walled, stellate hairs, two or three times as long as the glands, often containing air, which do not exhibit any peculiarity of form but resemble the hairs of other plants, as Verbascum or Althoea.

Chemical Composition-Kamala has been analysed by Anderson of Glasgow (1855) and by Leube (1860). From the labours of these chemists, it appears that the powder yields to alcohol or ether nearly 80 per cent. of resin. We find it to be soluble also in glacial acetic acid or in bisulphide of carbon, not in petroleum ether. By treatment of the resin extracted by ether with cold alcohol, Leube resolved it into two brittle reddish yellow resins, of which the one termed resin $a$. is more easily soluble and fuses at $80^{\circ} \mathrm{C}$., and the other called resin $\beta$. dissolves less readily and fuses at $191^{\circ} \mathrm{C}$. Both dissolve in alkaline solutions and can be precipitated by acids without apparent change. Leube assigns to Resin $a$. the composition $\mathrm{C}^{30} \mathrm{H}^{9} \mathrm{O}^{8}$, and to Resin $\beta$. $\mathrm{C}^{16} \mathrm{H}^{6} \mathrm{O}^{10}$.

Anderson found that a concentrated ethereal solution of kamala allowed to stand for a few days, solidified into a mass of granular crystals, which by repeated solution and crystallization in ether, were obtained in a state of purity. This substance, named by Anderson Rottlerin, forms minute, platy, yellow crystals of a fine satiny lustre, readily soluble in ether, sparingly in cold alcohol, more so in hot, and insoluble in water. The mean of four analyses gave the composition of rottlerin as $\mathrm{C}^{22} \mathrm{H}^{5} \mathrm{O}^{6}$. 
No definite compound of the substance with a metallic oxide could be obtained.

We have been able to confirm the foregoing olsservations so far as that we have once obtained an abundance of minute acicular erystals, by allowing an ethereal solution of kamala to evajorate spontaneously to a syrupy state. But the purification of these crystals which was attempted by our friend Mr. 'I. I3. Groves, ${ }^{1}$ was unsuccessful, for when frecd from the protecting mother-liquor, they underwent a change and assumed an amorphous form. Witl many samples of kamala we find that no crystals whatever can be obtained by evaporation of an ethereal solution: such was also the experience of Leube, who was led from it to question the existence of rottlerin. Kamala contains traces of citric and tannic acids, gum, and volatile oil, besides about 3 per cent. of hygroscopic water.

Uses-The drug is administered for the expulsion of tapeworm; it has also been used as an external application in herpes eircinnatus. In India it is employed for dyeing silk a rich orange-brown.

Adulteration-Kamala is very liable to adulteration with earthy substances, even to the extent of 60 per cent. This contamination may easily be known by the grittiness of the drug, and by a portion of it sinking when it is stirred up with water, but in the most decisive manner, by incineration. Sometimes kamala contains an undue proportion of foreign vegetable matter, as remains of the capsules, leaves, \&c., which can partly be separated by a lawn sieve.

Substitute-A very remarkable form of kamala was imported a few year's ago from Aden by Messrs. Allen and Hanburys, druggists, of London." It arrived neatly packed in oblong, white calico bags, of three sizes, each inscribed with Arabic characters, indicating with the name of the vendor or collector, the net weight, which was either 100,50 , or 25 Turkish ounces.

The drug was in coarser particles than ordinary kamala, of a deep purple and had a distinct odour resembling that which is produced when a tincture of common kamala is poured into water. It had been carefully collected and was free from earthy admixture, yet it left upon incincration 12 per cent. of ash. Under the microscope, it presented still greater differences, the grains being cylindrical or subconical, 170 to $200 \mathrm{mkm}$. long, by 70 to $100 \mathrm{mkm}$. broad, with oblong resin-cells, arranged perpendicularly in three or four storeys; mixed with the grains were a few long, simple hairs. Another fact of some interest is, that at a temperature of $93^{\circ}$ to $100^{\circ} \mathrm{C}$., this kamala becoures quite black, while common kamala undergoes no change of colour.

No information as to the place of production of this drug could be obtained, nor more than two supplies, in all $136 \mathrm{Hb}$. There can be little doubt that it is derived from a species of Mallotus, but whether Indian, Arabian or African, is a point on which there is no evidence. Through the kindness of Mr. Binnendyk of the Botanical Garden at Buitenzorg in Java, we have been enabled to examine the fruits of numerous species of Mallotus (Rottlera), and those of Corlodepas, Mappa and

1 Yearbook of Pharmacy, 1872. 599.

2 It has been particularly doscribed by one of us in Pharm. Journ. ix. (1868) $27 \%$, with wood-cuts. 
Chloradenia; but not one of them bear's glands resembling those under notice. We have also examined the specimens of Rottlerc in the Kew herbarium, and consulted Dr. Müller of Geneva, author of the memoir on Euphorbicaece in the Prodromus of De Candolle, but without discovering any clue to the name of the plant supplying the drug under notice.

\section{PIPERACEA.}

\section{FRUCTUS PIPERIS NIGRI.}

Piper nigrum; Blacte Pepper; F. Poivre noir; G. Sehwarzer Pfeffer.

Botanical Origin.-Piper nigrum L.-The pepper plant is a peremnial climbing shrub, with jointed stems branching dichotomously, and broadly ovate, 5 - to 7 -nerved, stalked leaves. The slender flowerspikes are opposite the leaves, stalked and from 3 to 6 inches long; and the fruits are sessile and fleshy.

Piper nigrum is indigenous to the forests of Travancore and Malabar, whence it lias been introduced into Sumatra, Java, Borneo, the Malay Peninsula, Siam, the Philippines and the West Indies.

History.-Pepper ${ }^{1}$ is one of the spices earliest used by mankind, and although now a commodity of but small importance in comparison with sugar, coffee and cotton, it was for many ages the staple article of trade between Europe and India.

In the 4th century B.c., Theophrastus noticed the existence of two

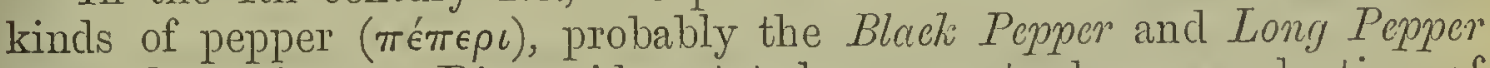
of modern times. Dioscorides stated pepper to be a production of

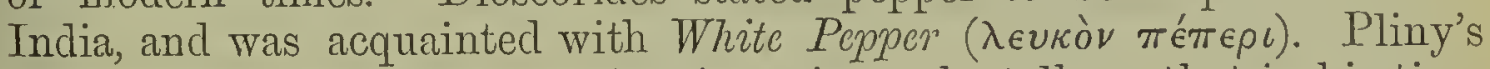
information on the same subject is curious; he tells us that in his time a pound of long pepper was worth 15 , of white 7 , and of black pepper 4 denarii; and expresses his astonishment that mankind should so highly esteem pepper, which has neither a sweet taste nor attractive appearance, or any desirable quality besides a certain pungency.

In the Periplus of the Erythrean Sea, written about A.D. 64, it is stated that pepper is exported from Baraké, the shipping place of Nelkunda, in which region, and there only, it grows in great quantity. These have been identified with places on the Malabar Coast between Mangalore and Calicut. ${ }^{2}$

Long pepper and Black pepper are among the Indian spices on which the Romans levied duty at Alexandria about A.D. $176 .^{3}$

Cosmas Indicopleustes, ${ }^{4}$ a merchant and in later life a monk, who wrote about A.D. 540, appears to have visited the Malabar Coast, or at all events had some information about the pepper plant from an eyewitness. It is he who furnishes the first particular's about it, stating

1 The word pepper, which with slight variations has passed into almost all languages, comes from the Sanskrit name for Long Pepper, pippali, the change of the $l$ into ${ }^{*}$ having been made by the Persians, in whose ancient language the $l$ is wanting.
2 Vincont, Commerce and Navigation of the Ancicnts, ii. (1807) 458.

3 Vincent, op. cit. ii. (1807) 754; also Meyer, Geschichtc der Botaniti, ii. (1865) 167. 4 Migne, Patrologice Carsus, series Greca, Ixxxviii. (1860) 443. 446 . 
that it is a climbing plant, sticking close to high trees like a vine. Its native country he calls Male. ${ }^{1}$ The Arabian authors of the middle ages, as Ibn Khurdádbah (eirca A.D. 869-885), Edrisi in the middle of the 12 th, and Ibn Batuta in the 14th century, furnished nearly similar accounts.

Among Europeans who described the pepper plant with some exactness, one of the first was Jienjamin of Tudela, who visited the Malabar Coast in A.D. 1166. Another was the Catalan friar, Jordanus, ${ }^{2}$ about 1330 ; he described the plant as something like ivy, climbing trees and forming fruit, like that of the wild vine. "This fruit," he says, "is at first green, then when it comes to maturity, black." Nearly the same statements are repeated by Nicolo Conti, a Venetian, who at the beginning of the 15th century, spent twenty-five years in the East. He observed the plant in Sumatra, and also described it as resembling ivy. ${ }^{3}$

In Europe, pepper during the middle ages was the most esteemed and important of all spices, and the very symbol of the spice trade, to which Genoa, Venice and the commercial cities of Central Europe were indebted for a large part of their wealth; and its importance as a means of promoting commercial activity during the middle ages, and the civilizing intercourse of nation with nation, can scarcely be overrated.

Tribute was levied in pepper, ${ }^{4}$ and donations were made of this spice, which was often used as a medium of exchange when money was scarce. During the siege of Rome by Alaric, king of the Goths, A.D. 408 , the ransom demanded from the city, included among other things, 5000 pounds of gold, 30,000 pounds of silver, and 3000 pounds of pepper. ${ }^{5}$ Facts of this nature, of which a great number might be enumerated, sufficiently illustrate the part played by this spice in mediæval times.

The general prevalence during the middle ages of pepper-rents, which consisted in an obligation imposed upon a tenant to supply his lord with a certain quantity of pepper, generally a pound, at stated times, shows how acceptable was this favourite condiment, and how great the desire of the wealthier classes to secure a supply of it when the market was not always certain. ${ }^{6}$

The earliest reference to a trade in pepper in England that we have met with, is in the Statutes of Ethelred, A.D. 978-1016,7 where it is enacted that the Easterlings coming with their ships to Billingsgate should pay at Christmas and Easter for the privilege of trading with London, a small tribute of cloth, five pairs of gloves, ten pounds of pepper, and two barrels of vinegar. ${ }^{8}$.

The merchants who trafficked in spices were called Piperarii,-in

1 Bar (as in Malabar) merely signifies in Arabie, coast.

"Mirabilia descripta by Friar Jordanus, translated by Col. Yule. Iondon, Hakluyt Society, 1863. 27.

3 "Piperis arbor" persimilis est ederæ, grana ejus viridia ad formam grani juniperi, qua modico einere aspersa torrentur ad solem."-Kunstmann, Kenntuiss Tudicns im xv. Jahrhundcrt, Mïnchen (1863) 40.

${ }^{4}$ For some examples of this, see Histnire de la vie privée des Frang is, par Le Grand d'Aussy, nouvelle écl., ii. (1815) 182.
5 Zosimus, Historia (Lips. 1784) lib. v. c. 41.

${ }^{6}$ Rogers, Agriculture and Priccs in England, i. (1866) 626. The term pepplercorn rcnt, which has survived to our times, now only signifies a nominal payment.

7 Anciont Laus and Institutes of England, published by the Record Commission, i. (1840) 301.

8 A striking eontrast to the announcement in a eommereial paper, $27 \mathrm{Feb}$. 1874, that the stock of pepper in the public warehouses of London the previous week was 6035 tons! 
English Pepperers, in French Poivrier's or Pebriers. As a fraternity or guild, they are mentioned as existing in London in the reign of Henry II. (A.D. 1154-1189). They were subsequently incorporated as the Grocers' Company, and had the oversight and control of the trade in spices, drugs, dye-stuffs, and even metals. ${ }^{1}$

The price of pepper during the middle ages was always exorbitantly high, for the rulers of Egypt extorted a large revenue from all those who were engaged in the trade in it and other spices. ${ }^{2}$ Thus in England between A.D. 1263 and 1399, it averaged 1s. per tb., equivalent to about 8s. of our present money. It was however, about 2s. per $1 \mathrm{~b} . \quad(=16 s$. between 1350 and 1360. ${ }^{3}$ In 1370, we find pepper in France valued 7 sous 6 deniers per Hb. (= fr. 21. c. 30$)$ :-in 1542 at a price equal to fr. 11 per $1 \mathrm{t} .{ }^{+}$

The high cost of this important condiment contributed to incite the Portuguese to seek for a sea-passage to India. It was some time after the discovery of this passage (A.D. 1498) that the price of pepper first experienced a considerable fall; while about the same period, the cultivation of the plant was extended to the western islands of the Malay Archipelago. The trade in pepper continued to be a monopoly of the Crown of Portugal as late as the 18th century.

The Venetians used every effort to retain the valued traffic in their own hands, but in vain; and it was a fact of general interest when on the 21st of January 1522, a Portuguese ship brought for the first tine the spices of India direct to the city of Antwerp. Strange to say, they were received with great mistrust!

Pepper was heavily taxed in England. In 1623, the imposts levied on it amounted to 5 s. per $\mathrm{lt}$. ; and even down to 1823 , it was subject to a duty of $2 s .6 d$. per $1 \mathrm{tb}$.

Production-In the south-west of India, the plant, or Pepper $V$ ine as it is called, grows on the sides of the narrow valleys where the soil is rich and moist, producing lofty trees by which a constant, favourable coolness, is maintained. In such places, the pepper-vine runs along the ground and propagates itself by striking out roots into the soil. The natives tie up the end of the vines lying on the ground to the nearest tree, on the bark of which the stems put out rocts so far as they have been tied, the shoots above that hanging down. The plant is capable of growing to a height of 20 or 30 feet, but for the sake of convenience it is usually kept low, and is often trained on poles. In places where no vines occur naturally, the plant is propagated by planting slips near the roots of the trees on which it is to climb.

The pepper plants if grown on a rich soil, begin to bear even in the first year, and continue to increase in productiveness till about the fifth, when they yield 8 to $10 \mathrm{mb}$. of berries per plant, which is about the average produce up to the age of 15 to 20 years; after this they begin to decline.

When one or two berries at the base of the spike begin to turn red, the whole spike is pinclied off. Next day the berries are rubbed off with

${ }^{1}$ Herbert, Ifist. of the twolve great Livery Companics of London, Lond. 1834. 303, 310.

2 Peinand, Noureau. Journal asiatique, 1829, Juillet, 22-51.
3 Roggers, op. eit. i. 641.

4 Leber, Appréciation de la fortune privée. au moyen-âge, éd. 2, Paris 1847. 95. 305. 
the hands and picked clean; then dried fur threc days on mats, or on smooth hard ground, or in bamboo baskets near a gentle fire.

In Malabar, the pepper-vine flowcrs in May and June, and the fruits become fit for gathering at the commencement of the following year. ${ }^{1}$

Description-The small, round, bcrry-like fruits grow somewhat looscly to the number of 20 to 30 , on a common pendulous fruit-stalk. They ar'c at first green, then become red, and if allowed to ripen, yellow; but they are gathered before complete maturity, and by drying in that state turn blackish grey or brown. If left until quitc ripc, they lose some of their pungency and gradually fall off.

'T'he bcrrics after drying are spherical, about $\frac{7}{6}$ inch in diametcr, wrinklcd on the surface, indistinctly pointcd below by the remains of the very short pedicel, and crowncd still more indistinctly by the $3-$ or 4-lobed stigma. The thin pericarp tightly encloses a single sced, the embryo of which in consequence of prematurc gathering is undeveloped, and mercly replaced by a cavity situated below the apex. The sced itself contains within the thin red-brown testa, a shining albumen, grcy and horny without, and mealy within. The pungent taste and peculiar smell of pepper are familiar to all.

Microscopic Structure-The transverse section of a grain of black pepper exhibits a soft yellowish epidcrmis, covering the outer pericarp. This is formed of a closely-packed, ycllow layer of large, mostly radially-arranged, thick-walled cells, each containing in its small cavity a mass of dark-brown resin. The middle layer of the pericarp consists of soft, tangentially-extended parenchyme, containing an abundance of extremely small starch granules and drops of oil. The shrinking of this loose middle layer is the chief cause of the deep wrinkles on the surface of the berry. The next inner layer of the pericarp exhibits towards its circumference, tangentially-arranged, soft parenchyme, the cells of which possess either spiral striation or spiral fibres, but towards the interior, loosc parenchyme free from starch and containing very large oil-cells.

The testa is formed in the first place of a row of small yellow thickwalled cells. Next to them follows the truc testa, as a dense, darkbrown laycr of lignified cells, the individual outlines of which are undistinguishable.

The albumen of the seed consists of angular, radially-arranged, large-celled parenchyme. Most of its cells are colourless and loaded with starch; others contain a soft yellow amorphous mass. If thin slices are kept under glycerin for some time, these masses are slowly transformed into needle-shaped crystals of piperin.

Chemical Composition-Pepper contains resin and essential oil, to the former of which its sharp pungent taste is due. The essential oil has more of the smell than of the taste of peppcr. ${ }^{2}$ The drug yields from $1 \cdot 6$ to $2 \cdot 2$ per cent. of this volatile oil, which agrees with oil of

1 For a full accomt of the cultivation of pepper, seè Buchanan, Journcy from Madras through NIysore, Cancira and Nalabar, ii. (1807) $455-520$; iii. 158 .

2 As noticed by Kheede in 1688-"... oloum ex pipere destillatum levem piperis odorem spirans, saporis parum aeris."- - Hort. Malab. vii, 24. - The oil was howerer obtained about a century before this by J. 13 . Porta of Naples (NIagice Nat. lib. ax., 1589. 185). 
turpentine in composition as well as in specific gravity and boiling point. We find it, in a column $50 \mathrm{~mm}$. loug, to deviate the ray of polarized light $3^{\circ} \cdot 4$ to the left.

The most interesting constituent of pepper, Piperin, which pepper yields to the extent of 2 to 3 per cent., agrees in composition with the formula $\mathrm{C}^{3+} \mathrm{H}^{3 S} \mathrm{~N}^{2} \mathrm{O}^{6}$, and is therefore isomeric with morphine. Piperin has no action on litmus paper; it is not capable of combining directly with an acid, yet unites with hydrochloric acid in the presence of mercuric and other metallic chlorides, forming crystallizable compounds. It is insoluble in water; when perfectly pure, its crystals are devoid of colour, taste and smell. Its alcoholic solution is without action on polarized light. Piperin may be resolved, as found by Anderson in 1850, into Piperic Acid, $\mathrm{C}^{12} \mathrm{H}^{10} \mathrm{O}^{4}$, and Piperidin, $\mathrm{C}^{5} \mathrm{H}^{11} \mathrm{~N}$. The latter is a liquid colourless alkaloid, boiling at $106^{\circ} \mathrm{C}$., having the odour of pepper and ammonia, and directly yielding crystallizable salts.

Besides these constituents, pepper also contains some fatty oil in the mesocarp. Of inorganic matter, it yields upon incineration about 5 per cent.

Commerce-The import of pepper into the United Kingdom during 1872 , was $27,576,710 \mathrm{Hb}$. valued at $£ 753,970$. Of this quantity, the Straits Settlements supplied 25,000,000 th., aud British India 256,000 th. Black Pepper is imported into the colony of Singapore (the chief port of the Straits Settlements) from Rhio, the Malayan Peninsula and Penang :-WTite Pepper almost exclusively from Rhio. ${ }^{1}$

The exports of pepper from the United Kingdom in 1872, amounted to $17,891,620$ 1b., the largest quantity being taken by Germany $(5,201,574 \mathrm{mb}$. $)$ Then follows Italy $(2,288,647 \mathrm{mb}$.) ; and Russia, Holland and Spain, each of which took more than a million pounds. ${ }^{2}$

The varieties of pepper quoted in price-currents are Malabar, Aleppee and, Cochin, Penang, Singapore, Siam.

Uses-Pepper is not of much importance as a medicine, and is rarely if ever prescribed, except indirectly as an ingredient of some preparation.

Adulteration-Whole pepper is not, we believe, liable in Europe to adulteration $;^{3}$ but the case is widely different as regards the pulverized spice. Notwithstanding the enormous penalty of $£ 100$, to which the inanufacturer, possessor, or seller of adulterated pepper is liable, ${ }^{4}$ and the low cost of the article, ground pepper has hitherto been frequently sophisticated by the addition of the starches of cereals and potatoes, of sago, mustard husks, linseed and capsicum. The admixture of these substances may for the most part be readily detected after some practice, by the microscope. ${ }^{5}$

\section{White Pepper.}

This form of the spice is prepared from black pepper by removing its dark outer layer of pericarp, and thereby depriving it of a portion of its pungency.

\footnotetext{
1 Blue Bool of the Straits Settoments for 1871 .

2 Annual statement of the Tracte of the U.K. for 1872.59 .125$.

3 Aceording to Mondeen Sheriff (Sumpl. to Pharm. of India, 131) the berries of Embetia

for adulterating black pepper in the Indian bazaars.

4 By the 59 George III. c. $53 \$ 22$ (1819).

5 Consult, Hassall, Food and its Adullerations, Lond. 1855. 42; Lvans, Pharm. Journ. i. (1860) 605.
} Ribes Burm. are said to be sometimes used 
Buehanan, referring to Travancore, remarks that white pepper is made by allowing the berries to ripen; the bunehes are then gathered, and having been kept for thrce days in the house, are washed and bruised in a basket with the hand till all the stalks and pulp are removed.

The finest white pepper is obtained from Tellicherry, on the Malabar Coast, but only in small quantity. The more important plaees for its preparation are the Straits Settlements, whence 2 to $2 \frac{1}{2}$ millions of pounds are ammally exported. Most of the spiec finds its way to China, where it is highly esteemed. In Europe, pepper in its natural state is with good reason preferred.

The grains of white pepper are of rather larger size than those of blaek, and of a warm greyish tint. They are nearly spherical or a little flattened. At the basc, the skin of the fruit is thiekened into a blunt prominence, whenee about 12 light stripes rum meridian-like towards the clepressed summit. If the skin is seraped off, the dark-brown testa is seen enelosing the hard transluecnt albumen. In anatomical strueture, as well as in taste and smell, white pepper agrees with blaek, whieh in fact it represents in a rather more fully-grown state.

\section{FRUC'TUS PIPERIS LONGI.}

\section{Piper longum; Long Pepper; F. Poivre long; G. Langer Pfeffer.}

Botanical Origin-Piper offieinarum C. DC. (Chaviea ${ }^{3}$ offieinarum Miq.), a diœcious shrubby plant, with ovate-oblong acuminate leaves, attenuated at the basc, and having pinnate nerves. It is a native of the Indian Arehipelago, as Java, Sumatra, Celebes and Timor. Long pepper is the fruit-spike, collected and dried shortly before it reaches maturity.

Piper longum L. (Chaviea Roxburghii Miq.), a shrub indigenous to Malabar, Ceylon, Eastern Bengal, Timor and the Philippines, also yields long pepper, for the sake of which it is eultivated along the eastern and western eoasts of India. It may be distinguished from the previous speeies, by its 5 -nerved leaves, cordate at the base. ${ }^{2}$

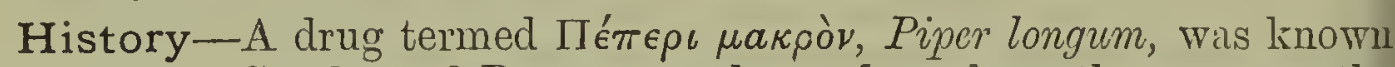
to the ancient Greeks and Romans, and may have been the same as the Long Pepper of modern times.

In the Latin verses bearing the name of Macer Floridus, ${ }^{3}$ which were probably writtcn in the 10th century, mention is made of Black, White, and Long Pepper. The last-named spicc, or Maeropiper, is named by Simon of Genoa, ${ }^{4}$ who was physician to Pope Nicolas IV. and chaplain to Boniface VIII. (A.D. 1288-1303), and travelled in the East for the study of plants. Saladinus ${ }^{5}$ in the middle of the 15 th eentury enumcrates long pepper among the drugs necessary to be kept by apotheearies, and it has had a place in the pharmaeopœias to the present time.

Production-In Bengal, the plants are eultivated by suckers, and require to be grown on a rich, high and dry soil; they should be set

1 The genus Chavica separated from Piper by Miquel, has been re-united to it by Casimir de Candolle (Prod. xvi. s. 1). The latter genus is now composed of not fewcr than 620 species!
2 For good figures of the trro plants, sec Hnyme's Ar:ncy-Gcuächse, xiv. tabb. 20. 21.

3 Chonlant, Mracer Floridus de Firibus Herbarum, Lipsix, 1532. 114.

+ Clavis Sanationis, Venet. 1510.

5 Sce p. 388, note 8 . 
about five feet asunder. An English acre will yield in the first year about three maunds ( 1 maund $=80 \mathrm{Hb}$.) of the pepper, in the second twelve, and in the third eighteen; after which as the plant becomes less and less productive, the roots are grubbed up, dried, and sold as Pipli-nuil, of which there is a large consumption in India as a medicine. The pepper is gathered in the month of January, when full grown, and exposed to the sun until perfectly dry. After the fruit has been collected, the stem and branches die down to the ground. ${ }^{1}$

Description-Long pepper consists of a multitude of minute baccate fruits, closely packed around a common axis, the whole forming a spike of $1 \frac{1}{2}$ inch long and $\frac{1}{4}$ of an inch thick. This spike is supported on a stalk $\frac{1}{2}$ an inch long; it is rounded above and below, and tapers slightly towards its upper end. The fruits are ovoid, $\frac{1}{10}$ of an inch long, crowned with a nipple-like point (the remains of the stigma), and arranged spirally with a small peltate bract beneath each. A transverse section of a spike exhibits 8 to 10 separate fruits, disposed radially with their narrower ends pointed towards the axis. Beneath the pericarp, the thin brown testa encloses a colourless albumen, of which the obtuser end is occupied by the small embryo.

The long pepper of the shops is greyish-white, and appears as if it had been rolled in some earthy powder. When washed, the spikes acquire their proper colour,-a deep reddish-brown. 'The drug has a burning aromatic taste, and an agreeable but not powerful odour.

The foregoing description applies to the long pepper of English commerce, which is now obtained chiefly from Java (see next page), where $P$. officinarum is the common species. In fact the fruits of this latter, as presented to us by Mr. Binnendyk, of the Botanical Garden, Buitenzorg, near Batavia, offer no characters by which we can distinguish them from the article found in the London shops. Those of $P$. Betle L. var. $\gamma$. densum are extremely similar, but we do not know that they are collected for use.

Microscopic Structure-The structure of the individual fruits resembles that of black pepper, exhibiting however some characteristic differences. The epicarp has on the outside, tangentially-extended, thick-walled, narrow cells, containing gum; the middle layer consists of wider, thin-walled, obviously porous parenchyme containing starch and drops of oil. In the outer and middle layers of the fruit, numerous large thick-walled cells are scattered, as in the external pericarp of Piper nigrum; in long pepper however, they do not form a closed circle. The inner pericarp is formed of a row of large, cubic or elongated, radiallyarranged cells, filled with volatile oil. A row of smaller tangentiallyextended cells separates these oil-cells from the compact brown-red testa, which consists of lignified cells like the inner layer of the testa of black pepper, but without the thick-walled cells peculiar to the latter. The albumen of long pepper is distinguished from that of black pepper by the absence of volatile oil.

Chemical Constituents-The constituents of long pepper appear to be the same as those of black pepper. We are not aware of any recent analysis, or whether the proportions of piperin and of volatile oil 
have been determined. The resin and volatile oil reside exclusively in the pericarp.

Commerce-Long pepper is at present exported from Singapore, whither it is brought chiefly. from Java, and to a mucls smaller extent from Rhio. The quantity exported from Singapore in 1871., announted to 3366 cut., of which only 44.7 cwt. were shipped to the United Kingdom, the remainder being sent chiefly to Britisl India." There is a considerable export of long pepper from Calcutta.

Uses-Long pepper is scarcely used as a medicine, black pepper having been substituted in the few preparations in which it was formerly ordered, but it is employed as a spice and in veterinary medicine.

The aromatic root of Piper longum, called in Sanskrit Pippali-mula (whence the modern name pipti-muil), is a favourite remedy of the Hindus and also known to the Persians and Arabs.

\section{CUBEBA.}

\section{Fructus vel Baeea vel Piper Cubcba ${ }^{2}$; Cubebs; F. Cubèbes; G. Cubeben.}

Botanical Origin-Piper Cubeba Linn. f. (Cubeba offeinalis Miq.), a climbing, woody, dicecious shrub, indigenous to Java, Southern Borneo and Sumatra.

History-Cubebs appear to lave been introduced into medicine by the Arabian physicians of the middle ages, who describe them as having the form, colour, and properties of pepper. Masudi ${ }^{3}$ in the 10th century stated them to be a production of Java. Edrisi ${ }^{4}$ the geographer, in A.D. 1153, enumerated them among the imports of Aden.

Among European writers, Constantinus Africanus of Salerno was acquainted with this drug as early as the 11th century; and in the beginning of the 13th, its virtues were noticed in the writings of the Abbess Hildegard in Germany, and even in those of Henrik Harpestreng in Denmark. ${ }^{5}$

Cubebs are mentioned as a production of Java"("grant isle cle Javra") by Marco Polo; and by Odoric, an Italian friar, who visited the island about forty years later. In the 13th century, the drug was an article of European trade. Duty was levied upon them as Cubebas sitvestres at Barcelona in $1271 .{ }^{6}$ They are mentioned about this period as sold in the fairs of Champagne in France, the price being 4 sous per $16 .{ }^{7}$ They were also sold in England: in accounts under date 1284, they are enumerated with almonds, saffron, raisins, white pepper, graius [of paradise], mace, galangal and gingerbread, and entered as costing $2 s$. per tb. In 1285-2s. 6d. to 3s. per $\mathrm{tb}$.; while in 1307, $1 \mathrm{Hb}$. purchased for the King's Wardrobe cost $9 s .^{8}$

From the journal of expenses of John, king of France, while in England during 1359-60, it is evident that cubebs were in frequent

1 Blue Book of the Straits Settlements for 1871.

2 Cubcba from the Arabic KababuT.

3 Les Prairies d'or, i. 341.

4 Géographie, trad. par Jaubert, i. 51. 89.

5 Meyer, Gesehiehte der Botanit, iii. 537.

6 Capmany, Memorias sobre la Marina, ete. de Burcelonci, i. 44.
T Bourquelot, Etudes sur les foires de Champagne, Mémoires etc. de l'Institut, v. (1865) 2 SS.

s Rogers, Hist. of Agrieulture and Pricas in Finyland, i. 627-8, ii. 544.-To get somo idea of the relative ralne of commodities then and now, numltiply the ancient prices by 8 . 
use as a spice. Among those who could command such luxuries, they were eaten in powcler with meat, or they were candied whole. A patent of pontage granted in 1305 by Edward I., to aid in repairing and sustaining the Bridge of London, and autlorizing toll on various articles, mentions among groceries and spices, cubcbs as liable to impost. ${ }^{1}$ Cubebs are mentioned in the Confectbuch of Hans Folcz of Nuremberg, clating about $1480 .^{2}$

It cannot however be said that cubebs were a common spice, at all comparable with pepper or ginger, or even in such frequent use as grains of paradise or galangal. Garcia d'Orta (1563) speaks of them as but seldom used in Europe; yet they are named by Saladinus as necessary to be kept in every apothcca. ${ }^{3}$ In a list of drugs to be sold in the apothecaries' shops of the city of Ulm, A.D. 1596, cubebs are mentioned. as Fructus carpesionum vel cubebarum, the price for half an ounce being quoted as 8 krcuzers, the same as that of opium, best manna, and amber, while black and white pepper are priced at 2 kreuzers. ${ }^{4}$

The specific action of cubebs on the urino-genital organs has been known only in very recent times. Writers on materia medica even at the commencement of the present century, mention the drug simply as an aromatic stimulant resembling pepper, but inferior to that spice and rarely employed, ${ }^{5}$-in fact it had so far fallen into disuse that it was omitted from the London Pharmacopœia of 1809. According to Crawfurd, its importation into Europe, which had long been discontinued, recommenced in. 1815, in consequence of its medicinal virtues having been brought to the knowledge of the English medical officers serving in Java, by their Hindu servants. 6

Cultivation and Production ${ }^{7}$-Cubebs are cultivated in small special plantations and also in coffee plantations, in the clistrict of Banjoemas in the south of Java. The fruits are bought by Chinese who carry them to Batavia. They are likewise produced in Eastern Java and about Bantam in the north-west; and extensively in the Lampong country in Sumatra. There has of late been a large distribution of plants among the European coffee planters.

The cultivation of cubebs is easy. In the coffee estates certain trees are required for shade: against these, Pipcr Cubebc is planted, and climbing to a height of 18 to 20 feet, forms a large bush.

Description-The cubebs of commerce consist of the dry globose fruits, gathered when full grown, but before they have arrived at maturity. The fruit is about $\frac{1}{5}$ of an inch in diameter, when very young sessile, but subsequently elevated on a straight thin stalk, a little longer

Liber niger Scacccurii, Lond. 1771, i. * 478. - A translation may be found in the Chronicles of London Briclge, 182\%. 155.

2 Choulant, Macer Floriches etc., Lips. 1832. 188.

${ }^{3}$ Compendium aromatariorum, Bonon., 1488.

${ }^{4}$ Reiehard, Beiträge zur. Geschichte cter Apotheken, 1825. 124.

"In Dumean's Eddinburgh New Dispenscatory, ed. 2. 1804, Piper Crebebe is very briefly described, but with $n 0$ allusion to it possessing any speeial medicinal properties. In the 6th edition of the same work (1811) it was altogether omittecl. See also MIurray's System of MLat. Mled. and Pharm. i. (1S10) 266.

6 Dictionary of the Indian Istands, 1856. 117.-Mr. Crawfurd himself eommunicated to the Edlinbungh MIedical and Surgieat Journcel of 1818 (xiv. 32) a paper maling known the "wouderful sneeess" with which eubebs had been used in gonorrhoea.

7 We are indebted for some partieulars under this head to my friend Mrr. Bimendyk, of the Bnitenzorg Botanical Garden near. Batavia.-D. H. 
or even twice as long as itself. By this stalk the fruit is attached in considerable numbers (sometimes more than 50 ) to a common thickened stalk or rachis, about $1 \frac{1}{2}$ inch long.

Commercial cubebs are splherical, sometimes depressed at the base, ver'y slightly pointed at the apex, strongly wrinkled by the shrinking of the fleshy pericarp; they are of a greyish-brown or blackish liue, frequently covered with an ashy-grey bloom. The stalk is the elongated base of the fruit, and remains permanently attached. The common axis or rachis, which is almost devoid of essential oil, is also frequently mixed with the drug.

The skin of the fruit covers a hard, smooth brown shell containing the seed, which latter when developed, has a compressed spherical form, a smooth surface, and adheres to the pericarp only at the base; its apex either projects slightly or is pressed inwards. The albumen is solid, whitish, oily, and encloses a small embryo, below the apex. In the cubebs of the shops, the seed is mostly undeveloped and shrunken, and the pericarp nearly empty.

Cubebs have a strong, aromatic, persistent taste, with some bitterness and acridity. Their smell is highly aromatic and by no means disagreeable.

Microscopic Structure-This exhibits some peculiarities. The skin of the fruit below the epidermis, is made up of small, cubic, thickwalled cells, forming an interrupted row, and only half as large as in black pepper. The broad middle layer consists of small-celled undeveloped tissue, containing drops of oil, granules of starch, and crystalline groups of cubebin, probably also fat. This middle layer is interrupted by very large oil-cells, which frequently enclose needle-shaped crystals of cubebin, united in concentric groups. The much narrower inner layer consists of about four rows of somewhat larger, tangentiallyextended, soft cells, holding essential oil. Next to these comes the light-yellow brittle shell, formed of a densely packed row of encrusted, radially-arranged, elongated, thick-walled cells. Lastly, the embryo is covered with a thin brown membrane, and exhibits the structure and contents of that of Piper nigrum, excepting that in $P$. Cubeba the cells are rounder, and the crystals consist of cubebin and not of piperin.

Chemical Composition-The most obvious constituent of cubebs is the volatile oil, the proportion of which yielded by the drug, varies from 6 to 15 per cent. The causes of this great variation may be found in the constitution of the drug itself, as well as in the alterability of the oil, and the fact that its boiling point, 220 to $250^{\circ} \mathrm{C}$., is so much higher than that of water. This oil, which is the source of the aroma of the fruit, is polymeric with oil of turpentine, and strongly deviates the ray of polarized light to the left. In cold weather, old oil of cubebs deposits large, rhombic octohedra of a substance which has been termed Camphor of Cubebs or Hydrate of Cubebene, having the composition $\mathrm{C}^{30} \mathrm{H}^{45}, 2 \mathrm{H}^{2} \mathrm{O}$; by long keeping we find it sometimes assumes the form of a viscid liquid, in this respect resembling anethol. The liquid portion of the oil, termed Cubcben, is indicated by the formula, $\mathrm{C}^{30} \mathrm{H}^{48}$.

Another constituent of cubebs is Cubebin, crystals of which may sometimes be seen in the pericarp even with a common lens. It was discovered by Soubeiran and Capitaine in 1839; it is an inodorous. 
tasteless, neutral substance, crystallizing in small needles or scales, of a pearly lustre, nearly insoluble in cold but slightly soluble in hot water. It dissolves freely in boiling alcohol, but is mostly deposited upon cooling; it requires 30 parts of cold ether for solution. Bernatzik obtained from cubebs 0.40 per cent. of cubebin, ${ }^{1}$ Schmidt 2.5 per cent. ${ }^{2}$ The crystals which are deposited in an alcoholic or ethereal extract of cubebs, consist of cubebin in an impure state. Cubebin is devoid of any remarkable therapeutic action; its composition answers to the formula, $\mathrm{C}^{33} \mathrm{H}^{34} \mathrm{O}^{10}$.

The resin extracted from cubebs consists of an indifferent portion, nearly 3 per cent., and of Cubebic Acid, amounting to about 1 per cent. of the drug. Both are amorphous, and so according to Schmidt, are the salts of cubebic acid. Bernatzik however, found some of them, as that of barium, to be crystallizable. Schulze (1873) prepared cubebic acid from the crystallized sodium-salt, but was unable to get it other than amorphous. The resins, the indifferent as well as the acid, passess the therapeutic properties of the drug.

Schmidt further pointed out the presence in cubebs, of gnm ( 8 per cent.), fatty oil, and malates of magnesium and calcium.

Commerce-Cubebs were imported into Singapore in 1872 to the extent of 3062 cwt., of which amount $2348 \mathrm{cwt}$. were entered as from Netherlands India. The drug was re-shipped during the same year to , the amount of $2766 \mathrm{cwt}$., the quantity exported to the United Kingdom being $1180 \mathrm{cwt}$., to the United States of America $1244 \mathrm{cwt}$., and to British India 104 cwt. $^{3}$ In the previous year, a larger quantity was shipped to India than to Great Britain.

Uses-Cubebs are much employed in the treatment of gonorrbœa. The drug is usually administered in powder; less frequently in the form of ethereal or alcoholic extract, or essential oil.

Bernatzik and Schmidt, whose chemical and therapentical experiments have thrown much light on the subject, have shown that the efficacy of cubebs being dependent on the indifferent resin and cubebic acid, preparations which contain the utmost amount of these bodies and exclude other constituents of the drug, are to be preferred. They would reject the essential oil, as they find its administration devoid of therapeutic effects.

The preparations which consequently are to be recommended, are the berries deprived of their essential oil and constituents soluble in water, and then dried and powdered; an alcoholic extract prepared from the same, or the purified resins.

Adulteration-Cubebs are not much subject to adulteration, though it is by no means rare that the imported drug contains an undue proportion of the inert stalks (rachis) ${ }^{4}$ that require to be picked out before the berries are ground. Dealers judge of cubebs by the oiliness and strong characteristic smell of the berries when crushed. Those which

1 Bernatzik, in Canstatt's Fothresbcricht über dic Fortschritte in der Pharmacic, xiv. (1866) i. 15.

Wiggers and Husemann, Jahresbericht, 1870.52 .
3 Straits Settlements Blue Book for 1872. 294. 338. - There are no statistics for showing the total import of cubebs into the United Kingdom.

${ }^{4}$ They fiulded to Schmidt 1.7 per cent. of oil and 3 per cent. of resin. 
have a large proportion of the pale, smooth, ripe berries, which look dry when broken, are to be avoided.

We have ocensionally found in the commercial drug a small, smouth, two-celled fruit, of the size, shape, and colour of cubebs, but wanting the long pedicel. A slight examination suffices to recognize it as not being cubebs. We have also met with some cubebs of larger size than the ordinary sort, much shrivelled, with a stouter and flattened pedicel, one and a half times to twice as long as the berry. The drug has an agreealsle odour different from that of common cubebs, and a very bitter taste. From a comparison with herbarium specimens, we judge that it may possibly be derived from Piper crassipes Korthals (Cubeba erassipes Miq.), a Sumatran species.

The fruits of Piper Lowong B1. (Cubeba Lowong Miq.), a native of Java, and those of $P$. ribesioides Wall. (Cubeba Wallichii Miq.) are extremely cubeb-like. Those of Piper caninum A. Dietr. (C'ubeba eanina Miq.), a plant of wide distribution thronghout the Malay Archipelago, for a specimen of which we have to thank Mr. Binnendyk of Buitenzorg, are smaller than true cubebs, and have stalks only half the diameter of the berry.

In the south of China, the fruits of Laurus Cubeba Lour. have been frequently mistaken by Europeans for cubebs. The tree which affords them is unknown to modern botanists; Meissner refers it doubtfully to the genus Totranthera. ${ }^{2}$

\section{African Cubebs or West African Black Pepper.}

This spice is the fruit of Piper Clusii Cas. DC. (Cubeba Clusii Miq.); it is a round berry having a general resemblance to common cubebs but somewhat smaller, less rugose, attenuated into a slender pedicel once or twice as long as the berry and usually curved. The berries are crowded around a common stalk or rachis; they are of an ashy grey tint, and have a hot taste and the odour of pepper. According to Stenhouse, they contain piperin and not cubebin. ${ }^{2}$

The fruit of Piper Clusii was known as early as 1364 to the merchants of Rouen and Dieppe, who imported it from the Grain Coast, now Liberia, ${ }^{3}$ under the name of pepper. The Portuguese likewise exported it from Benin as far back as 1485 , as Pimienta de rabo, i.e. tailed pepper, and attempted in vain to sell it in Flanders. ${ }^{4}$ Clusius received from London a specimen of this drug, of which he has left a good figure in his Exotiea. ${ }^{5}$ He says that its importation was forbidden by the King of Portugul for fear it should depreciate the pepper of India. The spice was also known to Gerarde and Parkinson; in our times it has been afresh brought to notice by the late Dr. Daniell. ${ }^{6}$ In tropical Western Africa, it is used as a condiment. ${ }^{7}$

1 De Candolle, Prod. xv. sect. i. 199 ; Hanbury in Pharm. Journ. iii. (1862) 205, with figure.

2 Pharm. Journ. xiv. (1855) 363.

3 Margry, Les navigations françaises et $7 \alpha$ révolution maritime du XIVe au XVIe siecte, 1867. 26.
4 Giovanni di Barros, l'A sia, i. (Venet. 1561) 80.

5 Lib. i. c. 22. p. 184.

6 Pharm. Journ. xiv. (1855) 198.

7 One cask of it was offered for sale in London as "Cubcbs," 11 Feb. 185 s. 


\section{HERBA MATICO.}

Matico.

Botanical Origin-Piper angustifolium Ruiz et Pavon (Artanthe clongata Miq.) a shrub growing in the moist woods of Bolivia, Peru, Brazil, New Granada and Venezuela, also cultivated in some localities. A slightly different, somewhat stouter form of the plant with leaves 7 to 8 inches long (var. a. cordulatum Cas. DC.), occurs in the Brazilian provinces of Bahia, Minas Geraes and Ceará, as well as in Peru and the northern parts of South America.

History-The styptic properties of this plant are said to have been discovered by a Spanish soldier named Matico, ${ }^{1}$ who having applied some of the leaves to his wounds, observed that the bleeding was thereby arrested; hence the plant came to be called Yerba or Palo del Soldado (soldier's herb or tree). The story is not very probable, but it is current in many parts of South America, and its allusion is not confined to the plant under notice.

The hæmostatic powers of matico, which are not noticed in the works of Ruiz and Pavon, were first recognized in Europe by Jeffreys, ${ }^{2}$ a physician of Liverpool, in 1839, but they had already attracted attention in North America as early as 1827.

Description-Matico, as it arrives in commerce, consists of a compressed, coherent, brittle mass of leaves and stems, of a light green hue and pleasant herby odour. More closely examined, it is seen to be made up of jointed stems bearing lanceolate, acuminate leaves, cordate and unequal at the base, and liaving very short stalks. The leaves are rather thick, with their whole upper surface traversed by a system of minute sunk veins, which divide it into squares and give it a tessellated appearance. On the under side, these squares form a corresponding series of depressions which are clothed with shaggy hairs. The leaves attain a length of about 6 inches by $1 \frac{1}{2}$ inches broad. The flower and fruit spikes which are often 4 to 5 inches long, are slender and cylindrical with the flowers or fruits densely packed. The leaves of matico have a bitterish aromatic taste.

Chemical Composition-The leaves yield a small amount of essential oil, which we find slightly ${ }^{3}$ dextrogyre; a large proportion of it distills at $180^{\circ}$ to $200^{\circ} \mathrm{C}$., the remainder becoming thickish. Both portions are lighter than water; but another specimen of the oil of matico which we had kept for some years, sinks in water. We have observed that in winter the oil deposits remarkable crystals of a camphor, more than half an inch in length, fusible at $103^{\circ} \mathrm{C}$.

Matico further affords, according to Marcotte (1864), ${ }^{4}$ a crystallizable acid, named Artanthic Acid, besides some tannin. The latter is made evident by the dark brown colour which the infusion assumes on addition of ferric chloride. The leaves likewise contain resin, but as shown by as the so-called Maticin formerly supposed to exist in them.

1 Matico is the diminutive of Mateo, the Spanish for Hatthere.

2 Ficmarks on the efficaey of Matico as a styptic and astringent, 3rd ed., Tond. 1845.
${ }^{3}$ Deviating only $0.5^{\circ}$ in a column $50 \mathrm{~mm}$.

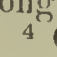

${ }^{4}$ Guibourt (et Planchon), Hist. des
Drogues, ii. (1869) 278 . 
Commerce-The drug is imported in bales and serons by way of
Panama.

Uses-Matico leaves previously softened in water, or in a state of powder, are sometimes employed to arrest the bleeding of a wound. 'The infusion is taken for the cure of internal hæmorrhage.

Substitutes-Several plants have at times been brought into the market under the name of matico. One of these is Piper aduncum I. (Artanthe adunca Miq.), of which a quantity was imported into London from Central America in 1863, and first recognized by Bentley. ${ }^{1} I_{n}$ colour, odour, and shape of leaf it nearly agrees with ordinary matico; but differs in that the leaves are marked beneath by much more prominent ascending parallel nerves, the spaces between which are not rugose but comparatively smooth and nearly glabrous. In chemical character's, the leaves of $P$. aduncum appear to accord with those of $P$. angustifolium.

Piper aduncum is a plant of wide distribution throughout Tropical America. Under the name of Nhandi or Pipcr longum, it was mentioned by Piso in $1648^{2}$ on account of the stimulant action of its leaves and root,-a property which causes it to be still used in Brazil, where however, no particular styptic virtues seem to be ascribed to it. ${ }^{3}$ The fruits are there employed in the place of cubebs.

According to Triana, Piper lanceafolium HBK. (Artanthe Miq.) and another species not recognized, yield matico in New Granada. ${ }^{4}$ Waltheria glomerata Presl (Sterculiacea) is called Palo del Soldado at Panama and its leaves are used as a vulnerary. ${ }^{5}$

\section{ARISTOLOCHIACEA.}

\section{RADIX SERPENTARIÆ.}

Radix Scrpentaria Virginiana; Virginian Snake-root, Scrpentary Root; F. Serpentaire de Virginie; G. Schlangcnwurzcl.

Botanical Origin-Aristolochica Scrpcntaria L., a perennial herb, commonly under a foot high, with simple or slightly branched, flexuose stems, producing small, solitary, dull purple flowers, close to the ground. It grows in shady woods in the United States, from Missouri and Indiana to Florida and Virginia,-abundantly in the Alleghanies and in the Cumberland Mountains, less frequently in New York, Michigan and the other Northern States. The plant varies exceedingly in the shape of its leaves.

History-The earliest account of Virginian snake-root is that of Thomas Johnson, an apothecary of London who published an edition of Gerarde's Herbal in 1636. It is evident however that Johnson confounded a species of Aristolochic from Crete, with what he calls "that

1 Pharm. Journ. v. (1864) 290.

2 De Mcdicina Brasiliensi, lib. 4. c. 57.

3 Langgaard, Diecionario de Medicina dnmestica e popular, Rio de Janciro, ii. (1865) 14.
4 Exposition de 1867-Catalogne de M. José Triana, p. 14.

${ }^{5}$ Scemann, Botany of the Hcrald, 1S5:57. 85 . 
snake-weed that was brought from Virginia and grew with Mr. John Tradescant at South Lambeth, anno 1632." It was very briefly noticed by Cormuti in his Canadensium Plantarum Historia (1635), and in a nuuch more intelligent mamner by Parkinson in 1640. These author's, as well as Dale (1693) and Geoffroy (1741), extol the virtues of the root as a remedy for the bite of the rattlesnake, or of a rabid dog. Serpentary was introduced into the London Pharmacopœia in 1650.

Description-The snake-root of commerce includes the rhizome, which is knotty, contorted, scarcely 1 inch in length by $\frac{1}{8}$ of an inch in thickness, bearing on its upper side the short bases of the stems of previous years, and throwing off from the under, numerous, slender, matted, brauching roots, 2 to 4 inches long. The rhizome is often still attached to portions of the weak, herbaceous stem, which sometimes bear's the fruit,-more rarely flowers and leaves. The drug has a dull brown hue, an aromatic odlour resembling valerian but less unpleasant, and a bitterish aromatic taste, calling to mind camphor, valerian and turpentine.

Microscopic Structure-In the rhizome, the outer layer of the bark consists of a single row of cuboid cells; the middle cortical portion (mesophloum) of about six layers of larger cells. In the liber, which is built up of numerous layers of smaller cells, those belonging to the inedullary rays are nearly cuboid with distinctly porous walls, those of the liber bundles being smaller and arranged in a somewhat crescentshaped manner. Groups of short, reticulated or punctuated vessels alternate in the woody rays with long, porous, ligneous cells, those close to the pith having thick walls. The largest cells of all are those composing the pith; the latter, seen in transverse section, occupies not the very centre of the rootstock, but is found nearer to its xpper side. The rootlets exhibit a central fibro-vascular bundle, surrounded by a nucleus sheath. In the mesophloum both of the rootstock and the rootlets, there occur a few cells containing a yellow essential oil. The other cells are loaded with starch.

Chemical Composition-Essential oil exists in the drug to the extent of about $\frac{1}{2}$ per cent.; and resin in nearly the sarne proportion. The outer cortical layer, as well as the zone of the nucleus-sheath, contains a little tannin, and a watery infusion of the drug is coloured greenish by perchloride of iron. Neutral acetate of lead precipitates some mucilage as well as the bitter principle (the so-called A ristolochin of Chevallier?) which latter may also be obtained by means of tannic acid. It is an amorphous, bitter substance, which deserves further investigation. By an alkaline solution of tartrate of copper the presence in serpentary of sugar is made evident.

Commerce-Virginian snake-root is imported from New York and Boston, in bales, caskiks or bags.

Uses - The drug is employed in the form of an infusion or tincture as a stimulating tonic and diaphoretic; it is more often prescribed in combination with cinchona bark than by itself. Its ancient reputation for the cure of snake-bites is now disregarded.

Adulteration and Substitution-Virginian snake-root is said to be sometimes adulterated with the root of Spigelia Marilandica L., 
which has neither its smell nor tastc (sce p. 389); or with that of Cypriperium pubcsecns L., which it scarcely at all resembles. It is not uncommon to find here and there in the serpentary of commerce, a root of Ponax quinqucfolium L. accidentally collected, but nevcr added for the purpose of adultcration.

The root of Aristolochia reticulate Nutt., a plant of Louisiana and Arkansas, has been brought into commerce in considerable quantity as Texan or Red River Snake-root. ${ }^{1}$ We are indebted for an authentic spccimen from the Cherokee conntry, to Mr. Merrell, a large dealer in herbs at St. Louis, Missouri, who states that all the serpentary grow'i south-west of the Rocky Mountains is the produce of that species. The late Prof. Parrish of Philadelphia was kind enough to supply us with specimens of the same drug, as well as with reliable samples of true Virginian or Middle States Snake-root.

The Texan snake-root is somewhat thicker and less matted than that derived from $A$. Scrpentaria, but has the odour and taste of the latter; some say it is less aromatic. The plant, portions of which arc often present, may be easily distinguished by its leaves being coriaceous, sessile and strongly retieulated on their under surface.

\section{CUPULIFER $A$.}

\section{CORTEX .QUERCUS.}

Oak Bark; F. Ecorce de Chênc; G. Eichenrinde.

Botanical Origin-Qucrcus Robur L., a tree, native of almost the whole of Europe, from Portugal and the Greek Peninsula as far north as $58^{\circ} \mathrm{N}$. lat. in Scotland, $62^{\circ}$ in Norway, and $56^{\circ}$ in the Ural Mountains.

Therc are two remarkable forms of this tree which are regarded by many botanists as distinct species, but which are classed by De Candolle ${ }^{2}$ as sub-species.

Sub-species I. Pcdunculata-with leaves sessile or shortly stalked, and acorns borne on a long peduncle.

Sub-species II. Sessitiflora - with leafstalks more or less elongated, and acorns either sessile or growing on a short peduncle.

Both forms occur in Britain. The first is the common oak of the greater part of England and the lowlands of Scotland. The second is frequently scattered in woods in which the first variety prevails, but it rarely constitutes the mass of the oak woods in the south of England. In North Wales however, in the hilly parts of the north of England, and in Scotland, it is the commoner of the two forms (Bentham).

History-The astringent properties of all parts of the oak ${ }^{3}$ were well known to Dioscorides, who recommends a decoction of the imer bark in colic, dysentery and spitting of blood. Yet oak bark seems at no time to have been held in great esteem as a medicine, probably on

1 Wiegand in Ameriean Journ. of Pharm. x. (1845) 10-also Proceedings of the Amerieun Pharmeceutient, Association, xxi. (1573) 441.
2 Prodromus, xvi. (1564) sect. 2. fasc. 1.

3 P'robably not Q. Robur L. 
account of its commonness; and it is now almost superseded by other astringents. For tanning leather, it has always been largely employed.

Description-For medicinal use, the bark of the younger stems or branches is collected in the early spring. It varies somewhat in appearance according to the age of the wood from which it has been taken: that usually supplied to English druggists is in channelled pieces of variable length and a tenth of an inch or less in thickness, smooth, of a shining silvery grey variegated with brown, dotted over with little scars. The inner surface is light rusty-brown, longitudinally striated. The fracture is tough and fibrous. A transverse section shows a thin, greenish cork-layer, within which is the brown parenchyme, marked with numerous rows of translucent colourless spots. The smell of dry oak bark is very faint; but when the bark is moistened, the odour of tan becomes evident. The taste is astringent and in old barks, slightly bitter.

Microscopic Structure-The outer layer of young oak bark consists of small flat cork-cells; the middle layer of larger thick-walled cells, slightly extended in a tangential direction and containing brown grains and chlorophyll. This tissue passes gradually into the softer narrower parenchyme of the inner bark, which is irregularly traversed by narrow medullary rays. It exhibits moreover a ring, but slightly interrupted, of thick-walled cells (sclerenchyme) and isolated shining bundles of liber fibres.

Groups of crystals of calcium oxalate are frequent in the middle and inner bark, but the chief constituents of the cells are brown granules of colouring matter and tannin. As the thickness of the bark increases, the liber is pushed more to the outside, the middle cortical layer being partly thrown off by secondary cork-formation (rhytidoma, see p. 317). Hence the younger barks, which alone are medicinal, are widely different from the older in structure and appearance.

Chemical Composition-The most interesting constituent is a peculiar kind of tannin. Stenhouse pointed out in 1843, that the tannic acid of oak bark is not identical with that of nutgalls; and such many years afterwards was proved to be the case.

The first-named substance, now called Querci-tannic Acid, yields by destructive distillation, pyrocatechin but not pyrogallol. It does not afford by oxidation, gallic acid. A solution of gelatine is precipitated by querci-tannic acid as well as by gallo-tannic acid; yet the compound formed with the latter is very liable to putrefaction, whereas the tannin of oak bark, which is accompanied by a large amount of extractive matter, furnishes a stable compound, and is capable of forming good leather.

As querci-tannic acid has not yet been isolated in a pure state, the exact estimation of the strength of the tanning principle in oak bark has not been accomplished, although it is important from an economic as well as from a scientific point of view. The best method is that of Neubauer (1873), which depends upon the amount of permanganate of potassium decomposable by the extract of a given weight of oak bark. Neubauer found in the bark of young stems, as grown for tanning purposes, from 7 to 10 per cent. of querci-tannic acid, soluble in cold water.

A colourless, crystallizable, bitter, neutral substance, soluble in water but not in absolute alcohol or ether, was extracted from oak bark in 
184:3 by Gerber, and named Quercin. It requires further examination:

C. Hekert ${ }^{1}$ could not detect its existence in young oak bark.

Uses-Occasionally employed as an astringent, chielly for external application.

\section{GALLAE HALEPENSES.}

Gallew Irureice; Galls, Nutgalls, Oak Galls, Aleppo or 'Turkey Galls; F. Noix de Galle, Galle d'Alep; G. Levantische oder Aleppische Gallen, Gallüpfel.

Botanical Origin-Quercus Iusitaniea Webb, var. infectoria (Q. infectoric Oliv.), ${ }^{2}$ a shrub or rarely a tree, found in Greece, Asia Minor, Cyprus and Syria. It is probable that other varieties of this oak, as well as allied species, contribute to furnish the Aleppo galls of commerec.

History-Oal galls are named by Theophrastus who lived in the ird or 4 th century B.c., and were well known to other ancient writers. Pliny ${ }^{3}$ mentions the interesting fact that paper saturated with an infusion of galls may be used as a test for discovering sulphate of iron, when added as an adulteration to the more costly verdigris: this, according to Kopp, is the earliest instance of the scientific application of a chemical reaction. ${ }^{4}$ For tanning and dyeing, galls have been used from the earliest times.

Nutgalls have long been an object of commerce between Westeru Asia and China. Barbosa in his Description of the East Indies ${ }^{5}$ written in 1514, calls them Magican ${ }^{6}$ and says they are brought from the Levant to Cambay by way of Mekka, and that they are worth a great deal in China and Java. From the statements of Porter Smith, ${ }^{7}$ we learn tlat they are still prized by the Chinese.

Formation-Many plants are punctured by insects for the sake of depositing their eggs, which operation gives rise to those excrescences which bear the general name of gall. ${ }^{8}$

Oaks are specially liable to be visited for this purpose by insects of the order Hymenoptera and the genus Cynips, one species of which, Cynips Gallo tinctorice Olivier (Diplolepis Galla tinctoria Latreille), occasions the galls under. notice.

The female of this little creature is furnished with a delicate borer or ovipositor, which she is able to protrude from the extremity of the abdomen: by means of it, she pierces the tender shoot of the oak, and deposits therein one or more eggs. This minute operation occasions an abnormal affluence to the spot, of the juices of the plant, the result of which is the growth of an excrescence often of great magnitude, in the centre of which (but not as it appears until the gall has become fullgrown) the larva is hatched and undergoes its transformations.

1 Wittstein, Vierteljahressehr. für prakt. Pharm. xiii. (1864) 494.

2 De Candolle, Prodromus, xvi. sect. 2. fase. i. 17.

3 Lib. 34 . c. 26.

${ }^{4}$ Gesehichte der Chemie, ii. (1844) 51.

5 Published by the Hakluyt Society, Lond. 1866. 191.

"Nearly the same name is still used in the Tamil, Telugu, Malayalim and Canarese languages.

7 Mat. DLed. and Nat. Hist. of China, 1871. 100.

8 French writers, as Moquin-Tandon, distinguish the thick-walled galls of Cynits from the thin, capsular galls formed by Aphis, torming the former galles and the latter coques (shells). 
When the larva has assumed its final developement and become a winged insect, which requires a period of five to six months, the latter bores itself a cylindrical passage from the centre of the gall to its surface, and escapes.

In the best lind of gall found in commerce, this stage has not yet arrived, the gall having been gathered while the insect is still in the larval state. In splitting a number of galls, it is not difficult to find specimens in all stages, from those containimg the scarcely distinguishable remains of the minute larva, to those which show the perfect insect to have perished when in the very act of escaping from its prison.

Description-Aleppo galls ${ }^{1}$ are spherical, and have a diameter of $\frac{t}{10}$ to $\frac{8}{10}$ of an inch. They have a smooth and rather shining surface, marked in the upper half of the gall by small pointed knobs and ridges, arranged very irregularly and wide apart; the lower half is more frequently smooth. The aperture by which the insect escapes is always near the middle. When not perforated, the galls are of a dark olive green, and comparatively heavy; but after the fly has bored its way out, they become of a yellowish brown hue, and lighter in weight. Hence the distinction in cornmerce of Blue or Green Galls, and White Galls.

Aleppo galls are hard and brittle, splitting under the hammer; they have an acidulous, very astringent taste followed by a slight sweetness, but have no marked odour. Their fractured surface is sometimes closegrained, with a waxy or resinous lustre; sometimes (especially towards the kernel-like centre) loosely granular, or sometimes again it exhibits a crystalline-looking radiated structure or is full of clefts. The colour of the interior varies from pale brown to a deep greenish yellow. The central cavity, sometimes nearly $\frac{1}{4}$ of an inch in diameter, which served as a dwelling for the insect, is lined with a thin hard shell. If the insect has perished while still very young, the central cavity and the aperture contain a mass of loose starchy cellular tissue, or its pulverulent remains : if the insect has not been developed at all, the centre of the gall is entirely composed of this tissue.

Microscopic Structure-The cellular tissue of the gall is formed in the rniddle layer of large spherical cells with rather thick porous walls, becoming considerably smaller towards the circumference. The outermost rows are built up of cells having but a very small lumen and comparatively thick walls, so that they form a sort of rind. Here and there throughout the entire tissue, there occur isolated bundles of vessels which pass through the stalk into the gall. Towards the kernel, the parenchyme gradually passes into radially-extended, wider, thin-walled cells, the walls of which are marked with spiral striæ. The hard shell of the chamber ${ }^{2}$ is composed of larger, radially-extended, thickwalled cells, with beautifully stratified porous walls. On the inner side of this shell there are found after the escape of the insect, the remains of the starchy tissue already mentioned, which originally filled the chamber and had been consumed by the insect as nourishment.

1 There are many other varieties of oak gall, for descriptions of some of whieh, see Guibourt, Ifist. des Irogues, ii. (1869) 292 ; and for information on the various gallinseets of the family Cynipsielce and the exereseenees they produce, consult a paper by $\triangle \mathrm{bl}$ in Wittstein's Vierlcljahresschrift für prakt. Pharm. vi. (1857) 343-361.

2 Couche proleetriee of Laenze-DuthiersRecherches pour scrvir à l'histoine des yall's. -Ann. des Sciences Nal., Bot., xix. (1S53) 
The parenchyme-cells ontside the shell contain chlorophyll and tamnin; the lattcr is in transparent, colourless, sharp-cdged masses, insoluble in benzol, but dissolving slowly in watcr; quickly in alcohol. Thin slices soaked in glyccrin, appear after some time covered witl benutiful crystals of gallic acid. The thick-walled cells (stonc-cells) and the neighbouring striated cells, are rich in octahedra of calcium oxalate. 'The tissue of the gall situated within the shell of thick-walled cells, contains starch in large, compressed, mostly splicrical granules; also isolated masses of brown resin. Besides these, there appears to be in this part of the tissue an albuminoid compound.

Chemical Composition-The rough taste of galls is due to their chicf constituent, I'annic or Gallo-tannic Acid, the type of a numerous family of substances ${ }^{1}$ to which vegetables owe their astringent properties. Tamnic matter was long supposed to be of one kind, namely that found in the oak gall, but the researches of latcr ycars have proved the tannin of different plants to possess distinctive characters: hence the term gallo-tannic acid to distinguish that of galls, from which it is principally derived. It was however shown by Stcnhousc as far back as the ycar 1843, again in 1861, as well as by still morc recent unpublished experiments, that the tannic acid found in Sicilian sumach, the leaves of Rhus Coriaria L., is identical with that of oak galls. Löwe in 1873 came to the samc conclusion. The best oak galls yield of this acid, from 60 to 70 per cent.

Gallic Acid is also contained in galls ready-formed to the extcnt of about 3 per cont. Frec sugar, resin, protein-substances, have also been found. Neither gum nor dextrin is present.

Commerce-The introduction into dyeing of new chemical substances, and the increascd cmployment of sumach and myrobalans, have caused the trade in nutgalls to decline considcrably during the last few years. The province of Aleppo which used to export annually 10,000 to 12,000 quintals, exported in 1871 only 3000 quintals. $^{2}$ A staple market for the galls which are collected in the mountains of Kurdistan is Diarbekir, whence they arc sent to Trebizond for shipment. Galls are also shipped in some quantity at Bussorah, Bagdad, Bushire, and Smyrna.

There were imported - into the United Kingdom from ports of Turkey and Persia during 1872, $6349 \mathrm{cwt}$. of galls, valued at $£ 18,581$.

Uses-Oak galls in their crude state are seldom used in medicine unless it be externally; but the tannic and gallic acids cxtracted from thein, are often administered.

\section{Other kinds of Gall.}

Chinese or Japanese Galls-The plant which bears this important kind of gall, is Rhus scmialata Murray (Rh. Bucki-amcla Roxb.), a small trce of the order Anacardiacce, common in Northern India, China and Japan. The galls began to be imported into Europe about 1724, and are noticed by Gcoffroy ${ }^{3}$ as Orcilles des Indes, but they secm to have

1 Gmelin, Chcmistry, xv. (1862) 449 ; Schorlemmer, Chemistry of the Carbon Compounds, 1874. 468 .
2 Consul Skene-Reports of H.M. Consuls, No. 1. 1872. 270.

3 Mém. de l'Académie royule des Scrences, paris, 1724. 324 . 
soon disappeared from the market. Pereira directed attention to them in 18t4, since which time they have formed a regular and abundant article of import both from China and Japan. At present the supplies arrive chiefly from Hankow, from which great trading city, the export in 1872, was no less than 30,949 peculs, equal to 36,844 cwt. ${ }^{1}$ The quantity imported from China into the United Kingdom in 1872, was S621 cwt, valued at $£ 20,098$.

Chinese galls are vesicular protuberances formed on the leafstalks and branches of the above-mentioned tree, by the puncture of an insect, identified and figured by Doubleday ${ }^{2}$ as a species of Aphis, and subsequently named provisionally by Jacob Bell, ${ }^{3}$ A. Chinensis. We have no account by any competent observer of their growth and collection; and as to their development, we can only imagine it from the analogous productions seen in Europe. According to Doubleday, it is probable that the female aphis punctures the upper surface of a leaf (more probably leafstalk), the result of the wound being the growth of a hollow expansion in the vegetable tissue. Of this cavity the creature takes possession and brings forth a progeny which lives by puncturing the inner surface of their home, thus much increasing the tendency to a morbid expansion of the soft growing tissue in an outward direction. Meanwhile the neck of the sac-like gall thickens, the aperture contracts and finally closes, imprisoning all the inmates. Here they live and multiply until, as in the case of the pistacia gall of Europe, the sac ruptures and allows of their escape. This, we. may imagine, takes place at the period when, after some generations all wingless and perhaps all female (for the female aphis produces for 'several generations without impregnation), a winged generation is brought forth of both sexes. These may then fly to other spots, and deposit eggs for a further propagation of their race.

The galls are light and hollow, varying in length from 1 to $2 \frac{1}{2}$ inches, and of extremely diverse and irregular form. The simplest are somewhat egg-shaped, the smaller end being attached to the leafstalk; but the form is rarely so regular, and more often the body of the gall is distorted by numerous knobby or horn-like protuberances or branches; or the gall consists of several lobes uniting in their lower part and gradually attenuated to the point by which the excrescence is attached to the leaf. ${ }^{4}$ But though the form is thus variable, the strncture of these bodies is very characteristic. They are striated towards the base, and completely covered on other parts with a thick, velvety, grey down, which rubbed off on the prominences, displays the reddish brown colour of the shell itself. The latter is $\frac{1}{10}$ to $\frac{1}{20}$ of an inch in thickness, translucent and horny, but brittle with a smooth and shining fracture. It is rather smoother on the inner surface and of lighter colour than on the outer.

The galls when broken are generally found to contain a white, downylooking substance, together with the minute, dried-up bodies of the insect.

1 Returns of Trade at the Treaty Ports of China for 1872. 154. - In the China trade returns, the drug is always misealled "Nut Galls" or "Gallnuts."

2 Pharm. Journ. vii. (1848) 310.

3 Ilirl. x. (1851) 128.

4 We have onee met with galls imported from Shaughai which cliffered from ordinary
Chinese galls in not being horned, but all of an elongated ovoid form, often pointed at the upper end, and having moreuver a strong cheesy smell. They may be derived from Distylizen racemosum S. et Z., though they do not perfectly accord with the depressed pear'shaped forms figured by Sicloold and Zuecarini (Flora Joponice, tab. 94). 
Chinese galls contain about 70 per cent. of a tannic acid which Stenhouse ${ }^{1}$ regards as identical with that derived from oak galls. It is worthy of note that those who manufacture pyrogallol for photographic purposes, declare that Chinese galls and common galls do not yicld that substance in precisely the sane form. Chinese galls are employed, chiefly in Germany, lor the mannfacture of tannic and gallic acids.

Pistacia Galls-The genus Pistacia, which belongs to the same order as Rhus, is very liable to the attacks of Aptis, which produce upon its leaves and branches, excrescences of exactly the same nature as Chinese galls. In the south of Europe, horn-like follicles, often several inches long, ${ }^{2}$ are frequently met with on the branches of Pistacia 'Terebinthus; while much smaller excrescences of the same nature but of different shape, occur on the leaves of $P$. Lentiscus. Another growth of the same character, constitutes the small and very astringent galls known in the Indian bazaars by the names of Bazghanj and Gule-pistah, the latter signifying flowor of pistachio ; they have been termed in Europe, Bolihara Galls. They were imported by sea into Bombay in the year $1872-73$, to the extent of 184 cwt., chicfly from Sind; ${ }^{3}$ and are also carried into North-western India by way of Peshawar and by the Bolán Pass. Occasionally a package finds its way into a Loudon drug sale.

Tamarist Galls-These are roundish knotty excrescences of the size of a pea up to $\frac{1}{2}$ an inch in diameter, found in North-western India on the branches of Tamarix oricntalis L., a large, quick-growing tree, common on saline soils. The galls are used in India in the place of oak galls, and are mentioned as "non-officinal" in the Pharmacopceia of India 1867. We are not aware that they lave been the subject of any particular chemical research.

\section{SANTALACEA.}

\section{LIGNUM SANTALI.}

Lignum Santalinum album vel citrinum; Sandal Wood; F. Bois de Santal citrin; G. Wcisses odcr Gclbcs Sandclloolz.

Botanical Origin-Suntalum album L., a small tree, 20 to 30 feet high, with a trunk 18 to 36 inches in girth, native of the mountainous parts of the Indian peninsula, but especially of Mysore and parts of Coimbatore and North Canara, in the Madras Presidency; it grows in dry and open places, often in hedge-rows, not in forests. The same tree is also found in the islands of the Eastern Archipelago, notably of Sumba (otherwise called Chandana or Sandal-wood Island) and Timur.

In later times, sandal wood has been extensively collected in the Hawaiian or Sandwich Islands, where its existence was first pointed out about the year 1778, from Santalum Frcyeinetianum Gaud. and S. pyrularium A. Gray ; in the Viti or Fiji Islands from S. Y asi Seen. ; in New Caledonia from S. Austro-caledonicum, Vieill. ; ${ }^{5}$ and in Western Australia

1 Proceedings of the Royal Sucicty, xi. (1862) 402 .

2 For a figure, see Pharm. Journ. iii. (1844) 387.

3 From the Returns quotel at p. 297, nute 5 .
'Seemann, F'lora Viticnsis, 1865-73. 210-215.

5 Souberran in Joutrn. de Pharm. xi. (1870) 243. 
from Fusanis spicatus Br. (Santalum spicatum DC., S. cygnomum Miq.) In India, the sandal-wood tree is protected by Government and is the source of a profitable commerce. In other countries it has been left to itself, and has usually been extirpated, at least from all accessible places, within a few years of its discovery.

History-Sandal wood, the Sanskrit name for which, Chandana, has passed into many of the languages of India, is mentioned in the Nimikta or writings of Yaska, the oldest Vedic commentary extant, written not later than the 5th century B.c. The wood is also referred to in the ancient Sanskrit epic poems, the Ramayand and Mahabharata, parts of which may be of nearly as early date.

The author of the Periplus of the Erythrean Sea, written about the

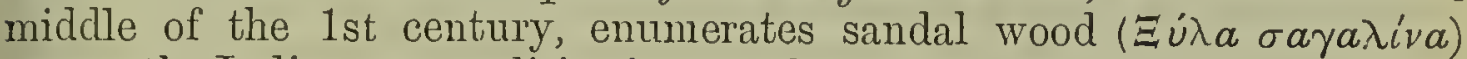
among the Indian commodities imported into Omana in the Persian Gulf. ${ }^{2}$

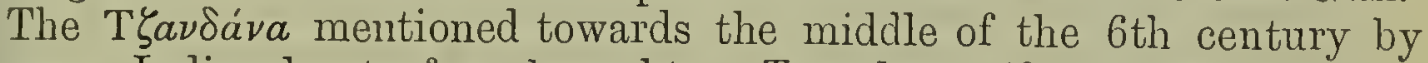
Cosmas Indicoplenstes ${ }^{3}$ as brought to Taprobane (Ceylon) from China and other emporia, was probably the wood under consideration. In Ceylon, its essential oil was used as early as the 9th century in embalming the corpses of the princes.

Sandal wood is named by Masudi ${ }^{4}$ as one of the costly aromatics of the Eastern Archipelago. In India, it was used in the most sacred buildings, of which a memorable example still exists in the famous gates of Somnath, supposed to be 1000 years old. ${ }^{5}$

Among European writers, Constantinus Africanus, who flourished at Salerno in the 11th century, was one of the earliest to mention Sandalum. ${ }^{6}$ Ebn Serabi, called Serapion the Younger, who lived about the same period, was acquainted with white, yellow, and red sandal wood. ${ }^{7}$ All three kinds of sandal wood also occur in a list of drugs ${ }^{8}$ in use at Frankfort, circa A.D. 1450 ; and in the Compendium Aromatariorum of Saladinus, published in 1488, we find mentioned as proper to be lept by the Italian apothecary,- "Sandali trium generum, scilicet albi, rubii ct citrini."

Whether the red sandal here coupled with white and yellow, was the inodorous wood of Pterocarpus santalinus, now called Lignum santalinum rubrum or Red Sanders (see p. 175), is extrenely doubtful. It may have meant real sandal wood, of which three shades, designated white, red and yellow, are still recognized by the Indian traders. ${ }^{9}$

1 Whether Santalum laneeolatum Br., a tree found throughout N. and E. Australia and ealled sandal wood by the eolonists, is an objeet of trade, we know not.

2 Vincent, Commeree and Navigation of the Aneients, ii. (1807) 378.

${ }^{3}$ Migne, Patrologice Cursus, series Græca, tom. 88. 446 .

${ }^{4}$ Les Prairies d'Or, texte et traduction par Barbier de Meynard et Pavet de Courteille, i. (1861) 222.

5 They are 11 feet high and 9 feet wide, and richly carved out of sandal wood ; they were construeted for the temple of Somnath in Cruzerat, once esteemed the holiest temple in India. On its destruetion in A.D. 1025, the gates werc carried off to Ghuzni in Afghanistan, where they remained until the eapture of that eity hy the English in 1842, when they were taken baek to India. They are now preserved in the eitadel of Agrr. For a representation of the gates, see Arehowologia, xxx. (1844) pl. 14. 369.

Opera, Basil. 1536-39, Lib. de Gradibus,

7 Liber Serapionis aggregatus in medieinis simplicibus, 1473 .

8 Flüekiger, Die Frankfurter Liste, Halle, 1873. 11.

9 Thus Milburn in his Oriental Commeree (1813), says-". . . the deeper thc colour, the higher is the perfune ; and hence the merchants sometimes divide sandal into rcd, yellow, and white, but these are all different sharles of the samc colour and do not arise from any differcuee in the species of the
trcc."-(i. 291.) 
On the other hand we learn from Barbosa, ${ }^{2}$ that about 1511, while and yellow sandal wood were worth at Calicut on the Malabar Coast, from eight to ten times as much as the red, which would show that in his day, the red was not a mere variety of the other two lut something far cheaper, like the Red Sanders Wood of modern commerce.

In 1635 , the subsidy levied on sandal wood imported into England was $1 . s$. per th. on the white, and $2 s$. per 16 . on the yellow.2

'The first figure and satisfactory description of Sanlalum album, occur in the Herbarivm Amboinense of Rumphius (ii. tab. 11).

Production-The dry tracts producing this valuable wood, occupy patches of a strip of country lying chiefly in Mysore and Coimbatore, about 250 miles long, north and north-west of the Neilgherry Hills, and having Coorg and Canara between it and the Indian Ocean; also a piece of country further eastward in the districts of Salem and North Arcot, where the tree grows from the sea-level up to an elevation of 3000 feet. In Mysore where sandal wood is most extensively produced, the trees all belong to Government and can only be felled by the proper officers. This privilege was conferred on the East India Company by a treaty with Hyder Ali, made 8 August, 1770, and the monopoly has been maintained to the present day. The Mysore annual exports of sandal wood are about 700 tons, valued at $£ 27,000 .^{3}$ They are shipped from Mangalore.

A similar monopoly existed in the Madras Presidency until a few years ago, when it was abandoned. But sandal wood is still a source of revenue to the Madras Government which by the systematic management of the Forest Department has of late years been regularly increasing. The quantity of sandal wood felled in the Reserved Forests during the year $1872-73$, was returned as 15,329 maunds (547 $\frac{1}{2}$ tons). ${ }^{4}$

The sandal-wood tree, which is indigenous to the regions just mentioned, used to be reproduced by seeds sown spontaneously or by birds; but it is now being raised in regular plantations, the seeds being sown two or three in a hole with a chili (Capsicum) seed, the latter producing a quick-growing seedling which shades the sandal while young. ${ }^{5}$ It is probable that the nurse-plant affords sustenance, for it has been lately shown ${ }^{6}$ that Santalum is parasitic, its roots attaching themselves by tuber-like processes to those of many other plants; and it is also said that young sandal plants thrive best when grass is allowed to grow up in the seed-beds.

The trees attain their prime in 20 to 30 years and have then trunks as much as a foot in diameter. A tree having been felled, the branches are lopped off, and the trunk allowed to lie on the ground for several months, during which time the white ants eat away the greater part of the inodorous sapwood. The trunk is then roughly trimmed, sawn into billets 2 to $2 \frac{1}{2}$ feet long, and taken to the forest depots. There the wood

1 Ramusio, Navigationi et Viaggi, etc., Venet. 1554. fol. 357 b., Libro di Ocloardo Barbosa Portoghese.

${ }_{2}$ The Rates of Mareluanclizes, Lond. 1635.

3 B. H. Baden Powell, Report on the Administration of the Forest Department in the several provinces under the Government of India, 1872-73, Calcutta, 1874. vol. i. 27.
4 Report of the Administration of the Madras Presidency during the year" 1872-73, Madras, 1874. 18. 143.

5 Beddome, Flore Sylratiea for Southerm India, 1872. 256.

${ }_{6}^{6}$ Scott in Journ. of Agricult. and Horticult. Soc of India, Calcutta, vol. ii. part 1 (1871) 287. 
is weighed, subjected to a second and more careful trimming, and classified according to quality. In some parts, it is customary not to fell but to dig the tree up; in others, the root is dug up after the trunk has been cut down,- - the root affording valuable wood, which with the chips and sawdust are preserved for distillation, or for burning in the native temples. The sap wood and branches are worthless. ${ }^{2}$

In 1863, a sort of sandal wood afforded by Fusanus spicatus (p. 541), was one of the chief exports of Western Australia, whence it was shipped to China. A trifling payment for permission to cut growing timber of any kind, was the only barrier placed on the felling of the trees. The farmers employed their teams during the dull season in bringing to Perth or Guildford the logs of sandal which had been felled and trimmed in the bush; and there was a flourishing trade so long as trees of a fair size could be obtained within 100 or even 150 miles of the towns, where the commodity was worth $£ 6$ to $£ 610$ s. per ton. But the ill-regulated and improvident destruction of the trees in the more easily accessible districts, has so reduced their numbers that the trade in that part of Australia soon came to an end. ${ }^{2}$ Australian sandal wood appears however to be still an article of commerce, if one may draw such an inference from the fact that $47,904 \mathrm{cwt}$. of sandal wood were imported into Singapore from Australia in the year 1872. It was niostly re-shipped to China. ${ }^{3}$

Description-Sandal wood is not much known in English commerce, and is by no means always to be found even in London. That which we have examined and which we believe was Indian, was in cylindrical logs mostly about 6 inches in diameter (the largest 8 inches-smallest 3 inches) and 3 to 4 feet long, extremely ponderous; the bark had been removed. A transverse section of sandal wood exhibits it of a pale brown, marked with rather darker concentric zones and (when seen under a lens) numerous open pores. The tissue is traversed by medullary rays, also perceptible by the aid of a lens. The wood splits easily, emitting when comminuted an agreeable odour which is remarkably persistent; it has a strongish aromatic taste.

The varieties of sandal wood are not classified by the few persons who deal in the article in London, and we are unable to point out characters by which they may be distinguished. In the price-currents of commercial houses in China, three sorts of sandal wood are enumerated, namely South Sea Island, Timor and Malabar; the last fetches three or four times as high a price as either of the others. Even the Indian sandal wood may vary in an important manner. Beddome, ${ }^{4}$ conservator of forests in Madras, and an excellent observer, remarks that the finest sandal wood is that which has grown slowly on rocky, dry and poor land; and that the trees found in a rich alluvial soil, though of very fine growth, produce no heart-wood and are consequently valueless. A variety of the tree with more lanceolate leaves (var. $\beta$. myrlifolium DC.), native

1 Elliot, Experiences of a Planter in the Jungles of Mysore, ii. (1871) 237 ; also verbal information communicated by Capt. Campbell Walker, Deputy Conservator of Forests, Madras.

2 Millett, An Austratian Parsonage, I ond., 1872, 43. 95. 38 ?.
3 Straits Settlements Blue Book for 1872 , Singapore, 1873. 298. 347.- It is possible that the sandal wood in question may have been the produce of the South Sea Islands, shipped from an Australian port.

${ }_{4}^{4}$ O1) cit. 
of the castern mountains of the Madras Presidency, affords a sandal wored which is nearly inodorous.

Microscopic Structure-The woody rays or wedges show a breadth varying from 35 to $420 \mathrm{mkm}$, the primary being frequently divided by secondary medullary rays. These latter rays consist of one, often of two rows of cells of the usual form. The woody tissue which they enclose, is chiefly made up of small ligneous fibres with pointed ends, some larger parenchymatons cells, and thick-walled vessels. The resin and essential oil reside chiefly in the medullary rays as shown by the darker colour of these latter.

Chemical Composition-The most important constituent is the essential oil, which the wood yields to the extent of about 1 per cent. It is a light yellow, thick liquid, possessing the characteristic odour of sandal; that which we examined had a sp. gr. of 0.963 . We did not succeed in finding a fixed boiling point of the oil : it began to boil at $214^{\circ} \mathrm{C}$., but the temperature quickly rose to $255^{\circ}$, the oil acquiring a darker hue. Oil of sandal wood varies much in the strength and character of its aroma, according to the sort of wood from which it is produced.

From the wood treated with boiling alcohol, we obtained about 7 per cent. of a blackish extract, from which a tannate was precipitated by alcoholic solution of acetate of lead. Decomposed by sulphuretted hydrogen, the tanuate yielded a tannic acid haviug but little colour, and striking a greenish hue with a ferric salt. The extract also contained a dark resin.

Commerce-The greatest trade in sandal wood is in China, which country in the year 1866, imported at the fourteen treaty ports then open 87,321 peculs, equivalent to 5197 tons; of this vast quantity, the city of Hankow on the river Yangtsze, received no less than 61,414 peculs, or more than seven times as much as any other port. ${ }^{1}$ The imports into Hankow have recently been much smaller, namely 14,989 peculs in 1871 , and 12,798 peculs in $1872 .^{2}$ On the other hand, Shanghai lying near the mouth of the same great river, inported in $1872,59,485$ peculs of sandal wood, the estimated value of which was about $£ 100,000$.

A considerable trade in sandal wood is done at Bombay, the quantity imported thither annually being about 650 tons, and the annual export about 400 tons. $^{3}$

Oil of sandal wood is largely manufactured on the ghats between Mangalore and Mysore, where fuel for the stills is abundant. Official returns ${ }^{4}$ represent the quantity of the oil imported into Bombay in the year $1872-73$, as $10,348 \mathrm{lb}$., value $£ 8374 ; 4500 \mathrm{lb}$. were re-exported by sea.

Uses--The essential oil has of late been prescribed as a substitute for copaiba, otherwise sandal wood las hardly any uses in modern European medicine. It is employed as a perfume and for the fabrication of small articles of ornament. Among the natives of India.

1 Reports on Trade at the ports in China open to forcign trade for 1866, published by orler of the Inspector-General of Customs, Shanghai, 1S67. 120. 121.-One peenl $=13: ? \mathrm{lb}$.
2 Commercial Reports of H.M. Consuls in Chine for 1871 (p. 50) and 1872 (p). (i2. 15.9).

3 From the official document puoted at 1. 5.2 , note 3.

4 See 1. 297, note 5. 
it is largely consumed in the celebration of sepulchral rites, wealthy Iindus showing their respect for a departed relative by adding sticks of sandal wood to the funereal pile. The powder of the wood made into a paste with water, is used for making the caste mark, and also for medicinal purposes. The consumption of sandal wood in China appears to be principally for the incense used in the temples.

\section{CONIFERA.}

\section{TEREBINTHINA VULGARIS.}

\section{Crude or Common Turpentine; F. Térébenthine commune; G. Gemeiner} Terpenthin.

Botanical Origin - The trees which yield Common Turpentine may be considered in two groups, namely, European and American.

1. European-In Finland and Russia Proper, the Scotch Pine, Pinus silvestris L.; in Austria and Corsica, P. Larieio Poiret; and in Southwestern France, $P$. Pinaster Solander ( $P$. maritima Poiret), known as the $P$ in maritime, yield turpentine in their respective conntries.

2. Ameriean-In the United States, the coniler's most important for terebinthinous products, are the Swamp Pine, Pinus australis Michaux (P. palustris Mill.), and the Loblolly Pine, P. Tada L.

History-The resin of pines and firs was well known to the ancients, who obtained it in much the same mamner as that practised at the present day. The turpeutine used in this country has for many years past been derived from North America. Up to the last century, both it and the substance called Common Frankincense were imported from France. The late civil war in the United States and the blockade of the Southern ports, occasioned a great scarcity of American turpentine ; and terebinthinous substances from all other countries were poured into the London market. The actual supplies however, were mainly furnished
by France

Kopp ${ }^{1}$ quotes a passage showing that the essential oil of turpentine was known to Marcus Græcus, who termed it Aqua ardens. This almost unknown personage is the reputed inventor of Greek fire, a dreaded engine of destruction in mediæval warfare.

Secretion-The primary formation of resin-dncts in the bark of coniferous trees has been explained by I)ippel, ${ }^{2}$ Miiller, ${ }^{3}$ and Frank, The subsequent diffusion of the resinous juice through the heart-wood, sap-wood, and bark, has been elaborately investigated by Hugo von Mohl. ${ }^{5}$ From the various forms under which this diffusion exists in the different species, have arisen the diverse methods of obtaining the
terebinthinous resins.

Thus in the wood of the Silver Fir (Pinus Picea L.), resin-ducts are altogether wanting; - and led by experience, the Alpine peasant collects the turpentine of this tree by simply puncturing the little cavities which form under its bark. In the Scotch Pine (P. silvestris L.), they are more

1 Geschichte der Chemic, iv. (1847) 392.

2 Botanische Zeitung, 1863.

3 Pringsheim, Jahub. fiur wisscnschufu. Bolanite. 1866.

\footnotetext{
6 Beiträge zur Pflanzenphysiologie, Leipzig, 1868. 119.

Botcuisehe Zeitung, 1859. 329.
} 
abmudant in the work than in the bark, a lact which might lye anticipated by observing how rarely this tire exules l'esin spontaneously.

Oil of turpentine, like volatile vils in general, undergoes on exposure to the air certain alterations giving rise to what is called resinificution. The formic acid which is producerl in small quantity during this change, chancterizes it as one of oxidation; the chief prodncts however are not exachly known, and not one of them has been proved identical with any natural resin. 'The common assinnption that resins are produced from volatile oils by simple oxidation, is consequently not yet entirely justified. Hlasiwetz and Barth however, have ubtained substances coming cxtremely near to the resins of coniferons trees, by lieating essential oils of tnipentine, juniper and the like, in sealed tubes with alcoholic solution of potash. ${ }^{1}$

Extraction-In the United States, ${ }^{2}$ turpentine is obtainerl to the largest extent from Pinus australis, of which tree there are vast forests in North and Sotuth Carolina, Georgia and Alabama. But it is in Nortl Carolina that the extraction of turpentine is principally carried on.

In the winter, i.e. from November to March, the negroes in a Turpentine Orchard, as the district of forest to be worked is called, are occupied in making in the trunks of the trees; cavities which are technically known as boxes. For this purpose a long narrow axe is used, and some skill is required to wield it properly. The boxes are made from 6 to 12 inches above the ground, and are shiaped like a distended waistcont-pocket, the bottom being abont 4 inches below the lower lip, and 8 or 10 below the ripper. On a tree of medium size, a box should be made to hold a quart. The less the uxe approaches the centre of the tree, the better, as vitality is the less endangered. An expert workman will make a box in less than 10 minutes. From one to four boxes are made in each tree, a few inches of bark being left between then. The greater number of trees from which turpentine is now obtained, are from 12 to 18 inches in diameter, and have three boxes each.

The boxes having been made, the bark and a little of the rood immediately beneath it, which are above the box, are hacked; and from this excoriation, the sap begins to flow about the middle of March, gradually filling the box. Each tree requires to be freshly hacked every $S$ or 10 days, a very slight wound above the last being all that is needed. The hacking is carried on year after year, until it reaches 12 to 15 feet or more, ladders being used. The turpentine, which is called dip, is removed from the boxes by a spoon or ladle of peculiar form, and collected into barrels, which are made on the spot and are of very rude construction. The first year's flow of a new tree, having but a small surface to traverse lefore it reaches the box, is of special goodness and is terned Tirgin dip.

The turpentine which concretes upon the trunk is occasionally scraped off' and barrelled by itself, and is known in the market as scrape, or by English druggists as Common Frankincense or Gum Thus.

Although a large amount of turpentine is shipped to the northern ports for distillation, a still larger is distilled in the neighbourhood of

1 Wiesner, Die Gummiarten, Ilsrace und Balsume, Fillangen, 1869. 78.

a The accumb here given is taken from
F. L. Olmsted's Journey in the Scaboard slure States, New lork, 1856 . 1. 338, di. 
the turpentine orchards. Copper stills are used, capable of containing 5 to 20 harrels of turpentine. 'The turpentine is distilled without water, the rolatile oil as it flows from the worm being received in the barrel in which it is afterwarls sent to market, When all the oil that cun be profitably drawn olf has been obtained, a spigot is removed from an opening in the bottom of the still, and the residual Rosin, appearing as a viscid fluid like molasses, is allowed to flow out. Only the first yualities of rosin, as that obtained from Virgin dip, are generally consideied worth saving, the less pure sorts being simply allowed to run to waste. When it is intended to save the rosin, the latter is drawn of into a vat of water, which separates the chips and other rubbish, and the rosin is then placed in barrels for the market. A North Carolina turpentine orchard will remain productive under ordinary treatment for fifty years.

The collection of turpentine in the departments of the Landes and Gironde in the south-west of France, is performed in a more rational manner than in America, inasmuch as the plan of making deep cavities in the tree for the purpose of receiving the resin, is avoided by the simple expedient of placing a suitable vessel beneath the lowest incision. ${ }^{1}$ The turpentine which concretes ripon the stem is termed in France, Galipot or Barras.

Description-Common turpentine is chiefly of two varieties, nanely, American and Bordeaux; the first alone is commonly found in the Eunglish market.

American Turpentine - A viscid honey-like fluid, of yellowish colour, somewhat opaque, but becoming transparent by exposure to the air; it has an agreeable odour and warim bitterish taste. When long kept in a bottle, it is seen to separate into two layers, the upper clear and faintly fluorescent, the lower somewhat turbid or granular. When the latter portion is examined under the nicroscope, it is found to consist mainly of minute crystals of peculiar curved or bluntly elliptic form. These crystals are abietic acid; when the turpentine is warned,
the crystals are speedily dissolved.

Bordcaux Turpentisu-in all essential particulars agrees with American turpentine; it appears to separate rather more readily than the latter iuto two layers, - a transparent and an opaque or crystalline.

Chemical Composition-The turpentines are mixtures of resin and essential oil. The latter which amounts to from 15 to 30 per cent. consists for the greater part of various hydrocarbons, all corresponding to the formula $\mathrm{C}^{10} \mathrm{H}^{16}$. Many of the crude turpentine oils, and some of them even after rectification, are energetically acted on by metallic sodium. This reaction proves the presence of a certain quantity of
uxycrenated oils, not one of which has thus far been isolated.

The turpentine oils although agreeing in composition, exhibit a series of physical differences according to their origin. One and the same tree, indeed, yields frum its several organs, oils of different proper-
ties. The boiling point varies between $152^{\circ}$ and $172^{\circ} \mathrm{C}$. The sp. gr.
at mean temperatures ranges from 0.856 to 0.870 . at mean temperatures ranges from 0.856 to 0.870 . Greater differences are exhibited in the optical properties, sonce varieties of the

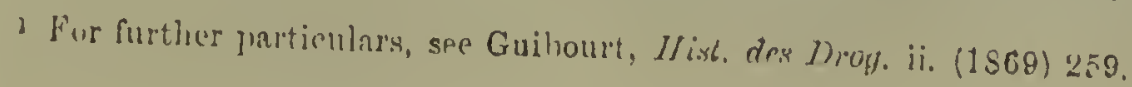


oil turning the plane of polarization to the right, others to the left. 'This rotatory power differ's in many cases from that of the turpentine from which the oil was derived. ${ }^{1}$ 'T'he odour of oil of turpentine varies with the species from which it has been obtained.

When ernde turpentine is distilled with water, nearly the whole of the oil passes over, while the resin remains. This resin is called Colophony or Rosin. When it still contains a little water, it is distinguished in English trade as Yellow Rosin; when fully depriver of water, it becomes whit is called Transparent Rosin. That of deeper colour acquired by a still longer application of heat, bears the name of Black Rosin.

Colophony softens at $80^{\circ} \mathrm{C}$., and melts completely at $100^{\circ}$ into a clear liquid. At about $150^{\circ}$, it forms a somewhat darker liquid, but without undergoing a loss in weight; at higher temperatures, it gradually decomposes. Pure colopliony has a sp. gr. of $1 \cdot 07$, and is homogeneous, transparent, amorphous, and very brittle. At temperatures between $15^{\circ}$ and $20^{\circ} \mathrm{C}$., it requires for solution 8 parts of dilute alcohol $(0.883)$. On addition of a caustic alkali, it dissolves in spirit much moredireely. It is plentifully soluble in acetone or benzol.

The composition of colophony agrees with the formula, $\mathrm{C}^{44} \mathrm{H}^{62} \mathrm{O}^{4}$. By shaking coarsely powdered colophony with warm dilute alcohol, it is converted into a crystalline body, Abietic Acid, $\mathrm{C}^{44} \mathrm{H}^{64} \mathrm{O}^{5}$, - a result due simply to hydration. Under such treatment, colophony yields 80 to 90 per cent. ${ }^{2}$ of abietic acid, and therefore consists chiefly of the anhydride of that acid. This is probably the case with the resins of other conifers. The living tree contains only the anhydride, for the fresh resinous juice is clear and amorphons after the expulsion of the oil ; and when exposed to the air it loses oil, takes up water and solidifies as the crystalline acid, - a change which may easily be traced by the aid of the microscope, in drops taken direct from the trunk. . Amorphous colophony retains its transparency even in a moist atmosphere, and appears to be capable of passing into the state of abietic acid, only when the assumption of the needful molecule of water is aided, in nature by the presence of the essential oil, or artificially by that of alcohol.

Colophony when boiled with alkaline solutions, forms greasy salts of abietic acid, the so-called resin-soaps, which are used as additions to other soaps.

Siewert's Sylvic Acid is regarded by Maly (1864) as a product of the decomposition of abietic acid; and the Pimaric, Pinic and Sylvic Acids of former investigators, as impure abietic acid. Pimaric acid however, which is the chief constituent of Galipot, appears to be decidedly different, so far as we can judge from the experiments of Duvernoy (1865) and of one of ourselves (F.)

Abietic acid, as well as the unaltered coniferous resins, deviate the ray of polarized light, whereas American colophony, dissolved in acetone, is devoid of optical power.

Commerce-The supplies of turpentine are chiefly derived from the United States, but the trade has undergone a great change, as shown by

${ }^{1}$ For some particulars, see my notice in the Jahresbericht of Wiggers and Husemann for 1869 , p. 36. F. $\Lambda$. I'.

2 Fliickiger in 1oc. cit. 1867. 36. 
the following figures, which represent the quantities imported in the several years:-
1869
60,408 cwt.
1870
1871
2,231 cw.t.
1872
1,000 cwit.

This greatly diminished importation of the crude article is partially explained by a larger importation of Oil of Turpentine and Rosin; but the increase is by no means sufficient to account for the vast diminution indicated by the above figures. The quantities of these latter articles imported into the United Kingdom during the year 1872, were as follows:--Oil of Turpentine, 220,292 cwt, value $£ 470,085$, six-sevenths being furnished by the United States of America and the remainder chiefly by France. Rosin, 919,494 cwt., value $£ 492,246$; of this quantity, the United States supplied nine-tenths, and France the larger part of the remainder. ${ }^{1}$

Uses-Turpentine, Common Frankincense and Colophony are ingredients of certain plasters and ointments. Oil of turpentine is occasionally administered internally as a vermifuge or diuretic, and applied externally as a stimulant. But these substances are immeasurably

\section{Thus Americanum vel vulgare.}

This substance, known among druggists as Common Frankineense or Gum Thus, is the resin which, as explained at p. 546, concretes upon the stems of the pines in the American turpentine orchards, and is there called Scrape. It corresponds to the Galipot or Barras of the French, which in old times supplied its place.

It is a semi-opaque, softish resin, of a pale yellow colour, smelling of turpentine; it is generally mixed with pine leaves, bits of wood and other impurities, so that it requires straining before it is used. By keeping, it becomes dry and brittle, of deeper colour and milder odour. Under the microscope, it exhibits a crystalline structure due to Abictic Acid, of which it chiefly consists. It is imported from America in barrels, but in insignificant quantities and only for the druggist's use. Sometimes however, it is distilled as common turpentine.

Dry pine resin, of which Common Frankincense is the type, evolves when heated an agreeable smell : hence in ancient times it was commonly used in English churches in place of the more costly olibanum. At present, it is scarcely employed except in a few plasters.

\section{TEREBINTHINA VENETA:}

Terebinthina Laricina; Venice Turpentine, Larch Turpentine; F. Térébenthine de Venise ou de Briancon, Térébcnthine du mélèzé

Botanical Origin-Pinus Larix L. (Larix Europaca DC.), a tall forest tree of the mountains of Southern Central Europe, from Dauphiny through 3000 to 5500 feet a and the Carpathians, ascending to an elevation of tions in England and Scotland.

History-The turpentine of the larch was known to Dioscorides as imported from the Alpine regions of Gaul. ${ }^{2}$ Pliny also was acquainted

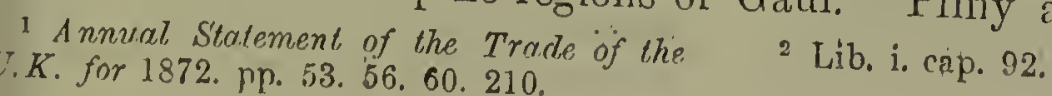


with it, for le correctly remalks that it Joes not hadele. Gallen in the 2nd century also mentions it, ndmitting that it may well be sulistituted for Chian turpentine, then regaded as the legitimate 'Ifrobinthina. In later times, Mattioli (circa 1550) gave an accomnt of the method of collecting it about l'rent in the 'lirol, by boring the trees to the centre, which is true to the present day. It used formerly to be exported fiom Venice.

The name lurch sems to belong to the turpentine rather than to the tree. Dioscorides says the resin is called by the natives $\lambda a ́ p$ a similar nane is mentioned by Galen. In a commercial gruide, called "I'ariffe de pesi $c$ misure, which first appeared at Venice in 1503, we find "T'omentine sive Larga," - and largu is still an Italian nane for larch turpentine. The peasants of the Sonthern Tirol call it Lergut, and in Switzerland the common name is Lörtsch.

Extraction-Larch turpentine is collected in the Tirol, chiefly about Meran, Botzen and Trent. A very small amount is obtained occasionally in the Valais in Switzerland, and in localities in Piedmont and France where the larch is found. The resin is obtained from the heartwood, by making in the spring a narrow cavity reaching to the centre of the stem, at about a foot from the ground. This is then stopped uj uutil the autumn of the same or of the following year, when it is opened and the resin taken ont with an iron spoon. If only one hole is thus made, the tree yields about half a pound yearly without appreciable detriment. But if on the other hand a number of wide holes are inade, and especially if they are left open, as was formerly the practice in the Piedmontese and French Alps, a larger product amounting to as much as $8 \mathrm{fb}$. is obtained annually, but the tree ceases to yield after some years, and its wood is much impaired in value.

Mohl, who witnessed the collection of this turpentine in the Southeru Tirol, ${ }^{1}$ observed that when a growing larch stem was sawn through, the resin flowed most abundantly from the heart-wood, and in smaller quantity, though somewhat more quickly, from the sap-wood, and that the bark contained but few resin-ducts. The practice of closing the cavities is adopted, not only for the sake of preserving the wood and for the greater convenience of removing the turpentine, but also because it tends to maintain the transparency and purity of the latter.

Description-Venice turpentine is a thick, loney-like fluid, slightly turbid, yet not granular and crystalline $;^{2}$ it has a pale-yellowish colour and exhibits a slight fluorescence. Its odour resembles that of common turpentine but is less powerful; its taste is bitter and aromatic. I'heu exposed to the air, it thickens but slowly to a clear varmish; it does not luarden when mixed with magnesia, Larch turpentine though common on the Continent, is seldom imported into England, ${ }^{3}$ and the article sold for it is almost always spurious.

Chemical Composition-Larch turpentine dissolves in spirit of wine, forming a clear liquid which reddens litmus; hot water agitated with it also acquires a faint acid reaction, due to formic and probably also to succinic acid. Glacial acetic acid, amylic alcohol, and acetono

1 Bolanische Zeitung, xvii. (1859) 329.

II once net witl resin in erystallino drops on the stem of a larel near Bern.F. A. F.
3 On one occasion I observed Tenice Tur. prentinc in a mblic drue sale in lomon, 21 liarrols imported from Trieste being offered, 24 . Wily, $1864-1$. 11 . 
mix with it perfectly. By distillation, it yields on an average 15 per cent. of essential oil of the composition, $\mathrm{C}^{10} \mathrm{H}^{10}$, which boils at $157^{\circ} \mathrm{C}$., and when saturated with dry hydrochloric acid gas, easily prodnces crystals of the componnd $\mathrm{C}^{10} \mathrm{H}^{10}+\mathrm{HCl}$. The residual resin is soluble in two parts of warm alcohol of 75 per cent., and more copiously in concentrated alcolıol.

'Two parts of the turpentine diluted with one of benzol or acetone, deviate the ray of polarized light $9.5^{\circ}$ to the right. The essential oil deviates $6.4^{\circ}$ to the left; the resin perfectly freed from volatile oil and dissolved in half its weight of acetone, deviates $1.2 \cdot 6^{\circ}$ to the right, in a column $50 \mathrm{~mm}$. long.

We have not succeeded in preparing a crystallized acid from the resin of Venice turpentine, although its composition according to Maly (1S64), is the same as that of American colophony, which is easily transformed into crystallized abietic acid.

Uses - Venice turpentine appears to possess no medicinal properties that are not equally found in other substances of the same class, and as a medicine it has fallen into disuse. But in name at least, it is in frequent requisition for horse and cattle medicines.

Adulteration-Alston (1\%40-60) said of Venice turpentine ${ }^{1}$ that it is seldom found in the shops, - a remark equally true at the present day, for but few druggists trouble themselves to procure it genuine. The Venice turpentine usually sold is an artificial mixture of common resiu and oil of turpentine, which may be eașily distinguished from the product of the larch by the facility with which it dries when spread on a piece of raper, ${ }^{2}$ and by its stronger turpentine smell.

\section{CORTEX LARICIS.}

\section{Lareh Bark.}

\section{Botanical Origin-Pinus Larix L.-see p. 549.}

History - The bark of the larch has long been known to possess astringent properties; hence it has been used in tamuing. Gerarde, ${ }^{3}$ who wrote llear the close of the 16th century; likened it to that of the pine, which he described to be of a binding natmre; but there is no evidence that it was an officinal drug.

About the year 1858, larch bark was recommended by Dr. Frizell of Dnblin, and afterwards by other physicians, as a stimulating astringent and expectorant. In consequence of the favourable effects which have resulted from its use, it has been inclnded in the Additions to the Pharmacopreic of 1867 , published during the present year.

Description-The bark that we have seen is in Hattish jieces ol large quills, externally reddish-brown. In those taken from older wood, there is a large amount of an exfoliating corky coat, displaying as it is removed, bright rosy tints, while the liber is of a different texture, slightly fibrous and whitish. The inner surface is smooth and of a pinkish brown,

1 Lencures on the Materia Hedica, Lond. ii. (1770) 398.

2 Thus if at thin layer of true Venice turpentine and another of conmon turpentise his sprearl on two shcets of paper, it will he foumb alter the lipke of some wecks that the former earnot be tonched withont nhering to the fingers, while the latter will hase become a dry, hard riarnish.

"Herball, cenlaryal by Johnsene, Luind. 
or palte yellow. The burk breaks with a short fracture, exhaling an anreeable bilsamic terebinthinous odour ; it has a well-marked astringent taste. For medicinal use, the imer bark is to be preferred.

Microscopic Structure-A transverse section exlibits resin-ducts, but fir less numerons than in the bark of many allied trees. The medullary rays are not very distinct. 'Throughout the middle layer of the bark, large isolated thick-walled cells of vory irregular shape are scattered.

Chemical Composition-Larch bark has been examined by Stenhonse, who tinds it to contain a considerable amount of a peculiar tamnin, yielding olive-green precipitates with salts of iron. 'The same chemist also discovered ${ }^{2}$ in larch bark an interesting crystallizable substance called Larixin or Larixinic Acid, which has the composition, $\mathrm{C}^{10} \mathrm{H}^{10} \mathrm{O}^{5}$. It may be obtained by digesting the bark in water at $80^{\circ} \mathrm{C}$. and evaporating the infusion to a syrupy consistence. From this by still further cautious heating in a retort, the larixin may be distilled, during which operation some of it crystallizes on the inner surface of the receiver, the remainder being dissolved in the distilled liquor. From the latter it may be obtained in crystals by evaporation. The substance forms colourless crystals, sometimes as much as an inch long; it volatilizes even at $93^{\circ} \mathrm{C}$., and melts at $153^{\circ}$. It requires about 88 parts of water for solution at $15^{\circ} \mathrm{C}$., but more freely dissolves in boiling water or in alcohol. From ether, in which it is but sparingly soluble, it separates in brilliant crystals. The solutions have a bitterish astringent taste and a slightly acid reaction, and assume a purple hue on addition of ferric chloride. When a solution of baryta is added to a concentrated solution of larixin, the latter being in excess, a bulky gelatinous precipitate falls; it is readily soluble in boiling water and is deposited again on cooling. Larixin is allied to pyrogallol and pyrocatechin, but differs from both in that it exists ready formed, and is an educt, not a product. Stenhouse failed to obtain it either from the bark of Pinus Abies L., or from that of $P$. silvestris L.

Uses-Larch bark, chiefly in the form of tincture, has been prescribed to check profuse expectoration in cases of chronic bronchitis; it has also been found useful in arresting internal hæmorrhage.

\section{TEREBINTHINA CANADENSIS.}

Balsamum Canadense; Canadia Balsam, Cañadian Turpentine; F. Térébenthine ou Baume de Canada; G. Canada-Balsam.

Botanical Origin-Pinus balsamea L. (Abies balsamea Marshall), the Balsan Fir or Balm of Gilead Fir, a handsome tree, 20 to 40 feet high, with a trunk 6 to 12 inches in diameter, sometimes attaining still larger dimensions, growing in profusion in the Northem and Westem United States of America, Nova Scotia and Canada, but not observed beyond $62^{\circ} \mathrm{N}$. lat. It resembles the Silver Fir of Europe (Pinus Picea L.), but has the bracts short-pointed and the cones more acute at each end.

1 Procentings of the Royal Socicty, xi. (1862) 404 .

2 Phil. Trans., vol. 152 (1862) 53.-Wo write the name Larivin instead of Larixine, with the concurreuce of Dr. Stenhonse. 
Canada balsan is also furnished by Pinus Fraseri Pursh, the Smallfruited or Double Balsam Fir, a tree found on the mountains of Pemnsylvania, Virginia, and southward on the highest of the Alleghanies. ${ }^{2}$

Pinus Canadensis L. (Abies Canatensis Michx.), the Henlock Spruce or Pérnsse, a large tree abundant in the sane comntries as $P$. balsamea, and extending throughout British America to Alaska, is said to yield a similar turpentine, which however las not yet been' sufficiently examined. The Hemlock Spruce is of considerable importance on account of the resin collected from its trunk, and the essential oil distilled from its foliage, the latter operation being performed on a large scale in Madison Comnty, New York. The inner bark of the tree is a valuable material for tanning.

History-Lewis, in his History of the Materia Medica published in 1761, says that "an elegant balsam" obtained from the Canada Fir, is sometimes brought into Europe under the name of Balsamum Canadense. Canada balsam was first introduced into the London Pharmacopceia in 1788. From the books of a London druggist, J. Gurney Bevan, we find that its wholesale price in 1776 was $4 s$, in 1788 , $5 \dot{s}$ : per $1 \mathrm{~b}$.

Description-Canada balsam is a transparent resin of honey-like consistence, and of a light straw-colour with a greenish tint. By keeping, it slowly becomes thicker and of a samewhat darker hue, but always retains its transparency. When carefully examined in direct sinnliglit, it exhibits a slight greenish fluorescence in the same degree as other turpentines or as copaiba ; this optical power appears to increase if the balsam is exposed to a heat of about $200^{\circ} \mathrm{C}$.

Canada balsam has a pleasant aromatic odour and bitterish, feebly acrid, not disagreeable taste. On account of its flavour it is sometimes called Balm of Gilead, but erroneously, as this latter is derived from a tree of the genus Balsamocteridron growing in Arabia. We found a good commercial balsam to have a sp. gr. of 0.998 at $14 \cdot 5^{\circ} \mathrm{C}$., water at the same temperature being 1:000. Four parts, mixed with one of benzol and examined in a column of $50 \mathrm{~mm}$. in length, deviated a ray of polarized light $2^{\circ}$ to the right. The balsam is perfectly soluble in any proportion in chloroform, benzol, ether, or warm anylic alcohol; and the solution in each case reddens litmus. With sulphide of carbon, it mixes readily, but the mixture is somewhat turbid. Glacial acetic acid, acetone or absolute alcohol dissolve the balsam partially, leaving after ebullition and cooling, a considerable amount of amorphous residue. Colophony and Venice turpentine are completely dissolved by the liquids in question, as well as by spirit of wine containing 70 to 75 per
cent. of alcohol.

Chemical Composition ${ }^{2}$-Like all analogous exudations of the Coniferce, Canada turpentine is a mixtiure of resins with an essential oil. If the latter is allowed to evaporate, the former are left as a transpareit somewhat tongh and elastic mass. The proportion of the components is within certain limits, variable in different samples. The specimen beforementioned lost after an exposure in a steam-bath during several days, no

1 Asa Gray, Botany of the Northern United Stucks, New York, 1865. 422.
2 The experiments detailed under this head were performed by Dr. F. 
less than 20 per cent. of volitile oil, or even 2t jer cent. if the experiment was made on a very smill seale, as with 20 griammes or less in a thin linyer:

By distillation with water, it is not easy tir obtain more thin 17 to 18 per cent. of essential oil. 'The resin in this cuse is a tough, celastic, non-transparent mass, retaining olsstinately a laroge proprotion ol water, whieh can onty be removed hy lieeping it for some time at in temporature of $100^{\circ}-1766^{\circ} \mathrm{C}$.

The oil as obtained hy distillation with water is colourless, and has the odour of common oil of turpentine rather than the agreealyle smell of the balsam; it eonsists of an oil, $\mathrm{C}^{10} \mathrm{H}^{16}$, mixed with an insignificant lnoportion of an oxygenated oil, the presence of which may be proved by the slight evolution of hydrogen on adclition of metallic sodium, after the oil has been freed from water by contaet with fused chloride of ealeium. After this treatment, a small proportion begins to distil at about $160^{\circ} \mathrm{C}$., but by far the larger part boils at $167^{\circ} \mathrm{C}$., a small jortion only distilling at last at $170^{\circ} \mathrm{C}$. and above. The oil obtained at $167^{\circ}$ examined under the eonditions already mentioned, has a sp. gr. of 0.863 , and the power of rotating a ray of polarized light, $5 \cdot 6^{\circ}$ to the left. The portion distilling at $160^{\circ}$ does not differ in this respect; but that passing over at $170^{\circ}$, deviates the ray $7 \cdot 2^{\circ}$ to the left. 'The oil readily dissolves a large proportion of glacial aeetic aeid; an equal weight of each mixes perfeetly at about $54^{\circ} \mathrm{C}$., but some acetic acid separates on cooling.

The essential oil of Canada balsam, saturated with dry hydrochloric acid, does not yield a solid crystallizable compound ; but this is easily obtained on addition of fuming nitrie acid and gently heating, when the inside of the retort beeomes eovered by sublimed crystals of $\mathrm{C}^{10} \mathrm{H}^{16}+\mathrm{H} \mathrm{Cl}$.

Thus, this oil in its general eharaeters, bears a close resemblance to the essential oils of the eones of Pinus Picec L., and of the leaves of P. Prmilio Hänke, and to most of the Freneh varieties of oil of turpentine, rather than to the Anieriean turpentine oils, which rotate to the right, and combine immediately with $\mathrm{H} \mathrm{Cl}$ to form a solid erystalline eomponnd.

On the other hand, the resin of Canada balsam is dextrogyre: two parts of it, entirely deprived of essential oil and dissolved in one of beuzol, deviating the ray $8.5^{\circ}$ to the right. The optical powers of the two components (oil and resin) are therefore antagonistic.

The resin of Canada balsam consists however of two difierent bodies, 78.7 per eent. of it being soluble in boiling absolute alcoliol, and $21 \%$ (in our specimen) remaining as an anıorphous mass, readily soluble in ether. Neither the alsoholie nor the ethereal solution yields iz crystalline residue if allowed to evaporate. They redden litmus, but we did not sueceed in obtaining any erystallized resinous aeid, sueh as abictic, crystals of which are so readily formed if common turpentine or colophony is digested with dilute aleohol. Glacial aeetic acid aets upon the resins like absolute aleohol. Caustie alkalis do not dissolve eithel the balsam or the resin; the former however is eonsiderably thickened by incorporation with $\frac{1}{5}$ of its weight of recently calcined magnesia. if the mixture, moistened with dilute alcohol, is liept at $93^{\circ} \mathrm{C}$. for some days and frequently stirred, a mass of har'l consistence, finally trinslucent, results. Canstie ammonia heated with the balsann in a elosed bottle, forms a thick milky jelly, which does not afterwatds separatc. 
Hence, according to our investigations, 100 parts of Canlada turpentine consist of

Essential oil, $\mathrm{C}^{10} \mathrm{H}^{16}$, with a very small proportion of an oxygenated oil $\ldots \quad \ldots \quad \ldots \quad \ldots \quad$...

Resin soluble in boiling alcohul $\quad \ldots \quad \ldots \quad \ldots \quad \ldots \quad 60$

$\begin{array}{llllll}\text { Resin soluble only in ether } & \ldots & \ldots & \ldots & \ldots & 16\end{array}$

The result of Wirzen's examination of Canada balsam ${ }^{1}$ are not in complete accordance with those here stated. He found 16 per cent of nil and three different amorphous reșins, one of which had the composition of abietic acid.

Production and Commerce-Canada balsam is obtained either by puncturing the vesicles which form under the bark of the trunk and branches, and collecting their fluid contents in a bottle, or by making incisions. It is obtained principally in Lower Canada, and is shipped from riontreal and Quebec, in keg's or large barrels. In the neighbourhood of Quebec, about 2000 gallons (20,000 tb:) used to be collected anmually; but in 1868, owing to distress anong the farmers, the quantity obtained was unusually large, and it was estimated that nearly 7000 gallons would be exported to England and the United States. ${ }^{2}$ During a recent scarcity (1872-73) a sort of balsam from Oregon has been substituted in the American market for true Canada balsam. ${ }^{3}$

Uses-The medicinal properties of Canada balsam resemble those of copaiba and other terebinthinous oled-resins, yet it is now rarely employed as a remedy. The balsam is much valued for monnting objects for the microscope, as it remains constantly transparent and uncrystalline. It is also used for making varnish.

\section{TEREBINTHINA ARGENTORATENSIS.} Strassburg Turpentine; F. Térébenthine d'Alsace ou de Strasbourg, Téré-
benthine du sapin; G. Strassburger Terpenthin.

Botanical Origin-Pinus Picea L. (Abies pectinata DC.), the Silver Fir, ${ }^{4}$ a large handsome tree, growing in the mountainous parts of Middle and Southern Europe from the Pyrenees to the Caucasus, and extending under a slightly different form (var. B. Cephalonica) into continental Greece and the islands of Euboea and Cephalonia.

History-Belon in lis treatise De A Arborizus coniferis (1553) described this turpentine, which is also briefly yet accurately noticed by Samuel Dale, ${ }^{5}$ a learned apothecary of London and the friend of Sloane and Ray. It had a place in the London Pharmacopoia until 1788, when it was nmitted from the materia medica:

Extraction-The resin of $P$. Picea, like that of P. balsamea, is contained in little swellings of the bark of young stems, and is extracted by

1 De balsamis el prosertim de Batsumo runudense, Helsingforsire, 1849, - -abstracted in the Jaluresbericht of Wigsers for 1849.38. 2 From information obligingly communi(:atel by Mr. N. Mereer of Monticul and Mr. 11. Sugden Evans of London.
3 Procedings of the Amorican Pharma. centical Associotion, Philadelphia, is73. 119
-also 1874. 433 .

+ Sorpin in French; Weisstanne or Edeltenne in frerman.

3 Pharmarologia, Lbind. 1693. 395. 
the tedious process of punchuring then and receiving in a suital,le vessel the one or two drops which exucle from each. It is still collected near Bancr in the Vosges (1873), though only to a very small extent.

Description-An authentic sample collected for one of us by the Surveyor of Forests in the Bermese Jura, resembles very closely Canada balsam, but is devoiel of any distinct fluorescence. It hias a light yellow colour, a very fragrant odour, ${ }^{1}$ more agreeable than that of Canada balsam, and is devoid of the acrid bitterish taste of the latter.

We found our specimen to lave the sp. gr. of distilled water. It deviates a ray of polarized light $3^{\circ}$ to the left, if examined either pure or diluted with a fourth of its weight of benzol, in the manner described at p. 553. Onr drug is soluble iu the same liquids as the Canadian, yet is miscible with glacial acetic acid, absolute alcohol and acetone, without leaving any considerable flocculent residue. It is even soluble in spirit of wine, the solution being but very little turbid. The solutions have an acid reaction.

Chemical Composition-After the complete desiccation of a small quantity, there remained $72 \cdot 4$ per cent. of a brittle, transparent resin, soluble in glacial acetic acid, but not entirely in absolute alcohol or in acetone. By submitting half a pound of the turpentine to distillation with water, we obtained 24 per cent. of essential oil, the remaining resin being when cold, perfectly friable. The fresh oil, purified by sodium, deviates the ray of polarized light to the left, whereas the remaining resin, dissolved in half its weight of benzol, shows a weak dextrogyre rotation. The oil boils at $163^{\circ} \mathrm{C}$. After having kept it for two years and a half in a well-stopped bottle, we find that it has become considerably thicker and now deviates to the right. If saturated with dry hydrochloric acid, the oil does not yield a solid compound.

This oil has nearly the same agreeable odour as the cride oleoresin, yet the essential oil of the cones of the same tree is still more fragrant. The latter is one of the most powerfully deviating oils, the rotation being $51^{\circ}$ to the left, and it is consequently extremely different from the oil obtained from the turpentine of the stem, though its composition is represented by the same formula, $\mathrm{C}^{10} \mathrm{H}^{16}$.

A peculiar sugar called Abictitc, nearly related to mannite but having the composition, $\mathrm{C}^{12} \mathrm{H}^{16} \mathrm{O}^{6}$, laas been detected by Rochleder ${ }^{2}$ in the leaves of the Silver Fir.

Uses-Strassburg turpentine possesses the properties of common turpentine, with the advantage of a very agreeable odour. It was forrnerly held in great esteem, but has now become nearly forgotter.

\section{PIX BURGUNDICÁ.}

Pix abictina ; Burgundy Pitch ; F. Poix de Bourgogne ou des Vosges, Poix jaune; G. Fiehtenharz, Tannenharz.

Botanical Origin-Pinus Abics L. (Abics cxeclsa DC.), the Norway Spruce Fir, ${ }^{3}$ a noble tree attaining an elevation of $100-160$ feet, widely

1 Hence it is sometimes called in French Térébenthine au cition.

2 Wiggers and Husemann, Jahresberichl,

3 Pesse or Epicén of the Freuch; Fichle or 1868. 53 . 
distributed throughout Northern and the mountainous parts of Central Europe, but not indigenous to Great Britain, though extensively planter. In Russian Lapland, it reaches at $68^{\circ} \mathrm{N}$. lat., almost the extreme limit of tree-vegetation, while southward it extends to the Spanish Pyrenees. In the Alps, it ascends to 6000 feet above the level of the sea.

History-In accordance with the definition of the London Pharmacopcias and the custom' of English druggists, the name Burgundy Pitch is restricted to the product of the above-named species. The pharmacologists of France use an equivalent term with the same limitations ; but in other parts of the Continent, Pix Burgundica has a wider meaning, and is allowed to include the turpentines of other Coniferce. We here employ it in the Euglish sense.

Parkinson, an apothecary of London and herbarist to King Charles I., speaks of "Burgony Pitch" as a thing well known in his time." Dale in his Pharmacologia (1693) mentions Pix Burgundica as being imported into England from Germany, and it is also noticed by Salmon (1693), who says "it is brought to us out of Burgundy, Germany and other" places near Strasburgh." 2

Pomet, writing in Paris about the same period, discards the prefix Burgundy as a fiction, remarking that the best Poix grasse comes from Holland and Strassburg. ${ }^{3}$

Whether this resin ever was collected in Burgundy, we are unable to determine. It may probably have acquired the name through having been brought into commerce from Switzerland and Alsace, by way of Franche Comté, otherwise called Comté de Bourgogne or Haute Bourgogne. ${ }^{4}$

Burgundy pitch is enumerated among the materia medica of the London Pharmacopoeia of 1677 , and in every subsequent edition. In that of 1809 , it was defined under the name of Pix arida, as the prepared resin of Pinus. Abies.

Production-Burgundy pitch is produced in Finland, in the Black Forest in the Grand Duchy of Baden, Austria and Switzerland. On the estate of Baron Linder at Svarta near Helsingfors, it is obtained by melting the crude resin in contact with the vapour of water, and straining. The quantity annually produced there, was stated in 1867 to be 35,000 kilogr. $(689 \mathrm{cwt} \text {. })^{5}$; that afforded by an establishment at $\mathrm{Ilm}$ in the same country, amounted to 80,000 kilogr. (157j crvt.). ${ }^{6}$

In the neighbourhood of Oppenau and on the Kniebis mountain in the Grand Duchy of Baden, the stems of the firs are wounded at equal distances by making perpendicular channels, $1 \frac{1}{2}$ inches wide and the same in depth. The resin which exudes from these cliannels, is scraped off with an iron instrument made for the purpose, and purified by being melted in hot water, and strained. This is performed in three or four sinall establishments at Oppenau and the neighbouring village of Löcherberg. In this state the resin, which is opaque and contains much

1 Theater of Plants, 1640. 1542.

2 Compleal English Plyysiciun, 1693. 1031. 287

3 Hist. des Drogues, Paris, 1694. part i.

4 Chabreus in his Stirpium Sciagraphia (1666), remarks that he had seen the Pesse
[P. Abies L.] in great plenty " in Burgundieis montibus," yet makes no particular allusion to it yielding resin.

5 Pharm. Journ. ix. (1867) 164.

'Oesterreichischer Ausstellungs - Bericht. $\mathrm{x}$ (Wien, 1868) 471 . 


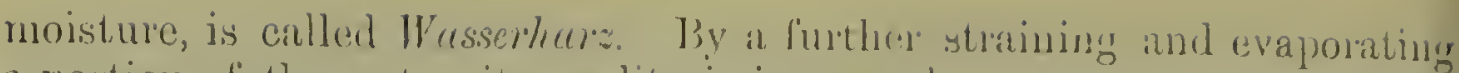
a portion of the water, its quality is impruved.

'The manufiacture in that pat of Genmany js on the decline, partly in consequenee of the timber being injured by the wommling of the trees. so that the collecting of resin is not pernitted in the lange forests belonging to the governments of Baden and IV in remberes. II (z have had the opportmity of observing ${ }^{1}$ that in the estahlishonents in question,

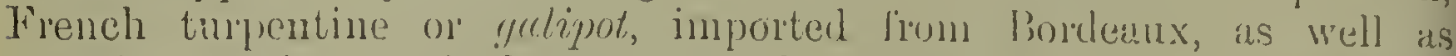
American rosin or colophony, are used in quantities certainly excesding that of the resin grown on the spot.

In the midale of the last century, some Bumbudy piteh was produced, according to Duhanel ${ }^{2}$ in the present canton of Neuchâtrel, but no such branch of industry is now pursued there, at least on a linge scale. On the othey hand, in the districts of Moutier and I elénont in the Berllese Jura, this resin is still collected though it is not known as Burgundy Pitch, but is termed simply Poix blanchc (White Pitch). The surveyor of the forests of this district, which is one of the richest in Pinus Abies, has informed one of us that from 790 to 850 quintals are collested, and exported to Basle, Zürich, Aarau and Vaud. The pitch is worth in loco (1S68), 100 to 110 francs ( $£ 4$ to $£ 48$ s.) the bossc of 6 quintals. The quantities collected in otler parts of switzerland are even less considerable.

Description-Pure Bursundy pitch, of which we have numerous anthentic specinens, is a rather opaque, yellowish-brown substance, had and brittle when cold, yet gradually taking the form of the vessel in which it is kept. It is strongly adhesive, breaks with a clear conchoidal fracture, and has a very agreeable, aromatic odour, especially when lieated. It does not exhibit a crystalline structure, although, as we have frequently observed, the resin on the stem of the tree is distinctly crystalline.

Burgundy pitch is readily soluble in glacial acetrc acid, acetone, absolute alcohol, and even in alcohol of 75 per cent. (sp. gr. 0.860), jet its solubility in these liquids is considerably altered by the presence of water or essential oil ; and still more by the formation of abietic acid in the resin itsell.' The same influences also affect the melting point.

The crude resin of Pinus Abies, ${ }^{3}$ deprived of essential oil and dissolved in one part of absolute alcohol, was found to deriate a ray of polarized light $3^{\circ}$ to the left, in a column of $50 \mathrm{~mm}$; the essential oil deviated $8.5^{\circ}$ to the same direction. The oil contains a small amount of an oxygenated oil. After treatment with sodium, the oil which remains does not form a solid compound if saturated with hydrochloric acid.

Chemical Composition-The investigations of Maly mentioned at p. 548 afford a satisfactory elucidation of the chemical properties of the pinic resinous exudations. They all, according to that cliemist, are mixtures of the sante amorphons resin, $\mathrm{C}^{4+} \mathrm{H}^{62} \mathrm{O}^{4}$, with essential oils of the composition $\mathrm{C}^{10} \mathrm{II}^{16}$. These terebinthinous juices are collected and sold either in their natural state as turpcintine, or deprived more or less completely of their volatile oil, in which condition they are represented by Buryundy Pitch, and finally by rosin or colophony.

1 I spent several days in the localities in 1873.-F'. A. H.
2 Traite des alobes, etc. i. (1755) 12.

3 Collected ly mysill.-F. A. I 
The turpentines Howing rown the stems of the trees, gradually lose their transparency if allowed to dry slowly in the air, becoming at the same time harder and somewhat granulnr. This alteration is due to the incorporation of water, which at last is not only mixed with the components of the resinous juice, but to some extent combines chemically with the resin so as to transform it into a crystalline body having the characters of an acicz. The fact is easily observed if clear drops of the turpentine of Pinus silvestris, P. Abies or P. Picea are collected in vials and kept perfectly dry. Thus treated, these turpentines remain transparent, but the additiou of water causes after a short time the formation of microscopic crystals of abietic acid, rendering them more or less opaque.

If turpentines are collected before they lose their essential oil by evaporation and oxidation, and before they have become crystalline, they can be retained perfectly transparent by distilling off the volatile oil without water. The distillation being most commonly carried on with watcr, the remaining resin is opaque.

Maly is of opinion that the same amorphous resin occurs in all the Coniferce, and that it yields by hydration the same acid, nanely Abietic, which has been described by former chemists as Pinic, Sylvic and Pimaric acids, all of which indeed are admitted to have the same composition. We must however remember that several sorts of turpentine, as Canada Balsam, appear incapable, according to our experiments, of yielding any crystalliue resinoid compound whatever; and that their amorphous resin being but partially soluble, is certainly not a homogeneous substance.

The crystals as formed naturally in the common turpentines, do not exhibit precisely the same forms as those obtained artificially, when the resins are agitated with warm diluted alcohol, as in the preparation of abjetic acid. As to Pimaric Acid, we have prepared it in quantity from galipot, the resin of Pinus Pinaster, but have always found its crystalline character entirely different from that of abietic acid. ${ }^{1}$

We are inclined, therefore, to think that the composition of the resins of Conifcrce is not so uniform as Maly suggests. The remarkable variety of their essential oils is a fact which seems in favour of our view.

Uses-Burgundy pitch is prescribed as an ingredient of plasters, and thus employed is useful as a mild stimulant. In Germany, it has some economic applications, one of which is the lining of beer-casks, for which purpose a composition is used called Brauerpech (brewer's' pitch),

Adulteration-No drug is the subject of more adulteration than Burgundy pitch, so much so that the very name is understood by some pharmacologists to be that of a inanufactured compound. The substance commonly sold in England, is made by melting together colophony with palm oil or some other fat, water being stirred in to rendet the mixture opaque. In appearance it is very variable, different samples presenting different shades of bright or dull yellow or yellowish-brown.
Many when broken exhibit numerous cavities containing air or water'; all are more or less opaque, becoming in time transparent on the surface

1 Juhresbericht of Wiggers and Husemann for 1867. 37. 
by the loss of water. Artificial Burgundy pitch is offered for sale in bladders; it has a weak terebinthinous odour and is devoid of the peculiar fragrance of the grenuine. 'The presence of a fatty oil is easily discovered by treatment with double its weight of glacial acetic acid, which forms a turbid mixture, separating by repose into two layers, the upper being oily.

\section{PIX LIQUIDA.}

Wood Tar; F. Goudron véyélal, Poix liquide; G. Holathecr, Fichtentheer.

Botanical Origin-Tar is obtained by submitting the wood of the stems and roots of coniferous trees to dry or destructive distillation. That found in commerce is produced in Northern Europe, chiefly from two species, namely Pinus silvestris L. and P. Leclebourii Lindl. (Laris Sibirica Ledeb.) These trees constitute the vast forests of Arctic Europe and Asia.

History-Theophrastus gives a circumstantial description of the preparation of tar, which applies with considerable accuracy to the processes still practised in those districts where no improved methods of manufacture have yet been introduced.

Production-The great bulk of the vegetable tar used in Europe, and known in commerce as Archangel or Stockholm 'Tur, is prepared in Finland, Central and Northern Russia, and Sweden.

The process is conducted in the following manner:-vast stacks of pine wood consisting chiefly of the roots and lower portions of the trunks (the more valuable parts of the trees being used as timber), and containing as much as 30,000 to 70,000 cubic feet, are carefully packed together, and then covered with a thick layer of turf, moss, and earth, beaten down with heavy stampers. The whole stack of billets is coustructed over a conical or funnel-like cavity made in the ground, if possible on the side of a hill, this arrangement being adopted for the purpose of carrying on a downward distillation. Fire being applied, the combustion of the mass of wood has to be carried on very slowly and without flame, in order to obtain the due amount of tar, and a charcoal of good quality. During its progress, the products, chietly tar, collect in the funnel-like cavity, from which they are discharged by a tube into a cast-iron pan placed beneath the stack, or simply into hollow tree trunks. The tinne required for combustion varies from one to four weeks, according to the size of the stacis.

During the last few years, this rude process has been improved and accelerated by the introduction of rationally constructed wrought-irou stills, furnished with refrigerating condensers, as proposed in Russia by Hessel in 1861. By this mode of manufacture, the yield in tar of pine wood, is about 14 per cent. from stems, dried by exposure to the open air ; and 16 to 20 per cent. from roots. Large quantities of pyroligneous acid and oil of turpentine are at the same time secured. The wood of the beech and of other non-coniferous trees, appears not to afford more than 10 per cent. of tar, while turf yields only from 3 to 9 per cent.

Description-The mumerous empyreunatic products which result from the destructive distillation of pine wood, and which we call hur, 
constitute a dark brown or blackish seni-liquid substance, of peculiar odour and sharp taste. When deprived of water and seen in thin layers, tar is perfectly transparent. The magnifying glass shows some of the varieties to contain colourless crystals of Pyrocatechin, scattered throughout the dark viscid substance, and to these tar owes its occasionally granular, honey-like consistence. ${ }^{1}$ A gentle lieat causes them to melt and mix with the other constituents.

True vegetable tar has always a decidedly acid reaction. It is readily miscible with alcolıol, glacial acetic acid, ether, fixed and volatile oils, chloroform, benzol, anyylic alcohol or acetone. It is soluble in caustic alkaline solutions, but not in pure water or watery liquids. The sp. gr. of tar from the roots of conifers is about 1.06 (Hessel), yet at a somewhat elevated temperature, it becomes lighter than warm water.

Water agitated with tar acquires a light yellowish tint, and the taste and odour of tar, as well as an acid reaction. On evaporation the solution becomes brown, and at last microscopic crystals are obtained with a brown residue like tar itself, which is no longer soluble in water. A microscopical examination of tar which lias been exhausted with water, shows that all crystals liave clisappeired.

Chemical Composition-Try wood may be lieated to about $150^{\circ} \mathrm{C}$. without decomposition; but at a nore elevated temperature, it commences to undergo a change, yielding a large number of products, the nature and comparative quantity of which depend upon circumstances. If the process is carried on in a closed vessel, a residue will be got which has more or less resemblance to coal. By heating fir-wood enclosed with some water to $400^{\circ}$ C., Daubrée (1857) obtained a coallike substance, which yielded by a subsequent increase of temperature scarcely any volatile products.

The results are widely different if a process is followed whicli permits the formation of volatile bodies; and these substances are formed in largest proportion, if the leat acts quickly and intensely. At lower degrees of heat, more charcoal results and more water is evolved.

Among the volatile products of destructive distillation, those alone which are condensed at the ordinary temperature of the air are of pharmacentical interest; and of these, chiefly the portion not soluble in water, or that which is called Tar or Liquid Pitch. The aqueous portion of the products consists principally of empyremmatic acetic acid, to which tar owes its acid reaction.

The tissue of wood is chietly formed of cellulose, intimately combined with a saccharine substance, which may be separated if the wood is boiled with dilute acids. The remaining cellulose is however not yet pure, but is still uniter to a substance which, as shown by Erdmann, ${ }^{2}$ is capalble of yielding pyrocatechin.

It is well known that sugar subjected to an elevated temperature, yields a series of pyrogenous products ; and the same fact is observed if purified cellulose is heated in a similar manner. But for tar-making, wood is preferrer which is impregnated with resins and essential oils, and these latter furuish anotlier series of empyreumatic products. Fron

I The crystals are a pretty object for the microscope, when examined by polurized
light.
${ }^{2}$ Liebig, Annalen der Chemie u. Pharmacie, suppl. r. (1867) 229 . 
these circumstances, the emmponemts of woodtar are of an extremely complicated character, which is still more the case when other woods than those of conifors form part of the material submitted to distillation. In the case of beechwood, C'reasole is former, which is obtainad only in very smmll quantity from the Conifere. Volatile alkaloids and carbolic acid, which are largely prodneed in the destructive distillation of conl, appear not to be present in wood-tar.

The components of the latter may be considered under two heads: -first, the lighter aqueons portion, which separates from the other procincts of distillation, forming what is called Impure Pyroligneous Acid. 'l'his contains chiefly acetic acid and Methyl Alcohol or Wood Nuphtha, CH${ }^{4} \mathrm{O}$; Acctone, $\mathrm{C}^{3} \mathrm{H}^{6} \mathrm{O} ;$ Mesit, $\mathrm{C}^{6} \mathrm{H}^{12} \mathrm{O}^{2}$; Furfurol, ${ }^{1} \mathrm{C}^{5} \mathrm{H}^{4} \mathrm{O}^{2}$; besides other liquid products abundantly soluble in water and acetic acid. In this portion, some pyrocatechin also occurs.

The second cliss of pyrogenous products of wood, consists of an homologous series of liquid hydrocarbons, sparingly soluble in water, and which therefore are chiefly retained in the heavy layer below the pyroligneous acid, forming the proper wood-tar. The liquid in question furnishes the following compounds:- Toluol or Toluene $\mathrm{C}^{7} \mathrm{O}^{8}$ (boiling point $114^{\circ} \mathrm{C}$.), Eylene $\mathrm{C}^{8} \mathrm{H}^{10}$, Cumol or Cumene $\mathrm{C}^{9} \mathrm{H}^{12}\left(148^{\circ} \mathrm{C}.\right)$, Methol $\mathrm{C}^{9} \mathrm{H}^{12}\left(160^{\circ}.\right)$

The wood of the beech which is employed in some comntries for making tar yields Creasote, consisting chiefly of $C^{r}$ cosol $\mathrm{C}^{8} \mathrm{H}^{10} \mathrm{O}^{2}$, boiling at $219^{\circ} \mathrm{C}$.; while that of the pine affords some oil of turpentine or pyrogenous oils of the same formula. Besides all these well-defined bodies, tar contains sereral less known and not yet perfectly isolated compounds, such as Capnomor, Eupione, Assamar \&c.

If tar is redistilled, an elevated temperature being used torards the end of the process, some crystallizable solid bodies are obtained, the most important of which is that called Parafin, having the formula $\mathrm{C}^{\mathrm{n}} \mathrm{H}^{2 \mathrm{n}}, n$ varying from 20 to 24. Naphthalene, $\mathrm{C}^{10} \mathrm{H}^{8}$, and Anthracene $\mathrm{C}^{14} \mathrm{H}^{10}$, also occur under the same circumstances.

The crystals already mentioned as occurring in tar are Pyrocatechin. They are easily sublimed at some degrees above their fusing point $\left(111^{\circ} \mathrm{C}\right.$.), or removed by acetic acid, in which as well as in water they are readily soluble. Hence in some sorts of tar this substance does not occur, it having probably been removed by water.

Pyrocatechin, $\mathrm{C}^{6} \mathrm{H}^{6} \mathrm{O}^{2}$, can be obtained by the destructive distillation of many other substances, as catechu, kino, the extracts of rhatany and bearberry leaves, and other extracts rich in that form of tamnin which produces grecnish (not blue-black) precipitates in salts of iron. It is extracter from the granular sorts of wood-tar, by exposing them at a proper temperature to a current of heated dry air, or by exhausting them with water. Ether when shaken with the concentrated aqueous solution aud left to evaporate, leaves colourless crystals of pyrocatechin which after purification are devoid of acid reaction. Thoy have a peculiar wurning persistent taste, and are very pungent and irritating when allowed to evaporate. A solution of pyrocatechin yields with perchloride of iron, a dark green coloration changing to black after a few noments,

1 This anomatic liquid being found in the drstructive listillation of sugar, it is very probable that it must also exist among tle products of wood, as pine timber contains cellulose combined with sugar. 
and becoming red on the addition of potash. This mixture finally acquires a magnificent violet hue, like a solution of alkaline permanganate. To alteration is produced in a solution of pyrocateclin by protosalts of iron.

Among the few medicinal preparations of tar, is Tar Water, called Aqua vel Liquor Picis, made by agitating wood-tar with water. The presence in it of pyrocatechin is easily proved by the above-mentioned reactions, or by a few drops of red chromate of potassium which produces a brownish black coloration. It may hence be inferred that pyrocatechin is perhaps the active ingredient in tar-water, and that for making this liquid, the granular, crystalline sorts of tar should be preferred. ${ }^{1}$

Commerce-Tar as well as pitch is manufactured in Finland, and shipped from various ports in the Gulf of Bothnia, as Uleaborg, Gamla Carleby, Jacobstaci, Ny Carleby and Christinestad; also from Archangel and Onega on the White Sea. Some tar is also produced in Volhynia, and finds its way by the Dnieper to the Black Sea.

The North of Sweden likewise produces tar, chiefly about Umea and Lulea, the distillation being now performed in well-constructed apparatus of iron.

The pine forests of North America affurd tar and pitch. Wilmington in North Carolina exported in 1871, 25,260 barrels of tar, and 3788 barrels of pitch. ${ }^{2}$

The imports of tar into the United Kingdom in 1872, were 189,291 barrels, valued at $£ 218,339$. Of this quantity, 145,483 barrels were shipped from the northern ports of Russia.

The barrels in which tar arrives hold about 30 gallons. Smaller sized vessels termed half-barrels are also used, though less frequently.

Uses-In medicine of no great importance: an cintment of tar is a common remedy in cutaneous diseases, and tar water is sometimes taken internally. The consumption of tar in ship-building and for the preservation of fences, sufficiently explains the large importations.

\section{Other Varieties of Tar.}

Inniper Tar, Pyroleum Oxycedri, Oleum Juniperi empyreumaticum, Oleum Cadinum, Huite de Cade.-This is a tar originally obtained by the destructive distillation of the wood of the Cade, Juniperus Oxycedrus L., a shrub or small tree, native of the countries bordering the Mediterranean. It was formerly used in the South of France as an external remedy, chiefly for domestic animals, but had fallen into complete ollivion until a few year's ago, when it hegan to be prescribed in skin complaints.

The Huile de Cade now in use, is transparent and devoid of crystals. It is somewhat thinner than Swedish tar, but closely agrees with it in other respects. It is imported from the Continent, but where made and fron what wood, we know not. Huile de Caule is mentioned by

We may suppose that the authors of the Freuch Corlex were not of this opinion, inasmuch as in making lau de Goudron, they orclel that the liquicl obtained lyy the first maceratiou of the tar, shall bo thrown uway.

2 Consul Walker, Report on the Trade of North and South Carolina-Consular Repurits presented to Parliament, May, 1872. 
Olivier de Scrres, ${ }^{1}$ a celebrated French writer on agriculture of the 1rith century ; it is named by l'arkinson ${ }^{2}$ in 1640 ; also by l'omet ${ }^{3}$ in whose time (1.694) it was limely gemune, common till being sold in its place.

Beech Tar-Tir is also manulinctured from the wood of the beech, Fagus sirutica I., and has a place in some pharnacoporias as the best source of creasote.

Birch Tar-is made to a small extent in Russia, where it is called Drgggt, from the wood of Bctula alba L. It contains an abundance of pyrocatechin, and is esteemed nu account of its peculiar odour well known in the Russia leather. A purified nil of birch tar is sold by the Leipzig distiller's.

\section{PIX NIGRA.}

Pix sicen vel solicta vel navalis; Pitch, Black Pitch; F. I'oixs noive; G. Schiffspech, Schustcrpech, Schwerzes Pech.

\section{Botanical Origin-see Pix liquida.}

Production-When the crude products of the dry distillation of pine wood, as described in the previous article, are submitted to re-distillation, the following results are obtained. The first 10 to 15 per cent. of volatile matter, consists chiefly of methylic alcohol and acetone. A higher temperature causes the vaporization of the acetic acid, while the still retains the tar. This last subjected to a further distillation, may be separated into a liquid portion called Oil of Tar (Oloum Picis liquidce). and a residuum which on cooling, hardens and forms the product under notice, namely Black Pitch. Again heated to a very elevated temperature, it is capable of yielding paraffin, anthracene and naphthalene.

Description - Pitch is an opaque-looking, black substance, breaking with a shining conchoidal fracture, the fragments showing at the thin translucent edges a brownish colonr. No trace of distinct crystallization is observable when very thin fragments are examined, even by polarized light. Pitch has a peculiar disagreeable odonr, rather different from tliat of tar. Its alcoholic solution has a feeble taste somewhat like that of tar, but pitch itself when masticated is almost tasteless. It softens by the warmth of the hand and may then be kneaded. It readily dissolves in thase liquids which are solvents of tar. Alcohol of 75 per cent. acts freely on it, leaving behind in small proportion a dark riscid residue. The brown solution reddens litmus paper, and yields a dingy brownish precipitate with perchloride of iron, and whitish precipitates with alcoliolic solution of neutral acetate of lead, or with pure water. Pitch dissolves in solution of caustic potash, evolving an offensive odour.

Chemical Composition-From the methor in which pitch is prepared, we may infer that it contains some of the less rolatile and less crystallizable compounds found in tar.

According to Völckel, the pitch of beechwood boiled with a caustic alkali, yields a foetid volatile oil ; when this solution is acidulated, fatty volatile acids are evolved. These principles however have not yet been

1 Théulre d Aqriculture, Paris, 1600. 941.

- Theatrum Bolanicum, 1033.

3 Irist. des Drogurs, Paris, 1694. part i. chap xii. xiv. 
isolated, either from the pitch of pine or beech, nor has any other constituent of the bulk of the drug been separated. The whitish compound formed by acetate of lead in an alcoholic solution of pitch deserves investigation, and perhaps might be the starting point for acquiring a better knowledge of the chemistry of this substance.

Commerce-The same countries that produce tar, produce also pitch. The quantity of the latter imported into the United Kingdom during 1872 was $35,482 \mathrm{cwt}$., four-fiftlis of which were supplied by Russia. Pitch is also manufactured from tar in Great Britain.

Uses-Pitch is occasionally administered in the form of pills, or externally as an ointment, but its medicinal properties are, to say the least, very questionable.

\section{FRUCTUS JUNIPERI.}

\section{Bacea vel Galbuli Juniperi; Juniper Berries; F. Baies de Genièvre; G. Wachtholierbeeren, Kuddigbeeren.}

Botanical Origin-Juniperus communis L., a diøecious evergreen, occurring in Europe from the Mediterranean to the Arctic regions and throughout Russian Asia; found also in North America. Dispersed over this vast area, the Common Juniper presents several varieties. In England and in the greater part of Eirrope, it forms a bushy shrub from 2. to 6 feet high; but in the interior of Norway and Sweden it becomes a small forest tree of 30 to 36 feet, often attaining an age of hundreds of years. ${ }^{1}$ In high momntain regions of temperate Europe and in Arctic countries, it assumes a decumbent habit (Juniperus nana Willd.), rising only a few inches above the soil.

History-The fruits of juniper, though by no means exclusively those of $J$. communis, were commonly used in medicine by the Greek and Koman, as well as by the Arabian physicians; and are mentioned in some of the earliest printed herbals. rThe oil was distilied by Schnellenberg $^{2}$ as early as 154.6 .

Popular uses were formerly assigned in various parts of Europe to juniper berries. They were employed as a spice to food; ${ }^{3}$ and a spirit, of which wormwood was an ingredient, was obtained from them by fermentation and distillation. This spirit called in French Genièvre, became known in English as Geneva, a name subsequently contracted into Gin."

Description-The flower's form minute axillary catkins; those of the female plant consist of 3 to 5 whorls of imbricated biacts. Of these, the uppermost three soon become fleshy and scale-like, and alternate with three upright ovules having an open pore at the apex. After the Hower's have faded, these three fleshy bracts grow together to form a berry-like fruit terned a galbulus, which encloses three seeds. The three points and sutures of the fruit-scales are conspicuous in the upper part of the young fruit; but after maturity the sutures alone are visible,

1 Scliibeler, C'ullurpoflenzen Norweyens, Christiania 186255.

2 Arlaneybuch, Königsbercs, 1556. 35.

3 Valmont de Bomale, Dict. d'Hist. nat. ii. $(1775) 45$.
4 The gin distilled in Holland is ftaroured with juniper berries, yet, as we are told, but very slightly, only $2 \mathrm{lb}$. being used to 100
gatluns. 
forming a depressed mark at its smmmit. A small point, surrounded by two or three trios of mimute bracts, indicates the base of the fruit.

This fruit or psendo-herry renains ovate and green during its first year, and it is not mutil the second antumn that it beconess riper. It is then spherical, ${ }_{10}^{3}$ to $\frac{4}{10}$ of an inch in diameter, of a deep purpulisls colour with a blue-grey hloom. Its internal structure nay he thins described:-beneatl the thin epicarp, there is a loose yellowish-hrown sarcocarp, enclosing large cavities, the oil-ducts; the three hard seeds lying close together, triangular and sharp-edged at the top, are attacherl to the sarcocin' at their onter sides and only as far as the lower half. The mpper half, which is fre, is covered by a thin membrane. In the longitudinal furrows of the hard testa towards the lower half of the seed, are small prominent sacs growing out into the sarcocarp. Each seerl bear's on its inner' side 1 or ' 2 , and on its convex outer surface, 4 to 8 of these sacs, which in old fruits contain the resinified oil in an amorphous colourless state.

Juniper berries when crushed have an aromatic odour and a spicy, sweetish, terebinthinous taste.

Microscopic Structure-The outer layer of the fruit consists of a colourless transparent cuticle, which covers a few rows of large cubic or tabular cells liaving thick, brown, porous walis. These cells contain a dark, granular substance and masses of resin. The sarcocarp, which in the ripe state consists of large, elliptic, thin-walled, loosely coherent cells, contaius chlorophyll, drops of essential oil and a crystalline substance soluble in alcohol,-no doubt a stearoptene. Before maturity, it likewise contains starch granules and large oil-cells. This tissue is traversed by very small vascular bundles containing amnulated and dotted vessels.

Chemical Composition-The most important constituent of juniper berries is the volatile oil, obtainable to the extent of 1 to 2 per cent. It is a mixture of two levogyre oils, the one of which having the composition $\mathrm{C}^{10} \mathrm{H}^{16}$, boils at $155^{\circ} \mathrm{C}$.; the other which predominates in the ripe fruit, lias the formula $\mathrm{C}^{20} \mathrm{H}^{32}$, and boils at $205^{\circ} \mathrm{C}$. The crude oil as distilled by one of ourselves, deviated $3^{\circ} .5$ to the left in a column of $50 \mathrm{inm}$.

The berries are rich in sugar (33 per cent., Trommsdorff $1822,-29$ per cent. Donath, 1873), and contain also according to Donath, small amounts of formic, acetic and malic acids, besides resil and a substance called Juniperin. This last, which exists in very small proportion, is soluble in hot water but uncrystallizable.

Collection and Commerce-Juniper berries are largely collected in Savoy, and in the clepartments of the Doubs and Jura in France, whence they find their way to the hands of the Geneva druggists. They are also gathered in Austria, the South of France and Italy. In Hamburis price-currents, they are quoted as German and Italian.

Uses-The berries and the essential oil obtained from them are rejuted diuretic, yet are not often prescribed in English medicine.

I The proxluce is sometimes much smaller; $245 \mathrm{lb}$. distilled by Messis. Allon and Hanburys, Pourgh Court, Lomhatditret, 8 II:y,
1868, yielled only $17 \frac{1}{2}$ ounees of essential oil, or 0.4 jer ecut. 


\section{HERBA SABINE.}

\section{Cacumina vel Summitates Sabince; Savin or Savine; F. Sabine; G. Seventircul.}

Botanical Origin-Juniperus Sabina L., a woody evergreen shrub, usually of small size and low-growing, spreading habit, but in some localities erect and arborescent.

It occurs in the Southern Alps of Austria and Switzerland, and in the adjacent mountains of France and Piedmont, ascending to elevations of 4000 to 5000 feet. It is also found in the Pyrenees, Central Spain, Italy and the Crimea; likewise in the Caucasus, where it r'caches 12,000 feet above the sea level. Eastward, it extends to the Elbur's range south of the Caspian, and throughout Southern Siberia. In Nortli America, it has been gathered on the banks of the river Saskatchewan, at Lake Huron and in Newfoundland.

History-Savin is mentioned as a veterinary drug by Marcus Porcius Cato, ${ }^{1}$ a Roman writer on husbandry who flourished in the second century B.C. ; and it was well known to Dioscorides and Pliny. The plant which is frequently named in the early English leech-books written before the Norman Conquest, ${ }^{2}$ may probably have been introduced into Britain by the Romans. Charlemagne ordered that it should be cultivated on the imperial farns of Central Europe. Its virtues as a stimulating application to wounds and ulcers are noticed in the verses of Macer Floridus, ${ }^{3}$ composed in the 10 th century.

Description-The medicinal part of savin is the young and tender green shoots, stripped from the more woody twigs and branches. These are clothed with minute scale-like rhomboid leaves, arranged alternately in opposite pairs. On the younger twigs, they are closely adpressed, thick, concave, rounded on the back, in the middle of which is a conspicuous depressed oil gland. As the shoots grow oliter', the leaves become more pointed, and divergent from the stem. Savin evolves when rubbed or bruised, a strong and not disagreeable odour. The fruit or galbulus resembling a small berry of the size of a pea, grows on a short recurved stalk, and is covered with a blue bloom. It is globular, dry, but abounding in essential oil, and contains 1 to 4 little bony nuts.

Chemistry-The odour of savin is due to an essential oil, of which the fresh tops afford 2 to $2 \frac{3}{4}$ per cent., and the berries about 10 per cent. Examined in a colimm 50 millimetres long, it was formd to deviate the ray of polarized light $27^{\circ}$ to the right, the oil nsed having been distilled by one of us in London from the fresh plant cultivated at Mitcharn. The same result was obtained from the oil extracted ten year's previously from savin collected wild on the Alps of the Canton de Vaud. We find that by the prolonged action of the air, if the oil is liept in a ressel not carefully closed, the rotatory power after the lapse of years is greatly reduced. Savin oil has the same composition as oil of turpentine; we have not been able to obtain from it a crystallizerl lyydrochloride. Savin tops contain traces of tannic matter.

1 Cap. 1xx. (Bubus medicamentum).

2 Cockarne, Leechdoms, dec. of Early lingland, ii. (1865) xii.
3 Choulant, Macer Filoridus de virilus her. barum, Lipsia, 1832. 48. 
Uses-Sivin is a powerlul nterine stimulant, producing in overdoses very serions effects. It is but larely administered internally. An ointment of savin, which from the chlorophyll it contains is of a tine green colour, is used as a stimulating chessing for blisters.

Substitutes-There are several species of juniper which have a considerable resemblance to savin; and one of them, commonly grown in gardens and shrubberies, is sometines mistaken for' it. 'This is Juniperus Virginiana L., the Ried Cedar or Savin of North Anerica. In its native country it is a tree, attaining a height of 50 feet or more, but in Britain it is seldom more than a large shrub, of loose spreading growth, very different from the low, compact liabit of savin. ${ }^{1}$ The foliage is of two sorts, consisting either of minute, scale-like, rhomboid leaves like those of savin, more rarely of elongated, sharp, divergent leaves, a quarter of an inch in length, resembling those of Common Juniper. Both forms often occur on the same branch. The plant is much less rich in essential oil than true savin ${ }^{2}$ for which it is sometimes substituted in the United States.

The foliage of Juniperus Plocnicea L, a Mediterranean species, has a considerable resemblance to savin for which it is sometimes substituted, ${ }^{3}$ but it is quite destitute of the peculiar odour of the latter.

I We have examined numerous herbarium specimens (wild) of $J$. Virginiana and $J$. Sabina, but except difierence of stature and habit, can observe scarcely any characters for separating them as species. The fruit-stalk in $J$. Virginiana is often pendulous as in $J$. Sabina. Each plant has two forms, -arboreous and fruticose.
2 This we ascertained by distilling under precisély similar conditions $6 \mathrm{fb} .6 \mathrm{oz}$. of the fresh shoots of each of the tro plants, Juniperus Sabina and $J$. Virginiana: the first gave 9 drachms of essential oil, the second only $\frac{1}{2}$ a drachm. The latter was of a distinct and more feeble odour, and a different dextrogyre power.

3 Bonplandia x. (1862) 55. 


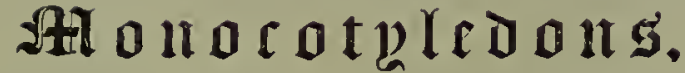

\author{
CANNACEA.
}

\section{AMYLUM MARANTES.}

Arrouroot.

Botanical Origin - Naranta arundinacea L. - An herbaceous branching plant, 4 to 6 feet high, with ovate-lanceolate, puberulous or nearly glabrous leaves, and small white flowers, solitary or in lax racemes. It is a native of the tropical parts of America from Mexico to Brazil, and of the West Indian Islands; and under the slightly different form known as $M$. indica Tussac, it occurs in Bengal, Java and the Philippines. This Asiatic variety is now found in the West Indies and Tropical America, but apparently as an introduced plant: ${ }^{1}$

History - The history of arrowroot is comparatively recent. Passing over some early references of French writers on the West Indies to an Herbe aux flèches, which plant it is impossible to identify with Maranta, we find in Sloane's catalogue of Jamaica plants (1696), Cañica Indica radice alba alcxipharmicaca. This plant discovered in Dominica, was sent thence to Barbados and sibsequently to Jamaica, it being, says Sloane, "very much esteemed for its alcxiphiarmack qualities." It was observed, he adds, that the native Indians used the root of the plant with success against the poison of their arrows, "by only mashing and applying it to the poison'd v:ounds": and further, that it cures the poison of the manchineel (Hippomane Mancinclla L.), of the wasps of Guadaloupe, and even stops "a begun gangreen." "2

Patrick Browne (1756) notices the reputed alexipharmic virtues of Maranta, which was then cultivated in many gardens in Jamaica, and says that the root "washed, pounded fine and bleached, makes a finc. flour and starch," - sometimes used as food when provisions are scarce."

1 We aceept the opinion of Koninive (Monoyraghia: Marantermem Prodromis, Bull. de lo. Soc. imp. des Naturalistes de Moscone, Xxxv. 1862, i.) that Merranta armedinacer $\mathrm{T}$. and $M$. indiea Tuss, are ons: and the same speeies. Grisebach mintains them as distinet (Fifora of the British West Indian Istands, 1864, 605), allowing both to be natives of Propieal Aneriea; but he fails to point out any important character hy whirh they may be distinguished from careh other. Aceorling to Mipuel (Limace xviii. 1844. 71) the plant in the herbarinm of Iinnaus labelled $M$; arundinaicr, is $M$ indica. We have omselves made ariowroot from the fresh rhizomes of $\lambda$. arnendinacer, in order to comprare it with an anthentic specimen obtained in Java from $M I$. indica : no difference could be found between them.

2 Sloane, Catal. plant. qua in ins. Jamaica spontc proveniunt, vel vulgò coluntur, Lond. 1696. 122 ; also Hist. of Jamaica, i. (1707)
253.

3 Civil and Nutural History of Jamaica, 1756.112 .113 
Hughes, when writing of Barharlos in 1750 , desromes arowroot as a very useful plant, the juice mixed with water and drunk, being regarder as "a preservative ayninst uny poison of ron hot malure"; while from the root the finest starch is male, far excelling that of wheat." The properties of Marantre armolinacce as a commer-poison are insister upon at some length by Imman," who concludes his notice of the plant by detailing the process for extracting starch from the rhizonic.

Arrowrnot came into use in England about the conmencement of the present century, the supplies being obtainer, as it would appear, from Jannaica."

The statements of Sloane, which are confirmed by Browne and Juman, plainly indicate the origin and meaning of the word arrowroot, and disprove the notion of the learned C. F. Ph. von Martius. (1867) that the name is derived from that of the Aruac or Aroaquis Indians of South America, who call the finest sort of fecula they obtain from the Mandioc: Aru-aru. It is true that Maranta arundinacee is known at the present day in Brazil as Araruta, but the name is certainly a corruption of the English word arrowroot, the plant according to general report having been introduced. ${ }^{4}$

Manufacture-For the procluction of arrowroot, the rlizonies are dug up after the plant has attained its complete maturity, which in Georgia is at the beginning of winter. The scales which 'cover them are removed and the rhizomes washed; the latter are then ground in a mill, and the pulp is washed on sieves, or in washing machines constructed for the purpose, in order to remove from it the starch. This is allowed to settle down in pure water, is then drained and finally dried with a gentle heat. Instead of being crushed in a mill, the rhizomes are sometimes grated to a pulp by a rasping machine.

In all stages of the process for making arrowroot, nice precantions have to be taken to avoid contamination with dust, iron mould, insects, or anything which can inpart colour or taste to the product. The rlizome contains about 68 per cent. of water, and yields about a fifth of its weight of starch. ${ }^{5}$

Description-Arrowroot is a brilliant white, insipid, inodorous powder, more or less aggregated iuto lumps which seldom exceed a pea in size; when pressed, it emits a slight crackling sound. It exhibits the general properties of starch, consisting entirely of granules which are subspherical, or broadly and irregularly egg-shaped; when seen in water they show a distinct stratification in the form of fine concentric rings around a small star-like hilum. They have a diameter of 5 to $7 \mathrm{mkm}$. when observed in the air or under benzol. If the water in which they lie be cantiously heated on the object-stage of the microscope, the turnefaction of the granules will be found to begin exactly at $70^{\circ} \mathrm{C}$.

1 Natural History of Barbados, 1750.221.

2 Hortus Jamaicensis, i. (1814) 30.

3 Thus in 1798 , there were exported from Jamaica 24 casks and boxes of "Indien Arrow-ront." - Renny, Jist. of Jamaica, 235.

4 Since the ahove was written, the followiug lines bearing on this question have been received from Mr. Spruce :- ". . 1 kun not Jiartius' derivation of 'arrowroot.' On the
Amazon, it is called 'ararute'-plainly a corruption of the English name, and explaimed by the fact that it was first cultivated, as I was told, from tubers obtained in the East Inclies."

5 This was in the German colony of Blumenan in Sontheru Brazil-Eberluarl, Arch. der Plarm. 134 (1868) 257. 
Heated to $100^{\circ} \mathrm{C}$. with 20 parts of distilled water, arrowroot yields a semitransparent jelly of somewhat earthy taste and smell. By hydrochloric acid of sp. gr. 1.06, arrowroot is but imperfectly dissolved at $40^{\circ} \mathrm{C}$.

The specific gravity of all varieties of starch is affected by the water which they retain at the ordinary temperature of the air. Arrowroot after prolonged exposure to an atmosphere of average moisture, and then kept at $100^{\circ} \mathrm{C}$. till its weight was constant, was found to have lost $13 \cdot 3$ per cent. of water. On subsequent exposure to the air, it regained its former proportion of water.

Weighed in any liquid which is entirely devoid of action on starch, as petroleum or benzol, the sp. grr. of arrowroot was found by one of ns to be 1.504 ; but 1.565 when the powder had been previously dried at $100^{\circ} \mathrm{C}$.

Microscopic Structure of Arrowroot and of Starch in general. - The granules are built up of layers, - a structure which may be rendered evident by the gradual action of chloride of calcium, chromic acid, or an ammoniacal solution of cupric oxide. When one of these liquids in a proper state of dilution is made to act upon starch, or when for that purpose a linquid is chosen which does not act upon it energetically, such as diastase, bile, pepsin, or saliva, it is easy to obtain a residue, which according to Nïgeli, is no longer capable of swelling up in boiling water, nor is immediately turned blue by iodine, except on the addition of snlphuric acid; but which is dissolved by ammoniacal cmpric oxide. These are the essential properties of cellulose; and this residue has been regarded as such by Nägeli, while the dissolved portion has been distinguished as Granulose (Maschke, 1852).

Nägeli in his important monograph on starch, ${ }^{1}$ has described the action of saliva when digested with starch for a day, at a temperature of $40^{\circ}$ to $\pm 7^{\circ} \mathrm{C}$; he says that the residue is a skeleton, corresponding in form to the original grain but somewhat smaller, light, and very mobile in water. He concludes that its interstitial spaces must have been previously filled with granulose.

This experiment which has been repeated by one of us (F.), does not in our opinion warrant all the inferences that Nägeli has drawn from it: it is true that many separate parts of the grain are dissolvel by the saliva, while otbers have disappeared down to a mere filn, and others again have been attacked in a very irregular manner. But we cannot asree with the statement that anything comparable to a skeleton of the hrain has been left. After longer action at a higher tenperature, which however nust not exceed $65^{\circ} \mathrm{C}$, a more copious dissolution of the starch either by saliva or by bile, takes place; but in no case is it
complete.

Chemistry of Starch-The formula, $\mathrm{C}^{6} \mathrm{H}^{10} \mathrm{O}^{5}$, is commonly assigned to starch, from whatever plant derived. Nusculus lowever showed in 1861, that by the action of dilute acids or of Diastose, starch is resolved into Dextrine, $\mathrm{C}^{12} \mathrm{H}^{20} \mathrm{O}^{10}$, and Dextrose, $\mathrm{C}^{6} \mathrm{H}^{12} \mathrm{O}^{6}$, with which decomposition, the formula, $\mathrm{C}^{18} \mathrm{H}^{30} \mathrm{O}^{15}$, would be more in accord.

Cold water is not withont action on starch: if the latter be con-

1 Die Slürlenkörner, Ziurich. 1858. 4".

2 Further particulars on this question may be found in my paper Ucber Slälle und Cei.

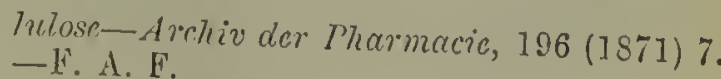


tinnonsly nitnated with it, the filtrate, in which no particles can be detected by the mineroscope, will assume a blue colom on addition of iodine, without the formation of a precipitate. 'The proportion of starch thus bronght into solution is infinitely small, and always at the expense of the integrity of the grains. It is even probable that the solution in this case is rue to the minute amomnt of heat, which must of necessity he developed by the trituration.

Certain reagents calpable of attacking starch, act upon it in very different ways. 'l'he action in the cold of concentrated arqueons solntions of easily soluble neutral silts or of chloral lydrate is remarkable. l'otassimm bromide or iodide, or calcim chloride for instance, cause the grains to sivell, and render them soluble in cold water. At a certain degree of dilution, a perfectly clear liquid is formed, which at first contains neither dextrin nor sugar; it is coloured blue but is not precipitated by iodine water; and starch can be thrown down from it by alcoliol. This precipitate, though entirely devoid of the structural peculiarity of starch, still exhibits some of the leading properties of that substance; it is colonued in the same manner by iodine, does not dissolve even when fresh in ammoniacal cupric oxide, and after drying, is insoluble in water whether cold or boiling. 'The jrogress of the solvent is most easily traced when calcium chloride is used, as this salt acts more slowly than the others we have mentioned. It leaves scarcely any perceptible residue. This fact in our opinion militates against the notion that starch is composed of a peculiar amylaceous substance, deposited within a skeleton of cellulose.

The remarkable action of iodine upon starch was discovered in 1814 by Colin and Gaultier de Claubry It is extrenrely different in degree according to the peculiar kind of starch, the proportion of iodine, and the nature of the substance the grains are impregnated with, before or after their treatment with iodine. The action is even entirely arrested (no blue colour being produced) by the presence in certain proportion of quinine, tannin, A'qua picis, and of other borlies.

The combination of iodine with starch does not take place in equivalent proportions, and is moreover easily overcome by heat. The iodine combined with starch amounts at the utmost to $7 \cdot 5$ per cent. The compound is most readily formed in the presence of water, and then produces a deep indigo blue. Almost all other substances capable of penetrating starch grains, weaken the colour of the iodine compound to violet, reddish yellow, yellow or greenish blue. These different shades, the production of which has been described by Nägeli with great diffuseness, are merely the colours which belong to iodine itself in the solid, liquid or gaseous form. They must be referred to the fact that the particles of iodine diffuse themselves in a peculiar but hitherto nuexplained manner, within the grain or in the swollen and dissolved starch.

Commerce of Arrowroot-The chief kinds of arrowroot found in commerce are known as Bermuda, St. Vincent, and Natal; but that of Jamaica and other West India Islands, of Brazil, Sierra Leone and the East Indies are quoted in price-currents, at least occasionally. Of these, the Bermuda enjoys the highest reputation and commands by far the highest price; bitt its good quality is shared by the arrowroot of other localities, from which when equally pure, it can in nowise be distinguished. 
The importations of arrowront into the United Kingdom during the year 1870 , amounted to 21,770 cwt., value $\$ 33,063$. Of this quantity, the island of St. Vincent in the IVest Indies furmished nearly 17,000 cwt., and the colony of Natal about $3000 \mathrm{cwt}$. The inanufacture of arrowroot in the Mest India Islands appears to be on the decline, and the Bermudas in particular, now ship but an insignificant quantity. ${ }^{1}$

Uses-Arrowront boiled with water or milk is a mnch-valued food in the sick-room. It is also an agreeable article of diet in the form of pudding or blancmange.

Adulteration-Other starches than that of Maranta are occasionally sold under the name of Arrownoot. Their recognition is only possible by the aid of the microscope.

\section{Substitutes for Arrowroot.}

Potato Starch-This substance known in trade as Farina or Potato Flour is marle from the tuber's of the potato (Solcmum tuberosum L.) by a process analogous to that followed in the preparation of arrowroot. It has the following characters:-examined under the nicroscope, the granules are seen to be chiefly of two sorts, the first small and spherical, the second of much larger size, often $100 \mathrm{mkm}$. in length, having an irregularly circular, oval or egg-shaped outline, finely marked with concentric rings round a minute inconspicuous hilum. When heated in water, the grains swell considerably even at $60^{\circ} \mathrm{C}$. Hydrochloric acid, sp. gr. 1.06, dissolves them at $40^{\circ} \mathrm{C}$. quickly and almost completely, the granules being no longer deposited, as in the case of arrowroot similarly treated. The mixture of arrowroot and hydrochloric acid is inodorous, but that of potato starch has a peculiar though not powerful odorur.

Canna Starch, Tous-les-Mois, ${ }^{2}$ Toulema, Tolomane-A species of Canna is cultivated in the West India Islands, especially St. Kitts, for the sake of a peculiar starch which, since about the year 1836, has been extracted from its rhizomes by a process sinnilar to that adopted in making arrowroot. The specific nane of the plant is still undetermined : though we have obtained living roots from St. Kitts, and have cultivated the plant for several years, it has not hitherto flowered, and the foliage affords no characters sufficient for distinguishing the species.

The starch, which bears the same name as the plant, is a dull white powder, laving a peculiar satiny or lustrous aspect, by reason of the extraordinary magnitude of the starch granules of which it is composed. These gramules examined under the microscope, are seen to be flattened and of irregular form, as circular, oval, oblong, or oval-truncate. The centre of the numerous concentric rings with which each granule is marked, is usually at one end rather than in the centre of a granule. The hilum is inconspicuous. The granules though far larger than those of

1 In the year 1868, only 60 cwt., in 1869 , $91 \mathrm{cwt}$.

2 It is commonly stated that the nane Tous-les-mois was given in consequence of the plant flowering all the year round. But this explanation applears inprobable: no such name is mentimed by Rochefort, Aublet, or Deceourtilz, who all descrihe the Batisior or Canna. It seems more likely that the term is the result of an attempt to confer a meaning on an ancient name-perhaps Touloula, which is one of the Carib designations for C'enma and Calathea. 
the potato, are of the same lensity as the smaller forms of that starch, and like them, float perfietly on chloroform. When heaterl, they hegin to burst at $72^{\circ} \mathrm{C}$. I)ilnte liydrochloric acid acts 11 on then as it does onl arlouwroot.

Canna starch boiled with 20 times its weight of water, afforrls a jelly less clear and nore teniacious thian that of arrownot, yet applicable in exactly the sane purposes. The starch is producer on a very small scale, and is but little known and not much esteemer in Finrope.

Curcuma Strinch, Tilior, Thifher. - The penchulons, colourless tnber's of some species of C'urcuma, bnt especially of $C$. angustifolia Roxb). and C. lencomriza Roxb., have long been utilized in Sonthen India for the preparation of a sort of arrowroot, known by the Hinlustani name of Tikihar, and sometimes called by Europealis, Eust Indirin Arrouroot. ${ }^{2}$ 'The gramules of this substance much resemble those of Marantr, lut they are neither spherical nor egg-shaped. On the contrary, they are rather to be described as flat discs, 5 to $7 \mathrm{mkm}$. thick, of elliptic or ovoir outline, sometimes truncate; many attain a length of 60 to $70 \mathrm{mkm}$. They are always beautifully stratified both on the face and on the edge. The hilum is generally situated at the narrower end. We have observed that when heated in water, the tunefaction of the grains commences at $72^{\circ} \mathrm{C}$.

Curcuma starch, which in its general properties agrees with common arrowroot, is rather extensively manufactured in Travancore, Cochin and Canara on the south-western coast of India, but in a very rude manner. Drury $^{3}$ states that it is a favourite article of diet among the natives, and that it is exported from Travancore and Madras; we can add that it is not known as a special kind in the English market, and that the article we have seen offered in the London drug sales as East Indirn Arowroot, was the starch of Marantel.

\section{ZINGIBERACE $\mathrm{E}$.}

\section{RHIZOMA ZINGIBERIS.}

\section{Rudix Zingiberis; Ginger; F. Gingembre; G. Ingwer.}

Botanical Origin-Zingiber officinale Roscoe (A momum Zingiber L.), a reed-like plant, with ammual leafy stems, 3 to 4 feet high, and flowers in cone-shaped spikes borne on other stems thrown up from the rhizome. It is a native of Asia, in the warmer countries of which it is universally cultivated, ${ }^{4}$ but not known in a wild state. It has been introduced into most tropical countries, and is now found in the West Indies, South America, Tropical Western Africa, and Queensland in Anstralia.

History-Ginger has been known in India from the remotest times under the old Sanskrit name of Sringavera, from which lias been derived the Greek name Zıryißepı and the Latin Zingiber. As a spice it was

120 barrels from St. Kitts were oflered in public sale in I,ondon, $10 \mathrm{May}, 1871$, and bought in at $2 \frac{1}{2} d$. jer tb.

2 Living roots of the plant used for making this arrowroot at Cochiu, lave been kindly forwarded to us by A. L. Sealy, Lsy. of that place.

3 Viscul Plants of Indin, al. 2. 15\%3. 16 s.

4 The mode of cultivation is describel by Buchanan, Journey from dfactres, through Musore, clc, ii. (1sot) 409. 
used among the Greeks and Romans, who appear to have received it by way of the Red Sea, inasmuch as they considered it to be a production of Southern Arabia.

In the list of imports from the Red Sea into Alexandria, which in the second century of our era were there liable to the Roman fiscal duty (vcetigal), Zingiber occurs among other Indian spices. ${ }^{1}$ During the middle ages it is frequently mentioned in similiar lists, and evidently constituted an important item in the commercial relations between Europe and the East. Ginger thus appears in the tariff of duties levied at Acre in Palestine about A.D. $11.73 ;^{2}$ in that of Barcelona ${ }^{3}$ in 1221; Marseilles ${ }^{4}$ in 1228 ; and Paris ${ }^{5}$ in 1296. The Tarif des Péages, or customs tariff, of the Counts of Provence in the middle of the 13th century, provides for the levying of duty at the towns of Aix, Digne, Valensole, Tarascon, Avignon, Orgon, Arles, \&c., on various commodities imported from the East. These inciuded spices, as pepper, ginger, cloves, zedoary, galangal, cnbebs, saffron, "canella," cumin, anise ; dye stuffs, such as lac, indigo, Brazil wood, and especially alum; and groceries, as sugar, rice and dates. ${ }^{6}$

In England, ginger must have been tolerably well known even prior to the Norman Conquest, for it is frequently named in the AngloSaxon leech-books of the 11th century. During the 13th and 14th centuries, it was next to pepper, the commonest of spices, costing on an average nearly $1 s .7 d$. per $\mathrm{fb}$., or about the price of a sheep. ${ }^{7}$

The merchants of Italy about the middle of the 14 th century, knew three kinds of ginger, called respectively Belledi, Colombino, and Micchino. These terms may be explained thus:-Belledi or Baladi is an Arabic word, which as applied to ginger, would signify country or wild, i.e. common ginger. Colombino refers to Columbum, Kolam or Quilon, a port in Travancore frequently mentioned in the middle ages. Ginger termed Micchino, denotes that the spice had been brought from or by way of Mecca. ${ }^{8}$

Ginger preserved in syrup, and sometimes called Green Ginger, was also imported during the middle ages, and regarded as a delicacy of the choicest kind.

The plant affording ginger must have been known to Marco Polo (eirca 1280-90), who speaks of observing it both in China and India. John of Montecorvino, who visited India about 1292 (see p. 468), describes ginger as a plant like a flag, the root of which can be dug up and transported. Nicolo Conti in the beginning of the 15 th century also gave some description of the plant and of the collection of the root, as witnessed by him in India. ${ }^{9}$

The Venetians received ginger by way of Egypt; yet some of the superior kinds were conveyed from India overland by the Black Sea, as stated by Marino Sanudo ${ }^{10}$ about 1306 .

1 Vincent, Commeree and Nevigation of the Ancionts, ii. (1807) 695.

2 Recucil des Jistoricns des Croisudes; Lois, ii (1843) 176.

3 Capmany, Memorias solve la Marina, ele. de Bercelona, Madrid, ii. (1779) 3.

4 Méry et Guindon, ITist. des Actes.

de la Municipalité de Marseille, i. (1841) 372.

"Revue archéologique, ix. (185,2) 213.
${ }^{6}$ Collection de Cartulaires de Franee, l'aris, viii. (1857) pp. lxxiii-xci.

7 Rogers, Hist. of Agrioullure and Prices in England, i. (1S66) 629 . 316.

8 Yule, Bool of Ser Mareo Polo, ii. (1871)

See p. 469, note 3 .

${ }_{10}$ Marinus Santutus, Liber secrclorum fidelium crucis, Hanov. (1611) 22. 
Ginger was introduced into Ameriea ly Franciseo de Mendoca, who took it from the liast Intles to New Spain. It was shipped for commercial purposes from the islmo of St. Domingo as early at least as 1585; and from Barbados in 1 (654:" According to lienny, very large quantities were exported from the West Indies to spatin in 1547.

Description-Ginger je known in two forms, namely the rinzome dried with its epidermis, in which case it is called cocted"; or deprived of epidernis, and then termed seraped or uncorted. The pieces, which are called by the spice-dealers races or hand.s, rarely exceed 4 inches in length and have a somewhat palmate form, being marle up of a series of short, laterally compressed, lobe-like shoots or knobs, the summit of each of which is marked by a depression indicating the former attachment of the leafy stem.

To produce the uncocten ginger, which is that preferred for medicinal use, the fresh rhizome is scraped, washed, and then dried in the sun.

Thus prepared, it has a pale buff lue, and a striated, somewhat fibrous surface. It breaks easily, exhibiting a sloort and farinaceous fracture with numerous bristle-like fibres. When cut with a knife, the younger or terminal portion of the rhizome appears pale yellow, soft and amylaceous, while the older part is flinty, hard and resinous.

Coated ginger, or that which has been dried without the removal of the epidermis, is covered with a wrinkled, striated, brown integument, which imparts to it a somewhat coarse and crude appearance. Internally, it is usually of a less bright and delicate hne than ginger from which the cortical part has been removed. Much of it indeed, is dark, homy and resinous.

Ginger has an agreeable aromatic odour with a strong pungent taste.e.

Varieties-Those at present found in the London market, are distimguished as Jamaiea, Coehin, Bengal, and African. The first three are scraped gingers; the last named is a encted ginger, that is to say, it still retains its epidermis. Jamaica Ginger is the sort nost esteemed; and next to it, the Cochin. Bnt of each kind there are several qualities, presenting considerable variation inter se.

Scraped or decorticated ginger is often bleached, either by being subjected to the fumes of brining sulphur, or by immersion for a short time in solution of chlorinated lime. Mnch of that seen in the grocer's' shops looks as if it had been whiterwashed, and in fact is slightly coated with calcareous matter, - either sulphate or carbonate of calcium. ${ }^{4}$

Microscopic Structure-A transverse section of coated ginger exhibits a brown, horny external layer, abont one nillimètre broad, separated by a fine line from the whitisl mealy interior portion, through the tissue of which numerous vascular bundles and resin-cells are irregularly scattered. The external tissue consists of a loose outer layer, and an inner composed of tabular cells: these are followed by peculiar short prosenchymatous cells, the walls of which are sinnous on trunsverse

1 Monaries, Mistoria de 7ris cosas que se trren de nuestros Indias occidentales, Sevilla, (1574) 99.

2 Calendar of strute Paper's, Colomiat, Series, 1574-16tio. I.ond. 1860 p. 4 : see also ?I. $414,4 \% 4$.
3 22.053 cwt. See Tienny, Hist. of $J a$ maica, l.ond. $1807,154$.

4 Mr. Garside (Phrrm. Jorm. April 18, 1574) fouml both. We lave not observed the carbonate to be used. 
section and partially thickened, imparting a horny appearance. This delicate felted tissue forms the striated surface of seraped ginger, and is the principal seat of the resin and volatile oil, which here fill large spaces. The large-celled parenchyme which succeeds, is loaded with starch, and likervise contains numerous masscs of resin and drops of oil. The starch granules are irregularly spherical, attaining at the utmost $40 \mathrm{mkm}$. Certain varieties of ginger, owing to the starch having been rendered gelatinous by scalding, are throughout horriy and translucent. The circle of vascular bundles which separates the outer layers and the central portion, is narrow, and has the structure of the corresponding circle or nucleus sheath in turmeric.

Chemical Composition-Ginger contains a volatile oil which is the only constituent of the drug that has hitherto been investigated. By distilling $112 \mathrm{mb}$. of Jamaica ginger with water in the usual way, we obtained $4 \frac{1}{2}$ ounces of this oil, or about $\frac{1}{4}$ per cent. It is a pale yellow liquid of sp. gr. 0.878, having the peculiar odour of ginger, but not its pungent taste. It has no acid reaction; dissolves but sparingly in spirit of wine $(0.83)$; and deviates the ray of polarized light $21^{\circ} 6$ to the left, when examined in a column $50 \mathrm{~mm}$. long.

The burning taste of ginger is due to a resin which we have not examined, but which well deserves careful aualysis.

Commerce-Great Britain imported of ginger as follows :-

$\begin{array}{ccccc}1868 & 1869 & 1870 & 1871 . & 1872 \\ 52,194 \text { cwt. } & 34,535 \text { cwt. } & 33,854 \text { cwt. } & 32,723 \text { cwt. } & 32,174 \text { cwt. }\end{array}$

The drug was received in 1872 thus :-

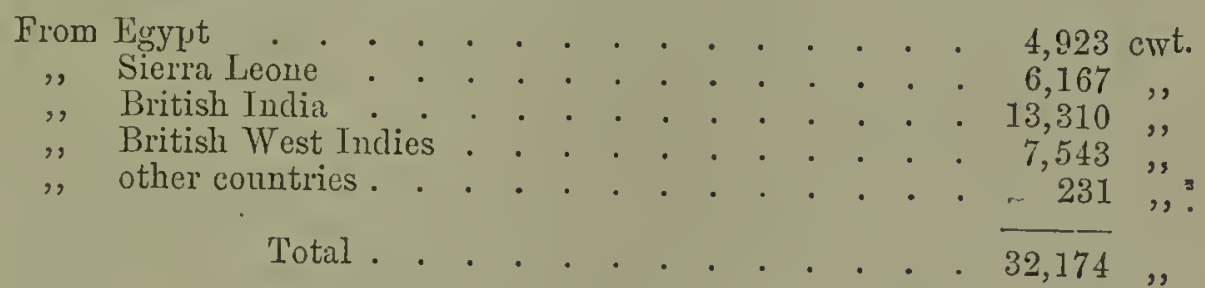

The importations of ginger from the West Indies have of late years much declined.

Uses-Ginger is an agreeable aromatic and stomachic, and as such is often a valuable addition to other medicines. It is much more largely employed as a condinient than as a drug.

\section{RHIZOMA CURCUMÆ.}

Fialix Curcuma; ${ }^{1}$ Turneric; F. Curcuma; G. Gelbuuracl, Kurtuma.

Botanical Origin-Cureuma longa L.-Turmeric is indigenous to Southern Asia and is there largely cultivated both on the continent and in the islands.

History-Dioscorides mentions an Indian plant as a kind of Cyperus

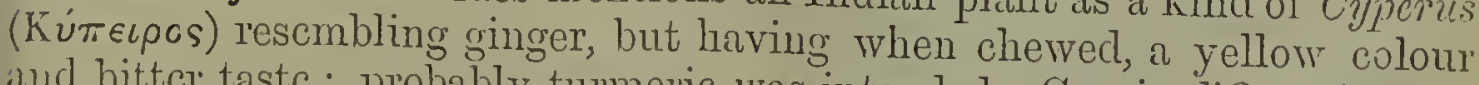
and bittcr tastc: probably turmeric was intended. Garcia d'Orta (156:3), as well as Tingoso (1572), describe tumeric as Crocus indicus. A list of

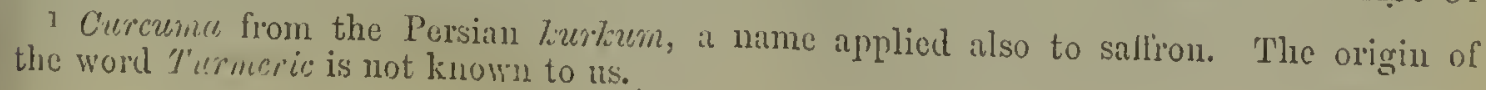


drugs sold in the eity of lirankfort about the year 1450, names C'ureumu along with zedoary and ginger: ${ }^{1}$

In its native countries, it has from remote times been highlily esteened both as a conclinent and a dye-stuff; in Europe, it has always bcen less appreciated than thic allied spices of the ginger tribe. In an inventory of the effects of a Yorkshine tradesman, dated 20 Scpt. 1578, we find enumerated-" $x$. owncis of turmerackc, $x$ cl." 2

Description-The base of the scape thickens in the first ycar intor an ovate root-stock; this afterwards throws out shoots, forming lateral or secondary rhizomes, each emitting roots, which branch into fibres or are sometimes enlarged as colourless spindle-shaped tubers, ricli in starch. The lateral rhizomes are doubtless in a condition to develope themselves as independent plants when separated from the parent. The central rhizomes formerly known as Curcuma rotunila, and the elongated lateral ones as Curcuma longa, were regarded by Linnæus as the production of distinct species.

The radical tubcrs of some species of Curcuma as $C$. angustifolica Roxb., are used for making a sort of arrowroot (p. 574). Sometimes they are dried, and constitute the peculiar kind of turmeric which the Chincse call. Yuch-kin. ${ }^{3}$

The turmeric of commerce consists of the two sorts of rhizorne just mentioned, namely, the central or round and the lateral or long. The former arc ovate, pyriform or subspherical, sometimes pointed at the upper end and crowned with the remains of leaves, while the sides arc beset with those of roots and marked with concentric ridges. The diameter is very variable, but is seldom less than $\frac{3}{4}$ of an inch, and is frequently much more. They are often cut and usually scaldcd in order to destroy thcir vitality and facilitate drying.

The lateral rhizomes are subcylindrical, attcnuated towards either end, generally curved, covered with a rugose skin, and marked more or less plainly with transverse rings. Sometimes one, two or more short knobs or shoots, grow out on one side. The rhizomes, whether round or long, arc very hard and firn, cxhibiting when broken a dull, waxy, resinous surface, of an orange or orangc-brown hue, more or less brilliant. They have a peculiar aromatic odour and taste.

Several varieties of turmeric distinguished by the names of the countries or districts in which they are produced, are found in the English market: but although they present differences which are sufficiently apprcciable to the eye of the cxperienced dcaler, the charactcrs of cach sort are scarcely so marked or so constant as to bc recognizablc by mere verbal description. The principal sorts now in commerce are known as China, Madras, Bengal, Java, and Cochin. Of these the first named is the most esteemed, but it is seldom to be met with in the European market. ${ }^{4}$

Madras Turmeric is a fine sort in large, bold pieccs. Somctimes packages of it contain cxclusivcly round rhizomes, while othcrs arc made up cntirely of the long or latcral.

1 Fliickigcr, Die Franl:furtcr Liste, Halle, 1873. 11 .

2 Raine, Wills and Inventorics of the Archdcaconry of Richmond (Surtces Socicty): 1853. 277.

${ }_{3}^{3}$ Pharin. Journ. iii. (1862) 260, fig. 11.-
It is not wholly devoid of ycllow colouring matter.

${ }^{4} \Lambda$ good deal is exported from Takow in Formosa, but mostly to Chincse ports. Returns of T'rade at the Treaty Ports of China for 1872. p. 106. 
Bengal Turmoric differs from the other varieties chiefly in its deeper tint, and hence is the sort preferred for dyeing purposes.

Jar 'Turmoric presents no very distinctive features; it is dusted with its own powder, and does not show when broken a very brilliant colour. Judging by the low price at which it is quoted, it is not in great esteem. It is the prodnce of Curcuma longa var. $\beta$ minor ${ }^{1}$ Hassk.

Microscopic Structure-The suberons coat is made up of 8 to 10 rows of tabular cells; the parenchyme of the middle cortical layer, of large roundish polyhedral cells. Towards the centre, the transverse section exhibits a coherent ring of fibro-vascular bundles, representing a lind of medullary sheath. The parenchyme enclosed by this ring is traversed by scattered bundles of vessels, and in most of its cells contains starch in amorphous, angular or roundish masses, which are so far disorganized that they no longer exhibit the usual appearance in polarized light, but are nevertheless turned blue by iodine. The starch has been reduced to this condition by scalding.

Resin likewise occurs in separate cells, forming dark yellowish-red particles. The entire tissue is penetrated with yellow colouring matter, and shows numerous drops of essential oil, which in the fresh rhizome is no doubt contained in peculiar cells.

Chemical Composition-The drug yields about one per cent. of essential oil which, according to Suida and Daube (1868), consists of an oil homologous or isomeric with carvol and thymol, $\mathrm{C}^{10} \mathrm{H}^{14} \mathrm{O}$, combined with a small proportion of a hydrocarbon.

The colouring matter called Curcumin is obtained by exhausting the drug with benzol, after the essential oil has been distilled off. The crude crystals obtained from benzol are dissolved in spirit of wine, and precipitated with basic acetate of lead. The latter is then removed by sulphuretted hydrogen, and the curcumin re-crystallized from spirit of wine. It then forms yellow crystals, having an odour of vanilla, and exhibiting a fine blue in reflected light. Daube ${ }^{2}$ assigns them the formula, $\mathrm{C}^{10} \mathrm{H}^{10} \mathrm{O}^{13}$. The best produce of curcumin is stated by IvanowGajewsky $^{3}$ to be obtained by washing an ethereal extract of turmeric with weak ammonia, dissolving the residue in boiling concentrated ammonia, and passing into the solution carbonic acid, by which the curcumin is precipitated in flakes.

Paper tinged with an alcoholic solution of curcumin displays ori addition of an alkali a brownish-red coloration, becoming violet on drying. Boracic acid produces an orange tint, turning blue by addition of an alkaline solution. ${ }^{4}$ This behaviour of (impure) curcumin was pointed out by Vogel as early as 1815, and has since that time been utilized as a chemical test.

Borax added to an alcoholic solution of curcumin, gives rise to a pink substance, the Rosocyanin of Schlumberger (1866), which Daube

1 From information communicated by $\mathrm{Mr}$. Binnendyk, of the Botanical Garden, Buitcn. zorg, Java.

2 Journ. für malct. Chcmic, ii. (1871) 86.

3 Journ. of Chem. Soc. xi. (1873) 504 .

4 The following is a striking experiment; showing some of these changes of colour:Place a little crushed turmeric or the powder on blotting paper, and moisten it repeatedly with chloroform, allowing the latter to evaporate. 'Thero will thus be formed on the paper a yellow stain which on addition of a slightly acidulated solution of borax and drying assumes a yurple huo. If the papor is now sprinkled with dilute ammonin, it will acquire a transicnt blue. This reaction cllables ono to ronognize the presonce of turmeric in powdered rhubarb or mustard. 
also obtained, and in erystals. Ivanow-Gajewsky, who isolated it by henting an alcoholic extract of turmeric with boracic and sulphuric acids, describes it as a purple crystalline powder with a metallic green lustre, insoluble in water but soluble in alcoliol. Its solution is coloured dark blue by an alkali.

Aceording to the same chemist, there aiso exists in curcuma, an alkaloid in very small quantity. ${ }^{1}$ Kachler ${ }^{2}$ found in the aqueous decoction an abundance of Bioxalate of Potassium.

Commerce-In the year 1869, there were imported into the United Kingdom, $64,280 \mathrm{cwt}$. of turmeric; in 1870,44,900 cwt.,-a very large proportion being furnished by Bengal and Pegu. The export from Calcutta ${ }^{3}$ in the year $1870-71$, was $59,352 \mathrm{cwt}$.

Bombay exported in the year 1871-72, 29,780 ewt., of which the greater portion was shipped to Sind and the Persian Gulf, and only 910 cwt. to Europe. ${ }^{4}$

Uses-Turmeric is employed as a condiment in the shape of curry powder, and as such is often sold by druggists; but as a medicine, it is obsolete. It is largely consumed in dyeing.

Substitute-The London market has latcly been supplied with considerable quantities of a drug called Cochin Turmcric, which is the produce of some other specics of Curcuma than C. longa. It consists exclusively of a bulb-shaped rhizome of large dimensions, cut transversely or longitudinally into slices or segments. The cortical part is dull brown; the inner substance is horny and of a deep orange-brown, or when in thin shavings, of a brilliant yellow. Mr. A. Forbes Sealy of Cochin has been good enough to send us (1873) living rhizomes of this Curcuma, which he states is mostly grown at Alwaye, north-east of Cochin, and is never used in the country as turmeric, though its starchy tubers are employed for making arrowroot. The rhizomes sent are thick, short, conical and of enormous size, some attaining as much as $2 \frac{1}{2}$ inches in diameter. Internally they are of a bright orange-yellow.

\section{RHIZOMA GALANGÆ.}

Radix Galanges ${ }^{5}$ minoris; Galangal; F. Racine de Gulcunga; G. Galgant.

Botanical Origin-Alpinia officinarum Hance, ${ }^{6}$ a flag-like plant, with stems about 4 feet high, clothed with narrow lanceolate leaves and terminating in short and simple racemes of clegant white flowers, shaded and veined with dull red. It grows cultivated in the island of Haiuan in the south of China, and, as is supposed, in some of the southern provinces of the Chinese Empire.

1 Berichte der Dcutschen Chem. Gcsellsch. iii. (1870) 624 .

2 Ibid. 713 .

3 Returns quoted at p. 514, note 3.

4 s'tatement of the Trade and Narigation of Bombay for 1871-72, pt. ii. 95.

"Galanga appars to be derived from the Arabic name Khulenjan, whieh in tum comes from the Chinese Kar-liang Kiang, signifying, as Dr. F. Porter Snith has in- formed us, Kau-liang ginger. Kan-liang is the ancient name of a distriet in the province of Kwangtung.

6 Journ. of Linnean Society, Botany, xiii. (1873) 1; also Trimen's Journ. of Bot., ii. (1873) 175.-D1. 'Thwaites of Ceylon, who has the plant in cultivation, has been good enongh to send us a fine coloured drawing of it in flower. 
History-The earliest reference to galangal we have met with, occur's in the writings of the Arabian geographer Ibn Khurdádbah ${ }^{1}$ about A.D. 869-885, who in enumerating the productions of a country called Sila, names galangal together with musk, aloes, camphor, silk, and cassia. Edrisi, ${ }^{2}$ three hundred years later is more explicit, for he mentions it with many other productions of the far East, as brought from India and China to Aden, then a great emporium of the trade of Asia with Egypt and Europe. The physician Alkindi, ${ }^{3}$ who lived at Bassora and Bagdad in the second half of the 9th century, and somewhat later Rhazes and Avicenna, notice galangal, the use of which was introduced into Europe through the medical system promulgated by them and other writers of the same school.

Many notices exist showing that galangal was imported with pepper, ginger, cloves, nutmegs, cardamoms and zedoary; and that during the middle ages it was used in common with these substances as a culinary spice, which it is still held to be in certain parts of Europe. ${ }^{4}$ The plant affording the drug was unknown until the year 1870, when a description of it was communicated to the Linnean Society of London, by Dr. H. F. Hance, from specimens collected by Mr. E. C. Taintor, near Hoihow in the north of Hainan.

Description-The drug consists of a cylindrical rhizome, having a maximum diameter of about $\frac{3}{4}$ of an inch, but for the most part considerably smaller. This rhizome has been cut while fresh into short pieces, $1 \frac{1}{2}$ to 3 inches in length, which are often branched, and are marked transversely at short intervals by narrow raised sinuous rings, indicating the former attachment of leaves or scales. The pieces are hard, tough and shrivelled, externally of a dark reddish-brown, displaying when cut transversely, an internal substance of rather paler hue (but never white), with a darker central column. The drug exhales when comminuted an agreeable aroma, and has a strongly pungent, spicy taste.

Microscopic Structure-The central portion of the rhizome is separated from the outer tissue by the nucleus sheath, which appears as a well-defined darker line. Yet the central tissue does not differ much from that surrounding it, both being composed of uniform parenchyme cells, traversed by scattered vascular bundles. There also occur throughout the whole tissue, isolated cells loaded with essential oil or resin. But the larger number of cells abound in large starch granules of an unusual club-shaped form. Some cells contain a brown substance, differing from resin in being insoluble in alcohol. The corky layer is remarkable from its cells having undulated walls.

Chemical Composition-The odour of galangal is due to an essential oil, which the rhizoma yields to the extent of only $\frac{1}{3}$ to $\frac{1}{2}$ per cent, and which appears from the experiments of Vogel, to have the composition, $\mathrm{C}^{10} \mathrm{H}^{16} \mathrm{H}^{2} \mathrm{O}$. Brandes ${ }^{5}$ extracted from galangal by means

1 Work quoted at p. 251, note 5.-tome v. 294. 2 G'́ograplic d'Edrisi, traduite par Jall-
bert, i. (1836) 51. 162.

3 De Tierum gradibus, Argentorati, 1531.

4 Hanbury, Historical. Notes on the Rectix Galengo of pharmacy-Joum. of Limneru Socicty, Bot. xiii. (1873) 20; Pham. Joum. Sept. 23, 1871. 248.

"Archiv der Pharm. xix. (1839) 52. 
of ether, in neutral inodorons and tasteless crystalline borly called Käminferid, which is worthy of further examination.

'The pungent principle of the drug, which is probably aualogous to that of ginger, has not been studied.

Commerce-Galangal is shipped from Canton to other ports of China, to India and lurope, but there are no general statistics to give an iclea of the total production. From official returns quoted by Hance, the export in the year 1869 , which seems to have been exceptionally large, amounted to $370,800 \mathrm{Hb}$. Bombay in the year 1870-71, imported the drug to the extent of $335 \mathrm{cwt}^{1}$

Uses-The drug is an aromatic stimulant of the nature of ginger, now nearly obsolete in British medicine. It is still a popular remedy and spice in Livonia, Esthonia and Central Russia, and by the Tartars is taken with tea. It is also in some requisition in Russia among brewers, and the manufacturers of vinegar and cordials, and finally as a cattle medicine.

Substitute-The rhizoma of Alpinia Galanga Willd., a plant of Java, constitutes the drug known as Factix Galanga majoris or Greater Galangal, packages of which occasionally appear in the London drug sales. It may be at once distinguished from the Chinese drug by its much larger size and the pale buff hue of its internal substance, the latter in strong contrast with the orange-brown outer skin.

\section{FRUCTUS CARDAMOMI.}

Semina Cardamomi minoris; Cardamoms, Malabar Cardamoms; F. Cardamomes; G. Cardamomen.

Botanical Origin-Elettaria ${ }^{2}$ Cardamomum Maton (Alpinia Cardamomum Roxb.), a flag-like perennial plant, 6 to 12 feet high, with large lanceolate leaves on long sheathing stalks, and flowers in lax flexuose horizontal scapes, 6 to 18 inches in length, which are thrown out to the number of 3 or 4 , close to the ground. The fruit is ovoid, three-sided, plump and smooth, with a fleshy green pericarp.

The cardamom plant grows abundantly, both wild and under cultivation, in the moist shady mountain forests of North Canara, Coorg and Wynaad on the Malabar Coast, at an elevation of 2500 to 5000 feet above the sea. It is truly wild in Canara and in the Anamalai, Cochin and Travancore forests. The cardamom region has a mean temperature of $22^{\circ} \mathrm{C}$. $\left(72^{\circ} \mathrm{F}\right.$ ), and a mean rainfall of 121 inches.

A well-marked variety, differing chiefly in the elongated form and large size of its fruits, is found wild in the forests of the central and southern provinces of Ceylon. It was formerly regarded as a distinct species under the name of Elcttaria major, but careful observation of growing specimens has shown that it possesses no characters to warrant it being considered more than a variety of the typical plant, and it is therefore now called $E$. Cardamomum var. $\beta$. It is only limown to occur

1 Peturns quoted at p. 366, note 3.

From Elcttari, the Nalyalim name of the plant. 
in Ceylon, where the ordinary Cardamom of Malabar is not found exccpt as a cultivated plant. ${ }^{1}$

History-The Malabar cardamom is mentioned in the writings of Susruta, and hencè may have becn used in India from a remote period. It is not unlikely that in common with ginger and pepper it reached Europe in classical times, although it is not possible from the descriptions

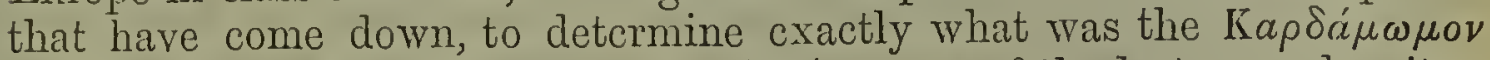
of Theophrastus and Dioscorides, or the 'A $\mu \omega \mu$ y of the last-named writer. The Amomum, Amomis and Cardamomum of Pliny are also doubtful, the description he gives of the last being unintelligible as applied to anything now known by that name.

In the list of Indian spices liable to duty at the Roman custom house at Alexandria, circa A.D. 176-180, Anomum as well as Cardamomum is mentioned. ${ }^{2}$ St. Jerome names Anomum together with musk, as perfumes in use among the voluptuous ecclesiastics of the 4 th century. ${ }^{3}$

Cardamoms are named by Edrisi ${ }^{4}$ about A.D. 1154 as a production of Ceylon, and also as an article of trade from China to Aden; and in the same century they are mentioned together with cinnamon and cloves (p. 250) as an import into Palestine by way of Acre, then a trading city of the Levant.

The first writer who definitely and correctly states the country of the cardamom, appears to be the Portuguese navigator Barbosa ${ }^{5}$ (1514) who frequently names it as a production of the Malabar Coast. Garcia d'Orta, ${ }^{6}$ physician to the Viceroy at Goa about 1563, mentions the shipment of the dring to Europe; he also ascertained that the larger sort was produced in Ceylon. The Malabar cardamom plant was figured by Rheede under its indigenous name of L'lettari.

Cultivation and Production-Although the cardamom plant grows wild in the forests of Southern India, where it is commonly called Ilactir, its fruits are largely obtained from cultivated plants. The methods of cultivation, which vary in the different districts, may be thus described :-

1. Previous to the commencement of the rains, the cultivators ascend the mountain sides, and seek in the shady evergreen forests a spot where some cardamom plants are growing. Here they make small clearings, in which the admission of light occasions the plant to develope in abundance. The carclamom plants attain 2 to 3 feet in height during the following monsoon, after which the ground is again cleared of weeds, protected with a fence, and left to itself for a year. About two years after the first clearing, the plants begin to flowcr, and five months later ripen some fruits, but a full crop is not got till at least a year after. 'The plants continue productive six or seven years. A garden, 484 squarc yards in area, four of which may be made in an acre of forcst, will give on an average, an annual crop of $1.21 \mathrm{tb}$. of garbled cardamoms. ${ }^{\text {L }}$ Ludlow, an Assistant Conservator of Forests, reckons

1 Thwaites, Enumeratio Plantarum Zoylanich, 1S64. 318.

2 Mifeyer, Geselichte d. Botanik, ii. (1855) 167; Vincent, Commerec of the Ancionts, ii. (1807) 698.

3 S. Hicronymi Opera Omnia, cl. Migne, ii. (1845) 297.

'Géographic d'Edrisi, traduite par Jau- bert, i. (1836) 73, 51.- It is questionable whether Elcttaria is intended at p. 51.

5 Description of the Cocists of East Africe and Malabar, Hakluyt Soeicty, 1866. 59. 64, 147. 154. \&e.

6 In the work quoted at p. 492, note 7 .

7 Hortus Malabaricus, xi. (1692) tab. 4-5.

.8 Repnit on the Administration of Coorg for the year 1872-73, Bangulne', 1873. 44. 
that not more than $28 \mathrm{Hb}$. can be got from an acre of forest. From what he says, it further appears that the plants which come up on clearings of the Coorg forests are mainly seculings, which make their appearance in the same quasi-spontaneous manner as certain plants in the clearings of a wood in Europe. He says they commence to bear in about $3 \frac{1}{2}$ yenrs after their first appearance. ${ }^{1}$ The plan of cultivation above described is that pursued in the forests of Travancore, Coorg and Wynaad.

2. On the lower range of the Pulney Hills, near Dindigul, at an elevation of about 5000 feet above the sea, the cardamom plant is cultivated in the shade. The natives burn down the underwood, and clear away the small trees of the dense moist forests called sholas, which are damp all the year round. The cardamoms are then sown, and when a few inches high, are planted out, either singly or in twos, under the shade of the large trees. They take five years before they bear fruit; "in October" remarks our informant, " "I saw the plants in full flower" and also in fruit,- the latter not however ripe."

3. In North Canara and Western Mysore, the cardamom is cultivated in the betel-nut plantations. The plants, which are raised from seed, are planted between the palms, from which and from plantains, they derive a certain amount of shade. They are said to produce fruit in their third year.

Cardamoms begin to ripen in October, and the gathering contimues during dry weather for two or three months. All the fruits on a scape do not become ripe at the same time, yet too generally the whole scape is gathered at once and ciried,- to the manifest detriment of the drug. This is done partly to save the fruit from being eaten by snakes, frogs and squirrels, and partly to avoid the capsules splitting, which they do when quite mature. In some plantations however, the cardamoms are gathered in a more reasonable fashion. As they are collected, the fruits are carried to the houses, laid out for a few days on mats, then stripped from their scapes, and the drying completed by a gentle fire-heat. In Coorg, the fruit is stripped from the scape before drying, and the drying is sometimes effected wholly by sun-heat.

In the native states of Cochin and Travancore, cardamoms are a monopoly of the respective governments. The rajah of the latter state requires that all the produce shall be sold to his officials, who forward it to the main depôt at Alapalli or Aleppy, a port in Travancore, where his commercial agent resides. The rajah is tenacious of his rights, and inserts a clause in the leases he grants to European coffee-planters, of whom a great many have settled in his territory, requiring that cardamoms shall not be grown.

The cardamoms at Aleppy are sold by auction, and bought chiefly by Moplah merchants for transport to different parts of India, and also, through third parties, to England. All the lower qualities are consumed in India, and the finer alone shipped to Europe.

In the forests belonging to the British Govermment, cardamoms are

1 Elliot, Experionces of a Planter in the Jungles of Mysore, Lond. ii. (1871) 201. 209.

2 Colonel Beddone, Conscrvator of Forests, IIadras. We have likewise to acknowledge information on this lical from Dr. Brandis, Inspector-General of Forests in India, and Dr. King, Director of the Botanic Garden, Calcutta. 
mostly reckoned among the miscellaneous items of produce; but in Coorg, the cardamom forests are now let at a rental of $£ 3000$ per annum, under a lease which will expire in $1878 .^{1}$

Dr. Cleghorn, late Conservator of Forests in the Madras Presidency, observes in a letter to one of us, that the rapid extension of coffee culture along the slopes of the Malabar mountains has tended to lessen the production of cardamoms, and has encroached considerably upon the area of their indigenous growth. A recent writer ${ }^{2}$ has shown from his own experience, that the cultivation of the cardamom is a branch of industry worth the attention of Europeans, and has given many valuable details for insuring successful results.

Description-The fruit of the Malabar cardamom as found in commerce, is an ovoid or oblong, three-sided, three-valved capsule, containing numerous seeds arranged in three cells. It is rounded at the base, and often retains a small stalk; towards the apex it is more or less contracted and terminates in a short beak. The longitudinally-striated, inodorous, tasteless pericarp is of a pale greyish-yellow, or buff, or brown when fully ripe, of a thin papery consistence, splitting lengthwise into three valves. From the middle of the inner side of each valve, a thin partition projects towards the axis, thereby producing three cells, each of which encloses 5 to 7 dark brown, aromatic seeds, arranged in two rows and attached in the central angle.

The seeds, which are about 2 lines long, are irregularly angular, transversely rugose, and have a depressed hilum and a deeply channelled raphe. Each seed is enclosed in a thin colourless aril.

Cardamoms vary in size, shape, colour and flavour: those which are shortly ovoid or nearly globular, and $\frac{4}{10}$ to $\frac{6}{10}$ of an inch in length, are termed in trade language shorts; while those of a more elongated form, pointed at each end, and $\frac{7}{10}$ to $\frac{9}{10}$ of an inch long, are called shortlongs. They are further distinguished by the names of localities, as Malabar, Madras, and Aleppy. The Malabar Cardamoms, which are the most esteemed, are of full colour, and occur of both forms, namely shorts and short-longs; they are brought to Europe vîu Bombay. The Madras are chiefly of elongated form (short-longs) and of a more pallid hue; they are shipped at Madras and Pondicherry. Those termed Aleppy are generally shorts, plump, beaked and of a peculiar greenish tint; they are imported from Calicut, and sometimes from Aleppy.

Cardamoms are esteemed in proportion to their plumpness and heaviness, and the sound and mature condition of the seeds they contain. Good samples afford about three-fourths of their weight of seeds. ${ }^{3}$

The fruits of the second form (var. $\beta$ ) of Elctaria Cardamomum, known in trade as Ceylon Cardamoms, are from 1 to 2 inches in length, and $\frac{3}{10}$ to $\frac{4}{10}$ of an inch in breadth, distinctly three-sided, often arched, and always of a dark greyish-brown. The seeds are larger and more numerous than those of the Malabar plant and somewhat different in
odour and taste.

Microscopic Structure-The testa of the seed consists of three distinct layers, namely an exterior of thick-walled, spirally-striated cells,

1 Report quoted at p. 583 , note 8 .

2 Elliot, op. cit., chap. 12 .

3 Thus $202 \mathrm{tb}$. shelled at various times luring 10 years, afforded $154 \frac{1}{2} \mathrm{tb}$. of seeds.
(Information from the laboratory accounts of Messi's. Allen and Hanburys, Plough
Court, Lombarc St.) 
somewhat lonyitudinally extended, and exhibiting on transverse section, square, not very large, cavities; then a row of linrge cells with thin transverse wills ; and finally, an internal layer of deep brown, radiallyarranged cells, the walls of which have so thick a deposit that at the most only small cavities remain.

'The granular, colourless, sac-shaped albumen cncloses a horny endospcrm, in which the embryo is inserted, the projecting radicle being directed towards the hilum. 'The cclls of the albumen have the form of clongated polyhedra, almost entirely filled with very small starch grannles. Besicles them, there occur in most of the cells, somerwhat larger masses of albuminoid matter having a rlombohedric form, distinctly obscrvable when thin slices of the sced are examined under almond oil in polarized light. These rcmarkable crystalloid bodies rescmble thosc occurring in the secds of cumin (p. 296).

Chemical Composition - The parcnchyme of the albumen and embryo is loaded witl fatty oil and essential oil, the former existing in the seed to the extent of about $10 \mathrm{pcr}$ cent.

The cssential oil, which amounts on an average to 4.6 per cent., has a sp. gr. of about 0.93 , and the odour and flavour of the seeds. It appear's to consist of two bodies, a liquid volatile oil, and a crystalline solic camphor, having the "formula, $\mathrm{C}^{10} \mathrm{H}^{16}\left(\mathrm{H}^{2} \mathrm{O}\right)^{3}$, and therefore isomeric or identical with turpentime-camphor. Esscntial oil of cardamoms has been found by Luboldt $(1860)$ to be strongly dextrogyre. The water which comes over when cardamoms are distilled, contains acetic acid. The ash of cardamoms, in common with that of several other plants of the same order, is rcmarkably rich in manganese. ${ }^{1}$

Commerce-There are no statistics to show the production of cardamoms in the south of India or even the quantity exported. The shipments in the year 1872-73 from Bombay, to which port the drug is largely sent from the Madras Presidency, amounted to $1650 \mathrm{crtt}$., of which 1055 ciwt. were exported to the United Kingdom. ${ }^{2}$

Cardamoms, the produce of Ceylon and therefore of the large variety, were exported from that island in 1872 , to the extent of $9273 \mathrm{Hb}$.the whole quantity being shipped to the United Kingdom. ${ }^{3}$

Uses-Cardamoms are an agreeable aromatic, often administered in conjunction with other medicines. As an ingredient in curry powder, they have also some use as a coudiment. But the consumption in England is small in comparison with what it is in Russia, Sweden, Norway and parts of Germany, where they arc constantly employed as a spice for the flavouring of cakes. In these countries, Ceylon cardamoms are also used, but exclusively for the manufacture of liqueurs. In India, cardamoms, besides being used in medicine, arc cmployed as a condiment and for chewing with betel.

\section{Other sorts of Cardamom.}

The fruits of scveral other plants of the order Zingiberacce have at various times been employed in pharmacy under the common name

1 Pharm. Journ. iii. (1872) 208.

Statcment of the Trate, de. of Bombay

3 Coylon Blue Baok for 1572, Colombo, for 1872-73. ii, 58. 90. 
of Cardamom. We shall here notice ouly those which have some importance in European or Indian commerce. -

Round or Cluster Cardamom-Amomum Cardamomum L., the mother-plant of this drug, is a native of Cambodia, Siam, Sumatra and Java.

During the intercourse with Siam, which was frequent in the early part :of the 17th century, this drug, which is there in common use, occasionally found its way into Europe. Clusius received a specimen of it in 1605, as the true Amomum of the ancients, and figured it as a great rarity. ${ }^{2}$ As Amomum verum, it had a place in the pharmacopœias of this period. Parkinson (1640), who figures it as Amomum genuinum, says that " of late days it hath been sent to Venice from the East Indies." Dale (1693) and Pomet (1694) both regarded it as a rare drug; the latter says it is brought from Holland, and that it is the only thing that ought to be used when Amomum is ordered. In 1751, it was so scarce that in making the Theriaca Andromacti, some other drug had always to be substituted for it. ${ }^{3}$

Thus, it had completely disappeared, when about the year 1853 , commercial relations were re-opened with Siam; and among the commodities poured into the market, were Round Cardanoms. They were not appreciated, and the importations becoming umprofitable, soon ceased. ${ }^{4}$ They are nevertheless an article of considerable traffic in Eastern Asia.

Round Cardamoms are produced in small compact bunches. Each fruit is globular, ${ }_{10}^{5}$ to $\frac{7}{10}$ of an inch in diameter, marked with longitudinal furrows, and sometimes distinctly three-lobed. The pericarp is thin, fragile, somewhat hairy, of a buff colour, enclosing a three-lobed mass of seeds, which are mostly shrivelled as if the fruit had been gathered unripe. The seeds which have a general resemblance to those of the Malabar cardamom, have a strong camphoraceous, aromatic taste.

There is a large export from Siam of cardamoms of this and the following sort. The shipments from Bangkok in 1871, amounted to 4678 peculs $(623,733 \mathrm{mb}$.), value 232,464 dollars, and were all to Singapore and China. ${ }^{5}$ There were also imported into Singapore cluring the same year, 102 cwt. from Java, and 75 cwt from Sumatra of [Round?] Cardamoms. ${ }^{6}$

Xanthioid Cardamom; Wild or Bastard Cardamom of SiamThis is afforded by Amomum xanthioides Wallich, a native of Tenasserim and Siam. During the past twenty years, the seeds of this plant, deprived of their capsules, have often been imported into the London market, and they are now also common in the bazaars of India. ${ }^{7}$ They closely resemble the seeds of the Malabar cardamom, differing chiefly in flavour and in being rather more finely rugose. Occasionally they

1 For adclitional information on the various sorts of Cardamom, consult Guibourt, Hist. des Droy. ii. (1869) 215-227; Pereira, Elements of Mat. Med. ii. (1850) $1128 \mathrm{et}$ seq.; Hanbury in Pluarm. Journ. xiv. (1855) 352 . 416.; Joum. de Pharm., Mai et Juin, 1855.

Exoticorum Libri, 377.

${ }^{3}$ Hill, Mistory of the MIat. MICd., Lond. (1751) 472 .

4 Thus 43 bacs, inported direet from: Bangkok, were offered for salo in Londou, 26 March, 1857, and bought in at $1 s .6 d$. per $\mathrm{lb}$.

5 Commercial Report of II. MI. ConsulGencral in Sicum for 1871. 1871.

6 Blue Book of the Straits Setllements for

7 Moodeen Sheriff, Srupplement to Pharmaconozice of Inctice, Aradras, 1S6. 44. 270. 
are imported still eohering in ovoid, three-lobed masses, as packed in the periearp. Sometimes they are distinguished as Bastard or Wild, but are more generally termed simply Cardamom, Seeds. T'ley are a considerable artiele of trade in Sian, but in eommereial returns are not distinguished from the preceding.

The fruits of this species grow in round clusters and are remarkable for having the periearp thiekly beset with weak fleshy spines, ${ }^{1}$ which gives thein some resemblanee to the fruits of a Xanthium, and has suggested the specifie name.

Bengal Cardamom-This drug, which with the next two has been hitherto confounded under one name, ${ }^{2}$ is afforded by Amomum aromaticum. Roxb., a native of the valleys on the eastern frontier of Bengal. According to Roxburgh, ${ }^{3}$ the plant blossoms during the hot season before the periodieal rains, and matures its fruit in September; the latter is then gathered and sold to the drug dealers, under the name of Morung Elachi.

Bengal cardamoms ${ }^{4}$ average about an ineh in length, and are of ovoid or slightly obconic form, and obseurely 3 -sided; the lower end is rounded and usnally devoid of stalk. The upper part of the fruit is provided with 9 narrow jagged wings or ridges, which become apparent after maceration; and the summit terminates in a truneate bristly nipple,-never protracted into a long tube. The pericarp is coarsely striated, and of a deep brown. It easily splits into 3 valves, inelosing a 3-lobed mass of seeds, 60 to 80 in number, agglutinated by a viseid saecharine pulp, due to the aril with which each seed is surrounded. The seeds are of roundish form, rendered angular by mutual pressure, and about $\frac{1}{8}$ of an inch long; they have a highly aromatie, eamphoraceous taste.

Nepal Cardamom-The deseription of the Bengal cardamom applies in many points to this drug, to which it has a singularly close resemblanee. The fruit is of the same size and form, and is also crowned in its upper part with thin jagged ridges, and marked in a similar manner with longitudinal strix; and lastly, the seeds have the same shape and flavour. But it differs, firstly, in bearing on its summit a tubular calyx, which is as long or longer than the fruit itself; and secondly, in the fruit being often attached to a short stalk. The fruits are borne on an ovoid scape, 3 to 4 inches long, densely crowded with overlapping bracts, which are remarkably broad and truncate with a sharp central claw,very distinct from the much narrower ovate bracts of $A$. aromaticum, as shown in Roxburgh's unpublished drawing of that plant.

The plant, which is unquestionably a species of Amomum, has not yet been identified with any published description. We have to thank Colonel Riehard C. Lawrence, British Resident at Katmandu, for sending us a fruit-seape in alcohol, some dried leaves, and also the drug itself, - the last agreeing perfectly with speeimens obtained through other ehannels. 418

1 See figure in Pharm. Joum. xir. (1855)

As by Percirn, Elem. of Mat. Nea. ii. 1850) 1135.

3 Flora Indica, Scrampore, i. (1832) 45.

4 Mr. John Seott, of the Royal Botanical

Gardens, Caleutta, has been good cuough to send us a large sample of Bengal eardanoms, which he says are best kuown in the bazanrs as Buro Elachi. 'They quite agree with specimens previously in our possession. 
The Nepal cardamom, the first account of which is due to Hamilton, ${ }^{1}$ is cultivated on the frontiers of Nepal near Darjiling. The plant is stated by Col. Lawrence to attain 3 to 6 feet in height, and to be grown on well-watered slopes of the hills, under the shelter of trees. The fruit is exported to other parts of India.

Java Cardamom-A well-marked fruit, produced by Amomum maximum Roxb., a plant of Java. The fruits are arranged to the number of 30 to 40 on a short thick scape, and form a globose group, 4 inches in diameter. 'They are stalked, and of a conical or ovoid form, in the fresh state as much as $1 \frac{1}{2}$ inches loug, by 1 inch broad. Each fruit is provided with 9 to 10 prominent wings, $\frac{1}{8}$ of an inch high, running from base to apex, and coarsely toothed except in their lowest part. The summit is crowned by a short, withered, calycinal tube.

Mr. Binnendyk, of the Botanical Garden of Buitenzorg, in Java, who has kindly supplied us with fine specimens of $A$. maximum, as well as with an admirable coloured drawing, states that the plant is cultivated, and that its fruits are sold for the sake of their agreeable edible pulp. We do not know whether the dried fruits or the seeds are ever exported. Pereira confounded them with Bengal and Nepal cardamoms.

Korarima Cardamom - The Arab physicians were acquainted with a sort of cardamom called Heil, which was later known in Europe and is mentioned in the most ancient printed pharmacopœias, as Cardamomum. majus. $^{2}$ Like some other Eastern drugis, it gradually disappeared from European commerce, and its name came to be transferred to Grains of Paradise, which to the present day are known in the shops as Semina Cardamomi majoris.

The true Cardamomum majus is a conical fruit, in size and shape not unlike a small fig reversed, containing roundish angular seeds, of an agreeable aromatic flavour, much resembling that of the Malabar cardamom, and quite devoid of the burning taste of grains of paradise. Each fruit is perforated, having been strung on a cord to dry; such strings of cardamoms are sometimes used by the Arabs as rosaries. The fruit in question is called in the Galla language Korarima, but it is also known as Guragi spice, and by its Arabic names of Heil and Habhal-habashi. ${ }^{3}$ According to Beke, it is conveyed to the market of Báso in Southern Abyssinia from Tumhé, a region lying in about $9^{\circ} \mathrm{N}$. lat. and $35^{\circ} \mathrm{E}$. long; thence it is carried to Massowah on the Red Sea and shipped for India and Arabia. ${ }^{4}$ Von Heuglin ${ }^{5}$ speaks of it as brought from the Galla country. It is not improbable that it is the same fruit which Speke ${ }^{6}$ saw growing in 1862 , at Uganda in lat. $0^{\circ}$, and which he says is strung like a necklace by the Wagonda people. Pereira proposed for the plant the name of Amomum Korarima, but it has never been botanically described.
1 Aceount of the Kingdom of Nepal, Edinb. 1812. 74-75.
${ }^{2}$ As the Tesanrus Aromatariorum, printed at Milan in 1496, in which it is called Heil or Gardamomum majus.
$=3$ So named by Forskal in 1775 (Materia Hedica Kahirince, 151. 11. 41) who says

\footnotetext{
"frequens in re eutinaria et medieâ, loco piperis."

4 Pereira, Pharm. Journ. vi. (1847) 466: Elem. of Mat. Med. ii. (1850) 1136 ; Vaughan, Pharm. Joum. xii. (1853) 587.

5 Reise nach Abcssinien, Jena, 1868. 223.

"Joumal of the discorery of the source of the Nile, 1863. 648 (appendix).
} 


\section{GRANA PARADISI.}

Somina Cardamomi majoris, Piper Mclegucta; Grains of Paiadise, Guinca Grains, Melegueta Pepper ${ }^{1}$; F. Graines de P'aradis, MFaniguette; C. Paradicsliörner.

Botanical Origin-Amomum Mclegueta Roscoe-an herbaceous, reed-likc plant, 3 to 5 feet high, producing on a scape rising scarcely an inch above the ground, a delicate wax-like, pale purple flower, which is succecded by a smooth, scarlet, ovoid fruit, 3 to 4 inches in length, rising out of sheathing bracts.

It varies considerably in the dimensions of all its parts, according to morc or less favourable circumstances of soil and climate. In Demerara, where the plant grows luxuriantly in cultivation, the fruit is as large as a fine pear, measuring with its tubular part as much as 5 inchos in length by 2 inches in diameter; on the other hand in somc parts of West Africa, it scarcely exceeds in size a large filbert. It has a thick flcshy pericarp, enclosing a colourlcss acid pulp of pleasant taste, in which are imbedded the numerous seeds.

A. Melegueta is widely distributed in tropical West Africa, occurring along the coast region from Sierra Leone to Congo. . Of its distribution in the interior, we have no cxact information. The littoral region, tcrmed in allusion to its producing grains of paradise, the Grain Coast, lies between Liberia and Cape Palmas; the Gold Coast whence the seeds are now principally exported, is in the Gulf of Guinea, further eastward.

History-There is no evidence that the ancients werc acquainted with the seeds called Grains of Paradisc; nor can we find any reierence to them earlier than an incidental mention under their African name, in the account ${ }^{2}$ of a curious festival held at Treviso in A.D. 1214: it was a sort of tournament, during which a sham fortress held by twelve noble ladies and their attendants, was besieged and stormed by assailants armed with flowcrs, fruits, swectmeats, perfumes and spices, amongst which last figure-Mclegetoe!

After this period therc are many notices, showing the seeds to have been in gencral use. Nicolas Myrepsus, ${ }^{3}$ physician at the court of the

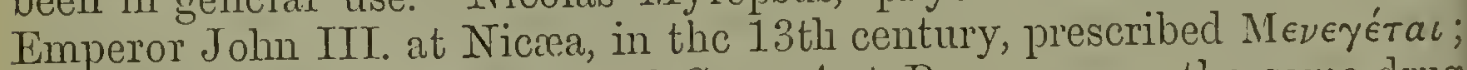
and his contemporary Simon of Genon ${ }^{4}$ at Rome, names the same drug as Mclegete or Mclegette. Grana Paradisi are enumcrated among spices sold at Lyons ${ }^{5}$ in 1245 ; and, as Groyn Paradijs, in a tariff of duties levied at Dordrccht in IIolland ${ }^{6}$ in 1358 . And again, among the spices used by John, king of France when in England, A.D. 1359-60, Grainne de Paradis is repeatedly mentioned. ${ }^{7}$

1 The name Melcgucla spelt in various ways, as Melcgettc, Melligetla, Mallaguetia, Manigele, Maniguctlc, is an Afriean designation for grains of Paradise.

2 Rolandini Patavini Chroniea-Pert\%, Monumcnla Germanice historice; scriptores, xix. (1866) 45-46.

${ }^{3}$ De Compositione Medicumontorum; de antidotis, eap. xxii.

${ }^{4}$ Clavis Sanationis, Vellet. 1510. 19. 42.

5 Bibliolhck d. lit. Vercins, Stuttgart, xri. p. xxiii.

${ }_{6}$ Sartorius und Lappenberg, Geschiche. der Deutschen IIansa, ii. 448.

7 Doüet d'Arcq, 219. 266-see p. 478, note 4 . 
In the earliest times, the drug was conveyed by the long land journey from Tropical Africa to the coast of Tripoli, ${ }^{1}$ as it is in small quantities up to the present day; and being the produce of an unknown region and held in grent esteem, it acquired the name of Grains of Paradise.

Towards the middle of the 14th century, there began to be direct conmercial intercourse with Tropical Western Africa. Margry ${ }^{2}$ relates that ships were sent thither from Dieppe in 1364, and took cargoes of ivory and malaguette, from near the mouth of the river Cestos. A century later, the coast was visited by the Portuguese, who termed it Terra de malaguet. The celebrated Columbus also, who traded to the coast of Guinea, called it Costa di Maniguetta. Soon after this period, the spice became a monopoly of the kings of Portugal.

English voyagers visited the Gold Coast in the 16 th century, bringing thence in exchanging for European goods, gold, ivory, pepper, and Grains of Paradise. ${ }^{3}$ The pepper was doubtless that of Piper Clusii (p. 530).

Grains of paradise, often called simply grains, were anciently used as a condiment like pepper. They were also employed with cinnamon and ginger in making the spiced wine called hippoeras, in vogue during the 14 th and 15 th centuries.

In the hands of modern botanists, the plant affording this drug has been the subject of a complication of errors which it is needless to discuss: Suffice it to say, that Amomum Granum Paradisi as described by Linnæus cannot be identified; - that in 1817, Afzelius, a Swedish botanist, who resided some years at Sierra Leone, published a description of "Amomum Granum Paradisi? Linn.," " but that the specimen of it alleged to have been received from him, and now preserved in the herbarium of Sir J. E. Smith, belongs to another species. Under these circumstances, the name given to the graius of paradise plant by Roscoe, A. Melegueta, has been accepted as quite free from doubt. ${ }^{5}$

Description-The seeds are about $\frac{1}{10}$ of an inch in diameter, rather variable in form, being roundish, bluntly angular or somewhat pyramidal. They are hard, with a shining, reddish-brown, shagreen-like surface. The hilum is beak-shaped and of paler colour. The seeds when crushed are feebly aromatic, but have a most pungent and burning taste.

Microscopic Structure-In structure, grains of paradise agree in most respects with cardamom seeds. Yet in the former, the cells of the albumen have very thin, delicate walls which are much more elongated. Of the testa, only the innermost layer agrees with the corresponding part of cardamom; whilst the middle layer lias the cell walls so much thickened that only a few cavities, widely distant from one another, remain open. The outer layer of the testa consists of thick-walled cells, the cavities of which appear on transverse section, radially extended. The albumen is loaded with starch granules of 2 to $5 \mathrm{mkm}$. diameter, the whole amount in eacli cell being agglutinated, so as to form a coherent mass.

\section{Chemical Composition-Grains of paradise contain a small pro-}

1 G. di Barros, Asia, Venet. 1561. 33 (65).

2 Quoted at n. 530, note 3.

3 Hakluyt, Principal Navigations, ii. pt. 2. - First Voiage of the Primerose and Lion to Guinea and Benin, A. D. 1553.

4 licmedia Guincensia. Upsatios. p. 71.
5 I have repeatedly raised Amomum Nclcgucta from eommereial Grains of Paradise, and have eultivated the plant for some years, obtaining not ouly flowers, but large wellripened fruits containing fertile seeds.- 
portion of essential oil; $53 \mathrm{Hb}$. yielded us only $2 \frac{1}{2}$ o\%, equivalent to nearly 0.30 per cent. ${ }^{1}$ 'The oil is faintly yellowish, neutral, of an agreeable odour reminding one of the seeds, and of an aromatic, not acrid taste. Tt has a sp. gr. at $1.5 \cdot 5^{\circ} \mathrm{C}$, of 0.825 . It is but sparingly soluble in absolute alcohol or in spirit of wine; but mixes clearly with bisulphide of carbon; it dissolves iodine without explosion. When saturated with dry hydrochloric gas, no solid compound is formed.

The oil begins to boil at about $236^{\circ} \mathrm{C}$., and the chief bulk of it distils at $257^{\circ}-258^{\circ}$ : the residual part is a thick brownish liquid. Examined in a column of $50 \mathrm{~mm}$. long, the crude oil deviates $1.9^{\circ}$ to the left. The portion passing over at $257^{\circ}-258^{\circ}$ deviates $1 \cdot 2^{\circ}$, the residue $2^{\circ}$ to the left. The optical behaviour is consequently in favour of the supposition that the oil is homogeneous. This is corroborated by the results of three elementary analyses which lead to the formula, $\mathrm{C}^{20} \mathrm{H}^{32} \mathrm{O}$, or $\mathrm{C}^{10} \mathrm{H}^{16}+\mathrm{C}^{10} \mathrm{H}^{16} \mathrm{O}$.

In order to ascertain whether the seed contains a fatty oil, 10 grammes, powdered with quartz, were exhausted with boiling ether. This gave upon evaporation $0.583 \mathrm{grm}$. of a brown viscid residue, almost devoid of odour, but of intense pungency. As it was entirely soluble in glacial acetic acid or in spirit of wine, we may consider it a resin, and not to contain any fatty matter.

The seeds, dried at $100^{\circ}$ C., afforded us $2 \cdot 1$ o per cent. of ash, which, owing to the presence of manganese, had a green hue.

Commerce-Grains of paradise are chiefly shipped from the settlements on the Gold Coast, of which Cape Coast Castle and Accra are the more important. Official returns ${ }^{2}$ show that the exports in 1871 from this district, were as follows:- to Great Britain 85,502 17., the United States 35,630 Hb., Germany 28,501 7b., France 27,125 Hb., Holland 14,250 \#.- -total, 191,011 1b. (1705 cwt.)

Uses-The seeds are used in cattle medicines, occasionally as a condiment, but chiefly, we believe, to give a fiery pungency to cordials.

\section{ORCHIDACEE.}

\section{SALEP.}

Radix Salep, Radix Satyrii; Salcp; F. Salcp; G. Salcplenollcn.

Botanical Origin-Most, if not all, species of Orchis found in Europe and Northern Asia, are provided with tubers which, when duly prepared, are capable of furnishing salep. Of those actually so used, the following are the more important, namely-Orchis mascula L., O. Morio L., $O$ militaris L., O. ustulatc L., O. pyramidalis L., O. coriophor L., and $^{2}$ O. longicruris Link. These species which have the tubers cntirc, are natives of the greater part of Central and Southerm Europe, Turkey, the Caucasus and Asia Minor. ${ }^{3}$

I This oil was obtained and tried in medicine in the beginning of the 17 th century.Porta, De Distillatione, liome, 1608, lib. iv. c. 4.
2 Blue Book for the Colony of the ciold Coast in 1871.

3 'T'chilintchefi entumerates 36 species of Orehis as occurring in $A$ sia Mlinor- - licic Mincure, Bot. ii. 1860 . 
The following species with palmate or lobed tubers have a geographical area no less extensive, namely, $O$. maeulata L., O. saeeifera Brongn., O. conopsea L., and"O. latifolia L. The last-named reaches North-Westem India and Tibet; and O. conopsea occurs in Amurland in the extreme east of Asia.

The salep of the Indian bazaars, known as Sálib misrí, for fine qualities of which the most extravagant prices are paid by wealthy orientals, is derived from certain species of Eulopthia, as E. campestris Lindl., E. herbacea Lindl., and probably others. ${ }^{1}$

History-Under the superstitious influence of the so-called doetrine of signatures, salep ${ }^{2}$ has had for ages a reputation in Eastern countries as a stimulant of the generative powers; and many Europeans who have lived in India, although not prepared to admit the extravagant virtues ascribed to it by Hindus and Mahommedans, yet regard it as a valuable nutrient in the sick room.

The drug was known to Dioscorides and the Arabians, as well as to the herbalists and physicians of the middle ages, by whom it was mostly prescribed in the fresh state. Gerarde (1636) has given excellent figures of the various orchids whose tubers, says he- "our age useth."

Geoffroy ${ }^{3}$ having recognized the salep imported from the Levant to be the tubers of an orchis, pointed out in 1740 how it might be prepared from the species indigenous to France.

Collection-The tubers are dug up after the plant has flowered, and the shrivelled ones having been thrown aside, those which are plump are washed, strung on threads and scalded. By this process their vitality is destroyed, and the drying is easily effected by exposure to the sun or to a gentle artificial heat. Though white and juicy when fresh, they become by drying hard and horny, and lose their bitterish taste and peculiar odour. The drug found in English trade is. mostly iniported from Smyrna. That sold in Germany is partly obtained from plants growing wild in the Taunus mountains, Westerwald, Rhön, the Odenwald, and in France. Salep is also collected in Greece, and used in that country and Turkey in the form of decoction, which is sweetened with honey and taken as an early morning drink. ${ }^{4}$ The salep of India is produced on the hills of Afghanistan, Beluchistan, Kabul and Bokhara $;^{5}$ the Neilgherry Hills in the south, and even Ceylon, are said likewise to afford it.

Description-Levant salep, such as is found in the English market, consists of tubers half an inch to an inch in length, of ovoid or oblong form, often pointed at the lower end, and rounded at the upper where is a depressed scar left by the stem; palmate tubers are unfrequent. They are generally shrunken and contorted, covered with a roughly granular skin, pale brown, translucent, very liard and horny, with but little odour and a slight not unpleasant taste. After maceration in water for several

1 The Indian species of Euloplice have been reviewed by Lindley in Journ. of Limn. Soc., Bot., iii. (1859) 23.

2 Salep is the Arabic for fox, and the drug is called in that language Khus yatu's salat, i.e. fox's testicle; or Khus yatu'l kalb, i.e. dog's testiele. The word Orehis, and the old English names Doystones, Foxstones, IFare- stones and Goutstones, have all been given in allnsion to the form of the tubers.

3 Mém. de l'Acad. des Sciences for 1740. 99.

4 Heldreich, Nutzpflanzen Gricehentands, A then, 1862. 9.

${ }^{5}$ Powell, Economic Products of the Punjad, Poorkee, i. (1868) 261; Stewart, Punjal
Plants, Lahore, 1869. 236. 
hours, they regain their original form and volume. Cierman salep is more translucent and gummy-looking, and las the aspect of being more trimmed anci prepared.

Microscopic Structure-The fresh tuber exhibits on transverse section, a few outer rows of thin-walled cells rich in starch. These are followed by parenchyme of elongated colourless cells likewise containing starch, and isolated bundles of acicular crystals of oxalate of calcium. In this parenchyme, there are numerous larger cells filled with hoinogeneous mueilage. Small vascular bundles are irregularly scattered throughout the tuber. In Orchis mascula and O. latifolia, the starch grains are nearly globular, and about $25 \mathrm{mkm}$. in diameter. In dried salep, the cell-walls are distorted and the starch grains agglomerated.

Chemical Composition-The most important constituent of salep is a sort of mucilage, the proportion of which according to Dragendorff (1865) amounts to 48 per cent.; but it is doubtless subject to great variation. Salep yields this mucilage to cold water, forming a solution which is turned blue by iodine, and mixes clearly with neutral acetate of lead like gum arabic. On addition of ammonia, an abundant precipitate is formed. Mucilage of salep precipitated by alcohol and then dried, is coloured violet or blue, if moistened with a solution of iodine in iodide of potassium. The dry mucilage is readily soluble in ammoniacal solution of oxide of copper; when boiled with nitric acid, oxalic, but not mucic acid is produced. In these two respects, the mucilage of salep agrees with cellulose, rather than with gum arabic. In the large cells in which it is contained, it does not exhibit any stratification, so that its formation does not appear due to a metamorphosis of the cellwall itself. Mucilage of salep contains some nitrogen and inorganic matter, of which it is with difficulty deprived by repeated precipitation by alcohol.

It is to the mucilage just described that salep chiefly owes its power of forming with even 40 parts of water a thick jelly, which becomes still thicker on addition of magnesia or borax. The starch however assists in the formation of this jelly; yet its amount is very small, or even nil in the tuber bearing the flowering stem, whereas the young lateral tuber abounds in it. The starch so deposited is evidently consumed in the subsequent period of vegetation, thus explaining the fact that tubers are found, the decoction of which is not rendered blue by iodine. Salep contains also sugar and albumin, and when fresh, a trace of volatile oil. Dried at $1.10^{\circ} \mathrm{C}$., it yields 2 per cent. of ash, consisting chiefly of phosphates and chlorides of potassium and calcium (Dragendorff)。

Uses-Salep possesses no medicinal powers; but from its property of forming a jelly with a large proportion of water, it lias come to be regarded as highly nutritious, - a popular notion in which we do not concur. A decoction flavoured with sugar and spice, or wine, is an agreeable drink for invalids, but is not much used in England. ${ }^{1}$

1 As powdered salep is difficult to mix with water, many persons fail in preparing this decoetion; but it may be easily managed by first stimring tho salep with a littlo spirit of wine, then adding the water suddenly and boiling the mixture. The proportions are powdered salep 1 drachm, spirit It fluid drachms, water $\frac{1}{2}$ a pint. 


\section{VANILLA.}

$$
\text { Vanilla; 'F. and G. Vanille. }
$$

Botanical Origin - Vanilla planifolia Andrews-Indigenous to the hot regions (ticrra calicnte) of Eastern Mexico, diffused by cultivation through other tropical countries. The plant, which is rather fleshy and has large greenish inodorous flowers, grows in moist, shady forestis, climbing the trees by means of its aërial roots.

History-The Spaniards found vanilla in use in Mexico as a condiment to chocolate, and by them it was brought to Europe; but it must have long remained very scarce, for Clusius, who received a specimen in 1602 from Morgan, apothecary to Queen Elizabeth, described it as Lobus oblongus aromaticus, without being in the least aware of its native country or uses. ${ }^{2}$ In the Thesaurus of Hernandez, there is a figure and account of the plant under the name of Araco aromatico. ${ }^{3}$

In the time of Pomet (1694), vanilla was imported by way of Spain, and was much used in France for flavouring chocolate and scenting tobacco. It had a place in the materia medica of the London Pharmacopoia of 1721; and was well known to the druggists of the first half of the 18th century, after which it seems to have gradually disappeared from the shops. Of late times it lias been imported in great abundance, and is now plentifully used, not only by the chocolate manufacturer, but also by the cook and confectioner.

Cultivation-The culture of vanilla is very simple. Shoots about three feet long having been fastened to trees and scarceily touching the ground, soon strike roots on to the bark, and form plants which commence to produce fruit in three years, and remain productive for thirty to forty.

The fertilization of the flower is naturally brought about by insect agency. Morren, ${ }^{4}$ the director of the Botanical Garden of Liésge, showed in 1837 that it might be efficiently performed by man, ${ }^{5}$ since which the production of the pods has been successfully carried on in all tropical countries without the aid of insects. Evell in European forcing houses, the plant produces fruits of full size, which for aroma bear comparison with those of Mexico.

In vanilla plantations, the pods are not allowed to arrive at complete maturity but are gathered when their green colour begins to change. According to the statements of De Vriese, ${ }^{6}$ they are dried by a rather circuitous process, namely by exposing them to heat alternately uncovered, and wrapped in woollen cloths, whereby they are artificially ripened and acquire their ultimate aroma and dark hue. They are then tied together into small bundles.

Description-The fruit when fresh is of the thickness of the little

a Diminutive of the Spanish vaina, a pod or capsule.

2 Exotica (1605) lib. iii. c. 18. 72.

3 Rerum Medicarum Nove Ifispania Thesaums, liomx, 1651. P. 38.-The original drawing was one of a series of 1200 , exeented at great cost in Mexico by order of the King of Spain during the previous century

${ }_{4}^{4}$ Ann. of Nat. Hist. iii. (1839) 1.

5 This observation was made independently by Edmond, a Creole of the island of Reunion, shortly after 1817 .

- De Vanicljc, Leyden, 1856. 22. 
finger, obscurely triquetrous, opening longitudinally by two unequal valves. It is fleshy, firm, smootl and plump; when cut transversely, it exudes an inodorous sliny jnice, abounding in spiculce of oxalate of calcimm. It is one-celled, with a three-sided cavity, flon each wall of which projects a two-branched placenta, each branch subdividing into two backward-curling lobes. There are thus in all 12 ridges, which traverse the fruit lengthwise, and bear the seeds. Fine hair-like papillice line as a thick fringe the three angles of the cavity, and secrete the odorous matter, which after drying is diffused through the whole pod. The papilla likewise contain drops of oil, which is freely absorled by the paper in which a pod is wrapped. That the odorous matter is not resident in the fleshy exterior mass, we have ascertained by slicing off this portion of a fresh fruit and drying it separately; the interior alone proved to be fragrant.

The vanilla of commerce occurs in the form of fleshy, flexible, stick-like pods, 3 to 8 inches long, and $\frac{3}{10}$ to $\frac{4}{10}$ of an inch wide, of a compressed cylindrical form, attenuated and hooked at the stalk end. The surface is finely furrowed lengthwise, shining, unctuous, and often beset with an efflorescence of minute colourless crystals. The pod splits lengthwise into two unequal valves, revealing a multitude of minute, shining, hard, black seeds of lenticular form, imbedded in a viscid aromatic juice.

The finest vanilla is the Mexican. Bourbon Vanilla, which is the more plentiful, is generally shorter and less intense in colour, and commands a lower price.

Microscopic Structure-The inner half of the pericarp contains about 20 vascular bundles, arranged in a diffuse ring. The epidermis is formed of a row of tabular thick-walled cells, containing a granular brown substance. The middle layer of the pericarp is composed of large thin-walled cells, the outer of which are axially extended, while those towards the centre have a cubic or spherical form. All contain drops of yellowish fat, and brown granular masses which do not decidedly exhibit the reaction of tannin. The tissue further encloses needles of oxalate of calcium and prisms of vanillin.

On the walls of the outer cells of the pericarp ${ }^{2}$ are deposited spiral fibres, which occur still more conspicuously in the aërial roots and in the parenchyme of the leaves of other orchids. The placentæ are coated with delicate, thin-walled cells.

Chemical Composition-Vanilla does not contain an essential oil, but owes the fragrance for which it is remarkable, to the substance which is found in a crystalline state in the interior or on the surface of the fruit, or dissolved in the viscid oily liquid surrounding the seeds. It was formerly regarded as cinnamic or benzoic acid, and then as cumarin, until Gobley demonstrated its peculiar nature (previously asserted by Bley) and gave it the name of Vanillinc, now changed to Vanillin. ${ }^{3}$

1 This juice like that of the squill has an irritating effeet on the skin, a faet of which the enltivators in Manritius aro well aware.

2 Vanilla grown in Europe is devoid of such eells. We can fully eorroborate this statement (first mado by Berg) from the examination of very aromatie pods produeed in 1871 at Hillfield House, Reigate.

3 Journ. de Pharm. xxxiv. (1858) 401. 
Stokkebye ${ }^{1}$ proved vanillin to possess feebly acid properties, and in consequence termed it Vanillic Acid. It may be obtained in the following manner : vanilla is exhausted by alcohol sp. gr. 850 , and the alcohol removed by evaporation. To the extract, sufficient water is to be added to form a syrupy liquid, which is then to be agitated with successive quantities of ether. The ether having evaporated, an odorous brown extract will remain; from it the vanillin may be dissolved out by boiling water and crystallized, and afterwards purified by animal charcoal. Vanillin forms hard, 4-sided, acicular prisms, having a weak vanillalike odour and slightly pungent taste; they fuse at $82^{\circ} \mathrm{C}$. and can be sublimed, though not easily, unchanged. It is soluble in ether or spirit of wine, especially warm; and the solution in each case feebly reddens litmus. It dissolves in 11 parts of boiling water, is soluble in fatty and volatile oils, and in alkaline solutions, from which last it can be precipitated unaltered by addition of a stronger acid. It does not decompose carbonates even when heated. With chemical reagents, its most interesting character is that of striking a fine dark violet with perchloride of iron.

A later student of the chemistry of vanillin, P. Carles, ${ }^{2}$ assigned to it the formula $\mathrm{C}^{16} \mathrm{H}^{8} \mathrm{O}^{6}$. He obtained crystallized compounds of it with magnesium, lead and zinc. The vanillates of potassium and sodium darken on exposure to air, or when their watery solutions are heated. One or two equivalents of hydrogen are easily replaced by iodine or bromine, the compounds thus obtained being crystallizable.

W. von Leutner ${ }^{3}$ extracted from vanilla nearly 1 per cent. of vanillin, which he found to afford with 182 parts of water at $18^{\circ} \mathrm{C}$., a solution reddening litmus.

Some interesting researches performed in Hofmann's laboratory at Berlin by Tiemann and Haarmann, have shown (1874) that vanillin may be formed artificially. In the sapwood of pines, there occurs a substance called Conifcrin, $\mathrm{C}^{16} \mathrm{H}^{22} \mathrm{O}^{8}+2 \mathrm{H}^{2} \mathrm{O}$, first observed in 1861 by Hartig, and examined in 1866 by Kubel. By means of emulsin, coniferin taking up $\mathrm{H}^{2} \mathrm{O}$, can be resolved into sugar and another crystallizable substance, according to the following equation:- $\mathrm{C}^{16} \mathrm{H}^{22} \mathrm{O}^{8}+\mathrm{H}^{2} \mathrm{O}=$ $\mathrm{C}^{6} \mathrm{H}^{12} \mathrm{O}^{6}+\mathrm{C}^{10} \mathrm{H}^{12} \mathrm{O}^{3}$. The second substance thus derived, may be collected by means of ether, which dissolves neither coniferim nor sugar. By oxidizing it, or coniferin itself, by bichromate of potassium and sulphuric acid, Vanillin was obtained. Upon fusing it with potash, Protocatechric Acid, $\mathrm{C}^{7} \mathrm{H}^{6} \mathrm{O}^{4}$, is formed. In fact, according to these researches, vanillin, $\mathrm{C}^{16} \mathrm{H}^{8} \mathrm{O}^{6}$, must be regarded as the methylic aldehyde of that acid. This view is confirmed by the decomposition that ensues upon heating vanillin in a closed tube with hydrochloric acid, during which methylic chloride, $\mathrm{CH}^{3} \mathrm{Cl}$, is formed.

Leutner also found in vanilla, fatty and waxy matters $11 \cdot 8$, resin $4 \cdot 0$, gum and sugar 16.5 per cent.; and obtained by incineration of the drug 4.6 per cent. of ash.

Production and Commerce-The chief seats of vanilla-production in Mexico are the coast-regions of the State of Vera Cruz, the centre of

${ }^{1}$ Wittstein's Vicrtcljahressehrifl f. pratct. Pharm. xiii. (1864) 481.

2 Journ. de Pharm. xii. (1870) 254 ;
Bull. de Ta Soc. ehimique de Paris, xrii. (1872) 12.

3 Wiggers and Husemann, Jahresbericht. fiir 1872.35 . 
the culture being Jicaltepec in the vicinity of Nautla. ${ }^{1}$ Vanilla is likewise obtained on the western declivity of the Cordilleras in the State of Oaxaca, and in lesser quantity in those of 'Tabasco, Chiapas, and Yucatan. The eastern parts of Mexico exported in 1864, by way of Vera Cruz and '́ampico, about 20,000 kilo. of vanilla, cliefly to Bordeaux. Since then, the production seems to have mucli dechined, the importation into France having been only 6869 kilo in 1871, and 1938 in $1872 .{ }^{2}$

The cultivation of vanilla in the small French colony of Ríunion or Bourbon ( 40 miles long by 27 miles broad), introduced by Marchant in 1817 from Mauritius, has of late been very successful, notwithstanding many difficulties occasioned by the severe cyclones which sweep periodically over the island; in 1871, the quantity exported was $39,200 \mathrm{Ht}$. ${ }^{3}$ The neighbouring island of Mauritius also produces vanilla, of which it shipped in 1872, $7139 \mathrm{lb}^{4}$ There is likewise a very extensive cultivation of vanilla in Java.

Vanilla comes into the market chiefly by way of France, which country, according to the official statistics just quoted, imported in 1871, 29,914 kilo. $(65,981 \mathrm{ft}$.) ; in $1872,26,587$ kilo. $(58,643 \mathrm{lb}$.) Of the lastnamed quantity, only about half was retained for home consumption.

Uses-Vanilla has long ceased to be used in medicine, at least in this country, but is often sold by druggists for flavouring chocolate, ices, creams, and confectionary.

\section{IRIDACE $\nexists$.}

\section{RHIZOMA IRIDIS.}

Radix Iridis Florentina; Orris Root; F. Racine d'Iris; G. Fcilchenwurzel.

Botanical Origin-This drug is derived from three species of Iris, namely :-

1. Iris Germanica L., a perennial plant with beautiful large deep blue flowers, common about Florence and Lucca, ascending to the region of the chestnut. It is also found dispersed throughout Central and Southern Europe, and in Northern India and Morocco; and is one of the commonest plants of the gardens round London, where it is known as the Bluc Flag.

2. I. pallida Lam., a plant resembling the preceding, but with flowers of a delicate pale blue, growing wild in stony places in Istria. It is abundant about Florence and Lucca in the region of the olive, but is a doubtful native.

3. I. Florentina L., a species bearing large white flowers, indigenous to the coast region of Macedonia and the south-western shores of the

1 Culture clu vanillier an Mcarinu, in the Revue Coloniale, ii. (1849) 383-390.

2 Documents S'tatistiques réurris par l'Administration des Dounes sur le Commerce 1le la Erance, année $1872,1 \% 6$.
3 Consul Segrave of Rémion in the Consuler. lieports, liresented to l'arliament, Aug. 1872 .

- Heuritius Bluc Book, for the year 185 . 
Black Sea, Hersek in the Gulf of Ismid, and about Adalia in Asia Minor. It also occurs in the neighbourhood of Florence and Lucca, but in our opinion only as a maturalized plant. ${ }^{1}$

These three species, but especially I. Gormanica and I. pallida, are cultivated for the production of orris root in the neighbourhood of Florence. They are planted on the edges of terraces and on waste, stony places contiguous to cultivated ground. I. Florentina is seldom found beyond the precincts of villas, and is far less common than the other two.

History-In ancient Greece and Rome, orris root was largely used in perfumery ; and Macedonia, Elis, and Corinth were famous for their unguents of iris. ${ }^{2}$ Theophrastus and Dioscorides were well acquainted with orris root; the latter, as well as Pliny, remarks that the best comes from Illyricum, the next from Macedonia, and a sort tstill inferior from Libya ; and that the root is used as a perfume and medicine. Visiani ${ }^{3}$ considers that Iris Gcrmanica is the Illyrian iris of the ancients, which is highly probable, seeing that throughout Dalmatia (the ancient Illyricum) that species is plentiful, and I. Florentince and $I$. pallida do not occur. At what period the two latter were introduced into Northern Italy we have no direct evidence, but it was probably in the early middle ages. The ancient arms of Florence, a white lily or iris on a red shield, seem to indicate that that city was famed for the growth of these plants. Petrus de Crescentiis ${ }^{4}$ of Bologna, who flourished in the 13th century, mentions the cultivation of the white as well as of the purple iris, and states at what season the root should be collected for medicinal use.

But the true Illyrian drug was held to be the best; and Valerius Cordus ${ }^{5}$ (ob. 1544) laments that it was being displaced by the Florentine, though it might easily be obtained through the Venetians.

Orris root mixed with anise was used in England as a perfume for linen as early as 1480 (p. 277), under which date it is mentioned in the Wardrobe Accounts of Edward IV.

All the species of iris we have named were in cultivation in England in the time of Gerarde,- that is, the latter end of the 16th century. The starch of the rhizome was formerly reckoned medicinal, and directions for its preparation are to be found in the Traicté dc la Chymic of Le Febvre, published in 1660.

Production-The above-mentioned species of iris are known to the Tuscan peasantry by the one name of Giaggiolo. The rhizomes are collected indiscriminately, the chief quantity being doubtless furnished by the two more plentiful species, I. Gormanica and I. pallida. They are dug up in August, are then peeled, trimmed, and laid out in the sunshine to dry, the larger bits cut off being reserved for replanting. At the establishment

1 From observations made at Florenee in the spring of 1872 , I am led to regard the three speeies here named as quite distinet. The following comparative characters are perhaps worth recording :-

I. Cormanice - flower-stem searcely $1 \frac{1}{2}$ times as tall as lenves; flower's more crowiled than in $I$. pallided, varying in depth of colour but never pale bluc.

1. pazlidre - bracts brown and seariose; flower-stem twice as high as leaves.
I. Florentina - bracts green and fleshy; flower-stem short as in I. Germanica; is a more tender plant than the other two and blossoms a little later.-D. H.

${ }^{2}$ For furtlier information, consult Blümner, Dic gowerbliche Thätigkcit der Vötkcr des Filcussischen Altcrthums, 1869.57. 76. 83.

3 Florce Datmatioa, i. (1842) 116.

4 De ommibus agriculture partibus, Basil. 1548. 219.-

5 Dispensatorium, Norimb, 1529. 288. 
of Count Strozzi, founded in 1806 at Pontasieve near Florence, which lies in the midst of the orris district, the rhizomes, collected from the peasants by itinerant dealers, are separated into different qualities, as selecled (secli i) and sorls (in sortc), and are ultimatcly offered in trade either: entire, or in small bits (franlumi), parings (raspalure), powder (polvere di giaggiolo o d' ireos), or manufactured into orris peas.

'The growing of orris is only a small branch of industry, the crops being a sort of side-product, but it is nevertheless shared between the tenant and landowner as is usual on the Tuscan system of husbandry.

Description-The rootstock is fleshy, jointed and branching, creeping horizontally near the surface of the ground. It is formed in old plants of the annual joints of five or six successive years, the oldest of which are evidently in a state of decay. These joints are mostly dichotomous, subcylindrical, a little compressed vertically, gradually becoming obconical, and attaining a maximum size when about three years old. They are 3 to 4 inches long and sometimes more than 2 inches thick. Those only of the current year emit leaves from their extremities. The rhizome is externally yellowish-brown, internally white and juicy, with an earthy smell and acrid taste. By drying, it gradually acquires its pleasant violet odour, but it is said not to attain its maximum of fragrance until it has been kept for two years.

We have carefully compared with each other the fresh rhizomes of the three species under notice, but are not able to point out any definite character for distinguishing them apart.

Dried orris root as found in the shops, occurs in pieces of 2 to 4 inches long, and often as much as $1 \frac{1}{4}$ inches wide. A full-sized piece is seen to consist of an elongated, irregularly subconical portion emitting at its broader end one or two (rarely three) branches which, having been cut short in the process of trimming, have the form of short, broad cones, attached by their apices to the parent rootstock. The rootstock is flattened, somewhat arched, often contorted, shrunken and furrowed. The lower side is marked with small circular scars, indicating the point of insertion of rootlets. The brown outer bark has been usually entirely removed by peeling and paring; and the dried rhizome is of a dull, opaque white, ponderous, firm and compact. It has an agreeable and delicate odour of violets, and a bitterish, rather aromatic taste, with subsequent acridity.

A sort of orris root which has been dried without the removal of the outer peel, is found under the name of Irisa in the Indian bazaars, and now and then in the London market. It is, we suppose, the produce of Iris Germanica L. (I. Nepalensis Wall.), which according to Hooker, is cultivated in Kashmir. Orris root of rather low quality is now often imported from Morocco; it is obtained, we believe, exclusively from $I$. Germanica.

Microscopic Structure-On transverse section, the white bark about $2 \mathrm{~mm}$. broad, is seen to be separated by a fine brown line from the faintly yellowish woody tissue. The latter is traversed by numerous vascular bundles, in diffuse and irregular rings, and exhibits here and there small shining crystals of oxalate of calcium. It is

1 Groves, Pharm. Journ. Sopt. 21, 1872. 229. - We havo also to thank him for information communicated personally. 
made up uniformly of large thick-walled spherical porous cells, loaded with starch granules, which are oval, rather large and very numerous; prisms of calcium oxalate are also visible. The spiral vessels are small and run in very various directions. The foregoing description is applicable to any one of the three species we have named.

Chemical Composition-When orris root is distilled with water, a solid crystalline substance, called Orris Camphor, is found floating onl the aqueous distillate. This substance, which we obtained from the laboratory of Messrs. Herrings \& Co. of London, is yielded, as we learn from Mr. Umney, to the extent of 0.12 per cent.-that is to say, $3 \mathrm{cwt} .3$ qrs. $23 \mathrm{lt}$. of rhizome afforded of it $8 \frac{1}{2}$ ounces. ${ }^{1}$ We liave purified it by means of charcoal, and recrystallization from dilute alcohol, when we finally got it in very light voluminous scales, which fuse at $51.5^{\circ} \mathrm{C}$., but do not volatilize to any considerable extent even at $150^{\circ}$. These crystals we found to contain on an average of three analyses, carbon 73.96, and hydrogen $12 \cdot 26$ per cent. This leads to the formula $\mathrm{C}^{14} \mathrm{H}^{28} \mathrm{O}^{2}$, which is that of Myristic Acid (see p. 455). The crystals have an acid reaction; they are easily soluble in caustic alkali, and are again separated by an acid:-in fact, we believe them to be simply myristic acid, impregnated with a little essential oil which they obstinately retain. The results obtained by Dumas in 1835, do not accord with ours.

By exhausting orris root with spirit of wine, a soft brownish resin is obtained, together with a little tannic matter. The resin has a slighlitly acrid taste; the tamin strikes a green colour with persalts of iron.

Commerce-Orris root is shipped from Leghorn, Trieste and Mogador,-from the last-named port, to the extent in 1872 of 456 cwt. $^{2}$ There are no data to show the total imports into Great Britain. France imported in the year 1870, about 50 tons of orris root.

Uses-Frequently employed as an ingredient in tooth-powders, and in France for making issue-peas; but the chief application is as a perfume.

\section{CROCUS.}

Croci stigmata; Saffron; ${ }^{3}$ F. and G. Safran.

Botanical Origin-Crocus sativus L., a small plant with a fleshy, bulb-like corm and grassy leaves, much resembling the common Spring Crocus of the gardens, but blossoming in the autumin. It has an elegant purple flower, with a large orange-red stigma, the three pendulous divisions of which are protruded beyond the perianth.

The Saffron Crocus is supposed to be indigenous to Greece, Asia Minor, and perhaps Persia, but it has been so long under cultivation in the East that its primitive home is somewhat doubtful.4

I The producc of some previous operations, in which $23 \mathrm{cwt}$. of orris were distilled, afforded but littlc over one-tenth per ccnt.

2 Consular lieports, Ang. 1873. 917.

3 The word Saffron is derived from the Arabic Asfar, ycllow.
4 Chappellier has pointed out that Crocus sutivus $\mathrm{L}_{\text {. }}$ is unknown in a wild state, and that it hardly crer produces sced even though artificially fertilized; and has argued from thesc facts that it is probably a liybrid.-Bulletin de la Soc. bot. de France, xx. (1873) 191. 
History-Saffron, either as a medicine, condiment, perfume, or dye, has been highly prized by mankind from a remote period, and has played an important part in the history of commerce.

Under the Hebrew name Carcôm, which is supposed to be the root of the word Crocus, the plant is alluded to by Solomon; ${ }^{1}$ and as K póros, by Homer, Hippocrates, Theophrastus, and 'Theocritus. Virgil and Colnmella mention the saffron of Monnt 'lmolus; tle latter also names that of Corycus in Cilicia, and of Sicily, both which localities are alluded to as celebrated for the drug by Dioscorides and Pliny.

Saffron was an article of traffic on the Red Sea in the first century; and the author of the Periplus remarks that Kpókos is exported from Egypt to Southern Arabia, and from Barygaza in the gulf of Cambay. ${ }^{2}$

It was cultivated at Derbend and Ispahan in Persia, and in Trans oxania in the 10th century, whence it is not improbable the plant was carried to China, for according to the Chinese it came thither from the country of the Mahommedans. Chinese writer's have recorded that under the Tuen dynasty (A.D. 1280-1368), it became the custom to mix Sa-fa-lang (Saffron) with food. ${ }^{4}$

There is evidence to show that saffron was a cultivated production of Spain ${ }^{5}$ as early as 4.D. 961; yet it is not so mentioned, but only as an eastern drug, by St. Isidore, archbishop of Seville in the 7th century. As to France, Italy, and Germany, it is commonly said that the saffron crocus was introduced into these countries by the Crusaders. Porchaires, a French nobleman, is stated to have brought some bulbs to Arignon towards the end of the 14th century, and to have commenced the cultivation in the Comtat Venaissin, where it existed down to recent times. About the same time, the growing of saffron is said to lave been introduced by the same person into the district of Gâtinais, south of Paris. ${ }^{6}$ At that period, saffron was one of the productions of Cyprus, ${ }^{7}$ with which island France was then, through the princes of Lusignan, particularly related.

During the middle ages, the saffrom cultivated at San Gemignano in Tuscany was an important article of exportation to Genoa. ${ }^{8}$ That of Aquila in the kingdom of Naples was also famous, and was still distinguished in price-lists at the beginning of the present century. The growing of saffron in Sicily which was noticed even by Columella, is carried on to the present day, but the quantity produced is insufficient even for home consumption. ${ }^{9}$ In Germany and Switzerland, where a more rigorous climate must liave increased the difficulties of cultivation, the production of saffron was an object of industry in many localities..$^{10}$

The saffron crocus is said to have been introduced into England during the reign of Edward III. (A.D. 1327-1377). ${ }^{11} \quad$ Two centuries

1 Canticles, eh. ir. 14.

2 Lassen, Indische Altcithumshunde, iii. (185\%) 52.

3 Istachri, Buch der Ländcr, iibersetzt ron Mordtmann, 87. 93. 124. 126; Edrisi, G'́ograptic, trad. par Jaubert, 168. 192.

${ }^{4}$ Bretschneider, Chinesc Botanical Works, Foochow, 1870. 15.

5 Le Calendricr de Cordone de l'année 961, Leycle, 1873. 33. 109.

"Comral et Waldmann, Iraité du Súfican ex ratinuis, Paris, 1846.
7 De Mas I atric, Hist. de l'ille de Chypre, iii. 498 .

s Bourquelot, Foires de 7a 'Champragne, Mém. de l'Acad. des inseript. ct belles-lettres cle l'Iustitut, v. (1565) 286.

9 Inzenga, in Amuali di Agricoltura Siciliana, i. (1851) 51.

10 Tragus, De Stimpium, ete. 1552. 1. 763 ; Ochs, Geschichte der Stade und Landschaft. Bossl, iii. (1S19) ] 89 .

II Mornat, Hist. and Autiq. of Esscr, ii. (1768) 545. 
later, it appears that English saffron was even exported to the Continent, for in a priced list of the spices sold by the apothecaries of the north of France, A.D. 1565-1570, mention is made of three sorts of saffron, of which "Safren d"Engleterre" is the most valuable. ${ }^{1}$

In the beginning of the last century (1723-28), the cultivation of saffron was carried on in what is described by a contemporary writer ${ }^{2}$ as-" all that large tract of ground that lies between Saffron Walden and Cambridge, in a circle of about 10 miles diameter." The same writer remarks that saffron was formerly grown in several other counties of England. The cultivation of the crocus about Saffron Walden, which was in full activity when Norden ${ }^{3}$ wrote in 1594, had ceased in 1768, and about Cambridge at nearly the same time. ${ }^{4}$ Yet the culture must have lingered in a few localities, for in the early part of the present century, a little English saffron was still brought every year from Cambridgeshire to London, and sold as a choice drug to those who were willing to pay a high price for it.

Saffron was employed in ancient times to a far greater extent than at the present day. It entered into all sorts of medicines, both internal and external; and it was in common use as a colouring and flavouring ingredient of various dishes for the table. The drug, from its inevitable costliness, has been liable to sophistication fron the earliest times. Both Dioscorides and Pliny refer to the frauds practised on it, the latter remarking- - adulteratur" nitil ceque."

During the middle ages, the severest enactments were not only made, but were actually carried into effect, against those who were guilty of sophisticating saffron, or even of possessing the article in an adulterated state. Thus at Pisa in A.D. 1305, the fundacarii, or keepers of the public warehouses, were required by oath and heavy penalties to denounce the owners of any falsified saffron consigned to their custody. ${ }^{5}$ The Pepperers of London about the same period were also held responsible to check dishonest tampering with saffron. ${ }^{6}$

In France, an edict of Henry II., of 18 March, 1550, recites the advantages derived from the cultivation of saffron in many parts of the kingdom, and enacts the confiscation and burning of the drug when falsified, and corporal punishment of offenders. ${ }^{\top}$

The authorities in Germany were far more severe. A Safranschau (Saffron-inspection) was established at Nuremberg in 1441, in which year $13 \mathrm{kt}$. of saffron was publicly burnt at the Schönen Brunuen in that city. In 1444, Jobst Findeker was burnt together with his adulterated saffron!-And in 1456, Hans Kölbele, Lienhart Frey and a woman, implicated in falsifying saffron, were buried alive. The Sufranschou was still in vigour as late as 1591; but new regulations

1 The other sorts are "Safren Caluzome" and "Scufren Noort."-Arehives générales elu Pas de Calais, quoted by Dorvault, Revuce pharmuceutique de 1858. p. 58.

2 Douglass, Phil. Truns. Nov. 1728. 566.

3 Jescription of Hssex, Camden Society, 1840. 8.

${ }^{4}$ Morant, op. cit. ; Lysons, Meegna, Britanicia, vol. ii. pt. i. (1808) 30. Lyssons recorrls that at Fulbouru, a village near Cambridge, there had been no titlue of saffion since 1774 .

5 Bonaini, Statuti incediti della cittò di Pisa dal xii. al xiv. sceolo, iii. (1557) 101.

- Riley, Mcmoriats of London and London life in the 13th, 14th, and 15th centurics, 1868. 120.

${ }^{7}$ De la Mare, Traité te Ta Policc, Puris, 
for the inspection of saffron were passed in $1613 .{ }^{1}$ There was also in the same city a Govuriraschan, or Spice-inspection, from 1441 to 1797.

Description-The flower of the saffron crocus has a style 3 to 4 . inches long, which in its lower portion is colourless and included within the tube of the perianth. Tn its upper part it becomes yellow, and divides into three tubular, filiform, orange-red stigmas, each about an inch in length. The stigmas expand towards their ends, and the tube of which they consist, is toothed at the edge and slit on its inner side. The stigma is the only part officinal, and alone is rich in colouring matter.

Commercial saffron (Hay Saffron of the druggists) is a loose mass of thread-like stigmas, which when unbroken are united in threes at the upper extremity of the yellow style. It is unctuous to the touch, tough and flexible; of a deep orange-red, peculiar aromatic smell, and bitter and rather pungent taste. It is hygroscopic and not easily pulverized; it loses by drying at $100^{\circ} \mathrm{C}$. about 12 per cent. of moisture which it quickly reabsorbs. ${ }^{2}$

The colouring power of saffron is very remarkable: we have found that a single grain rubbed to fine powder with a little sugar, will impart a distinct tint of yellow to 700,000 grains (10 gallons) of water.

Microscopic Structure-The tissue of the stigma consists of very thin, sinuous, closely-felted, thread-shaped cells, and small spiral ressels. The yellow colouring matter penetrates the whole, and is partly deposited in granules. The microscope likewise exhibits oil-drops, and small lumps probably of a solid fat. Large isolated pollen grains are also present.

Chemical Composition-The splendid colouring matter of saffrom has long been known as Polychroit; but in 1851, Quadrat, who instituted some fresh researches on the drug, gave it the name of Crocin, which was also adopted in 1858 by Rochleder. ${ }^{3}$ The experiments of Weiss in $1867^{4}$ have shown :-

1. That this substance (Polychroit, Crocin of Rochleder) is a peculiar glucoside which by the action of acids, splits into sugar, volatile oil and a new colouring matter.

2. That saffron contains only a minute quantity of ready-formed essential oil and sugar.

3. That this free essential oil is probably identical with that which is produced in the decomposition of polychroit.

4. That polychroit as hitherto prepared, has always contained a certain proportion of the new colouring matter produced by decomposition.

For the natural glucoside, Weiss retains the name of Polychroit, while the new colouring matter which results from its decomposition by an acid, he terms Crocin. It agrees with the Crocctin of Rochleder.

Polychroit was prepared by Weiss in the following mamer: saffron

1 J. F. Roth, Geschichte des Nïnntergischen Irandels, 1800-1802, iv. 221.

2 Eight lots of saffron weighing in tolo $61 \mathrm{lb}$., dried at various times during the course of nine venrs, lost $7 \mathrm{lb} .2 \frac{1}{4}$ oz., i.e. 11.7 per eent.- (Laboratory reeords of Messrs.
Allen \& Hamburys, Plough Court, Lombard Strect.)

3 Gmelin, Chomistry, xvi. (1864) 507.

4 Wiggers and Husemann, Jchrosbricht fol 1868. 35 . 
was treated with ether, by which fat, wax, and essential oil were removed; and it was then exhausted with water. From the aqueous solution, gummy matters and some inorganic salts were precipitated by strong alcohol. After the separation of these substances, polychroit was precipitated by addition of ether. Thus obtained, it is an orange-red, viscid, deliquescent substance, which, dried over sulphuric acid, becomes brittle and of a fine ruby colour. It has a sweetish taste but is devoid of odour, readily soluble in spirit of wine or water, and sparingly in absolute alcohol. By dilute acids, it is decomposed into Crocin, sugar, and an aromatic volatile oil having the smell of saffron. Weiss gives the following formula for this decomposition :-

$$
\underset{\text { polychroit }}{\mathrm{C}^{48} \mathrm{H}^{60} \mathrm{O}^{18} \mathrm{H}}=\underset{\text { crocin }}{\mathrm{H}^{2} \mathrm{O}}=\underset{\text { essential oil }}{2\left(\mathrm{C}^{16} \mathrm{H}^{18} \mathrm{O}^{6}\right)}+\underset{\text { sugar }}{\mathrm{C}^{10} \mathrm{H}^{14} \mathrm{O}}
$$

Crocin is a red powder, insoluble in ether, easily soluble in alcohol, and precipitable from this solution on addition of ether. It is only slightly soluble in water, but freely in an alkaline solution, from which an acid precipitates it in purple-red flocks. Strong sulphuric and nitric acids occasion the same colours as with polychroit; the former producing deep blue, changing to violet and brown, and the latter green, yellow, and finally brown. It is remarkable that hydrocarbons of the benzol class do not dissolve the colouring matter of saffron.

The oil obtained by decomposing crocin is heavier than water; it boils at about $209^{\circ} \mathrm{C}$., and is easily altered,-even by water. It is probably identical with the volatile oil obtainable to the extent of one per cent. from the drug itself, and to which its odour is due.

Saffron contains sugar (glucose ?), besides that obtained by the decomposition of polychroit. It leaves after incineration 5 to 6 per cent. of ash.

Production and Commerce-In France, the flowers are collected at the end of September or in the beginning of October. The stigmas are quickly taken out, and immediately dried on sieves over a gentle fire, to which they are exposed for only half an hour. According to Dumesnil ${ }^{1} 7000$ to 8000 flowers are required for yielding 500 grammes (17 $\frac{1}{2}$ oz.) of fresh saffron, which by drying is reduced to 100 grammes.

Notwithstanding the high price of saffron, its cultivation is by no means always profitable, from the many difficulties by which it is attended. Besides occasional injury from weather, the bulbs are often danaged by parasitic fungi as stated by Duhamel in $1728^{2}$ and again by Montagne in $1848 .^{3}$

The most considerable quantity of saffron is now produced in Lower Arragon, Murcia and La Mancha in Spain, and brought into commerce as Alicante and Valencia Saffron. The quantity of saffron exported from Spain in 1864 was valued at $£ 190,062$; in 1865 , $£ 135,316$; in 1866, £47,083. The drug was chiefly exported to France. ${ }^{4}$

French saffron, which enjoys a better reputation for purity than the Spanish, is cultivated in the arrondissement of Pithiviers-en-Gâtinais, in the department of the Loiret, which district annually furmishes a

1 Bullctin de la S'ociété impérialc d'acclimatation, Avril, 1869.

100. Mém. de l'Acad. des Scicnccs, 1728. p.
3 Etude mierographique de la maladic du Safran, connu sous le nom de tacon.

4 Statistical Tables relcting to Foreign C'ountries (Blue Book), 1870. 286. 289. 
quantity valued at $1,500,000(£ 60,000)$ to $1,800,000$ francs. ${ }^{1}$ 'The cultivation is carried on by small pensant-proprictors.

In Austria, Maissau, north-east of Krems on the Danube, still produces excellent saffron though only to a very small extent; the district was formerly celebrated for the drug, Saffron is produced in considerable quantity in Ghayn, an elevated mountain region separating Western Afghanistan from Persia. ${ }^{2}$ A very little is collected at Pampur in Kashmir, under heavy imposts of the Maharaja. ${ }^{3}$ Saffron is also cultivated in some districts of China. Finally, the cultivation has been introduced into the United States, and a little saffron is collected by the German inhabitants of Lancaster County, Pennsylvania. ${ }^{4}$ But in almost all countries the cultivation of saffron is on the decline, and in very many districts has altogether ceased.

The imports of saffron into the United Kingdom amounted in 1870 to $43,950 \mathrm{fb}$., valued at $£ 95,690$. The article is largely exported to India, but there are no general statistics to show the amount. Bombay imported in the year 1872-73, 21,994 1 ., value $£ 35,115 .^{5}$

Uses- Saffron is of no value for any medicinal effects, and retains a place in the pharmacopœia solely on the ground of its utility as a colouring agent. A peculiar preference for it as a condiment exists in various countries, but especially in Austria, Germany and some districts of Switzerland. This predilection prevails even in England,-at least in Cornwall, where the use of saffron for colouring cakes is still common. Saffron is largely used by the natives of India in 'religious rites, in medicine and for the colouring and flavouring of food.

As a dye-stuff saffron is no longer employed, at least in this country, its use having been superseded by less costly substances.

Adulteration-Saffron is often adulterated, but the frauds practised on it are not difficult of detection. Sometimes the falsification consists in the addition of florets of Calendula dyed with logwood, or of safflower, or the stamens of the saffron crocus, any of which may be detected if a small pinch of the drug be dropped on the surface of warm water, when the peculiar form of the saffron stigma will at once become evident.

Another adulteration of late much practised, and not always easy to detect by the eye, consists in coating genuine saffron with carbonate of lime, previously tinged orange-red. If a few shreds of such saffron be placed on the surface of water in a wineglass and gently stirred, the water will immediately become turbid, and the carbonate of lime will detach itself as a white powder and subside. Saffron thus adulterated will freely effervesee when dilute hydrochloric acid is dropped upon it. We have examined Alicante Saffron the weight of which had been increased more than 20 per cent. by this fraudulent admixture. The earthy matter employed in sophisticating saffron is said to be sometimes emery powder, rendered adherent by honey. We have found that adulterated with carbonate of lime to leave from 12 to 28 per cent. of ash.

I Dumesnil, 1. c.

2 Bellew, From the Indus to the Tigris, Lond. 1874. 304.

3 Powell, Punjab Produets, i. (1868) 449.

4 Proc. of the American Pharm. Assoc. 1S66. 254.

5 Ammal Statement of the Trade and Navigation of the Presidcncy of Bombay for 1872-73. pt. ii. 30 . 


\section{PALMAE.}

\section{SEMEN ARECAE.}

Nuees Areece vel Betel; Areca Nuts, Betel Nuts; F. Semenee ou Noix d'Aree; G. Arekanüsse, Betelnüsse.

Botanical Origin-Areea Cateehu L., a most elegant palm, with a straight smooth trunk, 40 to 50 feet high and about 20 inches in circumference. The inflorescence is arranged on a branching spadix, with the male flowers on its upper portion and the female near its base. The tree is cultivated in the Malayan Archipelago, the warmer parts of the Indian Peninsula, Ceylon, Indo-China and the Philippines. It is probably indigenous to the first-named region.

History-The Areca palm is mentioned in the Sanskrit writings as Guváca. It is called in Chinese Pin-lang, a name apparently derived from Pinang, a designation for the tree in the Malay Islands, whence the Chinese anciently derived their supply of the seeds. The oldest Chinese work to mention the pin-lang, is the San-fu-huang-tu, a description of Chang-an, the capital of the Emperor Wi-ti, B.c. 140-86. It is there stated that after the conquest of Yunnan, B.c. 111, some remarkable trees and plants of the south were taken to the capital, and among them more than 100 pin-lang, which were planted in the imperial gardens. Bretschneider, ${ }^{1}$ to whose researches we are indebted for this information, cites several other Chinese works, from the first century downwards, showing that areca nuts were brought from the then unsubdued provinces of Southern China, the Malayan Archipelago and India. The custom of presenting areca nut to a guest, is alluded to in a work of the 4 th century.

The Arabian writers were well acquainted with the areca nut, which they called $F$ of $f($, and with the Indian custom of masticating it with lime.

Areca nut though held in great estimation among Asiatics as a masticatory, and supposed to strengthen the gums, sweeten the breath and improve digestion, has not until recently been regarded as possessing any particular medicinal powers beyond those of a mild astringent. It has often been administered as a vermifuge to dogs, and in India and China is given with the same intent to the human subject. Some successful trials recently nuade of it for the expulsion of tapeworm, have led to it being included in the Additions to the British Pharmacopceic of 186\%, published in 1874.

Description-The areca palm produces a smooth ovoid fruit, of the size of a small hen's egg, slightly pointed at its upper end, and crowned with the remains of the stigmas. Its exterior consists of a thick pericarp, at first fleshy, but when quite mature, composed of fine stringy fibres running lengthwise, with much coarser ones below them. This fibrous coat is consolidated into a thin crustaceous shell or endocarp, which surrounds the solitary seed. The latter has the shape of a very short rounded cone, scarcely an inch in height; it is depressed at the centre of the base, and has frequently a tuft of fibres on one side of the depression, indicating its connexion with the pericarp. The testa, which seems to be partially adherent to the endocarp, is obscurely defined, and insepa-

I On the study of Chincse botanical works, Foochow, 1870. 27. 
rable from the nucleus. Its surface is conspicuously marked with a network of veins, running chielly from the hilum. When a seed is split open, it is seen that these veins extend downwards into the white albumen, reaching almost to its centre, thus giving the seed a strong resemblance both in structure and appearance to a nutmeg. The embryo, which is small and conical, is seated at the base of the seed. Areca nuts are dense and ponderous, and very difficult to break or cut. 'They have when freshly broken a weak cheesy odour, and taste slightly astringent.

Microscopic Structure-The white horny albumen is made up of large thick-walled cells, loaded with an albuminoid matter, which on addition of iodine assumes a brown hue. The cell-walls display large pores, the structure of which, after boiling in caustic ley, becomes clearly evident in polarized light. The brown tissue which runs into the albumen is of loose texture, and resembles the corresponding structure in a nutmeg. The thin walls of its cells are marked with fine spiral striations, and in this tissue, as well as on the brown surface of the seed, delicate spiral vessels are scattered. All the brown cells assume a rich red if moistened with caustic lye, and a dingy green with ferric chloride.

Chemical Composition-We have exhausted the powder of the seeds, previously dried at $100^{\circ} \mathrm{C}$., with ether; and thereby obtained a colourless solution, which after evaporation left an oily liquid, concreting on cooling. This fatty matter, representing 14 per cent. of the seed, was thoroughly crystalline and melted at $39^{\circ} \mathrm{C}$. By saponification, we obtained from it a crystalline fatty acid fusing at $41^{\circ} \mathrm{C}$., which may consequently be a mixture of lauric and myristic acids. Some of the fatty matter was boiled with water: the water on evaporation afforded an extremely small trace of tannin but no crystals, which had catechin been present should have been left.

The powdered seeds which had been treated with ether, were then exhausted by cold spirit of wine ( 832 ), which afforded 14.77 per cent. (reckoned on the original seeds) of a red amorphous tannic matter, which after drying, proved to be but little soluble in water, whether cold or boiling. Submitted to destructive distillation, it afforded Pyrocatechin. Its aqueous solution is not altered by ferrous sulphate, unless an alkali is added, when it assumes a violet lue, with separation of a copious dark purplish precipitate. On addition of a ferric salt in minute quantity to the aqueous solution of the tannic matter, a fine green tint is produced, quickly turning brown by a further addition of the test, and violet by an alliali. An abundant dark precipitate is also formed.

The seeds having been exhausted by both ether and spirit of wine, were treated with water, which removed from them chiefly mucilage precipitable by alcohol. The alcohol thus used afforded on filtration, traces of an acid, the examination of which was not pursued. After exhaustion with ether, spirit of wine and water, a dark brown solution is got by digesting the residue in ammonia: from this solution, an acid throws down an abundant brown precipitate, not soluble even in boiling alcohol. We have not been able to obtain crystals from an aqueous decoction of the seeds, nor by exhausting them directly with boiling spirit of wine. We have come therefore to the conchusion that Catechin (p. 215) is not a constituent of areca nuts, and that any extract made from them must be essentially different to the Catechu of Acacia or of 
Nauclec, and rather to be considered a kind of tannic matter of the nature of Ratantia-red or Cinchona-red.

By incinerating the powdered seeds, $2 \cdot 26$ per cent. were obtained of a brown ash, which besides peroxide of iron, contained phosphate of magnesium.

Commerce-Areca nuts are sold in India both in the husk (pericarp) and without it, and the two sorts are enumerated in the Customs Returns under distinct heads. Their widespread consumption in the East gives rise to an enormous trade, of which some notion may be formed by a consideration of the few statistics bearing upon it which are accessible.

Thus, Ceylon exported of areca nuts in the year 1871, 66,543 cwt., value $£ 62,593$; in $1872,71,715$ cwt,- - the latter quantity entirely to India. ${ }^{1}$ The Madras Presidency largely trades in the same commodity. In the year 1872-73, there were shipped thence to Bombay, 43,958 cwt., besides about two millions of the entire fruit. ${ }^{2}$ An extensive traffic in areca nuts is carried on at Singapore and especially in Sumatra.

Uses-Powdered areca nut may be given for the expulsion of tapeworm in the dose of 4 to 6 drachms, taken in milk. The remedy should be administered to the patient after a fast of about twelve hours; some recommend the previous exhibition of a purgative. It is said to be efficacious against lumbricus as well as tcenia.

The charcoal afforded by burning areca nuts in a close vessel is sold as a tooth powder; but except greater density, it possesses no advantage over the charcoal from ordinary wood.

As a masticatory, areca nut is chewed with a little lime and a leaf of the Betel Pepper, Piper Betlc L. The nut for this purpose is used in a young and tender state, or is prepared by boiling in water; it is sometimes combined with aromatics, as camphor or cardamom.

\section{SANGUIS DRACONIS.}

\section{Resina Draconis; Dragon's Blood; F. Sang-dragon; G. Draehenblut.}

Botanical Origin-Calamus Draco Willd. (Dcemonorops Draco Mart.) - This is one of the Rotang or Rattan Palms, remarkable for their very long flexible stems, which climb among the branches of trees by means of spines on the leafstalk. The species under noticn, called in Malay Rotang Jernang, grows in swampy forests of the Residency of Palembang and in the territory of Jambi, in Eastern Sumatra, and in Southern Borneo, which regions furnish the dragon's blood of commerce. It is said to occur also in Penang and in various islands of the Sunda chain.

History-The substance which is mentioned by Dioscorides under the name of Kıvváßapıs, as a costly pigment and medicine brought from Africa, and which is also described by Pliny who distinguished it from minium, was certainly the resin called Dragon's Blood. It was not

1 Ceylou Blue Books for 1871 and 1872.

2 From the returns quoted at p. 514, note 6 .

R R 
however that of the Rotang Palm, Calamus Draco, or even of any tree of the Indian Arehipelago, bnt was on the eontrary a produetion of the island of Socotra (see p. 612).

Dragon's blood is, we believe, not named by any of the earlier voyacrers to the Indian islands. Ibn Batuta, who visited both Java and Sumatra between A.D. 1325 and 1349, and notices their produeing benzoin (see p. 361), cloves, camphor, and aloes-wood, is silent about dragon's blood. Barbosa, whose intelligent narrative (A.D. 1514) of the Last Indies ${ }^{1}$ is full of referenee to the trade and productions of the different loealities he visited, states that aloes and dragon's blood are produced in Soeotra, but makes no mention of the latter eommodity as found at Malacca, Java, Sumatra, or Borneo.

The fact we wish to prove is corroborated by the accounts of early eommercial intercourse between the Chinese and Arabs reeently published by Bretsehneider.2 From the 10th to the 15th eentury, there was earried on between these nations a trade, the objeets of whieh were not only the produetions of the Arabian Gulf and eountries further north, but also those of the Indian Arehipelago. One of the islands with whieh the Arabs and Persians earried on a great commeree was Sumatra, whenee they obtained the preeious eamphor so mueh valued by the Chinese, but not, so far as appears, the resin dragon's blood. As to the productions brought from Arabia, they are enumerated as Ostriehes, Olibanum, Liquid Storax, Myrrh, and Dragon's Blood, beside a few other artieles not yet determined. It is worthy of remark that the Chinese are still the prineipal eonsumers of dragon's blood, thongh like the rest of mankind, they have to eontent themselves with the plentiful drug of Sumatra and Borneo, instead of the more aneient sort produced in Soeotra.

The first elear aeeount of the production of the resin in India, is that given by Rumphius, who in his Herbarium Amboinense ${ }^{3}$ ueseribes the proeess by which it is eollected at Palembang.

Production-The fruit of Calamus Draco, whieh is produeed in panieles in great profusion, is globose and of the size of a large eherry, clothed with smooth downward-overlapping seales. These scales are sub-quadrangular, thick and shell-like, marked with. a longitudinal furrow; the largest, whieh are found towards the middle of the fruit, are 2 lines long by 3 broad. At maturity, the fruit is covered with an exudation of red resin, which enernsts it so abundantly that the form of the seales ean hardly be seen.

The resin, whieh is naturally friable, is eollected by gathering the fruits, and shaking or beating them in a saek, by which proeess it is soon separated. It is then sifted, to remove from it seales and other portions of the fruit. By exposure to the heat of the sun, or in a covered vessel to that of boiling water, the resin is so far softened that it can be moulded into sticks or balls, whieh are forthwith wrapped in a piece of palm leaf. It is thus that the best dragon's blood, or jornang, is obtained. An inferior quality is got by boiling the pounded fruits in water, and making the resin into a mass, frequently with the addition

Description of the coasts of Eash Africa and Malabar (Hakluyt Socicty), 1866. 30. 191-197.

\footnotetext{
2 Knoutcdge possesscd by the Chinese of the Arabs, se. 1871.

3 l'ars. v. (1747) 114-115. tab. 58.
} 
of other substances by way of adulteration. The foregoing is the account of the manufacture of the drug given by Blume. ${ }^{1}$

Description-Dragon's Blood is found in commerce chiefly in two forms, known respectively as Recd and Lump.

1. Reed Dragon's Blood (Dragon's Blood in sticks, Sangnis druconis in baculis). Some of fine quality purchased in London in 1842 , is in sticks 13 to 14 inches in length, and $\frac{3}{4}$ to 1 inch in diameter, neatly wrapped in palm-leaf, secured by $S$ or 9 transverse bands of some flexible grass. The average weight of each stick, including the enveloping leaf, is five ounces. The resin has evidently been wrapped up while soft, as the sticks are furrowed longitudinally by pressure of the surrounding leaf. The smooth surface is of an intense blackish-brown; when seen in thin splinters, the resin appears transparent, and of a pure and brilliant crimson. The fractured surface looks resinous and rough, is a little porous, and contains numerous particles of the scales of the fruit. Rubbed on paper, it leaves a red mark, of not very splendid tint. Heated with spirit, it left 20 per cent. of pulverulent residue consisting chiefly of vegetable matter. Sticks of smaller size are more common.

2. Lump Dragon's Blood (Sanguis draconis in massis) is imported in large rectangular blocks, or irregular masses. From the fine Recd Drayon's Blood, just described, it differs in containing a larger proportion of remains of the fruit, including numerous entire scales. Hence it has a coarser fracture, and the fractured surface is less intense in tint. Its taste is slightly acrid. Exhausted with spirit of wine it leaves a residue amounting in the specimen we tested, to 27 per cent.

Dragon's blood is abundantly soluble in the usual solvents of resins, namely, the alcohols (even in dilute spirit of wine), benzol, chloroform, bisulphide of carbon and the oxygenated essential oils, as that of cloves. The residue left after the evaporation of these liquids, is amor-phous and of the original fine red colour. The drug is likewise dissolved by glacial acetic acid, as well as by caustic soda; the latter solution, on addition of an excess of acid, yields a dingy brown, jelly-like precipitate which on drying turns dark red like the original drug. In ether, dragon's blood is sparingly soluble and still less so in oil of turpentine; but in the most volatile portions of petroleum, the so-called petroleum ether, we find it to be entirely insoluble. It has a slightly sweetish and somewhat acrid taste; melts at about $120^{\circ} \mathrm{C}$., evolving the aromatic but irritating fumes of benzoic acid; boiled with water, the resin becomes soft and partially liquid.

Chemical Composition-Dragon's blood is a peculiar resin, which according to Johnston, ${ }^{2}$ answers to the formula $\mathrm{C}^{20} \mathrm{H}^{20} \mathrm{O}^{4}$. By heating it and condensing the vapour, an aqueous acid liquid is obtained, together with a heavy oily portion of a pungent burning taste, and crystals of benzoic acid. The composition of these products has not yet been thoroughly ascertained, but the presence of acetone, Toluol, $\mathrm{C}^{7} \mathrm{H}^{8}$ (the Dracyl of Glénard and Boudault, 1844) and Styrol, $\mathrm{C}^{3} \mathrm{H}^{\mathrm{s}}$ (Draconyl), has been pointed out, ${ }^{3}$ - the latter perhaps due to the existence in the drug

liumphia, iii. (1847) 9. tab. 131. 132.

Phil. Trans. 1839. $134 ; 1840.381$.

${ }^{3}$ Gmelin, Chemistry, xvii. (1866) 387. 
of metastyrol (p. 244), as suggested by Kovalewsky. ${ }^{1}$ Both these liydrocarbons are lighter than water; yet we find that the above oily portion yielded by dry distillation, sinks in water, a circumstance possibly occasioned by the presence of benzoic alcohol, $\mathrm{C}^{7} \mathrm{I}^{8} \mathrm{O}$.

As benzoic acid is freely soluble in petroleum ether, it ought to be removed from the drug by that solvent: on making the experiment, we got traces of an amorplious red matter, a little of an oily liquid, but nothing crystalline. As to the watery liquid, it assumes a blue colour on addition of perchloride of iron, whence it would appear to contain phenol or pyrogallol, rather than pyrocatechin (p. 172).

By boiling dragon's blood with nitric acid, benzoic, nitro-benzoic and oxalic acids are chiefly obtained, and only very little picric acid. Inlasiwetz and Barth melted the drug with caustic potash and found among the products thus formed, phloroglucin (p. 172), para-oxybenzoic, protocatechuic and oxalic acids, as well as several acids of the fatty series. Benzoin yiclds similar products.

Commerce-Dragon's blood is shipped from Singapore and Batavia. Large quantities are annually exported from Banjarmasin in Borneo to these places and to China. ${ }^{2}$

Uses-In medicine, only as the colouring agent of plasters and tooth powders: in the arts, for varnish.

Adulteration-Dragon's blood varies exceedingly in quality, ${ }^{3}$ of which the principal criterion regarded by the dealers, is colour. Some of the inferior sorts make only a dull brick-red mark when rubbed on paper, and have an earthy-looking fracture. The sticks moreover do not take the impression of the enveloping leaf, as when they are more purely resinous. A sample of inferior Reed Dragon's Blood afforded us 40 per cent. of matter, insoluble in spirit of wine.

\section{Other sorts of Dragon's Blood.}

Dragon's Blood of Socotra-We have already stated (p. 609) that the Cinnabar mentioned by Dioscorides was brought from Africa. That the term really designated dragon's blood, seems evident from the fact that the author of the Periplus of the Erythrean Sea, ${ }^{4}$ written circa A.D.

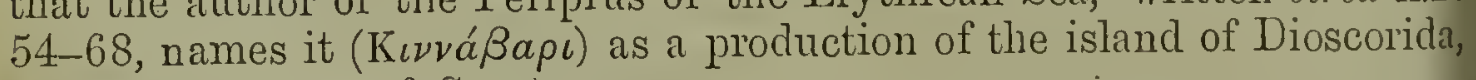
the ancient name of Socotra.

The Arabians, as Abu Hanifa and Ibn Baytar, describe dragon's blood as brought from Socotra, giving to the drug the very name by which it is known to the Arabs at the present day, namely, Dam-ulathawein. Barbosa (1514) as well as Giovanni di Barros ${ }^{6}$ mention it as a production of the island; and in our own times it has beell noticed by Wellstead, ${ }^{7}$ Vaughan, ${ }^{8}$ and Von Kremer. ${ }^{9}$ It is now but little collected.

1 Gmelin, Chemistry, xvii. 38s; also Ann. c. Chcmic, cxx. (1861) 68 .

${ }^{2}$ Low, Sarawak, its inhabilanls and prochections, 1848. 43.

3 'The present price, £3 to $£ 11$ per cwt., sufficiently indicates this.

${ }^{4}$ Voyage of Nearchus and Periplus of the
Erylhrean Sca, translated by Vincent, Oxford, 1809. 90 .

5 Sontheimer's ed. i. 104. 426. ii. $11 \%$.

${ }^{6} L^{\prime}$ Asia. sec. deca, Venet. 156]. p. 10. 3.

7 Trarels in Arabia, Lond. 1S3S. ii. 44?.

8 Pharm. Joum. xii. (1S53) $3 s_{5}$.

9 Acgypten, Leipzig, 1863. 
Vaughan states, as well as Von Wrede, that the tree is found in Hadramaut and on the east coast of Africa. Species of Draccena occur in these regions, but of the botany of Socotra itself, nothing is known.

The Drop Dragon's Blood, of which small parcels imported from Bombay or Zanzibar, occasionally appear in the London market, is however this drug. It is in small tears and fragments, seldom exceeding an inch in length, has a clean, glassy fracture, and in thin pieces is transparent and of a splendid ruby colour. From Sumatran dragon's blood, it may be distinguished by not containing the little shell-like scales, constantly present in that drug, and by not evolving when heated on the point of a knife, the irritating fumes of benzoic acid.

Dragon's Blood of the Canary Islands-This substance is afforded by Dracana Draco L., a liliaceous tree ${ }^{1}$ resembling a Yucca, of which the famous specimen at Orotava in Teneriffe has often been described on account of its gigantic dimensions and venerable age. ${ }^{2}$

On the exploration of Madeira and Porto Santo in the 15th century, dragon's blood was one of the valued productions collected by the voyagers, and is named as such by Alvise da ca da Mosto in 1454. ${ }^{3}$ It is also mentioned by the German physician, Hieronymus Münzer, who visited Lisbon about 1494. ${ }^{4}$

The tree yields the resin after incisions are made in its stem; but so far as we know, the exudation has never formed a regular and ordinary article of commerce with Europe. It has been found in the sepulchral eaves of the aboriginal inhabitants.

The name Dragon's Blood has also been applied to an exudation obtained from the West Indian Pterocarpus Draco L., and to that of Croton Draco Schlecht.; but the latter according to Henkel is of the nature of kino, and neither substance is met with in European commerce.

\section{AROIDEA.}

\section{RHIZOMA CALAMI AROMATICI.}

Radix Calami aromatici, Radix Acori; Sweet Flag Root; F. Acore odorant ou vrai, Roscau aromatique; G. Kalmus.

Botanical Origin-Acorus Calamus L., an aromatic, flag-like plant, growing on the margins of streams, swamps and lakes, from the coasts of the Black Sea, through Southern Siberia, Central Asia and India, as far as Amurland, Northern China and Japan ; indigenous also to North America. It is now established as a wild plant in the greater part of Europe, reaching as far north as Scotland, Scandinavia and Northern Russia; and is cultivated to a small extent in Burma and Ceylon.

1 Histologieal observations on the structure of the stem, aceompanied by exeellent figures, will be fcund in a memoir by Rauvenloff (Bijarage tot de.lennis van Draeana Draco pp. 55. tabb. 5) in the Verhand $d$. Kon. Acarl. v. Wetcrisch., afd. Natuurk. x. 1863.
2 It was destroyed in 1867 by a hurricane.

3 Ramusio, Raccolta delle Navigationi ct Viaggi, Veuet. i. 97.

4 Kunstmann, Abhandlungen der Baicrisehen Aleademic der Wissenschajten, vii. (1855) 342. ct seq. 
Regarding the introduction of $A$ conus Culumus into Western Europe, Clusins ${ }^{1}$ relates that he first received a living plant in 1.574 , sent from the lake Apollonia near Brussa in Asia Minor. Camernrins, ${ }^{2}$ writing in 1588, speaks of it as introduced some years previously, and then plentiful in Germany, which seems to show a rapid propagation. Gerarde at the close of the century, looked upon Acorns as an Kastern plant, which he says, is grown in many English gardens, and might hence be fitly called the "Sweet Garden Flag." Berlu ${ }^{3}$ in 1724, observes of the root, that"it is brought in quantities from Gcrmany:" hence we may infer that it was not then collected in England, as we know it was at a later period."

History-Sweet Flag root has been from the earliest tirnes a favourite medicine of the natives of India, in which country it is sold in every bazaar. Ainslie ${ }^{5}$ asserts that it is reckoned so valuable in the bowel complaints of children, that there is a penalty incurred by any druggist who will not open his door in the middle of the night to sell it, if demanded!

The descriptions of Acoron, a plant of Colchis, Galatia, Pontus and Crete, given by Dioscorides and Pliny, certainly refer to this drug. We

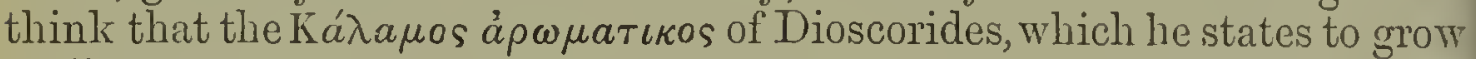
in India, is the same, though Royle regards it as an Andropogon. The Ká $\lambda a \mu o s$ of Theophrastus, and the Calamus of the English Bible ${ }^{6}$ are considered by some authors to refer to the Sweet Flag.

Celsus in the first century, mentioned Calamus Alexandrinus, the drug being probably then brought from India by way of the Red Sea. We know by the testimony of Amatus Lusitanus ${ }^{\top}$ that in the 16th century, it used to be so imported into Venice. Rheede ${ }^{8}$ moreover described and figured Acorns Calamus as an Indian plant under the name $V a c h \alpha$, which it still bears on the Malabar Coast.

Murray ${ }^{9}$ states expressly that in his time (1790), Asiatic calamus was still met with in the pharmacies of Continental Europe, but that it had mostly been replaced by the home-grown drug. At the present time, the Calamus aromaticus of commerce is European; in all essential characters it agrees with that of India, a package of which is now and then offered in the London drug sales.

Collection-The London market is supplied from Germany, whither the drug is brought we believe, from Southern Russia. It is no longer collected in England, - at least in quantity, though it used to be gathered some years ago in Norfolk.

Description - The rootstock of sweet flag occurs in somewhat tortuous, subcylindrical or flattened pieces, a few inches long, and from $\frac{1}{2}$ to 1 inch in greatest diameter. Each piece is obscurely marked on

1 Rariorum Stivpium Historia, Antv. 1576. 520 .

2 Hortus medicus ct phitosophicus, Francof., 1588. 5 .

3 Treasury of Dnuss, ed. 2. 1724. 115.

4 Sce also Trimen in Journ. of Botany, ix. (1871) 163.
5 Mrat. Mred. of IIindoosten, Mradras, 1813. 54.

"Exod. xxx. 23. ; Cant. ir. 14. ; Ezek. xxvii. 19. - See also prage 650 , footnote 2.

F In Diose. de Mlut. Mcd. Enarrationes, Argent. 1554. 33.

Hortus Mulabur. xi. (1692) tab. 48. 99.

- Apparatus Medicaminum, i. 10. 
the upper surface with the scars, often hairy, of leaves, and on the under with a zigzag line of little, elevated, dot-like rings,-- the scars of roots. The rootstock is risually rough and shrunken, varying in colour from dark brown to orange-brown, breaking easily with a short corky fracture, and exhibiting a pale brown spongy interior. The odour is aromatic and agreeable; the taste, bitterish and pungent.

The fresh rootstock is brownish-red or greenish, white or reddish within, and of a spongy texture. Its transverse section is tolerably uniform; a fine line (medullary sheath) separates the outer tissue from the lighter central part, the diameter of which is twice or three times the width of the former.

Microscopic Structure-The outermost layer is made up of extended epiblema-cells or of a brown corky tissue, the latter occurring in the parts free from leaf-scars. The prevailing tissue, both of the outer and the central part, consists of uniform nearly globular cells, traversed by numerous vascular bundles, especially at the boundary line (medullary sheath). Besides them, the rootstock like that of many fresh-water plants, exhibits a large number of intercellular holes. These air-holes, or more correctly water-holes, are somewhat longitudinally extended, so as to form a kind of net-work ${ }^{1}$ imparting a spongy consistence to the fresh rootstock. At certain places, where the series of cells cross one another, especially in the outer part, there are single cells, filled with essential oil, ${ }^{2}$ which may be made very conspicuous by adding to sections dilute potash or perchloride of iron. The other cells are loaded with small starch granules; a little mucilage and tannic matter is met with in the exterior coat.

Chemical Composition-The dried rhizome yielded us 1.3 per cent. of a yellowish neutral essential oil of agreeable odour, which in a column of $50 \mathrm{~mm}$. long, deviates the ray of polarized light $13 \cdot 8^{\circ}$ to the right. According to Kurbatow (1873) this oil contains a hydrocarbon, $\mathrm{C}^{10} \mathrm{H}^{16}$, boiling at $159^{\circ} \mathrm{O}$., and forming a crystalline compound with $\mathrm{HCl}$, and another hydrocarbon boiling at $255-258^{\circ} \mathrm{C}$., affording no crystallizable hydrochloric compound. The crude oil acquires a dark brownish colour on addition of perchloride of iron, but is not at all soluble in concentrated potash solution; it mixes with spirit of wine, and with 4 to 5 volumes of bisulphide of carbon, yet not so as to form with the latter a clear solution.

The bitter principle, Acorin, was isolated by Faust in 1867, as a semifluid, brownish glucoside, containing nitrogen, soluble both in ether and in alcohol, but neither in benzol nor in water. In order to obtain this substance, we precipitated the decoction of $10 \mathrm{Hb}$. of the drug by means of tannic acid, and followed the method commonly practised in the preparation of bitter principles. By finally exhausting the residue with chloroform, we succeeded in obtaining a very bitter, perfectly crystalline body, but in so minute a quantity, that we were unable to. investigate its nature.

1 This moniliform or stellate arrangement of cells was observed by Albertus Magnus (^.T). 1193-1280), who says :-(Calamus aromatieus)-nascitur in Inclia et Ethiopia sub cancro, et liabct interius cx parte concava "pcllem subtilem, sicut telo sunt ara-
nearum."-De Vegetabilibus, Jessen's cl. 1867. 376 .

2 Hence the practice of peeting the rhizome which prevails in some parts of the Continent ought to be abandoned. 
Uses-Sweet Flag is an aromatic stimulant and tonic, now rarely used in regular medicine. It is sold by the herbalists for flavouring beer, and for masticating to clear the voice. It is said to be also used by suuff manufacturers.

Adulteration-The rhizome of the Yellow Flag, Iris Pscudacorus L., is occasionally mixed with that of the Sweet Flag, from which it may be distinguished by its want of aroma, astringent taste, dark colour, and dissimilar structure.

\section{LILIACE $\#$.}

\section{ALOË.}

\section{Alocs; F. Aloès ou Suc d'Aloès; G. Aloë.}

Botanical Origin-Several species of $A l o \ddot{e}^{1}$ furnish a bitter juice which when inspissated, forms this drug. These plants are for the most part natives of arid, sunny places in Southern and Eastern Africa, whence a few species have been introduced into Northern Africa, Spain, and the East and West Indies.

The aloes are succulent plants of liliaceous habit, with persistent fleshy leaves, usually prickly at the margin, and erect spikes of yellow or red flowers. Many are stemless; others produce stems some feet in height, which are woody and branching. In the remote districts of Namaqua Land and Damara Land in Western South Africa, and in the Transkei Territory and Northern Natal to the eastward, aloes have been discovered which attain 30 to 60 feet in height, with stems as much as 30 feet in circumference. $^{2}$ The following species may be named with more or less of certainty as yielding the drug :-

Aloë Socotrina Lam. (A.vcra Miller), native of the southern shores of the Red Sea and Indian Ocean, Socotra, and Zanzibar (?). It is the source of the Socotrine and Moka Alocs. A. officinalis Forsk. and $A$. rubescens $\mathrm{DC}$. are considered to be varieties of this plant. A. Abyssinica Lam. may probably contribute to the aloes shipped from the Red Sea.

A. vulgaris Lan. (A. perfoliata, var. m. vera Linn., A. Barbadcnsis Mill.), a plant of India and of Eastern and Northern Africa, now found also on the shores of Southern Spain, Sicily, Greece, and the Canaries; introduced into the West Indies, or as some think, possibly a true native. It affords Barbados and Curaçao Alocs. A. indica Royle, ${ }^{3}$ a plant of the North-west Provinces of India, common in Indian gardens, appears to be a slight variety of $A$. vulgaris Lam. A. litoralis König, said to grow in abundance at Cape Comorin, is unknown to us. Dr. Bidie suggests that

1 Apparently derived from the Syrine Alwai. It is important to bear in mind that the word Aloes or Lign Aloës, in Latin Lignum aloës, is used in the Bible and in nrany ancient writings, to designate a substance totally distinct from the modern Alocs, namely the rosinous wood of Aquilaria Agallocha Roxb., a drug which was once generally valucd for usc as ineensc, but now esteemed only in the East.
Various specics of Agave, especially $A$. Americana L., are popularly called Aloë. All of them are plants of Mexico, while the true aloes are natives of the old world. Botanieally the gemus Agave differs from $A$ lo $\ddot{e}$, in that the formcr has the ovary in. ferior, whilo in the latter it is supcrior.

2 Dyer in Gardener's' Chronicle, May 2, 1874, with figures.

3 Dr. Bidic of Madras has kindly sent us a living specimen of this plant. 
it is a form of the preceding, stunted by a poor saline soil and exposure to the sea breeze. Both $A$. indica and $A$. litoralis are named in the Pharmacopcica of India.

Aloë fcrox L., and hybrids obtained by crossing it with A. Africana Mill. and A. spicata Thunb., A. perfoliata Linn. (quoad Roxb.) and A. linguceformis are reputed to yield the best Cape Aloes.

A. Africanc Mill. and its varieties, and A. plicatilis Mill. afford an extract which Pappe ${ }^{1}$ says, is thought to be less powerful.

A. arborescens Mill., A. Commelini Willd. and A. purpurescens Haw. are stated to produce a portion of the Cape Aloes of commerce. ${ }^{2}$

History-Aloes was known to the Greeks as a production of the island of Socotra as early as the 4th century B.C., if we might credit a remarkable legend thus given in the writings of the Arabian geographer Edrisi. ${ }^{3}$ When Alexander had conquered the king of the Persians and his fleets had vanquished the islands of India, and he had killed Pour, king of the Indies, his master Aristotle recommended him to seek the island that produces Alocs. So when he had finished his conquests in India, he returned by way of the Indian Sea into that of Oman, conquered the isles therein, and arrived at last at Socotra, of which he admired the fertility and the climate. And from the advice which Aristotle gave him, he determined to remove the original inhabitants and to put Greeks in their place, enjoining the latter to preserve carefully the plant yielding aloes, on account of its utility, and because that without it, certain sovereign remedies could not be compounded. $\mathrm{He}$ thought also that the trade in and use of this noble drug would be a great advantage for all people. So he took away the original people of the island of Socotra, and established in their stead, a colony of Ionians, who remained under his protection and that of his successors, and acquired great riches, until the period when the religion of the Messiah appeared, which religion they embraced. Then they became Christians, and so their descendants have remained up to the present time (circce A.D. 1154).

This curious account, which Yule ${ }^{4}$ says is doubtless a fable, but invented to account for facts, is alluded to by the Mahommedan travellers of the 9 th century ${ }^{5}$ and in the 10 th by Masudi, ${ }^{6}$ wlio says that in his time aloes was produced only in the island of Socotra, where its manufacture had been improved by Greeks, sent thither by Alexander the Great.

Aloes is not mentioned by Theophrastus, but appears to have been well known to Celsus, Dioscorides, Pliny and the author of the Periplus of the Erythrean Sea, as well as to the later Greek and the Arabian physicians. From the notices of it in the Anglo-Saxon leech-books, and a reference to it as one of the drugs recommended to Alfred the

1 Florce Capensis Meclice Prodromus, ed. $2,1857.41$.

2 In the above revision of the medicinal speeies of $A l o \ddot{e}$, we have made free use of M. Baillon's reeent observations on the same subject, eontained in the Dietionnaire des Seicnces Médiectes, iii. 360, also Journ. de Pharm. v. (1867) 406. We have also had the advantage of eonsulting W. Wilson Saunders, Esq., F.R.S., whose long famili- arity with these plants in eultivation impart great weight to his opinion.

${ }^{3}$ Géographic d'Edrisi, traduite par P. A. Jaubert, Paris, i. (1836) 47.

4 Mareo Polo, ii. 343.

5 Anciennes Relations des Indes et de la Chine de deux Voyageurs Mahometans, qui allèrent dans te ncuvième siècle, traduites de l'Arabe, Paris, 1718. 113.

${ }^{6}$ Tome iii. 36. - See p. 541, note 4 . 
Great by the Patriarch of Jerusalem, we may infer that its use was not unknown in Britain as early as the 10th century. ${ }^{1}$

At this period and for long afterwards, the drug was imported into Europe by way of the Red Sea and Alexandria. After the discovery of a route to India by the Cape of Good Hope, the old line of commerce probably began to cliange.

Thomé Pyres, an apothecary at Cochin, in a letter on Eastern drugs ${ }^{2}$ addressed to Manuel, king of Portugal, in 1516, reports that aloes grows in the island of Cacotora, Aden, Cambaya, Valencia of Arragon, and in other parts, - the most esteemed being that of Cacotora, and next it that of Spain; while the drug of Aden and Cambaya is so bad as to be worthless.

In the early part of the 17th century, there was a direct trade in aloes between England and Socotra; and in the records of the East India Company, there are many notices of the drug being bought of the "King of Socotra." Frequently the king's whole stock of aloes is mentioned as having been purchased. ${ }^{3}$

Wellstead, who travelled in Socotra in $1833,{ }^{4}$ says that in old times the aloë was far more largely grown there than at present, and that the walls which enclosed the plantations may still be seen. He adds, that the produce was a monopoly of the Sultan of the island. At the present day, the few productions of Socotra that are exported, are carried by the Arab coasting vessels, coming annually from the Persian Gulf to Zanzibar, at which place they are transhipped for Indian and other ports. Dr. Kirk, who has resided at Zanzibar from 1866 to 1873, informs us that aloes from Socotra arrives in a very soft state packed in goatskins. From these it is transferred to wooden boxes, in which it concretes, and is shipped to Europe and America. To avoid loss, the skins have to be washed; and the aloetic liquor evaporated.

Ligon, ${ }^{5}$ who visited the island of Barbados in 1647-50, that is about twenty years after the arrival of the first settlers, speaks of the aloë as if it were indigenous, mentioning also the useful plants which had been introduced. At that period, the settlers knew how to prepare the juice for medicinal use, but had not begun to export it. Barbados aloes was in the drug warehouses of London in $1693 .^{\circ}$

The manufacture of aloes in the Cape Colony of South Africa, was observed by Thunberg in 1773, on the farm of a boer named Peter de Wett, who was the first to prepare the drug in that country. ${ }^{7}$ Cape Aloes is enumerated in the stock of a London druggist in 1780, its cost being set down as $£ 10$ per cwt. (1s. $9 \frac{1}{2} d$. per 17 .)

A new and distinct sort of aloes, manufactured in the colony of Natal, appeared in English commerce in 1870. It will be described further on.

Structure of the Leaf-The stout fleshy leaves of an aloë have a strong cuticle and thick-walled epidermis. Their interior substance is formed of very loose, large-celled, colourless, mucilaginous pulp,

1 Sec p. 394, note 1. 36.

2 Journ. de Soc. Pharm. Lusit. ii. (1838)

3 Calendar of State Papers, Colonial Series, Fast fndies, China and Japan, 1513-1616, Lond. 1862.
4 Journ. of the Roy. Goograph. Soc. r. (1835) 129-229.

"IIistory of Barbadoes, Lond. 1673. 98.

6 Dale, Pharmacologia (1693) 361.

7 Thumberg, Travels in Europe, Asia and Africe, ii. 49. 50 . 
occupying ten times or more the breadth of the layer of small-celled parenchyme containing chlorophyll, which separates the pulp from the cuticle.

The inner cortical layer contains at its junction with the pulp, numerous bundles of vessels, which on transverse. section, are seen to be arranged at equal distances around the pulp. The inner part of each bundle consists of delicate, elongated tissue, and several rows of thinwalled cells adjoining a remarkable layer of smaller, prismatic, truncated cells. They are laid quite simply one upon the other and side by side, and therefore bear no resemblance to the system of vessels seen in milky plants. These cells in a leaf of Aloë Socotrina, examined in the summer, are found to be filled with a transparent, yellow, viscid substance, which crystallizes when a section moistened with glycerin is left for a few days. Trécul ${ }^{1}$ also found the peculiar cells containing the bitter juice in Aloë mitrceformis, grown at Paris. He observed that the transverse walls of these cells sometimes disappear, and then considerable ducts loaded with the peculiar juice are formed. In southern regions, this process probably goes on to a large extent, thus explaining how the juice is abundantly obtained without pressure. The remaining portion of the cortical tissue is filled with granules of chlorophyll, and exhibits between the cells, groups of needles of calcium oxalate. Similar crystals are also found sparingly in the pulp.

The transparent pulp-tissue is filled with a viscid, colourless, tasteless mucilage, which after dilution with water is precipitated by neutral acetate of lead, but is not coagulated by boiling even after acidulation with nitric acid. ${ }^{2}$ In an alkaline solution of cupric tartrate, it occasions slight reduction on heating. It does not become coloured by exposure to the air. The bundles of cells surrounding the vessels, contain on the other hand (abundantly in A. Socotrina and A. spicata, less so in $A$. vulgaris and $A$. arborescens) a colourless juice, which when exposed to the air, especially in contact with iron, quickly assumes a deep violet colour. That the bundles of vessels are the seat of this chromogen, is easily seen when a thin section of a fresh aloë-leaf is quickly exposed to the vapour of ammonia.

The amount of bitter principles in the leaf probably varies with the age of the latter and with the season of the year. Haaxman mentions that in Curaçao, the maximum is found when the leaves are changing from green to brown.

Cultivation and Manufacture-In Barbados, ${ }^{3}$ where Aloë vulgaris is systematically cultivated for the production of the drug, the plants are set 6 inches apart, in rows which are 1 to $1 \frac{1}{2}$ foot asunder, the ground having been carefully prepared and manured. They are kept free from grass and weeds, but yams or pulse are frequently grown between them. The plants are always dwarf, never in the least degree arborescent; almost all of those above a year old, bear flowers, which being bright yellow, have a beautiful effect. The leaves are 1 to 2 feet

\section{5}

2 This central pulpy tissuc is quite tasteless, and is actually used as food in times of searcity in some parts of India. - Stewart, Punjab Plants, 1869. 232.
${ }^{3}$ For the particulars we here give respecting Barbados aloes, we have cordially to thank Sir R. Bowcher Clarke, C'lief Justice of Barbados, and also Major-General Miumo now (1574) stationed at Barbados iu command of troops. 
long; they arc cut ammually, but this does not destroy the plant which, under good cultivation, lasts for several years.

The cutting takes place in March and April, and is performed in the heat of the day. 'The leaves are cut off close to the plant, and placed very quickly, the cut ends downwards, in a $\mathrm{V}$-shaped wooden trough, about 4 fcet long and 12 to 18 inches dccp. This is set on a sharp incline, so that the juice which trickles from the lcaves very rapidly, flows down its sides, and finally cscapes by a holc at its lower end into a vesscl placed beneath. No pressure of any sort is applicd to the leaves. It takes about a quarter of an hour to cut leaves cnough to fill a trough. The troughs are so distributed as to be casily acccssible to the cuttcrs. Their number is generally five; and by the time tlic fifth is filled, the cuttcrs return to the first and throw out the leaves, which they regard as exhaustcd. The leaves are ncither infused nor boiled, nor is any use afterwards madc of them except for manure.

When the vesscls receiving the juice become filled, the latter is removed to a cask and reserved for evaporation. This may be donc at once, or it may be delayed for weeks or evcn months, the juice, it is said, not fermenting or spoiling. The evaporation is gcnerally conducted in a copper vessel; at the bottom of this is a large ladle, into which the impurities sink, and are from time to time removed as the boiling goes on. As soon as the inspissation has reached the proper point, which is determined solely by the experienced eye of the workman, the thickened juice is poured into large gourds or into boxes, and allowed to harden.

The drug is not always readily saleable in the island, but is usually bought up by speculators who keep it till there is a demand for it in England. The cultivators are small proprietors, but little capable as to mind or means, of making experiments to improve the manufacture of the drug. It is said however, that occasionally a little aloes of very superior kind is made for some special purpose by exposing the juice in a shallow vessel to solar heat till completely dry. But such a drug is stated to cost too much time and trouble to be profitable. ${ }^{1}$ The manufacture of aloes in the Dutch West Indian island of Curaçao is conducted in the same manner. ${ }^{2}$

The manufacture of aloes in the Cape Colony has been thus described to us in a letter ${ }^{3}$ from Mr. Peter MacOwan of Gill College, Somerset East:-The operator scratches a shallow dish-shaped hollow in the dry ground, spreads thcrein a goatskin, and then proceeds to arrange around the margin, a radial series of aloë leaves, the cut ends projecting inwards. Upon this, a second series is piled, and then a third,-care being taken that the ends of each series overhang sufficiently, to drop clear into the central hollow. When these preparations have been made, the operator either "loafs about" after wild honey, or more likely, lies down to slecp. The skin being nearly filled, four skewers run in and out at the edge square-fashion, give the means of lifting this primitive saucer from the ground, and cmptying its contents into a cast-iron pot. The liquid is then boiled, an operation conducted with the utmost

1 Some extremely fine Barbados aloes in the London market in 1842, was said to have been manufactured in a vacumm-pan.
2 Oudemans, Handleiding tot de Pharmacognosic, 1865. 316.

3 Under date Miny $\tau$, 1871, addressed to myself. $-\mathrm{D}$. H. 
carelessness. Fresh juice is added to that which has nearly acquired the finished consistence; the fire is slackened or urged just as it happens, and the boiling is often interrupted for many hours, if neglect be more convenient than attention. In fact, the process is thoroughly barbarous, conducted without industry or reflection; it is mostly carried on by Bastaards and Hottentots, but not by Kaffirs. "The only aloë I have seen used," says Mr. MacOwan, "is the very large one with di- or tri-chotomous inflorescence,- $A$. ferox, I believe." Backhouse ${ }^{1}$ also names "Aloë ferox?" as the species he saw used near Port Elizabeth in 1838 .

From another correspondent, we learn that the making of aloes in the Cape Colony is not carried on by preference, but is resorted to when more profitable work is scarce. The drug is sold by the farmers to the merchants of the towns on the coast, some of whom have exerted themselves to obtain a better commodity, and have even imported living aloeplants from Barbados.

Nothing is known of the manufacture of the so-called Socotrine Aloes, or even with certainty in what precise localities it is carried on.

General Description-The differences in the several kinds of commercial aloes are due to various causes, such as the species of Alö̈ employed and the method of extracting the juice. The drug varies exceedingly: some is perfectly transparent and amorphous, with a glassy conchoidal fracture; some is opaque and dark with a dull waxy fracture, or opaque and pallid; or it may be of a light orange-brown and highly crystalline. It varies in consistence in every degree, from dry and brittle to pasty, and even entirely fluid and syrup-like.

These diverse conditions are partially explained by an examination of the very fluid aloes that has been imported of recent years from Bombay. If some of this aloes is allowed to repose, it gradually separates into two portions,- the upper a transparent, black liquid,- the lower, an orange-brown crystalline sediment. If the whole be allowed to evaporate spontaneously, we get aloes of two sorts in the same mass; the one from the upper portion being dark, transparent and amorphous, the other rather opaque and highly crystalline. Should the two layers become mixed, an intermediate form of the drug results.

The Hepatic Aloes of the old writers ${ }^{2}$ was doubtless this rather opaque form of Socotrine Aloes; but the term has come to be used somewhat vaguely for any sort of liver-coloured aloes, and appears to us unworthy to be retained. Much of the opaque, so-called Hepatic Aloes, does not however owe its opacity to crystals, but to a feculent matter the nature of which is doubtful.

The odour of aloes is a character which is much depended on by dealers for distinguishing the different varieties, but it can only be appreciated by experience, and certainly cannot be described. ${ }^{3}$

1 Visit to Mauritius and South Africa, 1844. 157 , also 121 .

${ }^{2}$ As Macer Floridus in the 10th eentury, who writes :-

"Sunt $\Lambda$ loës species geminæ, qua subrubet estque Intus sicut hepar cunn lringitur, hace epatite Dicitur et magnas habet in incdicnunine vires, Utilior picco rux fracti colore videtur."
3 Thus the pale, liver-eoloured aloes of Natal is invariably assoeiated with the transparent Cape Aloes, simply from the fact that the two drugs have a similar smell. Again, the aloes of Curaçao is at once reeognized by its odour, whieh an experieneed druggist pronounees to be quite different from that of the aloes produced in Barbados. 
Varieties-The principal varieties of aloes found in English commerce are the following:-

1. Socotrine Alocs-also called Bombay, Hast Indian, or Zanzibar Aloes, and when opaque and liver-coloured, Hepatic Aloes. It is imported in kegs and tin-lined boxes from Bombay, whither it has been carried by the Arab traders from the African coast, the Red Sea ports, or by way of Zanzibar, from Socotra. When of fine quality, it is of a dark reddish-brown, of a peculiar, rather agreeable odour, comparable to myrril or saffron. In thin fragments, it is seen to be of an orange-brown; its powder is of a tawny reddish-brown. When moistened with spirit of wine, and examined in a thin stratum under the microscope, good Socotrine Aloes is seen to contain an abundance of crystals. As imported, it is usually soft, at least in the interior of the mass, but it speedily dries and hardens by keeping. ${ }^{1}$ It is occasionally imported in a completely fluid state (Liquid Śocotrine Alocs, Aloë Juice), and is not unfrequently somewhat sour and deteriorated.

Some fine aloes from Zanzibar, of which a very small quantity was offered for sale in 1867, was contained in a skin, and composed of two layers, the one amorphous, the other a granular translucent substance of light colour, which when softened and examined with a lens, was seen to be a mass of crystals. A very bad, dark, fœetid sort of aloes is brought to Aden from the interior. It seems to be the Mokch Alocs of some writers.

The quantity of aloes imported into Bombay in the year 1871-72 was $892 \mathrm{cwl}$., of which $736 \mathrm{cwt}$. are reported as shipped from the Red Sea ports and Aden. ${ }^{2}$

2. Barbados Aloes-Characteristic samples show it as a hard dry substance of a deep chocolate-brown, with a clean, dull, waxy fracture. In small fragments it is seen to be translucent and of an orange-brown hue. When breathed upon, it exhales an odour analogous to but easily distinguishable from that of Socotrine aloes. It is imported in boxes, and gourds. The gourds, into which the aloes has been poured in a melted state through a square hole, over which a bit of calico is afterwards nailed, contain from 10 to $40 \mathrm{Hb}$. or more. Of late years, Barbados aloes having a smooth and glassy fracture has been imported; it is known to the London drug-brokers as "Capey Barbados." By keeping, it passes into the usual variety having a dull fracture.

The export of aloes from Barbados in 1871, as shown by the Bluc Book for that colony, was 1046 cwt., of which $954 \mathrm{cwt}$. were shipped to the United Kingdom.

3. Curcuccoo Aloes-manufactured in the Dutch West Indian island of Curaçao, is imported into this country by way of Holland, packed in boxes of 15 to $28 \mathrm{Ht}$. each. In appearance, it resembles Barbados aloes, but has a distinctive odour.

4. Cape Aloes-The special features of this sort of aloes are its brilliant conchoidal fracture and peculiar odour. Small splinters seen

1 The average loss as estimated in the drying of $560 \mathrm{lt}$., upon several occasions, was abont 14 per cent. - Laboratory statistics, communicatcel by Messis. Allen and Hanburys, London.
Statement of the Trade and Navigation of the Presildoncy of Bombay for 1871-i2, pt. ii. 19. 
by transmitted light, are highly transparent and of an amber colour ; the powder is of a pale tawny yellow. When the drug is moistened and examined under the microscope, no crystals can be detected, even after the lapse of some days. Cape aloes has the odour of other kinds of aloes, with a certain sourish smell which easily distinguishes it. Several qualities are recognized, chiefly by the greater or lesser brilliancy of fracture, and by the tint of the powder.

From the Blue Book for the Colony of the Cape of Good Hope, published at Cape Town in 1873, it appears that the export of aloes in 1872, was $484,532 \mathrm{fb}$. (4326 cwt.); and that the average market value during the year was $3 \frac{3}{4} d$., the lowest price, $1 \frac{1}{2} d$. being at Riversdale and Mossel Bay, and the highest, $11 d$. at Swellendam. The drug is shipped from Cape Town, Mossel Bay and Algoa Bay.

5. Natal Aloes-Aloes is also imported from Natal, and since 1870 in considerable quantity. Most of it is of an hepatic kind and completely unlike the ordinary Cape aloes, inasmuch as it is of a greyishbrown and very opaque. Moreover it contains a crystalline principle which has been found in no other sort of aloes.

The drug is manufactured in the upper districts of Natal, between Pietermaritzburg and the Quathlamba mountains, especially in the Umvoti and Mooi River Counties, at an elevation of 2000 to 4000 feet above the sea. The plant used is a large aloë which has not yet been botanically identified. ${ }^{1}$ The people who make the drug are British and Dutch settlers, employing Kaffir labourers. The process is not very different from that followed in making Cape aloes, but is conducted with more intelligence. The leaves are cut obliquely into slices, and allowed to exude their juice in the hot sunshine. The juice is then boiled down in iron pots, some care being taken to prevent burning, by stirring the liquid as it becomes thick. The drug while still hot, is poured into wooden cases, in which it is shipped to Europe. ${ }^{2}$ The exports from the colony have been as follows :- ${ }^{3}$

$\begin{array}{ccccc}1868 & 1869 & 1870 & 1871 & 1872 \\ \text { none } & 38 \mathrm{cwt} . & 646 \mathrm{cwt} . & 372 \mathrm{cwt} . & 501 \mathrm{cwt} .\end{array}$

Chemical Composition-All kinds of aloes have an odour of the same character and a bitter disagreeable taste. The odour which is often not unpleasant, especially in Socotrine aloes, is due to a volatile oil, which the drug contains only in minute proportion. T. and $\mathrm{H}$. Smith of Edinburgh, who contributed a specimen of it to the Vienna Exhibition of 1873 , inform us that they obtained it by subjecting to distillation with water, $400 \mathrm{lb}$. of aloes, which quantity they estimate to have yielded about an ounce. The oil is stated in a letter we have received from them, to be a mobile pale yellow liquid, of sp. gr. 0.863 , with a boiling point of $266-271^{\circ} \mathrm{C}$.

Pure aloes dissolves easily in spirit of wine with the exception of a few flocculi; it is insoluble in chloroform and bisulphide of carbon, as well as in the so-called petroleum ether, the most volatile portion of

I I have small specimens of it raised from seeds communicated by a maker of the drug throngh the good offices of a Natal merchant in London.-D. H:
2 Wc have to thank J. W. Akerman, Esq., of Pictermaritzburg, for the foregoing information as to the manufacture of this drug. Bluc Books for the Colony of Natal for 1868, 1869, 1870, 1871, 1872. 
American petrolcum. The sp. gr. of fine transparent fragments of aloes, dried at $100^{\circ} \mathrm{C}$., and weighed in the last-named fluid at $16^{\circ} \mathrm{C}$., was found by one of us (F.) to be 1:364; showing that aloes is much more ponderous than most of the resins, which seldom have a higher sp. gr. than 1.00 to $1 \cdot 10$. In water, aloes dissolves completcly only when heated. On cooling, the aqueous solution, whcther concentrated or dilute, becomes turbid by the scparation of resinous drops, which unite iuto a brown mass, - the so-called Resin of Alocs. ' The clear solution, after separation of this substance, has a slightly acid reaction; it is coloured dark brown by alkalis, black by ferric chloride, and is precipitated yellowish-grey by neutral lead acetate. Cold water dissolves about half its weight of aloes, forming an acid liquid which cxhibits similar reactions. The solution of aloes in potash or ammonia is precipitated by acids, but not by water.

The most intcresting constituents of aloes, are the substances known as Aloïn. This name was originally applied to an aloïn which, as it appears to be found exclusively in Barbados aloes, is now termed Barbaloön, in order to distinguish it from allied substances occurring in Natal and Socotrine aloes.

Barbaloïn was discovered by T. and H. Smith of Edinburgh in 1851,2 and was shortly afterwards described by Stenhouse. ${ }^{3}$ From good qualities of the drug, it can be obtained according to Tilden ${ }^{4}$ as a crystalline mass, to the cxtent of 20 to 25 per cent., but in others it appear's to occur partly amorphous or in a chemically altered state. Barbaloïn is a neutral substance, crystallizing in tufts of small yellow prisms, which appear doubly refractive by polarized light. These crystals represent hydrated aloïn, and part with one equivalent of water $(=2.69$ per ccnt.) by desiccation in vacuo, or by the prolonged heat of a water-bath. Barbaloïn, $\mathrm{C}^{34} \mathrm{H}^{36} \mathrm{O}^{14}+\mathrm{H}^{2} \mathrm{O}$, dissolves sparingly in water or spirit of wine, but very freely if either liquid be even slightly warmed; it is insoluble in ether.

The solutions alter quickly if made a little alkaline, but if neutral or slightly acid, are by no means very pronc to decomposition. By oxidation with nitric acid, barbaloïn yields, as Tilden has shown, about a third of its weight of chrysammic acid, besides aloëtic, oxalic and picric acids. It easily combines with bromine to form a neutral substance, crystallizing in yellow necdles, named Bromaloün, $\mathrm{C}^{34} \mathrm{H}^{30} \mathrm{Br}^{6} \mathrm{O}^{14}$. A chloro-derivative, Chlorculoön, crystallizing in prisms, and having the formula, $\mathrm{C}^{34} \mathrm{H}^{30} \mathrm{Cl}^{6} \mathrm{O}^{14}+6 \mathrm{H}^{2} \mathrm{O}$, has likewise been obtained. ${ }^{5}$

In examining Natal aloes in 1S71, we observed it to contain a crystalline body, much less soluble than the ordinary aloïn of Barbados aloes. Further cxamination proved its distinctness from this latter; and wc have accordingly named it Nataloün.

Nataloïn cxists naturally in Natal aloes, from which it can be easily prepared in the crnde statc, if the drug is triturated with an equal

1 The average yield of aqueous cxtract made by the pharmacopœia process from commcreial Socotrine aloes containing about $14 \mathrm{per}$ cent. of water, was found from the record of five experiments, in which $179 \mathrm{lt}$. were used, to be 62.7 per ecnt. Barbados aloes, which is always much drier, afforded on an average 80 per cent.
2 Most beantiful specimens liave been presented to each of us by these gentlemen.

3 Phit. Mag. xaxvii. (1851) 481.

4 Pharm. Joum. April 20, 1872. 845. Sec also Nov. $5,1870.375$. 204. 
weight of spirit of wine at a temperature not exceeding $48^{\circ} \mathrm{C}$. This will dissolve the amorphous portion, from which the crystals should be separated by a filter, and washed with a small quantity of cold spirit. From 16 to 25 per cent. of crude nataloïn in pale yellow crystals may be thus extracted. When purified by crystallization from methylic alcohol or spirit of wine, it forms thin, brittle, rectangular scales, often with one or more of their angles truncated. The formula assigned to nataloïn by Tilden, ${ }^{1}$ which is supported by the composition of the acetyl derivative lie has succeeded in obtaining is, $\mathrm{C}^{25} \mathrm{H}^{28} \mathrm{O}^{11}$.

At $15.5^{\circ}$ C., 60 parts of spirit of wine, 35 of methylic alcohol, ${ }^{2} 50$ of acetic ether, 1236 of ether, and 230 of absolute alcohol, dissolve respectively one part of nataloin. It is scarcely more soluble in warm than in cold spirit of wine, so that to obtain crystals it is best to allow the solution to evaporate spontaneously. Water, hot or cold, dissolves it very sparingly. Nataloïn gives off no water when exposed over oil of vitriol, or to a temperature of $100^{\circ} \mathrm{C}$. By the action of nitric acid, it affords both oxalic and picric acids, but no chrysammic acid. It appears not to combine with chlorine or bromine, and we lave failed in obtaining from it any such body as bromaloïn.

Liquid Socotrine aloes imported into London about 1852, was noticed by Pereira to abound in minute crystals, which he termed the Aloin of Socotrine Aloes, and regarded as probably identical with that of Barbados aloes. Groves (1856) obtained it from commercial Socotrine aloes, which when of a light brownish orange, opaque and soft, as it often is when freshly imported, is easily seen to be extremely crystalline. Some fine dry aloes from Zanzibar of very pale hue, in our possession, is in reality a perfectly crystalline mass.

Histed, who at the request of one of us had undertaken the examination of some samples of aloes, was the first to assert that the crystalline matter of Socotrine or Zanzibar aloes is a peculiar substance, according neither with barbaloïn nor with nataloïn. This observation was fully corroborated by our own experiments, ${ }^{3}$ made chiefly on the Zanzibar aloes just described, and we shall call the substauce thus discovered Socaloïn. ${ }^{4}$ In this drug, the crystals are prisms of comparatively large size, such as we have never observed in Natal aloes. They cannot be so easily isolated as nataloïn, since they are nearly as soluble as the amorphous matter surrounding them. Histed, who has supplied us with beautiful specimens, recommends treating the powdered crude drug; with a little alcohol, sp. gr. 0.960 , and strongly pressing the pasty mass between several thicknesses of calico; then dissolving the yellow crystalline cake in warm weak alcohol, and collecting the crystals which are formed by cooling and repose.

Socaloïn forms tufted acicular prisms, which by solution in metlyylic alcohol, may be got 2 to 3 millimetres long. It is much more soluble than nataloin. At ordinary temperatures, 30 parts of spirit of wine, 9 of acetic ether, 380 of ether, 90 of water, are capable of dissolving respectively one part of socaloïn; while in methylic alcohol, it is most abundantly soluble. Socaloin is a hydrate, losing when dried over oil of

1 Chemical News, Nay 17, 1872. 229 ; Plurm. Journ. May 25, 1872. 951.

2 The best erystals can be got by this solvent.
3 Fliickiger, Crystalline Principles in Alocs,-Pharm. Journ. Sept. '2, 1871. 195.

4 'The term Zanzibar Aloin first employed, being a somewhat elumsy phrase and not partieularly correct. 
vitriol 1.1. to 12 per cent. of water, but slowly regaining it if afterwards exposed to the anl. Its clementary composition according to the analysis mate by one of us ( $\mathrm{F}$.) is $\mathrm{C}^{134} \mathrm{H}^{38} \mathrm{O}^{15}+5 \mathrm{IL}^{2} \mathrm{O}$. We have not suceceded in obtaining any well-defned bromine compound of socaloün.

The three aloïns, Barbaloün, Natalö̈n, and S'ocaloün, are casily distinguished by the following beautiful reaction first noticed by Iisted : - a diols of nitric acid on a porcelain slab gives witl a few particles of barbaloïn or nataloün, a vivid climson, ${ }^{1}$ but produces little effect with socalö̈n. 'T'o distinguish barbaloïn from nataloïn, test each by adding a minute quantity to a drop or two of oil of vitriol, then allowing the vapour from a rod touched with nitric acid to pass over the surface. Barbaloïn (and socaloïn) will undergo no change, but nataloïn will assume a fine bluc.2

The latest rescarches on aloïn are those of E. von Sommaruga and Egger in Prof. Rochleder's laboratory in Vicuna (1874), and have been directed in particular to the aloin of Socotrine aloes. The melting point of this aloin was found to be between $118^{\circ}$ and $120^{\circ} \mathrm{C}$., that of barbaloin being much higher. Comparing the published analyses of the two other kinds of aloïn with those obtained by themselves for socaloin, the authors conclude that the three form an homologous series, and that their composition may probably be represented thus:-

$\begin{array}{lllllll}\text { Barbaloïn } & \ldots & \ldots & \ldots & \ldots & \ldots & \mathrm{C}^{17} \mathrm{H}^{20} \mathrm{O}^{7} \\ \text { Nataloïn } & \ldots & \ldots & \ldots & \ldots & \ldots & \mathrm{C}^{16} \mathrm{H}^{18} \mathrm{O}^{7} \\ \text { Socaloïn } & \ldots & \ldots & \ldots & \ldots & \ldots & \mathrm{C}^{15} \mathrm{H}^{16} \mathrm{O}^{7}\end{array}$

The portion of aloes insoluble in cold water, was formerly distinguished as Resin of Aloes, from the soluble portion which was called Bitter of aloes or Aloëtin. From the labours of Kosmann (1863), these portions appear to have nearly the same composition. The soluble portion treated with dilute sulphuric acid, is said to yield Aloëresie and Aloër'ctic Acids, both crystallizable, besides the indifferent substance Aloëretin. These observations have not to our knowledge been confirmed.

It has been shown by Tilden and Rammell ${ }^{3}$ that the Resin of Aloes (p. 624) may by prolonged treatment witl boiling water be separated into two bodies, which they distinguish as Soluble Resin $A$. and Insoluble Resin $B$. With the first, it is possible to form a brominated compound, which though non-crystalline is apparently of definite composition. In the view of these chemists the Resin $A$. is a kind of anhydride of barbaloïn, standing in the same relation to barbaloin that ether does to alcohol, or tannic acid to gallic acid, thus :-Barbaloïn, $2\left(\mathrm{C}^{34} \mathrm{H}^{36} \mathrm{O}^{14}\right)$ less $\mathrm{H}^{2} \mathrm{O}=$ Aloe Resin A., $\mathrm{C}^{65} \mathrm{H}^{70} \mathrm{O}^{27}$. The resin boiled with nitric acid, yields a large amount of chrysammic acid, together with picric and oxalic acids, and carbonic anlyydride. Insoluble Resin $B$. was found to have nearly the same composition as Resin $A$.

Aloes treated with various reagents, affords a number of remarkable products. Thus, according to Rochleder and Czumpelick (1861), it yiclds when boiled with soda-lye, colourless crystals an incl long, which appear. to consist of a salt of Paraenmarie Acid, together with small quantities of fragrant essential oils, volatile fatty acids, and a volatile base.

1 Rapidly fading in the case of barbaloï, but permanent with untaloin unless hent be apjlied. a These reactions may be sometimes got eren with the crude drugs.

3 Pham. Journ. Sept. 21, 1872. 235. 
When boiled with dilute sulphuric acid, it yields paracumaric acid, from which by fusion with caustic potash, as also directly from aloes, Hlasiwetz (1S65) obtained 'Para-oxybcnzoic Acicl (p. 365). Weselsky (1872-73) has shown that accompanying the last two products, there is a peculiar acid, $\mathrm{C}^{9} \mathrm{H}^{10} \mathrm{O}^{3}$, which lie has named Aloreinic Acid.

By distillation with quick-lime, E. Robiquet (1846) obtained Alö̈sol, a yellowish oil, liquid at $-20^{\circ} \mathrm{C}$., which Rembold (1866) proved to be a mixture of $\mathrm{I} y l e n o l, \mathrm{C}^{8} \mathrm{H}^{10} \mathrm{O}$, with acetone and lyydrocarbons.

Nitric acid forms with Barbados aloes, but still better as Tilden has shown, ${ }^{1}$ with barbaloïn, Aloëtic Acid, $\mathrm{C}^{14} \mathrm{H}^{4}\left(\mathrm{NO}^{2}\right)^{4} \mathrm{O}^{2}$, Chrysanmic Acid, $\mathrm{C}^{14} \mathrm{H}^{4}\left(\mathrm{NO}^{2}\right)^{4} \mathrm{O}^{4}$, and finally Picric Acid, together with Oxalic Aciol. The first two of these acids are distinguished by the splendid tints of their salts, which might be utilised in dyeing.

Chlorine passed into an aqueous solution of aloes, forms a variety of substitution-products, and finally Chloranil, $\mathrm{C}^{6} \mathrm{Cl}^{4} \mathrm{O}^{2}$.

When somewhat strongly heated, aloes swells up considerably, and after ignition, leaves a light, slow-burning charcoal, almost free from inorganic constituents. Ordinary Cape aloes, for example, dried at $100^{\circ} \mathrm{C}$., leaves only 1 per cent. of asl.

Commerce-There were imported into the United Kingdom in the year 1870,6264 cwt. of aloes. Of this quantity, South Africa shipped $4811 \mathrm{cwt}$; and Barbados $970 \mathrm{cwt}$. The remainder was probably furnished by Eastern Africa.

The commercial value of the varieties of aloes is very different. At present (June 1874) Barbados Alocs is quoted in price-currents at $£ 35 \mathrm{~s}$. to $£ 910$ s. per cwt.; Socotrine at $£ 5$ to $£ 13$; while Cape Alocs is offered at $£ 110$ s. to $£ 2$. In England, the first two alone are allowed for pharmaceutical preparations. Even the Vetcrinary Pharmacopceia ${ }^{2}$ names only Alö̈ Barbadensis. Cape Aloes is esteemed on the Continent, and chiefly consumed there.

Use-Aloes is a valuable purgative in very common use; it is generally given combined with other drugs.

Adulteration-The physical characters of aloes, such as colour of the powder, odour, consistence and freedom from obvious impurity, coupled with its solubility in weak alcohol, usually suffice for determining its goodness.

\section{BULBUS SCILLAE.}

Radix Scilles; Squill ; F. Bulbe ou squames de Scille, Ognon marin; G. Meerzwiebcl.

Botanical Origin-Urginea maritima Baker ${ }^{3}$ (Scilla maritima L., Urginca Scilla Steinheil). It is found generally in the regions bordering the Mediterranean, as ill Southern France, Italy, Dalmatia, Greece, Asia Minor, Syria, North Africa and the Mediterranean islands. It is very common throughout the South of Spain, where it is by no means confined to the coast; it occurs also in Portugal.

I Pharm. Journ. April 20, 1872. 845.

¿ By R. V. Tuson, London, 1869.

3 Journ. of Linn. Soc., Bot., xiii. (1872) 221.-The genus Urgince has liat, discoid. seeds, while in scilla proper they are trique. trous. The name $U_{r}$ gince was given in allusion to the Algerian tribe Ben Urogin, near Bona, where Steinheil (183t) examined this plant. 
Two varieties of squill, termed respectively while and recl, are distinguished by druggists. In the first, the bulb-scales are colourless; in the second they are of a roseate hue. No other difference in the plants cass be pointed out, nor have the two varieties distinct arcas of growth.

History-Squill is one of the most ancient of medicines. Epimenides, a Greek who lived in the 30th Olympiad, is said to have made nuch use of it, irom which circumstance it cane to be called Epimenidea. ${ }^{1}$ It is also mentioned by Theoplirastus, and was probably well known to all the ancient Greek physicians. Pliny was not only acquainted with it, but had noticed its two varieties. Dioscorides describes the method of making vinegar of squills; and a similar preparation, as well as compounds of squill with honey, were administered by the Arabian physicians, and still remain in use.

Description-The bulb of squill is pear-shaped, and of the size of a man's fist or larger, often weighing more than four pounds. It has the usual structure of a tunicated bulb; its outer scales are reddish-brown, dry, scarious, and marked with parallel veins. The inner are fleshy and juicy, colourless or of a pale rose tint, thick towards the middle, very thin and delicate at the edgres, smooth and shining on the surface. The fresh bulb has a mucilaginous, bitter, acrid taste, but not much odour.

For medicinal use, squill is mostly imported ready dried. The bulbs are collected in the month of August, at which period they are leafless; freed from their dry outer scales, cut transversely into thin slices, and dried in the sun. Thus prepared, the drug appears in the form of narrow, flattish or four-sided curved strips, 1 to 2 inches long, and $\frac{3}{8}$ to $\frac{5}{8}$ of an inch wide, flexible, translucent, of a pale dull yellowish colour, or when derived from the red variety, of a decided roseate hue. When thoroughly dried, they become brittle and pulverizable, but readily absorb water to the extent of about 11 per cent. Powdered squill by the absorption of water from the air, readily cakes together into a liard mass.

Microscopic Structure-The officinal portion of the plant being simply modified leaves, lias the histological character's proper to many of those organs. The tissue is made up of polyhedral cells, covered on both sides of the scales by an epidermis provided with stomata. It is traversed by numerous vascular bundles, and also exhibits smaller bundles of laticiferous vessels. If thin slices of squill be moistened with dilute alcohol, most of the parenchyniatous cells are seen to be loaded with mucilage, which contracts into a jelly on the aldition of alcohol. In the interior of this jelly, crystalline particles are met with consisting of oxalate of calcium. This salt is largely deposited in cells, forming either bundles of needlc-shaped crystals, or large solitary squarc prisms, frequently a millimetre long. In either case, they are enveloped by the mucilaginous matter already mentioned. Oxalate of calcium as occurring in other plants has been shown in many instances to originatc in the midst of mucilaginous matter. The fact is remarkably evident in Scilla, especially when examined in polarized light.

On shaking thin slices of the bulb with water, the crystals are deposited in sufficient quantity to become visiblc to the naked eyc, though their weight is actually very small. Direct estimation of the oxalic acid (by titration with chameleon solution) gave us only 3.07 per cent. of 1 Haller, Bibliothece Botanica, i. 12. 
$\mathrm{C}^{2} \mathrm{CaO}^{4}, 3 \mathrm{H}^{2} \mathrm{O}$ from white squill dried at $100^{\circ} \mathrm{C}$., which moreover yielded only 2 to 5 per cent. of ash. It is these extremely sharp brittle crystals which occasion the itcling and reduess, and sometimes even vesication, which result from rubbing a slice of fresh squill on the skin. These effects which have long been known, were attributed to a volatile acrid principle, until their true cause was recognized by Schroff. ${ }^{1}$

The mucilage also contains albuminous matters, hence the orange colour it assumes on addition of iodine. The vascular bundles are accompanied by some rows of longitudinally extended cells, containing a small number of starch granules. In the red squill, the colouring matter is contained in many of the parenchymatous cells, others being entirely devoid of it. It turns blackish-green, if a persalt of iron be added.

Chemical Composition-The most abundant among the constitnents of squill is Mucilagc, which may be precipitated by neutral acetate of lead. Alcohol added to an aqueous infusion of squill, causes the separation of the mucilage together with albuminoid matter. If the alcohol is evaporated and a solution of tannic acid is added, the latter will combine with the bitter principle of squill, which has not yet been isolated, although several chemists have devoted to it their investigations and applied to it the names of Scillitin or Skuleinn. We have obtained a considerable amount of an uncrystallizable levogyre sugar, by exhausting squill with dilute alcohol. ${ }^{2}$ Schroff, to whom we are indebted for a valuable monograph on Squill, ${ }^{3}$ infers from his physiological experiments, the presence of a non-volatile acrid principle (S7zulcin ?), together with scillitin, which latter he supposes to be a glucoside.

Commerce-Dried squill, usually packed in casks, is imported into England from Malta.

Use-Commonly employed as a diuretic and expectorant.

Substitutes-There are several plants of which the bulbs are used in the place of the officinal squill, but which, owing to the abundance and low price of the latter, never appear in the European market.

1. Urginea altissima Baker (Ornithogalum altissimum L.), a South African species, very closely related to the common squill and having, as it would appear, exactly the same properties. ${ }^{4}$

2. U. indica Kth. (Scilla indica Roxb.), a widely diffused plant, occurring in Northern India, the Coromandel Coast, Abyssinia, Nubia, and Senegambia. It is known by the same Arabic and Persian names as $U$. maritima, and its bulb is used for similar purposes. But according to Moodeen.Sheriff ${ }^{5}$ it is a poor substitute for the latter, having little or no action when it is old and large.

3. Scilla indica Baker ${ }^{6}$ (non Roxb.), (Ledcbouria hyacinthina Roth), native of India and Abyssinia, has a bulb which is often confused in the

1 We have found that the slimy juice of the leaves of Agaponthus umbellatus Hérit., which is very rich in spieular erystals, also nceasions when rubbed on the skin both itehing and redness lasting for several hours.

2 In Greece, they have evell attempted to manufacture aleohol by fermenting and clistilling stuill bulbs. - Heldreieh, Nutzpflanzen Gricchenlands, 1862. 7.
${ }^{3}$ Reprinted from the Zeitschrift der Gesellschaft der Acrate zu IVien, No. 42 (1864). Abstracted also in Canstatt's Jahresbericht 1864. 19, and 1865. 238.

4 Pappe, Florce Hedice Caponsis Prodromus, ed. 2, 1857. 41.

5 Srupplement to the Pharmacopocia of India, Madrns, 1869. 250.

'S Saunders, Refugium Botanioum, iii. (1870) appendix, p. 12. 
Indian bazans with the preceding, but is ensily distinguishable when entire, hy being sealy (not tunicated); it is said to be a better represen-
tative of the European squill.

4. Drimice ciliaris Jace., a plant of the Cape of Good Hope, of the order Litiacee. Its bull, much resembles the officinal squill, but has a juice so irritating if it comes in contact with the skin, that the plant is called by the colonists. Jenlibol, i.e. Ileh-bulb. It is used medicinally as an emetic, expectorant and diuretic. ${ }^{2}$

5. Crinum A sirticum var. toxicarium, Herbert (C. toxicarinm Roxb.), a large plant with handsome white flowers and noble foliage, cultivated in Indian gardens, and also found wild in low humid spots in various parts of. India and the Moluccas, and on the sea-coast of Ceylon. The bulb lias been admitted to the Pharmacoperia of India (1868), chiefly on the recommendation of O'Shanghnessy, who considers it a valuable emetic. We have not been able to examine a specimen, and cannot learn that the drug has been the subject of any chemical investigation.

\section{MELANTHACE正.}

\section{RHIZOMA VERATRI ALBI.}

Radix Veratri, Radix Hellebori albi; White Hellebore; F. Racine d'Ellébore blane; G. Weisse Nieswurzel, Germer.

Botanical Origin-Veratrum album L.-This plant occurs in moist grassy places in the mountain regions of Middle and Southern Europe, as Auvergne, the Pyrenees, Spain, Switzerland and Austria. It also grows throughout European and Asiatic Russia, as far as $61^{\circ} \mathrm{N}$. lat., in Amurland, the island of Saghalin, Northern China and Japan.

History-The confusion that existed among the ancients between Melampodium, Helleborus and Veratrum, makes the identification of the plant under notice extremely unsatisfactory. ${ }^{3}$

It was perfectly known to Gerarde (eirea A.D. 1600); and under the names of Elleborus (or Helleborus) albus and Veratrum, it has had a place in all the London Pharmacopceias. In the British Pharmacopœia (1867), it has been replaced by the nearly allied American species, Veratrum viride Ait.

Description-White Hellebore has a cylindrical, fleshy, perennial rootstock, 2 to 3 inches in length, and $\frac{3}{4}$ to 1 inch in diameter, beset with long stout roots. When fresh, it has an alliaceous smell. In the dried state as it occurs in commerce, it is cylindrical or subconical, of a dull earthy black, very rough in its lower half with the pits and scars of old roots; more or less beset above with the remains of recent roots. The top is crowned with the bases of the leaves, the outer of which are coarsely fibrous. The plant has generally been cut off close to the summit of the rhizome, which latter is seldom quite entire, being often broken at its lower end, or cut transversely to facilitate drying. Internally, it is nearly colourless: a transverse section shows a broad white ring, surrounding a spongy pale buff central portion.

1 Supptement to the Pharmacopocicu of India, Madras, 1869. 250.

2 Pajpe, op. cit. 42.
3 Those who wish to study the question, can consult MLurny's Apmaratus Mledicamiun, vol. v. (1790) 142-166. 
The drug has a sweetish, bitterish acrid taste, leaving on the tongue a sensation of numbness and tingling. In the state of powder, it occasions violent sneezing.

Microscopic Structure-When cut transversely, the rhizome shows at a distance of $2-4 \mathrm{~mm}$. from the thin dark outer bark, a fine brown zigzag line (medullary sheath) surrounding the central part, which exhibits a pith, not well defined. The zone between the outer bark and the medullary sheath is pure white, with the exception of some isolated cells containing resin or colouring matter, and those places where the rootlets pass from the interior. The latter is sprinkled as it were, with short thin somewhat lighter bundles of vessels which run out irregularly in all directions. The parenchyme of the entire rhizome is filled with starch, and contains numerous needles of calcium oxalate. The rootlets, which the collectors usually remove, are living and juicy only in the upper half of the rhizome, the lower lialf of which is rather woody and porous.

Chemical Composition-In 1819, Pelletier and Caventou detected in the rhizome of Veratrum, a substance which they regarded as identical with veratrine, the existence of which had just been discovered by W. Meissner in cebadilla seeds. But according to the recent observations of Dragendorff, ${ }^{1}$ the veratrine of cebadilla cannot be found either in Vercatrum album or $V$. viride.

Simon (1837) found in the root a second alkaloid, Jervine, $\mathrm{C}^{30} \mathrm{H}^{46} \mathrm{~N}^{2} \mathrm{O}^{3}$, said to be distinguished from veratrine by the sparing solubility of its salts, especially its sulphate, in water. C. L. Mitchell (1874) has extracted jervine from both Veratrum album and $V$. viride. He obtained in the first instance the sulphate in the form of a granular powder: from this he separated the allaloid as a light white substance, tasteless and inodorous, of feebly alkaline reaction, capable of crystallizing from alcoho!. Its most characteristic reaction is said to be with strong sulphuric acid, which colours it first yellow, then green.

Weppen (1872) has isolated from this drug Veratramarin, an amorphous, deliquescent, bitter principle. It occurs in minute quantity only, and is resolvable into sugar and other products. Veratramarin dissolves. in water or spirit of wine, not in ether or in chloroform. The same. observer has also isolated to the extent of $\frac{1}{2}$ per mille, Jervic Acid in hard crystals of considerable size, of the composition, $\mathrm{C}^{14} \mathrm{H}^{10} \mathrm{O}^{12}+2 \mathrm{H}^{2} \mathrm{O}$. The acid requires 100 parts of water for solution at the ordinary temperature, and a little less of boiling alcohol. It is decidedly acid, and forms well-defined crystallizable salts, containing 4 equivalents of metal.

By exhausting the entire rhizome (roots included) with ether and anhydrous alcohol, we obtained 25.8 per cent. of soft resin, which deserves further examination. Pectic matter to the amount of 10 per cent. was. pointed out by Wiegand in 1841.

According to Schroff (1860) the active principle of white hellebore resides in the cortical part of the rootlets, the woody central portion being inert. He also asserts that the rhizome acts less strongly than the rootlets, and in a somewhat different manner.

Commerce-The drug is imported from Germany in bales. The price-currents distinguish Swiss and Austrian, and generally name the drug as "without fibre."

1 Bcitr. zur gerichu. Chrmic, St. Petersb., 1572. 95. 
Uses-Veratrum is an emetic and drastic purgative, rarely used intermally. It is occasionally employed in the form of ointment in scabies. Its principal consumption is in veterinary medicine.

Substitutes-The rlizome of the Austrian Veratrum nigrum L. is said to be sometimes collected instead of White Hellebore; it is of much smaller size, and according to Schroff, less potent. That of the Mexican Helonias frigida Iindl. (Veratrum frigidum Schl.) appears to exactly resemble that of Veratrum album.

\section{RHIZOMA VERATRI VIRIDIS.}

\section{American White Hellebore, ${ }^{1}$ Indian Poke.}

Botanical Origin-Veratrum viride Aiton, a plant in every respect closely resembling $V$. album, of which it is one of the numerous forns. In fact, the green-flowered variety of the latter ( $V$. Lobelianum Berml..), a plant not uncommon in the mountain meadows of the Alps, comes so near to the American $V$. viride that we are unable to point out any important character by which the two can be separated. ${ }^{2}$ The American Veratium is common in swamps and low grounds from Canada to Georgia.

History-The aborigines of North America were acquainted with the active properties of this plant before their intercourse with Europeans, using it according to Josselyn, ${ }^{3}$ who visited the country in 1638-1671, as a vomit in a sort of ordeal. He calls it White Hellebore, and states that it is employed by the colonists as a purgative, antiscorbutic and insecticide.

Kalm (1749) states ${ }^{4}$ that the early settlers used a decoction of the roots to render their seed-maize poisonous to birds, which were made "delirious" by eating the grain, but not killed; and this custom was still practised in New England in 1835 (Osgood).

The effects of the drug have been repeatedly tried in the United States during the present century; and about 1862, in consequence of the strong recommendations of Drs. Osgood, Norwood, Cutter, and others, it began to be prescribed in this country.

Description-In form, internal structure, odour and taste, the rhizome and roots accord with those of Veratrum album; yet owing to the method of drying and preparing for the market, the American veratrum is immediately distinguishable from the White Hellebore of European commerce. We have met with it in three forms :-

1. The rhizome with roots attached, usually cut lengthwise into quarters, sometimes transversely also, densely beset with the pale brown

1 The name Green Hellebore is sometimes applied to this drug, but it properly belongs to Hcllcborus viridis $\mathrm{L}$., which is medicinal in some parts of Europe.

2 Sims in contrasting Veratrum viride with $V$. album observes that the flowers of the former are "more inclined to a yellow green," the petals broader and more erect, with the margins, esprecially about the claw, thickened and covered with a white mealiness. Hot. Mau. xxvii. (1808) tab. 1096.-Tiegel has described four varietics of Vcratrum allum L., as occurring in the region of the Lower Ussuri and Anurland, one of which, var. $\gamma_{.}$, he has identified with the American V. viridc. - Tentamen Flore L'ssuricnsis, St. Petersb. 1861. 153.

${ }^{3}$ N'cw England's Rarities discovercd, Lond. 16\%2. 43 ; also Account of two loyjages to T'ce England, Lond., 167t, 60. 76.

${ }^{4}$ Tharels in North Ameried, vol. ii. (17i1) 91. 
roots, which towards their extremities are clothed with slender fibrous rootlets.

2. Rhizome and roots compressed into solid rectangular cakes, an inch in thickness.

3. The rhizome $p e r$ se, sliced transversely and dried. It forms whitish, buff, or brownish discs, $\frac{1}{2}$ to 1 inch or more in diameter, much shrunken and curled by drying. This is the form in which the drug is required by the United States Pharmacopœia.

Chemical Composition-No chemical difference between Veratrum viride and $V$. album has yet been ascertained. The presence of veratrine, suspected by previous chemists, was asserted by Worthington ${ }^{1}$ in 1839 , J. G. Richardson of Philadelphia in 1857, and S. R. Percy in 1864. Scattergood ${ }^{2}$ obtained from the American drug, 0.4 per cent. of this alkaloid, which however, in consequence of some observations of Dragendorff (p. 631), we must hold to be doubtfully identical with that of cebadilla. As stated in a previous page, jervine is present as in the White Hellebore of Europe. The resin may be prepared by exhausting with strong alcohol and precipitating with boiling acidulated water, repeating the process in order to entirely eliminate the alkaloids. It is a dark brown mass, yielding about a fourth of its weight to ether. Scattergood obtained it to the extent of $4 \frac{1}{2}$ per cent. By exhausting the drug successively with ether, absolute alcohol and spirit of wine, we extracted from it not less than 31 per cent. of a soft resinoid mass. Worthington pointed out the presence of gallic acid and of sugar.

Uses-Veratrum viride has of late been much recommended as a cardiac, arterial and nervous sedative. It is stated to lower the pulse, the respiration and heat of the body, not to be narcotic, and rarely to occasion purging ; $;$ but to. what principle these effects are due, has not yet been ascertained. By some observers, as Bigelow, ${ }^{4}$ Fée, ${ }^{5}$ Schroff, ${ }^{6}$ and Oulmont, ${ }^{7}$ it is alleged to have the same medicinal powers as the European Veratrum allum.

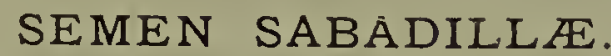

Fructus Sabadille:; Cebadilla, Covadilla; F. Céradille; G. Sabadillsamen, Läusesamen.

Botanical Origin-Asagrea officinalis Lindley (Veratrum offieinale Schlecht., Sabadilla officinarum Brandt, Schonocanion officinale A. Gray). -A bulbous plant, growing in Mexico, in grassy places on the eastern declivities of the volcanic range of the Cofre de P'erote, and Orizaba, near Teosolo, Huatusco and Zacuapan, down to the sea-shore, also in Guatemala. Cebadilla is (or was) cultivated near Vera Cruz, Alvarado and Tlacatalpan in the Gulf of Mexico.

Another form of Asagrece, first noticed by Berg,s but of late more particularly by Ernst of Caracas, who thinks it may constitute a distinct

1 Am. Journ. of Pharm. iv. (1839) 89.

2 Proc. of Am. Pharm. Assoc. 1862. 226.

3 Cutter, Lancet, Jan. 4, Augr. 16, 1862 ; Pharm. Jouriz. iv. (1863) I3t.

4 American Hedical Buiany, ii. (1819) 121-136.

"Cours d'Hist. Nut. Hiarm. i. (1828) 319.
6 Meclizinische Juhrbüchcr, xix. (Vienna, 186:3) $129-148$.

7 Buchner's Repcrtorium für Pharmacic, xviii. (1868) 50 ; also Wigger's and Huscmanu's Jahresbcricht, 1868. 505.

8 Berg u. Schmidt, Offi. Gcwüchse, i. (1858) tab. ix, e. 
species, is found in plenty on srassy slopes, 3500 to 4000 feet above the sea-level, in the neighbourhnod of Caracas, and sonthward in the hilly regions bordering the valley of the 'T'uy. ${ }^{1}$ It differ's chiefly in having broader and more carinate leaves. Of late years it has furnished large quantities of seed, which, freed from thein capsules, have been shipped from La Guaira to Hamburg. ${ }^{2}$

History_Cebadilla was first described in 1571 by Monardes, who states that it is used by the Indians of New Spain as a caustic and corrosive application to wounds; but it does not seem to have been brought into European commerce, for neither Parkinson who described it in 1640 as the Indian Causticke Barley, nor Ray (1693) did more than copy from Monardes.

In the latter half of the last century, it began to be recommended in France and Germany for the destruction of pediculi. A famous composition for this purpose was the Poudre des Capucins, consisting of a mixture of stavesacre, tobacco, and cebadilla, which was applied either dry or made into an ointment with lard. ${ }^{3}$ Cebadilla was also administered combined into a pill with gamboge and valerian, ${ }^{4}$ for the destruction of intestinal worms, but its virulent action made it hazardous.

Upon the introduction of veratrine into medicine about 1824 , cebadilla attracted some notice, and was occasionally prescribed in the form of tincture and extract; but it subsequently fell into disuse, and is now only employed for the manufacture of veratrine.

Description-Each fruit consists of three oblong pointed follicles, about $\frac{1}{2}$ an inch in length, surrounded below by the remains of the 6-partite calyx, and attached to a short pedicel. The follicles are united at the base, spread somewhat towards the apex, and open by their ventral suture. They are of a light brown colour and papery substance. Each usually contains two pointed narrow black seeds, $\frac{3}{10}$ of an inch in length, which are shining, rugose, and angular or concave by mutual pressure. The compact testa encloses an oily albumen, at the base of which, opposite to the beaked apex, lies the small embryo. The seed is inodorous and has a bitter acrid taste; when powdered, it produces violent sneezing.

Microscopic Structure-A transverse section shows the horny, concentrically radiated albumen, closely attached to the testa. The latter consists of an outer layer of cuboid cells, and three rows of smaller, thinwalled, tangentially-extended cells, all of which have brown walls. The tissue of the albumen is made up of large porous cells, containing drops of oil, granules of albuminoid matter, and mucilage. Traces of tannic acid occur only in the outer layers of the seed.

Chemical Composition-W. Meissner in 1818, discovered in cebadilla the alkaloid Veratrine, ${ }^{5}$ which in the following year was more closely

1 Ernst, communication to the Liunean Society of London, 15 Dcc. 1870.

2 Veralrum Sabadilla Retzius is stated by Lindley (Flore Medica, p. 586) to be a native of Mcxico and the West Indian Islands, and to furuish a portion of tho cebadilla seeds of commcrec. The plant is unkllown to us: we have searched for it in vain in the lerbaria of $\mathrm{Kcw}$ and the British Museum. It is not mentioned as West Indian by Grisebach (Flor: of Brit. IV.I. Islands, 1864; Cal. Plant. Cubcrsinm,
1866). The figure by Descourtilz (Flor. méd. des Antilles, iii. 1S27. t. 195), who had the plant growing at $S t$. Domingo, shows it to l'esemble Verairum album L., and therefore to be very different from $A$ sagraca.

3 Munny, Apparalus Mcdicaminum, $r$. (1790) 171; Mérat and De Lens, Dict. Mrat. Méd. vi. (1S34) S62.

${ }^{4}$ Peyrilhe, Cours's d'Hist. Nat. Mćd. ii. (1804) 490.

5 So called from Schlechtendal's name for the plant, Veratrum officinalc. 
investigated by Pelletier and Caventou. For many years this substance was known only as an amorphous powder, in which state it frequently contained a considerable proportion of resin; but in 1855, it was obtained by G. Merck in large rhombic prisms. Cebadilla yields only about 3 per mille of veratrine. The alkaloid is easily soluble in spirit of wine, ether or chloroform; these solutions; as well as the watery solutions of its salts, are devoid of rotatory porver. Veratrine, like the drug from which it is derived, occasions, if inhaled, prolonged sternutation. It is still doubtful whether the carpels contain the alkaloid, or whether it is confined to the seed.

The alkaloids of cebadilla have been afresh investigated in Dragendorff's laboratory by Weigelin, ${ }^{1}$ who has found that veratrine exists under two isomeric modifications, the one soluble in water, the other insoluble, having the formnla $\mathrm{C}^{52} \mathrm{H}^{86} \mathrm{~N}^{2} \mathrm{O}^{15}$. Although he succeeded in crystallizing the alkaloid, he could obtain the sulphate and hydrochlorate only in an amoirphous state.

Couerbe (1834) discovered a second crystallizable alkaloid called Sabadilline, insoluble in ether, but according to Weigelin, soluble more or less freely in water, benzol, petroleum ether, amylic alcohol, or chloroform. From the benzol solution, it may be obtained in long colourless needles. It saturates acids, and forms with sulphuric or hydrochloric acids amorphous gummy salts. The new analyses of Weigelin give to sabadilline the formula, $\mathrm{C}^{41} \mathrm{H}^{66} \mathrm{~N}^{2} \mathrm{O}^{13}$. Unilike veratrine, sabadilline does not occasion sneezing.

Weigelin in the course of his researches, detected in cebadilla a third alkaloid, which he has named Sabatrine, assigning, to it the formula $\mathrm{C}^{51} \mathrm{H}^{56} \mathrm{~N}^{2} \mathrm{O}^{17}$. It is an uncrystallizable resin-like mass, soluble in ether, benzol, petroleum ether, amylic alcohol, or chloroform, and sparingly in water. It neutralizes acids, forming amorphous salts. The veratrine supplied in commerce, is stated by Weigelin always to contain more or less of sabadilline and sabatrine.

Cebadilla yielded to Pelletier and Caventou, a volatile fatty acid, Sabadillic or Ccvadic Acid, the needle-shaped crystals of which fuse at $20^{\circ} \mathrm{C}$. Lastly, E. Merck (1839) found a second peculiar acid termed Veratric Acid, $\mathrm{C}^{18} \mathrm{H}^{20} \mathrm{O}^{8}$, affording quadrangular prisms, which can be sublimed without decomposition. It is yielded by cebadilla to the extent of but $\frac{1}{6}$ per mille.

Commerce-According to Ernst, the quantity of cebadilla (seeds only) shipped from La Guaira, the port of Caracas, is from 3000 to 3600 quintals amnually. No other sort is now imported.

Uses-Cebadilla is at present, we believe, only used as the source of veratrine. In Mexico, the bulb of the plant is employed as an anthelmintic, under the name of Cebolleja, but it is said to be very dangerous in its action.

I Untersuchungen ïber die Alkaloide des Sabadillsumens, Dornat, 1871-an abstract of which may be found in Wiggers and Husemann's Jahresberieht for 1871. 24-30. 


\section{CORMUS COLCHICI.}

\section{Thuber vel Bulbus vel Radix Colchiei; Meadow Sufron Root; F. Bulbe de Colehique; G. Zeitlosenknoilen.}

Botanical Origin-Colelieum autumnale L.-This plant grows in mearlows and pastures over the greater part of Middle and Sonthern Europe, and is plentiful in many localities in England and Ireland. In the Swiss Alps, it ascends to an elevation of 5500 feet above the sea level.

History.-Dioscorides drew attention to the poisonous properties

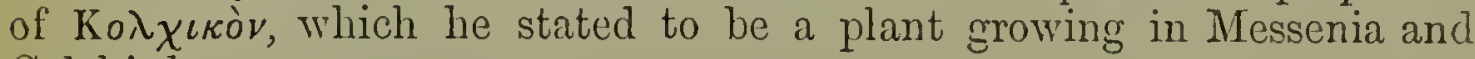
Colchis. ${ }^{1}$

This character for deleterious qualities seems to have prevented the use of colchicum both in classical and mediæval times. Thus Tragus (1552) warns his readers against its use in gout, for which it is recommended in the writings of the Arabians. Jacques Grévin, a physician of Paris, author of Deux Livres des Venins, dedicated to Queen Elizabeth of England, and printed at Antwerp in 1568, observes- "ce poison est ennemy de la nature de l'homme en tout et par tout." ${ }^{2}$ Dodoens calls it pernieiosum Colehieum; and Lyte in his translation of this author (1578) says, - " Medow or Wilde Saffron is corrupt and venemous, therefore not used in medicine." Gerarde declares the roots of "Mede Saffron" to be "very hurtfull to the stomacke."

Wedel published in 1718 , an essay De Colehico veneno et alexipharmaeo, ${ }^{3}$ in which, to show the great disfavour in which this plant had been held, he remarks, - " hactenus . . velut infame habitum et damnatum fuit colchicum, indignum habitum inter herbas medicas vel officinal es .." He further states, that in the 17th century, the corms were worn by the peasants of some parts of Germany as a charm against the plagne.

In the face of these severe denunciations, it is strange to find that in the London Pharmacopœia of 1618 (the second edition), "Radix Colehiei," as well as Hermodaetylus, is enumerated among the simple drugs ; and again in the editions of 1627,1632 and 1639 . It is omitted in that of 1650, and does not reappear in subsequent editions until 1788, when owing to the investigations of Störck (1763), Kratochwill (1764), De Berge (1765) Ehrmann (1772), and others, the possibility of employing it usefully in medicine had been made evident.

Development of the Corm ${ }^{4}$-At the period of flowering, the corm is surrounded with a brown, closed double membrane or tunic, which is prolonged upwards into a sheath around the flowering-stem; at the base of the corm is a tuft of simple roots. On removing the membranes, we find a large, ovoid, fleshy body (Corm No. 1), marked at

${ }_{1}$ His deseription is exaet, exeept that he declares the eorm to have a swect taste, whieh seems not true for Colchicum autum. nale, but may be so for some other species.

2 Anvers, 4to. p. 228.

3 Jena, 4to.
4 The term $\operatorname{cor}^{\prime} m$ is applied by English writers to the short, fleshy, bulb-shaped base of an anmual stem, either lateral as in Colchicum, or terminal as in Crocus. $\mathrm{By}$ many continental botanists, : the corm of Colchicum is regarded either as a form of tuber, or of bulb. 
its apex by a depressed scar, the point of attachment of the flower-stem of the previous year; it is on one side flattened, and traversed by a shallow longitudinal furrow, from the upper part of which arises a much smaller and rudimentary corm (No. 2), bearing a flower-stem. After the production of the flower in the autumn, Corm No. 2 increases in size, throwing up as spring advances, its fruit-stem and leaves, and acquires after these latter have come to maturity, its full development. Corm No. 1 on the other hand, having performed its functions, shrivels and diminishes in size, in proportion as No. 2 advances to maturity, and ultimately decays, leaving a rounded cicatrix, showing its point of attachment to its successor.

Collection-In England, the corms are usually dug up and brought to market in July, at the period between the decay of the foliage and the production of the flower, or even after the latter has appeared. For some preparations, they are used in the fresh state. If to be dried, it is customary to slice them across thinly and evenly with a knife, and to dry the slices quickly in a stove with a gentle heat; the membranes are afterwards removed by sifting or winnowing.

Schroff has stated as the result of his experiments, ${ }^{1}$ that the corms possess the greatest medicinal activity when collected in the autumn during or after inflorescence; that they ought to be dried entire, by exposure to the sun and air; and that if thus preserved, they lose none of their strength, even if kept for several years.

Description-The fresh corm is conical or inversely pear-shaped, about 2 inches long by an inch or more wide, rounded on one side, flattish on the other, covered by a bright brown, membranous skin, within which is a second of paler colour. When cut transversely, it appears white, firm, fleshy and homogeneous, abounding in a bitter, starchy juice, of disagreeable odour. The dried slices are inodorous, and have a bitterish taste. They should be of a good white, clean, crisp and brittle,-not mouldy or stained.

Microscopic Structure-The outer membrane is formed of tangentially-extended cells, with thick brownish walls; the main body of the corm, of large thin-walled, more or less regularly globular cells, loaded with starch, and interrupted by vascular bundles containing spiral vessels. The original form of the starch granules is globular or eggshaped, but from mutual pressure and agglutination, many are angular or truncated. A large proportion are more or less compound, consisting of several granules united into one. In all, the hilum is very distinct, appearing in some as a mere point, but in most as a line or star.

Chemical Composition-The corms contain Colchicin (see next article), about 10 per cent. of starch, besides sugar, gum, resin, tannin, and fat. When sliced and dried, they lose about 70 per cent. of water. ${ }^{2}$ By drying, the (probably) volatile body upon which the odour of the fresh corm depends, is lost.

Uses-Colchicum is much prescribed in cases of gout, rheumatism, dropsy and cutaneous maladies.

1 Ocsterreichische Zeitschrift für praltischc Ifci7lkunde, 1856, Nos. 22-24; also Wiggers, Jahresbericht der Iharm. 1856. 15.
2 This is the avcrage obtained during ten ycars in drying $16 \mathrm{cwt}$, in the laboratory of Messrs. Allen and Hanburys, London. 


\section{Other medicinal species of Colchicum.}

Under the name $H_{c r m a l a c h y l u s,}{ }^{1}$ the corms of other species of Colchicum of 'Sastern origin, anciently enjoyed great reputation in medicine. 'These corms are in structure precisely like those of ordinary colchicum; they are entire, but deprived of membranous envelopes, of a flattened, heart-shaped form, not wrinkled on the surface, and often very small in size. The starch graius they contain are similar to those of $C$. autrmnale, but in some specimens twice as large.

'There is great uncertainty as to the species of Colchicum which fumish hermodactyls. Prof. J. E. Planchon, who has written a learned and elaborate article on the subject, ${ }^{2}$ is in favour of $C$. varicgatum L., a native of the Levant. But one can hardly suppose this plant to be the source of the hermodactyls (Surinjún) of the Indian bazaars, which are stated to be brought from Kashmír.

\section{SEMEN COLCHICI.}

\section{Colchicum Sced; F. Semencc de Colchique; G. Zcitloscnsamen.}

Botanical Origin-Colchicum autumnale L., see page 636.-The inflated capsule, which grows up in the spring after the disappearance of the flower in the autumn, is three-celled, dehiscent towards the apex by its ventral sutures, and contains, attached to the inner angle of the carpels, numerous globular seeds, which arrive at maturity in the latter part of the summer.

History-Colchicum seeds were introduced into medical practice by Dr. W. H. Williams, of Ips.wich, about 1820, on the ground of their being more certain in action than the corm. ${ }^{3}$ They were admitted to the London Pharmacopœia in 1824.

Description-The seeds are of globose form, about $\frac{x}{10}$ of an inch in diameter, somewhat pointed by a strophiole, which when dry is not very evident. They are rather rough and dull; when recent of a pale brown, but become darker by drying, and at the same time exude a sort of saccharine matter. They are inodorous even when fresh, but have a bitter acrid taste; they are very hard and difficult to powder.

Microscopic Structure-The reticulated, brown coat of the seed, consists of a few rows of large, thin-walled, tangentially-extended cells, considerably smaller towards the interior, the outermost containing starch grains in small number. The thin testa is closely adherent to the horny greyish albumen. The cells of the latter are remarkable for their thick walls, showing wide pores; they contain granular plasma and oil-drops. The very small leafless embryo may be observed on transverse section close beneath the testa on the side opposite the strophiole.

Chemical Composition-The active principle of colchicum seed,

\footnotetext{
1 The Bitter Hermodactyl of Royle, is not in our opinion the produce of a Colchicum at all; see also Cooke in Pharm. Journ. April 1, 1871.
}

"Ann. des Sciences Sixt., Bot., ir. (1S55) 132 ; abstract in Pharm. Joum. xr. (1S56) 465. 1820. 
termed Colchicin, is said to amount to only about 0.05 per cent.; but the chemists who have made it the subject of investigation are not agreed as to its properties. Thus Oberlin (1856) showed it to contain nitrogen, but without possessing basic properties. By treatment with acids, the amorphous colchicin yields a crystallizable body, Colchiceïn. Hübler (1864) assigned to the latter, acid qualities and, strangely enough, the same formula he gave for colchicin itself, namely, $\mathrm{C}^{17} \mathrm{H}^{19} \mathrm{NO}^{5}$. Maisch ${ }^{1}$ as well as Diehl ${ }^{2}$ again obtained discrepant results, and it seems probable that Colchicin of definite composition has not yet been isolated.

The seeds contain traces of gallic acid, sugar and fatty oil. Of the last, we obtained 6.6 per cent. by exhausting the dried seed with ether. The oil concreted at $-8^{\circ} \mathrm{C}$.

Uses-The same as those of the corm.

\section{SMILACEA.}

\section{RADIX SARSAPARILL $Æ$.}

\section{Radix Sarze vel Sarsa; Sarsaparilla; F. Racine de Salsepareille; G. Sarsaparillwurzel.}

Botanical Origin-Sarsaparilla is afforded by several plants of the genus Smilcux, indigenous to the northern half of South America, and the whole of Central America as far as the southern and western coast-lands of Mexico.

These plants are woody climbers, often ascending lofty trees by the strong tendrils which spring from the petiole of the leaf. Their stems are usually angular, armed with stout prickles, and thrown up from a large woody rhizome. The medicinal species inhabit swampy tropical forests, which are extremely deleterious to the health of Europeans and can only be explored amid great difficulties. This circumstance taken in connexion with the facts that the plants are diøcious, that their scandent habit often renders their flowers and fruits (produced at different seasons) inaccessible, and that their leaves vary exceedingly in form, ${ }^{3}$ explains why we are but very imperfectly acquainted with the botanical sources of sarsaparilla.

It is not too much to assert that the sarsaparilla plant of no district in Tropical America is scientifically well known. The species moreover, to which the drug is assigned, have for the most part been founded upon characters that are totally insufficient, so that after an attentive study of herbarium specimens, we are obliged to regard as still doubtful several of the plants that have been named by previous writers.

Having made these preliminary remarks, we will enumerate the plants to which the sarsaparilla of commerce has been ascribed.

1. Smilax officinalis H.B.K.-This plant was obtained in the year 1805, by Humboldt, at Bajorque, a village on the Magdalena in New

1 Phorm. Journ. ix. (1867) 249.

2 Proc. Americ. Pharm. Assoe. 1867. 363

3 The common S'milcas aspcra L., of Southern Europe, is a plant which presents sueh diversity of foliage, that if like its congeners of Tropieal Amerien, it were known only by a few leafy seraps preservod in herbaria, it would assuredly have been referred to several speeies. 
Granada. The specimens, comprising only a few imperfect leaves, which we have examined in the National Herbarium of Paris, are the materials upon which Kunth founded the species. Humboldt ${ }^{2}$ states, that quantities of the root are shipped by way of Mompox and Cartagena to Jamaica and Cadiz.

In 1853 , this plant was again gathered at Bajorque by the late De Warszewicz, who sent to one of us (H.) leaves and stems, accompanied by the root, which latter agrees with the Jamaica Sarsaparilla of commerce. But at Bajorque, the root is no longer collected for exportation.

The same botanical collector, at the request of one of us, obtained in the year 1851, on the volcano and Cordillera of Chiriqui in Costa Rica, fruits, leaves, stems, and roots, of the plant there collected by the Indians as Sarsa peluda or Sarson. These specimens agree, so far as comparison is possible, with those of the Bajorque plant, while the root is undistinguishable from the Jamaica sarsaparilla of the shops. Other specimens of the same plant, gathered by the same collector in 1853 , were forwarded to England with a living root, which latter however could not be made to grow.

Finally, in 1869, Mr. R. B. White obligingly communicated to us, leaves and roots of a sarsaparilla collected at Patia in New Granada, which apparently belongs to the same species.

In the island of Jamaica, there has been cultivated for many years, and of late with a view to medicinal use, a sarsaparilla plant which appears to be Smilax officinalis. The specimens transmitted to us, ${ }^{2}$ include neither flowers nor fruits; but the leaves and square stem accord exactly with those of the plant collected at Bajorque. The root is of a light cinnamon-brown, and far more amylaceous than the so-called Jamaica Sarsaparilla of commerce (see p. 645).

2. Smilax medica Schl. et Cham.-This species, ${ }^{3}$ which was discovered in Mexico by Schiede in 1820, is without doubt the source of the sarsaparilla shipped from Vera Cruz. According to our observations, it has a flexuose (or zigzag) stem, and much smaller foliage than S. officinalis: the leaves, though very variable, often assume an auriculate form, with broad, obtuse, basal lobes.

It grows on the eastern slopes of the Mexican Andes, and is the only species of that region of which the roots are collected. These, according to Schiede, are dug up all the year round, dried in the sun and made into bundles.

Doubt and confusion hang over the other species of Smilax which have been quoted as the sources of sarsaparilla. S. syphilitica H.B.K., with flowers in a raceme of umbels, discovered on the Cassiquiare

1 Kunth, Synopsis Plant. i. (1822) 278.Smilax officinalis is a large, strong elimber, attaining a height of 40 to 50 feet, with a perfectly square stem ar'med with prickles at the angles. The leaves are often a foot in length, of variable form, being triangular, ovate-oblong, or oblong-lanecolate, either gradually narrowing towards the apex or rounded and apiculate, and at the base either attenuated into the petiole, or truncate, or cordate. They are usually 5 -nerved, the 3 inner nerves being mominent and enelosing an elliptic area. The flowers are in stalked umbels. A fine specimen of the plant is growing (1874) in the Royal Gardens, lier, but has not flowered.

2 We owe them to the kinduess of H. J. Kemble, Ess.., who procured them with speeimens of the root, from the Goremment garden at Castleton.

3 Figured in Nees ron Esenbeeli's Planter Mcdicinales, suppl. tab. 97. 
in New Granada, and well figured by Berg and Schmidt from an anthentic specimen, appears from Pöppig's statements to yield some of the sarsaparilla shipped at Pará. But Kunth states that Pöppig's plant gathered near Ega, is not that of Humboldt and Bonpland. Spruce, who collected S. syphititica (herb. No. 3779) in descending the Rio Negro in 1854, has informed us that the Indians in various places in the Amazon valley always strenuously asserted it to be a species worthless for "Salsa."

S. papyracca, described by Poiret ${ }^{1}$ in 1804, and figured by Martius ${ }^{2}$ is but very imperfectly known. It has foliage resembling that of S. officinalis, but, judging from Spruce's specimens (No. 1871) collected on the Rio Negro, a multangular stem. It is probably the source of the Parí Sarsaparilla.

S. cordato-ovata Rich. is a doubtful plant, perhaps identical with S. Schomburgkiance Knth., a Panama species. Pöppig alleges that its root is mixed with that of the plant which he calls S. syphilitica.

S. Purhampuy Ruiz, a Peruvian species, said to afford a valuable sort of sarsaparilla, is practically unknown, and is not admitted by Kunth. ${ }^{3}$

History-Monardes ${ }^{4}$ has recorded that sarsaparilla was first introduced to Seville about the year 1545, from New Spain; and a better variety soon afterwards from Honduras. He further narrates that a drug of excellent quality was subsequently imported from the province of Quito, that it was collected in the neighbourhood of Guayaquil, and was of a dark hue, and larger and thicker than that of Honduras.

These statements are confirmed by the testimony of earlier writers. Thus, João Rodriguez de Castello Branco, commonly known as Amatus Lusitanus, a Portuguese physician of Jewish origin, who practised chiefly in Italy, has left a work (1556) recording his medical experiences and narrating cases of successful treatment. ${ }^{5}$ One of the latter concerns a patient suffering from acute rheumatism, for whom he finally prescribed Sarsaparilla. This drug, he explains, has of late years been brought from the newly found country of Peru, that it is in long whip-like roots, growing from the stock of a sort of bramble resembling a vine, that the Spaniards call it Zarzc parrilla, and that it is an excellent medicine.

About the same period, sarsaparilla was described by Auger Ferrier, ${ }^{6}$ a physician of Toulouse, who states that in the treatment of syphilis, which he calls Lucs Hispanica, it is believed to be better than either China root or Lignum sanctum. Girolamo Cardano of Milan, in a little work called Do radice Cina ct Sarza Parilic judicium, expresses similar opinions. Turner in the third part of his Herball, printed in 1568, mentions Salsaperilla, to which he says new writers ascribe the same virtues as to guaiacum.

Pedro de Cieza de Leou, in his Chronicle of Peru, ${ }^{7}$ which contains the

1 Lamarek, Encyclopédic méthodinue, Bot., vi. 1804. 468 .

2 Flor. Bres. i. (1842-71) tab. 1.

3 It must not be supposed that all species of Smilax are eapable of furnishing the drug. 'I'here are many, even Sontl Ameriean, which like the s. asperce of Europe, have thin, viry roots, which would never pass for medicinal sarsapnrilla.

+ Pages 18 and 88 of the work quoted at p. 480 , note 5 .

- Curationum medicinalium conturise quatnor, Basilex, 1556. 365.

${ }^{6}$ De Pudendagra lue IIispanica, libri duo, first published at 'Ionlouse in 1553 , and many times reprinted. We have consulted the Antworp odition of 1564, with which Cardano's work is printed. The latter is said to have first appeared in 1559.

7 Parte mimera de la Chronica del Peru. Scvilla, 1553. folio lxix. - a translation for the Hakluyt Society in 1864, by Markham, who observes that Cieza de Leon never lim. self visited Guayaquil. 
observations made by him in South America between 1532 and 1550, gives a particular account of the sarsajarilla which grows in the province of Guayaquil and the adjacent island of T'una, and recommends the sudorific treatment of syphilis, exactly as pursued at the present time. Cerarde, ${ }^{1}$ who wrote about the close of the century, states that the sarsaparilla of Peru is imported into England in abundance.

Collection of the root-Mr. Richard Spruce, the enterprising hotanical explorer of the Amazon valley, has communicated to us the following particular's on this subject, which we give in his own graphic words :-

"When I was at Santarem on the Amazon in 1849-50, where consiilerable quantities of sarsaparilla are brought in from the upper regions of the river Tapajóz, and again when on the Upper Rio Negro and Uaupés in 1851-53, I often interrogated the traders about their criteria of the good kinds of sarsaparilla. Some of them had bought their stock of Indians of the forest, and had themselves no certain test of its genuineness or of its excellence, beyond the size of the roots, the thickest fetching the best price at Pará. Those who had gathered sarsaparilla for themselves, were guided by the following characters :-1. Many stems from a root. 2. Prickles closely set. 3. Leaves thin. - The first character was (to them) alone essential, for in the species of Smilax that have solitary stems, or not more than two or three, the roots are so few as not to be worth grubbing up; whereas the multicaul species have numerous long roots,- - three at least to each stern,-extending horizontally on all sides.

"In 1851, when I was at the falls of the Rio Negro, which are crossed by the equator, nine men started from the village of St. Gabriel to gather Salsa, as they called it, at the head of the river Cauaburís. During their absence I made the acquaintance of an old Indian, who told me that four years ago he had brought stools of Salsa from the Canaburís and had planted them in a tabocál, - a clump of bamboos, indicating the site of an ancient Indian village,-on the other side of the falls, whither he invited me to go and witness the gathering of his first crop of roots. On the 23rd March, I visited the tabocal, and found some lialf-dozen plants of a Smilar with very prickly stems, but no flowers or fruit. At my request the Indian operated on the finest plant first. It had five stems from the crown, and numerous roots about 9 feet long, radiating horizontally on all sides. The thin covering of earth was first scraped away from the roots by hand, aided by a pointed stick; and had the salsa been the only plant occupying the ground, the task would have been easy. But the roots of the salsa were often difficult to trace among those of bamboo and other plants, which had to be cut throngh with a knife whenever they came in the way. The roots being at length all laid bare--(in this case it was the rwork of half a day, but with large plants it sometimes takes up a whole day or even more) - they were cut off near the crown, a few slender ones bring allowed to remain, to aid the plant in renewing its growtl. The stems also were shortened down to near the ground, and a little enrth and dead leaves heaped over the crown, which would soon shoot out new stems.

"The yield of this plant, of four years' growth, was $16 \mathrm{lb}$. - half a Portuguese arroba-of roots; but a well-grown plant will afford at the first cutting from one to two arrobas. In a couple of years, a plant may be cut again, but the yield will be much smaller and the roots more slender and less starchy."

1 ITerball, onlarged by Johnson, 1636. 859. 
General Description-The medicinal species of Smilax have a thick, short, knotty rhizome, called by the druggists chump, from which grow in a horizontal direetion, long fleshy roots, from about the thickness of a quill to that of the little finger. These roots are mostly simple, forked only towards their extremities, beset with thread-like branehing rootlets of nearly uniform size, which however are not emitted to any great extent from the more slender part of the root near the stock. When fresh, the root is plump, ${ }^{1}$ but as found in eommerce in the dried state, it is more or less furrowed longitudinally, at least in the vicinity of the rhizome. When examined with a good lens, both roots and rootlets may be seen in some specimens to be clothed with short velvety or shaggy hairs.

The presence or ahsence in greater or less abundanee, of starch in the bark of the root, is regarded as an important criterion in estimating the good quality of sarsaparilla. In England, the non-amylaceous or nonmealy roots are preferred, they alone being suitable for the manufacture of the dark fluid-extract that is valued by the public. On the Continent, and especially in Italy, sarsaparilla whieh when cut exhibits a thick bark, pure white within, is the esteemed kind.

The more or less plentiful cceurrenee of starch in the roots of Smilax is a eharacter whieh has no great botanieal significanee, and appears, indeed, to vary in the same speeies. If one examines Jamaica sarsaparilla by shaving off a little of the bark, one finds the large majority of roots to be non-amylaeeous in their entire length; but others ean be pieked out which, though non-amylaceous for some distance from the rbizome, aequire a starehy bark, which is white internally in their middle and lower portions; - and there are still others whieh are slightly starehy even as they start from the parent rhizome, becoming still more so as they advance. In Guatemala sarsaparilla, which is considered a very mealy sort, it is easy to perceive that the bark is hardly amylaceous in the vicinity of the rhizome, but that it acquires an enormous deposit of feeula as it proeeeds in its growth.

Sarsaparilla varies greatly in the abundance of rootlets, technically ealled beard, with which the roots are clothed. This eharacter depends partly on natural eircumstances, and partly on the praetice of the collectors who remove or retain the rootlets at will. Dr. Rhys of Belize has stated that the proportion of rootlets depends much on the nature of the soil, their development being most favoured by moist situations.

Dry sarsaparilla has not mueh smell, yet when large quantities are boiled, or when a decoetion is evaporated, a peculiar and very perceptible odour is emitted. The taste of the root is earthy and not well marked, and even a decoetion has no very distinetive flavour.

Microscopic Structure-On a transverse section of the root, its fibro-vaseular bundles are seen to be restricted to the eentral part, being all enclosed by a brown ring. Within this ring, the bundles are densely paeked so as to form a ligneous zone. The very centre of the section eonsists of white medullary tissue, through whieh sometimes a certain number of fibro-vascular bundles are scattered. A similar medullary parenehyme is met with between the brown ring or nucleus sheath and the epidermis. On a longitudinal scetion, the latter exhibits several rows

1 We have been kindly permitted to examine the fresh root of the large plant of Smilax officinatis in the Royal Gardens, kew ; and have found that it agrees in ap. pearance and in structure with Jamaica sar-
saparilla. 
of elongated eells, having their outer brown walls thickened by seeondary deposits. 'The brown nueleus sheath, on the other hand, consists of only one row of prismatic cells, their inner and lateral walls alone having seeondary deposits. The vaseular bundles contain large sealariforn vessels and lignified prosenehymatous cells.

The parenchymatous eells, if not devoid of solid eontents, are loaded with large eompound stareh granules; some eells also exhibit bundles of acieular erystals of calcium oxalate. In non-mealy sarsaparilla, the vessels and ligneous eells sometimes eontain a yellow resin.

The various sorts of sarsaparilla differ, not only in being mealy os non-mealy, but also as regards the thickness of the ligneous zone, which in some of them is many times thinner than the diameter of the ecntral medullary tissue. In other kinds, this diameter is very much smaller. Yet the nucleus sheath affords still better means for distinguishing the sorts of this drug, if we examine its single cells in a transverse section. The outline of such a cell may be of a square or somewhat rounded shape, or it may be more or less extended. In this ease it may be extended in the direction of a radius, or in the direction of a tangent. The secondary deposits may vary in thickness.

Sorts of Sarsaparilla-In the present state of our knowledge, no botanieal classification of the different kinds of sarsaparilla being possible, we shall resort to the arrangement adopted by Pcreira and place them in two groups, - the mealy or those of which starch is a prevalent constituent, and the non-mealy or those in which starch exists to a com. paratively small extent.

\section{(A). Mealy Sarsaparillas.}

1. Honduras Sarsaparilla-This drug is exported from Belize. It is made up in hanks or rolls, about 30 inches long and $2 \frac{1}{2}$ to 4 inches or more in diameter, closely wound round with a long root so as to form a neat bundle. The hanks are united into bales by large pieces of hide, placed at top and bottom, and held together with thongs of the same, further strengthened with iron hoops.

The roots are deeply furrowed, or sometimes plump and smooth, more or less provided with beard or rootlets. In a very large proportion of their length, they exhibit when eut, a thick bark loaded with starch; yet in those parts which are near the rhizome, the bark is brown, resinous and non-amylaceous. They are of a pale brown, sometimes verging into orange. But the drug is subject to great variation, so that it is impossible to lay down absolutcly distinctive characters.

The ammal imports into the United Kingdom of sarsaparilla from British Honduras during the five years ending with 1870, averaged about $52,000 \mathrm{lb}$.

2. Guatemala Sarsaparilla-This sort of sarsaparilla, which first appeared in commerce about 1852, resembles the Honduras kind in many of its characters and is packed in a similar mamner. But it has a more dccided orcungc hue ; the roots as they start from the rhizome are lean, shrunken and but little starchy, but they become gradually stouter ( $\frac{3}{10}$ inch diam.) and aequire a thick bark which is internally very white and mealy. There is a tendeney in the bark of this sarsaparilla to crack and split off, so that bare spaces showing the eentral woody column are not unfrequent. 
According to Bentley, ${ }^{1}$ who examined specimens of the plant, this Arug is derived from Smilax papyracea; we are not prepared to agree in this opinion.

3. Bravilian, Parde or Lisbon Sarsaparilla-Though formerly held in high esteem, Brazilian sarsaparilla is not now appreciated in England, and is rarely seen in the London market. ${ }^{2}$ It is packed in a very distinctive manner, the roots being tightly compressed into a cylindrical bundle, 3 feet or more in lengtl and about 6 inches in diameter, firmly held together by the flexible stem of a bignoniaceous plant, closely wound round them, the ends being neatly shaved off.

(B). Non-mealy Sarsaparillas.

4. Iamaica Sarsaparilla-To the English druggist this is the most important variety; it is that which appears to have the greatest claim to possess some medicinal activity, and it is the only sort admitted to the British Pharmacopceia. Although constantly called Jamaica Sarsaparilla, it is well known that it only bears the name of Jamaica through having been formerly shipped from Central America by way of that island. $^{3}$ At the commencement of the last century, Jamaica was an emporium for sarsaparilla, great quantities of which, according to Sloane, ${ }^{4}$ ivere brought thither from Honduras, New Spain and Peru. Its actual place of growth, according to De Warszewicz (1851), is the mountain range known as the Cordillera of Chiriqui, in that part of the istlumus of Panama adjoining the republic of Costa Rica: here the plant grows at an elevation of 4000 to 8000 feet above the level of the sea. The root is brought by the natives to Boca del Toro on the Atlantic coast for shipment.

The drug consists of roots, 6 feet or more in length, bent repeatedly so as to form bundles about 18 inches long, and 4 in diameter, which are secured by being twined round (but less trimly and closely than the Honduras sort) with a long root of the same drug. The rhizome is entirely absent, but the fibre or beard is preserved, and is reckoned a valuable portion of the drug. The roots are deeply furrowed, shrunken, and generally more slender than in the Honduras lind; the bark when shaved off with a penknife is seen to be brown, hard and non-mealy throughout. Yet it is by no means uncommon to find roots which have a smooth bark rich in starch. In colour, Jamaica sarsaparilla varies from a pale earthy brown to a deeper more ferruginous hue, the latter tint being the most esteemed.

The sarsaparilla referred to at p. 640 as grown in the island of Jamaica, is a well-prepared drug, yet so pale in colour and so amylaceous, that it finds but little favour in the English market. There were exported of it from Jamaica in 1870, $1747 \mathrm{Hb}$; ; in 1871, $1290 \mathrm{Hb} .^{5}$

5. Mexican Sarsaparilla-The roots of this variety are not made into bundles, but are packed in straight lengths of about 3 feet into bales,

1 Pharm. Journ. xii. (1853) 470, with figure.

${ }_{2}^{2}$ We noticed 66 rolls of it from Pará, offered for sale 15 Dec. $1853 .-\mathrm{D}$. H.

3 The connexion between Jamaiea and Central America dates back from the time of Charles II., during whose reign (1661-85), the king of the Mosquito Territory, a district never conquered by the Spaniards, applied to the governor of Jamaica for proteetion, which was accorled The protectoratc lasted until 1860, wnen Mosquitia was ceded to the goverument of Nicaragua.

* Nat. Hist. of Jamaica, i. (1707), introduction p. lxxxvi.

5 Blue Books-Isiand of Jumaica for 1870 and $187 \mathrm{~L}$. 
the cliump and portions of an angular (but not squarc) thon ny stem being frequently retained. The roots are of a pale, dull brown, lean, slnivelled, and with but few fibres. When thick and large, they have a somewhat starcliy bark, but when thin and near the rhizonne, they are nonamylaceous.

6. Guayaquil Sarsaparilla-An estecmed kind of sarsaparilla las long been exported from Guayaquil (p. 641). Mr. Spruce has informed us that it is obtained in most of the valleys that deboucl into the plain on the westem side of the Equatorial Andes, but chiefly in the valley of Alausi, where in 1859, he saw plants of it at the junction of the small river Puma-cocha with the Yaguachi. The plant appears to be rery productive, an instance being on record of as mucl as $75 \mathrm{Hb}$. of fresh roots having been obtained from a single stock. ${ }^{1}$

Guayaquil sarsaparilla differs considerably from the sorts previously noticed. It is rudely packed in large bales, and is not gencrally made into separate hanks. The rhizome (chump) and a portion of the stem are often present, the latter being round and not prickly. The root is dark, large and coarse-looking, witl a good deal of fibre. The bark is furrowed, rather thick, and not mealy in the slenderer portions of the root which is near the rootstock; but as the root becomes stout, so its bark becomes smoother, thicker and amylaceous, exhibiting when cut a fawn-coloured or pale yellow interior.

The quantity exported from Guayaquil in 1871, was 1017 quintals, value $£ 3814 .^{2}$

Chemical Composition-Galileo Pallotta, abont the year 1824, first succeeded in obtaining from sarsaparilla a peculiar principle, which he believed to be an alkaloid, and termed Pariglina, or as now written, Parillin. He exhausted the crude drug with boiling water and mixed the decoction with milk of lime, whereby a greyish precipitate was produced. This was dried, and treated with hot alcohol which extracted the parillin. Pallotta says the substance slightly reddens litmus, but does not explicitly state whethcr he got it in crystals or not. It appear's however to agree with the body which other chemists obtained crystallized, and which was called Salscparin by Thubeuf in 1831, Parillinic Acid by Batka in 1833, and Smilacin by others.

We have isolated parillin by exhausting Mexican sarsaparilla with boiling spirit of wine, and evaporating the tincture. 'The brown residue after repeated treatment witl alcohol and charcoal, afforded crystals which we purified by re-crystallization from spirit of wine. We also got it from the knotty rhizomes. The process in this case was the following. The rhizomes coarsely powdered were exhausted by water at a not higher temperature than $60^{\circ} \mathrm{C}$, in order not to take up starch. The aqueous liquid was then evaporated to the consistence of a syrup, and mixed with twice its volume of spirit of wine, by which mucilaginous matter and salts were separated. From the filtered liquid, the alcohol was distilled off, and the rcmaining solution then deposited a crop of ycllowish warty crystals of parillin, which were purified by repeated re-crystallization from dilute alcohol and the use of a little charcoal.

1 Journ. of Linn. Soc., Bot., iv, (1860)
185.
$=$ Vice-Consul Smitli on the commerce of Jicnador-Consular Reports, presented to Payliament, July 1872. 
Parillin forms colourless acicular crystals, soluble in 1200 parts of water at $20^{\circ} \mathrm{C}$, and much more abundantly in hot water. The solutions: are nentral, and frotl when shaken. Parillin at $25^{\circ} \mathrm{C}$. requires 25 parts of alcoliol, sp. gr. 0.814 , for solution; the latter is of a persistently acrid taste, and devoid of rotatory power. In warm concentrated sulphuric acid parillin turns reddisl brown, and on addition of stannous chloride assumes a fine violet hue. Parillin is insoluble in ether and nearly so in chloroform. Its hot aqueous solution is capable of separating a little cuprous oxide from an alkaline solution of tartrate of copper; if parillin is boiled for several days with dilute sulphuric acid, the liquid after having been duly neutralized, exhibits an increased reducing power; we have not been able, however, to ascertain that in this process there is any formation of sugar. According to the researches of Klunge at present (1874) being carried on in the laboratory of one of us (F.), the formula of parillin is nearly $\mathrm{C}^{15} \mathrm{H}^{26} \mathrm{O}^{5}+3 \mathrm{H}^{2} \mathrm{O}$. At $100^{\circ} \mathrm{C}$., the substance loses $3 \mathrm{H}^{2} \mathrm{O}$.

By boiling parillin with moderately dilute sulphuric acid (about 1.42 sp. gr.) or with concentrated hydrochloric acid, Klunge obtained brilliant scaly crystals of a body which we call Parigenin. Its composition appears nearly to answer to the formula, $\mathrm{C}^{14} \mathrm{H}^{24} \mathrm{O}^{2}+\mathrm{H}^{2} \mathrm{O}$. But parigenin is well marked as a distinct substance from parillin by the following characters:-it is less soluble in water; it requires for solution 44 parts of alcohol, sp. gr. 0.814; its solutions do not froth, mor have they any acrid taste. With warm concentrated sulphuric acid, parigenin: affords a yellow solution, which is not altered by stannous chloride, but displays a greenish fluorescence. Parigenin, unlike parillin, is freely soluble in etller or chloroform; it is energetically acted upon by acetyl chloride,-not so parillin. We cannot regard the above formulre as ultimately settled; perhaps the formation of parigenin is due to or connected with the elimination of water. Parigenin may also be obtained directly by heating with concentrated sulphuric or hydrochloric acid, the syrupy solution, obtained in the process for making parillin.

The presence in sarsaparilla of starch, resin, and calcium oxalate, as revealed by the microscope, has been already pointed out. Pereira ${ }^{3}$ examined the essential oil, which is heavier than water and has the odour and taste of the drug; $140 \mathrm{tb}$. of Jamaica sarsaparilla afforded of it only a few drops.

The nature of the dark extractive matter which water removes from the root in abundance, and the proportion of which is considered by druggists a criterion of goodness, has not been stndied.

Commerce-The importation of sarsaparilla into the United Kingdom in 1870 (later than which year we have no returns) amounted to $345,907 \mathrm{Hh}$., valued at $£ 26,564$.

Uses-Sarsaparilla is regarded by many as a valuable alterative. and tonic, but by others as possessing little if any renedial powers. It is still much employed, though by no means so extensively as a few years ago. The preparations most in use, are those obtained by a prolonged boiling of the root in water.

1 Elenents of Mat. Med. ii. (1850) 1168. 


\section{TUBER CHIN $A$.}

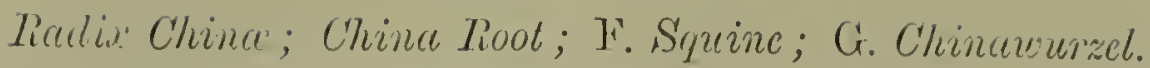

Botanical Origin-Smilax China L. (S. feros: Wallich), a woody, thomy, climbing shrub, untive of China and Japan, also of Eastern India, as Nepal, Khasia, Sikkim, aml A.ssam, is commonly said to afford this drug. 'The chief authority for this statement is Kiimpfer', who figured the plant in his Amanitates in 1712, and whose specimen is still preserved in the British Museun.

S. glabre Tioxb. and S. lancecefolia Roxb., natives of India and Southern China, have tubers which, according to Roxburgh, cannot be distinguished from the China root of medicine, though the plants are perfectly distinct in appearance from S. China. 1)r. Hance, ${ }^{1}$ of Whampoa, reccived a living specimen of China root, which proved to be that of $S$. glabra. The threc above-named species all grow in the island of Hongkong.

History-The use of this drug as a remedy for syphilis was made known to the Portuguese at Goa by Chinese traders about A.D. 1535. Garcia d'Orta, who makes this statement, further narrates that so great was the reputation of the new drug, that the small quantities first brought to Malacca were sold at the rate of 10 crowns per ganta, a weight of 24 ounces.

The reported good effects of China root on the Emperor Charles V. who was suffering from gout, acquired for the drug a great celebrity in Europe, and several works ${ }^{2}$ were written in praisc of its virtues. But though its powcrs were soon found to have been greatly over-rated, it still retained some reputation as a sudorific and alterative, and was much used at the end of the 17th century in the same way as sarsaparilla. It still retains a place in some modern pharmacopoias.

Description-The plant produces stout fibrous roots, lere and there thickcned into large tubcrs, which when dried become the drug China root. These tubers as found in the market, are of irregularly cylindrical form, usually a little flattened, sometimes producing short knobby branches. They are from about 4 to 6 or more inches in length, and 1 to 2 inches in thickness, covered with a rusty-coloured, rather shining bark, which in some specimens is smooth and in others more or less wrinkled. They have no distinct traces of rudimentary leaves, which however are perceptible on those of some allied species. Some still retain portions of the cord-like woody runners on which they grew ; the bases of a few roots can also be observed. The tubers mostly show marks of having been trimmed with a knife.

China root is inodorous and almost insipid. A transverse section cxhibits the interior as a clense granular substance of a pale fawn colour.

Microscopic Structure-The outermost cortical layer is made up of brown, thick-walled cells, tangentially extended. They enclose

1 Trimen's Journ. of Bot. i. (1S72) 102. $-S$. glabra and $S$. lanccafolia have been figured by Secmann in lis Botany of the Herald, 1852-57, tabb. 99-100. S. Chinu is well represented in the Kew Horbarium, where we have examined speeimens from Nagasaki, Hakodadi, and Yokohama; from Loochoo, Corea, Formosa, Niugpo; and
Indian oncs from lihasia, Assam, and Nepal.

2 The carliest of which is by Andreas Vesalius, Epistola rationem, modumquc mropinandi radicis Chyma decocti, quo muser invictissimus Carolus 1". impurator" usus est, Venct. 1546. 
numerous tufts of needle-shaped crystals of calcium oxalate, and reddish brown masses of resin. The bark is at once succeeded by the inner parenchyme which contrasts strongly with it, consisting of large, thinwalled, porous cells which are completely gorged with starch, but here and there contain colouring matter and bundles of crystals. The starch granules are large (up to $50 \mathrm{mkm}$.), spherical, often flattened and angular from mutual pressure. Like those of colchicum, they exhibit a radiate hilum: very frequently they have burst and run together, probably in consequence of the tubers having been scalded. The vascular bundles scattered through the parenchyme, contain usually two large scalariform or reticulated vessels, a string of delicate thin-walled parenchyme, and elegant wood-cells with distinct incrusting layers and linear pores.

Chemical Composition-The drug is not known to contain any substance to which its supposed medicinal virtues can be referred. We have endearoured to obtain from it Parillin, the crystalline principle of sarsaparilla, but without success.

Commerce-China root is imported into Europe from the South of China-usually from Canton. The quantity shipped from that port in 1872 , was only 384 peculs $(51,20017$.) ; while the same year there was shipped from Hankow, the great trading city of the Yangtsze, no less than 10,258 peculs $\left(1,367,733 \mathrm{th}\right.$.), all to Chinese ports. ${ }^{1}$

Uses-Notwithstanding the high opinion formerly entertained of the virtues of China root, it has in England fallen into complete disuse. In China and India, it is still held in great esteem for the relief of rheumatic and syphilitic complaints, and as an aphrodisiac and demulcent. Polak asserts that the tubers of Smilax are consumed as food by Turcomans and Mongols."

Substitutes-Several American species of Smilax furnish a drug which at various times has been brought into commerce as Radio Chince occidentalis. Of the exact species it is difficult to speak with certainty : but S. Pscudo-China L. and S. tamnoidcs L., growing in the United States from New Jersey southward ; S. Balbisianc Knth, a plant common in all the West Indian Islands; and S. Japicanga Griseb., S. sypingoides Griseb. and S. Brasilicnsis Spreng., are reputed to afford large tuberous rhizomes which in their several localities, replace the China root of Asia, and are employed in a similar manner.

\section{GRAMINEÆ.}

\section{SACCHARUM.}

Sugar, Cane Sugar, Sucrose; F. Sucre, Sucre de canne; G. Zucker, Rohrzucticr.

Botanical Origin-Saccharum officinarum L., the Sugar Cane. The jointed stem is from 6 to 12 feet high, solid, hard, dense, internally

1 Returnes of Trade at the Treaty Poris in Chine for 1872 , pp. 34, 154.

2 We quote this statement with reserve, knowing that both Chinese and Europeans sometimes confound China root with the singular fungoid production termed Pachyma Cocos. The first is called in Chinese Tu. futh-ling,-the second Futh-ling or Pe-fuk7ing. - Pharm. Jonme. iii. (1862) 421 ; F. Porter Smith, Mat. MIcd. and Nat. Hist. of Chince, 1871. 198; Dragendorff. Vollesmedicin Turkestans in Buchner's Reper. torium, xxii. (1873) 135. 
jnicy, and hollow only in the flowering tops. Several varietics are cultivated, as the Country Cane, the original form of the species; the Ribloon Cane, with purple or yellow stripes along the stem; the Bourbon or Tatiti Cane, a more clongated, stronger, more lairy and very productive variety. Saceluanm violaceum Tussac, the Biatuvian C'une, is also considered to be a variety; but the large S. Clinense Ioxb. introduced from Canton in 1796 into the Botanie Ciardens of Calcutta, may be a distinct specics; it has a long, slender, crect panicle, while that of S' officinarum is hairy and spreading, with the ramifications alternate and more compound, not to inention other differences in the leaves and flowers.

The sugar cane is cultivated from cuttings, the small seeds very seldom ripening. It succeds in almost all tropical and subtropical countries, reaching in South Amcrica and Mexico an clevation above the sca of 5000-6000 feet. It is cultivated in most parts of India and China up to $30-31^{\circ} \mathrm{N}$. lat., the mountainous regions excepted.

From the claborate investigations of Ritter, ${ }^{1}$ it appear's that Sacecerum offeinarum was originally a native of Bengal, and of the IndoChinese countries, as well as of Borneo, Java, Bali, Celebes, and other islands of the Malay Archipclago. But there is no evidence that it is now found anywhere in a wild state.

History-The sugar cane was doubtless known in India from time immemorial, and grown for food as it still is at the present day, chicfly in those regions which are unsuited for the manufacture of sugar. ${ }^{2}$

Herodotus, Theophrastus, Seneca, Strabo, and other early writers had some knowledge of raw sugar, which they speak of as the Honey of Canes or Honey made by human hands, not that of bees; but it was not until the commencement of the Christian cra, that the ancients manifested an undoubted acquaintance with sugar, under the name of Saccharon.

Thus Dioscorides ${ }^{3}$ about A.D. 77, montions the concreted honey called

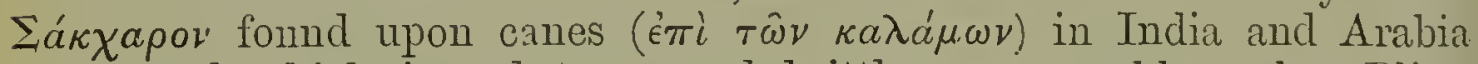
Felix, and which in substance and brittleness resembles salt. Pliny evidently knew the same thing under the name Sacehamm; and the author of the Periplus of the Erythrean Sea, A.D. 54-68, states that honey from canes, called $\sigma a ́ \kappa \chi a \rho \iota$, is cxported from Barygnaza, in the Gulf of Cambay, to the ports of the Red Sea, west of the Promontorizm Aromatumi, that is to say to the coast opposite Aden. Whether at that period sugar was produced in Western India, or was brought thither from the Ganges, is a point still doubtful.

Bengal is probably the country of the carliest manufacture of sugar; hence its names in all the languages of Western-Asiatic and Europenn nations are derived from the Sansknit Sharkar'ú, signifying a substance in the shape of small grains or stones. It is strange that this word contains no allusion to the taste of the substance.

C'andy, as sugar in large crystals is called, is derived from the Arabic Kand or Kandat, a name of the same signification. An old Sanslirit

1 Erdtunde von, Asicn, ix. West-Asien, Berlin, 1840. pp. 230-291.

2 The production which the English translators of the Bible liare rendered s'wect Canr, and which is alluded to by the prophets Isainh (ch. xliii. 24) and Jcromiah (ch. vi. 20) as a commodity imported from a distant country, has becu the suhipect of much disenssion." Some have supposed it to be the sugar eanc; others, an aromatic grass (Andropogon). In our opinion, there is more reason to conclude thit it was Cressia Baik:

3 Lib. ii. c. 104. 
name of Central Bengal is Gura, whence is derived the word Gula, meaning raw sugar, a term for sugar universally employed in the Malayan Archipelago, where on the other hand they have their own names for the sugar cane, although not for sugar. This fact again speaks in favour of Ritter's opinion, that the preparation of sugar in a dry crystalline state is due to the inhabitants of Bengal. Sugar under the name of Shi-mi, i.e. Stone-honcy, is frequently mentioned in the ancient Chinese annals among the productions of India and Persia; and it is recorded that the Emperor Tai-tsung, A.D. 627-650, sent an envoy to the kingdom of Magadha in India, the modern Bahar, to learn the method of manufacturing sugar. ${ }^{1}$ The Chinese, in fact, acknowledge that the Indians between A.D. 766 and 780 were their first teachers in the art of refining sugar, for which they liad no particular ancient written character.

An Arabian writer, Abu Zayd al Hasan, ${ }^{2}$ informs us that about A.D. 850, the sugar cane was growing on the north-eastern shore of the Persian Gulf; and in the following century, the traveller Ali Istakhri ${ }^{3}$ found sugar abundantly produced in the Persian province of Kuzistan, the ancient Susiana. About the same time (A.D. 950), Moses of Chorene, an Armenian, also stated that the manufacture of sugar was flourishing near the celebrated school of medicine at Jondisabur in the same province, and remains of this industry in the shape of millstones, \&c. still exist near Ahwas.

Persian physicians of the 10th and 11th centuries, as Rhazes, Haly Abbas, and Avicenna, introduced sugar into medicine. The Arabs cultivated the sugar cane in many of their Mediterranean settlements, as Cyprus, Sicily, Italy, Northern Africa and Spain. The Calendar of Cordova ${ }^{4}$ shows that as early as A.D. 961, the cultivation was well understood in Spain, which is now the only country in Europe where sugar mills still exist. ${ }^{5}$

William II., King of Sicily, presented in A.D. 1176 to the convent of Nomreale, mills for grinding cane, the culture of which still lingers at Avola near Syracuse, though only for the sake of making rum. In 1767 , the sugar plantations and sugar houses at this spot were described by a traveller " as "worth seeing."

During the middle ages, England in common with the rest of Northern Europe, was supplied with sugar from the Mediterranean countries, especially Egypt and Cyprus. It was imported from Alexandria as early as the end of the 10th century by the Venetians, with whom it long remained an important article of trade. Thus we find ${ }^{7}$ that in A.D. 1319, a merchant of Venice, Tommaso Loredano, shipped to London $100,000 \mathrm{Hb}$. of sugar, the proceeds of which were to be returned in wool, which at that period constituted the great wealth of England. Sugar was then very dear: thus from 1259 to 1350 , the average price in England was about 1s. per 1 b., and from 1351 to 1400 , 1s. $7 d .^{8}$ In France during the same period, it must have been largely obtainable, though doubtless expensive. King John IT. ordered in 1353, that the apothe-

1 Bretsehneider, Chinese Botcunical $\mathrm{W}$ orks, 1870. 46.

2 Ritter, l.e. 286.

3 Buch der Lü̈nder, translated by Mordtmann, Hainburg, 1845. 57.

${ }^{4}$ Le Calcndrier de Cordone de l'année ๑61, par R. Dozy, Leyde, 1873.25. 41. 91.
5 There are several in the neighbourhood of Malaga.

${ }^{6}$ Riedesel, Trrovels through Sicily, Lond. 1773.67

7 Narin, Commereio de' Tenczicui, v. 306.

s Rogers, Hist. of Agriculturie and Prices in England, i. (1866) 633. 641. 
caries of Paris should not use honey in making those confections which ought to be prepared with the good white sugrar called cofetin.?

'The importance of the sngar manufincture in the Tast was witnessed in the latter half of the 13 th century by Marco l'olo ; ${ }^{2}$ and in 1510 by Barbosa and other European travellers; and the trading nations of Europe rapidly spread the cultivation of the cane over all the countries, of which the climate was suitable. 'Thus, its introduction into Madeira goes back as far as A.D. 1420 ; it renched St. Domingo in 1494,3 the Canary Islands in 1503, Brazil in the beginning of the 16th century, Mexico about 1520, Guiana about 1600, (xuadaloupe in 1644, Martinique in 1650, Mauritius towards 1750, Natal ${ }^{5}$ and $\mathrm{New}_{\mathrm{w}}$ South Wales ${ }^{6}$ about 1852 , while from a very early period, the sugar cane had been propagated from the Indian Archipelago over all the islands of the Pacific Ocean.

The ancicnt cultivation in Egypt, probably never quite extinct, has been revived on an extensive scale by the present viccroy, Ismail Pasha. There were 13 sugar factorics, making raw sugar, belonging to the Egyptian government at work in 1872, and about 100,000 acres of land devoted to sugar cane. The export of sugar from Egypt in 1872, rcached 2 millions of leantars or about 89,200 tons. $^{7}$

The imperfection of organic chemistry previous to the middle of the 18th century, permitted no exact investigations into the chemical nature of sugar. Marggraf of Berlin ${ }^{8}$ proved in 1747 , that sugar occurs in many regetables, and succeeded in obtaining it in a pure crystallized state from the juice of beet-root. The enormous practical importance of this discovery did not escape him, and he caused serious attcmpts to be made for rendering it available, which were so far successful that the first manufactory of bcet-sugar was established in 1796 by Achard at Kunern in Silesia.

This new branch of industry ${ }^{9}$ was greatly promoted by the prohibitive measures, whereby Napoleon excluded colonial sugar from almost the whole Continent; and it is now carried forward upon such a scale that 640,000 to 680,000 tons of beetroot sugar are annually produced in Europe, the entire production of cane sugar being estimated at 1,260,000 to $1,413,000$ tons. $^{10}$

Among the British colonies, Mauritius, British Guiana, Trinidad, Barbados, and Jamaica produce at present the largest quantity of sugar.

Production-No crystals are found in the parenchyme of the cane, the sugar existing as an aqueous solution, chiefly within the cells of the centre of the stem. The transverse section of the cane exhibits numerous fibro-vascular bundles, scattered through the tissne, as in other monocotyledonous stems; yet these bundles are most abundant towards the

1 Ordonnances iles rois de France, ii. (1729) 535 .

2 Yule, Bool of Ser Mareo Polo, ii. (1871) 79. 171. 180. \&e.

3 Lellcrs of Christ. Columbus (Hakluyt Society) 1870. 81-84.

4 De Cindolle, Géogr. botaniquc, 836.

5 The value of the sugar exported from Natal in 1871 reached the astonishing amount of $£ 180,496$.

i Yet owing to the gold diseoveries, the propagation of the cane in Australia was little thought of until abont 1866 or 1867 , when small lots of sugar werc made.
7 Consul Rogers, Ricport on the Trade of Cairo for IS72, presented to Parliament.

8 Experiences chymiques faites dans lc dessein de tircr un véritable sucre de direrses plantes qui croisscnt dans nos contrées, par MIr. Marggraf, traduit dı latiu-IIist. de l'Academic royale des Scicnecs et belles lctircs, amnée 1747 (Berlin 1749) 79-90.

9 And also that of milli sugar, which was then much used on the Continent to adulle. rate eane sugir.

10 Produce Markets Revieu, Mareh 2\&; 1868. 
exterior, where they form a dense ring covered with a thin epidermis, which is very hard by reason of the silica which is deposited in it. ${ }^{1}$ In the centre of the stem the vascular bundles are few in number; the parenchyme is far more abundant, and contains in its thin-walled cells an almost clear solution of sugar, with a few small starch granules and a little soluble albuminous matter. This last is met with in larger quantity in the cambial portion of the vascular bundles. Pectic principles are combined with the walls of the medullary cells, which however do not swell much in water (Wiesner).

From these glances at the microscopical structure of the cane, the process to be followed for obtaining the largest possible quantity of sugar, becomes evident. This would consist in simply macerating thin slices of the cane in water, which would at once penetrate the parenchyme loaded with sugar, without much attacking the fibro-vascular bundles containing more of albuminous than of saccharine matter. By this method, the epidermal layer of the cane would not become saturated with sugar, nor would it impede its extraction,--resuits which necessarily follow when the cane is crushed and pressed. ${ }^{2}$

The process hitherto generally practised in the colonies, - that of extracting the juice of the cane by crushing and pressing,- has been elaborately described and criticized by Dr. Icery of Mauritius. ${ }^{3}$ In that island, the cane, six varieties of which are cultivated, is when mature, composed of Cellulose, S to 12 per cent.; Sugar, 18 to 21 ; Water includ-. ing albuminous matter and salts, 67 to 73 . Of the entire quantity of juice in the cane, from 70 to 84 per cent. is extracted for evaporation, and yields in a crystalline state about three-fifths of the sugar which the cane originally contained. This juice, called in French vesori, has on an average the following composition :-

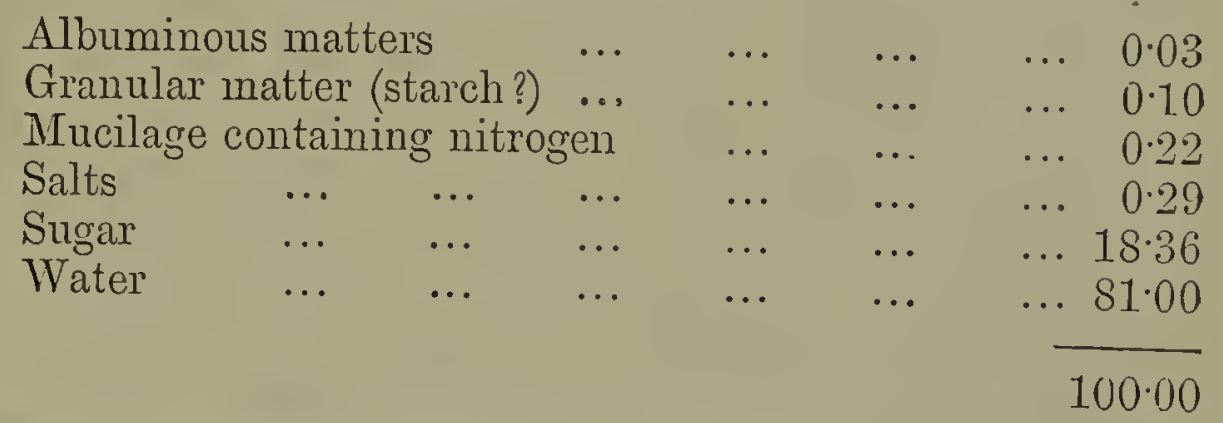

The first two classes of substances render the juice turbid, and greatly promote its fermentation, but they easily separate by boiling, and the juice may then be kept a short time without undergoing change. In many colonies the yield is said to be far inferior to what it should be; yet the juice is obtained in a state allowing of easier purification, when its extraction is not carried to the furthest limit.

1 Stems of American sugar cave, dried at $100^{\circ} \mathrm{C}$, yielded 4 pcr cent. of ash, ncarly half of which was silica. - Popp, in Wiggcrs'
Jehresbcricht, 1870.35 .

2 'The plan of obtaining a syrup by macerating the sliced fresh cane, has bcen tried in Guadaloupe, but abandoned owing to some practical difficulties in exhausting the cane, and in carrying on the craporatiou of the liquors with stuficicnt rapidity. Experiments for extracting a pure syrup by means of cold water from the sliced anu? dried cane, seem to promise good results. See a paper by Dr. H. S. Mitchell in Journ. of Soc. of Arts, Oct. 23, 1868 .

3 Annales de. Chimic ct de Physique, r. (1865) 350-410.-See also, for Cuba, Alvaro Reynoso, Ensayyo sobre al cultivo de la caña cle Azuccer, Madrid, 1865. 359.-For British Guiana, Catal. of Contributions from Brit. Giaiance to Paris Exhib. 1867. pp. xxxviii.
xli. 
In beet root as well as in the sugar cane, cane sugar only was sail to be present; Icery lowever las proved that in the cane, some uncrystallizable (inverted) sugar is always present. Its quantity varies much, according to the places where the cane grows, and its age. 'The tops of quickgrowing young canes yielded a vesou containing $2 \cdot 4$ per' cent of uncrystallizable sugar; 3.6 of cane sugar; and 94 : of water. Moist and shady situations greatly promote the formation of the former kind of surar, which also prevails in the tops, chiefly when immature. Hence that observer conclucles that at first the uncrystallizable variety of sugar is formed, and subsequently transformed into cane sugar by the force of vegetation, and especially by the influence of light. Perfectly ripened canes contain only $\frac{7}{75}$ to $\frac{3}{30}$ of all their sugar, in the uncrystallizalule state.

Description and Chemical Composition-Cane sugar is the type of a numerous class of well-defined organic compounds, of frequent occurrence throughout the regetable and animal kingdoms, or artificially obtained by decomposing certain other substances; in the latter case however, glucose or some other sugar than cane sugar, is obtained. Cane sugar $\mathrm{C}^{12} \mathrm{H}^{22} \mathrm{O}^{11}$ melts, without change of composition, at $160^{\circ} \mathrm{C}$., several other kinds of sugar giving off water, with which they form crystallized compounds at the ordinary temperature.

Cane sugar forms hard crystals of the oblique rhombic system, having a sp. gr. of 1.59. Two parts are dissolved by one part of cold water, and by much less at an elevated temperature; a slight depression of the thermometer is observable in the former case. One part of sugar dissolved in one of water, forms a liquid of sp. gr. 1.23; two of sugar in one of water, a liquid of sp. gr. 1333. Sugar requires 65 parts of spirit of wine (sp. gr. 0.84 ) or 80 parts of anhydrous alcohol for solution; ether does not act upon it.

A ray of polarized light is deviated by an aqueous solution of cane sugar to the right, but by some other kinds of sugar to the left, as first shown by Biot. These optical powers are highly important, both in the practical estimation of solutions of sugar, and in scientific studies connected with sugar or saccharogenous substances. The optical as well as chemical properties of sugar are altered by many circumstances, as the action of dilute acids or alkalis, or by the influence of minute fungi. Yeast occasions sugar to undergo alcoholic fermentation. Other ferments set up an action by which butyric, lactic or propionic acid are produced.

Cane sugar is of a purer and sweeter taste than most other sugars. Though it does not alter litmus paper, yet with alkalis it forms compounds some of which are crystallizable. From an alkaline solution of tartrate of copper, cane sugar throws down no protoxide, unless after boiling.

If sugar is kept a short time in a state of fusion at $160^{\circ} \mathrm{C}$., it is converted into one equivalent of Grape Sugar and one of Levulosan; the former can be either isolated by crystallization or destroyed by fermentation, the latter being incapable of crystallizing or of undergoing fermeritation.

Cane sugar which has been melted at $160^{\circ} \mathrm{C}$., is deliquescent and readily soluble in anliydrous alcohol, and its rotatory power is diminished or entirely destroyed. It is no longer crystallizable, and its fusing point

1 It is commonly stated that three parts can be dissolved in one of cold water; but this is not the fact. 
has become reduced to about $93^{\circ} \mathrm{C}$. Yet before undergoing these evident alterations, it assumes an amorphous condition if allowed to melt with a third of its weight of water, becoming always a little coloured by pyrogenous products. In the course of time however, this amorphous sugar loses its transparency and reassumes the crystalline form. Like sulphur and arsenious acid, it is capable of existing either in a crystallized or an amorphous statc.

If sugar is heated to about $190^{\circ} \mathrm{C}$., water is evolved, and we obtain the dark brown products commonly called Caramcl or Burnt Sugar. They are of a peculiar sharp flavour, of a bitter taste, incapable of fermenting and deliquescent. One of the constituents of caramel, Carcamelane, $\mathrm{C}^{12} \mathrm{H}^{18} \mathrm{O}^{9}$, has been obtained by Gélis (1862) perfectly colourless. When the heat is augmented, the sugar at last suffers a decomposition resembling that which produces tar (see p. 561), its pyrogenous products being the same or very analogous to those of the dry distillation of wood.

Varieties of Cane Sugar-The experiments of Marggraf referred to at p. 652, showed that cane sugar is by no means confined to the sugar cane; and it is in fact extracted on an extensive scale from several other plants, of which the following deserve mention.

Beet Root-The manufacture of cane sugar from the fleshy root of a cultivated variety of Beta maritima L., is now largely carried on in Continental Europe and in America, and with admirable results.

Of fresh beet root, 100 parts contain on an average 80 per cent. of water, 11 to 13 of cane sugar, and about 7 per cent. of pectic and albuminous matters, cellulose and salts. Of the total amount of juice which the root contains, eight-ninths are extracted: and by the best process now in practice, 8 to 9 parts of sugar from every 100 parts of fresh root. The yield of crystalline sugar is still on the increase, owing to continual improvements in the mechanical and chemical parts of the process.

Palm-Several species are of great utility for the production of the sugar called by Europeans Jaggery. ${ }^{1}$ This substance is obtained by the natives of India in the following manner:- The young growing spadix, or Howering shoot, of the palm is cut off near its apex; and an earthen vessel is tied on to the stump to receive the juice that flows out. This vessel is emptied daily; while to promote a continuous flow of sap, a thin slice is cut from the wounded end. The juice thus collected, if at once boiled down, yields the crude brown sugar known as jaggcry. If allowed to ferment, it becomes the inebriating drink called Toddy or palm wine; or it may be converted into vinegar. The spirit distilled from todldy is Arrcick.

Of the sugar-yielding palms of Asia, Phcenix silvestris Roxb., which is supposed to be the wild form of the date palm, is one of the more important. The coco-nut palm, Cocos nucifcrce L. ; the magnificent Palmyra palm, Borassus fabclliformis L.; and the Bastard Sago, Caryota urcns L., also furnish important quantities of sugar. In the Indian Archipelago, sugar is obtained from the sap of Arcnga saccharifcre Mart., which grows there in abundance as well as in the Philippines and the Indo-Chinese countries. It is also got from Nipa fruticans Thunb., a tree of the low coast regions, extensively cultivated in Tavoy.

I A word of_Sauskrit origin, corrupted from the Canarese, sharkari. 
De Vry ${ }^{1}$ has advocated the manufacture of sugar from the palm as the most pliilosophical, seeing that its juice is a nearly pure aqueons solution of sugar: that as no mineral constituents are removed from the soil in this juice, the costly manuring, as well as the laborious and destruetive processes required to eliminate the juice from such plants as the sugnr cane and beet root, are avoided. And finally, that palms are perennial, and can many of them be eultivated on a soil unsuitable for any cereal.

Maplc-In America, considerable quantities of sugar identieal with that of the cane, are obtained in the woods of the Northern United States and of Canada, by evaporating the juiee of maples. The species chiefly employed are Accr saccharinum Wang., the Common Sugar Maple, and its variety (var. nigrum) the Black Sugar Maple. A. Pcnnsylvanicum L., $A$. Nernindo L. (Negundo accroidcs Moench.) and A. dasycarpum Ehrh. are also used; the sap of the last is said to be the least saccharine.

As the juice of these trees yields not more than about 2 per cent. of sugar, it requires for its solidification a large expenditure of fuel. The manufacture of maple sugar can therefore be advantageously carried on only in countries remote from markets whence ordinary sugar can be procured, or in regions where fuel is extremely plentiful. In North America, it flourishes only between $40^{\circ}$ and $43^{\circ} \mathrm{N}$. lat. We are not aware of any estimate of the total production of maple sugar. The Census of Pennsylvania of 1870 , gave the following figures as referring to its manufacture in that State:-

$$
\begin{array}{ccc}
1850 & 1860 & 1870 \\
2,326,525 \mathrm{mb} . & 2,768,965 \mathrm{ib} . & 1,545,917 \mathrm{ib} .^{2}
\end{array}
$$

Sorghum-Another plant of the same order as Sacchamm, is Sorghum saccharatum Pers. (Holcus saccharatus L.) a native of Northern China, ${ }^{3}$ which has of late been much tried as a sugar-yielding plant both in Europe and North America; yet without any great success, as the purification of the sugar is accomplished with peculiar difficulty. As in the sugar cane, there are in sorghum, crystallizable and uncrystallizable sugars, the former being at its maximum amount when the grain reaches maturity. The importance of the plant however, is rapidly increasing on account of the value of its leaves and grain, as food for horses and cattle, and of its stems which can be employed in the manufacture of paper and of alcohol.

Commerce-The value of the sugar imported into the United Kingdom is constantly increasing; as shown by the following figures:-

$$
1868 \quad 1870 \quad 1872
$$

$$
\begin{aligned}
& \text { Unrefined . . } £ 13,339,758 \\
& £ 14,440,502 \quad £ 18,044, \$ 98 \\
& \text { Refined : : £1,156,188 } £ 2,744,366 \\
& £ 3,142,703
\end{aligned}
$$

The quantity of Unrefincd Sugar imported in 1872, was $13,776,696$ cwt., of which about $3,000,000$ cwt. were furnished by the Spanish West India Islands, 2,700,000 cwt. by the British West India Islands, 1,800,000 cwt. by Brazil, 1,100,000 cwt. by France, and 960,000 cwt. by Mamritius.

1 Journ. de Pharm. i. (1865) 270.

2 Consul Kortright, in Consular Iicporls presented to Parliament; Jnly 1872. p. 988.

Introducel into Lurope in 1850 , by $\mathrm{MI}$. de Nontigny, French Consul at Shanghai.
- Sicard, Monograpthic de Ta Canne ì sucre de $7 a$ Chine, dite Sorghn-it-sucre, Marseille, 1856 ; Joulic, Joum. de Pham. i. (1865) 188. 
Uses-Refined sugar is employed in pharmacy for making syrups, electuaries and lozenges, and is useful not merely for the sake of covering the unpleasant taste of other drugs, but also on account of a preservative influence which it exerts over their active constituents.

Muscovado or Raw Sugar is not used in medicine. The dark uncrystallizable syrup, known in England as Molasses, Golden Symup, and Treacle ${ }^{1}$ and in foreign pharmacy as Symupus Hollandicus vel communis, which is formed in the preparation of pure sugar by the influence of heat, alkaline bodies, microscopic vegetation, and the oxygen of the air, is sometimes employed for making pill-masses. The treacle of colonial sugar alone is adapted for this purpose, that of beet root having a disagreeable taste, and containing from 19 to 21 per cent. of oxalate, tartrate and malate of potassium, and only 56 to 64 of sugar. ${ }^{2}$ The treacle of colonial sugar usually contains 5 to 7 per cent. of salts.

\section{HORDEUM DECORTICATUM.}

\section{Hordeum perlatum, Fructus vel Semen Hordei; Pearl Barley; F. Orge monclé ou perlé; G. Gerollte Gerste, Gerstegraupen.}

Botanical Origin-Hordcum distichum L., - the Common or Longeared Barley, is probably indigenous to western temperate Asia, but has been cultivated for ages throughout the northern hemisphere. In Sweden, its cultivation extends as far as $68^{\circ} 38^{\prime} \mathrm{N}$. lat.; on the Norwegian coast up to the Altenfjord in $70^{\circ} \mathrm{N}$. lat. ; even in Lapland, it succeeds as high as 900 to 1350 feet above the level of the sea. In several of the southern Swiss Alpine valleys, barley ripens at 5000 feet, and in the Himalaya at 11,000 feet. In the Equatorial Andes, where it is extensively grown, it thrives up to at least 11,000 feet above the sea. No other cereal can be cultivated under so great a variety of climate.

According to Bretschneider,3 barley is included among the five cereals which it is related in Chinese history were sowed by the Emperor Shen-nung, who reigned about 2700 B.C.; but it is not one of the five sorts of grain which are used at the ceremony of ploughing and sowing as now annually performed by the emperors of China.

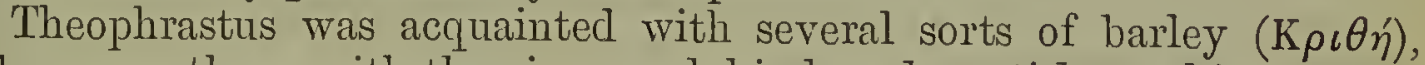
and among them, with the six-rowed kind or hexastichon, which is the species that is represented on the coins struck at Metapontum ${ }^{4}$ in Lucania, between the 6 th and 2 nd centuries B.c.

Strabo and Dioscorides in the 1st century allude to drinks made from barley, which according to Tacitus were even then familiar to the German tribes, as they are known to have been still earlier to the Greeks and Egyptians.

Barley is mentioned in the Bible as a plant of cultivation in Egypt and Syria, and must have been, among the ancient Hebrews, an important

1 How the word Treacle eame to be transferred from its application to an opiatc medicine to become a name for molasses, wc know not. In the description of sugarmaking given by Salmon in his English Physician or Druggist's Shop opcned, Lond. 1693 , treacle is never mentioned, but only "mclussas."
2 Landolt, Zcitschr. f. ancalyt. Chem. vii. (1868) 1-29.

3 On Chincsc Botanical Worlss, \&c., Foochow, 1870. 7. 8 .

4 Mctapontum lay in the plain between the rivers Bradano and Basento in the gulf of Taranto. 
article of food, judging from the quantity allowed by Solomon to the servants of Hiran, king of Tyre (B.C. 1015). The tribute of barley paid to King Jotham by the Ammonites (B.C. 741.) is also exactly recorded. The ancients were frequently in the practice of removing the hard integuments of barley by roasting it, and using the torrefied grain as food.

Manufacture-For use in medicine and as food for the sick, barley is not employed in its crude state, but only when deprived more or less completely of its husk. The process by which this is effected, is carried on in mills constructed for the purpose, and consists essentially in passing the grain between horizontal millstones, placed so far apart as to rub off its integuments without crushing it. Barley partially deprived of its husk, is known as Seoteh, hulled or Pot Barley. When by longer and closer grinding, the whole of the integuments liave been removed, and the grain has become completely rounded, it is termed Pearl Barley. In the British Pharmacopceia, it is this sort alone which is ordered to be used.

Description-Pearl Barley is in subspherical or somewhat ovoid grains about 2 lines in diameter, of white farinaceous aspect, often partly yellowish from remains of the adhering husk, which is present on the surface, as well as in the deep longitudinal furrow with which each grain is indented. It has the farinaceous taste and odour which are common to most of the cereal grains.

Microscopical Structure-The albumen which constitutes the main portion of the grain, is composed of large thin-walled parenchyme, the cells of which on transverse section, are seen to radiate from the furrow, and to be lengthened in that direction rather than longitudinally. In the vicinity of the furrow alone, the tissue of the albumen is narrower. Its predominating large cells show a polygonal or oval outline, whilst the outer layer is built up of two, three or four rows of thick-walled, coherent, nearly cubic gluten-cells. This layer, about $70 \mathrm{mkm}$. thick, is coated with an extremely thin brown tegument, to which succeeds a layer about $30 \mathrm{mkm}$. thick, of densely packed, tabular, greyish or yellowish cells of very small size; this proper coat of the fruit in the furrow, is of rather spongy appearance.

In some varieties of barley, the fruit is constituted of the above tissues alone and the shell, but in most the palex are likewise present. They consist chiefly of long fibrous, thick-walled cells, two or four rors deep, constituting a very hard layer. On transverse section, this layer forms a coherent envelope, about $35 \mathrm{mkm}$. thick; its cells when examined in longitudinal section, show but a small lumen of peculiar undulated outline from secondary deposits.

The gluten-cells varying considerably in the different cereal grains, afford characters enough to distinguish them with certainty. In wheat, for instance, the gluten-cells are in a single row, in rice they form a double or single row, but its cells are transversely lengthened.

The inner tissue of the albumen in barley is filled up with large irregularly lenticular, and with extremely small globular starch gramules, the first being 20 to $35 \mathrm{mkm}$, the latter' 1, 2 to $3 \mathrm{mkm}$. in diameter', with no considerable number of intermediate size. The concentric layers constituting the large granules, may be made conspicuous by moistening with chromic acid.

The layer alluded to as being composed of gluten-cells, is loaded with 
extremely small granules of albuminous matters (gluten), which on addition of iodine, are coloured intensely yellow. These granules, which considering barley as an article of food, are of prominent value, are not confined to the gluten-cells, but the neighbouring starch-cells also contain a small amount of them: and in the narrow zone of denser tissue projecting from the furrow into the albumen, protein principles are equally deposited, as shown by the yellow coloration which iodine produces.

The gluten-cells, the membrane embryonnaire of Mège-Mouriès, coutain also, according to the researches on bread ${ }^{1}$ made by this chemist (1856), Cerealin, an albuminous principle soluble in water, which causes the transformation of starch into dextrin, sugar, and lactic acid. In the husks (épiderme, épicarpe and endocarpe) of wheat, Mège-Mouriès found some volatile oil and a yellow extractive matter, to which, together with the cerealin, is due the acidity of bread made with the flour containing the bran.

Chemical Composition-Barley lias been submitted to careful analyses by many chemists, more especially by Lermer. ${ }^{2}$ The grains contain usually 13 to 15 per cent. of water; after drying, they yield to ether 3 per cent. of fat oil, with insignificant proportions of tannic and bitter principles, residing chiefly in the husks. Lermer further found in the whole grains, 63 per cent. of starch, 7 of cellulose, 6.6 of dextrin, 25 of nitrogen, a small amount of lactic acid, and 2.4 of ash.

The analysis of Poggiale (1556) gave nearly the same composition, namely, water 15 , oil $2 \cdot 4$, starch 60 , cellulose $8 \cdot 8$, albuninous principles $10 \cdot 7$, ash $2 \cdot 6$.

The protein, or albuminous matter, consists of different principles, chiefly insoluble in cold water. The soluble portion is partly coagulated on boiling, partly retained in solution : 2.5 per cent. of nitrogen, as above, would answer to about 16 per cent. of albuminous matters. Their soluble part seems to be deposited in the starch-cells, next to the glutencells, which latter contain the insoluble portion.

The ash according to Lermer, contains 29 per cent. of silicic acid, 32.6 of phosphoric acid, 22.7 of potash, and only 3.7 of lime. In the opinion of Salm-Horstmar, fluorine and lithia are indispensable constituents of barley.

The fixed oil of barley, as proved in 1863 by Hanamann, is a compound of glycerin with either a mixture of palmitic and lauric acids, or less probably with a peculiar fatty acid. Beckmann's Hordeinic Acid obtained in 1855 by distilling barley with sulphuric acid, is probably lauric acid. Lintner (1868) has shown barley to contain also a little C'holesterin (p. 678).

Barley when malted loses 7 per cent.; it then contains 10 to 12 per cent. of sugar, produced at the expense of the starch; before malting, no sugar is to be found, but only dextrin.

Uses-Barley as a medicine is unimportant. A decoction is sometimes prescribed as a demulcent or as a diluent of active remedies. An aqueous extract of malt lias been employed.

He actually examined wheat, not barley; we assume the ehemieal constitution of the two grains to be similar.

2 Wittstein, Vierteljaleresschr. fiur prakt. Pluerm. xii. (1863) 4-23. 


\section{OLEUM ANDROPOGONIS.}

\section{Oleum Graminis Indici; Indian Grass Oil.}

Botanical Origin-Among the numerous species of Andropogon ${ }^{1}$ which have foliage abounding in essential oil, the following furnish the fragrant Grass Oits of commerce :-

1. Androporgon Nardus L., ${ }^{2}$ - a noble-looking plant, rising when in flower to a height of 6 or more feet, extensively cultivated in Ceylon and Singapore for the production of Citronella Oil.

2. A. citratus DC.,3 Lemon Grass,-a large coarse glaucous grass, known only in a cultivated state, and very rarely producing flowers. It is grown in Ceylon and Singapore for the sake of its essential oil, which is called Lemon Gross Oil, Oil of Verbence or Indian Melissa Oil; it is also commonly met with in gardens throughout India and is not unfrequent in English hothouses. In Java it is called Sirch.

3. A. Schonanthus L., ${ }^{4}$ a grass of Northern and Central India, having leaves rounded or slightly cordate at the base, yielding by distillation the oil known as Rúsa Oil, Oil of Ginger Grass or of Geranium.

History-The aromatic properties of certain species of Andropogon were well known to Rheede, Rumphius, and other early writers on Indian natural history; and an oil distilled from the Sirch grass in Amboyna was known as a curiosity, as early as $1717 .^{5}$

But it is only in very recent times that the volatile oils of these plants have become objects of commerce with Europe. Lemon grass oil is mentioned by Roxburgh in 1820, as being distilled in the Moluccas; and it was first imported into London about the year 1832. Citronella oil is of much more recent introduction. Ginger grass oil, called in Hindustani, Rúsc $k c$ tel, is stated by Waring ${ }^{6}$ to have been first brought to motice by Dr. N. Maxwell in 1825 .

Production-Citronella and Lemon grass are cultivated about Galle and at Singapore, the same estate often producing both. The grasses are distilled separately, the essential oils being regarded as entirely distinct, and having different market values. In Ceylon they are cut for distillation at any time of year, but mostly in December and January.

On the Perseverance Estate at Gaylang, Singapore, belonging to Mr. John Fisher, an area of 950 acres is cultivated with aromatic grasses and other plants, for the production of essential oils. The manufacture was tried on a small scale in 1865 , and has been so successful that an aggregate of $200 \mathrm{lt}$. of various essential oils is now produced daily. These oils

1 Major-General Munro has at our request investigated the botanical characters of the fragrant species of Andropogon, and examined a numerous suite of speeimens in our possession. The synonyms in foot-notes are given upon his authority.

¿A. Martini Thwaites, Enum. Plantam Zcylanice nee aliorum.

3. citratum A.P. De Candolle, Catalogus Plantarum Horti Bolanici Monspolicnsis, $1813 ; A$. Schonanthus Walliel,, P'lan:. Asiat. rariores, iii. (1832) tab. 280 ; Rox- burgll, Flora Indica, i. (1S20) 278, quond observationes, sed nou quond diagnosis.

4 Ventenat, Jardin dc Ccls, 1803. tab s9 ; A. Martini Roxb. Flor. Ind. i. (1s20) 280 ; A. prachnodes Trinins, Spocics Grominum, iii. (1836) tab. 327 ; $A$. Calamus aromaticus Royle, Illustrations of Bot. of Himalayan Mlountains, 1839. tab. 97. LF

5 Ephenerides Nature Curiosorum, cent. v.-vi. (1717), appendix 157 . п्.

6 Pharmacopecia of India, 1868. 465. 
are stated to be Citronella, Lemon Grass, Patchouly, Nutmeg, Mace, Pepper, and Omam (p. 269): and mint is now being cultivated. ${ }^{1}$

Ginger grass oil is distilled in the collectorate of Khandesh in the Bombay Presidency. That produced in the district of Nimár in the valley of the Nerbudda, is sometimes called Grass Oil of Nimúr. We have no particulars of the distillation, which however must be carried on extensively.

Description-The Indian grass oils are lighter than water, devoid of rotatory power when examined by polarized light, and do not alter litmus paper. They are all extremely fragrant, having an odour like a mixture of lemon and rose. Lemon grass, which in colour is a deep golden brown, has an odour resembling that of the sweet-scented verbena of the gardens, Lippia citriodora H.B.K. Ginger grass oil, the colour of which varies from pale greenish yellow to yellowish-brown, has the odour of Pelargonizm Radula Ait. The colour of citronella oil is a light greenish-yellow. The manufacture of Winter of Ceylon, and of Fisher of Singapore, have a reputation for excellence, and are generally indicated by name in drug sale catalogues.

Chemical Composition-Stenhouse ${ }^{2}$ examined in 1844, oil of ginger grass given to him by Christison as Oit of Namur (or Nimár). The sample was of deep yellow, and apparently old, for when mixed with water and subjected to distillation, it left nearly one-half its bulk of a fluid resin, the oil which passed over being colourless. After rectification from chloride of calcium, it was shown to consist of a hydrocarbon mixed with a small proportion of an oxygenated oil. The latter having been decomposed by sodium, and the oil again rectified, a second analysis was made which proved it isomeric with oil of turpentine.

A genuine grass oil from Khandesh, derived as we suppose from the same species, which was examined by one of us (F.), yielded nothing crystalline when saturated with dry hydrochloric acid; but when the liquid was afterwards treated with fuming nitric acid, crystals of the compound, $\mathrm{C}^{10} \mathrm{H}^{16}, \mathrm{HCl}$, sublimed into the upper part of the vessel. We have observed that the oils both of lemon grass and citronella yield solid compounds, if shaken with a saturated solution of bisulphite of sodium.

Citronella oil was found by Gladstone (1872) to be composed chiefly of an oxidized oil, which he called Citronellol, and which he separated by fractional distillation into two portions, the one boiling at $202-205^{\circ} \mathrm{C}$., the other at $199-202^{\circ} \mathrm{C}$. The sp. gr. of the first at $20^{\circ} \mathrm{C}$. was 0.8749 , of the second 0.8741 . The composition of each portion is inclicated by the fornula, $\mathrm{C}^{10} \mathrm{H}^{16} \mathrm{O}$.

Commerce-The growing trade in grass oil is exemplified in a striking manner by the following statistics. The export of Citronclla Oil from Ceylon in 1864, was 622,000 ounces, valued at $£ 8230$. In the Ceylon Blue Book, published at Colombo last year, the exports for 1872 are returned thus :-

To the United Kingdom

British India United States of North America

$$
\begin{gathered}
1,163,074 \text { ounees } \\
5,713 ", \\
426,470 \quad " \\
\hline 1,595,257 \text { ounees. }
\end{gathered}
$$

1 Struits Setilements Blue Book for 18ד2, Singapore, 1873. 465.

2 Mem. of Chem. Soc. ii. (1845) 122.
3 In addition to which, there were " 248 dorens and 33 packages" of the same oil shipped to the United Statcs. 
Oil of Lemon Grass, which is a more costly article and less extensively produced, was exported from Ceylon during the same year to the extent of 13,515 ounces, more than half of which quantity was shipped to the United States. There are 110 analogous statisties for these two oils from Singapore, where, as stated at p. 660, they are now largely manufactured.

By the official Report on the External Commeree of Bombay, published in 1867, we find that during the year ending 31. March, 1867, Grass Oil [i.e. Cringer-grcess or lirusc oil] was exported thence to the amount of $41,643 \mathrm{lb}$. This oil is shipped to England and to the ports of the Red Sea.

Uses-Grass oils are much esteemed in India as an external application in rheumatism. Ritisa oil is said to stimulate the growth of the hair. Internally, grass oil is sometimes administered as a carminative in colic ; and an infusion of the leaves of lemon grass is prescribed as a diaphoretic and stimulant. In Europe and America, the oils are used almost exclusively by the soapmakers and perfumers. ${ }^{1}$

But the most remarkable use made of any grass oil, is that for adulterating Attar of Rose in European Turkey. The oil thus employed is that of Andropogon Sehonanthus L. (see p. 237); and it is a curious fact that its Hindustani name is closely similar in sound to the word rose. Thus under the designation Rusa, Rowsah, Rosa, Rosé, or Roshé, ${ }^{2}$ it is exported in large quantities from Bombay to the ports of Arabia, probably chiefly to Jidda, whence it is carried to Turkey by the Mahonmedan pilgrims. In Arabia and Turkey, it appears under the name Idris ycighi, while in the attar-producing districts of the Balkan it is known, at least to Europeans, as Geranium Oil or Palmarosa Oit. Before being mixed with attar, the oil is subjected to a certain preparation, which is accomplished by shaking it with water acidulated with lemon juice, and then exposing it to the sun and air. By this process recently described by Baur, ${ }^{3}$ the oil loses a penetrating after-smell, and acquires a pale straw colour. The optical and chemical differences between grass oil thus refined and attar of rose, are slight and do not indicate a small admixture of the former. If grass oil is added largely to attar, it will prevent its congealing.

Adulteration-The grass oil prepared by the natives of India is not unfrequently contaminated with fatty oil.

\section{Other Products of the genus Andropogon.}

Herba Schœnanthi vel Squinanthi, Juneus odoratus, Fenum Camelorum.

The drug bearing these names has had a place in pharmacy from the days of Dioscorides down to the middle of the last century, and is still met with in the Fast. The plant which affords it, formerly confounded with other species is now known to be Andropogon laniger Desf., a grass of wide distribution, growing in hot dry regions in Northern Africa (Algeria), Arabia, and North-western India, reaching Tibet, where

1 The folinge of the large odoriferons species of Andropogon is nsed in India for thatehing. It is enten vorneiously by eattle, whose flesh and milk become flavoured with its strong aroma.
250 eases, eontaining about $2250 \mathrm{1b}$.. importerl from Bombay, were offered as "Ilose Oil" at publie snle, by a London drugbroker, 31 July, 1873.

${ }^{3}$ See p. 235 , note 1. 
it is found up to an elevation of 11,000 feet. Mr. Tolbort has sent ns specimens under the name of Klucivi, gathered by himself in 1869 between Multán and Kot Sultín, and quite agreeing with the drug of pharmacy. The grass has an aromatic pungent taste, which is retained in very old specimens. We are not aware that it is distilled for essential oil.

Cuscus or Vetti-ver ${ }^{1}$-This is the long fibrous ront of Andropogon muricutus Retz, a large grass found abundantly in rich moist ground in Southern India and Bengal. Inscriptions on copper-plates lately discovered in the district of Etawah, south-east of Agra, and dating from A.D. 1103 and 1174, record grants of villages to Brahmins by the kings of Kanauj, and enumerate the imposts that were to be levied. These include taxes on mines, salt pits and the trade in precious metals, also on mahwah (Bassia) and mango trees, and on Cuscus Grass. ${ }^{2}$

Cuscus, which appears occasionally in the London drug sales, is used in England for laying in drawers as a perfume. In India, it serves for making tattics or screens, which are placed in windows and doorways, and when wetted, diffuse an agreeable odour and coolness. It is also nsed for making ornamental baskets and many small articles, and has some reputation as a medicine.

\section{RHIZOMA GRAMINIS.}

Fadix Graminis; Conch Grass, Quitch Grass, Dog's Grass; F. Chicndcnt commun on Petit Chiendent; G. Qucckcnuvurzel, Graswurzcl.

Botanical Origin-Agropyyrum repens P. Beauv. (Triticum repens L.), a widely diffused weed, growing in fields and waste places in all parts of Europe, in Northern Asia down to the region south of the Caspian, also in North America; and in South America to Patagonia and Tierra del Finego.

History-The ancients were familiar with a grass termed "A $\gamma \rho \omega \sigma \tau \iota s$ and Gramon, having a creeping rootstock like that under notice. It is impossible to determine to what species the plant is referable, though it is probable that the grass Cynodon Dactylon Pers., as well as Agropyrum. repens, was included under these names.

Dioscorides asserts that its root taken in the form of decoction, is a useful remedy in suppression of urine and vesical calculus. The same statements are made by Pliny ; and again occur in the writings of Oribasius ${ }^{3}$ and Marcellus Empiricus ${ }^{4}$ in the 4 th, and of Aëtius ${ }^{5}$ in the 6 th century, and are repeated in the medireval herbals. ${ }^{6}$ Turner ${ }^{7}$ and Gerarde both ascribe to a decoction of grass root, diuretic and lithontriptic virtues. The drug is still a domestic remedy in great repute in France, being taken as a demulcent and sudorific in the form of tisane.

Description-Couch-grass has a long, stiff, pale yellow, smooth

1 Cuscus, otherwise written Kluus-khus, a name adorterl by the English in India, is jrobably from the Persian Khas. "Velti-ver is the Malyalim name of the plant.

2 Proc. of Asial. Soc. of Rengal, $\Lambda \mathrm{ug} .1873$. 161.

"De viviule simplicium, cap. i. (Agrostis).

- De medicamentis, cap. xxvi.
5 Tetrabibli prima, sermo i.

6 As in the Horburius Patavice printed in: 1485, in which it is said of Gramen-" aqua decoctionis cjus . . . valet contra dissuriam ... et frangit lapiılem et curat vulnera vesicre et provocat urinam ...."

7 Hcrball, part 2, 1.568. 13. 
rhizone, $\frac{1}{10}$ of an inch in diameter, creeping close under the surface of the ground, occasionally branching, marked at intervals of about an inch by nodes, which bear slender branching roots and the remains of sheathing rudimentary leaves.

As found in the shops, the rhizome is always free from rootlets, cut into short lengths of $\frac{1}{8}$ to $\frac{1}{4}$ of an inch, and dried. It is thus in the form of little, shining, straw-coloured, many-edged, tubular pieces, which are without odour, but have a slightly sweet taste.

Microscopic Structure-A transverse section of this rhizome shows two different portions of tissue, separated by the so-called nucleus-sheath. The latter consists of an unbroken ring of prismatic cells, analogous to those occurring in sarsaparilla. In Rhizoma Graminis, the outer part of the tissue exhibits a diffuse circle of about 20 liber bundles, and the interior part about the same number of fibro-vascular bundles more densely packed. The pith is reduced to a few rows of cells, the rhizome being always hollow, except at the nodes. No solid contents are to be met with in the tissue.

Chemical Composition-The constituents of couch-grass include no substance to which medicinal powers can be ascribed. The juice of the rhizome afforded to $\mathrm{H}$. Müller ${ }^{1}$ about 3 per cent. of sugar, and 7 to 8 per cent. of Triticin, $\mathrm{C}^{12} \mathrm{H}^{22} \mathrm{O}^{11}$, a tasteless, amorphous, gummy substance, easily transformed into sugar if its concentrated solution is kept for a short time at $110^{\circ} \mathrm{C}$. When treated with nitric acid, it yields oxalic acid. The rhizome affords also another gummy matter containing nitrogen, and quickly undergoing decomposition; the drug moreover is somewhat rich in acid malates. Mannite is probably occasionally present as in taraxacum (p. 353), for such is the inference we draw from the opposite results obtained by Stenhouse and by Völcker. Starch, pectin and resin are wanting. The rhizome leaves $4 \frac{1}{2}$ per cent. of ash.

Uses-A decoction of the rhizome has of late been recommended in mucous discharge from the bladder.

Substitutes-Agropyrum acutum R. et S., A. pungens R. et S., and A. junceum P. Beauv., by some botanists regarded as mere maritime varieties of $A$.repens, have rootstocks perfectly similar to this latter.

Cynodon Dactylon Pers., a grass very common in the South of Europe and Northern Africa, affords the Gros Chicndent or Chiendent pied-de-poule of the French. It is a rhizome differing from that of couch-grass in being a little stouter. Under the microscope, it displays an entirely different structure, inasmuch as it contains a large number of much stronger fibro-vascular bundles, and a cellular tissue loaded with starch, and is therefore in appearance much more woody. It thus approximates to the rhizome of Carex arenaria L., which is as much used in Germany as that of Cynodon in Southern Europe. The latter appear's to contain Asparagin (the Cynodin of Semmola ${ }^{2}$ ), or a substance similar to it.

1 Archiv der Pharm. 203. (1873) 17.

2 Della Cinodina, nuovo jrodotto organieo, trovato nella igramigna oflicinale, Cynzodon Dactylon. - Opere minori di Giovanni Sem- mola, Napoli, 1841. - Abstraeted in the Jahvesbericht of Berzelins, 'Tiibiugen, 1845. 535. 


\section{II.-CRYPTOGAMOUS OR FLOWERLESS PLANTS.}

\section{$\mathfrak{A} \mathfrak{i} \mathfrak{a} \mathfrak{g} \mathfrak{H} \mathfrak{s}$}

\section{LYCOPODIACE $Æ$.}

\section{LYCOPODIUM.}

Scmen vel Sporulce Lycopodii; Lycopodium; F. Lycopodc;

G. Bärlappsamen, Hexcnmchl.

Botanical Origin-Lycopodium clavatum L.-This plant, the Common Clubmoss, is almost cosmopolitan. It is found on hilly pastures and heaths throughout Central and Northern Europe from the Alps and Pyrenees to the Arctic regions, in the mountains of the east and centre of Spain, throughout Russian Asia to Amurland and Japan, in North and South America, the Falkland Isles, Australia and the Cape of Good Hope. It occurs throughout Great Britain, but is most plentiful on the moors of the northern counties.

The part of the plant employed in pharmacy, is the minute spores, which, as a yellow powder, are shaken out of the kidney-shaped capsules or sporangia, growing on the inner side of the bracts covering the fruit-spike.

History-The Common Clubmoss was well known as Muscus terrestris or MInscus clavatus, to the older botanists, as Tragus, Dodonæus, Tabernæmontanus, Bauhin, Parkinson and Ray, by most of whom its supposed virtues as a herb have been commenorated. Though the powder (spores) was officinal in Germany, and used as an application to wounds in the middle of the 17 th century, ${ }^{1}$ it does not appear to have been known in the English shops until a comparatively recent period. It is not included by Dale ${ }^{2}$ in the list of drugs sold by London druggists in 1692, nor enumerated in English drug lists of the last century; and it never had a place in the London Pharmacopœia.

Description-Lycopodium is a fine, mobile, inodorous, tasteless powder of pale yellow hue, having at $16^{\circ} \mathrm{C}$., a sp. gr. of 1.062 . It floats on water and is wetted with difficulty, yet sinks in that fluid after

\footnotetext{
I Schröder, Pharmacopocia Mcdico-chymica, 2 Pharmacologia, I.ond, 1693.
} ed. 4, Lugd. 1656. 538. 
boiling. By strong trituration it coheres, assumes a grey tint, and leaves an oily stain on paper ; it may then be mixed with water. It is immediately moistened by oily and alcoliolic liquids, chloroform, or ether. It luses only 4 per cent. of moisture when clied at $100^{\circ} \mathrm{C}$. When slowly leated, it bulus away quietly, but when projected into flame, it ionites instantly and explosively, buming with much light, an effect exhibited by some other pulverulent bodies liaving a peculiar structure, as fern spores and kamala.

Microscopic Structure-Under the microscope, lycopodium is seen to be composed of uniform cells or granules, $25 \mathrm{mkm}$. in diameter, each bounded by four faces, one of which (the base) is convex, while the others terminate in a triangular pyramid, the three furrowed edges of which do not reach quite to the base. These tetrahedral gramules are warked by minute ridges, forming by their intersections, regular five- or six-sided meshes. At the points of intersection, small elevations are produced, which under a low magnifying power, give the granules a speckled appearance. Below this network, lies a yellow, coherent, thin, but compact membrane, which exhibits considerable power of resistance, not being ruptured either by boiling water or by potash lye. Dil of vitriol does not act upon it in the cold, even after several days; but it instantly penetrates the grains and renders them transparent, while at the same time numerous drops of oil make their appearance and quickly exude.

Chemical Composition-One of the most remarkable constituents of lycopodium spores is a fixed oil, which they contain to the astonishing amount of 47 per cent. Bucholz pointed out its existence in 1807, but obtained it only to the extent of 6 per cent. Yet if the spores are thoroughly comminuted by prolonged trituration with sand, and are then exhausted with chloroform or ether, we find that the large proportion above mentioned can be obtained. The oil is a bland liquid, which does not solidify even at $-15^{\circ} \mathrm{C}$.

By subjecting lycopodium or its extract to distillation with or without an alkali, Stenhouse obtained volatile bases, the presence of which we can fully confirm; but they occur in exceedingly small proportion. The ash of lycopodium amounts to 4 per cent.; it is not alkaline; it contains alumina, and one per cent. of phosphoric acid, constituents likewise found in the green parts of the plant.

Production and Commerce-To obtain lycopodium, the tops of the plant are cut as the spikes approach maturity, taken bome, and the powder shaken out and separated by a sieve. It is collected chiefly in July and August, in Russia, Germany and Switzerland. The quantity obtained varies greatly by reason of frequent failures in the growth of the plant.

France imported in 1870, 7262 kilo. (16,017 fb.) of lycopodium, chiefly from Germany. The consumption in England is probably very much smaller, but there are no data to consult.

Uses-Lycopodium is not now regarded as possessing any medicinal virtues, and is only used externally for dusting excoriated surfaces and for placing in pill boxes to prevent the mutual adhesion of pills. It is also employed by the pyroteclinist. 
Adulteration-The spores are so peculiar in structure, that they can be distinguished with certainty by the microscope from all other substances. It is only the species of clubmoss that are nearly related to $L$. clavatum, ${ }^{1}$ that yield an analogous product, and this may be used with equal advantage.

Starch and dextrin, which are sometimes fraudulently mixed with the spores, are easily recognized by the well-known tests. Inorganic admixtures, as gypsum or magnesia, may be detected by their sinking in bisulphide of carbon, whereas lycopodium rises to the surface; or by incineration, a good commercial drug leaving about 4 per cent. of ash. The pollen of phænogamous plants, as of Pinus silvestris, looks at first sight much like lycopodium, but its structure is totally different.

\section{FILICES.}

\section{RHIZOMA FILICIS.}

Radix Filicis maris; Male Fern Rhizome, Male Fern Root; F. Racine de Fougère mâle; G. Farnwurzel.

Botanical Origin-Aspidium Fitix-mas Swartz (Polypodium L.) The male fern is one of the most widely distributed species. It occurs all over Europe from Sicily to Iceland, in Greenland, throughout Central and Russian Asia to the Himalaya and Japan; is found throughout China, and again in Java and the Sandwich Islands. In North America it is wanting in the Eastern United States, being principally replaced by the nearly allied Aspidium marginale Sw. and A. Goldicanum Hook.; but it is met with in Canada, California and Mexico, as well as in New Granada, Venezuela, Brazil, and Peru; and througliout Africa from Algeria to the Cape Colony and Mauritius.

History-The use of the rhizome of ferns as a vermifuge, was known to the ancients, ${ }^{2}$ but was subsequently nearly forgotten until revived by the introduction of certain secret remedies for tapeworm, of which powdered male fern rhizome, combined with drastic purgatives, was a chief constituent.

A medicine of this kind was prepared by Daniel Mathieu, a native of Neuchâtel, born in 1741, who established himself as an apothecary in Berlin. His treatment for the parasite was so successful that it attracted the notice of Frederick the Great, who purchased his nostrum for an annuity of 200 thalcrs (£30), besides conferring upon him the dignity of
Aulic Councillor.

Great celebrity was also gained for the method of treating tapeworm practised by Madame Nuffler or Nuffer, the widow of a surgeon at Murten (Morat) in Switzerland, who in 1775 obtained for the secret from Louis XIV., after an inquiry by savans of the period, the sum of 18,000 livres. Her method of treatment consisted in the administration of-1. Panada made of bread with a little butter. 2. A clyster of salt water and olive oil. 3. The "spécifique"-simply porodered forn-root. 4. A purgative

I Especially $L$. annotinum, L. complanatum, and $L$. inundatum.

2 Murray, Apparalus Mcelicaminum, v. (1790) $453-471$.
3 Cornaz, Les familles mélicules de la ville de Ncuchâtel, 1864. 20. 
bolus of calomel, gamboge, scammony, and Confeetio hyacinthidis,-given in the foregoing order. ${ }^{1}$

Pesclicer 2 of Geneva r'ccommended as a substitute for the bulky powder of the root, an cthcreal cxtract, an efficient preparation, which though proposed in 1825, was scarcely used in England until about 1851 ; at present it is the only form in which male fcrn is employed.

Description - The fresh rhizome or caudex is short and massive, 2-3 inches in diametcr, decumbent, or rising a fow inches above the ground, and bcaring on its summit a circular tuft of fronds, which in their lower part are thickly beset with brown chaffy scales. Below the growing fronds are the rcmains of those of previous seasons, which retain in their firm, flcshy bascs, vitality and succulence for years after their upper portion has perished. From among these flcshy bases, spring the black, wiry, branching roots. The rhizome is rather flcshy, and easily cut with a linife, internally of a bright palc ycllowish grcen; it has very little odour and a sweetish astringent taste. For pharmaceutical use, it should bc collected in the late autumn, winter or carly spring, divested of the dead portions, split open, dried with a gentle heat, reduccd to coarse powder, and at once exhausted with ether. Extract obtained in this way is more efficicnt than that which has been got from rhizome that has been kept some timc.

Microscopic Structure-On transversc section of the rootstock, the tissue, shows rounded, somewhat polyhedral cclls with porous walls; the outcr cells are brown and rather smaller, but do not exhibit the regular flattencd shape, usual in many suberous coats. Within this cortical layer, there is a circle of about 10 large vascular bundles, besides a large number of smaller ones scattered beyond the circle. The leaf-bases exhibit a somewhat different structure, their vascular bundles, usually 8 , forming but one diffuse circle.

The cclls of the parenchyme contain starch, greenish or brownish granules of tannic matter, and drops of oil. In the green, vigorously vegetating parts of the rootstock there are numerous smallcr and larger intercellular spaces, into which a few stalked glands project, as shown by Prof. Schacht of Bonn in 1863. These globular glands originate from the cells bordering the intercellular spaces. After thcir completc development, and the appearance of starch in the adjacent parenchyme, they exude a greenish fluid, which when thin slices of the rhizome are kept some time in glycerin, solidifies in acicular crystals. ${ }^{3}$ Such glands appear to bc wanting in most of the allicd ferns, such as Aspidium Oreopteris Sw. and Asplenium Filix-fremina Bernh. They have been observed by one of us (F.), in the rhizome of $A$. spinulosum Sw: Similar glands but not exuding a green liquid, occur betwcen the palexe below the vegetating cone of the rootstock.

Chemical Composition-Of the numerous examinations which have becn made of this drug, those of Bock (1852), and of Luck (1S60),

1 Traitcment contre le T'énia ou ver solitaire, pratiqué à Morat en Suisse, examiné ct éprouvé à Paris. Publié par ordre du Roi, 1775 . $4^{\circ}$, pp. 30. 3 plates, onc representing the plant, its rhizome and leaves. Also English translation by Dr. Simmons, London, 1778. S०.
2 Bibliothèque Universclle, xxx. (1825) 205; xxx. (1826) 326.

3 The ehemical mature of this body re. mains to be ascertained. The erystals are probably Filicic Acid, accompanied hy chlorophyll and essential oil. 
may be especially mentioned. Besides the universally distributed constituents of plants, there have been found in the rhizome 5 to 6 per cent. of a green fatty oil, traces of volatile oil, resin, tamnin (Luck's Tannaspidic and Ptcritannic Acids). and crystallizable sugar, which according to Bock, is probably cane sugar.

The medicinal ethereal extract, of which the rhizome yields about 8 per cent, deposits a colourless, granular, crystalline substance, noticed by Peschier as early as 1826 , and subsequently designated by Luck, Filicic Acicl. Grabowski (1867) assigned it the formula, $\mathrm{C}^{14} \mathrm{H}^{18} \mathrm{O}^{5}$. We learn from Prof. Buchheim that he regards filicic acid as the source of the medicinal efficacy of the drug. By fusion with potash, filicic acid is converted into phloroglucin and butyric acid. The green liquid portion of the extract consists mainly of a glyceride called Filixolin, from which Luck obtained by saponification two acids, the one volatile, Filosmylic Acid, the other non-volatile, termed Filixolic Acid.

Malin (1867) showed that the tannic acid of male fern may be decomposed by boiling dilute acids, into sugar and a red substance, Filix-red, $\mathrm{C}^{26} \mathrm{H}^{18} \mathrm{O}^{12}$, analagous to Cinchona-red.

Schoonbroodt ${ }^{1}$ performed some interesting experiments with fresh fern root, showing that it contains volatilc acids of the fatty series, among which is probably formic; but also a fixed acid, accompanied by an oil of disagreeable odour. The liquid distilled from the dried root did not evolve a similar odour, nor did it contain any acid body. A small quantity of essential oil was obtained by means of ether from the alcoholic extract of the fresh but not of the dried rootstock.

The substance called Aspidine, regarded by Pavesi as the active constituent, seems to be essentially filicic acid. The rhizome of male fern yields 2 to 3 per cent. of ash, consisting mainly of phosphates, carbonates, and sulphates of calcium and potassium, together with silica.

Uses-The ethereal extract has been prescribed for all kinds of intestinal worms; but recent experience goes to prove that its effects are chiefly exhibited in cases of tapeworm. It is equally and thoroughly efficacious in the tluree kinds respectively termed Tonia sotium, T. medio-canncllata and Bothrioccphalus latus.

Substitution-The rhizomes of Asplcnium Filix-famina Bernh., Aspidium Oreopteris Sw., and $A$. spinulosum Sw. may be mistaken for that of A. Filix-mas. The best means of distinguishing them is afforded by transverse sections of the leaf-bases. In Filix-mas, the section exhibits 8 vascular bundles,-in the other ferns named, only 2,- a difference easily ascertained by examination under a lens.

1 Journal de Medecine de Bruxclles, 1867 and 1868-also Wittstein's Vierteljahres. schrift für prakt. Pharm. xviii. (1869) 106. 


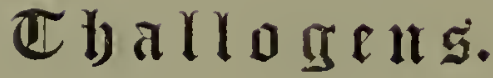

\section{LICHENES.}

\section{LICHEN ISLANDICUS.}

Iceland Moss; F. Lichen ou Mousse d'Islande; G. Isländisches Moos.

Botanical Origin-Cetraria Islandica Acharius. ${ }^{1}$ - It is abundant in high northern latitudes, as Greenland, Spitzbergen, Siberia, Scandinavia and Iceland, where it grows even in the plains. It is found in the mountainous parts of Great Britain, France, Italy and Spain, in Switzerland and in the Sonthern Danubian countries. It also occurs in North America and in the Antarctic regions.

History-In the North of Europe, this lichen has long been used under the general name of Mosi, Mossce or Mus as an article of food. Ole Borrich, of Copenhagen (1671), called it Muscus catharticus, under the notion that in early spring it possesses purgative properties. ${ }^{2}$ Its medicinal employment in pulmonary disorders was favourably spoken of by Hjärne in $1683,{ }^{3}$ but it is only since 1757 that it has come into general use as a medicine, chiefly on the recommendation of Linnæus and Scopoli.

Description-The plant consists of an erect, foliaceous, branching thallus, about 4 inches high, curled, channelled or rolled into tubes, terminating in sprearing truncate, flattened lobes, the edges of which are fringed with short thick prominences. The thallus is smooth, grey, or of a light olive-brown; the under surface is paler and irregularly beset with depressed white spots. The apothecia (fruits), which are not very common, appear at the apices of the thallus, as rounded boss-like bodies, $\frac{2}{10}$ to $\frac{3}{10}$ of an inch across, of a dark, rusty colour. The colour and mode of division of the thallus vary greatly, so that many varieties of the plant have been distinguished.

In the dry state, Iceland moss is light, harsh and springy; it absorbs water in which it is placed, to the extent of a third of its weight, becoming soft and cartilaginous; it ordinarily contains about 10 per cent. of hygroscopic water. It is inodorous, but when wetted has a slight seaweed-like smell; its taste is slightly bitter.

1 Cetretrice from cetra, an ancient shield of hide, in allusion to the eireular apothecia.

2 Bergius, Natcrice ILedica, Stockholm, ii.

(1778) 856 .
3 Murray, Amparatus Mcdicaminum, r. (1790) 510 . 
Microscopic Structure-A transverse section exhibits when strongly magnified, a broad loose central layer of long, thick-walled branching cells or hyphe, containing air, and enclosing wide hollow spaces. This middle layer encloses a certaiu number of larger cells called gonidia, coloured with chlorophyll. The gonidia are not destroyed either by strong sulphuric acid, or by boiling them with potash. They assume however a deep violet colour when treated with caustic potash and then left for 24 hours in a solution of iodine in potassium iodide.

The tissue on either side of this central layer consists of very thickly felted hyphæ, without intervening spaces, and does not appear to contain any particular substance. This compact and tenacious tissue passes into a thin cortical layer consisting of cells very closely bound together. Under the influence of reagents this layer becomes very evident: thus when moistened with strong sulphuric or hydrochloric acid, it separates from the rest of the tissue as a coherent membrane, and rolls itself backward. On boiling with water the inner tissue swells up, the cell-walls being partly dissolved. Thin slices of the lichen are coloured reddish or pale blue by iodine water,-more distinctly blue, if previously treated with sulphuric acid. The colour spreads uniformly over the inner tissue, but no starch granules can be detected; the cortical layer is merely coloured brown by iodine. The white spots on the outer surface of the thallus are resolved by pressure under a plate of glass into minute round transparent granules, not coloured by iodine, and thick branched cells like those of the central layer.

The short, thick prominences on the edge of the thallus, frequently terminate in one or more sac-like cavities (spermogonic) containing a large number of simple bar-shaped cells (spcrmatia), only $6 \mathrm{mkm}$. long; they are enveloped in transparent mucus, and may be expelled by pressure under glass. It has been shown by Stahl (1874) that they represent the fertilizing corpuscles of seaweeds of the class Floridece.

The observations of De Bary (1866) and Schweudener (1867-70) confirmed and much extended by the researches of Bornet ${ }^{1}(1873-74)$, have shown that the gonidia of lichens are referable to some species of Alga, and are capable of au independent existence; that the relations of the hyph to the gonidia are of such a nature as to exclude the possibility of either of those bodies being produced by the other; and further, that the theory of parasitism is the only one capable of explaining these relations in a satisfactory manner. Under this singular theory, lichens are compound organisms, formed of au alga, and of a fungus living upon it as a parasite.

Chemical Composition-Boiling water extracts from Iceland moss, as much as 70 per cent. of the so-called Lichenin or Lichen-starch, a body which is perfectly devoid of structure. The decoction $(1: 20)$ gelatinizes on cooling, and assumes a reddisl or bluish tint by solution of iodine. This property of lichenin is plainly seen, when the drug is first exhausted by boiling spirit of wine containing some carbonate of potassium ; and then boilcd with 50 to 100 parts of water, and the decoction precipitated by means of alcohol. The lichenin thus obtained in a purer state, unust be deprived of alcohol by cautiously washing it with

I liceherehes sur les gonidies des Lichens. - Ann. ues Seicnecs nat. (Bot.) xvii.
$5-110,11$ plates ; also xis. (1ST4) $314-320$. 
water. Powdered iocline will now immediately impart to it while still moist an intense blue. Its composition, $\mathrm{C}^{10} \mathrm{H}^{20} \mathrm{O}^{10}$, agrees with that of starch and cellulose; and it must be regarded as a modification of the latter, being likewise soluble in water and in ammoniacal solution of copper. Lichenin is not a kind of mucilage, because it yields but insignificant traces of mucic acid, if treated with concentrated nitric acid; and also because it contains no inorganic constituents. ${ }^{i}$ T'he very trilling proportion of mucic acid it furnishes, may depend upon the presence, in small amount, of an independent mucilaginous body.

The chlorophyll of the gonidia is not soluble in liydrochloric acid, and lence is distinguished by Knop and Schnedermann as Thallochlor; its quantity is extremely sinall.

The bitter principle of cetraria, called Cetraric Acid or Cctrarin, $\mathrm{C}^{15} \mathrm{H}^{16} \mathrm{O}^{8}$, crystallizes in microscopic needles, is nearly insoluble in cold water, and forms with alkalis, yellow, easily soluble, bitter salts. The lichen also contains a little sugar, and about 1 per cent. of a peculiar body, Licheno-stearic Acid, $\mathrm{C}^{14} \mathrm{H}^{34} \mathrm{O}^{3}$, the crystals of which melt at $120^{\circ} \mathrm{C}$. The Lichcnic Acid found by Pfaff in 1826 in Iceland moss, and formerly regarded as a peculiar compound, has been proved identical with fumaric acid.

In common with many lichens, cetraria contains Oxalic Acid and is said to yield also some tartaric acid. The ash which amounts to 1-2 per cent., consists to the extent of two-fifths, of silicic acid combined chiefly with potash and lime.

Collection and Commerce-Iceland moss is collected in many districts where the plant abounds, at least for local use, as in Sweden, whence some is shipped to other countries. It is also gathered in Switzerland, especially on the mountains of the canton of Lucerne, and in Spain. ${ }^{2}$ None is exported from Iceland.

Uses-It is given in decoction as a mild tonic, combined with more active medicines. It is very little employed in Iceland, and only in seasons of scarcity, when it is sometimes ground and mixed with the flour used in making the grout or grain soup. Occasionally it is taken boiled in milk. It is not given, as has been asserted, to domestic animals.

An interesting application of Iceland moss has recently been tried in Sweden. Sten-Stenberg treats it with sulphuric or hydrochloric acid, when 72 per cent. of grape sugar are formed, which may be converted into alcohol. ${ }^{3}$

\section{FUNGI.}

\section{SECALE CORNUTUM.}

Ergota $^{4}$; Ergot of Ryc, Spurred Rye; IF. Seigle ergoté; G. Mutterkorn.

Botanical Origin-Claviceps purpurce Tulasne, a fungus of the order Pyrenomyectes, of which ergot is all immature form, it being the

1 The various mucilages and gums yield from 4 to 20 per cent. of ash, but puxe ichenin yields none.

${ }_{2}$ Cat. of Spanish Productions,-London Exhibition, 1851.
3 Dingler's Polytechnisches Joumal, 197 (1870) 177; also Chemisches Centralblat, 1870. 607 .

4 From the French crgot, anciently argot, a cock's spur. 
sclerotium (termed in the British Pharmacopœia compact mycclium or spawn) developed within the palex of numerous plants of the order Graminco.

Ergot is obtained almost exclusively from rye, Secalc cereale L.; but the same fungus is produced on grasses belonging to many other genera, as Agropyrum, Alopccurus, Ammophila, Anthoxanthum, Arrhcnatherum, Avena, Brachypodium, Calamagrostis, Dactylis, Glyceria, Hordcum, Lolium, $P o d$, and Triticum. Other organisms of diverse form, but of doubtful specific distinctness, are developed in Molinia, Oryza, Phragmites, and other grasses. In the order Cyperacece (e.g. Scirpus), peculiar ergots are known.

History-Although it is hardly possible that so singular a production as ergot should be unnoticed in the writings of the classical author's, we believe no undoubted reference to it has been discovered. ${ }^{1}$ The earliest date under which we find ergot mentioned on account of its obstetric virtues, is towards the middle of the 16th century, by Adam Lonicer of Frankfort, who describes its appearance in the ears of rye, and adds that it is regarded by women to be of remarkable and certain efficacy. ${ }^{2}$ It is also very clearly described in the writings of Johannes Thalius (1588), who speaks of it as used, "ad sistcndum sanguinem." ${ }^{3}$ In the next century, it was noticed by Caspar Bauhin (1623), who termed it Sccule luxurians ${ }^{*}$ and in 1693 , by the English botanist Ray, with allusion to its medicinal properties. ${ }^{5}$

Rathlaw, a Dutch accoucheur, employed ergot in 1747. Thirty years later, Desgranges of Lyons prescribed it with success; but its peculiar and important properties were hardly allowed until the commencement of the present century, when Dr. Stearns of New York succeeded in gaiming for them fuller recognition. ${ }^{6}$ Ergot of rye was not however admitted into the London Pharmacopoia until 1836. ${ }^{7}$

The use of flour containing a considerable proportion of ergot, gives rise to a very formidable disease, distinguished in modern medicine as Ergotism, but known in early times by a variety of names, as Morbus spasmodicus, convulsivus, malignus, cpidcmicus vol cercalis, Raphania, Convulsio raphania ${ }^{8}$ or Ignis sancti Antonii.

Some of the malignant epidemics which visited Europe after seasons of rain and scarcity during the middle ages, have been referred with more or less of probability to ergot-disease. ${ }^{9}$ The chroniclers of the 6 th and 8th centuries note the occurrence of maladies which may be suspected as due to ergotized grain. There is less of doubt regarding the epidemics that prevailed from the 10th century and were frequent in France, and in the 12th in Spain. In the year 1596, Hesse and the adjoining regions were ravaged by a frightful pestilence, which the Medical Faculty of Marburg attributed to the presence of ergot in the cereals consumed by the population. The same disease appeared in

1 Consult Pliny's Nat. Hist, book 18. ch. 44.

2 Kreuterbuch, ed. 1582. 285 (not in the edition of 1560$)$.

3 Sylva Horcynia, Francof. 1588. 47.

4 Pinax Theatri Botanici, Basil. 1623. 23.

5 Hist. Plant. ii. (1693) 1241.

6 Stillé, Thucrapeutics and Mat. Med. ii. (1868) 609 .

7 From 1825 to 1828 , the wholesale price of ergot of ryc in London was from 36s. to 50s. per th., that is to say, from twelve to fifteen times its prescnt value.

8 Pereira, Elcm. of Mat. Med. ii. (1850) 1007 .

9 Consult Häscr, Lchrbuch der Geseltichte der Mcdicin und der Volkskrankhicitcn, 1845. i. 256.830 , ii. 94 ; C. F. Heusingcr, Rechcrches de Pathologie comparée, Cassel, i. (1853) 543-554; Mérat et De Lens, Dicl. Mlat. Med. iii. Iș1, vii. 268. 
France in 1630, in Voigtlandia (Saxony) in the year's 1648, 1649 and 1675; Rain in varions parts of France, as Aquitaine and Sologne, in 1650,1670 and 1674. Freiburg and the neighbouring region were visited by the same malady in 1702 ; other parts of Switzerland in 171.j-16; Saxony and Lusatia in 171.6 ; many other disstricts of Germany in 1717, 1722, 1736 and $1741-2 .^{1}$ 'The last epidemic in Europe occasionerl by ergot, appenrs to be that which, after the rainy season of 1816 , visited Lorraine and Burgundy, and proved fatal to many people of the poorer class. Ergot disease is sometimes observed in Abyssinia at the present day, and a few cases of it have even been lately recorded in Bavaria."

Formation-The true nature of ergot lias long been the source of a great diversity of opinion, now set at rest by the admirable researches of L. R. Tulasne, from whose Mémoire suir l'Errgot des Glumacées, ${ }^{ \pm}$the following account is for the most part extracted:

The formation of ergot often affects only a few caryopsides in a single ear'; sometimes however, more than twenty. In the former case, the healthy development of the other caryopsides is not prevented, but if too many are attacked; the entire ear decays. The nore isolated ergots generally grow larger, and attain their greatest size on rye which springs up here and there among other cereals.

The first symptom of ergot-formation is the so-called honey-dew of rye, a yellowish mucus, having an intensely sweet taste, and the peculiar disagreeable odour frequently belonging to fungi. Drops of this mucus show themselves here and there on the ears in the neighbourhood of diseased grains, and attract ants and beetles of various kinds, especially the yellowish-red Rhagonyeha melanura Fabr., but not bees. On this account, the beetle in question has been supposed to be instrumental in the development of ergot, and it may possibly be so, but only by transporting the saccharine mucus from one plant to another.

The honey-dew of rye contains neither oil-drops nor starch. After dilution with water, it produces a rapid and abundant separation of cuprous oxide from an alkaline solution of cupric tartrate. Dried over sulphuric acid, it solidifies into a crystalline mass. After a few days, the drops of honey-dew dry up and clisappear from the ear. The grain at this period becomes completely disintegrated, and devoid of starch.

The ergotised soft ovaries are covered with, and penetrated by a white, spongy, felted tissue, the mycelium of the young fungus. It is made up of slender, threadlike cells, the hypha, the outer layer of which consists of radially-diverging cells, the basidia. The whole mycelium forms by its crevices and folds, a number of cavities opening exterually; from its outer layer, which is also called the hymenium or spermatophornm, an immense number of agglutinated, elongated granules, the conidia, are separated. These cells, the products of the basidia, are not more than $4 \mathrm{mkm}$. in length, and give the floral organs the appearance of being covered with a whitish dust. The honey-dew likewise contains an abundance of conidia, but it is only on dilution that they are precipitated and become easily perceptible; the formation of the loney-dew is

1 Tissot of Lausanne, Phit. Trans. lv. (1766) 106. - See also Hist. de Ta Soc. roy. dc Méd., année 1776.345 ; and MIém. de LFéd. et de Phys. méd. annéc 1776. 260-311. 417.
2 Th. von Heuglin, Reise nach Abcssinici, \&e. Jenia, 1868. 180.

3 Wiggers and Husemamn, Jahrcsbcricht for 1870.582 .

A Ann. des Scicnces nat., Bot., xr. (1853) $1-56$ and 4 plates. 
intimately connected with that of the conidia themselves. Ercrot in this primary or myceliun. stage was regarded as an independent fungris by Léveillé (1S:7), who named it Sphacelia segetiom. According to Kiihn (1863), it may even be directly reproduced by germination of the conidia within the ears of rye.

The mycelium penetrates and envelops the caryopsis, with the exception of the apex, and thereby prevents its further growth, destroying especially the epicarp and the embryo. At the base of the caryopsis, there is formed by tumefaction and gradual transverse separation of the thread-cells of the mycelium, a more conpact kernel-like body (the future ergot) violet-black without, white within, which gradually but largely increases in size, and ultimately separates from the mycelium as the loose tissue of the latter dries and shrinks up after the completion of its functions: By this growth, the remains of the caryopsis, still recognizable by their hairs and by the rudiments of the style, as well as by the surviving portions of the mycelium-tissue, become visible above the palex on the apex of the mature ergot, now projecting prominently from the ear. Very rarely the ergot is crowned by a fully developed seed; in the commercial drug, the apex is usually broken off.

It is evident that in the process of developnient just described, the very tissue of the caryopsis of the rye does not undergo a transformation, but that it is simply destroyed. Neither in external form, nor in anatomical structure does ergot exhibit any resemblance to a caryopsis or a seed, although its development takes place between the flowering time and that at which the rye begins to ripen. It has been regarded as a complete fungus, and as such was named by De Candolle (1S16) Selerotium Clarus and by Fries Spermoedica Clavus.

No further change in the ergot occurs while it remains in the ear; but laid on damp earth, interesting phenomena take place. At certain points, small orbicular patches of the rind, fold themselves back, and gradually throw out little white heads. These increase in size, whilst the outer layers of the neighbouring tissue gradually lose their firmness and become soft and ratler granular, at the same time that the cells, of which they are made up, become empty and extended. In the interior of the ergot, the cells retain their oil drops unaltered. The heads assume a greyish-yellow colour, changing to purple, and finally after some weeks stretch themselves towards the light on slender shining stalks of a pale violet colour. The stalks often attain an inch in length, with a thickness of about $\frac{1}{2}$ a line. They consist of thin, parallel, closely felted cell-threads, devoid of fat oil. Ergot is susceptible of this further developinent only so long as it is fresh, that is to say, at most until the next flowering time of rye. Within this period however, even fragments are capable of development. There are sometimes also produced colourless threads of mould which belong to other fungi, as $V$ erticillium cylindrosporum Corda, and which frequently overgrow the Claviceps. ${ }^{1}$

1 Ergot of rye collected by myself in August, placed upon eartl in a garden-pot and left in the open air unprotected through the winter, began to develope the Claviceps oll the 20th Mareh, and on another oceasion on the 20th $A$ pril, at whien date some sowed in February also began to start. Slinrp frost appears to retard the vegetation; thus,

after the cold winter of 1869-70, Claviceps, even in the greenhonse, did not make its appearance before the 11th May. The earliest instance of fully developed crgots which I ever observed, occurred on the 11th of June; more frequently they are secn only in the begiming of July.-F. A. F. 
At the point where the stalk joins the spherical or somewhat flattened liead, the latter is depressed and surronnds the stalk with an annular bordcr. After a short time there appear on the surface of the hear, which is $\frac{1}{10}$ of an inch in diameter, a number of brownish warts, in which are the openings of minute cavities, the conceptacula or perithecio. On transverse scction, they appear arranged radially round the circumference of the head. In each cavity are a large number of delicatc sacs, only 3-5 mkm. thick, and about $100 \mathrm{mkm}$. long, the thecen or asci, each containing, as is usual in fungi, 8 spores. These are simple threadshaped cells, filled with a homogeneous solid mass.

The thicker ends of the spore-sacs (asci) open while still within the perithccium; the spores issue united in a bundlc, and are emitted from the aperture of the perithecium. In consequence of their somewhat glutinous consistence, they remain unitcd even after their extrusion, and form white silky flocks; their number in the 20 or 30 heads sometimes produced from a single ergot, often cxcceds a million. The heads themselves dic in two or thrce weeks after thcy have begun to make thcir appcarance. Thcy represent the truc fructification of the fungus. This state of the plant appears to have been first noticed in 1801 by Schumacher, who called it Sphceria; it was subsequently known as Cordiceps, Cordyliceps, Kcntrosporium, \&c., until Tulasne proved it to be the final stage of development of ergot.

The three different forms of this structure, namely, the mycelium, the ergot, and the fruit-bearing heads, are therefore merely successive states of one and the same biennial fungus, which have been appropriately united by Tulasne under the name of Claviceps purpurea. The middle stage forms the sclcrotinm, which occurs in a large number of the most various fungi, and is a special state of rest of these plants. The direct proof that the mycelium is produced from spores of the fruithead sown on ears of rye, was supplicd by Kühn in 1863. It has - alrcady been mentioned that the same organism is produced from conidia; whence it appears that a twofold formation of ergot is possible, as is frequently the case in other fungi.

Description-Spurred rye, as found in commerce, consists of fusiform grains, which it is convenient to term crgots. They are from $\frac{1}{3}$ to $1 \frac{1}{3}$ inch in length, and $\frac{1}{2}$ to 4 lines in diameter; their form is subcylindrical or obtusely prismatic, tapering towards the cnds, generally arched, with a longitudinal furrow on each sidc. At the apex of cach ergot, therc is often a small whitish easily detached appendagc, while the opposite extremity is somewhat rounded. The ergots are firm, horny, somewhat elastic, have a close fracturc, arc brittle whon dry, yet difficult to pulverize. The whitish interior is frcquently laid bare by deep transverse cracks. The tissue is but imperfectly penetrated by water, even the thinnest sections swelling but slightly in that fluid.

Ergot of rye has a peculiar offensive oclour, and a mawlish, rancid taste. It is apt to bccome deteriorated by keeping, especially when pulverizcd, partly from oxidation of the oil, and partly from the attacks of a mitc of the genus Trombidium. To assist its preservation, it should be thoroughly dried, and kept in closed bottles.

Microscopic Structure-In fully devcloped ergot, no organs can be distinguished. It consists of uniform, densely felted tissue of short, 
thread-like, somewhat thick-walled cells, which are irregularly packed and so intimately matted together that it is only by prolonged boiling of thin slices with potash, and alternate treatment witl acids and ether, that the individual cells can be made evident. Without such treatment, the cells even in the thinnest sections show a somewhat rounded, nearly isodiametric outline. This pseudo-parenchyme of ergot exhibits therefore an aspect somewhat different from that of the loosely felted cells ( hyphac) of other fungi. Ergot nevertheless is not made up of cells differing from those of fungi generally. If thin longitudinal slices of the inmermost tissue are allowed to remain in a solution of chromic acid containing about 1 per cent., they will distinctly show the hyphce, which are however considerably shorter than those of other fungi. They contain numerous drops of fat oil, but neither starch nor crystals. It is remarkable that this nearly empty and not much thickened parenchyme should form so compact and solid a tissue.

The cell-walls of the tissue of ergot are not coloured blue, even after prolonged treatment with iodine in solution of potassium iodide; or when the tissue has been previously treated with sulphuric acid, or kept for days in contact with potash and absolute alcohol at $100^{\circ} \mathrm{C}$. In this respect the cellulose of fungi differs from that of phanerogamic plants.

Of the outermost rows of cells in ergot, a few only are of a violet colour, but they are not otherwise distinguishable from the colourless tissue,-or at most by the somewhat greater thickness of their walls.

Chemical Composition-The composition of ergot has been several times investigated, and elaborately by Wiggers as early as 1830 . The drug contains about 30 per cent. of a fatty, non-drying, yellowish, saponifiable oil, chiefly consisting of olein, palmitin, and small proportions of volatile fatty acids, especially acetic and butyric, combined with glycerin. The oil is accompanied by small quantities of resin and cholesterin. It is erroneous to attribute to this oil the poisonous properties of ergot, althougl it has been shown by Ganser, ${ }^{1}$ to display irritating properties when taken in doses of about 6 grammes. But the effects observed appear dependent on the presence in it of resin ( 7 per cent.)

According to Wenzell (1864), ergot of rye contains two peculiar alkaloids, which he designated Ecbotine and Ergotine. ${ }^{2}$ They are soluble in water, and have an alkaline reaction and a bitterish taste. They were not got in a state of purity, but merely as brownish substances forming deliquescent compounds with acids, - in either case, amorphous. Ganser however, claims to have obtained long acicular crystals of the hydrochlorate of ergotine. Ecboline possesses in a high degree the special medicinal properties of ergot of rye; ergotine, which is less bitter, is but little active. Manasservitz (1867) obtained 0.12 per cent. of ergotine; Ganser, 0.04 of the same alkaloid, and 0.16 of ecboline. The two bodies may be easily separated by mercuric chloride, which yields an insoluble conpound with ecboline only. Manassewitz assigned to ergotine the formula $\mathrm{C}^{50} \mathrm{H}^{52} \mathrm{~N}^{2} \mathrm{O}^{3}$, which requires confirrnation.

The two bases of ergot were found by Wenzell, to be combined with

I Rrchiv der Pharm. exliv. (1870) 200.

2 The name Eryotine has also been given to a medieinal extraet of ergot, frepared after a method devised by Bonjean, a phar- macien of Chambéry, vide Journ. de Pharm. jv. (1843) 107 ; Pereira, Elem. of Mrat. HIect. ii. (1850) 1012 . 
Ergotic Acirl, the existence of which has been further proved by Ganser. It is a volatile body yielding crystallizable salts.

Frgot in common with other fungi, ${ }^{1}$ contains a sugar termed Mycose, closely allied to cane sugar, and still more so to Trehalose, from which it differs only in having a rather less dextrogyre power. Nycose crystallizes in rhombic octohedra, having the composition $\mathrm{C}^{12} \mathrm{H}^{2 \pm 2}()^{11}+$ $2 \mathrm{H}^{2} \mathrm{O}$. Mitscherlich obtained of it about one-tenth per cent. It appears that the sugar exuded in the first stage of growth of the fungus,-- the so-called rye honcy-dew, - is in its principal characters different from mycose. Instead of the latter, Mitscherlich as well as Fiedler and Ludwig, sometimes obtained from ergot, Mannitc.

The red colouring matter of ergot is soluble neither in benzol, alcohol, nor ether, but is easily extractable by alcolnol or water mixed with a little ammonia, or by a mincral acid (not acetic). From its neutralized alcoholic solution, it may be precipitated by acetate of lead. It appears to contain iron and nitrogen (Winckler, Manassewitz). Spectroscopically examined, we find its solution to extinguish the blue and the green ray.

Schoonbroodt in 1866, as well as Ludwig in 1869, pointed out the presence in ergot of Cholestcrin, a crystallizable principle widely distributed in the animal kingdom, and which has been detected in other fungi. It may be isolated by shaking the fat oil of ergot with warm alcohol. Ganser thus obtained 0.036 parts of chloresterin from 100 of the drug. Schoonbroodt also found in ergot, Lactic Acicl. Several other chemists have further proved the presence of acetic and formic acids.

Starch is entirely wanting in ergot at all times. The drug yields about 3 per cent. of nitrogen, corresponding probably to a large amount of albuminoid matter. Ganser however obtained only 3.2 per cent. of albumin soluble in water.

When ergot or its alcoholic extract is treated with an alkali, it yields as products of the decomposition of the albuminoid matters, ammonia or ammonia-bases,-according to Ludwig and Stahl, Mcthylamine,-according to others, Trimethylamine. Manassewitz, as well as Wenzell, state that phosphate of trimethylamine is present in an aqueous extract of ergot, but Ganser ascertained that no such base pre-exists in ergot. We have found that the crystals which abound in the extract after it lias been kept for some time, are an acid phosphate of sodium and ammonium with a small proportion of sulphate. ${ }^{2}$

Production and Commerce-Ergot of rye is chiefly imported into London from Vigo in Spain and from Teneriffe; it is also shipped from Hamburg and France. Dr. de Lanéssan, writing to one of us from Vigo in 1872, remarks that vast quantities of rye are grown in Galicia, and that owing to the humidity of the climate, the grain is extensively ergotized,-in fact the parasite is present in one ear out of every three. At the time of harvest the ergots are picked out, and the rye is thus rendered fit for food.

Southern and Central Russia furmish considerable supplies of the drug. In the central parts of Europe, ergot does not everywhere occur

1 See Müntz in Comptes Rendus, lxxvi. (1873) 649.

${ }_{2}$ The red colour of an alcoholic solution may serve for the detection of small quantitics of crgot in flowr. The reaction with potash, and cvolution of the characteristic

odour of herring brine may assist in the same object. Extrnetion of the fatty oil with carbon bisulphide may also be recominended as a test, inasmuch as good cercal grains contain but a very small perecntage of fat. 
in sufficient abundance to be collected, and it greatly diminishes as the state of agriculture improves. We have noticed that ergot from Odessa was of a slaty hue and in much smaller grains than that from Spain.

Uses-Ergot is principally used on account of its specific action on the uterus in parturition.

Other Varieties of Ergot-Ergot of Wheat, which is in shorter and thicker ergots than that of rye, is picked out by hand in some parts of Italy and France, from grain intended to be used for the manufacture of vermicelli and other pastes; and such ergot is sold to druggists. Carbonneaux Le Perdriel ${ }^{1}$ has endeavoured to show that it is less prone to become deteriorated by age than that of rye, and that it never produces the deleterious effects sometimes occasioned by the latter.

The same writer asserts that Ergot of Oat is sometimes collected and sold either per se, or mixed with that of rye. It differs from the latter in the ergots being considerably more slender.

Ergot of the North African grass known as Diss, Arundo Ampelodesmos Cirillo, has been collected for use, and according to Lallemant ${ }^{2}$ is twice as active as that of rye. It is from 1 to 3 inches long by only about $\frac{1}{10}$ of an inch broad, generally arched, or in the large ergots twisted spirally. We find it to share the structural character of the ergot of rye.

\section{ALGA.}

\section{CHONDRUS CRISPUS.}

Fucus Hibernicus; Carrageen, ${ }^{3}$ Irish Moss ; F. Mousse d'Irlande, Mousse perlé; G. Knorpeltang, Irländisehes Moos, Perlmoos.

Botanical Origin-Chondrus crispus Lyngbye (Fueus crispus L.), a sea weed of the class Floridece, abundant on rocky sea-shores of Europe from the North Cape to Gibraltar, also on the eastern coasts of North America.

History-Carrageen was introduced to the notice of the medical profession in England in 1831, and shortly afterwards attracted attention in Germany. It was never admitted to the London or British pharmacopocia, and is but little esteemed in medicine.

Description-The entire plant is collected : in the fresh state it is soft and cartilaginous, varying in colour from yellowish-green to livid purple or purplish-brown, but becoming after washing and exposure to the sun, white or yellowish, and when dry, shrunken, horny and translucent.

The base is a small flattened disc, from which springs a frond or thallus 4 to 6 inches or more in length, having a slender subcylindrical stem, expanding fan-like into wedge-shaped segments, of variable breadth, flat or curled, and truncate, emarginate or bifid at the summit.

1 De l'Ergot de Froment ct de ses propriétés méd. (thèse) M Montpellier, 1862.

2 Etude sur l'Ergot du Diss, Alger et Paris, 1863 ; Journ. de Pharm. i. (1865) 444.
${ }^{3}$ Carragecn in Irish signifies moss of the rock. We learn from an Irish scholar that it would be more correctly written carraigecn. 
The fructification consists of tetraspores or cystocarps, rising but slightly from the substance of the thallus, and appearing as little wartlike protuberances.

In cold water, carrageen swells up to its original bulk, and acquires a distinct seaweed-like smell. A quantity of water equal to 20 or 30 times its weight, boiled with it for ten minutes, solidifies on cooling to a pale mawkish jelly.

Microscopic Structure-The tissue of Chondrus crispus is made up of globular or elongated, thick-walled cells. The superficial layers on botli sides of the lobes constitute a kind of peel, easily separable in microscopic sections. The interior or medullary part exhibits a much less densely packed tissue formed of larger cells. The larger cavities of this tissue contain a granular mucilaginous matter, assuming a slight violet tinge on addition of iodine. In water however, the cell-walls swell up so as to form a gelatinous mass, in which separate cells can at last be scarcely distinguished. ${ }^{1}$ In the fresh state, its cells also contain granules of chlorophyll imbued with a red matter, termed Phyco-erythrin. But by washing and exposure to the air, these colouring substances are removed or greatly altered, and are no longer visible in the commercial drug.

Chemical Composition-The constituents of carrageen are those generally found in marine algæ, especially as regards the mucilage. This latter is insoluble in an ammoniacal solution of copper' (Schweizer's test); by the action of fuming nitric acid, it yields, in common with gum, an abundance of mucic acid. The mucilage of carrageen, like many similar bodies, obstinately retains inorganic matter; after it had three times been dissolved in water, and as many times precipitated with alcohol, we fornd it still to yield the same quantity of ash as the raw drug itself, that is to say, more than 15 per cent. The mucilage perfectly dried, is a tough horny substance, of a greyish colour; it quickly swells up in water, forming a jelly which is precipitable by neutral acetate of lead.

According to Blondeau, ${ }^{2}$ the mucilage of carrageen contains 21 per cent. of nitrogen and 2.5 of sulphur, a statement which we are able to point out as erroneous. We find in it no sulphur, and only 0.88 per cent. of nitrogen. The drug itself yielded us not more than 1.012 per cent. of nitrogen.

When thin slices of the plant are treated with alcoholic potash, and then after washing left for 24 hours in contact with a solution of iodine in potassium iodide, they acquire a deep blue; yet, starch granules are not found in this seaweed. Lastly in connexion with carrageen may be mentioned Fucusol, an oily liquid isomeric with furfurol, obtained by boiling seaweeds with dilute sulphuric acid.

Commerce-The plant is collected on the west and north-west coast of Ireland: Sligo is said to be a great depôt for it. It is also gathered to some extent on the coast of Massachusetts, where a systematic process of preparing it for the market is adopted. ${ }^{3}$ Carrageen of superior quality is sometimes imported from Hamburg.

1 Spirit of wine, glyeerin or a fatty oil, are the liquids inost suited for the microscopic examnination of this drug.
2 Journ. de Pharm. ii. (1865) 159.

G. H. Bates in P'harm. Joum, xi. (1870) 298. 
Uses-The mucilaginous decoction and jelly which carrageen affords, are popular remedies in pulnonary and other complaints; but as nutriment, such preparations are much over-estimated. ${ }^{1}$

Carrageen is sometimes used for feeding cows and calves; and under the name of Alga marina, for stuffing mattresses. Its mucilage serves for thickening the colour's employed in calico-printing, and as size for paper and for cotton goods. In America it is used for fining beer.

Substitutes-Gigartina mammillosa J. Ag. (Chondrus mammillosus Grev.) is collected indiscriminately with Ch. crispus. It is distinguished from the latter chiefly by having the flat portion of the thallus beset with elevated or stalked tubercles, bearing the cystocarps; but it has the same properties. G. acicularis Lamour., a species common on the coasts of France and Spain, and having slender cylindrical branches, is occasionally collected along with Chondrus crispus. Dalmon (1874) who has examined it, asserts it to be less soluble in boiling water than true carrageen. Small quantities of other sea weeds are often present through the negligence of the collec tors.

\section{FUCUS AMYLACEUS.}

\section{Alga Zcylanica; Ceylon Moss, ${ }^{2}$ Jaffna Moss.}

Botanical Origin-Sphcerococcus lichenoidcs Agardh. (Gracillaria lichenoides Grev., Plocaria candida Nees), a light purple or greenish sea-weed, belonging to the class Floridew, occurring on the coasts of Ceylon, Burma and the Malay islands. ${ }^{3}$

History-Ceylon moss has long been in use among the inhabitants of the Indian Archipelago and the Chinese. It is probably one of the plants described by Rumphius ${ }^{4}$ as Alga coralloidcs. In recent times it was brought to the notice of European physicians by O'Shaughnessy. ${ }^{5}$

Description-The plant, which as found in commerce is opaque and white, having been deprived of colour by drying in the sun and air, consists of cylindrical ramifying stems or filaments, $\frac{7}{10}$ of an inch in diameter and from 1 to 6 or more inches in length. The main stems bear numerous branches, simple or giving off slender secondary or tertiary ramifications, ending in a short point. When moistened, the plant increases a little in volume, becomes rather translucent, and frequently exhibits whitish globular or mammiform fruits (cystocarps). It is somewhat friable, and after drying at $100^{\circ} \mathrm{C}$. may easily be powdered. It is devoid of taste and smell, in this respect differing from most sea weeds.

1 A person must eat a pound of stiff jelly madc of the powdercd sen-weed, before he would have swallowed half an ounce of dry solid matter.

2 For convenicnce we accept the popular name of moss, though it is incorrect.

3 The Pharmacopaia of India (1868) names Sphcerococeus confervoides Ag. (Grarilluria (Grev.), a plant of tho Atlantic Ocean and Mediterranean, not uncommon on tho shores of Britain, as furnishing a portion of the drug under notice. Speeimens which we have examined, aro widely diffcrent in strueture from S.lichenoidcs, and are apparently devoid of starch.

${ }^{4}$ Herb. Amboin. vi. lib. xi. c. 56.

5 Indian Joum of MICd. Seicnee, Calcutta, March, 1834; Bengal Dispensatory, 1841. 668. 
Microscopic Structure-'The trinsverse section shows a loose lissue made up of large empty cells, enclosed ly a cortical zone 30 to $70 \mathrm{mkm}$. thick. This zone consists of small cells, loaded witl globular stareli-gramules, from less than 1 up to $3 \mathrm{mkm}$. in diameter, so densely packed as to form what seems at first sight a single mass in each cell. In the:larger cells, the granules are attached to the walls; they ro rot display in polarized light the usual cross. The thick walls of the cells slow a stratified structure, especially after having been moistened with chronic acid; on addition of a solution of iodine in an alkaline indide, they assume a deep brown, but the starch-granules, which also abound in the cystocarps, display the usual blue tint.

Chemical Composition-The drug, as examined by O'Shaughnessy, yielded in 100 parts, of vegetable jelly $54 \cdot 5$, starch $15 \cdot 0$, ligneous fibre (cellulose ?) $18 \cdot 0$, mucilage $4 \cdot 0$, inorganic salts $7 \cdot 5$.

Cold water removes the mucilage, which after due concentration, may be precipitated by neutral acetate of lead. This mucilage when boiled for some time with nitric acid, produces oxalic acid and microscopic crystals of mucic acid (beautifully seen by polarized light), soluble in boiling water and precipitating on cooling. With one part of the drug and 100 parts of boiling water, a thick liquid is obtained which affords transparent precipitates with neutral acetate of lead or alcohol, in tlie same way as carrageen. With 50 parts of water, a transparent tasteless jelly, devoid of viscosity, is produced; in common with the mucilage, it furnishes mucic acid, if treated with nitric acid. Micro-chemical tests do not manifest albuminous matter in this plant.

Some chemists have regarded the jelly extracted by boiling water as identical with pectin, but the fact requires proof. Payen ${ }^{1}$ called it Gelose, and found it composed of carbon 42.77 , hydrogen $5 \cdot 77$, and oxygen $51 \cdot 45$ per cent. Gum Arabic contains carbon $42 \cdot 12$, hydrogen 6.41 and oxygen $51 \cdot 47=\mathrm{C}^{12} \mathrm{H}^{22} \mathrm{O}^{11}$. Payen's gelose imparts a gelatinous consistence to 500 parts of water; it is extracted by boiling water from the plant previously exhausted by cold water slightly acidulated. ${ }^{2}$

The inorganic salts of Ceylon moss consist, according to O'Shaughnessy, of sulphates, phosphates, and chlorides of sodium and calcium, with neither iodide nor bromide. Dried at $100^{\circ} \mathrm{C}$., it yielded us $9 \cdot 15$ per cent. of ash.

Uses-A decoction of Ceylon moss made palatable by sugar and aromatics, has been recommended as a demulcent, and a light article of food for invalids. In the Indian Archipelago and in China, immense quantities of this and of some other species of sea weed ${ }^{3}$ are used for making jelly and for other purposes.

I Comptes Rendus, xlix. (1859) 521; P'harm. Journ. i. (1860) 470.508.

2 Gelose evell in the moist state is but little prone to change, and the jelly made by the Chinese as a swcetmeat which

consists mainly of it, will keep good for year's.

3 Consult Martius, Neucs Jahrb. f. Pharm. Bu. ix. Mrärz 1858; Coole, Pharm. Journ. i. $(1560) 504$. 
INDEX. 



\section{N D E X.}

Natural Orders are printed in small capitals, as ACANTH $\triangle \mathrm{CE}$ E : headings of articles in thick type, as Ammoniacum.

Abelmoschus esculentus . . . . 86 Abies balsamea . . 552 " Canadensis . . 553 " excelsa . . . 556 "pectinata . . 555 Abietic Acid . 548, 559 Abietite . . . . 556 Abrus precatorius . . 164 Abuta rufescens . 29 Abutua . . . . 25 Acacia arabica . . 207 $"$ capensis . . 207 " Catechu . . 213 " dealbata . . 207 " decurrens . . 207 "Fistula - 206, 210 " homalophylla 207 " homalophylla . 207 " horrida . . 207 " mollissima . 207 " nilotica . . 207 , pycnantha . 207

"Seyal . 206, 210

, stenocarpa 206, 210

"Suma . . . 213

"Verek . 206, 210

Acacien-Gumni . . 206 ACANTHACER . . . 424 Acer, sugar - yielding species . . . 656 Acotone in tar . . 562 Acolyctine . . . 10 Aconella . . . 10, 12 Aconite Leaves . . 11 "Root . . 7 $" \quad$ Indian . 12 " $"$ Nepal . 12

\begin{tabular}{|c|c|c|}
\hline & & $\operatorname{AGE}$ \\
\hline Aconitic A & $\operatorname{Acld} \cdot \cdot$ & 12 \\
\hline Acomine & $\cdot$ & 9 \\
\hline conitum & Anthora & 11 \\
\hline " & Cammarum & 11 \\
\hline$"$ & ferox . & 12 \\
\hline$"$ & $\begin{array}{c}\text { heterophyl- } \\
\text { lum . . }\end{array}$ & 14 \\
\hline " & luridum & 13 \\
\hline$"$ & 'Lycoctonum & 11 \\
\hline "9 & Napellus . & 7 \\
\hline$"$ & palmatum . & 13 \\
\hline$"$ & paniculatum & 11 \\
\hline$"$ & Störckeanuun & 11 \\
\hline 3 & uncinatum. & 13 \\
\hline & variegatum. & 11 \\
\hline
\end{tabular}

Acore odorant . . 613

Acorin . . . .615

Acorus Calamus . 613

Acraconitine . . 9

Acrinyl sulpho-cyanate 65 Actra racemosa . . 15

" spicati . . . 3

Adragante . . . 151

Adraganthin . . . 155

Agle Marmelos . 116

Escylic Alcohol . 216

Athusa Cynapium . 269

Agaricus Oreades . . 222

Agropýrum acutum . 664

" junceum . 664

, pungens . 664

" repens .663

Ajowan or Ajvan . 269

Akulkara . . . . 343

Alantcamphor . . . 341

Alantwurzel . . . 340

Alga marina . . 681
Alga Zeylanica . $\begin{gathered}\text { PAGE } \\ \text {. } 681\end{gathered}$

ALG $A$ • . . . 679

Alhagi Camelorum . 371

Allspice • . . . 255

Allyl cyanide . . 63

, sulphocyanide . 62

Almond, bitter . . . 219

, $\quad$ ess. oil of 220,227

" -legumin . . 219

" Oil . . 218

"sweet . . 216

Aloë . • . . 616

," species yielding the drug 616,617

Aloëresic Acic . . 626

Aloëretic Acid . . . 626

Aloëretin . . . 626

Aloes . . . . 616

, Barbados . . 622

" bitter of . . . 626

"Bombay . . . 622

"Cape . . . 622

"Curaça . . . 622

" East Indian . . 622

" hepatic . 621, 622

"Moka. . . 622

"Natal . . . 623

" resin of . 624,626

"Socotrine . .622

" , liquid 622

"Zanzibar . . .622

Aloëtic Acid . . . 627

Aloëtin . . . . 626

Aloïn . . . . . 624

Aloisol . • . . 627

Alorcinic Acid . . . 627 
Alpinia Cardamomum 582 $"$ Galangal . . 582 " oflicinarum . 580 Alstonia constricta . 378 $" \quad$ scholitris . . 378 Althica ofticinalis . . 84 Altingia cxcclsi 242,247 Amandes amères . . 219 , douces . . 216 Amandin . . . 219 Ammi Copticum . . 269 , majus 271

Ammoniacum . . . 288 African 289 Ammoniak-gummilharz 288 Ammoniaque, gommerésinc . . . . 288

Amomum aromaticum 588 Cardamomum 587 Korarina . . 589 maximuin . 589 Melegueta . 590 xanthioides . 587 Zingiber . . 574 AMPELIDEe . . 140 Ampelopsis hederacen 172 Amygdalæ amaræ . 219 "dulces . 216 Amygdalin . . . 220 Amygdalus communis 216,219

Amylum Marantæe . 569 Amyrin . . . . 133 Avacardiacese . 142 Anacyclus officinarum 343 Pyrethrum 342 Anamirta Cocculus . 30 Anamirtic Acid . . 32 Ananto-mul . . . 379 Andrographis panicu-

lata. 424 Andropogon citratus . 660 $" \quad$ laniger . 662 , Nardus . 660 " muricatus 663 "Schœnanthus . 660 Anethene . . . 293 Anethol . . 275, 277 Anethum Fœniculum . 274

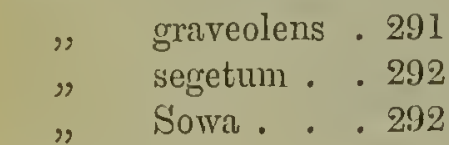

Angelic Acid . . 345
Angelic Acid in Sumbul . . . . . 279 Angelin . . . . 75 Angostura Birk . . 97 Animi . . 131, 135 Anis étoilé . . . $20^{\circ}$ .Anise or Anisced . .276 $"$-crmphor. 275, 277 "Star- . . . 20 Antanul . . . . 382 Anthemic Acid . : 345 Anthemine . . . 345 Anthemis nobilis . . 344 $" \quad$ Pyrethrum 342 Anthophylli . . . 255 Anthracenc . . . . 562 Anthriscus vulgaris . 269 Aphis Chinensis . 539 " Pistacix . . . 146 Apocodeine . . . 55 Apocynez . . . 378 Apomorphine . . . 55 Aporetin . . . . 448 Aqua Aurantii florum 113 " Naphæ . . . 113 Aquilaria Agallocha . 616 Arabic Acid . . . 211 Arabin . . . . 211 Arabisches Gummi . 206 Arachic Acid . 164,376 Arachide . . . .163 Arachis hypogæa . . 163 " oil . . . . 163 Arbol-a-brea . 130, 131 Arbutin . . . . 359 Arbutus Uva-ursi . . 359 Arctostaphylos Uva-

ursi . . . . . . 359

Arctuvin . . . . 359

Areca Catechu . . .607 $"$ nut . . . . 607 " , Catechu 216,608 Arekanüsse . . . .607 Arcnga saccharifera . 655 Argel plant . . . . 194 Aricine . . . . . 321 Aristolochia reticulata 534 " Serpentaria 532 ARISTOLOCHIACE⿺ . 532 Arnica angustifolia . 349

$\begin{array}{llll} & \text { Flowers . } & . & .351 \\ " & \text { montana } & \text {. } & .349 \\ " & \text { Root . . } & . & 349\end{array}$
Arnicin . . . . 350
Arnicine . PAs Arolues: Arrack . . . . 655 Arrowroot . . . 50? $"$ Eust Indian 574 Artanthe adunci . . 592 $" \quad$ elongata. . 531 $" \quad$ lanccicfolial . 582 Artanthic Acid . . 5:31 Artcmisia Cina $\quad$. $\quad 347$ " Lerchcana . 34c; " maritina . 346; $\triangle$ RTOCARP $\triangle$ CEA $\quad .487$ ArundoAmpelodesmos 679 Asafoetida . : . 280 Asagræen officinalis . 633 Asant . . . . 280 Asclepiadex . . $\quad 379$ Asclcpias asthmatica , 382 " gigantea . 380 " Pseudo-sarza 379 Asparagin " in belladonna 412 $"$ in liquorice . 159 Asparagus sarmcntosus 15 Aspartate of ammonium 86 Aspic . . . . . 430 Aspidine . . . . 669 Aspidium Filix-mas . 667 " Oreopteris . 669 Asplenium spinulosum 6369 mina . . . . 669 Assafotida, see Asafœetida.

Assamar . . . . 562 Astragalus adscendens 152 " brachycalyx 152 ", Cylleneus . 152 " gummifcr . 152 " Kurdicus . 152 " microcephalus . . . 152 pycnocladus 152 stromatodes 152 $\mathrm{y}$ ielding manna . 372

Atís or Atees . . . 14 Atraphaxis spinosa , 372 Atropa Belladonna . 409 Atropic Acid . . . 411 Atropinc . . 411, 412 Atrosin . . . . 411 Attar of rose . . . 233 
Attar of rose, adulta- Page ration of . . 237,662 Aunée . . . . 340 AURANTIACEA . . 103 Aurantiin . . . 105 Azadirachita indica . 135

Babul or Babur . 207 Bacce Spina cervinæ . 139 Bactyrilobium Fistula 195 Badiane . . . . 20 Badiyane-khatai . . 22 Bael Fruit . . . . 116 Baldrianwurzel . . . 337 Baliospermum montanum . . . . 510

Balsam, Canada . . 552 "Capivi . . 200 $"$ Copaiba . . 200 " Gurjum . . 81 " of Peru . . 179 $"$ of Tolu . . 177 Balsamo blanco . . 184 Balsamodendron . . 125 Balsamum Canadense 552

" Copaiba . . 200 Dipterocarpi 81 Gurjunæ . . 81 Indicum . . 179 Nucistre . . 456 Peruvianum 179 Styracis . . 241 Tolutanum . 177

Barbaloïn . . . .624

Barberry, Indian . . 33

Barbotine . . . . 346

Bärcntraubenblätter . 359

Bärlappsamen . . . 665

Barley, pearl . . . 657

Barosma betulina . . 99

" Camphor. . 100

$"$ crenata . . 98

" crenulata . . 98

" Eckloniana . 101

" serratifolia . 99

Barras or Galipot . . 547

Bassora Gum . . . 156

Bassorin . . . . 155

Batatas Jalapa . . . 398

Baume de Canada. . 552

$\begin{array}{lll}" & \text { Copahu } .200 \\ " & \text { Pérou . } .179 \\ " & \text { S. Salvador } 179 \\ " & \text { Tolu } \quad . \quad 177\end{array}$

Batumöl .. . $\begin{array}{r}\text { PACR } \\ 374\end{array}$

Bazghanj . . . . 540

Bcurbcriy Leaves . 359

Bebeeru or Bibiru Bark 481

Bebirine or Bibirine . 482

Bcla . . . . . 116

Belladonna Leaves . 411

"Root. . 409

Belladomuine . . . 411

Bendi-kai . . . 86

Benic'Acid . . . . 66

Benjoin . . . . 361

Benné Oil . . . . 425

Benzoëharz . . . 361

Benzoic Acid . . . 365

" " in Balsam.

Peruv. . 182

, in Dragon's

Blood . 611

Benzoin . . . . 361

" Penang . . 364

" Siam . . . 364.

"Sumatra . . 364

Benzylic alcohol . 244

$"$ cinnamate . 183

Berberide. • . . 33

Berberine in Berberis . 35

" in Calumba . 24

, in Coptis . . . 5

" in Podophyllum 37

Berberis aristata . . 33

$\begin{array}{llll}" & \text { asiatica . . } & 33 \\ " & \text { Lycium . } & \text {. } & 33 \\ & \text { vulgaris . . } & 35\end{array}$

Berganot Camphor . 111

$" \quad$ essence of . 108

Bergaptene . . 108, 111

Bertramwurzel . . . 342

Besenginster . . . 148

Beta maritima . . . 655

", -quinine . . .321

Betel Nuts . . . 607

Betelnïsse . . . 607

Betula alba, tar of. . $56 \pm$

Beurle de Cacao . . 87

, "Muscade . 456

Bevilacqua . . . . 264

Bhang . . . . . 493

Bibiric Acid . . . 482

Bibirine . . . . 482

" sulphate . . 482

Bibiru Bark . . . 481

Bigaradier . . . . 111

Bikh .
Bilsenkrint : . . 416

Bish . . . . 12

Bishop's Wecd. . . 269

Bissa 1 bol . . . . 129

Bitter Apple . . . 263

, Wood. . . 118

$" \quad$ Surinam 119

Bittersüss . . . 404

Bitter-sweet . . 404

Bixine.E . . . 70

Blauholz . . . . 186

Blumea balsamifera . 466

Bockshornsamen . . 150

Bois amer . . . . 118

" de Campèche 186

" " gayac . . . 92

, d'Inde . . . 186

" de quassia. . . 118

", santal . . . 510

" " $"$ rouge . 175

Bonduc Seèds . . . 185

Bonplandia trifoliata . 97

Borassus flabelliformis 655

Bormeene or Valerene

$$
340,465
$$

Bormeol . . . . . 465

$"$ in Valerian . 340

Boswellia Bhau-Diljiana . .120

" Carterii . . 120

" Frereana 121, 135

" glabra . . 121

$"$ papyrifera . 121

$"$ sicra . . 120

$"$ serrata . . 121

$"$ thurifera . 121

Botryopsis platyphylla 25

Brasilin . . . . . 189

Brassic Acid . . . 63

Blassica alba . . 64

" juncea . . . 64

$"$ nigra . . . 61

Bramerpech . . . . 559

Brayera anthelmin-

thica . . . . . 228

Brazil wood . . . 189

Brechnïsse . . . 384

Brechwurzel . . . 331

Bréidine . . . . 134

Bréine . . . . 133

Brindonia indica . . 79

Bromaloin . . . . 624

Broom Tops . . 148

Brucine . . 385,388 
Bryoidin . . . . 13:3

Buchu or Bucco Leaves 98

Buckthorn Berries . 139)

Buena hexandra . . 321 " magnifolia . . 326

Bugbane. . . . 15

Buka Leares . . 98

Bukublïtter . . . 98

Bulbus Scilla . . 627

Burseracese • . 120

Busserole . . . 359

Butea frondosa. . . 173

" Kino . . . . 173

» parviflora . . 173

" superba . . . 173

Butua . . . . 25

Butyrum Cacao . . 87

Buxine in Bibiru . . 482 , in Pareira . . 27

Cabbage Rose . . . 232

Cacao Butter . . . 87

Cachou . . . . 213

" jaune on Gambir 298

Cade, huile de . . 563

Cresalpinia Bonduc . 185

" Bonducella 185

, echinata . 288

" Sappan 189, 288

Cajuput Oil . • . 247

Cajuputene or Cajuputol . . . . 248

Calabar Bean . . . 167

Calamus aromaticus . 613 , Draco . . 609

Calisaya Bark . . . 315

Calotropis gigantea . 380

" Hamiltonii. 380

" procera . . 380

Calumba Root . . . 22

Cambogia . . . 77

Camomille Romaine . 344

Campecheholz . . 186

Caruphor, barosma $\cdot 100$

\begin{tabular}{|c|c|}
\hline , & Barus . \\
\hline 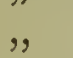 & bergamot \\
\hline , & blumea . \\
\hline & Borneo . \\
\hline , & China . \\
\hline , & cinæebene \\
\hline & common \\
\hline ", & cubebs . \\
\hline " & $\begin{array}{c}\text { dryobala- } \\
\text { nops '. }\end{array}$ \\
\hline
\end{tabular}

Cimphor, Formosa . PAGE:

" Japan . . 46:3

" linurel . . 458

" Malayan . 464

" Neroli . . 114

" ngai . . . 466

$"$ oils . . . 464

$"$ orris . . 601

" sassafias . 484

, thyme 437,438

" tobacco . . 421

Camphora . . . 458

" officinarum 458

Cimphoric Acid . . 463

Camphre . . . . 458

Camphretic Acid . . 463

,", from

galbanum 288

Camphyl alcohol . . 465

Canarium . . . 130

Cane Sugar . . . 649

" $"$ varieties of 655

Canefice . . . . 195

Canella alba . . 68

CANellace

Canellin . . . . 70

Canna Starch . . 573

Cannabene . . . 494

Cannabinea . . . 491

Cannabis Indica . . 491

" sativa . .491

CannaCeE . . . 569

Cannelle blanche . . 68

, de Ceylan . . 466

Capivi . . . . 200

Capnomor . . . 562

Caprifoliace . .297

Capsicin . ... . 408

Capsicum annuum . 406

" fastigiatum. 406

, grossum . 406

$"$ longum . . 406

" minimum . 406

Capsulæ Papaveris . 38

Caqueta Bark . . . 316

Caramelane . . . 655

Caraway . . . . 271

Cardamom . . . 582

" bastard . 587

$"$ Bengal . . 588

" Ceylon . . 585

" cluster . . 587

" Javi . 589

" Korarima . 589
Cilldamom, Malabar PAgre

" Nepal . . 588

round . . 587

Siam . . 587

xanthioid. 587

Carex arenaria . . . 664

Carícæ . . . . . 487

Carmufellic Acid . . 253

Carolina Pink Root . 389

Carony Bark . . . 97

Carrageen . . . . 679

Carthagena Bark . . 316

Carum Carvi . . . 271

" Ridolfia . . 292

Carvene . . . . 273

Carvi . . . . . 271

Carvol . . . . 273

Caryophylli • . . 249

" festucæ vel stipites . 254

Caryophyllin . . . 253

Caryophyllinic Acid . 253

Caryophyllum regium 255

Caryophyllus aromati-

cus . . . . . 249

Caryota urens . . . 655

Cascarilla Bark . . 505

Cascarillin . . . . 507

Casse ou canefice . 195

Cassia acutifolia . 190

" angustifolia - 190

, Bark . . . 474

, Brasiliana . . 197

" buds . . . . 479

, Fistula . . . 195

" grandis . . . 197

" lignea . . . 474

" moschata . . 197

" obovata . . 190

$" \quad$ oil of . : . . 478

" vera Birk . 477

Castor Oil . . . . 512

" , Seeds . . 510

Catechin . . 215, 301 in Kino . . 174

Catechu . . . . 213

"Areca-nut 216, 608

" black . . . 213

" Gambier . . 298

" pale. . . . 298

" pallidum . . 298

" Pegu . . . 213

Catecinuic Acid . 215, 301

Catechuretin . . .216 
Catechu-tannic Acid . PAGE 216 Cathartic Acid . . . 193 Catliartocarpus Fistula 195 Catliartogenic Acid . 193 Catharto-mannite . . 193 Cayenne Pepper . . 406 Cebadilla . . . . 633 Cedrat, essence of . . 115 Centifolienrosen . . 232 Cephaëlis Ipecacuanha 331 Cerasus serotina . . 224 Cerealin . . . . 659 Cerotyl, cerotate . . 53 , palmitate. . 53 Cetraria Islandica . 670 Cetraric Ácid . . 672 Cetrarin . . . . 672 Cevadic Acid . . . 635 Cevadilla . . . 633 Chrrophyllum Anthriscus . . . 269 Chamomile, common . 345 Flowers . 344 Roman . 344

Chanvre indien . . 491 Charas . . . . 494 Chardinia xeranthemoides. . . . 222 Chaulmugra Seed. . 70 Chavica officinarum . 524 " Roxburghii . 524 Chêne, écorce de . . 534 Cherry-laurel Leaves . 226 Chiendent . . . 663 " gros . . 664 Chillies . . . . 406 China bicolorata . . 321 " Carthagène rosé 321 " nova . . . 326 China Root . . . 648 Chinarinde . . . 302 Chinawurzel . . 648 Chinovic Acid . . . 326 Chinovin . . . 326 Chiratin . . . . 393 Chiratogenin . . . 393 Chiretta or Chirayta . 392 Chloraloïn . . . 624 Chloranil. . . . 627 Cholesterin . . . 376 " in barley . 659 in ergot 677,678

Chondodendron tomentosum . . . . 25
PAGE houdodendron tomentosum, stcms of 29

Chondrus crispus $\quad .679$ mammillosus 681 Chop-nut . . . . 167 Christmas Rose . . 1 Chrysammic Acid . . 627 Chrysanthemum Parthenium . . . 345 Chrysophan . . . .448 $" \quad$ in Senna. 193 Chrysophanic Acid . 448 Chrysoretin . . . . 193 Chrysorhamnino . . 140 Churrus . . . . 494 Cicuta virosa 266, 270, 296 Ciguë, feuilles de . . 268 " fruits de. . . 266 Cimicifuga racemosa . 15 Cimicifugin . . . 16 Cinæbene . . . 348 , -camphor . 348 Cinchona, acid principles of . . . 325 Cinchona alkaloids . 322 , " estimation of 327 , propor-

tion in barks . . 324 Cinchona Bark . . 302 " ", chemical composition of 320

$"$ " commerce in 310 $"$ " pale . . 315 $"$ " red . . . 316 " , structure . 317 , ,, yellow . . 315 Cinchona Calisaya . 303

" conspectus of 318 " cultivation of 311 $"$ listory of . 304 " lancifolia $\quad 316$ " officinalis . 303 " Pitayensis 316 " Pitayensis . 316 $" \quad$-red . . . 326 , succirubra . 304 " works relating to . 328 Cinchonicine . . 322 Cinchonidine . 320,323 Cinchonine . . 320,323 Cincho-tannic Acid . 326 Cinchovatine . . . 321 Cinene or Cynenc . . 348
Cimuancin pacie . . . 18i

Cimnamenc . . . 244 Cinnamic Acid. . . 244 " , iuBals.Pcruv. 182 " " Tolut. 179 $"$, in benzoin . 365 " aldeliyde. . . 473 Cinuamodendron . . 19 Cinnamol . . . 244 Cinnamomin . . 473 Cinnamomum Burmanni. . 475 Camphorn . 458 Cassia . . 475 iners . . . 475 obtusifolium 475 pauciflorum . 475 Tamala . . 475

Zeylanicumı 466 Cinuamon . . . 466 " Chinese . 477 " chips . . 472 " lenf, oil of . 474 $"$ oil of . . 473 $"$ root, oil of . 474 Cinnamylic cinnamate 244 Cissampelos Pareira . 28 Cistus ladaniferus . . 373 Citric Acid . . . . 105 Citridic Acid . . . 12 Citron . . . . 103 Citronella Oil . . .660 Citronellul . . . 661 Citrullus Colocynthis. 263 Citrus Aurantium . . 111 $"$ Bergamia . . 108

$"$ Bigaradia . . 111

" decumana . 105

" Limonum 103, 106

$"$ medica . 103, 115

$"$ vulgaris . 111, 113

Claviceps purpurea . 672

Clous de girofles . 249

Clove Leaves . . . 255

"Stalks . . . 254

Cloves . . . . 249

" Mother . . 255

$"$ oil of . . 253

" Royal . . 255

Cniquier . . . . 185

Cocculus Chondoden-

drou . . 25

" cordifolius . 32

"Indicus . 30 Y $Y$ 
Coehlearia Arinoracis:

Cocos nucifera . . . 655 Codamine . . . 55

Codeine . . .54, 55, 58

Colıosh . . . . 15

Coing, semenees de . 239

Colehieeïn . . . . 639

Colchiein 639

Colchieum autummale 636 " other specics 638 $" \quad$ Sẻed . . . 638

Colchique, bulbe de . 636 " seinenee de 638

Colocynth . . . 263

Colocyntheïn . . . 261

Coloeynthin . .. . . 264

Colocynthitin . . . 261

Colombo Root . . . 22

Colophonia Mauritiana 134

Colophony . . . 548

Coloquinte .. . . 263

Coloquintida . . 263

Columba-Bitter . . 24

Columbian Bark . . 316

Columbic Aeid . . . 24

Columbin . . . . 24

Colutea arborescens . 194

Comenic Acid . . . 56

Composita . . . 340

Coneombre purgatif ou

sauvage . . . 260

Conglutin . . . 219

Conhydrine . . . 267

Conia or Conine . .267

Coniferat . . . 545

Coniferin . . . . 597

Conine . . . . 267

Conium maeulatum . 266

Conquinine . . . 320

Convolvulaces . $\quad 394$

Convolvulie Aeid . . 400

Convolvulin . . 400, 404

Convolvulinol . . . 402

Convolvulinolic Acid. 400

Convolvulus Nil . . 402

Purga . . 398

Scammonia 394

Conylene. . . . 267

Copahu . . . . 200

Copaiba or Copaiva . 200

Copaifera bijuga . . 201

$\begin{array}{ll}" & \text { cordifolia } .201 \\ " & \text { coriacea } . .201 \\ " & \text { glabra . . } 201\end{array}$

Copaifera muianensis PAGE "Jacyuini . 201

" Jussieui . . 201

" Langsidorffii 201

" laxa . . 201

" multijugi . 201

$"$ nitida . . 201

$"$ officinalis . 201

" Sellowii . . 201

Copaivic Acid . . . 204

Copalehi Bark . . 507

Coptis Root. . . . 3

"Teetr. . . . 3

$"$ trifolia. . . 5

Coque du Levant . . 30

Coquelicot . . . . 37

Corail des jardins . . 406

Coriander . . . 293

Coriandrum sativum . 293

Coriaria myrtifolia . 194

Cormus Coilchici . . 636

Cortex Alstoniæ . 378

" Angosturæ . 97

Aurantii . . 111

Berberidis . 33

Bibiru . . . 481

Canellæ albæ 68

Cascarillæ . 505

Cassiæ ligneæ 474

Chinæ . . 302

Cinchonæ . 302

Cinnamomi . 466

Cuspariæ . . 97

Eleutherix . 505

Granati fruc-

tus . . . 257

Granati radi-

cis . . 259

Laricis . . 551

Limonis . . 104

Magellanieus . 17

Margosæ . 135

Mezerei . . 486

Mudar . . 380

Nectandræ . 481

Peruvianus . 302

Pruni sero-

tinæ . . 224

Quercus . . 534

Soymidæ . . 137

Swieteniæ . . 137

Thymiamatis . 245

Uimi . . 500

" fulve. 501
Cortex Winteranus. 17

Cotirnine . . 5, 55

Cotoneaster nummu-

laria . . . . 372

Conch Grass . . . 6163

Cowljerry . . . . 360

Cowlange . . . . 1655

Cow-iteh . . . . 165)

Cran de Bretargne . . 66

Cratcua Marmelos . 116

Creasote . . . . 562

Creosol or Kreosol 96, 562

Creyat or Kariyat . . 424

Crinum Asiaticum . 630

" toxiearium . 630

Crocetin . . . . 604

Crocin . . . . 604

Crocus . . . . 601

" sativus . . .601

Croton Casearilla . . 505

" Draco . . . 613

" Eluteria . . 505

$"$ lucidus . . . 507

" nireus . . . 507

$"$ oblongifolius . 510

" Oil . . . . 508

" Pavanx . . 510

" Philippense . 515

$"$ polyandrum . 510

" Pseudo-China 507

$"$ Seeds . . . 508

" Tiglium . . 508

Crotonic Acid . . . 509

Crotonol . . . . 509

Crown Bark . . . . 315

CRUClFER E . . . 61

Cryptopine . . 55, 59

Cubeba canina . . 530

" Clusii . . 530

" Lowong . . 530

$"$ officinalis . . 526

$"$ Wallichii . . 530

Cubebæ . . . . 526

Cubeben . . . . 528

Cubebene, hydrate . 528

Cubebic Acid . . . 529

Cubebin . . . . 528

Cubebs . . . . . 526

$"$ African . . 530

" camphor . . 528

Cuclumber, squirting

or wild . . . 260

Cucunis Colocynthis . 263

Hardwickii . 264 


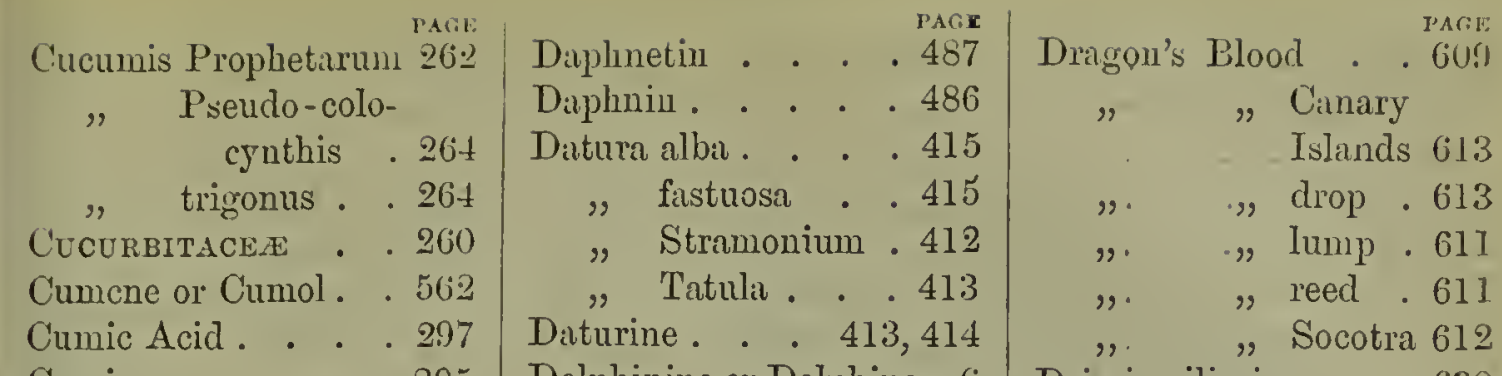

Cumin . . . . . 295

Delphinine or Delphine 6 Delphiniun Staphisagria 5

Desoxycodeine . . 55

Desoxymorphine . . 55

Deuteropine. . . 55

Dextrine. . . . 571

Dextrose. . . . 571

Dhak Tree . . . 173

Digitaléin . . . 423

Digitalin . . . . 423

Digitaliretin . . . 423

Digitalis púrpurea. . 422

Digitasolin . . . 423

Dill . . . . . 291

Dimethylnornarcotine 55

Diospyros Embryopteris . 360

Virginiana 361

Diplolepis Gallæ tinc-

toriæ . . . . 536

DIPTEROCARPEA . . 81

Dipterocarpus alatus . 81

" gracilis . 81

$"$ hispidus . 81

$"$ incanus . 81

$"$ indicus . 81

$"$ lavis . . 81

$" \quad$ littoralis . 82

" retusus . 82

" Spanoghei 82

" trinervis 81

" trinervis . 81

" turbinatus 81

Diserneston gummi-

ferum . . . . 288

Diss . . . . . 679

Ditaïn . . . . 378

Dog's Grass . . . . 663

Dolichos pruriens . . 165

Dorema Amınoniacum 288

Aucheri . . 289

Dæmonorops Draco . 609

Dalleiochine . . 322

Dandelion Root . . 351

Daphne Gnidium . . 487

" Laureola . . 487

" Mezercun . 486
Drinia ciliaris . . .630

Dryobalanops aroma-

tica . 464

Camphora 464

Dulcamara . . . . 40t

Dulcamarine . . . 405

Earth-nut Oil . . 163

Ebenacez.. . . 360

Ecballin ... . . . 262

Ecballium Elaterium . 260

Ecboline . . . . 677

Echinus Philippinensis 515

Echites scholaris . . 378

Ecorce de Winter . . 17

Eibischwurzel . . 84

Eichenrinde. . . 534

Eisenhut . . . . 7, 11

Elaïdic Acid . . . 164

" , from Sesamé 426

Elateric Acid . . . 262

Elaterin . . . . 262

Elaterium Fruit . .260

Elder Flowers . . . 297

Elecampane . . . 340

" Camphor. 341

Elemi.

129

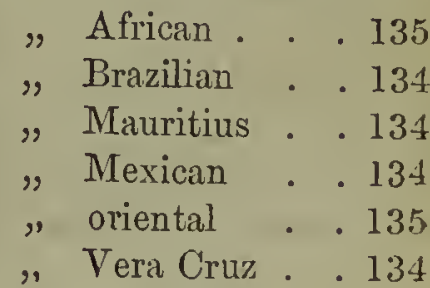

Elettaria Cardamomum 582 major . . 582

Eleutlıera Bark . . 505

Ellagic acid . . . 259

Ellébore blanc . . 630

" noir . . . 1

Elm Bark . . . . 500

" " slippery .501

Embryopteris glutin-

Emetine . . . . 335

$\mathrm{Y} \times 2$
Drimys Winteri . . 17

Elateride. . . . 262

ifera . . . 360 
Empleurum serrula-

tum . . . . . 101

Emulsin . . . . 219

Encens . . . . 120

Enzianwurzel . . . 389

Equisetic Acid . . . 12

Erdnussöl . . . . 163

Ergot of diss . . . 679

, , oat . . 679

" " rye . . 672

" "whent . . 679

Ergota . . . .672

Ergotine . . . . 677

Ericace程 . . . 359

Ericinol . . . . 360

Ericolin . . . . 360

Erucic acid . . .63, 141

Erucin . . . . 66

Erythroretin . . .448

Eseré Nut . . . . 167

Eserine . • . 169

Essigrosenblätter 230

Eucalyptus Kino . . 174

$$
\begin{array}{lll}
" & \text { Manna } & \text {. } 373 \\
" & \text { Oil . . } & .249
\end{array}
$$

Eugenia caryophyllata 249 , Pimenta . . 255

Eugenic Acid . . 253

$" \quad$ " in Canella 70

Eugenol . . . . 253

Eugetic Acid . . . 281

Eulophiayiclding Salep 593

Euphorbia resinifera ..502

Euphorbiaceæ . .502

Euphorbium . . . 502

Euphorbon . . . 501

Eupione . . . . 562

Euryangium Sumbul . 278

Exacum . . . . 393

Exogonium Purga . 398

Extractum Glycyrrhizæ 159

Uncarix . 298

Faba Calabarica . . 167

„Physostigmatis. 167

" Sancti Ignatii . 387

Fafgus silvatica, tar of 564

Farnwurzel . . . 667

Feigen . . . . 487

Fenchel . . . . 274

Tennel . . . . 274

, bitter . . 275
Faci:

Fennel, German . . 275

"Indian. . . 275

" oils of . . 276

" Roman . . 274

" Saxon . . . 275

" sweet . . . 274

$"$ wild . . . 275

Fenouil . . . . 274

Fenugreek . . . 150

Fern Root . . . . 667

Fcronia Elephantum . 117

gum . . . 212

Ferreirca spectabilis . 75

Ferula alliacea. . . 281

" Asafœtida . . 281

" erubescens . . 286

" galbaniflua . . 285

"Narthcx . . 280

" rubricaulis . . 286

" teterrima . . 281

" Tingitana . . 289

Ferulaic Acid . . . 284

Fève de Calabar . . 167

" , Saint Ignace . 387

Feverfew . . . . 345

Fichtenharz . . . 556

Fichtentheer . . 560

Ficus Carica . . . 487

Figs . . . . . 487

Filices . . . . 667

Filicic Acid . . . . 669

Filixolic Acid . . . 669

Filixolin . . . . 669

Filix-red . . . . 669

Filosmylic Acid . . 669

Fingerhutblätter . . 422

Fir, Balsam or balm of

Gilead.

552

„Norway Spruce . 556

"Silver. . . 555

Flachssamen . . 89

Flag, blue . . . 598

$"$ root, sweet . . 613

"yellow. . . 616

Flax Seed . . . 89

Fliederblumen . . . 297

Flores Anthemidis . 341

Arnica . . 351

Cine . . 346

Koso . . 228

Lavandulæ . 482

Rosæ incarnate 232

, pallidw . 232

$"$ rubre . 230
Flores Sambuci PAGiB

I'oniculum Panmorium 275 vulgare .274

Fonum Camelorum . (562

Folia Aconíti . . . 11

" Belladonnxe. . 411

" Buchu . . . 98

"Conii . . 268

" Daturse albæe . 415

" Digitalis . . 422

"Hyoscyami. . 416

"Lauro-cerasí . 226

" Malabathri . . 480

" Sennæe . . . 189

"Tabaci . . . 418

"Tylophoræ . . 382

" Uræ Ursi . . 359

Fool's Parsley . . . 269

Fougère mâle . . . 66 i

Foxglove Leaves . . 422

Frankincense . . 120

" common $5 \pm 9$

Fraxetin . . . . 370

Fraxin . . . .370

Fraxinus excelsior . . $366^{\circ}$

$"$ Ornus . . 366

Fructus Ajowan . .269

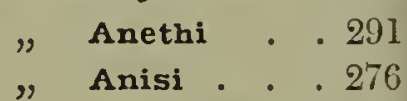

, stellati. 20

Belæ . . 116

Capsici . . 406

Cardamomi . 592

Caricæ . . . 487

Carui . . 271

Cassiæ fistulæ 195

Cocculi. . . 30

Colocynthidis 263

Conii . . . 266

Coriandri $\quad .293$

Cumini . . 295

Diospyri . . 360

Ecballii . . 260

Fœniculi . . 27t

Hibisci . 86

Juniperi . . 565

Limonis . . 103

Mori . . 489

Pimentæ . . 255

Piperis longi 524

nigri 519

Pruni . . . 223

Rhamni . . 139

Rosre caninz 238 
Fucus amylaceus . 681 crispus . . 679

" Hibernicus . . 679

Fucisol . . . . 680

Fuval . . . .672

Furfurol . . . . 562

Fusanus spicatus. 541, 543

Flisti . . . . . 254

Griclinic Acid . . . 164

Galanga major . . 582 minor . . 580

Galangal . . . . 580

" greater . . 582

Galbanum . . . 285

Galgant . . . . 580

Galipea Cusparia $\quad .97$

" officinalis . . 97

Galipot or Barras . . 547

Gallæ Halepenses . 536

Galläpfel. . . . 536

Galle d'Alep . . 536

Gallic Acid from galls 538

Gallo-tannic Acid . . 538

Galls, Aleppo . . . 538

" blue . . . . 537

" Bokhara . . . 540

"Chinese . . . 538

" green . . . 537

"Japanese. . . 538

$"$ oak . . . 536

" pistacia . 146, 540

" tamarisk . . 540

"Turkey . . .536

" white. . . 537

Gambier. . . . 298

Gamboge . . . 77

Ganja . . . . 493

Garcinia indica . . 79

" Morella . 77, 79

" pictoria . . 79

" purpurea. . 79

" Travancorica 79

Garou . . . . . 487

Gayac, bois de . . . 92

" résine de . . 94

Gaz Alefi . . . 372

"-anjabin . . . 371

"Khonsari . . . 372

Gelbwurzel . . . 577

Gelose . . . . 682

Genêt à halais . . . 148

Genièvrc. . . . 565

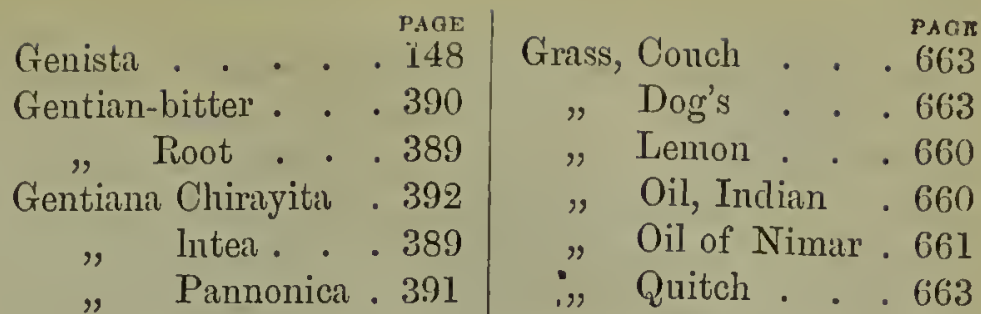

Graswurzel . . . 663

Greenheart Bark . . 481

Grenades, écorce de . 257

Grenadier, écorce de

racine de . . . 259

Grieswurzel . . . 25

Ground-nut Oil . 163

Guaiac Beta-resin . . 96

Guaiac-yellow . . . 96

Guaiacene . . . . 96

Guaiacic Acid . . 95, 96

Guaiacol . . . . 96

Guaiaconic Acid . . $\quad 95$

Guaiacum officinale . 92

Gigartina acicularis . 681

" mammillosa 681

Gingeli Oil . . . . 425

Gingembre . . . 574

Ginger . . . . 574

$"$ grass oil . . 660

Gingili Oil • . . . 425

Ginseng, American . 73

Girofles . . . . 249

" griffes de . . 254

Glandulæ Humuli . 498

$"$ Rottlerie. 515

Glycyrretin . . . 158

Glycyrrhiza echinata . 157

$$
\begin{aligned}
& \text { glabra } \cdot 156 \\
& \quad \text { glanduli- } \\
& \text { fera } .156
\end{aligned}
$$

Glycyrrhizin . . 158

Gombo . . . . 86

Golmme Arabique . .206

" Gutte . . . 77

Gouclron végétal . 560

Gracilaria lichenoides 681

Grains, Guinea. . . 590

" of Paradise . 590

Graincs des Moluques 508

, de Tilly . . 508

Graminex . . . 649

Grana Paradisi . 590

Granatem . . . 257

Granatill . . . .508

Gralnatin . . . . 260

Granatschalen . . 257

Granatwurzclrindc . 259

Granulose . . . 571 $\begin{array}{lll}" & \text { Resin . } ~ & 94 \\ " & \text { sanctum } & 9 \\ " & \text { Wood } & 92\end{array}$

$"$ Wood • . 92

Guaiacyl-hydricle . . 96

Gmaiakharz . . . . 94

Guaiakholz . . . 92

Guaiaretic Acid . 95, 96

Gnajol . . . . 96

Guaza . . . . . 493

Guilandina Bonducella 185

Guimauve . . . . 84

Guinea Grains . . . 590

" Pepper. . . 408

Gulancha . . . 32

Gule-pistall . . . . 540

Gum Arabic . . 206

"Anstralian . . 210

" Barbary . . . 210

" Bassora . . . 156

" Benjamin . . 361

"Cape . . . . 210

"Caramania . . 156

"Eust India . . 210

"Feronia . . . 212

"Gedda . . 208

" Hog . . . . 156

, Jiddah . . . 208

"Mogidor. . . 210

"Morocco . . . 210

"Mosul . . . 156

"Senegal • . 20 ?

"Suakin . . . 210

" Tilea or Talha . 210

"Thus . . . . 510 
Gum Tragacinth. Page "Wattlo . . .210

Gummi Acacixe . 206 Arabicum . 206

Gummigutt . . . 77

Gurjun Balsam . 81

Gurjunic Acid . . . 84

Gutti . . . . 77

Guttifere. . . . 77

Gynocardia odorata . 70

Hrmatein . . . . 188

Hrematoxylin . . . 188

Hrematoxylon Cainpe-

chianuı . . . . 1\&6

Hagebutten . . . 238

Hagenia Abyssinica . 228

Hagenic Acid . . 230

HaMamelided . 241

Hanflkrut . . . 491

Hardwickia pinnata . 205

Hashab . . . . 206

Hishish . . . . .493

Hawkbit . . . . 353

Helenin . . . . . 341

Hellebore, Black . . 1

"White . . 630

, American . 632

Helleborein . . . 3

Helleboresin . . . 2

Helleboretin . . . 3

Helleborin . . . . 2

Helleborus niger . . 1

viridis . 3

Helonias frigida . . 632

Hématine . . . 188

Hemidesmus Indicus . 379

Hemlock Fruits . . 266

Leaves . . 268

Hemp, Indian . . . 491

Henbane Leaves . . 416

Herapathite . . . 323

Herba Andrographi-

dis . . 424

Anthos . . . 438

" Cannabis . . 491

, Chirata . 392

, Hydrocotyles 261

, Lactucæ . 353

" Lobelix . . 357

" Matico . . 531

"Menthr pipe-

ritæe. . 432

Menthæ vixidis 431
Herbats

Herba Pulegii. . . $4: 36$

" Rosmarini . 4:38

" Sabinx . . . 567

" Scoparii . . 148

" stramonii. 412

" Thymivulgaris $4: 37$

Hermodactylus . 638

Hesperidin . . . 101

Hexcnmehl . . . 665

Hibiscus esculentus . 86

Hing and Hingra . . 284

Hips . . . . . 238

Holcus saccharatus .656

Holunderblüthe . 297

Holztheer . . . 560

Hopfen . . . . 495

Hopfenbittersäure . 499

Hopfendrüsen . . . 498

Hopfcnstaub . . . 498

Hops . . . . . . 495

Hordeinic Acid . 659

Hordeum decorti-

catum . 657

, distichum . 657

$"$ perlatum . 657

Horse-radish . . . 66

Houblon . • . . 495

Huile de Cade . . 563

" d'Enfer . . . 375

" fermentée. . 375

" d'Olives . . . 371

" tournante . . 375

Humulus Lupulus . 495

Hydnocarpus . . 70,71

Hydrocotarnine . . 55

Hydrocotyle asiatica . 264

, rotundi-

folia . 266

vulgaris . 266

Hydrocyanic Acid 220, 227

Hydro-elaterin . . . 262

Hydrokinone . . 359

Hyoscine. . . . 418

Hyoscinic Acid . . $41 \mathrm{~s}$

Hyoscyamine . . . 418

Hyoscyamus albus . 418

" insanus . 418

niger . . 416

Hypogreic Acid . . 163

Hypopicrotoxic Acid . 32

Iceland Moss . . . 670

Icica Abilo . . . 129

" various species. 134
Idris yaghi PASit.

Tgasuric Acid * .

Igasurine. . . . 381;

Ignatiana Philippinica 387

Ignatius Bears. . . 387

Illicium anisatum . . 21

religiosumn - 20)

Indian Bael . . . . 116

, Hemp . . . 491

" Pink Root . . 389

" Poke . . 632

Ingwer . . . . .574

Inosite . . 353, 424

Inula Heleniumn . 340

Inulin . . . . 341

" from arnica. . 350

, " taraxacum $35: 3$

Inuloïd . . . . 342

Ionidium . . . . 336

Ipéca sauvage . . . 38:3

Ipecacuanha . . . 331

„ Carthagena 334

" Indian . 382

New Gra-

nada . 334

striated 336,337

undulated 337

Ipecacuanhic Acid . 335

Ipomoea dissecta . . 222

" Jalapa. . . 398

" Purga . . . 398

" simulans . . 402

Ipomœic Acid . 400, 104

IRIDACEA . . . 598

Iris Florentina . . . 598

„ Germanica . . 598

"Nepalensis . . 600

" pallida . . . 598

" Pseudacorus . . 616

Irläudisches Moos . . 679

Isatropic Acid . . . 411

Ishpingo . . . . . 480

Isländisches Moos $\quad 670$

Isobutyric Acid . . 350

Isocajuputene . . 245

Isolusin . . . . . 73

Ispaghứl Seeds . . . 440

Jaggery . . . . . 655

Jalap . • . . . . 393

" fusiform, light, or male • . 401 resin of . . 40()

" stalks or tops. 401 
Jalap, Tampico. . . . 402

"Vera Cluz . . 398

" woody . . . 401

Jalapin . . . . 400

" of Mayer . . 401

$"$ in scammony 396

Jateorhiza palmata . 22

Jervic Acid . . . 631

Jerrine . . . .631

Jinjili Oil . . . . 425

Juckborsten . . . 165

Juncus odoratus . .662

Juniper Berries . . 565

$"$ Tar. . . 563

Juniperin . . . 566

Juniperus communis . 565

$" \quad$ Oxycedrus 563

" Phœnicea. 568

" Sabina. . 567

" Virginiana 568

Jusquiame . . . . 416

Justicia paniculata . 424

Kaddigbeeren . . . 565

Kaladana • . . 402

Kalmus . . . . 613

Kalumbawurzel . . 22

Kamala or Kamela . 515

Kamillen . . . . 344

Kämpferid . . . . 582

Kaneel . . . . 466

Kapila or Kapila-podi 515

Kariyat or Creyat . 424

Kat or Kut . . . . 214

Kayu-pati Oil . . 247

Kikar • . . . . 207

Kinic Acid . . 325, 326

Kino . . . . . 170

$"$ African . . . 173

"Australian . . 174

" Bengal . . . 173

"Botany Bay . 174

$"$ butea . . . 173

$"$ East Indian . 170

" " eucalyptus . . 174

" Gambia . . . 173

" palas or pulas . 173

Kinone • . 325, 359

Kino-red . . . . 172

Kino-tannic Acid . . 172

Kirschlorbcerblätter . 226

Klatschroscn

Knorpeltang
Kokkelskörner • $\quad \begin{array}{r}\text { PAG E } \\ \hline\end{array}$

Kokum Butter. . . 79

Korarina • . . . 589

Kordofan-Gummi . 206

Koriander • . . 293

Kosin . . . . . 229

Koso, Kosso, Koursso . 228

Krameria argentea . 76

$" \quad$ cistoidea . 77

, grandifolia 76

, Ixina . . 76

" secundiflora 77

$"$ tomentosa . 76

" triandra . 74

Kreasote (Creasote) . 562

Kreosol or Creosol 96, 562

Kreuzdornbeeren . . 139

Kreuzkïmmel . . . 295

Kümmel . • • . . 271

,$\quad$ langer oder

Römische. 295

Kurkuma . . . . 577

Kut or Kat . . . . 214

Kyphi . . . . 125

LABIATE. . . . 428

Laburnine . . . 150

Lactic Acid in opinm 56

Lactuca altissima . 354 , sativa . . 354

" Scariola . . 354

$"$ virosa . 353, 354

Lactucarium . . . 354

Lactucerin . . . 356

Lactucic Acid . . 356

Lactrcin . . . . 356

Lactucone . . . 356

Lactucopicrin . . 357

Laituc vireuse . . 353

Lakriz . . . . 159

Lakrizwurzel . . . 156

Lanthopinc . . . 55

Larch Bark . . . . 551

" Turpentine . . 549

Larix Europera . . . 549

"Sibirica .' . 560

Larixin . . . . 552

Larixinic Acid . . 552

Laudanine . . . 55

Laudanosinc . . 55

LAURACEAE . . . . 458

Laurel, Common . . 226

Lauricr-cerise . . . 226
Laurus Camphora. . 458

"Cubeba. . . 530

" Sassafras . . 483

Läusesamen . . 5, 633

Lavandula Spica . . 430

"Stœchas . 430

" vera. . . 428

Lavendelblumen . 428

Lavcuder Flowers . . 428

" oil of . . . 429

Ledebouria hyacinthina . . . . 629

Leguminose . . 148

Leinsamen . . . 89

Lemon . . . . 103

" essence of . . 106

$"$ grass . . . 660

Leontodon hispidus . 353

Taraxacum 351

Leontodonium . . . 352

Lerp . . . . . 373

Lettuce, garden . . 354

" Opium . . 354

", prickly . . 353

Levulin . . . . 353

Levulosan . . . 654

Liane à réglisse . . 164

Lichen Islandicus . 670

"starch . . . 671

LICHENES. . . . 670

Lichenic Acid . . .672

Lichenin . . . . 671

Licheno-stearic Acid . 672

Lignum Aloës . . . 616

"Bràsile . . 189

" Campechianum 186

" Guaiaci . . 92

" Hæmatoxyli. 186

" Pterocarpi . 175

"Quassiæ . . 118

" sanctum . . 92

" Santali . . 540

" santalinum

rubrum . 175

$" \quad$ Vite . . . 92

LILIACE 2 . . . 616

Limettic Acid . . 440

Limon . . . . 103

Limonin . . . . 105

Lin . . . . . 89

LINEE . . . .

Linoleic Acid . . . 90

Linoxyn . . . . 90

Linseed . . . . . 89 
Linum usitatissimum . $\quad 89$ Lippia citriodola . . 661 Liquidambar Altingi-

ana . 217

Formosana . 246

inberbe . . 241

orientalis . 241

styraciflua . 246

Liquiritice radix . . 156 succus . . 159

Liquorice, extract of . 159

"Indian . . 164

" paste . . 161

, root. . 156.

" , Russian 158

" "Spanish 158

" Solazzi . . 161

" Spanish . 159

Lobelacrin . . . 358

Lobelia inflata . . 357

LOBELIACEE • . 357

Lobelianin . . . . 358

Lobelic Acid . . . 359

Lobeliin . . . . 358

Lobelina . . . . 358

LOGANIACEE . . 384

Logwood . . . . 186 extract of . 188

Long Pepper . . . 524

Lopez Root . . . . 101

Löwenzahnwurzel . . 351

Loxa Bark . . . . 315

Luban . . . . 120

, Meyeti . . 135

Lukrabo . . . . 71

Lupulin . . . . . 498

Lupuline (alkaloid) . 498

Lupulinic Grains . . 498

Lupulite . . . . 499

Lupulus . . . . . 495

Lycium . . . . 31

LYCOPODIACE $Æ .665$

Lycopodium . . 665

" clavatum 665

Nace . . . . . 456

, oil of . . . 456

Macene . . . . 457

Macis . . . . 456

Macrotin. . . . 16

Magellanischer Zimmt 17

Magnoliaces . 17

Maha-tita . . . 425
Mralumim Paces

Malabatluri folia . .480

Mile Fern . . . 667

Maleic Acid . . . 504

Malic Acid in euphor-

bium . . . . 504

Mallotus Plilippinen-

sis . . . . 515

MALVACEA . . . 84

Mandeln, bitter . 219

" suisse. . . 216

Mangosteen, oil of $\quad 79$

Maniguette . . . 590

Manihot utilissina . 222

Manna . . . . 366

„ Alhagi . . 371

" Australian . 373

, Briançon . . 373

, flake . . . 368

" Lerp . . . 373

" oak. . . . 372

" -sugar . . 369

" tamarisk . . 371

"Tolfa . . . 368

Mannitan . . . 326

Mannite . . . . 369

,$\quad$ in aconite . 11

,$\quad$ in ergot . . 678

" in taraxacum 353

Mannitic Acid . . . 369

Mannitose . . . 369

Maranta arundinacea. 569

, inclica . . 569

Margarin . . . 376

Margosa Bark . . . 135

Margosic Acid . . . 137

Margosine . . . . 137

Marshmallow Root . 84

Mastich, Alpha-resin 145

" Beta-resin . 145

" Bombay . . 145

" East India . 145

Mastiche . . . 142

Masticin . . . . 145

Maticin . . . .531

Matico . . . . 531

Matricaria Chamo-

milla . 345

$\begin{aligned} & \text { suavealens } 346 \\ \text { Maulbceren . } & 489\end{aligned}$

Meconille . . . 50

Mccrrettig . . . e $\mathbf{e}$

Meerzwiebel . . 627

Melaleuca ericifolin . 249

, Lcucadendron 247

$"$ linariifolia . 249

$"$ minor . . 247

Merantinacex: . 630

Melegueta Pepper . 590

Melezitose . . . 373

Mclia Azadirachta . 135

"Azcdaraclı . . 136

$"$ indica . . 135

Melrace环 . . 135

Melitose . . . . 373

Menispermacex 。 $\quad 22$

Menispermine . . . 32

Menispermum Cocculus 30

Mentha crispa . . 432

" pipcrita . . 432

" Pulegium. . 436

" viridis . . .431

Menthe poivrée . . 432

" pouliot . . 436

Menthol . . . . 434

Mesit . . . . . 562

Mespilodapline . . 485

Metacopaivic Acid 84, 204

Metastyrol . . . 244

Methol . . . . 562

Methyl alcohol in tar. 562

Methylamine in ergot 678

Methylnornarcotine . 55

Mezereon Bark . . 486

Mimosa Catecluu . . 213

" Suma . . . 213

$"$ Sundra . . 213

Mint, Black . . 435

"White . . 435

Mishmi Bitter . . . 3

Mohnkapseln . . . 38

Mohrenkïmmel . 295

Molasses . . . . 657

Momiri . . . . 5

Momordica Elaterium 260

Mor $\Lambda$ CE $\approx$. . . 489

Morelle grimpante . 404

Moringa . . . . 68

Morintannic Acid . . 497

Morpline or Morplia 54

May Applc . . . . 35 ", estimation 59

Mcadow Saffrou . . 636 Mortus alba . . . 490

Meconic Acid . . 56, 59 " uigra . . . 489

Meconidine . . . $55 /$ Moschuswurzel . . 27S 
Moss, Ceylon . . . . 681

"Irish . . . 679

"Jaftina. . . 681

Mother Cloves . . 255

Moussc d'Irlande . . 679 "d'Islande . . 670 " perlée . . .679

Moutarde Anglaise 64 " blanche" . 64 " grise . . 61 " noire . . 61

Mucuna pruriens . . 165 $"$ pruritil . . 165

Mudar . . . . 380

Mudarine . . 381, 382

Mulberries. . . . 489

Mûres . . . . . 489

Muscade. . . 451 " beurre de . 456

Nuskatbliithe . . 456

Muskatbutter . . .456

Muskatnuss •. .451

Muskatnussöl . • . 456

Mustard, black, brown,

$\begin{array}{rrrrr} & \text { red } & . & . & 61 \\ \# & \text { oil of . } & . & 62 \\ \% & \text { white } & . & . & 64\end{array}$

Mutterharz ... . . 285

Muttcrkorn . . . 672

Mutterkïmmel . 295

Mycose . . . 678

Myricylic palmitate . 499

Myristic Acid . . . 456

" „ from kokum 81

" " " orris . 601

Myristica . . . .451

" fatua . . 455

" fragrans . 451

" moschata . 451

" officinalis . 45I

Myristlceж . . . . 451

Myristicene . . . 455

Myristicin . . . 455

Myristicol . . . 455

Myristin . . . 456

Myrocarpus frondosus 184

Myronate of potassium 62

Myrosin . . . 62

Myrospemum Perciræ 179

$"$ toluife-

rum 177

Myroxocarpin . . 184

Myroxylon Percire $\quad 179$

peruiferum 184
Myroxylon Toluifcra . 177

Myrrh . . . . 124

"Arabian . . 129

Myrrha . . . . . 124

Myrtacex . . . 247

Myrtus Pimenta . . 255

Napclline . . 9

Naphthalene . . 562

Narceine. . . 55, 59

Narcotine . . 54, 55, 59

Nardostachys . . 278

Narthex Asafoetida . 280

Nataloïn : . . . 624

Nauclea Gambir . 298

Nectandra cinnamo-

moides. 480

Cymbarum 485

" Rodiæi . . 481

Nectandria . . . 482

Nelkenköpfe . . . 255

Nelkenpfeffer . . . 255

Nelkenstiele . . $25 t$

Nepaline . . . 9

Neroli Camphor . . 114

, oil of . . . 113

Nerprun . . . . 139

Neugewürz . . . 255

Ngai Camphor . . 466

Nicker seeds . . 185

Nicotiana multivalvis 422

" Persica . . 422

", quadrivalvis 422

" repanda. . 422

" rustica . . 421

"Tibacum . 418

Nicotianin . . . .421

Nicotine . . . .420

Nieswurzel . . . 1

weisse . . 630

Nightshade, deadly . 411 woody . 404

Nim Bark . . . . 135

Nipa fruticans . . . 655

Noix d'arec . . . 607

„Igasur . . . 387

" dc muscade . . 451

"vomique . . 384

Normarcotine . . 55

Nunnari Root . . . 379

Nutgalls . . . . 536

Nutmeg . . . . 451

" Butter . . 456
Nutmeg, cxpressed oil

of . . . . . 456

Nuts, Areca . . . 607

" Betel . . . .607

Nux moschata . . . 451

Nux Vomica . . . 384

Oak bark . . . .534

"galls . . . . 536

„manna. . . 372

Ognon marin . . 627

Oil, citronella . . . 660

"geranium . 660,662

"ginger grass . . 660

"lemon grass . . 660

"melissa . . . 660

"Namur or Nimar 661

", palmarosa . . . 662

"rusa . . 660,662

" theobroma • 87

"verbena. • . 660

Okro . . . . 86

Olea cuspidata . • 374

" Europen . . . 374

OLEACE

Oleic Acid in almonds 219

" $"$ in arachis . 163

Olein . . . . . . 376

Oleum Andropogonis 660

Arachis . . 163

Aurantii flormm113

Bergamii . . 108

Bergamottæ 108

Cacao . . 87

cadinum . . 563

Cajuputi . . 247

Crotonis . . 508

Garciniæ . . 79

Graminis In-

dici . . 660

Juniperi empy-

reumaticum 563

Limonis . . 106

Macidis . . 456

Myristicæ expres-

sum . . . 456

Neroli . . 113

Nucistre . . 456

Olivæ . . . 374

Rosæ . . 233

Sesami . . 425

Spicee . . 430

Theobromatis. 87

Tiglii . . 50s 
PAnE

Olíbanum . . . . 120

Olive oil . . . . 374

Olivenöl . . . . . 374

Onin . . . . 269

Opliclia augustifolia . 393

$\begin{array}{lll}\text { " Chilata } & \text { - } 392 \\ \text { " densifolia: } & \text {. } 393 \\ \text { " } & \text { elegans } ~ & \text {. } 393 \\ \text {, multiflora } & \text {. } 393\end{array}$

Ophelic Acid . . 393

Opianic Acid . . 54

Opianyl . . . . 56

Opium . . . . 40

, Abkari. . . 49

" of Asia Minor 43

"Clinese . . 50

"Constantinople 43

"East Indian . 47

, Egyptian . . 45

" European . . 46

"Malwal . . 50

$\therefore$ Patina . 48, 58

$\because$ Persian . . 45

"Smyrna . . 43

, Turkej • . . 43

Opopinax . • . . 291

Orange, Bigalade . . 111

, bitter . . . 111

, Flower Water 113

$"$ Peel . . 111

", oil of . 115

" Seville. . 111

ORCHIDACEA . . 592

Orchis, species yielding

Salep . . 592, 593

Ordeal Bean . . . 167

Oreodiphne opifera . 485

Orge mondé ou perlé . 657

Orizaba Root . . . 401

Orme . . . . . 500

Ornithogalum altissi-

mum . . . . 639

Ornus Europrea . 366

Orris Camphor . . 601

, Root . . . .598

Otto of Rose . . . 233

Oxyacanthine . . . 35

Oxycamphor . . 463

Oxycannabin . . 494

Oxycopaïvic Acid. . 204

Oxylinoleic Acid . . 90

Palas Tree . . . . 173

Palma Christi Seeds . 510
PALMA . . . 607

Palmarosia Oil . . 662

Palniitic Acid . . 376

, in arachis 163

Palo del Śoldato . . 531

Panax quinquefolium

73,534

Papaver dubium . . 37

$\because \quad$ officinale . . 38

"Rhocas. . . 37

" setigerum . . 38

" somniferum . 38

Papiveracez $\quad \cdot \quad 37$

Papaveric Acid . . 38

Papaverïn . . . 40

Papaverine . . 55, 59

Papaverosine . . 40

Paracajuputene . . 248

Paracumaric Acid. . 626

Paradieskörner. . . 590

Paradigitaletin. . . 423

Paraffiu . . . 562

Paramenispermine . 32

Para-oxybenzoic Acid from aloes. . 627 " "benzoin . . 365 " " dragon's blood 612

Pareira Brava . . . 25 " " false . 28

" " white. 29

$"$ " yellow 30

Paricine . . . . 321

Parigenin . . . . 647

Pariglina . . . 646

Parillin . . . . 646

Parillinic Acid. . 646

Passulæ majores . 140

Parot. . . . 38

Paytine . . . . 322

Peach wood . . . . 186

Pellitory Root . . . 342

Pelosine in bibiru . . 482

, in pareira . 27

Pennyroyal . . . 436

Pennywort, Indian . 264

Pepper, black . . . 519

" African . 530

" Cayenne . . 406

$"$ Grinea. . . 406

" Jamaica . . 255

$" \quad$ long. . . .524

$"$ pod or red. . 406

" white. . . 523

Peppernint. . . 432
Peppemint camphor 。 434

$"$ oil . . . 4i3t

" ,Chinese 434

Periploca indica . . 379

Perlınoos . . . . 679

Perubalsam . . . 179

Peruvian Bark . . 302

Peruvin . . . . 18:3

Petala Rhœados . $\quad 37$

"Rosx centifolix 232

" " Gallica . 230

Petit Grain, essence . 115

Pfeffer ' . . . . 519

$"$ langer . . . 524

"Spanischer .406

Pfefferminze . . . 4332

Pfriemenkraut . . 148

Phæoretin . . . 448

Pharbitis Nil . . 402

Pharbitisin . . . 404

Phenol . . . . 179

Phloroglucin from cate-

chin . . . . 216

, , dragon's

blood . 612

" , gamiboge 79

" "kino. . 172

" , scoparin 149

Phœnix silvestris . . 655

Photo-santonin . 349

Phyco-erythrin . . .680

Pliysostigma reneno-

sum . . . . 167

Physostigmine . . 169

Pichurim Beans . . 485

Picræna excelsa . . 118

Picrasma excelsa . . 118

Picric Acid . . . .627

Picrotoxin . . . 31

Pignons d'Inde . . 508

Pimaric Acid . 548, 559

Piment des Anglais . 255

" , jardins . 406

Pimenta acris . . 257

officinalis .255

" Pimento . . 257

Pimento . . . . 255

Pimienta de Tabasco . 257

Pimpinella Anisum . 276

Pine, loblolly . . . 545

, Scotch . . . 545

$"$ swamp . . . 545

Pinic Acid . . . 548

Pink Root . . . 389 
Pintar

Pinus Abies . . . 556

,$\quad$ australis. . . 545

"balsamea . . 552

" Canadcnsis . . 553

" Cedrus . . . 373

" Fraceri . . 553

" Laricio . . . 545

" Larix . . . 549

" Ledebourii . . 560

" maritima .545

$"$ palustris . . 545

" Picen . . .555

$"$ Pinlister . . 545

" Pumilio . . 554

$"$ silvestris . .545, 560

"Treda . . . 545

Piper aduncum . . 532

" angustifolinm . 531

., Betle . . . 525

" caninum . . 530

" Clusii . . . 530

" crassipes . . . 530

" Cubeba . . . 526

, lancerfolium . 532

" longum . . . 524

" Lowong . . . 530

$"$ nigrum . . . 519

" officinarum . . 524

" ribesioides . .530

Piperaceæ . . . 519

Piperic Acid . . . 523

Piperidin . . . 523

Piperin . . . . 523

Pipli-mul . . 525, 526

Pirus Cydonia . . 239

" glabra. . . 373

Pissenlit . . . . 351

Pistache de terre . . 163

Pistacia Atlanticil . . 146

" Cabulica 145, 146

$"$ galls . . .540

" Khinjuk . . 145

" Lentiscus . . 142

" Palostina. . 146

"Terebinthus . 146

Pitayo Bark . . . 317

Pitch, black . . . 564

" Burgundy . . 556

Pitoya Bark . . . 321

Pitoyine . . . . 321

Pix abictina . . . 556

, Burgunciica . . 556

" liquida. . . 560

, navalis. . . 564
Pix nigra . . . 564

, sicca . . . . 564

"solida . . . 564

Plantalinez. . . 440

Plantago Cynops . . 441

$"$ decumbens . 440

"Ispaghula . 440

" Psyllium . . 44]

Plocaria candida . . 681

Plösslea floribunda . 121

Poaya . . . . 332

Pockholz . . . 92

Podophyllin . . . 36

Podophyllum peltatum 35

, resin . 36

Pois à gratter . . . 165

"Guénic . . . 185

"pouillieux. . . 165

"Quéniques . . 185

Poivre . . . . . 519

,, de Guinée . . 406

$"$ d'Inde . . . 406

" de li Jamaïque 255

", loug . . . .524

Poix de Bourgogne . 556

" jaune. . . 556

" liquide . . .560

$"$ noire . . . .564

, des Vosges . . 556

Poke, Indian . . . 632

Polei . . . . . 436

Polychroit . . . 604

Polygala Senega . . 72

PoLYGLlem . . 72

Polygalic Acid . . 73

Polygonacez . 442

Pomegranate Feel . . 257

Pomegranate-root Bark 259

Pomeranzenschale. . 111

Pontefract Cakes . . 162

Poppy Capsules . . 38

, Heads . . 38

$"$ red . . . 37

Potato Starch . . . 573

Pouliot vulgaire . . 436

Prophetin . . . 262

Protocatechuic Acid

from Kino . 172

" " Scoparin 149

Protopine . . . 55

Provencer Oel . . . 37t

Pruneaux ì médecine 223

Prunes

Prunier de St. Julien 223
Prunus Amygdalus . 219 domestica . . 223

" Lauro-cerasus 226

" œeconomica . 224

$"$ serotina . . 224

$"$ Virginiana . 224

Pseud-aconitine . . 9

Pseudo-morpline . 55, 58

Psychotria emetica . 336

Pteritannic Acid . 669

Pterocarpus Draco . 613 erinaceus . 173 indicus . . 170

Marsupium 170 santalinus . 175

Ptychotis Ajowan . 269

"Coptica . 269

Puchury Beans. . . 485

Punica Granatum . . 257

Punicin . . . . 260

Punico-tannic Acid . 259

Purgo macho . . . 401

Purga de Sierra Gorda 402

Purgirkörner . . . 508

Pyrèthre. . . . 342

Pyrethrin . . . 343

Pyrocatechin from

Areca nut . 608

$"$ from bearberry. 358

" , cutch . . . 216

" , kino $172,173,174$

, in tar . 561, 562

Pyro-guaiacic Acid . 96

, guaiacin . . . 96

Pyroleum Oxycedri . 563

Pyroligneous Acid . 562

Qimnab . . . . 493

Quartenylic Acid . 509

Quassia anara . 118, 119

,, excelsa . . 118

"Wood . . . 118

, $\quad$ Surinam 119

Quassiin . . . . 119

Queckenwurzel. . .663

Quercetin . 216,301

Quercin . . . .536;

Quercitannic Acid . 535

Quercitrin . . . 231

Qucreus infectoria. . 536

" Lusitanica . . 536

"Robur. . . .53t

" species yielding

Manna . . 372 
Quetschen or '/wet-Pagis schen . . . . 224

Quinamine . 320, 32-t Quince, Bengal . . 11 (; Seeds . . 23!) Quinieine . . . 321 Quinidine . . 320,32:3 Quinine . . 320,322 " iodo-sulphate. 323 Quinoidine . . . 322 Quinone or Kinone 326, 359 Quinovic or Chinovic

Acid . . . . 326 Quinovin or Chinovin 326 Quinquina • . . 302 Quitch Grass . . . 663 Quittensamen . . 239

Radix Abri . . . 164

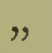

,

\begin{tabular}{|c|c|}
\hline Althææ . & \\
\hline Armoraciæ & \\
\hline Arnicæ . & \\
\hline Belladonnx & \\
\hline nbæ . & \\
\hline
\end{tabular}
"oceidentalis 649 Cimicifugæ . 15 Columbo . . 22 Ellebori nigri . 1 Enulæ . . . 34n Filicis . . 667

Gentianæ . 389

Glycyrrhizæ . 156 Graminis . . 6063 Helenii . . 340 Hellebori albi . 630 Hellebori nigri 1 Hemidesmi . 379 Inula . . 340 Ipecacuanhæ 331 Jalapæ . . 398 Kramerix . . 74 Lopeziana . . 101 Melampodii . 1 Pyrethri . $3 \pm 2$ Ratanhix . . 74 Rhei . . . 442 Sarsaparillx . 639 Sassafras . . 483
Radix Satyrii .

$"$ Sealmmonia . $3 ! 17$

$"$ Senegx. . . 72

$" \quad$ Serpentarix . 5132

$"$ Spigelix . . 389

" Sumbul . . 278

" Taraxaci . . 301

"Toddalize . . 101

" Tylophore. . $38: 3$

" Valerianæ. . 3:37

Raifort 60

Raisins 140

Ranunculaces . . 1

Rasamala . . 242, 247

Rilsot or Rusot . . . 34

Rattanliit-red . . 75

" -tannie aeid. 75

Ratanhiawurzel . 74

Ratanhin. . . . 75

Red Poppy Petals . . 37

"Sanders Wood . 175

Réglisse . . . . 156

" d'Amérique . 164

" suc de. . 159

Reseda lutea . . 63

" luteola. . . 63

Resina Benzoë . . 361

"Druleonis . . 609

"Guaiaci . . 94

", Jalipe. . . 400

" Podophylli . 37

" Scammonix . 397

Resorein . . 176, 288

Rhabarber . . . 442

Rhabarberin . . 448

Rhabarbie Aeid . . 448

Rhamnacese . . 139

Rhamnegine . . . 140

Rhamnetin . . . 140

Rhamnetine. . . 140

Rhamnine . . . 140

Rhamnocathartin . . 139

Rhamnus eathartica . 139

Rhatania Root . . . $7 \frac{1}{4}$

Rlatiny, Brazilian . 76

" New Granada 76

, Pará . . . 76

"Payta . . 74

" Peruvian . . 74

" Savanilla. . 76

Rheïn . . . . . . 448

Rheo-tamnie Acid . . 448

Rhenm australe . . t5l

eompactum . 450
Rhoum Emori offieinale . . 442 palusatum . . 450 Rhaponticun 4.50) undulatum . 4501

Rheumic Acid . . . 448

Rheumin. . . . 418

Rhizoma Calami aromaticí . 613

Coptidis . . :3

Curcumx . . 577

Filicis . . . 6607

Galangुæ . . 580

Graminis . . $60 \% 3$

Iridis . . . 598

Podophylli . 35

Veratri albi . 630

, viridis 632

Zingiberis . 574

Rhœadic A eid . . . 38

Rhœadine $38,40,55,59$

Rhœagenine. . . . 55

Rhubarb. . . . 442

" Cinton . . 445

China . . 445

erown . . 445

East India . 445

English . . 449

French . . 450

German . . 450

Museovitic . 445

Russian . . 445

Turkey . . 445

Rhubarb-bitter . . 448

Rhubarb-yellow . . 448

Rhus Bueki-amela . 538

„ Coriaria . . . 538

" semialata. . . 538

Richardsonia seabra . 337

Rieineläidie Acid . . 513

Ricinclaïlin . . . . 513

Rieinine . . . . 513

Rieinoleie Acid . . 513

Rieinus communis . .510

Röhreneassie . . . 195

Rohrzueker . . . .649

Rohun Bark . . . 137

Romarin . . . . 438

Rosa bifera . . . .232

, canina . . 236, 238

" centifolia . . . 232

"Daniscena . . 233

" Gallica . . . 2:30

Ros.lce.e . . . $21(i$ 


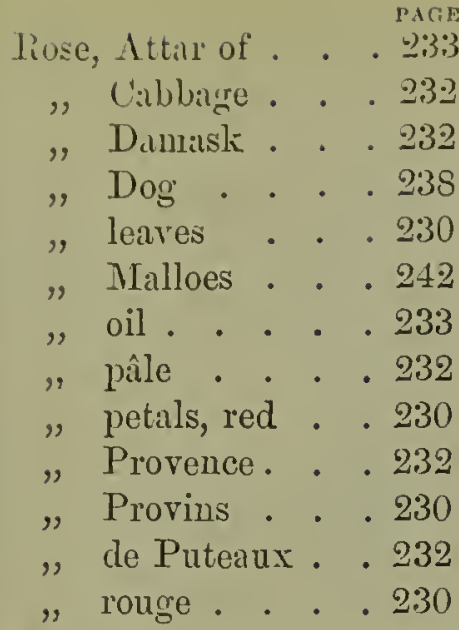

Roseau aromatique . 613

Rosemary . . . 438

$"$ oil of . . 439

Rosenöl . . . . 233

Rosin, black . . 548

" transparent . 548

$"$ yellow . . . 548

Rosinen . . . . 140

Rosmarinus officinalis $4: 38$

Rosocyanin . . . 579

Rottlera tinctoria . . 515

Rottlerin . . . 517

Rubiaced . . . 298

Ruby Wood . . . 175

Rusa ka tel . . . 660

Rusot or Rasot . . . 34

Rüsterrinde . . . 500

Rutacese . . . 97

Rye, spurred . . 672

Sabadilla officinarum. 633

Sabadillic Acid . . 635

Sibadilline . . . 635

Sabatrine . . . 635

Sabine . . . .567

Sabzi . . . . . 493

Saccharum . . . 649

" officinarum 649

Saffron . . . 601

" meadow . . 636

Safran . . . . 601

Safrene . . . . . 484

Safrol . . . . 484

Sagapenum . . . . 291

Salad Oil 1. . . . .374

Salep . . . . 592

Salib misri . . . . . 593

Salicylic Acir . . . 253

Salix fragilis . . $\quad 373$

Salseparcille

639

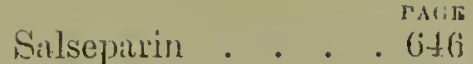

Samiaderr indical . 120

Sambolit . . . 278

Sambucus nigria . .297

Sindal Wood . . . 540

$" \quad \# \quad$ red . . 175

Sandelloolz . . . 540 rothes . . 175

Sanders Wood, red . 175

Sang-dragon . . . 609

Sanguis Draconis . 609

Santal . . . . 176

Santal citrin, bois de . 540

Santalacere . . 540

Santalic Acid . . . 176

Santalin . . . . 176

Santalum album . . 540

"Austro-caledonidicum . . 540

cygnorum . . 541

" Freycinetianum. 540

" pyrularium . . 540

" rubrum . . . 175

" spicatum . . . 541

"Yasi . . . 540

Santonic Acid . . 349

Santonica . . . 346

Santonin . . . . 348

Santoninic Acid . . 349

Sapogenin . . . 73

Saponin . . . . 37

Sarothamnus vulgaris 148

Sarsa . . . . 639

Sarsaparilla . . . 639

\begin{tabular}{|c|c|c|}
\hline & Brazilian & .64 \\
\hline & Guatemala & 64 \\
\hline & Guayaquil & .64 \\
\hline & Honduras . & \\
\hline & Indian . & \\
\hline & Jamaica & \\
\hline & Lisbon . & \\
\hline & Mexicin & \\
\hline & Pará. . & \\
\hline
\end{tabular}

Sarza . . . . . 639

Sassafras Bark . . . 483

" Camphor. . 484

$" \quad$ Nuts . . .485

" officinale. . 483

" Oil 203, 484, 485

" Root . . . 483

Sassafrasholz . . . 483

Sassafrid. . . . 485

Sassafrin . . . . 485

Sassurubiu . . . 485
Satyrii maldix . . . 592

Sivin . . . . 567

Scammonium . . . 394

Scammony . . . 394

$" \quad$ resin . . 397

" root . . 397

Schierlingsblätter . . 268

Schierlingsfrucht . . 266

Schiffspech . . . . 564

Schlangenwurzel . . 532

Schœnanthus . . . 662

Schœenocaulon offici-

nale . . . . 633

Schusterpecli . . 564

Schwarzes Pech . . 564

Scilla indica. . . 629

" maritima . . 627

Scillitin . . . 629

Sclerotium Clavus . 675

Scoparii cacumina . 148

Scoparin . . . . 149

Scorodosma foetidum . 280

Scrophularia frigida . 373

SCrophulariace. .422

Secale cornutum . . 672

Seidelbaste-Rinde . . 486

Seigle ergoté . . . 672

Semen Ajavæ . . 269

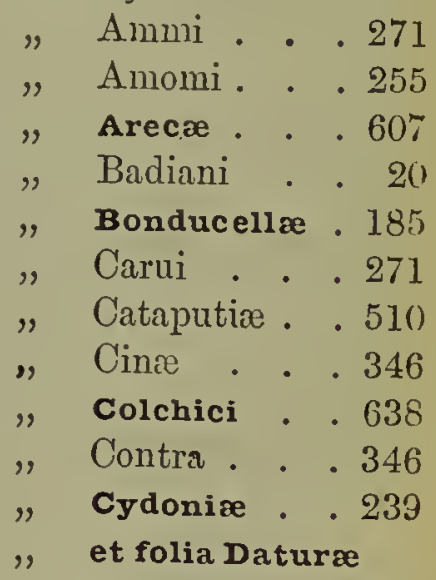

albæ .

415

Fœni-græci . 150

Gynocardiæ . 70

Iguatii . . . 387

Ispaghulæ . 440

Kaladanæ . 402

Lini . . . 89

Nucis vomice 384

Physostigma-

tis. . . . 167

Ricini . . 510

Sabadillæ . .63:3

sanctum . . 346

Santonica . . 346 
PACI:

Scmen Sinapis nigrae (il

\begin{tabular}{|c|c|c|}
\hline ? & albae & $6+1$ \\
\hline " & Staphisagria & \\
\hline , & Stramonil. & - 411 \\
\hline$"$ & Tiglii . & 508 \\
\hline & Zedonrie & 34 \\
\hline
\end{tabular}

Scnicncine . . . . 316

Séné, fcuilles de . 189

Senega Root . . . 72

Senegin . . . . 73

Scnelia Root . . . 72

Scnf, schwarzcr . . 61

"weisser . . 64

Senna... . . . 189

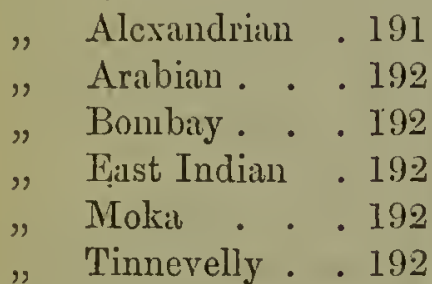

Sennacrol . . . 193

Sennapicrin . . . 193

Serpentaire . . . 532

Serpentary Root . . 532

Sesamé Oil . . . 425

Sesamex . . . 425

Sesamöl. . . . . 425

Sesamum indicum . 425

Setæ Mucunæ . . 165

Setwall . . . . 338

Sevenkriut . . .567

Shir-khisht . . . 372

Siddhi . . . . 493

Simaruba excelsa . . 118

Simapubee. . . 118

Sinalbin . . . . 65

Sinapic Acid . . 66

Sinapine, sulphate . 65

Sinapis alba . . . 64

$"$ juncea . . 64

" nigṛa . . . 61

Sinapoleic Acid . . 63

Sinigrin . . . . 62

Sireh Grass . . . 660

Sison Amomum . . 271

Skuleïn . . . . 629

Slevogtia orientalis . 393

SMiLACEA . . . . 639

Smilacin . . . . 646

Smilix Balbisiana. . 649

" Brissilicnsis . 649

"China . . 648

" cordata-ovata. 641

"ferox . . 648
Sunilax glablral . . .

"Jipicinga . . (449)

$"$ lancerfolia . 648

" medicis . . . 640

$"$ officinalis . . 639

$"$ palpyraccir . . 641

" Psendo-China 649

" Purhampuy .641

"Schomburg-

kiana . . . 441

" syphilitica . .640

" syringoides . 649

" tamnoides . .6.19

Snalke-root, black . . 15

" Red River 534

" Texan . . 534

" Virginian 532

Socaloin . . . . 625

SOlaANaCEe. . . 404

Solanicine . . . 405

Solanidine . . .405

Solanine . . . 405

Solanum Dulcamara . 404

$" \quad$ nigrum . . 405

$"$ tuberosum . 573

Solazzi Juice . . . 161

Solenostemma Argel . 194

Sont . . . . 207

Sorghum saccharatum 656

Soymida febrifugal . 137

Spanish Juice . . . 159

Sparteine . . . 149

Spartiun Scoparium . 148

Spearmint . . . 431

Spermodia Clavus . 675

Sphacelia segetum . 675

Sphærococcus lichen-

oides . . . . . 681

Spigelia Marilandica . 389

Spike, oil of . . . 430

Spogel Seeds . . . 440

Springgurke.. . . 260

Spurred Rye . . 672

Squill . . . . .627

Squinanthus . . 662

Squine . . . 648

Stacte . . . . 126

Staphisagrine . . 7

Staphisaigre. . . 5

Staphisaïne . . . 6

Star-Anise . . . 20

Starch, Cannit. . . 573

" chemistry of . 571

$"$ Gurcuma . . 574
Starch, Potato .

$"$ structure of . 571

Stalvesicle . . . 5

Stearoplimic Acid . 32

Stechapfelbliittcr . . 412

Stcchaptelsanen . . 414

Stcplıanskümer . . 5

Sterculace. $\quad . \quad 87$

Sterianis . . . 20

Stinkasant . . . 280

Stipes Dulcamaræ . 404

Stizolobium pruriens. 165

Storax, liquid . . . 241

$"$ true . . . 246

Stramoine, herbe . .412

semences . 414

Stramonium . . . 412 $" \quad$ Seeds . 414

Strobili Humuli . . 495

Strychnic Acid . . 386

Strychnine . . 385, 388

Strychnos colubrina . 386

, Ignatii . . 387

" Nux-vomica 384

Philippensis 387

Tieute . . 386

Sturmihut . . 7,11

Styphnic Acid . . 288

STYRACE E . . . 361

Styracin . . . . 244

Styrax Benzoin . . 361

" calamita . . 245

"Finlaysonianum 361

, liquida . . 241

officinale . . 246

subdenticulatum 365

Styrol. . . . . 244

, from Balsam of

Tolu . 179

" " Benzoin . 365

, , Dragon's

Blood . 611

Styrone . . . . . 244

Suc d'Aloès . . . . 616

Succus Glycyrrhizæ 159

Sucre de canne. . . 649

Sucrose . . . . 649

Sugar . . . . . 649

$"$ bect root. . 655

" burnt . . . 65.5

" niaple. . . 656

" palu . . . 655

" sorglium . . . 656

Sumbul Root . . . 278 
\begin{tabular}{ll|ll} 
Sumbulamic Acid. & .279 & Térébenthine de Chio & Page \\
116
\end{tabular}

Sumbulic Acid .

Sumbulin . . . . 279

Sumbulolic Acid . $\quad 279$

Sureau . . . . 297

Süssholz . . . . . 156

Sweet Flag root .. . 613

Gum. . . 246

Wood bark . 505

Swietenia febrifuga .137

Sylvic Acid . . 548, 559

Synanthrose .. . . 342

Syrup, golden . . . 657

Syrupus communis $\cdot 657$

, Hollandicus . 657

Tabac . . . . . 418

Tabakblätter . . . 418

Taj-pat . . . . .480

Talch or Talha . 206, 210

Tamarind . . . 197

Tamarindi pulpa . .197

Tarnarindus indica . 197

" occicdentalis 198

Tamarix gallica . . 371

" orientalis . . 540

Tamnaspidic Acid . . 669

Tannenharz . . . 556

Tannic Acid from galls 538

Tar

" beech . . . 564

" birch. . . . .564

" juniper . . . .563

" oil of. . . . .56t

, water . . . 563

Taraxacerin . . . 353

Taraxacin . . . 353

Taraxacum Dens-leonis 351

officinale . 351

Tecamez Bark . . . 321

Teel Oil . . . . 425

Tephrosia Apollinea . 194

Terebinthina Argen-

toratensis 555

Canadensis 552

Chia . . 146

Cypria . . 140

laricina . . 519

Veneta . 519

vulgaris . $5 \pm 5$

Térébenthine d'Alsace 555

" de Briançon . 549

" de Canada . 552
" de Chypres . 146

$"$ commune. . 545

" clu mélèze. . 549

" du sapin . . 555

" de Strasbonrg 555

" de Venise. . 549

Terpenthin, Chios . 146

"Cyprischer . . 146

" gemeine . . . 545

"Lärchen-. . . 549

"Strassburger . 555

"Venetianischer . 549

Terra Japonica (catechu) .213

" " (Gambier) 298

Tetracetylene . . . 244

Thalictrum foliolosum 5

Thalleioquin . . . 322

Thallochlor . • . 672

Thebaicine . . . 55

Thebaine. . . 55, 58

Thebenine . . . 55

Thebolactic Acid . . 56

Theobroma Cacao . . 87

" leiocarpum . . $\varepsilon 7$

$"$ oil of . . . . 87

" pentagonum. . 87

"Salzmannianum 87

Thornapple . . . 412

Thridace . . . . 354

Thus Americanum 549

" masculum. . . 120

" vulgare . . . 549

Thyme . . . . 437

" Camphor . . 437

$"$ oil of . . . 435

Thrmele.e . . . 486

Thymene . . . 438

Thymiankraut . . .437

Thymol . . . . 438

, from ajowan . 270

Thymus vulgaris . . 437

Tigala. . . . . 373

Tiglinic Acid . . . 509

Tiglium officinale . . 508

Tikhar or Tikor . . 574

Til Oil . . . . . 425

Tinospora cordifolia . 32

" crispa . . 33

Tita . . . . 4

Tobicco . . . 418

" Camphor . . 421

$"$ Indian . . 357
Toddalia aculeata . . 101

Toddy . . . . 655

Tolene . . . . 179

Tollkraut . . . 411

Tolomane . . . 573

Tolubalsam . . . . 177

Toluene . . . . 562

Toluifera Balsamum . 177

Toluol or Toluene 1S3, 562

" from Dragon's

Blood . . 611

Toulema . . . . 573

Tous-les-mois . . 573

Toute-épice . . . 255

Tragacanth, flake . . 154

,$\quad$ Syrian . 155

" vermicelli 154

Tragacantha . . . 151

Traganthin . . . 155

Treacle or Molasses . 657

Trehala . . . . 373

Trehaloșe . . . 878

Trigonella Fœnum-

grrecum . . . 150

Trimethylamine

in ergot . 678

" in hop . 498

Triolein . . . . 376

Tripalmitin . . . 376

Triticin . . . .664

Triticum repens . . 663

Tropic Acid . . . . 411

Tropine . . . .411

Tuber Chinæ . . .648

Turanjabin . . . . 37 I

Turmeric. . . . . 577

Turpentine, American 547

" Bordeaux . 547

" Canadian . 552

" Chian . . 146

" common . 545

" Cyprian . 146

" larch . . 549

, Strassburg 555

$"$ Venice . 549

Tylophora asthmatica 392

Tyrosin . . . . 75

ULMACEE . . . 500

Ulmenrinde . . . 500

Ulmin . . . . 501

Ulmus campestris . $\quad 500$

" fulva . . .501

"montana . .600 


\begin{tabular}{|c|c|c|c|c|c|c|c|c|}
\hline UMULLLIFLRA. & $\begin{array}{r}\operatorname{sen} \\
. \quad 264\end{array}$ & Vanillic Acid . & & $\begin{array}{l}\text { PACE } \\
697\end{array}$ & Wild black Cher & rry & & $\mathrm{k} 224$ \\
\hline Umbelliferono. & .287 & Vanillin . · & • & 596 & Winter's Bark . & & & \\
\hline$"$ from asafoet & ida 285 &,$\quad$ artificial & • & 597 & & fals & & 19 \\
\hline$, \quad, \quad$ mezcre & 011487 & Veilchenwurzcl. & • & 598 & Wood Applc & & & .118 \\
\hline$" \quad, \quad$ sumbu & 1 . 27!) & Vellarin . . & • & 265 &, Oil. & & & \\
\hline Uncaria acida. . & . 298 & Vcratramarin & • & $6: 31$ & Wormseed & & & 346 \\
\hline „, Gambier . & . 298 & Veratric Acid . & • & 635 & Wurmsamen & • & & 346 \\
\hline Urginea altissima . & . 629 & Vcratriuc . . & • & 634 & & & & \\
\hline " indica. . & - 629 & Veratrum album & • & & & & & \\
\hline maritima . & . 627 & "frigidum & & 632 & Ximenia Amcri & ican & & - 222 \\
\hline "Scilla . & 627 & Lobeliar & numı & 632 & Xylene . . & & • & .562 \\
\hline Ursone . . . & .360 & nigrum & & 632 & Xylenol . • & & . & 627 \\
\hline Uvæ passæ & 140 & $\begin{array}{ll}\prime & \text { oflicinal } \\
& \text { viride }\end{array}$ & & & & & & \\
\hline Vitis-id & 36 & $\begin{array}{l}\text { Verek . } \cdot \text {. } \\
\text { Verzino }\end{array}$ & $\cdot$ & $\begin{array}{l}206 \\
189\end{array}$ & Yegaar & & & 135 \\
\hline Valerene. . & .340 & Vetti-ver. . & . & 663 & & & & \\
\hline Valerian Root . . & . . 337 & Vikunia . . . & & 255 & Zanthoxylum . & & . & .101 \\
\hline Valeriana angustifo & olia 3 & Virginic Acid . & & 73 & Zeitlosenknollen & & . & . 636 \\
\hline , officinali & $s$. : & Vitis vinifera & & 140 & Zeitlosensamcn & & - & .638 \\
\hline " Phu . . & . 340 & & & & Zimmt $\therefore$ & & • & - 460 \\
\hline VALERIANACEE & . 337 & & & & Zingiber officina & & - & . 574 \\
\hline Valerianic Acid & . 339 & Wachholderbeeren & & 565 & ZINGIBERACE无. & & • & . 574 \\
\hline Valerol • • . & $\cdot 3$ & Waltheria glomera & & 532 & Zitwersamen & & • & . 346 \\
\hline$"$ from hop & & Wattle tree & & 207 & Zucker • • & & • & . 649 \\
\hline anilla $:$ : & & Weihrauch - · & & 120 & Zwetschen . & & • & 224 \\
\hline " planifolia . & & Whortleberr'y, red. & & 360 & ZYGOPHYLLEE & & • & \\
\hline
\end{tabular}
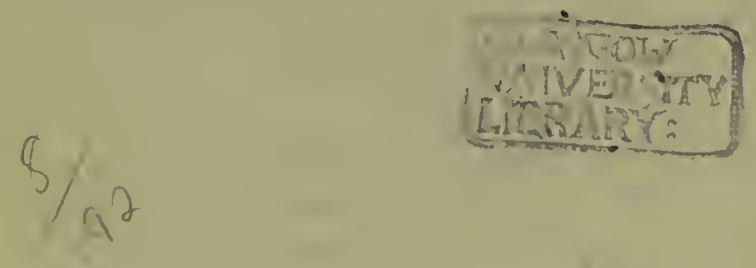

LONDON : R. CJAY, SONS, AND TAYLOR, PRINTRRS, BREAD STREET HILL. 



